\title{
DIE KAAPSE HELPMEKAAR C.1916-C.2014
}

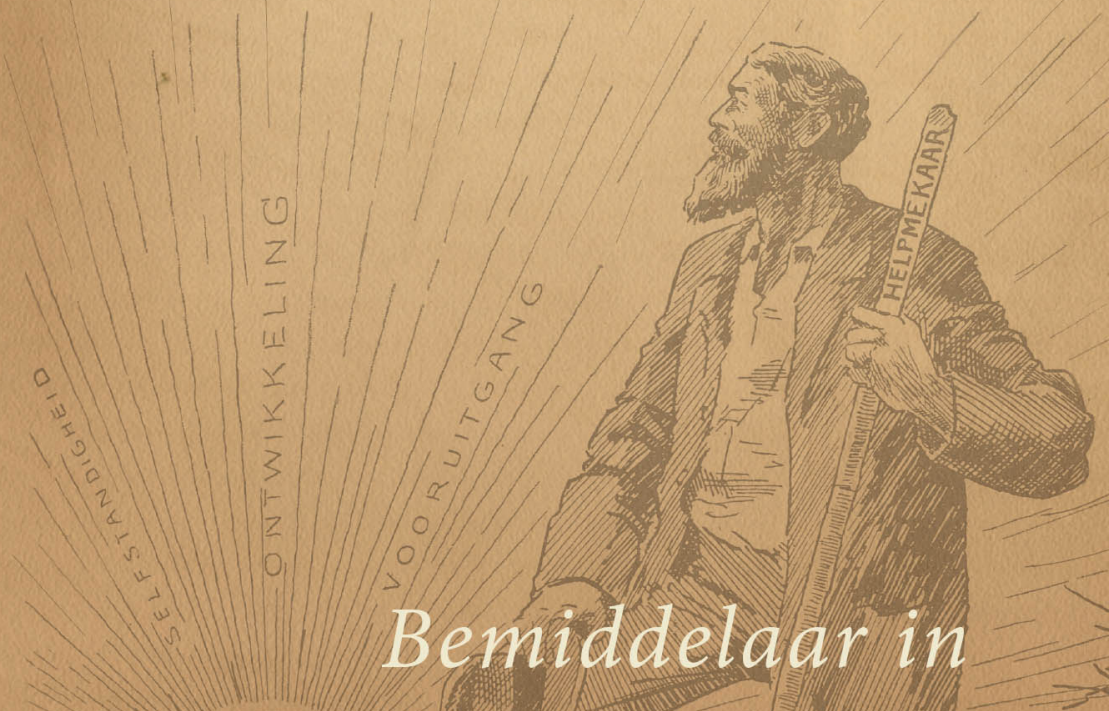

Afrikaner opheffing.

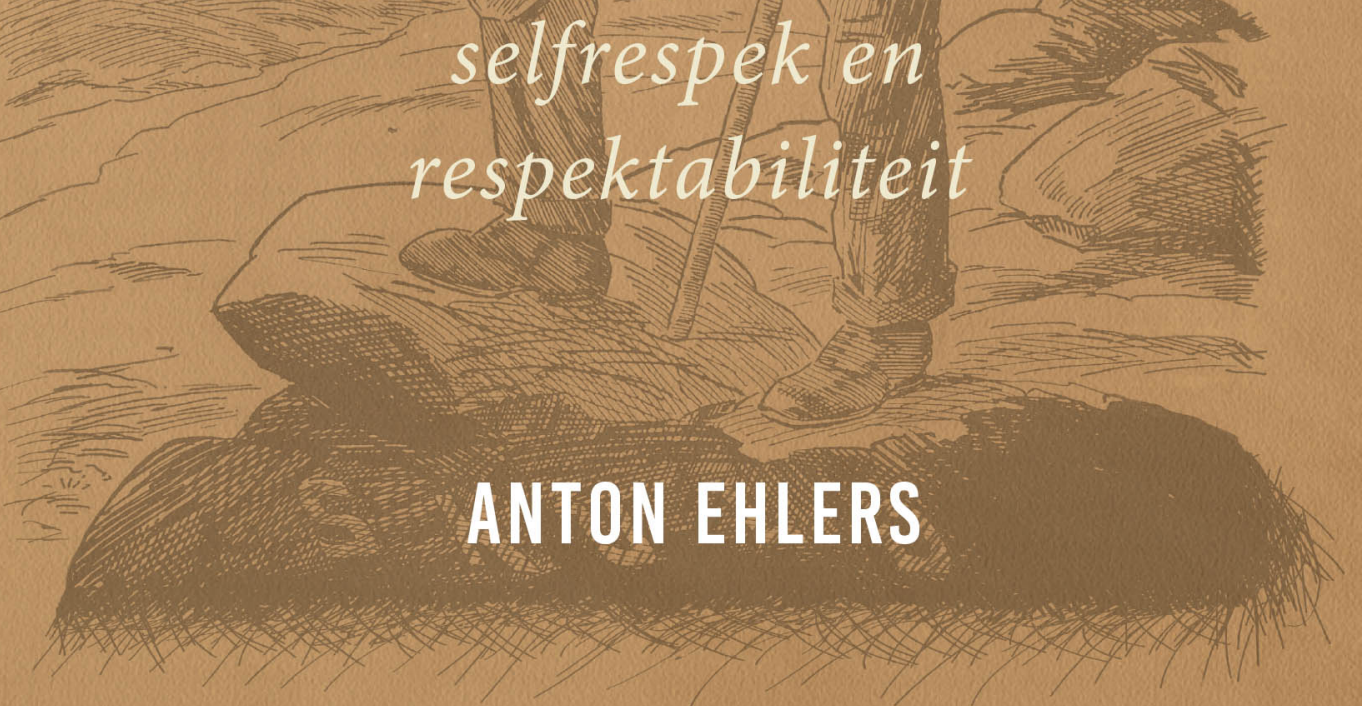




\section{DIE KAAPSE \\ HELPMEKAAR}

C.1916-C.2014

Bemiddelaar in Afrikaner opheffing,

selfrespek en respektabiliteit

\section{ANTON EHLERS}

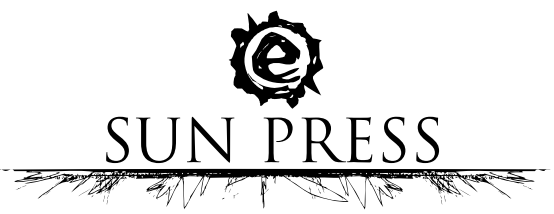


Die Kaapse Helpmekaar c.1916-c.2014

Bemiddelaar in Afrikaner opheffing, selfrespek en respektabiliteit

Uitgegee deur AFRICAN SUN MeDIA onder die SUN PReSS druknaam.

Alle regte voorbehou

Kopiereg @ 2018 AFRICAN SUN MeDIA en die outeur

Hierdie publikasie is deur die Uitgewer aan 'n onafhanklike dubbel-blinde portuurevaluering onderwerp.

Die outeur en die uitgewer het alles moontlik gedoen om toestemming te verkry vir die gebruik van materiaal met kopiereg en om sodanige gebruik te erken. Verwys asseblief navrae na die uitgewer.

Geen gedeelte van hierdie boek mag sonder die skriftelike verlof van die uitgewer gereproduseer of in enige vorm deur enige elektroniese, fotografiese of meganiese middel weergegee word nie, hetsy deur fotokopiëring, plaat-, band- of laserskyfopname, mikroverfilming, via die Internet of e-pos of enige ander stelsel van inligtingsbewaring of -ontsluiting.

Menings uitgespreek in hierdie publikasie weerspieël nie noodwendig die menings van die uitgewer nie.

Eerste uitgawe, eerste druk 2018

ISBN 978-1-928357-78-0

ISBN 978-1-928357-79-7 (e-boek)

DOI: https://doi.org/10.18820/9781928357797

Geset in Minion Pro 10/14

Bandontwerp en bladuitleg deur AFRICAN SUN MeDIA

SUN PReSS is 'n druknaam van AFRICAN SUN MeDIA. Vakkundige, professionele en navorsingswerk word onder hierdie druknaam gepubliseer in druk- en elektroniese formaat. Hierdie publikasie kan direk bestel word by www.sun-e-shop.co.za

Produksie deur AFRICAN SUN MeDIA

www.africansunmedia.co.za

africansunmedia.snapplify.com (e-boeke)

www.sun-e-shop.co.za 


\section{INHOUDSOPGAWE}

Voorwoord

Inleiding

Afdeling A Die Helpmekaarbeweging in SA: die storm- en drangjare, c1915-c1920

Hoofstuk Een "Die Helpmekaar is uit God gebore" die Helpmekaarbeweging c1915-c1920 ..

Hoofstuk Twee Die ontstaan, stigting en vestiging van die Helpmekaarvereniging van die Kaapprovinsie, c.1916-c.1920

Afdeling B Die Helpmekaarvereniging van die Kaapprovinsie, 1920-1965

Hoofstuk Drie

Die kongres- en takstelsel: van aanwins tot albatros

Hoofstuk Vier

Die Helpmekaar en Onderwys: lees, skryf en reken

Hoofstuk Vyf Helpmekaar-studiebeurse en lenings

\section{Afdeling C Die Hulp-studieleningsfonds of B-fonds, 1941-1966}

Hoofstuk Ses $\quad \mathrm{DH}$ van Zyl en die ontstaan, stigting en funksionering van die B-fonds

Hoofstuk Sewe Van B-fonds tot Helpmekaar Studiefonds

Hoofstuk Agt

"Twee fondse in een pot" die Helpmekaar Studiefonds amalgameer met die Helpmekaarvereniging van die Kaapprovinsie, 1966

Afdeling D Die Helpmekaar Studiefonds, 1966-2006

Hoofstuk Nege In die vaarwater van Afrikaner- politieke en ekonomiese hoogty, 1966-c. 1990: bloei, beloon, beleër

Hoofstuk Tien Die "Wisseling van die Wag": herbesinning, heroriëntering, herstrukturering, 1990-2002

Hoofstuk Elf Helpmekaar, 2002-2014: op pad na 'n "goeie dag”

\section{Afdeling E Evaluering}

Hoofstuk Twaalf Bemiddelaar in Afrikaner opheffing, selfrespek en respektabiliteit:

'n balansstaat

Bronne

Indeks 


\section{VOORWOORD}

My persoonlike verbintenis met die Helpmekaar Studiefonds (HS) strek terug na 30 Julie 1980. Op die dag het ek en prof Diko van Zyl (my studieleier) vir mnr Fanie Pretorius in die kantoor van die HS in die Grootte Kerk-gebou in Adderleystraat, Kaapstad besoek. Die doel was om 'n Helpmekaarbeurs vir my MA-studie oor die Helpmekaarbeweging te beding. Hoewel mnr Pretorius gemeen het die R6,500 bod wat prof Van Zyl ingesit het te hoog was, is ons uiteindelik daar weg met 'n belofte van 'n R6,000 beurs. Die beurs sou my instaat stel om vir 1981 onbetaalde studieverlof te neem om my navorsing van die Helpmekaar vir die periode 1915-1920 te kon doen. Dié dag was ook my eerste ontmoeting met die Helpmekaar se administratiewe personeel, mev Steyn en Nita van Zyl. Nita het oor die jare vir my soos familie begin voel. Na die voltooiing van my MA-studie in 1986, het die menigde bokse vol ongebruikte navorsingsmateriaal oor die Helpmekaar altyd die belofte ingehou om eendag hulle verhaal te vertel.

In 1992 het die HS, by monde van mnr Hannes Oberholster, my probeer oorreed om die Studiefonds-verhaal te voltooi sodat dit met hul $75^{\text {ste }}$ bestaansjaar kon saamval. Die voorgestelde tydsraamwerk vir die voltooiing van die studie en ' $\mathrm{n}$ finansiële bod wat waarskynlik te hoog ingesit is, die poging laat skipbreuk ly. In Augustus 2005 het mnr Tex de Swardt (die Bestuurder van die HS) vir my en my kollega, prof Albert Grundlingh, vir ' $n$ middagete by die Volkskombuis in Stellenbosch genooi. Die gesamentlike oortuigingskrag van Tex en Albert, en my verswakte weerstand weens die kombinasie van die Volkskombuis se kos en wyn, het my laat instem om my te verbind tot die voltooiing van die Kaaplandse Helpmekaar se geskiedenis. Die R40,000 beurs het ook gehelp. Die belofte dat die studie in 2007 afgehandel sou wees, het uiteindelik 2018 geword.

Oor meer as ' $n$ dekade het talle persone en instansies ' $n$ bydrae gelewer om die publikasie moontlik te maak en ek betuig my opregte dank en waardering aan hulle: die HS, die personeel en direksie vir die beskikbaarstelling van hulle argiewe, hul finansiële ondersteuning en hulle eindelose geduld. ' $n$ Spesiale dank aan Barry van der Merwe - veral vir sy rol as weerligafleier; Elize van Heerden vir die pynlik akkurate wyse waarop sy elke Helpmekaarbeurs en -lening statisties vasgelê het; Hanlie Roux vir haar toegewyde taalversorging; prof Martin Kidd vir die statistiek en grafieke; Emily Vosloo en haar span by African Sun Media vir 'n pragtig versorgde publikasie; prof Rufus Gouws wat op nommer nege en negentig die Kaapse Helpmekaar se status van handelaars tot bemiddelaars versag het; my kinders, Righardt, Hannu en Annemien (almal Helpmekaar leningshouers) vir die geamuseerdheid waarmee hulle my nimmereindigende werk aan die Helpmekaar oor jare gade geslaan het; Salomé vir haar geduld, aanmoediging en ondersteuning wat my veral in die pylvak die lint laat breek het; en laastens, maar nie die minste nie: my Skepper.

\section{Anton Ehlers}

23 Mei 2018 


\title{
"ROMA DIE UNO NON AEDIFICATA EST"
}

\author{
MH de Kock, ${ }^{1}$ CGW Schumann, ${ }^{2}$ Frederik Meyer, ${ }^{3}$ Francois C Erasmus, ${ }^{4}$ Piet Koornhof, ${ }^{5}$ \\ Chris en Marius Barnard, ${ }^{6}$ MC Botha, ${ }^{7}$ Frederick Van Zyl Slabbert, ${ }^{8}$ Breyten Breytenbach, ${ }^{9}$ \\ Jannie Gagiano, ${ }^{10}$ Pieter Dirk Uys ${ }^{11}$ en Arno Carstens. ${ }^{12}$ Bogenoemde is 'n indrukwekkende en \\ diverse groep Afrikaanse, openbare figure wat op 'n uiteenlopende aantal terreine beduidende \\ bydraes tot die Suid-Afrikaanse samelewing gelewer het. Dit is egter nie hierdie hoëprofiel \\ Helpmekaar-begunstigdes wat primêr die impak en bydrae van die Kaapse Helpmekaar
}

1 President van die Suid-Afrikaanse Reserwebank (1945-1962). Hy het 'n deurslaggewende rol gespeel in die vestiging van die sentrale bankwese en die gepaardgaande finansiële instellings in Suid-Afrika. Suid-Afrikaanse Biografiese Woordeboek, vol V, 188-189, RGN, Pretoria, 1987.

2 Stigter van die Fakulteit Ekonomiese en Bestuurswetenskappe aan Universiteit Stellenbosch. Suid-Afrikaanse Biografiese Woordeboek, vol V, 738-739, RGN, Pretoria, 1987.

3 Chemiese en metallurgiese kenner en die dryfkrag agter die stigting van YSKOR en 'n yster- en staalbedryf in Suid-Afrika. Hy het ook aanvoorwerk gedoen vir die stigting van KRYGKOR, terwyl sy navorsing oor die olie-uit-steenkool-proses bygedra het tot die lê van 'n grondslag vir die industriële prosesse wat uiteindelik tot die stigting van SASOL gelei het. Suid-Afrikaanse Biografiese Woordeboek, vol V, 538-539, RGN, Pretoria, 1987.

4 Minister van Verdediging in DF Malan se kabinet van 1948 en latere Minister van Justisie wat die verbanningsbevel op die ANC en PAC na die Sharpeville-protes in Maart 1960 beteken het. Suid-Afrikaanse Biografiese Woordeboek, vol V, 261-263, RGN, Pretoria, 1987.

$5 \quad$ Kleurvolle en omstrede NP-politikus en kabinetsminister. Hermann Giliomee, Die laaste Afrikaner-leiers. ' $n$ Opperste toets van mag, 169, 258, Tafelberg, Kaapstad, 2012.

6 Baanbrekers op die gebied van kardiologiese chirurgiese prosedures wat hulle in staat gestel het om die eerste menslike hartoorplanting in die wêreld te doen. M. Malan, Heart Transplant: The Story of Barnard and the "Ultimate In Cardiac Surgery, Johannesburg, Voortrekkerpers, 1968.

7 Dr MC Botha was die immunoloog wat saam met Chris Barnard se hartspan gewerk het wat die ontwikkelingswerk gedoen het om verwerping teen te werk - en dus die eerste hartoorplanting moontlik gemaak het. Standard Encyclopaedia of Southern Africa, vol 2, BAC-CAL, 454.

8 Hy het as alternatiewe Afrikaner die leier van die Progressiewe Federale Party geword en was saam met ander die verpersoonliking van wit Afrikaner-weerstand teen apartheid. Frederik van Zyl Slabbert, The Other Side of History: An Anecdotal Reflection on Political Transition in South Africa, 2006, Jonathan Ball; Hermann Giliomee, Die ANC, die Afrikaners en die storie van die bobbejaan, Die Suid-Afrikaan, Sept 1987, 9-10, 30.

9 Bekende figuur in die literêre wêreld, ontvanger van die Hertzogprys en 'n vurige kritikus van apartheid. Die Suid-Afrikaan, Winter 1985, Van Zyl Slabbert in Gesprek met Breyten Breytenbach, 47-48,

10 Kleurvolle en uitgesproke politieke wetenskaplike en saam met Van Zyl Slabbert en Breytenbach lede van die groep Afrikaner- en ander leiers wat die ANC in 1987 in Dakar, Senegal ontmoet het. Frederik van Zyl Slabbert, The Other Side of History: An Anecdotal Reflection on Political Transition in South Africa, 2006, Jonathan Ball.

11 Sosiale kommentator, komediant en skepper van die Evita Bezuidenhout persona. Die Burger, 31 Mei 2016, "The Echo of a Noise". Fokus op familiegeskiedenis. "Uys se 7 000ste optrede begin vandag", 11. 
definieer nie. Hierdie eer kom eerder die 8381 studente en ongeveer 100 instellings en sake toe wat tussen 1916-2014 met miljoene (1916-1960: $£ 302053$ en 1961-2014: R350 209 999) gefinansier is. Hierdie is bereik deur 'n benadering wat reeds in 1920 deur die toenmalige voorsitter van die Kaapse Helpmekaar, advokaat HS van Zijl, gepropageer is:

"Die beste en standhoudendste werk, selfs filantropiese en opbouende volkswerk, word op 'n stille, bedaarde wyse gedaan. En dit is op die wyse dat die Helpmekaar, wat vir die eerste paar jaar van sy leeftyd die gevierde was op publieke platforms en nuusbladkolomme, moet leer om te werk as dit 'n blywende krag ten goede in ons land wil word." ${ }^{13}$

Die Helpmekaarverhaal kan teruggevoer word na 31 Mei 1902 met die beëindiging van 'n seisoen van dood en verwoesting by Melrose Huis in Vereeniging. Die voortdurend langerwordende skaduwee van dié seisoen het die voedingsbron, motivering, geborgenheid en uiteindelik wasdom vir 'n embrionale Afrikaner-etnisiteit verskaf. Dit het oor tyd verander vanaf' $n$ staat van skok, verslaendheid en passiwiteit tot 'n magtige politieke, sosiale en ekonomiese beweging, wat die 20 ste eeu se Suid-Afrikaanse geskiedenis sou domineer. Die Helpmekaarbeweging was beide die wegbereider en produk van die proses. Die wortels van die Helpmekaarbeweging lê in hierdie onstuimige tydperk van opkomende Afrikanernasionalisme en etniese mobilisasie in die vroeg 20 ste eeu.

Die meer direkte historiese ontstaan van die Helpmekaar was gesetel in die uitbreek van die Eerste Wêreldoorlog en spesifiek in die Afrikaner-rebellie van 1914-1915 wat dit sou voortbring. Hierdie gewapende protes deur Afrikaners was 'n reaksie op die regering se

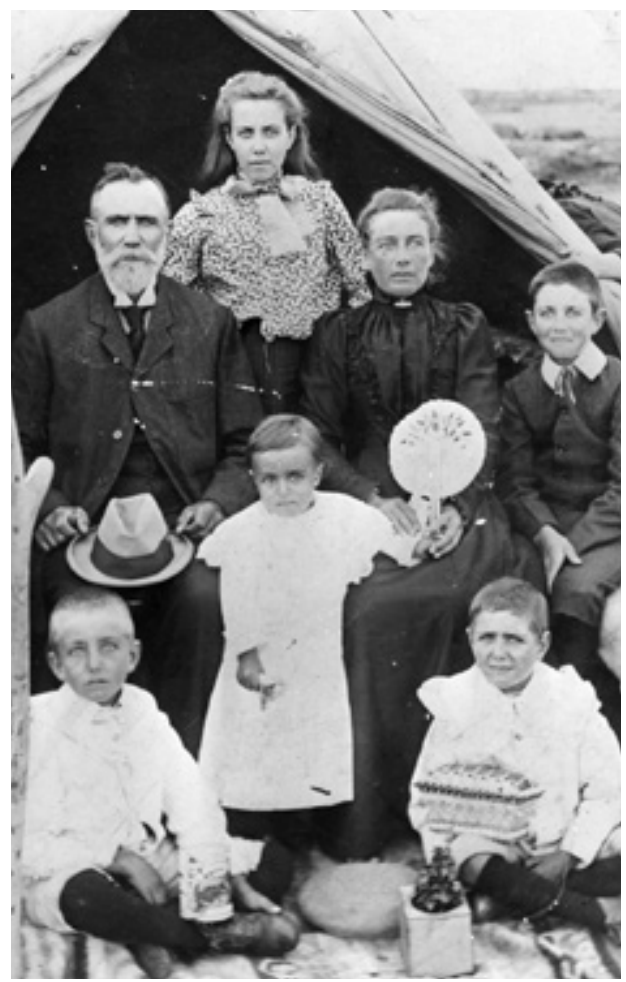

Mnr en mev Van Zyl met hul kinders in 'n konsentrasiekamp in Bloemfontein tydens die Anglo Boereoorlog. David Hermanus van Zyl, Helpmekaar van die Kaapprovinsie sekretaris, bestuurder en stigter van die B-fonds sit voor links.

13 Helpmekaar Studiefonds Argief, Parow (hierna HSA): Helpmekaarvereniging van die Kaapprovinsie (hierna HVKP), Notuleboek 26-27 Mei 1920, Kongres, 2. 
besluit om in die Eerste Wêreldoorlog as 'n Britse bondgenoot aktief teen Duitsland deel te neem. ${ }^{14}$ Die Helpmekaarbeweging verteenwoordig dus die ekonomiese nadraai van die Rebellie. As 'n "armoede-verligtingsprogram" - 'n plan om 'n toename van die armblankevraagstuk te voorkom deur te verseker dat 11000 rebelle nie permanent tot die geledere van die armblankes toetree nie - was dit in die periode 1915-1917 een van die mees suksesvolle skemas van sy soort in die geskiedenis van die Afrikaner.

Gedurende die Rebellie, met sy episentrum in die Noord-Vrystaat en Wes-Transvaal, ${ }^{15}$ het die rebelle 'n stelsel van opkommandering van goedere en eiendom van lojaliste (mense wat nie die wapen teen die regering opgeneem het nie) gebruik om tydens die Rebellie toerusting en voorrade vir hulself te bekom. ${ }^{16}$ Die verliese wat die lojaliste gely het, het in die nasleep van die Rebellie tot die indien van 'n stortvloed van lojalis-eise om skadevergoeding teen die rebelle gely. ${ }^{17}$ Omdat 'n groot aantal rebelle afkomstig was van die sogenaamde bywoner- of armblanke Afrikaners, ${ }^{18}$ het dit gou duidelik geword dat hulle nie in 'n finansiële posisie was om hierdie eise te betaal nie. Die Helpmekaargedagte het teen hierdie agtergrond ontstaan en in die nadraai van die Rebellie gemanifesteer in die Helpmekaarbeweging.

Die Helpmekaarbeweging het nie net 'n ekonomiese invloed gehad nie, maar ook 'n beduidende invloed op die geestelike ingesteldheid van Afrikaners uitgeoefen. Dit het aan Afrikaners bewys dat, hoewel hulle as individue nie besonder kapitaalkragtig was nie, hulle deur samewerking en die vereniging van hul kapitaal in groepsverband aansienlike kapitaalhulpbronne kon byeenbring. ${ }^{19}$

Op 'n ideologiese vlak het die Rebellie die geledere van Giliomee se wyn- en graanboere waarna hy in sy 1987-artikel "Western Cape Farmers and the beginnings of Afrikaner nationalism, 1870-1915" verwys as "arguably ... the firmest pillar of support for the Afrikaner nationalist movement", ${ }^{20}$ tot buite die grense van die Wes-Kaap uitgebrei om Afrikanerboere

14 A Grundlingh en S Swart, Radelose rebellie? Dinamika van die 1914-1915 Afrikanerrebellie, Protea Boekhuis, Pretoria, 2009, 14-18.

15 SB Spies, The Rebellion in South Africa, 1914-1915, 232.

16 Ons Land, 21 Nov 1914, Rebellen te Harrismith; Cape Times, 17 Apr 1915, Allegations of Looting; Cape Times, 28 Nov 1914, Methods of the rebels.

17 UG 46-16, Report of the Rebellion Losses Commission, 9.

18 UG 28-15, Department of Justice. Annual Report for the Calendar Year 1914, 186; A Grundlingh en S Swart, Radelose rebellie? Dinamika van die 1914-1915 Afrikanerrebellie, 23-26, Pretoria, 2009.

19 De Burger, 23 Nov 1917, Open brief.

20 H Giliomee, Western Cape Farmers and the beginnings of Afrikaner nationalism, 1870-1950, Journal of Southern African Studies, Vol 14, No 1, Oct 1987, 38. 


\section{Die Kaapse Helpmekaar}

van die Vrystaat en Transvaal in te sluit. Hulle het in tandem met 'n klein, maar groeiende professionele klas hul verworwe Afrikanerkapitaal en organisatoriese vaardighede in diens van die Helpmekaarbeweging gestel.

Die Helpmekaarbeweging bevestig ook O’Meara se siening in sy 1983-publikasie Volkskapitalisme: class capital and ideology in the development of Afrikaner nationalism, 1934-1948 dat die:

"Helpmekaar movement significantly demonstrated how nationalist sentiment, coordinated through press, party and special institutions, could be an extremely powerful mobiliser both of the revenue of rich farmers ... and the meagre savings of the petty bourgeoisie and workers."21

Die Helpmekaarbeweging weerspieël ook die ontstaan en vroeë patroon van O'Meara se Afrikaner "economic movement" wat uiteindelik gelei het tot die alliansie tussen die belange van die boere en die kleinburgery (petty bourgeoisie) wat die oorwinning vir die NP in die 1948-verkiesing verseker het. ${ }^{22}$

Die studie beoog om die verhaal van die Kaapse Helpmekaar as katalisator in die ekonomiese opheffing van Afrikaners in die vaarwater van die Rebellie van 1914-15 te vertel, asook hoe die rol en fokus oor tyd ontwikkel het. Die Kaapse Helpmekaar het 'n tweeledige doelwit beoog. Eerstens om Afrikaner-rebelle en hul gesinne van ekonomiese ondergang te red. Die tweede doel was meer gekompliseerd. Dit was die bevordering van die algemene ontwikkeling en welsyn van die Hollandssprekende deel van die Suid-Afrikaanse bevolking, met die fokus op die ontwikkeling van 'n spesifieke Afrikaanse kultuur. As instelling het dit die Kaapse Helpmekaar in die raamwerk van Afrikaner-organisasies geplaas wat 'n deurslaggewende rol in die etniese mobilisering van Afrikaners in die 20ste eeu gespeel het.

Die verhaal van die Kaapse Helpmekaar volg dan ook die ideologiese kontoere van die geskiedenis van nasionaalgesinde Afrikaners in die 20ste eeu - en meer spesifiek die belewenis van die Kaapse elite wat die Helpmekaar oor die jare gedomineer het. Die tweede doelstelling het mettertyd in 'n dominante, opvoedkundige fokus ontwikkel, naamlik om die armblankevraagstuk op te los deur die opvoeding van die Afrikanerjeug deur hulle potensiaal te ontsluit. Hierdie proses en die praktiese implementering daarvan oor tyd vorm die kern en fokus van hierdie studie. Die Kaapse Helpmekaar is die verhaal van die ontwikkeling van 'n Afrikaner-volksinstelling met 'n sosio-ekonomiese kulturele en politieke oorsprong. Dit

21 D O'Meara, Volkskapitalisme: class, capital and ideology in the development of Afrikaner nationalism, 1934-1948, 97, Cambridge, Cambridge University Press, 1983. 
het ontwikkel tot sy huidige status as 'n nie-winssoekende, openbare weldaadorganisasie wat as geregistreerde kredietverskaffer onder die Nasionale Kredietwet binne die korporatiewe wêreld van die 21ste eeu moet funksioneer. Verder verteenwoordig die studie ook in 'n sekere sin die verhaal van Afrikaners - van hul armblankestatus in die vroeg 20ste eeu tot vooruitstrewende burgers van die kapitalistiese verbruikerskultuur van die 21 ste eeu. Dit is dan ook die verhaal van die kronkelgang en aanpassing, die strategieë, taktiek en reaksies om hierdie oorgang te onderhandel binne spesifiek die Kaapse konteks waarbinne die Kaapse Helpmekaar gefunksioneer het.

Die Helpmekaar was nie 'n neutrale beweging ontdaan van alle ander motiewe nie, hoewel die fokus op die insameling van fondse en steun aan studente op 'n "stille, bedaarde wyse" wat Van Zijl voorgestel het gefokus het. Onderliggend was dit vermeng met ideologiese motiewe en het dit in die breë oor die politiek van identiteit gegaan, maar ook om die Afrikaner gunstiger teenoor aanvanklik die Engelssprekendes, maar toenemend ook teenoor swartmense te posisioneer. ${ }^{23}$ In die proses was die Kaapse Helpmekaar met sy fokus op opvoeding en onderwys 'n bemiddelaar in Afrikaner opheffing, selfrespek en respektabiliteit en dus 'n fasiliteerder van Afrikaner sosiale mobiliteit. In dié sin vind die studie dus ook aansluiting by 'n breër historiografie oor respektabiliteit en sosiale mobiliteit waarin die smeebaarheid van respektabiliteit as ideologie geillustreer word. ${ }^{24}$ Enkele internasionale voorbeelde in die verband sluit in Richard Hoggarts se 1957 publikasie oor die veranderinge in die Britse werkersklas in reaksie op die ontwikkeling van massa media, The Uses of Literacy ${ }^{25}$ en die meer onlangse werk van Lynsey Hanley Respectable: The Experience of Class. ${ }^{26}$ Volgens Vivian Bickford-Smith het respektabiliteit as ideologie as produk van Britse kolonialisme veral sedert die 1870's en 1880's in Suid-Afrika gemanifesteer. ${ }^{27}$ In die Suid-Afrikaanse historiografie tel Nicholas Cope se artikel oor Zoeloe nasionalisme in die $1920{ }^{28}$ en Lynn Thomas se

23 Met erkenning aan Albert Grundlingh vir hierdie insig.

24 L M Thomas, The Modern Girl and Racial Respectability in 1930's South Africa, 467, Journal of African History, 47, 2006.

R. Hoggarts, The Uses of Literacy. Aspects of Working Class Life, Penguin, 2009. https://www.penguin.co.uk/ books/175505/the-uses-of-literacy/

26 Lynsey Hanley, Respectable: The Experience of Class, Alan Lane, 2016. Hanley se werk oor die hedendaagse manifestasie van klas in Brittanje word beskryf as: "In this empathic, wry and passionate exploration of class in Britain today, Lynsey Hanley looks at how people are kept apart, and keep themselves apart - and the costs involved in the journey from 'there' to 'here." https://www.goodreads.com/book/show/29744398 respectable

27 L M Thomas, The Modern Girl and Racial Respectability in 1930's South Africa, 466, Journal of African History, 2006, 47.

28 N Cope, The Zulu Petit Bourgeoisie and Zulu Nationalism in the 1920's: Origins of Inkatha, Journal of Southern African Studies, vol. 16, no 3 (Sep 1990). 
artikel oor die rol van voorkoms in respektabiliteit en aanvaarding onder swartmense in Suid-Afrika. ${ }^{29}$ Verdere voorbeelde hiervan is werke soos die van Robert Ross, Status and Respectability in the Cape Colony 1750-1870. A Tragedy of Manners ${ }^{30}$ en die onlangse werk van Roger Southall oor die stryd van die swart middelklas vir sosiale opwaartse mobiliteit en 'n soeke na respektabiliteit in post-apartheid Suid-Afrika. In laasgenoemde twee werke kom onder andere die rol van opvoeding en onderwys in die soeke na respektabiliteit onder die loep. In Southall se eie woorde:

"In writing about the struggles for upward mobility and respectability of the black middle class in post-apartheid society, I recognised much from my own family background in the 1950's and 1960's England, in particular the determination and sacrifices made by my own parents to provide myself, my brother and sister with a good education." ${ }^{31}$

Soos aangedui deur Shula Marks ten opsigte van sekere Zulu groeperinge in Natal in die periode voor 1949 het Afrikaner reaksie op die ontwrigting van armoede, verstedeliking en proletarisering ook gelei tot "the construction of an ethnic answer to the problems of urbanization and modernity" ${ }^{32}$ waarin "Respectability came to be joined with ethic consciousness" ${ }^{33}$ Soos vir die 19de eeu se Europese intellektuele en regerende klasse was dit ook vir Afrikaners in die 20ste eeu: "nationalism and respectability jointly provided a reference point in an unsettling world, a piece of eternity which could be approriated by those caught up in the vibrations of modernity" ${ }^{34} \mathrm{Op}$ 'n ideologies vlak het die Helpmekaar binne 'n soortgelyke konteks gefunksioneer en deur hul ondersteuning en betrokkenheid by onderwys en opvoeding 'n bydrae gelewer tot die vorming van Afrikaner "AmaRespectables". ${ }^{35}$ Gevorm deur ideologieë van etnisiteit, ras en klas het die Helpmekaar deur sy finansiële bydraes en as kampvegter vir opvoedkundige sake 'n beduidende rol in die bevordering van onderwys en die opvoeding in die soeke na respektabiliteit gespeel.

29 L M Thomas, The Modern Girl and Racial Respectability in 1930's South Africa, 466, Journal of African History, 2006, 47.

30 Robert Ross, Status and Respectability in the Cape Colony 1750-1870, A Tragedy in Manners. Cambridge University Press, 2009.

31 Roger Southall, The New Black Middle Class in South Africa, pp, viii, ix. Jacana, 2016.

32 Shula Marks, Patriotism, Patriarchy and Purity: Natal and the Politics of Zulu Ethnic Consciousness, 39 (University of the Witwatersrand. African Studies Institute. African Studies Seminar Paper no 193, Monday 4 August 1986.

33 Ibid., 20.

34 GL Mosse, "Nationalism and respectability: normal and abnormal sexuality in the nineteenth century", 242-3, Journal of Contemporary History, 17, 2 (1982) soos aangehaal deur Shula Marks in Ibid., 31.

35 Ibid., 33; L M Thomas, The Modern Girl and Racial Respectability in 1930's South Africa, 466, Journal of African History, 2006, 47. 
Ten spyte van die aanvanklike eng etniese en nasionalisteise fokus en die gepaardgaande sosiale ingenieurswese is 'n veel wyer gemeenskap as wat aanvanklik beoog is uiteindelik bevoordeel.

As 'n kredietverskaffer vir tersiêre opleiding van Afrikaanse studente oor 'n honderd jaar, verteenwoordig dié verhaal die ervaringe en antwoord op die uitdagings van 'n agtergeblewe segment van die Suid-Afrikaanse samelewing in hul soeke na respektabiliteit deur die uitwissing van hul ekonomiese agterstande. In die sin resoneer die verhaal van die Kaapse Helpmekaar ook met die huidige debatte rondom die finansiering van tersiêre onderrig. Dit verskaf 'n Afrikaner antwoord op 'n 20ste eeuse \#feesmustfall-uitdaging wat ten spyte van die verskil in konteks 'n templaat en 'n benadering voorhou waarby'n 21 ste eeuse Suid-Afrika steeds baat kan vind. 
wato tiok

Ulequ afeer

\section{four}

e pacap

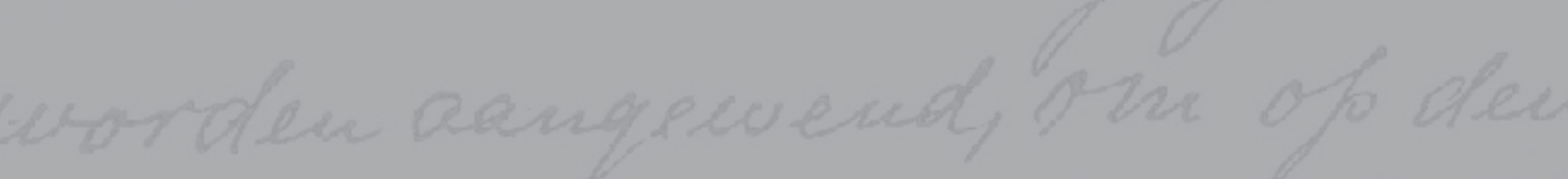

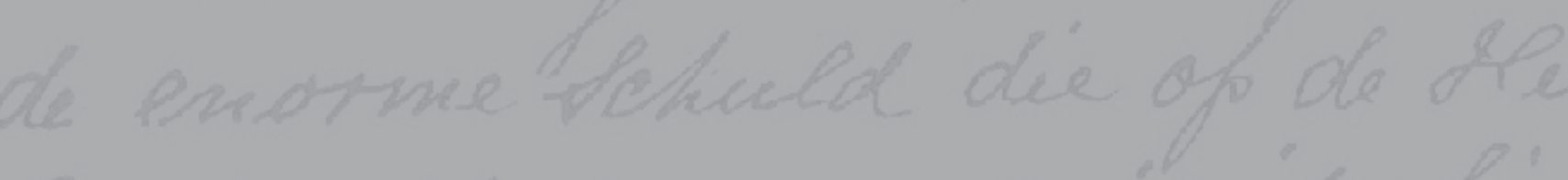

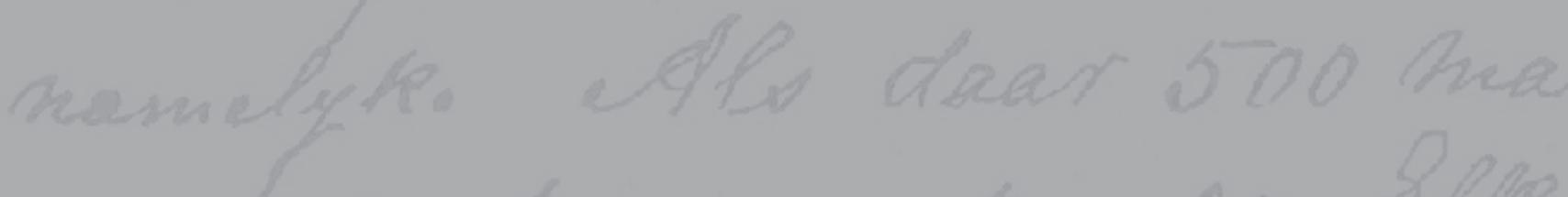

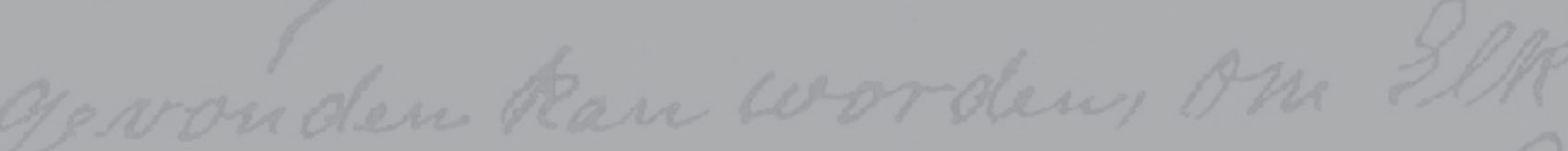
aple abeve hate whe hee

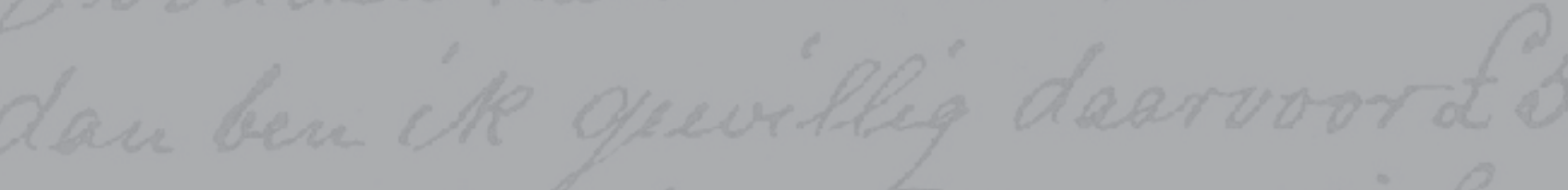

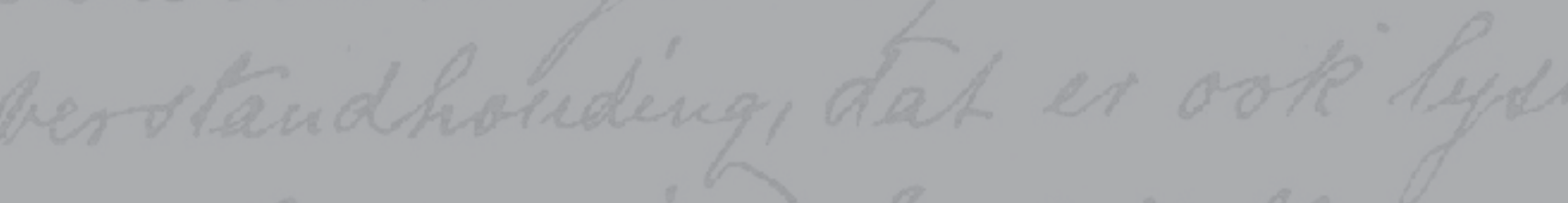
Eousland qeerr cacleend Sulleu wer AFDELING A t50, o-o sehuld excet

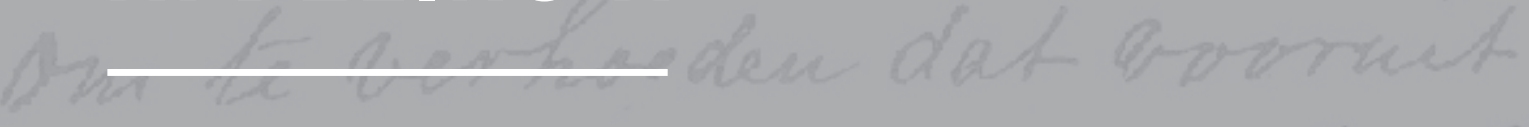

Die Helpmekaarbeweging in SA: die storm-en drangjare, c1915-c1920 


\title{
"DIE HELPMEKAAR IS UIT GOD GEBORE" DIE HELPMEKAARBEWEGING C1915-C1920
}

\begin{abstract}
"Die Helpmekaar is uit God geboren. De Helpmekaar was de enige in de wereld waar een volk dat in opstand was, zich had samengespannen om de schade te vergoeden en zelfs door hun opponenten word geholpen. De man die tegen zulk een beweging werkte, zou geen vriend van het volk zijn."1
\end{abstract}

\section{DIE REBELLIE VAN 1914-1915 AS OORSPRONG VAN DIE HELPMEKAARBEWEGING}

Op 4 Augustus 1914 het die langverwagte Europese oorlog uitgebreek met Brittanje se oorlogsverklaring teen Duitsland. Die regerende Suid-Afrikaanse Party (SAP) se aanvaarding van die Britse versoek om Duits-Suidwes-Afrika namens Brittanje te verower ${ }^{2}$ was die vonk vir 'n gewapende rebellie teen die regering. Slegs 'n gedeelte van die Afrikaners het aan die Rebellie deelgeneem. Die Rebellie is veroorsaak vanweë n toenemende, onderliggende gevoel van politieke en ekonomiese ontevredenheid en ontnugtering onder sekere Afrikaners rakende die beleidsrigtings van die SAP.

Die beleid van konsiliasie tussen wit Afrikaans- en Engelssprekende Suid-Afrikaners tot één Suid-Afrikaanse nasie, soos gepropageer en geïmplementeer deur die Eerste Minister, Louis Botha, was die oorsaak en teiken van baie van die politieke ontevredenheid binne Afrikanergeledere in die aanloop tot die Rebellie. Die krisis in die kabinet in 1912, en die uitsetting van JBM Hertzog - die voorvegter van die anti-Botha drukgroep binne Afrikaner-geledere - uit die kabinet, het gelei tot 'n gevoel onder spesifiek Afrikaners in die Vrystaat, dat die regering nie meer hulle belange verteenwoordig nie. Hierdie anti-Botha sentiment het uiteindelik uitgeloop op die stigting van die Nasionale Party (NP) in die Vrystaat in Januarie 1914. Kaapstad, 1921, 349. 
Verskeie emosionele gebeure tydens die verloop van die Rebellie, soos die dood van generaal Koos de la Rey toe hy per ongeluk by 'n polisieblokkade doodgeskiet is, die dood van Jopie Fourie deur 'n vuurpeloton nadat hy skuldig bevind is aan hoogverraad met die regering wat geweier het om sy straf te versag en die gevangenisstraf van 'n Anglo-Boereoorlog-ikoon soos generaal De Wet vir sy rol in die Rebellie, het die vure van ontevredenheid aangeblaas wat uiteindelik in die nasleep van die Rebellie gelei het tot grootskaalse simpatie vir die rebelle. ${ }^{3}$

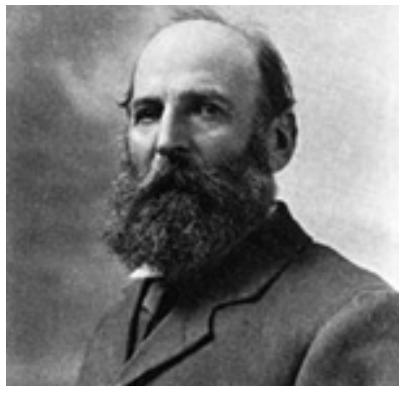

Gen. Koos de la Rey

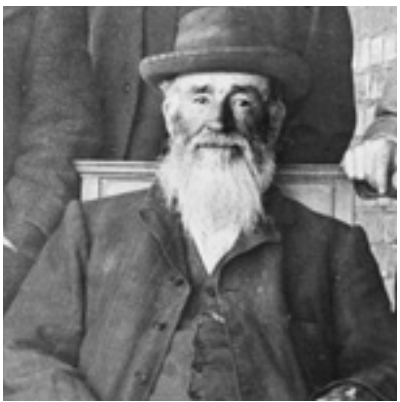

Gen. Christiaan de Wet
Politieke motiewe, soos die republikeinse ideaal en die idee van die stryd teen Duitsland, hul Anglo-Boereoorlogbondgenoot, en samewerking met Brittanje die voormalige vyand $^{4}$ het die ontevredenheid laat toegeneem soos die Rebellie gevorder het. Dit was duidelik dat die onderliggende motiewe wat baie van die $11472^{5}$ rebelle van die NoordVrystaat en Wes-Transvaal aangedryf het aanvanklik van 'n ekonomiese aard was. Dit het egter desperate mense geskep en hulle roekeloos laat optree. Hoewel prominente Afrikanerfigure soos generaals De Wet en Beyers by die rebellie aangesluit het, het 'n groot gedeelte van die rebelle uit bywoners of armblanke Afrikaners bestaan. ${ }^{6}$ Regeringstroepe wat met rebellemagte gebots het, het getuig van hul gebrek aan basiese toerusting en voorrade. Fluffy Webber, 'n lid van die Unie se Verdedigingsmag, het berig dat "they seemed to be terribly short of ammunition and supplies, in fact ammunition was the first thing they went for"? Die vlak van ammunisievoorrade in die kommando van generaal De Wet is op slegs 50 rondtes per rebel geskat, terwyl ander skattings Deel I, Bloemfontein, 1983, 219, 229-232, 235-237); SB Spies: The Rebellion in South Africa, 1914-1915 220-221, MA thesis, University of the Witwatersrand, 1962.

4 AH Marais: Die oorlogsbesluit, die Rebellie en die NP (O Geyser en AH Marais (reds), Die Nasionale Party, Deel I, Bloemfontein, 1983, 228-229).

5 SB Spies, The Rebellion in South Africa, 1914-1915, 232, MA thesis, University of the Witwatersrand, 1962.

6 UG 40-16, Report of the Rebellion Losses Commission, 5-6; J Bottomley, The Orange Free State and the Rebellion of 1914: the influence of industrialization, poverty and poor whiteism. In: R Morrell, (ed) White but poor: essays on the history of poor whites in Southern Africa 1880-1940, 29, 31-33; S Swart, "Desperate men": the 1914 rebellion and the politics of poverty, South African Historical Journal, 42 (May 2000), 161-164.

7 The Star, 28 Nov 1914, Rebel chasing. 
so laag as vyf of tien rondtes was. Baie van sy volgelinge was ook sonder vuurwapens, ${ }^{8}$ terwyl daar ook onder die rebelle in die algemeen 'n tekort aan perde ${ }^{9}$ en $\operatorname{kos}^{10}$ was. Getuienis dui ook op die swak ekonomiese posisie van die families en gesinne van die rebelle. Ene mev $\mathrm{M}$ Marais getuig onder andere in 'n brief:

"Ik kryg nou dageliks aanvrage om hulp, en vele van die families van onze dierbare krygsgevangenen, is in 'n treurige toestand. In die stad [Pretoria] zelf, is daar zoowat tien families, zonder kos en in 'n paar gevalle zonder dak." ${ }^{11}$

Uit Villiers in die Oranje-Vrystaat is berig dat daar gesinne was:

“... zommigen met een 5 tal en meer kinderen nog eenvoudig op die genade van anderen geworpen ... en dat daar gene was ... die werkelijk niet eens mielies meer hebben om van te leven". ${ }^{12}$

Die enigste wyse waarop die rebelle in die veld hul tekort aan toerusting en voorrade kon oorkom, was deur'n stelsel van opkommandering in die distrikte en dorpe wat deur hulle beset is. Die algemene patroon wat hulle gevolg het, was dat die rebelleleiers kwitansies uitgereik het aan winkeliers en ander persone van wie hulle voorrade geneem het. ${ }^{13}$ Die veronderstelling was dat die betrokke persone weer ná die Rebellie - deur die nuwe rebelleregering - vergoed sou word vir die goedere of diere wat deur hulle afgestaan is. Die stelsel van opkommandering is op groot skaal in die noordelike distrikte van die Vrystaat geïmplementeer in dorpe soos Winburg, ${ }^{14}$ Reitz, ${ }^{15}$ Harrismith, ${ }^{16}$ Vredefort ${ }^{17}$ en vele ander. Gesien in die lig van die omstandighede, naamlik dié van 'n gewapende rebellie, het rebelleleiers en hul volgelinge in

8 The Star, 18 Nov 1914, The Rebellion.

9 Ons Land, 21 Nov 1914, Rebellen te Harrismith; The Star, 18 Nov 1914, In Harrismith; Ons Land, 12 Des 1914, Wat de Rebellen te Kuruman deden; Cape Times, 17 Apr 1915, Allegations of looting.

10 Ons Land, 3 Des 1914, Rebellen verzoeken om levensmiddelen.

11 (KAB) Privaatversameling 1469 HVKP Versameling no 1. Korrespondensie 1914-1915, M Marais-G Hofmeyr, 15 Feb 1915.

12 Ibid; JC le Roux-Miss W de Villiers, 16 Mrt 1915. Winifred de Villiers was die dogter van Charles de Villiers die jonger broer van Lord Henry de Villiers.

13 Ons Land, 21 Nov 1914, Rebellen te Harrismith; Cape Times, 17 Apr 1915. Allegations of looting; Cape Times, 28 Nov 1914, Methods of the Rebels.

14 De Volkstem, 24 Nov 1914, Hoe Rebellen huishouden.

15 De Volkstem, 22 Des 1914, Brieven uit de Vrijstaat.

16 Ons Land, 21 Nov 1914, Rebellen te Harrismith.

17 Ons Land, 24 Des 1914, De ervaringen van Vredefort. 
die algemeen beheers opgetree in die proses van die opkommandering van goedere. ${ }^{18}$ Daar is egter ook talle gevalle aangemeld waar vandalisme, vernielsugtigheid, plundery en 'n gevoel van afkeer teenoor die lojaliste die oorhand gekry het en gelei het tot 'n aansienlike verlies aan roerende en onroerende eiendom van lojaliste. Die optrede van die kommando van generaal De Wet wat Lindley beset het, is n voorbeeld hiervan. Die korrespondent van The Star het soos volg daaroor berig:

"The merchants were at once ordered to open their stores, and the crowd streamed in. Each one helped himself not only to what he required for the road, but everything that came in his way. Watches, jewellery, ladies' overcoats and blouses, children's boots, etc. came in handy. In one store all the ostrich feathers were torn from the ladies' trimmed hats, because each rebel wore a feather. All foodstuffs in the way of meat, flour, sugar, coffee and tinned foods were swept away and that evening very little in that line was left in town. Even some private houses were robbed. The merchants lost at least over $£ 8000$. Furthermore, all horses, forage and many carts were taken from the inhabitants." ${ }^{19}$

Uit Kroonstad is berig:

"Practically all the country stores in this district have been looted and the damage done has been very considerable. As an example of rebel methods, the house of a well-known English farmer was looted, anything of use was taken, and foodstuffs, such as bottled fruits and jams, which could not be taken, were deliberately smashed all over the floors of the house."20

In Marquard "the rebels took everything from a horse to a needle". ${ }^{21}$ So vroeg as Desember 1914 het $O n s$ Land die direkte verliese van lojalis-handelaars en boere as gevolg van rebelle-optrede op $£ 200000$ beraam. $^{22}$

In die nadraai van die rebellie het die lojaliste self ook pogings aangewend om hul verliese te verhaal. Plaaslike sakekamers en die pers wat die lojaliste ondersteun het, het sterk druk op die regering uitgeoefen om 'n standpunt in te neem oor die kwessie van vergoeding aan lojaliste deur rebelle vir verliese en skade wat gedurende die Rebellie gely is. ${ }^{23}$ Deur middel

18 UG 28-15 Department of Justice. Annual Report for the Calendar Year 1914, 188.

19 The Star, 30 Nov 1914, Rebel doings at Lindley; Ons Land, 5 Des 1914, De Wet's kommando's te Lindley.

20 The Star, 1 Dec 1914, Rebel doings-How Kroonstad fared.

21 The Star, 30 Nov 1914, Two visits.

22 Ons Land, 19 Des 1914, De enorme schade veroorsaakt.

23 Ons Land, 19 Des.1914, De enorme schade veroorsaakt; (INEG) PV 38 Dr JHO du Plessis versameling, lêer 43.I no 36 Inligtingstuk (Brosjure in verband met die ontstaan van die Helpmekaar); Ons Land, 10 Des 1914, Kompensatie van schade door Rebellen gedaan; Ons Land, 31 Des 1914, Oranje-Vrijstaat. 
van verskeie verklarings gedurende die verloop van die Rebellie het die regering die beginsel aanvaar dat die rebelle verantwoordelik gehou sou word om te vergoed vir die verliese wat hulle veroorsaak het en dat hul eiendom gekonfiskeer sou word en vir hierdie doel aangewend sou word. ${ }^{24}$ In Januarie 1915 het die regering 'n geregtelike kommissie aangestel om die hele aangeleentheid van die vergoeding te ondersoek. Die kommissie het besluit dat persone wat voorheen rebelle was of op enige wyse met rebelle of rebellebedrywighede gesimpatiseer het of geassosieer is, van die reg uitgesluit sou word om te eis vir enige verliese wat hulle gely het.

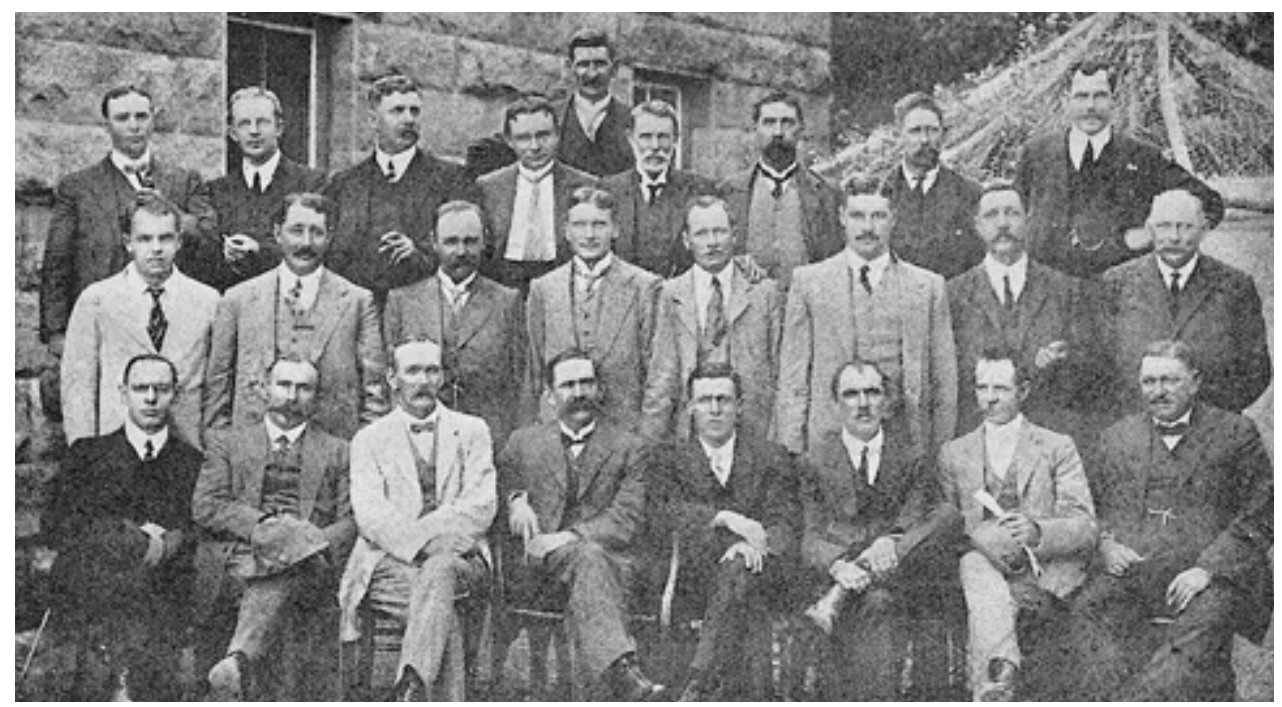

Bestuur van die Sentrale Rebellefonds. Voor van links: DG Conradie, JH Barneveld, T Verster, P Fourie (voorsitter), dr CP van der Merwe (sekretaris), EM Morrison, DJP Scholtz, B Bester.

Tweede ry van links: G Tomlinson, JB Wessels, MH Wessels, P Graphorn, MC de Jager, WJM Visser, PR van Rensburg, GS van der Merwe. Derde ry van links: SP du Toit, DJ du Plessis, M Prinsloo, JG Vorster, E Serfontein, PR Fourie, $P$ Wiegand, $W$ du Plessis. Agter: RT van der Merwe (organiserende sekretaris).

Die kommissie het ook bepaal dat verdere eise net voor die kommissie ingedien kon word nadat die eisers alle moontlike pogings langs die gewone regsproseskanale en -prosedures aangewend het om hul verliese van die skuldige persone te verhaal. ${ }^{25}$ Hierdie uitspraak het gelei tot 'n toenemende stroom van eise om skadevergoeding deur lojaliste teen die voormalige rebelle. In 'n poging om hul kanse op skadevergoeding te verhoog, was daar 'n

24 UG 46-16, Report of the Judicial Commission of Inquiry, 75; Ons Land, 21 Nov 1914, Eigendom van Rebellen. 25 UG 40-16, Report of the Rebellion Losses Commission, 9. 


\section{Die Kaapse Helpmekaar}

neiging onder eisers om die ryker lede onder die voormalige rebelle te teiken. ${ }^{26}$ In baie gevalle moes die vroue van rebelle die eise alleen in die gesig staar, aangesien hulle mans nog steeds gevange gehou was. Hoewel baie eisers billike eise ingedien het, was daar ook baie gevalle van oordrewe en selfs onwettige eise. ${ }^{27}$ Dit het ook gou duidelik geword dat die rebelle as individue nie in 'n finansiële posisie was om hierdie eise (van altesaam $£ 300000$ in direkte eise) te betaal nie. ${ }^{28}$ Die potensiële ekonomiese sneeubaleffek van die eise op die ekonomiese posisie van die rebelle en die Vrystaat is soos volg deur RT van der Merwe, die sekretaris van die Sentrale Rebellefonds, geskets:

"Daar word 'n rebel aangeskrijf vir verskillende eise, wat vir hem aansprekelik maak vir $£ 10000$. Hij kan nie betaal nie, en daar is niemand om hem te help nie. Hij het wel grond en goed wat die waarde het van die bedrag van die eis. En wat gebeur daar? Grond wat $£ 5$ die morge wêrd is, word nou dat alles so verward is, vir $£ 210$ s verkoop. Sij skape sou hij self vir nie minder dan een pond van die hand set nie, maar op die vendusie gaan almaal vir vijf shilling stuk. Sij beeste word so te sê weggegee vir minder dan die helfte van hul waarde, en hij moet toesien: want die hele distrik is in finansiële wanorde. Die één boer koop die ander boer se goed, of dit is waarskijnlik dat die vreemdeling dit doen. So daal die markwaarde van alles, en dit gaan van sleg tot slegter, totdat dit nie alleen in die dele waar die opstand was nie, maar in die hele Vrijstaat, die toestand gevoel werd. Dit geld die rebel nie alleen nie; maar ook elke grondeienaar. Die besitters van plase, wat verbande op hul grond het, ontdek hoe vreselik die toestand is, als aan hulle aangeseg word, dat hulle die geheel of 'n gedeelte van hul verbande moet afbetaal. Wie kan nie sien wat uit dit alles sou voortgespruit het nie? Nie alleen die distrikte waar die opstande was nie - nie alleen dié distrikte sou in die diepste ellende gedompel gewees het nie, maar die omliggende ook. Ja, die gehele finansiële toestand sou in verwarring gekom het en daar sou bankroetskap op bankroetskap gevolg het." ${ }^{29}$

Die enigste redding van totale finansiële ondergang het vir die rebelle gelê in georganiseerde en beplande samewerking tussen die rebelle onderling, hul ondersteuners, asook welmenende, kundige professionele persone soos prokureurs met die nodige regskennis om die eise te

26 Ibid., 5-6.

27 Het Westen, 16 Mrt 1915, Helpmekaar te Reitz; Het Westen, 9 Mrt. 1915, Hoofartikel; Het Westen, 2 Mrt 1915; Het Volksblad, 3 Des 1915, Rapport en Verslag voor de Leden Vergadering van de Reitz Helpmekaar Vereniging.

28 De Burger, 29 Des 1915, OVS Saamwerk.

29 RT van der Merwe, sekretaris van die Sentrale Rebellefonds, soos aangehaal deur JD Kestell, Helpmekaar Gedenkboek, 8-9, De Nationale Pers, Kaapstad, 1918. 
hanteer en te betwis. ${ }^{30}$ Teen hierdie agtergrond het die Helpmekaargedagte in die betrokke distrikte van die Noord-Vrystaat ontstaan en gestalte gekry in die Helpmekaarbeweging, wat uiteindelik in die loop van 1915 en 1916 oor die hele Unie versprei het.

\section{DIE HELPMEKAARBEWEGING, 1915-1920}

\section{Organisatoriese struktuur}

Wat die organisatoriese struktuur en metodes, middele en mobilisering van kapitaal betref, het twee Helpmekaarmodelle in die loop van 1915 gekristalliseer. Die eerste een was vir die distrikte van die Noord-Vrystaat wat die ergste deur die eise getref is. Die beginsel is aanvaar om die eise by wyse van samewerking te vereffen. Hoewel dit moeilik is om die presiese oorsprong van die idee vas te stel, dui die beskikbare getuienis daarop dat die besef van samewerking en saamstaan die enigste manier was om die rebelle van ekonomiese ondergang te red. Hierdie besef het in Februarie/Maart 1915 ontstaan.

Die Bethlehem-model, wat uiteindelik in die rebelle-distrikte van die Noord-Vrystaat aanvaar is, het voorsien dat 'n vereniging gestig word - in Bethlehem was dit die "Bethlehem Saamwerk" - bestaande uit die voormalige rebelle, asook persone wat nie by die Rebellie betrokke was nie. Alle lede van die Vereniging sou gesamentlike verantwoordelikheid neem vir al die eise wat teen die Vereniging ingedien word. 'n Uitvoerende Komitee (UK) sou die reg verkry om alle geldige en billike eise teen lede van die rebellekommando van Bethlehem, wat by die Vereniging sou aansluit, te oorweeg en te vereffen. Ongeldige of onbillike eise sou in die hof betwis word, indien nodig. Die kapitaal om die eise te betaal sou op drie maniere verkry word. Eerstens, om toegang tot onmiddellike kapitaal te kry sou lenings van banke verkry word waar lede kollaterale versekering verskaf. Tweedens sou lede 'n verpligte bydrae maak wat vasgestel word volgens die waarde van hul besittings (die "taksasiebeginsel") en laastens sou lyste gesirkuleer word vir vrywillige bydraes. 'n Keerdatum vir aansluiting by die Bethlehem Saamwerk is vir 31 Maart 1915 bepaal.

Rebelle wat ná daardie datum nog nie as lede aangesluit het nie, sou self moes omsien na eise wat teen hulle ingestel sou word. ${ }^{31}$ Die Bethlehem-model is gevolg deur Reitz, ${ }^{32}$ Lindley, ${ }^{33}$

30 Het Westen, 2 Mrt 1915, Een waarschuwing; 9 Mrt 1915, Onder geldwolven; JD Kestell, Helpmekaar Gedenkboek, 51, 57, 59.

31 JD Kestell, Helpmekaar Gedenkboek, 11-14; Het Volksblad, 30 Mrt 1915, Bethlehem.

32 Het Westen, 16 Mrt 1915, Helpmekaar te Reitz.

33 Het Volksblad, 16 Apr 1915, De Lindley Helpmekaar Vereniging. 
Frankfort, ${ }^{34}$ Ventersburg, ${ }^{35}$ Vredefort ${ }^{36}$ en uiteindelik byna al die Noord-Vrystaatse dorpe waar daar rebelle was. 'n Behoefte aan groter koördinering en samewerking het gelei tot die vestiging van die Sentrale Rebellefonds in April/Mei 1915 wat die Helpmekaarverenigings van 16 dorpe in die Noord-Vrystaat verteenwoordig het. ${ }^{37}$

Die tweede model wat na vore gekom het, was gegrond op die beginsel van vrywillige bydraes om die rebelle te help met die terugbetaling van eise wat teen hulle ingedien is. Individue wat op hierdie grondslag betrokke geraak het, was in die algemeen gemotiveer deur 'n gevoel van solidariteit met die lot van hul mede-Afrikanervolksgenote. Hulle is in die oorgrote meerderheid van gevalle gedryf deur hul teenkanting teen die SAP en hulle beleid. Dit is dan ook nie verbasend dat die ondersteuners van die NP, wat in Januarie 1914 gestig is ná 'n skeuring in die $\mathrm{SAP}^{38}{ }^{3}$ ' $\mathrm{n}$ leidende rol in baie van hierdie inisiatiewe gehad het nie. In die proses is onafhanklike provinsiale Helpmekaarverenigings in die Suid-Vrystaat, Kaapprovinsie, Transvaal en Natal gestig in pogings om geld in te samel om die rebelle-eise te skik.

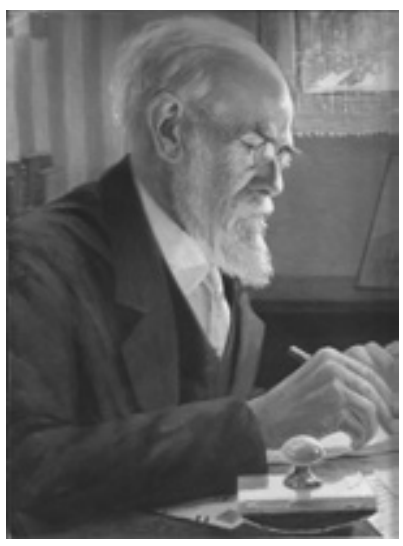

JD Kestell

In die Suid-Vrystaat is pogings om die rebelle te ondersteun in Maart 1915 geïnisieer toe ds JD Kestell, dr JC Pretorius, dr Colin Steyn, PU Fischer en JL van Heerden, onder voorsitterskap van Gordon Fraser, vergader het om die kwessie te bespreek. ${ }^{39}$ Hierdie inisiatief het uiteindelik uitgeloop op die stigting van die Afrikaner Nationale Helpmekaar Vereniging (Afrikaner Nasionale Helpmekaarvereniging) (ANHV) wat pogings in die Suid-Vrystaat gedryf en gekoördineer het. Die Vereniging is bestuur deur 'n sentrale bestuur wat die verskeie distrikte verteenwoordig het en 'n UK, wat in Bloemfontein gesetel was, om die dag-tot-dag-bestuur van die Vereniging te behartig. Plaaslike kommissies is in die verskillende distrikte gestig. ${ }^{40}$

34 De Volkstem, 30 Mrt 1915, Vrystaat.

35 Het Volksblad, 30 Mrt 1915, Ventersburg OVS

36 Het Westen, 19 Mrt 1915, Vredefort laat niet op zich wachten.

37 Het Volksblad, 28 Mei 1915, Kroonstad Centraal Saamwerkbestuur; Het Volksblad, 25 Mei 1915, Centraal Rebellen Fonds, OVS; Ons Land, 3 Jun 1915, Centraal Rebellenfonds.

38 FJ van Heerden, Die geboorte van die NP (1913-1915) (O Geyser, AH Marais (reds) Die Nasionale Party, Deel I, Agtergrond, stigting en konsolidasie, 136-138).

39 (VKA) Helpmekaar van die Oranje-Vrystaat, Notuleboek (16 Mrt 1915-18 Aug 1926), 16 Mrt 1915, 1-4.

40 Ibid., 13 Apr 1915, 9, 12-13. 
Die eerste georganiseerde Helpmekaarvereniging in die Transvaal is in April 1915 in Wolmaransstad gestig. ${ }^{41}$ Rustenburg, ${ }^{42}$ Schweizer- Reneke, ${ }^{43}$ Bloemhof ${ }^{44}$ en Potchefstroom ${ }^{45}$ het gevolg, wat bevestig het dat die aanvanklike konsentrasie van Helpmekaarverenigings in die Wes-Transvaal was - die middelpunt van Transvaalse rebellebedrywighede gedurende die Rebellie. Afgesien van Lichtenburg, wat die verpligte "taksasie" van lede (die taksasiebeginsel) voorgestaan het, ${ }^{46}$ is die Helpmekaarverenigings in die Transvaal bedryf op die grondslag van vrywillige bydraes deur hul lede.

Die behoefte aan die vestiging van Helpmekaarverenigings in ander dele van die Transvaal en 'n provinsiale oorkoepelende hoofbestuur het gelei tot die vestiging van De Transvaalse Helpmekaar-vereniging (Transvaalse Helpmekaarvereniging) in September 1915. ${ }^{47}$

Doeltreffende provinsiale koördinering en samewerking is egter eers in Januarie 1916 bereik gedurende die eerste provinsiale kongres van die Vereniging, wat bygewoon is deur 44 verteenwoordigers van 26 dorpe en distrikte. ${ }^{48}$ By die geleentheid is die naam van die Vereniging verander na "Die Helpmekaar Vereniging in Transvaal".99 In teenstelling met die ander provinsiale verenigings, is daar besluit om die Helpmekaarvereniging in Transvaal as 'n privaat maatskappy met beperkte verantwoordelikheid te registreer. ${ }^{50}$ Bydraes aan die Vereniging was vrywillig en geen lid sou verantwoordelik gehou word vir enige skuldverpligtinge van die Vereniging nie. ${ }^{51}$ Die enigste uitsondering was Lichtenburg, wat die taksasiebeginsel verkies het en dus nie deel van die provinsiale organisasie geword het nie. ${ }^{52}$

Het Volksblad, 16 Apr 1915, De opstand eisen; Het Volksblad, 16 Apr 1915, De Wolmaransstad Helpmekaar.

42 Het Volksblad, 21 Mei 1915, Rustenburg.

43 Het Volksblad, 1 Jun 1915, De Schweizer Reneke Helpmekaar Vereniging.

44 Het Volksblad, 15 Jun 1915, Helpmekaar te Bloemhof.

45 Het Volksblad, 13 Jul 1915, Regels en Regulaties van de Potchefstroom Helpmekaar Vereniging.

46 Het Volksblad, 29 Jun 1915, Distrik Lichtenburg.

47 De Burger, 20 Sep 1915, Open brief; De Burger, 24 Sep 1915, De Transvaal Helpmekaar Vereniging.

48 De Volkstem, 14 Jan 1916, Helpmekaar Konverentie.

49 Het Volksblad, 18 Jan 1916, Helpmekaar Kongres te Pretoria.

50 De Volkstem, 1 Des 1916, De Transvaalse Helpmekaar.

51 De Volkstem, 14 Jan 1916, Helpmekaar Beweging in Transvaal.

52 JD Kestell: Helpmekaar Gedenkboek, 23. 


\section{HELPMEKAAR.}

HELPMEKAARDAG-10 NOVEMBER 1921.

Dit is nou vier jaxr sinds die roemryke vitredding deur die Heipmekas van talle van ons volks. genote en die gedagtenis aan daardie gebeurtenis mog noois yitgrwis and niei oss as Mfrikaecers

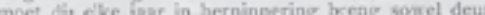
dukbare gifte as Acur blye feesviering.

Die jaar 1917 bet ons getoon wat ons kan doen

Die jaar 1917 bet ons getoon wat ons kan doen as das opregte belangsteang, vurige ywer en een.

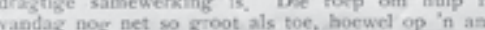
der gebied anamilk op die gebied van Onderuys on Studic.

's frooo woed recte jaarliks hiervoor gebruik en dit moet jarliks bymekaar gelkeng word want has is geen ander bron om dit uit te has' nie dan dic Volkbeurs en die bestuur vertrou dat nolk vanjas die beurs wyd cop sal wees. Want bebslwe hierdie noodsankinke f, 1000 moet daar nog 's 6500 aan Rhodesix vir Kristelik Nasionaal Onder.

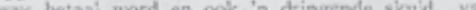
eveen om allerdriagendste hale te werlecn.

Taksbesture word vrindelik versoek om huille Giterste kragte in te span tes einde fondse bymekaar te kry en waar geen takke bestaan nic wocd wolksirethebbende vrinde gevra om kifine komiter te rorm om hierin te help

Betulue howevermelde 62500 is ruim nog "ip 61000 nodig as die bestum wil voldeen aan die hansoeke vir studiehulp, wat nou reeds wag op be hasdeling. Die tye is base swaar en juis dasom is dit dringernd noodsaaklik dat elkeen sal probeer om sy hietise by te breng tot steun van hiendie sank. Alie heloers en helpaters word by noorboat 4 e harteilke dank yan die bestuge noegebreng. Hoogagtead uw dienstwilliges, J. A. JOUBERT, Voorsitter.

D. G. CILI.IF,

F l. ie ROUX.

W, J. vas HEERDEN,

J. G. BEZUIDENHOUT,

M. W. PRETORIUS,

B. R. HATTINGH,Sekretaris.

Bus 337. Pretoria, to Stptember.

Helpmekaarvereniging van Transvaal se 1921 Helpmekaardagoproep

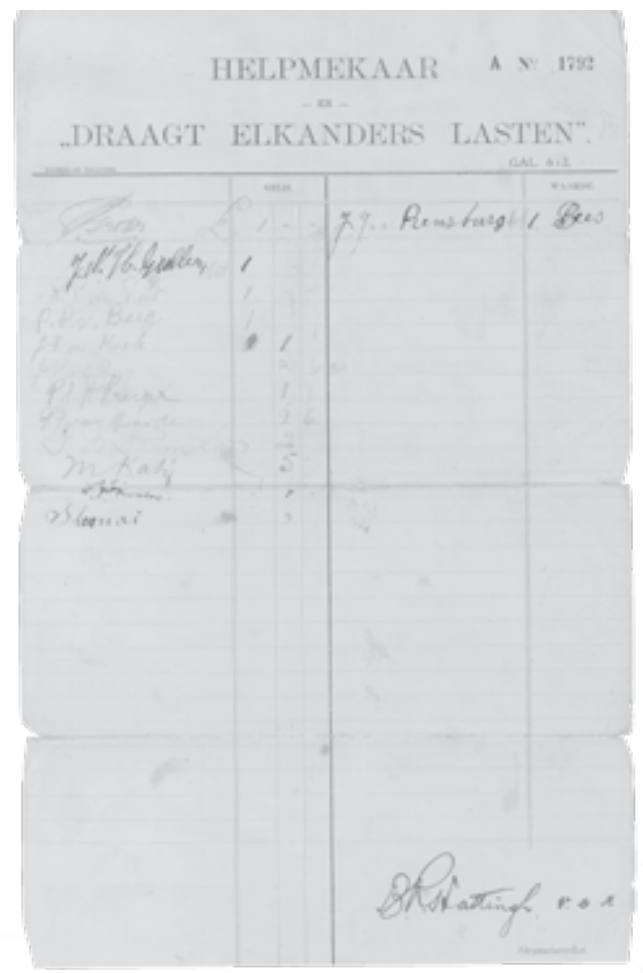

Helpmekaarvereniging van

Transvaal kollektelys

Die inwoners van die Kaapprovinsie was militêr minimaal by die Rebellie betrokke. Dit het hulle egter nie verhinder om die rebelle op ander maniere te ondersteun nie. So vroeg as Februarie 1915 is die Nationale Weldadigheids Genootschap (Nasionale Weldadigheidsgenootskap) gestig. Vroue van onder andere Stellenbosch, Paarl en Kaapstad het geld, kos en klere ingesamel om die behoeftige gesinne van rebelle te help. ${ }^{53}$ Hoewel daar nog geen ander georganiseerde bewegings in die Kaapprovinsie was wat fondse ingesamel 
het vir die skikking van die eise teen die rebelle nie, het gemeenskappe in baie dorpe in die Kaapprovinsie gedurende die tweede helfte van 1915 basaars en konserte gereël om geld in te samel vir die Helpmekaarbeweging in die Vrystaat en Transvaal. ${ }^{54}$

In reaksie op oproepe van die Helpmekaarbeweging in Transvaal en die Vrystaat vir groter steun van die Kaapprovinsie om die rebelleskuld te delg, het die Nasionale Weldadigheidsgenootskap besluit om hul naam te verander na die "Nationale Vrouwe Helpmekaar Genootschap" (Nasionale Vroue-Helpmekaargenootskap) en die doel van die genootskap verbreed om nie net by te dra tot die behoeftes van die families en gesinne van die rebelle nie, maar ook tot die behoeftes van die rebelle self. ${ }^{55}$ Dorpe en stede in die Kaapprovinsie is genooi om takke van die Genootskap te stig en hul bydraes aan die hoofbestuur in Kaapstad te stuur. ${ }^{56}$ Hoewel hierdie versoek 'n positiewe reaksie gehad het en gelei het tot die vestiging van talle nuwe takke, is hierdie aktiwiteite hoofsaaklik deur vroue geïnisieer met baie min betrokkenheid van die mans; veral in die Kaapstad-omgewing.

Inisiatiewe onder die leierskap van dr DF Malan, redakteur van De Burger, om die mans betrokke te kry, het in Januarie 1916 uitgeloop op die stigting van die "Helpmekaar Vereniging voor het Kaapse Schiereiland" (Helpmekaarvereniging vir die Kaapse Skiereiland), ${ }^{57}$ wat die Nasionale Vroue-Helpmekaargenootskap, wat besluit het om met die mans kragte saam te snoer, ingesluit het. ${ }^{58}$ Die behoefte aan 'n oorkoepelende provinsiale organisasie in die Kaapprovinsie het uitgeloop op 'n kongres in Junie 1916 in Kaapstad onder die vaandel van die Helpmekaarvereniging vir die Kaapse Skiereiland. Die kongres, onder waarnemende voorsitterskap van dr DF Malan, en bygewoon deur 37 afgevaardigdes van 42 takke en 'n groot aantal belangstellendes en vriende, het besluit op die stigting van 'n Helpmekaarvereniging vir die Kaapprovinsie met 'n grondwet wat hoofsaaklik op dié van die Helpmekaarvereniging van die Kaapse Skiereiland gebaseer was. ${ }^{59}$ Wat die organisasie van die Vereniging betref, is besluit dat die kongres die hoogste gesagsliggaam sou wees en sou bestaan uit een verteenwoordiger

54 De Burger, 31 Jul 1915, Swellendam; De Burger, 23 Aug 1915 Nationale Bedrijvigheid; De Burger, 25 Aug 1915 , Dordrecht; De Burger, 16 Sep 1915, Worcester.

(HSA) Nationale Vrouwe Helpmekaar Genootschap, Notuleboek (16 Feb 1915-20 Des 1915), 22 Sep 1915.

(HSA) Nationale Vrouwe Helpmekaar Genootschap, Notuleboek (16 Feb 1915-20 Des 1915), 1 Nov 1915; De Burger, 24 Nov 1915, Nationale Vrouwe Helpmekaar Genootschap.

De Burger, 7 Des 1915, Helpmekaar; De Burger, 14 Jan 1916, Helpmekaar Vereniging voor het Kaapse Schiereiland. 


\section{Die Kaapse Helpmekaar}

vir elke 100 lede van elke distrikstak. 'n Sentrale bestuur van nege lede sou die administrasie van die Vereniging behartig en die besluite van die kongres uitvoer. ${ }^{60}$

Soos in die Kaapprovinsie is die Helpmekaarwerk in Natal aanvanklik deur vroue oorheers. In vergelyking met die ander provinsies het Natal relatief laat daartoe oorgegaan om 'n oorkoepelende provinsiale Helpmekaarvereniging te stig. Hoewel daar vroeër pogings was om geld te genereer vir die Helpmekaargedagte in Greytown, ${ }^{61}$ Utrecht, ${ }^{62}$ Weenen ${ }^{63}$ en Krantzkop, ${ }^{64}$ is 'n organisatoriese struktuur daarvoor eers gevorm ná die stigting van die Helpmekaarvereniging vir vroue, naamlik die Nasionale Vroue-Helpmekaarvereniging, in die Oranje-Vrystaat. ${ }^{65}$ Takke van hierdie Vereniging is gedurende 1916 in dorpe soos Winterton, ${ }^{66}$ Greytown, Weenen, ${ }^{67}$ Middlerest (Mooirivier) ${ }^{68}$ en Ladysmith ${ }^{69}$ gestig. 'n Afsonderlike oorkoepelende provinsiale organisasie vir Natal het eers in Junie 1917 'n werklikheid geword by 'n kongres in Winterton waar'n besluit geneem is om 'n onafhanklike afdeling, die Nasionale Vroue-Helpmekaarvereniging van Natal te stig. ${ }^{70}$

\section{Mobilisasie van kapitaal: bronne en metodes}

Die vereffeningsproses van die rebelleskuld is gekenmerk deur vier chronologiese fases. Elk is onderskei volgens hul kernbedrywighede en geografiese middelpunt. Die eerste fase in 1915 is gekenmerk deur die evaluering van die finansiële omvang (waarde) van direkte eise teen die rebelle. Dit het die beraming van metodes om die eise te vereffen en die pogings om hierdie metodes te implementeer ingesluit. Die besef dat die rebelle en hul volgelinge in die Vrystaat nie in staat sou wees om die las alleen te dra nie het ook gelei tot 'n oproep aan die res van die land, in die besonder die Kaapprovinsie, om die saak van die rebelle te ondersteun.

\footnotetext{
60 (HSA) Helpmekaar Studiefonds (HS), Argiefstukke, Koncept-Konstitutie (pamflet).

61 De Burger, 21 Apr 1916, Greytown.

62 De Burger, 6 Jan 1916, Utrecht.

63 De Burger, 27 Jan 1916, Mooirivier, Natal; De Burger, 7 Mrt 1916, Mooirivier, Natal.

64 De Burger, 31 Mrt 1916, Krantzkop, Natal.

65 De Burger, 10 Apr 1916, De Vrouwen Nationale Helpmekaar.

66 De Burger, 25 Jul 1916, Korrespondentie.

67 Het Volksblad, 11 Apr 1916, De vrouw organiseerd.

68 Het Volksblad, 28 Apr 1916, Nationale Vrouwe Helpmekaar.

69 De Burger, 21 Nov 1916, Ladysmith, Natal.

70 (HSA) Die Helpmekaar van Natal, Notuleboek (6 Jun 1917-24 Aug 1940), 6 Jun 1917; Die Burger, 30 Jun 1917, De Nasionale Vroue-Helpmekaarvereniging Kongres te Winterton.
} 
Hierdie gebeure het hoofsaaklik in die Vrystaat plaasgevind en veral in die distrikte van die Noord-Vrystaat wat die ergste deur die rebellebedrywighede geraak is. Die tweede fase - in 1916 - is oorheers deur die instelling van indirekte eise teen die rebelle en pogings om hierdie nuwe bedreiging die hoof te bied. Die derde fase, van Junie 1916 tot Junie 1917, was een van wanhoop en 'n stryd om oorlewing van die Sentrale Rebellefonds en die rebelledistrikte van die Noord-Vrystaat. In die vierde fase gedurende die tweede helfte van 1917 het die inisiatief vir die skikking van die rebelleskuld verskuif na die Helpmekaarvereniging van die Kaapprovinsie, wat in tandem met De Burger en sy redakteur, dr DF Malan, wyer steun gesoek het onder Afrikaners oor die hele Suid-Afrika.

Die werkswyse van die verteenwoordigers in distrikte in die Noord-Vrystaat wat lede van die Sentrale Rebellefonds was, was om al die rebelle in hul onderskeie distrikte op te spoor en hulle as lede van daardie distrik se Helpmekaarvereniging te laat aansluit. Die meeste van die rebelle het besef hoe belangrik lidmaatskap aan so 'n vereniging was vir hul ekonomiese oorlewing. Die volgende stap was om die totale bedrag aan eise wat teen die lede van die Vereniging ingedien is, vas te stel. Bereken volgens die totale eise wat teen 'n vereniging ingebring is, is die individuele lede dan volgens die taksasiebeginsel belas, volgens hul onderskeie finansiële vermoëns, om 'n bydrae te lewer tot die delging van die totale skuld van die Vereniging. Die

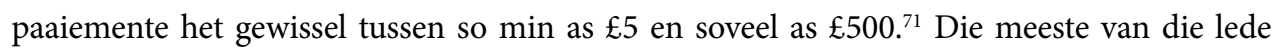
het getrou hul getakseerde bydraes betaal ten spyte van sommiges se gebrekkige finansiële omstandighede. In Desember 1915 het RT van der Merwe, die sekretaris van die Sentrale Rebellefonds, soos volg berig:

"Als 'n bewijs van hoe die arme mense swoeg om hul deel te doen, dat'n seker arm paar getrouwde mense sijn kantoor instap, stukken en verskeur, om hul $£ 2$ af te betaal op $£ 5$, wat hulle moet opbreng. Dis om 'n mens se hart te breek." ${ }^{72}$

Al die lede was egter nie so toegewyd soos bogenoemde nie. Teen Desember 1915 was daar nog 72 van die 624 lede van die Reitz Helpmekaarvereniging wat nog nie hul getakseerde bedrae betaal het nie. JH van Barneveld, die tesourier van Reitz, se ontevredenheid met dié lede se traagheid het geblyk in sy opmerking:

"Ik zal liever niet verder van deze leden spreken, want ik heb geen woorden sterk genoeg om hun treurig gedrag uit te drukken." ${ }^{3}$ De nood in de OVS is hoog!; De Burger, 3 Des 1915, De Helpmekaar Verenigingen. 
Hoewel die omstandighede van die nie-betalers nie bekend is nie, is dit nie onredelik om te argumenteer dat hul gebrek aan toewyding waarskynlik 'n manifestasie was van die opportunistiese ekonomiese motiewe waarmee sommige rebelle aanvanklik by die rebellie aangesluit het nie.

Een van die grootste bydraes van die onderskeie verenigings was om die individuele eise te laat ondersoek en professionele regskennis en advies deur plaaslike Afrikanerprokureurs - wat in baie gevalle hul dienste gratis gelewer het ${ }^{74}$ - te verskaf. Deur skakeling met die Rebellie-Verliesekommissie ${ }^{75}$ is onderhandel met die eisers om oordrewe eise te verminder en te verhoed dat hierdie gevalle in die howe beland. ${ }^{76}$ Die tussenkoms van die Verenigings in hierdie verband het die monetêre waarde van eise met gemiddeld 30 persent verminder. ${ }^{77}$

Vrywillige bydraes was die ander grootbron van kapitaalinkomstevir die Helpmekaarbeweging. In hierdie opsig het die vroue 'n groot rol gespeel deur die organisering van 'n eindelose stroom van basaars, konserte, etes, veilings en deur middel van kollektelyste. ${ }^{78}$ Dit was nie beperk tot die noordelike Vrystaat nie, maar het onder die vaandel van die ANHV ook oorgespoel na die Suid-Vrystaat. ${ }^{79}$ Hoewel dit nie afdwingbaar was nie het die ANHV die teiken vir die distrikte geaffilieer by die Vereniging vasgestel op $£ 1$ per lid..$^{80}$ Die reaksie in die Suid-Vrystaat het gewissel van totale toewyding tot 'n lustelose en trae houding. Vanuit Bethulie is berig dat die mense “... bijna dag en nag aan die werk is, viral in verband met konsert, eetmaal en bazaar, vir die Helpmekaar Fonds”. ${ }^{11}$ In Rouxville en Edenburg was die

74 Het Westen, 9 Mrt 1915, Onder geldwolven; JD Kestell, Helpmekaar Gedenkboek, 51, 57, 59; Het Volksblad, 7 Des 1915, Rapport en Verslag voor de Leden Vergadering van de Reitz Helpmekaar Vereniging; Beskikbare getuienis dui daarop dat prokureurs soos MJ Vermeulen (Lindley), RM Scholtz (Bethlehem), Gordon Tomlinson (Heilbron) en DG Conradie (Reitz) waarskynlik deur etniese en nasionalistiese oorwegings gemotiveer is om hul dienste aan hul mede-Afrikaner-volksgenote beskikbaar te stel.

75 UG 40-16, Report of the Rebellion Losses Commission, 6.

76 Het Volksblad, 25 Mei 1915, Centraal Rebellen Fonds, OVS; De Burger, 24 Sep 1915, Steun uw broeders in het Noorden.

77 Het Volksblad, 6 Aug 1915, "Eendracht maakt macht”. Lindley Helpmekaar; De Burger, 31 Aug 1915, Heilbron Rebelle Vereniging; De Burger, 4 Des 1915, Rapport en Verslag voor de Ledenvergadering van de Reitz Helpmekaar.

78 De Volkstem, 2 Jul 1915, Saamdraag's Bazaar; Het Volksblad, 13 Jul 1915, Lindley Helpmekaar; De Burger, 27 Jul 1915, Vrouwe Bazaar te Heilbron.

79 (VKA) Helpmekaar van die Oranje-Vrystaat, Helpmekaar Korrespondensie 1916-1919; Cape Times, 12 Jun 1915, Mr Fichardt discusses the rebellion; Het Volksblad, 13 Jul 1915, Smithfield OVS; Het Volksblad, 20 Jul 1915, Helpmekaar te Philippolis.

80 Het Volksblad, 6 Jul 1915, Die suidelike Vrijstaters woel ook.

81 Het Volksblad, 9 Jul 1915, Korrespondentie van Bethulie. 
reaksie die teenoorgestelde met inwoners wat nie hul beloofde ondersteuning met dade bevestig het nie. ${ }^{82}$ Hoewel in Julie 1915 bevind is dat die vordering in die Suid-Vrystaat nie na wense was nie en die plaaslike takke aangemoedig moes word om meer te doen, ${ }^{83}$ was die ANHV teen September 1915 in staat om hul eerste $£ 10000$ na die Sentrale Rebellefonds te stuur vir die betaling van rebelle eise. ${ }^{84}$

Die Vrystaters het teen Julie 1915 besef dat hulle nie alleen in staat was om die skuldlas van die rebelle te vereffen nie. Dit alles ten spyte van die pogings van die Sentrale Rebellefonds en sy verenigings en die ANHV se hulp. Die direkte eise teen die rebelle, wat aanvanklik beraam is op $£ 236000,{ }^{85}$ het toegeneem tot $£ 300000 .{ }^{86}$ Daarby is 'n verdere $£ 22000$ gevoeg in die vorm van boetegeld wat deur die howe aan rebelleleiers opgelê is as straf vir hul deelname aan die Rebellie. ${ }^{87}$ Dit is verder vererger deur die wesenlike verliese wat deur rebelle gely is as gevolg van die regering wat die eiendom van rebelle tydens die Rebellie gekonfiskeer het - 'n bedrag beraam op $£ 250000$ - en waarvoor die rebelle geen vergoeding ontvang het nie. ${ }^{88}$ Gedurende Augustus/September 1915 het die prentjie selfs droewiger geword met die instelling van indirekte eise teen die rebelle. Hierdie eise is gemaak om te vergoed vir skade wat mense persoonlik gely het, soos vir 'n gebrek aan inkomste, onwettige gevangeneming en aanhouding, verwonding of ander vorms van liggaamlike leed. ${ }^{89}$ RT van der Merwe van die Sentrale Rebellefonds het die waarde van hierdie potensiële eise op soveel as $£ 750000$ beraam. $^{90}$

Teen hierdie agtergrond is 'n verskeidenheid inisiatiewe gedurende die tweede helfte van 1915 van stapel gestuur, wat gewissel het van ope briewe in die pers tot 'n propagandakomitee, ${ }^{91}$ om die Afrikaners van die Kaapprovinsie bewus te maak van die lot van die rebelle in die Vrystaat en om hulle te oortuig om hul gewig agter die Helpmekaarbeweging

82 De Burger, 19 Aug 1915, Rouxville, OVS; (VKA) Helpmekaar van die Oranje-Vrystaat, Helpmekaar Korrespondensie 1916-1919, PE Havenga-JL van Heerden, 12 Aug 1915.

83 (VKA) Helpmekaar van die Oranje-Vrystaat, Notuleboek (16 Mrt. 1915-18 Aug. 1926), 2 Jul 1915, 17 en 2 Sep 1915, 21.

84 Ibid., 2 Sep 1915, 23.

85 Het Volksblad, 16 Jul 1915, Helpmekaar in die OVS.

86 De Burger, 18 Nov 1915, De nood in de OVS is hoog!

87 De Burger, 20 Aug 1915, Indrukken van't Hof.

88 De Burger, 25 Sep 1915, Open brief.

89 Ibid.

90 De Burger, 29 Des 1915, OVS Saamwerk.

91 De Burger, 25 Sep 1915, Open brief; De Burger, 24 Sep 1915, Steun uw broeders in het noorden. 


\section{Die Kaapse Helpmekaar}

in te gooi. Hierdie oproepe het 'n sterk beroep gedoen op die etniese volksbande wat die Afrikaners van die Vrystaat, die Kaapprovinsie en die res van Suid-Afrika gebind het met die gedeelde verantwoordelikheid om 'n deel van die volk van finansiële ondergang te red. Gordon Tomlinson ${ }^{92}$, voorsitter van die propaganda-komitee, het 'n beroep om hulp gerig in 'n brief in De Burger: “... van Afrikaners in die Vrijstaat aan Afrikaners in die Kaap-Provincie ... Kom ower en help ons!" 93

Hierdie oproepe het 'n sterk nasionalistiese ondertoon gehad wat per geleentheid baie openlik en onbeskaamd in die mobilisasieproses gebruik is. In September 1915 het JH van Barneveld die vraag gestel of dit billik was dat hulle (die rebelle in die Vrystaat en hul ondersteuners) alleen die las van die skuld moes dra wat aangegaan is om 'n nasionalistiese herlewing onder die volk te bewerkstellig. Hy was van mening dat elke nasionalis moreel verplig was om die rebelle te ondersteun en dat, as dit moontlik was, elke nasionalis selfs ' $n$ tyd in die tronk moes deurbring sodat die las wat alleenlik aan die rebelle opgelê is eweredig verdeel kon word. ${ }^{94}$ In 'n brief in November 1915 - ná die 1915-verkiesing waarin die NP in die Vrystaat byna skoonskip gemaak het ${ }^{95}$ - het hy in dieselfde trant voortgegaan deur die Vrystaat te vergelyk met 'n seëvierende soldaat wat van die slagveld terugkeer en oorlaai word met lof, maar wat geen finansiële vergoeding ontvang het vir sy opofferings wat hy in die proses gemaak het nie. Volgens Van Barneveld was die Rebellie en rebelleskuld die prys wat betaal is vir die nasionale oorwinnings. Daarom moes die rebelleskuld deur alle Nasionaliste, en nie net die Vrystaters gedra geword het nie. ${ }^{96}$

Die indiening van indirekte eise het reeds tydens die laaste maande van 1915 begin. Die praktiese implikasies van hierdie soort eise vir die ekonomiese oorlewing van die rebelle en hul simpatiseerders het eers in die eerste helfte van 1916 tot die algemene publiek deurgedring. Helpmekaarbedrywighede gedurende 1916 is dus deur die kwessies rondom indirekte eise oorheers. Die vernietigende impak van die indirekte eise op die Helpmekaarbeweging in die distrikte van die Noord-Vrystaat is die beste geillustreer deur De Burger se korrespondent in

92 Gordon Tomlinson was 'n Hertzog ondersteuner en betrokke by die Afrikaanse Taalvereniging. Pieter Kapp, Die verhaal van Jannie Marais en die Marais-broers. Nalatenskappe sonder einde, 107, 108, 111. Tip Africa Publishing, Soutrivier, 2015.

93 De Burger, 25 Sep 1915, Open brief; Het Volksblad, 5 Nov 1915, Meer Helpmekaar vereis; De Burger, 2 Nov 1915, Helpmekaar.

94 De Burger, 24 Sep 1915, Steun uw broeders in het noorden.

95 MPA Malan en MC van Rensburg, Verkiesingsuitslae 1910-1943 met volledige naamlys van Volksraadslede vanaf 1910, 29-35.

96 De Burger, 18 Nov 1915, De nood in de OVS is hoog! 
Reitz. Hy het geskryf dat die Reitz Helpmekaarvereniging gepoog het om al hul direkte eise wat teen die rebelle van die distrik ingedien is te betaal. Om dit te bereik het hulle $£ 20000$ by die bank geleen, wat hulle nog gesukkel het om terug te betaal. $\mathrm{Na}$ alles wat hulle opgeoffer het om dit te bereik, was hulle nou gekonfronteer met die realiteit dat die indirekte eise van slegs twee eisers meer was as die totale skuld van die distrik met betrekking tot direkte eise. In die lig van hierdie ontwikkeling het die toekoms vir hulle somber gelyk en was dit onmoontlik om te voorspel waar dit alles sou eindig. ${ }^{97}$ Minder as 'n maand later het JH van Barneveld die impak van indirekte eise op die distrik Reitz bevestig toe hy geskryf het:

“... Op Reitz hebben wij al het begin der smarte, en is vandaag de baljuw uitgegaan om de goederen van een zekere mnr B Duminy te gaan opschrijven en in beslag te nemen voor een indirekte eis tegen hem. Al het werk tot heden door de Helpmekaar gedaan was tevergeefs, en alle moeite, zorgen en opofferingen welke gemaakt zijn om het totaal ruïneren te voorkomen zijn als met een pennestreep tot niet gemaakt. Er heerst dan ook een volslagen geest van moedeloosheid, welke dreigt in wanhoop over te slaan." ${ }^{\prime 9}$

Teen hierdie agtergrond het die sentrale bestuur van die Sentrale Rebellefonds 'n drieledige strategie geïmplementeer om die potensieel vernietigende bedreiging van indirekte eise teen te werk. Eerstens is daar ooreengekom dat die Fonds die direkte eise sal betaal, maar dat dit sou weier om die indirekte eise te betaal. Tweedens is daar besef dat die regering die enigste instelling was wat die vermoë gehad het om die saak vir die rebelle te beredder deurdat hulle wetlik 'n einde kon maak aan die instelling van verdere eise. Die regering moes dus versoek word om deur wetgewing 'n einde te maak aan die instelling van indirekte eise. 'n Keerdatum moes ook vasgestel word waarna daar geen verdere eise ingestel kon word nie. Derdens moes die openbare mening gemobiliseer word teen die instelling van indirekte eise. In die proses moes koerante, politieke partye, die kerk en die algemene publiek geteiken word. ${ }^{99}$

Oproepe uit verskeie oorde vir die regering om in te gryp, ${ }^{100}$ en 'n afvaardiging bestaande uit verteenwoordigers van die Sentrale Rebellefonds en ANHV, bygestaan deur verteenwoordigers

97 De Burger, 4 Feb 1916, Saamwerk.

98 De Burger, 2 Jun 1916, Een volkskongres nodig.

99 Het Volksblad, 25 Jan 1916, Helpmekaar NO Vrijstaat; Ons Land, 25 Jan 1916, Het Centraal Rebellefonds; De Volkstem, 28 Jan 1916. Het Vrijstaatse Kongres.

100 De Burger, 17 Jan 1916, Het vormen van arme blanken; De Volkstem, 21 Jan 1916, Hoofartikel; De Burger, 4 Feb 1916, Hoofartikel; Ons Land, 19 Feb 1916, hoofartikel; (VKA) Vrystaatse Nederduitse Gereformeerde Kerk-versameling, Acta Sinodi, 1916, 14-15. 
van die SAP, ${ }^{101}$ het uiteindelik uitgeloop op die aanvaarding van wetgewing deur die Parlement met ingang van 30 Mei 1916. Die Wet op Regsvorderinge 1916, het bepaal dat die eisers een maand vanaf die datum waarop die Wet in werking getree het, toegelaat is om eise teen die rebelle in te stel. Daarna sou geen verdere eise toegelaat word nie. Hoewel die wetgewing nie indirekte eise verbied het nie, het dit finaliteit vir die rebelle gebring in soverre dit hulle ten minste in staat gestel het om die omvang van hulle skuldlas ná 30 Junie 1916 te kon vasstel. ${ }^{102}$

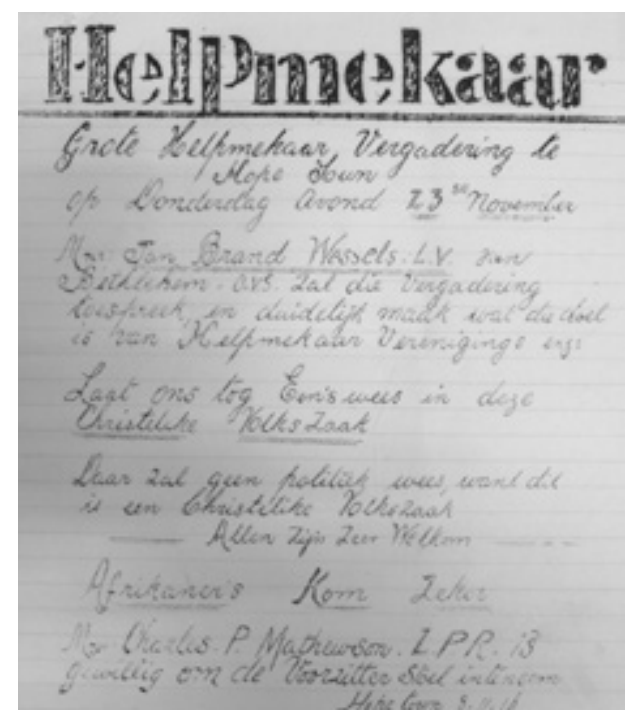

Uitnodiging na Helpmekaar byeenkoms te Hopetown op 23 November 1916. (Kaapse Argiefbewaarplek) A1469 Helpmekaarvereniging van die Kaapprovinsie versameling.

Die keerdatum vir indirekte eise, in samewerking met die invloed van die openbare mening, die taktiek van die Sentrale Rebellefonds om versoening tussen die partye te soek en indirekte eise buite die hof te skik, het die impak aansienlik verminder. ${ }^{103}$ Dit is onmoontlik om die totale bedrag van indirekte eise wat uiteindelik teen die rebelle ingedien is presies te bepaal. Beskikbare getuienis dui daarop dat dit ongeveer $£ 75000$ was. Dit was net sowat tien persent van die $£ 750000$ wat aan die einde van 1915 deur die Sentrale Rebellefonds geraam is. Dit is 'n aanduiding van die waardevolle bydrae wat die Helpmekaarbeweging gelewer het in hierdie verband om rebelle van finansiële ondergang te red en te verhoed dat hulle tot armblankes gereduseer word. ${ }^{104}$

Die vasstelling van 'n keerdatum vir eise teen die rebelle het die aanbreek van die derde fase in die betaling van die rebelleskuld ingelui. Dit is gekenmerk deur 'n hernude uitreik na die Afrikaners van die Suid-Vrystaat, Kaapprovinsie en die res van Suid-Afrika vir hulp vir die

101 (VKA) Helpmekaar van die Oranje-Vrystaat, Notuleboek (16 Mrt 1915-18 Aug 1926), 10 Feb 1916, 25-27; De Burger, 24 Feb 1916, hoofartikel; De Volkstem, 18 Apr 1916, Vrystaatse mensen en dinge; Het Volksblad, 7 Apr 1916, Notulen van een Kongres van de Cent. Rebelle Fonds.

102 Union of South Africa Statutes, 1916, Act no 24 of 1916, 439.

103 Het Volksblad, 30 Mei 1916, Greyling Kontra Rebelle; De Volkstem, 2 Jun 1916, Afzien van Rebellevervolging; De Volkstem, 6 Jun 1916, Skikking insake onregstreekse eisen.

De Burger 17 Jan 1916, Het vormen van arme blanken. 
rebelle en - met die balansering van die boeke van die Sentrale Rebellefonds vir die tydperk tot 31 Desember 1916 - die berekening van die omvang van die uitstaande rebelleskuld. Die klem op die kwessies rakende indirekte eise het gedurende die eerste helfte van 1916 die aandag weggeneem van die direkte eise en van die 1915-pogings om die Afrikaners van die Kaapprovinsie te mobiliseer om hul gewig agter die Helpmekaarbeweging en die saak van die rebelle in te gooi. Met die potensiële katastrofe van die indirekte eise grootliks afgeweer, kon die Sentrale Rebellefonds weer gefokus op die uitstaande direkte eise.

Deur 'n reeks van inligtings- en propagandavergaderings gedurende die tweede helfte van 1916 in die Suid-Vrystaat ${ }^{105}$ en die Kaapprovinsie, ${ }^{106}$ het die Sentrale Rebellefonds gepoog om die finansiële toestand van die rebelle toe te lig en om Afrikaners te inspireer om takke van die Helpmekaarbeweging te stig en fondse te genereer om die rebelleskuld te betaal. Die ekonomiese bydrae van die Helpmekaarbeweging in die Noord-Vrystaat is ook beklemtoon. Sonder die inmenging van die Helpmekaar sou honderde plase en duisende stuks vee waarskynlik op die mark kom. Dit kon moontlik 'n landswye daling in veepryse en grondwaardes tot gevolg hê en sodoende is 'n potensiële destabilisering van die SuidAfrikaanse ekonomie verhinder. Steun vir die Helpmekaarbeweging is ook voorgehou as die kenmerk en plig van 'n ware Afrikaner. Op 'n vergadering te Prins Alfred Hamlet het advokaat Conradie (NP LV van 1938-1960) ${ }^{107}$ na die Helpmekaarbeweging verwys as een wat “... tot het hart van elke ware Afrikaner moet spreken. Hij die zijn mede-Afrikaner weigert te helpen is geen Afrikaner." ${ }^{108}$ Die propagandapogings van die Sentrale Rebellefonds het gemengde reaksie ontlok. Dit het gewissel van hernude ywer om vir die Helpmekaarbeweging te werk ${ }^{109}$ tot apatie met 'n lustelose houding wat gemanifesteer het uit die swak bywoning van vergaderings of pogings om die beeld van die Helpmekaarbeweging te bederf. Agterdog is ook gewek deur die Helpmekaarbeweging as 'n politieke instrument in die hande van die NP te etiketteer. ${ }^{110}$

105 (VKA) Helpmekaar van die Oranje-Vrystaat, Helpmekaar Korrespondensie 1916-1919, pamflet, 16 Sep 1916, Helpmekaar; (VKA) Helpmekaar van die Oranje-Vrystaat, Helpmekaar Korrespondensie 1916-1919, RT van der Merwe-JL van Heerden, 22 Sep 1916.

106 (HSA) HVKP, Notuleboek (3 Jul 1916-20 Mei 1919), Sentrale Bestuur 8 Aug 1916, 7; (VKA) Helpmekaar van die Oranje-Vrystaat, Helpmekaar Korrespondensie 1916-1919, H Roux (mev P Roux)-JL van Heerden, 22 Aug 1916.

107 Parlementêre Register 1910-1961, 80, Uitgegee deur die Volksraad, Elsiesrivier, 1970.

108 De Burger, 3 Jan 1917, Adv Conradie te Prins Alfred Hamlet.

109 De Burger, 21 Sep 1916, Fauresmith, OVS.

110 De Burger, 6 Feb 1917, Helpmekaar; De Burger, 26 Jan 1917; De Burger, 22 Nov 1916, De Helpmekaar Beweging; De Volkstem, 24 Nov 1916, Helpmekaar Uitleg; De Burger, 23 Jan 1917, Steynsburg; De Burger, 26 Jan 1917, Paterson. 


\section{Die Kaapse Helpmekaar}

Die harde werklikheid van die uitstaande fondse vir die Sentrale Rebellefonds is in April 1917 onderstreep. Dit het op 'n konferensie gebeur waar die verteenwoordigers van die Helpmekaarverenigings van die Noord-Vrystaat se ouditeursverslag hul finansiële posisie vir die tydperk tot 31 Desember 1916 bekend gemaak het. ${ }^{111}$ Volgens die projeksies in die verslag van die ouditeur van die Helpmekaarvereniginge in die Vrystaat, J Botha, was die totale tekort van die Helpmekaarverenigings van die Noord-Vrystaat $£ 104250$ 6s 3d. ${ }^{112}$ Dit was die bedrag nadat, onder andere, die uitstaande bydraes volgens die taksasiebeginsel wat nog deur lede betaal moes word en die vrywillige bydraes wat van simpatiseerders en ondersteuners ontvang is in berekening gebring is. Teen hierdie agtergrond het die konferensiegangers hul opsies vir die pad vorentoe oorweeg.

$\mathrm{Na}$ 'n indringende bespreking op die konferensie is die volgende besluite geneem. Eerstens, is die ouditeur opdrag gegee om onmiddellik die uitstaande bedrag aan taksasiebydraes vir elke vereniging vas te stel. Die sekretarisse van die onderskeie verenigings moes dan probeer om soveel as moontlik van daardie uitstaande bedrae in te vorder. Tweedens is daar besluit om 'n afvaardiging na die regering te stuur om te vra dat'n onversekerde lening van $£ 104000$ aan die Helpmekaarbeweging toegestaan word. 'n Alternatief vir laasgenoemde sou wees dat die regering die lening toestaan op die voorwaarde dat elke individuele, belasbare lid van die Helpmekaarverenigings in die Noord-Vrystaat vir 'n gedeelte van die delging van die lening verantwoordelik gemakk sou word. Die regering moes dan die bewyse van sekuriteit wat elke individuele lid vir hul gedeelte van die skuld aanbied, aanvaar. Sodoende sou die Helpmekaar nie verantwoordelik wees vir die lening nie, maar elke individuele lid sou aan die regering aanspreeklik wees vir sy deel.

Op die konferensie is ook weer besin oor die idee van propaganda om die saak van die Helpmekaar te bevorder. Twee menings het oorheers. CPJ Fourie, voorsitter van die Sentrale Rebellefonds, was van mening dat die Helpmekaarbeweging weinige gebaat het by die propagandiste se inligtingsreise aan dorpe in die Suid-Vrystaat en die Kaapprovinsie en dat nie genoeg finansiële bydraes uit sulke reise verkry is nie. Terwyl hy wel groot bewondering gehad het vir die werk wat deur vroue gedoen is in die organisering van konserte en basaars om geld in te samel vir die Helpmekaarbeweging, was hierdie metodes alleen nie genoeg om die finansiële probleme van die rebelle op te los nie. Die ander mening was dié van RT van der Merwe. Hy het gewaarsku dat die sentrale bestuur nie voeling moes verloor met die "siel" van die volk nie. Hy was daarvan oortuig dat die haglike finansiële posisie van die rebelle soos

111 Het Volksblad, 10 Apr 1917, Vrijstaatse Helpmekaar.

112 (INEG) PV 138 M Hutton-versameling, lêer no. 6 Inligtingstukke (Auditeurs Rapport van de Helpmekaar Verenigingen in de OVS). 
geopenbaar deur die ouditeursverslag die oë van baie Afrikaners sou laat oopgaan en hulle motiveer om die Helpmekaarbeweging te ondersteun. Van der Merwe het dit ook betreur dat die koerante min dekking aan die doel en werk van die Sentrale Rebellefonds gegee het. Op die konferensie is toe besluit om 'n kommissie aan te stel om die hele kwessie met betrekking tot die propagering van die Helpmekaarbeweging te ondersoek. ${ }^{113}$

Teen die einde van Junie 1917 het dit duidelik geword dat die regering nie die voorstelle gaan aanvaar om die Helpmekaarskuld oor te neem of om die geld aan hulle voor te skiet nie. Die enigste opsie wat oorgebly het, was om, soos in die verlede, 'n beroep te doen op hul medeAfrikaners om tot hul redding te kom. Hierdie keer was dit egter anders. Met die vorige oproepe was daar nog altyd die hoop dat, in die geval van 'n onsuksesvolle reaksie, daar nog 'n moontlikheid was dat hulle in staat sou wees om die nodige fondse uit hul eie geledere sou kon byeenbring.

Op 1 Julie 1917 was dit anders: "Hulle het gedoen wat hulle kan en is vandag so-te-sê hulpeloos." ${ }^{114}$ Teen hierdie agtergrond het JS Botha, WJM Visser en RT van der Merwe namens die sentrale bestuur van die Sentrale Rebellefonds 'n ope brief om hulp, gedateer 1 Julie 1917, aan hul mede-"volksgenote" geskryf. In 'n kort geskiedenis van die Helpmekaarbeweging in

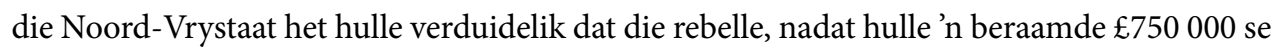

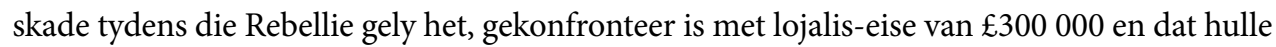
nie in staat was om die uitstaande skuld te betaal nie. Hulle het beklemtoon dat die versuim om die skuld te betaal 'n aansienlike gedeelte van die Afrikaners finansieel sou ruïneer en dat hulle tot die geledere van die armblankes sou verval. Hul oproep om hulp is so wyd as moontlik gemaak om alle politieke partye of verenigings, van watter politieke oortuiging ookal, in te sluit. Die NP, die SAP, die ACVV, die Oranje Vrouevereniging, die Nasionale Vroue Helpmekaarvereniging die SA Vrouwe Federasie, die kerkrade van die Nederlandse Kerke, die Nederlandse en die Nasionalistiese Pers is almal, onder andere, uitgesonder as belangrike instellings wat kon bydra tot die sukses van die oproep. Die hoop is uitgespreek dat daar aan die oproep gehoor gegee sou word en dat die verskille van die verlede opsy gesit sou word in 'n poging om "ons verdrukte broeders met hul families te help". ${ }^{115}$

Hierdie oproep van die Sentrale Rebellefonds het die vierde en finale fase in die delging van die rebelleskuld ingelui. Die gebeure wat hierdie populistiese fase van die Helpmekaarbeweging begin het, het die verbeelding van 'n groot deel van die Afrikaners in Suid-Afrika aangegryp.

113 Het Volksblad, 10 Apr 1917, Vrijstaatse Helpmekaar.

114 Ons Land, 26 Jul 1917, De Vrijstaatse Helpmekaar.

115 De Burger, 25 Jul 1917, Een dringend beroep op ons volk. 


\section{Die Kaapse Helpmekaar}

Hulle het hulle oorsprong in die Helpmekaarvereniging van die Kaapprovinsie gehad. Teen Junie 1917 het beide die provinsiale Helpmekaarverenigings in die Kaapprovinsie en die Transvaal hul vestigingsprobleme oorkom en het relatief glad gefunksioneer. Met die April 1917-kongres van die Helpmekaarvereniging in Transvaal het daar al 72 takke met 'n geskatte 4000 lede in Transvaal bestaan. ${ }^{116}$ Teen die einde van Julie 1917 het die Helpmekaarvereniging in Transvaal net 'n verdere $£ 6000$ benodig om die skuld van die Transvaalse rebelle te vereffen. ${ }^{117}$ Weens die relatief klein aantal Transvaalse rebelle en die aard van hul rebellebedrywighede - hulle het in die landelike gebiede opgetree sonder om dorpe te beset - is hulle met veel minder rebelleskuld gelaat. Teen Junie 1917 het die Helpmekaarvereniging in die Kaapprovinsie uit 70 takke en 3564 bevestigde lede bestaan. Die beperkte finansiële bydrae wat die Helpmekaarvereniging vir die behoeftes van die rebelle in die Transvaal en die Noord-Vrystaat deur middel van hul vrywillige bydraes kon maak, is duidelik uit hul inkomste vir die 1917 finansiële jaar, wat slegs $£ 9508$ beloop het, bevestig. ${ }^{118}$

Die lot van die Sentrale Rebellefonds en die rebelle wat deur hulle verteenwoordig is, was hoog op die agenda van die Helpmekaarvereniging van die Kaapprovinsie gedurende sy tweede kongres in Julie 1917. 'n Aanbieding deur RT van der Merwe van die Sentrale Rebellefonds het die finansiële realiteite waarmee die rebelle te kampe gehad het, en wat hy twee weke vroeër in sy ope brief uitgespel het, duidelik tuisgebring. In reaksie op hierdie pleidooi om steun, het die kongres 'n voorstel aanvaar wat gevra het vir die vestiging van 'n Helpmekaarfonds om die rebelleskuld so gou as moontlik te vereffen. Geen daadwerklike stappe is egter tydens die kongres aan die hand gedoen om so 'n fonds te stig nie. Die regering is ook versoek om die uitstaande rebelleskuld, wat slegs 'n derde van hul aanvanklike skuld verteenwoordig het, oor te neem. ${ }^{119}$ Ten spyte van die aanvaarding van hierdie voorstelle, het die verteenwoordigers na hul dorpe en distrikte teruggekeer sonder 'n werklike of duidelike oplossing vir die skuldprobleem.

Die drie jaar termyn van die lenings wat die Noord-Vrystaatse Helpmekaarverenigings by die banke aangegaan het om solank eise te kon vereffen terwyl geld ingesamel word, sou vroeg in 1918 verstryk en dan sou die lenings terugbetaal moes word. Buitengewone metodes en aksies was dus nodig om die nodige fondse te genereer. 'n Reeks gebeure, geïnisieer deur

116 De Volkstem, 10 Apr 1917, Helpmekaar Kongres.

117 De Volkstem, 24 Apr 1917, Transvaalse Helpmekaar.

118 (HSA) HVKP, Notuleboek, 11-12 Jul 1917, Kongres, 4-5, 6, 9-10, 17-18.

119 (HSA) HVKP, Notuleboek, 11-12 Jul 1917, Kongres, 1, 10, 16; De Burger, 16 Jul 1917, Helpmekaar Kongres; De Burger, 17 Jul 1917, Helpmekaar Kongres. 
gewone mense, in die weke ná die Kaapse Helpmekaarkongres het die antwoord verskaf wat gelei het tot die buitengewone oplossing wat nodig was om die finansiële nood van die rebelle op te los. Twee inisiatiewe staan uit en het gedien as die dinamo vir die sukses van die Helpmekaarbeweging in die tweede helfte van 1917. Op 28 Julie het die Helpmekaartak van Middelburg in die Kaapprovinsie die sentrale bestuur van die Helpmekaarvereniging van die Kaapprovinsie versoek om Saterdag 10 November 1917 as 'n Unie-wye "Helpmekaar Dag" opsy te sit met die doel om op daardie dag fondsinsamelings te hou om geld in te samel vir die uitstaande rebelleskuld. Daar is met hierdie verenigde poging - "volkspoging" - gehoop dat die rebelleskuld vir eens en vir altyd afgehandel kon word. ${ }^{120}$ Die sentrale bestuur het die voorstel aanvaar en hom verbind tot die mobilisering van die lede van die Helpmekaarbeweging en alle ander belanghebbende partye agter die inisiatief. ${ }^{121}$

Geïnspireer deur die idee van die Helpmekaardag, het JE de Villiers van die Paarl in 'n brief, gedateer 29 Augustus, aan dr DF Malan, redakteur van De Burger, aangebied om $£ 500$ te skenk tot die vereffening van die uitstaande rebelleskuld as 500 individue in die res van die Unie bereid was om elk $£ 100$ te skenk. Die tweede deel van sy voorstel het bepaal dat kollektelyste ook deur die hele land gesirkuleer moes word om kleiner bedrae in te samel sodat die ander uitstaande $£ 50000$ van die skuld moontlik op hierdie wyse ingesamel kon word. De Villiers het sy brief afgesluit deur die motivering agter sy voorstel te stel, naamlik "Om te verhoeden dat vooruitstrevende landbouwers tot de bedelstaf gebracht zullen worden en 't getal arme blanken zal vermeerderen, ..." ${ }^{122}$

Die sentrale bestuur van die Helpmekaarvereniging van die Kaapprovinsie was verdeeld oor die haalbaarheid van die voorstel. Terwyl mej W de Villiers die aanbod as "a splendid 'spurt' ... to the collection, or to donors rather!" beskryf het, het die voorsitter HS van Zijl dit as "an absurd offer" ${ }^{123}$ afgemaak. Van Zijl se pessimisme is egter verkeerd bewys. Die belangstelling wat deur die idee van 'n Helpmekaar Dag gewek is, gekombineer met die voorstel van die $£ 100$-fonds deur De Villiers, ondersteun deur die Afrikaanse pers ${ }^{124}$ en met die seën van die

120 De Burger, 3 Aug 1917, Helpmekaar Dag; Ons Land, 7 Aug 1917, Helpmekaar Dag; Het Volksblad, 7 Aug 1917, Helpmekaar Dag in die Kaapprovinsie; De Burger, 17 Aug 1917, Helpmekaar Dag.

121 (HSA) HVKP, Notuleboek (3 Jul 1916-20 Mei 1919), Sentrale Bestuur 11 Aug 1917, 69.

122 De Burger, 5 Sep 1917, Hoofartikel.

123 (KAB) Aanwins 1469 HVKP Versameling no. 2, Ontvange Briewe 1917, mej W de Villiers-mev Roux, 1 Sep 1917.

124 Het Volksblad, 24 Aug 1917, Hoofartikel; De Burger, 30 Aug 1917, Hoofartikel. 
Kerk $^{125}$ het gelei tot 'n ongekende stortvloed van steun vir die Helpmekaarbeweging - en het 'n instroming van fondse in die tydperk September/Desember 1917 teweeggebring. Die $£ 100$-fonds het uiteindelik 1415 bydraes gegenereer ( $£ 141500) ;{ }^{126}$ tesame met die inkomste uit die fondsinsamelings van 10 November $(£ 62000) .{ }^{127}$ Dit was voldoende om die rebelleskuld te delg en die Helpmekaarbeweging met 'n aansienlike oorskot van $£ 92000$ te laat. ${ }^{128}$

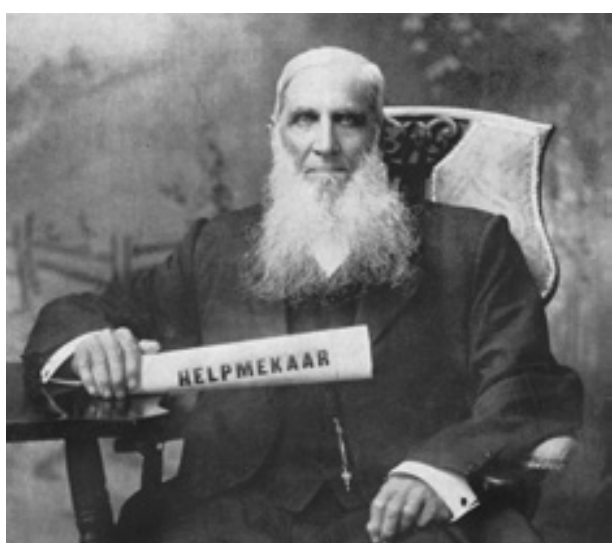

JE de Villiers, vader van die $£ 100-$ fonds

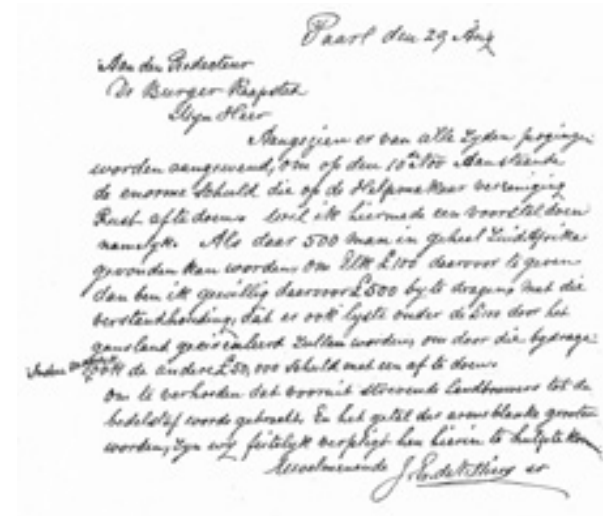

JE de Villiers se brief aan die redakteur van Die

Burger, dr DF Malan. Gedateer 29 Augustus 1917

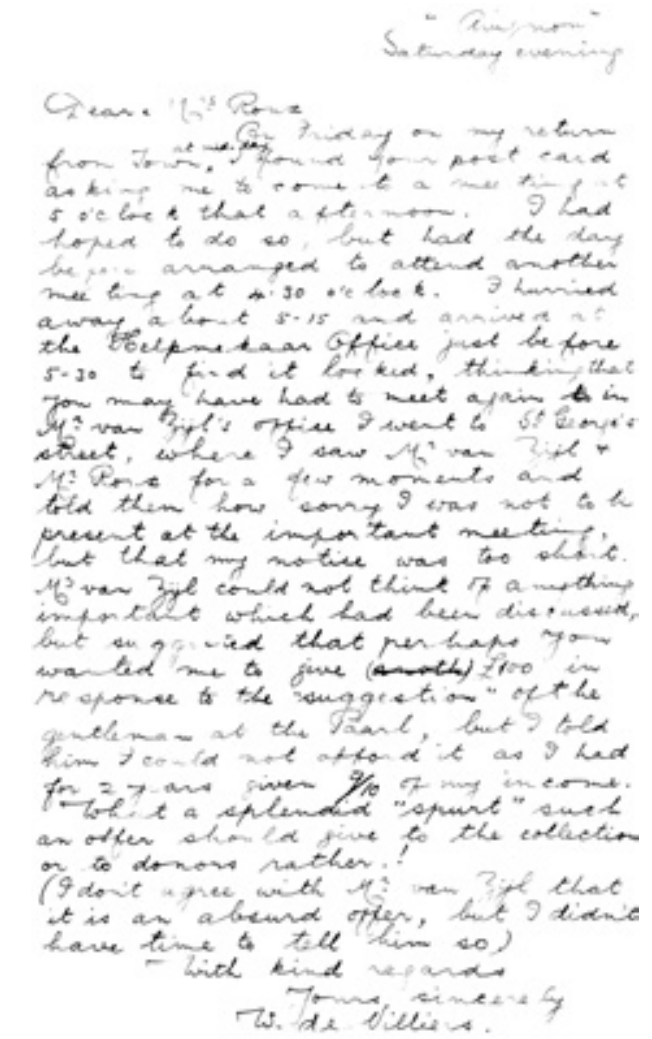

Brief van Winifred de Villiers, penningmeester van die Helpmekaarvereniging van die Kaapprovinsie aan mev Hester Roux, sekretaresse van die Vereniging waarin HS van Zijl, voorsitter, die JE de Villiers $£ 100$-aanbod as ' $n$ "absurd offer" beskryf.

125 De Kerkbode, 6 Sep 1917, Helpmekaar Dag-10 Nov 1917; Cape Times, 21 Sep 1917, "Helpmekaar" effort at Stellenbosch; De Burger, 29 Sep 1917; De Volkstem, 25 Sep 1917, Hulp van ons Kerk vir Helpmekaar Dag; De Kerkbode, 4 Okt 1917, NG Kerk van OVS; De Kerkbode, 18 Okt 1917, NG Kerk van Natal.

JD Kestell, Helpmekaar Gedenkboek, 241-262.

127 (KAB) Aanwins 1469 HVKP Versameling no.1 Sentrale Rebelle Fonds, 9 Jul 1919.

128 (HSA) HVKP, Notuleboek, 21-22 Mei 1919, Kongres, 5, 7. 


\section{Pal, sele sery}

Or. Hala.

hationale tor bett

becolit Hor a bived.

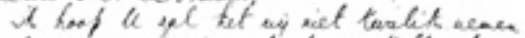

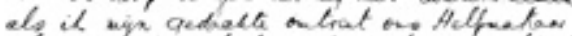

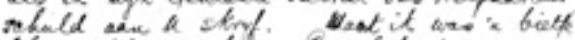
Elloraceteld on of kew toso lipt de navere

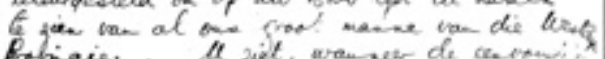

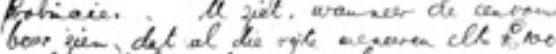

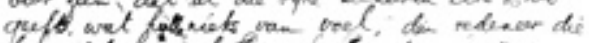

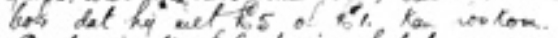

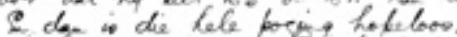

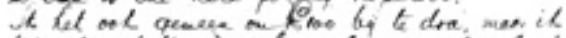

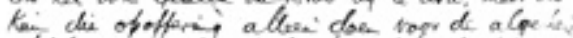

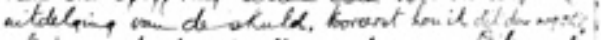

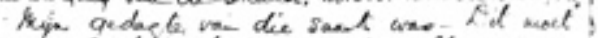

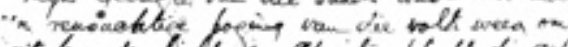

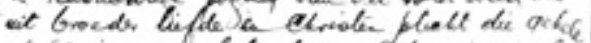

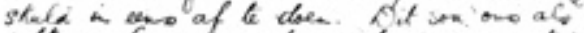

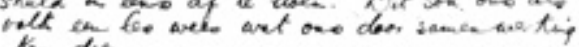
the dow

\section{3.}

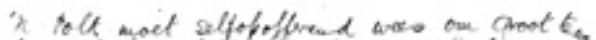

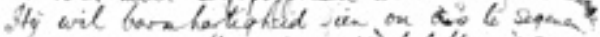

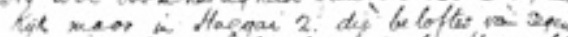

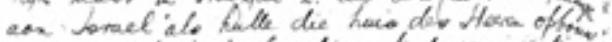

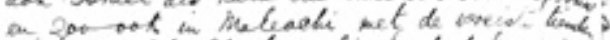

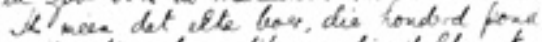

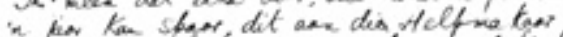

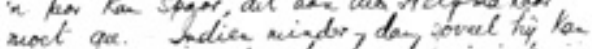

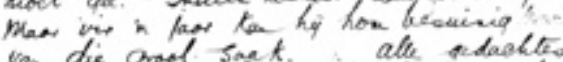

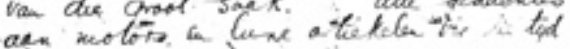

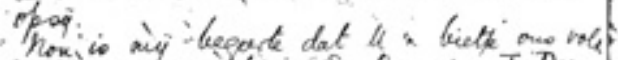

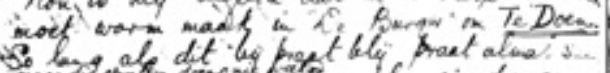

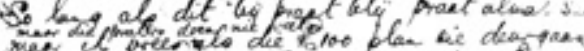

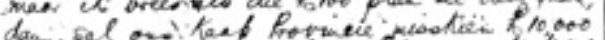

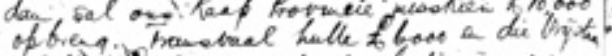

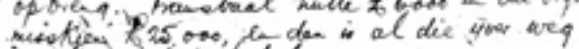
a die sant is hopuloos.

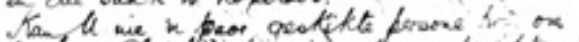

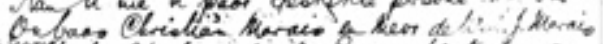

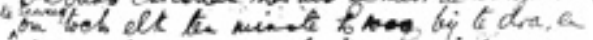

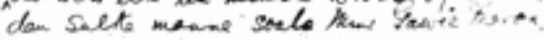

2

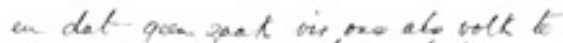
grow son wee on $a$ bowe la tore.

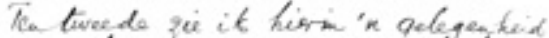

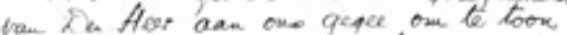

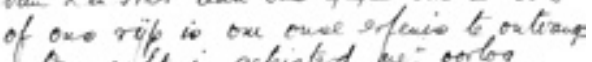

Ore voll is quliebed he oorbg.

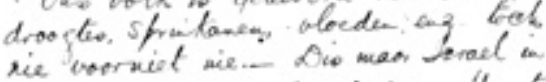

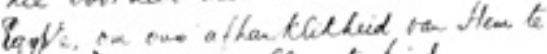

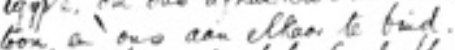

Nox is bye de hele fand floreras.

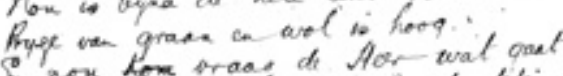

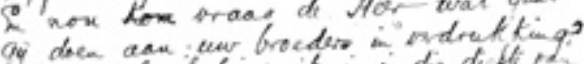
at overal of levese it is a de defte the

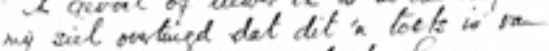
de Hes i one are adegd. Sare wy

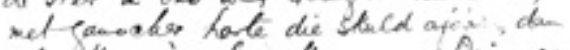

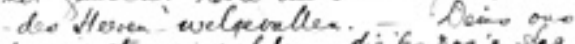

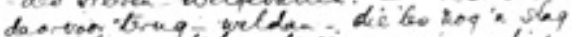

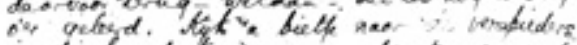

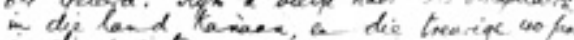
in die tresetyon.

4

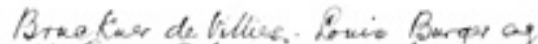

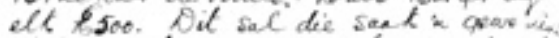

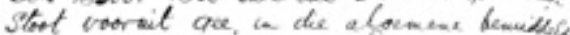

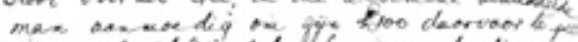

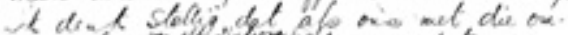

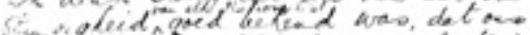

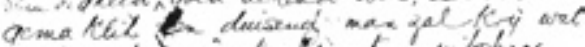

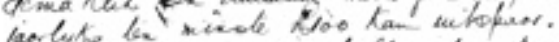

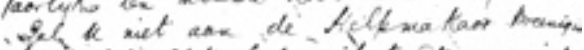

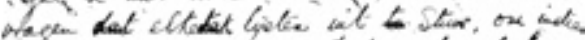

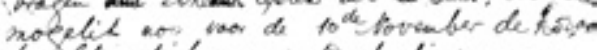

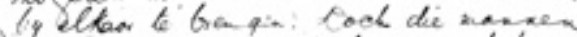

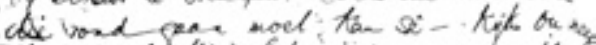

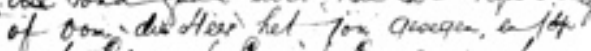
woet 6100 of 850 of Ero ace i hem

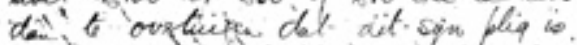
in was "de bolot the wer die wet

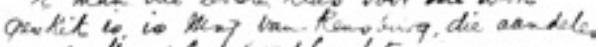
toer de Haw delotwio blacke

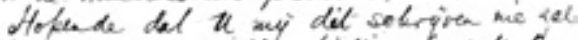

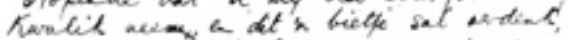
thet it wa welwerende ovied

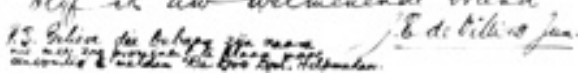

JE de Villiers Junior se brief (gedateer 14 September 1917) aan dr DF Malan oor sy

Vader, JE de Villiers se $£ 100$-aanbod. Hy versoek Malan om nie meer sy Vader se naam so prominent te plaas nie maar slegs te verwys na: "De $£ 100$ Lyst. Helpmekaar" 


\section{Lijgt van Intekenaars op het Honderdpond.Helpmekarfonds.}

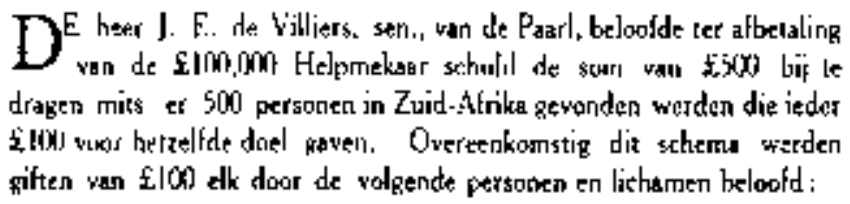

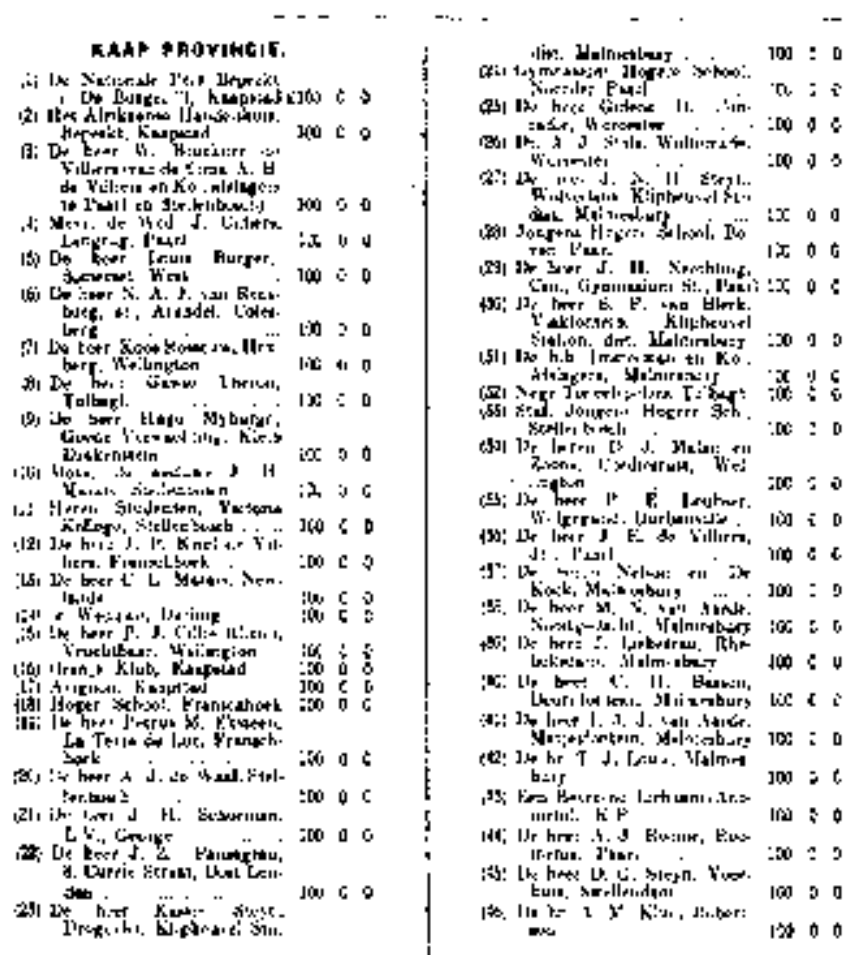

Die £100-lys soos dit in JD Kestell se Helpmekaar Gedenkboek van 1918 verskyn het

\section{Finansiële konsolidasie, afsluiting en verdeling}

In die vaarwater van die suksesvolle 1917-insamelingsveldtog het die Helpmekaarbeweging hom met veral drie belangrike kwessies besig gehou, naamlik die bepaling van die omvang van die surplusfondse, die vraag wat met die surplus gedoen moes word en laastens die institusionele vorm wat die Helpmekaar in die toekoms moes aanneem. Hoewel die idee van 'n surplus met die aanvang van die insamelingsveldtog ondenkbaar was, het dr Malan na die insameling van 
die eerste vyfhonderd $£ 100$-bydraes in Oktober 1917 dit vir die eerste keer gewaag om in 'n hoofartikel in De Burger na 'n moontlike surplus te verwys. Hy het die surplus geoormerk vir'n fonds waarvan die rente jaarliks gebruik kon word "om enig deel van ons volk dat in armoede en onkunde en ellende dreigt te verzinken, op te helpen en te redden". ${ }^{129}$

In sy laaste oorsig oor die $£ 100$-lys op 16 November 1917 het hy enkele voordele van so 'n volksfonds uitgelig. Een van die voordele sou wees dat dit as 'n permanente monument vir die reddingsdaad van 1917 kon dien. Aangesien slegs die rente aangewend sou word, sou die kapitaalfonds onaangeraak bly indien 'n saak wat ondersteun is, sou misluk. 'n Verdere voordeel sou ook wees dat die Fonds 'n geleentheid aan welgestelde Afrikaners kon bied om hul volk te dien deur die bemaking van geld aan die Fonds. Op dié wyse sou die Fonds vinnig groei en altyd daaraan herinner word dat die Fonds deur die volk begin is. Dit was sy verwagting dat die Helpmekaarbesture spoedig oor die aangeleentheid sou beraadslaag en hul besluite aan die publiek sou bekendmaak. ${ }^{130}$

Op inisiatief van die Helpmekaarvereniging van die Kaapprovinsie is al die provinsiale institusionele rolspelers in die Helpmekaarbeweging uitgenooi na 'n konvensie op De Aar op 20 Desember 1917. Die taak van die konvensie sou wees om te besin oor die afbetaling van die rebelleskuld, die besteding van die surplus en die toekoms van die Helpmekaarbeweging. Besluite wat deur die meerderheid geneem sou word, sou nie noodwendig bindend wees op besture wat nie daarmee saamgestem het nie. ${ }^{131}$ Die konvensie onder voorsitterskap van advokaat HS van Zijl is deur die Verenigings van die Kaapprovinsie, Transvaal, Natal, die SuidVrystaat (ANHV) en Noord-Vrystaat (Sentrale Rebellefonds) bygewoon. ${ }^{132}$ Daar is aanvaar dat die konvensie raadgewend van aard was en 'n geleentheid was om gedagtes uit te ruil. Slegs voorlopige besluite sou geneem word, wat eers bindend sou word nadat dit deur die provinsiale Helpmekaarkongresse aanvaar is. Afgesien van aspekte soos die vasstelling van die presiese

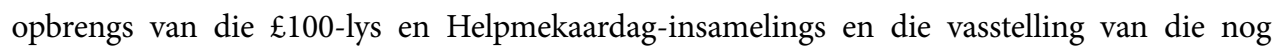
uitstaande rebelleskuld, is ' $n$ aanbeveling van die Kaapprovinsie ten opsigte van die toekomstige hantering van die surplus ook aanvaar. Die aanbeveling het voorgestel dat:

“... die Helpmekaar surplus intakt behou word en gebruik word om één uniale fonds te vorm, die rente waarvan, pro rata, hulle bijdraë tot die Helpmekaar fondse in verband met Helpmekaar Dag 1917, onder die vier provinsies verdeeld word om deur die Helpmekaar

129 De Burger, 20 Okt 1917, Hoofartikel.

130 De Burger, 16 Nov 1917, Hoofartikel.

131 (HSA) HVKP, Notuleboek (3 Jul 1916-20 Mei 1919), Sentrale Bestuur 17 Nov 1917, 84-85.

132 De Burger, 25 Des 1917, Helpmekaar Konvensie; (HSA) Die Helpmekaar van Natal, Notuleboek (6 Jun 1917 24 Aug 1940), 20-21 Jun 1918 Kongres. 


\section{Die Kaapse Helpmekaar}

Bestuur van elke provinsie gebruik te word ter bevordering van die doeleindes uiteengesit in die konstitusie van die Kaap Provinsie, met die verstande dat met toestemming van die Helpmekaar besture die hele rente of gedeelte daarvan vir één doel besteed kan word."133

Wat die finansies betref, het die konvensie besluit dat die provinsiale Helpmekaarbesture 'n finansiële kommissie, bestaande uit een verteenwoordiger elk van die Kaapprovinsie, Transvaal, Natal, Suid-Vrystaat en Noord-Vrystaat, moes aanstel om oor die insameling van die beloofde geld en die afhandeling van die skuld toesig te hou. ${ }^{134}$ Die taak van die afgevaardigdes by die konvensie was om die besluite aan hul besture oor te dra en dit deur hulle provinsiale kongresse aanvaar te kry.

Die De Aar-besluite het algemene byval gevind by die ANHV en Sentrale Rebellefonds wat op 31 Maart 1918 in Bloemfontein vergader het. Hulle het die gedagte van 'n onaangeraakte surplus en 'n uniale fonds onderskryf. Oor die toekoms van die Helpmekaarbeweging is besluit dat dit aan die Algemene Finansiële Kommissie opgedra sou word om, nadat die skulde afgesluit was, 'n volkskongres te hou waarop verteenwoordigers van al die takke van die Helpmekaar in die vier provinsies oor die saak kon besin. ${ }^{135}$ Op die Helpmekaarvereniging in Transvaal se kongres in April 1918 in Pretoria is die De Aar-besluite aanvaar met as belangrike uitsondering die surplusbesluit. Daar was sterk teenkanting teen die gedagte dat die hele surplus aan 'n uniale bestuur toevertrou moes word terwyl afgevaardigdes ook gevoel het dat nie slegs die rente op die surplus nie, maar ook die kapitaal aangewend moes word om mense te help. Die kongres het dus met 'n groot meerderheid besluit dat die Helpmekaarbesture wel 'n liggaam soos deur die De Aarvoorstel voorsien is, in die lewe moes roep, maar met die kwalifikasie dat Transvaal sy eie deel van die Fonds sou administreer en die rente self sou kon gebruik. ${ }^{136}$

Dit is ironies dat die Transvaalse besluit geneem is op die eerste Transvaalse Helpmekaarkongres. By hierdie kongres is baie van die ander provinsies deur amptelike verteenwoordigers verteenwoordig. Dit was juis op dié kongres dat van die groot eenheid en groter kontak en afbreuk van provinsialisme deur sprekers melding gemaak is, en dat dit juis die sekretaris van die Transvaalse vereniging was wat in sy verslag 'n pleidooi gelewer het dat: "wedersijdse kennismaking en betoning van belangstelling seker baie daartoe (sal) bijdra om, wat gewis 'n ieder verlang, die Helpmekaar ideaal te bereik namelik slegs één

133 De Burger, 25 Des 1917, Helpmekaar Konvensie; Ons Land, 27 Des 1917, Helpmekaar Konvensie.

134 De Burger, 11 Jan 1918, Korrespondentie.

135 (VKA) Helpmekaar van die Oranje-Vrystaat: Notuleboek (16 Mrt 1915-18 Aug 1926), 21 Mrt 1918, 43, 44, 45, 47-49.

136 De Volkstem, 5 Apr 1918, ‘t Helpmekaar Kongres. 
groot algemene Helpmekaar-Vereniging in Suidafrika van Tafelbaai strand tot oor die Sambesie. Mag die tyd spoedig aanbreek dat ons in Helpmekaar sake veral vergeet dat ons Transvalers is en slegs besef, ja ten volle besef, dat ons Afrikaners is en dat onse toekoms één is - in die éénheid van doel en strewe lê ons heil!"137

In die lig van die Transvaalse besluit wou dit voorkom asof die Transvalers nie heeltemal eens was met dr Malan se uitspraak op die kongres dat:

"de Kapenaar was altijd in de eerste plaats Kaapkolonist, en zo had de Transvaler voor niets anders tijd dan de Transvaal. De Helpmekaar had deze toestand verwijderd."138

Die Helpmekaarvereniging in Transvaal se weiering om afstand te doen van sy deel van die surplus, tesame met hul begeerte om ook die kapitaal, en nie net die rente te gebruik nie, het die praktiese toepassing van die uniale fondsgedagte effektief gekelder - 'n besef wat weerspieël is in die besluite wat in Mei 1918 op die Helpmekaarvereniging van die Kaapprovinsie se kongres oor die De Aar-besluite geneem is. Die De Aar-konvensie se besluit oor die surplus is in 'n gewysigde vorm aanvaar, hoofsaaklik om die Transvaalse sienswyse te akkommodeer.

'n Beginsel wat nie in soveel woorde by De Aar geformuleer is nie, maar wel as norm deur die konvensie aanvaar en ook by die Kaapse kongres bevestig is, was dat alle gelde wat in verband met die Helpmekaar Dag ingesamel is as één fonds behandel sou word en slegs aangewend moes word vir die rebelleskulde waarvoor in die oproep voorsiening gemaak is. Die beginsel dat die surplus onaangeraak gelaat en as een kapitaalfonds, waarin elke provinsie 'n pro rata aandeel sou hê, beskou moes word, is behou. ${ }^{139}$ Dit was opvallend dat, terwyl daar in die De Aar-besluit ' $n$ beklemtoonde verwysing na "één uniale fonds" was, daar in die Kaapprovinsie se formulering geen melding gemaak is van 'n uniale fonds nie en dit slegs vervang is met 'n verwysing na 'n onbeklemtoonde "een kapitaalfonds". Dit was omdat die Kaapprovinsie besef het dat, as gevolg van die Transvaalse sienswyse, één uniale fonds onder 'n sentrale bestuursliggaam prakties onuitvoerbaar was.

In 'n toevoeging tot die De Aar-besluit het die kongres die Transvaalse beginsel dat elke provinsie sy deel van die kapitaalfonds self beheer, belê, administreer en by implikasie die rente sowel as die kapitaal kan aanwend, aanvaar. Dat die kongres die beginsel teësinnig aanvaar het, blyk duidelik uit die laaste deel van die toevoeging. Daarin is bepaal dat die Vereniging slegs die kapitaal kon gebruik met die toestemming van die ander provinsiale kongresse. Indien enige sodanige aangewende kapitaal verlore sou gaan, was dit die betrokke vereniging se plig om

137 Het Volksblad, 9 Apr 1918, Helpmekaar Kongres te Pretoria.

138 De Volkstem, 5 Apr 1918, 't Helpmekaar Kongres.

139 (HSA) HVKP, Notuleboek, 22-23 Mei 1918, Kongres, 1, 3-4. 


\section{Die Kaapse Helpmekaar}

weer die gedeelte van die kapitaal onder sy beheer tot die oorspronklike bedrag te herstel. ${ }^{140}$ Laasgenoemde reëling, wat aanvaar is om gebruik van die kapitaal te ontmoedig en 'n mate van beheer daaroor te verseker, was slegs 'n Kaapse besluit wat nie bindend was op die ander verenigings alvorens hulle dit onderskryf het nie. Al sou hulle dit ook goedkeur, was dit te betwyfel of die toesighoudende rol van die provinsiale kongresse oor die kapitaal voldoende was om doeltreffende beheer te verseker. Die oorspronklike voorstel van één uniale fonds met 'n sentrale bestuur sou die taak baie meer effektief kon uitvoer.

Die NVHV van Natal het na 'n lang bespreking die De Aar-besluite goedgekeur ${ }^{141}$ en ook die besluite van die Kaapse kongres in verband met die surplus met enkele wysigings aanvaar. ${ }^{142}$

Die finale finansiële afsluiting van die Helpmekaarbeweging se sake is tydens twee vergaderings van die Inter-provinsiale Finansiële Kommissie (waarvoor die De Aar-konvensie voorsiening gemaak het) in September $1918^{143}$ en Maart 1919, afgehandel. ${ }^{144}$ Die finale opbrengs van die Helpmekaardagoproep is deur die Finansiële Kommissie op $£ 204479$ 14s $6 \mathrm{~d}$ bereken. Die bedrag het bestaan uit bydraes van die Kaapprovinsie $£ 90074$ s $11 \mathrm{~d}$, Natal $£ 4$ 500, Transvaal $£ 36387$ 8s 6d, die Suid-Vrystaat $£ 43088$ 16s 8d en die Noord-Vrystaat $£ 40429$ 0s 5 d. Die totale tekort van uitstaande skuld van die Helpmekaarbeweging wat die Kommissie op $£ 111978$ 4s 6d bereken het, is proporsioneel volgens bogenoemde bydraes verdeel. Dit het beteken het dat die Kaapprovinsie $£ 49$ 300, Natal $£ 2500$, Transvaal $£ 14$ 300, Suid-Vrystaat $£ 23600$ en die NoordVrystaat $£ 222784$ s $6 \mathrm{~d}$ moes betaal. ${ }^{145}$ Hiermee het elke provinsie dus geweet wat hy moes betaal en wat sy aandeel in die surplus was.

Afgesien van die finansiële afrekening het die Finansiële Kommissie ook oor die toekoms van die Helpmekaar besin. Tydens die September 1918-vergadering is 'n aanbeveling aan die provinsiale Helpmekaarverenigings gedoen om 'n "Unie Kongres" te hou om die toekoms van die Beweging te bespreek. Sodanige kongres moes nie later as Junie 1919 gehou word nie. Die sentrale besture is versoek om magtiging te verleen aan die Inter-provinsiale Finansiële Kommissie om reëlings vir die kongres te tref, asook om 'n voorlopige grondwet vir 'n "Unie-Helpmekaarvereniging"

$140 \quad$ Ibid., 3.

141 (HSA) Die Helpmekaar van Natal, Notuleboek (6 Jun 1917-24 Aug 1940), 20-21 Jun 1918, Kongres.

142 (HSA) HVKP, Notuleboek (3 Jul 1916-20 Mei 1919), Sentrale Bestuur 13 Jul 1918, 125.

143 (VKA) Helpmekaar van die Oranje-Vrystaat, Helpmekaar Korrespondensie 1916-1919, RT van der MerweJL van Heerden, 17 Aug 1918.

144 (VKA) Helpmekaar van die Oranje-Vrystaat, Helpmekaar Korrespondensie 1916-1919, JL van HeerdenHelpmekaar Vereniginge in die Unie van SA, 13 Mrt 1919.

145 (KAB) Aanwins 1469 HVKP Versameling no. 1 Sentrale Rebelle Fonds, 9 Jul 1919; (HSA) HVKP, Notuleboek, 21-22 Mei 1919, Kongres, 5. 
op te stel. ${ }^{146}$ Die gedagte van 'n uniale Helpmekaarvereniging was dus nog lewend, ten spyte van die praktiese probleme wat onstaan het deur die Transvaal wat besluit het om oor sy eie fondse te beskik. Die realisering van so 'n vereniging was egter in die hande van die sentrale besture, aangesien die Finansiële Kommissie nie sonder hul toestemming die gedagte verder kon voer nie.

Sover vasgestel kon word, was die Kaapse sentrale bestuur die enigste bestuur wat die aanbevelings van die Finansiële Kommissie oorweeg en aanvaar het in die periode voor die tweede vergadering van die Kommissie. ${ }^{147}$ Tydens die tweede vergadering van die Kommissie in Maart 1919 in Kaapstad was daar geen terugvoering van die provinsiale besture aangaande die aanbeveling oor 'n "Unie-Kongres" en "Unie-Helpmekaarvereniging" met 'n eie grondwet nie. Die gedagte van 'n uniale Helpmekaarvereniging met een uniale fonds het eenvoudig in die niet verdwyn. Die laaste verwysing na die gedagte was deur JL van Heerden in sy sekretariële verslag aan die ANHV-kongres in Julie 1919. Een van die punte in sy verslag het as volg daarna verwys:

“... verder sou dit wenselik wees te bespreek in hoever 'n federasie met die Helpmekaar

Vereniginge van die ander Provincies voordelig sal wees vir die hele beweging."148

Die standpunt het egter nooit tydens die kongres ter sprake gekom nie en daar is deur geen Helpmekaarvereniging weer daarna verwys nie. Redes vir die verdwyning van die uniale gedagte is moeilik bepaalbaar. Die Transvaalse houding oor die beheer van hul deel van die surplus en die aanwending daarvan het waarskynlik die grootste rol gespeel. 'n Besef by die ander provinsiale besture dat bogenoemde 'n Helpmekaarvereniging op 'n uniale grondslag prakties onuitvoerbaar gemaak het, het moontlik hul vertroue in die gedagte, en hul entoesiasme vir die uitvoering daarvan, laat taan en uiteindelik laat verdwyn. Hierdeur het die verenigende invloed wat van 'n uniale fonds kon uitgaan, as gevolg van die nouer kontak wat dit tussen verenigings sou bewerkstellig, verlore gegaan. Die Transvaalse houding het verder die weg gebaan vir die permanente vestiging van vier afsonderlike, geïsoleerde provinsiale Helpmekaarverenigings. Daardeur is samewerking op 'n nasionale vlak, volgens 'n nasionale strategie, in die nasionale belang van die Afrikaner grootliks ongedaan gemaak.

146 (KAB) Aanwins 1469 HVKP Versameling: no.1 Helpmekaar (Notule van die eerste vergadering van die Finansiële Kommissie van die Helpmekaar Vereniginge, 19 Sept 1918); (INEG) PV 21 NP van die OranjeVrystaat-versameling: Lêer no 39 Deel I 8 Jan 1918-25 Apr 1919, Onderwerp: Finansies Sentrale Rebelliefonds Korrespondensie, Helpmekaar (Notule van die eerste vergadering van die Finansiële Kommissie van die Helpmekaar Vereniginge, 19 Sept 1918).

147 (HSA) HVKP, Notuleboek (3 Jul 1916-20 Mei 1919), Sentrale Bestuur, 14 Des 1918, 133.

148 (VKA) Helpmekaar van die Oranje-Vrystaat: Helpmekaar Korrespondensie en Finansiële Stukke 1916-1919, Afrikaner Nasionale Helpmekaar Vereniging (Verslag van die Sekretaris, 4 Jul 1919). 


\title{
HOOFSTUK TWEE
}

\section{DIE ONTSTAAN, STIGTING EN VESTIGING VAN DIE HELPMEKAARVERENIGING VAN DIE KAAPPROVINSIE, C.1916-C.1920}

\begin{abstract}
"Vernomen dat Uw Genootschap hulp geeft aan familiën van Gevangenen, wilt toch ook om zien en doen wat $U$ kunt aan de familie, bestaande uit Vrouw en vijf jonge kinders van mijn vriend en mede gevangene Brigdr. H Kennedy van Dam, die door zijn langdurige politieke krygsgevangeneschap zich in behoeftige omstandigheden verkeren." ${ }^{1}$

"Uw brief het ons hart zeer verblij. Ons voel ons lij niet alleen, daar is darem nog baing, baing Afrikaners die saam met ons voel. Och! Of het Afrikaner hart by gansch ons volk ontwaakt!"2
\end{abstract}

\section{VAN 'HET NATIONALE WELDADIGHEIDS GENOOTSCHAP’ TOT DIE HELPMEKAARVERENIGING VAN DIE KAAPPROVINSIE}

In vergelyking met die Vrystaat en Transvaal was die Afrikaners in die Kaapprovinsie se deelname aan die Rebellie minimaal. Ten spyte van die relatiewe onbetrokkenheid het dit hul nogtans nie verhoed om van die eerste pogings in die Unie aan te wend om die rebelle en hul gesinne te help nie. Die eerste georganiseerde poging in die Kaapprovinsie het vanuit Stellenbosch gekom. Op 2 Februarie 1915 het die dames van die ACVV (Afrikaanse Christelike Vroue-vereniging) van Stellenbosch, onder leiding van die eggenotes van professore Muller en De Vos, die saak na afloop van die maandelikse vergadering van die ACVV bespreek. Aangemoedig deur die versoeke van ds Rabie en eerwaarde Van Rensburg, in verband met die rebelle in die gevangenis van Tokai en Kimberley-Beaconsfield, het hulle besluit om op Maandag 8 Februarie 'n vergadering te hou om die saak in diepte te bespreek. Op laasgenoemde vergadering het die dames oorgegaan tot die stigting van "Het Nationale Weldadigheids Genootschap" vir Stellenbosch met die doel om:

\footnotetext{
1 (KAB) Aanwins 1469, HVKP, Korrespondensie 1914, CR de Wet-W de Villiers, 21 Jun 1915.

2 (KAB) Aanwins 1469, HVKP, Korrespondensie 1915, JP van der Spuy-mev Hofmeyr, 24 Mrt 1915.
} 
“... het leed van de krijgsgevangenen en gewonden, alsook de lijdende vrouwen en kinderen van ons volk, veroorsaakt door de oorlog, te verzachten."

Die Genootskap het 'n bestuur van nege lede gehad met mev Muller as voorsitter, mev De Vos as visevoorsitter en mej Maria de Kock as sekretaresse en tesouriere. ${ }^{4}$ 'n Soorgelyke poging om die rebelle te help het ook in die Paarl begin, hoewel daar nie melding gemaak is van 'n amptelike vereniging wat gestig is nie. ${ }^{5}$

Gelyktydig met die stigting van die Genootskap in Stellenbosch het die vroue in Kaapstad ook pogings aangewend om die families van rebelle te help. Die eerste stap in dié rigting was toe 'n klompie vroue van Kaapstad op 3 Februarie 1915 bymekaargekom het om “... planne te beramen waardoor zij konden voorzien in de groote behoefte, die er heerscht onder de families der rebellen". ${ }^{6}$ Op die vergadering is besluit om 'n groter vergadering te belê en vir dié doel is vroue wat bekend was vir hul liefdadigheidswerk uitgenooi om die vergadering in Kaapstad by te woon. Die vergadering op 16 Februarie $^{7}$ is onder andere bygewoon deur dames van die Kaapse Skiereiland, Stellenbosch, Paarl, Malmesbury, Worcester en Tulbagh. ${ }^{8}$ Op die byeenkoms is besluit om 'n organisasie te stig om die rebellegesinne se nood te verlig. Die naam van die nuwe organisasie is van die Stellenbosse Genootskap oorgeneem, naamlik die "Nationale Weldadigheids Genootschap". Die reëls van die "Transvaalse Komitee" (waarskynlik die Suid-Afrikaanse Ondersteuningsfonds) is onveranderd oorgeneem. Die bestuur van die Genootskap het bestaan uit mev De Bruyn (president), mej W de Villiers (sekretaresse) en mev W Hofmeyr (tesouriere). Al die ander teenwoordige lede is ook tot die bestuur verkies, ${ }^{9}$ naamlik mevroue Roos, Roux, A Louw, P Roux, GC de Villiers, CL Marais, IO Naude, E van der Merwe, Alheit, Retief, De Waal-Davies, Kuhn, Le Roux, Greeff, Louw, Le Roux, P Fischer, Malan, CF Muller, JD Horak, P de Klerk, Werdmüller, JJC Esterhuijsen en mej Louw. Voorsiening is ook gemaak vir 'n dagbestuur van 14 lede, asook'n uitvoerende bestuur bestaande uit die voorsitter, tesouriere en sekretaresse. ${ }^{10}$

\footnotetext{
3 Ons Land, 24 April 1915, Het Nationale Weldadigheidsgenootschap.

$4 \quad$ Ibid.,

5 Ons Land, 2 Februarie 1915, Het Nationale Weldadigheidsgenootschap.

6 (HSA) Nationale Vrouwe Helpmekaar Genootschap, Notuleboek (16 Feb 1915-20 Des 1915), 16 Feb 1915.

$7 \quad$ Ibid.,

8 Ons Land, 20 Feb 1915, Het Nationale Weldadigheidsgenootschap.

9 (HSA) Nationale Vrouwe Helpmekaar Genootschap, Notuleboek (16 Feb 1915-20 Des 1915), 16 Feb 1915.

10 (HSA) Nationale Vrouwe Helpmekaar Genootschap, Notuleboek (16 Feb 1915-20 Des 1915), Nationale Weldadigheids Genootschap; (los kollektelys).
} 


\section{Die Kaapse Helpmekaar}

Die verteenwoordigers van die verskillende dorpe is opdrag gegee om plaaslike takke in hul omgewings te stig. Die noodsaaklikheid vir die stigting van sulke takke en die insameling van fondse het duidelik na vore gekom uit briewe wat deur van die dames aan die vergadering voorgelê is en waaruit die benarde posisie van die rebellegesinne in dele van die Vrystaat duidelik geblyk het. Melding is gemaak van die:

“... groote armoede, die meestal onstaat om rede al het goed, geld, vee en als anderzins,

weggenomen worden van de vrouwen der rebellen, die in de Tronk zijn." ${ }^{11}$

Die stigting van die Genootskap is nie oral met ewe veel entoesiasme ontvang nie. Op die vergadering van 24 Februarie het mev De Bruyn gerapporteer dat ds Marchand van Kaapstad erg teen die Genootskap gekant was en geweier het om die kerkkantoor verder tot die beskikking van die Genootskap te stel vir hul vergaderings nadat hy verneem het dat dit 'n nasionale genootskap was om die protesterende burgers te help. In teenstelling hiermee was daar egter ook 'n brief van 'n “... Engelschman, WW Johnson ... die in volle sympathie was, met het werk waar voor het Genootschap gevormd was". ${ }^{2}$

Die swak toestand en groot behoefte van die rebellegesinne in Transvaal en die Vrystaat is voortdurend in verskeie briewe wat die Genootskap ontvang het, onderstreep en die toestand is selfs beskryf as erger as wat gedurende die Anglo-Boereoorlog van 1899-1902 ondervind is. ${ }^{13}$ Op hul vergadering van 28 April het die bestuur van die Genootskap dus besluit om deur middel van die koerante weer 'n beroep op die mense te doen om hul te help met geld, klere of voedsel, aangesien hulle voortdurende oproepe uit die Vrystaat en Transvaal gekry het wat gevra het om hulp vir rebellefamilies. Verskeie kollektelyste is ook aan kollektante gestuur om geld in te samel. ${ }^{14}$

Die Nasionale Weldadigheidsgenootskap wat op daardie stadium die enigste georganiseerde beweging in die Kaapprovinsie was, het fondse vir die rebellegesinne ingesamel. Hulle het ook ander pogings aangewend om geld vir die Helpmekaarbeweging in die Vrystaat en Transvaal te in. In enkele gevalle is oorgegaan tot die stigting van Helpmekaarverenigings op die Vrystaatse en Transvaalse patroon. In Julie 1915 is byvoorbeeld in Mafeking 'n komitee gekies om 'n Helpmekaarvereniging vir die distrik Mafeking op te rig. ${ }^{15}$ Op 24 Julie is H Heymans tot voorsitter van die Vereniging aldaar gekies. Die doel was om 'n fonds vir die rebelle daar

\footnotetext{
11 (HSA) Nationale Vrouwe Helpmekaar Genootschap, Notuleboek (16 Feb 1915-20 Des 1915), 16 Feb 1915.

12 (HSA) Nationale Vrouwe Helpmekaar Genootschap, Notuleboek (16 Feb 1915-20 Des 1915), 24 Feb 1915.

13 Ibid.,

14 (HSA) Nationale Vrouwe Helpmekaar Genootschap, Notuleboek (16 Feb 1915-20 Des 1915), 28 Apr 1915.

15 Het Volksblad, 23 Jul 1915, Mafeking Helpmekaar.
} 
te stel, die handel tussen Hollands-Afrikaanssprekendes te bevorder, die Afrikaans-Hollandse kultuur en kuns te bevorder en ook te poog om groot handelsondernemings daar te stel. Die skade wat in die distrik Mafeking aangerig is, sou eers vereffen word en daarna moes na die Vrystaters omgesien word. R van Rooyen, H le Roux en T en W Nel is as kollektante aangestel. ${ }^{16}$

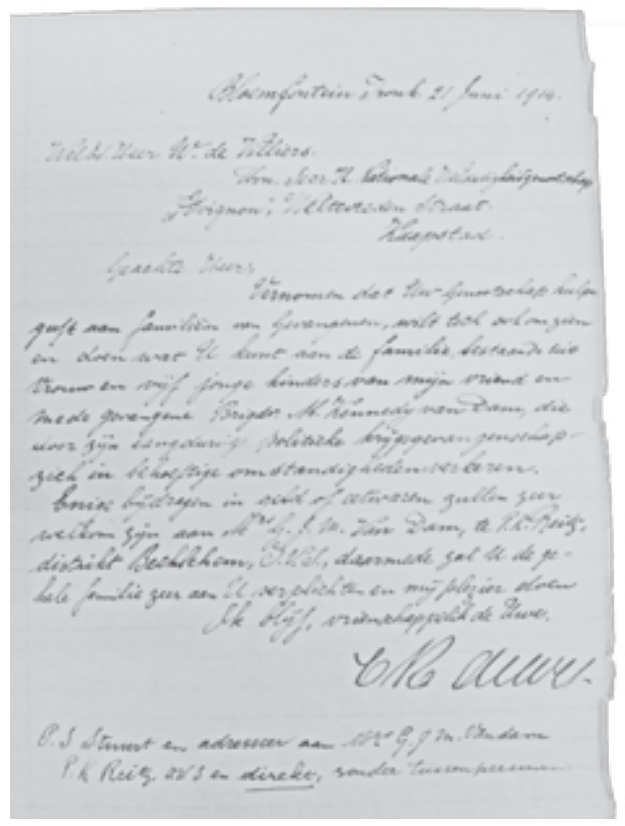

Brief van generaal Christaan Rudolf de Wet (gedateer 21 Junie 1915) aan Winifred de Villiers waarin hy hulp van die Nasionale Weldadigheidsgenootskap vra vir die gesin van een van sy mede-gevangenes in die Bloemfonteinse tronk

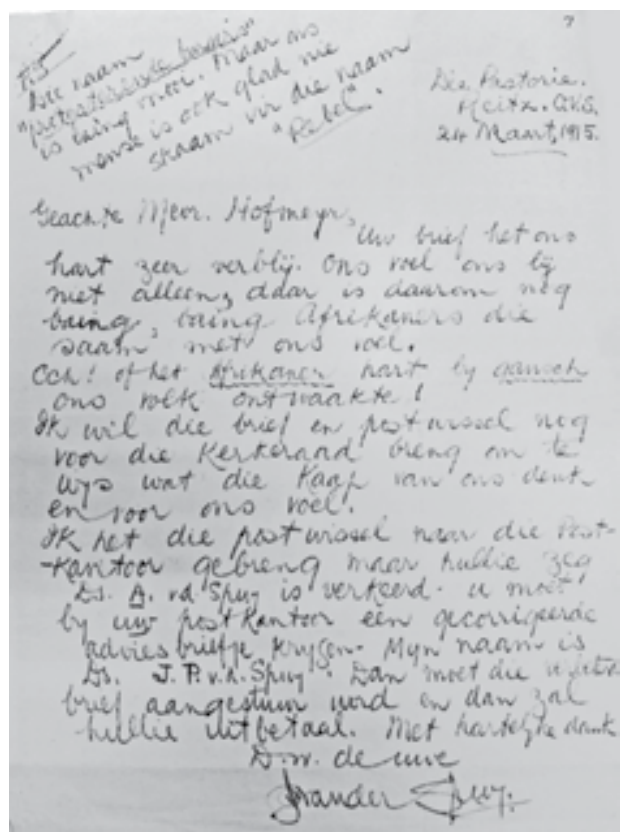

Brief van ds JP van der Spuy aan mev Hofmeyr (gedateer 24 Maart 1915) waarin hy erkenning gee vir die hulp wat hulle van die Nasionale Weldadigheidsgenootskap ontvang het en aandui dat hulle nie omgee om rebelle genoem te word nie

Die mees algemene manier van fondsinsameling was deur middel van basaars of konserte. Verskeie dorpe soos Swellendam, ${ }^{17}$ Molteno, ${ }^{18}$ Dordrecht, ${ }^{19}$ Heidelberg, ${ }^{20}$ Humansdorp, ${ }^{21}$

16 Het Volksblad, 6 Aug 1915, Helpmekaar Verenigingen.

17 De Burger, 31 Jul 1915, Swellendam.

18 De Burger, 23 Aug 1915, Nationale Bedrijvigheid.

19 De Burger, 25 Aug 1915, Dordrecht.

20 De Burger, 2 Sep 1915, Heidelberg.

21 De Burger, 14 Sep 1915, Humansdorp. 


\section{Die Kaapse Helpmekaar}

Worcester $^{22}$ en Robertson ${ }^{23}$ het gedurende die tweede helfte van 1915 sulke pogings aangewend om geld vir die Helpmekaarbeweging in te samel. Die geld is na die Vrystaat, Transvaal en in sommige gevalle ook na die Nasionale Weldadigheidsgenootskap gestuur, om daarmee in rebelle se behoeftes te voorsien.

Dat die poging wat tot op daardie stadium in die Vrystaat en Transvaal aangewend is om rebelleskuld te betaal, onvoldoende was, het baie duidelik geblyk uit die oproep wat die organiserende sekretaris van die Sentrale Rebellefonds op 18 Augustus in De Burger gemaak het. Hy het gevra dat die Kaapprovinsie behulpsaam moes wees met die vereffening van die $£ 250000$ se eise waarmee die Vrystaat te kampe gehad het. Hy het ook’n beroep gedoen op die Kaapprovinsie om "Saamwerk-takken" te stig ter ondersteuning van die Helpmekaarfonds. ${ }^{24}$ Die nood in die Noorde is verder onderstreep op die vergadering van 22 September van die Weldadigheidsgenootskap toe mev De Bruyn 'n boodskap van mev Kestell (JD Kestell se eggenote) van Bloemfontein oorgedra het waarin sy “... om hulp vragende voor het Helpmekaar Fonds niet alleen voor eten voor de gevangene, maar ook om rechts geleerde advies te verschaffen" ${ }^{25}$

Die oproep van mev De Bruyn het ook die Nasionale Weldadigheidsgenootskap sy eerste gedaanteverwisseling laat ondergaan. Na aanleiding van mev De Bruyn se brief is 'n voorstel op bogenoemde vergadering van 22 September aangeneem dat die naam van die Genootskap verander word na die:

"Nationale Vrouwe Helpmekaar Genootschap, sodat wij in het vervolg niet alleen werken voor de families van die protesteerende burgers, maar ook voor de Protesteerende Burgers self." ${ }^{26}$

Die doel van die Genootskap het dus verbreed en 'n baie groter element van die Helpmekaarbeweging, soos dit in Transvaal en Vrystaat daar uitgesien het, is in die Genootskap ingebou. Hoewel die Genootskap tot op daardie stadium geen formele grondwet gehad het nie, het die hoofbestuur as 'n skakel gedien wat die gelde ontvang het en dit dan aan die Helpmekaarverenigings in die Noorde gestuur het. ${ }^{27}$ Tot voor die naamsverandering het die Genootskap reeds $£ 296$ gekollekteer, waarvan $£ 286$ na Transvaal, die Vrystaat en

\footnotetext{
22 De Burger, 16 Sep 1915, Worcester.

23 De Burger, 24 Sep 1915, Robertson.

24 De Burger, 18 Aug 1915, De Opstand: Haar oorzaak en gevolge.

25 (HSA) Nationale Vrouwe Helpmekaar Genootschap, Notuleboek (16 Feb 1915-20 Des. 1915), 22 Sep 1915.

26 Ibid.,

27 De Burger, 24 Nov 1915, Nationale Vrouwe Helpmekaar Genootschap.
} 
die noordelike dele van die Kaapprovinsie gestuur is. Die geld is hoofsaaklik aangewend vir voedsel. Behalwe vir Kaapstad en sy onmiddellike omgewing het Porterville, Tulbagh, Worcester en Clanwilliam die meeste tot bogenoemde fondse bygedra. ${ }^{28}$ Een van die weinige takke van die Genootskap wat buite die Skiereiland en omgewing gestig is, was die "Nationale Weldadigheids Vereniging" wat op 30 Oktober te Cradock gestig is. Dié vereniging, wat met 53 lede begin het, se bestuur het bestaan uit mev W van Rensburg (presidente), mev G Jordaan ${ }^{29}$ (visepresidente) en mej A van Rensburg (tesouriere). ${ }^{30}$ 'n Helpmekaarvereniging het ook op 12 Oktober op Middelburg die lig gesien. ${ }^{31}$

Tydens die Nasionale Vroue-Helpmekaargenootskap se vergadering van 1 November 1915 het die sekretaresse opdrag gekry om aan elke stad en dorp in die Kaapprovinsie te skryf om hulle te versoek om takke van die Nasionale Vroue-Helpmekaargenootskap te stig. ${ }^{32}$ Die gedagte was dat die takke hul bydraes aan die hoofbestuur in Kaapstad moes stuur om “... aldus onze krachten niet te verbrokkelen en op die wijze te weten te komen hoeveel geld door de Kaap Provincie bijeengebracht wordt." ${ }^{33}$ Op daardie stadium het baie van die dorpe wat vir die Helpmekaar gewerk het, hul geld direk na die Transvaal en veral die Vrystaatse verenigings gestuur. ${ }^{34}$

In antwoord op die sekretaresse se skrywe om Nasionale Vroue-Helpmekaargenootskaptakke te stig, het 27 persone van verskillende dorpe en distrikte van hulle laat hoor. ${ }^{35}$ Dit is onbekend of in elke dorp of distrik wat geantwoord het, wel 'n liggaam soos die Genootskap gestig is, maar daar was beslis 'n toename in die stigting van Helpmekaartakke in die Kaapprovinsie in die laaste twee maande van 1915. Plekke waar daar in daardie periode takke

28 Ibid.,

29 Elizabeth Jordaan was ook 'n lid van die ACVV en sou later die nasionale president van die ACVV word terwyl haar man Gert Jordaan 'n stigterslid van die Helpmekaarvereniging was en van 1916-1935 op die Sentrale Bestuur gedien het. A Ehlers, The Helpmekaar: rescuing the 'volk' through reading writing and arithmetic, c1916-c1965, Historia, 60, 2, 92-93.

30 De Burger, 9 Okt 1915, Nationale Weldadigheids Vereniging, Nov 2015.

31 De Burger, 21 Okt 1915, Middelburg.

32 (HSA) Nationale Vrouwe Helpmekaar Genootschap, Notuleboek (16 Feb 1915-20 Des 1915), 1 Nov 1915.

33 De Burger, 24 Nov 1915, Nationale Vrouwe Helpmekaar Genootschap.

34 De Burger, 29 Nov 1915, Bethlehem Saamwerk Vereniging; De Burger, 10 Des 1915, Bethlehem Saamwerk.

35 (HSA) Nationale Vrouwe Helpmekaar Genootschap, Notuleboek (16 Feb 1915-20 Des 1915), 22 Nov 1915; 20 Des 1915. 
gestig is, het ingesluit Philipstown, ${ }^{36}$ Wellington, ${ }^{37}$ Brandwacht (in die Mosselbaai-distrik), ${ }^{38}$ Graaff-Reinet, ${ }^{39}$ Lady Grey, ${ }^{40}$ Malmesbury ${ }^{41}$ en Colesberg. ${ }^{42}$ Daar is egter op baie ander dorpe en distrikte vir die Helpmekaar gewerk. Politieke teenkanting en ander faktore teen die Vereniging het in sommige gevalle samewerking bemoeilik en in gevalle soos Montagu ${ }^{43}$ en Burghersdorp ${ }^{44}$ selfs die stigting van nuwe takke verhoed.

Tot die begin van Desember 1915 was alle pogings wat in die Kaapprovinsie aangewend is om die rebelle en hul gesinne te help, hoofsaaklik gekonsentreer in die hande van die vroue. Die gevoel het in Kaapstad en omgewing ontstaan dat die mans 'n groter bydrae moes lewer en ook aktief betrek moes word by die pogings om die rebelle te help. Twee persone wat veral hieroor sterk gevoel het, was A van Reenen en A Benning. ${ }^{45}$ Die twee here het hieroor met die redakteur van De Burger, dr DF Malan, geskakel waarop daar besluit is om vir 6 Desember 'n vergadering in Kaapstad te belê onder voorsitterskap van dr DF Malan. ${ }^{46}$ Die doel daarvan was “... om met elkander te raadplegen over de nood van onze broeders in het Noorden, en om middelen te beramen om ze zodanig te hulp te komen dat niemand van hen te gronde zal gaan". ${ }^{47}$ Daar sou besin moes word wat die mans van die Skiereiland in dié verband sou doen.

36 De Burger, 19 Nov 1915, Nationale Vrouwe Vereniging.

37 De Burger, 25 Nov 1915, Wellington; (KAB) Aanwins 1469 HVKP -versameling: no 1 Korrespondensie 1914-1915 B Joubert- JGC de Bruyn, 20 Nov 1915.

38 De Burger, 8 Des 1915, Brandwacht Helpmekaar.

39 De Burger, 14 Des 1915, Graaff-Reinet.

40 De Burger, 15 Des 1915, Helpmekaar Vergadering.

41 De Burger, 16 Des 1915, Malmesbury.

42 De Burger, 25 Des 1915, Colesberg.

43 (KAB) Aanwins 1469 HVKP-versameling: no 1 Korrespondensie 1914-1915 mev HW van der Merwe-mej W de Villiers, JGC de Bruyn, 22 Nov 1915.

44 (KAB) Aanwins 1469 HVKP-versameling: no1 Korrespondensie 1914-1915 A Boje-mej W de Villiers, 26 Des 1915.

Anthony Frederik Jacobus Benning was die seun van 'n Hollandse immigrant. Hy was 'n bouer wat onder andere sy kapitaal gemaak het deur sy boubedrywighede op die delwerye in Kimberley en Johannesburg waarna hy hom in Kaapstad gevestig het. Hy was onder andere verantwoordelik vir die bou van die Kaapse Hooggeregshofgebou en 'n gedeelte van die Nasionale Pers gebou in Keeromstraat. Hy was aktief in die Kaapse openbare lewe, 'n goeie vriend van Willie Hofmeyr, een van die stigterslede van Santam en Sanlam en "'n warm Afrikaner". JP Scannell, Uit die volk gebore. Sanlam se eerste vyftig jaar, 7, Nasionale Boekhandel Beperk, Kaapstad, 1968.

46 De Burger, 7 Des 1915, Helpmekaar.

47 De Burger, 4 Des 1915, Helpmekaar. 
$\mathrm{Na}$ aanleiding hiervan het $\mathrm{dr}$ Malan 'n beroep in De Burger gedoen op “... alle mannen en vrouwen die ons volk liefhebben ..."48 om die vergadering by te woon. Hy het 'n spesiale beroep op die mans gedoen om nie afsydig te staan teenoor die poging nie, maar om hul besigheidstalent en ruimer middele in te span om van die poging 'n sukses te makk. Prominente Vrystaatse persone sou die vergadering inlig oor die toestand van die rebelle en die werk van die Helpmekaar in die Noorde. ${ }^{49}$

Die vergadering is onder andere bygewoon deur AJ van Reenen, advokaat HA Fagan, ds CA van der Merwe, H Serfontein, ZJ de Beer, J Brand Wessels, advokaat HS van Zijl, R Cloete, AJ Benning, ds en mev De Bruyn, eerwaarde en mev Karremacher, mnr en mev WA Hofmeyr, mej Annie Visser, mevv CC de Villiers, Melt Brink, Scholtz, Van Velden en mej $\mathrm{W}$ de Villiers.

As voorsitter van die vergadering het dr Malan klem gelê op die groot behoefte wat in die Noorde bestaan het deurdat direkte eise van $£ 300000$ alreeds teen rebelle ingebring is. Die behoefte is verder onderstreep deur die inligting wat aan die vergadering verskaf is deur die Vrystaters wat teenwoordig was, naamlik J Brand Wessels, Z de Beer (LV), mnr Serfontein (LV) en dr Van der Merwe, die sekretaris van die Sentrale Rebellefonds. Dr Malan het ook daarop gewys dat, terwyl die vroue van die Kaapse Skiereiland alreeds sowat $£ 500$ bymekaargemaak het deur middel van die Nasionale Vroue-Helpmekaargenootskap, die mans nog geen bydrae gelewer het nie. Volgens dr Malan moes daar besluit word of slegs 'n tak en of 'n groot Helpmekaarvereniging vir die hele Kaapprovinsie gestig moes word. Hy het dit egter benadruk

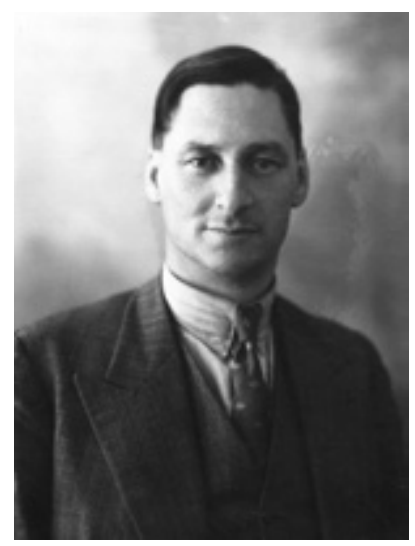

HA Fagan, Stigterslid van Nasionale Pers en Die Burger en voorsitter van die Helpmekaarvereniging van die Kaapprovinsie in 1921. Ook die vader van die bekende argitek Gawie Fagan.

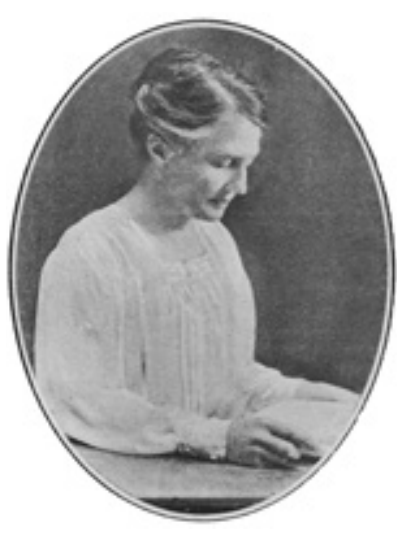

Winifred de Villiers, penningmeester van die Helpmekaarvereniging van die Kaapprovinsie dat die doel van die vergadering was om te besin of die mans van die Skiereiland die beweging aktief sou steun.

$\begin{array}{ll}48 & \text { Ibid. } \\ 49 & \text { Ibid. }\end{array}$


$\mathrm{Na}$ breedvoerige bespreking is besluit dat die mans wel die beweging sou steun en 'n permanente vereniging, wat met die vrouevereniging moes saamsmelt, is in die vooruitsig gestel. Die standpunt is veral sterk ondersteun deur advokaat HS van Zijl ${ }^{50}$ en WA Hofmeyr. ${ }^{51}$ Op voorstel van dr Malan en mnr Dormehl ${ }^{52}$ is besluit om 'n komitee aan te stel om die nodige reëls op te stel en om met die Nasionale Vroue-Helpmekaargenootskap oor amalgamasie te onderhandel. As komiteelede is W Hofmeyr, ds De Bruyn, advokaat HS van Zijl, A Benning en CC de Villiers aangewys. ${ }^{53}$

Op die vergadering van die Nasionale Vroue-Helpmekaargenootskap wat op 20 Desember gehou is, het die vroue eenparig besluit om by die beoogde Helpmekaarvereniging van die mans aan te sluit. ${ }^{54}$ 'n Gesamentlike kommissie, bestaande uit mevv CC de Villiers en JG de Bruyn, asook ds JG de Bruyn en mnr WA Hofmeyr, is benoem om 'n konsepgrondwet vir'n Helpmekaarvereniging, wat uit beide mans en vroue sou bestaan, op te stel. Die grondwet sou daarna op 'n openbare vergadering bespreek word. Die hoop is uitgespreek dat die grondwet as basis sou dien vir ander Helpmekaarverenigings wat nog in die Kaapprovinsie gestig sou word “... en dat men ter geschikter tyd zal overgaan tot het daarstellen van een groot behoorlik georganiseerd lichaam voor de Provincie met een Centraal Bestuur". ${ }^{55}$

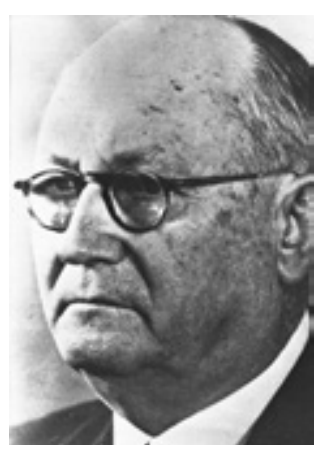

DF Malan, redakteur van Die Burger en latere eerste minister van Suid-Afrika

Die stigtingsvergadering van die nuwe Helpmekaarvereniging is op 13 Januarie 1916 in Kaapstad onder voorsitterskap van ds JG de Bruyn gehou. Op die vergadering is, op voorstel van WA Hofmeyr, amptelik oorgegaan tot die stigting van 'n Helpmekaarvereniging vir die Kaapse Skiereiland. Hofmeyr het beklemtoon dat die Skiereilandse vereniging as model vir die res van Kaapland moes dien en dat later oorgegaan kon word tot die stigting van 'n

50 HS van Zijl was 'n stigterslid van die NP in Kaapland en is in 1920 as regter in die Kaapse Hooggeregshof aangestel. Suid-Afrikaanse Biografiese Woordeboek V, 887-888, RGN, Pretoria, 1987.

51 Willie Hofmeyr was 'n prokureur en 'n stigterslid van Die Burger en eerste voorsitter van die direksie van Nasionale Pers. Na die stigting van die NP word hy onder DF Malan die organiserende sekretaris van die NP in Kaapland. Hy was sy hele lewe lank tot sy dood in 1953 by Nasionale Pers en Die Burger betrokke. Suid-Afrikaanse Biografiese Woordeboek, III, 416-417, Tafelberg Uitgewers, Kaapstad, 1977.

52 Fred Dormehl het as hoofbestuurder en sekretaris 'n belangrike rol in die vroeë vestigingsjare van Die Burger gespeel. Hy was een van die stigterslede en ook besturende direkteur van Santam en direkteur van Sanlam. Hy is in 1918 tydens die Griepepidemie aan longontsteking oorlede. Suid Afrikaanse Biografiese Woordeboek, III, 242, Tafelberg Uitgewers, Kaapstad, 1977.

De Burger, 7 Des1915, Helpmekaar.

54 (HSA) Nationale Vrouwe Helpmekaar Genootschap, Notuleboek (16 Feb 1915-20 Des 1915), 20 Des 1915.

55 De Burger, 22 Des 1915, Helpmekaar. 
algemene bestuur vir al die Verenigings. Die konsepgrondwet is aan die vergadering voorgelê en aanvaar. ${ }^{56}$ Die doel van die Vereniging was tweeledig van aard. As onmiddellike doel moes die persone wat weens die rebellie in 'n finansiële verknorsing beland het, gehelp word. Verder het die Vereniging hom ten doel gestel om die “... algemene ontwikkeling, opheffing en welvaart van het Hollandssprekende deel van het Zuidafrikaanse volk te bevorderen, een eigen Afrikaanskultuurleven op te bouwen, en meerdere samenwerking en onderlinge ondersteuning tot stand te brengen". ${ }^{57}$

Ingevolge die goedgekeurde grondwet sou die hoogste gesagsliggaam van die Vereniging die algemene vergadering wees, wat uit al die lede van die Vereniging sou bestaan. Die algemene vergadering sou driemaandeliks vergader. Die sake van die Vereniging sou behartig word deur die bestuur, wat gekies sou word uit die geledere van en deur die algemene vergadering. Die bestuur sou bestaan uit 'n voorsitter, visevoorsitter, sekretaris en penningmeester, plus vyf ander lede. Hulle sou maandeliks vergader. ${ }^{58}$ Die eerste bestuur, wat tydens die stigtingsvergadering verkies is, het bestaan uit WA Hofmeyr (voorsitter), mev De Bruyn (visevoorsitter), mev Paul Roux (sekretaresse), en mej W de Villiers (penningmeesteres). Die addisionele lede was mevv Christiaan Marais ${ }^{59}$ en CC de Villiers, asook AJ Benning, HS van Zijl en Steyn. ${ }^{60}$

Met die stigting van die Helpmekaarvereniging van die Kaapse Skiereiland het die Nasionale Vroue-Helpmekaargenootskap opgehou funksioneer en opgegaan in die nuwe vereniging. Die Nasionale Weldadigheidgenootskap, later die Nasionale Vroue-Helpmekaargenootskap, het in die loop van 1915 op tweërlei wyse 'n belangrike bydrae tot die Helpmekaarwerk in die Kaapprovinsie gelewer deurdat hulle eerstens 'n som van byna $£ 1000^{61}$ bymekaar gemaak het vir die Helpmekaar en tweedens ook die grondslag gelê het vir die Helpmekaarvereniging van die Kaapprovinsie, wat in 1916 tot stand sou kom.

\footnotetext{
56 De Burger, 14 Jan 1916, Helpmekaar Vereniging voor het Kaapse Schiereiland.

57 De Burger, 15 Jan 1916, Helpmekaar.

$58 \quad$ Ibid.

59 Sy was die eggenote van Christiaan Marais, een van die welgestelde en invloedryke Marais-broers van Stellenbosch. Pieter Kapp, Die verhaal van Jannie Marais en die Marais-broers. Nalatenskappe sonder einde, 24, Tip Africa Publishing, Soutrivier, 2015.

60 Ons Land, 15 Jan 1916, Helpmekaar Vereniging.

61 De Burger, 15 Jan 1916, Hoofartikel.
} 

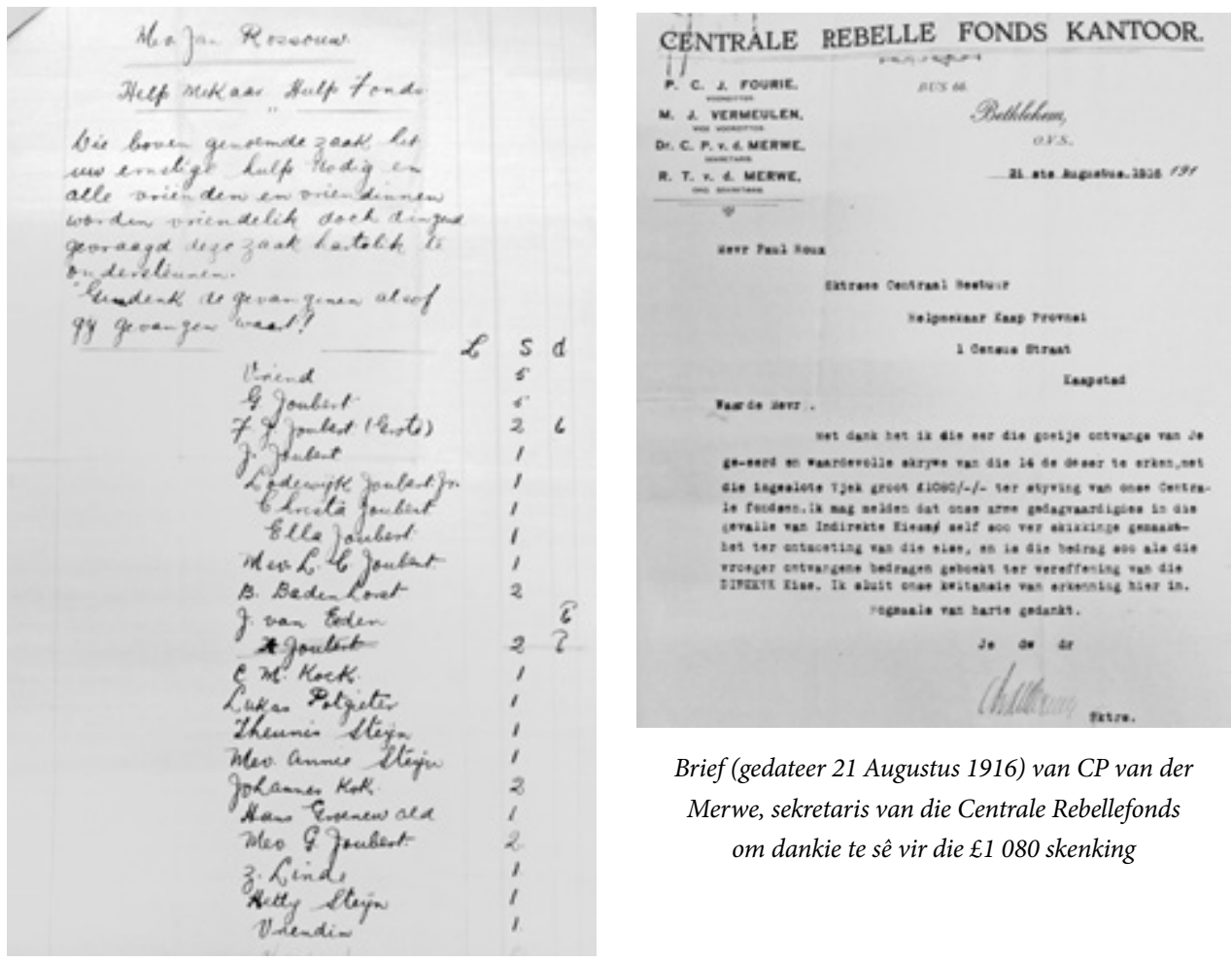

Brief (gedateer 21 Augustus 1916) van CP van der Merwe, sekretaris van die Centrale Rebellefonds om dankie te sê vir die $£ 1080$ skenking

'n Kaapse Helpmekaar kollektelys van 1915

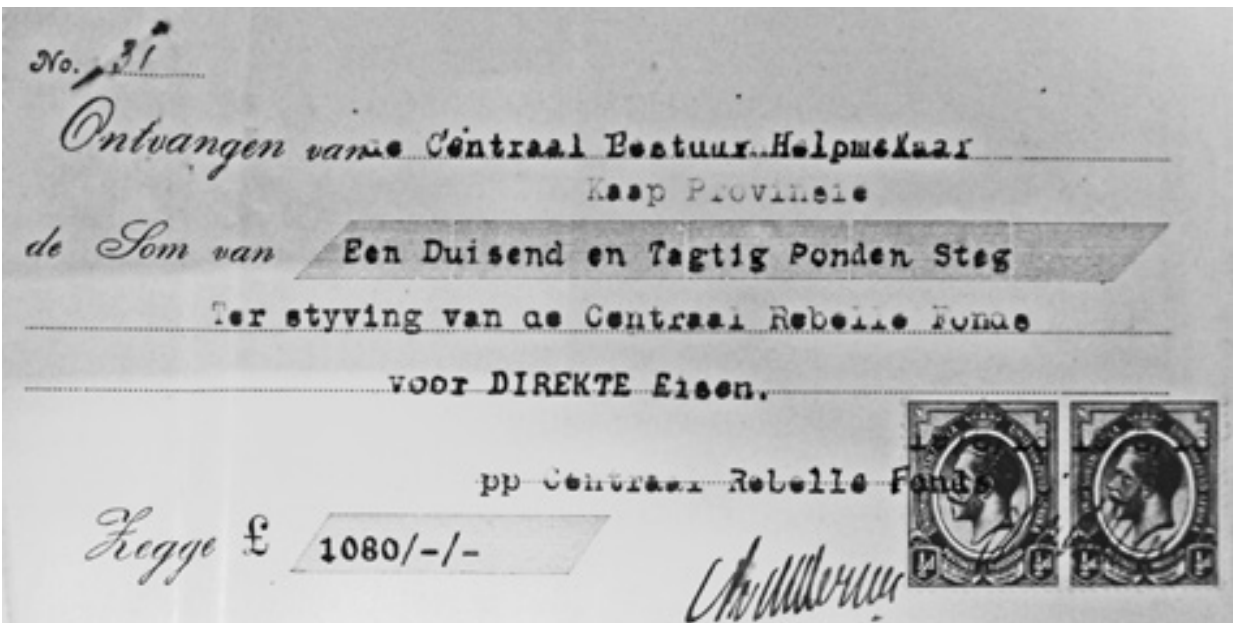

Kwitansie waarin die Centrale Rebelle Fonds van die Vrystaat ontvangs erken van ' $n$ bydrae van $£ 1080$ van die Helpmekaarvereniging van die Kaapprovinsie 
In die loop van Februarie 1916 het die Helpmekaarvereniging van die Kaapse Skiereiland deur middel van De Burger 'n beroep gedoen op reeds gestigte verenigings om met hom in verbinding te tree. Hy het ook simpatiekgesinde persone in distrikte waar daar nog geen Helpmekaarvereniging was nie versoek om oor te gaan tot die stigting van dergelike verenigings. ${ }^{62}$ Dr Malan het ook weer eens 'n beroep gedoen op die Kaapprovinsie, om die Vrystaters en Transvalers, wat veral na die aanvang van die instelling van indirekte eise in 'n hopelose situasie verkeer het, te help deur die Helpmekaarverenigings te ondersteun. Terselfdertyd het parlementslede van die NP wat vir die parlementsitting in Kaapstad was, hulle bereidwilligheid verklaar om op versoek takke te stig en basaars as eregaste by te woon sover dit binne hul vermoë was. ${ }^{63}$

Die uitbreiding van die Helpmekaarbeweging is egter in 1916 in dele van die Kaapprovinsie aan bande gelê deur die groot droogte wat in die middellandse en noordwestelike distrikte geheers het. Die droogte het welgestelde boere geruïneer en grootskaalse werkloosheid veroorsaak, sodat die middele om die Helpmekaar in dié dele te ondersteun ontbreek het. ${ }^{64}$ Ten spyte van die droogte is talle basaars gehou om fondse in te samel en verskeie nuwe Helpmekaartakke is in die eerste helfte van 1916 gestig, soos byvoorbeeld op Cedarville, ${ }^{65}$ Kimberley-Beaconsfield, ${ }^{66}$ Malmesbury, ${ }^{67}$ Middelburg, ${ }^{68}$ Bedford, ${ }^{69}$ Noorder-Paarl ${ }^{70}$ en op talle ander dorpe. By die basaars en stigting van takke het prominente figure van veral die NP, soos WA Hofmeyr, organiserende sekretaris van die $\mathrm{NP}^{71}$ generaal Hertzog, ${ }^{72} \mathrm{dr} \mathrm{Malan}^{73}$ en vele ander, deur hul persoonlike ondersteuning aan die beweging 'n belangrike bydrae tot die bevordering en die groei van die Helpmekaarbeweging in die Kaapprovinsie gelewer. Hulle het die nood van die rebelle verduidelik en het die doelwit van die Helpmekaar uitgelig.

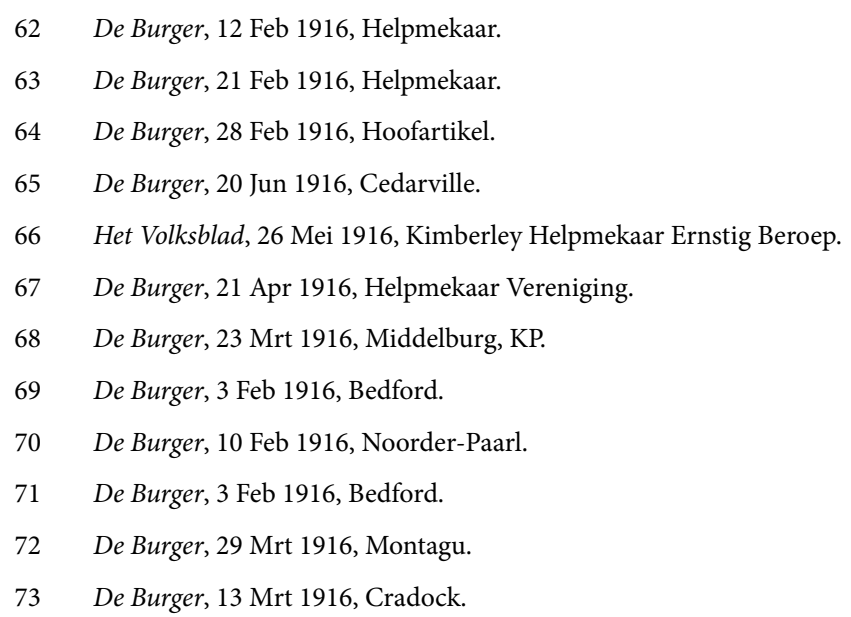




\section{Die Kaapse Helpmekaar}

$\mathrm{Na}$ die stigting van die Helpmekaarvereniging van die Kaapse Skiereiland het die noodsaaklikheid vir die totstandkoming van 'n oorkoepelende Helpmekaarvereniging vir die hele Kaapprovinsie algaande duideliker geword. Op die bestuursvergadering van die Helpmekaarvereniging van die Kaapse Skiereiland van 8 Maart 1916 is besorgdheid uitgespreek oor die feit dat elke tak beskik het oor sy eie fondse en daar nie 'n sentrale liggaam was waarheen alle fondse gekanaliseer kon word nie. Gevolglik is HS van Zijl opdrag gegee om die saak in De Burger aan te roer. ${ }^{74}$ 'n Artikel het hierop in De Burger verskyn waarin die voordele van 'n sentrale bestuur vir die Helpmekaar in die Kaapprovinsie beklemtoon is en 'n beroep is op alle takke gedoen om die saak te oorweeg en met die sekretaresse van die Kaapse Vereniging in verbinding te tree..$^{75}$

Op die bestuursvergadering van 4 April het die kwessie van 'n kongres om die Helpmekaarbeweging in die Kaapprovinsie te koördineer ter sprake gekom en is besluit om so spoedig moontlik so 'n kongres te hou. ${ }^{76}$ Deur middel van 'n omsendbrief in De Burger is alle takke ingelig oor die kongres ${ }^{77}$ wat vir 28 en 29 Junie beplan is. 'n Beroep is op takke gedoen om afgevaardigdes te stuur en waar daar nog nie takke bestaan het nie, oor te gaan tot die stigting van sodanige takke voor die aanvang van die kongres. ${ }^{78}$

By die kongres wat op 28 Junie in Kaapstad geopen is, was 37 afgevaardigdes van 42 takke plus 'n groot aantal belangstellendes en vriende teenwoordig. Dr DF Malan het opgetree as waarnemende voorsitter. Op voorstel van APN du Toit van Worcester het die kongres besluit om 'n Helpmekaarvereniging vir die Kaapprovinsie te stig. Hoewel daar baie meningsverskille oor die naam en die invoeging of weglating van die woord "nasionaal" was, is uiteindelik besluit dat die Vereniging as die "De Helpmekaar-Vereniging van de Kaapprovincie" sou bekendstaan. ${ }^{79}$

74 (HSA) Helpmekaarvereniging van die Kaapse Skiereiland, Notuleboek (9 Feb 1916-12 Feb 1931), 8 Mrt 1916, 9.

75 De Burger, 10 Apr 1916, Hoofartikel.

76 (HSA) Helpmekaarvereniging van die Kaapse Skiereiland, Notuleboek (9 Feb 1916-12 Feb 1931), 4 Apr 1916, 11.

77 De Burger, 6 Mei 1916, Een Helpmekaar Kongres.

78 De Burger, 16 Mei 1916, Het Helpmekaar Kongres.

79 De Burger, 29 Jun 1916, Helpmekaar Kongres te Kaapstad; (HSA) HVKP, Notuleboek, 28-29 Jun 1916, Kongres, 3. 


\section{STRATEGIE, FOKUS EN STRUKTUUR}

\section{Struktuur: die kongres- en takstelsel}

Wat die organisasie van die Vereniging betref, is besluit dat die kongres die hoogste gesagsliggaam sou wees. Die kongres het bestaan uit een afgevaardigde per 100 lede van elke tak. Jaarliks sou 'n sentrale bestuur, bestaande uit 'n voorsitter, vise-voorsitter, sekretaris, penningmeester en vyf ander lede, deur die kongres verkies word. Dit was die taak van die sentrale bestuur om die administratiewe sake van die Vereniging te behartig en die besluite van die kongres uit te voer ${ }^{80}$ Die eerste sentrale bestuur van die Helpmekaarvereniging van die Kaapprovinsie het bestaan uit advokaat HS van Zijl (voorsitter), WA Hofmeyr (visevoorsitter), mev Paul Roux (sekretaresse), mej $\mathrm{W}$ de Villiers (penningmeesteres) en addisionele lede Tobie Louw, mev G van Heerden, APN du Toit, mev Johan Greeff en Gert Jordaan. ${ }^{81}$

In elke distrik sou 'n tak gestig word, bestaande uit minstens tien lede en 'n plaaslike komitee. Nuwe lede moes aansluit by die tak in die distrik waar hulle woonagtig was. Elke tak moes 'n naamregister van sy lede hou. Takke kon ledegeld self vasstel, maar was verplig om jaarlikse lidmaatskapgeld van een sjieling per lid aan die sentrale bestuur oor te betaal. Lidmaatskapgeld moes jaarliks binne drie maande na die einde van die finansiële jaar aan die penningmeester van die sentrale bestuur gestuur word. Indien 'n lid in gebreke bly om ses maande na skriftelike kennisgewing sy lidmaatskapgeld te betaal word sy lidmaatskap beëindig en sy naam van die register geskrap. 'n Lid kon bedank deur skriftelik kennis te gee aan die sekretaris van sy tak. Die aantal takke in 'n fiskale afdeling sou beperk word tot die aantal dorpe in die afdeling. Daar sou slegs in besondere gevalle en met toestemming van die sentrale bestuur van die bepaling afgewyk kon word.

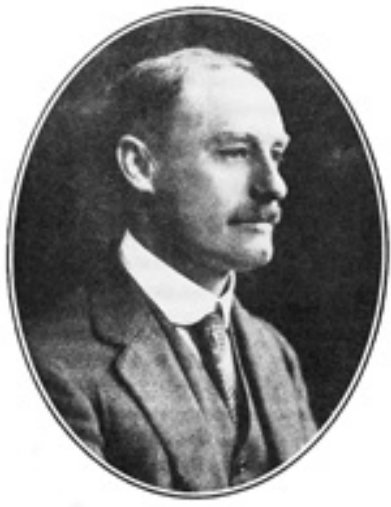

WA Hofmeyr, stigterslid van Nasionale Pers en voorsitter van Sanlam en Santam wat ook by die vroeë pogings om die Helpmekaarvereniging van die Kaapprovinsie te stig, betrokke was

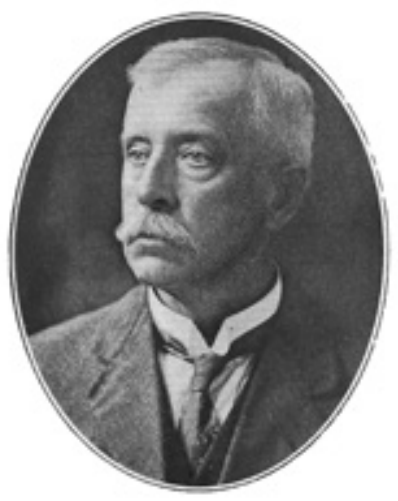

APN du Toit van Worcester, 'n prokureur wat later regter sou word, was visevoorsitter van die eerste Sentrale Bestuur van die Helpmekaarvereniging van die Kaapprovinsie

$80 \quad$ Ibid.

81 (HSA) HVKP, Notuleboek, 28-29 Jun 1916, Kongres, 9. 
Die besture van takke in 'n fiskale afdeling sou onderling die grense van die takke bepaal. In geval van geskille sou die sentrale bestuur as finale beslisser optree. Die takke sou poog om die doelwitte van die Vereniging te bevorder. Elke tak sou ook 'n eie stel huishoudelike reëls saamstel. Takbesture moes jaarliks in Januarie verkies word en bestaan uit 'n voorsitter, visevoorsitter, sekretaresse en penningmeester. Addisionele lede kon volgens die tak se behoefte bygevoeg word. Takke moes ook jaarliks 'n takverslag van alle inkomstes en uitgawes aan die penningmeester van die sentrale bestuur stuur. Takke moes ook afgevaardigdes na die jaarlikse kongres van die Vereniging stuur. Takke met minder as 100 lede was geregtig op een afgevaardigde en takke met meer as 100 lede twee afgevaardigdes. ${ }^{82}$ Hiermee was die Helpmekaarvereniging van die Kaapprovinsie as behoorlik georganiseerde en gekonstitueerde liggaam gevestig. Die takke sou voortaan op 'n vaste basis georganiseer en bestuur word, met die sentrale

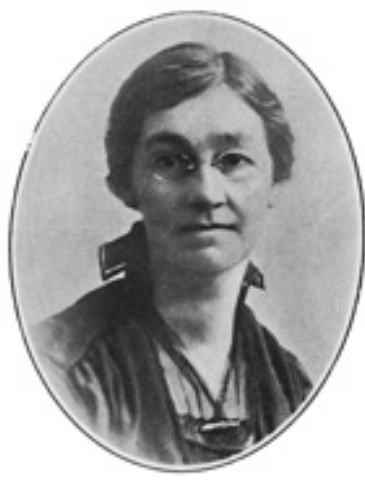

Hester Roux, sekretaresse van die Helpmekaarvereniging van die Kaapprovinsie tot met haar skielike dood in September 1938. Sy was met ds Paul Hendrik Roux wat ook as generaal in die AngloBoereoorlog gedien het, getroud. bestuur wat die leiding vanuit Kaapstad sou verskaf.

\section{Die debat oor die strategie en fokus van die Helpmekaar}

Die konsepgrondwet is met enkele veranderings deur die 1916-kongres aanvaar. Die grondwet was in 'n groot mate gebaseer op dié van die Skiereilandse tak. Die onmiddellike doel van die Vereniging was die:

“... tegemoetkoming van personen, die wegens die gevolgen van de recente opstand met schade worden bedreigd. De vereniging stelt zich verder ten doel de algemene ontwikkeling, opheffing en welvaart van het Hollands-sprekende deel van het Zuidafrikaanse volk te bevorderen, een eigen Afrikaans kultuurleven op te bouwen, en meerdere samenwerking en onderlinge ondersteuning tot stand te brengen." ${ }^{83}$

Om dié doelwitte te bereik, sou gepoog word om fondse in te samel.

“... ter tegemoetkoming aan personen, tegen wie eisen wegens schadevergoeding, ontstaat uit de recente opstand reeds zijn of nog mogen worden ingesteld, alsook aan andere, die zich in behoeftige omstandigheden bevinden en ondersteuning verdienen

82 (HSA) HS, Argiefstukke, Koncept-Konstitutie (pamphlet); (HSA) HVKP, Notuleboek, 28-29 Jun 1916, Kongres, 4-5; (HSA) Reëls en Regulasies van die HVKP, 3-5.

83 (HSA) HS, Argiefstukke. Koncept-Konstitutie (pamflet). 
en verder ter algemene bevordering van bovengenoemde doeleinden. De aankweking by Hollandssprekende Afrikaners van 'n gevoel van zelfbewustzijn en van waardering van hun taal, geschiedenis, tradities en godsdienst. De verspreiding van geskikte Hollandse lektuur, het houden van lezingen, konserten, opvoeringen, voordrachten, gezellige bijeenkomsten met dien verstande sat zij niet in strijd zijn met bogenoemde. De bevordeing van grotere zelfstandigheid op het gebied van handel en nijverheid. De samenwerking met andere bevriende lichamen." ${ }^{44}$

Met die bereiking van die eerste doel van die grondwet van die Helpmekaarvereniging van die Kaapprovinsie met die suksesvolle 1917-insamelingsveldtog en die terugbetaling van die rebelleskuld het die Vereniging sy aandag aan sy tweede doel gewy, naamlik die algemene ontwikkeling, opheffing en welsyn van die Hollandssprekende deel van die Suid-Afrikaanse nasie, en die ontwikkeling van 'n unieke Afrikaanse kultuurlewe en 'n gevoel van gemeenskaplikheid. ${ }^{85}$

In die nadraai van die 1917-gebeure moes die Vereniging na vore kom met praktiese maniere om hul tweede grondwetlike doelwit ten beste te verwesenlik. In die debatte wat ná 1917 hieroor in Helpmekaar-geledere gevoer is, het die oplossing van die armblankevraagstuk sentraal gestaan. Die voorstelle in dié verband was legio. Die versoeke om hulp was divers. Uiteindelik sou die beperkinge van die Helpmekaar se finansiële middele, die praktiese uitvoerbaarheid en implikasies van hulpverlening en die vraag na hoe daar binne dié beperkinge die maksimum impak bewerkstellig kon word van deurslaggewende belang wees vir die bepaling van die fokus van die Helpmekaar.

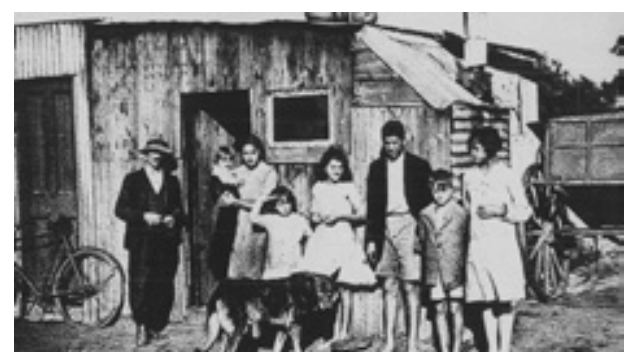

Armblanke gesin: $\mathrm{Pa}$

met sy sewe kinders voor

hul plakkershut

Selfs voor die afhandeling van die rebelleskuld was daar tekens dat die Helpmekaarbeweging verwagtinge by minstens sommige van sy ondersteuners geskep het dat dit as redmiddel vir die armblankevraagstuk kon dien. Die armblankevraagstuk het reeds by die 1916-kongres neerslag gevind toe die reg aan plaaslike takke toegestaan is om plaaslike armes te help. ${ }^{86}$ 'n Belangrike inisiatief om die kwessie op 'n nasionale vlak te benader

84 Ibid.

85 (HSA) Reëls en Regulasies van die HVKP, 1. De Nationale Pers, Beperkt, 1919.

86 (HSA) HVKP, Notuleboek, 28-29 Jun 1916, Kongres, 7. 


\section{Die Kaapse Helpmekaar}

het ook tydens die kongres beslag gekry met die aanvaarding van die voorstel van Cradock/ Worcester dat:

"Met het oog op de omvang en de ingewikkeldheid van de arme-blankekwestie, en met het oog op de noodzakelikheid om de aandacht van het volk op dit allerbelangrijkste en allerdringendste vraagstuk te vestigen, en in het leven te roepen die welingelichte volksdrang die voor een doeltreffende en finale oplossing nodig is, spreke de vergadering de wenselikheid uit dat er over deze kwestie zo spoedig als mogelik is een volkskongres zal gehouden worden, waarop de verschillende onderdelen van het vraagstuk behandeld zullen worden door personen die daartoe biezondere bevoegdheid bezitten en die vooraf daartoe gevraagd zijn, en verzoeke de vergadering de Kommissie voor de Inwendige Zending van de Ned. Geref. Kerk om zodanige kongres te beleggen, en voor dit doel de samenwerking te verzekeren van de verschillende Helpmekaar-organisaties en Vrouweverenigingen in de Unie." 87

Die sekretaresse van die sentrale bestuur is ook opdrag gegee om die besluit aan die sekretaris van die "Inwendige Zending Kommissie" mee te deel en dat die tyd en plek van so 'n kongres deur die Kommissie bepaal moes word. ${ }^{88}$

Aanduidings dat die Helpmekaarvereniging vroeg reeds deur die publiek en simpatiseerders "getaak" is om 'n rol in die oplossing van die armblankekwessie te speel was die aanbod wat die sentrale bestuur in Maart 1917 van CC de Villiers, met 'n aanbeveling en resolusie van die Kaapse Skiereiland-tak, ontvang het. In die aanbod het De Villiers'n plaas wat hy in die Prins Albert-distrik besit het aan die Helpmekaar aangebied om vir 'n periode van 5 jaar sonder

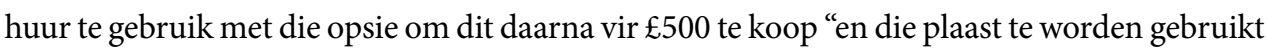
als 'n 'nedersetting' voor enige arme blanke families'.

Die sentrale bestuur het De Villiers versoek om meer besonderhede oor die plaas te verskaf en sy aanbod ook met 'n maand te verleng om hul meer tyd te gee om 'n besluit te neem. ${ }^{89}$ Praktiese betrokkenheid op dié vlak - die stigting van nedersettings - het egter op dié stadium nie in die smaak van die Helpmekaar geval nie en mnr Gert Jordaan, 'n lid van die sentrale bestuur, was van mening dat "ons eerste werk is te helpen met de rebellie ondergang bedreigde vrienden" en dat hy die aangeleentheid as 'n saak vir die "Inwendige Sending Kommissie"

87 (HSA) HVKP, Notuleboek, 28-29 Jun 1916, Kongres, 9.

$88 \quad$ Ibid.

89 (HSA) HVKP, Notuleboek (3 Jul 1916-20 Mei 1919), Sentrale Bestuur 31 Mrt 1917, 53-54. 
beskou het. Aangesien ondersoek getoon het dat die plaas ook ongeskik vir die vestiging van 'n nedersetting was, het die sentrale bestuur besluit om die aanbod van die hand te wys. ${ }^{90}$

Tydens die 1917-kongres het die sentrale bestuur in hul verslag gerapporteer dat die besluit oor die hou van 'n armblanke-volkskongres aan die "Inwendige Zending Kommissie" oorgedra is en dat sodanige kongres in November 1916 in Cradock gehou is en deur Gert Jordaan bygewoon is. WA Hofmeyr is ook deur die sentrale bestuur afgevaardig, maar hy kon ongelukkig nie die kongres bywoon nie. ${ }^{91}$ Die kongres het ook besluit dat die Vereniging in die volgende jaar spesiaal op maniere moes fokus om die armblankekwessie op te los en op voorstel van JE Vosloo/TJ Louw is besluit dat:

"Die Sentraal Bestuur mag 'n kommissie benoem van 3 uit sigself of andersins, om afsonderlik, of in oorlog met andere liggame spesiale aandag aan die Arme Blanke vraagstuk te wy gedurende die volgende jaar - om dan met praktiese wenke voor die volgende kongres te kom, om aan te toon op hoe danige wyze die Helpmekaar Vereniging best kan bydra tot die oplossing van hierdie ernstige vraagstuk, en, volgens die besluit van die Kongres te Cradock, om gevallene (blanke) die in die gevangenisse is, weer op die been te help, als hulle uit die tronke kom."92

Die riglyne vir die administrasie en aanwending van die Helpmekaarvereniging van die Kaapprovinsie se deel van die surplus is op die Vereniging se kongres in 1918 neergelê. ${ }^{93}$ Alreeds voor die aanvang van die kongres is 'n kommissie, bestaande uit dr DF Malan, adv HS van Zijl en adv Wessel Roux, ${ }^{94}$ aangestel om die finansiële posisie van die Vereniging te ondersoek en voorstelle in dié verband te maak. ${ }^{95}$ Die voorstelle in verband met die surplus, soos deur die kommissie aanbeveel, is deur die sentrale bestuur ${ }^{96}$ en ook die kongres aanvaar. Die geld sou as 'n vaste fonds deur die sentrale bestuur belê word. Vyf trustees, wat deur die kongres benoem is, sou vir regsdoeleindes as eienaars van die Fonds optree en die Helpmekaarvereniging in alle regsgedinge verteenwoordig. In geval waar die Vereniging sou ophou om te bestaan, sou alle magte en funksies wat in die kongres en sentrale bestuur

90 (HSA) HVKP, Notuleboek (3 Jul 1916-20 Mei 1919), Sentrale Bestuur 5 Mei 1917, 56.

91 (HSA) HVKP, Notuleboek, 11-12 Jul 1917, Kongres, Verslag Sentrale Bestuur, 3.

92 (HSA) HVKP, Notuleboek, 11-12 Jul 1917, Kongres, 14.

93 (HSA) HVKP, Notuleboek, 22-23 Mei 1918, Kongres, 3.

94 Wessel Roux was 'n Kaapstadse advokaat, Hertzog-ondersteuner, een van die eerste lede van die Nasionale Party in Kaapland en was sedert 1917 'n NP- lid van die Volksraad. Hy was ook 'n stigters- en direksielid van Nasionale Pers. Suid-Afrikaanse Biografiese Woordeboek IV, 550.

95 (HSA) HVKP, Notuleboek (3 Jul 1916-20 Mei 1919), Sentrale Bestuur, 11 Mei 1918, 106.

96 (HSA) HVKP, Notuleboek (3 Jul 1916-20 Mei 1919), Sentrale Bestuur, 21 Mei 1918, 112. 


\section{Die Kaapse Helpmekaar}

gevestig was, deur die trustees oorgeneem word. Die besteding van die rente wat jaarliks op die vaste fonds verdien sou word, sou volgens besluit van die kongres en op aanbeveling van die sentrale bestuur bestee word. ${ }^{97}$

Die Kaapprovinsie se deel van die surplus het op $£ 39432$ 12s 8d te staan gekom. Op die 1919-kongres is besluit om die bedrag, wat as die "Afrikanerdag Helpmekaar Surplus Fonds" bekend sou staan, na $£ 40000$ te vermeerder. ${ }^{98}$ Die beskikbaarheid van die Surplusfonds na die 1917-fondsinsameling het die verwagtinge van die Helpmekaar as redmiddel vir die armblankekwessie hernude stukrag gegee wat aanleiding gegee het tot 'n wye verskeidenheid voorstelle wat deurlopend op die oplossing van die armblankevraagstuk gerig was. ${ }^{99}$ ZB Jansen van Richmond se voorstel namens sy tak tydens die 1919-kongres, was 'n goeie voorbeeld, naamlik dat die

“... Kongres nederig tog dringend” versoek word "om planne te beraam om die deel van die Helpmekaarsurplus wat die Kaapprovinsie toekom tot meer algemeen nut van land en volk te bestee dan tot hiertoe die geval was, deur bv. arme blanke op die platteland neer te set; behoeftige huisgesinne wat in verwaarloosde omgewinge woon van beter huisvesting te voorsien; die oprigting van Losiesinrigtinge vir Hollandssprekende meisies wat vir geringe salarisse in groot stede werk; die opleiding van verdienstelike Hollandssprekende Afrikaners wat behoeftig is; die oprigting van'n Volkshospitaal in die Middellandse Distrikte, ens."

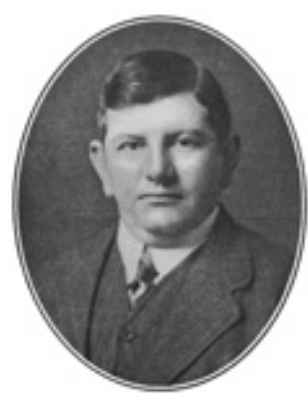

Adv JWJW (Wessel) Roux, penningmeester van die Helpmekaarvereniging van die Kaapprovinsie, 1916-1958

Sy voorstel het gelei tot die benoeming van 'n kommissie om spesifiek die oprigting van 'n Volkshospitaal vir die Middellandse Distrikte te ondersoek. By die volgende kongres moes gerapporteer word oor die insluiting van die voorwaarde wat ook gespreek het van 'n versigtigheid en onsekerheid oor waartoe die Helmekaar hom finansieel moet verbind “... dat hierdie besluit die Helpmekaar-Vereniging nie verbind om geld uit te gee in verband met die ondersoek van die Kommissie of met die oprigte van 'n hospitaal nie". ${ }^{100}$

\footnotetext{
97 (HSA) HVKP Notuleboek, 22-23 Mei 1918, Kongres, 3.

98 (HSA) HVKP, Notuleboek, 21-22 Mei 1919, Kongres, 4, 6.

99 (HSA) HVKP, Notuleboek, 22-23 Mei 1918, Kongres, 5.

100 (HSA) HVKP, Notuleboek, 21-22 Mei 1919, Kongres, 7, 8.
} 
Ander behoeftes het die vorm aangeneem van voorstelle vir "die daarstelling van inrigtings op die mees sentrale plekke, op die pond-vir-pond-stelsel, om die griepwese en arme blanke kinders op te neem en hulle tegemoet te kom in die lyn van opvoeding", ${ }^{101}$ verligting van die behuisingsnood van armblankes in stede en dorpe ${ }^{102}$ en werkverskaffing aan armblankes deur die opneem van minstens 5000 aandele in 'n beoogde wolfabriek wat op Harrismith opgerig sou word

“daar die fabriek aldaar 'n onmiddellike voorsiening gaat maak vir minstens 800 arme-

blankes van ons land, en dit juis die hoofdoel van ons Vereniging is". ${ }^{103}$

Die groot fokus van die Helpmekaar op armoede is weerspieël deur die voorsitter, dr AJ Stals, ${ }^{104}$ se aansporing tot erns tydens die eerste vergadering van die sentrale bestuur in 1923 en sy uitspraak dat die "armoede onder ons volk neem dageliks toe en op ons rus 'n groot verantwoordelikheid". ${ }^{105}$ Die 1923-kongres het dan ook 'n beskrywingspunt aanvaar waarin die Helpmekaar sy bekommernis uitgespreek het oor die voortdurende ekonomiese agteruitgang van die volk en toename in die getal armblankes en die sentrale bestuur opgedra om in oorleg met bevriende liggame so spoedig moontlik 'n volkskongres byeen te roep, ten einde die staat dringend te versoek om dadelik in te gryp en 'n einde te maak aan die proses van agteruitgang en verarming. ${ }^{106}$

Te midde van die geraas oor die armblankevraagstuk se oplossing het die Helpmekaar op beide sentrale en plaaslike vlak versoeke ontvang om finansiële steun van organisasies soos hospitale, skole, kerke, asook van individue met verdienste of nood. Onder die individuele versoeke het 'n nuwe kategorie hom toenemend aangemeld, naamlik versoeke van skoliere en studente vir beurse of lenings vir verdere onderwys en opleiding. ${ }^{107}$ Reeds in September 1916, terwyl hulle nog gesukkel het om die rebelleskuld te delg, het die sentrale komitee 'n versoek van die Riebeek-Oos-tak ontvang vir finansiële steun vir hul plaaslike skool.

101 (HSA) HVKP, Notuleboek, 26-27 Mei 1920, Kongres, 7.

102 (HSA) HVKP, Notuleboek, 26-27 Mei 1920, Kongres, 5; (HSA) HVKP, Notuleboek 25-26 Apr 1923, Kongres, 13.

103 (HSA) HVKP, Notuleboek, 25-26 Mei 1921, Kongres, 7-8.

104 Stals was 'n mediese dokter wat op Worcester gepraktiseer het. In 1924 is hy as NP LV vir Hopetown verkies. Hy sou later ook in die sakewêreld 'n rol speel en was onder andere 'n direkteur van Volkskas en Voortrekkerpers. Hy was ook lid van Malan se 1948 kabinet as Minister van Onderwys, Gesondheid en Volkswelsyn. Suid-Afrikaanse Biografiese Woordeboek III, 772.

105 (HSA) HVKP, Notuleboek (19 Mrt 1921- 15 Apr 1924), Sentrale Bestuur 16 Feb 1923, 142.

106 (HSA) HVKP, Notuleboek, 25-26 Apr 1923, Kongres, 12-13.

107 (HSA) HVKP, Notuleboek (3 Jul 1916-20 Mei 1919), 2 Feb 1918, 97 en 20 Apr 1918, 104. 
Die Helpmekaar het aangedui dat hulle nie op daardie stadium kon help nie en die tak na die ACVV verwys. ${ }^{108}$ Ten spyte van die afwysing van die versoek het die Helpmekaar oor die daaropvolgende vyf jaar 'n duidelike opvoedkundige fokus ontwikkel. Hierdie fokus is gevorm deur die veranderende aard van die versoeke om hulp wat hulle ontvang het en die alomteenwoordigheid van die armblankeprobleem.

Aanvanklike versoeke van skoliere en studente om finansiële ondersteuning kon nie toegestaan word nie, aangesien die Helpmekaar Kongres nie enige fondse daarvoor bewillig het nie. Tydens die 1918-kongres het die sentrale bestuur egter $£ 800$ bewillig vir beurse vir "Afrikaner-seuns" wat reeds 'n eerste graad voltooi het vir "handelsopleiding" oorsee. ${ }^{109}$ Hierdie belegging in opvoeding, spesifiek in handelsopleiding, het gestrook met die neiging om 'n oplossing vir die armblankeprobleem en die onderverteenwoordiging van Afrikaners in die ekonomiese wêreld in opvoeding, die verowering van die handelswêreld en entrepreneurskap te soek. ${ }^{110}$ Die doel van die handelsopleiding oorsee was nie net gemik op die verwerwing van teoretiese kennis nie, maar ook bedoel om praktiese ervaring in aspekte soos die bestuur van besighede te verwerf ${ }^{111}$ - met die doel om hul kennis en ervaring met hul terugkeer in die ontwikkeling van die Suid-Afrikaanse ekonomie en handelswêreld terug te ploeg. ${ }^{112}$ Die motief van die inisiatief is tydens die 1920-kongres as volg deur die voorsitter van die Helpmekaar, HS van Zijl, toegelig:

"Neem verder die hulp deur die Helpmekaar verskaf aan jonge mense die sig op gebied van Handelsekonomie op te werk. Reeds is daar drie gegradueerde studente in Holland en een in Amerika wat met behulp van die Helpmekaar in die handel studeer, en twee sal deur die loop van die jaar na Holland gaan. Dit is op hierdie gebied veral waar die Helpmekaar Suid-Afrika tot groot diens kan wees. Op ekonomiese gebied is daar'n groot ontwaking gekom onder ons volk, maar jong Afrikaners met 'n grondige ekonomiese opleiding is nodig om die heersende onkunde op die gebied te verplaas met kennis.

108 (HSA) HVKP, Notuleboek (3 Jul 1916-20 Mei 1919), Sentrale Bestuur, 2 Sep 1916, 13.

109 (HSA) HVKP, Notuleboek, 22-23 Mei 1918, Kongres, 1, 4. In die oorspronklike voorstel wat deur die Kongres aanvaar is en waarvan hierdie besluit 'n uitvloeisel was, is aangedui dat die beurse aan "Afrikanerseuns" vir oorsese studie toegeken moes word. In die toekenning van beurse wil dit voorkom asof aan die twee voorwaardes voorkeur gegee is. (HSA) HVKP Notuleboek (3 Jul 1916-20 Mei 1919), Sentrale Bestuur 8 Jun 1918, 115; 10 Aug 1918, 131; 1 Feb 1919, 144; 8 Mrt 1919, 157; (HSA) HVKP, Notuleboek, 21-22 Mei 1919, Kongres, Sentrale Komitee-verslag, 3.

110 A Ehlers, "Die Helpmekaarbeweging in Suid-Afrika: die Storm- en-Drangjare, 1915-1920", MA, Universiteit Stellenbosch, 1986, 146-148.

111 (HSA) HVKP, Notuleboek (28 Jun 1919-19 Feb 1921), Sentrale Bestuur, 28 Jun 1919, 3.

112 (HSA) HVKP, Notuleboek (3 Jul 1916-20 Mei 1919), Sentrale Bestuur, 5 Apr 1919, 165-166; (HSA) HVKP, Notuleboek (28 Jun 1919-19 Feb 1921), Sentrale Bestuur, 28 Jun 1919, 9 en 12 Aug 1919, 24. 
Kyk die moeilikheid wat ons vandag in sit met betrekking tot die wisselkoers. Die algemene onkunde wat daaromtrent heers, maak ons volk die prooi van alle soorte bangmakery wat tot noodwendig gevolg het 'n ongesonde, onbestendige maatskappelik lewe. Die mense wat tot nog toe in die sake belang gestel het en daar iets van af weet, is maar meest almal mense wat een hele oog en die grootste gedeelte van die ander oog op die belange van die Empire het. Suid-Afrika het haar eie seuns nodig, wat goed in die vak opgelei is, en wat albei hul oë op die belange van Suid-Afrika het - nie om daardeur die Empire te benadeel nie, maar om daardeur Suid-Afrika sonder enige agterdog te dien. Ek was bly om laaste Saterdag 'n artikel in "De Burger" te sien oor die wisselkoers tussen Amerika en Europa, geskrewe deur MH de Kock, ons Helpmekaar-student in Amerika. Dit is 'n mooi teken."113

Hierdie handelsfokus het soos dit verder ontwikkel het 'n tweeledige benadering behels. Eerstens die bou van intellektuele kapitaal deur die toekenning van beurse en later lenings aan studente om handelskwalifikasies en praktiese ervaring oorsee te verwerf en tweedens pogings om 'n plaaslike institusionele basis/inrigting vir opleiding in handelstudies daar te stel.

Die sentrale bestuur het in die maande na die 1918-kongres verskeie versoeke om finansiële steun van studente ontvang. Daar was egter nie veel versoeke vir handelstudies nie. Die wat wel aansoek gedoen het, is nie as behoeftig beskou nie. Van die drie aansoeke wat vir studie in die handel ontvang is, is aan twee (JS Wapenaar and Philip R Botha) beurse van $£ 100$ per jaar vir oorsese studie toegeken. ${ }^{114}$ Botha het uiteindelik handelsekonomie in Holland gaan studeer terwyl Wapenaar later sy aansoek teruggetrek het. ${ }^{115}$ 'n Besluit oor die aansoek van Mariaan Strijdom, wat haar handelstudies in Kaapstad wou doen, is tot na die 1919-kongres uitgestel ${ }^{116}$ en is uiteindelik afgewys, aangesien sy weens haar welgestelde ouers nie as

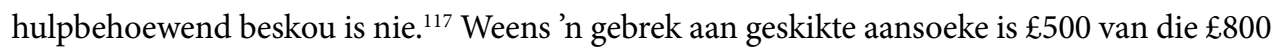
wat vir beurse vir handelstudies bewillig is uiteindelik aan die Griepwese Fonds geskenk. ${ }^{118}$

113 (HSA) HVKP, Notuleboek, 26-27 Mei 1920, Kongres, Voorsittersrede, 2.

114 (HSA) HVKP, Notuleboek (28 Jun 1919-19 Feb 1921), Sentrale Bestuur, 26 Jun 1920, 101; (HSA) HVKP, Notuleboek, 21-22 Mei 1919, Kongres, Sentrale Komitee-verslag, 3.

115 (HSA) HVKP, Notuleboek, 3-4 Apr 1929, Kongres, Sentrale Komitee-verslag, 3.

116 (HSA) HVKP, Notuleboek (3 Jul 1916-20 Mei 1919), Sentrale Bestuur, 10 Mei 1919, 174-175.

117 (HSA) HVKP, Notuleboek (28 Jun 1919-19 Feb 1921), Sentrale Bestuur, 28 Jun 1919, 8.

118 (HSA) HVKP, Notuleboek, 21-22 Mei 1919, Kongres, Sentrale Komitee-verslag, 3. 


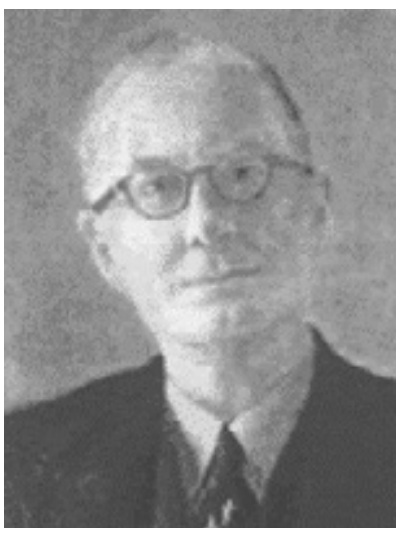

MH de Kock, president van die Suid-Afrikaanse Reserwebank, 1 Julie 1945-30 Junie 1962. De Kock was een van die eerste studente wat deur die Helpmekaarvereniging van die Kaapprovinsie gehelp is.
Ten spyte van die aanvanklike trae reaksie het die inisiatief uiteindelik 'n uitsonderlike groep studente opgelewer. Hoewel dit nie 'n volledige lys is nie, is die volgende voorbeelde 'n aanduiding van die impak wat individue gehad het wat deel was van die inisiatief op sleutelgebiede en -instellings in die ekonomiese ontwikkeling van Suid-Afrika. MH de Kock119 het met sy Helpmekaar gefinansierde Harvard $\mathrm{PhD}$ die President van die Suid-Afrikaanse Reserwebank geword en was tydens sy termyn (1945-1962) instrumenteel in die vestiging van die sentrale bankwese en die gepaardgaande finansiële instellings in Suid-Afrika.120 CGW Schumann121 het met sy "Economische Hoogeschool”, Rotterdam $\mathrm{PhD}$ die grondlegger en stigter van die Fakulteit van Ekonomiese en Bestuurswetenskappe aan Stellenbosch Universiteit geword en ook 'n belangrike rol in die Eerste Ekonomiese Volkskongres van 1939 gespeel.122 Frederik

119 In Oktober 1919 het die Sentrale Komitee aan MH de Kock, “'n verdienstelike jong man", 'n beurs toegeken om sy handelsopleiding aan Harvard in Amerika voort te sit. De Kock het sy PhD met die onderwerp "Finances of the Union of South Africa" voltooi. Met sy terugkeer na Suid-Afrika is hy as senior lektor in Ekonomie aan die Universiteit van Kaapstad aangestel. Die Sentrale Komitee het De Kock se sukses geïnterpreteer as "'n vrug van die Helpmekaar-werk". (HSA) HVKP, Notuleboek (19 Mrt 1921-15 Apr 1924), Sentrale Bestuur, 5 Jul 1922, 102; 18 Aug 1922, 107; 22 Mrt 1923, 162; (HSA) HVKP, Notuleboek (21 Mei 1924-3 Apr 1928), Sentrale Bestuur 15 Feb 1928, 231.

120 Beyers en Basson (reds) Suid-Afrikaanse Biografiese Woordeboek, V, 188-189, RGN, Pretoria, 1987.

121 Hoewel CGW Schumann se aansoek vir 'n "Handels Beurs" aanvanklik weens 'n gebrek aan fondse nie toegestaan kon word nie, is 'n beurs in Desember 1919 aan hom toegeken wat later met 'n $£ 50$-lening aangevul is. Beide beurs en lening is later in 'n beurs omskep wat deur die Universiteit van Stellenbosch befonds is uit die jaarlikse $£ 300$ wat die Helpmekaar aan die instelling geskenk het vir die daarstelling van 'n "Handelstoel". Na voltooiing van sy PhD in Holland in 1923 is hy in 1924 as senior lektor in handelswetenskappe aan die Universiteit van Stellenbosch aangestel - wat die begin van die Fakulteit van Ekonomiese en Bestuurswetenskappe was. (HSA) HVKP, Notuleboek (28 Jun 1919-19 Feb 1921), Sentrale Bestuur 22 Nov 1919, 54-55; 20 Des 1919, 61; 20 Nov 1920, 142; (HSA) HVKP, Notuleboek (19 Mrt 1921-15 Apr 1924), Sentrale Bestuur 30 Jul 1921, 31, 36; (HSA) HVKP, Notuleboek, 26-27 Apr 1922, Kongres, Verslag van die Sentrale Bestuur, 4; (HSA) HVKP, Notuleboek (19 Mrt 1921-15 Apr 1924), Sentrale Bestuur 30 Mei 1923, 181; 30 Jul 1923, 195-196; 17 Mrt 1924, 257; (HSA) HVKP, Notuleboek, 15-17 Apr 1924, Kongres, Sentrale Komitee verslag, 4.

122 Beyers en Basson (reds) Suid-Afrikaanse Biografiese Woordeboek, V, 738-739, RGN, Pretoria, 1987. 
Meyer, ${ }^{123}$ met sy Charlottenburg, Berlyn cum laude $\mathrm{PhD}$ in Ingenieurswese, het 'n Suid-Afrikaanse kenner van chemiese en metallurgiese ingenieurswese geword. Hy was die dryfkrag agter die vestiging van 'n yster en staal nywerheid in Suid-Afrika en die uiteindelike stigting van YSKOR - 'n instelling waarvan hy ook lank die voorsitter was. Hy het ook vroeë aanvoorwerk vir die stigting van KRYGKOR gedoen, terwyl sy basiese navorsing oor die vervaardiging van olie uit steenkool bygedra het tot die lê van die grondslag vir die industriële prosesse wat uiteindelik tot die stigting van SASOL gelei het. ${ }^{124}$ AJ Bruwer, ${ }^{125}$ wat as voorsitter van die Raad vir Handel en Industrie (1926) 'n belangrike rol gespeel het om Meyer in die yster en staal industrie betrokke te kry. ${ }^{126}$ RL Barry met sy belangstelling in die vrugtebedryf en veral vrugte-uitvoer het sy teoretiese opleiding in Holland gedoen, waarna hy dit met praktiese ondervinding in die vrugteuitvoerbedryf in Amerika opgevolg het. Daarna het hy hom by Imperial Cold Storage aangesluit en ook betrokke geraak in vroeë pogings om 'n institusionele basis vir handelsopleiding by die Universiteit van Stellenbosch te vestig. ${ }^{127}$

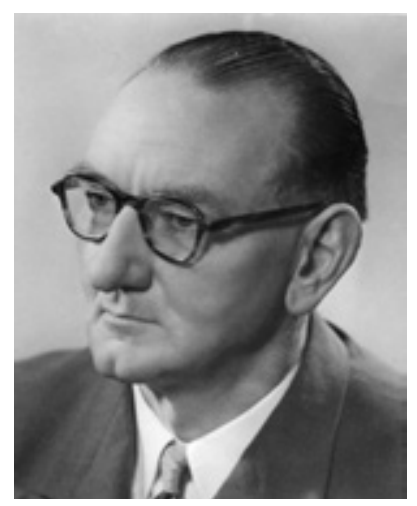

Prof CGW Schumann, eerste professor en dekaan van die Fakulteit Ekonomiese en Bestuurswetenskappe by die Universiteit van Stellenbosch. Christie Schumann is finansieel deur die HVKP ondersteun met die doel om ' $n$ Handelsfakulteit op Stellenbosch totstand te bring.

123 Die Helpmekaar het in 1921 'n lening aan Frederik Meyer toegeken om Industriële Chemie in Duitsland te gaan studeer. (HSA) HVKP, Notuleboek (19 Mrt 1921-15 Apr 1924), Sentrale Bestuur, 1 Okt 1921, 47; 12 Nov 1921, 51. (HSA) HVKP, Notuleboek (19 Mrt 1921-15 Apr 1924), Sentrale Bestuur, 18 Aug 1922, 110. (HSA) HVKP, Notuleboek (19 Mrt 1921-15 Apr 1924), Sentrale Bestuur, 15 Apr 1924, 260. (HSA) HVKP, Notuleboek (21 Mei 1924-3 Apr 1928), Sentrale Bestuur, 25 Jul 1924, 25.

124 Beyers en Basson (reds) Suid-Afrikaanse Biografiese Woordeboek, V, 538-539, RGN, Pretoria, 1987.

125 Nadat AJ Bruwer se aansoek aanvanklik geweier is omdat hy as "onstandvastig" beskou is, is 'n beurs in 1920 aan hom toegeken om sy "handelstudies" in Amerika voort te sit. Ten spyte van sy blootstelling aan Amerikaanse kapitalisme en sy posisie as staatsdiensamptenaar, het hy 'n uitgesproke teenstander geword van die kapitalisme wat hy as "'n vloek vir die mensdom" beskryf het. In sy 1934-publikasie Kapitalisme Party-Politiek en Armoede, (Nasionale Pers Beperk, Bloemfontein, 1934) het hy 'n stelsel van Nasionaal-Sosialisme vir Suid-Afrika bepleit. (HSA) HVKP, Notuleboek (28 Jun 1919-19 Feb 1921), Sentrale Bestuur, 7 Feb 1920, 76; 16 Okt 1920, 128.

126 Beyers en Basson (reds) Suid-Afrikaanse Biografiese Woordeboek, V, 539, RGN, Pretoria, 1987.

127 (HSA) HVKP, Notuleboek (19 Mrt 1921-15 Apr 1924), Sentrale Bestuur, 30 Jul 1921, 36; 22 Sep 1922, 121; 16 Feb 1923, 145; 22 Mrt 1923, 161; 28 Jun 1923, 193. (HSA) HVKP, Notuleboek, 26-27 Apr 1922, Kongres, Verslag van die Sentrale Bestuur, 4. 
Pogings om 'n plaaslike institusionele basis/inrigting vir handelsopleiding te vestig is in Julie 1918 deur die sentrale bestuur geïnisieer toe besluit is om die daarstelling van so 'n instelling, asook koshuisgeriewe vir die studente te ondersoek. ${ }^{128}$ Daar is ook pogings aangewend om inligting te bekom oor die funksionering van "Handels Skole" in Holland en die tipe vakke wat hulle aan "jong manne" aanbied. ${ }^{129}$ Hierdie fokus op handelsopleiding ${ }^{130}$ was waarskynlik die gevolg van die invloed van 'n groep bestaande en ontluikende Afrikanerkapitaliste en ander lede van die Kaapse Afrikaner-elite wat die nasionalistiese beweging en Afrikaner-etniese mobilisasie van die periode ondersteun het. ${ }^{131}$

Die sentrale bestuur en beurskomitee, ${ }^{132}$ wat getaak was om die inisiatief uit te voer, het onder andere bestaan uit lede soos WA Hofmeyr, ${ }^{133}$ Fred Dormehl, ${ }^{134}$ dr DF Malan and dr GG Cillié. ${ }^{135} \mathrm{Na}$ Dormehl se afsterwe weens griep ${ }^{136}$ is Ludwig Wiener, prominente Kaapstadse sakeman en eienaar van die groothandelaar Wiener and Company, ${ }^{137}$ op die Beurskomitee gekoöpteer. ${ }^{138}$ Deur Wiener se bemiddeling het hulle die kennis en ondervinding van simpatiekgesinde plaaslike Kaapstadse besighede probeer benut en daarin geslaag om lede van die Afrikaanse Handelshuis, ${ }^{139}$ Santam en Nasionale Pers in die aanbieding

(HSA) HVKP, Notuleboek (3 Jul 1916-20 Mei 1919), Sentrale Bestuur, 13 Jul 1918, 123.

(HSA) HVKP, Notuleboek (28 Jun 1919-19 Feb 1921), Sentrale Bestuur, 28 Jun 1919, 12-13; 9 Aug 1919, 19; 18 Okt 1919, 28.

(HSA) HVKP, Notuleboek (3 Jul 1916-20 Mei 1919), Sentrale Bestuur, 10 Aug 1918, 131.

(HSA) HVKP, Notuleboek (3 Jul 1916-20 Mei 1919), Sentrale Bestuur, 8 Jun 1918, 118-119.

(HSA) HVKP, Notuleboek (3 Jul 1916 - 20 Mei 1919), Sentrale Bestuur, 13 Jul 1918, 123.

NJ le Roux, WA Hofmeyr - sy werk en waarde ,128-129, Nasionale Boekhandel, Kaapstad, 1953.

Hy was ook 'n lid van die Helpmekaar se Beleggingskomitee wat die Helpmekaar surplus belê het. NJ le Roux, WA Hofmeyr - sy werk en waarde, 128; (HSA) HVKP, Notuleboek (3 Jul 1916-20 Mei 1919), Sentrale Bestuur, 8 Jun 1918, 117.

Dekaan van die Fakulteit Opvoedkunde en later die eerste rektor van Universiteit Stellenbosch. CJ Beyers (red) Suid-Afrikaanse Biografiese Woordeboek, IV, 85, Butterworth, Durban, 1981.

(HSA) HVKP, Notuleboek, 21-22 Mei 1919, Kongres, Verslag van die Sentrale Bestuur, 3.

Kruger en Beyers (reds.) Suid-Afrikaanse Biografiese Woordeboek, III, 863-864, Tafelberg-Uitgewers, Kaapstad, 1977.

(HSA) HVKP, Notuleboek (3 Jul 1916-20 Mei 1919), Sentrale Bestuur, 14 Des 1918, 134.

Die Afrikaanse Handelshuis is in 1918 as algemene handelsaak deur Kaapse Afrikaners soos Anthonie Benning gestig. Die onderneming, op die hoek van Burg- en Kasteelstraat in Kaapstad, het veral op die behoeftes van die boeregemeenskap gekonsentreer en ' $n$ groot- en ' $n$ kleinhandel afdeling gehad wat onder andere ysterware en plaasgereedskap verkoop het. Die Burger het baie van die Handelshuis se advertensies hanteer. Eric Rosenthal, Manne en Maatskappye. Die Geskiedenis van die Eerste Afrikaanse Sakemanne, 81-82, Human \& Rousseau, Kaapstad, 1963. 
van aandklasse geïnteresseerd te kry. ${ }^{140}$ Die simpatie en ondersteuning van die plaaslike ondernemings is verder onderstreep deur ' $n$ inisiatief van die eienaars van die Afrikaanse Handelshuis wat die stigting van 'n fonds vir "behoeftige leerjongens" met die oog op "die opleiding van jong Afrikaners in die handel" - 'n inisiatief waarvoor hulle die Helpmekaar se ondersteuning gesoek het. ${ }^{141}$

In 1919 is die pogings om 'n instelling vir ekonomiese en handelsopleiding daar te stel na die Universiteit van Stellenbosch gekeer. Die 1919-Helpmekaar Kongres het besluit om $£ 300$ aan die universiteit te skenk op voorwaarde dat hulle'n "Handel Stoel" tot stand bring ${ }^{142}$ of die geld aanwend om iemand vir die posisie op te lei. ${ }^{43}$ Daar is ook besluit om dit' $n$ jaarlikse donasie te maak. ${ }^{144}$ Volgehoue druk deur die Helpmekaar ${ }^{145}$ het vrugte afgewerp toe die Senaat van die Universitet in 1921 besluit het om die Helpmekaargeld aan te wend as beurs van $£ 150$ per jaar vir CGW Schumann vir sy doktorale studies ter voorbereiding vir die daarstelling van 'n

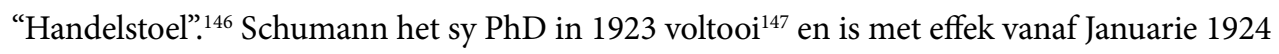
as senior lektor in handelstudies aangestel. ${ }^{148}$ Van die nege studente wat in 1924 vir'n B.Comkursus geregistreer het, het die getalle tot 68 in 1929 toegeneem ${ }^{149}$ met die eerste doktorsgraad wat einde 1930 toegeken is. ${ }^{150}$ In sy 1930- verslag aan die Helpmekaar het die registrateur van die Universiteit van Stellenbosch, TJP Dekker, bevestig dat die doelwitte van die Helpmekaarinisiatief om op handelsopleiding te fokus en soos in 1920 deur Van Zijl uitgespel is op pad was om verwesenlik te word toe hy die tersiêre funksie van die Fakulteit onderstreep het.

140 (HSA) HVKP, Notuleboek (3 Jul 1916-20 Mei 1919), Sentrale Bestuur, 8 Mrt 1919, 150-151.

141 (HSA) HVKP, Notuleboek (28 Jun 1919-19 Feb 1921), Sentrale Bestuur, 4 Sep 1920, 120; 16 Okt 1920, 126; (HSA) HVKP, Notuleboek (19 Mrt 1921-15 Apr 1924), Sentrale Komitee, 12 Nov 1921, 54.

142 (HSA) HVKP, Notuleboek (28 Jun 1919-19 Feb 1921), Sentrale Bestuur, 28 Jun 1919, 7.

143 (HSA) HVKP, Notuleboek (28 Jun 1919-19 Feb 1921), Sentrale Bestuur, 26 Jun 1920, 98.

144 (HSA) HVKP, Notuleboek (28 Jun 1919-19 Feb 1921), Sentrale Bestuur, 16 Okt 1920, 124.

145 (HSA) HVKP, Notuleboek (19 Mrt 1921-15 Apr 1924), Sentrale Bestuur, 23 Apr 1921, 9.

146 (HSA) HVKP, Notuleboek, (19 Mrt 1921-15 Apr 1924), Sentrale Bestuur, 24 Mei 1921, 13; (HSA) HVKP, Notuleboek, 25-26 Mei 1921, Kongres, Verslag van die Sentrale Bestuur, 3.

147 (HSA) HVKP, Notuleboek (19 Mrt 1921-15 Apr. 1924), Sentrale Bestuur, 30 Jul 1923, 195-196.

148 (HSA) HVKP, Notuleboek (19 Mrt 1921-15 Apr 1924), Sentrale Bestuur, 17 Mrt 1924, 257; (HSA) HVKP, Notuleboek, 15-17 Apr 1924, Kongres, Verslag van die Sentrale Bestuur, 4.

149 (HSA) HVKP, Notuleboek, 16-17 Apr 1930, Kongres, Aanhangsel C. Verslae van inrigtings wat finansiële ondersteuning van die Helpmekaarvereniging ontvang, 14.

150 Dit was ook die eerste PhD in Handelswetenskappe wat in Suid-Afrika aan 'n Suid-Afrikaanse universiteit toegeken is. 
Hy het beklemtoon dat die primêre funksie van die Fakulteit nie die opleiding van studente vir normale roetine kantoor- of besigheidstake of ander sleurwerk was nie:

"Ons doel is om die student ' $n$ insig te gee in die breëre vraagstukke waarvoor die besigheidsbestuurder te staan kom, en om wetenskaplike belangstelling en navorsing by hom aan te moedig. Die oogmerk van die Fakulteit is veral om deur wetenskaplike studie ons kennis van die ekonomiese en besigheidsvraagstukke, veral van Suid-Afrika, te verryk." 151

Die Helpmekaar het sy steun aan die Fakulteit na 1924 voortgesit en in die periode 1920-1957

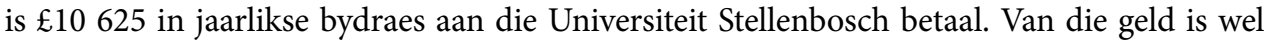
ook later vir die oprigting van 'n Mediese Fakulteit aangewend. Die oorgrote meerderheid van hierdie geld is vir die uitbouing van die Handelsfakulteit aangewend. Daardeur het die Helpmekaar bygedra tot die versekering van die voortbestaan van een van die belangrikste instellings wat basiese voorbereiding vir die Afrikaner se uiteindelike bekering tot die kapitalisme gedoen het.

Vanweë die Helpmekaar se aanvanklike voorkeur vir die ondersteuning van handelsopleiding op tersiêre vlak, het die lys van hul jaarlikse bydraes aan verdienstelike sake ook 'n sterk voorkeur vir steun aan instellings wat handelsopleiding op 'n sekondêre vlak bevorder het, getoon. Die Helpmekaar was instrumenteel in die totstandkoming van die Paarlse Hoër Handelskool in 1929. Verskeie ander instellings wat handelsopleiding verskaf het, soos die ACVV se opleidingsfasiliteite in Cradock en die onderwyskollege in Steynsburg, het jaarliks bydraes van die Helpmekaar ontvang. ${ }^{152}$

In die vyfjaarperiode na die aanvanklike toekenning van $£ 800$ vir beurse vir handelsopleiding het die betrokkenheid van die Helpmekaar as finansier van Afrikaner-opvoeding snel uitgebrei en ook van die aanvanklike beurse na die toekenning van lenings ontwikkel. Die groeiende

151 (HSA) HVKP, Notuleboek, 7-9 Apr 1931, Kongres, Verslae van inrigtings wat finansiële ondersteuning van die Helpmekaarvereniging ontvang, 6.

152 (HSA) HVKP, Notuleboek, 16-17 Apr 1930, Kongres, Aanhangsel C. Verslae van inrigtings wat finansiële ondersteuning van die Helpmekaarvereniging ontvang, 14; (HSA) HVKP Notuleboek, 7-9 Apr 1931, Kongres, Verslae van inrigtings wat finansiële ondersteuning van die Helpmekaarvereniging ontvang, 6, 7. 
aanvraag vir studielenings ${ }^{153}$ het die sentrale bestuur oortuig dat deur ondersteuning van die jeug deur studielenings vir verdere onderwys en opleiding die Helpmekaar'n groot diens aan die volk bewys. Hulle het dus die kongres aangemoedig om soveel as moontlik geld vir die doel toe te ken, ${ }^{154}$ aangesien op dié wyse "veel nuttig werk gedaan kan word". ${ }^{155}$ Die fondse wat vir opvoeding bewillig is, het gestrook met adv HS van Zijl, voorsitter van die sentrale bestuur, se siening dat die klem van die Helpmekaarvereniging se optrede gerig moes wees op 'n beleid om te verhoed dat meer persone tot die geledere van die armblankes toetree. ${ }^{156}$ Hy het dus voorkomende eerder as remediërende hulp voorgestaan. Deur studielenings sou mense gekweek word wat vir hulself sou kon sorg.

In 1919 is besluit om ook beurse vir studierigtings anders as net handelsopleiding toe te ken en is $£ 300$ vir die doel bewillig. ${ }^{157}$ Die besluit het algemene byval gevind. Aansoeke vir beurse en lenings het tot meer as 130 verdubbel. ${ }^{158}$ Tien beurse met 'n totale waarde van $£ 342$ en 25 lenings met 'n totale waarde van $£ 1291$ is uiteindelik vir die 1921-finansiële jaar toegeken. ${ }^{159}$ Die feit dat die sentrale bestuur by die 1921-kongres kon rapporteer dat een van die studente wat 'n Helpmekaarlening ontvang het, IW Olivier, 'n betrekking by 'n skool in Rustenburg aanvaar het en alreeds met die terugbetaling van sy lening begin het, was 'n aanduiding dat die ontwikkeling en opheffing van Afrikaners deur opvoeding suksesvol was en dat die

153 In die 1919/1920-kongresjaar het die aanvraag na finansiële studiehulp drasties toegeneem. Die Sentrale Bestuur het 62 aansoeke ontvang. Daarvan was 12 vir handelswetenskappe, 10 vir mediese en tandheelkunde en die res vir 'n verskeidenheid ander rigtings soos prokureurs, onderwys en wiskunde. Die Sentrale Bestuur het ook meer as 12 aansoeke vir studielenings ontvang van studente wat plaaslik of oorsee wou studeer. Die eerste lening ( $£ 30$ ) is aan 'n mediese student, GC Malherbe, wat in Dublin, Ierland, gaan studeer het, toegeken. Die voorwaardes van die lening was dat hy 'n skuldbewys (IOU) moes teken en dat die lening op aanvraag terugbetaalbaar was. Rente sou op die uitstaande kapitaal betaalbaar wees. (HSA) HVKP, Notuleboek (28 Jun 1919-19 Feb 1921), Sentrale Bestuur 28 Jun 1919, 11-12; 9 Aug 1919, 19; (HSA) HVKP, Notuleboek, 26-27 Mei 1920, Kongres, Verslag van die Sentrale Bestuur, 3.

154 (HSA) HVKP, Notuleboek, 25-26 Apr 1923, Kongres, Verslag van die Sentrale Bestuur, 6.

155 (HSA) HVKP, Notuleboek, 26-27 Mei 1920, Kongres, 4.

156 (HSA) HVKP, Notuleboek, 22-23 Mei 1918, Kongres, 2.

157 (HSA) HVKP, Notuleboek, 21-22 Mei 1919, Kongres, 8, 9.

158 (HSA) HVKP, Notuleboek, 25-26 Mei 1921, Kongres, Verslag van die Sentrale Bestuur, 3.

159 (HSA) HVKP, Notuleboek, 25-26 Mei 1921, Kongres, Verslag van die Sentrale Bestuur, 4; (HSA) HVKP, Notuleboek (28 Jun 1919-19 Feb 1921), Sentrale Bestuur, 27 Aug 1921, 40. 
sirkulasie en groei van die Helpmekaar se kapitaal deur die stelsel van studielenings besig was om vrugte af te werp. ${ }^{160}$

In 1921 het die kongres 'n voorstel aanvaar dat alle toekomstige hulp aan studente in die vorm van lenings sou wees. Die enigste uitsondering sou ten opsigte van handelsopleiding geld wat voorlopig steeds as beurse beskou sou word. ${ }^{161}$ Hierdie uitsondering het bevestig dat handelsopleiding steeds die eerste prioriteit was. Terwyl die 1923-jaarverslag van die sentrale bestuur die sukses van die stelsel van finansiële ondersteuning aan skoliere en studente beklemtoon het, ${ }^{162}$ het hul ook gewaarsku dat die volle verantwoordelikheid vir die taak nie op die skouers van die Helpmekaar gelaai moes word nie. Hierdie waarskuwing was gebaseer op die talle aanbevelingsbriewe vir studielenings aan studente wat hulle ontvang het. ${ }^{163}$ Ten spyte van die vermaning was die sentrale bestuur oortuig dat hulle op die regte pad was deur te konsentreer op "opheffing deur opleiding. Ons kan nooit ons geld beter bestee as om dit in die onderwys te belê nie". ${ }^{164}$

Daar was 'n stortvloed voorstelle en aanbevelings hoe om die armblankekwessie aan te spreek en op te los. Dit het gebeur teen die agtergrond van die suksesvolle vestiging van 'n studiehulpfunksie aan skoliere en studente. Die 1923-kongres was 'n belangrike keerpunt in dié sin dat dit groter helderheid gebring het oor wat die Helpmekaar se fokus en strategie moes wees in die lig van die beskikbare Helpmekaar-hulpbronne en waartoe die Helpmekaar as redmiddel vir die armblankekwessie realisties in staat was. Die verkreë

160 (HSA) HVKP Notuleboek, 25-26 Mei 1921, Kongres, Verslag van die Sentrale Bestuur, 4; (HSA) HVKP, Notuleboek (28 Jun 1919-19 Feb 1921), Sentrale Bestuur, 19 Mrt 1921, 3; Olivier, wat van Oudtshoorn afkomstig was, het in $1921 £ 60$ geleen om 'n BA-graad aan Universiteit Stellenbosch te behaal. Hy het in 1925 sy lening met 'n laaste betaling van $£ 313$ s 4 d vereffen en in totaal $£ 6413$ s 4 d terugbetaal.

161 Die laaste beurstoekenning in die kategorie was in 1923. Daarna is slegs lenings toegestaan. Na 1923 is beurse slegs in hoogs uitsonderlike gevalle toegeken.

162 Sedert 1918 is 180 skoliere en studente deur beurse en lenings ondersteun. Van hulle het 70 onafhanklik geword deur hul studies te voltooi, terwyl 110 nog besig was om te studeer. (HSA) HVKP Notuleboek, 25-26 Apr 1923, Kongres, Verslag van die Sentrale Bestuur, 6.

163 Dit is nie seker vir wie die waarskuwing bedoel was nie. In die lig van die voortdurende korrespondensie met die staat in verband met die beskikbaarstelling van regeringsbeurse en vertoë dat vry onderwys uitgebrei moes word, was dit moontlik deel van die Sentrale Bestuur se strategie om die Staat aan te moedig om vry onderwys uit te brei. In die lig van die vele aansoeke vir studiehulp wat die Kaapse Helpmekaar van buite die provinsie ontvang het, was die vermaning ook moontlik gemik op die ander provinsiale Helpmekaarverenigings. (HSA) HVKP, Notuleboek, 25-26 Apr 1923 Kongres, Verslag van die Sentrale Bestuur, 6.

164 (HSA) HVKP, Notuleboek (28 Jun 1919-19 Feb 1921), Sentrale Bestuur, 3 Des 1923, 231. 
helderheid was 'n uitvloeisel van 'n voorstel van dr WP Steenkamp ${ }^{165}$ van Namakwaland oor die daarstelling van 'n Helpmekaar Arbeidskolonie. Op die 1922-kongres het die SomersetOos-tak 'n beskrywingspunt ingedien waarin die kongres versoek is om die wenslikheid en noodsaaklikheid te onderskryf dat dadelik stappe geneem word om Steenkamp se voorgelegde plan ten uitvoer te bring. In reaksie hierop het PP du Toit en F Joubert, die afgevaardigdes van die Paarl, voorgestel dat:

"met die oog op die verslapping wat daar by lede van die Helpmekaar te bespeur is, benoem die kongres 'n kommissie om grondig ondersoek te doen na alle moontlike Helpmekaar-aangeleenthede. As sulks by die volgende kongres te rapporteer oor 'n praktiese, opbouende skema, wat tot inspirasie kan dien vir die Helpmekaar-beweging."166

Die voorstel is aangeneem en 'n kommissie (wat as die Cillie Kommissie bekend geword het), bestaande uit dr SFN Gie (Stellenbosch), PJ Cillie (Villiersdorp, sameroeper), PP du Toit (Paarl) en dr WP Steenkamp is aangestel om by die 1923-kongres verslag te doen. ${ }^{167}$ Die voorstel se aanvaarding het waarskynlik gespruit uit 'n behoefte na groter duidelikheid oor die fokus en metodiek van Helpmekaarhulp en in die hoop dat groter duidelikheid en 'n skerper fokus die verslapping in die belangstelling en betrokkenheid wat daar sedert die vroeë twintigerjare in die Helpmekaar te bespeur was - onder sy lede sowel as by die breë publiek - sou kon teenwerk.

Die opdrag van die kommissie was besonders breed geformuleer en dit het teen die agtergrond en konteks waarin dit tot stand gekom het in wese beteken dat hulle oor twee aspekte moes uitspraak lewer en aanbevelings doen. In die eerste plek het dit gehandel oor die standpunt wat die Helpmekaar teenoor die armblankevraagstuk moes inneem en tweedens wat gedoen kon word om belangstelling in die Helpmekaar op te wek in die lig van tekens dat die euforia van 1917 iets van die verlede was.

Te midde van die legio voorstelle om die armblankevraagstuk op te los wat sedert 1916 op Helpmekaar-kongresse gedien het, het die kommissie hom spesifiek met drie bemoei: Steenkamp se voorstel vir 'n Helpmekaar Arbeidskolonie; die aankoop van goedkoop grond geskik vir veeboerdery en die beskikbaarstelling daarvan op 'n huurkoopbasis vir die hervestiging van verarmde Afrikaner-veeboer-afstammelinge en die gebruik

165 Steenkamp was 'n NG predikant en later ook medikus en politikus wat hom veral ook vir die belange van die mense van Namakwaland en die Noordweste beywer het. Suid-Afrikaanse Biografiese Woordeboek IV, 643-645, Butterworth \& Kie, Durban, 1981.

166 (HSA) HVKP, Notuleboek, 26-27 Apr 1922, Kongres, 7.

167 Ibid. 
van Helpmekaargeld om armblankes in industriële sentrums van geskikte behuising in 'n fatsoenlike omgewing te voorsien. Die kommissie het bevind dat in al drie gevalle die Helpmekaar hom liefs van dié terreine moes weerhou, onder andere vanweë die hoë risiko's verbonde aan die projekte, die kapitaal bronne wat dit geverg het en die feit dat dit terreine was wat die verantwoordelikheid van die staat of plaaslike owerhede, soos munisipaliteite, was. Arbeidskolonies, plattelandse hervestiging en stedelike behuisingskemas was dus terreine wat liefs vermy moes word.

Die komitee het dus tot die gevolgtrekking gekom dat "ons Vereniging nie op 'n enigsins groot finansiële skaal tot die praktiese oplossing van hierdie (armblanke-) vraagstuk kan bydra nie". ${ }^{168}$ Die komitee het wel bevind dat die Vereniging 'n bydrae sou lewer indien hy hom sou beywer vir 'n poging om die oorsake "van hierdie kanker in ons volkslewe"169 te laat ondersoek. In dié verband het die kommissie 'n ondersoek deur kundiges in samewerking met "praktiese kenners van die toestande"170 aanbeveel. Die kommissie het eerstens bevind dat die Vereniging met sy huidige werk in verband met opvoeding op die regte spoor was aangesien die volk daardeur "vir die stryd om te bestaan gewapen"171 word. Hulle het dus as hoofdoel vir die Vereniging aanbeveel "die redding en handhawing van ons volk deur die onderwys" ${ }^{172}$ Afgesien van die onderwysfokus kon die Helpmekaar voortgaan om "goeie en nuttige sake in verband met ons volksbestaan"173 te ondersteun, op voorwaarde dat hulle nie die verantwoordelikheid vir die sake aanvaar nie en dit nie sy kapitaalfonds aantas nie. Oor die kapitaalfonds van die Helpmekaar was die komitee van mening dat aangesien die rente wat daarop verdien word nooit genoeg sou wees vir al die versoeke wat ontvang is nie, die Fonds jaarliks sterk aangevul moes word sodat dit as waarborg en gerusstelling - “"n versekeringspolis vir ons volk"174 - vir die toekoms kon dien.

Wat die tweede deel van hul opdrag betref, het die komitee aanbeveel dat daar jaarliks 'n verslag van die Helpmekaar se werk vir propagandadoeleindes opgestel moes word en 'n paar duisend eksemplare daarvan versprei word. Hulle kon nie die aanstelling van 'n reisende

\footnotetext{
168 (HSA) HVKP, Notuleboek, 25-26 Apr 1923, Kongres, Rapport van Kommissie om ondersoek in te stel en te rapporteer oor 'n praktiese, opbouende skema wat tot inspirasie kan dien vir die Helpmekaar-beweging, 8 .

169 Ibid., 9.

$170 \quad$ Ibid.

171 Ibid.

172 Ibid.

173 Ibid.

174 Ibid.
} 
sekretaris vanweë die hoë koste daaraan verbonde ondersteun nie en moes die goeie werk wat deur hoofbestuurslede verrig is deur besoeke aan takke en die oprigting van nuwe takke ondersteun. Die voorstel om Helpmekaardag na 16 Desember te verskuif het sterk steun in die kommissie gekry, maar die kommissie kon egter nie hieroor eenstemmigheid bereik nie. Die kommissie se verslag is met dank deur die kongres aanvaar.

Die waarde van die kommissie se aanbevelings en die kongres se aanvaarding daarvan was geleë daarin dat dit die basiese templaat bevestig en verwoord het van waarmee die Helpmekaar - beide op sentrale en plaaslike vlak - hom veral na 1917 oorwegend in die praktyk mee besig gehou het. Dit was onder andere die ondersteuning van onderwys en opvoedingsinisiatiewe en om langs dié weg 'n bydrae tot die uiteindelike oplossing van die armblankevraagstuk te lewer dat dit daardeur amptelike status verkry het. Die drie kategorieë waarin die kommissie die terrein van die Helpmekaar verdeel het, naamlik opheffing van die volk deur onderwys, ondersteuning van goeie en nuttige sake tot voordeel van die volksbestaan en die stywing van die kapitaalfonds as versekeringspolis vir die volk, het die strategie en fokus vir die aanwending van Helpmekaar-hulpbronne geformaliseer. Hoewel veranderende kontekste oor tyd nuanseverskille in strategie en fokus sou meebring, het dié kategorieë as die somtotaal van die Helpmekaar se fokus en aktiwiteite en hul gerigtheid op die "Afrikanervolk" vir die duur van die bestaan van die kongresstelsel geldig gebly. 
- capelor

Ulequ afeer

\section{ef}

e 1/acequ

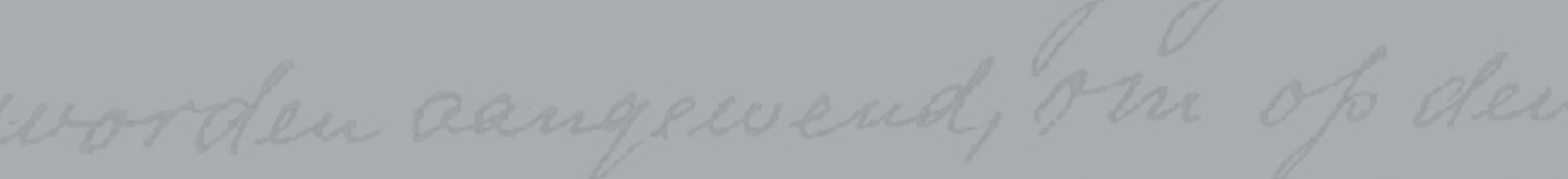

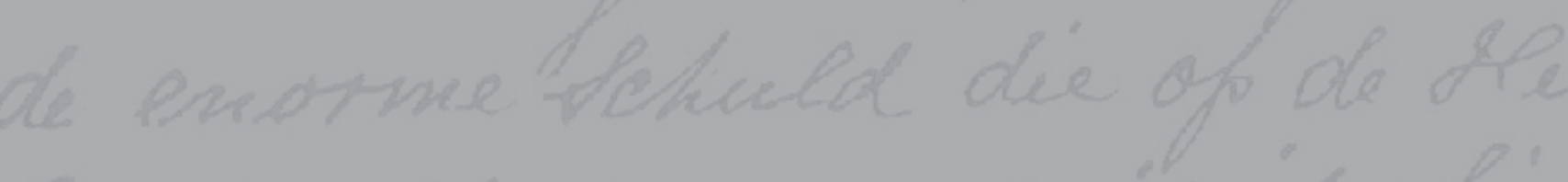

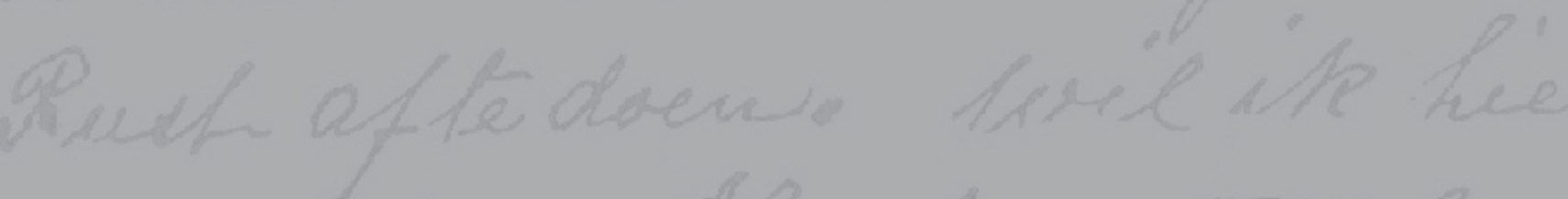

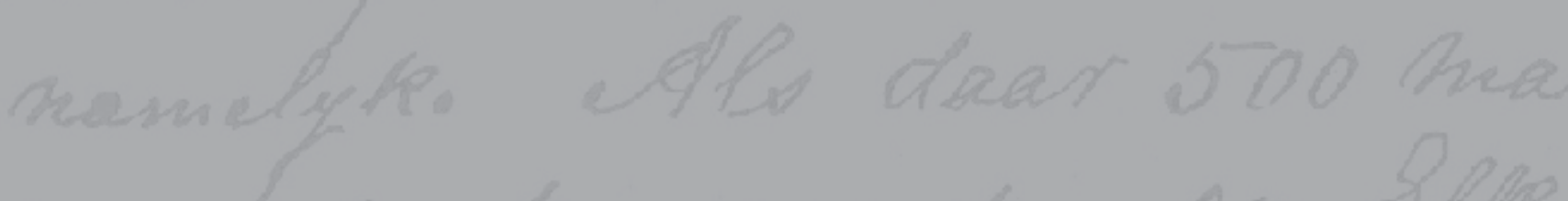

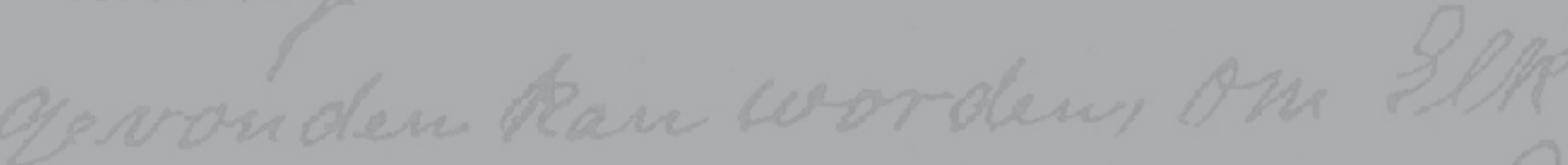

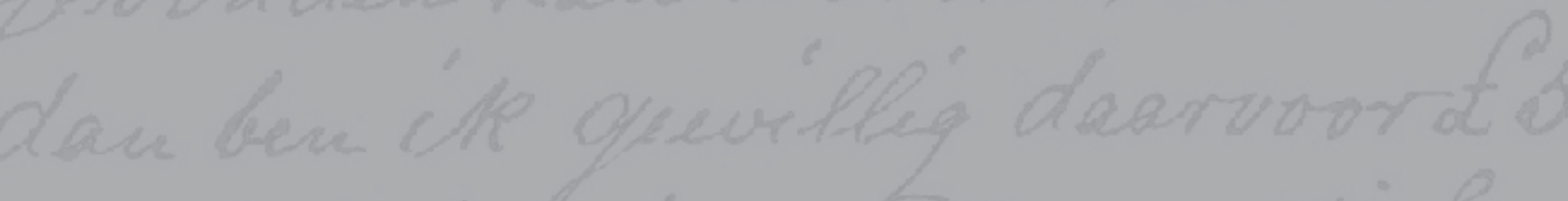
herdiandhouding, dat et ook bes

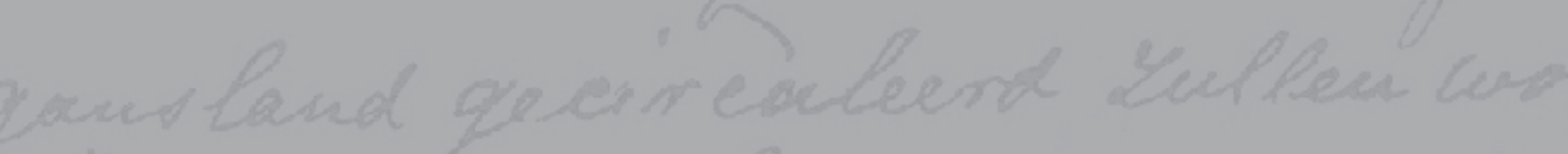

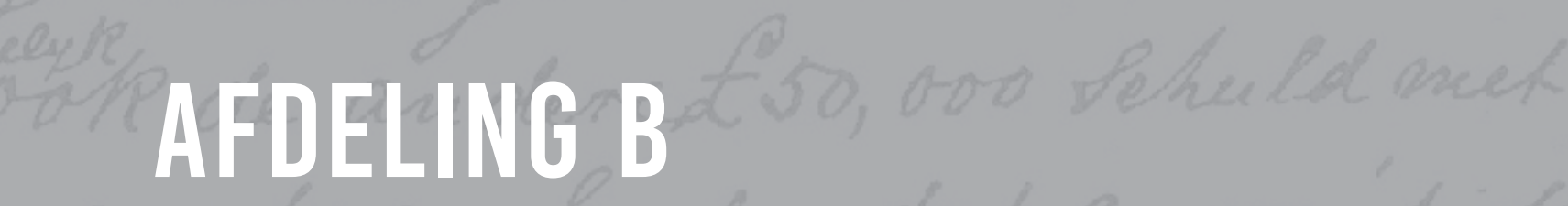
AFDELIIIG B - dew dat qoornet Die Helpmekaarvereniging van
die Kaapprovinsie, 1920-1965

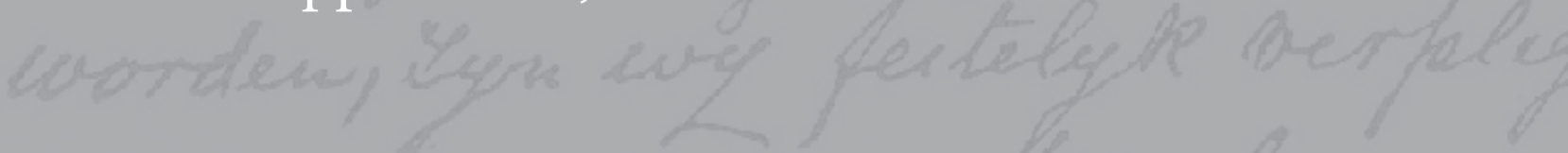




\section{HOOFSTUK DRIE}

\section{DIE KONGRES- EN TAKSTELSEL: VAN AANWINS TOT ALBATROS}

Die geskiedenis van die Helpmekaar se kongres- en takstelsel is in 'n groot mate'n spieëlbeeld van die geskiedenis van die opkoms, groei en verwelking van Afrikaner-nasionalisme en etniese mobilisasie in die 20ste eeu. Dit is in dié sin dat die kongresse en takke se funksionering en manifestering dieselfde kontoere in terme van bekommernisse, uitdagings, belange en oplossings as dié van die breër verhaal van Afrikanernasionalisme vertoon het. Die fokus was op die armblankevraagstuk en die Afrikaner se ekonomiese posisie sedert die twintigerjare, die populistiese nasionalisme en die aangryp van rasseskeiding as oplossing vir Afrikaneroorlewing van die dertiger- en veertigerjare, die verlies van sy greep op sy ondersteuningsbasis en die heroriëntering sedert die sestigerjare. In dié sin was die Helpmekaar soos dit in sy kongresse en takke neerslag gevind het dus 'n voorbeeld van Christelik-nasionale Afrikaner-nasionalisme in aksie.

"Maar dit is nie soseer die werk van die kongres en sentrale bestuur wat die Helpmekaar 'n krag in die land maak nie. Dit is veral die werk van die takke wat die Helpmekaar maak wat hy is. Die takke moet die sentrale bestuur voed en moet hulle gekombineerde invloed deur die ganse land deur middel van die kongres laat voel. Maar veel hang af van die individuele werk wat deur die takke plaselik gedaan word, en dit is hier ook waar daar veel te bespeur is wat aanmoedigend is."

Hierdie siening van die rol van die takke wat in 1920 deur adv HS van Zijl in sy voorsittersrede gehuldig is, was waarskynlik hoofsaaklik gebaseer op die deurslaggewende rol wat hulle in die storm-en-drang-beginjare van die Helpmekaarbeweging binne 'n spesifieke konteks en stel unieke omstandighede gespeel het. Dit als om die rebelleskuld uit te wis. Die konteks en omstandighede het na die Helpmekaarhoogtepunt in 1917 mettertyd verander. Die rol wat aan die takke toegeken is, het onveranderd gebly en uiteindelik 'n mantra geword wat onkrities oor jare herhaal sou word ten spyte daarvan dat dit in toenemende mate nie met die realiteite gestrook het nie.

Op plaaslike vlak was die Helpmekaartakke en hul besture die kanaal vir plaaslike Helpmekaarhulpverlening. Ten spyte van die sukses wat takke wel in dié hoedanigheid behaal

1 (HSA) HVKP, Notuleboek, 26-27 Mei 1920, Kongres, 2. 
het, is die oorheersende tendens in die verhaal van die Helpmekaartakke een van agteruitgang en 'n toenemende gebrek aan plaaslike belangstelling, met eindelose planne en inisiatiewe om die takstelsel, wat as die lewensbloed van die organisasie gesien is, lewend te hou. Teen hierdie agtergrond sal in hierdie hoofstuk gepoog word om 'n oorsig te gee van die evolusie van die rol/funksie en bydraes van die Helpmekaartakke en die kongres struktuur waarvan hulle deel was. Die takke en die beleidmakende kongres waarin hulle verteenwoordig was, was die plaaslike openbare gesig van die Helpmekaar wat die denke, prioriteite en aktiwiteite van sy lede weerspieël het. As sodanig was dit 'n refleksie - het dit 'n venster verskaf - van die gees van die tyd in terme van hoofsaaklik nasionaalgesinde Afrikaners se sosio-ekonomiese en politieke stand en die ontwikkeling daarvan deur die loop van die $20^{\text {ste }}$ eeu.

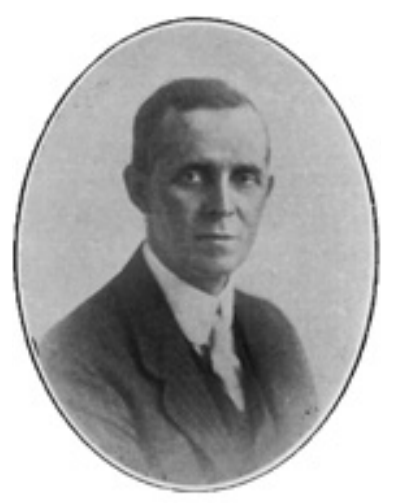

HS van Zijl was die eerste voorsitter van die HVKP. Hy het in 1935 regter-president van die Kaapse Hooggeregshof geword.

\section{DIE HS VAN ZIJL-ERA VAN "ABNORMALE GEESDRIF”, C. $1916-1920$}

Die verhouding tussen die sentrale bestuur en die takke is van meet af deur 'n "ons is familie"-gemoedelikheid en intimiteit gekenmerk. ${ }^{2}$ Dit was die grootste uitdaging vir die sentrale bestuur tydens die Helpmekaar se stigting en vestigingsjare om die takke te oorreed om hulle aan die konstitusionele voorskrifte, oor die toesig en administratiewe beheer van die sentrale bestuur, as uitvoerder van kongresbeleid en -besluite te onderwerp. Ander kwessies wat die Helpmekaartakagenda gedomineer het, was aspekte soos beheer oor die fondse wat takke ingesamel het en waarop gefokus moes word in die plaaslike besteding daarvan.

In die vaarwater van die 1916-stigting is verskeie pogings tot die vestiging van sentrale beheer en toesighouding aangewend. 'n Beskrywingspunt is reeds tydens die 1916-kongres aanvaar dat takke die reg het om plaaslike armes te help. Daar was 'n voorstel waarin die kongres aanbeveel het dat die takke soveel as moontlik van die geld deur hulle ingesamel na die sentrale bestuur moes stuur sodat dit volgens die doelwitte van die Vereniging bestee kon word. Dit is egter ook aanvaar. ${ }^{3}$ Hierdie was reeds 'n vroeë aanduiding van die spanning en toutrekkery

2 Die intimiteit wat die verhouding tussen die Sentrale Bestuur en die takke gekenmerk het, is bewys deur die feit dat sekretaresses van takke met hul huwelike gelukgewens is en met lede van plaaslike besture gesimpatiseer is in geval van sterftes, ens. (HSA) HVKP, Notuleboek (3 Jul 1916-20 Mei 1919), Sentrale Bestuur, 8 Jun 1918, 115. 
wat daar mettertyd rondom die besteding van die takke se inkomste sou ontstaan. Wat betref die betaling van ledegeld is besluit dat die bepalings van die grondwet eers op 1 Januarie 1917 in werking sou tree. Daar sou ook van die takke verwag word om met die ingang van die 1917-kongres van hul aktiwiteite verslag te doen. Die sentrale bestuur is ook opdrag gegee om kopieë van die grondwet soos deur die kongres goedgekeur aan alle takke te stuur. ${ }^{4}$

Op 'n sentrale bestuursvergadering van September 1916 is die noodsaaklikheid dat daar kennis gegee moet word aan die sentrale bestuur indien nuwe Helpmekaar-takke gestig word, onderstreep en is besluit om so 'n beroep op die belanghebbendes deur 'n berig in De Burger te doen. ${ }^{5}$ Die status van takke as die poort tot Helpmekaar-finansiële ondersteuning is in Desember 1916 vir die eerste keer amptelik bevestig met die sentrale bestuur se besluit dat die Desember 1916-uitbetalings aan hulpbehoewendes die laaste sou wees wat direk deur die sentrale bestuur hanteer sou word. Voortaan sou versoeke om hulp via die takke gerig moes word. ${ }^{6}$ In Maart 1917 is 'n vorige versoek dat takke wat nog nie by die Helpmekaar aangesluit het nie dit onmiddellik moes doen deur 'n berig in De Burger herhaal. ${ }^{7}$ Slegs twee nuwe takke, naamlik Ceres en Cathcart, het op dié oproep gereageer en by die Vereniging aangesluit. Daar is dus besluit om 'n omsendskrywe na al die takke te stuur waarin diegene wat nog nie aangesluit het nie versoek is om so te doen sodat hulle ook in die voorreg kon deel om afgevaardigdes na die kongres te stuur. ${ }^{8}$ Teen Mei het nog takke, naamlik Aberdeen, Brakfontein en Mosselbaai aangesluit. ${ }^{9}$ Die sentrale bestuur het ook besluit om 'n verslagvorm te laat druk waarop die takke kon verslag doen van hulle aktiwiteite. ${ }^{10}$

Afgesien van aansluiting by die Vereniging het die probleme met die takstruktuur aanvanklik gesentreer rondom die traagheid van takke om die plaaslik geïnde fondse aan die sentrale bestuur af te staan. Die verslag van die sentrale bestuur tydens die 1917-kongres het spesifiek verwys na takke in die Kaapprovinsie wat ten spyte van oproepe in De Burger nog nie by die Vereniging geaffilieer het nie. Die verslag het egter ook met dankbaarheid kennis geneem van bedrae (deur basaars en konserte geïn) wat ontvang is van plekke waar geen takke bestaan het nie. Daar was egter ook 'n paar takke wat nog nie aan die versoek van die 1916-kongres,

$4 \quad$ Ibid., 10.

5 (HSA) HVKP, Notuleboek (3 Jul 1916-20 Mei 1919), Sentrale Bestuur, 2 Sep 1916, 14.

6 (HSA) HVKP, Notuleboek (3 Jul 1916-20 Mei 1919), Sentrale Bestuur, 9 Des 1916, 26.

7 (HSA) HVKP, Notuleboek (3 Jul 1916-20 Mei 1919), Sentrale Bestuur, 3 Mrt 1917, 45.

8 (HSA) HVKP, Notuleboek (3 Jul 1916-20 Mei 1919), Sentrale Bestuur, 31 Mrt 1917, 50, 52.

9 (HSA) HVKP, Notuleboek (3 Jul 1916-20 Mei 1919), Sentrale Bestuur, 5 Mei 1917, 55.

$10 \quad$ Ibid., 58. 
naamlik dat takke hulle gelde aan die sentrale bestuur vir besteding moet stuur, voldoen het nie. Die verslag het dit onderstreep dat "Het is uiters wenselik dat aan dit besluit stiptelik voldoen zal worden". ${ }^{11}$ Dit was opmerklik dat volgens die aanvanklike subskripsiegeld wat ontvang is, daar baie lede was wat nog nie betaal het nie. Mev Roux, die sekretaresse, het verduidelik dat lede na die einde van die jaar (Desember 1917) nog drie maande grasie gehad het om hul geld te betaal. ${ }^{12}$ By die 1917-kongres het mev J Greef van die sentrale bestuur die aanvanklike probleme om die samewerking van alle takke te verkry toegeskryf aan 'n oorbeklemtoning van die finansiële doelwitte van die Helpmekaar ten koste van die sosiale doelwitte. Sy was van mening dat daar by die meeste lede die indruk gewek word dat "dit net 'n geldvraery is". Sy het dus aanbeveel dat die organiseerders die sosiale sy meer op die voorgrond moes plaas as wat daar in die verlede gedoen is. ${ }^{13}$

Die komitee wat die takverslae by die 1917-kongres moes verwerk, het melding gemaak van die feit dat die syfers van die takverslae nie in alle gevalle met dié van die sentrale bestuur se verslae ooreengestem het nie. Hulle het versoek dat takke hulle bydraes en noukeurige en korrekte verslae na die sentrale bestuur moes stuur. Die komitee het ook bevestig dat nie enige geld vir politieke doeleindes bestee is nie. Met die oog op beter organisasie van die takke het die 1917-kongres besluit dat die takke in elke kiesafdeling 'n afdelingsbestuur moes vorm wat uit lede van elke tak in die afdeling bestaan. Die afdelingsbestuur moes minstens twee keer per jaar bymekaargekom het om verslag te doen oor die verhouding tussen die verskillende takke in die kiesafdeling. Die afdelingsbestuur moes ook 'n wakende oog oor die organisasie van hul kiesafdeling hou. ${ }^{14}$ By die 1918-kongres was dit egter duidelik dat die voorstel van afdelingsbesture nooit sou realiseer nie. In die verslag van die sentrale bestuur is aangedui dat geen vordering in dié verband gemaak is nie en was die bestuur van mening dat praktiese oorwegings altyd die uitvoering van die voorstel in die wiele sou ry. ${ }^{15}$

Die ongekende entoesiasme wat deur die 1917-fondsinsamelingspogings gegenereer is, het ook neerslag gevind in 'n toename van Helpmekaartakke en -lede. Die penningmeester het in sy 1918-verslag aangedui dat die ledetal van 1917 tot 1918 verdubbel het indien die ledegeld as 'n maatstaf gebruik sou word. Deur die loop van die jaar het daar 28 nuwe takke bygekom, wat die aantal takke op 70 te staan gebring het met 'n ledetal van 4480 . Geld is ook ontvang

\footnotetext{
11 (HSA) HVKP, Notuleboek, 11-12 Jul 1917, Kongres, 6.

12 (HSA) HVKP, Notuleboek, 11-12 Jul 1917, Kongres, 10

13 (HSA) HVKP, Notuleboek, 11-12 Jul 1917, Kongres, 15.

14 (HSA) HVKP, Notuleboek, 11-12 Jul 1917, Kongres, 17, 18.

15 (HSA) HVKP, Notuleboek, 22-23 Mei 1918, Kongres, 4-7.
} 
van plekke waar daar geen takke bestaan het nie. Die penningmeester was dus van mening dat daar baie Helpmekaarvriende was wat nog nie lede was nie. ${ }^{16}$

In die vaarwater van die populistiese euforie van die 1917-insamelingsveldtog het die periode van "abnormale geesdrif” teen 1920 plek gemaak vir 'n templaat van kenmerke wat takke vir die duur van die kongresbedeling van die Helpmekaar se bestaan sou kenmerk en wat jaarliks op kongresse en in die verslae van die sekretaresse, sentrale bestuur en penningmeester neerslag sou vind. Die templaatkenmerke was onder andere: Die kwessie van beheer oor en aanwending van plaaslike takfondse, die impak van omgewingsfaktore op takke se funksionering, verhale van groei en vooruitgang, maar veral ook van stagnasie en verval, administratiewe probleme met takverslae en rapportering en pogings om hernude belangstelling in die Helpmekaar te wek.

Met die delging van die rebelleskuld afgehandel, het die kwessie van beheer oor en die aanwending van plaaslike takfondse as kwessie meer prominent na vore getree. Op 'n vraag van die Aliwal Noord-tak in 1918 of hulle plaaslike armes mag help, het die sentrale bestuur geantwoord dat dit aan die diskresie van die plaaslike bestuur oorgelaat word. ${ }^{17}$ Hierdie tipe navrae het die kongres genoop om op die 1918-kongres 'n duideliker standpunt oor die besteding en beheer van plaaslike fondse in te neem. Wat die verdeling van plaaslike inkomste betref, het die kongres dus 'n voorstel aanvaar dat plaaslike takke die reg sou hê om maksimum een derde van hul inkomste plaaslik te bestee. Vir die doel van die besluit is "plaaslike inkomste" gedefinieer as die inkomste wat jaarliks deur pogings op Afrikanerdag (10 November) deur takke ingesamel is. Die voorsitter, HS van Zijl, het bevestig dat takke geregtig was om plaaslike hulp uit hul kas te verleen en dat enige tak fondse vir plaaslike doeleindes bymekaar kon maak, maar dat Afrikanerdag-inkomste volgens bogenoemde verdeling hanteer en spandeer moes word vir die doel wat jaarliks deur die kongres bepaal word. Lede kon ook gratis deur die takke opgeneem word, maar dan moes die takke namens die lede die intekengeld aan die sentrale bestuur betaal. ${ }^{18}$

Die beginsel is dus hierdeur aanvaar dat die takke as fondsegenereerders ' $n$ finansiële verpligting teenoor die sentrale kas gehad het. Benewens die ledegeld moes hulle twee derdes van hul plaaslike Afrikanerdag-inkomste in die sentrale kas stort. Ten spyte van die 1918-besluit het die kwessie oor die verdeling van plaaslike fondse tussen die sentrale kas en plaaslike takke 'n nimmereindigende debat in die kongresbestaan van die Helpmekaar

16 Ibid., 4-7, 6.

17 (HSA) HVKP, Notuleboek (3 Jul 1916-20 Mei 1919), Sentrale Bestuur, 2 Feb 1918, 95-96.

18 (HSA) HVKP, Notuleboek, 22-23 Mei 1918, Kongres, 4-7. 


\section{Die Kaapse Helpmekaar}

verteenwoordig. Die kwessie het feitlik sonder uitsondering op jaarlikse kongresse ter sprake gekom, meesal met versoeke dat takke 'n groter deel van hul fondse plaaslik moes kon bestee. Reeds by die 1919-kongres het voorstelle gedien wat takke wou toelaat om tot 50 persent van hul fondse plaaslik te bestee. Hoewel hierdie voorstel verwerp is ${ }^{19}$ het die deel waaroor takke kon beskik oor die jare gewissel van een derde in 1918, die helfte in $1922^{20}$, twee derdes in 1924 (vir net een jaar) ${ }^{21}$ en een vyfde in 1945 met 'n minimum storting van $£ 5$ in die sentrale kas. ${ }^{22}$

Die sentrale bestuur het ook deurlopend versoeke van takke ontvang om vir 'n spesifieke jaar al of meer van hul fondse plaaslik te spandeer - gewoonlik vir een of ander verdienstelike saak wat hulle ondersteun het. Reeds in Maart 1919 het die Colesberg-tak die sentrale bestuur versoek om hul van die 1918-bepaling vry te stel aangesien hulle die fondse vir hul "Kleermakerij" benodig het. Hoewel die sentrale bestuur nie bereid was om die sentrale kas se deel prys te gee nie het hulle toestemming verleen dat Colesberg geld insamel vir die spesiale projek. ${ }^{23}$ Hoewel die sentrale bestuur die versoeke konsekwent in die lig van die heersende kongresbesluit geweier of na die volgende kongres verwys het, is versoeke met besondere meriete wel per geleentheid toegestaan.

In 1919 is die Loxton-tak byvoorbeeld toegelaat om 25 persent van die tweederde-opbrengs agter te hou vir die koshuis te Loxton. ${ }^{24}$ Hierteenoor is Cedarville-tak se versoek vir $£ 100$ om 'n saal te bou gestol deur dit na die kongres te verwys. ${ }^{25}$ Takke het nie altyd die beslissings ewe gedweë aanvaar nie. In 1921 het 'n versoek van Murraysburg-tak om twee derdes van hul geld plaaslik te gebruik tot onenigheid in die plaaslike bestuur gelei. Volgens die plaaslike voorsitter was daar "verskil van gevoele onder die bestuurslede van die tak, en groot moeilikhede" ${ }^{26}$ wat uiteindelik tot die bedanking van drie lede van die plaaslike bestuur gelei het. ${ }^{27}$ In 1924 het 'n soortgelyke skeuring oor die beskikking van plaaslike fondse in die Molteno-tak gedreig

19 (HSA) HVKP, Notuleboek, 21-22 Mei 1919, Kongres, 6.

20 (HSA) HVKP, Notuleboek, 26-27 Apr 1922, Kongres, 7.

21 (HSA) HVKP, Notuleboek, 15-17 Apr 1924, Kongres, 8.

22 (HSA) HVKP, Notuleboek, 4-5 Apr 1945, Kongres, 12.

23 (HSA) HVKP, Notuleboek (3 Jul 1916-20 Mei 1919), 8 Mrt 1919, 156.

24 (HSA) HVKP, Notuleboek 21-22 Mei 1919, Kongres, 9.

25 (HSA) HVKP, Notuleboek (28 Jun 1919-19 Feb 1921), 24 Apr 1920, 81.

26 (HSA) HVKP, Notuleboek (28 Jun 1919-19 Feb 1921), 20 Nov 1920, 139-140.

27 (HSA) HVKP, Notuleboek (19 Mrt 1921-15 Apr 1924), 19 Mrt 1921, 2. 
wat die plaaslike bestuur laat weier het om die tak se ingesamelde fondse vir die jaar aan die sentrale kas oor te betaal. ${ }^{28}$

By die 1920-kongres was HS van Zijl van mening dat, hoewel sommige takke nog gevoel het hulle word beperk in hulle werk omdat hulle twee derdes van hulle fondse na die sentrale bestuur moes stuur, die meeste besef het dat dit nie 'n struikelblok in hulle plaaslike werk hoef te wees nie. ${ }^{29}$ Hierdie siening van hom is onderskryf deur die wye verskeidenheid bydraes wat op plaaslike vlak deur takke gelewer is. Worcester-tak het 'n stuk grond vir $£ 1750$ aangekoop met soveel geboue daarop dat hulle deur slegs 'n verderde $£ 500$ te spandeer tien behoorlike huise sou hê om aan armblankes te verhuur wat in die "lokasie" gewoon het omdat hulle nie huise in die dorp kon kry nie. Die sentrale bestuur kon nie voldoen aan die tak se versoek vir 'n lening van $£ 2500$ om die skema te finansier nie, maar Worcester is gelukgewens met hul inisiatief en ook versoek om 'n berig in Die Burger te plaas oor die skema om "als 'n spoorslag (te) kan dien vir ons ander takke om ook iets van die aard te onderneem, daar dit die regte soort Helpmekaar is". ${ }^{30}$

Dat Worcester nie die enigste aktiewe tak was nie, is deur die 1920-verslag van die sentrale bestuur bevestig, waarin melding gemaak is van die goeie werk wat plaaslik deur takke gedoen word. Voorbeelde in dié verband was onder andere: Carnavon-tak wat $£ 360$ afbetaal van hul skuld van $£ 400$ op 'n koshuis waar 105 arm kinders gehuisves is; Ceres-tak se ernstige poging om 'n koshuis vir arm kinders in die distrik op te rig waarvoor hulle reeds $£ 225$ byeengebring het; Uniondale-tak wat hulp verskaf het aan behoeftige kinders met hul studies en wat lenings van $£ 30$ elk per jaar sonder rente toegestaan het; Danielskuil-tak wat'n boekery vir jongmense opgerig het; Hanover-, Loxton-, Montagu-, Philipstown- en Burgersdorp-takke wat bygedra het tot koshuise vir behoeftige kinders; Victoria-Wes wat $£ 100$ vir behoeftige kinders geskenk het; Robertson-tak wat vir 'n sopkombuis bygedra het en Somerset-Oos-tak wat gesorg het vir die daaglikse voeding van arm kinders. ${ }^{31}$

Hoewel die 1919-verslag van die penningmeester en die takverslag van die sekretaresse in die gees van die impak van die 1918-griepepidemie gestaan het, was dit duidelik dat die emosionele euforie en ongekende geesdrif van die 1917-insamelingsveldtog en die entoesiasme en groei wat dit vir die Helpmekaar gebring het grootliks verdamp het. Die eerste tekens van agteruitgang was reeds duidelik waarneembaar. Slegs 28 uit 73 takke het hulle ledegeld betaal 
en slegs 44 uit 73 takke het verslae voorgelê. Gebaseer op die takke van wie verslae ontvang is, was daar wel 'n toename in ledetal van 3337 tot $3446 .{ }^{32}$ Dit was egter aansienlik minder as die 4480 lede wat in 1918 vir die 70 takke van die jaar gerapporteer is. ${ }^{33}$ Die sekretaresse het dan ook gerapporteer dat sy rede het om te glo dat van die takke so agteruitgegaan het dat hulle slegs met 'n spesiale poging vir die Vereniging gered sou kon word.

Teen hierdie agtergrond is daar by die 1919-kongres vir die eerste keer verskeie beskrywingspunte ingedien wat vir die aanstelling van 'n organiserende sekretaris gevra het met die doel om takke te besoek en belangstelling in die Vereniging op te wek. So 'n sekretaris is nie aangestel nie, maar die sentrale bestuur is deur die kongres gemagtig om, waar nodig, 'n lid van die Vereniging af te vaardig om op koste van die Vereniging organisasiewerk te doen. ${ }^{34} \mathrm{Na} 1919$ het die kwessie van 'n organiserende sekretaris om propaganda te maak vir die Helpmekaar en die verval by baie takke teen te werk - in wisselende gedaantes - 'n feitlik permanente item op die jaarlikse kongresagendas geword. Die 1920-kongres het die basiese patroon, wat die takke van die Helpmekaar vir die res van hul bestaan tot 1965 sou vertoon, bevestig. Die langtermyn tendens wat gemanifesteer het, was een van tanende belangstelling met verloop van tyd. ${ }^{35}$

Daar was opflikkerings wat gewoonlik gevolg het op 'n inisiatief van die kongres en sentrale bestuur om groter belangstelling in die Helpmekaar se aktiwiteite op te wek of dit was die gevolg van 'n kulturele of sosio-ekonomiese stimulus vanuit die breër Afrikaner-gemeenskap. Te midde van die breë tendens was daar altyd takke wat ontbind het, ${ }^{36}$ nuwes wat gestig is en die staatmakers ${ }^{37}$ wat oor jare heen konstante, goeie Helpmekaar-werk op plaaslike vlak verrig het. Veral laasgenoemde kategorie is gewoonlik gedra deur 'n kerngroepie entoesiastiese Helpmekaar-ondersteuners op die plaaslike besture of 'n ywerige plaaslike voorsitter, sekretaresse, sekretaris of penningmeester. Die verlies van hierdie sleutelpersoon

32 (HSA) HVKP, Notuleboek, 21-22 Mei 1919, Kongres, 2-6.

33 Ibid., 6.

34 Ibid.

35 (HSA) HVKP, Notuleboek, 25-26 Mei 1921, Kongres, Voorsittersrede, 2 en Sentrale Bestuur verslag, 3. Caledon-tak is nie in 'n florerende toestand nie. Die voorsitter betreur dit aangesien Caledon met die 1917-oproep oor die £2 000, waaronder $12 £ 100$-ponders, ingesamel het. Die voorsitter meen egter dat daar warm harte vir die saak op Caledon is en die Kommissie hoop dat die tak op Caledon uiteindelik weer opgerig sal word en sal floreer.

36 (HSA) HVKP, Notuleboek (19 Mrt 1921-15 Apr 1924), 27 Aug 1921, 40. Jamestown-tak het verval en die gewese sekretaresse, mej Wagenaar, betreur dit maar sê dat sy altyd 'n vriend van die Helpmekaar sal bly.

37 (HSA) HVKP, Notuleboek, 25-26 Mei 1921, Kongres, Voorsittersrede, 2. Mnr Wium, die Wellingtonvoorsitter, is "omring van vrouens en manne met warme harte vir die groot volksaak" en Malmesbury se taksekretaris "is omring deur warme harte vir die goeie saak". 
of persone het dan ook in baie gevalle die einde van die tak beteken. ${ }^{38}$ Op takvlak was die swak bywoning van vergaderings en onkunde oor die werk van die Helpmekaar die oorheersende en herhalende klagtes. ${ }^{39}$ Die jaarlikse kongresverslae het bogenoemde patrone en tendense soos 'n herhalende refrein weerspieël. Terwyl die 1920-verslag van die sentrale bestuur die goeie werk wat plaaslik deur die takke gedoen is, geprys het, ${ }^{40}$ het die sekretaresse in haar takverslag gekla oor takverslae wat nie ontvang is nie (van 16 takke) of onvolledig was of ongeteken en selfs naamloos was. Daar is tot die gevolgtrekking gekom dat "in vele gevalle skyn dit of daar agteruitgang is, en min belangstelling by die takke om verslae op te stuur" ${ }^{41}$

Die twintigerjare het ook 'n periode ingelui waarin die insentief wat aan Helpmekaarondersteuners voorgehou is vir formele takstigting en aansluiting by die Vereniging 'n klemverskuiwing ondergaan het wat oor die langtermyn onbedoelde negatiewe gevolge vir die Vereniging sou inhou. In Maart 1917 het die sentrale bestuur besluit om 'n omsendskrywe na takke te stuur wat nog nie by die Vereniging aangesluit het nie om hulle aan te moedig om aan te sluit, sodat hulle ook in die voorreg mag deel om afgevaardigdes na die kongres te stuur. By die 1920-kongres het die voorsitter vir die eerste keer aangedui dat geen tak moes ophou bestaan nie, aangesien hulle dan alle reg op die Surplusfonds van die Helpmekaar sou verbeur. ${ }^{42}$ Dit was 'n waarskuwing wat deur die sentrale bestuur herhaal is toe Cedarville in Maart 1923 aangedui het dat hul moontlik kon ontbind en wat daarna by herhaling oor jare deur die sentrale bestuur in hul korrespondensie met takke of op kongresse herhaal is. ${ }^{43}$

Die insentief het dus onbedoeld verskuif van 'n diensmotief - om deel te word van die kongres waar besluit word hoe, waarvoor en deur wie daar aan die Helpmekaar en by implikasie aan die "volk" diens gelewer gaan word - na 'n ontvang en bakhandmotief, naamlik watter voordele lede en hul plaaslike omgewings deur lidmaatskap uit die Helpmekaar en sy Surplusfonds kon trek. Hierdie mentaliteit het mettertyd 'n beduidende vastrapplek in Helpmekaargeledere gekry wat 'n bepalende impak op die funksionering, bestuur en uiteindelike lotgevalle van die takstelsel sou hê.

38 (HSA) HVKP, Notuleboek, 21-22 Mei 1919, Kongres, Voorsittersrede, 2; Sentrale Bestuur verslag 3, 5; (HSA) HVKP, Notuleboek, 25-26 Mei 1921, Kongres, Sentrale Bestuur verslag, 5.

39 (HSA) HVKP, Notuleboek, 26-27 Apr 1922, Sentrale Bestuur verslag, 5; (HSA) HVKP, Notuleboek (19 Mrt 1921-15 Apr 1924), Sentrale Bestuur, 22 Mrt 1923, 158-160.

40 (HSA) HVKP, Notuleboek, 26-27 Mei 1920, 4.

41 (HSA) HVKP, Notuleboek, 26-27 Mei 1920, Kongres, 9.

42 Ibid.

43 (HSA) HVKP, Notuleboek (28 Jun 1919-19 Feb 1921), Sentrale Bestuur, 26 Jun 1920, 96-97; (HSA) HVKP, Notuleboek (19 Mrt 1921-15 Apr 1924), Sentrale Bestuur, 3 Des 1923, 230. 


\section{Die Kaapse Helpmekaar}

Takke se posisie as hekwagters vir toegang tot Helpmekaar-fondse is reeds in 1916 die eerste keer bevestig met 'n besluit dat slegs versoeke om Helpmekaar-ondersteuning wat via 'n plaaslike tak ontvang word voortaan oorweeg sou word. In 1916 was Helpmekaar-hulp nog op rebelle en hul families gefokus. Met die era van dié tipe hulpverlening as iets van die verlede het die kongres die beginsel in 1921 na aanleiding van 'n soortgelyke voorstel deur Danielskuil herbevestig. ${ }^{44}$

Ten spyte van die duidelike tekens van 'n afname in die belangstelling van die breë publiek en die impak wat dit op die bedrywighede en aktiwiteite op plaaslike takvlak gehad het teen circa 1920 het dit nie die sentrale bestuur se entoesiasme en geloof in die waarde van die Helpmekaar geblus nie:

"Dit mag in sommige opsigte die skyn gee of daar agteruitgang is in die beweging; maar as ons let op die getalle van applikasies van studente, en die aantal wat hulp uit die kas ontvang, dan sê ons die Helpmekaar leef, werk en sal leef en werk tot in lengte van dae; en die jongmans en -dogters wat nou hulp uit Helpmekaar bronne ontvang, sal wanneer hul hulle doel bereik het - na ons hoop - getroue ondersteuners van die beweging wees, wat sal strek tot opbouing, uitbreiding en welvaart van ons onmisbaar filantropies Vereniging." ${ }^{45}$

\section{DIE AJ STALS-TWINTIGERJARE: \\ DIE FOKUS OP DIE ARMBLANKEVRAAGSTUK}

Die geskiedenis van die Helpmekaartakke in die twintigerjare is gekenmerk deur stagnasie, agteruitgang en pogings tot herlewing te midde van die uitdagings van 'n groeiende armblankevraagstuk. Vir die grootste gedeelte van die dekade het die Helpmekaar dié uitdagings aangepak onder leiding van dr AJ Stals, wat hom veral as medikus, politikus en ekonoom/ sakeman sou onderskei. Met sy verkiesing as voorsitter in 1922 het Stals as mediese dokter op Worcester gepraktiseer en weens sy belangstelling en betrokkenheid in die politiek is hy in 1924 as NP LV vir Hopetown verkies. ${ }^{46}$ Die perspektief en denkraamwerk van waaruit die Helpmekaar bogenoemde

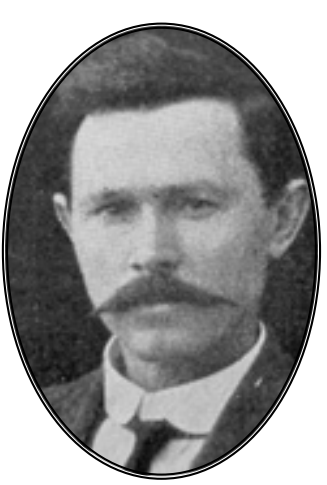

Dr AJ Stals, voorsitter van die HVKP in die twintigerjare. Stals wat hom ook as ekonoom en sakeman onderskei het, is deur Anton Rupert as sy mentor beskou.

44 (HSA) HVKP, Notuleboek, 25-26 Mei 1921, Kongres, 8.

45 (HSA) HVKP, Notuleboek, 25-26 Mei 1921, Kongres, Sentrale Bestuur verslag, 5.

46 Suid-Afrikaanse Biografiese Woordeboek deel III, 772. 
uitdagings sou aanpak, is die beste af te lei uit Stals se voorsittersredes tydens die jaarlikse kongresse. Die sentrale fokus was volksopbou deur volksopvoeding. As Afrikanernasionalis was die verkryging en behoud van volkseenheid vir hom 'n allesoorheersende strewe en was hy oortuig dat selfbehoud deur middel van die geheel die enigste hoop vir die Afrikaner was. ${ }^{47}$ Die "volk" was in 'n oorlewingstryd gewikkel om die beskawing en sedes wat die "edele voorvaders" ("Hugenoot, Geus en Voortrekker" ${ }^{3}$... "Piet Retief, Paul Kruger en Marthinus Steyn" ${ }^{\prime 9}$ ) gevestig het, te handhaaf. In die gees van die idealisering van die Afrikaners se voorvaders en hul stryd om in die wildernis te oorleef is Helpmekaar-ondersteuners opgeroep tot die "vurige liefde en taaie volharding ... (en) die geloof wat hulle besiel het". ${ }^{50}$ In die strewe na die behoud van die geheel was die armblankekwessie:

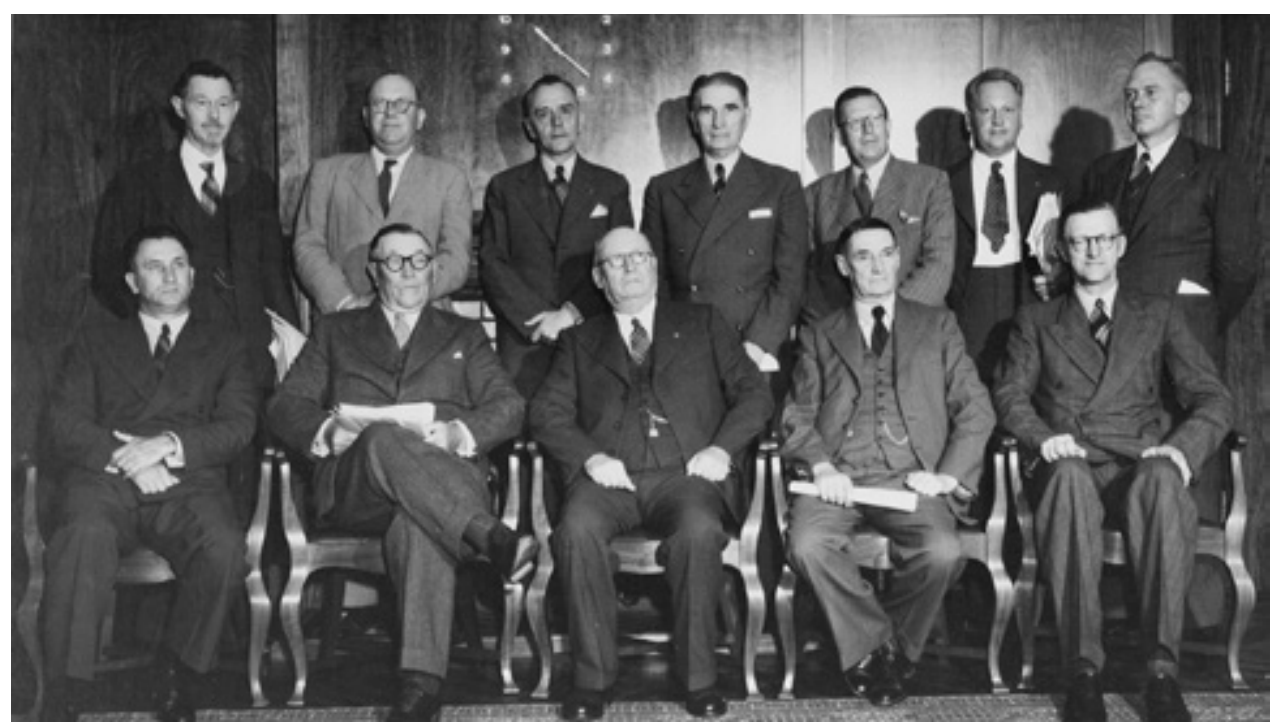

DF Malan se 1948 kabinet. AJ Stals was minister van gesondheid in die kabinet. Nog ' $n$ lid van die kabinet, FC Erasmus, het in 1922/23 'n Helpmekaarlening vir sy studies ontvang. Voor van links: mnr JG Strydom, mnr NC Havenga, dr DF Malan, dr EG Jansen, adv CR Swart. Agter van links: dr AJ Stals, mnr PO Sauer, mnr EH Louw, mnr SP le Roux, dr TE Donges, mnr FC Erasmus, mnr BJ Schoeman.

\footnotetext{
47 (HSA) HVKP, Notuleboek, 7-8 Apr 1926, Kongres, Voorsittersrede, 2.

48 (HSA) HVKP, Notuleboek, 25-26 Apr 1923, Kongres, Voorsittersrede, 3.

49 (HSA) HVKP, Notuleboek, 15-17 Apr 1924, Kongres, Voorsittersrede, 2.

50 (HSA) HVKP, Notuleboek, 7-8 Apr 1926, Kongres, Voorsittersrede,1-2.
} 


\section{Die Kaapse Helpmekaar}

"die kankerkiem wat knaag aan die wortel van ons volkslewe in hierdie geliefde vaderland van ons - waar daar sovele faktore saamwerk om die posiesie van die blanke beskawing en die kristelike tradisies te help omverwerp." ${ }^{51}$

Die armblankekwessie was dus 'n kernfokus aangesien die verlies van so 'n aansienlike deel van die volk die volkseenheid en daardeur ook die vermoë om te oorleef, ernstig in gevaar sou stel. Die Afrikaner is steeds as 'n landbou-adel gesien wie se heil in die platteland gelê het - en die ontvolking van die platteland en verstedeliking is gesien as prosesse wat omgekeer moes word deur die wekroep van "terug na die platteland". Armblankes moes in die proses toegerus word vir die lewenstaak deur opvoeding - wat breër gedefinieer is as slegs onderwysopleiding - wat vir Stals slegs die meedeling van kennis was. Vir hom het opvoeding ook ingesluit die "ontwikkeling van karakter met die vorming van gesonde oordeel" en was sy vraag ten opsigte van die finansiële investering wat die Helpmekaar op die terrein mak of dit "die vorming van doelbewuste kinders, kinders van karakter, van deug, goed voorberei vir die praktiese lewe - kinders wat sal steunpilare uitmaak van die maatskappy, die Kerk en die Staat"52 sal verseker. Sy klem was op die bereiking van ekonomiese selfstandigheid vir armblankes omdat dit volkselfstandigheid sou bevorder. Hy het gewaarsku teen die oneweredige verspreiding van rykdom onder die volk aangesien dit "as geheel die bevolking weinig baat as die besitting van 'n paar groot geldkonings of goedkonings geweldig vermeerder, sonder 'n eweredige verdeling of vermeerdering van die individuele verdienste of inkome. Ek vrees dat dit juis op hierdie gebied nog veel te wense oorlaat".53

Die einddoel was dus die bereiking van 'n selfstandige ekonomiese bestaan vir die armblankes. In dié verband was die staat se beleid van beskaafde arbeid volgens Stals 'n hoopvolle ontwikkeling aangesien dit langs dié weg moontlik gemaak is vir 'n groot aantal "arme blanke om werkkringe te kry om sodoende 'n lewensbestaan te maak langs die weg van eer, en om sodoende selfstandig eie haard en huis en famielie op te bou". ${ }^{4}$

Die opvoedingswerk van die Helpmekaar deur middel van lenings was ook vir hom so 'n weg na 'n selfstandige bestaan aangesien "die selfstandig ontwikkelde jong seuns en dogters kan nie anders dan 'n lig te laat skyn in eie omgewing, wat ander sal sterk om die gees van selfstandigheid en eie waarde op te bou". ${ }^{55}$

\footnotetext{
$51 \quad$ Ibid.,2.

52 (HSA) HVKP, Notuleboek, 15-17 Apr 1924, Kongres, Voorsittersrede, 3.

53 (HSA) HVKP, Notuleboek, 7-8 Apr 1926, Kongres, Voorsittersrede, 2.

$54 \quad$ Ibid.

$55 \quad$ Ibid.
} 
Vir Stals was die lenings dus 'n geleentheid om persone op te hef en selfstandig te maak sodat hulle op hulle beurt ook weer die eie kring (gesin, familie, ens.) kon ophef en selfstandig maak. Dié opheffing was ook ter bevordering van die volksbelange wat weer gelyk gestel is aan die belange van God.

Stals het die groot uitdagings of behoeftes wat steeds bestaan het, geïdentifiseer as: volksopvoeding, werksverskaffing op die platteland en sosiale werk. Wat die lenings aan studente betref, was die aanvraag baie groter as die aanbod en die uitdaging was geleë in die groot aantal studente aan wie nie hulp verleen kon word nie. In Februarie 1926 is 136 aansoeke deur die sentrale bestuur oorweeg. Aan 98 hiervan is hulp toegestaan. Hiervan was 50 hernude lenings aan aansoekers van 27 verskillende distrikte uit die Kaapprovinsie ten bedrae van $£ 1508$. Daar is 48 nuwe lenings toegestaan aan aansoekers van 32 distrikte ten bedrae van $£ 1585$. Wat egter uitstaan, is die groot aantal aansoeke wat nie toegestaan kon word nie. Vir diegene wat nie deur die Helpmekaar gehelp kan word nie, was daar volgens Stals net een van drie uitweë. Hulle kan óf van die staat hulp ontvang óf die Helpmekaar moes 'n groter poging aanwend sodat hy hulle ook kon help:

"of hulle moet die groot stroom volg van die wat ongesiens, ongehoord, die lewe onvoorbereid tegemoet gaan om daarvan 'n mislukking te maak, saam met die wat uit hulle gebore sal word - 'n treurige alternatief." ${ }^{56}$

Wat werkverskaffing op die platteland betref, het Stals nog steeds vasgeklou aan die landbou as die kern van Afrikaners se voorspoed: "Ons Afrikaanse volk was en is nog altyd 'n landbou-adel of aristokrasie ... Ons landbousamelewing moet nog steeds die adel van die volk bly." Daarom was sy wekroep nog steeds "terug ... na die platteland". ${ }^{57}$ Die doel agter die opheffingswerk van die armblankes was om die volksverband te handhaaf. Stals was van mening dat:

"hierdie aansienlike deel van ons vlees en bloed verband kan verloor met die ander groter meer selfstandige deel. Die gevaar is dat die Kerk van die vadere, die Godsdiens van die vadere, die sedes van die vadere, en die kultuur van die vadere, wat almal deel uitgemaak het van 'n selfstandige Suid-Afrikaanse volkslewensbeskouing, hulle invloed kan kwytraak. Daarom, ... is dit noodsaaklik dat stappe moet geneem word om die volksverband te bly handhaaf. Vir die uitgeweke dele is daar geen vooruitsig hoegenaamd om by ' $n$ ander selfstandige volksdeel ingelyf te word nie. Vir die ander deel van die volk is dit ondenkbaar dat so 'n aansienlike deel sy verwantskap moet kwytraak. Ons is èèn

\footnotetext{
$56 \quad$ Ibid.,3.

57 Ibid.
} 


\section{Die Kaapse Helpmekaar}

in oorsprong en èèn in belang. Ons moet èen bly in strewe vir die handhawing van die volkstradiesies en volksideale." ${ }^{58}$

Teen dié agtergrond van Stals se "Die volk bloei dood"59-benadering met sy gedetailleerde jaarlikse statistiese evaluerings van die tekortkominge in die nasionale onderwysstelsel, die hoë kindersterftessyfer, die stroom na die stede en die volk se sedelike verval het die Helpmekaar die uitdagings van die twintigerjare aangepak.

\section{Pogings tot herlewing deur propaganda-inisiatiewe}

Die twintigerjare is gekenmerk deur verskeie inisiatiewe om die agteruitgang en verval van takke teen te werk en herlewing in die aktiwiteite van die Helpmekaar te bewerkstellig. Die tyd en energie wat hieraan bestee is, was die gevolg van die opvatting dat dit die takke was wat die Helpmekaar gemaak het wat hy was, dat die Vereniging se voortgesette bestaan dus van die takke afgehang het en dat in hul pogings om die armblankevraagstuk aan te spreek die takke deur hul plaaslike betrokkenheid en bydraes in die voorste linie geveg het. Die twee vernaamste inisiatiewe was die aanstelling van 'n organiserende of reisende sekretaris en die benutting van die gedrukte media deur die verkryging van publikasieruinte vir Helpmekaarnuus in Die Huisgenoot. Daar sal vervolgens kortliks na die twee inisiatiewe verwys word.

Vanuit takgeledere was daar uit wans uit beduidende steun vir die gedagte dat die oplossing vir die agteruitgang en verval van takke en die soeke na herlewing gelê het in die aanstelling van 'n organiserende of reisende sekretaris. Die sekretaris moes deur takbesoeke nuwe lewe in takke blaas en as skakel tussen die Kaapstad gebaseerde sentrale bestuur en die meestal plattelandse takke, dien. Die gedagte is minder entoesiasties in die geledere van die sentrale bestuur ondersteun. Die finansiële implikasies wat so 'n aanstelling ingehou het en bedenkinge oor die vrugte wat in terme van finansiële opbrengs daarvan gepluk sou kon word, was hoofsaaklik hiervoor verantwoordelik. Aanduidings is dan ook dat die penningmeester, advokaat Wessel Roux, die sentrum van die bedenkinge verteenwoordig het. Aanvanklike oprigtingswerk is dus deur lede van die sentrale bestuur deur middel van takbesoeke gedoen. Nadat verskeie beskrywingspunte vir die aanstelling van 'n organiserende sekretaris by die 1921-kongres ontvang is, is besluit om 'n propaganda kommissie van vyf lede aan te stel "om in oorleg met die sentrale bestuur sake te reël en hulp aan te bied waar nodig". ${ }^{0}$

\footnotetext{
$58 \quad$ Ibid., 4.

59 (HSA) HVKP, Notuleboek, 25-26 Apr 1923, Kongres, Voorsittersrede, 2.

60 (HSA) HVKP, Notuleboek, 25-26 Mei 1921, Kongres, 7-8, 9.
} 
In die periode ná die 1921-kongres het die lede van die Propaganda Kommissie en die sentrale bestuur hul bes gedoen om te voldoen aan die versoek van takke om hul te besoek en weer op te rig of te bemoedig. ${ }^{61}$ Die voorsitter en sentrale bestuur was dus by die 1922-kongres van mening dat, al was daar takke wat kwyn en agteruitgaan, die Helpmekaar steeds vooruitgaan en daar nog baie belangstelling in die werk van die Vereniging was ${ }^{62}$ en dat die aantal nuwe takke en vermeerdering in ledetal 'n aanduiding was dat die Propaganda Kommissie goeie werk gedoen het. ${ }^{63}$ Die werk van die Propaganda Kommissie het nie die takversoeke vir die aanstelling van 'n reisende sekretaris besweer nie. Die 1922-kongres het dus besluit dat aangesien daar so 'n groot beroep op die steun van die Helpmekaar, veral ten opsigte van opvoeding, gedoen is en die fondse beperk was, daar propaganda gemaak moes word deur die sentrale bestuur. Hulle moes van tyd tot tyd iemand aanstel om takke te besoek ten einde kwynende takke wakker te makk en nuwes te stig. ${ }^{64}$

Die werk van die Propaganda Kommissie het in die vaarwater van die 1922-kongres met wisselende sukses te doen gekry en hoewel mev Greeff, lid van die sentrale bestuur, berig het van verskeie takbesoeke wat sy afgelê het en deur suksesvolle vergaderings nuwe lede te laat aansluit het, kon die teenstand teen die Helpmekaar in sommige gebiede nie besweer word nie. ${ }^{65}$ In Maart 1923 het mev Greeff in 'n ontmoeting met die dagbestuur van die Helpmekaar verskeie versoeke gerig wat 'n uitvloeisel was van haar ervarings tydens haar besoeke aan takke.

Sy is getref deur die baie onkunde oor die doel en werk van die Helpmekaar en het dus versoek of daar nie 'n referaat by die kongres gelewer kon word om dit uiteen te sit nie. Sy het ook gevra of die besluit dat takke 50 persent van hul inkomste plaaslik kon bestee nie herroep kon word nie en weer na een derde verander kon word nie. Geld is vir allerlei plaaslike doeleindes gegee en die Helpmekaar het dus daardeur die werk van ander liggame gedoen. Haar ondervinding was ook dat artikel 2 (b) van die grondwet (wat verwys het na die skepping van 'n eie Afrikaanse kultuurlewe) baie moeilikheid by mense veroorsaak het en het gevra of daar nie 'n ander interpretasie daaraan gegee kon word nie. Die vergadering het geen besluite geneem nie, behalwe om te onderneem om die beskrywingspunte wat in verband

\footnotetext{
61 (HSA) HVKP, Notuleboek (19 Mrt 1921-15 Apr 1924), 30 Jul 1921, Sentrale Bestuur, 27.

62 (HSA) HVKP Notuleboek, 26-27 Apr 1922, Kongres, Sentrale Bestuur verslag, 4.

63 (HSA) HVKP, Notuleboek, 26-27 Apr 1922, Kongres, Voorsittersrede, 2.

64 (HSA) HVKP, Notuleboek, 26-27 Apr 1922, Kongres, 6.

65 (HSA) HVKP, Notuleboek, (19 Mrt 1921-15 Apr 1924), 18 Aug 1922, Sentrale Bestuur, 106-107; 22 Sep 1922, 114-115; 27 Okt 1922, 123-124; 16 Feb. 1923, 153.
} 


\section{Die Kaapse Helpmekaar}

met bogenoemde aangeleenthede van Burgersdorp ontvang is op die kongres in behandeling te neem. ${ }^{66}$

Uit die verslag van die sentrale bestuur wat voor die 1923-kongres gedien het, was dit duidelik dat ten opsigte van propagandawerk daar nie veel vordering gemaak is nie. Enkele lede van die sentrale bestuur het takke besoek om probleme op te los en agteruitgang te stuit en in 'n enkele geval 'n nuwe tak te stig. Weens die droogte was dit egter onmoontlik om plekke te besoek wat hulle in die oog gehad het. Dit was ook moeilik vir die bestuur om uit hulle werk afwesig te wees om sodanige besoeke te doen. ${ }^{67}$ Die takverslag het'n soortgelyke verhaal vertel met tien uit die 31 takke wat verslae gestuur het waar geen pogings aangewend is om fondse tydens die jaar in te samel nie. Die heersende droogte was blykbaar 'n groot rede daarvoor.

Van vier takke is verneem dat hul niks het om te rapporteer nie, "want die toestand onder ons mense was te haglik om te probeer om iets bymekaar te bring". Drie het laat weet dat hul voorsitters afwesig was en dat dit dus onmoontlik was om verslae op te stel. Die tak Graaff-Reinet het ten spyte van die reorganisasiepogings van die sentrale bestuurslid, mnr G Jordaan, besluit om te ontbind. Takke het ook bestuurslede deur die dood of verhuising verloor. ${ }^{68}$ Daar was steeds die tradisionele klagte van die vergaderings wat sleg bygewoon is, maar in ander gevalle is weer berig van die belangstelling wat toeneem. Die verslag het ook meegedeel dat 'n geleentheid na die afloop van die kongres geskep sou word sodat afgevaardigdes die toestande in die verskillende takke kon bespreek. ${ }^{69}$

Ten spyte van die Cillie Kommissie (wat oor die fokus van Helpmekaar-hulp besin het) se aanbeveling dat hulle vanweë die koste daaraan verbonde nie die idee van 'n organiserende sekretaris kon ondersteun nie, het die kwessie teen die bogenoemde toestand van die takke weer in 1923 aan die orde gekom. Verskeie voorstelle vir en teen 'n organiserende sekretaris is ingedien. Die kongres het uiteindelik 'n voorstel om wel 'n organiserende sekretaris aan te stel met 19 teen 11 stemme aanvaar. Aangesien die voorstel wat aanvaar is geen melding van 'n datum van aanstelling van so 'n organiserende sekretaris gemaak het nie, is 'n verdere voorstel ingedien dat die aanstelling van die organiserende sekretaris in die hande van die sentrale bestuur gelaat sou word en dat hulle kon besluit wanneer en hoe dit moes geskied, selfs al was die aanstelling nie binne die volgende 12 maande nie. Dié voorstel is met 13 stemme teen 12

66 (HSA) HVKP, Notuleboek (19 Mrt 1921-15 Apr 1924), 22 Mrt 1923, Sentrale Bestuur, 158-160.

67 (HSA) HVKP, Notuleboek, 25-26 Apr 1923, Kongres, Sentrale Bestuur verslag, 5.

68 (HSA) HVKP, Notuleboek, 25-26 Apr 1923, Kongres, Verslag oor takke, 7.

69 Ibid. 
aanvaar ${ }^{70}$ wat 'n aanduiding was dat daar geen eenstemmigheid oor die aanstelling van die organiserende sekretaris was nie.

Die besluit van die 1923-kongres dat ' $n$ organiserende sekretaris aangestel moes word, is in Junie 1923 deur die sentrale bestuur met die aanstelling van mev Greeff geïmplementeer. Mev Greeff se opdrag was om volgens kongresbesluit die sake van armblankes en werkloosheid voor die aandag van die takke te bring en om die Helpmekaar werk aan te moedig, uit te brei en belangstelling op te wek. In die proses het sy 32 dorpe besoek - 15 met werkende takke, vier vervalle takke wat herstel is, agt nuwe takke wat gestig is en vyf plekke om voorbereidingswerk vir takstigting te doen. In die proses is 638 nuwe lede vir die Helpmekaar gewerf. Greeff se indrukke in haar omgang met Helpmekaar-takke was dat daar 'n besliste verslapping in die Helpmekaarbeweging gekom het, maar dat daar wel 'n "redmiddel" was om dit teen te werk.

Sy het die verslapping toegeskryf aan onkunde, vooroordeel en misverstand oor die werk van die Helpmekaar. Volgens haar oordeel kon die toestand slegs teengewerk word "deur die volk deeglik inligting te gee”. Die grootste probleem in haar organisasiewerk was om 'n geskikte en gewillige persoon te kry om 'n vergadering te reël. Sy moes soms herhaaldelik korrespondeer om sulke reëlings gefinaliseer te kry en haar ondervinding was dat die verantwoordelike persone gewoonlik agterna spyt was dat nie meer moeite gedoen is om meer mense vir die vergadering te werf nie. Haar ervaring was "belangstelling volg dadelik op inligting". Dit was vir haar verbasend hoe min mense bewus was van die doel, werksaamhede en omvang van die Helpmekaar se werk. Dit was haar oordeel dat vooroordeel en misverstand alleenlik deur persoonlike kontak en mededeling oor die Helpmekaar se werk uit die weg geruim kon word. Sy was oortuig dat daar voldoende bewys was dat indien die Helpmekaar reg begryp word dit 'n baie groot plek in die Afrikanervolk se hart sou inneem.

Die ondersteuning van die predikante en die onderwysers was ook vir haar 'n verblydende teken. Sy het ook 'n politieke doel vir die Helpmekaar voorsien met haar uitspraak dat "een van die heerlikste vrugte van die Helpmekaar is seker dat hy ons verdeelde volk beslis help op die weg na hereniging."71 In dié verband is sy in haar oordeel waarskynlik deur die politieke tydsgees, wat in die vroeë 1920's deur NP/SAP-herenigingspogings gekenmerk is, meegesleur.

Teen die agtergrond van bogenoemde pogings van mev Greeff het die sentrale bestuur dus by die 1924-kongres rapporteer dat daar nuwe lewe en vooruitgang asook meer belangstelling

70 (HSA) HVKP, Notuleboek, 25-26 Apr 1923, Kongres, 12, 15.

71 (HSA) HVKP, Notuleboek, 15-17 Apr 1924, Kongres, Sentrale Bestuur verslag, 4-5. 


\section{Die Kaapse Helpmekaar}

in die Helpmekaar gekom het gedurende die verslagjaar. ${ }^{72}$ Die voorsitter (Stals) het die sentimente van vooruitgang en herlewing gedeel. Die ywer waarmee basaars gehou en Afrikanerdag gevier is en die feit dat takke nie ontbind het nie en van die ou takke weer opgerig is, is as bewyse deur hom aangevoer. ${ }^{73}$ Die 1924-kongres moes beslis tevrede gewees het met die propagandapogings van die organiserende sekretaresse, aangesien 'n voorstel van B Louw van Malmesbury, gesekondeer deur dr Werdmuller, dat sy weer deur die sentrale bestuur aangestel moes word om propaganda te maak vir die Helpmekaar om nuwe takke te stig, algemeen aanvaar is. ${ }^{74}$

Te midde van die optimisme oor die Helpmekaar-"herlewing" het die penningmeester se verslag egter die harde finansiële realiteite van die aanstelling van 'n organiserende sekretaris uitgewys. Ten spyte van die positiewe werk wat sy gedoen het, was dit uit 'n finansiële oogpunt nie 'n lonende onderneming nie. Volgens die penningmeester se berekenings het sy aan salaris en reiskoste-uitgawes die Helpmekaar $£ 139$ 11s 7d gekos, terwyl die inkomste wat ontvang is van die nuwe takke wat sy gestig het of dié waarin sy nuwe lewe geblaas het slegs $£ 8614$ s $2 \mathrm{~d}$ was. Saam daarmee het die nuwe takke wat sy gestig het en heropgerig het baie aansoeke om studielenings ingestuur wat die werk en dus ook die administrasiekoste vermeerder het. Dit het ook beteken dat meer aansoeke om die beskikbare geld meegeding het. Die penningmeester het ook daarop gewys dat die takke wat by die vorige kongres in 1923 so entoesiasties oor organisasie en propoganda was slegs $£ 26$ ingestuur het ter delging van die koste van die organiserende sekretaresse. ${ }^{75}$ Uit die trant van die verslag was dit duidelik dat die penningmeester waarskynlik nie ten gunste van 'n organiserende sekretaris was nie. Ten spyte hiervan is sy in Junie 1924 vir 'n verdere drie maande deur die sentrale bestuur aangestel. ${ }^{76}$

Greeff het die verlengde aanstelling aanvaar, maar versoek om nie onmiddellik met propaganda en organisasie te begin nie - wat toegestaan is. Die sentrale bestuur het Greeff meegedeel dat haar eerste prioriteit moes wees om takke waar verslapping ingetree het te besoek. As die stigting van nuwe takke in die proses op haar weg kom, was dit goed so. ${ }^{77}$ In vergelyking met die 1924-poging het die 1925-verslag van die organiserende sekretaresse

\footnotetext{
$72 \quad$ Ibid.,5.

73 (HSA) HVKP, Notuleboek, 15-17 Apr 1924, Kongres, Voorsittersrede, 2.

74 (HSA) HVKP, Notuleboek, 15-17 Apr 1924, Kongres, 9.

75 (HSA) HVKP, Notuleboek, 15-17 Apr 1924, Kongres, Penningmeester verslag, 12.

76 (HSA) HVKP, Notuleboek (21 Mei 1924-3 Apr 1928), 30 Jun 1924, Sentrale Bestuur, 11-12.

77 (HSA) HVKP, Notuleboek (21 Mei 1924-3 Apr 1928), 1 Sep 1924, Sentrale Bestuur, 27-28.
} 
aangedui dat haar organisasiewerk op veel kleiner skaal as die vorige jaar plaasgevind het, aangesien sy weens omstandighede eers in Januarie 1925 met haar werk kon begin. Hoewel sy nie so wyd gereis het soos die vorige jaar nie was sy diep oortuig dat organisasiewerk noodsaaklik was vir die voortbestaan van die Helpmekaar en dat indien daar nie voortdurend 'n persoonlike verband met die takke sou bestaan nie baie van hulle sou ophou bestaan. Volgens Greeff is die saak nie fluks genoeg op die voorgrond gehou nie - vandaar die floue belangstelling en ondersteuning. ${ }^{78}$

In die lig van die kwessie om meer belangstelling te wek is die saak van plaaslike fondse weer geopper en as 'n moontlike oplossing voorgehou. 'n Voorstel is aanvaar dat:

"met die oog op meer geesdrif en belangstelling in plaaslike Helpmekaar takke, besluit

die kongres dat takke tweederdes van hul jaarlikse opbrengs plaaslik mag spandeer".79

'n Mosie is ook aanvaar dat mev Greeff weer vir die jaar as organiserende sekretaresse aangestel word. 'n Voorstel is ook aanvaar dat die kongres 'n kommissie moet benoem om praktiese wenke aan die hand te doen van hoe propaganda gemaak kan word. ${ }^{80}$

Ten spyte van die besluit om Greeff weer as organiserende sekretaris aan te stel is die organisasiewerk nie in die 1926-kongresjaar voortgesit nie en by die kongres is slegs gerapporteer dat omstandighede dit onmoontlik gemaak het. Uit beskikbare getuienis is daar aanduidings dat die verhouding tussen Greeff en die sentrale bestuur stram geraak het. In 'n brief aan die sentrale bestuur waarin sy om verskoning vra dat sy nie die sentrale bestuur se vergadering kan bywoon nie en hulle ook meedeel dat sy die 1926-kongres sou misloop, het sy verwys na die sentrale bestuur se houding teenoor haar gedurende die afgelope jaar en het sy die bestuur versoek "om takt te gebruik om nie verder aanleiding te gee om openbare mening teen haar op te werp nie". ${ }^{81}$ Die sentrale bestuur het haar brief bespreek, maar geen besluite daaroor geneem nie. Hoewel dit onseker is waarna sy verwys het, was dit waarskynlik 'n verwysing na die teenstand wat daar op finansiële gronde by ten minste sekere lede van die sentrale bestuur teen die aanstelling van 'n organiserende sekretaris bestaan het.

79 (HSA) HVKP, Notuleboek, 15-16 Apr 1925, Kongres, 10.

$80 \quad$ Ibid., 10.

81 (HSA) HVKP, Notuleboek (21 Mei 1924-3 Apr 1928), 7 Apr 1926, 134. 


\section{Die Kaapse Helpmekaar}

Daar is in verslae van takke ${ }^{82}$ en by die daaropvolgende kongresse weer die gebruiklike voorstel vir die aanstel van 'n organiserende sekretaris gemaak. Die finansiële implikasies van die pos - ironies genoeg vanweë die sukses wat Greeff behaal het - het egter enige verlenging van haar aanstelling gekelder. 'n Voorstel vir 'n amptelike kwartaalblad vir die Helpmekaar is waarskynlik om dieselfde rede afgekeur. ${ }^{83}$ In die plek daarvan is by beide die 1927 - en 1928-kongresse besluit dat die bestuur gemagtig word om 'n maksimum bedrag van $£ 100$ uit die lopende rente van die jaar vir organisasie te bewillig. ${ }^{84}$

Naas die aanstel van 'n organiserende sekretaris is 'n tweede propaganda-voorstel op die 1921-kongres aanvaar, naamlik dat die uitgewers van Die Huisgenoot genader moet word. Daar moes gevra word om 'n rubriek beskikbaar te stel waar nuus van die Vereniging en sy werk geplaas kon word en dat takke moes versoek word om die rubriek deur nuusbydraes te ondersteun. ${ }^{85}$ Die verwagting was dat die rubriek skakeling en kontak tussen die takke sou bevorder. Hulle sou op dié wyse van mekaar se bedrywighede kon kennis neem en ook die breër publiek sou van die Helpmekaar se aktiwiteite te wete kom. Dit sou tot groter belangstelling in die Vereniging lei omdat daar besef sou word "wat 'n heil die Helpmekaar vir land en volk is" ${ }^{86}$ In die lig van die groeiende status van Die Huisgenoot as die "volk se universiteit" en die tydskrif se stygende sirkulasiesyfers, wat teen 1930, 40000 kopieë per uitgawe bereik het, was dit 'n uitstekende medium om die Helpmekaar groter blootstelling te gee. Die lesers van Die Huisgenoot en die Helpmekaar het boonop in dieselfde kulturele en politieke dampkring beweeg. ${ }^{87}$

Die aanvanklike indrukke van die impak van die rubriek (wat die Helpmekaar jaarliks $£ 50$ gekos het $)^{88}$ met sy uittreksels uit die notules van die sentrale bestuur en die nuus van takke was positief, maar die sentrale bestuur se verslag het reeds in 1922 sy teleurstelling uitgespreek "dat die takke so min gebruik maak van die kolom en dit so skraal ondersteun met leesstof". ${ }^{99}$ Ten spyte van die goeie werk van mev Greeff van Burgersdorp, wat as redaktrise van die

\footnotetext{
82 (HSA) HVKP, Notuleboek, 13-14 Apr 1927, Kongres, 5.

83 (HSA) HVKP, Notuleboek, 4-5 Apr 1928, Kongres, 14, 15.

84 (HSA) HVKP, Notuleboek, 13-14 Apr 1927, Kongres, 6; (HSA) HVKP, Notuleboek, 4-5 Apr 1928, 14, 15.

85 (HSA) HVKP, Notuleboek, 25-26 Mei 1921, Kongres, 5, 7.

86 (HSA) HVKP, Notuleboek, 25-26 Apr 1923, Kongres, Sentrale Bestuur verslag, 6.

87 H Giliomee, The Afrikaners. Biography of a People, 375, Tafelberg, Cape Town, 2012.

88 (HSA) HVKP, Notuleboek (19 Mrt 1921-15 Apr 1924), 25 Jun 1921, Kongres, 19; (HSA) HVKP, Notuleboek (19 Mrt 1921-15 Apr 1924), 30 Jul 1921, 29.

89 (HSA) HVKP, Notuleboek, 26-27 Apr 1922, Sentrale Bestuur verslag, 3.
} 
rubriek opgetree het, en 'n besluit van die 1922-kongres dat elke Helpmekaar-tak ten minste eenmaal per jaar van hom moet laat hoor deur'n berig in Die Huisgenoot-rubriek te plaas, het die situasie nie verbeter nie. ${ }^{90}$ Hierdie gebrekkige takdeelname is vererger deur probleme soos ontevredenheid oor die redaksionele ingrepe deur Die Huisgenoot ten opsigte van die inhoud van die berigte, ${ }^{91}$ die persepsie dat Die Huisgenoot se redaksie die kolom "stief" behandel ${ }^{92}$ en die lang tyd wat verloop het voor berigte geplaas is. Die takke is gemotiveer om eerder berigte oor hul aktiwiteite na Die Burger te stuur. Dit het ongelukkig spoedig die doodsklok vir die inisiatief laat lui.

In 1924 het die bestuur dus die kongres meegedeel dat hulle nie die vrymoedigheid het om aan te beveel dat met die kolom voortgegaan moet word nie. ${ }^{93}$ Hoewel die kongres die aanbeveling aanvaar het, was die gevoel dat die mag van die pers steeds benut moes word om die werk van die Helpmekaar beter bekend te stel. Na heelwat bespreking is dus besluit dat in die lig van die beëindiging van Die Huisgenoot-rubriek $£ 25$ aan die sentrale bestuur beskikbaar gestel sou word vir propagandawerk deur die pers. ${ }^{94}$

Benewens die organiserende sekretaris en Huisgenoot-kolom-inisiatiewe het die Helpmekaar ook op verskeie ander maniere sy aktiwiteite probeer bekendstel om op dié wyse steun vir die werk van die Vereniging te werf. 'n Standaard prosedure was om eksemplare van die jaarlikse kongresnotules aan alle takke, kongres-afgevaardigdes, sekretarisse van ander provinsies se Helpmekaarverenigings, studente wat deur die Helpmekaar in die buiteland ondersteun word, NG en Gereformeerde kerkrade en ander belangstellendes te stuur. ${ }^{95}$ In 1926 is byvoorbeeld 200 kongresnotules aan NG predikante en kerkrade, 24 aan Gereformeerdes, 30 aan oudstudente en persone deur die bestuur benoem, gestuur. ${ }^{96}$

Die sentrale bestuur het ookopverskeie ander maniere probeer om die werk van dieHelpmekaar aan die breër publiek bekend te stel. In 1926 is die pers ingespan deur byvoorbeeld kort voor Afrikanerdag 'n klein kommissie aan te stel om 'n verslag op te stel van die hoogtepunte

\footnotetext{
90 (HSA) HVKP, Notuleboek, 26-27 Apr 1922, Kongres, 7.

91 (HSA) HVKP, Notuleboek (19 Mrt 1921-15 Apr 1924), 11 Feb 1924, Sentrale Bestuur, 241.

92 (HSA) HVKP, Notuleboek, 15-17 Apr 1924, Kongres, Sentrale Bestuur verslag, 5, 6.

93 (HSA) HVKP, Notuleboek, 15-17 Apr 1924, Kongres, Penningmeester verslag, 12.

94 (HSA) HVKP, Notuleboek, 15-16 Apr 1925, Kongres, 7.

95 (HSA) HVKP, Notuleboek, 25-26 Mei 1921, Kongres, 3; (HSA) HVKP, Notuleboek 25-26 Apr 1923, Sentrale Bestuur verslag, 4-5; (HSA), HVKP Notuleboek (19 Mrt 1921-15 Apr 1924), 3 Des 1923, 238; (HSA) HVKP, Notuleboek (21 Mei 1924-3 Apr 1928), 21 Mei 1924, Sentrale Bestuur, 2.

96 (HSA) HVKP, Notuleboek (21 Mei 1924-3 Apr 1928), 24 Jun 1926, Sentrale Bestuur, 145.
} 


\section{Die Kaapse Helpmekaar}

van die laaste tien kongresse en die werk wat die Helpmekaar gedoen het. Dit is na 'n aantal Hollandse (Afrikaanse) dagblaaie gestuur en ook na twee Engelse dagblaaie. Afdrukke is ook na takke en belangstellendes gestuur. Die notules van bestuursvergaderings is ook op gereelde basis na agt Hollandse (Afrikaanse) dagblaaie gestuur, asook na sekretarisse van takke met die opdrag om dit tydens hul vergaderings voor te lees. Aangesien die Huisgenoot-rubriek nie meer bestaan het nie is van die takke se aktiwiteite ook saam met die notule gepubliseer terwyl die redaktrise van "Vrouesake" in Die Burger ook somtyds van die Helpmekaar se werk gepubliseer het. ${ }^{97}$

In 1923 is 'n voorstel aanvaar dat die afgevaardigdes na die kongres by hul onderskeie takke verslag doen oor die werksaamhede en besluite van die kongres en dat die jaarverslag van die sentrale bestuur en die penningmeester gelees moet word. ${ }^{98}$ 'n Ander benadering was 'n voorstel van Philipstown vir die hou van 'n inter-provinsiale kongres om belangstelling vir die Helpmekaar op te wek. Mnr van Rooyen van die Vrystaatse Helpmekaar het voorgestel dat die sentrale bestuur moet kennis neem van die werk van die Onderwysersunie en het ook gepleit vir 'n Federale Raad vir die Helpmekaarverenigings. 'n Besluit is uiteindelik aanvaar dat die sentrale bestuur opdrag kry om vas te stel in hoeverre daar uitvoering aan die sentimente gegee kan word. ${ }^{99}$

Die harde realiteit van die twintigerjare, in terme van die pers, was egter dat die Helpmekaar sy nuuswaardigheid verloor het. Ten spyte van die sentrale bestuur se klagte by Die Burger omdat die 1925-kongres op Kimberley nie deur die koerant gedek is nie - dit terwyl die Helpmekaar kennis gegee het van die kongres deur middel van 'n advertensie in Die Burger ${ }^{100}$ - en die redakteur die versekering gegee het dat dit nie weer sou gebeur nie ${ }^{101}$ het dieselfde scenario hom in 1926 herhaal. ${ }^{102}$ Die Helpmekaar se protesbrief hieroor aan die redakteur, WA Hofmeyr, is ook nie deur hom persoonlik beantwoord nie, maar dit is aan mnr Frederick Rompel, nuusredakteur, oorhandig om te beantwoord. ${ }^{103}$ By die 1926-kongres het Stals

97 (HSA) HVKP Notuleboek, 7-8 Apr 1926, Kongres, Sentrale Bestuur verslag, 5.

98 (HSA) HVKP, Notuleboek, 25-26 Apr 1923, Kongres, 15.

99 (HSA) HVKP, Notuleboek, 15-16 Apr 1925, Kongres, 9.

100 (HSA) HVKP, Notuleboek (21 Mei 1924-3 Apr 1928), 28 Mei 1925, Sentrale Bestuur, 82-83.

101 (HSA) HVKP, Notuleboek (21 Mei 1924-3 Apr 1928), 24 Apr 1925, Sentrale Bestuur, 86.

102 (HSA) HVKP, Notuleboek (21 Mei 1924-3 Apr 1928), 12 Mei 1926, Sentrale Bestuur, 142.

103 (HSA) HVKP, Notuleboek (21 Mei 1924-3 Apr 1928), 24 Jun 1926, Sentale Bestuur, 144. 
versoek dat benewens die normale verspreiding van die kongresnotules iemand aangestel moet word om ook 'n kort verslag in Engels vir die nuusagentskap Reuters op te stel. ${ }^{104}$

'n Voorstel is ook aanvaar dat 'n kommissie aangestel moet word om tydens die volgende kongres met 'n voorstel vorendag te kom oor "Wat kan gedoen word om ons Helpmekaar te inspireer en meer belangstelling by die lede op te wek, veral die bywoon van vergaderings". ${ }^{105}$ $\mathrm{Na}$ afloop van die 1926-kongres het die sentrale bestuur ook'n voorstel van mev Roux aanvaar dat in die toekoms jaarverslae van takke een vir een op die kongres voorgelees sal word. Daar is gehoop dat dit meer belangstelling by die afgevaardigdes sou opwek en as inspirasie sou dien. ${ }^{106}$ 'n Versoek van die Beaufort-Wes-tak dat iets oor die werk van die Helpmekaar in die Kerkbode geskryf moet word "omdat daar nog so baie onkunde en vooroordeel bestaan in sommige plekke" is ook aanvaar en die sekretaresse is opdrag gegee om die Kerkbode se redakteur, ds Meiring, te vra om 'n stuk te skrywe. ${ }^{107}$

\section{Enkele kenmerke/tendense van takbedrywighede in die 1920's}

Afgesien van die normale templaat van takbedrywighede waarna reeds in die vorige afdeling verwys is, is takbedrywighede in die twintigerjare deur veral drie tendense gekenmerk. Eerstens was dit takke se beperkte vermoë om grootskaalse plaaslike projekte volhoubaar te bedryf. Tweedens, die impak van verstedeliking op takstigting, uitbreiding en bedrywighede en laastens was dit die toenemende fokus op bydraes vir opvoedingsbehoeftes as teenvoeter vir die armblankevraagstuk - dus volksopbou deur volksopvoeding.

Die Cillie Kommissie van 1923 se bevinding dat die Helpmekaar nie oor die finansiële middele beskik om op 'n substansiële wyse betrokke te raak by groot skemas om die armblankevraagstuk op te los nie, het in die praktyk ook vir die plaaslike takke gegeld. Hierdie realiteit is eerstens bevestig deur die onophoudelike versoeke aan die sentrale bestuur dat takke oor 'n groter deel van hul plaaslik ingesamelde fondse moet kan beskik "met die oog op die toename van die getal arme blankes". ${ }^{108}$ Tweedens het dit geblyk dat waar plaaslike takke

104 (HSA) HVKP, Notuleboek, 7-8 Apr 1926 Kongres, 8.

105 Ibid.,10.

106 (HSA) HVKP, Notuleboek (21 Mei 1924-3 Apr 1928), 24 Jun 1926, Sentrale Bestuur, 145.

107 Ibid.,147.

108 (HSA) HVKP, Notuleboek, 25-26 Mei 1921, Kongres, 6. 


\section{Die Kaapse Helpmekaar}

wel skemas van groter omvang en 'n meer langdurige aard aangepak het, hulle weldra gestuit is deur die plaaslike tekort aan fondse om die skemas deur te voer of te onderhou. ${ }^{109}$

Twee voorbeelde van uiteenlopende aard het die tendens bevestig. Daar is reeds verwys na die inisiatief van die Worcester-tak om eiendom vir armblanke behuising in Worcester aan te koop, asook die lof wat hulle in dié verband deur die sentrale bestuur vir hul inisiatief toegeswaai is. Die tak se aanvanklike versoek aan die sentrale bestuur vir'n lening van $£ 2500$ vir die finansiering van die skema is egter van die hand gewys ten spyte van die waardering wat daar vir die inisiatief bestaan het. ${ }^{110}$ Die 1920-versoek van die voorsitter van die Worcestertak, mnr JPP Hugo, dat die tak die volle opbrengs van hul Afrikanerdag-insameling mag hou en aanwend vir die eiendom wat hulle aangekoop het, is egter wel goedgekeur. As plaaslike tak het hulle egter ook probleme met die registrasie van die eiendom ondervind. Die Registrateur van Aktes wou bewys hê dat die reëls en regulasies van die Helpmekaar daarvoor voorsiening gemaak het dat takke die reg het om sulke transaksies aan te gaan.

Die sentrale bestuur het dus onderneem om die Registrateur in dié verband te gaan sien. ${ }^{111}$ In Mei 1925 was die Worcester-tak genoodsaak om hul weer tot die sentrale bestuur te wend met die versoek of hulle hul hele opbrengs van die jaar mag behou en mag gebruik om hul skuldlas ligter te maak. Die sentrale bestuur het nie die gesag gehad om aan die versoek te voldoen nie. Hulle was wel bereid om afhangende van die bedrag ter sprake, die versoek by die kongres aan te beveel. ${ }^{112}$ Teen 1926 het die skema dus die Worcester-tak gelaat met 'n skuldlas van $£ 2500$ op die eiendomme wat hulle aangekoop het - met weinig hoop dat hulle ooit die skuld sou kon delg. ${ }^{113}$

Die inisiatief van die Kaapse Skiereiland-tak om 'n sosiale werkster aan te stel om onder die "verwaarloosde en veragtende" in Kaapstad te werk was, hoewel van 'n uiteenlopende aard, 'n soortgelyke voorbeeld. Hoewel dit 'n lofwaardige inisiatief was wat hulle vir 'n aantal jare saam met die ACVV volgehou het, moes die tak in 1922 die sentrale bestuur versoek om die volle basaaropbrengs wat hulle met die 1922-Afrikanerdag geïn het, terug te hou omdat daar nie genoeg geld in hulle kas was om die salaris van mej Wahl, die sosiale werkster, te betaal nie. ${ }^{114}$

\footnotetext{
109 (HSA) HVKP, Notuleboek, (28 Jun 1919-19 Feb 1921), 28 Jun 1919, Sentrale Bestuur, 10.

110 (HSA) HVKP, Notuleboek (28 Jun 1919-19 Feb 1921), 20 Des 1919, Sentrale Bestuur, 62.

111 (HSA) HVKP, Notuleboek (28 Jun 1919-19 Feb 1921), 16 Okt 1920, Sentrale Bestuur, 128.

112 (HSA) HVKP, Notuleboek (21 Mei 1924-3 Apr 1928), 28 Mei 1925, Sentrale Bestuur, 84.

113 (HSA) HVKP, Notuleboek, 7-8 Apr 1926, Sentrale Bestuur verslag, 5.

114 (HSA) HVKP, Notuleboek (19 Mrt 1921-15 Apr 1924), 29 Nov 1922, Sentrale Bestuur, 138.
} 
Verstedeliking het in die vroeë twintigerjare gelei tot 'n takfenomeen in Helpmekaar-terme met die enorme uitbreiding wat deur die Port Elizabeth- en Uitenhage-takke ervaar is. Die Uitenhage-tak het reeds vanaf 1917 bestaan en in die twintigerjare snel gegroei. Soveel as 54 lede het op 'n enkele vergadering lidmaatskap aanvaar. ${ }^{115}$ Hoewel die PE-tak eers in 1922 gestig is, het hul aanvanklike lidmaatskap van 42 lede reeds teen 1924 op 81 gestaan. Hierdie groei is veroorsaak deur die trekkrag van die skoen- en motorvervaardigingsindustrieë wat in hierdie omgewing gevestig is en veral armblanke Afrikaners van die platteland na die sentrums gelok het. ${ }^{116}$

In teenstelling met die meerderheid ander takke is die twee takke se vergaderings uitstekend bygewoon en is gekenmerk deur kulturele aktiwiteite waaraan lede entoesiasties deelgeneem het en waarvan skakeling tussen die twee takke'n belangrike element gevorm het. Interdebatte tussen die twee takke was veral gewild en die onderwerpe wat aan die orde gekom het, soos "Het die Helpmekaar sy doel bereik?" en "Wat kan die Helpmekaar doen om die euwel van saamwoon van blankes en gekleurdes te bestry?", 117 was waarskynlik 'n aanduiding van die kwessies wat vir die gemeenskappe belangrik was. Afgesien van die debatte was Uitenhage en PE van die eerste takke wat elk oor 'n openbare Afrikaanse leeskamer beskik het wat jaarliks geldelik deur die kongres ondersteun is. ${ }^{118}$ Die PE/Uitenhage-fenomeen sou 'n blywende kenmerk van die Helpmekaar-taklandskap bly vir die duur van sy kongresbestaan - selfs tot in die laat vyftigerjare toe die Helpmekaar tot slegs 'n handvol aktiewe takke gereduseer is.

'n Laaste taktendens van die twintigerjare was die konsolidering van plaaslike hulp om "volksopbou deur volksopvoeding" te bevorder. Die takke het druk uitgeoefen om 'n groter deel van hulle fondse te behou. In 1922 het die kongres besluit dat takke die helfte van hul opbrengste plaaslik mag gebruik, maar dat die ander helfte in die sentrale kas gestort moes word. ${ }^{119}$ In 1924 is besluit dat die takke vir een jaar tweederdes van hul inkomste plaaslik kon spandeer. ${ }^{120}$

115 (HSA) HVKP, Notuleboek (19 Mrt 1921-15 Apr 1924), 3 Des 1923, Sentrale Bestuur, 236-237.

116 Teen 1919-1920 was daar reeds 19 skoenfabrieke in PE wat hom die naam as die "Northhampton of South Africa" besorg het. Tussen 1924 en 1926 het beide Ford en General Motors motor-monteerfabrieke in PE opgerig en is ook na die stad as die "Detroit of South Africa" verwys. Teen 1929 was daar reeds 900 blanke werkers by General Motors indiens. Die getal Afrikaanssprekendes in die PE magistraatsdistrik het van 4900 in 1918 na 20500 in 1936 toegeneem. HO Terblanche, Die Afrikaner in Port Elizabeth, 1902-1937: 'n Kultuurhistoriese ondersoek, 35-36, 39-41, 83, Ongepubliseerde PhD, Universiteit Port Elizabeth, 1993.

117 (HSA) HVKP, Notuleboek, 7-8 Apr 1926, Kongres, Takverslae, 7; (HSA) HVKP, Notuleboek (21 Mei 1924-3 Apr 1928), 23 Sep 1925, Sentrale Bestuur, 97-98.

118 (HSA) HVKP, Notuleboek (21 Mei 1924-3 Apr 1928), 2 Sep 1926, Sentrale Bestuur, 153.

119 (HSA) HVKP, Notuleboek, 26-27 Apr 1922, Kongres, 7.

120 (HSA) HVKP, Notuleboek, 15-17 Apr 1924, Kongres, 8. 
Uit die takverslae was dit duidelik dat die meeste van die takbydraes gemik was op die onderwys en opvoedingsbehoeftes van plaaslike behoeftiges. ${ }^{121}$ Hierdie plaaslike fokus is by die 1924-kongres onderstreep deur Petrusville-tak se protes teen die feit dat Helpmekaar-geld vir ander doeleindes as opvoeding aangewend is, soos uit die vorige kongresnotule geblyk het. Die sentrale bestuur het egter die versekering gegee dat alle geld wat van takke ontvang is vir 1923 en 1924 aan opvoeding bestee is. Geld wat vir ander doeleindes bestee is, is uit die rente op die Surplusfonds betaal. Petrusville het ook by die kongres kennis gegee dat hulle by die volgende kongres 'n beskrywingspunt sou indien wat vra dat Helpmekaar-hulp in die toekoms uitsluitlik vir opvoeding aangewend moes word. ${ }^{122}$ Hierdie voorneme is deur die 1927-kongres verder gefokus deur die versoek dat takke sover moontlik plaaslike behoeftige kinders ondersteun wat in Afrikaans-medium skole verder as standerd ses wil studeer. ${ }^{123}$

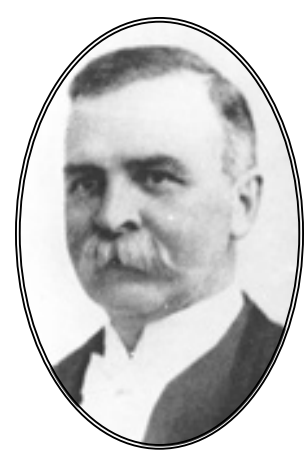

Ds FX Roome, voorsitter van die HVKP in die dertigerjare. Room was getroud met Minnie Roome, een van die sogenaamde "vierskaar" (Minnie Roome, Elizabeth Jordaan, Maria Rothmann, Alida Theron) wat die ACVV in die 1920's en 1930's gedomineer het. (Suid Afrikaanse Biografiese Woordeboek, vol V, 306)

\section{DIE FX ROOME-DERTIGERJARE: VERBREDING VAN DIE HELPMEKAAR-FOKUS MET GROTER KLEM OP KULTUURWERK}

Die werksaamhede van die Helpmekaartakke in die dertigerjare het gestaan in die konteks van 'n groeiende Afrikanernasionalisme in sy populistiese fase. Die fase is gekenmerk deur 'n opwelling in kultuurbevordering: die stigting van die FAK in 1929 en die kulminasie in die eeufeesherdenking van die Groot Trek in 1938, Afrikanerekonomiese bemagtiging deur die Eerste Ekonomiese Volkskongres in $1939^{124}$ en die groeiende prominensie van die gedagte van rasseskeiding en apartheid as redmiddel vir die behoud van die Afrikanervolk en sy gewaande rassesuiwerheid. Hierdie elemente het gesamentlik beoog om Afrikanerbehoud deur Afrikanereenheid te verseker en is verweef met die Helpmekaar se grondliggende strategie van Afrikaneropheffing deur opvoeding. Die Helpmekaar

121 (HSA) HVKP, Notuleboek, 15-17 Apr 1924, Kongres, Takverslae, 6-7.

122 (HSA) HVKP, Notuleboek (21 Mei 1924-3 Apr 1928), 25 Jul 1924, Sentrale Bestuur, 22-23.

123 (HSA) HVKP, Notuleboek (21 Mei 1924-3 Apr 1928), 15 Jun 1927, Sentrale Bestuur, 187.

124 L Koorts, DF Malan and the Rise of Afrikaner Nationalism, 348-349, Tafelberg, Cape Town, 2014. 
het hom by monde van sy voorsitter ds FX Roome ${ }^{125}$ en sy jaarlikse voorsittersredes, asook gepaardgaande kongresbesluite met hierdie strewes vereenselwig. By die jaarlikse kongresse is die takke tot die ondersteuning en uitvoering van die strewes opgeroep, toegerus en finansieel ondersteun. Vervolgens word die vernaamste kenmerke van die periode kortliks toegelig.

Die FX Roome-fase (die dertigerjare) in die geskiedenis van die Helpmekaar en sy takke is gekenmerk deur 'n strewe om die werksaamhede van die organisasie te herbedink. Die strategie vir die strewe tot 'n breër en meer aktiewe betrokkenheid op ekonomiese, opvoedkundige en kulturele gebied is deur Roome in sy eerste voorsittersrede in 1929 vir die eerste keer aan die kongres voorgehou. Hy het aangevoer dat die ekonomiese, opvoedkundige en kulturele eise van die tyd, in tandem met die verwagtinge en potensiaal van die jeug, van die Helpmekaar vereis het om meer te doen as om net geld in te samel en by wyse van lenings en andersins te bestee. Hy het dus 'n beroep gedoen op die kongres vir 'n uitbreiding van die gewone werksaamhede van die Vereniging sodat hulle nie net 'n "administratiewe vereniging" sal wees nie, maar ook 'n "werkende organisasie".

Hy wou ook die jeug betrek om sodoende nuwe bloed vir die Vereniging te bekom. As motief vir die uitbreiding van die Helpmekaar se werksaamhede het hy aangevoer "dat ons daardeur ons jeug sal vernu, en sluimerende kragte wakker maak onder ons eie lede wat tot hiertoe ongebruik gelaat is" ${ }^{126}$ Die verwagting was dus dat die nuwe arbeidsterreine/geleenthede wat die uitbreiding van die werksaamhede van die Helpmekaar sou skep as oplossing vir die gebrek aan lewe en geesdrif by baie Helpmekaartakke sou dien vanweë die nuwe moontlikhede wat dit vir hulle "opgehoopte energie" sou verskaf. In die proses moes die Helpmekaar 'n "Help-u-self"-gees onder mede-Afrikaners aankweek wat tot 'n gevoel van "meerderwaardigheid en selfrespek" en 'n "gees van selfstandigheid" sou lei. Sy lys van aktiwiteite het onder andere die bevordering van 'n eie Afrikaanse kultuur, onderwys, volksgesondheid, die kweek van 'n gesonde spaarsin en groter ondersteuning aan blindes ingesluit. Die aard van die meer daadkragtige Helpmekaar wat Roome gepropageer het, het ook geblyk uit sy oproep dat die Vereniging hom meer moet

"laat gelde in belang van opvoedkundige, industriële, sosiale, en kulturele werk, en ... moet aandring op verteenwoordiging en seggenskap in die beheer en kontrole van sake, veral met die finansiële steun wat ons verleen." ${ }^{127}$

125 Suid-Afrikaanse Biografiese Woordeboek Vol IV, 545. Francis Xavier Roome was van Ierse afkoms. Ten tyde van sy voorsitterskap was hy NG predikant in Seepunt, Kaapstad. Hy het in verskeie kerklike en welsynsorganisasies gedien en was onder andere 24 jaar lank voorsitter van die Bybelgenootskap van Suid-Afrika. Hy was ook 'n stigterslid van die Volkshospitaal in Kaapstad en 'n entoesiastiese lid van die Stedelike Behuisingsbond van Kaapstad.

126 (HSA) HVKP, Notuleboek, 3-4 Apr 1929, Kongres, Voorsittersrede, 2.

127 (HSA) HVKP, Notuleboek, 3-4 Apr 1929, Kongres, Voorsittersrede, 1-2. 


\section{Die Kaapse Helpmekaar}

In van sy latere voorsittersredes het die omvang van Roome se ambisie van 'n meer selfgeldende en sigbare Helpmekaar wat nie net as 'n "noodlenigingsvereniging" bekend moes staan nie verder gestalte gekry. Hy was van mening dat, behalwe die gee van lenings en invordering van skuld, die Helpmekaar oor "geen selfstandige inrigting of werksaamheid wat ons as ons eie kan bestempel nie" beskik het nie. Hy wou dus iets skep of stig wat die Helpmekaar se naam dra en waarop hulle trots kon wees. Baie van die ondersteuning wat die Helpmekaar gegee het, was in samewerking met of vir ander liggame en organisasies. Roome wou dus hê dat die Helpmekaar hom meer doelbewus en daadwerklik moes laat geld. ${ }^{128}$ Die noodsaaklikheid vir Roome se oproep is bevestig deur 'n vraelys van 18 vrae wat in 1936 aan al die takke gestuur is. Uit die antwoorde van takke hierop het die sentrale bestuur tot die gevolgtrekking gekom dat "die Helpmekaar-Vereniging nie alleen aan kwyn is nie, maar gevaar loop om die Dooie-See-stadium te bereik".

In sy 1936-voorsittersrede het hy dus 'n direkte en pertinente beroep op die kongres gedoen om te besin of die tyd nie aangebreek het om aan 'n "nuwe beleid en 'n nuwe program van aksie" te dink nie. ${ }^{129}$ Roome se verbreding van die Helpmekaar se aktiwiteite het veral ook gefokus op 'n groter betrokkenheid by kultuurbevordering. Die voorsitter en sekretaresse van die sentrale bestuur is in 1930 onder andere opdrag gegee om 'n omsendbrief aan takke op te stel met praktiese wenke van hoe hulle te werk moes gaan en wat hulle moes doen om mense in digkuns, musiek en skilderkuns geïnteresserd te kry. ${ }^{130}$ Hoewel dit onbekend is wat die praktiese wenke behels het, het Roome se 1938-voorsittersrede waarskynlik 'n goeie aanduiding verskaf. In 'n oproep op die takke om die Afrikaner se eie kultuurgoedere te eerbiedig, te huldig en te bewaar het hy aangedui dat dit slegs kan geskied "deur persoonlike belangstelling in die produkte van ons skrywers, kunstenaars en musici ... Tot bemoediging moet ons hul boeke lees, hul skilderstukke in ons huise ophang en hul liedere sing." ${ }^{131}$ In dié sin wou Roome dus hê dat die Helpmekaar 'n sterker rol as kulturele intrepreneur in die skep van 'n eie Afrikaner-kultuur vervul.

Afgesien van die skep van 'n eie Afrikaner-kultuur as vereiste vir Afrikaner-oorlewing, was daar'n ander kenmerk van die Roome-era in die dertigerjare wat groter premie en prominente steun aan die behoud van "rassesuiwerheid" as noodsaaklike element in die oorlewingstryd

128 (HSA) HVKP, Notuleboek, 23-24 Apr 1935, Kongres, Voorsittersrede, 2; (HSA) HVKP, Notuleboek, 20-21 Apr 1938, Kongres, Voorsittersrede, 1.

129 (HSA) HVKP, Notuleboek, 15-16 Apr 1936, Kongres, Voorsittersrede, 2.

130 (HSA) HVKP, Notuleboek (21 Mei 1924-3 Apr 1928), 16 Aug 1930, Sentrale Bestuur, 62-63.

131 (HSA) HVKP, Notuleboek, 20-21 Apr 1938, Kongres, Voorsittersrede, 3. 
van die Afrikaner toegeken het. Dit het neerslag gevind in die propagering van die gedagte van skeiding of apartheid van rasse as oplossing vir rassevermenging. In sy 1937-voorsittersrede het Roome hom pertinent oor die kwessie van rassesuiwerheid uitgespreek:

"Ons moet help om die Suid-Afrikaanse blanke ras suiwer te hou, te meer daar medeAfrikaners onverskillig of positief ten gunste is van rasvermenging. Ons moet rekening hou met die pogings om sosiale gelykstelling te verkry, wat bereken is om rassevermenging in die hand te werk. Die mindergegoede seuns en dogters wat noodwendig met naturelle en kleurlinge in fabrieke, in winkels, in hotels en elders moet saam werk, en soms hul bevele van hul moet kry, wat nie anders as 'n demoraliserende uitwerking op hulle moet hê nie, verdien ons beskerming."

In die afgelope jaar het ons 'n besoek gehad van iemand wie se roem deur die lees van sy boek, 'The Christ of the Indian Road', hom vooruitgegaan het. Na nader kennismaking met die landsomstandighede en rassetoestande, het hy voor sy vertrek dit nodig gevind om hom soos volg uit te druk: 'This unity should not merely be between the churches, it should be between the races within the churches. The principal Colour Bar within the Churches in South Africa is a standing blot upon the Christianity of the land. It should be wiped out' (The South African Outlook, 1 Sept 1936, p.208). Dit is wat Stanley Jones gesê het. Hierdie 'unity between the races' geniet die ondersteuning in sekere kringe in ons land, bygestaan deur selfs enige van ons stam- en geloofsgenote. Ook die Helpmekaar moet daarvan kennis neem."132

Roome het in 1938 op die tema van Afrikanereenheid voortborduur en die Helpmekaar se werk gesien as deel van die nasiebouprojek en in diens van die Afrikaner. Die opheffing van alle klasse en stande en die eenheid van die Afrikaner is beklemtoon met enige iets wat die eenheid of die gewaande Afrikanerskap of erfenis kon "besoedel" as 'n vyand wat beveg moes word. Van die volgende was uitdagings vir die Afrikanereenheid. Staatsloterye, wat hy 'n monster genoem het en gestel het teenoor die Goddelike wet wat lui: "In die sweet van jou aangesig sal jy brood eet". ${ }^{133}$ Die "euwels van die huurkoopstelsel" wat tot nadeel van die armes is. Die taalstryd wat steeds gestry word. Verstedeliking wat 'n onkeerbare stroom geword het en die gevare wat dit ingehou het dat verstedelikte Afrikaners vir Afrikanerdom verlore mag gaan vanweë die stedelike volksvreemde invloede en dat dit "ons" plig was om alles binne vermoë te doen "om hulle in hul wese Afrikaners te hou". Om die eenheidsband tussen die Afrikaners op die platteland en dié in die stede te behou, het hy hom ook weer tot

132 (HSA) HVKP, Notuleboek, 30-31 Mrt 1937, Kongres, Voorsittersrede, 9-10.

133 (HSA) HVKP, Notuleboek, 20-21 Apr 1938, Kongres, Voorsittersrede, 3. 


\section{Die Kaapse Helpmekaar}

die gevare van rassevermenging gewend. Hy het aparte woonbuurte sterk ondersteun (hy was lid van die Stedelike Behuisingsbond van Kaapstad) en kritiek uitgespreek teenoor die pogings wat segregasie probeer teenstaan het. Hy was ook van mening dat die Helpmekaarkongres deur 'n mosie die hande van die Administrateur in dié verband moes versterk sodat die nodige wetgewing ingevoer kon word:

"Aparte woonbuurte is absoluut noodsaaklik ter wille van 'n gesonde gemeenskap in meer dan een opsig. Deur die behuisingskemas word daar reeds voorsiening gemaak vir aparte woonbuurte wat algemeen byval vind by beide seksies. Die deurmekaar of huis-aan-huis woon in dieselfde straat, met die straat as speelplek vir die kinders is krimineel en afkeurenswaardig. Dit werk familiariteit in die hand en gee aanleiding tot rassevermenging." 134

In 1939 het Roome op dieselfde trant voortgegaan. Die gevare wat geïdentifiseer is, was: die wurggreep van die vreemde geldmag; toenemende mag en kompetisie van swart arbeid in die arbeidsmark en die sedelike verval wat gestop moes word aangesien dit besig was om die goeie sedes van ons seuns en dogters te bedreig. Hy was van mening dat "die oorsaak van die kwaal moet ontdek en uitgebrand word". Hy soek dan die oorsaak van hierdie verval in rassevermenging as hy voortgaan:

"Daar is te veel aanleiding tot gemeensaamheid en familiariteit tussen blankes en nieblankes, vandaar die besluite en petisies en opwagtings dwarsdeur die land om segregasie wat woonbuurte en werkplase betref. Ten spyte van 'n dowe oor hier, en 'n afjak daar, moet ons volhard totdat verkry is wat ons beoog. Aparte woonbuurte, beter en goedkoper behuising is wat nodig is vir albei seksies. Wil ons die rasse suiwer hou, dan moet ons ook verder aandring op wetgewing om gemengde huwelike te verhinder. Gemengde huwelike is 'n gruwel wat deurgaans 'n nasleep van hartseer en ellende met hom bring. Ons het diepe medelye met die kinders uit so 'n huwelik gespruit. Persoonlik het ons met sulke gevalle in Kaapstad te doen gekry. Die gemengde huwelik veroorsaak verdeeldheid in die huisgesin, en in die familie- en vriendekring. Die kinders, weens die skakering van kleur word gesegregeer. Die een word in die skool opgeneem, en die ander afgewys; die een word in sosiale kringe verwelkom, en die ander die rug toegekeer. Ons wil segregasie vóór en nie na die huwelik hê nie." 
Onder die opskrif Die Wet van Selfbehoud het hy hierop voortborduur:

"Om die suiwerheid van ras te behou, moet ons waak teen bloedvermenging wat in die hand gewerk word deur die menigte mengelmoes-elemente in ons land. Moenie vergeet nie dat daar agt miljoen naturelle en kleurlinge is teenoor slegs twee miljoen blankes in die Unie. As ons nie wette kry om ons blankes te beskerm nie, dan loop ons gevaar om te verdwyn. Raadpleeg die wetenskap en die geskiedenis tot bevestiging van hierdie vrees."135

Vir die eerste keer het Roome ook die kommunisme as vyand van die Afrikaner nadergehark en is die vakbonde in die stede voorgehou as die verderflike gesig van die kommunisme. Dié bedreiging moes teengewerk word deur eie vakbonde te stig en te sorg dat lidmaatskap die regte egte tipe is. Volgens Roome het die kommunisme 'n swart republiek in SA beoog en hom daarop toegelê om al wat godsdienstig was te ondermyn en af te breek. Roome het 'n beroep gedoen dat die Helpmekaar:

“... as 'n reddingsorganisasie moet (ons) byspring en onsself red. Met groot klem wil ons op hierdie kongres 'n wekroep aanhef, aangesien ons as Afrikaners met ondergang bedreig word. Ons godsdiens, ons goeie sedes, ons sosiale welsyn, alles verkeer in gevaar, daarom moet ons defensief, ja, ook aggressief optree, en red wat nog gered kan word. Dit is nie maar so 'n blinde alarm nie. Die gevaar bestaan en ons moet toesien dat ons nie oorrompel word nie."136

Hy het die Helpmekaarvereniging opgeroep om hul rol in nasiebou te vervul deur die algemene ontwikkeling van veral die kind: hoof, hand en hart. Hy het ook gefokus op die opheffing van dié wat reeds in die moeras gesak het en die strewe dat alles die stempel van "eg Afrikaans" moet dra. Laastens het hy ook'n beroep op die kongres gedoen om die 250-jarige herdenking van die koms van die Franse Hugenote te vier en voorbrand gemaak vir die ekonomiese volkskongres wat beplan is vir 1939 en die "Groot Reddingsdaadfonds" wat nodig was om die Afrikaner op ekonomiese gebied te red. ${ }^{137}$

“Die ossewatrek het 'n wonderlike opskudding, 'n nugtere ontwaking in ons geledere veroorsaak. Ons is wakker, helder wakker, en ook ... gewapen vir die listige aanslae van die goedafgerigte en deeglik georganiseerde slagordes van die vyande van die Afrikaner." ${ }^{138}$

\footnotetext{
135 (HSA) HVKP, Notuleboek, 12-13 Apr 1939, Kongres, 9.

136 Ibid.

137 Ibid., 9-10.

138 Ibid., 9.
} 


\section{Die Kaapse Helpmekaar}

Die Helpmekaar se "nugtere ontwaking" en "wakker" wees, het die vorm aangeneem van die nuwe strategie van die dertigerjare soos dit onder Roome se leiding verwoord en gepropageer is. Die strategie is konkrete struktuur gegee deur 'n stelsel van subsidies aan takaktiwiteite - gefinansier vanuit die sentrale kas - wat tydens die eerste helfte van die dertigerjare geïmplementeer is. Die subsidies het plaaslike takke groter toegang tot kapitaal gebied om hul plaaslike aktiwiteite te finansier, maar was afhanklik van 'n eie poging vanuit plaaslike takgeledere, aangesien toekennings deur die sentrale bestuur op 'n pond-vir-pond basis sou geskied. Die Help-u-self-gees sou dus geld, aangesien die sentrale bestuur binne die gestelde limiete van die kongresbesluit oor 'n spesifieke saak een pond sou bydra vir elke pond wat deur die tak bygedra word.

Die kongres het reeds sedert $1924^{139}$ leeslus probeer aanwakker deur fondse op 'n jaarlikse ad hoc-basis te stem vir Afrikaanse leeskamers in plekke soos Port Elizabeth, Uitenhage en Somerset-Oos. 'n Voorstel is in 1929 aanvaar dat die sentrale bestuur 'n bedrag van maksimum $£ 25$ op die pond-vir-pond-stelsel mag spandeer op die aansoeke van takke vir bydraes tot plaaslike boekerye/leeskamers. ${ }^{140}$ In 1931 is die totale subsidie van $£ 25$ na $£ 50$ verhoog. ${ }^{141}$ Die subsidie is voortgesit tot $1950^{142}$ en in die periode het die sentrale bestuur 'n totale bedrag van $£ 669$ 18s 6d vir die doel uitbetaal (indien die pre-pond-vir-pond-stelsel bydraes bygetel word, is die bedrag $£ 789$ ). Die aanvulling van die takke op die pond-vir-pond-stelsel het beduidende bydraes gelewer tot die instandhouding van Afrikaanse leeskamers/boekerye in veral die Oos Kaap.

In 1930 het die kongres 'n tweede subsidie ingestel. Hul het besluit om met die pond-virpond-stelsel, met nie meer as $\mathfrak{E} 5$ nie, hulp te verleen aan plaas- en dorpskoolbiblioteke waar Helpmekaar-takke bestaan het. Die hulp was om geskikte Afrikaanse literatuur te voorsien. ${ }^{143}$ Die besluit het heelwat reaksie ontlok. 'n Aansienlike aantal aansoeke is ontvang en van 'n aantal plekke is drie tot vier aansoeke van verskillende skole ontvang. Die sentrale bestuur het egter besluit om slegs $£ 5$ per tak toe te ken en nie per skool nie en ook dat alle aansoeke deur die plaaslike tak moes geskied. Die geld sou aan die plaaslike takke uitbetaal word op voorwaarde dat die tak moes verseker dat 'n behoorlik gesertifiseerde faktuurbrief voorgelê word en dat

139 (HSA) HVKP, Notuleboek, 15-16 Apr 1925, Kongres, Penningmeester verslag, 15.

140 (HSA) HVKP, Notuleboek, 3-4 Apr 1929, Kongres, 5, 7.

141 (HSA) HVKP, Notuleboek, 7-9 Apr 1931, Kongres, 8.

142 (HSA) HVKP, Notuleboek, 3-4 Apr 1951, Kongres, Penningmeester verslag, 3.

143 (HSA) HVKP, Notuleboek, 16-17 Apr 1930, Kongres, 6, 7. 
die boeke uitsluitlik vir die aankoop van Afrikaanse literatuur aangewend word. ${ }^{144}$ In die 1930 -finansiële jaar is skoolbiblioteeksubsidies van tussen $£ 2$ en $£ 5$ vir' $n$ totaal van $£ 165$ aan 34 takke toegeken. ${ }^{145}$ In die praktyk het dit beteken dat $£ 330$ plaaslik gespandeer is vir die aankoop van Afrikaanse lektuur vir skoolbiblioteke. Die subsidie sou 'n instelling word wat tot 1957 toegeken is. ${ }^{146}$ In die periode 1930-1957 het die sentrale bestuur se subsidie in totaal $£ 2447$ beloop, wat saam met die bydrae van die takke op die pond-vir-pond-stelsel 'n aansienlike belegging vir die aankoop van Afrikaanse lektuur vir skoolbiblioteke verteenwoordig het.
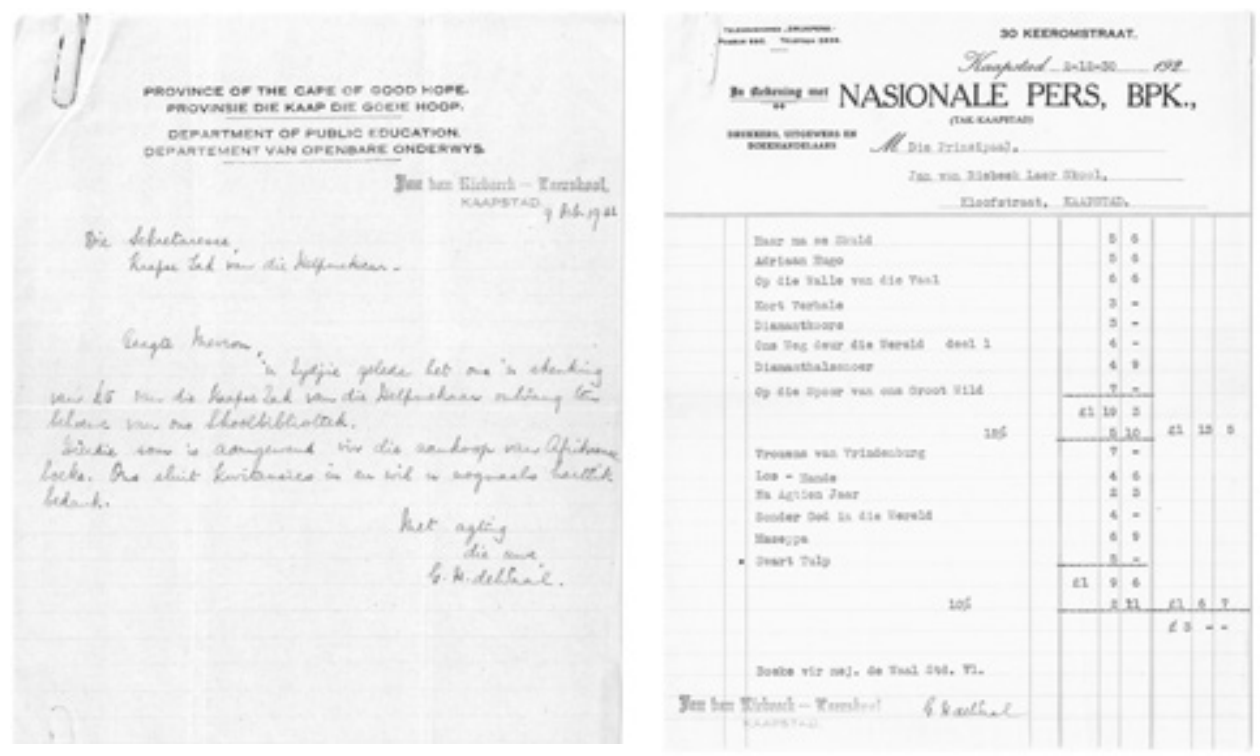

Brief en faktuur van Laerskool Jan van Riebeeck wat Helpmekaar bedank vir die bydrae tot hul biblioteek. Dit was deel van die Helpmekaar se skoolbiblioteek subsidiestelsel.

Die derde en verreweg die omvangrykste en invloedrykste subsidie wat in die dertigerjare ingestel is, was die aanvaarding van 'n voorstel van die penningmeester, adv Wessel Roux en die sekretaresse, mev H Roux tydens die 1936-kongres, dat 'n maksimum bedrag van $£ 500$ jaarliks aan die sentale bestuur beskikbaar gestel word om subsidies te gee aan plaaslike takke op die pond-vir-pond-stelsel om leerlinge in plaaslike skole te ondersteun. Takke sou geregtig

144 (HSA) HVKP, Notuleboek (13 Jun 1928-12 Des 1935), 16 Aug 1930, Sentrale Bestuur, 61.

145 (HSA) HVKP, Notuleboek, 7-9 Apr 1931, Kongres, Bylae A, Penningmeester verslag, 13.

146 (HSA) HVKP, Notuleboek, 11 Jul 1958, Kongres, Penningmeester verslag, 2, 6. 
wees op 'n jaarlikse maksimum subsidie van $£ 20 .{ }^{147}$ Die instelling van dié subsidie was die resultaat van 'n breër debat wat deurlopend in die bestaan van die Helpmekaar gevoer is, naamlik of sy opvoedingshulp op primêre, sekondêre of tersiêre vlak gesentreer moes wees.

In reaksie op 'n beskrywingspunt van die Kaapse Skiereiland-tak wat deur mev A Geyer ${ }^{148}$ by die 1935-kongres voorgedra is, het die tak versoek dat, in die lig van die lae opvoedingspeil van die helfte van die bevolking, 'n kommissie van vyf lede die wenslikheid daarvan moes ondersoek dat die Helpmekaar die fokus van sy opvoedkundige hulp en steun verskuif van hoër opvoeding na skoolopvoeding (van hoër onderwys na onderwys op skool) en dat die kommissie by die volgende kongres verslag moes doen. In haar motivering vir haar voorstel het mev A Geyer aangevoer dat, hoewel die Helpmekaar 'n baie goeie diens gelewer het met die opvoeding van 'n groep Afrikaanse "geleerdes" toe Afrikaners sulke leiers nodig gehad het, daar op daardie tydstip 'n ooraanbod was en dat baie opgevoede Afrikaners werkloos was.

Sy het verder aangevoer dat die ooraanbod vererger is deur die baie beurse wat op daardie tydstip deur die regering vir hoër opvoeding beskikbaar gestel is. In kontras met die ooraanbod, het 46 persent van die blanke bevolking nie 'n standerd ses-sertifikaat besit nie. Van al die boere in die Unie van Suid-Afrika het 58 persent nie 'n standerd ses-sertifikaat gehad nie - 'n persentasie wat in sekere armer streke van die land so hoog as 71 persent was. Sy was dus van mening dat, gegrond op genoemde syfers, die "volk" nie in 'n posisie was om te baat by die "geleerdheid" van die deskundiges (die geleerde mense wat deur die Helpmekaar kon leer) nie. Volgens haar moes die Helpmekaar liewer die laer segment van die "volk" bystaan om 'n hoër vlak van opvoeding te bekom.

Deur op skoolopvoeding te fokus sou die Helpmekaar in staat wees om vyf keer meer skoliere as studente te help. Die fokus moes dus op liefdadigheidswerk van 'n opheffende aard wees, wat 'n groter diens aan die "volk" sou wees. Volgens haar sou so 'n aanslag met 'n ander fokus lei tot 'n groter herlewing in Helpmekaar-geledere. Die groter getalle wat bygestaan sou word, sou plaaslik meer sigbaar wees en so sou groter openbare belangstelling gewek word as in die geval van steun aan studente (hoër opvoeding). Nadat die voorstel eenparig deur die kongreslede aanvaar is, is verder besluit dat die voorgestelde kommissie die opdrag sou kry om vas te stel in watter mate dit wenslik en moontlik sou wees dat die Helpmekaar met die ACVV in hierdie verband kon saamwerk. Ds FX Roome het homself genomineer, as

147 (HSA) HVKP, Notuleboek, 15-16 Apr 1936, Kongres, 10.

148 Anna Elizabeth Geyer was met AL Geyer, redakteur van Die Burger en later Hoë Kommissaris in Londen, getroud. Anna Geyer was ook lid van die Kaapstadse tak van die ACVV en het ook vanaf 1946-1950 en 1954-1964 as president van die organisasie gedien. Sy was'n opgeleide kindertuinonderwyseres. Suid-Afrikaanse Biografiese Woordeboek, V, 306. 
voorsitter, en mev A Geyer, drCF Albertyn, ${ }^{149}$ mev MCBotha ${ }^{150}$ en mevH Roux askommissie om die voorstel uit te voer. Mev Roux het prof CGW Schumann genomineer om haar te vervang en dit is deur die kongreslede aanvaar. ${ }^{151}$ In die gees van die Kaapse Skiereiland-voorstel het die kongres 'n voorstel van die Malmesbury-tak aanvaar dat die kongres $£ 5$ bewillig vir elke tak wat ook $£ 5$ stort om standerdsesse te help om hul skoolloopbaan verder voort te sit met die verdere voorwaarde dat die kinders van Helpmekaar-lede voorkeur sal geniet. ${ }^{152}$

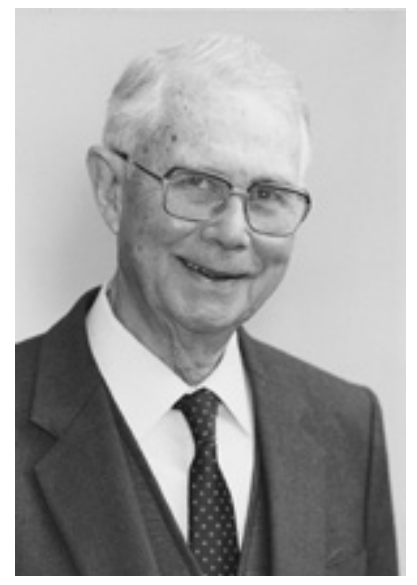

CF Albertyn wat die HVKP en Helpmekaar Studiefonds in verskeie hoedanighede gedien het en veral sedert die sestigerjare 'n leidende rol gespeel het 'n Afskrif van die verslag van die kommissie het nie behoue gebly nie, maar dit was duidelik uit die terugvoer wat die kommissie by die 1936-kongres gegee het dat die voorstel, dat die Helpmekaar sy opvoedkundige steun op skole en skoliere moet toespits in plaas van op studente, nie deur die kommissie bevestig is nie. Die bevindinge van die kommissie was ook'n onmiddellike antwoord op Roome se oproep vir 'n herbesinning oor die beleid en program van die Helpmekaar. Dit het nie sy oproep om 'n breër en meer kragdadige betrokkenheid deur die Helpmekaar afgekeur nie, maar dit tog herbevestig dat ondersteuning van tersiêre opvoeding en opleiding die kernfunksie - ten minste in monetêre terme van die Helpmekaar moes bly. 'n Gebrek aan getuienis maak dit egter moeilik om vas te stel wat die kommissie laat besluit het om voor te stel dat die Helpmekaar by sy oorspronklike fokus van studente of tersiêre opvoedkundige steun, bly.

149 Albertyn het 'n lang verbintenis met Nasionale Pers gehad. Hy was vanaf 1930 vir ses jaar 'n verslaggewer by Die Burger. Later was hy redakteur van Die Jongspan, en hoof van die boekuitgewery-afdeling van Nasionale Pers. In 1947 het hy bestuurder van die Kaapse tak van Nasionale Pers geword en vanaf 1953-1958 was hy besturende direkteur van Nasionale Tydskrifte en hoofbestuurder van Nasionale Pers. Vanaf 1942 tot 1972 was hy redakteur van Afrikaanse Kinderensiklopedie en na sy uittrede in 1958 het sy eie uitgewersmaatskappy, CF Albertyn Uitgewers, Die kinders van die Wêreld en die Ensiklopedie van die Wêreld gepubliseer. Albertyn was 'n belangrike figuur in die Kaapstadse Afrikaner-netwerk van sake en beroepslui en was 'n stigterslid van die Klub Here XVII in Kaapstad, 'n belangrike sosiale bymekaarkomplek in veral die vyftiger- en sestigerjare vir "die immigrante in die Moederstad" soos Albertyn die Afrikaners in Kaapstad beskryf het omdat "geen sakeman, predikant, onderwyser of dokter of manne in watter beroep ookal in die stad gebore of getoë was nie”. Die Burger, 3 Feb 1999, oudhoofbestuurder (89) van Naspers oorlede, 12; Die Burger, 5 Mei 1986, Klub Here XVII. 'n Tyd om te herdenk, 15.

150 Mev MC Botha was die eggenote van die Superintendent Generaal van Onderwys in die Kaapprovinsie, prof MC Botha. Sy was die dogter van ds Paul Roux, 'n generaal in die Anglo-Boereoorlog. Sy is in 1919 met Botha getroud. Standard Encyclopaedia of Southern Africa, vol 2, BAD-CAR, 453. 


\section{Die Kaapse Helpmekaar}

'n Rede hiervoor mag die teenwoordigheid van lede met tersiêre opleiding, soos ds FX Roome, dr CF Albertyn en prof CGW Schumann, in die kommissie wees, aangesien hulle waarskynlik die waarde van sulke opleiding besef het. Die feit dat prof CGW Schumann sy posisie aan Stellenbosch Universiteit (Hoof van die Handelsfakulteit) grootliks aan die vrygewige steun van die Helpmekaar te danke gehad het, aangesien hulle sy studies tot op doktorale vlak gesteun het, mag ook die kommissie se bevindinge beïnvloed het. Die opvatting dat skoolopvoeding primêr die staat se verantwoordelikheid was en die Helpmekaar nie die staat met sy fondse moes "subsidieer" nie het waarskynlik ook 'n rol in die besluit gespeel.

$\mathrm{Na}$ 'n bespreking van die verslag is die voorstel van die $£ 500$-subsidie van advokaat Wessel Roux - 'n uitvloeisel van bogenoemde $\mathfrak{E 5}$-subsidie vir standerdsesse - deur die lede van die 1936-kongres aanvaar. Die voorstel was 'n poging om gedeeltelik die sentimente van die Geyer-voorstel, dat meer geld aan skoolopvoeding bestee word, te akkommodeer. Wessel Roux se voorstel was nie nuut nie, aangesien die sekretaresse, mev Hester Roux, reeds in 1924 die sentrale bestuur versoek het om dit te oorweeg om $£ 20$-beurse aan die takke te gee vir "behoeftige en veel belowende kinders met dien verstande dat die takke wat dit aanneem ook $£ 20$ sou bydra”. ${ }^{153}$ Die voorstel is egter weens onbekende redes nooit verder gevoer nie.

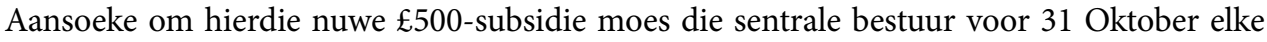
jaar bereik. ${ }^{154}$ Toegang tot hierdie subsidie was afhanklik van die bydraes van die takke en het hulle gedwing om ook plaaslik geld vir skoolopvoeding te genereer - wat dan sou lei tot 'n bydrae deur die sentrale bestuur tot 'n maksimum van $£ 20$.

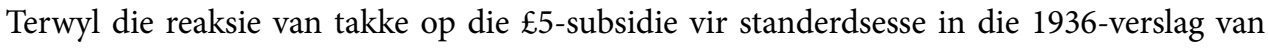
die sentrale bestuur as "teleurstellend" beskryf is, aangesien slegs 14 takke vir 'n totaal van $£ 70$ daarvan gebruik gemaak het, was die reaksie teenoor die $1936 £ 20$-subsidievoorstel oorweldigend positief. Dit ten spyte van aanvanklike onsekerheid oor die praktiese implementering, asook die aanwending van die subsidiegeld. Die sentrale bestuur het die onsekerhede egter spoedig deur korrespondensie en 'n omsendskrywe aan takke uit die weg geruim. Die bestuur het dit duidelik gemaak dat die subsidie vir laer onderwys bewillig word op die basis van 'n maksimum van $£ 20$ per tak met teenprestasie dat die tak moet kan bewys dat 'n gelyke bedrag reeds in hande is of gedurende die jaar uitbetaal is vir laer onderwys plaaslik.

Die subsidiebetalings kon ook proporsioneel tot 'n maksimum van $£ 20$ per tak per jaar gedoen word. Takke is in kennis gestel dat alle aansoeke die sentrale bestuur voor 31 Oktober moes bereik en dat die geld daarna uitbetaal sou word. Takke is ook daaraan herinner dat

153 (HSA) HVKP, Notuleboek (21 Mei 1924-3 Apr 1928), 23 Okt 1924, Sentrale Bestuur, 42-43.

154 (HSA) HVKP, Notuleboek, 15-16 Apr 1936, Kongres, 10. 
hulle aan die kongres verslag moes doen van hoe die geld plaaslik bestee is. Uit navrae van takke soos Venterstad en die Paarl het die sentrale bestuur uitdruklik bevestig dat die geld slegs vir laer onderwys plaaslik gebruik mag word ${ }^{155}$ met laer onderwys wat omskryf is as "onderwys terwyl die leerling nog op skool is". In hierdie gees het die sentrale bestuur dus die Wellington-tak se betaling van $£ 8$ van hul subsidie aan die Sending-Instituut afgekeur en aangedui dat die geld terugbetaal moes word. ${ }^{156} \mathrm{Op}$ soortgelyke wyse is die Cradock-tak meegedeel dat die subsidiegeld vir laer onderwys nie vir skoolpryse nie, maar vir opvoeding aangewend moes word. ${ }^{157}$

Uit die 1937-takverslae het dit geblyk dat van die subsidiegeld van $£ 500$, wat die sentrale bestuur vir laer onderwys op 'n pond-vir-pond-stelsel beskikbaar gestel het, het 26 takke 'n totaal van $£ 44910$ s opgeneem. In die praktyk het dit beteken dat $£ 900$ deur die subsidie alleen in 1936 aan skoolkinders plaaslik bestee is. Uit die takverslae is daar ook aanduidings dat die benadering van pond-vir-pond-subsidiebydraes deur die sentrale bestuur ten opsigte van die bevordering van plaaslike laer onderwys en die skoolbiblioteke die effek gehad het dat dit takke angevuur het om ten minste genoeg fondse plaaslik te genereer om die subsidievoordele te kan benut - iets wat hulle andersins waarskynlik nie sou gedoen het nie. Dordrecht was 'n goeie voorbeeld waar hulle ten spyte van die feit dat hulle nie Afrikanerdag gevier het nie - dit was die mees basiese aktiwiteit van takke - hulle tog "£25 ingesamel het om gebruik te kan maak van die $£ 20$ vir laer onderwys en $£ 5$ vir skoolbiblioteke, op die $\mathfrak{E}$-vir- $\mathfrak{E}$-stelsel”. ${ }^{158}$ In 'n poging om die $\mathfrak{£} 5$-skoolbiblioteek- en $£ 20$-laeronderwyssubsidie te benut het Murraysburg-tak bydraes van nie-Helpmekaar instellings soos "Huisvlyt, die Munisipaliteit, die Afdelingsraad, die Kerkraad en die ACVV" verkry. Kirkwood-tak het berig dat geen behoeftige kind by hulle die skool na standerd ses hoef te verlaat weens gebrek aan geld nie. Hulle kom almal terug vir sekondêre onderwys - te danke aan die werk van die Helpmekaar. Die prinsipaal van die skool op Victoria-Wes was van mening dat:

“... as op al ons dorpe gedoen word wat die Helpmekaar op Victoria-Wes doen ten behoewe van die behoeftige leerling, dan kan die armblankevraagstuk opgelos word, as ons eerlik wil aanneem dat die oplossing van genoemde vraagstuk langs die weg van opvoeding lê."159

\footnotetext{
155 (HSA) HVKP, Notuleboek (15 Apr 1936-6 Des 1939), 25 Jun 1936, Sentrale Bestuur, 174.

156 (HSA) HVKP, Notuleboek (15 Apr 1936-6 Des 1939), 10 Des 1936, Sentrale Bestuur, 178.

157 (HSA) HVKP, Notuleboek (15 Apr 1936-6 Des 1939), 15 Feb 1938, Sentrale Bestuur, 210.

158 (HSA) HVKP, Notuleboek, 30-31 Mrt 1937, Kongres, Takverslae, 8.

159 Ibid.
} 


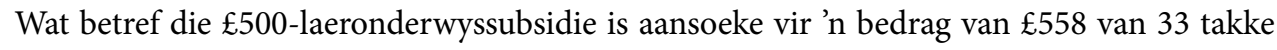
in 1937 ontvang, met slegs vyf takke wat geen aansoek ingedien het nie. Die geld moes dus proporsioneel verdeel word omdat slegs $£ 500$ beskikbaar was. ${ }^{160}$ In 1938 is besluit dat aan elke tak die maksimum bedrag van $£ 20$ op die pond-vir-pond-stelsel betaal sou word wat in praktyk beteken het dat die proporsionele verdeling en die $£ 500$ beperking dus weggeval het. ${ }^{161}$ Die laerskoolonderwyssubsidie het deurlopend gewild gebly met 'n hoogtepunt in 1941 toe $£ 756$ aan 32 takke uitbetaal is. ${ }^{162}$ In die periode $1936-1963$ het die sentrale bestuur $£ 9433$ in die vorm van laerskoolonderwyssubsidies uitbetaal, wat saam met die takke se pond-vir-pond-bydraes 'n aansienlike bydrae tot opvoeding op plaaslike vlak gelewer het.

Roome se oproep tot 'n kragdadiger Helpmekaar met 'n uitgebreide terrein van aktiwiteite, wat veral ook kultuurbevordering moes insluit, het beslis oor die algemeen tot 'n groter kultuurbetrokkenheid van plaaslike takke bygedra. Sommige takke het sy oproep baie ernstig opgeneem en het daadwerklik op plaaslike vlak dit probeer implementeer. Die Paarl-tak was waarskynlik die ekstreme voorbeeld. In die dorp het die plaaslike kultuurvereniging in 1930 ontbind en is die lede by die plaaslike Helpmekaar-tak ingelyf, wat toe as die plaaslike Helpmekaar Kultuurvereniging gefunksioneer het. Uit die nuwe saamgestelde ledetal is twee persone elk aangestel om te sorg vir toneelopvoerings, musiekkonserte en tentoonstellings van skilderstukke, terwyl een persoon verantwoordelik was vir die reël van voorlesings. Op dié wyse het hulle probeer om gehoor te gee aan FX Roome se oproep om hul toe te lê op die opbou van die kuns, kultuur en wetenskap. ${ }^{163}$ Op Uitenhage is Heldedag (10 Oktober) onder beskerming van die Helpmekaar-tak gevier. H Gerdener, lid van die sentrale bestuur, ${ }^{164}$ wat die geleentheid bygewoon het, het 'n kopie van die program waarin al die voordragte in Afrikaans gelewer is aan die sentrale bestuur gestuur met groot lof vir "wat die Helpmekaar vriende daar in 'n Engelse sentrum aanpak. Ons kan nie die moed en durf van die Helpmekaar tak aldaar te hoog roem nie ..."165 Middelburg se tak het met hul 1930-Afrikanerdagviering die klem op kultuur geplaas en die hoop is uitgespreek dat dit die begin mag wees "van meer sulke aande waar die kulturele sy van die Vereniging aangepak word". 166

\footnotetext{
160 (HSA) HVKP, Notuleboek (15 Apr 1936-6 Des 1939), 8-9 Des 1937, Sentrale Bestuur, 200.

161 (HSA) HVKP, Notuleboek, 20-21 Apr 1938, Kongres, 11.

162 (HSA) HVKP, Notuleboek, 8-9 Apr 1942, Kongres, 7.

163 (HSA) HVKP, Notuleboek (13 Jun 1928-12 Des 1935), 16 Aug 1930, Sentrale Bestuur, 61-62.

164 (HSA) HVKP, Notuleboek, 16-17 Apr 1930, Kongres, 6.

165 (HSA) HVKP, Notuleboek (13 Jun 1928-12 Des 1935), 6 Des 1930, Sentrale Bestuur, 72.

166 (HSA) HVKP, Notuleboek (13 Jun 1928-12 Des 1935), 25 Okt 1930, Sentrale Bestuur, 66.
} 
In 1938 is ' $n$ voorstel van die Paarl-tak aanvaar waarin aanbeveel is dat die bestuurstruktuur van die plaaslike takke uitgebrei word deur in elke tak van die Helpmekaar 'n inligting- en adviserende komitee te benoem. Die komitee moes hom beywer om inligting en advies aan lede en ander persone te verskaf van hoe en waar onderwysfasiliteite en hulp verkry kan word, hoe en waar werksgeleenthede vir mans en vroue, sowel as seuns en dogters, verkry kan word en hoe en waar fatsoenlike huise in aparte woonbuurtes verkry kan word. ${ }^{167}$ Hierdie was waarskynlik 'n poging om die sosiale netwerke en sosiale kapitaal van die plaaslike Helpmekaar-takke te mobiliseer om Afrikanereenheid en oorlewing ook op plaaslike vlak te versterk. Dit is nie bekend in watter mate hierdie aanbeveling prakties geïmplementeer is nie, maar as die kategorieë van inligting waarna verwys word in ag geneem word, het dit'n goeie skoot van Roome se voorwaardes/voorskrifte vir Afrikaner-selfbehoud en -oorlewing bevat en geresoneer met die oproep van sy 1939-voorsittersrede:

"n Volksreddingsdaad hierdie jaar moet ons strydleuse wees. Nasiebewus, doelbewus, roep ons mekaar toe: Rep u, ruk op, val aan en doen wat $\mathrm{u}$ hand vind om te doen met al u mag." ${ }^{\text {"168 }}$

\section{DIE WA LANDMAN-VEERTIGERJARE: DIE HERFOKUS OP FINANSIERING VAN BEHOEFTIGE EN VERDIENSTELIKE LEERLINGE EN STUDENTE (“ELKE BELOWENDE SEUN OF DOGTER VAN ONS VOLK MOET TOEGERUS dIE LEWE INGAAN")}

Die konteks waarbinne die Helpmekaar gefunksioneer het, het in die laat dertigerjare en vroeë veertigs belangrike veranderinge ondergaan, beide ten opsigte van die Helpmekaar intern, asook die breër Afrikaner-leefwêreld waarbinne dit gefunksioneer het. Die Helpmekaar se jarelange sekretaresse, mev Hester Roux, is in September 1938 oorlede. Haar dogter, mev MH van der Merwe, het aanvanklik haar werk oorgeneem, maar was slegs beskikbaar tot 31 Januarie 1939, waarna die penningmeester, Wessel Roux, tydelik ook as sekretaris opgetree het. ${ }^{169}$

167 (HSA) HVKP, Notuleboek, 20-21 Apr 1938, Kongres, 12.

168 (HSA) HVKP, Notuleboek, 12-13 Apr 1939, Kongres, 10.

169 (HSA) HVKP, Notuleboek, 12-13 Apr 1939, Kongres, Sentrale Bestuur verslag, 1-2. 
In Julie 1939 het die sentrale bestuur vir mnr DH van Zyl ${ }^{170}$ teen 'n salaris van $£ 180$ per jaar met ingang 1 Augustus 1939, presies 'n maand voor die uitbreek van die Tweede Wêreldoorlog, as sekretaris aangestel. ${ }^{171}$ In 1941 is ds WA Landman, medeleraar van die Swartland NG Kerk in Malmesbury, tot voorsitter verkies. ${ }^{172}$ In die breër Suid-Afrikaanse konteks het dit saamgeval met die intensifisering van Afrikaner-etniese mobilisasie rondom die 1938 Groot Trek Eeufees, die 1939 Eerste Ekonomiese Volkskongres, die totstandkoming van organisasies soos: die Reddingsdaadbond (RDB), ${ }^{173}$ die gepaardgaande Reddingsdaadfonds, Federale Volksbeleggings en die Afrikaanse Handels Instituut. ${ }^{174}$

Hierdie etnifisering van Afrikaner-nasionalisme het reeds sedert 1929 met die stigting van die FAK gelei tot 'n verdigting van Afrikanerkultuur- en verwante organisasies wat oorvleueling ten opsigte van funksies tot gevolg gehad het. Ten spyte van die ekonomiese behoeftes onder Afrikaners moes die Helpmekaar ook rekening hou met die ontluikende klasseverskille onder Afrikaners in hierdie periode. Hoewel Stals al in 1926 gewaarsku het teen die gevaar van die oneweredige verdeling van rykdom vir die ekonomiese selfstandigheid van die volk en Roome in 1930 gewaarsku het teen 'n oorbeklemtoning van beroepsopleiding en 'n verwaarlosing van die ambagte en in 1934 'n "evangelie van spaarsaamheid" gepropageer het, was Landman die eerste om pertinent te waarsku teen die ontluikende klasseverskille in Afrikanergeledere:

170 David Hermanus van Zyl was 'n reisende organiseerder van die NP in Kaapland. In Augustus 1937 is Van Zyl en sy vrou, Bess, se enigste seun, Frikkie, op 17-jarige ouderdom in 'n motorongeluk in Kaapstad oorlede. Hierdie tragedie het bygedra tot Van Zyl se besluit om sy tyd en middele aan die opheffing van die jeug te wy. Sy meer aktiewe betrokkenheid by die Helpmekaar was waarskynlik 'n uitvloeisel hiervan. Van Zyl sou later 'n NP senator word. Sy aktiewe betrokkenheid by die Helpmekaar sou oor feitlik drie dekades strek - 'n periode waartydens hy die verpersoonliking van die Helpmekaar geword het. Die Helpmekaar sou ook later die begunstigde van sy boedel word. Die Burger, 20 Aug 1937, Mnr DH van Zyl se seun oorlede; (KAB), AG 14128, Photograph with the organizers of the NP, Cape, 1936; AG 14130, Photograph with NP delegates, c1926; AG 14211, Senator David Hermanus van Zyl, his wife Bess and their only son Frikkie. Frikkie was killed in 1937 during a motor-car accident.

(HSA) HVKP, Notuleboek, 27-28 Mrt 1940, Sentrale Bestuur verslag, 2.

172 (HSA) HVKP, Notuleboek, 16-17 Apr 1941, Kongres, 14. Landman is in 1958 as eerste Direkteur van die NGK se Inligtingsburo verkies. Hoewel hy aanvanklik die beleid van afsonderlike ontwikkeling van volke as oplossing vir Suid-Afrika se rasse-uitdagings gesteun het, het hy vroeg reeds die onwerkbaarheid van die denkrigting besef en 'n uitgesproke teenstander van apartheid geword. Hy was een van net vier lede van die NGK se Federale Raad wat die besluite van die Cottesloe kerkeberaad van 1960 gesteun het. Hiervoor is hy in sekere kringe verguis wat hom waarskynlik verdere vordering in die strukture van die NG Kerk gekos het. Die Universiteit van Stellenbosch het in Desember 1978 'n eredoktorsgraad aan hom toegeken. Die Burger, Hoofartikel, 28 Aug 1986; Die Burger, 4 Des 1986, Brief van Vivia Ferreira.

173 Die RDB is gestig as 'n uitvloeisel van die Eerste Ekonomiese Volkskongres van 1939 en was 'n fonds wat die ekonomiese bemagtiging van Afrikaners ten doel gehad het. Die Fonds het onder andere geld vir studiedoeleindes aan Afrikaners bewillig.

174 H Giliomee, The Afrikaners. Biography of a People, 436-439, Tafelberg, Cape Town, 2012. 
"daar ontstaan in ons volkslewe 'n soort klasseverskil. Die meerbevoorregte se kind gaan na die hostel. Die arm kind gaan na die koshuis. Daar ontstaan so maklik 'n minderwaardigheidsgevoel ... op een of ander wyse moet ons geleidelik daartoe oorgaan om die arm man se kind en die ryk man se kind bymekaar te bring."175

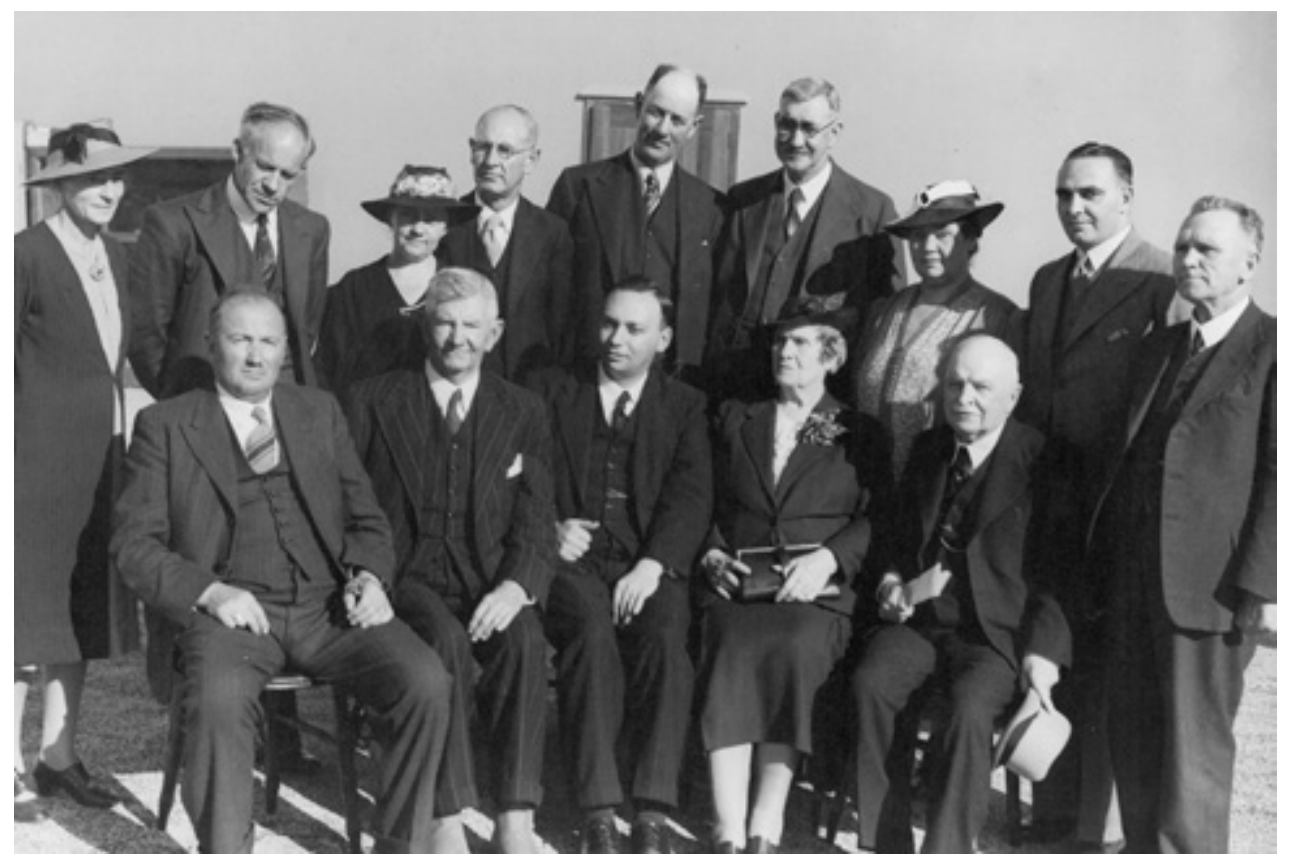

Hoofbestuur van die Helpmekaarvereniging van die Kaapprovinsie, 1941-1942.

Agter van links: mev TC Trouw, ds PGH Jordaan, mev SM Coetzee, ds DG Venter, mnr JJ van der Berg, mnr FK Siebrits, mev HS van Heerden, ds JT de Janse van Arkel, ds CP Pauw. Voor van links: sen DH van Zyl, adv Wessel Roux, ds WA Landman (voorsitter), mev JG de Bruyn, ds FX Roome.

Die verdeling tussen "Armkoshuis" en "Hostel" moes dus uitgewis word. ${ }^{176}$ Teen hierdie agtergrond en die talle kulturele, ekonomiese en maatskaplike uitdagings waarmee die Afrikaners geworstel het, was 'n besinning oor die Helpmekaar se doel en strewe - sy kernfokus - 'n toenemende behoefte en noodsaaklikheid. Vervolgens word die vernaamste ontwikkelings op tak- en kongresvlak in die veertigerjare bespreek.

175 (HSA) HVKP, Notuleboek, 31 Mrt-1 Apr 1943, Kongres, Voorsittersrede, 12.

176 (HSA) HVKP, Notuleboek, 31 Mrt-1 Apr 1943, Kongres, Voorsittersrede, 12-13. 
Die herbesinning en hersiening van die Helpmekaar se beleid en program van aksie is reeds in 1936 deur FX Roome in sy voorsittersrede aangeroer toe hy aan die hand gedoen het dat 'n kommissie benoem moes word om die reëls en regulasies van die organisasie te hersien en te besin oor die aanstelling van 'n organiserende sekretaris(esse) om kwynende takke te besoek en nuwes te stig. ${ }^{177}$ Die sentrale bestuur het aanvanklik nie op Roome se voorstelle gereageer nie, maar die 1937-kongres het die sentrale bestuur versoek om, indien moontlik, uitvoering aan Roome se wenke te gee. ${ }^{178}$ Hoewel die sentrale bestuur in Junie 1937 besluit het om dr PJ van Nierop aan te stel om takke te besoek en waar wenslik nuwes te stig, is niks oor die wenke in verband met die doel, strewe, reëls en regulasies van die Helpmekaar gedoen nie. ${ }^{179}$ Roome het waarskynlik met sy voorstel in dié verband die verwagting gekoester dat die breër werksterrein en groter klem op kultuurbetrokkenheid en -bevordering wat hy vir die Helpmekaar in die dertigerjare gepropageer het, in die grondwet sou neerslag vind.

Tydens die 1941-kongres is verskeie besprekingspunte ingedien met die versoek vir nouer samewerking met die RDB veral ten opsigte van hul opvoedkundige doelwitte. Murraysburg het self voorgestel dat die Helpmekaarvereniging moes ophou bestaan en sy lot by die RDB moes inwerp, of soos Molteno gevra het, met die RDB moes saamsmelt. In reaksie hierop het die voorsitter, ds WA Landman, en ds PHG Jordaan voorgestel dat 'n interim-kommissie van vyf lede benoem word met die opdrag om:

"die Konstitusie van die Helpmekaar met al die wysigings en aanvullings van die laaste jare (op te stel) sal opstel en in hersiening neem en met aanbevelings sal kom oor die volgende sake: die besondere terrein waarop die Helpmekaar hom moet beweeg ten einde onnodige oorvleueling met ander verenigings en bewegings te voorkom; die verhouding en samewerking al dan nie met die Reddingsdaadbond te bepaal." 180

Die verslag moes dan deur die hoofbestuur met aanbevelings aan die volgende kongres voorgelê word. Die interim-kommissie het bestaan uit di PHG Jordaan, WA Landman, TN Hanekom, ${ }^{181}$ sen DH van Zyl en DJ Kritzinger. ${ }^{182}$ Behalwe vir die feit dat die kommissie vier vergaderings gehou het, waarvan die laaste ook deur die hoofbestuur bygewoon is, het die erns waarmee die kommissie die opdrag benader het ook geblyk uit die feit dat hulle met

177 (HSA) HVKP, Notuleboek, 15-16 Apr 1936, Kongres, Voorsittersrede, 2.

178 (HSA) HVKP, Notuleboek, 30-31 Mrt 1937, Kongres, 11.

179 (HSA) HVKP, Notuleboek (15 Apr 1936-6 Des 1939), 16 Jun 1937, Sentrale Bestuur, 196.

180 (HSA) HVKP, Notuleboek, 16-17 Apr 1941, Kongres, 13, 15.

181 Tobie Hanekom was professor in Ekklesiologiese vakke in die Fakulteit Teologie by die Universiteit van Stellenbosch. Universiteit Stellenbosch Jaarboek 1965, 48.

182 (HSA) HVKP, Notuleboek, 16-17 Apr 1941, Kongres, 13. 
die 42 takke gekonsulteer het deur 'n omsendbrief uit te stuur waarop 36 takke antwoorde ingestuur het. Uit die reaksie van die takke was dit duidelik dat die algemene gevoel was dat die Helpmekaar onafhanklik moes bly voortbestaan en dat amalgamasie met die RDB verwerp word. Alle takke het verlang dat die Helpmekaar se terrein duidelik afgebaken word en dat hulle hul moes toespits op "studielenings en subsidies vir middelbare onderwys".

Die reaksie van takke was positief ten opsigte van die uitbreiding van die Helpmekaar deur propaganda, aangesien die meerderheid toegegee het dat hulle plaaslik 'n kwynende belangstelling in die Helpmekaar ervaar het. Die meerderheid takke het ook gevoel dat nuwe takke gelyke toegang tot Helpmekaar-fondse moes hê soos die ouer gevestigde takke. Uit die reaksie van takke was dit duidelik dat die entoesiasme vir leeskamers afgeneem het en daar was ook 'n gevoel by baie takke dat die subsidies aan inrigtings gestaak moes word. Die kommissie se anbevelings wat in 1942 voor die Wynberg-kongres gedien het, het by vernuwing bevestig "dat die Helpmekaar hom sal toespits op opvoeding". Die konteks waarin hierdie besluit geneem is, is duidelik deur Landman in sy voorsittersrede uitgespel:

"Die afgelope 20 jaar het daar verskillende ander verenigings ontstaan en die gevaar van oorvleueling het aktueel geword. Ons leef in die eeu van spesialisasie. Dit is nodig dat die Helpmekaar sy arbeidsfeer duidelik omlyn en hom uitsluitlik toelê op die onderwys, meer bepaald om behoeftige en verdienstelike leerlinge en studente finansieel te help. Ons het veels te breedlopig geword en daar is sekere terreine wat ons aan ander verenigings en bewegings moet oorlaat om te behartig, soos bv. kulturele sake, ekonomiese sake en liefdadigheid. Ons moet helder wees in ons doelstelling en doelbewus werk in hierdie bepaalde rigting. Solank ons volk 'n arm volk is, net so lank sal daar 'n noodsaaklikheid wees vir die voortbestaan van die Helpmekaar. Dit is daarom dat daar geen sprake kan wees van amalgamasie met die Reddingsdaadbond. Ons taak is om lewende boustene te lewer vir die gebou van ons volk in die vorm van seuns en dogters wat met ons hulp, toegerus en bekwaam gemaak is. Ons moet die materiaal lewer in die vorm van manne en vroue wat hul plek sal volstaan op al die terreine van die lewe. Manne en vroue wat sal dien in ons volksraad, in ons hospitale as geneeshere, in ons skole, in die besigheid en op die kansels. Met hierdie doel voor oë moet ons met vasberadenheid, met doelbewustheid, met geesdrif werk, mekaar se laste dra en die Wet van Christus vervul. In Hom is beliggaam die gees van Helpmekaar. Lank lewe die Helpmekaar." ${ }^{\prime 13}$

Die Kommissie het sy anbeveling vir 'n voortgesette opvoedingsfokus gebaseer op 'n verskeidenheid redes. Dit het oorvleueling met die RDB, FAK en ACVV uitskakel. Die oorgrote meerderheid van die takke het dit so verlang. Daar was $\mathrm{n}$ groot behoefte aan 
dié soort hulp in Kaapland en daar was die feit dat geen ander organisasie al sy kragte op dié terrein gefokus/konsentreer het nie. Die Kommissie was ook van oordeel dat met die fokus die hele kwessie oor samewerking met die RDB ook nie meer ter sake was nie omdat hulle op verskillende terreine werk. ${ }^{184}$ In die konteks van die opwelling van populistiese nasionalisme in Afrikanergeledere, soos vergestalt in die 1938-eeufees van die Groot Trek, die entoesiasme wat daarna oorgespoel het na die Eerste Ekonomiese Volkskongres en die stigting van organisasies soos die RDB, het Landman in sy voorsittersrede ook gewaarsku teen:

“oppervlakkige geesdrif ... Te veel van 'n geskreeu: 'Vir Volk en Vaderland' en daarmee doodtevrede is. Te veel van handhaaf en te min van bou. Hierdie oppervlakkige geesdrif word soms geneem vir vaderlandsliefde en patriotisme. Dit verwelk gou, want daar is geen diepte nie. Dit bereik niks en bring niks tot stand nie. Laat ons onsself toets in hierdie dae van geesdrif en vir onsself rekenskap gee. Wat doen $\mathrm{u}$ om ons geestesgoedere te bevorder? Wat doen $\mathrm{u}$ aan ons taalerfenis? Het $\mathrm{u}$ iets positiefs gedoen in die stryd om ons volk ekonomies te rehabiliteer? Dit is die dinge wat saak maak en nie luidrugtigheid en welsprekendheid nie."185

Afgesien van die herbevestiging van die opvoedingsfokus van die Helpmekaar en sy verhouding met die RDB is die twee ander aanbevelings van die kommissie na bespreking en enkele herformulerings ook deur die kongres aanvaar. 'n Voltydse organiserende sekretaris sou voorlopig vir een jaar aangestel word met die hoofdoel om fondse in te samel en verder sou dit sy taak wees om die Hulpleningsfonds (B-fonds) te styf, die werksaamhede van die Vereniging te propageer, takke te inspireer en met groot versigtigheid nuwe takke te stig. Die B-fonds was die skepping van DH van Zyl en is teen die einde van 1941 bekendgestel as 'n skema waarvolgens privaat beleggers fondse in die skema kon belê wat dan aan voornemende studente in die vorm van studielenings beskikbaar gestel kon word. Die motief agter die stigting van die Fonds was om te voorsien in die groot vraag na studielenings - 'n behoefte waarin die Helpmekaar met sy beperkte fondse nie voldoende kon voorsien nie. Die 1942-kongres het DH van Zyl se voorstel van 'n B-fonds wat parallel met die oorspronklike fonds geadministreer word, goedgekeur. ${ }^{186}$ Hierdie fonds is bedryf op die beginsel van 'n deposito-nemende instelling en het 'n hele nuwe dimensie aan die Helpmekaar verleen wat volledig in 'n volgende hoofstuk bespreek sal word.

184 Ibid.,13.

185 Ibid., 14.

186 (HSA) HVKP, Notuleboek, 8-9 Apr 1942, Kongres, Hoofbestuur verslag, 4. 
'n Laaste aanbeveling was dat subsidies aan takke mettertyd verhoog moes word. Die motivering hiervoor was dat die oorgrote meerderheid takke dit versoek het, dit plaaslike belangstelling en inisiatief gestimuleer het en die plaaslike gemeenskappe se aandag op die Helpmekaar gevestig het as 'n liggaam wat ook plaaslik werk. ${ }^{187}$

Terwyl die Landman-era enersyds 'n hernude skerper en enger fokus op die Helpmekaar se opvoedingshulpfunksie geplaas het, het dit andersyds ook 'n breër visie gebring wat tydens die Roome-era afwesig was. Landman het die Helpmekaar in die dampkring van die roeping van die Afrikanervolk aan die suidpunt van Afrika geplaas. Die Helpmekaar is gesien as 'n instrument om die roeping te vervul. Terwyl Landman 'n volk se roeping teenoor homself erken het, het sy brëer visie ook die roeping teenoor ander volke - dus die interafhanklikheid tussen volke - beklemtoon.

Anders as Roome, met sy fokus op die rassesuiwerheid van Afrikaners wat met wetgewing afgedwing en as voorvereiste vir Afrikaneroorlewing beklemtoon is, het Landman op die interafhanklikheid tussen groepe gefokus. Hierdie klemverskil het besonderse insigte weerspieël waarmee Landman sy tyd ver vooruit was, veral in die lig van die feit dat die Afrikaner-nasionalistiese politiek van die veertigerjare juis toenemend deur die Roomebenadering gekenmerk is. Die tweede roeping - dié teenoor ander volke - kon volgens Landman egter slegs uitgevoer word as die eerste een volbring is. Die volle potensiaal van die volk moes dus ontwikkel word. Die aparte bestaansreg van die volk moes dus eers bevestig word voordat wyer gekyk kon word - dit was dus 'n selfverwesenliking van die eie volk, maar dan ook in diens van ander volke. Teen dié agtergrond moes die Helpmekaar ook sy bydrae lewer:

“'n Volk het 'n roeping teenoor homself, maar ook teenoor ander volke. 'n Volk, net soos die individu, kan nie geïsoleerd lewe nie. Ons neem ons plek in tussen ander volkere. Ons is afhanklik van mekaar op industriële, ekonomiese, kulturele en wetenskaplike gebied. Niemand leef vir homself nie. Ook die volke moet mekaar dien. Elke volk moet sy bydrae lewer tot die wêreldgeheel, die mensheid en die algemene beskawing ... As ons streef na grootheid om die grootheid selfsugtig te gebruik en te geniet sal en kan ons die grootheid nooit behou nie. Dit is 'n ewige wet wat geld nie net vir die indivudu nie, maar ook vir 'n volk."'188

Landman se 1947-voorsittersrede, waarin hy 'n verdere verklaring en regverdiging vir die Helpmekaar se hernude opvoedingsfokus en die siening dat opvoeding die enigste

187 (HSA) HVKP, Notuleboek, 8-9 Apr 1942, Kongres, 13.

188 (HSA) HVKP, Notuleboek, 8-9 Apr 1942, Kongres, Voorsittersrede, 14. 
volhoubare en regverdigbare redmiddel vir die Afrikanervolk was, verskaf het, is ten spyte van die onbeskaamde Afrikaner fokus deur sy breër visie deursuur en in perspektief gestel. Op die vraag of die Helpmekaar nog 'n bestaansreg het, het Landman sy bevestigende antwoord met drie redes gemotiveer. Eerstens, dat Afrikaner-seuns en -dogters oor die voldoende intellektuele potensiaal beskik wat verdien om ontwikkel te word. Dit is deur jaarlikse prestasies in die Senior en Junior Sertifikaat-eksamens bevestig. Tweedens, dat die Afrikaner se agterstande op ekonomiese gebied opvoeding noodsaaklik maak. Hul aandeel in die mynbou en industriële sektore was nog onbeduidend. Laastens, dat die toekoms van die Afrikanervolk dit vereis: met slegs 27 persent van standerd ses-leerders wat uiteindelik matrikuleer; die sterk korrelasie tussen skoolstanderd verwerf en werkloosheid; en blankes wat toenemend 'n kleiner deel van die bevolking word. Hy het ten opsigte van laasgenoemde daarop gewys dat die getal Kleurling-kinders op skool in 1946 vir die eerste keer die getal blanke kinders oortref het:

"Daar is 'n ongekende ontwaking by beide Kleuringe en Naturelle. Beide seksies is bereid om groot opofferings in belang van hul kinders te maak. Ons kan voorbeelde vir u noem. Die blanke seun en dogter sal hulself moet handhaaf. Die kleurling en naturel kan nie met wetgewing onder gehou word nie. Dit sou oneties en onChristelik wees. Ons het as blankes 'n groot voorsprong gehad. Dit is nie die skuld van die kleurling en naturel as die blankes ingehaal word nie. Die Helpmekaar moet as vereniging al hierdie feite onder die oë sien. Ons moet nugter en realisties wees. Die Helpmekaar moet sy deel doen om die voortbestaan van ons volk te verseker, en om elke seun en dogter 'n bate te maak." 189

Teen die agtergrond van dié benadering en die hernude fokus op die Helpmekaar se opvoedingsfunksie is die Landman-era deur'n aantal ineengestrengelde temas en inisiatiewe gekenmerk wat as onderliggende dryfveer die behoefte na meer fondse gedeel het. Dit was onder andere die opwekking van groter belangstelling in die Helpmekaar deur die plaaslike takke te inspireer tot aksie. Dit was die uitbreiding van die takstelsel deur die stigting van nuwe takke, beide met die oog op die generering van 'n groter inkomstestroom vir die sentrale kas via die takke en hul plaaslike netwerke. Dit was ook die immer teenwoordige kwessie van die aanstelling van 'n organiserende sekretaris om die propagandawerk in dié verband te doen. Die kwessie van die finansiële lewensvatbaarheid van dié werkwyse teen die agtergrond van die kostes daaraan verbonde en die werklike bydrae van die takke tot die sentrale kas was ook een van die inisiatiewe. Laastens was dit die instel van verdere aansporings aan takke om hul tot aksie te inspireer en te aktiveer. Vervolgens word bogenoemde temas en inisiatiewe kortliks bespreek. 
Die katalisator vir die hernude inisiatiewe en debatte in dié verband was DH van Zyl se aanstelling as sekretaris van die Vereniging in 1939 en sy fokus op vernuwende maniere om Helpmekaar-fondse uit te brei, soos die instelling van die B-fonds, wat met sy aanstelling gepaardgegaan het. Hoewel die B-fondskonsep nuut was en nuwe metodes en kategorieë skenkers geteiken het, was die plaaslike takke en hul sosiale kapitaal soos verteenwoordig deur hul plaaslike netwerke, steeds gesien as die poort tot die ontginning van die fondse. Aktiewe takke en die uitbreiding van takke was dus 'n belangrike element in die nuwe fondswerwingsbenadering.

Dit het weer die kwessie van die aanstelling van 'n organiserende sekretaris ter sprake gebring - waaroor die penningmeester reeds in sy 1924-verslag tot die gevolgtrekking gekom het dat dit 'n onwinsgewende manier van doen was omdat die uitgawes aan die pos verbonde meer was as die fondse wat gewerf is of wat deur nuwe takke wat gestig is, gegenereer is. Sedert veral die vroeë dertigerjare het die dalende bydraes van die takke tot die fondse van die sentrale kas in teenstelling met die steeds stygende uitbetaling in die vorm van studielenings die penningmeester bekommer. Sy verwysings hierna het teen die veertigerjare 'n al hoe dringender refrein geword. Die dreinerende effek wat takke op die fondse van die sentrale kas gehad het weens die subsidiestelsel wat sedert 1931 geïmplementeer is, het geïntensifiseer. ${ }^{190}$ Dit het dus die kwessie rondom die sinvolheid van die stigting van nuwe takke verder gekompliseer. In sy 1941- Penningmeestersverslag het Roux hom as volg daaroor uitgelaat:

"Soos herhaaldelik reeds deur my gerapporteer, stort takke weinig geld in die sentrale kas. Dit lyk vir my dat die meeste takke van die Vereniging nou bestaan om gehelp te word en nie om te help nie. In 1940 het ons van takke ontvang $£ 49217$ s 2 d. Daarenteen het takke uit die sentrale kas direk ontvang $£ 518$ 10s subsidie; $£ 49$ 8s vir skoolbiblioteke, en $£ 30$ vir leeskamers; dus $£ 59718$ s of $£ 105$ 0s 10 d meer as wat alle takke gestort het. Daar en bowe het applikante deur takke aanbeveel $£ 3804$ aan studielenings ontvang." ${ }^{191}$

Die historiese perspektief op dié ontwikkeling was dat takke tot 1931 slegs geld gestort en niks uit die sentrale kas getrek het nie, behalwe natuurlik die studielenings wat op hul aanbevelings toegestaan is. In 1931 het takke geld vir skoolbiblioteke uit die sentrale kas begin trek. In 1935 het hulle begin subsidie trek. In 1946 het Roux bereken dat vir die periode 1935-1945 (elf jaar)

190 (HSA) HVKP, Notuleboek, 12-13 Apr 1939, Kongres, 3. Takke het in $1938 £ 286$ 2s 10d bygedra tot die inkomste van die sentral bestuur en vir lenings aan studente. Aansoeke om lenings deur takke aanbeveel het daarteenoor byna $£ 8000$ bedra.

191 (HSA) HVKP, Notuleboek, 16-17 Apr 1941, Kongres, Penningmeester verslag, 5. Die 1942-penningmeestersverslag bevestig ook dat takke baie meer van die sentrale kas ontvang as wat hulle bydra. ( $£ 8932$ s is uitbetaal en $£ 49915$ s 6 d is van takke ontvang. Studente deur takke aanbeveel, het $£ 4272$ aan studielenings ontvang.)(HSA) HVKP, Notuleboek, 8-9 Apr 1942, Penningmeester verslag, 4. 
takke $£ 7221$ uit die sentrale kas getrek en $£ 5880$ gestort het - wat hulle met 'n nadelige saldo van $£ 1341$ gelaat het. Benewens die subsidies het die tendens waarskynlik ook verband gehou met 'n neiging wat sedert die dertigerjare toenemend gemanifesteer het en ten beste deur die takverslag by die 1937-kongres as volg verwoord is: "Die tak (Cradock) rapporteer dat die persone wat die meeste belang in die Vereniging stel, die is wat meen om ten behoewe van hul kinders voordeel daaruit te trek". ${ }^{192}$ Roux het dus in dié verband opgemerk:

"Omdat rentekoerse nou baie laer is as vroeër is ons inkomste op belegde kapitaal kleiner as vroeër. As takke dus elke jaar of byna elke jaar meer trek as wat hulle stort, moet ons fondse uitgeput raak ... Tot my spyt moet ek sê dat dit vir my lyk of die offervaardigheid en vrygewigheid wat daar was net na die opstand verdwyn het. Baie mense het nou afgeleer om te gee en het geleer om te vra. Miskien het die uitbetaling van so baie soorte subsidie deur die Regering daar wat mee te doen. Ek kan slegs hoop dat wat ons Vereniging betref die lus om te gee weer sal terugkom." 193

Teen die agtergrond van die realiteit dat takke vir die Helpmekaar eerder 'n uitgawe as inkomste verteenwoordig het en druk op die fondse van die sentrale kas geplaas het, moes die sentrale bestuur die besluit van die 1942-kongres om 'n organiserende sekretaris aan te stel, implementeer. ${ }^{194}$ By die hoofbestuursvergadering van 9 Februarie 1942 het die bestuur besluit om in opdrag van die kongres die pos van organiserende sekretaris teen $£ 40$ per maand plus reiskoste in die pers te adverteer. ${ }^{195}$

Aangesien geen geskikte aansoek vir die pos van organiserende sekretaris ontvang is nie ${ }^{196}$ is sen Van Zyl vir 'n periode van ses maande vanaf 1 Augustus 1942 as organiserende sekretaris aangestel teen $£ 40$ per maand plus reiskoste. Adv Wessel Roux is as waarnemende sekretaris vir die ses maande aangestel teen 'n addisionele vergoeding van $£ 15$ (dit is $£ 15$ plus sy honorarium van $£ 9$ per maand as penningmeester). ${ }^{197}$ In Desember is besluit om die organisasiewerk met nog ses maande te verleng na 31 Januarie $1943 .{ }^{198}$ Die verstandhouding was dat sen Van Zyl bo en behalwe die organisasiewerk ook die administrasie van die B-fonds

192 (HSA) HVKP, Notuleboek, 30-31 Mrt 1937, Kongres, Takverslae, 8.

193 (HSA) HVKP, Notuleboek, 3-4 Apr 1946, Kongres, Voorsittersrede, 11-12.

194 (HSA) HVKP, Notuleboek, 2-3 Apr 1947, Kongres, Takverslae, 9.

195 (HSA) HVKP, Notuleboek (8 Feb 1940-9 Des 1966), 7 Apr 1942, Hoofbestuur, 275.

196 (HSA) HVKP, Notuleboek (8 Feb 1940-9 Des 1966), 2 Mei 1942, Hoofbestuur, 277.

197 (HSA) HVKP, Notuleboek (8 Feb 1940-9 Des 1966), 16 Jun 1942, Hoofbestuur, 278.

198 (HSA) HVKP, Notuleboek (8 Feb 1940-9 Des 1966), 2-3 Des 1942, Hoofbestuur, 283. 
sou waarneem. Op 31 Januarie 1942 is die reëling op versoek van adv W Roux beëindig en het Van Zyl ook die algemene sekretarisskap van die Vereniging waargeneem.

Hy is bygestaan deur 'n assistent teen 'n salaris van $£ 8$ per maand plus 'n lewenskostetoelae. As organiserende sekretaris het Van Zyl in die periode 1 Augustus tot einde Oktober 194220 takke besoek en 5800 myl per trein en motor afgelê. In die proses het hy bydraes en donasies tot die Hooffonds en die B-fonds verkry en was daar $£ 160$ op beloftekaarte uitstaande wat oor 'n tydperk van 3 jaar ingevorder sou word. Hy het ook 'n vyftigtal bemiddelde Afrikaners genader waarvan die meerderheid beloof het om in hul boedels 'n bemaking aan die Vereniging te doen. Baie van die takke wat besoek is, was kwynend en sy besoeke het nuwe belangstelling gewek. ${ }^{199}$ Die 1943-kongres het dan ook besluit om die hoofbestuur te magtig om die dienste van die organiserende sekretaris te behou tot die sitting van die volgende kongres. ${ }^{200}$

Uit die penningmeester se verslag was dit duidelik dat hy nog steeds sy 1924-standpunt oor die sinvolheid van 'n organiseerder gehandhaaf het, aangesien hy deur sy syfers duidelik probeer illustreer het dat die pos die Helpmekaar meer geld gekos het as wat dit na die sentrale kas laat vloei het. Sy berekenings het aangedui dat, as daar nie georganiseer was nie, die gewone fondse van die Vereniging - ingesluit die Jacob de Villiers-Helpmekaarstudieleningsfonds (dit is ook die eerste keer dat die benaming pertinent in sy penningmeestersverslag gebruik word, waarskynlik om dit duidelik van die B-fonds te onderskei) tussen $£ 100$ - $£ 200$ sterker sou wees. Die kostes verbonde aan die organiserende sekretaris het ongeveer $£ 100$ meer gekos as wat dit in die 1943 lopende jaar geïn het. ${ }^{201}$

Uit die penningmeester se verslag aan die 1943-kongres was dit duidelik dat hy nie ten gunste van 'n organiserende sekretaris, die stigting van nuwe takke en die B-fonds was nie. Sy opmerkings in dié verband het aan die negatiewe gegrens. Hy het die verhoogde uitgawes van die Vereniging aan die kongres se besluit om 'n organiserende sekretaris aan te stel toegeskryf en die finansiële sin agter die stigting van nuwe takke bevraagteken, aangesien hulle nie winsgewend was nie en net bestaande takke benadeel het:

“Die organiserende sekretaris het 'n nuwe tak - George - help stig. Hierdie nuwe tak het in $1943 £ 715$ s in ons kas gestort en $£ 20$ subsidie en $£ 5$ vir'n skoolbiblioteek getrek. Dan het die nuwe tak George $£ 105$ aan studielenings vir 1944 gevra, waarvan $£ 30$ toegeken is. Ek kan nie verstaan hoe dit in die belang van die Vereniging as geheel kan wees om

199 (HSA) HVKP, Notuleboek, 31 Mrt-1 Apr 1943, Kongres, Hoofbestuur verslag, 4.

200 (HSA) HVKP, Notuleboek, 31 Mrt-1 Apr 1943, Kongres, 15.

201 (HSA) HVKP, Notuleboek, 31 Mrt-1 Apr 1943, Kongres, Penningmeester verslag, 5. 


\section{Die Kaapse Helpmekaar}

sulke nuwe takke te laat stig nie. Ek het reeds herhaaldelik opgemerk dat sommige takke bestaan nie om te help nie, maar wel om gehelp te word. Moet ons nou koste maak om takke te stig wat drie keer soveel aan kontant uit ons sentrale kas ontvang as wat hulle stort? Dan beveel sulke takke nog aansoeke om studielenings aan wat alleen toegeken kan word ten koste van bestaande takke."202

Die penningmeester se opmerking oor die George-tak, sekere opmerkings oor die organiserende sekretaris, die invordering van studieskuld van die Hooffonds en die fondswerwing vir die B-fonds het ongelukkigheid onder sommige lede van die kongres veroorsaak. Soveel so dat sekere dele van die penningmeester se verslag se bewoording met sy instemming herformuleer is. Ten spyte van die penningmeester se besware is besluit om te hou by die besluit van die Wynberg-kongres ten opsigte van uitbreiding. Mnr Siebrits het ook sy steun vir die stigting van die B-fonds uitgespreek omdat dit meer kanse aan behoeftige studente bied. Hy het egter 'n beroep gedoen op die kongres om nie die B-fonds teenoor die Hooffonds te stel nie. ${ }^{203}$

By die 1944-kongres is ook verslag gedoen oor die sekretaris se organisasiewerk. Hy het alle takke behalwe vier besoek - die takke kon nie by sy skedule inpas nie of het hom versoek om hulle later te besoek. 'n Aantal nuwe takke is gestig en 'n aantal dorpe het versoek dat takke daar gestig word. Hy het weer meer as 4000 myl afgelê en die rede vir die lae reiskoste was dat hy 'n groot deel van die koste self gedra het. Die toename in ledetal weens sy werk was aansienlik en belangstelling in die Helpmekaar se werk is oral aangekweek. Hy het die Helpmekaar ook wyer bevorder soos tydens die FAK-kongres in Bloemfontein. ${ }^{204}$ Die hoofbestuur het dus besluit om die organisasiewerk deur die sekretaris voort te sit vir altesaam vier maande in die jaar teen 'n besoldiging van $£ 25$ per maand. ${ }^{205}$

Wat betref die stigting van nuwe takke, het die sekretaris in November 1944 gerapporteer dat daar gedurende die jaar ses nuwe takke gestig is. $\mathrm{Na}$ aanleiding hiervan het die hoofbestuur besluit dat die sekretaris kon voortgaan met die stigting van nuwe takke, maar slegs in gevalle waar daar 'n dringende versoek van plaaslike belangstellendes gekom het en slegs indien die sekretaris van oordeel was dat die takke 'n aanwins vir die organisasie sou wees. Hierdie voorwaarde, wat waarskynlik sy oorsprong by die penningmeester se standpunt oor

202 (HSA) HVKP, Notuleboek, 4-5 Apr 1944, Kongres, Penningmeester verslag, 4.

203 Ibid., 10.

204 (HSA) HVKP, Notuleboek, 4-5 Apr 1944, Kongres, Hoofbestuur verslag, 3.

205 (HSA) HVKP, Notuleboek (8 Feb 1940-9 Des 1966), 4 Apr 1944, Hoofbestuur, 313. 
die stig van nuwe takke gehad het, het 'n beduidende demper op takstigting geplaas. ${ }^{206}$ Die hoofbestuur was ook van oordeel dat dit noodsaaklik was dat groter bydraes deur takke aan die sentrale kas gemaak word en di Landman en Van Arkel is opdrag gegee om die saak te ondersoek en by die volgende kongres daaroor te rapporteer. ${ }^{207}$

In tandem met die aanstelling van 'n organiserende sekretaris het die 1943-kongres ook voorstelle vir die aanmoediging van takke deur die toekenning van jaarlikse pryse goedgekeur. 'n Bedrag van $£ 50$ uit die gewone fondse van die Vereniging is bewillig vir aanmoedigingspryse vir takke in 'n verskeidenheid kategorieë. Eerstens is 'n bedrag van $£ 15$ as eerste prys en $£ 10$ as tweede prys aangebied aan die tak wat oor die jaar, 1943, die grootste groei per 100 lede getoon het. Tweedens is 'n bedrag van $£ 15$ as eerste prys en $£ 10$ as tweede prys vir die tak wat die grootste vermeerdering per $£ 100$ toon in die bedrag wat in die fondse van die Vereniging gestort word aangebied.

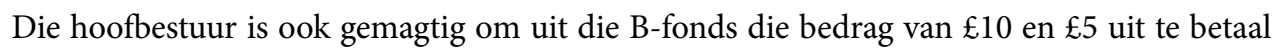
as eerste en tweede prys aan dié takke wat respektiewelik die meeste en tweede meeste goedgekeurde persone werf wat gelde beskikbaar stel in die jaar 1943 vir die B-fonds. Die kongres het dit ook aan die hoofbestuur opgedra om 'n plan te beraam waardeur pryse aan takke toegeken word. ${ }^{208}$ ' $n$ Vorm is ook vir die wedstryde ontwerp en lede van die hoofbestuur is opdrag gegee om takke aan te moedig om aan die wedstryde deel te neem. ${ }^{209}$ Die eerste B-fonds-prys van $£ 10$ is aan die Kirkwood-tak toegeken en saam daarmee 'n wisselbeker wat deur mej HE Coetzee geskenk is. ${ }^{210}$ Die werk van die organiserende sekretaris en die aansporing van die pryse het 'n gedeeltelike en tydelike opflikkering in takaktiwiteite veroorsaak. Terwyl daar in 1943 slegs 9 takke was met 'n ledetal van oor die 100, was daar in 194416 takke wat beskik het oor 'n ledetal van meer as $100{ }^{211}$

Die oplewing was egter van korte duur en op die 1945-kongres het die hoofbestuur besluit dat die idee om takke aan te spoor deur die toekenning van pryse nie die gewensde uitwerking gehad het nie. Baie min takke het hul doelbewus daarop toegespits om die doelwitte te bereik.

206 In die 1945 verslag van die hoofbestuur is gerapporteer dat in die afgelope ses jaar daar as gevolg van die bestuur se beleid om slegs daar waar daar groot behoefte aan 'n tak bestaan een te stig slegs sewe nuwe takke gestig is. (HSA) HVKP, Notuleboek, 4-5 Apr 1945, Kongres, Hoofbestuur verslag, 3.

207 (HSA) HVKP, Notuleboek (8 Feb 1940-9 Des 1966), 8-9 Nov 1944, Hoofbestuur 317.

208 (HSA) HVKP, Notuleboek, 31 Mrt-1 Apr 1943, Kongres, 13.

209 (HSA) HVKP, Notuleboek (8 Feb 1940-9 Des 1966), 1-2 Des 1943, Hoofbestuur, 302.

210 (HSA) HVKP, Notueleboek, 31 Mrt-1 Apr 1943, Kongres, 13.

211 (HSA) HVKP, Notuleboek, 4-5 Apr 1944, Kongres, Takverslae, 10. 


\section{Die Kaapse Helpmekaar}

Die addisionele fondse wat op dié wyse vir die Hoof- en B-fondse geïn is, was nie genoeg om die beskikbaarstelling van geldpryse te regverdig nie. Die hoofbestuur het dus by die kongres aanbeveel dat weens die swak reaksie van die takke slegs met ' $n$ wisselbekerwedstryd vir die beste tak voortgegaan moet word en dat die toekenning daarvan voortaan in die hande van die dagbestuur gelaat sou word. ${ }^{212}$

Teen dié agtergrond het die kommissie (Landman/Van Arkel) wat 'n skema moes ondersoek waarvolgens die takke 'n groter bydrae tot die sentrale kas en die B-fonds moes lewer by die 1945-kongres met die volgende voorstel gekom: Hulle het aanbeveel dat die huidige verpligtinge van takke, naamlik een vyfde van die opbrengs van die Afrikanerdag-inkomste, met'n minimum van $\mathfrak{E} 5$, steeds moes geld. Hulle het verder by die kongres aanbeveel dat die takke versoek word om 'n spesiale poging aan te wend om die Hoof- en die B-fonds te sterk. Die kommissie het ook die noodsaaklikheid van groter stortings in die sentrale kas by die kongres beklemtoon. Die voorstelle is deur die kongres aanvaar. DJ Posthumus het 'n verdere voorstel gemaak dat takke soos gewoonlik die Hooffonds moes styf en dat hulle dan nog bo en behalwe dit hulle verantwoordelik stel om oor die volgende twee jaar minstens $£ 150$ by te dra om die reserwefonds van die B-fonds te styf. Hoewel die sekretaris, sen Van Zyl, daarop gewys het dat daar heelwat meriete in so 'n voorstel was, is die voorstel egter afgestem toe dit tot stemming gebring is. ${ }^{213}$

Dit was dus duidelik dat daar 'n behoefte na meer fondse was, maar daar was ook 'n ongemaklikheid of spanning in minstens 'n beduidende deel van die kongres oor die Hoof-/Bfonds-opset. Die weerstand en selfs vyandigheid teenoor die B-fonds het hoofsaaklik gespruit uit die vrees dat die Hooffonds sou moes pa staan vir moontlike verliese wat die B-fonds, wat met geleende geld van die publiek gewerk het, mag lei. ${ }^{214}$ Dit was ook duidelik dat daar nie veel entoesiasme onder die takke was om hulle tot groter geldelike verpligtinge te verbind nie. In die vaarwater van die 1945-kongres het die penningmeester voorgestel dat die reëls en regulasies ten opsigte van takke se bydraes verander moes word. Die hoofbestuur het egter na bespreking daarteen besluit en onderneem om eerder by die volgende kongres 'n dringende beroep op takke vir groter bydraes te doen. ${ }^{215}$

Terwyl die ou staatmakers (takke soos Victoria-Wes, Kirkwood, Uniondale en PE) steeds hul prestasies gehandhaaf het en Uniondale die beker vir die beste tak vir 1945 gewen het op grond

212 (HSA) HVKP, Notuleboek, 4-5 Apr 1945, Kongres, Hoofbestuur verslag, 3; (HSA) HVKP, Notuleboek (8 Feb 1940-9 Des 1966), 22 Jun 1944, Dagbestuur, 314 (a); (HSA) HVKP, Notuleboek (8 Feb 1940-9 Des 1966), 8-9 Nov 1944, Hoofbestuur, 317.

213 (HSA) HVKP, Notuleboek, 4-5 Apr 1945, Kongres, 12.

214 (HAS) HVKP, Notuleboek (8 Feb 1940-9 Des 1966), 26 Nov 1964, HS, Direksie, gp (geen pagina/bladsy).

215 (HSA) HVKP, Notuleboek (8 Feb 1940-9 Des 1966), 14-15 Nov 1945, Hoofbestuur, 339. 
van hul vermeerdering in ledetal, die aantal studente wat hulle gehelp het en die persentasie van totale inkomste aan opvoeding bestee, het die hoofbestuur in sy 1946-kongresverslag dit betreur dat daar nie 'n algemene verbetering ten opsigte van groter bydraes of die vermeerdering in ledetal van takke was nie. ${ }^{216}$ By die 1946-kongres was dit duidelik dat daar verdeeldheid was oor die hele kwessie van die bydraes van takke teenoor dit wat hulle uit die sentrale kas ontvang. 'n Beskrywingspunt van die Victoria-Wes-tak het versoek dat die reëls en regulasies ten opsigte van die jaarlikse $£ 20$-subsidie op 'n pond-vir-pond basis aan elke tak om kinders van die Vereniging op middelbare skole te ondersteun verander moet word. Hulle het voorgestel dat, as teenprestasie, takke wat wil kwalifiseer voor einde Oktober minstens $£ 15$, ledegeld uitgesluit, in die sentrale kas moet stort. Takke wat minder bydra as $£ 15$ moes pro rata minder van die

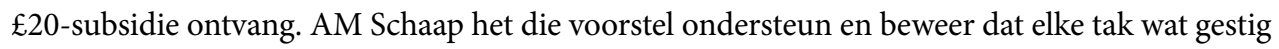
word 'n las vir die Hooffonds is. Hoewel die voorstel gesekondeer is en die penningmeester die hoop uitgespreek het dat die kongres die voorstel sal ondersteun, was daar teenkanting. Ander menings was dat op die platteland mense eerder wil sien dat die fondse plaaslik spandeer word. Die voorstel het uiteindelik weens die teenstand verval. ${ }^{217}$

In 1947 is 'n voorstel van die sekretaris, dat die kongres 'n beroep moes doen op alle takke om minstens twee donateurs in hul omgewing te werf wat dan elk minstens $£ 2$ per jaar tot die Beursfonds sal bydra, deur die hoofbestuur goedgekeur. ${ }^{218}$ Teen 1948 het die groot behoefte na fondse en die verwagting dat die takke hierin moes voorsien dus ten spyte van die inisiatiewe steeds bestaan. Die hoofbestuursverslag het gewag gemaak daarvan dat, hoewel takke sowat $£ 100$ meer as die vorige jaar tot die sentrale kas bygedra het en die Helpmekaar se kapitaal met

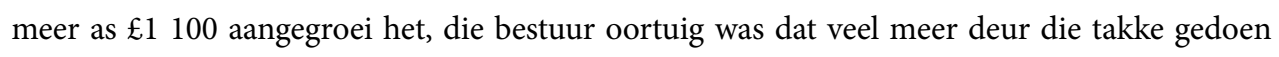
kon word om die Hooffonds te versterk en meer lede te werf. ${ }^{219}$ Die takverslae het die refrein ge-eggo met klagtes dat die takke meer lede moes werf (daar was 'n afname in lede by die meeste takke), dat groter bedrae in die Hoof- en B-fonds gestort moes word en dat spesiale pogings by Afrikanerdag aangewend moes word om fondse in te samel ${ }^{220}$ terwyl die penningmeester andermaal gewaarsku het teen die ongesonde toestand dat baie takke meer uit die Hooffonds getrek het as wat hulle daarin gestort het. ${ }^{221}$

\footnotetext{
216 (HSA) HVKP, Notuleboek, 3-4 Apr 1946, Kongres, Hoofbestuur verslag, 1.

217 (HSA) HVKP, Notuleboek, 3-4 Apr 1946, Kongres, 12.

218 (HSA) HVKP, Notuleboek (8 Feb 1940-9 Des 1966), 1-2 Apr 1947, Hoofbestuur, 369.

219 (HSA) HVKP, Notuleboek, 31 Mrt-1 Apr 1948, Kongres, Hoofbestuur verslag, 1.

220 (HSA) HVKP, Notuleboek, 31 Mrt-1 Apr 1948, Kongres, Takverslae, 6.

221 (HSA) HVKP, Notuleboek, 31 Mrt-1 Apr 1948, Kongres, Penningmeester verslag, 2.
} 


\section{DIE DPM BEUKES ${ }^{222}$-VYFTIGERJARE: FOKUS OP FONDSE EN HERVORMING VAN DIE KONGRES- EN TAKSTELSEL}

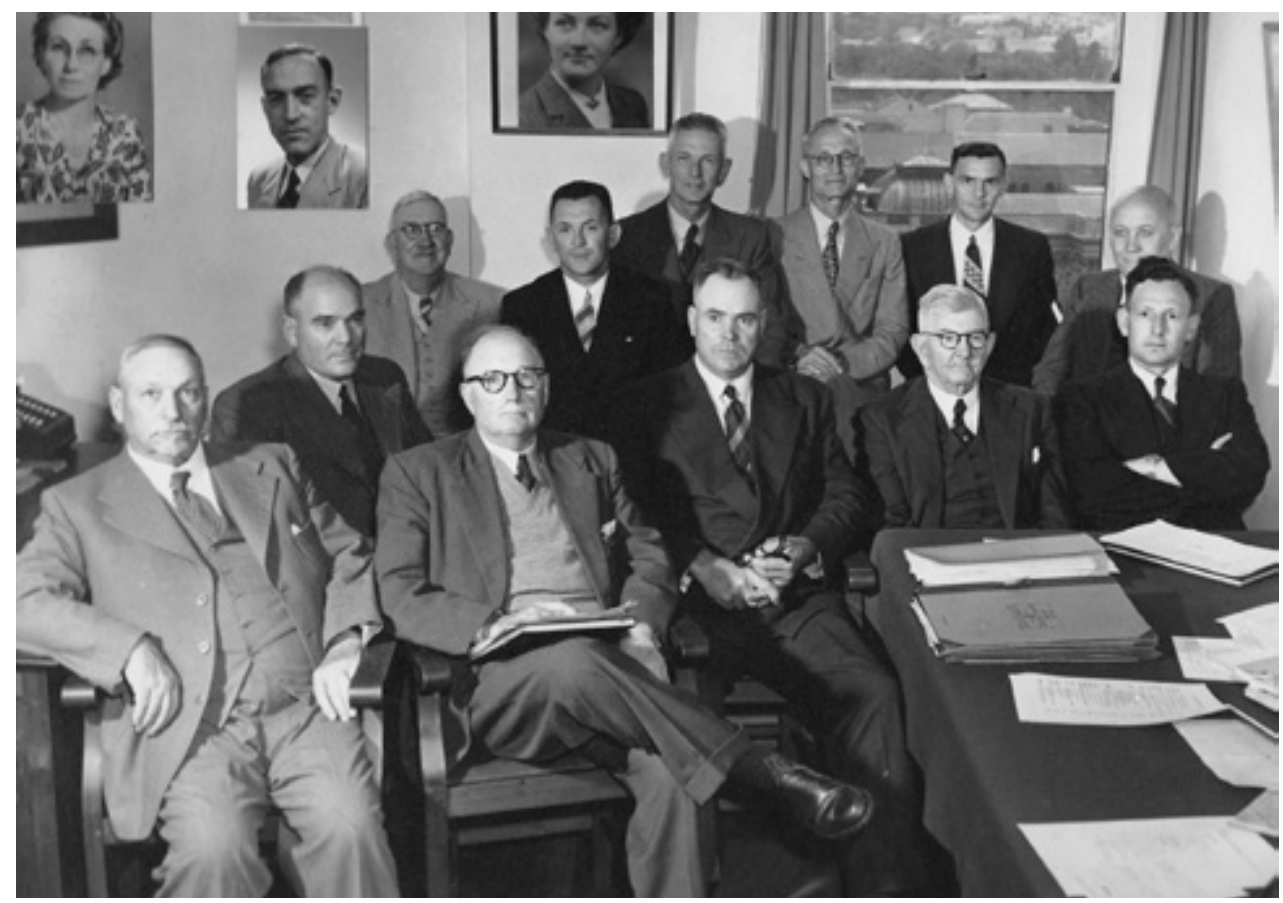

Hoofbestuur en personeel van die Helpmekaarvereniging van die Kaapprovinsie, 1952.

Agter van links: RA van Rensburg, FK Siebrits, MN Slabber, JF Burmeister, W Myburgh,

GJB Volschenk, CJ van Dyk. Voor van links: G Malherbe, sen DH van Zyl, KA Sinclair, $a d v$ Wessel Roux, ds DPM Beukes. Inlasse: mev PJ van der Merwe, SP Pretorius, mej AS Gouws.

In die vyftigerjare is die Helpmekaar gekonfronteer met die toenemende impak (sukses) van die pogings deur die staat, kerk, kultuur en burgerlike organisasies sedert die twintigerjare. Hierdie organisasies het die armblankevraagstuk probeer oorkom en Afrikaners is 'n groter aandeel in die ekonomie van 'n toenemend industrialiserende Suid-Afrika besorg. Afrikaners se veranderende ingesteldheid teenoor die groeiende stedelike verbruikerskultuur in die naaan die UOVS en sy MTh-graad aan die US het hy in 1940 die bediening as hulpprediker op VictoriaWes betree. Hy het van 1949-1961 as voorsitter van die Helpmekaar gedien en het veral na sy vertrek na Transvaal in 1961 'n leidende rol in Afrikaner kerk- en kultuurkringe gespeel. Hy was onder andere vanaf 1970 ses jaar voorsitter van die FAK; is in 1974 tot Moderator van die Algemene Sinode van die NG-Kerk verkies en was ook lid van die Afrikaner-Broederbond. Suid-Afrikaanse Biografiese Woordeboek Vol.V, 50. 
oorlogse periode en hul toenemende finansiële vermoë om aktiewe deelnemers daarin te word, het uitdagings gerig aan sogenaamde Afrikanereenheid. Dit was 'n eenheid waarvan die 1948-verkiesingsoorwinning waarskynlik die sigbaarste demonstrasie verteenwoordig het. Die gewaarwording van hierdie ekonomiese grondverskuiwing wat mettertyd gemanifesteer het en deur Grundlingh beskryf is in sy artikel, "Are We Afrikaners Getting too Rich?" Cornucopia and Change in Afrikanerdom in the 1960's, ${ }^{223}$ het ook in Helpmekaargeledere gemanifesteer.

Tekens en simptome van hierdie ekonomiese verskuiwing was egter veel vroeër as die sestigerjare reeds deel van Helpmekaar-debatte en -ervarings. In 1926 het Stals reeds getuig van die sukses wat behaal word om die Afrikaner ekonomies meer selfstandig te maak deur die regering se beleid van beskaafde arbeid. Terwyl daar in 19245321 blanke arbeiders in die Spoorweë in diens was, het die getal teen einde Desember 1925 tot 12137 gegroei. Die arbeiders is ook deur aandklasse, geleentheid gegee om hul te bekwaam vir meer lonende werk. Op dié wyse is daar geleenthede geskep vir baie arm blankes om 'n selfstandige bestaan te verseker. Hy het egter ook teen die gevare van verstedeliking, wat met die ekonomiese selfstandigmaking van die Afrikaners gepaardgegaan het, gewaarsku:

“'n groot deel van die Afrikaanssprekende volk, (word) onder ons oë oorgeplant uit die landboubedryf in die industriële- of amptenaarswêreld. Dit is iets heeltemal nuuts vir ons volk ... Die feit is dat daardie deel van die bevolking, in ander omstandighede, omgewinge geplant word, en aan nuwe, in baie gevalle, volksvreemde, invloede blootgestel word, waarteen baie nie opgewasse is nie ... Die gevare wat die hoof gebied moet word, is wesenlike gevare vir individue, famielies nie alleen nie, ook vir die volk, en veral vir die handhawing van die dure en kosbare volkstradiesies ... Die nuwe omstandighede, die nuwe leefwyse en die nuwe omgewing, en die nuwe ekonomiese uitsig bring mee, dat die ou oorerfelike lewensbeskouing sy skerp omlyning kan verloor. Dit bring mee dat miskien 'n heeltemal nuwe lewensbeskouing die oue kan vervang. Die gevolg is dat die ou ankers en bakens van die volkslewe hulle betekenis verloor. Ja, dit is moontlik - nee, dit is in die lewe reeds bewys - dat daardie ankers en bakens heeltemal kan verdwyn vir duisende van ons stamverwante, geesverwante en geloofsgenote. Die gevaar wat al meer en meer vandag gevoel word, is dat hierdie aansienlike dele van ons vlees en bloed verband kan verloor met die ander groter meer selfstandige deel. Die gevaar is dat die Kerk van die vadere, die Godsdiens van die vadere, die sedes van die vadere en die kultuur van die vadere, wat almal deel uitgemaak het van 'n selfstandige Suid-Afrikaanse volkslewensbeskouing hulle invloed kan kwytraak. Daarom, sonder om in die geringste

223 AM Grundlingh, "Are We Afrikaners Getting Too Rich?" Cornucopia and Change in Afrikanerdom in the 1960's, Journal of Historical Sociology Vol 21 No 2/3 Jun/Sep 2008, 143-165. 


\section{Die Kaapse Helpmekaar}

te reflekteer op die beste bedoelinge van duisende van hierdie nuwe stedelinge, sê ek, is dit noodsaaklik dat stappe moet geneem word om die volksverband te bly handhaaf." 224

Stals het dus ingesien dat die toenemende ekonomiese selfstandigheid Afrikaners kon vervreem van die "volksideale" en die strewe na volkseenheid. In die twintigerjare is die pad na ekonomiese selfstandigheid gesien as die Calvinistiese benadering van volgehoue arbeid in kombinasie met 'n sobere/spaarsamige/spartaanse lewenswyse. In 1928 sonder Stals "gesonde karakter en werklus" uit as "die sekerste middels" om "enige volk of deel van 'n volk, van ondergang te red". Hy waarsku teen die gevare van "Gemaksug en Plesiersug" wat in stryd is met opheffing en handhawing en kom dan tot die gevolgtrekking: "Ons volk en ons opkomende geslag is, helaas, nie hiervan vry nie!". 25

In 1929 besing FX Roome die belangrikheid van die rol van die ontwikkeling van 'n spaarsin om die volk ekonomies kragtig en sterk te maak en loof die werk van skole waar spaarklubs reeds gestig is. Hy beklemtoon dat 'n spaarsin nie net ekonomies nie, maar ook moreel sterk maak: "Dit vra nie veel kuns om geld te maak nie, maar wel om wat gemaak is te behou ... Om spaarsaamheid te beoefen kos baie. Dit vra selfbeheer, wilskrag, onselfsugtigheid en soveel meer." 226 In 1930 het FX Roome weer die belangrikheid van die ontwikkeling van 'n spaarsin beklemtoon as 'n deug wat van jongs af aangekweek moet word deur die instelling van spaarklubs en ander fasilitiete. ${ }^{227}$ Die strewe na ekonomiese vooruitgang het ook gemanifesteer in die beroepskeuses van Helpmekaar-leningsaansoekers na die meer professionele beroepe. In dié verband het Roome in 1930 die aandag daarop gevestig van hoe min kinders 'n ambag as lewensbestaan kies en die vraag gestel:

"Behoort ons nie lenings aan te bied aan jongens wat die beroepe van skrynwerker, messelaar, skilders en loodgieters wil kies nie? In dorpe soos Paarl, Worcester en Oudtshoorn was dit vroeër die reëI, vandag is dit 'n seldsaamheid om blanke ambagsmanne aan te tref." 228

In sy 1934-voorsittersrede het Roome weer die kwessie van spaarsin aan die bod gestel:

"As daar iets is wat tydig en ontydig verkondig moet word, dan is dit die evangelie van spaarsaamheid. Hoe vroeër hoe beter. Van jongs af moet die kind leer om nie verkwistend te wees, om nie te mors nie. Wat getuig die kinderkamer? Deur 'n inventaris

224 (HSA) HVKP, Notuleboek, 7-8 Apr 1926, Kongres, Voorsittersrede, 2-4.

225 (HSA) HVKP, Notuleboek, 4-5 Apr 1928, Kongres, Voorsittersrede, 3.

226 (HSA) HVKP, Notuleboek, 3-4 Apr 1929, Kongres, Voorsittersrede, 2.

227 (HSA) HVKP Notuleboek, 16-17 Apr 1930, Kongres, Voorsittersrede, 3.

228 Ibid.,4. 
op te trek sal ons miskien skrik en tot besinning kom. Hoeveel poppe, stelle breekgoed, motorkarre, treine, vliegtuie en dosyne van allerlei. En alles geïmporteer. Hoe selde sien jy wat eg Afrikaans is, en op eie werf vervaardig. Daardie oordaad, baie speelgoed, word onbewus die maatstaf, wat later in die lewe tot die insolvensiehof lei. Na wat die land in die laaste twee jaar deurgemaak het, is dit nog nodig om spaarsin aan te beveel? Laat ons as hulpbiedende liggaam deur woord en voorbeeld toon dat ons glo in vlyt en spaarsaamheid, sonder om ons aan inhaligheid en vrekkigheid skuldig te maak. Die gees van verkwisting is verderflik en aansteeklik en het al baie slagoffers geëis onder alle klasse en stande van die samelewing. Ons kredietstelsel werk hierdie euwel in die hand."229

In sy 1938-voorsittersrede het Roome die gevare vir die nasiebouprojek uitgesonder en onder andere te velde getrek teen "die euwels van die huurkoopstelsel, veral onder armes", asook die pogings om 'n staatslotery ingestel te kry. Hy het die kongres opgeroep tot 'n veldtog: “om die monster 'n doodsteek te besorg voordat wetgewing ingevoer word ... Ons het almal belang daarby, want dit geld die hele volk, wat afhanklik is van die Goddelike wet wat sê: 'In die sweet van jou aangesig sal jy brood eet'. Die brood van kans en toeval is in die begin soet, dog daarna bitter. Dit voed nie, maar teer uit. Dit bewerk die ondergang van ons volk. Om ons volk sedelik en geestelik te behou moet ons alle konstitusionele en geoorloofde middele gebruik om die euwel die voet dwars te sit."230

Hierdie temas was tekenend van Afrikaners wat toenemend by die stedelike verbruikerskultuur ingeskakel het en kultuurmakelaars en politieke leiers wat na Afrikanereenheid gestreef het, verontrus het.

Teen die laat dertigerjare het die realiteite van die demografiese uitdagings wat Afrikaners in die gesig gestaar het ook in die Helpmekaar neerslag gevind. In 1939 het Roome gewaarsku teen die wurggreep van die vreemde geldmag en die "nuwe verskynsel" in die arbeidsmark waar blank met nie-blank moet kompeteer. Hy het herinner aan die demografiese realiteit dat daar slegs twee miljoen blankes teenoor die agt miljoen "naturelle" en "kleurlinge" in Suid-Afrika was en tot die gevolgtrekking gekom dat "as ons nie wette kry om ons as blankes te beskerm nie dan loop ons gevaar om te verdwyn".231 In die Helpmekaar het die impak van die demografiese realiteite gelei tot 'n besef dat die maksimale ontginning van die potensiaal van die Afrikaner-jeug deurslaggewend geword het vir die oorlewing van die Afrikaner. Vir

229 (HSA) HVKP, Notuleboek, 3-4 Apr 1934, Kongres, Voorsittersrede, 2.

230 (HSA) HVKP, Notuleboek, 20-21 Apr 1938, Kongres, Voorsittersrede, 2-3.

231 (HSA) HVKP, Notuleboek, 12-13 Apr 1939, Kongres, Voorsittersrede, 9. 


\section{Die Kaapse Helpmekaar}

die Helpmekaar om net te konsentreer op die verdienstelike hulpbehoewende studente was nie meer genoeg nie. Die toekoms van die volk het vereis dat die net wyer gesprei word.

Landman se voorstel in sy 1943-voorsittersrede dat die leuse van die Helpmekaar moes wees "Elke belowende seun en dogter van ons volk moet toegerus die lewe ingaan"232, asook sy verwysing na die stigting van die B-fonds in 1942 as 'n "eerlike goedbedoelde poging" in hierdie rigting, was tekenend van dié besef en benadering. Met die ou spreekwoord van "Wiens brood men eet, diens woord men spreekt" in gedagte, kon studiehulp deur Helpmekaar in 'n bate vir die volk omskep word, dit kon vir die volk behoue bly en hulle sou nie slagoffers van volksvreemde elemente word nie. Landman het ook gewaarsku teen 'n ander uitvloeisel van die toenemende ekonomiese selfstandigwording van die Afrikaners, naamlik 'n soort klasseverskil wat in die volkslewe ontstaan. Daar is reeds verwys na sy "hostel" versus "koshuis"-onderskeid wat bestaan het en die noodsaaklikheid om die arm en ryk man se kind bymekaar te bring.

Teen die agtergrond van dié konteks is die Beukes/Sinclair-era, van die vyftigerjare en die eerste helfte van die sestigerjare, gekenmerk deur 'n herbesinning oor die Helpmekaar se strategie en struktuur. Die oog was op die akkommodering van die uitdagings wat die Afrikaner se veranderende ekonomiese, demografiese en politieke posisie aan die Helpmekaar, sy taak en terrein en sy funksionering gerig het. In die breë het die Helpmekaar se reaksie neergekom op 'n poging om die volle potensiaal van die Afrikanerjeug se breinkrag in diens van die volk se oorlewing en voortbestaan te benut. Hierdie gedagte het reeds in die veertigerjare sy ontstaan gehad. Dit was gebaseer op die reeds genoemde beginsel van "Wiens brood men eet, diens woord men spreek". Die doelwit, wat beteken het dat Helpmekaarfinansiële ondersteuning 'n veel breër spektrum van die Afrikanerjeug as net die kinders van lede van die Helpmekaarvereniging moes bereik (en waarmee alreeds met die B-fonds in die veertigerjare ' $n$ aanvang gemaak is), het by implikasie 'n drastiese vermeerdering van Helpmekaar-fondse vereis. ${ }^{233}$ Die bestaande Helpmekaar-strukture van 'n takstelsel wat in 'n besluitnemende kongres verteenwoordig word met 'n hoofbestuur wat die kongresbesluite geïmplementeer het, het toenemend geblyk nie in staat te wees om die strategie te verwesenlik nie. Dit was hoofsaaklik omdat die basis van die piramiede, naamlik die takke, weens 'n gebrek aan plaaslike belangstelling in 'n ernstige staat van agteruitgang en ontbinding was. Die periode is gekenmerk deur 'n lang en uitgerekte debat en proses om 'n geskikte struktuur vir die Helpmekaar se strategie te vind. In die eerste plek moes afskeid geneem word van 
die takstelsel en die tradisies en gevestigde belange wat oor 'n periode van ongeveer 40 jaar daaromheen opgebou is. In 'n verdere rondte van verandering moes die kongres oorreed word om te ontbind en sy gesag aan die hoofbestuur oor te dra. Die geboorteproses van dié veranderinge was langsaam en pynlik. Dit is uitgerek deur'n goeie skoot volstruisbenadering wat nie die skrif aan die muur, soos deur die visionêre in die Helpmekaar uitgewys is, wou lees nie. Die hooftrekke van die proses word vervolgens kortliks geskets.

In die geskiedenis van die Helpmekaar was die stryd om takke se belangstelling en meelewing te behou 'n deurlopende tema en soos reeds aangetoon kan die eerste verwysings van agteruitgang teruggevoer word na die vroeë twintigerjare en selfs vroeër. Die subsidiestelsel aan takke wat in die dertigerjare ingestel is in 'n poging om plaaslike belangstelling in Helpmekaar te wek, het wel tot ' $n$ groter investering in onderwys en opvoedingshulp deur takke op 'n plaaslike vlak gelei. Dit het egter ook toenemend gelei tot 'n dreinering van sentrale fondse na takke wat vroeër as kapitaalgenereerders bekendgestaan het, maar later permanente dreineerders geword het.

Bo en behalwe die uitbetaling van studielenings aan studente wat deur takke aanbeveel is, het takke vir die periode 1946-1949 $£ 2426$ in die sentrale kas gestort teenoor die $£ 2570$ wat hulle daaruit onttrek het. ${ }^{234}$ Afgesien van die finansiële dreinering het die gesukkel met takke om hul jaarlikse verslae in te dien, afgevaardigdes na kongresse te stuur en beskrywingspunte vir bespreking tydens kongresse in te dien 'n demoraliserende effek op die Helpmekaar gehad wat energie getap het wat eerder op ander terreine soos fondswerwing aangewend kon word. Geoordeel na takaktiwiteite en -deelname het die Helpmekaar die beeld van 'n sukkelende, disintegrerende organisasie geskep. Dit terwyl die hoofbestuur en administrasie op sentrale vlak nie kon voorbly met die stroom van versoeke na finansiële ondersteuning wat jaarliks van studente ontvang is nie. ${ }^{235}$ Die mantra dat dit die takke is wat die Helpmekaar maak wat hy is, het dus teen die vyftigerjare nie meer gegeld nie. Die situasie het die Helpmekaar genoop om bestek op te neem van die effektiwiteit van hul takstelsel wat oor jare geïdealiseer is as die netwerk waardeur nuwe kapitaal of nuwe bronne van kapitaal vir die sentrale kas gemobiliseer kon word.

234 (HSA) HVKP, Notuleboek, 3-4 Apr 1951, Kongres, Penningmeester verslag, 5.

235 Die Helpmekaar moes jaarliks aansoeke van sowat $£ 5000$ van die hand wys terwyl die omvang van die toekennings wat hulle wel toegestaan het ook onvoldoende was. (HSA) HVKP Notuleboek, 4-5 Apr 1950, Kongres, Voorsittersrede, 32-35. 
In Desember 1951 het die visevoorsitter van die Helpmekaar, KA Sinclair, ${ }^{236}$ tydens 'n hoofbestuursvergadering die debat oor die voortbestaan van Helpmekaartakke vir die eerste keer amptelik te berde gebring toe hy sy twyfel uitgespreek het oor die nut van hul voortbestaan in hul tradisionele formaat. Hy het sy standpunt gebaseer op die aansienlike afname in die ywer vir die saak van die Helpmekaar onder die algemene publiek, asook die hoë koste om takke in stand te hou. Hy het 'n paar stelsels wat die huidige takstelsel kon vervang om groter doeltreffendheid te bewerkstellig aan die hand gedoen met die versoek aan hoofbestuurslede om oor die saak na te dink. ${ }^{237}$ Sinclair se verwysing na die afnemende ywer vir die Helpmekaar-saak is bevestig deur die swak reaksie van takke op Beukes se dringende oproep op Helpmekaar-lede in sy 1950-voorsittersrede om te bewys dat die "Kainsgesindheid wat alle verbondenheid aan en verantwoordelikheid teenoor die broer wil afskud met die ontwykende vraag: Is ek my broer se wagter?" nie die algemene kenmerkende gesindheid van die volk geword het nie. ${ }^{238}$

Afgesien van die fondswerwingsinisiatiewe wat deur die hoofbestuur bestuur is, is aan takke ook 'n belangrike rol toegeken in die veldtog om alle moontlike bronne te mobiliseer om 'n vermoënde studiefonds daar te stel. 'n Voorstel is dus deur die 1950-kongres aanvaar waarin alle takke versoek is om in die betrokke boekjaar minstens $£ 40$ aan die Hoof- en B-fondse te skenk. 'n Besluit is ook aanvaar dat 'n beroep op takke gedoen word om beleggings wat hulle elders mag hê, in byvoorbeeld die poskantoor, in die Helpmekaar se B-fonds te belê. Hulle kon ook ander plaaslike liggame en verenigings met dieselfde doel nader en lyste van moontlike beleggers, erflaters en donateurs maak, hulle nader en lyste na die hoofbestuurslid van die sirkel stuur. ${ }^{239}$ Name van moontlike kollektante of organiseerders moes aan hoofbestuurslede verstrek word. ${ }^{240}$ By die 1951-kongres was dit duidelik dat die oproep en verbintenis van die vorige kongres, dat takke en lede'n spesiale poging sou aanwend om fondse in te samel, nie veel

236 Ken Sinclair het op die plaas Skraalfontein naby Victoria-Wes geboer. Hy was vir 15 jaar 'n lid van die Provinsiale Raad en vir vyf jaar voor sy uittrede uit die aktiewe politiek in 1970 'n lid van die Senaat. Hy was ook aktief in verskeie landbouverwante organisasies soos die Grondbewaringsraad, bestuurslid van die Karoo-Landbou-unie en ondervoorsitter van die Karoo-Ontwikkelingsvereniging. Die Burger, 11 Apr 1978, Oud-sen Sinclair oorlede, 11.

237 (HSA) HVKP, Notuleboek (8 Feb 1940-9 Des 1966), 19 Des 1951, Hoofbestuur, 422.

238 (HSA) HVKP, Notuleboek, 4-5 Apr 1950, Kongres, Voorsittersrede, 32-35.

239 Die Kongres het in 1930 besluit om ter wille van 'n meer eweredige verteenwoordiging van takke en streke op die sentrale bestuur takke in agt sirkels te verdeel met een lid van die sentrale bestuur wat uit elke sirkel verkies sou word. (HSA) HVKP, Notuleboek, 16-17 Apr 1930, Kongres, 6. 
van gekom het nie. Die hoofbestuursverslag het ook die tendens bevestig dat takke deurgaans meer uit die sentrale fonds van die Helpmekaar getrek het as wat hulle bygedra het. ${ }^{241}$

Teen hierdie agtergrond is Sinclair se 1951-voorstel oor aanpassings in die takstelsel vir die eerste keer in 1952 op kongresvlak gedebatteer na aanleiding van sy verwysings daarna in die voorsittersrede. Die 1952-kongres en die voorsittersrede het gestaan in die konteks en nasionalistiese gloed van die pas afgelope 300 -jarige vieringe van die landing van Jan van Riebeeck en die "volksplanting" waarmee dit vereenselwig is. Die tema van Sinclair se toespraak was die plan van God met die mens; waarin die Helpmekaar se rol was om veral in die lig van die reusetekorte aan mense in die "gespesialiseerde beroepe" toe te sien dat nie 'n enkele seun of dogter met hul talente verlore moet gaan nie. In sy toespraak het Sinclair twee nou verwante rigtinggewende voorstelle verwoord, naamlik dat takke:

"wat miskien nou net stremmend werk, vervang sal word met 'n komiteestelsel" en dat "met die uitgebreide onderwysfasiliteite by ons middelbare skole, ons die fondse van die Helpmekaarvereniging nou hoofsaaklik moet gebruik vir gevorderde studies, en alle pogings moet aanwend om ons beskikbare personeel en miskien met byvoeging van andere, soveel moontlik te konsentreer op insameling van fondse deur die hele provinsie ..." 242

Hierdie voorstelle van hom is vervat in 'n amptelike voorstel van die Victoria-Wes-tak wat na afloop van sy kongresrede gedebatteer is. Victoia-Wes het voorgestel dat:

"met die oog op die feit dat die onderwysfasiliteite in die afgelope tyd so verbeter en uitgebrei het dat 'n leerling nou feitlik gratis kan leer tot by St. X en aangesien die Helpmekaartakke voorheen hoofsaaklik dit as hulle taak beskou het om leerlinge te help tot by St. X, besluit die kongres nou om weg te doen met die takstelsel en oor te skakel na 'n komiteestelsel en versoek die hoofbestuur om die Konstitusie diensooreenkomstig te wysig volgens 'n konsepvoorstel wat aan die kongres voorgelê sal word."243

Die voorstel het nie algemene byval gevind nie en is uiteindelik in 'n ordemosie oorweldigend met 29 stemme teenoor 8 verwerp. Dit was egter duidelik dat daar veral op sentrale bestuursvlak, waar daar daagliks met die tekortkominge van die takstelsel geworstel is, steun vir die voorstel was. Hoewel die voorsitter, DPM Beukes, die verval onder takke aan 'n "tydelike geestelike insinking" toegeskryf het en hoopvol vir 'n verbetering in die toekoms was, het hy Sinclair gelukgewens met sy uiteensetting. Die sekretaris, DH van Zyl, het sy steun

241 (HSA) HVKP, Notuleboek, 3-4 Apr 1951, Kongres, Hoofbestuur verslag, 1.

242 (HSA) HVKP, Notuleboek, 8-9 Apr 1952, Kongres, Voorsittersrede, 9-10.

243 (HSA) HVKP, Notuleboek, 8-9 Apr 1952, Kongres, 10. 


\section{Die Kaapse Helpmekaar}

vir Sinclair se voorstelle getoon deur voor te stel dat die konsepvoorstelle vir die verandering van die Helpmekaar-grondwet na die hoofbestuur vir verdere ondersoek verwys word met die opdrag om aanbevelings in dié verband aan die volgende kongres voor te lê. Hoewel die voorstanders van die takstelsel die eerste geveg gewen het, sou hulle uiteindelik die oorlog verloor. Hul weerstand sou egter meer as 'n dekade duur voordat die veranderende sosioekonomiese omstandighede wat besig was om in Afrikanergeledere te ontvou hulle finaal sou agterhaal. ${ }^{244}$

Die hoofbestuur het tydens sy Desember 1952-vergadering besluit dat afskrifte van die Sinclair-konsepvoorstel aan alle lede van die hoofbestuur gestuur word met die oog op volledige bespreking daarvan tydens die volgende vergadering. 'n Komitee, bestaande uit ds DPM Beukes, mnre GJB Volschenk en KA Sinclair (sameroeper), is aangewys om op die hele saak van wysigings in te gaan en 'n behoorlik gemotiveerde verslag met aanbevelings op te stel vir voorlegging aan die hoofbestuursvergadering tydens die 1953-kongres. ${ }^{245}$ Die komitee se verslag het die weerstand teen verandering, soos op die 1952-kongres geillustreer is, bevestig deur aan te beveel dat die status quo in die bestuurstelsel vir eers gehandhaaf word. Die komitee was van mening dat die eenheid en ywer wat deur die kongres bewerkstellig word swaarder geweeg het as die nadele wat aan die huidige stelsel verbonde was. Die takbesture moes maar net voortdurend hard werk en geesdrif aanwakker en ten nouste saamwerk met die Hoofkantoor, dan sou die gees van die Helpmekaar onuitblusbaar wees en versprei na ander persone.

Die komitee het aanbeveel dat 'n organiserende sekretaris teen 'n goeie besoldiging aangestel word wat hom moes beywer vir die insameling van fondse en organisasiewerk onder takke. Die algemene gevoel op die hoofbestuur was dat die aanbevelings een van "bevrediging en verligting" was, maar almal was nie ewe ingenome nie. Sinclair het hom neergelê by die aanbeveling, maar was van mening dat, indien dit sou blyk dat die voorgestelde organiseerder nie kan doen wat verwag word nie, daar tog uiteindelik 'n stelsel gevind sou moes word wat beter resultate lewer. Sekretaris, sen Van Zyl, het meegedeel dat die hoofkantoor op 'n latere geleentheid sekere wysigings sou aanbeveel wat nodig sou word weens veranderde omstandighede. ${ }^{246}$ Die verslag van die grondwet-komitee is ook voor die 1953-kongres gelê

244 Ibid.,10.

245 (HSA) HVKP, Notuleboek (8 Feb 1940-9 Des 1966) 18 Des 1952, Hoofbestuur, 443.

246 (HSA) HVKP, Notuleboek (8 Feb 1940-9 Des 1966) 27 Jun 1953, Hoofbestuur, 448-449. 
wat dit aanvaar het en die hoofbestuur volmag gegee het om die organiserende sekretaris, wat moes fondse insamel en takke met organisasiewerk help, aan te stel. ${ }^{247}$

Die komitee se aanbeveling is aanvaar tydens 'n kongres wat later as gewoonlik moes plaasvind vanweë takke se laksheid om hul verslae in te stuur. Die hoofbestuursverslag het meegedeel "dat daar nog nooit soveel laksheid by taksbesture bestaan het om die vereistes van die grondwet na te kom as juis hierdie jaar nie". ${ }^{48}$ Dit was 'n aanduiding van die mate waarin die Helpmekaar-kongres bereid was om sy oë te sluit vir die realiteite wat die takstelsel in die gesig gestaar het. As kompromis het hulle hul gewend tot die ou tradisionele Helpmekaar"redmiddel", naamlik 'n organiserende sekretaris - 'n oplossing wat ten beste 'n rekord van wisselvallige resultate in die Helpmekaar-geskiedenis gehad het.

Die 1953-besluit oor die behoud van die takstelsel is deur verskeie inisiatiewe gerugsteun. Die kern hiervan was 'n "twaalf jaar skema vir fondse-insameling" wat gemik was op die uitbreiding van die kapitaal van beide die Hoof- en B-fonds. Die mikpunt vir die Hooffonds is gestel op $£ 100000$ en die strategie was om die mikpunt hoofsaaklik met die werwing van lewenslange lede te bereik. ${ }^{249}$ Die konsep van lewenslange lidmaatskap is by die 1953-kongres as 'n nuwe vorm van Helpmekaar-lidmaatskap, benewens die gewone lidmaatskap van 2/6 per lid per jaar, aanvaar. Hierdie lidmaatskap kon verkry word deur die eenmalige betaling van $£ 10$, wat in paaiemente betaal kon word solank dit binne een boekjaar geskied het. Die volle bedrag sou aan die sentrale kas oorbetaal word. Benewens gewone lede van takke, sou bevriende persone en oudstudente wat nie lede is nie en hulle nie aktief bemoei met die Helpmekaar nie, genader word om lewenslange lede te word. ${ }^{250}$

Die instelling van lewenslange lidmaatskap het aanvanklik groot belofte getoon. Veral met Sinclair se mededeling in Desember 1953 tydens die hoofbestuursvergadering dat hy reeds 19 lewenslange lede in sy distrik gewerf het en hy van mening was dat, indien takke hulle daarop toelê, daar honderde sulke lede ingeskryf kon word. Hy was ook van mening dat 'n voltydse organiseerder die Helpmekaar se kapitaal baie sou kon versterk met die werwing van lewenslange lede. Die Helpmekaar-kantoor is dan ook versoek om die moontlikheid op te volg sodra 'n organiseerder gevind is. ${ }^{251}$ Die hoofbestuur het ook besluit dat hulle in

247 (HSA) HVKP, Notuleboek, 27 Jun 1953, Kongres, 8.

$248 \quad$ Ibid., 1.

249 (HSA) HVKP, Notuleboek, 5-6 Apr 1955, Kongres, 2.

250 (HSA) HVKP, Notuleboek, 27 Jun 1953, Kongres, 8-9.

251 (HSA) HVKP, Notuleboek (8 Feb 1940-9 Des 1966), 15 Des 1953, Hoofbestuur, 454. 


\section{Die Kaapse Helpmekaar}

hul jaarlikse verslag aan die kongres 'n beroep op takke sou doen om elkeen sowat 20 (later vasgestel op 25) ${ }^{252}$ lewenslange lede te werf. ${ }^{253}$

'n Nuwe stel voorwaardes waarvolgens die takbeker-wenners aangewys sou word, is ook aanvaar. Aspekte soos konstantheid of toename van opbetaalde ledetal, bydraes tot die Hooffonds, B-fonds en Beursfonds, stiptheid met indiening van verslae en beantwoording van korrespondensie en kongresbywoning sou in gelyke gewigte deur die Hoofkantoor oorweeg word. ${ }^{254}$

Die soeke na 'n Helpmekaar-organiseerder en fondswerwer is teen die einde van 1954 met sukses bekroon toe HD Roux, voorheen skoolhoof van Diamantveld Laer in Kimberley, ingestem het om vanaf Februarie 1955 voltyds fondse vir die Helpmekaar in te samel. Sinclair het versoek dat hy hom veral ook op boedelbemakings aan die Helpmekaar moes toelê. ${ }^{255}$

Afgesien van die pogings om takke te motiveer om meer fondse vir die sentrale kas te genereer is verskeie ander pogings ook deur die Hoofkantoor as deel van die twaalf jaar skema vir fondsinsameling geïnisieer om die kapitaalposisie van die Helpmekaar te verstewig en propaganda op 'n nasionale vlak vir die organisasie te maak. Die sekretaris, senator DH van Zyl, het 'n goed verteenwoordigende vergadering van belangstellendes, bestaande uit koerantredakteurs, leiers van volksorganisasies, professore en onderwysmanne, in Johannesburg toegespreek oor twee aangeleenthede, naamlik 'n eie Transvaalse Helpmekaarfonds en tweedens 'n uniale Beursfonds. Die reaksie hierop was bemoedigend en na afloop van die ontmoeting is 'n verteenwoordigende komitee gestig om die sake verder op te volg. Van Zyl het ook onderhoude met verskillende groot maatskappye gevoer met die oog op die skenking van jaarlikse bydraes en deur sy bemiddeling is ook onderhandel vir die verkryging van beheer oor 'n boedel van sowat $£ 16000$ wat vir leningsfondse aangewend kon word. Daar is ook deur die loop van die jaar onderhoude gevoer met koerantredakteurs wat landswye propaganda vir die Vereniging tot gevolg gehad het. Die Kerkbode het ook in dié verband sy ondersteuning verleen deur as mondstuk vir die Helpmekaar te dien. ${ }^{256}$

Die 1955-kongres het ook pogings tot hernude propaganda probeer inisieer met twee voorstelle, naamlik eerstens, 'n versoek dat die hoofbestuur kontak moes hou met persone

\footnotetext{
252 (HSA) HVKP, Notuleboek, 5-6 Apr 1955, Kongres, 2.

253 (HSA) HVKP, Notuleboek (8 Feb 1940-9 Des 1966), 30 Mrt 1954, Hoofbestuur, 461.

254 (HSA) HVKP, Notuleboek, 27 Jun 1953, Kongres, Takverslae, 8.

255 (HSA) HVKP Notuleboek (8 Feb 1940-9 Des 1966), 14 Des 1954, Hoofbestuur, 465.

256 (HSA) HVKP, Notuleboek, 5-6 Apr 1955, Kongres, Hoofbestuur verslag, 1.
} 
wat studielenings of ander ondersteuning van die Helpmekaar ontvang het om te verseker dat hulle die Vereniging sal goedgesind wees en bly. Tweedens, is opdrag en volmag aan die hoofbestuur gegee om 'n nuwe pamflet op te stel om die onkunde onder die breë publiek aangaande die Helpmekaar uit die weg te ruim. ${ }^{257}$

Ten spyte van die positiewe ontwikkelinge het die 1955-kongres bevestig dat die basiese probleem van kwynende en disintegrerende takke nie oornag verdwyn het nie. Die verslag van die hoofbestuur het weer eens gewag gemaak van die algemene laksheid van takbesture in die uitvoering van hulle pligte teenoor die hoofbestuur en onder andere na die Oos-Londentak verwys wat reeds vir jare net uit een of twee persone bestaan het. ${ }^{258}$ Uit die verslag van die hoofbestuur was dit ook duidelik dat die idee van lewenslange lede nie die sukses was waarop gehoop is nie en dat, afgesien van enkele takke soos Victoria-Wes, Cradock, Wellington, Sunland en Malmesbury, die reaksie van die ander takke swak of totaal afwesig was. Die opmerking in die verslag dat dit ten minste van takbestuurslede verwag kon word om hulle hiervoor te beywer was 'n aanduiding dat dit nie die geval was nie - wat 'n aanduiding van die stand van die takke was. ${ }^{259}$ Takbesture was oor jare deurlopend die kern wat plaaslike Helpmekaar-aktiwiteite aan die gang gehou het. Die erodering van dié groep was waarskynlik die oorsaak van die toenemende ineenstorting van die takstelsel in die laat veertiger en vroeë vyftigerjare.

Die inisiatief om 'n fondsorganiseerder aan te stel, in die person van mnr HD Roux, het geblyk om lonend te wees aangesien die hoofbestuur in Desember 1955 gerapporteer het dat hy byna $£ 4000$ ingesamel het en dat na aftrekking van sy salaris en reiskoste 'n netto bedrag

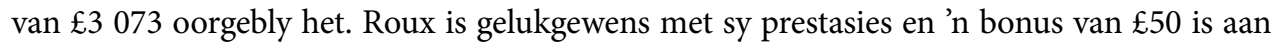
hom toegeken. Op Roux se aanbeveling het die hoofbestuur besluit om by die kongres aan te beveel dat nog 'n organiseerder aangestel word, aangesien Kaapland te groot was om deur een persoon gedek te word. Roux is ook versoek om met ander liggame wat fondse in, te koördineer, sodat hulle nie gelyktydig in dieselfde distrik fondse werf nie. ${ }^{260}$

Die steeds verslegtende toestand van takke ten spyte van pogings en inisiatiewe om nuwe lewe daarin te blaas het die Helpmekaar genoop om weer die debat oor die afskaffing of aanpassing van die takstelsel te heropen. In sy voorsittersrede tydens die 1956-kongres die veertigste bestaansjaar van die Helpmekaar - het DPM Beukes die noodsaaklikheid en

257 Ibid.,7.

258 (HSA) HVKP, Notuleboek, 5-6 Apr 1955, Kongres, Hoofbestuur, 1.

259 (HSA) HVKP, Notuleboek, 5-6 Apr 1955, Kongres, Hoofbestuur verslag, 1.

260 (HSA) HVKP, Notuleboek (8 Feb 1940-9 Des 1966), 12 Des 1955, Hoofbestuur, 481. 


\section{Die Kaapse Helpmekaar}

behoefte vir 'n voortsetting van die gees van die Helpmekaar se werk beklemtoon. 'n Pleidooi is egter gelewer dat die organisasie, in die lig van die veranderde omstandighede en die algemene laksheid wat ten opsigte van Helpmekaar-werksaamhede ingetree het, sy metodes moes wysig. In sy ontleding van die oorsake van die laksheid het hy 'n aantal faktore geïdentifiseer: die verdwyning van die behoefte aan Helpmekaar-hulp in plaaslike skole vanweë die verhoogde leerplig wat ingestel is; die oororganisasie van lewe en eindelose eise aan tyd en kragte wat van 'n klein groepie gewilliges geëis is; die gebrek aan entoesiasme vir 'n rustige en langtermyn onderneming wat hy toegeskryf het aan die neiging onder Afrikaners dat hul verbeelding deur 'n nuwe saak aangegryp word, maar dat die entoesiasme gou kwyn sodra die nuutheid verdwyn; onkunde by baie oor die groot werk wat die Helpmekaar verrig en die reusebehoefte en die "brandende volksnood" waarin dit gedeeltelik voorsien het; en laastens die gees van selfsug en materialisme waarin 'n groot deel van die volk verval het.

Daar is nie fout te vind met Beukes se ontleding nie, maar hy het nagelaat om die dieperliggende ideologiese verskuiwing, waarvan die verskynsel en al sy redes 'n simptoom was, te verwoord. Dit was dat etniese mobilisasie in die vorm van Afrikaner-nasionalisme toenemend sy greep op Afrikaners begin verloor het soos hulle ekonomiese posisie deur die loop van die vyftiger- en sestigerjare verbeter het. Afrikaners se motivering en behoefte om etnies gemobiliseer te word, het dus toenemend stoom verloor. In Helpmekaar-terme was die kwynende takstelsel hiervan 'n simptoon - 'n simptoon wat nie deur inisiatiewe en oproepe, wat steeds grootliks op etniese sentimente gesteun het, met sukses reggestel kon word nie.

Beukes het sy pleidooie vir verandering gebaseer op die groot taak en behoefte wat daar steeds vir Helpmekaar-hulp bestaan het en het veral 'n drieledige taak vir die Helpmekaar in dié verband voorsien. Die Helpmekaar moes die breinkrag van die Afrikanerjeug vir die Afrikanervolk behou deur sy fondse so uit te brei dat ook voldoen kon word aan die versoeke om studiehulp wat jaarliks deur die Helpmekaar weggewys moes word weens 'n gebrek aan fondse. Hy het in dié verband na die gebrek aan Afrikaansbeheerde studiefondse verwys. Na 'n opname het dit getoon dat daar slegs ses bestaan het met beheer oor ongeveer $£ 250000$ teenoor

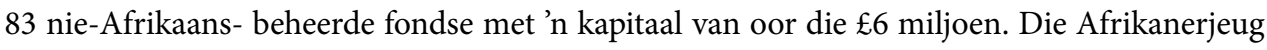
wat nie deur die Helpmekaar gehelp kon word nie het die gevaar geloop om weggelok te word tot "inrigtinge en ... invloede waar die positiewe Afrikanerskap omvorm kon word tot draers en propageerders van nie-Afrikaanse ideologieë", 'n geval van "Wiens brood men eet, diens woord men spreek". ${ }^{261}$ 
'n Tweede taak van die Helpmekaar was om die impak van die tradisionele ekonomiese agterstande van Afrikaners en die invloed wat dit op die maksimale ontwikkeling van die Afrikanerjeug se potensiaal gehad het, teen te werk en te verbreek. Weens die verhoogde skoolleerplig en die staat se voorsiening in dié verband het die primêre fokus van die Helpmekaar na "Hoëre Onderwys" verskuif. Die behoefte na gekwalifiseerde mense in die Suid-Afrikaanse ekonomie was groot en die Afrikanerjeug het oor die potensiaal beskik, maar omdat Afrikaners oor die algemeen die laer inkomstegroepe verteenwoordig het, was hulle nie in staat om hul kinders die beste moontlike opleiding te gee sodat hulle die hoogste sport kon bereik nie. Die Helpmekaar moes 'n bydrae lewer om die bose kringloop te verbreek.

Die derde taak vir die Helpmekaar was om die huidige geslag Afrikaners te oortuig dat hulle soos vorige geslagte 'n offer sou moes bring om die volk te laat groei en voortbestaan. Beukes het die "offer" vir die huidige geslag beskou as die bereidwilligheid "om 'n deel van die finansiële welvaart waarmee baie van ons tans begunstig is, te belê in die breinkrag van ons jeug"..62

Die drieledige taak van die Helpmekaar kon volgens Beukes slegs met die nodige fondse verrig word en daarom was dit die sleutel tot sukses dat elke "Helpmekaarvriend, dit wil sê, elkeen wat opreg belangstel in die toekoms van sy eie volk en sy eie kinders"263 hom vereenselwig met en die planne wat die hoofbestuur steun om die nodige fondse te bekom deur hul persoonlike en plaaslike netwerke te ontgin. As potensiële bronne van inkomste het hy die Kerk - as elk van ongeveer 300 gemeentes van die Kaapse Kerk alleen elk $£ 10$ per jaar insamel, sou dit oor 12 jaar meer as $£ 36000$ bydra -, lewenslange lede en die werwing van donasies en bemakings geïdentifiseer.

Die huidige takstelsel het volgens Beukes egter uitgedien geraak as voertuig vir die generering van fondse vir die Helpmekaar en die stryd om hulle aan die gang te hou het eerder gedemoraliseer as geïnspireer. Hy was oortuig dat daar 'n groot mate van eenstemmigheid was hieroor en dat die kwessie eerder was of dit moontlik was om iets beters in die plek van die takstelsel te stel. Teen dié agtergrond het Beukes 'n aantal tentatiewe gedagtes oor 'n moontlike alternatief aan die kongres voorgehou met die versoek dat, indien hulle meriete daarin sien, dit na die hoofbestuur vir finale verslag en aanbevelings aan die volgende kongres verwys moes word. Beukes se voorstelle het gebou op die Sinclair/Victoria-Wes-voorstelle van 1951. Takke wat verkies het om onder die huidige voorwaardes voort te bestaan sou toegelaat word om dit te doen, maar die kongres as finale beleidsliggaam sou afgeskaf word.

262 (HSA) HVKP, Notuleboek, 4-5 Apr 1956, Kongres, Voorsittersrede, 6-8.

263 (HSA) HVKP, Notuleboek, 4-5 Apr 1956, Kongres, Voorsittersrede, 7. 
'n Helpmekaarkomitee, bestaande uit minstens 'n Afrikaanse predikant, 'n skoolhoof en 'n verteenwoordiger van 'n skoolraad of, waar daar geen skoolraad was nie, 'n skoolkomitee, moes in elke dorp en stad in Kaapland gestig word. Die kongres sou vervang word deur 'n hoofbestuur wat die Helpmekaar se belange sou behartig. Die hoofbestuur sou bestaan uit ongeveer 8 verteenwoordigers van die Helpmekaarkomitees en -takke, sover moontlik verteenwoordigend van alle streke van Kaapland, en een verteenwoordiger van elk van die Suid-Afrikaanse Onderwys Unie (SAOU), die Sinodale Opvoedingskommissie van die NG Kerk, die Minister van Onderwys en die RDB-studiefondskomitee. Alle aansoeke vir studielenings sou deur die takke of komitees na die hoofbestuur gaan. Die hoofbestuur sou dit konsekwent as beleid volg dat die totale som van die toekennings aan nuwe applikante van 'n komitee nooit die totale som van die geld wat deur die bemiddeling van daardie komitee tot die fondse van die Helpmekaar bygedra is, oorskry nie. (Kollektes van die kerkrade, lewenslange ledegeld en so meer kon op die rekening van die komitees kom, maar nie die insamelings deur die fondsorganiseerders nie).

Wat betref die toekenning van hernude aansoeke sou dit gedek word uit die ander inkomstes van die Helpmekaar soos rente en die terugbetaling van studielenings. Beukes was van mening dat so 'n reëling die komitees sou prikkel om voortdurend te werk, wat 'n vinnige toevloei van kapitaal na die Helpmekaar sou bewerkstellig. ${ }^{264}$ Die hele verandering van struktuur was dus daarop gemik om 'n stroom nuwe kapitaal na die Helpmekaar te kanaliseer om sodoende sy fondse aan te vul sodat hulle meer effektief in die behoeftes na studielenings kon voorsien. Vir die toekennings van enige nuwe lenings sou dit dus 'n plaaslike teenprestasie vereis wat beteken dat plaaslike gemeenskappe dus eintlik self hul nuwe leningsapplikante moes finansier. Die stap was noodsaaklik om toegang tot die ou Helpmekaar-kapitaal te verkry aangesien hernude aansoeke daaruit gefinansier sou word. Op Sinclair se voorstel het die kongres besluit om Beukes se voorstelle na die hoofbestuur te verwys "om te kyk of daar nie iets goeds uit gebore kan word nie" met die versoek om aanbevelings aan die volgende kongres te maak. ${ }^{265}$

Die voorstelle vir die reorganisasie van die Helpmekaar het op die 1957-kongres op George gedien en die voorsitter het sy voorsittersrede gebruik om die hele kwessie uiteen te sit. Hy het hoofsaaklik drie redes vir die reorganisasie aangevoer. Eerstens het die kwynende toestand van die takstelsel dit vereis, aangesien die gebrek aan plaaslike ondersteuning $\mathrm{n}$ demoraliserende uitwerking op die Helpmekaar gehad het en ook die indruk gewek het dat daar nie meer 'n

264 (HSA) HVKP, Notuleboek, 4-5 Apr 1956, Kongres, Voorsittersrede, 6-8.

265 (HSA) HVKP, Notuleboek, 4-5 Apr 1956, Kongres, 8. 
behoefte vir die organisasie bestaan het nie. Tweedens het die beperkte geografiese reikwydte van die takstelsel 'n nuwe struktuur genoodsaak. Beukes het daarop gewys dat, terwyl daar net 41 Helpmekaartakke in die Kaapprovinsie bestaan het, daar 320 NG Kerk-gemeentes was, wat 'n aanduiding was van die groot persentasie van die Afrikanerjeug wat van Helpmekaarhulp uitgesluit was. Derdens het die betreklike stadige aanwas van die Helpmekaar se fondse ook'n nuwe stelsel genoodsaak.

Die geleidelik groei in Helpmekaar-kapitaal die afgelope veertig jaar was volgens hom eerder die gevolg van die versigtige bestuur en beheer van die fondse as deur die fondse wat van die takke na die sentrale kas gevloei het. Baie van die takke was eerder 'n las as 'n bate vir die Hooffonds, aangesien hul meer onttrek het as wat hulle bygedra het. Die Helpmekaar het 'n kragtige uitbou van sy fondse dringend benodig om aan die aansoeke om hulp te voldoen. Hierdie aansoeke sou nog meer raak as die Helpmekaar deur sy reorganisasie, sy net nog wyer sou span. 'n Stelsel wat dus die kapitaal kon versterk, moes verwelkom word.

Hierna het Beukes die veranderde organisasie verduidelik wat met enkele uitsonderings met sy 1956-voorstelle ooreengestem het en vir 'n stelsel van plaaslike Helpmekaar-komitees voorsiening gemaak het. Die argument was dat, terwyl dit moeilik sou wees om in elke gemeenskap genoeg mense te kry om 'n Helpmekaar-tak te vorm, dit met weinig uitsonderings moontlik behoort te wees om so 'n kerngroep bymekaar te kry wat die opvoeding van hul plaaslike kinders op die hart sou dra en bereid sou wees om iets daarvoor te doen. Die Helpmekaar-komitees sou 'n tweeledige funksie vervul. Eerstens, sou die komitees fondse vir alle nuwe lenings aan studente uit hulle omgewing moes genereer. Tweedens moes die komitees die aansoeke om lenings van studente uit hul eie gebied nagaan, rangskik en met aanbevelings aan die hoofbestuur vir verdere oorweging stuur. Beukes het gemaan dat daar nie onmiddellik aangeneem moes word dat die voorstel prakties onuitvoerbaar sou wees omdat komitees nie genoeg fondse plaaslik sou kon genereer vir eerstejaarlenings nie. Met die nodige propaganda en indien die inligting op die regte wyse aangebied word, behoort "elke wakker komitee wat die sakk op sy hart dra"266 die nodige fondse te vind.

Anders as met sy 1956-voorstelle sou die kongres behou word om die organisasie en ander werksaamhede van die Vereniging te bespreek, maar veral om 'n gesag te hê waaraan die hoofbestuur vir die uitvoering van sy pligte en die administrasie van die fondse verantwoording sou moes doen. Die gewone kongresse sou egter slegs elke vier jaar gehou word en bestaan uit afgevaardigdes van die takke en komitees. Die hoofbestuur sou bestaan uit ses lede wat deur die kongres verkies word, plus een verteenwoordiger elk van die NG Kerk in SA, die 


\section{Die Kaapse Helpmekaar}

Gereformeerde Kerk, die hoofbesture van die SAOU en die ACVV. Die hoofbestuur sou dus hoogstens uit tien persone bestaan plus twee persone wat gekoöpteer kon word indien die hoofbestuur dit sou verkies. Hierdie voorsiening is gemaak om die hoofbestuur in staat te stel om die waardevolle en selfs onontbeerlike dienste te verkry of te behou van 'n persoon wat nie deur verkiesing of afvaardiging reeds in die hoofbestuur dien nie.

Beukes het ook 'n verwagte sestal voordele wat die reorganisasie vir die Helpmekaar sou kon inhou, uitgespel. Die paar getroue Helpmekaar-ondersteuners in elke gemeenskap se energie sou nou eerder op fondswerwing as op die kunsmatige instandhouding van 'n tak gefokus kon word. Die groter geografiese reikwydte wat die nuwe stelsel sou meebring, sou die poel verdienstelike hulpbehoewende studente wat bereik kon word baie vergroot. Die nuwe stelsel sou ook die potensiële kapitaalbronne van die Helpmekaar uitbrei. Die verwagting was dat die persoonlike en plaaslike kleur wat die komiteestelsel aan fondsinsameling sou verleen as prikkel sou dien vir plaaslike gemeenskappe om fondse in te samel. Geld sou ingesamel kon word vir spesifieke verdienstelike plaaslike studente en nie meer vir 'n verdienstelike maar veraf Kaaps-gebaseerde fonds waarmee die plaaslike gemeenskap min kontak gehad het nie. Fondse sou dus nou tot voordeel van die plaaslike gemeenskap ingesamel word. Skenkers en Helpmekaar-werkers sou die vrug van hul arbeid kon sien en ervaar dat dit nie tevergeefs was nie.

Die potensiële kapitaalbronne sou almal getap kon word op die beginsel dat die fondse in die eerste instansie in belang van die plaaslike gemeenskap aangewend word. Die nuwe stelsel het 'n baie groter potensiaal gehad vir die toevloei van nuwe kapitaal na die Helpmekaar. Hy het beklemtoon dat, hoewel die Helpmekaar nie wou ryk word nie, hulle darem kapitaalkragtig genoeg wou word om min of meer in die groot behoefte aan studiehulp wat deur "baie van ons Afrikaanse seuns en dogters ondervind word" te kan voorsien. Hy het weer die enorme agterstand "van die Studiefondse vir die Afrikaner in vergelyking met dié van andere"267 beklemtoon. As voorbeeld het Beukes as mikpunt gestel dat indien 200 sulke komitees in Kaapland gestig kon word en elkeen jaarliks $\mathfrak{E 5 0}$ vir die ondersteuning van plaaslike behoeftige studente bymekaar kon maak dit 'n vermeerdering in kapitaal van $£ 10000$ per jaar vir die Helpmekaar kon beteken.

Dit sou groot potensiaal inhou vir die Helpmekaar indien dit vir die volgende 40 jaar volgehou kon word. Die komiteestelsel het ook die moontlikheid van groter samewerking met erkende en gevestigde organisasies met soortgelyke belang in die onderwys en opvoeding ingehou. Hy het hier spesifiek die Kerk, SAOU, en die ACVV uitgesonder. In die lig van die feit dat 
die Helpmekaar hom nou al vir 'n aantal jare uitsluitlik op die onderwys toegespits het, was dit vir hom vreemd dat die Helpmekaar tot dusver sy werk in soveel afsondering en met min kontak met dié organisasies gedoen het. Afgesien van die potensiële nuwe kapitaalbronne wat die nuwe stelsel kon ontsluit, was dit ook 'n goedkoper stelsel as die tak- en kongresstelsel, omdat die vierjaarlikse kongresse 75 persent van kostes van jaarlikse kongresse sou uitskakel. 'n Kongres het die Helpmekaar ongeveer $£ 400$ gekos. Deur dus slegs elke vier jaar 'n kongres te hou sou die Helpmekaar met sy huidige organisasie jaarliks $£ 300$ bespaar. ${ }^{268}$

Uit die bespreking van die konsep-grondwet wat op Beukes se voordrag gevolg het, was dit duidelik dat die kloof tussen die hoofbestuur/hoofkantoor en die plaaslike takke oor die nuwe stelsel nog nie oorbrug was nie en die versoek dat die grondwet deur die 1957-kongres goedgekeur moes word nie sou realiseer nie. Benewens talle besware van die Wellington- en Wynbergtakke het die PE-Noord-/Sydenham- en Uitenhage-takke dit veral teen die bepaling gehad dat takke die koste van die eerstejaarstudie van studente sou moes bybring voordat hulle vir die res van die studietermyn tot Helpmekaar-fondse sou toegang verkry. Hulle argument was dat hulle arm gemeenskappe verteenwoordig het wat moeilik die teenprestasie sou kon bybring. Hoewel die kongres bereid was om die beginsel van die voorgestelde reorganisasie goed te keur, het hulle 'n aantal wenke aan die hand gedoen en die hoofbestuur opgedra om die nuwe konsep aan takke uit te stuur vir hulle kommentaar. Die hoofbestuur sou 'n finale konsep by die volgende kongres voorlê vir goedkeuring. Die wenke was hoofsaaklik daarop gerig om te verseker dat takke wat armer gemeenskappe verteenwoordig het nie deur die nuwe stelsel benadeel word nie. ${ }^{269}$ Takbesware het dus die afskeid van die takstelsel met 'n verdere jaar uitgestel. Hoewel die bepaling van 'n teenprestasie in die eerste jaar van studie waarskynlik nie so bedoel was nie het dit 'n klassekleur getoon wat 'n onbedoelde demonstrasie gelewer het van die klasseverdelings in Afrikanergeledere. Dit het uiteindelik ook in die daaropvolgende dekades die opbreking van die Afrikaner- politieke monoliet ten grondslag gelê.

$\mathrm{Na}$ 'n langdurige bespreking en oorweging van al die takke se besware en wenke tydens die Desember 1957-vergadering van die hoofbestuur is besluit om met die beoogde reorganisasie voort te gaan. Die vergadering het ook besluit om af te sien van die plan dat takke die bedrag van nuwe aansoeke in die eerste jaar in die sentrale kas moes stort. In stede daarvan is besluit dat takke 'n minimum bedrag in die sentrale kas moes stort om hul aansoeke te laat kwalifiseer vir oorweging. Herbesinning oor die praktiese funksionering en samestelling

268 (HSA) HVKP, Notuleboek, 2-3 Apr 1957, Kongres, Voorsittersrede, 1-3.

269 (HSA) HVKP, Notuleboek, 2-3 Apr 1957, Kongres, 3-4. 


\section{Die Kaapse Helpmekaar}

van die komitees, hoofbestuur en kongres, asook die bestaande subsidies aan takke, het ook groter duidelikheid ten opsigte van die aspekte gebring. Die hoofbestuur het aanbeveel dat die volgende besluite in dié verband in die nuwe konsep-grondwet vervat word. Eerstens, elke tak moes jaarliks 'n minimum bedrag van $£ 40$ in die sentrale kas stort om te verseker dat hul studieleningaansoeke oorweeg sal word. Tweedens, indien 'n tak meer as $£ 40$ in een jaar stort, sou daardie gedeelte wat die $£ 40$ oorskry tot sy krediet gehou word om 'n latere storting van minder as $£ 40$ aan te vul tot die vereiste $£ 40$. Derdens, Helpmekaar-lidmaatskap sou as 'n kwalifikasie vir aansoekers wegval. Laastens, omdat takke in alle waarskynlikheid voortaan heelwat minder geld aan die Helpmekaar as bydraes sou stuur, sou alle geld wat deur fondsorganiseerders geïn word uitsluitlik na die B-fonds (sedert 1956 bekend as die Helpmekaar Studiefonds) gaan. Aansoeke om studiehulp van lewenslange lede of hulle kinders sou gelyke behandeling geniet saam met dié wat deur takke aanbeveel word. Vir die samestelling van die hoofbestuur is die provinsie in minstens vyf en hoogstens tien sirkels verdeel, waaruit een hoofbestuurslid per sirkel gekies sou word. Uit hierdie gekose lede sou 'n voorsitter en ondervoorsitter deur die kongres, wat elke twee jaar sou vergader, gekies word. Hierdie verkose lede sou die reg hê om nog lede te koöpteer in die verhouding van een gekoöpteerde lid vir elke drie verkose lede. ${ }^{270}$

By die 1958-kongres het die voorsitter die nuwe konsep-grondwet aan die lede vir goedkeuring voorgelê en veral twee voordele van die nuwe konsep uitgelig. Eerstens sou die storting van $£ 40$ per tak/komitee per jaar die Hooffonds voortaan van die gewenste groei verseker waarmee in toekomstige behoeftes voorsien sou kon word. Tweedens sou studente uit alle dele van Kaapland voortaan gehelp kon word en nie alleenlik diegene wat lede van die Helpmekaar is nie. Hoewel die jaarlikse skenking van $£ 40$ steeds vir sommige takke 'n probleem was en mnr Van Zyl van PE voorgestel het dat die bedrag na $£ 25$ verminder word, is 'n voorstel van Sinclair en sen Van Zyl, dat die konsep-grondwet in sy huidige vorm aanvaar word, deur die kongres goedgekeur. As toegewing is besluit dat weens die kort tyd wat daar oor was vir takke om die $£ 40$ bymekaar te kry die bepaling van die $£ 40$-storting eers vanaf 1 Januarie 1959 van krag sou wees. Volgens die nuwe grondwet sou slegs bestaande takke die reg hê op die $£ 20$-subsidie vir behoeftige leerlinge terwyl die $£ 5$-subsidie vir skoolbiblioteke geskrap is. Binne elke gemeente kon nou 'n komitee gestig word en bestaande takke kon omskep word in komitees maar geen nuwe takke kon gestig word nie. ${ }^{271}$

270 (HSA) HVKP, Notuleboek (8 Feb 1940-9 Des 1966), 12-13 Des 1957, Hoofbestuur, 498-499; 11 Jul 1958, 506; (HSA) HVKP, Notuleboek, 11 Jul 1958, Kongres, Hoofbestuur verslag, 1.

271 (HSA) HVKP, Notuleboek, 11 Jul 1958, Kongres, 5-6. 
Adv HS van Zyl se 1920 mantra, naamlik dat dit nie soseer die werk van die kongres en sentrale bestuur was wat die Helpmekaar 'n krag in die land maak nie, maar dat dit veral die werk van die takke was wat die Helpmekaar maak wat hy is, is hiermee'n nekslag toegedien wat die weg vir die uiteindelike finale afskaffing van die kongresstelsel voorberei het.

\section{DIE KA SINCLAIR-SESTIGERJARE: AFSKAFFING VAN DIE KONGRES- EN TAK / KOMITEESTELSEL}

Met die vertrek van die voorsitter, ds DPM Beukes, na die Transvaal in 1961 is dit aan die "siener" van Victoria-Wes, KA Sinclair, oorgelaat om as voorsitter die skrif wat hy reeds 'n dekade vroeër aan die muur gelees het, vir die Helpmekaar aan die verstand te bring. Dié, vir die Helpmekaar "rewolusionêre", voorstelle wat hy in 1951 voorgestel het, was nou 'n dekade later steeds op die tafel teen die agtergrond van 'n veel meer rewolusionêre nasionale milieu wat gekenmerk is deur die Sharpeville-krisis, die verbanning van die ANC en PAC en die begin van hul gewapende weerstand. Dit is geïntensifiseer deur die aanslag op Verwoerd se lewe, republiekwording en Suid-Afrika se uittrede uit die Britse Statebond en die ekonomiese krisis waarmee die gebeure gepaardgegaan het. Terwyl Afrikaners op hul tradisionele laertrekmentaliteit teruggeval het, is die laer se hekke toenemend oopgestel vir ander witmense soos Engelssprekendes wat hulle daarin tuisgevoel het. ${ }^{272} \mathrm{Op}$ 'n soortgelyke wyse sou dit Sinclair beskore wees om die veranderinge deur te voer wat die Helpmekaarlaer se hekke sou oopgooi vir nie-Helpmekaar Afrikaners om by die Helpmekaar-trog te kom drink.

Die idee van 'n komiteestelsel om die probleme en tekortkominge van die takstelsel te ondervang, het in teorie na 'n goeie werkbare alternatief gelyk. Dit het egter spoedig geblyk dat dit twee kante van dieselfde munt was. Op die Desember 1958-vergadering is op voorstel van Sinclair besluit dat hoofbestuurslede op hulle buurdorpe komitees sou gaan stig, maar dat voorlopig nie meer as drie komitees in 1959 deur elkeen van hulle gestig sou word nie en dat die fondswerwer, HD Roux, versoek sou word om na raadpleging met die hoofkantoor ook komitees te stig. Waar hy in die buurt van 'n hoofbestuurslid kom, moes hy egter eers oorleg pleeg met die lid. ${ }^{273}$

Teen April 1961 was dit duidelik dat die $£ 40$-kwota wat takke/komitee jaarliks in die Hooffonds moes stort weens die beperkte aantal takke/komitees nie aan die verwagtinge as 'n bron van nuwe fondse vir die Helpmekaar voldoen het nie. Aangesien die aannames oor die potensiaal

272 H Giliomee, Die laaste Afrikaner-leiers. ' $n$ Opperste toets van mag, 74-76, Tafelberg, Kaapstad, 2012.

273 (HSA) HVKP, Notuleboek (8 Feb 1940-9 Des 1966), 18 Des 1958, Hoofbestuur, 517. 
van die stelsel gebaseer was op 'n groot toename in komitees het die beperkte aantal komitees wat sedert die implementering van die stelsel gestig is die Helpmekaar met 'n tekort aan fondse gelaat. Die probleem was deels toe te skryf aan die onvermoë van die hoofbestuurslede om 'n groot genoeg area vir die stigting van nuwe komitees te bearbei. Die hoofbestuur het egter besluit dat sy lede sou voortgaan om soveel komitees te stig as wat hulle kon en dat nog fondsorganiseerders ook gesoek sou word. ${ }^{274}$ Op die 1961-kongres het bogenoemde saak oor fondswerwing verder aan die orde gekom en voorstelle soos die gebruik van bankaftrekorders en die meer effektiewe gebruikmaking van besighede as skenkers is as wenke vir die takke/ komitees aan die hand gedoen. ${ }^{275}$

Die lakmoestoets vir die stelsel van komitees was egter die landswye fondsinsamelingspoging wat in 1963 deur die Helpmekaar van stapel gestuur is en waarin swaar gesteun is op plaaslike ad hoc-komitees om geld vir die Helpmekaar in te samel. Baie van die komitees kon egter nie op dreef kom nie en by baie was daar ook 'n gebrek aan ywer wat bygedra het daartoe dat die mikpunte van die veldtog nie bereik is nie. Die hoofbestuursverslag aan die 1964-kongres het ook bevestig dat die probleem met die ou takstelsel onder die komiteestelsel voortgeduur en selfs vererger het. Tussen die 1961- en 1964-kongresse is vyf nuwe komitees gestig met 'n verdere drie wat oorweging daaraan geskenk het. Ongelukkig in dieselfde periode het nege takke ontbind terwyl die hoofbestuur se ou klagtes oor die traagheid van takke en komitees om te reageer op versoeke vir verslae en beskrywingspunte voortgeduur het. Die hoofbestuursverslag het dus tot die gevolgtrekking gekom dat "Die hele saak van die voortbestaan van die Helpmekaarkomitees in hulle huidige gedaante en werking kom in die gedrang, en die kongres sal moet aandag gee daaraan." ${ }^{276}$

Die voorsitter, KA Sinclair, het die agteruitgang bevestig toe hy tydens die opening van die kongres verwys het na die komiteestelsel wat in beginsel goed is, maar soos deur die insamelingsveldtog bewys is, in die praktyk nie doeltreffend gewerk het nie. Die swak bywoning van die kongres - slegs 15 afgevaardigdes - het ook vir hom gedui op 'n kwynende belangstelling in die werksaamhede van die beheerliggaam van die Helpmekaar wat die hoofbestuur se bedenkinge oor die raadsaamheid om die kongres as beheerliggaam te behou bevestig het. Hy het aangedui dat die afgevaardigdes oor die voortbestaan van die kongres en komiteestelsel sou moes besin. ${ }^{277}$ 
Die Villiersdorp-tak se beskrywingspunte by die 1964-kongres het twee belangrike aspekte, waarvan een Sinclair se voorstel geïnkorporeer het, aangespreek. Eerstens dat die kongres die verpligte jaarlikse bydraes van takke en komitees om te kwalifiseer vir geldelike hulp uit die Hooffonds vir lenings aan hulpbehoewende studente skrap en tweedens dat die kongres die voortbestaan van die takke en komiteestelsel moes bespreek. Ten opsigte van die eerste aspek het Jamneck van Villiersdorp geargumenteer dat die insamelingsveldtog bydraes uit alle oorde gelok het, wat dit onwenslik gemaak het om voortaan die verpligte bydrae van $£ 40$ (R80 sedert desimalisasie in 1961) van 'n tak te verwag. Hy het ook geargumenteer dat die stigting van komitees oral op die platteland ook nie verloop het soos verwag was nie en dat dit onwaarskynlik was dat die plan van 'n groot aantal komitees ooit sou realiseer.

In 'n bespreking van die hele kwessie van die voortbestaan van die tak/komiteestelsel en die kongres is verskeie perspektiewe gestel. Senator Van Zyl het aangedui dat nie alleen takke nie, maar bykans elke distrik toe reeds tot die Helpmekaar-fondse bygedra het. Alle distrikte en streke het dus toe al hul deel gedoen om die Helpmekaar te versterk en almal se kinders het op grond daarvan dus toe vir Helpmekaar-hulp gekwalifiseer. Hy was van mening dat die takke/komitees wat dit so verkies het, toegelaat moes word om voort te bestaan en dat op ander dorpe die skoolkomitee of 'n komitee bestaande uit die leraar en skoolhoof die werk van die Helpmekaar-komitee moes doen. Mnr JA van Zyl het die gedagte ondersteun op voorwaarde dat daar een of ander komitee op elke plek moes wees wat die aanbevelings en plaaslike ondersoeke vir leningsaansoeke kon doen.

Hy was ook van mening dat die kongres moes wegval en dat die hoofbestuur die magte en funksies van die kongres moes oorneem, - 'n standpunt wat ook deur sen Van Zyl ondersteun is. Laasgenoemde het die standpunt onderstreep deur te verwys na die karige aantal afgevaardigdes wat die kongres bygewoon het en die gevaar wat dit geskep het dat 'n kworum nie bereik kon word nie en dat die Helpmekaar dan sonder 'n beheerliggaam gestrand sou wees. Die kongres het dus na aanleiding van die bespreking besluit dat die hoofbestuur 'n beredeneerde formule oor die konstitusionele funksionering van die Helpmekaar sou opstel wat na die takke en komitees vir kommentaar gestuur moes word met die pertinente vraag of hulle as tak wou voortgaan en of hulle die kongres as beheerliggaam wou behou. Hierdie kommentaar sou dan deur die hoofbestuur in 'n konsep-grondwet vervat word wat na die takke/komitees vir bespreking op 'n spesiale kongres in 1965 gestuur sou word. ${ }^{278}$

Met die 1965-kongres was dit duidelik dat die gees van Helpmekaar-hulp nog steeds sterk geanker was in die strewe om die belange van die volk te dien en dus in diens van Afrikaner-

278 (HAS) HVKP, Notuleboek, 1 Apr 1964, Kongres, gp. 


\section{Die Kaapse Helpmekaar}

nasionalisme gestaan het met die bemagtiging deur kennis as deel van die wapenrusting wat die volk moes pantser teen die vele aanslae. Willem Delport, NP LPR en voorsitter van die PE Helpmekaar tak en Opvoedingsfonds, se welkomswoord tydens die laaste kongres van die Helpmekaar in 1965 het die sentimente geadem:

"Hy bring hulde aan die Helpmekaar, en sê dat geen jongmens uitgesluit mag word van die geleentheid om te studeer as hy wil nie. Ons sien die ontwaking van die swart nasionalisme. Ons beleef die verydeling van strewes wat mooi en edel is, ook in ons eie volk. Daar is geen beter wapen in die hand van ons jeug as kennis nie. Hulle moet ons volk se siel en karakter daarmee beskerm. Sy bede en geloof is dat daar geseënde samesprekings sal wees en dat hierdie mooi volksbesit en magtige wapen sal uitgebou en verstewig word."279

Die 1965-kongres is hoofsaaklik gewy aan die opdrag wat tydens die vorige kongres aan die hoofbestuur gegee is, naamlik om die gevoel van die takke en komitees oor die afskaffing van die kongresstelsel te toets en voorstelle vir 'n konsep-grondwet aan die kongres voor te lê. Van die 47 takke het net 11 op die versoek geantwoord. Sewe was ten gunste van die oordrag van beheer na die hoofbestuur, drie was daarteen en een was onseker. Sinclair het aangedui dat die hoofbestuur na aanleiding van die reaksie weer oor die aangeleentheid besin het en tot die gevolgtrekking gekom het dat die voorstelle soos in die konsep-grondwet vervat die beste opsie was. Sen Van Zyl het die voorsitter ondersteun deur te benadruk hoe die kantoor gesukkel het om inligting uit die takke te kry en hulle feitlik moes soebat om afgevaardigdes na die kongres te stuur.

Verskeie menings is vervolgens oor die nuwe grondwet gelug. Oos-Londen was sterk ten gunste van die oordrag van gesag na die hoofbestuur. RA van Rensburg, 'n lid van die hoofbestuur, het die proses van agteruitgang as volg verklaar:

"die Provinsiale Administrasie het sommige van die vroeëre funksies van die Helpmekaar oorgeneem soos bv. Vrye onderwys en boeke. Ons kan en moet ons derhalwe nou toespits op ons belangrikste en eerste doelstelling, naamlik naskoolse studiefinansiering. Waar ons tot dusver gekom het, was grootliks met behulp van die takke, maar soos die takke se funksies minder geword het, het hul belangstelling verflou. Ons is dankbaar vir wat die takke gedoen het om die Helpmekaar te bring waar hy nou staan, maar daar is nou geen ander uitweg dan om te doen wat vervat is in die konsep-konstitusie nie."280 
CP Jamneck het aangedui dat die Villiersdorp-tak sterk ten gunste van die behoud van die takstelsel en kongres was, maar dat hulle teen onomstootlike feite te staan gekom het en dat daar geen ander uitweg was nie. Volgens hom sou takke in elk geval nog kon voortgaan om plaaslike belange te behartig. Hubert van der Spuy van Uniondale het ook aangedui dat sy tak teen die veranderinge gekant was, maar dat die verduideliking hom anders oortuig het. Die beginsel van oordrag is hierna deur die kongres goedgekeur en die konsep-grondwet is met enkele wysigings aanvaar. In sy bedankingswoord het die voorsitter, KA Sinclair, die kongres bedank vir die eensgesindheid waarmee hulle die "delikate en amper rewolusionêre besluit" deurgevoer het waarna GJB Volschenk, visevoorsitter, Sinclair vir sy versiendheid bedank het en die kongres afgesluit het met 'n gebed en die perspektief dat:

"Vandag is nie die einde van die Helpmekaar nie. Dis die laaste paragraaf in 'n eervolle hoofstuk en die begin van 'n nuwe hoofstuk en vrugbare tydperk."281

Hiermee is HS van Zij se mantra oor Helpmekaar-takke finaal ter ruste gelê. 


\section{HOOFSTUK VIER}

\section{DIE HELPMEKAAR EN ONDERWYS: LEES, SKRYF EN REKEN}

“... groot getalle kinders van skoolgaande ouderdom loop verwaarloos rond”."

"Helpmekaar help in hierdie groot werk. Wyse om dit te doen: Swaeltjies Helpmekaar. Daarom kragte verenig, geledere sluit, saamstaan en saamwerk vir die opvoed en geestelike welsyn van die Afrikaner Kind - die volk van more! U werk sal nie verniet wees!”2

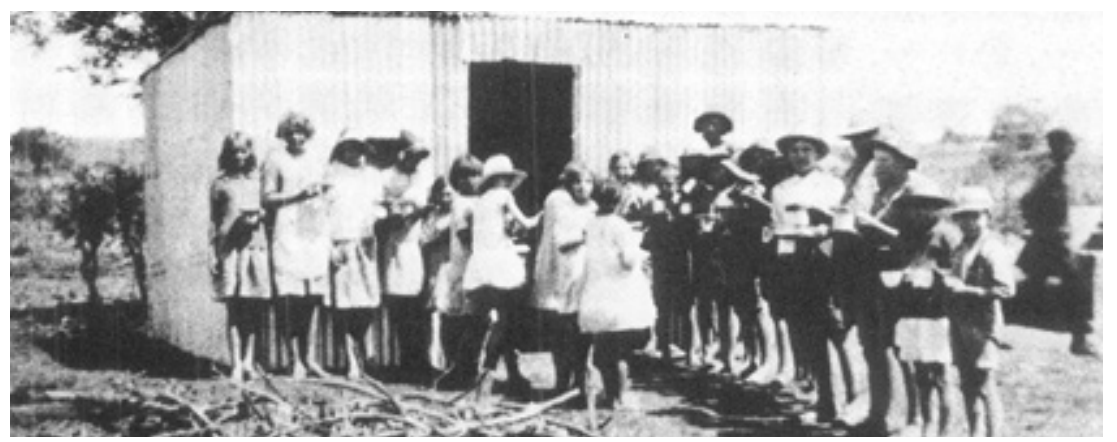

Armblankeskoolkinders by 'n skool sopkombuis

Die behoefte aan finansiële steun vir opvoedkundige doeleindes op primêre en sekondêre vlak het vroeg reeds in die geskiedenis van die Helpmekaar na vore gekom. Terwyl die Helpmekaar nog gewikkel was in die stryd om die rebelleskuld te vereffen, is in September 1916 'n versoek van die Riebeeck-Oos-tak ontvang vir finansiële ondersteuning vir die plaaslike skool. Die sentrale bestuur het geantwoord dat "hen voor eerst geen hulp kan geven" nie, en hulle na die ACVV verwys. ${ }^{3}$ In die lig van die groeiende aantal versoeke vir ondersteuning vir leerders in die primêre en sekondêre skoolfases was dit noodsaaklik dat die Helpmekaar sy strategie en strukture in dié verband formaliseer.

1 (HSA) HVKP, Notuleboek, 15-17 Apr 1924, Kongres, Voorsittersrede, 3.

2 (Beyers Naude Sentrum vir Openbare Teologie, Universiteit Stellenbosch), Beyers Naude Versameling, Afrikanerdag toespraak deur Beyers Naude, 19 November 1942.

3 (HSA) HVKP, Notuleboek (3 Jul 1916-20 Mei 1919), 2 Sep 1916, Sentrale Komitee, 13. 


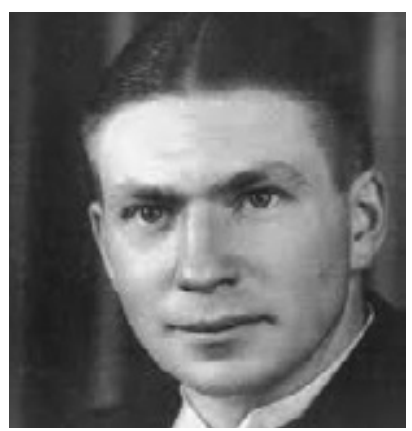

Beyers Naude het in 1942 'n kragtige oproep vir die opvoeding van die Afrikaner kind gelewer en na die Helpmekaar (wat hy as swaeltjies getipeer het) se belangrike bydrae in die verband verwys
Die doel van die afdeling is om 'n oorsig te gee van die Helpmekaar-betrokkenheid, rol en bydrae tot primêre en sekondêre onderwys en aanverwante aangeleenthede in die ongeveer halfeeu na sy stigting in 1916. Die betrokkenheid was van 'n tweeledige aard: eerstens finansiële ondersteuning wat hoofsaaklik deur die takstelsel gekanaliseer is en tweedens as pleitbesorger vir die belange van Afrikaner-skoolkinders in die Kaapprovinsie. As pleitbesorger het die Helpmekaar dikwels die klassieke rol van welsynsorganisasies gespeel deur 'n behoefte te identifiseer, eie bronne aan te wend om die behoefte aan te spreek en dan die regering te beweeg om uiteindelik verantwoordelikheid te aanvaar om in die behoefte te voorsien. Hierna is dan na 'n volgende saak aanbeweeg.

Dit het hoofsaaklik beslag gekry op kongresvlak in die vorm van resolusies wat aanvaar is en dan deur die sentrale bestuur uitgevoer is. Die fokus van hierdie betrokkenheid het Afrikanerbehoeftes in dié verband weerspieël en is gerig deur faktore soos die armblankevraagstuk, maar veral deur die onderwysbeleid en voorsiening van die Kaapse Provinsiale Administrasie en die Departement van Onderwys ten opsigte van veral verpligte en gratis skoolonderrig. 'n Kort oorsig oor die stand en ontwikkeling van veral laasgenoemde twee aspekte in die Kaapprovinsie is dus gepas as agtergrond.

Die uittreevlak vir verpligte skoolonderrig in die Kaapkolonie is deur die Skoolradewet van 1905 bepaal en vasgestel op standerd vier of die ouderdom van 14. In 1917 is dit verhoog na standerd vyf of die ouderdom van $15 .{ }^{4}$ Ordonnansie No 8 van 1919 het verpligte skoolonderrig aangekondig vir alle kinders wat binne drie myl van 'n openbare skool woon en wat sewe jaar of ouer was, ${ }^{5}$ met die boonste grens alle kinders onder die ouderdom van 16 jaar of wat nog nie standerd ses geslaag het nie. ${ }^{6}$ Vanaf 1950 is leerders verplig om skool by te woon tot na die aflegging van die standerd sewe eksamen. ${ }^{7}$ In 1952 is verpligte skoolonderrig uitgebrei

4 JT de Witt, dr WJ Viljoen as onderwyshoof van Kaapland 1918-1929, PhD, US, 1973, 188.

5 JT de Witt, dr WJ Viljoen as onderwyshoof ..., PhD, US, 1973, 184.

$6 \quad$ Ibid., 189-190.

$7 \quad$ PS du Toit, Onderwys in Kaapland, 1652-1975. 'n Oorsig, 116. 


\section{Die Kaapse Helpmekaar}

tot standerd agt of ouderdom 16. ' 'n Junior Sekondêre Fase (standerds ses, sewe en agt) is ingestel, wat die rol van standerd ses as 'n finale eksamen en 'n wettige uittreevlak, asook voorvereiste om die Senior Sekondêre Fase te betree, vervang het. ${ }^{9}$

Gratis skoolonderrig in die Kaapprovinsie het nie tred gehou met die uitbreiding van verpligte skoolonderrig nie. Volgens Ordonnansie No 27 van 1920 is gratis primêre skoolonderrig (tot standerd ses) vir alle rasse op 1 Julie 1920 in die Kaapprovinsie ingestel. ${ }^{10}$ Gedurende die 1920's het baie skoliere die skool na voltooiing van standerd ses verlaat om tot die arbeidsmark toe te tree ten einde 'n finansiële bydrae in gesinsverband te lewer vanweë die swak ekonomiese toestande.

Baie ouers was van mening dat standerd ses genoegsame opleiding vir hul kinders was, terwyl menige skolier die skool na standerd ses verlaat het omdat hulle wou ontsnap uit 'n skoolsisteem wat hulle nie gestimuleer het nie. Die probleem is vererger deur 'n arbeidsmark met 'n aanvraag na skoliere met standerd ses - veral in die Suid-Afrikaanse Spoorwegdiens. ${ }^{11}$ Om skoliere wat ver van skole gewoon het te help om skool te gaan, het die Kaapse Provinsiale Administrasie sedert $1921^{12}$ bystand verleen in die vorm van beurse vir kos, inwoning en 'n vervoersubsidie. Hulle het selfs skoliere wat nie meer skoolpligtig was nie op hierdie wyse ondersteun. Gedurende die 1923/24- finansiële jaar het die Onderwysdepartement R60 000 aan beurse vir losies en vervoer aan hoërskoolleerlinge uitbetaal. Gedurende 1923 is 1127 beurse vir losies aan junior sekondêre leerlinge (standerds sewe en agt) en 409 aan skoliere in standerds nege en tien toegeken (10.3 persent van die totale sekondêre skoolbevolking van die Kaapprovinsie het hierdie ondersteuning gedurende 1923 ontvang. $)^{13}$

Welsynsorganisasies - en ook die Helpmekaar - het gehelp om die tekort in hierdie kategorie aan te vul ${ }^{14}$ en het die baie plaaslike skoliere ondersteun wat behoeftig en verdienstelik was, maar nie vir staatsbeurse in aanmerking gekom het nie. Gratis verpligte skoolonderrig vir blanke kinders tot die ouderdom van 15 jaar, ongeag die standerd geslaag, is vanaf

8 CR Venter, Ontwikkelingsrigtings in die Onderwys van Kaapland hoofsaaklik met betrekking tot sekondêre onderwys 1930-1958, PhD, US, 1973, 70, 178.

9 CR Venter, Ontwikkelingsrigtings in die Onderwys ..., PhD, US, 1973, 178.

10 JT de Witt, dr WJ Viljoen as onderwyshoof ..., PhD, US, 1973, 210, 211.

11 Ibid., 194.

12 PS du Toit, Onderwys in Kaapland, 1652-1975. ' $n$ Oorsig, 102.

13 JT de Witt, dr WJ Viljoen as onderwyshoof ..., PhD, US, 1973, 204-205, 316.

14 Ibid., 206. 
1 Januarie 1931 met Ordonnansie No 17 van 1930 ingestel. ${ }^{15}$ Ongeag hierdie verlenging van gratis skoolonderrig tot 15 jaar oud was die Onderwysdepartement bereid om gratis skoolonderrig verder te verleng, onderworpe aan sekere voorwaardes (behoeftige en verdienstelike skoliere wat nie meer skoolpligtig was nie kon ondersteun word op voorwaarde dat die vrystellings nie 30 persent van die skoolgeld wat deur die skool betaal moes word, oorskry het nie). Weens die hoë koste van handboeke en ander noodsaaklikhede soos kos en verblyf was dit steeds vir menige kinders finansieel onmoontlik om sekondêre skoolonderrig te ontvang. ${ }^{16}$ Ordonnansie 31 van 1948 het gratis skoolonderrig uitgebrei tot standerd tien of 19 jaar oud. ${ }^{17}$ Vanaf 1 Januarie 1969 is gratis handboeke en ander noodsaaklikhede in die Kaapprovinsie verskaf. ${ }^{18}$

Die Helpmekaar-betrokkenheid in primêre en sekondêre opvoeding het mettertyd ontwikkel in tandem met die uitbreiding van staatsbetrokkenheid en verantwoordelikheid in verpligte en gratis primêre en sekondêre skoolonderrig soos hierbo aangedui. Afgesien van die eksterne milieu wat die Helpmekaar se betrokkenheid beïnvloed het, het die interne Helpmekaardinamika ook'n rol gespeel en gemanifesteer in 'n voortdurende debat oor die opvoedkundige fokus van die Vereniging. 'n Vroeë voorbeeld van kritiek teen die opvoedkundige fokus van die Helpmekaar, was gedurende die 1923-kongres toe die fokus op die steun vir studente wat hul studies in die kommersiële rigtings aan oorsese universiteite en instellings voortgesit het, bevraagteken is. 'n Resolusie is aanvaar dat meer geld verkieslik aan die "gesonke gedeelte van ons volk" bestee moes word as op beurse vir studente wat oorsee studeer. ${ }^{19}$ Hierdie kritiek was waarskynlik die gevolg van die groeiende prominensie van die armblankevraagstuk soos dit ook binne die Helpmekaar neerslag gevind het.

Die Geyer-voorstel van 1935 dat die Helpmekaar-fokus van tersiêre na primêre en sekondêre onderwys moes verskuif, waarna reeds verwys is, was nog 'n voorbeeld in die deurlopende debat oor die fokus van die Helpmekaar se onderwysbetrokkenheid. Veranderende verstedelikingspatrone het ook gelei tot die bevraagtekening van die Helpmekaar se fokus op tersiêre onderrig. Gedurende die 1947-kongres is die impak van Afrikaner-verstedeliking geillustreer deur 'n voorstel deur die Port Elizabeth-Wes-tak dat die Helpmekaar-beweging ook die "Afrikanerseun en -dogter" moes help om tegniese en vakleerlingopleiding te

15 JT de Witt, dr WJ Viljoen as onderwyshoof ..., PhD US, 1973, 212.

16 Ibid., 213.

17 CR Venter, Ontwikkelingsrigtings in die Onderwys ..., PhD US, 1973, 237, 260.

$18 \quad P S d u$ Toit, Onderwys in Kaapland, 1652-1975, JL Van Schaik Bpk, 1976, 167.

19 (HSA) HVKP, Notuleboek, 25-26 Apr 1923, Kongres, 13. 


\section{Die Kaapse Helpmekaar}

bekom, en nie slegs akademiese opleiding nie, angesien dit hulle ook sou toerus om hulle op industriële terrein te vestig. Mnr Burmeister, die verteenwoordiger vir Port Elizabeth, het geredeneer dat, omdat die salarisse wat vakleerlinge gedurende hul vakleerlingskap ontvang het so karig was, baie van die vakleerlinge slegs gewone werkers geword het omdat hulle nie kon oorleef op die salarisse wat aan vakleerlinge betaal is nie. Die voorsitter het egter die kongreslede die versekering gegee dat sulke aansoeke nooit in die verlede afgekeur is nie en dat die voorstel dus verwerp moes word. ${ }^{20}$ Dit het egter wel die bekommernisse gereflekteer van die nuut-verstedelikte gebiede met' $n$ groot persentasie armblankes, soos in die geval van Port Elizabeth.

\section{DIE HELPMEKAAR AS PLEITBESORGER VIR ONDERWYSSAKE}

Afgesien van sy finansiële betrokkenheid, het die Helpmekaar vanaf sy stigting opgetree as pleitbesorger vir opvoedkundige sake. ${ }^{21}$ Deur die resolusies wat by sy jaarlikse kongresse aanvaar is en wat gerig was aan sentrale en provinsiale regeringsgesag, het die Helpmekaar tesame met ander soortgelyke organisasies bygedra om druk uit te oefen op die onderwys en verwante owerhede oor die heersende brandende opvoedkundige kwessies. Die resolusies en beskrywingspunte op Helpmekaarkongresse het oor tyd in breë die kontoere van die behoeftes van Afrikaner-nasionalisme en Afrikaner-etniese mobilisering gevolg en was ook 'n weerspieëling van die ekonomiese ontwikkeling en opwaartse sosiale mobiliteit wat Afrikaners weens die sukses wat dié prosesse behaal het. Reeds in 1918 het die kongres op voorstel van Paul van der Merwe en mev GW van Heerden besluit om 'n kommissie, bestaande uit die voorsitter, penningmeester en Paul van der Merwe, te benoem om die regering te nader met die versoek "om meer van ons jong Afrikaners op te lei in vak-onderwijs"22 en het in 1919 by die Provinsiale Administrasie aangedring op die noodsaaklikheid van mediese inspeksie by skole. ${ }^{23}$

(HSA) HVKP, Notuleboek, 2-3 Apr 1947, Kongres, 9.

21 Met Uniewording in 1910 is 'n Departement van Onderwys ingestel. Ten spyte hiervan het die gewone skoolonderwys 'n provinsiale aangeleentheid gebly. Die SGO was verantwoordelik aan die Administrateur van die provinsie wat saam met die UK as 'n "onderwysraad" gefunksioneer het. Laasgenoemde was baie meer toeganklik as die betrokke minister onder die koloniale bedeling voor 1910. Die omstandighede sou die Helpmekaar en ander organisasies wat hulle vir die onderwys beywer het se taak as pleitbesorgers vergemaklik. PS du Toit, Onderwys in Kaapland, 1652-1975. 'n Oorsig, 86-87.

23 (HSA) HVKP, Notuleboek, 21-22 Mei 1919, Kongres, 8. 
Die kwessies wat in die 1920's geopper is, het die impak van die armblankekwessie en ontvolking van die platteland op die Afrikaner se psige geillustreer en het die opvatting dat opvoeding en onderwys die primêre oplossing vir die probleem was, weerspieël. Die groot uitdaging in dié verband is onderstreep deur die feit dat daar in die eerste helfte van die twintigerjare 'n drastiese afname was in die koers waarteen blanke kinders in die skoolstelsel opgeneem is en dr Stals, Helpmekaar-voorsitter, was van mening dat "groot getalle kinders van skoolgaande ouderdom loop verwaarloos rond". ${ }^{24}$ Gebaseer op die 135779 skoolgaande kinders in die Kaapprovinsie het hy dié groep in 1925 op tussen 15 000-20 000 blanke kinders gestel en was hy van mening dat hulle hoofsaaklik uit kinders van behoeftige ouers van die platteland bestaan het. ${ }^{25}$

Opvoeding het die ontwikkeling van die gees en die liggaam behels en die twintigerjare is dus gekenmerk deur versoeke vir tegniese of vakonderrig en industriële skole op die platteland; ${ }^{26}$ uitbreiding van mediese inspeksies by skole; ${ }^{27}$ meer landbou- en huishoudskole vir behoeftige kinders, en meer beurse vir sekondêre onderwys; ${ }^{28}$ oproepe vir die uitbreiding van gratis onderwys; ${ }^{29}$ implementering van moedertaalonderrig ${ }^{30}$ en versoeke dat die godsdienstige oriëntasie van onderwysers met die Christelike geloof strook alvorens hulle as aanstelbaar beskou word. ${ }^{31}$ Die versoeke van die 1920's is ook gekenmerk deur die hoë premie wat op landbou-vakonderwys as heenkome vir veral die leerlinge wat op 16-jarige ouderdom met standerd ses of sewe die skool verlaat, geplaas is. ${ }^{32}$ Dit was 'n aanduiding dat landbou steeds gesien is as 'n sentrale ekonomiese aktiwiteit vir Afrikaners in 'n tydperk toe die wekroep van "terug na die platteland" steed as teenvoeter vir toenemende verstedeliking gesien is.

Die voorstelle wat by die 1925-kongres goedgekeur is, is 'n goeie voorbeeld van die rol wat onderwys en opvoeding in die bestendiging van die Afrikaner- samelewingsorde van die twintigerjare moes speel:

24 (HSA) HVKP, Notuleboek, 15-17 Apr 1924, Kongres, Voorsittersrede, 3.

25 (HSA) HVKP, Notuleboek, 15-16 Apr 1925, Kongres, Voorsittersrede, 2-3.

26 (HSA) HVKP, Notuleboek, 25-26 Mei 1921, Kongres, 7; (HSA) HVKP, Notuleboek (19 Mrt 1921-15 Apr 1924), 11 Mrt 1922, Sentrale Bestuur, 81.

(HSA) HVKP, Notuleboek, 25-26 Apr 1923, Kongres, 13. Aanhangsel B: Kongresbesluite van 1929 en die reaksie van die Ministers van die Departemente, 6.

(HSA) HVKP, Notuleboek, 4-5 Apr 1928, Kongres, 13. 


\section{Die Kaapse Helpmekaar}

“die kongres dring beleef dog sterk by die Provinsiale Raad aan om 'n doeltreffende leerplan in ooreenstemming met die volksaard en landsomstandighede daar te stel. Die kongres dring aan by die betrokke outoritiete om voorsiening te maak op die buiteskole vir die opleiding van meisies in huishoudkunde, praktiese oefeninge in versorging en verwerking van plaasprodukte, sodat hulle kan voorberei word vir die lewe wat hulle ingaan na skool; die Kongres dring aan op meer landbou en industriële onderwys in die plattelandse skole; dat die kongres die betrokke owerhede versoek om in opleidingskole verpligtende kursusse in te stel in landbou, huishou en industriële opleiding." ${ }^{33}$

Die onderwysmodel moes die samelewingsorde bestendig en perpetueer. Die volgende beskrywingspunt wat in 1926 aanvaar is, is nog 'n aanduiding van die belangrikheid van onderwys in die Helpmekaar-denke en veral ook waar die klem in die 1920's geval het:

"Met die oog op beter toerusting vir die jeug van ons volk, dring die kongres by die betrokke outoriteite aan soveel moontlik in alle Opleidingskole die beste metode te laat doseer en (a) Dat die meisies besonder onderrig in huishou en gesondheidsleer sal ontvang (b) Seuns, landbou en industriële onderwys (c) En dat spesiale vakkundige onderwysers(esse) opgelei word vir die so nodige vakke: landbou, gesondheidsleer en huishoudkunde." ${ }^{34}$

Benewens die deurlopende versoeke vir die uitbreiding van die grense van verpligte en veral gratis onderwys het die resolusies van die dertigerjare veral aangedring op moedertaalonderrig. Dit was moontlik die resultaat van die populêre nasionalisme van die periode en in 'n groter mate van aanvaarding van die onafwendbaarheid van verstedeliking, wat moontlik die impak van die depressie was. By die 1937-kongres het verskeie variasies van beskrywingspunte wat vir gratis onderwys gevra het, gedien en almal is uiteindelik in die volgende formulering gekonsolideer:

"Die kongres dring by die Provinsiale Administrasie aan om, met die oog op die eventuele gelyke behandeling van die vier provinsies wat vry onderwys betref, voorsiening te maak vir vry onderwys aan alle blanke leerlinge tot hul 16de jaar." ${ }^{35}$

Daar is nog punte aanvaar. Die Provinsiale Administrasie is versoek om meer losiesbeurse beskikbaar te stel vir sekondêre onderwys. Daar is ook gevra vir 'n ondersoek na die opvoedingstelsel met die oog op beter aanpassing op nywerheidsgebiede. Verder is die SAOU gevra om so'n ondersoek te doen sodat die kinders in staat gestel kan word om by die nywerhede

\footnotetext{
33 (HSA) HVKP, Notuleboek, 15-16 Apr 1925, Kongres, 9-10.

34 (HSA) HVKP, Notuleboek, 7-8 Apr 1926, Kongres, 8, 9.

35 (HSA) HVKP, Notuleboek, 30-31 Mrt 1937, Kongres, 12.
} 
aan te pas as hulle die skool verlaat. Daar is ook weer 'n beroep op Afrikaanssprekende ouers gedoen om toe te sien dat hul kinders in sowel primêr as sekondêre skole deur medium van hul moedertaal onderrig word. Daar is ook 'n beroep op skoolhoofde en inspekteurs gedoen om toe te sien dat die wet sover dit primêre onderwys betref toegepas word. Laastens is ook by takke aangedring dat waar hulle hulp verleen aan leerlinge, voorkeur gegee moet word aan leerlinge wat deur hul moedertaal onderrig ontvang. ${ }^{36}$ Die volgende voorstel wat deur die 1939-kongres aanvaar is, was tiperend van die wyse waarop onderwys en armblankesake die denke van die Helpmekaar-kongresse oorheers het:

"Die kongres spreek sy besorgdheid uit oor die groot getal van ons volk wat van genadebrood moet lewe, en die jaarlikse aangroei van die getalle. Dit is die mening van die kongres dat die aangroei van die getal afhanklikes van die Staat en ander hulp byna geheel en al te wyte is aan die feit dat so baie kinders die skole verlaat lank voordat hulle bekwaam is om 'n lewensbestaan te maak. Dit is die gevoel van die kongres dat die tyd nou aangebreek het vir die Staat om na hierdie toestande ondersoek in te stel en middele daar te stel om hierdie euwel in ons land te keer en te verwyder sover moontlik. Die kongres is daarvan oortuig dat enige koste wat aan die uitvoer van hierdie besluit verbonde mag wees later meer as dubbel na die staat sal terugkeer in besparings op onderhoudskoste van die wat reeds van die Staat afhanklik is.

Die volgende besluite is deur die kongres aangeneem en vir ernstige oorweging voor die Staat, Kerk en Volk gestel: Verpligte onderwys vir normale blanke kinders tot en met St VIII en vry onderwys tot en met St X. Verpligte vakopleiding vir alle blanke kinders wat nie verstandelik bekwaam geag kan word om voordeel te trek uit sekondêre onderwys nie. Eenvormigheid in al vier provinsies ivm: Vry Onderwys; Ouderdom van verpligte skoolbesoek; vakke, leergange en voorgeskrewe literatuur.

Ten einde aan sekere van bostaande punte uitvoering te gee, versoek die kongres die UnieRegering baie dringend om die Kaapprovinsie nie langer minder gunstig te behandel insake onderwyssubsidies as die ander Provinsies nie, daar die onderwys as gevolg van die ongelyke behandeling baie daaronder ly."37

Hierdie besluit het die versugting van die 1920's en 1930's in Helpmekaar-geledere goed saamgevat en ook baie van die opvattings oor onderwys van die samelewing, waarvan die Helpmekaar 'n spieëlbeeld was, weerspieël. Dit het 'n onbeskaamde blanke fokus, provinsialisme, intellektuele kategorisering en die geloof in opheffing deur onderwys en opvoeding ingesluit.

36 Ibid.

37 (HSA) HVKP, Notuleboek, 12-13 Apr 1939, Kongres, 11. 
Die sentrale fokus van die resolusies was om kinders so lank moontlik op skool te hou en die neiging om die skool na standerd ses te verlaat teen te werk. ${ }^{38}$ Die 1937-kongres het byvoorbeeld'n resolusie aanvaar waarin hulle by die regering of provinsiale raad aangedring het op subsidie op die pond-vir-pond-stelsel vir alle bydraes wat deur liefdadigheidsverenigings beskikbaar gestel word om standerdsesse die geleentheid te bied om tot hoër onderwys te vorder. ${ }^{39}$ Die feit dat teen die middel dertigerjare 44 persent van leerders in die Kaapprovinsie die skool na standerd ses verlaat het, was 'n aanduiding van die omvang van die probleem. Dié statistiek in kombinasie met die steeds stygende kostes van onderwys, beide tendense wat in 1936 deur prof MC Botha in sy kongresrede aan die Helpmekaarafgevaardigdes uitgewys is, was 'n aanduiding van die groot werk wat in dié verband te doen was. ${ }^{40}$

Van die resolusies van die dertigerjare het ook die neiging na 'n meer eksklusiewe Afrikanerskap, wat vreemde elemente uitgeweer het, weerspieël en ook die gender-hiërargie in die Afrikanergemeenskap gereflekteer. Die 1934-kongres het die Departement van Onderwys versoek om geen buitelandse onderwysers of onderwyseresse aan te stel nie, behalwe in gevalle waar daar nie 'n geskikte persoon in Suid-Afrika gevind kon word nie, ${ }^{41}$ waarop die Departement bevestig het dat dit reeds hulle beleid was. ${ }^{42}$ Die kongres het ook die Departement van Onderwys versoek om geen getroude vroue van wie die mans leef en gesond is in skole aan te stel nie, ${ }^{43}$ waarop die Departement bevestig het dat dit reeds hulle algemene beleid was. In gevalle waar die man nie genoeg verdien om sy gesin te onderhou nie is die vrou wel toegelaat om 'n tydelike betrekking te aanvaar - wat veral gedoen is in gevalle waar daar kinders was wat versorg moes word. ${ }^{44}$

Die dertigerjare het ook geillustreer hoe die Helpmekaar alternatiewe metodes om onderwys te bevorder saam met ander organisasies ondersteun het. In 1937 het die kongres byvoorbeeld versoek dat die Suid-Afrikaanse Uitsaaikorporasie en die Provinsiale Owerheid die lesse wat

\footnotetext{
38 (HSA) HVKP, Notuleboek, 30 Mrt 1932, Kongres, 4, 5.

39 (HSA) HVKP, Notuleboek, 30-31 Mrt 1937, Kongres, 12.

40 (HSA) HVKP, Notuleboek, 15-16 Apr 1936, Kongres, 3. Botha was aanvanklik SGO van Onderwys in Kaapland, in 1934 het hy sekretaris van die Unie Departement van Onderwys geword en in 1936 is hy as die eerste voorsitter van die SAUK aangestel. In 1941 is hy as rektor van die Universiteit van Pretoria aangestel. SESA, vol 2, BAD-CAR, 454.

41 (HSA) HVKP, Notuleboek, 3-4 Apr 1934, Kongres, 6.

42 (HSA) HVKP, Notuleboek, 23-24 Apr 1935, Kongres, Sentrale Bestuur verslag, 3.

43 (HSA) HVKP, Notuleboek, 3-4 Apr 1934, Kongres, 6.

44 (HSA) HVKP, Notuleboek, 23-24 Apr 1935, Kongres, Sentrale Bestuur verslag, 3.
} 
deur eersgenoemde vir skole uitgesaai is in pamfletvorm te druk en versprei. ${ }^{45}$ Die sentrale bestuur het in dié verband 'n brief van dr CF Albertyn, die redakteur van die Jongspan, ontvang waarin hy aangedui het dat hulle in oorleg met die Departement van Onderwys die radiopraatjies in pamfletvorm aan skole gaan beskikbaar stel teen $4 \mathrm{~d}$ per kopie. Die Helpmekaar het op sy beurt onderneem om die publikasies onder die takke se aandag te bring. ${ }^{46}$

Soos met die vorige dekades het die 1940's 'n voortsetting van die deurlopende temas vertoon, maar het dit ook die spesifieke fokusse en omstandighede van die dekade verteenwoordig. Gratis onderwys vir die volle duur van die skoolloopbaan tot standerd tien het nou die norm geword. ${ }^{47}$ Die aandrang op moedertaalonderrig is 'n stap verder gevoer deur resolusies wat op enkelmediumskole en Christelike Nasionale Onderwys (CNO) aangedring het en dubbelmediumskole as ongewens uitgewys het. ${ }^{48}$ Die mate waarin die Helpmekaar hom met dié strewe geïdentifiseer het, is duidelik tydens die 1943-kongres geillustreer. DJ du Plessis het 'n referaat oor CNO gelewer wat baie positief deur die kongres ontvang is. Du Plessis is bedank vir sy "duidelike uiteensetting" van die saak en ds NFP Burger van Indwe wou selfs hê dat die referaat in die notule opgeneem word. Die kongres het dus die hoofbestuur opdrag gegee om soveel moontlik publisiteit daaraan te gee. Die referaat is gevolg deur verskeie beskrywingspunte oor CNO wat na bespreking uiteindelik in die volgende voorstel vervat en aanvaar is:

"Die Helpmekaarvereniging in kongres op Cradock spreek hom, na die bespreking van die beskrywingspunte van Lady Grey en Victoria-Wes, beslis uit ten gunste van die beginsel van $\mathrm{CNO}$; versoek verder die hoofbestuur om samewerking te soek met aksie vir $\mathrm{CNO}$ wat daar reeds is, maar stel ook, met raadpleging van die vakkundiges op 'n manifes wat die beginsel van CNO duidelik stel en wat die standpunt van Helpmekaar sal openbaar. Ook word die Departement van Onderwys gevra om in hierdie rigting te stuur." ${ }^{\prime 9}$

Op die 1944-kongres het die hele kwessie van moedertaalonderrig en enkelmediumskole weer ter sprake gekom en het die kongres hom duidelik uitgespreek teen dubbelmediumskole en sy onwrikbare vertroue in die enkelmediumskool bevestig. Die kongres het hom ook verbind tot

\footnotetext{
45 (HSA) HVKP, Notuleboek, 30-31 Mrt 1937, Kongres, 13.

46 (HSA) HVKP, Notuleboek, (15 Apr 1936-6 Des 1939), 16 Jun 1937, Sentrale Bestuur, 196; 8-9 Des 1937 Sentrale Bestuur, 200.

49 (HSA) HVKP, Notuleboek, 31 Mrt-1 Apr 1943, Kongres, 13.
} 


\section{Die Kaapse Helpmekaar}

die uitvoering van die besluite soos geneem op die FAK Moedertaalkongres op Bloemfontein (14 Desember 1943). Hierdie besluit is opgevolg deur nog 'n besluit van die kongres, naamlik dat die kongres dit aan die hoofbestuur opdra om na sy goeddunke 'n bedrag te gee aan die Moedertaalstrydfonds en het ook 'n dringende beroep op die takke gedoen om hul volle steun sover moontlik te gee aan pogings ten behoewe van "hierdie groot saak" ${ }^{50}$

Die omvang van die aandrang op die verafrikaansing van die samelewing en 'n afsonderlike staanplek vir Afrikaanse kinders in die vorm van enkelmediumskole, het verder gestrek as net sekondêre onderwysvlak. Dit is onderskryf deur die versoeke vir 'n Afrikaanse mediese fakulteit aan die Universiteit van Pretoria en 'n Afrikaanse ingenieursfakulteit aan die Universiteit van Stellenbosch. Die voorstellers was dr CF Albertyn (latere voorsitter van die Helpmekaar Studiefonds) en mev J le Roux. ${ }^{51}$

Die invloed van die oorlogsomstandighede van die 1940's en die onderwysimpak daarvan is ook op Helpmekaarkongresse weerspieël. Die werksgeleenthede wat deur die oorlogsekonomie gegenereer is, het vroeë skoolverlating aangemoedig wat die aandrang op verpligte onderwys tot en met standerd sewe of 'n ouderdomsgrens van 16 jaar, asook gratis onderwys tot standerd tien verskerp het. ${ }^{52}$ Die tekort aan onderwysers in die veertigerjare, waartoe die oorlog en die verhoogde lewenskostes waarskynlik ook 'n bydrae gelewer het, het gemanifesteer in 'n aandrang op beter diensvoorwaardes en ook opleiding vir onderwysers. ${ }^{53}$ Die strewe na Afrikanereenheid op politieke gebied, wat veral in die veertigerjare prominent gefigureer het, het ook in Helpmekaar-resolusies oor onderwys en opvoeding neerslag gevind in die vorm van sentimente wat klasse en ander verdelings veroordeel en onderspeel het. Benewens die deurlopende pogings om ook kinders wat nie in die hoofstroom geakkommodeer kon word nie te ondersteun, is veral teen klasseverdelings gewaak. 'n 1943-voorstel was 'n voorbeeld hiervan. Dit is aanvaar dat die ontoereikende toelaag (hoofsaaklik weens die stygende lewenskoste tydens die oorlog) vir arm kinders in Behoeftige Koshuise verhoog moes word omdat hulle nie net huisvesting nie, maar ook opvoeding en opheffing beoog het.

'n Die voorstel het aanleiding gegee tot nog 'n voorstel wat die gees van die tyd weerspieël het deurdat die Administrateur geloof is vir sy standpunt om die koshuise vir behoeftige kinders op 'n beter basis te plaas. 'n Beroep is op die Administrateur en Provinsiale Administrasie gedoen om verdere stappe te neem om die "ongesonde afskeidings en segregasie tussen twee

\footnotetext{
50 (HSA) HVKP, Notuleboek, 4-5 Apr 1944, Kongres, 14.

51 (HSA) HVKP, Notuleboek, 27-28 Mrt 1940, Kongres, 6.

52 (HSA) HVKP, Notuleboek, 31 Mrt-1 Apr 1943, Kongres, 11.

53 (HSA) HVKP, Notuleboek, 3-4 Apr 1946, Kongres, 8, 12, 14-15.
} 
groepe (arm en gegoedes) te elimineer. ${ }^{54}$ Versoeke vir die uitbreiding van gratis onderwys het dieselfde sentimente geopenbaar. In reaksie op 'n voorstel van Kimberley dat gratis onderwys tot standerd tien ingestel moes word, het mev TCC Trouw die mening uitgespreek dat dit nodig was, aangesien die huidige stelsel tussen die ryk en arm kind gediskrimineer het. ${ }^{55}$

Die identifisering met Afrikaner-nasionalisme se kulturele en politieke ideale in sover die onderwys'n rol in die bevordering daarvan kon speel, het ook in die veertigerjare gemanifesteer. Die impak van verstedeliking op die onderwysbehoeftes van Afrikaners en die "spanning" wat dit tussen platteland en stad geskep het, het duidelik gekristalliseer in 'n bespreking oor Huishoudkunde versus Huishoudekonomie as skoolvak tydens die 1947-kongres. Dit het onstaan as gevolg van die rol wat aan $\mathrm{CNO}$ in die Afrikaner-nasionalistiese projek ten opsigte van genderrolle binne die ideale Afrikanergesin toegeken is. Mnr Burmeister van Port Elizabeth-Wes het voorgestel dat die Onderwysdepartement versoek word om die huidige huiskoudkunde-kursus aan die primêre en hoërskool in huishoudekonomie te omskep en dit vir alle dogters verpligtend te maak. Sy motivering was dat "so 'n kursus ons jongdogters, vernaamlik in die stedelike gebiede, beter sal bekwaam as waardige toekomstige huisvrouens; die toekomstige eggenoot daardeur ekonomies aangehelp sal word; dit mag meewerk om egskeidings te verminder."56

Burmeister was van mening dat die omstandighede waaronder veral stedelike dogters opgegroei het, verander het. Dogters wat die skool vroeg verlaat en in fabrieke gaan werk het, het volgens hom loseerders by hul eie ouers geword. "Hulle trou nog voordat hulle 'n liefde vir eie huis aangekweek het. Huishou moet vir die dogters 'n plesier wees en die klaskamer moet 'n modelhuis wees." 57 Oosthuizen van Kakamas het die voorstel voorwaardelik gesekondeer, aangesien hy nie ten gunste van die uitskakeling van huishoudkunde was nie. "Aan die dogters moet 'n lewensbeskouing gegee word. Wat ons wil hê, is oefenhuise." ${ }^{58}$ Die kongres het uiteindelik 'n voorstel aanvaar waarin die Onderwysdepartement versoek is om die onderrig van huishoudkunde met meer huishoudkunde-ekonomie aan te moedig. ${ }^{59}$ Die 1949-kongres het ook die beginsel van apartheid in die onderwys onderskryf en op voorstel van CP Jamneck, met sekondant mev Boy Pienaar, eenparig besluit om die owerheid te

\footnotetext{
54 (HSA) HVKP, Notuleboek, 31 Mrt-1 Apr 1943, Kongres, 13.

55 (HSA) HVKP, Notuleboek, 31 Mrt-1 Apr 1943, Kongres, 11.

56 (HSA) HVKP, Notuleboek, 2-3 Apr 1947, Kongres, 9.

$57 \quad$ Ibid.

$58 \quad$ Ibid.

$59 \quad$ Ibid.
} 
versoek "om die beginsel van apartheid deur middel van wetgewing so gou as omstandighede dit toelaat toe te pas op alle onderwysinrigtings insluitende die vir hoër onderwys". ${ }^{60}$

Die onderwys in Kaapland in die vroeë 1950's is oorheers deur die aanbevelings van die De Villiers Onderwyskommissie wat in 1948 aanvaar is en wat die reorganisasie van onderwys in Kaapland beoog het. Dit het 'n proses ingesluit wat in 1953 geïmplementeer is en onder andere standerd ses deel van die sekondêre onderwysfase gemaak het. Die 1952-kongres het dan ook by die Onderwysdepartement daarop aangedring om sy voorgestelde reorganisasie van die onderwys van skole, om standerd ses by die sekondêre onderwys in te skakel, te bespoedig. Hulle het ook 'n ernstige beroep gedoen dat die Department moet verseker dat die kindertuinafdeling Sub A tot standerd twee ook spoedig vir kwotadoeleindes as 'n aparte eenheid behandel word om te voorkom dat'n leerkrag in hierdie afdeling met'n onaanvaarbare 35 leerlinge en meer belas word. Die kongres was van mening dat klasse van dié omvang individuele aandag onmoontlik gemaak het en dat dit ook'n uiters nadelige uitwerking op die werwing van rekrute vir die onderwysberoep en in besonder vir kindertuinwerk gehad het. ${ }^{61}$

In aansluiting hierby is die kongres se besluite in die vyftigerjare gekenmerk deur hul kommer oor die tekort aan onderwysers, in veral spesifieke vakrigtings soos Wiskunde, Musiek en Engels, ${ }^{62}$ en hul pogings om jongmense na die onderwysberoep te lok. Met die landswye fondsinsameling vir die B-fonds in die vroeë vyftigerjare het die kongres 'n besluit aanvaar dat die Helpmekaar hom ten doel stel om in die volgende jare die onderwysprofessie te propageer en meer fondse vir die opleiding van leerkragte beskikbaar te stel. Daar is ook 'n beroep op ouers gedoen om as gevolg van die groot tekort aan leerkragte hul kinders aan te moedig om die onderwysprofessie as loopbaan te kies. ${ }^{63}$

Die deurlopende tema in beskrywingspunte, naamlik om die skoolloopbane van kinders te verleng en om vroeë skoolverlating te verhoed, het in die vyftigerjare 'n addisionele fokus op die "begaafde kind" gekry. By die 1954-kongres is benewens die aanvaarding van 'n voorstel van Villiersdorp dat die Departement van Onderwys doeltreffende onderrig van die begaafde kind, veral in die junior kursus, moes verseker, 'n voorstel van die hoofbestuur in dié verband ook aanvaar, naamlik dat die kongres sy besorgdheid uitspreek:

"oor die groot aantal belowende en begaafde leerlinge wat vir aanloklike salarisse te vroeg die skool verlaat en derhalwe nie toegerus is om die hoër betrekkings in die land te vul

60 (HSA) HVKP, Notuleboek, 30-31 Mrt 1949, Kongres, 34.

61 (HSA) HVKP, Notuleboek, 8-9 Apr 1952, Kongres, 9.

62 (HSA) HVKP, Notuleboek, 27 Jun 1953, Kongres, 8.

63 (HSA) HVKP, Notuleboek, 3-4 April 1951, Kongres, 10; 5-6 April 1955, Kongres, 7. 
nie. 'n Dringende beroep word derhalwe gedoen op onderwysliggame in die algemeen en skoolhoofde in besonder, om buitengewone pogings aan te wend ten einde begaafde leerlinge solank moontlik op skool te hou; die regering, om veel meer studiebeurse beskikbaar te stel aan belowende universiteitstudente wat hulle in gespesialiseerde rigtings wil bekwaam". ${ }^{4}$

Die dryfveer agter hierdie besorgdheid was gesetel in die opvatting dat die Afrikanervolk en die "blanke beskawing" in 'n bestaanstryd gewikkel was waarin onderwys en opleiding as 'n deurslaggewende verdedigingskild gesien is. Die 1953-verslag van die hoofbestuur het die opvatting as volg verwoord:

"In 'n veelrassige land soos Suid-Afrika kan die blanke beskawing alleen gehandhaaf word as elke blanke seun en dogter opgevoed en opgewasse is vir die stryd om te bestaan. Elke greintjie van die sluimerende gawes en talente moet ontwikkel word. Elke seun en dogter aan wie 'n lening geweier word, vorm 'n swak skakel in die gordel van volksverdediging." 65

Die veertigerjare het reeds besluite opgelewer wat daarop gemik was om musiekonderrig en musiek as vak te bevorder. In die vyftigerjare is dit gekenmerk deur'n sterker aandrang op die bevordering van die kunste wat ook wyer as net musiek gestrek het. In 1950 het die kongres die hoofbestuur versoek om die Departement van Onderwys te nader om aan te dring op kwytskelding van musiekfooie vir leerlinge wat musiek op skool neem. ${ }^{66}$ Die versoek is in 1955 herhaal met 'n spesifieke verwysing na behoeftige leerlinge wat aanleg vir klavier en viool openbaar. ${ }^{67}$ In 1951 het kuns ook ter sprake gekom:

“ten einde ' $n$ intelligente en waarderende belangstelling in kuns in ons skole te bevorder beveel die kongres aan om onderhandelinge aan te knoop met die betrokke firmas om te voorsien in die nypende tekort aan kunsafdrukke van Suid-Afrikaanse kunstenaars; om die Departement van Onderwys te nader om ruimer voorsiening te maak ten einde skole in staat te stel om afdrukke van ons bekende Suid-Afrikaanse kunstenaars aan te koop." ${ }^{68}$

Die Helpmekaar was ook sensitief vir die negatiewe impak van verstedeliking en ander invloede op die plattelandse skole en hul leerlinge. In 1950 het die kongres die staat versoek om die kwynende plattelandse skole te help deur amptenare (soos polisiemanne, ens.)

64 (HSA) HVKP, Notuleboek, 30-31 Mrt 1954, Kongres, 5.

65 (HSA) HVKP, Notuleboek, 30-31 Mrt 1954, Kongres, Hoofbestuurverslag 1953, 1.

66 (HSA) HVKP, Notuleboek, 4-5 Apr 1950, Kongres, 30, 37.

67 (HSA) HVKP, Notuleboek, 5-6 Apr 1955, Kongres, 7.

68 (HSA) HVKP, Notuleboek, 3-4 Apr 1951, Kongres, 10. 
met groot gesinne na die kleiner plattelandse dorpies te stuur. ${ }^{69}$ In 1953 het die kongres by monde van sen Van Zyl hom uitgespreek teen die denke van dr W de Vos Malan, die Superintendent-Generaal van Onderwys (SGO), dat die sekondêre onderwyskursus tot twee jaar verleng word. Volgens Van Zyl sou dit tersiêre opleiding nog verder buite die bereik van die plattelandse kinders plaas. Hulle het alreeds 'n agterstand gehad teenoor die stedeling in soverre hulle reiskoste en losies moes betaal, terwyl die stedeling hierdie koste vrygespring het. In hierdie verband het hy die huidige beleid van onderwysfinansiering gekritiseer en die mening uitgespreek dat die staat losieskoste moes subsidieer in plaas van klasgelde sodat die student van die platteland nie langer aan die kortste ent trek nie." ${ }^{\prime 7}$

Die deurvoer van die kwessies waaroor die kongres oor jare besluit het, is aan die sentrale bestuur (later hoofbestuur) opgedra. In die proses het die sentrale bestuur'n kernrol gespeel in die aanspreek van oproepe aan die relevante departemente en die ontmoetings met amptenare soos die SGO in die Kaapprovinsie ${ }^{71}$ en die opvolg van response van staatsdepartemente. In die twintigerjare het die Helpmekaar se pogings om namens die Afrikanerjeug by die owerheid in te tree op goedgesinde en toeganklike ore geval. In 1918 is dr WJ Viljoen tot die eerste Afrikaanssprekende SGO in die Kaapprovinsie verkies, na 'n periode as direkteur van onderwys in die Oranje-Vrystaat ('n posisie waarin hy in 1910 deur general JBM Hertzog aangestel is). ${ }^{72}$ Met die bewindsaanvaarding van die Pakt-regering in 1924 is dr DF Malan as Minister van Binnelandse Sake, van Onderwys en van Volksgesondheid aangestel. ${ }^{73}$

Hulle het dus geredelike toegang gehad tot die owerhede wat moeite gedoen het om terugvoer op hul navrae te verskaf ${ }^{74}$ of dit na die relevante departemente te verwys indien versoeke buite hul jurisdiksie geval het. ${ }^{75}$ Uit die terugvoer wat verskaf is, was dit ook duidelik dat die owerhede oorwegend dieselfde doelwitte as die Helpmekaar nagestreef het en dat dit meestal finansiële beperkinge, en nie ideologiese verskille nie, was wat die Helpmekaar se versoeke

69 (HSA) HVKP, Notuleboek, 4-5 Apr 1950, Kongres, 30, 37.

70 (HSA) HVKP, Notuleboek, 27 Jun 1953, Kongres, 8.

71 (HSA) HVKP, Notuleboek (21 Mei 1924-3 Apr 1928), 28 Okt 1925, Sentrale Bestuur, 103-104.

72 WJ de Kock en DW Krüger (reds), Suid-Afrikaanse Biografiese Woordeboek Deel II, 835-836.

73 WJ de Kock en DW Krüger (reds), Suid-Afrikaanse Biografiese Woordeboek Deel III, 578-579.

74 In die vaarwater van die 1924 kongres het die sekretaresse, Hester Roux, en die penningmeester, adv Wessel Roux, die kongresbesluite in 'n onderhoud met Viljoen bespreek en hier in na bespreek het hy ook aan hulle terugvoering gegee oor wat die Departement reeds in dié verband gedoen het. (HSA) HVKP, Notuleboek (21 Mei 1924-3 Apr 1928), 4 Des 1924, Sentrale Bestuur, 47-48.

75 (HSA) HVKP, Notuleboek, 23-24 Apr 1935, Kongres, Sentrale Bestuur verslag, 3. 
en vertoë gedwarsboom het. ${ }^{76}$ In die proses is die opvoedkundige pogings en bydraes van die Helpmekaar begroet met waardering en erkenning deur owerhede soos die Kaapse Provinsiale Administrasie en Departement van Onderwys. ${ }^{77}$ In reaksie op die 1922-kongres se versoeke het die privaatsekretaris van die Administrateur, HA van Hoogstraten, as volg gereageer:

"De Administrateur heeft met belangstelling uw brief gelezen. Uw vereniging zal zeker weten dat het Parlement dit jaar geen voorziening gemaakt heft voor uitbreiding. Tengevolge hiervan was het onmogelik om meer dan $£ 30000$ op de begroting te plaatzen voor de opvoeding van belovende en behoeftige kinderen in de sekundaire scholen. Dit bedrag blijkt echter voor het tegenwoordige voldoende. Ook wordt voorziening gemaakt voor heel wat vrij onderwijs in sekundaire scholen voor hen, die geen logiesbeurse nodig hebben.

Wat $\mathrm{u}$ tweede besluit betreft, de ouderdom door de wet voorgeschreven is 16 en niet 17 jaar. Zodra het verplicht onderwijs zich tot het 17 de jaar uitstrekt, hetgeen we hopen spoedig zal geschieden, zal het door u verlangde als vanzelf volgen.

De voorsziening voor logies-toelagen aan behoeftige kinderen op het platteland is zeer groot. Een groot som geld wordt uitgegeven voor behoeftige kosthuizen, nl. $£ 110000$ per jaar, $£ 30000$ wordt uitgegewen aan beurzen voor sekundair onderwijs en $£ 12000$ voor special toelagen. Dit alles toont hoe gunstig de Provinciale Raad gezind is jegens plattelandskinderen, want geen van deze toelagen gelden voor stedelingen. Zodra de belastingmachten voor de provincie door de benoemde Financiele Kommissie onderzocht zijn, heeft de Administrateur de hoop bovengenoemde toelagen te kunnen verhogen. Inmiddels geeft de Administrateur u de verzekering, dat hij uwe resolusies in verband met een zaak welke hem zeer na aan hart ligt ten hoogste waardeert." ${ }^{\text {78 }}$

In dieselfde trant het die Sekretaris van Onderwys, JE van Zyl, as volg gereageer op die kongres se versoek vir meer industriële skole vir behoeftige kinders en om van regeringsweë meer geldelike ondersteuning vir sulke kinders te kry:

"Ek het die eer ontvangs te erken van u brief met betrekking tot besluit deur Helpmekaar kongres geneem om by die regering aan te dring om meer industriële skole vir behoeftige kinders op te rig. In antwoord daarop het ek die eer om mee te deel dat die Regering alles

76 (HSA) HVKP, Notuleboek (21 Mei 1924-3 Apr 1928), 24 Jul 1925, Sentrale Bestuur, 92; 28 Okt 1925, Sentrale Bestuur, 103-104; (HSA) HVKP, Notuleboek, 13-14 Apr 1927, Kongres, Sentrale Bestuur verslag, 3; 30 Mrt 1932, Kongres, Sentrale Bestuur verslag, 3.

77 (HSA) HVKP, Notuleboek, 23-24 Apr 1935, Kongres, Sentrale Bestuur verslag, 3.

78 (HSA) HVKP, Notuleboek, 25-26 Apr 1923, Kongres, 5. 


\section{Die Kaapse Helpmekaar}

in sy vermoë doen om die nodige voorsiening te maak vir behoeftige kinders, maar dat die tyd vir uitbreiding finansieel hoogs ongunstig is." ${ }^{79}$

Die waardering wat daar van owerheidsweë vir die Helpmekaar se werk was en die impak wat dit op die staat se denke oor hul fokus op opvoedingsbesteding gehad het, is duidelik geillustreer deur die SGO, prof MC Botha, se verslag vir die tweejaartydperk 1932/1933: ${ }^{80}$

"Die Helpmekaar was nie minder ywerig in hulle werk in belang van die onderwys van behoeftige leerlinge nie. Gedurende 1932 en 1933 het hierdie liggaam die aansienlike som van $£ 8784$ aan die onderwys bestee. Dit is wel nie net laer en middelbare onderwys wat die voordeel uit dié prysenswaardige belangstelling getrek het nie, maar verreweg die grootste gedeelte van die geld is gebruik om leerlinge aan verder skoolonderwys te help. Van diè bedrag is $\mathfrak{E 6} 088$ in die vorm van studielenings - sonder rente solank die lener geen betrekking het nie - uitbetaal, wat dit vir die Helpmekaar moontlik maak om voortdurend te help en tegelykertyd verantwoordelikheidsgevoel by die jeug te kweek. Etlike honderde is ook aan skoolbiblioteke bestee. Dit lyk my egter gewens vir die administrasie om baie meer geld vir skoolbiblioteke beskikbaar te stel sodat liggame soos die ACVV en die Helpmekaar hulle tyd en geld meer uitsluitend kan wy aan boekerye en leeskamers vir volwassene." ${ }^{11}$

Prof MC Botha het ook die 1936-kongres oor onderwys en opvoeding toegespreek, waartydens hy hulle sukses en voorspoed met hul werk toegewens het en weer verwys het na "die voortreflike werk wat die Helpmekaar op die gebied van onderwys doen en wat nog meer uitgebrei kan word as meer hulp verleen word aan kinders in middelbare skole". ${ }^{2}$ By die 1937-kongres het die goeie verstandhouding tussen die Provinsiale Departement van Onderwys en die Helpmekaar weer geblyk toe dr Stander van die Departement (hy het die Departement in die afwesigheid van die SGO, dr W de V Malan, verteenwoordig) die kongres alle sukses toegewens het en verseker het dat die Departement van Onderwys die werk van die Helpmekaar belangstellend en waarderend volg. ${ }^{83}$ Die impak wat die Helpmekaar op onderwysaangeleenthede op provinsiale vlak gehad het, is in 1937 prakties geillustreer toe die Provinsiale Raad die Helpmekaar geraadpleeg het oor hul studieleningstelsel en die

\footnotetext{
79 (HSA) HVKP, Notuleboek, 25-26 Apr 1923, Kongres, 5.

80 (HSA) HVKP, Notuleboek (13 Jun 1928-12 Des 1935), 9 Aug 1934, Sentrale Bestuur, 142.

81 (HSA) HVKP, Notuleboek, 23-24 Apr 1935, Kongres, Sentrale Bestuur verslag, 3.

82 (HSA) HVKP, Notuleboek, 15-16 Apr 1936, Kongres, 3.

83 (HSA) HVKP, Notuleboek, 30-31 Mrt 1937, Kongres, 1.
} 
penningmeester versoek is om getuienis te lewer voor 'n gekose komitee wat vir die ondersoek aangestel is. ${ }^{84}$

Die Helpmekaar het ook krediet gegee aan die regering vir goeie werk wat hulle ten opsigte van onderwysbevordering gedoen het. By die 1926-kongres het die kongres byvoorbeeld sy dank uitgespreek aan sir Frederic de Waal vir wat hy gedoen het vir opvoeding gedurende sy ampstyd as Administrateur van die Kaapprovinsie. Hy het die regering bedank vir beter onderwysfasiliteite en vir die opening van nuwe skole. Die Departement van Onderwys het landbou en veeteelt op die platteland aangemoedig en die Helpmekaar se sekretaresse, mev H Roux, is opdrag gegee om dank aan die betrokke owerhede oor te dra. ${ }^{85}$ In 1947 het die kongres sy waardering uitgespreek teenoor die owerheid vir die instelling van verpligte godsdiensonderrig en vir die stappe wat die Departement van Onderwys reeds gedoen het om die toepassing daarvan 'n sukses te maak. ${ }^{86}$

Die Helpmekaar het egter ook hoë verwagtinge gehad van die regering soos dit blyk uit die voorstel wat op die 1927-kongres aanvaar is, naamlik dat 'n amptenaar van die regering en provinsiale raad die jaarlikse kongres moet bywoon om verslag te doen oor beskrywingspunte en ander sake wat na hulle onderskeidelik verwys was. ${ }^{87}$ Die kommunikasie met die Departement van Onderwys het in die veertigerjare en vyftigerjare voortgeduur. Hoewel die kwessies mettertyd verander het en die frekwensie afgeneem het namate die staat sy verantwoordelikheid ten opsigte van gratis en verpligte onderwys uitgebrei het, het die hoofbestuur steeds die reaksie aan die kongresse gerapporteer en aan die takke gesirkuleer. ${ }^{88}$

Die Helpmekaar se rol as pleitbesorger vir primêre en sekondêre onderwys het teen die einde van die vyftigerjare vir alle praktiese doeleindes tot'n einde gekom. Die 1958-kongres was die laaste waarop daar enige beskrywingspunte oor onderwys gedien het. Die eerste verwysing hierna in die 1960's was by die 1964-kongres toe die debat gehandel het daaroor of die Helpmekaar in die lig van die vlak van gratis en verpligte onderwys wat deur die staat verskaf word, nog hoegenaamd hulp aan skoliere moes verskaf. ${ }^{89}$ Die mate waarin hy as pleitbesorger op die gebied van primêre en sekondêre opvoeding suksesvol was, is waarskynlik die beste

84 (HSA) HVKP, Notuleboek (15 Apr 1936-6 Des 1939), 16 Jun 1937, Sentrale Bestuur, 196.

85 (HSA) HVKP, Notuleboek, 7-8 Apr 1926, Kongres, 8.

86 (HSA) HVKP, Notuleboek, 2-3 Apr 1947, Kongres, 13.

87 (HSA) HVKP, Notuleboek, 13-14 Apr 1927, Kongres, 6.

88 (HSA) HVKP, Notuleboek (8 Feb 1940-9 Des 1966), 13-14 Nov 1946, Hoofbestuur, 359; 18 Des 1952 , Hoofbestuur, 437.

89 (HSA) HVKP, Notuleboek, 1 Apr 1964, Kongres, gp. 


\section{Die Kaapse Helpmekaar}

geillustreer deur die feit dat een van die hoofredes wat aangevoer is vir die agteruitgang en uiteindelike ontbinding van die Helpmekaar se takstelsel in 1965, die verlies aan behoefte aan opvoedkundige hulp op primêre en sekondêre vlak as gevolg van die instelling van gratis, verpligte onderwys deur die staat was. In hierdie opsig was die Helpmekaar - of ten minste sy takstelsel - 'n slagoffer van sy eie sukses.

\section{FINANSIËLE ONDERSTEUNING VAN ONDERWYSSAKE}

Die Helpmekaar se rol as pleitbesorger vir onderwys en opvoeding vir die Afrikaner in Kaapland wat via die kongres en die sentrale bestuur gespeel is, was nie al waar hulle betrokke was nie. Die kongres het ook 'n tweede bydrae gelewer deur die jaarlikse goedkeuring van finansiële hulp aan onderwys- en opvoedingsinstansies of -projekte. Anders as sy pleitbesorgerrol is dié bydraes kwantitatief meetbaar en die impak daarvan duideliker soos afgelei uit jaarverslae en korrespondensie van die instansies wat ondersteun is. Die sentrale bestuur was egter sensitief daarvoor om nie te veel wat hulle as die regering se werk beskou het op hulself te neem nie, veral in gevalle waar die regering reeds statutêr (soos met die bou van industriële skole) daarvoor verantwoordelikheid aanvaar het. ${ }^{90}$

Een van die eerste onderwysprojekte waarby die Helpmekaar betrokke geraak het, was die boufonds vir CNO "vir die behoud van ons volk in Rhodesië"91 en met die voorneme dat, indien die onderneming nie werk nie en die geboue verkoop moet word, die geld bestee moet word aan "die opvoeding van arme blanke kinders van Afrikaanssprekende ouers" in Rhodesië. Die eerste bedrag van $£ 700$ is in 1919 uitbetaal. 'n Bedrag van $£ 4840$ sou uiteindelik hiervoor uitbetaal word in 'n poging om onderwys aan die Afrikaners in Rhodesië te ondersteun. Dié betrokkenheid het geblyk 'n ingewikkelde en moeilike onderneming te wees wat die Helpmekaar op die 1925-kongres laat besluit het hy:

"doen afstand van al sy regte in of op vasgoed in Rhodesië, waarvoor gedeeltelik of in geheel betaal is met geld van hom afkomstig aan en ten gunste van die Kerkraad van die Ned. Geref Kerk van die plek waar die vasgoed geleë is, mits dat die vasgoed of die opbrengs daarvan gebruik word vir doeleindes van Godsdiens of Onderwys." ${ }^{\text {93 }}$

90 (HSA) HVKP, Notuleboek (19 Mrt 1921-15 Apr 1924), 11 Mrt 1922, Sentrale Bestuur, 81.

91 (HSA) HVKP, Notuleboek (28 Jun 1919-19 Feb 1921), 22 Nov 1919, Sentrale Bestuur, 44-45.

92 (HSA) HVKP, Notuleboek (28 Jun 1919-19 Feb 1921), 7 Feb 1920, Sentrale Bestuur, 67.

93 (HSA) HVKP, Notuleboek, 15-16 Apr 1925, Kongres, 9, 10. 
Die verwysing in die sentrale bestuur se verslag aan die 1926-kongres na die afsluiting van die betrokkenheid as: "Daarmee is die langhangende en moeilike sake in Rhodesië beëindig, wat 'n verantwoordelikheid van die skouers geneem het"94 was 'n aanduiding dat die projek minder suksesvol was as wat anvanklik gehoop is. Dit was ook'n erkenning dat die Helpmekaar as vereniging nie oor die kapitaal of bestuurskapasiteit beskik het om by sulke ambisieuse projekte betrokke te raak nie. Op 'n veel kleiner skaal, het die Helpmekaar se pogings om "onderwys van ons Afrikaner-kinders in Angola” te ondersteun, deur in 1923 $£ 50$ daarvoor te bewillig met die onderneming om die ondersteuning uit te brei, die besef bevestig. ${ }^{95}$ Teen Februarie 1925 was dit duidelik dat die Angola-inisiatief'n totale mislukking was en dat die kommissie wat hiermee gemoeid was nog $£ 80$ in hande gehad het wat hulle van die Helpmekaar ontvang het. Die sentrale bestuur het dus besluit om by die kongres aan te beveel dat, indien die geld nie binne drie maande gebruik word nie, dit aan die Helpmekaar terugbetaal moes word. ${ }^{96}$

'n Ander projek wat met groot sukses deur die Helpmekaar oor jare ondersteun is en waarin die betrokke plaaslike tak van die Helpmekaar ook 'n groot rol gespeel het, was die Aandskoolhandelsklasse in die Paarl. $\mathrm{Na}$ aanleiding van 'n beskrywingspunt by die 1924-kongres dat die wenslikheid van aandskole vir arm kinders bespreek moes word en die pleidooie van die verteenwoordiger van die Paarl vir ondersteuning vir wat reeds in dié verband in die Paarl gedoen is, het die kongres $£ 50$ vir die Paarl vir dié doel bewillig. ${ }^{97}$ Die aanvanklike idee was om deur 'n aandskool vir behoeftige seuns, wat reeds op 'n jong ouderdom die skool moes verlaat om te gaan verdien, dit moontlik te maak om verdere opleiding te ontvang. ${ }^{98}$

Daar is in 1929 ook met dagklasse begin en het die skool se bestuur dit met die opening van die skool deur die Minister van Onderwys, dr DF Malan, na die Paarlse Handelsklasse herdoop en in 1931 het dit die Hoër Handelskool Paarl geword. In 1929 het 170 leerlinge die dag- en aandklasse bygewoon en 56 leerlinge die Nasionale Eksamens in Snel- en Tikskrif,

\footnotetext{
94 (HSA) HVKP, Notuleboek, 7-8 Apr 1926, Kongres, Sentrale Bestuur verslag, 4.

95 (HSA) HVKP, Notuleboek, 25-26 Apr 1923, Kongres, 13.

96 (HSA) HVKP, Notuleboek (21 Mei 1924-3 Apr 1928), 16 Feb 1925, Sentrale Bestuur, 61.

97 (HSA) HVKP, Notuleboek, 15-17 Apr 1924, Kongres, 9.

98 (HSA) HVKP, Notuleboek, 15-16 Apr 1925, Kongres, Verslag in verband met die stigting van 'n aandskool vir die Perel, 6.
} 
Boekhou, Afrikaans en Engels met sukses afgelê. ${ }^{99}$ In 1934 is 'n kursus vir die opleiding van munisipale amptenare bygevoeg en vir 1935 is klasse beplan vir bankklerke wat hulle vir die verskillende bankeksamens wou voorberei. ${ }^{100}$ Tussen 1925 en 1951 het die Helpmekaar die skool met $£ 1740$ ondersteun. Die impak van die Helpmekaar se ondersteuning is ten beste deur die skoolhoof, JC Dreyer, in sy 1930-verslag aan die Helpmekaarkongres verwoord: "Namens die Aandskoolbestuur van die Paarl het ek u sy erkentelike dank te betuig vir die $£ 100$ deur u in 1929 toegeken. $U £ 100$ het vir die Bestuur $£ 300$ beteken." 101

Afgesien van bogenoemde voorbeelde word laastens enkele voorbeelde aangehaal wat meer spesifiek op skoolonderwys gemik was en ook insig verskaf oor hoe die Helpmekaar se finansiële ondersteuning aangewend is en watter tipe impak dit gehad het. In 1919 het die kongres in reaksie op 'n versoek van die Aliwal-Noord-tak om iets aan die hand te doen om die "toenemende en verderflike invloed van die Roomse Skole" onder die dogters van die Kerk te bestry besluit om $£ 50$ vir die Aliwal-Noord skoolkoshuis te bewillig. ${ }^{102}$

Die behoefte aan 'n Afrikaansmedium hoërskool in Kaapstad het in Mei 1926 met die stigting van Hoërskool Jan van Riebeeck onder voorsitterskap van DF Malan gerealiseer nadat die gelyknamige laerskool reeds in 1921 gestig is. Die Helpmekaar het hul ondersteuning vir die behoefte aan sodanige skool getoon deur reeds by hul April 1926-kongres $£ 50$ vir die doel te bewillig ${ }^{103}$ - 'n skenking wat hulle tot 1930 volgehou het en uiteindelik in totaal $£ 225$ tot die stigting en vestiging van die skool bygedra het. Die konteks, asook die impak van hierdie bydrae wat in die skool se skoolfonds gestort is, is as volg deur JJ Jordaan, die skoolhoof, in sy verslag aan die Helpmekaar verwoord:

"Hierdie fonds word hoofsaaklik gebruik om boeke en, in uitsondelike gevalle, die skoolgeld van behoeftige leerlinge te dek. Die Skoolfonds staan onder direkte beheer van die Skoolkomitee waarvan Senator WA Hofmeyr die voorsitter is. Duisende verarmde Afrikaners het die laaste jare hulle intrek in die stad geneem, waarvan baie begerig is om hulle kinders te red deur hulle 'n middelbare opleiding te gee, maar dit nie kan bekostig nie. Die hulp wat ons skool van die Helpmekaar-vereniging en uit ander bronne ontvang

99 (HSA) HVKP, Notuleboek, 7-9 Apr 1931, Kongres, 6; 16-17 Apr 1930, Kongres, Verslae van inrigtings en liggame ..., 14.

100 (HSA) HVKP, Notuleboek, 23-24 Apr 1935, Kongres, Bylaag B: Uittreksels uit rapporte van liggame ..., 12.

101 (HSA) HVKP, Notuleboek, 16-17 Apr 1930, Kongres, Bylaag C: Verslae inrigtings en liggame ..., 14.

102 (HSA) HVKP Notuleboek, 21-22 Mei 1919, Kongres, 9.

103 (HSA) HVKP, Notuleboek, 7-8 Apr 1926, Kongres, 6. 
het, het hom in staat gestel om dosyne van hierdie ouers tegemoet te kom. Met innig dank en waardering." ${ }^{104}$

Op soortgelyke wyse het die Helpmekaar ook die onderwysinisiatiewe van ander Afrikanerorganisasies ondersteun. 'n Voorbeeld in dié verband was hul ondersteuning aan die ACVV-Voortsettingsklasse op Cradock wat die Nasionale Handelseksamens, vir jongmense wat vroeg die skool verlaat het en hul verder wou bekwaam, sedert 1929 aangebied het. Met die aanvang van die klasse in Junie 1929 was daar 17 studente. Die behoefte waarin die klasse voorsien het, is bevestig deur die sekretaresse van die Voortsettingsklasse, mej HE Coetzee, wat gerapporteer het dat 45 jongmense gedurende die eerste ses maande van die klasse gebruik gemaak het. Van die 45 het almal reeds oor standerd ses beskik en die meeste reeds die ouderdom van 16 bereik. Die klasse het dus geleentheid geskep vir leerders wat die primêre skoolfase voltooi het en hulle verder wou bekwaam. ${ }^{105}$ Die impak van die Helpmekaar se bydraes wat tot 1950 volgehou is en oor die periode 'n totaal van $£ 775$ beloop het, is weerspieël deur die verslae wat van die ACVV ontvang is:

"Danksy die gewaardeerde bydrae van die hoofbestuur van die Helpmekaar, was dit moontlik om 'n aantal belowende leerlinge aan klasgeld en beurse te help. ${ }^{106}$ Die ondersteuning van die Helpmekaar doen reusewerk, en meer as een wat andersins niks vir die maatskaplike lewe sou beteken het nie, het deur middel van hierdie ondersteuning 'n eerbare plek in die sameleweing ingeneem. Baie van hulle is deur plaaslike werkgewers in diens geneem." 107

Selfs eenmalige skenkings soos die $£ 10$ wat in 1929 vir behoeftige kinders aan die GraaffReinetse hoërskool bewillig is, het 'n verskil gemaak en mnr Cronje, die skoolhoof, se uiteensetting van die aanwending van die geld verskaf insae wat in 1929 met so 'n skenking vermag kon word:

“£4 10s losies vir kind wat nie deur die departement wou gehelp word nie. $£ 410$ s inskrywing by Junior Sertifikaat vir 3 leerlinge wat andersins, of nie sou kon skryf nie of die geld net met groot moeite sou kon kry. Het $£ 1$ vir boeke bestee." 108

104 (HSA) HVKP, Notuleboek, 16-17 Apr 1930, Kongres, Bylaag C: Verslae inrigtings en liggame ..., 14.

105 Ibid.,15.

106 (HSA) HVKP, Notuleboek, 30 Mrt 1932, Kongres, Bylaag B: Verslae van inrigtings en liggame ..., 12.

107 (HSA) HVKP, Notuleboek, 23-24 Apr 1935, Kongres, Bylaag B: Uittreksels uit rapporte van die liggame ..., 12.

108 (HSA) HVKP, Notuleboek, 16-17 Apr 1930, Kongres, Bylaag C: Verslae van inrigtings en liggame ..., 15. 
Die Helpmekaar het dus beide deur middel van hul pleitbesorgerrol en hul meer konkrete finansiële bydraes 'n aktiewe rol gespeel om die belange van die onderwys en opvoeding van die Afrikanerjeug in Kaapland te bevorder. In die proses het hulle ook probeer verseker dat die templaat waarbinne onderwys en opvoeding gestalte gekry het, sover moontlik met die Afrikaner-nasionalistiese CNO en ideale ooreenstem. In dié sin het hulle ook as ideologiese werktuig binne die breër verband van Afrikaner-nasionalisme gefunksioneer. 


\section{HOOFSTUK VYF}

\section{HELPMEKAAR-STUDIEBEURSE EN LENINGS}

\section{VeStiging VAn die ReËLS, REgulasies en ProSedures}

Ten einde uitvoering te gee aan die besluit van die 1918-kongres, naamlik om beurse vir handelsopleiding aan studente toe te ken, het die sentrale bestuur 'n komitee aangestel om reëls en regulasies rakende die beurse op te stel. ${ }^{1}$ By sy eerste vergadering in Junie 1918 is ' $n$ subkomitee aangestel om die oprigting te ondersoek van 'n instelling vir handelsopleiding en ook 'n koshuis vir die studente. ${ }^{2}$ Die vordering deur beide komitees was stadig weens die afsterwe van Fred Dormehl (een van die sleutelfigure van die komitee wat 'n slagoffer van die griepepidemie geword het) ${ }^{3}$ en die bedanking van die voorsitter van die subkomitee, ds Luckhoff, wat weens sy herhaaldelike afwesigheid uit Kaapstad dit moeilik gevind het om komiteevergaderings by te woon. ${ }^{4}$

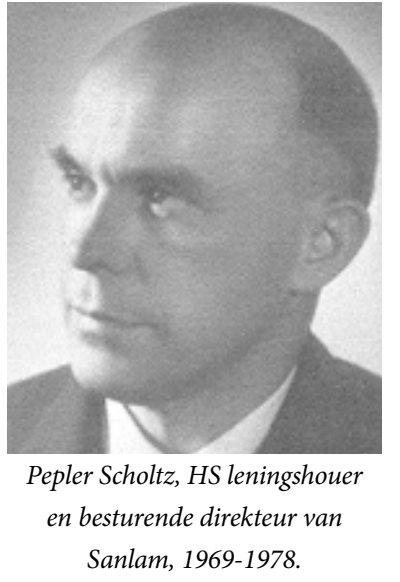

Die subkomitee het tog vordering gemaak met die vestiging van 'n instelling vir handelsopleiding. Met behulp van die tussenkoms van Ludwig Wiener, prominente sakeman van Kaapstad en eienaar van die groothandelmaatskappy Wiener en $\mathrm{Kie}^{5}{ }^{5}$ was hulle in staat om lede van die Afrikaanse Handelshuis, Santam en Nasionale Pers te laat belangstel om aandklasse aan te bied. ${ }^{6}$ Teen Mei 1919 het die Beurs-komitee nog nie na vore gekom met 'n stel reëls en regulasies as riglyne vir die toekenning en administrasie van beurse nie. Aangesien dit noodsaaklik geword het in die hantering van aansoeke wat van studente ontvang is, het die sentrale bestuur in

1 (HSA) HVKP, Notuleboek (3 Jul 1916-20 Mei 1919), 8 Jun 1918, Sentrale Bestuur, 118.

2 (HSA) HVKP, Notuleboek (3 Jul 1916-20 Mei 1919), 13 Jul 1918, Sentrale Bestuur, 123.

3 (HSA) HVKP, Notuleboek, 21-22 Mei 1919, Kongres, Sentrale Bestuur verslag, 3.

4 (HSA) HVKP, Notuleboek (3 Jul 1916-20 Mei 1919), 14 Des 1918, Sentrale Bestuur, 134; 5 Apr 1919, Sentrale Bestuur, 162.

5 Suid-Afrikaanse Biografiese Woordeboek, III, 863-864.

6 (HSA) HVKP, Notuleboek (3 Jul 1916-20 Mei 1919), 8 Mrt 1919, Sentrale Bestuur, 150-151. 


\section{Die Kaapse Helpmekaar}

Mei 1919 besluit om die UK te taak om reëls en regulasies op te stel ${ }^{7}$ - 'n proses wat eers in 1923 formeel afgehandel is.

Gesien teen bogenoemde agtergrond het die 1921-kongres twee besluite geneem wat 'n fundamentele impak op die toekomstige aard en toegang tot die Helpmekaar se finansiële bystand gehad het. Eerstens is 'n voorstel aanvaar dat alle toekomstige finansiële bystand aan studente in die vorm van lenings sou wees, met die aanvaarding van bystand vir handelsrigtings wat nog as beurse beskou sou word. ${ }^{8}$ Tweedens is eenparig besluit dat alle toekomstige versoeke om finansiële bystand wat aan die sentrale bestuur gerig sou word via 'n plaaslike Helpmekaartak gerig moes word, indien daar so'n tak bestaan het in die gebied/dorp vanwaar die versoek gerig is. Omdat die voorstel gesekondeer is deur die sekretaresse, mev Hester Roux, ${ }^{9}$ was die motivering waarskynlik om groter orde en sisteem in die administratiewe proses daar te stel. In die praktyk het dit egter die posisie van die plaaslike takke versterk, aangesien hulle toe die amptelike toegangskanale (die hekwagters) tot die Helpmekaar se finansiële bronne geword het. Hoewel dit waarskynlik nie as sulks beplan is nie, was dit ook 'n eerste stap van uitsluiting van toegang tot die Helpmekaar se finansiële bronne. Dit het voortgebou op die reeds bestaande praktyk dat versoeke om finansiële bystand vanaf individue uit provinsies waar 'n provinsiale Helpmekaarvereniging bestaan het (Transvaal, Oranje-Vrystaat, Natal) aan sodanige verenigings gerig moes word..$^{10}$ Dit het provinsialisme en die provinsiale aard en grense van Helpmekaar-hulp versterk.

In die afwesigheid van 'n amptelike stel reëls en regulasies is 'n aantal beginsels in die tydperk ná die 1918-kongres vasgelê in die hanteringsproses van aansoeke van studente en skoliere vir beurse en lenings. Dit het met verbasende kontinuïteit vir die duur van die kongresperiode van die Helpmekaar se bestaan, sy optrede gerig. Op 'n ideologiese vlak het die fokus van die Helpmekaar-grondwet op die Hollandssprekende deel van die Suid-Afrikaanse volk beteken dat Helpmekaar-hulp op 'n rasse- en etniese grondslag omskryf is en op ondersteuning vir wit Afrikaners neergekom het. Die behoeftigheid en verdienstelikheid van kandidate was belangrike oorwegings in die toekenning van Helpmekaar-hulp. ${ }^{11}$

7 (HSA) HVKP, Notuleboek (3 Jul 1916-20 Mei 1919), 10 Mei 1919, Sentrale Bestuur, 174.

8 Die laaste beurs is in 1923 toegeken. Daarna is slegs lenings toegestaan en beurse slegs in hoogs uitsonderlike gevalle.

9 (HSA) HVKP, Notuleboek, 25-26 Mei 1921, Kongres, 6, 8.

10 (HSA) HVKP, Notuleboek (28 Jun 1919-19 Feb 1921), 4 Sep 1920, Sentrale Bestuur, 121; 11 Des $1920,147$.

11 (HSA) HVKP, Notuleboek (28 Jun 1919-19 Feb 1921), 18 Okt 1919, Sentrale Bestuur, 33, 37. 
Die finansiële posisie van die ouers van kandidate was dus 'n oorweging en die fokus was op kandidate wie se ouers dit nie kon bekostig om vir hul kinders se opvoeding te betaal nie. ${ }^{12}$ Die Helpmekaar se definisie van behoeftigheid het nie noodwendig beteken dat kandidate se ouers armblankes moes wees nie. Dit het eerder verwys na 'n toestand waarin die kandidaat nie in 'n posisie was om sy/haar studies sonder hulp van buite voort te sit nie en teen dié agtergrond is voorkeur aan die mees behoeftige kandidate verleen. ${ }^{13}$ In Helpmekaar-terme het verdienstelikheid beide 'n intellektuele en morele komponent bevat. Hoewel intellegensie nie 'n voorwaarde vir finansiële ondersteuning was nie, was die mees gesogte kandidate dié wat beide behoeftig en skrander was. ${ }^{14}$

In die keuring van kandidate was hul karakter en morele waardes of sedelike gedrag ${ }^{15}$ - hul respektabilitiet ${ }^{16}$ belangrik. Lede van die plaaslike netwerke van kandidate soos predikante en onderwysers is genader om inligting oor die finansiële posisie en "karakter" van die aansoekers ${ }^{17}$ te bekom om te bepaal of hulle "verdienstelike jong Afrikaners"18 was. Respektabiliteit is deur die Helpmekaar beloon en terselfdertyd is gepoog om dit te versterk en te bevorder. Die Helpmekaar het kandidate wat as respektabel beskou is, ondersteun en

12 (HSA) HVKP, Notuleboek (3 Jul 1916-20 Mei 1919), 1 Feb 1919, Sentrale Bestuur, 143; 14 Des 1918, Sentrale Bestuur, 139; (HSA) HVKP, Notuleboek, 21-22 Mei 1919, Kongres, Sentrale Bestuur verslag, 3. Die vader van 'n aansoeker, DG Steyn, was te welvarend en sy aansoek is dus afgekeur. (HSA) HVKP (19 Mrt 1921-15 Apr 1924), 28 Jun 1923, Sentrale Bestuur, 188.

13 (HSA) HVKP, Notuleboek (19 Mrt 1921-15 Apr 1924), 15 Feb 1924, Sentrale Bestuur, 248.

14 (HSA) HVKP, Notuleboek, 21-22 Mei 1919, Kongres, 8.

15 (HSA) HVKP, Notuleboek (28 Jun 1919-19 Feb 1921), 22 Nov 1919, 53. In die geval van RL Barry het prof WE Malherbe van Stellenbosch, ds Gerdener, PG Roos, prof JT Morrison, prof AH Mackenzie en ds Kotze as referente opgetree. Barry het die toets vir sy "sedelike gedrag" en sy intellektuele vermoë geslaag, aangesien gerapporteer is dat hy "seer skrander" was en aan hom 'n beurs vir sy handelsstudies in Holland toegeken is.

Die soeke na respek en respektabilitiet as 'n integrale deel van Afrikaner-nasionalisme is breedvoerig behandel met betrekking tot die Afrikaner-werkersklasvroue van die Klerewerkersunie. Sien E Brink, “'Only Decent Girls are Employed': The Respectability, Decency and Virtue of the Garment Workers on the Witwatersrand during the Thirties", Paper presented at Wits History Workshop, The Making of Class, Johannesburg, 9-14 Feb 1987, 1-29; en L Vincent "Bread and Honour: White Working Class Women and Afrikaner Nationalism in the 1930's", Journal of Southern African Studies, 26, 1, 2000, 61-78.

(HSA) HVKP, Notuleboek (3 Jul 1916-20 Mei 1919), 14 Des 1918, Sentrale Bestuur, 139; 10 Mei 1919, Sentrale Bestuur, 175; 20 Mei 1919, 178.

(HSA) HVKP, Notuleboek (28 Jun 1919-19 Feb 1921), 28 Jun 1919, Sentrale Bestuur, 10, 11. In 1941 is die proses om die verdienstelikheid en respektabiliteit van studente wat Helpmekaar-ondersteuning ontvang het te verseker verder geformaliseer. Twee amptelike vorms moes jaarliks ingevul word; deur die plaaslike predikant, waarin hy moes kommentaar lewer op die spaarsamigheid en goeie gedrag van die kandidaat en of die kandidaat se lewenswyse verdere finansiële ondersteuning verdien; deur die hoof van die akademiese instelling waar die kandidaat gestudeer het, waarin hy oor die akademiese vordering en klasbywoning gerapporteer het en moes aandui of die kandidaat se vordering verdere finansiële ondersteuning verdien. (HSA) HVKP Notuleboek, 27-28 Mrt 1941, Kongres, 12-13. 
met hul geassosieer, maar het terselfdertyd respektabiliteit van hul kandidate verwag. Deur hul finansiële ondersteuning van respektabele kandidate is die respektabiliteit versterk deur die toegang wat sulke ondersteuning tot beter loopbaanmoontlikhede en opwaartse sosiale mobiliteit verskaf het. In Helpmekaar-terminologie het dit 'n "beter werkkring"19 en 'n "hoër Handelsstand" beteken. ${ }^{20}$ Die Helpmekaar was van mening dat opvoeding en onderwys, en spesifiek tersiêre opvoeding/onderwys, aan die gekose kandidate dié voordele gebied het. In dié sin was Helpmekaar-finansiële ondersteuning dus 'n oefening in die bevordering van die respektabiliteit van hul teikenmark - die Afrikaner-jeug.

Dit is moeilik om die Helpmekaar se siening of definisie van respektabilitiet te bepaal, maar Helpmekaar-korrespondensie met studente bied wel 'n blik daarop. Gedrag of karaktertrekke wat as negatief bejeen is, kon 'n kandidaat se kanse op finansiële ondersteuning benadeel. "Onstandvastigheid", oneerlikheid of 'n afwyking van wat as die norm beskou is, het Helpmekaar-wenkbroue laat lig en tot die afkeuring van aansoeke gelei - selfs van kandidate wat as intelligent of skrander beskou is. ${ }^{21}$ Rosa van der Merwe, 'n Helpmekaarbegunstigde, is byvoorbeeld deur die sentrale bestuur opdrag gegee om - op sterkte van haar korrespondensie met die sekretaresse - meer aandag aan haar taalgebruik te skenk. ${ }^{22}$ Dit wil dus voorkom asof respektabiliteit ook gemeet is aan die suiwerheid van 'n individu se gebruik van Afrikaans. BB Eybers, wat 'n sendeling wou word, se aansoek is verwerp op grond van die slordigheid daarvan, wat as 'n negatiewe refleksie van sy respektabiliteit beskou is. ("Sy applikasie is baie slordig ingevul en aangesien ons geld toeken aan verdienstelike jongmense word hy afgewys"). ${ }^{23}$

Dit is ook van Helpmekaar-begunstigdes verwag om die nodige dankbaarheid en waardering vir Helpmekaar-ondersteuning te toon en die afwesigheid daarvan is met afkeur en verontwaardiging begroet. Die sekretaresse het sulke kandidate berispe en meegedeel dat

\footnotetext{
19 (HSA) HVKP, Notuleboek (28 Jun 1919-19 Feb 1921), 22 Nov 1919, Sentrale Bestuur, 46.

20 (HSA) HVKP, Notuleboek (28 Jun 1919-19 Feb 1921), 7 Feb 1920, Sentrale Bestuur, 71.

21 (HSA) HVKP, Notuleboek (3 Jul 1916-20 Mei 1919), 10 Mei 1919, Sentrale Bestuur, 174-175; 20 Mei 1919, Sentrale Bestuur, 178.

22 (HSA) HVKP, Notuleboek (19 Mrt 1921-15 Apr 1924), 27 Aug 1921, Sentrale Bestuur, 38, 41.

23 (HSA) HVKP, Notuleboek (19 Mrt 1921-15 Apr 1924), 16 Feb 1923, Sentrale Bestuur, 152.
} 
hul gedrag aan die sentrale bestuur gerapporteer sou word. ${ }^{24}$ Die lening wat aan FJ Celliers toegeken is, is teruggehou nadat 'n negatiewe verslag oor sy gedrag aan die sentrale bestuur bekend geword het. ("Mnr JL Jordaan skrywe dat FJ Celliers, aan wie geld toegesê was, so sleg uitgedraai het.") ${ }^{25}$ Briewe van studente wat as onbeskof en disrespekvol ervaar is, is sterk afgekeur. ${ }^{26}$

Pligsversuim - soos om na te laat om gereelde terugbetalings op lenings te doen of om nie die Helpmekaar van 'n adresverandering in te lig nie - is as agterlosigheid en disrespek geïnterpreteer en met 'n streng vermanende brief van die sekretaresse begroet. ${ }^{27}$ Vertroue in en aanvaarding van die Helpmekaar en sy metodes was ook 'n oorweging. Toe die vader van Douw Steyn oor die formulering van die IOU (skulderkenning), wat hy namens sy seun moes onderteken, gekla het, is sy klagte begroet met 'n vermaning dat hy eenvoudig die sentrale bestuur moes vertrou of hy sou sy Helpmekaar- finansiële steun kwyt wees. ${ }^{28}$

Hierteenoor het aansoekbriewe van kandidate wat in 'n "mooi gees" geskryf is aanklank gevind by die sentrale bestuur. ${ }^{29}$ In reaksie op 'n versoek om oor die verdienstelikheid van 'n kandidaat (CG Greeff) kommentaar te lewer het Paul Roos, die skoolhoof van die gelyknamige skool in Stellenbosch, gerapporteer dat "hy is $n$ flinke jong man en verdien om gehelp te word" ${ }^{0}$ 'n Kandidaat se vermoë om finansiële steun uit ander bronne as die Helpmekaar te bekom of wat 'n bereidwilligheid getoon het om ook van sy/haar eie fondse vir studie aan te wend is deur die Helpmekaar gesien as 'n waarborg of bevestiging van die geskiktheid van die spesifieke kandidaat. ${ }^{31}$

24 (HSA) HVKP, Notuleboek (19 Mar 1921-15 Apr 1924), 22 Mar 1923, Sentrale Bestuur, 161. Die waarde wat aan die toon van dankbaarheid en waardering van studente vir Helpmekaar- ondersteuning geheg is, is ook geillustreer deur die feit dat sulke gevalle spesifiek genotuleer is. Die feit dat RL Barry, een van die eerste studente wat na Holland en Amerika gestuur is vir handelsopleiding, met sy terugkeer uit Amerika persoonlik die Helpmekaar-kantore besoek het om sy dankbaarheid te betuig, is spesifiek genotuleer. $\mathrm{MH}$ de Kock het op soortgelyke wyse erkenning aan Helpmekaar-ondersteuning vir sy oorsese studies gegee in die voorwoord van sy gepubliseerde $\mathrm{PhD}$-verhandeling. Hierdie erkenning is ook spesifiek in die notules vermeld. (HSA) HVKP, Notuleboek (19 Mar 1921-15 Apr 1924), 22 Mar 1923, Sentrale Bestuur, 161, 162.

(HSA) HVKP, Notuleboek (19 Mar 1921-15 Apr 1924), 28 Jun 1923, Sentrale Bestuur, 193.

(HSA) HVKP, Notuleboek (19 Mar 1921-15 Apr 1924), 3 Des 1923, Sentrale Bestuur, 228.

(HSA) HVKP Notuleboek (19 Mar 1921-15 Apr 1924), 17 Mar 1924, Sentrale Bestuur, 254; (HSA) HVKP, Notuleboek (21 Mei 1924-3 Apr 1928), 31 Aug 1927, Sentrale Bestuur, 193; 21 Mei 1924, Sentrale Bestuur, 4.

(HSA) HVKP, Notuleboek (19 March 1921-15 Apr 1924), 12 Nov 1921, Sentrale Bestuur, 54.

(HSA) HVKP, Notuleboek (28 June 1919-19 Feb 1921), 22 Nov 1919, Sentrale Bestuur, 46. 
In 1921 is goeie gesondheid tot respektabiliteit toegevoeg.'n Vraag oor die gesondheidstoestand van applikante is tot die aansoekvorm toegevoeg. ${ }^{32}$ Hardwerkendheid is ook hoog geag en het die potensiaal gehad om aan kandidate wat gefouteer het 'n tweede kans te bied. ${ }^{33}$ Die respektabiliteit van suksesvolle applikante is noukeurig gemonitor en die Helpmekaar het remediërend ingegryp indien hulle dit nodig geag het. In Maart 1926 het die sekretaresse aan die sentrale bestuur gerapporteer dat briewe waarin studente oor hul akademiese vordering gerapporteer het in 'n baie meer hoflike trant as voorheen geskryf is en dat sy net nodig gehad het om in een geval die brief aan die sender terug te stuur - in welke geval die student reeds verskoning aangebied het vir die onbeskofte trant van sy brief. ${ }^{34}$ Die sentrale komitee het ook aanbeveel dat takke "'n oog sal hou op die jong mense wat met Helpmekaar-geld ondersteun word". ${ }^{35}$ Daar was ook gevalle waar aan studente 'n tweede kans gebied is om hulself te rehabiliteer en respektabiliteit te herwin. Charl J Jooste van Colesberg wat betrokke was in 'n ongespesifiseerde voorval in Stellenbosch is byvoorbeeld meegedeel "dat wat voorgeval het vir hom as 'n waarskuwing moet dien, ons sal hom genadig wees en hom verder help". ${ }^{36}$

Die voldoening aan Helpmekaar-norme van respektabiliteit was dus 'n voorvereiste vir finansiële ondersteuning en 'n harmonieuse verhouding met die Helpmekaar. 'n Integrale deel van Helpmekaar-retoriek was die behoefte om ekonomies selfversorgende en onafhanklike individue $^{37}$ te skep van wie verwag is om die respektabiliteit waardig van 'n jong Afrikaner wat deur die Helpmekaar ondersteun word te vertoon.

Op administratiewe vlak is ook verskeie beginsels in die post 1918-periode gevestig. Fondse is op 'n jaarlikse basis deur die Kongres bewillig en toegewys. Studente moes elke jaar heraansoek doen om finansiële bystand en voortgesette hulp het afgehang van die kandidaat se akademiese vordering. ${ }^{38}$ Deur middel van 'n sisteem van gereelde terugvoering deur studente is ook gewaak oor die akademiese vordering van studente wat steun ontvang het. In die proses is ook opgetree as tussenganger om die studente te motiveer om hul akademiese vordering

\footnotetext{
32 (HSA) HVKP, Notuleboek (19 Mar 1921-15 Apr 1924), 10 Des 1921, Sentrale Bestuur, 64.

33 (HSA) HVKP, Notuleboek (19 Mar 1921-15 Apr 1924), 15 Okt 1923, Sentrale Bestuur, 215.

34 (HSA) HVKP Notuleboek (21 Mei 1924-3 Apr 1928), 19 Mar 1926, Sentrale Bestuur, 129.

35 (HSA) HVKP, Notuleboek, 7-8 Apr 1926, Kongres, Sentrale Bestuur verslag, 5.

36 (HSA) HVKP, Notuleboek (13 Jun 1928-12 Des 1935), 20 Feb 1929, Sentrale Bestuur, 23.

37 (HSA) HVKP Notuleboek (3 Jul 1916-20 Mei 1919), 1 Feb 1919, Sentrale Bestuur, 142.

$38 \quad$ Ibid., 144.
} 
vol te hou. ${ }^{39}$ Die administratiewe hantering van die aansoekprosedures vir finansiële bystand is ook vereenvoudig toe 'n aansoekvorm vir finansiële bystand deur die sentrale bestuur in Mei 1920 goedgekeur is. ${ }^{40}$ Die voltooide aansoekvorm moes saam met twee getuigskrifte by die sentrale bestuur ingedien word.

Die suksesvolle kandidate moes dan 'n ondertekende skuldbrief vir die bedrag wat hulle ontvang het, indien. Die oordrag van fondse is teruggehou totdat die sentrale bestuur die genoemde skuldbrief ontvang het. Die geld is rentevry aan die studente geleen gedurende die tydperk van studie. Sodra hulle in diens geneem is, is rente teen ses persent per jaar gehef en die student moes die kapitaal begin terugbetaal. Studente en skoliere moes ook gereeld vorderingsverslae oor hul studies indien. ${ }^{41}$ In gevalle waar die Helpmekaar waarborge vir hul kapitaal verlang het, was hulle ten gunste van 'n stelsel van borge. ${ }^{42}$ Hoewel waarborge van sekere studente vereis is vir die lenings aan hulle toegestaan - gewoonlik van hul vaders ${ }^{43}$ was dit aanvanklik nie 'n algemene praktyk nie en waarskynlik net beperk tot gevalle wat as finansieel riskant beskou is.

'n Verdere beginsel van Helpmekaar se finansiële bystand, naamlik dat die geld wat toegeken is slegs vir studiedoeleindes gebruik kon word, is gedurende hierdie tydperk gevestig. Toe Gert Puren, 'n beurshouer wat sy studies in Holland wou voortsit, 'n voorskot op sy beurs aangevra het om 'n deposito te betaal aan Union Castle Line om sy reis na Holland te bespreek, is dit geweier op grond daarvan dat die beurs vir studie- en nie vir reisdoeleindes was nie. Dit het ook die sentrale bestuur aangespoor om die beginsel te aanvaar dat geen geld vooruit aan studente betaal sou word nie, maar dat kandidate kwartaallikse paaiemente sou ontvang. ${ }^{44}$ Nog 'n kenmerk van die Helpmekaar se finansiële bystand wat vroeg reeds gemanifesteer het, was dat vraag altyd aanbod oorskry het met die onvermydelike antwoord aan aansoekers "daar is geen geld meer" nie. ${ }^{45}$

39 (HSA) HVKP, Notuleboek (3 Jul 1916-20 Mei 1919), 1 Feb 1919, Sentrale Bestuur, 143; 5 Apr 1919, Sentrale Bestuur, 165-166.

40 (HSA) HVKP, Notuleboek (28 Jun 1919-19 Feb 1921), 24 Apr 1920, Sentrale Bestuur, 81; 25 Mei 1920, Sentrale Bestuur, 89 .

41 (HSA) HVKP, Notuleboek, 25-26 Mei 1921, Kongres, Sentrale Bestuur verslag, 4; (HSA) HVKP Notuleboek (19 Mar 1921-15 Apr 1924), 27 Aug 1921, Sentrale Bestuur, 40.

42 (HSA) HVKP, Notuleboek (3 Jul 1916-20 Mei 1919), 10 Mei 1919, Sentrale Bestuur, 175.

43 (HSA) HVKP, Notuleboek (28 Jun 1919-19 Feb 1921), 7 Aug 1920, Sentrale Bestuur, 110-111; 4 Sep 1920, Sentrale Bestuur, 121.

44 (HSA) HVKP, Notuleboek (28 Jun 1919-19 Feb 1921), 22 Nov 1919, Sentrale Bestuur, 51-52.

45 (HSA) HVKP, Notuleboek (28 Jun 1919-19 Feb 1921), 7 Feb 1920, Sentrale Bestuur, 69. 


\section{Die Kaapse Helpmekaar}

Die 1923-finansiële jaar is gekenmerk deur die besinning oor en hersiening van die gebruike en administratiewe prosedures rakende die toekenning van lenings en beurse aan studente. Hierdie proses is genoodsaak deur die praktiese ondervinding wat oor die vyf jaar sedert die ontstaan van die stelsel opgedoen is en die feit dat die kongres nog nie voorheen 'n amptelike stel reëls en regulasies aanvaar het nie. Sommige van die sake wat aandag moes kry, was onder andere die frekwensie van betalings deur studente wat besig was om hul lenings terug te betaal, ${ }^{46}$ die agterlosigheid van studente in die terugbesorging van hul skuldbriefbewyse, ${ }^{47}$ studente wat om lenings aansoek doen en wat hul studies by ander instellings as in die Kaapprovinsie wil voortsit, ${ }^{48}$ die groot aantal aansoeke van studente buite die Kaapprovinsie ${ }^{49}$ en studente wat in hul kursusse druip en dan heraansoek doen om lenings. ${ }^{50}$

Teen hierdie agtergrond het die sentrale bestuur 'n komitee aangestel om 'n konsep van reëls en regulasies vir die toekenning en terugbetaling van lenings op te stel. ${ }^{51} \mathrm{Na}$ verskeie voorstelle rakende bogenoemde sake gedurende die kongres ter tafel gelê is, is die volgende aanbevelings van die sentrale bestuur deur die kongres aanvaar: dat die maksimum totale lening aan 'n individu nie $£ 200$ sou oorskry nie; daar na voltooiing van studies 'n rentekoers van ses persent op die leningskapitaal betaalbaar sou wees; 'n lening binne vier jaar na voltooiing van studies betaal moes word ( 'n bepaling wat deur die 1926-kongres herroep is) $;{ }^{52}$ in die aansoek om 'n lening die bestuur ingelig moes word oor (a) of die aansoeker oor enige ander lening beskik het, (b) die bedrag van enige sodanige lening en (c) wanneer, waar en met wie sodanige lening aangegaan is; dat 'n leningsapplikant deur 25 persent van die plaaslike takbestuur aanbeveel moes word; dat suksesvolle applikante een keer per jaar aan die bestuur moes rapporteer; en dat die suksesvolle leningsapplikante na voltooiing van hul studies lede van die Helpmekaar-vereniging moes word en die Vereniging in alle opsigte moontlik moes ondersteun.

Laasgenoemde bepaling het geblyk baie idealisties te wees en ook moeilik of onmoontlik om in die praktyk te implementeer - soos geillustreer in 1936 toe die idee om studente

47 (HSA) HVKP, Notuleboek (19 Mrt 1921-15 Apr 1924), 22 Sep 1922, Sentrale Bestuur, 116.

48 (HSA) HVKP, Notuleboek (19 Mrt 1921-15 Apr 1924), 22 Sep 1922, Sentrale Bestuur, 118-119; 16 Feb 1923 , Sentrale Bestuur, 143.

49 (HSA) HVKP, Notuleboek (19 Mrt 1921-15 Apr 1924), 27 Okt 1922, Sentrale Bestuur, 128-129.

50 (HSA) HVKP, Notuleboek (19 Mrt 1921-15 Apr 1924), 22 Mar 1923, Sentrale Bestuur, 160.

51 (HSA) HVKP, Notuleboek (19 Mrt 1921-15 Apr 1924), 24 Apr 1923, Sentrale Bestuur, 171.

52 (HSA) HVKP, Notuleboek, 7-8 Apr 1926, Kongres, 8-9.
} 
wat Helpmekaar-bystand ontvang het as lede van die Vereniging te werf weer op sentrale bestuursvlak ter sprake gekom het. Op die aansoekvorms vir lenings moes studente aandui of hulle bereid was om lede van die Helpmekaar-vereniging te word - waarop hulle uiteraard almal ingestem het. Die sentrale bestuur was egter in 1936 besluiteloos en onseker oor hoe om studente te hanteer wat versoek het om lede te word nadat hul lenings terugbetaal is. Baie van hulle was nie meer woonagtig in die dorpe waardeur hulle oorspronklik aansoek om lenings gedoen het nie en daar was nie in hul huidige woonplek'n Helpmekaar-tak nie. ${ }^{53}$ Die sentrale bestuur was van mening dat die takke verantwoordelik moes wees om lyste by te hou van studente wat lenings deur' $n$ tak ontvang het en om dit die tak se verantwoordlikheid te maak om hulle as lede van die Vereniging in te skryf nadat hul studies voltooi is.

Die penningmeester het ook in 1936 gesuggereer dat 'n voorstel by die kongres ingedien word dat wanneer 'n student sy/haar jaarlikse ledegeld van 2/6d betaal het die student dan 'n Helpmekaar-lid bly ongeag sy/haar woonplek binne die Unie. ${ }^{54}$ Geen besluite is egter oor die kwessie van studente se lidmaatskap geneem nie en weens die onsekerheid oor die status van studentelede is aansoeke wat wel van studente ontvang is selfs afgekeur. ${ }^{55}$ In 1948 het die hoofbestuur weer besluit om studente by wyse van 'n brief te versoek om lede van die Helpmekaar-vereniging te bly na voltooiing van hul studies en, indien moontlik, selfs 'n bydrae tot die fondse van die Helpmekaar te maak. ${ }^{56}$ Die reaksie op hierdie versoek is egter nie bekend nie.

Rakende studente wat heraansoek gedoen het om 'n lening nadat hulle nie die vorige jaar geslaag het nie, is besluit om sulke gevalle aan die diskresie van die sentrale bestuur oor te laat. ${ }^{57}$ In die 1923-jaarverslag van die sentrale bestuur aan die kongres het die bestuur herbevestig dat die volgende administratiewe prosedures en riglyne gevolg word in die proses van leningsaansoeke en -toekennings: met die uitsondering van spesiale gevalle, word lenings slegs vir een jaar toegeken met die verstandhouding dat, indien verdere bystand benodig word en die bestuur tevrede is met die student se vordering, hy/sy heraansoek kan doen; die bestuur behou die reg om enige lening volgens eie diskresie terug te trek; 'n skuldbrief word

53 (HSA) HVKP, Notuleboek, 30-31 Apr 1937, Sentrale Bestuur verslag, 10.

54 (HSA) HVKP, Notuleboek (15 Apr 1936-6 Des 1939), 25 Jun 1936, Sentrale Bestuur, 174.

55 Ibid., 20 Feb 1937 Sentrale Bestuur, 189.

56 (HSA) HVKP, Notuleboek (8 Feb 1940-9 Des 1966), 1948, 385.

57 (HSA) HVKP, Notuleboek, 25-26 Apr 1923, Kongres, 14. 
vereis vir alle geld wat aan studente betaal is; en die bestuur bly op hoogte van die akademiese vordering van studente deur aan te dring op gereelde verslae oor klas- en skoolwerk. ${ }^{58}$

Die bestuur het ook bevestig dat hy die besluit van die kongres, naamlik dat aansoekers om lenings deur hul plaaslike takke aanbeveel moes word en dat in die toekenning van lenings voorkeur gegee moes word aan studente vanaf plekke waar daar takke bestaan, streng toepas. ${ }^{59}$

Die laasgenoemde kwessie het nie eksplisiet verwys na leningsaansoeke vanaf buite die Kaapprovinsie nie, maar dit het die praktyk van die sentrale bestuur om aansoeke vanaf die Transvaal, Oranje-Vrystaat en Natal na die ooreenstemmende provinsiale Helpmekaarverenigings te verwys, bevestig. ${ }^{60}$ Hoewel hierdie praktyk die provinsialisme van die Helpmekaar se finansiële steun en hulp versterk het, was daar 'n mate van sensitiwiteit in die geledere van die sentrale bestuur dat provinsialisme nie te ver gevoer word nie. In hierdie gees is die praktyk om nie lenings toe te staan nie aan studente van die Kaapprovinsie wat aan instellings buite die Kaapprovinsie studeer, afgeskaf. ${ }^{61}$ Weens die groot aanvraag na lenings en die konstante gebrek aan kapitaal was die praktiese implikasies van hierdie bepalings dat Helpmekaar-lenings die voorreg van die inwoners van daardie distrikte en dorpe geword het wat deur 'n plaaslike Helpmekaar-tak bedien is. ${ }^{62}$

'n Tendens wat ook die eerste keer tydens die 1923-kongres gemanifesteer het, was die afkeer van die fokus wat die Helpmekaar tot dan gehad het om hoofsaaklik handelstudente te steun wat hul studies aan oorsese universiteite en instellings wou voortsit. 'n Resolusie is aanvaar dat meer geld verkieslik bestee word aan die "gesonke gedeelte van ons volk" as aan beurse vir studente wat oorsee studeer. ${ }^{63}$ Hierdie verwikkeling kon die gevolg wees van die groeiende

58 (HSA) HVKP, Notuleboek, 15-17 Apr 1924, Kongres, Sentrale Bestuur verslag, 5.

59 (HSA) HVKP, Notuleboek, 25-26 Apr 1923, Kongres, Sentrale Bestuur verslag, 6.

60 (HSA) HVKP, Notuleboek (19 Mrt 1921-15 Apr 1924), 27 Okt 1922, Sentrale Bestuur, 128-129.

61 (HSA) HVKP, Notuleboek (19 Mrt 1921-15 Apr 1924), 24 Apr 1923, Sentrale Bestuur, 171-172.

62 In kontras met die neiging tot eksklusiwiteit is die 1923-kongres deur die Burgersdorp-tak versoek om artikel 2(b) van die Helpmekaar-grondwet, wat bepaal het dat Helpmekaar-aktiwiteite en ondersteuning op die Hollandssprekende deel van die Suid-Afrikaanse volk moes fokus, te interpreteer. Die resolusie het gelei tot 'n voorstel dat versoeke vir ondersteuning vanaf Engelssprekende persone aan die diskresie van die sentrale bestuur oorgelaat word. Hoewel 'n amendement, dat die grondwet onveranderd gelaat word, uiteindelik aanvaar is, het die resolusie gedui op 'n inklusiwiteit wat progressief was vir die tydsgewrig. Terwyl sekere Afrikaners op 'n geografiese en klassebasis van Helpmekaar-hulp uitgesluit is, was daar in die vroeë 1920's ten minste 'n groepering binne die Helpmekaar wat bereid was om die deure van die organisasie vir Engelssprekendes oop te maak.

63 (HSA) HVKP, Notuleboek, 25-26 Apr 1923, Kongres, 13. 
prominensie van die armblankevraagstuk in die openbare gesprekvoering, soos dit ook binne Helpmekaar-geledere gemanifesteer het.

Wat die terugbetaling van lenings betref, het die sentrale bestuur in sy besinning oor die studieleningstelsel tydens die 1924-kongres aangedui dat, met die uitsondering van 'n paar probleemgevalle, die terugbetaling prysenswaardig was. In sommige gevalle is lenings binne 'n jaar terugbetaal en selfs binne die eerste termyn na voltooiing van studies. Die damestudente het ook ' $\mathrm{n}$ beter terugbetalingsrekord as die manstudente gehandhaaf. ${ }^{64}$ Ten spyte van die algemeen positiewe ervaring van die Helpmekaar tydens die eerste jare van sy studieleningstelsel - 'n ervaring wat 'n Helpmekaarnorm sou bly vir die duur van sy bestaan - was oninbare skulde ook deel van die realiteit van die stelsel.

Die eerste onderhandelinge met studente het ook getoon dat, hoewel die sentrale bestuur baie tegemoetkomend was teenoor studente, hulle ook bereid was om regsprosedures teen studente in te stel ten einde Helpmekaar-geld terug te kry waar studente nie hul deel van die ooreenkoms nagekom het nie. ${ }^{65}$ Hierdie benadering sou deurgaans deur die kongresperiode deel bly van Helpmekaar-metodiek. Gedurende die 1927-kongresjaar is amptelike rekeningstate die eerste keer gedruk om aan studente wat geld aan die Helpmekaar skuld te stuur. ${ }^{66}$ Gedurende die 1928-kongresjaar het dit onvermydelik geraak dat hulle as laaste uitweg moes begin om studente te dagvaar om verskuldigde geld terug te kry. ${ }^{67}$ Vir ene JH Barnard van De Aar het die proses selfs tot tronkstraf gelei. Hy is egter vrygelaat nadat van sy vriende sy boete betaal het. ${ }^{68}$ Hierdie werkswyse het resultate gelewer, aangesien die agt oudstudente wat in 1933 aan prokureurs oorhandig is daarna hul skulde in paaiemente begin terugbetaal het. ${ }^{69}$ In 1931 het die sentrale bestuur besluit om nie langer studente te akkommodeer wat hul aanvanklike studie voltooi het en dan na 'n jaar of twee teruggekeer het om hul studies voort te sit, met die versoek dat die rente betaalbaar op hul lenings vir die tydperk van hul verlengde studies kwytgeskeld word nie. ${ }^{70}$

64 (HSA) HVKP, Notuleboek, 15-17 Apr 1924, Kongres, Sentrale Bestuur, 5.

65 (HSA) HVKP, Notuleboek (28 Jun 1919-19 Feb 1921), 7 Feb 1920, Sentrale Bestuur, 75; 24 Apr 1920 Sentrale Bestuur, 80-81; 25 Mei 1920, Sentrale Bestuur, 88.

66 (HSA) HVKP, Notuleboek (21 Mei 1924-3 Apr 1928), 12 Mei 1926, Sentrale Bestuur, 140.

67 (HSA) HVKP, Notuleboek (21 Mei 1924-3 Apr 1928), 2 Nov 1927, Sentrale Bestuur, 198-199; 14 Des 1927, Sentrale Bestuur, 207.

(HSA) HVKP, Notuleboek (21 Mei 1924-3 Apr 1928), 3 Apr 1928, Sentrale Bestuur, 232.

70 (HSA) HVKP, Notuleboek (13 Jun 1928-12 Des 1935), 7 Apr 1931, Sentrale Bestuur, 80. 


\section{Die Kaapse Helpmekaar}

Teen 1934 was daar 'n beduidende verbetering in die terugbetaling van lenings. Hierdie verbetering is toegeskryf aan die groter gereeldheid van kontak en korrespondensie met studente en die bevordering onder studente van 'n stelsel van maandelikse paaiemente vir die terugbetaling van lenings (beskikbare bewyse suggereer dat dit waarskynlik in 1933 begin is) in plaas van die kwartaallikse terugbetalings. Hoewel hierdie stelsel 'n groter administratiewe werkslading tot gevolg gehad het, het die fondse wat vir addisionele administratiewe ondersteuning aan die sekretaresse bewillig is haar in staat gestel om die verhoogde werkslas te hanteer. ${ }^{71}$ Die algemene ekonomiese herstel na die depressiejare van die vroeë dertigs was waarskynlik ook'n faktor in die verbetering van terugbetalings.

Die kwessie van versekeringspolisse vir studente vir die duur van hul studies, om die Helpmekaar te vrywaar van enige verliese in die geval van die afsterwe van ' $n$ student, is die eerste keer in 1934 deur die sentrale bestuur ondersoek. In reaksie op die dood van SPB Buys, ' $n$ Helpmekaar-student wat nie lewensversekering gehad het nie en wat nie 'n boedel nagelaat het nie, is die Sekretaris opdrag gegee om inligting in hierdie verband van versekeringsmaatskappye te bekom en aan die sentrale bestuur verslag te doen. ${ }^{72}$ Gedurende

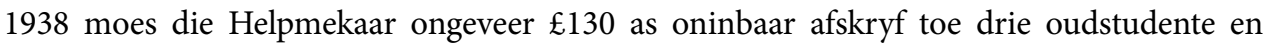
een huidige student gesterf het en hul uitstaande skuld nie ingevorder kon word nie. Teen hierdie agtergrond het die kongres 'n voorstel aanvaar wat die sentrale bestuur opdrag gegee het om die kwessie van versekering en borg vir studielenings te ondersoek en by die volgende kongres daaroor terugvoering te gee. ${ }^{73}$ In beide bogenoemde gevalle was daar geen verdere verwysings na die uitslag van die ondersoeke nie, en moes aanvaar word dat versekeringspolisse vir studente nie geïmplimenteer gaan word nie.

In 1942 is gyseling (tronkstraf vir uitstaande skuld) in Suid-Afrika afgeskaf. Dit het die raadsaamheid van die uitreik van dagvaardings aan studente wat die Helpmekaar geld geskuld het, bevraagteken. ${ }^{74}$ Die jaar 1943 is gekenmerk deur die afskryf van meer as die gewone kwota oninbare skuld. By hul vergadering in Desember het die hoofbestuur besluit om rekeninge ter waarde van $£ 1023$ as oninbaar af te skryf. Dit het die hoofbestuur gedwing om wyses te bespreek waarop hierdie verliese in die toekoms verhoed sou kon word.

71 (HSA) HVKP, Notuleboek, 3-4 Apr 1934, Kongres, Sentrale Bestuur verslag, 3; (HSA) HVKP, Notuleboek (13 Jun 1928-12 Des 1935), 7 Jul 1932, Sentrale Bestuur, 94; 7 Jun 1933, Sentrale Bestuur, 115; 26 Okt 1933, Sentrale Bestuur, 126; (HSA) HVKP, Notuleboek, 23-24 Apr 1935, Kongres, Sentrale Bestuur verslag, 4.

72 (HSA) HVKP, Notuleboek (13 Jun 1928-12 Des 1935), 14 Feb 1934, Sentrale Komitee, 132.

73 (HSA) HVKP, Notuleboek, 12-13 Apr 1939, Kongres, Sentrale Komitee verslag, 2.

74 (HSA) HVKP, Notuleboek (8 Feb 1940-9 Des 1966), 2-3 Des 1942, Hoofbestuur, 280. 
Hoewel geen definitiewe nuwe regulasies ingestel is nie, is besluit om takke in die algemeen te maan om versigtiger te wees met hulle aanbevelings van nuwe aansoeke/studente en dat die plaaslike takkomitees dit as een van hul verantwoordelikhede sou sien om in kontak te bly met studente wat lenings ontvang het. ${ }^{75}$

Die neiging tot oninbare skulde is in 1945 voortgesit toe $£ 800$ by die hoofbestuur se vergadering in November as oninbaar afgeskryf is. ${ }^{76}$ Die Wet op Landdroshowe 32 van $1944^{77}$ wat in 1945 van krag geword het, het dit moontlik gemaak om skuldenaars voor die landdros te daag sodat vasgestel kon word of 'n skuldenaar in staat was om sy skuld te delg. As die landdros van mening was dat die skuldenaar in staat was om te betaal, kon hy die skuldenaar se werkgewer opdrag gee om geld van die skuldige se salaris af te trek en dit direk aan die eiser te betaal. ${ }^{78}$ Die vraagstuk oor onbetaalde skuld het 'n uitdaging gebly en by die 1947-kongres het die hoofbestuur besorgd verslag gedoen dat 43.5 persent van die geld van die Hooffonds wat aan studente geleen is uitstaande was. Uitstaande studielenings het op 31 Desember 1946 $£ 21500$ beloop. Die hoofbestuur het dit as 'n dringende noodsaaklikheid beklemtoon dat takkomitees meer ondersteunend moes word in die opspoor van wanbetalers en om hulle aan te moedig om hul verpligtinge na te kom.

In die bespreking van onbetaalde skuld het die penningmeester bevestig dat skuldenaars soms verdwyn het en nie opgespoor kon word nie en dat onbetaalde skuld wel elke drie jaar as oninbaar afgeskryf is. Daar was egter'n stel prosedures wat gevolg is om agterstallige skuld in te vorder, maar wetlike prosedures is eers ingestel "as selfs op die blou aanmaning nie gereageer word nie". ${ }^{79}$ Ten spyte van die noodsaaklike maatreëls wat oor tyd geïmplementeer is om oninbare skulde te hanteer, was dit die getroue terugbetaling deur die meerderheid studente en nie die wanbetalers nie wat die Helpmekaar se ervaring oorheers het.

\footnotetext{
75 (HSA) HVKP, Notuleboek (8 Feb 1940-9 Des 1966), 1-2 Des 1943, Hoofbestuur, 299.

76 (HSA) HVKP, Notuleboek (8 Feb 1940-9 Des 1966), 14-15 Nov 1945, Hoofbestuur, 338.

77 https://store.lexisnexis.co.za/categories/products/butterworths-wetgewingsdiens-wet-op- landdroshowe32-van1944-skuZASKU060BWDLANDSYS/details

78 (HSA) HVKP, Notuleboek (8 Feb 1940-9 Des 1966), 14-15 Nov 1945, Hoofbestuur, 339.

79 (HSA) HVKP, Notuleboek, 3-4 Apr 1947, Kongres, Hoofbestuur verslag, 1-2, 6.
} 


\section{TOEGANG TOT HELPMEKAAR-HULPBRONNE - DIE BEWEGING NA EKSKLUSIWITEIT: "N LAER BINNE 'N LAER}

Teen die vroeë 1920's was die basiese model vir die Helpmekaar-studenteleningstelsel gevestig en hoewel klein aanpassings soms gemaak is, het dit deur die kongresperiode deurgaans dieselfde gebly. Sekere aspekte van die stelsel was egter meer aanvegbaar en het deurlopend debatte ontlok. Een van hierdie aspekte wat vroeg reeds gemanifesteer het, was toegang tot Helpmekaar-bronne. Hoewel nie verteenwoordigend van die totale aantal lenings wat oor die voorafgaande ongeveer dekade toegeken is nie, het die lenings wat vir 1927 toegestaan is twee duidelike tendense getoon wat deur die loop van die Helpmekaar se bestaan geldig sou bly. Die eerste tendens was dat die meeste lenings aan mans toegeken is (76 aan mans en 30 aan vroue) en dat tweedens Stellenbosch as plek van studie die voorkeur van die meeste leningshouers was (51 van die 106 studente). ${ }^{80}$

Toegang tot Helpmekaar-studentelenings het geneig om mettertyd meer eksklusief en uitsluitend te word met Helpmekaar-lidmaatskap wat uiteindelik deurslaggewend vir 'n aansoeker se kanse op sukses geword het. Die eerste stap in hierdie rigting was die kanalisering van leningsaansoeke deur die takke in 1921, en die hekwagterrol wat Helpmekaar-takke verkry het, sowel as die bevestiging dat slegs aansoeke vanuit die Kaapprovinsie oorweeg sou word.

Gedurende die 1923/24-finansiële jaar is die eksklusiwiteit van toegang tot Helpmekaarlenings 'n stappie verder gevoer. In Desember 1923 het die sentrale bestuur besluit om 'n vraag by te voeg tot die aansoekvorm, waar aansoekers moes invul of hul ouers lede van die Helpmekaar-vereniging was. ${ }^{81}$ Die impak van hierdie inligting is gedurende die 1924-kongres geformaliseer met die aanvaarding van 'n voorstel dat daar in die toekoms voorkeur gegee sou word aan studente wie se ouers of voogde lede en ondersteuners van die Helpmekaar was. ${ }^{82}$ Hierdie bepaling is daarna periodiek tot in die laat veertigerjare bevestig en kinders van nielede het slegs 'n geringe kans gehad om 'n lening te bekom..$^{83}$

Die reikwydte van moontlike aansoekers vir lenings is verder beperk met die aanvaarding van 'n besluit deur die kongres dat skoliere slegs vanaf standerd ses vir lenings kon aansoek

\footnotetext{
80 (HSA) HVKP, Notuleboek, 4-5 Apr 1928, Kongres, Sentrale Bestuur verslag, 5.

81 (HSA) HVKP, Notuleboek (19 Mrt 1921-15 Apr 1924), 3 Des 1923, Sentrale Bestuur, 237.

82 (HSA) HVKP, Notuleboek, 15-17 Apr 1924, Kongres, 10.

83 (HSA) HVKP, Notuleboek (8 Feb 1940-9 Des 1966), 12-13 Nov 1947, Hoofbestuur, 373.
} 
doen. ${ }^{84}$ Die bepaling was 'n aanduiding van die groeiende wedywering om Helpmekaarbronne en die toenemende magsposisie waarin Helpmekaar-takke hulself bevind het. Hierdie posisie is deur die 1924-verslag van die sentrale bestuur bevestig waarin dit gestel is dat so baie aansoeke van Helpmekaar-takke ontvang is dat daar geen kans was om enigiemand te help wat nie aan die Helpmekaar behoort het nie. ${ }^{85}$ In 1925 is die insette van die takke in die toewysingsproses verder versterk toe hulle deur die sentrale bestuur versoek is om hul aansoeke by wyse van voorkeur te gradeer wanneer meer as een aansoek ingedien word. ${ }^{86}$

'n Aanduiding dat die wedywering om bronne ook oor 'n intra-tak element beskik het en dat takke 'n behoefte gehad het om hulself daarteen te beskerm, is die besluit deur die 1924-kongres geneem dat die penningmeester ook moes aandui van watter dorp suksesvolle leningsaansoekers afkomstig was. ${ }^{87}$ Hierdie was 'n byvoeging tot 'n besluit wat by die 1923-kongres geneem is dat daar in die toekoms 'n jaarlikse lys met name en bedrae van suksesvolle leningskandidate in die notule van die kongres opgeneem word. ${ }^{88}$ Klagtes is van verskeie takke ontvang dat hulle nie hul regmatige deel aan lenings wat toegewys is, ontvang het nie. Die sentrale bestuur het egter statisties bewys dat in die meeste gevalle die takke meer as hul kwota ontvang het, as die beskikbare geld in ag geneem is. ${ }^{89}$

Die hele debat oor voorkeurbehandeling in die toewysing van lenings is by die 1926-kongres herbesoek. Een voorstel het gesuggereer dat in die toewysing van nuwe lenings voorkeur gegee moes word aan: applikante wat deur die tak aanbeveel is waaronder die applikant ressorteer; takke wat voldoen het aan hul finansiële verpligtinge deurdat hulle 'n derde van hul jaarlikse inkomste in die skatkis van die sentrale bestuur gestort het; en kandidate wat oor 'n matrieksertifikaat beskik het. Die voorstel is aanvaar met die uitsondering van die laaste kategorie wat as onprakties beskou is..$^{90}$ Wat nuut was omtrent die aanvaarde voorstel was dat

84 (HSA) HVKP, Notuleboek, 15-17 Apr 1924, Kongres, 10.

85 (HSA) HVKP, Notuleboek, 15-17 Apr 1924, Kongres, Sentrale Bestuur verslag, 5; Gemiddeld kon tussen 30-50 persent van die aansoekers wat deur takke aanbeveel is lenings ontvang uit die jaarlikse beskikbare fondse. Dit het beteken dat aansoekers sonder 'n takaanbeveling geen kans gestaan het om gehelp te word nie. (HSA) HVKP, Notuleboek (21 Mei 1924-3 Apr 1928), 3 Des 1925, Sentrale Bestuur, 111.

(HSA) HVKP, Notuleboek (21 Mei 1924-3 Apr 1928), 3 Des 1925, Sentrale Bestuur, 115.

(HSA) HVKP, Notuleboek, 27-28 Mar 1940, Kongres, Sentrale Bestuur verslag, 3-4. In 1939 het die sentrale bestuur byvoorbeeld oor $£ 3456$ beskik om lenings mee toe te ken. Verdeel tussen die 38 takke het dit neergekom op 'n kwota van $£ 91$ per tak. Die tak wat oor die aandeel wat aan hulle toegeken is, gekla het, het $£ 176$ ontvang - byna twee maal soveel as die kwota. 


\section{Die Kaapse Helpmekaar}

dit die eerste keer was dat die mate van die nakoming van die takke se finansiële verpligtinge aan die sentrale bestuur ter sprake was in die toewysingsproses.

In die praktyk het dit daarop neergekom dat die aansoekers vanaf onaktiewe takke gepenaliseer sou word. Die enigste manier waarop takke dit kon verhoed, was om nuwe Helpmekaarkapitaal te help genereer en medewerkers te word in plaas daarvan om slegs die bestaande Helpmekaar-bronne te onttrek en te gebruik. Die verwerping van die matrieksertifikaatbepaling was waarskynlik'n aanduiding van die algemene vlak van opvoeding van Afrikaners in die twintigerjare. 'n Voorwaarde van 'n matriekkwalifikasie sou te veel jong, behoeftige skoliere van tussen standerd ses en matriek uitsluit. In 1925 was slegs 14 persent van die skoliere aan sekondêre skole in die Kaapprovinsie in matriek ${ }^{91}$ en hulle het dan sonder Helpmekaar-bystand 'n goeie kans gestaan om deel te word van die armblankevraagstuk, iets wat die Helpmekaar ten alle koste wou probeer voorkom. Hierdie veronderstelling is onderstreep deur die aanvaarding van 'n aanbeveling van die kongres dat aansoeke om lenings deur kandidate wat weens hul behoeftige finansiële omstandighede gedwing is om in te skryf vir korter kursusse as graadkursusse, en sodoende uitgesluit was van finansiële bystand deur universiteite, spesiale oorweging van die Helpmekaar moes geniet. ${ }^{92}$

Gedurende die 1927-kongres het die sentrale bestuur ook beslis oor finansiële bystand aan Engelssprekende skoliere. In antwoord op 'n versoek wat van die Beaufort-Wes-tak in hierdie verband ontvang is, het die sentrale bestuur beslis dat lenings aan sulke skoliere toegewys sou word indien hul ouers lede van die Helpmekaar was. ${ }^{93}$ Hierdie beslissing het lidmaatskap aan die Helpmekaar verhef tot 'n belangriker kwalifikasie in die toewysing van finansiële bystand as die Helpmekaar-grondwetbepaling van bystand slegs aan die Hollandssprekende deel van die Suid-Afrikaanse "volk". Gedurende die 1927-kongres het die rol van die takke in die leningstoewysings ook weer onder die soeklig gekom. Die sentrale bestuur het die takke gekritiseer dat hulle nie altyd die korrekte prosedures, soos voorgeskryf deur kongresbesluite, gevolg het nie. Die sentrale bestuur het gevolglik daarop aangedring dat alle aansoeke in die toekoms deeglik deur die plaaslike komitees gekeur moes word voordat dit by die sentrale bestuur ingedien sou word.

In die keuringsproses moes hulle seker maak dat die aansoek deur die voorgeskrewe kworum onderteken is en dat die bedrae waarvoor aansoek gedoen is redelik en in ooreenstemming

\footnotetext{
91 JT de Witt, dr WJ Viljoen as onderwyshoof van Kaapland, 1918-1929, 338. PhD in Opvoedkunde, US, 1973.

92 (HSA) HVKP, Notuleboek, 7-8 Apr 1926, Kongres, 9.

93 (HSA) HVKP, Notuleboek (21 Mei 1924-3 Apr 1928), 26 Nov 1926, Sentrale Bestuur, 161.
} 
met die werklike behoeftes van die aansoeker was. ${ }^{94}$ Die takke het egter ook hulle irritasies gehad. Hulle voorstel is aanvaar dat die sentrale bestuur die toewysing van lenings jaarliks voor die einde van Desember moes afhandel en nie eers in die eerste week van Februarie nie. Takke het ook versoek dat hulle in kennis gestel moes word daarvan of hul leningsaansoeke suksesvol was. 'n Poging deur die takke om die geld vir suksesvolle applikante wat aan plaaslike instellings gestudeer het (hoofsaaklik skoliere aan plaaslike skole) deur die penningmeester van die plaaslike tak te kanaliseer in plaas daarvan dat dit direk aan die applikant betaal word, het gelei tot 'n konfrontasie tussen die bestuur se penningmeester, adv Roux, en die ondersteuners van die voorstel. Ten spyte daarvan dat Roux die voorstel teengestaan het, is dit aanvanklik deur die kongres aanvaar, maar later teruggetrek ná 'n reses van 15 minute gevolg deur 'n onbestrede mosie deur Roux dat die voorstel verwerp word. ${ }^{95}$

Gedurende die 1932-kongres is die eksklusiwiteit van Helpmekaar-bystand verder gevoer toe 'n voorstel aanvaar is dat geen lenings aan skoliere wat aan Katolieke skole studeer het, toegestaan sou word nie. Die verdeling van stemme in 12 ten gunste van die voorstel en agt daarteen was 'n aanduiding dat 'n beduidende deel van die kongreslede ongemaklik was met hierdie besluit. ${ }^{96}$ Die ongemak waarmee die kwessie van geloof as voorwaarde hanteer is, is in 1947 bevestig met 'n versoek van die Vryburg-tak dat die kongres leiding moes gee oor die kwessie van geloof as kriterium in die toewysing van lenings. Hoewel die punt deur die Vryburg-verteenwoordiger ter sprake gebring is, is die saak sonder enige verdere bespreking laat vaar. ${ }^{97}$

Teen die tweede helfte van die dertigerjare was dit duidelik dat daar veral vanuit die geledere van die Kaapse Skiereiland-tak van die Helpmekaar teenstand teen die toekenning van Helpmekaar-studielenings slegs aan lede van die Helpmekaar bestaan het. Tydens die 1936-kongres het die tak voorgestel dat die gebruik herroep moes word. Hoewel die kwessie laat vaar is na 'n verduideliking deur adv Roux ${ }^{98}$ het die 1937-kongres die opponerende denkrigtings oor die kwessie bevestig. Enersyds is voorstelle aanvaar wat die eksklusiwiteit van toegang verhoog het deur byvoorbeeld die byvoeging van die vraag op die aansoekvorm oor die duur van Helpmekaar-lidmaatskap van die ouers van 'n applikant. 'n Tweede voorstel was dat hierdie inligting as kriterium in die toewysing van lenings gebruik moes word. Dit is

94 (HSA) HVKP, Notuleboek, 13-14 Apr 1927, Kongres, Sentrale Bestuur verslag, 3-4.

95 (HSA) HVKP, Notuleboek, 13-14 Apr 1927, Kongres, 5, 6.

96 (HSA) HVKP, Notuleboek, 30 Mrt 1932, Kongres, 5.

97 (HSA) HVKP, Notuleboek, 2-3 Apr 1947, Kongres, 9.

$98 \quad$ Ibid., 11. 


\section{Die Kaapse Helpmekaar}

verwerp. Dit kan egter met redelikheid aanvaar word dat in gevalle van applikante met gelyke meriete, hierdie inligting waarskynlik as deurslaggewende faktor gebruik is. Verder is die prestasie van takke oorweeg as kriterium in die toewysing van lenings deurdat die nakoming van hul finansiële verpligtinge aan die sentrale bestuur, asook hul algemene prestasie en bydrae in ag geneem is.

In kontras met die neiging om toegang tot Helpmekaar se opvoedkundige steun te beperk tot Helpmekaar-lidmaatskap en die takstelsel, het nege lede van die Kaapse Skiereiland-tak die kongres versoek om slegs die meriete van Afrikaanssprekende applikante as kriterium, ongeag hul ouers se lidmaatskap, in die toewysingsproses te oorweeg. Helpmekaar-lidmaatskap kon slegs as kriterium gebruik word om tussen twee applikante met gelyke meriete te onderskei. $\mathrm{Na}$ 'n bespreking is besluit om die saak nie verder te voer nie. ${ }^{99}$ Ten spyte van die besluit was dit nie die einde van die debat nie.

Die 1939-kongres het ook 'n voorstel deur dr Albertyn, verteenwoordiger van die Kaapse Skiereiland-tak en latere voorsitter van die Helpmekaar, goedgekeur wat aangedring het op meer inligting oor die finansiële posisie van ouers wat om lenings vir hul kinders aansoek gedoen het. In die toekoms moes hulle hul jaarlikse inkomste verstrek, die bedrag wat hulle aan ander kinders in die gesin bestee het, hoeveel van hul ander kinders lenings of beurse ontvang het en die waarde van sodanige beurse of lenings. ${ }^{100}$ Die kongres het ook die hoofbestuur versoek om die plaaslike komitees te voorsien van riglyne waarvolgens hulle die leningsaansoeke volgens meriete kon rangskik. Daar is ook besluit dat takke elke kandidaat se leningsaanbeveling moes motiveer. ${ }^{101}$

Voorstelle is ook deur kongreslede bespreek waardeur die akademiese vordering en morele gedrag van studente wat aansoek gedoen het om hul Helpmekaar-lenings te hernu strenger gemonitor kon word, ten einde seker te maak dat hulle steeds waardig was om Helpmekaarsteun te ontvang. 'n Komitee wat gedurende die 1941-kongres aangestel is om met praktiese voorstelle vorendag te kom het die ingebruikneming van twee nuwe vorms in hierdie verband aanbeveel. Met die doel om die akademiese vordering van 'n student te monitor, moes 'n vorm twee keer per jaar deur die hoof van die opvoedkundige instelling waar die student ingeskryf was, voltooi word waarin verslag gedoen moes word oor die kandidaat se akademiese prestasie en klasbywoning. Aanbevelings moes gemaak word oor of die student se vordering voortgesette finansiële steun verdien het. Om die kandidaat se "matigheid" en

99 (HSA) HVKP, Notuleboek, 30-31 Apr 1937, Kongres, 12, 13.

100 (HSA) HVKP, Notuleboek, 12-13 Apr 1939, Kongres, 12.

101 (HSA) HVKP, Notuleboek, 27-28 Mrt 1940, Kongres, 6. 
goeie gedrag te monitor is voorgestel dat 'n vorm jaarliks deur die plaaslike predikant voltooi moes word waarin hy kommentaar moes lewer of getuig oor die student se matigheid (Is die student spaarsamig en bestee hy/sy geld in alle opsigte na behore?) en gedrag (Is hy/sy onberispelik in karakter en gedrag?). Die predikant moes ook 'n aanbeveling maak oor of die kandidaat se lewenswyse voortgesette finansiële steun verdien het. Hoewel geen besluit geneem is nie het die kongres die aanbevelings van die komitee na die hoofbestuur verwys. ${ }^{102}$

Die saak oor toegang tot Helpmekaar-lenings het weer ter sprake gekom by die 1941-kongres en sommige van die voorstelle het die groeiende verstedeliking van Afrikaners en die veranderende vestigingspatrone en klasseverskille wat deur hierdie geografiese mobiliteit teweeggebring is, weerspieël. 'n Voorstel is ter tafel gelê wat die hoofbestuur versoek het om 'n groter kwota lenings aan stedelike Helpmekaar-takke toe te wys op grond van hul bevolkingsdigtheid en strategiese posisies. Daar is besluit om hierdie voorstel na die hoofbestuur te verwys. ${ }^{103}$ Dit was ook 'n rede tot kommer vir die Helpmekaar-leierskap in die 1940's. In sy voorsittersrede tydens die 1940-kongres in die Paarl het FX Roome die pleidooie van die SGO, prof MC Botha, herhaal dat die vakskool/ambagskool sy plek naas die akademiese skool moes inneem sonder om as minderwaardig beskou te word. Roome was egter van mening dat nie almal in die Afrikanergemeenskap die siening deel nie en het 'n beroep gedoen op 'n terugkeer na die "klaslose" omgang van die verlede:

“Hierdie minderwaardigheidsbeskouing wat 'n ambag betref, het 'n nadelige invloed op ons seuns en dogters waar hulle die keuse van 'n lewensberoep moet doen. Die mark vir professies word oorlaai, terwyl die mark vir ambagte in gebreke bly. Die gebrek aan geskoolde, deeglik afgerigte vakmense onder ons Afrikaners is oorsaak van veel van die armoede en ellende onder ons. Vreemdelinge van elders neem die plek in van wat ons moet volgestaan het. Selfs die naturel wedywer, en dit met sukses, op byna elke gebied met die witman en die wit vrou, met die gevolg dat die ongeskoolde blanke die pos van "Klaas" in plaas van "Baas" beklee ... Jare gelede was die Perel een groot werkswinkel van Afrikaners. Om op 'n ambag te werk het die Afrikanergemeenskap nie as iets vernederend beskou nie. Smids, wamakers, timmermans, skilders, looiers, tuiemakers, kuipers, winkeliers, snyers, kleremaaksters, was almal Afrikaners, en van vooraanstaande families, beide seuns en dogters. Na die arbeid van die dag het die jongmense in verskillende familiekringe vir vermaak en ontspanning bymekaargekom, en het mekaar onderling op musiek vergas ... In die gesellige kringe het jy aangetref die ambagsman, die bankklerk, die siviele amptenaar, die onderwyser, en andere. Niks van die ploertigheid (snobbery) van ons tyd nie."104

102 (HSA) HVKP, Notuleboek, 27-28 Mrt 1941, Kongres, 12-13.

103 (HSA) HVKP, Notuleboek, 16-17 Apr 1941, Kongres, 13.

104 (HSA) HVKP, Notuleboek, 27-28 Mrt 1940, Kongres, Voorsittersrede, 10. 


\section{Die Kaapse Helpmekaar}

Roome se pleidooi was waarskynlik'n aanduiding van die mate waarin Afrikaners toenemend respektabiliteit met die verwerwing van 'n tersiêre akademiese kwalifikasie vereenselwig het. Dit was waarskynlik vanweë 'n persepsie dat die tipe kwalifikasie gunstiger resultate in terme van finansiële en sosiale mobiliteit verseker het.

'n Voorstel dat die kongres moes beslis oor die stand van lidmaatskap van 'n persoon wat verhuis vanaf 'n dorp met 'n Helpmekaar-tak na een sonder 'n tak is ook na die hoofbestuur verwys. Die kongres het ook 'n voorstel aanvaar dat takke aansoeke van mondige applikante aanbeveel en dat dit oorweeg sou word as die applikante self minstens een jaar lank al lede van die Helpmekaar was, ongeag of hul ouers lede van die Helpmekaar was. ${ }^{105}$ Hoewel dit nie by die 1941-kongres bespreek is nie, is 'n voorstel weer deur die Kaapse Skiereiland-tak na die kongres verwys om applikante te akkommodeer wat nie lede van die Helpmekaar was nie. In hierdie weergawe het hulle voorgestel dat 'n sekere bedrag geld jaarliks beskikbaar gestel moes word vir uitsonderlik verdienstelike kinders van nie-lede. Geen aanduiding is egter in die notule gegee waarom die voorstel nie bespreek is nie. ${ }^{106}$

Die kwessie oor die toewysing van lenings aan studente om oorsee te studeer het in 1946 ter sprake gekom toe mev De Bruyn, 'n lid van die hoofbestuur, versoek het dat die bestuur sy standpunt in hierdie verband moes stel. Mnr Siebrits, ook 'n lid van die hoofbestuur, het voorgestel dat in die toewysing van lenings voorkeur gegee moes word aan studente wat aan Afrikaanse universiteite studeer en dat aansoeke vir oorsese studies op meriete behandel moes word. Die saak is deur die hoofbestuur bespreek, maar geen besluit is geneem nie en dit is na die kongres verwys. ${ }^{107}$ By die 1946-kongres het mev De Bruyn 'n mosie ingedien wat gelui het dat die Helpmekaar ook lenings aan verdienstelike studente toewys vir oorsese studies aan universiteite en opvoedkundige instellings wat deur die Helpmekaar goedgekeur is. In hierdie weergawe was daar nie sprake van Suid-Afrikaanse of Afrikaanse universiteite nie, wat vertolk kan word as 'n aanduiding dat De Bruyn sterk ten gunste was van steun aan studente wat oorsee studeer en nie 'n isolerende/nasionalistiese aanslag in hierdie verband gehad het nie. In 'n wysiging het Siebrits voorgestel dat:

"Hierdie kongres dit as beleid bevestig dat lenings vanuit Helpmekaarfondse toegewys moet word aan studente wat aan Suid-Afrikaanse universiteite en instellings studeer en dat aansoeke vir oorsese studies volgens meriete behandel word." ${ }^{108}$

\footnotetext{
105 (HSA) HVKP, Notuleboek, 16-17 Apr 1941, Kongres, 13.

106 (HSA) HVKP, Notuleboek, 16-17 Apr 1941, Kongres, 14.

107 (HSA) HVKP, Notuleboek (8 Feb 1940-9 Des 1966), 3 Apr 1946, Hoofbestuur, 349.

108 (HSA) HVKP, Notuleboek, 3-4 Apr 1946, Kongres, 7, 14.
} 
Die Siebrits-wysiging, wat eenparig aanvaar is nadat De Bruyn haar aanvanklike voorstel teruggetrek het, was meer omvattend as die een wat Siebrits aanvanklik in die hoofbestuur gepropageer het in dié opsig dat dit na Suid-Afrikaanse, en nie slegs Afrikaanse, universiteite verwys het nie. ${ }^{109}$

Daar is reeds verwys na die komiteestelsel wat in 1958 aanvaar is en Helpmekaar lidmaatskap as kriterium vir toegang tot lenings, beëindig het. Aansoeke om lenings moes volgens die nuwe bedeling deur die onderskeie komitees gerig word, wat beteken het dat die Helpmekaar in staat was om studente van oraloor die Kaapprovinsie heen te help waar komitees gestig is en nie slegs diegene wat lede van takke was nie. In die proses is ten minste teoreties die eksklusiwiteit van toegang tot Helpmekaar-bronne beëindig. ${ }^{110}$

\section{DEBATTE OOR DIE UITBREIDING, ONTSLUITING EN BEHEER VAN HELPMEKAAR-KAPITAAL}

Vir die duur van die kongresstelsel was die voortdurende tekort aan leningsfondse die dinamo wat dedatte en pogings oor die uitbreiding van, beheer en kontrole oor die Helpmekaarkapitaal aangedryf het. Die debatte het gewentel rondom rentekoerse op lenings, stygende studiekoste en die behoefte na beurse, pogings om Helpmekaarkapitaal uit te brei of die bestaande kapitaal meer effektief vir studielenings te benut, te beskerm en te ontsluit. In tandem hiermee het dit ook gepaardgegaan met'n dieperliggende spanning tussen tradisie en die aanvaarding van 'n meer sake-georiënteerde benadering in die bestuur en aanwending van Helpmekaar-fondse wat berus het op verskillende sienings oor die aard en wese van die Helpmekaar. Die spanning het gemanifesteer in 'n stryd tussen die kongres/hoofbestuur en die amptenary (bestuur) wat in wese 'n stryd tussen Helpmekaar tradisie en die magte van moderniteit verteenwoordig het.

Vir die eerste keer in die geskiedenis van die Helpmekaar is daar in Oktober 1924 'n punt bereik waar die vlak van die onmiddellik beskikbare fondse so laag was dat beloftes wat reeds aan studente gemaak is nie nagekom kon word nie en sodanige studente moes ingelig word dat betalings aan hulle gemaak sou word sodra die situasie verbeter het. ${ }^{111}$ Dit het die sentrale bestuur aangespoor om 'n voorstel deur die sekretaris te aanvaar dat leningsaansoeke slegs een keer per jaar oorweeg sou word, naamlik in Februarie ná bekendmaking van die

109 Ibid.

110 (HSA) HVKP, Notuleboek, 11 Jun 1958, Kongres, 8.

111 (HSA) HVKP, Notuleboek, (21 Mei 1924-3 Apr 1928), 23 Okt 1924, Sentrale Bestuur, 42. 


\section{Die Kaapse Helpmekaar}

eksamenuitslae. ${ }^{12}$ Die 1925-finansiële jaar is gekenmerk deur 'n akute tekort aan fondse met tot 280 applikante aan wie nie lenings toegestaan kon word nie ${ }^{113}$ - 'n situasie wat vir die res van die twintigerjare sou voortduur. ${ }^{114}$

Die tekort aan fondse vir studielenings het in 1940 kritieke afmetings aangeneem. Terwyl leningsaansoeke ten bedrae van $£ 18000$ ( $£ 10000$ vanaf lede en $£ 8000$ vanaf nie-lede) in 1940 ontvang is, het die Helpmekaar net oor $£ 4500$ beskik om vir hierdie doel aan te wend. Nadat daar na die behoeftes van die bestaande studente omgesien is, was daar slegs $£ 1841$ beskikbaar vir nuwe leningsaansoeke en uiteindelik is dit aan 66 studente toegeken. Die sekretaris, DH van Zyl, het gevolglik die noodsaaklikheid beklemtoon dat studente hul lenings so gou as moontlik moes terugbetaal sodat ander verdienstelike jong Afrikaners ook deur die Helpmekaar bygestaan kon word. Hy het die enorme vraag na meer fondse benadruk en die noodsaaklikheid van kragdadiger steun deur takke en die algemene publiek in hierdie verband beklemtoon. ${ }^{115}$

Die stigting van die B-fonds om die kritieke tekort aan fondse aan te spreek en ook om die reikwydte van die Helpmekaar te verbreed sodat studente wie se ouers nie Helpmekaar-lede was nie ook gehelp kon word, het verligting gebring, maar nie die probleem opgelos nie. Die tekort aan fondse het voorgeduur en in 1946 het die penningmeester weer aangedui dat die Helpmekaar nie aan alle applikante se wense kon voldoen nie omdat daar aansoeke was ter waarde van $£ 20000$ terwyl daar net $£ 5000$ vir lenings beskikbaar was. Die voorsitter het die penningmeester ondersteun deur te verduidelik dat die Helpmekaar nie soos die RDB was wat net sekere studente ondersteun het nie, maar dat hulle alle studente moes ondersteun. Omdat heraansoeke vir bestaande lenings voorkeur gekry het, moes baie nuwe aansoeke weggewys word weens 'n tekort aan fondse. ${ }^{116}$

Te midde van die tekort aan fondse het die behoefte aan 'n fonds waaruit beurse toegeken kon word gedurende die 1946- kongres ter sprake gekom. 'n Voorstel is deur ds Lubbe ter tafel gelê dat die reserwefonds van die B-fonds aangewend moes word as 'n fonds vir 'n beurs en dat

112 (HSA) HVKP, Notuleboek (21 Mei 1924-3 Apr 1928), 23 Okt 1924, Sentrale Bestuur, 42; 4 Des 1924 , Sentrale Bestuur, 50; (HSA) HVKP, Notuleboek, 15-16 Apr 1925, Kongres, Sentrale Bestuur verslag, 6.

113 (HSA) HVKP, Notuleboek, 15-16 Apr 1925, Kongres, Sentrale Bestuur verslag, 5; (HSA) HVKP, Notuleboek (21 Mei 1924-3 Apr 1928), 16 Feb 1925, Sentrale Bestuur, 66-67. Die kongresreëling ivm die beskikking oor die 1924-Afrikanerdag-oproepgeld was gedeeltelik vir die tekort verantwoordelik.

114 (HSA) HVKP, Notuleboek, 4-5 Apr 1928, Kongres, Sentrale Bestuur verslag, 5.

115 (HSA) HVKP, Notuleboek, 16-17 Apr 1941, Kongres, Sentrale Bestuur verslag 4-5.

116 (HSA) HVKP, Notuleboek, 3-4 Apr 1946, Kongres, 12. 
dit die Jacob de Villiers Fonds genoem moes word. Hierdie beurs van $£ 150$ per jaar sou dan toegeken word vir verdere studie aan die beste beskikbare kandidaat. Dit moes onmiddellik beskikbaar wees uit die rente verdien op die reserwefonds van die B-fonds en as dit nodig sou wees, aangevul word met bydraes vanaf die takke en rente verdien op die Hooffonds. Lubbe was van mening dat daar 'n groot behoefte was aan beurse vir verdere studie. Daar was ook 'n nasionalistiese element in sy motivering, aangesien hy dit gestel het dat die tyd aangebreek het dat hulle die beste studente "vir ons eie behou". DH van Zyl was van mening dat die afwesigheid van die bestaan van 'n Afrikaanse Beursfonds fataal was en dat elke moontlike weg ondersoek moes word om so 'n fonds op die been te bring. ${ }^{117}$

Die hoofbestuur het na verdere besinning oor die Beursfonds besluit om by die kongres aan te beveel dat die eerste beurs aan 'n student in Geskiedenis gegee moet word. Vir verdere studie was die opdrag om 'n gesaghebbende werk oor die Kleurvraagstuk in Suid-Afrika te lewer. ${ }^{118}$ Die 1947-kongres het besluit om 'n Beursfonds onder die toesig van die B-fonds te stig waaruit 'n jaarlikse beurs van $£ 150$ toegeken sou word. Volgens die besluit sou die Beursfonds bestaan uit 'n jaarlikse bydrae van $£ 100$ vanaf die Hooffonds, plus spesiale bydraes vanaf die takke en weldoeners wat die ander $£ 50$ moes bybring. ${ }^{119}$ Die 1947 -kongres het 'n voorstel van Van Zyl aanvaar om 'n beroep op takke te doen om elk twee bydraers in hul omgewing te werf om vir 'n tydperk van drie jaar jaarliks elk $£ 1$ tot die Beursfonds by te dra. ${ }^{120}$ Die Beursfonds se vordering was egter nie na wense nie. In November 1947 het die Beursfonds $£ 128$ bedra, wat die Hooffonds se $£ 100$ ingesluit het, ${ }^{121}$ en teen November 1948 is slegs $£ 300$ ingesamel. ${ }^{122}$ Die hoofbestuur moes dus by die 1949-kongres rapporteer dat:

" $n$ baie klein persentasie van die takke ag geslaan (het) op die ernstige oproep wat daar deur die Kongres verlede jaar gedaan is. As gevolg hiervan kan daar nou geen toekenning van 'n beurs gemaak word nie." ${ }^{23}$

Ten spyte van die onbevredigende groei van die Beursfonds het die toekenning van beurse 'n ideaal van die Helpmekaar gebly. Tydens die 1964-kongres het ds Conradie, afgevaardigde vir Kimberley, versoek dat die Helpmekaar die toekenning van beurse sal oorweeg. Gebrek aan

117 Ibid.,13-14.

118 (HSA) HVKP, Notuleboek (8 Feb 1940-9 Des 1966), 13-14 Nov 1946, Hoofbestuur, 361.

119 (HSA) HVKP, Notuleboek, 2-3 Apr 1947, Kongres, Hoofbestuur verslag, 2.

120 (HSA) HVKP, Notuleboek, 2-3 Apr 1947, Kongres, 13.

121 (HSA) HVKP, Notuleboek (8 Feb 1940-9 Des 1966), 12-13 Nov 1947, Hoofbestuur, 370.

122 (HSA) HVKP, Notuleboek (8 Feb 1940-9 Des 1966), 19-20 Nov 1948, Hoofbestuur, 385.

123 (HSA) HVKP, Notuleboek, 30-31 Mrt 1949, Kongres, Hoofbestuur verslag, 2. 


\section{Die Kaapse Helpmekaar}

fondse het die uitvoering van die versoek egter onmoontlik gemaak, hoewel die gevoel was dat, indien die beplande insamelingsveldtog die beoogde R600 000 kon insamel, dit miskien moontlik sou wees om die lang gekoesterde ideaal te verwesenlik. ${ }^{124}$ Die beurs-ideaal sou egter eers in die doodsnikke van die twintigste eeu verwesenlik word.

In die vroeë 1950's het die stygende studiekoste 'n toenemende probleem geword wat 'n steeds groter wordende aanspraak op Helpmekaar-fondse teweeggebring het. Deur die loop van die vyftiger- en vroeë sestigerjare is verskeie pogings dus aangewend om die kapitaalbasis uit te brei en bestaande kapitaal meer effektief te benut en aan te wend. Na bespreking van die saak het die hoofbestuur besluit om die kongres aan te raai om by die 1953-kongres die maksimum bedrag wat 'n student van die Helpmekaar kon leen van $£ 200$ na $£ 300$ vir sy/haar hele kursus te verhoog. Daar is ook besluit om by die kongres aan te dring op die beskikbaarstelling van

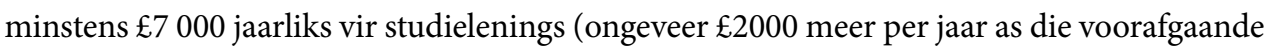
aantal jare). ${ }^{125}$ Beide hierdie maatreëls is deur die 1953-kongres goedgekeur. ${ }^{126}$

Hierdie verhoging in die totale bedrag geld wat beskikbaar gestel is vir lenings aan studente, is gesien as 'n mylpaal in die geskiedenis van die ontwikkeling van die Helpmekaar in die Kaapprovinsie. Die verhoging het die hoofbestuur in staat gestel om te voorsien in die verhoging in studiekoste van amper al die applikante en ook om meer studente as in die verlede met lenings te help. ${ }^{127}$ Verhogings in klas- en losiesgelde het teen die sestigerjare veroorsaak dat die heersende leningsbeperking van R600 ( $£ 300)$ per student onvoldoende was. Die kongres het gevolglik eenparig 'n voorstel aanvaar dat die hoofbestuur voortaan volgens hulle eie diskresie die waarde van 'n lening aan 'n spesifieke student kon vasstel. Die maksimum bedrag van R800 ( $£ 400)$ per lening wat op aansoekvorms aangedui sou word, was om die indruk te voorkom dat die Helpmekaar groot onbeperkte lenings toegestaan het. Die R800 was egter 'n riglyn wat slegs in uitsonderlike gevalle oorskry moes word. ${ }^{128}$

Pogings tot die uitbreiding en meer effektiewe benutting van Helpmekaar-fondse om in leningsbehoeftes te voorsien, was soos byvoorbeeld die reedsgenoemde lewenslange

124 (HSA) HVKP, Notuleboek, 1 Apr 1964, Kongres, gp. In 1963 is 'n nasionale fondswerwingsveldtog geloods met die doel om R600 000 vir die Helpmekaar in te samel. Uiteindelik is minder as 'n derde hiervan ingesamel. In die hoofstuk oor die B-fonds word die veldtog meer breedvoerig behandel. Notuleboek, 27 Jun 1953, Kongres, 5; 27 Jun 1953, Kongres, Hoofbestuur verslag, 2.

(HSA) HVKP, Notuleboek, 27 Jun 1953, Kongres, 5, 6. 
lidmaatskap. ${ }^{129}$ Dit was veral die debatte rondom rentekoerse, pogings tot meer vaartbelynde administrasie van studielenings om die sirkulering en benutting van leningsgeld te verbeter en pogings om nie net die jaarlikse inkomste of bedryfskapitaal nie, maar ook die vaste kapitaal van die Helpmekaar vir leningsfondse te ontsluit wat die debatte van die vyftiger en sestigerjare oorheers het.

Op 'n dieperliggende vlak was dit deel van die pogings van $\mathrm{DH}$ van $\mathrm{Zyl}$ om 'n meer sake ingestelde bestuursmodel (die Helpmekaar Studiefonds model) vir die Helpmekaar te implimenteer. Die magte van die uitgediende kongres moes aan die hoofbestuur oorgedra word met laasgenoemde wat die rol van 'n maatskappy direksie, wat beleide bepaal, moes vervul terwyl die uitvoering daarvan aan die amptenare/bestuur oorgelaat moes word.

Die rentekoersdebat het gesentreer rondom twee kwessie: die vraag of die ses persent rente wat studente moes betaal op geleende geld nadat hul, hul studies voltooi het nie te veel was nie en die vraag of studente nie ook rente op geleende geld moes betaal terwyl hulle nog studeer het nie (soos wat wel die geval was vir B-fonds studente). Beide die twee vrae het ten nouste saamgehang met die beskikbaarheid van voldoende Helpmekaar-fondse vir die vraag na studielenings. Verskillende standpunte oor die vrae het ook nou saamgehang met verskillende sienings oor die aard van die Helpmekaar en sy hulp aan studente. Na aanleiding van 'n 1946-voorstel van die Steynsburg-tak dat die rente wat gehef word, van ses persent na vier persent verlaag word, het die penningmeester, wat ten gunste daarvan was dat die rentekoers van ses persent behou moes word, geredeneer dat 'n laer rentekoers die studente sou aanmoedig om slegs die rente op hulle lenings te betaal en nie die kapitaal nie.

Die hoë rentekoers het ook bygedra om ander studente te help. 'n Laer rentekoers sou dus tot gevolg hê dat 'n kleiner bedrag vir lenings beskikbaar sou wees. Dit moes ook in aanmerking geneem word dat die studente geen rente op lenings betaal het vir die duur van hul studies nie. Hoewel daar beweer is dat sommige studente swaargekry het as gevolg van die hoë rentekoerse, was die teenargument ook dat die Helpmekaar niemand gedwing het om die Helpmekaar-geld te gebruik nie en dat daar meer as genoeg ontvangers was wat bereid was om ses persent rente op hul lenings te betaal. Die Steynsburg-voorstel is dus verwerp. ${ }^{130}$

Teen die einde van die vyftigerjare is die rentekoers debat oorheers deur die toenemende aandrang van persone soos $\mathrm{DH}$ van Zyl, sekretaris van die Helpmekaar, dat op

129 (HSA) HVKP, Notuleboek, 27 Jun 1953, Kongres, 8-9; 27 Jun 1953, Kongres, Hoofbestuur verslag, 2; (HSA) HVKP, Notuleboek (8 Feb 1940-9 Des 1966), 4 Apr 1956, Hoofbestuur, 484.

130 (HSA) HVKP, Notuleboek, 3-4 Apr 1946, Kongres, 12. 


\section{Die Kaapse Helpmekaar}

Hooffondslenings rente ook betaal moes word vir die duur van die studieperiode ${ }^{131}$ soos wat die geval met die lenings van die Helpmekaar Studiefonds (die B-Fonds) was. Van Zyl het ook aangedui dat klagtes ontvang is van studente oor die verskillende rentekoersstrukture van die Hoof- en Studiefonds. Hy was 'n voorstaander dat ses persent deurgaans gevra moes word soos in die geval van die Studiefonds. Die hoofbestuur het weens weerstand van sommige lede van die bestuur besluit om by die kongres aan te beveel dat drie persent tydens die studieperiode en ses persent daarna op Hooffondslenings betaal moes word. ${ }^{132}$

Ter verduideliking van die konteks van die voorstel het die voorsitter, DPM Beukes, tydens die 1959-kongres dit bestempel as 'n inisiatief in die voortdurende pogings van die Helpmekaar om sy fondse te vergroot. Hy het dit betreur dat die persone van wie 'n mens sou verwag om bydraes tot die fondse van die Helpmekaar te maak, naamlik die studente wat lenings ontvang het, dit nie doen nie. Vir hom het dit gelyk na 'n gees of houding dat die Helpmekaar moes help in plaas daarvan dat die Helpmekaar ook gehelp moes word. Volgens hom het ondervinding geleer dat die enigste wyse waarop bydraes van studente verkry kon word, was om dit verpligtend te maak en vandaar die voorstel dat drie persent rente vir die duur van die studietydperk op 'n lening gehef moes word. Ten spyte van weerstand teen die rentekoersvoorstel is dit deur die meerderheid aanvaar. ${ }^{133}$

Die besluit het egter omstrede gebly en is by beide die 1961- ${ }^{134}$ en 1964-kongresse uitgedaag as "buitensporige rentekoerse" en dat studente net sowel van handelsbanke of ander finansieringsondernemings gebruik kon maak. Uit die hoofbestuur se verdediging van die rentekoerse was dit duidelik dat die meningsverskille oor die beleid berus het op verskillende sienings oor die aard en rol van die Helpmekaar. Die hoofbestuur het dit onomwonde gestel dat "die Helpmekaar nie 'n welsynsorganisasie is nie en nooit voorheen was nie", maar dat dit 'n "studentebank" was waar 'n student "op 'n selfstandige wyse en met die behoud van selfrespek 'n lening kon bekom".'135

Dit het ook vier verskille tussen die Helpmekaar en 'n handelsbank of finansieringsonderneming geïdentifiseer en beklemtoon. Die Helpmekaar het nie 'n winsmotief nagejaag nie en het nie die lener primêr as 'n beleggingsmikpunt beskou nie. Verder het die

\footnotetext{
131 (HSA) HVKP, Notuleboek (8 Feb 1940-9 Des 1966), 11 Jul 1958, Hoofbestuur, 507.

132 (HSA) HVKP, Notuleboek (8 Feb 1940-9 Des 1966), 18 Des 1958, Hoofbestuur, 516-517; 3 Apr 1959, Hoofbestuur, gp.

133 (HSA) HVKP, Notuleboek, 3 Apr 1959, Kongres, 3.

134 (HSA) HVKP, Notuleboek, 3 Apr 1961, Kongres, gp.

135 (HSA) HVKP, Notuleboek, 1 Apr 1964, Kongres, Hoofbestuur verslag, gp.
} 
Helpmekaar kompeterende rentekoerse aangebied en het op minder waarborge vir lenings aangedring. Laastens moes die Helpmekaar-lener eers begin om die lening terug te betaal nadat hy/sy in diens geneem is/begin het om geld te verdien en nie onmiddellik soos in die geval van banke of finansieringsondernemings nie. Die hoofbestuur het ook die Helpmekaar se rentekoerse vergelyk met die 12 persent wat jongmense moes betaal wanneer hulle verbruiksgoedere op huurkoop aanskaf. In sulke gevalle is óf handelsmaatskappye óf individue deur hulle verryk. In die geval van 'n Helpmekaar-lening is bygedra om 'n "volksfonds" te versterk. Die vraag is ook gestel of dit so verkeerd was om van mense wat gehelp is te verwag om self 'n bydrae te maak tot 'n fonds wat later 'n groter aantal ander studente sou help.

Die Helpmekaar sou slegs in staat wees om laer rentekoerse te oorweeg sodra hulle genoeg fondse bymekaar kon kry om dit te kon bekostig. 'n Verlaging in rentekoerse sou beteken dat die Helpmekaar-kapitaal stagneer in plaas van toeneem en dit tydens 'n tydperk waarin juis gepoog is om die Fonds tot minstens R1 000000 ( $\$ 500$ 000) uit te brei. Die hoofbestuur het afgesluit met 'n beroep op "elkeen wat die toekoms van ons land en volk op die hart dra" om hulself hart en siel tot hierdie taak te verbind - met die vermaning dat daar meer op die spel was as wat vermoed is. ${ }^{136}$ Die hoofbestuur het dus die kwessie van rentekoerse geposisioneer as 'n nasionalistiese kwessie waarop die toekoms van die Afrikanervolk berus het.

Persone wat hul ten gunste van laer rentekoerse uitgespreek het soos CP Jamneck en ds Kobus van der Westhuyzen, was van mening dat dit die kritiek teen die Helpmekaar sou besweer en baie sou bydra tot die verandering in die publiek se houding teenoor die Helpmekaar - dit sou hulle beïnvloed om meer toegeneë te wees teenoor die Helpmekaar. Hul pleidooie is egter verwerp op grond van die negatiewe impak wat verlaagde rentekoerse op die Helpmekaar se groei sou hê. ${ }^{137}$ In wese was die meningsverskille oor die Helpmekaar se rentekoersbeleid 'n botsing tussen die tradisionele en meer moderne siening van sy aard en wese, naamlik die tussen 'n welsyns ingesteldheid teenoor'n meer moderne sake ingesteldheid. Te midde van die behoefte na meer fondse en die groot aanvraag na studielenings het die sake ingesteldheid teen die einde van die kongresera toenemend die oorhand gekry.

In 1957 het die hoofbestuur 'n komitee aangestel om die middele te ondersoek waarmee 'n vermindering in die administratiewe koste van die Helpmekaar teweeggebring kon word. Hoewel geen spesifieke punte geïdentifiseer kon word waarop bespaar kon word nie, was die komitee van mening dat sommige indirekte besparings 'n uitwerking kon hê. Die komitee het aanbeveel dat 'n minimum bedrag by die terugbetaling van lenings geïmplementeer moes

136 (HSA) HVKP, Notuleboek, 1 Apr 1964, Kongres, Hoofbestuur verslag, gp.

137 (HSA) HVKP, Notuleboek, 1 Apr 1964, Kongres, gp. 


\section{Die Kaapse Helpmekaar}

word. Dit sou lei tot 'n vinniger omset van leningskapitaal en sou terselfdertyd 'n besparing in tyd en administratiewe koste meebring. ${ }^{138}$ Op grond van hierdie aanbeveling het die hoofbestuur dus in Julie 1958 besluit om 'n bepaling in die voorwaardes van studielenings in te sluit dat studente hul lenings teen 'n bedrag van minstens $£ 5$ per maand moes terugbetaal. ${ }^{139}$

Die dood van adv Wessel Roux, die penningmeester van die Helpmekaar vir langer as 40 jaar, in 1958 het die geleentheid geskep om ook 'n moderner en minder gekompliseerde rekeningkundige stelsel vir die Helpmekaar in te stel. Dit het ook veranderinge in die administrasie van lenings meegebring, wat gepaardgegaan het met voorstelle vir veranderinge in verwante aangeleenthede rakende lenings. Op aanbeveling van die ouditeure is besluit dat rente op lenings in die toekoms aan die einde van elke jaar bereken sou word in plaas van by die ontvangs van elke betaling. Dit het beteken dat saamgestelde rente in die toekoms gehef sou word. Dit sou ook voortaan vir studente verpligtend wees om lenings teen 'n minimum bedrag van $£ 5$ per maand terug te betaal. Die sekretaris was van mening dat die behoefte aan waarborge vir alle toekomstige lenings, in die vorm van 'n versekeringspolis vir doodsdekking, ook wenslik geraak het. Na deeglike bespreking het die hoofbestuur ingestem om 'n nuwe rekeningkundige stelsel in te stel. Die implikasies van die nuwe stelsel was dat uitstaande lenings gekapitaliseer sou word en voortaan op die balansstaat aangedui sou word.

Lenings sou voortaan uit die kapitaal toegeken word en nie meer uit die inkomste en leningsterugbetalings soos in die verlede nie. Dit was dus nie meer nodig om die bedrag wat jaarliks aan lenings toegeken sou word tot die inkomste te beperk nie. In die verlede kon al die applikante nie gehelp word nie as gevolg van hierdie beperking. Die hoofbestuur was van mening dat dit onbillik was om lenings aan studente te weier terwyl die Helpmekaar oor genoeg kapitale fondse beskik het om hulle te help. Die hoofbestuur het dus voorgestel dat die oorspronklike $£ 40000$ beskou moes word as die kapitaal van die Helpmekaar wat belê moes word en nie vir studielenings aangewend moes word nie. Die balans van die bedryfskapitaal, wat bestaan het uit opgeloopte surplus inkomste, moes alles aangewend word volgens die aanvraag na lenings. Die hoofbestuur moes dus gemagtig word om lenings na goeddunke toe te staan en dat geen definitiewe boonste perk gestel word op die jaarlikse bedrag wat toegestaan kan word nie, onderhewig aan die bogenoemde voorstel oor die oorspronklike $£ 40000$. 
Die hoofbestuur het ook ingestem om aan die kongres aan te beveel: dat studente voortaan 'n tweede borg moes voorsien, naas die vader of voog van die student en dat lewensversekeringsdekking verpligtend moes wees. Die feit dat die kongres voortaan slegs al om die twee jaar sou vergader, in tandem met die onsekerheid oor die aantal plaaslike komitees wat volgens die nuwe stelsel in ooreenstemming met die nuwe grondwet gestig sou word, het dit onmoontlik gemaak om die bedrag geld te bereken wat jaarliks vir studielenings bewillig moes word. Die hoofbestuur het dus besluit om die kongres te versoek om die bestuur toe te laat om die bedrag te bepaal wat jaarliks aan studielenings bestee sou word, met die voorwaarde dat die aanvanklike kapitaal van $£ 40000$ onaangeraak gelaat sou word. ${ }^{140}$

Op grond van 'n aanbeveling van die ouditeure dat 'n reserwefonds van $£ 1000$ geskep word vir oninbare skulde het die bestuur ook besluit om die reserwefonds geleidelik te vermeerder totdat dit gelykstaande sou wees aan vyf persent van die uitstaande bedrag van die studielenings en dit dan op daardie vlak te hou. Hulle het ook besluit om aan te beveel dat die voorgestelde maatreëls rakende waarborge en die versekering van lenings vanaf Desember 1959 geïmplementeer sou word. Daar is ook besluit dat daar nie 'n definitiewe boonste perk geplaas sou word op die bedrag wat die bestuur deur die loop van die jaar aan lenings kon toewys nie, maar dat hulle moes probeer om dit onder $£ 1000$ te hou. ${ }^{141}$

By die 1959-kongres is die aanbevelings en voorstelle van die hoofbestuur vir bekragtiging voorgelê. Nie al die takverteenwoordigers was tevrede met die verreikende veranderinge nie. Afgesien van die beswaar dat takke en verteenwoordigers nie genoegsame geleentheid gehad het om die voorstelle te bespreek nie, was hulle ook van mening dat die kongres beheer moes behou oor die totale bedrag wat jaarliks aan studente geleen is. Die ondersteuners van die voorstel het egter gevoel dat dit nie moreel geregverdig was dat studente lenings geweier word terwyl daar in werklikheid genoegsame fondse beskikbaar was om hulle te help nie. Ten spyte van die besware is 'n voorstel deur die meerderheid aanvaar dat die hoofbestuur gemagtig sou word om jaarliks 'n onbeperkte bedrag aan studielenings te kon bestee in die tydperk tot die volgende kongres, waartydens konstitusionele veranderinge om die nuwe voorstelle te bekragtig, bespreek kon word. ${ }^{142}$ Die voorstelle oor die vereistes vir 'n ekstra borg naas die vader of voog en die versekeringspolis ter dekking van die borge in geval van sterfte is eenparig aanvaar. ${ }^{143}$

140 (HSA) HVKP, Notuleboek (8 Feb 1940-9 Des 1966), 18 Des 1958, Hoofbestuur, 516-517; (HSA) HVKP, Notuleboek, 3 Apr 1959, Kongres, 3.

141 (HSA) HVKP, Notuleboek (8 Feb 1940-9 Des 1966), 3 Apr 1959, Hoofbestuur, gp.

142 (HSA) HVKP, Notuleboek, 3 Apr 1959, Kongres, 3.

143 Ibid. 
Bogenoemde veranderinge is in 1959 en 1960 opgevolg deur voorstelle van DH van Zyl dat die bestuur dit moes oorweeg om die toewysing van studentelenings aan die administratiewe personeel van die Helpmekaar te delegeer en dat dit tweedens oorweeg moes word om die kongres te ontbind en die se funksies na die hoofbestuur oor te dra. Ten opsigte van eersgenoemde het hy geargumenteer dat die funksie van die bestuur vergelyk kon word met 'n raad (direksie), naamlik om beleide te bepaal en nie om roetine-administratiewe take te verrig nie. Hy het geredeneer dat die administratiewe personeel oor die tyd beskik het om elke applikant se agtergrond en verdienste te ondersoek en dat hulle ook applikante kon adviseer oor die beste manier waarop studente hulle leningsgeld kon aanwend. Volgens hom was hulle ook beter onderleg om die aard en omstandighede van elke applikant te keur. Dit is ook die stelsel wat deur die Helpmekaar Studiefonds gevolg word.

Hy het ook verduidelik dat die heersende prosedure 'n oorblyfsel was uit 'n tyd toe die Helpmekaar nie oor 'n kantoor en voltydse administratiewe personeel beskik het nie. Hy het aangevoer dat die doel van die Helpmekaar was om die studente finansieel te ondersteun en daarom moes die geld beskikbaar wees wanneer die studente dit benodig het en nie wanneer die Helpmekaar gekies het om die geld beskikbaar te maak nie. In die praktyk het studente om verskeie redes geld dringend benodig gedurende die loop van 'n jaar en dan kon hulle nie gehelp word nie. Nie weens 'n gebrek aan fondse nie, maar weens tegniese redes, naamlik dat die hoofbestuur slegs een keer 'n jaar in Desember lenings toegestaan het. Volgens hom was dit baie onbillik om van administratiewe personeel te verwag om so 'n dringende aansoek slegs om tegniese redes te weier.

Wat betref die sekretaris se eerste voorstel, het die hoofbestuur as interim besluit dat in geval van 'n krisis met aansoeke wat buite die jaarlikse toewysing deur die hoofbestuur val, die aansoeke deur die Helpmekaar-tak/-komitee, indien daar een in die spesifieke dorp bestaan, goedgekeur moes word. Daar is ook besluit om die uitvoerende bestuur toe te laat om lenings gedurende 1960 toe te wys, solank die perk vir die totaal vir die jaar, $£ 12000$, nie oorskry word nie. Ten opsigte van sy tweede voorstel was sy beswaar teen die heersende sisteem dat die kongres volle en finale beheer oor Helpmekaar-aangeleenthede uitgeoefen het, maar dikwels saamgestel was uit takverteenwoordigers wat lukraak gekies is - in sommige gevalle omdat hulle die enigstes was wat beskikbaar was. Die gevolg was dat die kongres dan bestaan het uit verteenwoordigers sonder grondige kennis van die Helpmekaar. Desnieteenstaande moes hulle besluite neem en oor baie belangrike sake stem.

Uit die lys van kongresverteenwoordigers was dit ook duidelik dat die takke nie baie belangstelling getoon het in die kongres nie (buiten deur die hoofbestuur, is die 1959-kongres 
net deur 13 afgevaardigdes bygewoon). Hy was ook van mening dat, weens die samestelling van die kongres, die hoofbestuur baie beter toegerus en in staat was om beheer uit te oefen. As sy idees uitgevoer kon word, sou die hoofbestuur beheer kon oorneem en toekomstige vakatures vul soos dit ontstaan. Aangesien so 'n verandering deur die kongres bekragtig moes word, is daar nie 'n besluit oor die aangeleentheid geneem nie. ${ }^{144}$

Die hoofbestuur se grootste bekommernis was dat die afskaffing van die kongres 'n nadelige invloed op die lojaliteit en belangstelling van die takke en die publiek sou hê, dat dit die gees van die ou Helpmekaar sou vernietig en dit in 'n finansieringsonderneming sou laat verander. Hulle het ook die toenemende invloed van die administratiewe amptenare teengestaan en het onlangse voorbeelde aangehaal van waar die besluite van die kongres en hoofbestuur geïgnoreer is. Hulle was huiwerig om die beheerfunksie van die kongres op te hef. Sommige lede was ook bang dat, wanneer die toewysing van lenings aan die administratiewe personeel gedelegeer word, dit kon lei tot 'n situasie waar die hoofbestuur verantwoordelikheid sou moes aanvaar vir foute wat deur amptenare gemaak word.

Vir die hoofbestuur was dit 'n keuse tussen burokrasie en die ou "demokratiese gees" van die Helpmekaar. Die voorgestelde wysigings sou ook die geografiese verteenwoordiging van die Helpmekaar verklein, aangesien die gevaar bestaan het dat die hoofbestuur later net uit drie lede (dit verwys waarskynlik na die sekretaris, penningmeester (van hieraf genoem rekenmeester) en voorsitter) van Kaapstad bestaan. Die sekretaris het gereageer deur te beklemtoon dat die amptenare mense met ondervinding was wat die daaglikse implikasies van kongresbesluite beleef het en dat sy aanbevelings gegrond was op praktiese ondervinding. Hy het benadruk dat hy nie die opheffing van beheer aanbeveel het nie, maar slegs die opheffing van die kongres en dat hulle mag na die hoofbestuur oorgedra moes word. Betreffende die negatiewe verwysings deur sekere lede na die Helpmekaar as 'n finansieringsonderneming het hy uitgewys dat, ongeag of hulle daarvan hou, die Helpmekaar vir alle praktiese doeleindes al geruime tyd as 'n finansieringsonderneming gefunksioneer het. Aangesien so 'n verandering deur die kongres bekragtig moes word, is daar nie 'n besluit oor die aangeleentheid geneem nie. ${ }^{145}$

Die negatiewe reaksie teenoor die sekretaris se idees vir vernuwing en verandering in die Helpmekaar-strukture kan moontlik gedeeltelik verklaar word deur die feit dat die hoofbestuur onder die indruk was dat die UK die bedrag wat deur die kongres en die hoofbestuur vir studentelenings vir 1960 bewillig het (die reeds genoemde $£ 12000$ ), oorskry

144 (HSA) HVKP, Notuleboek (8 Feb 1940-9 Des 1966), 15 Des 1959, Hoofbestuur, gp; 14 Des 1960 Hoofbestuur, gp.

145 (HSA) HVKP, Notuleboek (8 Feb 1940-9 Des 1966), 14 Des 1960, Hoofbestuur, gp. 


\section{Die Kaapse Helpmekaar}

het. Die voorsitter het die hoofbestuur se afkeer van hierdie toedrag van sake te kenne gegee en JA van Zyl, 'n lid van die hoofbestuur, het selfs gesuggereer dat die UK doelbewus die omvang van hul oorbesteding van die hoofbestuur weerhou het in plaas daarvan om die saak aan die hoofbestuur voor te lê vir goedkeuring.

Die rekenmeester het die bewering ontken en beklemtoon dat finansiële sake nooit by die Desember-vergaderings van die hoofbestuur bespreek is nie, maar gewoonlik by die daaropvolgende vergadering waar die geouditeerde state vir goedkeuring voorgelê is. Die sekretaris het die omstandighede van die oorbesteding verduidelik en erken dat hulle nie by die besluite van die hoofbestuur gehou het nie. Hulle is verder versoek om die omstandighede waaronder dit plaasgevind het in ag te neem, naamlik dat hulle versoeke om finansiële hulp van studente ontvang het wat baie moeilik was om te weier. Hoewel die lede van die hoofbestuur die optrede van die amptenare veroordeel het, het hulle die oorbesteding gekondoneer, gepaardgaande met 'n waarskuwing om in die vervolg by die besluite van die hoofbestuur te bly. ${ }^{146}$ Dit het later duidelik geword dat die amptenare/UK nie doelbewus die bedrag wat vir 1960 bewillig is oorskry het nie. ${ }^{147}$ Dié insident is aangehaal deur die teenstanders van verandering as 'n voorbeeld van wat kan gebeur as daar met die ou beheerstelsels gepeuter word.

Aangesien die 1961-kongres die bedrag vir die toewysing aan lenings vir 1961 moes bepaal, het die hoofbestuur voorgestel dat 'n onbeperkte bedrag toegelaat word op voorwaarde dat

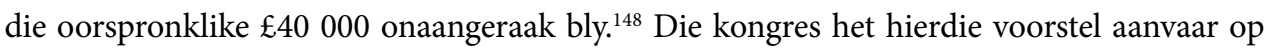
voorwaarde dat behoeftige en verdienstelike studente geakkommodeer word, dat lenings verstandig toegewys word, dat die beskikbare fondse nie oorskry word nie en dat die oorspronklike $\mathfrak{£ 4 0} 000$ onaangeraak bly. ${ }^{149}$

Die verslag van die hoofbestuur vir 1960 wat by die 1961-kongres gedien het, het melding gemaak van die bevredigende prentjie van die Vereniging se fondse ten spyte van die moeilike landsomstandighede (die Sharpeville-gebeure). Dit was beide ten opsigte van die toename uit gewone bronne van inkomste sowel as ten opsigte van die wyse waarop die afgestudeerde studente hulle verpligtinge nagekom het. Uitstaande geld is ook meer reëlmatig en op groter skaal geïn as gevolg van die strenger beheermaatreëls wat deur die kantoor uitgeoefen is. Met

\footnotetext{
146 Ibid.

147 (HSA) HVKP, Notuleboek (8 Feb 1940-9 Des 1966), 3 Apr 1961, Hoofbestuur, gp.

148 Ibid.

149 (HSA) HVKP, Notuleboek, 3 Apr 1961, Kongres, gp.
} 
die uitsondering van 'n paar swak betalers was daar in hierdie opsig niks om oor te kla nie. ${ }^{150}$ Die wysigings by die vorige kongres aangebring ten opsigte van rente, terugbetalings, borge ${ }^{151}$ en assuransie het 'n weldadige uitwerking op die organisasie gehad. Die verwagting was dat die tendens sou voortduur.

Die gewysigde aansoek en ander vorms waartoe die kongres besluit het, het ook daartoe bygedra om die werk van die kantoor oor die algemeen op te knap en te bespoedig. ${ }^{152}$ Die botsende standpunte tussen die hoofbestuur en die kantoorpersoneel ten opsigte van beleidsake wat by die Desember 1960-hoofbestuursvergadering na vore gekom het, is ook in perspektief gestel. Volgens die verslag kon die openhartige bespreking van hierdie konstitusionele sake alleen ten goede meewerk indien aanvaar word dat geen liggaam staties kan bly voortbestaan nie - ook nie die Helpmekaar nie:

"Dit is in hierdie gees dat die Hoofbestuur graag die toekoms wil benader, met een ideaal voor oë, naamlik doeltreffende beheer en uitvoering van sy doelstellings, te wete die verlening van hulp op die regte tyd en aan die regte persone wat van hulle bystand afhanklik is."153

In 1962 het die hoofbestuur besluit om by die volgende kongres aan te beveel dat die vorige besluit betreffende die terughouding van die R80 000 ( $£ 40000$ ) oorspronklike Helpmekaarkapitaal hersien word. Die hoofbestuur moes toegelaat word om die totale kapitaal van die Helpmekaar vir die doel van studielenings aan te wend. ${ }^{154}$ Hierdie besluit is in 1963 geformuleer as 'n resolusie om by die 1964-kongres voorgelê te word. Die hoofbestuur het verder besluit om intussen 'n konsep-grondwet vir voorlegging by die 1964-kongres te formuleer, waarin die nuwe voorgestelde bepalings vervat is. ${ }^{155}$

Die 1964-kongres was 'n mylpaal in dié sin dat hulle finaal 'n besluit geneem het oor wat die hoofbestuur reeds $n$ geruime tyd gepropageer het. Die oorspronklike stigtingskapitaal

150 (HSA) HVKP, Notuleboek, 3 Apr 1961, Kongres, gp.

151 Die sukses van die stelsel van twee waarborge wat van elke applikant om 'n lening verwag is, is by die 1965-kongres bevestig. Die rekenmeester het gepleit dat die bestaande stelsel behoue moes bly en hy het die sukses van die kredietkontrolestelsel van die Helpmekaar toegeskryf aan die dubbele waarborgstelsel - selfs al het hierdie stelsel primêr berus op die borge se morele verpligting. Hy het geredeneer dat ' $n$ wysiging in die stelsel die Helpmekaar-administrasie sou kompliseer en dat dit baie lenings in gevaar sou stel. (HSA) HVKP, Notuleboek, 30 Mar 1965, Kongres, gp.

152 (HSA) HVKP, Notuleboek, 3 Apr 1961, Kongres, gp.

153 Ibid.

154 (HSA) HVKP, Notuleboek (8 Feb 1940-9 Des 1966), 14 Des 1962, Hoofbestuur, gp.

155 (HSA) HVKP, Notuleboek (8 Feb 1940-9 Des 1966), 13 Des 1963, Hoofbestuur, gp. 


\section{Die Kaapse Helpmekaar}

van R80 000 is nou ook beskikbaar gestel vir die toekenning van studielenings. Dit was ten spyte van teenstand vanaf sekere lede van die kongres wat gevoel het dat minstens R40 000 uitgehou moes word as 'n onaangetaste reserwe vir moeilike geldelike depressie-tye en omdat Helpmekaar-geld in sekere uitstekende beleggings betrokke was wat nie net prysgegee moes word nie. Die teenargument van die amptenare/bestuur was dat die belegging in studielenings 'n wyer verspreiding van die risiko beteken het en dat in tandem met die feit dat geen slegte skuld oor die afgelope paar maande gely is met betrekking tot lenings nie, dit 'n baie veilige belegging was. Hulle het ook die versekering gegee dat toegang tot die kapitaal geleidelik sou plaasvind namate die geld beskikbaar word en dat dit nie beteken het dat alle bestaande beleggings meteens beëindig sou word nie. Hulle sou egter die beperking op die belegging van die kapitaal in studielenings opgehef wou hê. 'n Wysiging deur JA van Zyl, wat gevra het dat 'n onaangetaste reserwe van R40 000 uitgehou moes word, is afgekeur in 'n stemming oor die kwessie en die kongres het besluit om die hele kapitale bedrag van R80 000 beskikbaar te stel vir belegging in studielenings. ${ }^{156}$

Die uitwerking van die veranderinge wat gevolg het op die dood van die eerste rekenmeester van die Helpmekaar, Wessel Roux, in 1958, het gemanifesteer in die verslag van die hoofbestuur aan die 1965-kongres. Sedert 1958, toe die nuwe rekeningkundige stelsel ingestel is en hulle saam met hul surplus inkomste begin het om hul kapitaal uit te leen, het die jaarlikse bedrag wat aan studielenings aan studente bestee is, verhoog van R58 000 tot R167 000 in 1964. 'n Gevolg hiervan was dat die jaarlikse bedrag van lenings wat terugbetaal is ook toegeneem het en dit het 'n groot gedeelte van die geld gefinansier wat jaarliks aan studente uitbetaal is. Op hierdie wyse kon hulle ook voorsien in die groot toename in aanvraag na studielenings. ${ }^{157}$ 


\section{DIE HELPMEKAAR AS STUD ENTEVOORLIGTINGSENTRUM}

Die Helpmekaar het ook opgetree as 'n "loopbaan-voorligting-inligtingsentrum" vir skoliere en studente wat navraag gedoen het oor kursusse, loopbaangeleenthede en finansieringsmoontlikhede. ${ }^{158}$ Die 1920-kongres het 'n belangrike bydrae gelewer in die formalisering van hierdie sekondêre funksie van die Helpmekaar, naamlik hul rol as 'n sentrum/bron vir loopbaanvoorligting. 'n Oorspronklike voorstel deur die Victoria-Wes-tak dat die kongres 'n komitee moes nomineer om jongmense oor studiekursusse en -instellings te adviseer is in 'n gewysigde vorm aanvaar deurdat die sentrale bestuur die opdrag gekry het om so 'n komitee te nomineer. ${ }^{159}$ In reaksie op die 1920-kongres se besluit is daar voorts ooreengekom dat die sentrale bestuur sou dien as loopbaanvoorligter en dat studente hul navrae in hierdie verband aan die sekretaris moes rig. ${ }^{160}$

Teen 1931 het die sentrale bestuur dit vir die eerste keer nodig gevind om te verwys na die administratiewe impak van die toenemende aantal studente wat by die Helpmekaar aangedoen het. Teen die einde van 1930 het die sentrale bestuur berig dat 250 studente besig was om studielenings terug te betaal en 110 studente was nog besig met hul studies. Die persoonlike aandag wat hierdie studente geverg het en die meegaande korrespondensie wat ontstaan het, het die werkslading ontsaglik laat toeneem. ${ }^{161}$

Ten spyte van hierdie werkslading het die sentrale bestuur in hul 1934-verslag aan die kongres breedvoerig uitgebrei oor die innige verhouding tussen die studente ("ons jong mense") en die Helpmekaar. Die dankbaarheid en waardering van die oorgrote meerderheid studente vir die hulp wat hulle ontvang het en die Helpmekaar se bydrae tot opvoeding is ook uitgelig. Die korrespondensie tussen die sentrale bestuur en die studente getuig uitvoerig van hierdie

158 (HSA) HVKP, Notuleboek (3 Jul 1916-20 Mei 1919), 14 Des 1918, Sentrale Bestuur, 137; 8 Mrt 1919, Sentrale Bestuur, 151, 157; 5 Apr 1919, Sentrale Bestuur, 164-165; Die Departement van Onderwys het vir die grootste deel van die 1920's en 1930's oor geen amptelike stelsel van beroepsvoorligting beskik nie. Skoolhoofde het op informele wyse leerlinge oor beroepsmoontlikhede geadviseer. Beroepsvoorligting as 'n skoolvak is in 1937 vir standerd vyf en standerd ses ingestel. Die eerste inspekteur vir beroepsvoorligting is eers in April 1944 aangestel. CR Venter, Ontwikkelingsrigtings in die Onderwys ..., PhD, US, 1973, 467-468, 469, 471.

159 (HSA) HVKP, Notuleboek, 26-27 Mei 1920, Kongres, 4-5, 9-10, 16.

160 (HSA) HVKP, Notuleboek, 25-26 Mei 1921, Kongres, Sentrale Bestuur verslag, 4; (HSA) HVKP, Notuleboek (19 Mrt 1921-15 Apr 1924), 19 Mrt 1921, Sentrale Bestuur, 3.

161 (HSA) HVKP, Notuleboek, 7-9 Apr 1931, Kongres, Sentrale Bestuur verslag, 3. 


\section{Die Kaapse Helpmekaar}

verhouding. ${ }^{162}$ In hul verhouding met die studente het die sentrale bestuur, en meer spesifiek die bestuurslede soos die sekretaris, rekenmeester en voorsitter, wat die "openbare gesig" van die Helpmekaar was, meer gedoen as net die toewysing van finansiële hulp aan studente. In hul voortdurende korrespondensie met die studente het hulle ook opgetree as voogde wat loopbaanvoorligting gee en het op 'n gemeensame vlak met die persoonlike omstandighede van die studente meegewerk. In die proses het vriendskap en wedersydse vertroue tussen die bestuur en die studente ontwikkel. Daar is na studente verwys as "ons seuns en dogters".

Die sentrale bestuur was ook vervul met dankbaarheid vir hierdie bydrae wat die Helpmekaar kon maak tot die opvoeding van die jeug en het die eer aan God gegee "uit Wie die Helpmekaar gebore is". ${ }^{163}$ In 'n tyd toe daar weinig sulke fasiliteite beskikbaar was, het die Helpmekaar se hoofkantoor en die amptenare 'n studentevoorligtingsentrum geword wat studente van meer as finansiële steun voorsien het. Hierdie verhouding tussen studente en die Helpmekaar was veral relevant vir die eerste vier dekades van sy bestaan - die periode wat saamgeval het met die ontwikkeling en hoogtepunt van Afrikaner-nasionalisme en etniese mobilisasie. Vir baie studente het dit 'n tweede tuiste geword wat hulle met morele ondersteuning en raad bedien het en dit het die Helpmekaar die status van 'n uitgebreide familie gegee - met weinige aanduidings van enige afwykende ervarings.

Daar is egter aanduidings dat hierdie moederlike maar terselfdertyd paternalistiese verhouding teen die sestigerjare, toe Afrikaner-nasionalisme sy hipnotiese greep op veral verstedelikte en toenemend verbruikersgeoriënteerde Afrikaners begin verloor het, as voorskriftelik ervaar en uitgedaag is. Die voorskriftelike aard daarvan is geillustreer deur 'n resolusie van die Paarl-tak by die 1964-kongres met betrekking tot die wangebruik van Helpmekaar-lenings deur studente. Daarin het PS Meyer, ${ }^{164}$ lid van die hoofbestuur en Paarlse Helpmekaar-verteenwoordiger, gekla oor studente wat met Helpmekaar-lenings studeer maar wat onnodiglik voertuie besit het. In die resolusie is gevra dat Helpmekaar-studente nie toegelaat moes word om voertuie te besit sonder die toestemming van die plaaslike tak of komitee nie en dat sulke toestemming slegs in spesiale omstandighede gegee moes word. Die kongres was huiwerig om so 'n reël neer te lê en het besluit

162 "Hartlik dank vir u hulp. Dit het nie net my in staat gestel om myself te onderhou nie, maar ook my weduwee-moeder en klein sustertjie". "Ek kan werklik nie besef dat ek vanaand my laaste tjek aan u uitskryf nie en dank u vir die geduld deur al die jare, en veral vir u liefde en medelye vanaf my moeder se dood." (HSA) HVKP, Notuleboek, 3-4 April 1934, Kongres, Sentrale Bestuur verslag, 3.

Ibid.

164 PS Meyer het in die 1970's Direkteur van Onderwys in Kaapland geword en is in 1980 as Adjunkdirekteurgeneraal in die Departement van Nasionale Opvoeding aangestel. (2011) "Die Wynstok 1980," Die Wynstok: Vol. 1: Iss. 6, Article 1. Available at: http://dk.cput.ac.za/wynstok/vol1/iss6/1 (Die Wynstok, Nuusblad van die Onderwyserskollege Wellington, 1980, Jaargang 18 no 28, 5 (Uit die Kantoor)). 
dat, in plaas van 'n reël formuleer, die administrasie liewer die wangebruik van Helpmekaarfondse deur studente moes probeer verhoed deur 'n deeglike vooraf ondersoek na die finansiële posisie, omstandighede en behoeftes van studente te doen. ${ }^{165}$

Dat hierdie tipe paternalistiese toesig ten minste deur sommige studente as beperkend ervaar en uitgedaag is, is onderstreep deur Pieter-Dirk Uys se Helpmekaar-ervaring. Uys het in 1969 'n lening van die Helpmekaar ontvang vir sy studies in Televisie en Filmtegnologie by die Londonse Filmskool. Uys het onlangs aangedui dat met sy terugkeer na Suid-Afrika in 1972 die Helpmekaar daarop "aangedring" het dat hy by die SAUK in diens tree. In weerwil van die aandrang het hy hom eerder by die nie-rassige Ruimteteater in Kaapstad aangesluit. ${ }^{166}$

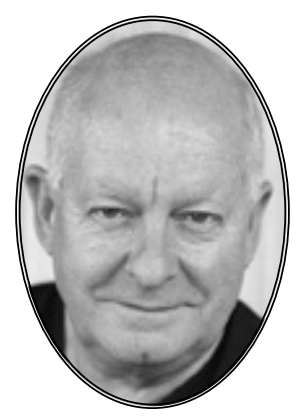

Pieter-Dirk Uys, satirikus, akteur, skrywer en sosiale aktivis wat ook 'n lening van die Helpmekaar vir sy studies ontvang het

165 (HSA) HVKP, Notuleboek, 1 Apr 1964, Kongres, gp.

166 Die Burger, 22 Jun 2015, 13. “Die Hardste Baklei met Homself: Uys vir Lewenswerk Vereer”. 


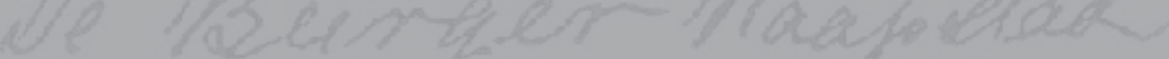

Qperee ofeer

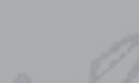

e pacapt

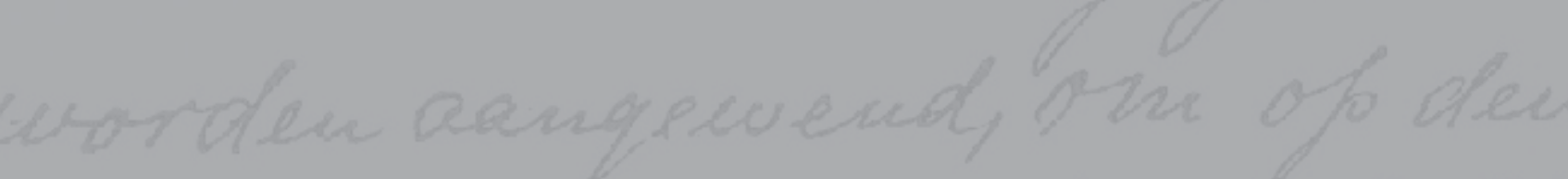

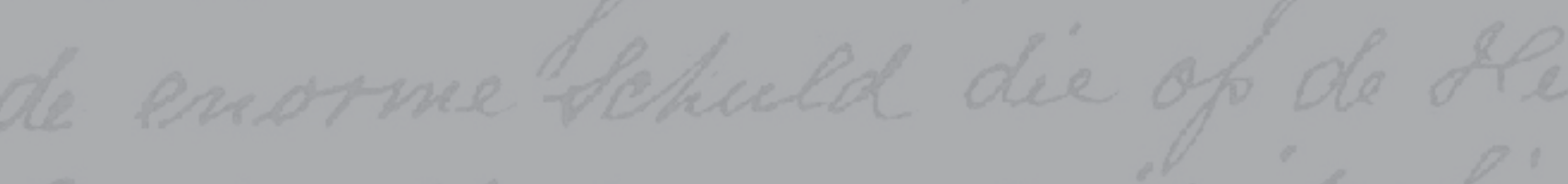
Gout aple areve namelyti cello daat 500 ma Qpronden Rav corordew the dau ben ith qeurlleg daarvoor ot 3 verdlandhording, dat et ork bed

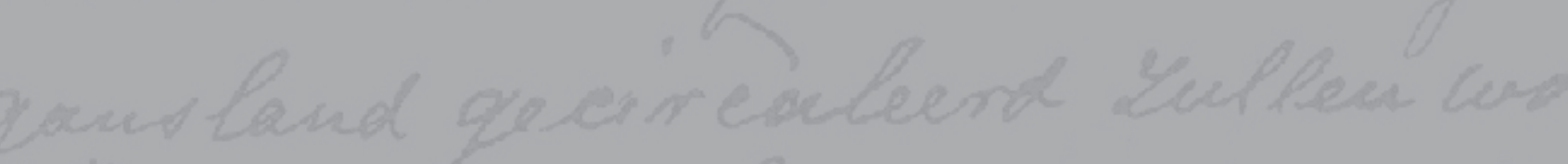

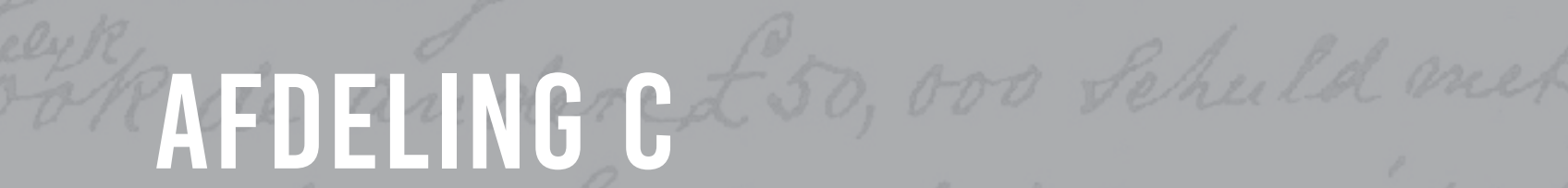

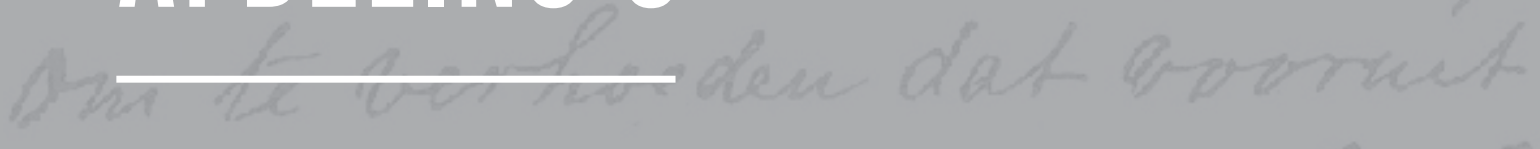
Die Hulp-studieleningsfonds of B-fonds, 1941-1966

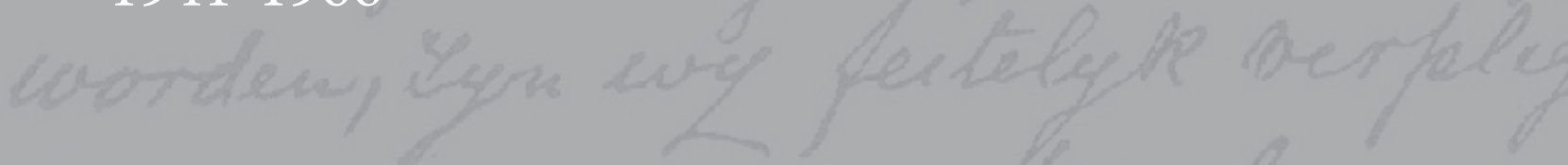




\title{
HOOFSTUK SES
}

\section{DH VAN ZYL EN DIE ONTSTAAN, STIGTING EN FUNKSIONERING VAN DIE B-FONDS}

\begin{abstract}
"Alles moontlik moet gedaan word om kapitaalkragtige Afrikaners te interesseer om geld onder hierdie skema te belê - 'n skema wat liefdadigheid en besigheid verbind."'

“Die voorsitter lees 'n brief van waardering voor van student Koornhof wat 'n beurs van die B-Fonds ontvang het vir gevorderde studie in Oxford."
\end{abstract}

Die breë Helpmekaar-konteks waarbinne die B-fonds ontstaan het, is reeds in die afdeling oor die Landman-era van die veertigerjare geskets. Die meer spesifieke konteks vir die stigting van die Hulp-studieleningsfonds of B-fonds soos in die algemene omgang daarna verwys is, is verskaf deur 'n kombinasie van 'n kroniese tekort aan fondse vir studielenings wat die Helpmekaar reeds sedert die vroeë twintigerjare ervaar het en die spesifieke agentskap en persoonlike omstandighede van $\mathrm{DH}$ van $\mathrm{Zyl}$, die inisieerder van die B-fonds-idee. Hoewel Van Zyl reeds sedert die stigting van die Helpmekaarbeweging op plaaslike takvlak as sekretaris of voorsitter betrokke was, het hy eers na die afsterwe van die sekretaresse, mev Hester Roux, in September 1938 op sentrale bestuursvlak betrokke geraak. ${ }^{3}$

Die sentrale bestuur het DH van Zyl in Julie 1939 teen 'n salaris van $£ 180$ per jaar met ingang 1 Augustus 1939 as sekretaris van die Vereniging aangestel. ${ }^{4}$ As lid van die Provinsiale Raad is daar as deeltydse amptenaar van die Helpmekaar van hom verwag dat hy drie halfdae per week op kantoor moes wees, met die verstandhouding dat as sy pligte by die Provinsiale Raad dit vereis hy op dié bepaalde dae van kantoorpligte vrygestel sou wees. Hy sou in sy vrye tyd van die Helpmekaarkantoor vir privaat sake gebruik kon maak. Sy besluit om op meer sentrale en formele vlak by die Helpmekaar betrokke te raak was waarskynlik die gevolg van die dood van sy seun en enigste kind op 17-jarige ouderdom in Augustus 1937. Die tragiese

1 (HSA) HVKP, Notuleboek, 8-9 Apr 1942, Kongres, Hoofbestuur verslag, 4.

2 (HSA) HVKP, Notuleboek (8 Feb 1940-9 Des 1966), 18 Nov 1950, Hoofbestuur, 414. Die student waarna verwys word is die latere NP-politikus en kabinetsminister, Piet Koornhof.

3 (HSA) HVKP, Notuleboek, 12-13 Apr 1939, Kongres, Sentrale Bestuur verslag, 1-2.

4 (HSA) HVKP, Notuleboek, 27-28 Mrt 1940, Kongres, Sentrale Bestuur verslag, 2. 
verlies het Van Zyl, wat ten tye van sy seun se dood reisende organiseerder van die NP was, ${ }^{5}$ laat besluit om al sy vrye tyd te bestee aan die finansiële behoeftes van die studerende jeug en ook tot sy latere besluit om die Helpmekaar (die B-fonds) die primêre erfgenaam in sy boedel te maak. ${ }^{6}$

Met die tekort aan leningsfondse teen 1940 het DH van Zyl 'n oproep vir 'n vinniger omsetsnelheid van leningskapitaal gedoen. Daar was ook'n groter behoefte aan ondersteuning van takke en die publiek vir fondse. ${ }^{7}$ Hierdie tipe appèl op donasies deur die publiek se kanse op sukses was weens die oorlogsomstandighede volgens Van Zyl uiters skraal. Hy was oortuig dat nuwe innoverende maniere gevind moes word om die tekort aan fondse aan te spreek. Van Zyl se ervaring was egter dat die organisasie by wie hy in 1939 op sentrale vlak betrokke geraak het, "weens die verstarde konserwatisme van sommige Helpmekaarleiers van destyds" staties was. Dit het dit uiters moeilik gemaak om die hoofbestuur te oortuig om die probleem van die gebrek aan fondse vir studielenings met vernuwende denke of benaderings op te los: ${ }^{9}$ "Alle nuwe planne om die Helpmekaar lewenskragtig te maak is teengestaan en moes met stryd en geloof deurgevoer word." 10

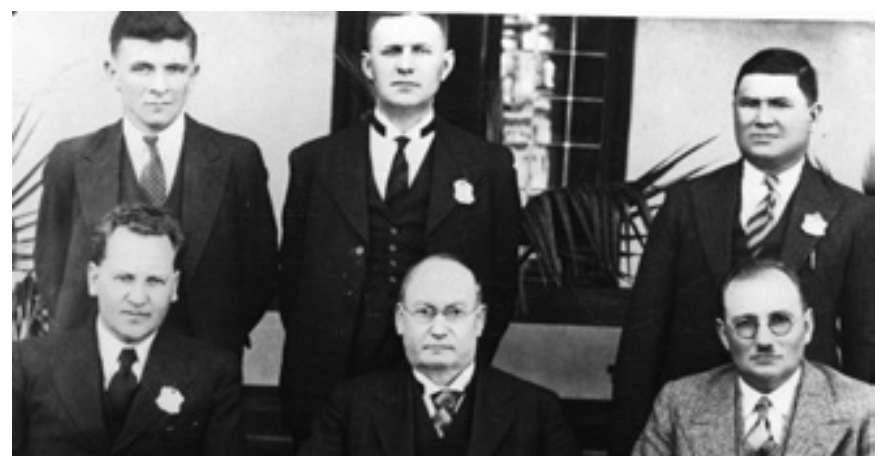

DH van Zyl saam met ander partyorganiseerders van die Nasionale Party van die Kaapprovinsie, 1936. Voorste ry van links na regs: Advokaat FC Erasmus, dr DF Malan, sen dr DH van Zyl. Agterste ry van links na regs: D van Vuuren, J du Toit, Chris Ebersohn.

5 Die Burger, 20 Aug 1937, Mnr DH van Zyl se seun oorlede.

6 (HSA) HVKP, Notuleboek (8 Feb 1940-9 Des 1966), 26 Nov 1964, HS Direksie, gp.

7 (HSA) HVKP, Notuleboek, 16-17 Apr 1941, Kongres, Hoofbestuur verslag, 4-5.

8 (HSA) HVKP, Notuleboek (8 Feb 1940-9 Des 1966), 5 Aug 1966, HS Direksie, gp.

9 (HSA) HVKP, Notuleboek (8 Feb 1940-9 Des 1966), 26 Nov 1964, HS Direksie, gp.

10 (HSA) HVKP, Notuleboek (8 Feb 1940-9 Des 1966), 5 Aug 1966, HS Direksie, gp. 


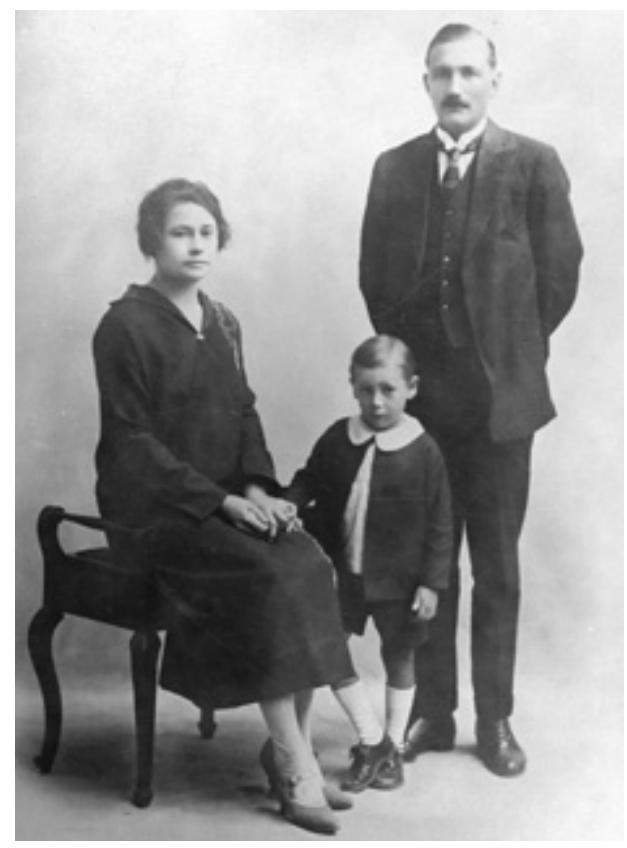

Sen DH van Zyl, sy vrou Bess en hul seun Frikkie
Teen dié agtergrond het Van Zyl 'n nuwe leningsfondsskema ontwerp om aan die dringende finansiële nood van studente te voldoen. Die basiese beginsel van die skema was om 'n fonds, gebaseer op'n sakegrondslag, tot stand te bring. Dit sou hoofsaaklik uit geleende kapitaal bestaan, deur deposito's wat van die publiek verwerf word, wat dan weer in die vorm van studielenings aan studente beskikbaar gestel kon word. Anders as die lenings uit die Hooffonds, wat vir alle praktiese doeleindes beperk was tot lede van die Helpmekaarvereniging van die Kaapprovinsie, moes die nuwe skema hierdie begrensing afbreek. Dit sou beteken dat dit geen provinsiale grense sou erken nie en ook nie Helpmekaar-lidmaatskap as voorwaarde sou stel nie.

Die voorgestelde fonds het dus ook voldoen aan die herhaalde versoeke vanuit veral die geledere van die Kaapstadse tak van die Helpmekaar vir hulp aan Afrikaners wat nie Helpmekaar-lede was nie. Soos wat die praktyk later sou illustreer, moes dit gemik wees op die ontginning en behoud van die beste "Afrikaner breins". Van Zyl het die idee eers aan Roux van der Poel van die Helpmekaar se ouditeursfirma, Theron, Van der Poel en Kie, voorgelê - wat die skema geesdriftig onderskryf het. ${ }^{11}$ Met die bekendstelling van die nuwe skema in Die Burger in November 1941 is angedui dat die motief agter die beoogde nuwe fonds was om in die groot behoefte na studielenings te voorsien en die leemte te vul wat deur die beperkte fondse van die bestaande Helpmekaarfonds veroorsaak is.

Die detail van die skema se funksionering was nog in konsepvorm, maar die verskille met die bestaande Helpmekaarstelsel is reeds uitgespel. Die nuwe beoogde B-fonds sou nie 'n liefdadigheidsfonds wees nie, maar 'n "winsdraende fonds" waarin lede van die publiek hul geld teen rente kon belê. Terwyl die lenings uit die bestaande fonds rentevry aan studente toegeken is vir die tydperk wat hulle studeer tot 'n maksimum bedrag van $£ 50$ per jaar, waarna die student ses persent rente op die lening betaal het, sou B-fonds-lenings ook rente dra tydens

11 (HSA) HVKP, Notuleboek (8 Feb 1940-9 Des 1966), 26 Nov 1964, HS Direksie, gp. 


\section{Die Kaapse Helpmekaar}

die periode van studie. Dié rente-opbrengs sou weer in die Fonds gestort word vir verdere lenings. Vir lenings uit die bestaande Hooffonds het die Helpmekaar geen ander sekuriteit as die goeie naam van die student en die waarborg van sy ouers gevra nie. Vir die B-fonds, waarin studente lenings van buitestaanders sou aanvaar, sou studente versoek word om meer sekuriteit te verskaf soos om leningspolisse uit te neem wat aan die leners gesedeer sou word. Aanvanklik was die idee dat fondse wat vir die B-fonds ontvang word onder die naam van die betrokke deposante sou bekend staan. ${ }^{12}$ Van Zyl het die skema in Desember 1941 vir die eerste keer aan die hoofbestuur ${ }^{13}$ voorgelê en die funksionering daarvan verduidelik. Die bestuur het tydens die vergadering die oproep in die pers vir die spesiale skema goedgekeur. Die sekretaris en rekenmeester is gemagtig om voort te gaan en by die volgende vergadering verslag te doen op die voorwaarde dat die Helpmekaar geen finansiële verantwoordelikhede op hom neem nie, behalwe die ekstra koste van administrasie wat die nuwe skema tot gevolg sou hê. Die voorwaardes vir die skema, soos in Die Burger en die brief van mnr HR van der Poel van 17 November 1941 uiteengesit is, is ook deur die hoofbestuur goedgekeur. ${ }^{14}$

Die 1942-kongres het die B-fonds-leningskema goedgekeur en 'n voorstel is aanvaar waarin by die takke aangedring is om die B-fonds "daadwerklik en met alle krag te steun" en die hoofbestuur is gemagtig om daarmee voort te gaan. Van Zyl het by die geleentheid groot waardering uitgespreek teenoor Roux van der Poel en dr JS du Toit, ${ }^{15}$ wat elk reeds $£ 100$ tot die B-fonds bygedra het, sowel as teenoor mnr CJ van Dyk, ${ }^{16}$ wat $£ 10$ geskenk het. Die kongres het ook 'n Van Zyl-voorstel dat 'n raad van vier of vyf kuratore - twee of drie

13 Vanaf ongeveer 1941 word verwys na die hoofbestuur en nie meer die sentrale bestuur nie.

14 (HSA) HVKP, Notuleboek (8 Feb 1940-9 Des 1966), 3-4 Des 1941, Hoofbestuur, 262.

15 JS du Toit was 'n bekende oogarts van Kaapstad. Hy is in Worcester gebore, het aanvanklik aan die Victoria Kollege gestudeer waarna hy in 1907 na Edinburg in Skotland is om sy studies voort te sit. Daar het hy in 1914 as mediese dokter gekwalifiseer waarna hy hom aan die Westminster Ooghospitaal in Londen as oogarts gekwalifiseer het. Hy het in 1916 na Suid-Afrika teruggekeer waar hy hom by die Universiteit van Kaapstad se Departement van Oogkunde aangesluit het. Du Toit was met Emmie Steyn, president MT Steyn van die Vrystaat se jongste dogter, getroud. Hulle was deel van die Kaapse Afrikaner sosiale en politieke elite. Du Toit was onder andere lid van die Federale Raad van die NP (1934), die SA Geneeskundige Vereniging (lank as erepenningmeester en in 1955 as president), Nasionale Pers se direksie, Universiteit van Kaapstad se raad, die bestuur van die Volkshospitaal en kurator van die Jan Marais-fonds. Die Burger, 4 Aug 1958, Dr JS du Toit bekende oogarts van Kaapstad aan hartaanval dood, 3; Die Burger, 7 Aug 1958, Treffende begrafnis vir Dr JS du Toit, 3.

16 CJ van Dyk was 'n lid van die Kaapse tak van die Helpmekaarvereniging. (HSA) HVKP, Notuleboek, 4-5 Apr 1945, Kongres, 1. 
benoem deur die hoofbestuur en twee van buite, waarvan een 'n medikus moes wees - vir die B-fonds benoem moes word, aanvaar. ${ }^{17}$

Die goedkeuring van die B-fonds-leningskema deur die 1942-kongres het egter nie beteken dat daar eenstemmigheid oor die skepping van 'n nuwe fonds was nie. Die beskikbare getuienis dui daarop dat die weerstand, of vyandigheid of kritiek, teen die B-fonds veral gesetel was in die persoon van die rekenmeester, advokaat Wessel Roux, en diegene wat sy denkwyses gedeel het. Soos reeds aangedui, het die vroeë veertigerjare en veral die 1942-kongres gestaan in die gees van besinning oor die Helpmekaar se pad vorentoe. Daar is besluit om die Vereniging se onafhanklikheid te handhaaf, sy fokus op opvoeding te herbevestig en deur die aanstelling van 'n organiserende sekretaris, met die hoofdoel om fondse in te samel maar ook takke te inspireer en met omsigtigheid nuwes te stig, die Vereniging uit te brei. Dit was egter ook die periode waarin die rekenmeester, adv Wessel Roux, by herhaling sy afkeur in die rol van 'n organiserende sekretaris vir fondswerwing en takstigting verwoord het op grond van sy argument dat statistieke bewys het dat die uitgawes aan so 'n onderneming die inkomstes en voordele oorskry - 'n standpunt wat hy reeds sedert die twintigerjare gehuldig het.

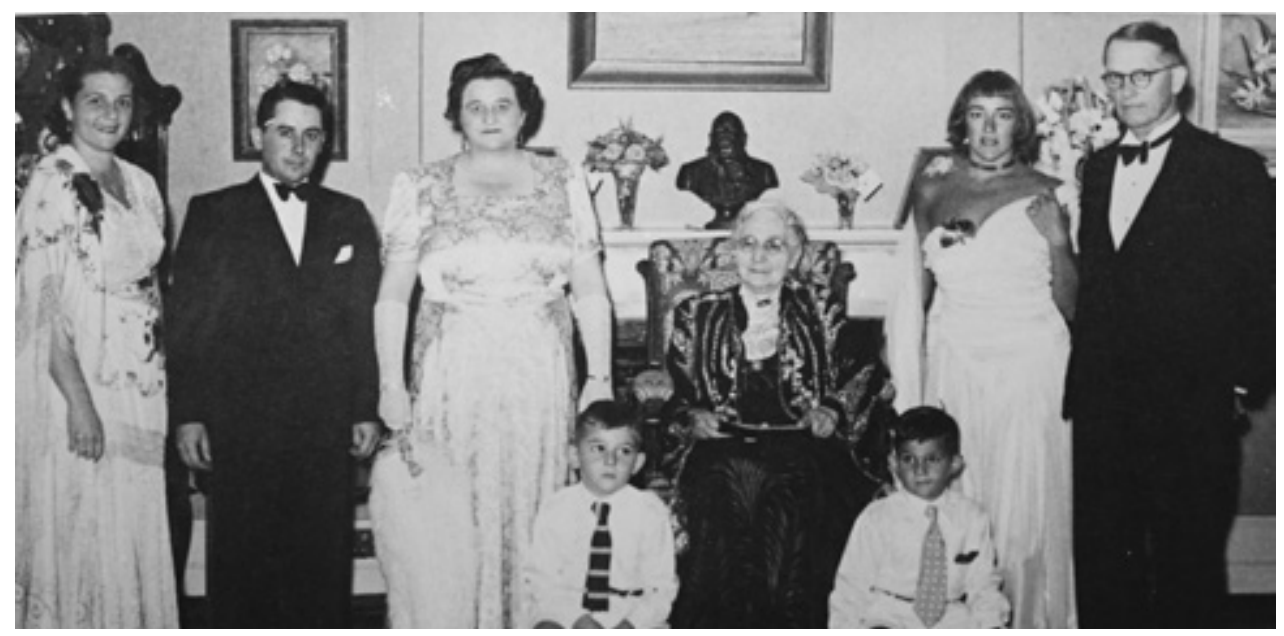

Dr JS du Toit op familiefoto van mev Steyn (President MT Steyn se weduwee) se verjaarsdag, 5 Maart 1954. Du Toit was getroud met Emiline, president Steyn se jongste dogter. Op die foto verskyn ook Adv De Vos wat met dr JS du Toit se dogter getroud was. De Vos het in 1957 saam met sy skoonvader op die eerste Direksie van die Helpmekaar Studiefonds gedien. Agter van links na regs: mev De Vos, adv De Vos, mev E du Toit, moeder van mev De Vos, mev Marthinus Theunis Steyn, weduwee van President Steyn, mev Nerina Ferreira, dogter van mev Du Toit en dr Du Toit. Voor van links na regs: Stephanus de Vos en Anton Ferreira. 


\section{Die Kaapse Helpmekaar}

As juris het hy hom ook in sy rekenmeestersverslae daarop geroem dat hy die besluite en reëls van die kongres nougeset en tot die letter uitvoer het en hy het dikwels 'n beroep op takke gedoen om dieselfde te doen. ${ }^{18}$ Hierdie ingesteldheid van Roux en die feit dat die B-fonds se administratiewe strukture en reëls, regulasies en prosedures nie van meet af in plek was nie het waarskynlik bygedra tot dit wat Van Zyl as vyandigheid teenoor die B-fonds ervaar het. Uit die vraelys wat die 1941-kommissie, wat oor die toekoms van die Helpmekaar besin het, onder 42 takke gesirkuleer het en waarop 36 geantwoord het, was dit ook duidelik dat die "idee van 'n Trustfonds sonder verband met Takke"19 nie by takke aanklank gevind het nie en verwerp is.

'n Kopie van die vraelys aan takke kon nie opgespoor word nie en het die vraag in dié verband waarskynlik die water getoets vir die Van Zyl-idee van 'n alternatiewe studieleningsfonds buite die tradisionele strukture van die Helpmekaar. Hierdie sentiment van takke was waarskynlik die oorsaak daarvan dat, te midde van die aanvaarding van die B-fonds deur die 1942-kongres en 'n oproep dat die takke die Fonds "daadwerklik en met alle krag" moes steun, 'n beskrywingspunt aanvaar is waarin die kongres hom ook verbind het tot " $n$ doelbewuste en grootskaalse uitbouing van die Helpmekaarfonds (die bestaande Hooffonds), ter huldiging van die Weledele Heer JE de Villiers, vader van die Helpmekaar. Dit is 'Die Jacob de Villiers Helpmekaar-Studieleningsfonds' genoem, en 'n spesiale jaarlikse beroep is voorts op takke vir die trustfonds gedoen." ${ }^{20}$ Uit 'n sake-oogpunt het dit nie sin gemaak om twee fondse wat in wese dieselfde doelwit nagestreef het terselfdertyd binne een organisasie te loods nie. In die lig hiervan en Van Zyl se getuienis dat daar aanvanklik groot vyandigheid teenoor die B-fonds-inisiatief geheers het, kan die oproep vir die Jacob de Villiers Fonds moeilik anders geïnterpreteer word as 'n teenvoeter vir en reaksie op die B-fonds.

Indien die reaksie van takke as aanduiding of maatstaf van ondersteuning gebruik word, is dit duidelik dat die bydraes van takke hoofsaaklik die Jacob de Villiers Fonds ondersteun het. Die B-fonds het in 1942 geen bydraes van takke ontvang, teenoor die $£ 36$ wat van drie takke vir die Jacob de Villiers Fonds ontvang is. ${ }^{21}$ In 1943 was die bedrae onderskeidelik $£ 90$ van ses takke vir die B-fonds en $£ 310$ van 26 takke vir die Jacob de Villiers Fonds. ${ }^{22}$ 'n Laaste moontlike verklaring vir die weerstand teen die B-fonds in sommige kringe binne

\footnotetext{
18 (HSA) HVKP, Notuleboek, 16-17 Apr 1941, Kongres, Penningmeester verslag, 5.

19 (HSA) HVKP, Notuleboek, 8-9 Apr 1942, Kongres, 13.

20 (HSA) HVKP, Notuleboek, 8-9 Apr 1942, Kongres, 15.

21 (HSA) HVKP, Notuleboek, 31 Mrt-1 Apr 1943, Kongres, 4, 6-7.

22 (HSA) HVKP, Notuleboek, 4-5 Apr 1944, Kongres, 7, 11-12.
} 
die Helpmekaar kan verband hou met die uitdruklike voorwaarde van die hoofbestuur dat die Helpmekaar nie enige verantwoordelikheid vir die verpligtinge van die B-fonds aanvaar nie. Dit was waarskynlik die feit dat die Fonds hoofsaaklik op geleende geld sou staatmaak wat tot die voorwaarde gelei het. Gesien in die lig van die klem op spaarsin, die herhaalde waarskuwings teen die toenemende effek van die huurkoopstelsel en die gevaar van skuld soos dit in voorsittersredes en beskrywingspunte neerslag gevind het, was die idee van geleende geld nie vir alle lede van die Helpmekaar ewe aanvaarbaar nie. Die verdere ontplooiing en vestiging van die $\mathrm{B}$-fonds moet dus teen hierdie agtergrond verstaan word.

\section{STRATEGIE, STRUKTUUR EN FUNKSIONERING}

Die beginsel van die B-fonds is deur die 1942-kongres aanvaar. Daar het geen goedgekeurde reglement vir die Fonds bestaan nie en die kuratore van die B-fonds het in die vaarwater van die 1942-kongres beleidsake oor die funksionering van die skema gefinaliseer. Op die eerste vargadering van die kuratore van die B-fonds in Mei 1942 was dr JS du Toit, mnr HR van der Poel en senator DH van Zyl teenwoordig, met ds WA Landman wat weens onvermydelike omstandighede afwesig was. WA Landman is in sy afwesigheid tot voorsitter verkies met $\mathrm{Du}$ Toit as alternatief en Van Zyl as sekretaris. 'n Kworum sou drie lede wees. Tydens die eerste vergadering is oor 'n verskeidenheid beleidsake asook metodes waarvolgens die Fonds uitgebou sou word, besluit. Die Fonds sou uitgebou word deur die werwing van deposito's ('n

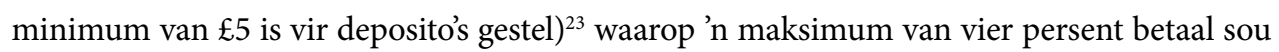
word, hoewel veral gepoog sou word om rentevrye deposito's of deposito's onder vier persent te werf. Verder sou persone ook genader word om bedrae van $£ 1$ of meer as "vrye gifte" of donasies aan die Fonds te skenk wat saam met die deposito's en enige kommissie of ander voordele wat van 'n assuransiemaatskappy op premies ontvang is in 'n B-Algemene Fonds gestort sou word. Donasies sou ook per aftrekorder betaal kon word. Plaaslike takke van die Helpmekaar sou ook genader word met die oog daarop dat hulle plaaslike koerante nader om gratis publisiteit aan die saak te gee en dat die hoofkantoor versoek sou word om 'n uiteensetting van die Fonds se doelstellings aan die takke beskikbaar te stel.

Wat betref die voorwaardes waarop die gelde aan studente geleen sou word, is besluit dat studente ses persent op die geleende geld betaal vanaf die datum waarop hy of sy enige bedrag of paaiement ontvang. Anders as die tradisionele Helpmekaar-lenings sou die lenings dus nie rentevry wees vir die duur van die student se studies nie. Van die ses persent sou vier persent na die belegger en twee persent na die B-Algemene Fonds gaan. Indien deposito's 


\section{Die Kaapse Helpmekaar}

teen laer rentekoerse as vier persent gewerf kon word, sou dié deel wat na die Algemene Fonds gaan dienooreenkomstig vergroot. Alle premies op lewenspolisse is deur studente as sydelingse sekuriteit gegee. Dit sou uit die B-Algemene Fonds gedek word met dien verstande dat die gemelde premies saam met die verskuldigde rente teen ses persent by die lening aan die student gevoeg word. ${ }^{24}$

Met die B-fonds se tweede vergadering van kuratore in September het Van Zyl gerapporteer dat reeds $£ 2300$ aan beleggings, bydraes en beloftes ontvang is. Die kuratore het ook besluit om nie beleggings wat van individue of liggame ontvang word te beperk nie, maar om tog te probeer om met die oog op die uiteindelike opvraging deur die beleggers die beleggings so wyd moontlik oor die land te versprei. Hulle moes poog om as beleid beleggings vir 'n tydperk van vyf jaar te verkry. Roux van der Poel is ook versoek om 'n behoorlike formule vir die B-fonds se beleggingskema op te stel en ook regsopinie daaroor in te win. Die kuratore het ook besluit om 35 persent van alle beleggings wat hulle van die publiek ontvang by SASBANK ${ }^{25}$ as 'n reserwe te belê. Die sekretaris en Van der Poel sou ook met die bank vir 'n gunstige rentekoers onderhandel.

Die sekretaris het ook gerapporteer dat hy in sy rondreise as organiserende sekretaris ontdek het dat groot bedrae kapitaal van kerke en ander liggame oral in die land by handelsbanke renteloos lê. Hy het sommige van die liggame genader vir gedeeltelike belegging van hul fondse by die B-fonds. Hy het ook die Volksbanke ${ }^{26}$ van die "bevrore" kapitaal in kennis gestel en gevra om, waar hulle sulke liggame nader met die oog op beleggings by hulle onderskeie inrigtings, die naam van die Helpmekaar B-fonds te noem as bron van belegging. Van Zyl het, soos reeds aangedui, die plaaslike taknetwerke gebruik om kapitaal vir die B-fonds te mobiliseer en ook bemiddelde Afrikaners geteiken om beleggings of boedelbemakings te bekom. Hierdie mobilisering van kapitaal het gestaan in die teken van die vaarwater van die Eerste Ekonomiese Volkskongres en die mobilisering van Afrikaner-kapitaal vir fondse soos die Reddingsdaadfonds en ook Volkskas wat hom in die veertigerjare as 'n handelsbank probeer vestig het.

24 (HSA) HVKP, Notuleboek (8 Feb 1940-9 Des 1966), 13 Mei 1942, B-fonds Kuratore, 1.

25 Die Suid-Afrikaanse Spaar- en Voorskotbank Beperk was 'n leningsbank geregistreer volgens die Bankwet van 1942. UG 8-1947, First annual report of the Registrar of Banks for the period ended 30th June 1946, 6.

Ons Eerste Volksbank en die Staalwerkers Ko-operatiewe Leningsvereniging Beperk wat albei in Pretoria gesetel was, was teen 1948 die enigste twee instellings wat as volksbanke volgens die Bankwet van 1942 geregistreer was. UG 59/1949, Derde Jaarverslag van die Registrateur van Banke vir die tydperk geeindig 31 Desember 1948, 1. 
Die B-fonds het van meet af aan ook 'n fondswerwer aangestel. Van Zyl het 'n mondelinge ooreenkoms met mnr E Schutte aangegaan om vir 'n maand lank vanaf 7 September 1942 tot 7 Oktober 1942 fondse vir die B -fonds in te samel. Schutte sou $£ 25$ salaris en hoogstens $£ 5$ reiskoste ontvang, mits hy afgesien van beleggings in die B-fonds, minstens $£ 100$ aan vrywillige bydraes tot die B-fonds vir die lopende maand insamel. Tot en met die vergadering het hy $£ 350$ aan beleggings en $£ 20$ aan bydraes ingesamel. Schutte het aangedui dat hy voortgaan met sy insamelings, dog het hy geen salaris verlang nie. ${ }^{27}$

Die verskil van mening oor die instelling van die B-fonds het tydens die hoofbestuursvergadering in Desember 1942 tot wrywing in die Helpmekaar se hoofbestuur gelei. Die rekenmeester, adv Wessel Roux, was van mening dat daar nie by die kongresbesluit in verband met die Fonds gehou is nie. Volgens hom sou die Helpmekaar slegs vir die ekstra koste van administrasie pa staan. Die meningsverskil tussen die rekenmeester en die sekretaris het gehandel oor die interpretasie omtrent die Vereniging se verantwoordelikheid teenoor die beleggers van die B-fonds, maar die spesifieke standpunte van Roux en Van Zyl, asook dit waaroor hulle spesifiek verskil het, is onduidelik. Roux se aanduiding dat hy as rekenmeester geen verantwoordelikheid op hom neem in verband met die B-fonds nie was 'n aanduiding dat hy onder die indruk verkeer het dat Van Zyl 'n groter verantwoordelikheid ten opsigte van B-fonds-verpligtinge voor die Vereniging se deur gelê het as dit waartoe die kongres en hoofbestuur aanvanklik ooreengekom het.

Wat wel duidelik is, is dat die geskil die organisasiewerk vir die vestiging van die B-fonds "tot 'n ruim mate gestrem" 28 het. Teen dié agtergrond het die hoofbestuur besluit om 'n subkommissie, bestaande uit ds DG Venter, ds FX Roome, sen DH van Zyl, FK Siebrits en met adv HA Fagan as regsadviseur, aan te stel. Hulle opdrag was om die hele aangeleentheid te ondersoek, indien nodig regsadvies in te win, 'n duidelike reglement vir die Fonds en die administrasie daarvan op te stel en by die volgende hoofbestuursvergadering verslag te doen. Vir die interim het die hoofbestuur die aanstelling van die kuratore (ds WA Landman, sen DH van Zyl, dr JS du Toit, mnr HR van der Poel) goedgekeur en hulle gemagtig om volgens die reeds goedgekeurde kongresbesluite en -prosedures voort te gaan met die organisasie en propagering van die B-fonds. Daar is ook besluit om voort te gaan met die spaarrekening vir die B-fonds by SASBANK en om 'n aparte lopende rekening vir die B-fonds by Volkskas te open. ${ }^{29}$ 


\section{Die Kaapse Helpmekaar}

Die aanbevelings deur bogenoemde komitee vir sekere wysigings aan die grondwet van die Helpmekaarvereniging om vir die B-fonds se funksionering as tweede studieleningsfonds voorsiening te maak, is in 1943 aan die kongres voorgehou en goedgekeur. Met die veranderings aan die grondwet is die B-fonds amptelik erken en dit sou voortaan as die Hulp-studieleningsfonds van die Helpmekaarvereniging van die Kaapprovinsie bekend staan. Die Fonds sou beleggings teen 'n vaste rentekoers per jaar, asook skenkings en erflatings aanneem. Die veranderings het dit ook duidelik gestel dat die Hulp-studieleningsfonds en die Vereniging geen verpligting ten opsigte van mekaar se laste en pligte het nie, behalwe dat die Vereniging die ekstra koste wat die administrasie en beheer van die Hulpstudieleningsfonds sou meebring, sou dra. Wat die beheer van die Hulp-studieleningsfonds betref, is voorsiening gemaak vir 'n raad van kuratore. Hulle het betstaan uit die voorsitter van die Vereniging (ampshalwe), twee lede van die hoofbestuur en twee lede (beleggers) buite die hoofbestuur. Een van die beleggers, indien moontlik, moes 'n medikus wees met stemreg op die hoofbestuursvergaderings, alleen ten opsigte van die Hulp-studieleningsfonds en met dieselfde magte en regte as dié van die dagbestuur tov die ander fondse van die Vereniging.

Die veranderings het ook voorsiening gemaak vir die verskille in die leningsvoorwaardes van die Vereniging en die Hulp-studieleningsfonds. Die ekstra sekuriteit wat laasgenoemde van sy leners geëis het, was in die vorm van borge deur kuratore goedgekeur, asook 'n assuransiepolis, rente teen ses persent op die leningskapitaal gereken vanaf die uitbetaling en die Fonds wat die rente op die lening betaal solank die student nog studeer. Na afhandeling van studie betaal die student dan die lening met die rente wat deur die Fonds vir hom betaal is, terug as geleende kapitaal. Wat die neem van deposito's betref, is bepaal dat geen belegger meer as vier persent sou ontvang nie. Uit die ses persent wat studente betaal, sou twee persent vir die administrasie en die reserwefonds van die Hulp-studieleningsfonds afgestaan word.

Die bestuur van die Vereniging sou van tyd tot tyd bepaal hoeveel van alle skenkings en erflatings oorgeplaas word in die Fonds se reserwefonds. ${ }^{30}$ Hoewel die weerstand teen die Hulp-studieleningsfonds nie oornag verdwyn het nie - die rekenmeester het in sy 1943-verslag weer 'n punt daarvan gemaak dat die uitgawes ten opsigte van die organiserende sekretaris van die Vereniging steeds meer was as die inkomste wat dit gegenereer het ${ }^{31}-$ het die Fonds ten minste nou amptelike konstitusionele status gehad. Met die verhouding met die Vereniging en die funksionering duideliker begrond het dit mettertyd tot 'n meer algemene aanvaarding gelei.

\footnotetext{
30 (HSA) HVKP, Notuleboek, 31 Mrt-1 Apr 1943, Kongres, B-fonds verslag, 14.

31 (HSA) HVKP, Notuleboek, 31 Mrt-1 Apr 1943, Kongres, Penningmeester verslag,5.
} 
$\mathrm{Na}$ die konstitusionele wysigings aanvaar is, kon die B-fonds aktief begin funksioneer en het die kuratore in die Afrikaanse Pers, asook in Wapenskou, Die Matie, Inspan en Die Suiderstem geadverteer dat die Helpmekaar nou oor meer fondse beskik om studente te help. ${ }^{32} \mathrm{JB}$ Bonthuys, lid van die Kaapse Skiereiland se Helpmekaartak, ${ }^{33}$ is ook as tweede lid van die Vereniging se hoofbestuur as kurator van die B-fonds benoem. ${ }^{34}$ Die B-fonds se keuse van finansiële instellings vir hul beleggings het verder bewys hoe hulle in die Afrikaner-wêreld se netwerke verweef was.

Benewens die Volkskas tjekrekening het die kuratore besluit om $£ 500$ elk in 'n spaarrekening by Volkskas, 'n spaarrekening by Spoorbondkas ${ }^{35}$ en 'n spaarrekening by SASBANK te belê. ${ }^{36}$ Ten opsigte van die deposito/fondswerwingsbeleid het die kuratore besluit om nie meer as

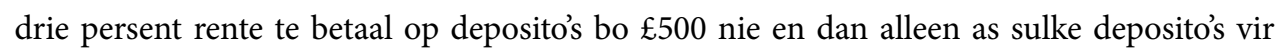
minstens vyf jaar beskikbaar gestel word. Hulle het ook besluit om meer op die verkryging van donasies te konsentreer om enige moontlike renteverlies te dek. ${ }^{37}$ Weens die uitbreiding van die omvang van die B-fonds se aktiwiteite het Roux van der Poel, wat sedert die aanvang van die Fonds sy dienste as boekhouer gratis aan die B-fonds beskikbaar gestel het, aangedui dat hy dit nie langer kon behartig nie. ${ }^{38}$ Die hoofbestuur het dus besluit om in die plek van Van der Poel iemand as boekhouer aan te stel teen hoogstens $£ 2$ per maand. ${ }^{39}$

Die 1944-kongres, waar vir die eerste keer oor die B-fonds se funksionering vir 'n volle finansiële jaar verslag gedoen is, het 'n goeie aanduiding van die Fonds se funksionering en vordering verskaf. Vir die jaar tot 31 Desember 1943 is $£ 12800$ by wyse van beleggings, donasies, kommissies en rente ingesamel. Hiervan is $£ 1534$ by die dood van beleggers aan hul boedels uitbetaal, wat 'n bedrag van $£ 11159$ op hande gelaat het. $£ 1000$ hiervan was rentevry, terwyl $£ 500$ daarvan as erflatings belowe is. Weens sekere tegniese probleme by die uitbetaling van lenings moes die kuratore van tyd tot tyd beleggings van die hand wys ten einde die verhouding van kapitaal op hande en uitbetalings in ewewig te hou. Die Fonds

32 (HSA) HVKP, Notuleboek (8 Feb 1940-9 Des 1966), 4 Jun 1943, B-fonds Kuratore, 16.

33 (HSA) HVKP, Notuleboek, 31 Mrt-1 Apr 1943, Kongres, 1.

34 (HSA) HVKP, Notuleboek, (8 Feb 1940-9 Des 1966), 4 Jun 1943, B-fonds Kuratore, 16.

35 Spoorbondkas Beperk was aanvanklik 'n leningsbank, maar is later as 'n deposito nemende instelling volgens die Bankwet van 1942 geregistreer. UG 8-1947, First annual report of the Registrar of Banks for the period ended 30th June 1946, 6.

(HSA) HVKP, Notuleboek (8 Feb 1940-9 Des 1966), 4 Jun 1943, B-fonds Kuratore, 16.

37 Ibid.

38 (HSA) HVKP, Notuleboek (8 Feb 1940-9 Des 1966), 26 Okt 1943, B-fonds Kuratore, 20.

39 (HSA) HVKP, Notuleboek (8 Feb 1940-9 Des 1966), 1-2 Des 1943, Hoofbestuur, 302. 


\section{Die Kaapse Helpmekaar}

was volgens die verslag kerngesond en het 'n surplus van $£ 228$ getoon. Die omvang van die lenings wat toegestaan is, het ook aangedui dat die Fonds in 'n besliste behoefte voorsien het. Lenings vir $£ 10300$ is oor die loop van die jaar toegeken wat oor 'n tydperk van drie tot vier jaar uitbetaal sou word. Die kuratore het ook aangedui dat hulle vir die huidige jaar sou voortgaan met die beleid om jaarliks nie meer as $£ 10000$ in beleggings te aanvaar nie. Donasies en erflatings sou egter nie beperk word nie. Die kuratore het ook die hoofbestuur, bestuurslede en takke aangemoedig om die gegoedes in hul omgewing meer doelbewus te teiken om dié tipe van bydraes tot die fondse van die Vereniging te maak. Skoolkomitees en kerkrade moes veral aangemoedig word om bydraes te lewer. ${ }^{40}$

Te midde van die anmoediging was dit duidelik dat die B-fonds daarin geslaag het om kapitaal te mobiliseer wat onder die tradisionele Helpmekaar-strukture waarskynlik onontgin sou gebly het. Die groothandelsfirma "Kopersbond" het byvoorbeeld 'n skenking van $£ 200$ aan die B-fonds gemaak. Dit is gedoen op voorwaarde dat die bedrag in die vorm van 'n studielening onder die naam "Kopersbond-Studiebeurslening" in jaarlikse paaiemente van $£ 50$ oor vier jaar versprei, aan 'n handelstudent toegeken moes word. Die lening moes na vier jaar terugbetaalbaar word, sou selfonderhoudend wees en by voortduring aan handelstudente toegeken word. ${ }^{41}$ Testamentêre bemakings soos dié van DJ Rabie van Hoërskool Grens in

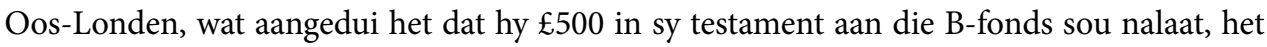
ook meer geredelik voorgekom. ${ }^{42}$ Die verslag van die hoofbestuur by die 1945 -kongres het bogenoemde bevestig, naamlik dat die B-fonds:

"in ruim mate die vertroue van beleggers gewin (het). Hierdie vertroue blyk uit die feit dat persone en groepe uit alle volkslae aansoek gedoen het om fondse aan ons beskikbaar te stel. O.a. het liggame soos Kerkrade, die Christelike Strewers-Unie, skoolkomitees, eksekuteurskamers, bankiers, ens. (w.o. Sasbank) ruime bedrae teen matige rente tot ons beskikking gestel."43

Teen 1945 het die praktiese realiteite van die B-fonds-skema - wat vir alle praktiese doeleindes soos 'n bank/depositonemende instelling gefunksioneer het - begin manifesteer. Volgens Van Zyl se eie erkenning het die hele skema ontwikkel "tot 'n bankinstellingskema wat groot sekuurheid vereis". ${ }^{44}$ Die B-fonds se administrasie het spoedig 'n ingewikkelde proses geraak

\footnotetext{
40 (HSA) HVKP, Notuleboek, 4-5 Apr 1944, Kongres, Hoofbestuur verslag, 3.

41 (HSA) HVKP, Notuleboek (8 Feb 1940-9 Des 1966), 4 Des 1944, B-fonds Kuratore, 29.

42 (HSA) HVKP, Notuleboek (8 Feb 1940-9 Des 1966), 5 Apr 1945, B-fonds Kuratore, 329-330.

43 (HSA) HVKP, Notuleboek, 4-5 Apr 1945, Kongres, Hoofbestuur verslag, 4.

44 (HSA) HVKP, Notuleboek, 4-5 Apr 1945, Kongres, 12.
} 
wat voortdurend gemonitor moes word. Die dubbele stelsel van renteberekenings, eerstens op beleggings en tweedens dié op studielenings en ander roetinewerk soos dié in verband met die Fonds se assuransieskema, het die administrasie baie ingewikkeld en moeisaam gemaak. Van Zyl het takke dus versoek om behulpsaam te wees met die invul van die vorms van aansoekers vir lenings uit die B-fonds aangesien die agterlosigheid van aansoekers in dié verband die administrasie verder bemoeilik het. ${ }^{45}$

Verder moes die likiditeit van die Fonds voortdurend gemonitor word ${ }^{46}$ en die balans tussen deposito's ingeneem en lenings toegestaan gehandhaaf word. In 1946 is die delikate balans tussen deposito's ingeneem en lenings toegestaan geillustreer toe die B-fonds met ' $n$ buitengewone groot bedrag aan deposito's ontvang voorhande gesit het. Die sekretaris is dus opgedra om nuwe deposito's teen 'n laer rentekoers te werf en beleggers te vra om beleggings tydelik teen drie persent rente beskikbaar te stel totdat die B-fonds in staat was om sulke deposito's aan studente uit te leen waarop die gewone vier persent dan weer betaal kon word. ${ }^{47}$

Te midde van die bewerings dat hulle beleggings uit "alle volkslae" getrek het en daar offervaardige beleggers was wat geld teen lae rentekoerse of rentevry - soos die $£ 3000$ wat rentevry van 'n belegger van Upington ontvang is ${ }^{48}$ - belê het, was daar aanduidings dat nie alle beleggers ewe offervaardig en edel in hul ondersteuning van die "volksaak" was nie. Volgens die kuratore het Helpmekaar-takbesture en gewone Helpmekaar-vriende dikwels beleggers aangemoedig om groot bedrae teen vier persent beskikbaar te stel, bloot met die oog op die winsmotief. Wanneer die kuratore dan weier om sulke groot bedrae teen hoë rente te aanvaar is die beleggings dikwels onttrek met teleurstellende gevolge vir beide kante. Die kuratore het dus lede van die Vereniging versoek om eerder die diensmotief in gedagte te hou en te beklemtoon wanneer hulle vriende aanmoedig om geld beskikbaar te stel vir belegging.

Beleggers moes dus aangemoedig word om kleiner bedrae vanaf $£ 25$ tot $£ 300$ vir 5 jaar rentevry of teen twee-tot-drie persent beskikbaar te stel terwyl die kapitaal gebruik word om “" $n$ jong Afrikaner in die lewe aan te help. Dit is dan 'n kwessie van jouself help deur ander te help." ${ }^{49}$ Soos met die Vereniging se fondswerwing oor jare het die B-fonds dus ook ten spyte van hul uitgangspunt dat hulle op sakebeginsels gebaseer was steeds swaar gesteun op

45 (HSA) HVKP, Notuleboek, 4-5 Apr 1945, Kongres, 12; (HSA) HVKP Notuleboek (8 Feb 19409 Des 1966), 29 Mei 1945, B-fonds Dagbestuur, 32.

46 (HSA) HVKP, Notuleboek (8 Feb 1940-9 Des 1966), 14-15 Nov 1945, Hoofbestuur, 336.

47 (HSA) HVKP, Notuleboek (8 Feb 1940-9 Des 1966), 28 Aug 1946, B-fonds Kuratore, 42-43.

48 (HSA) HVKP, Notuleboek, 2-3 Apr 1947, Kongres, 13-14.

49 (HSA) HVKP, Notuleboek, 4-5 Apr 1945, Kongres, Hoofbestuur verslag, 4. 


\section{Die Kaapse Helpmekaar}

Afrikaner-sentimente om hul doelwitte te bereik. Hoe suksesvol die etniese aanslag was om Afrikaners te oorreed om rente-inkomste prys te gee ter wille van die volksaak is moeilik statisties bepaalbaar. In Junie 1951 het die B-fonds oor beleggings van $£ 61000$ van die publiek beskik. Hiervan was $£ 10000$ onder vier persent belê en die ander $£ 51000$ teen vier persent. ${ }^{50}$ Indien dié verdeling as maatstaf gebruik word, het finansiële realiteite waarskynlik by die meeste beleggers swaarder geweeg as hul offervaardigheid ter wille van die "volksaak".

Die realiteit van die B-fonds was natuurlik ook dat hul vermoë om beleggings te aanvaar bepaal is deur hul vermoë om die geld as studentelenings te plaas, maw deur die aanvraag na studentelenings. Dit was teen 1946 duidelik dat die sukseskoers vir aansoekers vir B-fondslenings nie baie hoog was nie omdat die vereistes vir die lenings so hoog was. Slegs studente wat reeds hul eerstejaar aan 'n tersiêre inrigting geslaag het (wat beteken het dat hulle oor voldoende finansiële middele beskik het of toegang daartoe gehad het om die eerste jaar self te finansier) is aanvaar. Studente moes ook twee borge wat eiendom besit het (wat 'n sekere vlak van finansiële vermoë impliseer) as sekuriteit aanbied. Die sekretaris het dus aangedui dat "hoogstens 15 persent van alle aansoeke gunstige oorweging kan geniet omdat die groot gros van studente dit moeilik vind om die Fonds se vereistes tov borge en gevorderde studie na te kom". ${ }^{51}$ Dié statistiek het die kuratore tweemaal laat dink, aangesien besluit is om sulke gevalle (waar aansoekers nie aan die voorwaardes kon voldoen nie), na die volle kuratorium te verwys sodat daar op die meriete van elke afsonderlike geval ingegaan kan word. ${ }^{52}$

Anders as die tradisionele fokus van die Vereniging op behoeftige studente met potensiaal het die B-fonds se voorwaardes veroorsaak dat die Fonds hoofsaaklik vir die Afrikanermiddelklas of vir studente wat toegang tot borge (familie of vriende) in die Afrikanermiddelklas gehad het, toeganklik was. Hierdie fokus het gestrook met een van Van Zyl se hoofmotiverings vir die instelling van die Fonds, naamlik om meer doeltreffende hulp aan die beste studente te gee sodat "die leiers van ons volk toegerus word vir die toekoms" 53 om hulle sodoende vir die volk te behou - 'n funksie wat volgens sy mening in die verlede verwaarloos is. ${ }^{54}$ 'n Ontleding van die toekenning van B-fonds-lenings tot einde Januarie 1945 het dié fokus bevestig deurdat dit 'n disproporsionele toekenning van lenings aan studente in die natuur- en fisiese wetenskappe (mediese wetenskappe ongeveer 40 persent;

\footnotetext{
50 (HSA) HVKP, Notuleboek (8 Feb 1940-9 Des 1966), 4 Jul 1951, B-fonds Kuratore, gp.

51 (HSA) HVKP, Notuleboek (8 Feb 1940-9 Des 1966), 28 Aug 1946, B-fonds Kuratore, 43.

52 Ibid.

53 (HSA) HVKP, Notuleboek, 2-3 Apr 1947, Kongres, 13.

$54 \quad$ Ibid.
} 
wetenskapstudente ongeveer tien persent; ingenieurswese ongeveer nege persent) getoon het. Dit het op die tradisioneel duurste studierigtings gefokus wat die skranderste studente lok, asook op studente met die potensieel gunstigste vergoeding na voltooiing van hul studies. Dit het dus op studente gefokus wat die vereffening van die duurder B-fonds-lenings kon bekostig. Dat die B-fonds egter in 'n definitiewe behoefte voldoen het ten spyte van die lae sukseskoers van aansoekers is tydens die 1947-kongres bevestig toe die hoofbestuur aangedui het dat die aantal aansoeke vir studiehulp steeds die hulp waartoe die Fonds in staat was met meer as 70 persent oortref het..$^{55}$

\section{B-FONDS: GROEPSINDELING VOLGENS KURSUS EN DIE GETAL STUDENTE GEHELP EN BEDRAG TOEGEKEN TOT EINDE JANUARIE 1945. ${ }^{56}$}

\begin{tabular}{|l|l|l|}
\hline Kursus & Studente & Bedrag in pond \\
\hline Medisyne & 39 & 8947 \\
\hline Tandheelkunde & 1 & 450 \\
\hline Ingenieurswese & 9 & 1520 \\
\hline Handel & 6 & 825 \\
\hline Onderwysgraadkursus & 21 & 2585 \\
\hline Wetenskap & 10 & 1280 \\
\hline Argitektuur en Kuns & 2 & 175 \\
\hline Teologie & 4 & 275 \\
\hline Landbou & 3 & 450 \\
\hline Regte & 4 & 580 \\
\hline Aptekerswese & 2 & 300 \\
\hline Totaal & $\mathbf{1 0 1}$ & $\mathbf{1 7} 747$ \\
\hline
\end{tabular}

Teen 1947 was die B-fonds 'n gevestigde instelling in die Helpmekaar se strukture en het 'n bestekopname aangedui dat die Fonds reeds $£ 51000$ sedert sy stigting aan kapitaal ingesamel het. ${ }^{57}$ Aanduidings was dat die Fonds in sy eerste vyf jaar grootliks daarin geslaag het om

55 (HSA) HVKP, Notuleboek, 2-3 Apr 1947, Kongres, Hoofbestuur verslag, 2.

56 (HSA) HVKP, Notuleboek, 4-5 Apr 1945, Kongres, Hoofbestuur verslag, 4.

57 (HSA) HVKP, Notuleboek, 31 Mrt-1 Apr 1948, Kongres, Hoofbestuur verslag, 1-2. 
die beleggers wat oortuig is om by die Fonds te belê te behou. Vir 1947 moes die B-fonds voorsiening maak vir die terugbetaling van $£ 2600$ aan beleggers wat met die stigting van die Fonds geld vir vyf jaar belê het. Die sekretaris het die beleggers genader met die versoek om die geld vir 'n verdere vyf jaar beskikbaar te stel teen die bestaande of verminderde rentekoers of dit teen rente beskikbaar te stel vir hulle leeftyd en die bedrag uiteindelik aan die Fonds te skenk in die vorm van 'n erflating. Volgens Van Zyl was die resultate besonder bemoedigend deurdat vyf van die persone hul beleggings (ter waarde van $£ 450$ ) in die vorm van bemakings aangebied het, agt (ten bedrae van $£ 925$ ) besluit het om hul geld te herbelê en slegs vyf (ten bedrae van $£ 350$ ) versoek het dat die geld terugbetaal word. Die oproepe om testamentêre bemakings het ook positiewe resultate opgelewer deurdat verskeie persone - mej Annie de Villiers (Zederbergplein, Paarl), mej JS du Plessis (Paarl), mnr HH Roos (Wellington), mnr DJ Malan (Wellington), dr JS du Toit (Kaapstad), mnr HJ Otto (Kroonstad), mnr JL McHardy (PE), mnr PF Theron (Kaapstad) - te kenne gegee het dat hulle sekere bedrae in hul testamente aan die B-fonds sou nalaat. ${ }^{58}$ Die bydraes van die takke tot die B-fonds was egter nie na wense nie en in sy 1947-verslag het die hoofbestuur aangedui dat sonder die spesiale bydraes van die takke die B-fonds verplig sou wees om die leningsvoorwaardes aan die student te verswaar, iets wat tot elke prys vermy moes word. ${ }^{59}$ Ten spyte van die feit dat lenings ten bedrae van $£ 7000$ vir 1947 aan studente toegeken is, ${ }^{60}$ kon talle verdienstelike gevalle weens 'n gebrek aan fondse nie gehelp word nie.

Die uitbreiding van die B-fonds en die administrasie daaraan verbonde het teen 1948 'n punt bereik waar verdere uitbreiding slegs met addisionele administratiewe hulp moontlik sou wees. Roux van der Poel se ouditverslag het die administrasie van die Fonds beskryf as uitdagend en het die lae administrasiekoste uitgesonder, maar het ook aangedui dat dit moontlik was omdat Van Zyl vanaf die stigting van die Fonds self baie van die kostes gedra het. Hy het dan ook aanbeveel dat amptenare vergoed moes word vir hul addisionele werk ten opsigte van die B-fonds. ${ }^{61}$ Hoewel aanpassings aan die salarisse van die amptenare tydelike oplossings gebied het, is met die aankondiging van mej Dalene Binedell (wat vir sewe jaar as hulp-sekretaresse van die Vereniging gefunksioneer het) dat sy besluit het om

58 (HSA) HVKP, Notuleboek (8 Feb 1940-9 Des 1966), 7 Jul 1947, B-fonds Kuratore, 54-55; (HSA) HVKP, Notuleboek (8 Feb 1940-9 Des 1966), 12-13 Nov 1947, Hoofbestuur, 370.

59 (HSA) HVKP, Notuleboek, 2-3 Apr 1947, Kongres, Hoofbestuur verslag, 2.

60 (HSA) HVKP, Notuleboek (8 Feb 1940-9 Des 1966), 12-13 Nov 1947, Hoofbestuur, 370.

61 (HSA) HVKP, Notuleboek (8 Feb 1940-9 Des 1966), 11 Feb 1948, B-fonds Kuratore, 61-63; (HSA) HVKP, Notuleboek, 31 Mrt-1 Apr 1948, Kongres, Hoofbestuur verslag, 1-2. 
in Maart 1950 die diens van die Vereniging te verlaat, besluit om die Helpmekaar-kantoor te reorganiseer.

Vanweë beide Van Zyl en adv Roux se gevorderde leeftyd het die hoofbestuur besluit om iemand met ekonomiese opleiding aan te stel wat as opvolger van een of albei van hulle sou kon dien ingeval van dood of bedanking. SP Pretorius is dus met ingang 1 Februarie 1950 as hulp-sekretaris en rekenmeester van die Vereniging aangestel. ${ }^{62}$ Die kuratorium van die B-fonds het besluit dat Pretorius ook as voltydse boekhouer van die Fonds sal dien teen $£ 10$ per maand betaalbaar deur die Hooffonds. Die sekretaris (Van Zyl) is ook gemagtig om

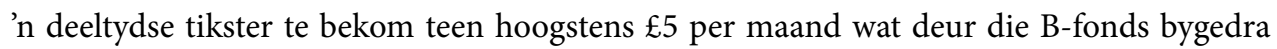
sou word. ${ }^{63}$

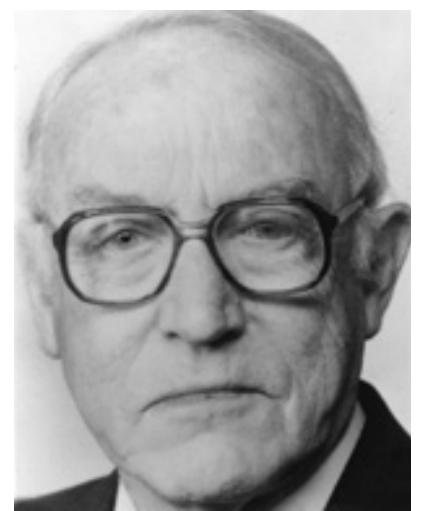

SP (Fanie) Pretorius, sekretaris en bestuurder van die Helpmekaar. Pretorius was 43 jaar by die Helpmekaar betrokke.
Met die B-fonds se vestiging in die veertigerjare het twee paralelle fondse in die Helpmekaar ontstaan wat, terwyl hulle dieselfde ideale gekoester het en op 'n administratiewe vlak grootliks dieselfde amptenare gedeel het wat bestuur betref, twee verskillende benaderings gevolg het. Die een was meer filantropies en welsynsgeoriënteerd en die ander meer sakeen korporatief georiënteerd, maar beide met dieselfde oorhoofse doelwit van die opheffing van Afrikaners deur onderwys en opvoeding. Die een was meer tradisioneel en konserwatief en die ander meer progressief. Die simbiotiese saambestaan van die twee benaderings sou periodiek tot spanning lei, wat veral in die vyftiger- en sestigerjare met die aanloop tot die samesmelting van die twee fondse 'n klimaks sou bereik.

62 (HSA) HVKP, Notuleboek, 4-5 Apr 1950, Kongres, Hoofbestuur verslag, 19-20; Pretorius het eers by 'n belowende Afrikaanse instelling gewerk wat in 1949 bankrot gegaan het. Senator Van Zyl, wat 'n direkteur van die bankrot instelling was, het hom gevra om deeltyds by die Helpmekaar te kom uithelp. Na 'n maand of drie het Van Zyl hom gevra om vir 'n permanente betrekking by die Helpmekaar aansoek te doen. Hy het die werk aanvaar al was dit, teen 'n salaris van $£ 2915 \mathrm{~s} 6 \mathrm{~d}$ plus 'n kantoormotor, minder as by sy vorige betrekking, maar dit het darem gratis inwoning by Leeuwenrusthof, die Helpmekaar se eiendom, ingesluit. (HSA) HVKP, Notuleboek (16 Feb 1973-10 Sep 1993), 15 Feb 1985, Trustees, Bestuurder jaarverslag 1984, 80.

63 (HSA) HVKP, Notuleboek (8 Feb 1940-9 Des 1966), 29 Nov 1949, B-fonds Kuratore, 84. 


\section{DIE SOEKE NA KAPITAAL: B-FONDS SE FONDSWERWINGSVELDTOG IN 1951 EN DAARNA}

Teen die einde van die veertigerjare was dit duidelik dat die groei van die B-fonds nie met die behoefte na lenings tred hou nie en dat drastiese stappe geneem sou moes word om die kapitaal van die Fonds uit te brei. Die kuratorium was van mening dat die kapitaal van die B-fonds slegs sou uitbrei as die sekretaris self weer, soos met die stigting van die Fonds, op kollekteertoere deur die land gaan. Die kwessie kon ook verbeter as die besture van die takke dit op hulle sou neem om vriende van die Helpmekaar te nader om hul spaargeld by die B-fonds te belê. Aangesien die sekretaris nie vir lang tye van die kantoor kon weg wees nie, was hy van mening dat die kongres druk op die takke moes uitoefen om te help. ${ }^{64}$

Met die oog op die algemene inkorting van krediet ${ }^{65}$ het die kuratore in Maart 1949 besluit dat lenings alleen in die uiterste gevalle oorweeg sou word en alleen minimum bedrae toegeken sou word. Hulle het ook besluit om maandelikse rekeninge aan alle skuldenaars uit te stuur en, waar nodig, drastiese stappe te neem om uitstaande skuld in te vorder. ${ }^{66}$ In sy verslag oor die B-fonds aan die hoofbestuur in Maart 1949 het die sekretaris, Van Zyl, aangedui dat, indien die Fonds nie deur nuwe beleggings en donasies versterk word nie, die kuratore verplig sou word om die lenings vir die jaar drasties in te kort. Aanduiding was dat daar nie meer as $£ 3000$ vir die jaar beskikbaar sou wees nie. Hiervan moes $£ 1500$ gehou word vir die terugbetaling van deposito's. Met die oorblywende $£ 1500$ kon hoogstens lenings aan ses of sewe studente voorsien word. Die voorsitter het dus voorgestel dat die sekretaris die posisie aan die kongres moes stel. ${ }^{67}$ Die verslag van die hoofbestuur aan die 1950-kongres het dus aangedui dat, hoewel die B-fonds bronne van kapitaal gemobiliseer het wat vroeër onontgin was, die Fonds 'n posisie bereik het dat hulle weens 'n tekort aan fondse feitlik alle aansoeke om studiehulp van die hand moes wys. Die verslag van die hoofbestuur het aangedui dat 'n meer aktiewe belangstelling tov fondsinsameling noodsaaklik was as die B-fonds nie wou voortgaan om soos toe, omtrent alle aansoeke vir studiehulp van die hand te wys nie:

64 (HSA) HVKP, Notuleboek (8 Feb 1940-9 Des 1966), 11 Feb 1948, B-fonds Kuratore, 61-63; (HSA) HVKP, Notuleboek, 31 Mrt-1 Apr 1948, Kongres, Hoofbestuur verslag, 1-2.

65 In 1949 het die Suid-Afrikaanse regering die Rand gedevalueer en die Suid-Afrikaanse Reserwebank vir die eerste keer sedert 1941 sy rentekoers van drie persent na drie en 'n half persent verhoog. Dit het 'n periode van die algemene inkrimping van krediet deur banke ingelui wat deur die Reserwebank as 'n anti-inflasionêre maatreël aangemoedig is. JJ Rossouw, Inflation in South Africa: 1921 to 2006. History, Measurement and Credibility, 162, PhD, UKZN, 2007.

67 (HSA) HVKP, Notuleboek (8 Feb 1940-9 Des 1966), 30 Mrt 1949, Hoofbestuur, 393. 
"Die hartroerende tonele wat tussen ons kantoorpersoneel en aansoekers afgespeel word wanneer studente moet verneem dat hulle hoop op ons verydel is en dat hulle hul studies moet onderbreek, wil ons nie hier beskryf nie." ${ }^{36}$

Omdat sy ander fondse uitgeput was, is die B-fonds ook genoodsaak om die laaste paar duisend pond uit die $£ 5000$ lening ${ }^{69}$ uit die Hooffonds te onttrek. Die B-fonds was dus van voorneme om vir 'n verdere soortgelyke lening uit die Hooffonds aansoek te doen.

Die hoofbestuur se verslag het ook meegedeel dat die aanstelling van 'n fondsorganiseerder in reaksie op die vorige kongres se besluit in dié verband nie aan die verwagtinge voldoen het nie. DJ Kritzinger, lid van die Provinsiale Raad, is vir 'n proeftyderk van drie maande aangestel, maar kon nie voltyds aandag aan die saak gee nie en het sy bedanking ingedien. Nadat sy salaris van $£ 50$ per maand afgetrek is, was daar ongeveer $£ 130$ beskikbaar om tussen die Hoof- en B-fonds te verdeel. Kritzinger het ook ongeveer $£ 300$ se beleggings, waarvan 'n deel rentevry was, ingesamel. Die vul van die vakature is in die hande van die dagbestuur gelaat terwyl die sekretaris versoek is om self organisasiereise te aanvaar wanneer hy tyd het teen 'n vergoeding van $£ 2$ 2s per dag plus reiskoste. ${ }^{70}$

Die groot tekort aan fondse vir studentelenings wat deur die verslag van die hoofbestuur blootgelê is, het tot wye bespreking oor fondsinsameling op die kongres aanleiding gegee en 'n besluit is geneem om 'n spesiale poging aan te wend om die fondse van die Helpmekaar te versterk. Verskeie voorstelle is aanvaar om die posisie aan te spreek. Die detail van die besluite het aangedui dat dit veral op die versterking van die B-fonds gerig was. 'n Voorstel is aanvaar waarin die kongres hom tot die takke gewend het met 'n versoek dat alle takke dringend minstens $\mathfrak{£} 40$ aan die Hoof- en B-fondse skenk. Takke is verder ook versoek om hul fondse in die B-fonds te belê en ander verenigings en liggame is aangemoedig om dieselfde te doen en om potensiële beleggers, erflaters en donateurs, asook moontlike kollektante en organiseerders te identifiseer. ${ }^{71}$ 'n Voorstel van die Kaapse Skiereiland dat daar weer 'n verdere $£ 5000$ van die Hooffonds in die B-fonds belê moes word, is ook aanvaar. ${ }^{72}$ In 'n verdere poging om die

69 (HSA) HVKP, Notuleboek, 2-3 Apr 1947, Kongres, 13; (HSA) HVKP, Notuleboek, 31 Mrt-1 Apr 1948, Kongres, 8; Hoewel die gedagte dat die Hooffonds van sy geld by die B-fonds moes belê in 1947 vir die eerste keer tydens 'n Kongres geopper is, is 'n voorstel eers tydens die 1948 Kongres aanvaar dat die dagbestuur gemagtig word om jaarliks geld aan die B-fonds te leen teen vier persent en dat die totale leningsbedrag vir eers nie $£ 5000$ mag oorskrei nie.

(HSA) HVKP, Notuleboek, 4-5 Apr 1950, Kongres, Hoofbestuur verslag, 18-19. 


\section{Die Kaapse Helpmekaar}

tekort aan fondse te bestuur het die kuratore in April 1950 besluit om ruimer van die Fonds se reserwes gebruik te maak op voorwaarde dat die likwiede reserwes nooit onder 30 persent daal nie. Hulle het ook die bestuur van die SAOU genader met die versoek om 'n deel van hul fondse in die B-fonds teen vier persent te belê. ${ }^{73}$

Die verbintenis van die kongres en takke by die 1950-kongres tot 'n spesiale poging om fondse in te samel, het nie die gewenste resultate gelewer nie en die hoofbestuur het gekla dat die "skyn verwek word dat afgevaardigdes en bestuurslede van takke net so gemaklik die beroepe vergeet wat daar op kongresse en deur ons hoofkantoor gedoen word as wat dit was om dit aan te hoor ... Dit skyn asof besture nie graag tot die fonds van ons Vereniging wil bydra tensy hulle meer uit die Hooffonds kry as wat hulle stort nie." ${ }^{74}$

Die ernstige tekort aan fondse vir studielenings teen die einde van die veertigerjare is deur die loop van 1950 die hoof gebied deur die verkryging van deposito’s van ongeveer $£ 5000$ en 'n lening van $£ 3000$ van die Hooffonds. Dit het nie die B-fonds se achilleshiel, naamlik die gebrek aan eie kapitaal, opgelos nie. Weens die handhawing van 'n likiede reserwe van ongeveer 40 persent van die B-fonds se leningskapitaal om vir opvragings voorsiening te maak kon baie van die kapitaal nie gebruik word vir die doel waarvoor dit geleen is nie, naamlik studielenings. ${ }^{75}$

Die kuratore van die B-fonds het dus in Oktober 1950 besluit om in Maart 1951 'n spesiale fondswerwingsveldtog van stapel te stuur met die doel om die eie kapitaal van die B-fonds van die heersende ongeveer $£ 6000$ tot $£ 30000$ uit te brei. Die sekretaris het ook aangedui dat Afrikaanse dagblaaie reeds genader is om met die poging te help en dat hulle positief gereageer het. ${ }^{76}$ Die hoofbestuur het in November sy goedkeuring aan die veldtog verleen met die nadruk daarop dat in die publisiteitsveldtog die hele Helpmekaarvereninging en nie net die B-fonds bevorder moet word nie. Die sekretaris het aangedui dat die Helpmekaar as geheel publisiteit sou ontvang, maar dat die insameling spesifiek vir die B-fonds sou wees. ${ }^{77}$

Die kuratore wou uit 'n sake-oogpunt 'n eie kapitaal vir die B-fonds met die insameling opbou

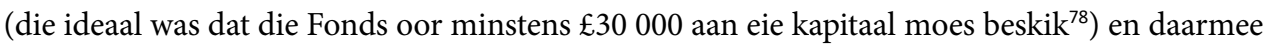
ook die verhouding tussen die Fonds se eie kapitaal en sy verpligtinge teenoor die publiek

73 (HSA) HVKP, Notuleboek (8 Feb 1940-9 Des 1966), 19 Apr 1950, B-fonds Kuratore, 91.

74 (HSA) HVKP, Notuleboek, 2-3 Apr 1951, Kongres, Hoofbestuur verslag, 1.

75 (HSA) HVKP Notuleboek, 3-4 Apr 1951, Kongres, 7.

76 (HSA) HVKP, Notuleboek (8 Feb 1940-9 Des 1966), 18 Okt 1950, B-fonds Kuratore, 96; (HSA) HVKP, Notuleboek, 3-4 Apr 1951, Kongres, 7.

77 (HSA) HVKP, Notuleboek (8 Feb 1940-9 Des 1966), 18 Nov 1950, Hoofbestuur, 411.

78 (HSA) HVKP, Notuleboek, 8-9 Apr 1952, Kongres, Hoofbestuur verslag, 1. 
verbeter. Die veel belangriker doelwit het egter op 'n ideologiese vlak gelê, naamlik om die kuratore "in staat te stel om te verhoed dat van ons volksjeug in die hande val van ongewenste geldskieters". Die kuratore se verduideliking van die tydsberekening van die insameling het ook verdere insig verskaf in hul spesifieke teikenmark en die rol wat die toenemende welvaart en die klasseverdelings wat dit in Afrikanergeledere geskep het, daarin gespeel het. Die afname in die aantal studente wat in 1950 aan die verskillende universiteite ingeskryf het, het volgens die kuratore die tydigheid van die veldtog bevestig:

"Hierdie afname is hoofsaaklik te wyte aan die voorspoed wat daar in sekere volkslae heers. Die gevolg daarvan is dat minder seuns van welvarende persone na die universiteit gaan, terwyl die meer behoeftige studente nie kan gaan nie omdat die koste in verband met sy kursus aan alle universiteite enorm toegeneem het. Dit is juis hierdie klas studente en dié wat reeds op universiteit is, en nie kan uitkom op vroeëre toekennings nie, wat nou in toenemende getalle hul toevlug na die Helpmekaar neem. Die ondervinding het geleer dat dit juis hierdie mense is wat, deur die ekonomiese drang gedwing om te presteer, uiteindelik die grootste bate vir ons volk is. Om dan in hulle behoeftes te voorsien, was een van die dryfvere vir die veldtog....79

Die strategie vir die veldtog was om die Afrikaner establishment - beide individue en instellings - vir die veldtog te mobiliseer en hulle ook te laat inkoop op die noodsaaklikheid vir die bestaan van 'n studiefonds soos die B-fonds. Die lys van leiers en koerantredakteurs met wie Van Zyl onderhoude gevoer het om die veldtog te bevorder het'n goeie aanduiding gegee van hoe wyd die net gespan is: dr DF Malan, regter HA Fagan, mev pres MT Steyn, mev DF Malan, dr MS Louw (ekonomiese leier), weleerwaarde dr AJ van der Merwe (moderator), mnr GJ Roussouw, mnr JH Moolman (Wolraad), ds DPM Beukes, prof dr HB Thom (US), mnre LC Bruwer en JB Bonthuys (voorsitter en sekretaris van die SAOU), redakteurs van Die Burger, Die Oosterlig, Die Huisgenoot, Sarie Marais, Die Kerkbode, Die Landstem, Die Jongspan, Die Landbouweekblad, Die Primêre Produsent, Die O.B., Die Unie, Die Kruithoring en Die Huisvrou. Die hoofbestuur het beweer dat die insameling en gesprekke met volksleiers op verskeie gebiede die besef vir die noodsaaklikheid vir so 'n studiefonds laat posvat het. Die hoofbestuur was egter van mening dat die sukses wat verwag word slegs sou realiseer as elke Helpmekaarlid in sy eie omgewing en ruimte die veldtog propageer en adverteer het. In dié verband kon "Predikante en onderwysers (kan) veel bydra deur van die kansel en in die skool die insamelingspoging onder die volk in te dra." ${ }^{80}$ Die etniese aard van die B-fonds se aanslag is verder bevestig deur die sekretaris se waarneming dat daar volgens getuienis nog baie takke en skoolkomitees is wat hul fondse

79 (HSA) HVKP, Notuleboek, 3-4 Apr 1951, Kongres, Hoofbestuur verslag, 1-2.

80 (HSA) HVKP, Notuleboek, 3-4 Apr 1951, Kongres, Hoofbestuur verslag, 2. 


\section{Die Kaapse Helpmekaar}

by "vreemde bougenootskappe" in plaas van die B-fonds belê. ${ }^{81}$ Benewens die mobilisering van bogenoemde netwerke sou ook van fondsorganiseerders gebruik gemaak word om die verskillende dele van Kaapland te bearbei. GR Malherbe het byvoorbeeld as fondsorganiseerder in die Boland gewerk, terwyl ds Beukes se kerkraad in Cradock aan hom twee maande verlof toegestaan het om as kollektant vir die B-fonds op te tree. ${ }^{82}$

Ten spyte van die positiewe verwikkelinge het die B-fonds se insamelingsveldtog egter ook weer die ou foutlyne tussen die Hoofonds en B-fonds-ondersteuners blootgelê. Besware teen die feit dat die insameling slegs die B-fonds finansieel sou bevoordeel, is van "verskeie kante" ontvang. Die hoofbestuur was van mening dat die besware berus het op die wanvoorstelling dat die twee fondse met mekaar meegeding het. Hulle het sodanige mededinging ten sterkste ontken en dit as feit gestel dat

“die B-fonds 'n aanvullende fonds is en slegs 'n langer Helpmekaar-arm van dieselfde liggaam is om te help waar die ander een nie kan bykom nie. Wat die een fonds versterk, versterk ook die ander. In ander woorde, ons is een liggaam met dieselfde doel en strewe wat sy ideale probeer bereik deur verskillende kanale." ${ }^{83}$

Dit was egter nie te ontken dat die twee "kanale" wesenlike strategiese verskille gehuisves het nie en dat die B-fonds-faksie en hul ondersteuners toenemend druk uitgeoefen het om die Vereniging te oortuig om hulle strategieë en strukture binne die Vereniging te aanvaar nie. Die B-fonds se finansiële "afhanklikheid" van die Hooffonds sou egter verseker dat die oortuigingswerk met groot omsigtigheid, inkrementeel en met verdrag sou plaasvind.

Behalwe vir die ontevredenheid in sekere kringe binne die Vereniging omdat die insameling slegs op die B-fonds sou fokus, het die insamelingsveldtog tog ook as inspirasie vir Helpmekaartakke en -lede gedien. Dit het selfs gelei tot pogings van takke en individue om weer die ou $£ 100$-insamelingsentimente van 1917 te laat herleef. Dr JC Rabie van die Port Elizabeth-tak het die tak tot 'n $£ 100$-skenking aan die B-fonds verbind met die hoop dat al die ander takke ook $£ 100$ sou gee. Hy het ook 'n vyfjaarplan van insameling vir die B-fonds voorgestel. HK Lombard van die Bedford-tak het ook belowe om benewens die tak se $£ 100$ 'n persoonlike bydrae van $£ 100$ tot die B-fonds by te dra. ${ }^{84}$ Met die politieke koninkryk reeds be-erwe en 'n toenemend welvarender Afrikaner-gemeenskap in wording, was die pogings om die etnies gedrewe 1917-insameling te laat herlewe egter doodgebore.

81 (HSA) HVKP, Notuleboek (8 Feb 1940-9 Des 1966), 18 Nov 1950, Hoofbestuur, 411.

82 (HSA) HVKP, Notuleboek (8 Feb 1940-9 Des 1966), 3-4 Apr 1951, Hoofbestuur, 417.

83 Ibid.,1-2.

84 (HSA) HVKP, Notuleboek, 3-4 Apr 1951, Kongres, 11. 
Teen Julie 1951 het die insamelingsveldtog ongeveer $£ 11000$ opgelewer. Hoewel nog kollektante aangestel is, moes daar nog kollektante gevind word vir sekere dele van Kaapland en is daar besluit om met die veldtog voort te gaan tot die einde van die jaar. Die struktuur van die B-fonds se sakemodel is ook'n stap verder gevoer met die aanvaarding van die sekretaris se versoek vir die aanstelling van vaste verteenwoordigers wat teen vergoeding van een persent op beleggings en vyf persent op bemakings kapitaal vir die B-fonds sou werf. ${ }^{85}$ Die aanstelling van mnr Philip van Zyl, 'n bekende sakeman van Kaapstad, as kurator in $1951^{86}$ het bygedra daartoe dat die kuratorium ook hul werwingswerk na die sakewêreld uitgebrei het. Hulle het Anton Rupert van Rembrandt Tabakkorporasie vir 'n jaarlikse bydrae van $£ 100$ genader. Philip van Zyl, wat Rupert genader het, was van mening dat, indien die skenking sou realiseer, dit as voorbeeld vir ander maatskappye kon dien om dieselfde te doen. ${ }^{87}$

Van Zyl se versoek aan Rupert is gevolg deur 'n uitnodiging om hom as kurator van die B-fonds beskikbaar te stel ${ }^{88}$ wat in Junie 1952 tot die verkiesing van Rupert as bykomstige lid op die kuratorium gelei het. ${ }^{89}$ Dit was 'n assosiasie wat die B-fonds, afgesien van die simboliese waarde daarvan, oor jare tot groot voordeel sou strek. Met die afsluiting van die finansiële jaar aan die einde van 1951 het die insamelingsveldtog 'n bedrag van $£ 12259$ 6s 11d opgelewer wat die B-fonds se eie kapitaal op $£ 19060$ 12s 2d te staan gebring het. Na die afsluiting van die boekjaar het nog bedrae ingekom wat die eie kapitaal op meer as $£ 20000$ te staan gebring het. Hoewel die veldtog "bevredigende vrugte afgewerp het", ${ }^{90}$ is besluit om nie die veldtog teen die einde van 1951 af te sluit soos aanvanklik beoog is nie, maar onbepaald daarmee voort te gaan. Die belangrikste oorwegings hiervoor was die ideaal dat die Fonds oor minstens $£ 30000$ aan eie kapitaal moes beskik. Oom Gawie Malherbe, een van die kollektante, was steeds in die veld en het reeds $£ 2300$ ingesamel. Hy, saam met ds DPM Beukes, was grootliks verantwoordelik vir die sukses van die veldtog alhoewel daar nog veel van hom verwag was. ${ }^{91}$

Die 1951-insamelingsveldtog het nie sy doelwit van 'n eie kapitaal van $£ 30000$ bereik nie. Ten spyte hiervan was die Fonds in 'n veel beter posisie as teen die einde van die veertigerjare en het

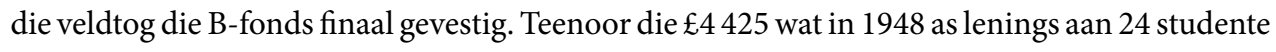

(HSA) HVKP, Notuleboek, 8-9 Apr 1952, Kongres, Hoofbestuur verslag, 1. 


\section{Die Kaapse Helpmekaar}

toegeken is ${ }^{92}$ en die geskatte ongeveer $£ 1500$ wat in Maart 1949 vir studielenings vir die jaar beskikbaar was - genoeg vir ses of sewe studente - is vir die 11 maande tot einde November $1951 £ 10000$ deur die B-fonds aan studente uitgeleen en is die vordering van die Fonds as baie goed beskryf. ${ }^{93}$ Soveel so dat die kuratorium in staat was om in die lig van die verbeterde posisie van die Fonds die vergoeding van die personeel aan te pas. ${ }^{94}$ Teen Desember 1952 was die Fonds se eie kapitaal tussen $£ 21000$ en $£ 22000$ en het die totale fondse ongeveer $£ 90000$ beloop. Van Zyl het ook aangedui dat weens die oordeelkundige beleggings en besteding, die eie kapitaal jaarliks met minstens $£ 2000$ aangroei. ${ }^{95}$ Senator Van Zyl het in Junie 1952 die kuratorium meegedeel dat hy en sy eggenote, met die uitsondering van 'n aantal direkte bemakings, die B-fonds volle erfgename van hul nalatenskap maak. Dit het nie 'n onmiddellike impak op die finansiële posisie van die Fonds gehad nie. Sy verbintenis het egter die sukses van die Fonds bevestig en hierdie wete het ten minste as morele sekuriteit die Fonds versterk. ${ }^{96}$

Ten spyte van die verbeterde posisie van die Fonds in die vroeë vyftigerjare was die realiteit steeds dat die aanvraag die aanbod verreweg oorskry het. Die uitbouing van die Fonds was 'n voortdurende, nimmereindigende proses. Hierdie realiteit is by herhaling deur Van Zyl tuisgebring. Die agterstand van Afrikaners ten opsigte van studiefondse is op die 1953-kongres deur Van Zyl benadruk. Hy het aangedui dat daar altesaam 83 nie-Afrikaanse studiefondse in die land was, met 'n gesamentlike kapitaal van sowat $£ 6000$ 000, terwyl die Afrikaners maar oor drie organisasies beskik het wat studielenings beskikbaar gestel het met 'n kapitaal van

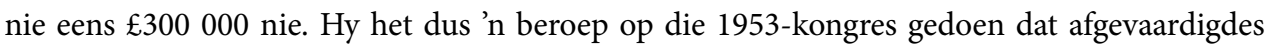
persone moet oorreed om hul geld in die B-fonds te belê en om geld in hul testamente vir die Helpmekaar te oormerk. ${ }^{97}$ By die 1954-kongres het Van Zyl weer die noodsaaklikbeid van 'n Afrikaanse Beursfonds as teenvoeter vir die Rhodes-Trustfonds en andere beklemtoon. ${ }^{98}$ Ten spyte daarvan dat die finansiële posisie van die B-fonds as kerngesond beskou is, was dit duidelik dat, indien die B-fonds die groeikoers in die aantal lenings wat hul toegestaan het, wou handhaaf en steeds hul likiede reserwes teenoor deposito's op 'n aanvaarbare vlak wou handhaaf, die leningskapitaal van die B-fonds verder vergroot sou moes word.

92 (HSA) HVKP, Notuleboek (8 Feb 1940-9 Des 1966), 19-20 Nov 1948, Hoofbestuur, 385.

93 (HSA) HVKP, Notuleboek (8 Feb 1940-9 Des 1966), 19 Des 1951, Hoofbestuur, 421.

94 (HSA) HVKP, Notuleboek (8 Feb 1940-9 Des 1966), 17 Nov 1951, B-fonds Kuratore, gp.

95 (HSA) HVKP, Notuleboek (8 Feb 1940-9 Des 1966), 18 Des 1952, Hoofbestuur, 437.

96 (HSA) HVKP, Notuleboek (8 Feb 1940-9 Des 1966), 11 Jun 1952, B-fonds Kuratore, 133.

97 (HSA) HVKP, Notuleboek, 27 Jun 1953, Kongres, 9.

98 (HSA) HVKP, Notuleboek, 30-31 Mrt 1954, Kongres, B-fonds verslag, 3. 
Die kuratorium het besluit om takke deur middel van 'n omsendbrief te versoek om beleggings te werf en ook besluit om die Hooffonds/Vereniging vir 'n verdere lening van $£ 5000$ - $£ 10000$ te nader met dien verstande dat die bedrag nie dadelik getrek sou word nie, maar as stille reserwe beskou sou word ${ }^{99}$ vir indien die B-fonds dit sou nodig kry. Die rekenmeester, adv Wessel Roux, het egter beswaar gemaak teen die toestaan van 'n verdere lening aan die B-fonds, aangesien hulle volgens sy mening geen dringende behoefte aan 'n verdere Hooffondslening gehad het nie en dit slegs as stille reserwe wou gebruik. Sy teenstand het die hoofbestuur genoop om die saak tot hul volgende vergadering te laat oorstaan. ${ }^{100}$

Roux se beswaar het waarskynlik gespruit uit die feit dat die lenings aan die B-fonds'n afwyking was van die Vereniging se gebruik oor jare om slegs die renteopbrengs op die Hooffonds, en nie die kapitaal nie, vir studielenings aan te wend. Deur geld by die Hooffonds te leen vir die gebruik van studielenings aan studente het die B-fonds dus daarin geslaag om die Hooffondskapitaal indirek vir studieleningsdoeleindes te ontsluit. Die debat hieroor sou toenemend 'n sentrale kwessie in die Vereniging en ook in die verhouding tussen die Hoof-en B-fonds word. Roux se beswaar was verteenwoordigend van die groepering in die Vereniging se geledere wat die afwyking van die tradisionele standpunt oor die aantasting van die Hoofondskapitaal met agterdog bejeën het.

Die steeds toenemende aanvraag na studielenings het die kuratore van die B-fonds ook genoop om te herbesin oor hul toekenningsbeleid ten opsigte van studielenings. In dié verband het veral twee aspekte onder oorweging gekom, naamlik finansiële ondersteuning aan teologiestudente en studente buite die grense van Kaapland en by name dié van Transvaal. Laasgenoemde kategorie het weer ten nouste verband gehou met die stigting van 'n studiefonds vir dié provinsie. Hoewel die Helpmekaarvereniging van die Kaapprovinsie reeds sy deure vroeg in sy bestaan vir die ander provinsies se aansoekers gesluit het, het die B-fonds se stigting in 1942 met sy duidelike nie-erkenning van provinsiale grense 'n nuwe heenkome vir veral Transvaalse studente gebied. Die B-fonds het geen bydraes uit die Transvaal ontvang nie, behalwe die $£ 6000$ wat deur die Zeerust Beursfonds by die B-fonds belê is en waarvan die rente aangewend is vir leningsaansoekers uit Zeerust. Aansoeke is uit die Transvaal toegestaan indien daar voldoende fondse was. ${ }^{101}$ Reeds in 1943 is 'n lening aan RE Bauling van Wolmaranstad vir $£ 72$ per jaar vir drie en 'n half jaar toegeken om Medies te studeer. ${ }^{102}$ Aansoeke uit die provinsie het egter teen die vroeë vyftigerjare so toegeneem dat dit 'n toenemende besprekingspunt geword het -

99 (HSA) HVKP, Notuleboek (8 Feb 1940-9 Des 1966), 14 Des 1953, B-fonds Kuratore, 156.

100 (HSA) HVKP, Notuleboek (8 Feb 1940-9 Des 1966), 15 Des 1953, Hoofbestuur, 453-454.

101 (HSA) HVKP, Notuleboek, 30-31 Mrt 1954, Kongres, 5.

102 (HSA) HVKP, Notuleboek, 4-5 Apr 1944, Kongres, Studielenings uit die B-fonds toegeken, 11. 


\section{Die Kaapse Helpmekaar}

veral in die lig van die groter wordende aanvraag na studielenings. ${ }^{103}$ Aangesien die B-fonds se stelsel en beleid ten opsigte van studielenings gebaseer was op die vinnige omset van lenings, het veral lenings aan teologiestudente stremmend op die B-fonds ingewerk vanweë die stadige terugbetaling van lenings. ' $n$ Brief is dus aan die Raad van Kerke (Sinode) gerig waarin versoek is dat sinodale en gemeentefondse bewillig word vir studiehulp aan teologiestudente om sodoende die las op die B-fonds te verlig. Die versoek is na die verskillende sinodes verwys en op die Kaapse Sinode is die saak verwys na 'n kommissie, wat bestaan het uit die Sinodale Kommissie van Toesig en Kontrole, die Sinodale Opvoedingskommissie en verteenwoordigers van die B-fonds.

Die Helpmekaar-voorsitter, ds Beukes, het die saak by die Sinode geopper en hoewel dit simpatiek ontvang is, het die kerk se saakgelastigde hom ingelig dat die kanse skraal was vir direkte studiehulp aan teologiestudente of vir die belegging van sinodale fondse by die B-fonds. Ds Beukes het ook gemaan dat die B-fonds nie die indruk moes wek dat hulle nie meer teologiestudente wou help nie, "aangesien die Helpmekaar soveel verskuldig is aan die kerk en die kerk nog altyd tot groot hoogte die Helpmekaar gedra het". ${ }^{04}$ Die kuratore het dus besluit dat leningsaansoeke van teologie-studente nog soos in die verlede op meriete beoordeel sou word. Aansoekers uit Transvaal sou alleenlik nog studiehulp ontvang tot tyd en wyl dit duidelik word of Transvaal'n eie studiefonds in die lewe gaan roep, al dan nie. As Transvaal nie sou voortgaan om voorsiening te maak vir hul eie studente nie, sou die B-fonds studente uit die provinsie nie verder help nie. ${ }^{105}$

Aangesien die Helpmekaarvereniging in Transvaal in die dertigerjare disfunksioneel geraak het en die laaste oorblywende fondse van die Vereniging aan die Universiteit van Pretoria geskenk is as bydrae vir die oprigting van 'n mediese fakulteit het die provinsie se studente nie 'n Helpmekaar-heenkome gehad nie. DH van Zyl se propaganda vir die herlewing van die Helpmekaargedagte met die oog op die voorsiening in die Afrikaner se onderwysbehoeftes en die neerslag daarvan in die B-fonds, het gelei tot hernude belangstelling in die Transvaal vir die werk van die Kaapse Helpmekaar. Die Kaapse hoofbestuur het dus op die 1945-kongres gerapporteer dat Van Zyl deur belangstellendes in Transvaal versoek is om die provinsie behulpsaam te wees met die stigting van 'n eie studiefondsbeweging en dat die bestuur aan hom toestemming verleen het om met die proses voort te gaan. ${ }^{106}$ In 1946 is gerapporteer dat 'n

103 (HSA) HVKP, Notuleboek, 30-31 Mrt 1954, Kongres, 5.

104 (HSA) HVKP, Notuleboek (8 Feb 1940-9 Des 1966), 14 Des 1953, B-fonds Kuratore, 156.

105 Ibid.

106 (HSA) HVKP, Notuleboek, 4-5 Apr 1945, Kongres, Hoofbestuur verslag, 1. 
organisasie op die grondslag van die B-fonds in Transvaal gestig is. ${ }^{107}$ Tydens die 1949-kongres het Van Zyl gesê dat die nodige stappe om 'n studiefonds in Transvaal te stig reeds geneem is, maar dat dit op 'n effens ander grondslag, naamlik as 'n maatskappy sonder winsbejag, bedryf sou word. ${ }^{108}$ Teen die einde van 1953 was dit egter duidelik dat Van Zyl se vroeëre mededelings prematuur was en dat die voornemens vir 'n Transvaalse Studiefonds nog nie gerealiseer het nie, ten spyte van pogings van die Kaapse bestuur om Transvaalse instansies van die noodsaaklikheid van so 'n fonds te oortuig. ${ }^{109}$ Die 1953-besluite oor hulp aan Transvaalse studente is dus teen bogenoemde agtergrond geneem.

As deel van bogenoemde pogings is ' $\mathrm{n}$ ambisieuse langtermynplan vir fondsinsameling ook geïmplementeer. Daar is reeds in 'n vorige afdeling verwys na die twaalfjaarskema vir fondsinsameling wat vroeër reeds bedink is, maar by die 1955-kongres bekendgestel is, en waardeur die Hooffonds deur hoofsaaklik die werwing van lewenslange lede uitgebrei moes word tot $£ 100$ 000. Hoe realisties die Hooffonds-metode en doelwit was, kan bevraagteken word, aangesien dit teen 1955 reeds duidelik was dat die lewenslange lidmaatskapkonsep wat in 1953 geïmplementeer is nie die sukses was wat verwag is nie. Die hoop was waarskynlik op die nuwe fondswerwer, HD Roux, gevestig om 'n sukses daarvan te maak.

Die twaalfaarplan het ook vir die B-fonds voorsiening gemaak. Anders as die Hooffonds sou die B-fonds-insamelings fokus op insameling deur spesiale kollektes by gemeentes en insamelings by skole. Helpmekaar-lede wat lede van kerkrade was of as onderwysers by skole betrokke was, is versoek om hul invloed te gebruik om die saak van die Helpmekaar te bevorder. Die mikpunt vir die B-fonds was dat sy eie kapitaal van $£ 26000$ oor die volgende dekade organies sou aangroei tot $£ 50$ 000. Die verwagting was dat oor ongeveer dieselfde tyd deur die insamelings

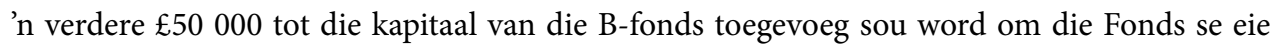
kapitaal ook op $£ 100000$ te staan te bring. Die Helpmekaar se berekeninge het daarop gedui dat eie kapitaal van dié omvang saam met die leningskapitaal van die B-fonds voldoende sou wees om in die afsienbare behoeftes aan studielenings te voldoen. Die doel van die fokus op die kerk en skool was dat gemeentekollektes sou kon voorsien in die spesiale behoeftes van teologiestudente, terwyl die skoolinsamelings geld sou genereer by juis die persone wat later van die Helpmekaar se hulp sou gebruik maak. Op dié manier sou die Helpmekaar ook aan skoliere bekendgestel word.

107 (HSA) HVKP, Notuleboek, 3-4 Apr 1946, Kongres, Hoofbestuur verslag, 1.

108 (HSA) HVKP, Notuleboek, 30-31 Mrt 1949, Kongres, 37.

109 (HSA) HVKP, Notuleboek (8 Feb 1940-9 Des 1966), 14 Des 1953, B-fonds Kuratore, 156; (HSA) HVKP, Notuleboek, 30-31 Mrt 1954, Kongres, 5. 


\section{Die Kaapse Helpmekaar}

Soos met die meeste Helpmekaarinsamelings sedert 1917 is Afrikaner-netwerke en -instellings aangewend in 'n poging om sukses te behaal. Aan kerklike kant is die ondersteuning van Die Kerkbode, asook die Moderator van die Kaaplandse Sinode van die NG Kerk, dr AJ van der Merwe, verkry en aan onderwyskant het Die Unie die pogings gesteun. Hoewel die 1955-kongres verdeeld was oor sekere aspekte van die insamelingskemas asook die tydsberekening daarvan het die hoofbestuur dit eenparig gesteun en kon dit dus geïmplementeer word. ${ }^{110}$

Die hoofbestuursverslag het ook weer die dieperliggende dryfveer en motiewe agter die Helpmekaar bevestig. Dit het deurlopend oor die jare dieselfde gebly, maar is net mettertyd in ander terminologie verwoord soos wat die konteks waarin die Afrikaner hom bevind het, verander het. Die verslag het, ten spyte van die sukses wat die B-fonds sedert sy ontstaan behaal het, gewaarsku dat toe (1955) voorspoedige jare beleef is en dat vir die maer jare voorsiening gemaak moes word:

"met 'n skrale 11 persent van die handel, nywerheid en finansies onder die beheer van die Afrikaner, is hy al klaar in die benarde posisie dat hy nie veel vinniger kan uitbrei nie omdat hy nie die opgeleide personeel daarvoor het nie. Dit is hier waar die Helpmekaar se taak lê, en ons moet ons posisie verstewig; ons moet meer beleggings kry om ons werkende kapitaal uit te brei ... Andermaal moet dit beklemtoon word dat die Witman alleen sy beskawing hier kan handhaaf as elke seun en dogter op sy of haar gebied tot die uiterste toe vir die lewenstryd bekwaam gemaak word. Trouens, dit moet die ideaal van elkeen wees om leiers op elke gebied aan die volk te voorsien." 111

Hier kry ons ook die teenstrydigheid van die vyftigerjare met die oorgang van 'n eksklusiewe Afrikaner-nasionalisme na 'n meer inklusiewe wit nasionalisme. Aan die een kant die oproep vir 'n Afrikaanse Beursfonds om die Rhodes- en soortgelyke volksvreemde Engelse Beursfondse teen te werk en die volk se breinkrag te behou. Aan die ander kant die oproep dat die witman, wat by implikasie ook wit Engelssprekendes insluit, sy beskawing alleen deur 'n superieure opvoeding sou kon handhaaf.

\footnotetext{
110 (HSA) HVKP, Notuleboek, 5-6 Apr 1955, Kongres, 2.

111 (HSA) HVKP, Notuleboek, 5-6 Apr 1955, Kongres, Hoofbestuur, 1-2.
} 


\section{HOOFSTUK SEWE}

\section{VAN B-FONDS TOT HELPMEKAAR STUDIEFONDS}

"Hy noem die sogenaamde "opstand" waarin die boere verkeer teen al die veldtogte ten behoewe van die universiteite, die blindes, die Lektuurfonds, die Sending en hulle eie plaaslike organisasies."

"Die bydraes wat tot dusver van sake-ondernemings ontvang is, is uiters teleurstellend, selfs dié van Afrikaanse Maatskappye wat die Helpmekaar baie goedgesind is ... Ook in die geval van individue word die Algemene klagte ontvang dat daar feitlik in elke dorp en distrik ook vir ander plaaslike doeleindes gekollekteer word."

\section{DIE B-FONDS, BANKWET EN AANVAARDING VAN 'N MAATSKAPPYSTRUKTUUR, 1956}

Die regsopinie wat met die stigting van die B-fonds in die vroeë veertigerjare van adv $\mathrm{JH}$ Conradie en adv (later regter) HA Fagan ingewin is, was van mening dat die tipe beleggings wat die B-fonds beplan het om in te neem hom nie sou verplig om onder die Bankwet te registreer nie. ${ }^{3}$ Desondanks het daar lank reeds 'n vermoede bestaan dat die B-fonds weens die aard van sy aktiwiteite - die inneem van deposito's van die publiek eintlik as 'n depositonemende instelling gefunksioneer het en dus onderhewig was aan die statutêre regulering van die Registrateur van Banke en by implikasie ook die Registrateur van Maatskappye. Hierdie vermoede is bevestig toe die Helpmekaar in die middel vyftigerjare deur die Registrateur ingelig is dat hul aktiwiteite hulle aan die Bankwet onderhewig stel en die Registrateur het beveel dat die B-fonds onverwyld as maatskappy moes registreer en ook vir registrasie as depositonemende instelling by die Registrateur van Banke moes aansoek doen.

In Oktober 1955 het die kuratore dus 'n konsep-grondwet goedgekeur waarvolgens beoog is om die B-fonds in 'n maatskappy sonder winsbejag onder die naam Helpmekaar Studiefonds

1 (HSA) HVKP, Notuleboek, (29 Nov 1963-9 Apr 1965), 9 Apr 1964, Helpmekaar Insamelingskomitee, Besoek aan De Doorns, gp.

2 (HSA) HVKP, Notuleboek, (29 Nov 1963-9 Apr 1965), 10 Feb 1964, Helpmekaar Insamelingskomitee, Verslag van werksaamhede, HL Greyling, 2, 3.

3 (HSA) HVKP, Notuleboek (8 Feb 1940-9 Des 1966), 1 Mrt 1957, Direksie HS, 191-192. 
(HS) te registreer. Dit het beteken dat die maatskappy geen inkomstebelasting of lisensiegeld sou betaal nie en dat sy direkteure geen vergoeding vir hul dienste mag ontvang het nie. $\mathrm{Al}$ die winste van die maatskappy moes ook by die kapitaal gevoeg word en vir studiehulp aangewend word. DH van Zyl en SP Pretorius is opdrag gegee om die Registrateur van Maatskappye in Pretoria te gaan besoek om enige probleme in dié verband uit te stryk. ${ }^{4}$ Die beoogde veranderinge is in Desember 1955 deur die hoofbestuur goedgekeur. Van Zyl het aangedui dat die konsep-grondwet voorsiening mak dat die lede van die hoofbestuur en ander lede van die Helpmekaar, sowel as skenkers aan die B-fonds, as lede van die te stigte maatskappy ingeskryf word en dat die kuratorium van die B-fonds die direksie sou vorm. Hy was van mening dat, behalwe vir die uiterlike veranderinge, die ou intieme verhouding tussen die twee fondse sou bly voortbestaan en dat die Vereniging nog seggenskap sou behou deur sy lede wat ook lede van die maatskappy sou wees. Die hoofbestuur se goedkeuring het ook die oordrag van die B-fonds se bates en laste aan die te stigte HS ingesluit. ${ }^{5}$

Die verwikkelinge ten opsigte van die B-fonds se status is ook in 1956 aan die kongres meegedeel. Om die kongres se goedkeuring te verseker het die hoofbestuur die veranderinge as 'n positiewe verwikkeling beskryf vanweë die groter sekerheid wat dit aan deposante sou verskaf. Dit het ook 'n etniese hoek bygesleep deur die verwikkeling as "iets van historiese betekenis" te beskryf, aangesien "die nuwe instelling een van slegs 'n paar volksbanke van ons land sal vorm". ${ }^{6}$ Daar is ook benadruk dat die verhouding tussen die twee fondse onveranderd sou bly en dat daar steeds jaarliks oor die B-fonds se bedrywighede verslag gelewer sou word. ${ }^{7}$ Hoewel die hoofbestuur se versekering waarskynlik die sentimente van die betrokkenes verwoord het, sou die veranderinge 'n maatskappy tot stand bring wat statutêr onafhanklik van die Vereniging sou staan. ${ }^{8}$

Op die kuratorevergadering van 23 November 1956 is die oorgang van die B-fonds na 'n maatskappy bespreek en die veranderinge uitgespel. Die registrasie van die B-fonds as maatskappy het beteken dat die kuratore nou direkteure sou word en dat 'n voorsitter vir

4 (HSA) HVKP, Notuleboek (8 Feb 1940-9 Des 1966), 27 Okt 1955, B-fonds Kuratore, 175; 2-3 Apr 1957, Hoofbestuur, 494; (HSA) HVKP, Notuleboek, 2-3 Apr 1957, Kongres, 8.

5 (HSA) HVKP, Notuleboek (8 Feb 1940-9 Des 1966), 12 Des 1955, Hoofbestuur, 479.

6 (HSA) HVKP, Notuleboek, 4-5 Apr 1956, Kongres, Hoofbestuur verslag, 2. Volgens die Registrateur van Banke se 1955-verslag was daar slegs twee volksbanke in Suid-Afrika - beide met hul hoofkantore in Pretoria: Ons Eerste Volksbank en die Staalwerkers Ko-operatiewe Spaarbank Beperk. Beide was etnies georiënteerde Afrikaner-instellings. UG no 34/1956, Registrateur van Banke, Tiende Jaarverslag, 31 Des 1955, Bylae A, 15.

7 (HSA) HVKP, Notuleboek, 4-5 Apr 1956, Kongres, Hoofbestuur verslag, 2.

$8 \quad$ Ibid. 
die maatskappy gekies moes word - 'n posisie waartoe dr JS du Toit eenparig verkies is. Die oorgang van B-fonds na Helpmekaar Studiefonds (HS) sou as formeel beskou word sodra die sertifikaat van inkorporasie van die Registrateur van Maatskappye ontvang word. Van Zyl het ook die geleentheid gebruik om oor die toekomsplanne uit te wy. Hy het ook verwys na die beoogde veranderinge aan die Vereniging se takstelsel, wat dit hopelik moontlik sou maak dat die fondsorganiseerders van die twee fondse dan uitsluitlik vir die B-fonds sou kollekteer.

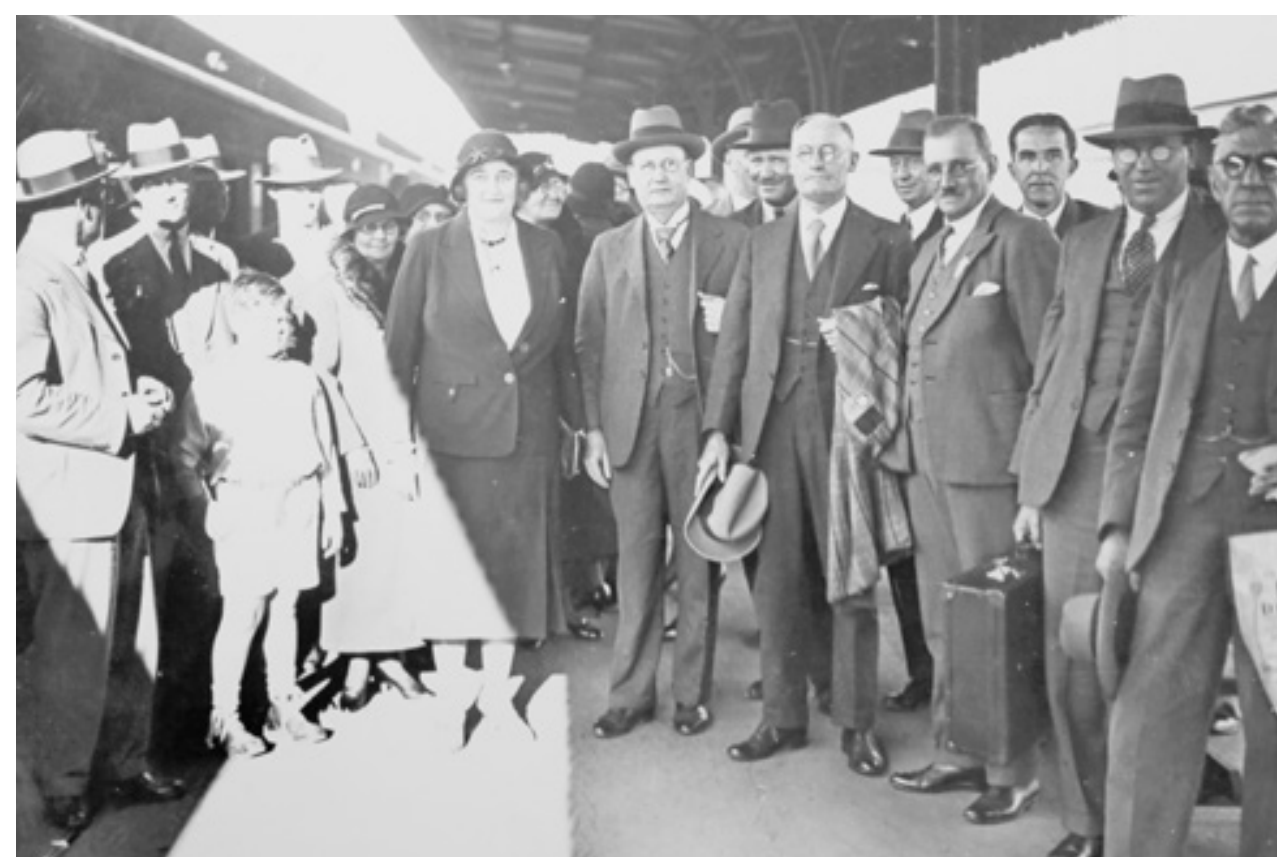

Lede van die Federale Raad van die NP op Kaapstad Stasie, Julie 1934. Onder andere op die foto is van links na regs: $d r J S$ du Toit (tweede van links agter jong seun), mev E du Toit (links van dr Malan), dr DF Malan, WA Hofmeyr (met jas), dr Van Nierop (tussen Hofmeyr en Sauer), P Sauer (met tas) en Bruckner de Villiers (regs van Sauer)

Hy het benadruk dat die B-fonds in 'n hoë mate afhanklik was van die bydraes wat hy van die Helpmekaar-takke ontvang en dat die nouste voeling nog met die Hooffonds gehandhaaf moes word. Verder was daar nog bydraes van kerke wat spesiale kollektes vir dié doel gehou het, asook skenkings van skole en bevriende persone en besighede wat ook op die plaaslike taknetwerke gesteun het. Die kuratorium het ook besluit dat die beleid ten opsigte van fondsinsameling, deposito's en studielenings sou bly soos dit in die verlede was. Ander besluite van die vergadering het die verwagting dat die maatskappy onder die Bankwet sou moes registreer, 


\section{Die Kaapse Helpmekaar}

weerspieël, naamlik 'n hersamestelling van die reserwefondsbeleggings om aan die bepalings van die Bankwet te voldoen. Daar is besluit om die Beursfonds na die reserwerekening oor te dra aangesien dit andersinds as 'n verpligting teenoor die publiek gesien sou word. Onder die nuwe bedeling sou DH van Zyl as hoofbestuurder en SP Pretorius as sekretaris dien. Die dagbestuur van die direksie en die beleggingskomitee sou bestaan uit die voorsitter en enige twee ander direkteure. Twee lede op 'n vergadering sou 'n kworum wees. ${ }^{9}$

Die nuwe grondwet van die B-fonds is reeds vroeër deur beide die Registrateur van Maatskappye en die Registrateur van Banke goedgekeur. ${ }^{10}$ Die HS is eers op 21 Desember 1956 kragtens die Maatskappyewet geregistreer. ${ }^{11}$ Die registrasie van die HS onder die Bankwet is aanvanklik as 'n onafwendbaarheid aanvaar, maar die besef van die onhoudbare administratiewe las, wat die nakoming van al die vereistes van die Bankwet op die Studiefonds se finansiële personeel, bestaande uit slegs een persoon, naamlik Pretorius, sou plaas, het mettertyd bedenkinge oor die uitvoerbaarheid van die stap laat ontstaan. Toe die Studiefonds se ouditeure dus in 'n toevallige gesprek die mening uitgespreek het dat die B-fonds nie deposito's hou nie, maar obligasies en dat 'n maatskappy geregtig is om obligasies (skuldbriewe) uit te reik al is hy nie 'n bankinstelling nie, is besluit om verdere regsopinie hieroor in te win.

Die Registrateur is dus op sterkte van die regsopinie, wat die interpretasie van die ouditeure ondersteun het, genader met die versoek om die Studiefonds van die registrasie onder die Bankwet vry te stel. Die Registrateur het gebonde gevoel aan die Bankwet se interpretasie van 'n obligasie, wat die Studiefonds sou dwing om as bankinstelling te registreer. Die Registrateur het aangedui dat 'n formele versoek (met 'n onderneming van die Studiefonds om geen verdere deposito's van die publiek in te neem nie as voorwaarde) vir uitsluiting van die Bankwetbepalings 'n redelike kans sou staan om te slaag. Die direkteure van die HS is dus tydens die eerste vergadering onder die nuwe bedeling op 1 Maart 1957 versoek om oor die Bankwet-kwessie 'n besluit te neem. Van Zyl se uiteensetting van die deposito's wat die Studiefonds gehou het, het aangedui dat die destydse ongeveer $£ 60000$ bestaan het uit $£ 10000$

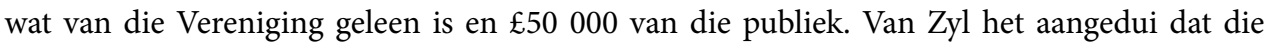
verwagting was dat die Vereniging mettertyd sy belegging by die Studiefonds sou aanvul totdat 'n aansienlike deel van sy beskikbare kapitaal van $£ 70000$ by die Studiefonds belê is.

Die $£ 50000$ van die publiek moes volgens hom vir die doel van die argument as min of meer 'n permanente belegging beskou word. Indien van laasgenoemde bedrag wel opgevra sou

9 (HSA) HVKP, Notuleboek (8 Feb 1940-9 Des 1966), 23 Nov 1956, B-fonds Kuratore, 184-185.

10 (HSA) HVKP, Notuleboek (8 Feb 1940-9 Des 1966), 12 Des 1956, Hoofbestuur, 486.

11 (HSA) HVKP, Notuleboek, 2-3 Apr 1957, Kongres, HS finansiële state, 7. 
word, sou die opvragings "uitgekanselleer" word deur die jaarlikse groei van ongeveer $£ 5000$ in die Studiefonds se eie fondse. Hy het geargumenteer dat, indien die leningskapitaal in so 'n mate verminder dat dit die Studiefonds in die bereiking van sy doelwitte strem, daar wel op 'n later stadium vir registrasie onder die Bankwet aansoek gedoen kon word met die oog op die inneem van deposito's. Die direksie het dus eenparig besluit om die Registrateur te versoek om die Studiefonds vry te stel van die Bankwet op die voorwaarde dat die Fonds onderneem om geen nuwe deposito van die publiek te neem nie, behalwe vir lenings van die Hooffonds en permanente deposito's wat lewenslank by die Fonds belê word. ${ }^{12}$ Die Registrateur het ná oorweging die versoek goedgekeur op die volgende voowaardes; geen verdere beleggings van die publiek geneem mag word nie; bestaande beleggings behou kon word; die Studiefonds onbeperk lenings by die Vereniging se Hooffonds kon aangaan; en beleggings wat rentedraend was tot die dood van die belegger en daarna as 'n bemaking na die Studiefonds gaan, sou nog geneem kon word. ${ }^{13}$

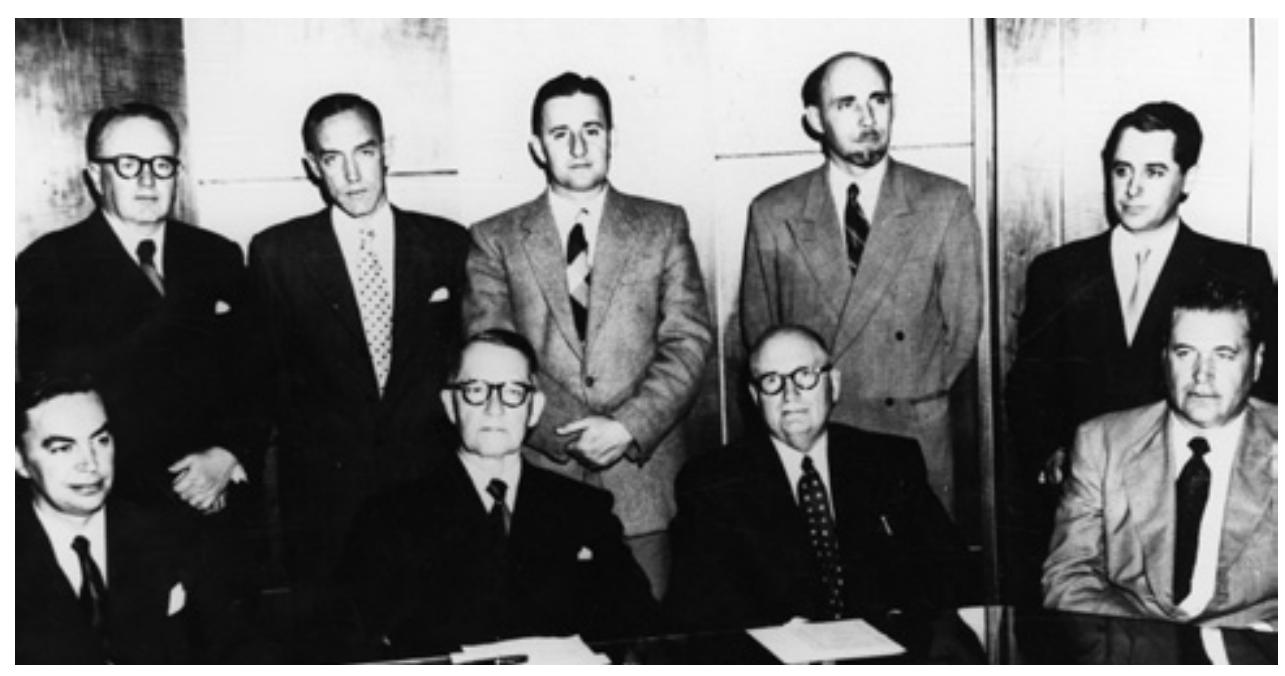

Eerste direksie van die Helpmekaar Studiefonds, 1956. Voor van links: mnr A Rupert, dr JS du Toit (voorsitter), sen DH van Zyl, mnr PJC van Zyl. Agter van links: $d r$ TN Hanekom, mnr SP Pretorius, mnr BJ Conradie, mnr GJ Horn, adv J de Vos.

13 (HSA) HVKP, Notuleboek (8 Feb 1940-9 Des 1966), 2-3 Apr 1957, Hoofbestuur, 494; (HSA) HVKP, Notuleboek, 2-3 Apr 1957, Kongres, 8. 


\section{Die Kaapse Helpmekaar}

Teen April 1957 was die ou B-fonds dus omskep in 'n aparte entiteit met regspersoonlikheid as die Helpmekaar Studiefonds wat as 'n maatskappy sonder winsbejag geregistreer was. Beheer was gesetel in 'n direksie bestaande uit dr JS du Toit (voorsitter en medikus, Kaapstad), PJC van Zyl (sakeman en advertensie-deskundige, Kaapstad), dr TN Hanekom (predikant en assistentredakteur van Die Kerkbode, Milnerton), AE Rupert (van Rembrandt, Stellenbosch), BJ Conradie (skrywer en onderwyser, Durbanville), GJ Horn (sakeman en besturende direkteur van 'n groot Afrikaanse saak, Kaapstad) en adv J de Vos (advokaat van die Kaapse Balie, Kaapstad), met senator Van Zyl as hoofbestuurder en mnr Pretorius as sekretaris.

Dr SJ du Toit se voorsittersrede tydens die eerste jaarvergadering van die HS op 14 Junie 1957 in Kaapstad was 'n terugskouing en viering van die sukses van die Fonds sedert sy stigting in 1942. Die konsep, waarvan DH van Zyl die vader was, het oor 14 jaar gegroei tot'n selfstandige fonds met eie kapitaal van $£ 36522$ wat teen 'n minimum van $£ 4000$ per jaar aangewas het. Geleende kapitaal het $£ 60000$ beloop en HS het 'n skoon rekord gehad wat die afskryf van slegte skuld betref. Dit was ook duidelik dat die vyftigerjare as 'n periode van toenemende voorspoed beskou is waaruit die Helpmekaar moes voordeel trek vir potensiële maer jare wat mag voorlê. Die sukses van die voltydse fondse-organiseerder in die veld, mnr HD Roux van Kimberley, wat oor die voorafgaande twee jaar meer as $£ 6500$ vir die twee fondse ingesamel het nadat sy kostes en salaris afgetrek is, was bewys hiervan. Du Toit, wat na die Helpmekaar as "'n troetelkind van die Afrikaner" en na sy twee vertakkings as 'n "volksfonds" verwys het, het by herhaling bevestig dat die primêre dryfveer van die Helpmekaar, en by implikasie dus ook die Studiefonds, op opheffing gegrond was:

"Elke pennie wat geskenk word aan die Helpmekaar, is 'n lewenslange belegging in die jeug van ons volk. Die geld word nie uitgedeel in die vorm van aalmoese nie, maar word oordeelkundig uitgeleen aan die een student na die ander, en sodoende word blywende rehabilitasiewerk verrig, beide ekonomies en kultureel." ${ }^{14}$

Die episode met die Bankwet het vir alle praktiese doeleindes die konsep waarvolgens die B-fonds oorspronklik tot stand gebring is, ongeldig gemaak. Met die vrye inneem van deposito's van die publiek wat nie langer'n opsie was nie, het die Hooffonds van die Vereniging die Studiefonds se grootste bron van potensiële leningsfondse geword. In dié sin was die HS dus in 'n groter mate afhanklik van die goeie gesindheid van die Vereniging en sy kongres en takke. Dié strukture kon nie meer as werwingsagente vir deposito's gebruik word nie. Dit was egter steeds die kanaal waardeur skenkings, asook kollektes van gemeentes en insamelings van skole na die Studiefonds gevloei het.

14 (HSA) HVKP, Notuleboek (8 Feb 1940-9 Des 1966), 14 Jun 1957, HS Voorsittersrede, 193-195. 


\section{DIE AANLOOP TOT EN AFLOOP VAN DIE 1963-FONDSWERWINGSVELDTOG}

In sy nuwe gedaante was dit gou duidelik dat die Studiefonds se grootste uitdaging was om in die vinnig groeiende behoefte na studielenings te bly voorsien; ongeag van die beperkings wat deur die ooreenkoms met die Registrateur van Banke op sy vermoë om kapitaal vir dié doel te bekom, gelê is. Die kapitaaltekort het 'n periode van debat ontketen, wat gekenmerk is deur insette van veral die sakeleiers op die Studiefonds-direksie en het ook saamgeval met 'n wisseling van leiersfigure in beide die Vereniging en Studiefonds wat 'n impak op die proses gehad het. Teen 1958 was die jaarlikse toename in studielenings ongeveer $£ 5000$ met 'n toenemende jaarlikse groei. Met die Studiefonds se reserwekapitaal wat ongeveer $£ 30000$ beloop het, was die projeksie dus dat die Fonds met die bestaande kapitaal nog vir ongeveer 5 jaar in die aanvraag sou kon voorsien.

Dié scenario het die Studiefonds dus 'n vensterperiode van ongeveer vyf jaar gegee om met 'n strategie en plan vorendag te kom. Dit was nie verbasend dat die direksie die Hooffonds as aangewese bron vir kapitaal geïdentifiseer het nie. Die voorsitter, Du Toit, het dan ook aangedui dat die grasieperiode van vyf jaar gebruik moes word om die kongres van die Vereniging te oorreed om die oorblywende beskikbare $£ 70000$ van die Hooffonds, wat op ander plekke belê is, geleidelik op te vra vir belegging by die Studiefonds. Die direksie het in Augustus 1957 besluit om so 'n versoek aan die Helpmekaar-kongres te rig. ${ }^{15}$ Ander faktore/ bronne van kapitaal, soos deposito's wat in bemakings omskep word, nuwe testamentêre bemakings of instemming deur die Vereniging dat die fondsorganiseerder uitsluitlik vir die Studiefonds kon kollekteer, kon ook die Studiefonds se kapitaal versterk. Die toekomstige lot van die Studiefonds was ten nouste verweef met en afhanklik van die toeganklikheid tot die Hooffondskapitaal en dus die goeie guns van die Vereniging en sy kongres. ${ }^{16}$

Soos reeds aangedui, het die afsterwe van die rekenmeester van die Vereniging, adv Wessel Roux, in 1958 die weg gebaan vir grootskaalse veranderinge in die rekeningkundige administrasie van die Hooffonds. Omdat Roux oor jare die verpersoonliking was van die weerstand teen die B-fonds en enige inisiatiewe wat die Hooffonds kon benadeel, het sy afsterwe die weerstand wat daar kon bestaan teen die Studiefonds se planne om deur middel van lenings van die Hooffonds die geld vir die gebruik van studielenings te ontsluit, aansienlik verswak. Met sy afsterwe het die pogings van $\mathrm{DH}$ van $\mathrm{Zyl}$ en die administrateurs van die Studiefonds, om die Hooffonds ten opsigte van hul leningsadministrasie en die jaarvergadering, gp. 
beginsels en voorwaardes waarvolgens lenings toegestaan is met dié van die Studiefonds te belyn, ten goede gekom. Die voorsitter van die Studiefonds, dr JS du Toit, is op 3 Augustus $1958^{17}$ oorlede en hy is in Januarie 1959 deur dr CF Albertyn as voorsitter opgevolg. Hoewel Du Toit vanaf die stigting van die B-fonds by die Studiefonds betrokke was en as voorsitter'n belangrike rol in die vestiging en uitbouing daarvan gespeel het, het die koms van Albertyn met sy uitgebreide sake-agtergrond 'n nuwe dinamika gebring wat veral in die versterking van die Studiefonds se fondse 'n belangrike rol sou speel. ${ }^{18}$

Benewens die leiersveranderinge het veral bekende sakeleiers op die Studiefonds se direksie, in die persone van Anton Rupert (van Rembrandt) en CH Brink (voorsitter en besturende direkteur van Federale Volksbeleggings Beperk), ${ }^{19}$ bygedra om die debat rondom die versterking van die Studiefonds se kapitaal te stimuleer. Afgesien van die tradisionele bronne van kapitaal, soos erflatings, het Rupert en Brink veral 'n groter fokus op bydraes deur die sakewêreld gepropageer, aangesien hulle die voordeel getrek het uit die opgeleide persone wat met Helpmekaar-hulp afgestudeer het. Brink was byvoorbeeld van mening dat indien bydraes aan die Studiefonds deur die owerheid as belastingaftrekbaar erken kon word, dit bydraes uit die sakewêreld sou aanmoedig.

Rupert het die Studiefonds veral aangemoedig om hul beleggings, wat as sekuriteite elders belê was, vir studielenings aan te wend, aangesien dit die fondse wat daardeur vir studielenings beskikbaar sou kom met vyf tot tien maal sou vergroot. Sy standpunt was dat, solank daar duisende ponde elders op belegging was, die argument dat daar nie voldoende fondse vir studielenings was nie, nie water gehou het nie. ${ }^{20}$ Met dié standpunt het Rupert die Studiefonds genoop om opnuut te bepaal of dit vir die belegging van hulle fondse gegeld het, ${ }^{21}$ maar dit het ook die toenemende aandrang by die kongres dat die Vereniging sy belegde fondse vir studielenings moes beskikbaar maak, stukrag gegee.

Die dreigende toekomstige tekort aan fondse wat die debatte in die eerste maande van die HS in sy nuwe formaat oorheers het, is in 'n mate verlig deur die 1958-kongresbesluit dat die opbrengs van die fondsorganiseerder se insamelings voortaan alles na die Studiefonds

\footnotetext{
17 Suid-Afrikaanse Biografiese Woordeboek Vol 3, 264-265.

18 (HSA) HVKP, Notuleboek (8 Feb 1940-9 Des 1966), 29 Jan 1959, Direksie HS, gp.

19 http://ujdigispace.uj.ac.za/handle/10210/3393?show=full (University of Johannesburg Library and Information centre).

20 (HSA) HVKP, Notuleboek, 11 Jul 1958, Kongres, 6-7; (HSA) HVKP, Notuleboek (8 Feb 1940-9 Des 1966), 17 Feb 1958, Direksie HS, gp; 16 Feb 1960, Direksie HS, gp.

21 (HSA) HVKP, Notuleboek (8 Feb 1940-9 Des 1966), 22 Feb 1960, Komitee Direksie HS, gp.
} 
sou gaan en nie meer met die Hooffonds gedeel sou word nie. ${ }^{22}$ Die hoofbestuur van die Vereniging het ook besluit om sekere beleggings van die Hooffonds, waaronder 'n verbandlening van $£ 11000$, by die Studiefonds te belê sodra dit beskikbaar raak. Verder is ook by wyse van 'n hofaansoek daarin geslaag om die Vorster-boedel ('n erflating van ongeveer $£ 16000$ van Jacoba Vorster van Colesberg ${ }^{23}$ vir die Studiefonds te bekom om in die vorm van 'n trustfonds geadministreer te word. ${ }^{24}$ Teen die begin van 1959 het die sekretaris meegedeel dat die Studiefonds se kapitaalbehoeftes grootliks vir die afsienbare toekoms opgelos was, aangesien $£ 30000$ van die Hooffondskapitaal in die loop van die volgende vyf maande beskikbaar sou raak. Dit sou volgends die Hooffonds se hoofbestuursbesluit by die Studiefonds belê kon word. Saam met die Vorster-boedel, met 'n geskatte waarde van $\mathfrak{1 0} 000$, en die Studiefonds se kontantreserwe van $£ 20$ 000, het dit 'n kontantreserwe van $£ 60000$ vir uitbetaling van deposito’s en studielenings beskikbaar gemaak. ${ }^{25}$

Die kapitaal van die Vereniging wat by die Studiefonds belê is, het in die onmiddellik afsienbare behoeftes van die Studiefonds voorsien. Van Zyl was egter bekommerd oor die toenemende dreinering van die Studiefonds se fondse deur Transvaalse studente en hy was van mening dat alles moontlik gedoen moes word om bydraes uit die Transvaal te kry. ${ }^{26}$ Aangesien die pogings in die vroeë vyftigerjare in dié verband niks opgelewer het nie is teen die einde van 1956 gepoog om deur bemiddeling van die Suid-Afrikaanse Vroue-Federasie 'n eie studiefonds in Transvaal daar te stel. ${ }^{27}$ In 1957 was ongeveer 65 persent van die totale aantal lenings wat vir die jaar toegestaan is uit die Transvaal afkomstig, terwyl Van Zyl in 1958 aangedui het dat ongeveer 40 persent van die Studiefonds se jaarlikse toekennings aan Transvaalse studente gaan. ${ }^{28}$ Begin 1959 was 46 persent van die Studiefonds se uitgeleende geld in sy finansiële state aan Transvaalse studente ${ }^{29}$ en dit terwyl daar uit die provinsie geen bydraes gekom het vir die Helpmekaar-fondse nie en hulle ook geen voorsiening plaaslik getref het vir hul studente se behoeftes nie.

22 (HSA) HVKP, Notuleboek, 11 Jul 1958, Kongres, 6.

23 (HSA) HVKP, Notuleboek, 4-5 Apr 1956, Kongres, Hoofbestuur verslag, 2; (HSA) HVKP, Notuleboek (8 Feb 1940-9 Des 1966), 12 Des 1955, Hoofbestuur, 481.

24 (HSA) HVKP, Notuleboek (8 Feb 1940-9 Des 1966), 30 Jul 1958, Direksie HS, gp.

25 (HSA) HVKP, Notuleboek (8 Feb 1940-9 Des 1966), 29 Jan 1959, Direksie HS, gp.

26 (HSA) HVKP, Notuleboek (8 Feb 1940-9 Des 1966), 28 Feb 1959, HS jaarvergadering, gp.

27 (HSA) HVKP, Notuleboek (8 Feb 1940-9 Des 1966), 23 Nov 1956, B-fonds Kuratore, 184-185.

28 (HSA) HVKP, Notuleboek, 11 Jul 1958, Kongres, 5.

29 (HSA) HVKP, Notuleboek (8 Feb 1940-9 Des 1966), 29 Jan 1959, HS Direksie, gp. 
Die Studiefonds het geen provinsiale grense erken nie, maar die mening is in die direksie geopper dat dit dalk oorweeg sou moes word om lenings aan Transvaalse studente te beperk om nie Kaaplandse aansoekers te kort te doen nie. ${ }^{30}$ Hierdie groot toename in Transvaalse aansoekers was die gevolg van die snelle verstedeliking van Afrikaners wat veral na die Rand gestroom het. In die periode 1936 tot 1960 het Afrikanergetalle aan die Rand met 167 persent toegeneem. Dit het gemanifesteer in 'n snelle toename in Afrikaanse laer- en hoërskole aan die Rand en die vestiging van tersiêre instellings soos die Goudstadse Onderwyskollege en die stigting van die Randse Afrikaanse Universiteit. ${ }^{31}$ Senator Van Zyl is in 1958 opdrag gegee om voorstelle vir Transvaalse bydraes aan dr PJ Meyer te maak. ${ }^{32}$ Meyer is waarskynlik genader vanweë sy invloedryke posisie in Afrikanergeledere aan die Rand (in 1959 het hy voorsitter van die SAUK-raad geword en van 1960-1972 was hy voorsitter van die Broederbond) en omdat hy ten nouste betrokke was by pogings om 'n Afrikaanse universiteit aan die Rand tot stand te bring in die vorm van die Randse Afrikaanse Universiteit. ${ }^{33} \mathrm{Na}$ aanleiding hiervan is samesprekings gevoer met verskeie instansies en voorlopig is besluit op 'n konferensie in die Transvaal, waar 'n versoek gerig sou word en planne bespreek sou word vir die insameling van fondse in Transvaal. ${ }^{34}$

Bogenoemde besluite het 'n periode ingelui vanaf die eerste maande van 1959 waarin pogings om die Jacob de Villiers Fonds of Hooffonds van die Vereniging, sowel as die HS te vergroot. ${ }^{35}$ In 1963 het dit gekulmineer in 'n landswye insamelingsveldtog vir die Helpmekaarbeweging. Die proses het onder andere die stigting van 'n HS vir die Transvaal, sowel as die oorweging van 'n Uniale studiefonds, ten doel gehad. Die insamelingsveldtog en sy afloop sou uiteindelik die Studiefonds en die Vereniging op verskeie vlakke beïnvloed.

Planne vir 'n uniale insamelingsveldtog waarin Anton Rupert en Rembrandt 'n belangrike rol sou speel, is aanvanklik vroeg in 1960 van stapel gestuur. Rupert sou genader word om beskermhere vir die veldtog te nader om saam met hom 'n oproep vir ondersteuning vir die veldtog te doen. Inligtingstukke in brosjurevorm wat deur Rembrandt-amptenare

30 (HSA) HVKP, Notuleboek (8 Feb 1940-9 Des 1966), 6 Aug 1957, HS Direksie, 196.

31 J Klee, "Die verwesenliking van 'n Afrikaner-droom": Die stigting van die Randse Afrikaanse Universiteit, 1955-1968, 139-141, New Contree, No 60 (Nov 2010).

32 (HSA) HVKP, Notuleboek (8 Feb 1940-9 Des 1966), 30 Jul 1958, HS Direksie, gp.

33 J Klee, "Die verwesenliking van 'n Afrikaner-droom”: Die stigting van die Randse Afrikaanse Universiteit, 1955-1968, 141-142, New Contree, No 60 (Nov 2010); PJ Meyer, Nog nie ver genoeg nie, Perskor, Johannesburg 1984.

34 (HSA) HVKP, Notuleboek (8 Feb 1940-9 Des 1966), 29 Jan 1959, HS Direksie, gp.

35 (HSA) HVKP, Notuleboek, 3 Apr 1959, Kongres, Hoofbestuur verslag , 1. 
opgestel en deur Rupert onderteken sou word, sou onder andere saam met versoekbriewe aan besighede gestuur word en die pogings sou met die ander provinsies gekoördineer word. ${ }^{36} \mathrm{Na}$ aanleiding van 'n bespreking oor die wenslikheid om 'n aparte fonds te stig waaruit lenings vir bruin mense toegestaan kon word, het die direksie besluit dat in die oproep voornemende donateurs gevra moes word of hulle 'n deel van hulle skenkings vir 'n Bruin-studiefonds wou oormerk. ${ }^{37}$ Bogenoemde pogings is egter op die lange baan geskuif weens die bekendmaking van die Universiteite van Stellenbosch en Kaapstad se planne om eeufeesinsamelings vir dié instellings van stapel te stuur. ${ }^{38}$

Twee faktore het egter in die eerste helfte van 1961 tot die heraktivering van die insamelingsveldtog gelei. Prof Hanekom, direksielid van die HS, se mededeling in Maart 1961 dat die Universiteit van Stellenbosch se insameling oor 'n periode van vyf jaar versprei gaan word, ${ }^{39}$ het die direksie laat besluit om voort te gaan met die veldtog. ' $n$ Voorstel is aanvaar dat afgesien van die plan om vir 'n Beursfonds geld in te samel, daar 'n uniale poging aangewend sou word om die twee fondse van Kaapland, sowel as dié van ander provinsies se Helpmekaar-organisasies, se kapitaal aan te vul. ${ }^{40}$ Die besluit is stukrag gegee deur die "ongekende stormloop" na studiehulp en die feit dat in die eerste vier maande van 1961 net soveel lenings toegestaan en uitbetaal is as wat oor twaalf maande uitbetaal is in vorige jare. Die ongekende toename het die Studiefonds se fondse teen Mei 1961 onder druk geplaas deurdat R26 000 van die beskikbare R32 000 vir die jaar alreeds toegeken was met die verwagting dat die droogte en vloedskade ${ }^{41}$ die aanvraag verder sou laat toeneem.

Die direksie het dus besluit dat onmiddellik voortgegaan moes word met 'n grootskaalse insameling, in medewerking met Transvaalse instansies. 'n Spesiale komitee, bestaande uit dr CF Albertyn, PJC van Zyl, GJ Horn, sen DH van Zyl en die sekretaris, is volmag gegee om met die Transvaalse Komitee te skakel en te onderhandel ten spyte van die bedenkinge (hoofsaaklik gegrond op die ervarings van vorige mislukte pogings tot samewerking met

36 (HSA) HVKP, Notuleboek (8 Feb 1940-9 Des 1966), 22 Feb 1960, HS Komitee Direksie, gp; 24 Mrt 1960, HS Direksie, gp.

37 (HSA) HVKP, Notuleboek (8 Feb 1940-9 Des 1966), 22 Feb 1960, HS Direksie, gp.

38 (HSA) HVKP Notuleboek (8 Feb 1940-9 Des 1966), 22 Mrt 1961, HS Direksie, gp.

39 Die Burger, 23 Feb 1961, Eeufeesfonds Gestig: Nuwe Uitdagings aan SA Universiteite. (Die Universiteit Stellenbosch wou R3 000000 oor die periode 1961-1966 insamel.)

40 (HSA) HVKP, Notuleboek (8 Feb 1940-9 Des 1966), 22 Mrt 1961, HS Direksie, gp.

41 Die Burger, 29 Mrt 1961, Vloedskade uit die lug gesien, 1; Vloedwaters bedreig Kakamas, Kenhardt en Prieska, 1; 30 Maart 1961, Riviere bars oor hul walle in Oos-Kaapland, 13; 4 April 1961, Vloedfonds staan al op R900, 1. 


\section{Die Kaapse Helpmekaar}

die Transvaal) wat daar teen samewerking met die Transvaal bestaan het. Die direksie het ook 'n aantal strategiese riglyne vir die veldtog bepaal. Die Burger sou genader word om die Kaaplandse insameling te onderneem, die insameling sou aan republiekwording gekoppel word en 'n paar geskikte persone sou getaak word om die groot bydraes te werf. Die direksie was ook van mening dat, aangesien die Helpmekaar die enigste openbare onderneming was wat geldelike steun aan studente verskaf het, die tesourie versoek moes word om skenkings aan die Helpmekaar belastingvry te maak en het die moontlikhede van regeringsubsidie aan die Helpmekaar ondersoek. ${ }^{42}$

Tydens die komitee se onderhandelings met die Transvaalse Komitee oor die insamelingsveldtog het laasgenoemde beweer dat hulle groter sukses sou behaal onder die Transvaalse publiek as hulle bydraes vir 'n Transvaalse Helpmekaar vra. Hulle het dus aangedui dat hulle 'n aparte insameling sou hou en nie maatskappye wat landswyd funksioneer vir bydraes sou nader nie. Die Studiefonds se insameling sou plaasvind na afloop van die Transvaalse poging en wel vanaf Maart 1962. Voorlopig sou niks gedoen word om die Transvaalse insameling te belemmer nie en samewerking met laasgenoemde sou op 'n later stadium bepaal word. Die Studiefonds sou ook voortgaan om leningsaansoeke uit Transvaal op meriete te oorweeg totdat die insameling in die provinsie afgehandel is en 'n nuwe ooreenkoms beding is. Die stigtingsvergadering van die Transvaalse HS is vir 22 Oktober 1961 beplan. Die Studiefonds sou egter nie 'n afgevaardigde stuur nie, maar wel 'n brief van aanmoediging en groete. ${ }^{43}$

Die Transvaalse besluit om 'n afsonderlike insameling te hou en deur die Studiefonds aanvaar is, het waarskynlik die idee van 'n uniale studiefonds 'n gevoelige knou toegedien (soos ook in 1917 die geval was). Die Studiefonds se gelate aanvaarding van die Transvaalse besluit moet egter verstaan word teen die realiteit dat, indien die Transvaalse planne suksesvol was, die Studiefonds "verlos" sou wees van toekomstige aansoeke uit die Transvaal - wat weer meer fondse vir die behoeftes van Kaaplandse studente sou beteken. Die Transvaalse besluit het ook die graad van provinsialisme onderstreep - in 'n periode wat populêr as die hoogty van Afrikanermag en nasionalisme en Afrikanereenheid getipeer word.

Die verwikkelinge in Transvaal en die Studiefonds se tekort aan fondse het die Studiefonds egter by 'n punt gebring dat die voorsitter gevoel het dat die Fonds 'n standpunt moes inneem ten opsigte van verdere hulp aan studente buite Kaapland. Daar was duidelik 'n ongedurigheid met die Transvaalse ingesteldheid teenoor finansiering van onderwys en

\footnotetext{
42 (HSA) HVKP, Notuleboek (8 Feb 1940-9 Des 1966), 25 Mei 1961, HS Direksie, gp.

43 (HSA) HVKP, Notuleboek (8 Feb 1940-9 Des 1966), 5 Okt 1961, HS Direksie, gp.
} 
tersiêre opleiding wat nie die direksie se goedkeuring weggedra het nie. Verskeie direkteure het hulle ten gunste van onttrekking van steun aan Transvaalse studente uitgespreek, tensy die provinsie bydraes tot die Studiefonds sou begin maak of met die insamelingsveldtog sou begin saamwerk. Die direksie het hul verbind om voorlopig nog te werk vir 'n uniale fonds en dat die Studiefonds tot 'n maksimum van R20 000 daartoe sou bydra, mits daar uit die ander provinsies nie minder as dit in die fonds gestort word nie. Die vergadering het ook besluit om die FAK te versoek om by hul vergadering in Februarie 1962 'n afvaardiging van die Studiefonds oor die aangeleentheid te woord te staan. ${ }^{44}$ Laasgenoemde besluit was waarskynlik 'n poging om die invloed van die FAK te gebruik om die Transvaal ook in die kraal te kry en nasionale steun vir 'n uniale insamelingsveldtog te verseker. Andersins was dit ook 'n aanduiding van die FAK se invloed en potensiële vermoë om Afrikanernetwerke, wat 'n belangrike rol in 'n nasionale insamelingsveldtog kon speel, te mobiliseer.

Die Studiefonds het in 1962 die punt bereik waar hulle feitlik net die bedrag wat deur studente terugbetaal word vir verdere toekenning van lenings beskikbaar gehad het. Teen dié agtergrond is besluit dat weens ontoereikende fondse voorlopig geen verdere lenings aan aansoekers uit ander provinsies as Kaapland toegestaan sou word nie. Aansoeke wat onder behandeling was, sou egter nog op meriete gekeur word. ${ }^{45}$ Die gesloer met die stigting van 'n Transvaalse Helpmekaar, waarvan die stigtingsdatum intussen na 2 Maart 1962 uitgeskuif is, asook die afwagting vir die FAK se standpunt ten opsigte van studiefondse waarvan die uitslag tydens die organisasie se hoofbestuursvergadering in Maart 1962 in Kaapstad verwag is, het die Studiefonds genoop om water te trap ten opsigte van hul aanvanklike teikendatum vir die afskop van die veldtog, naamlik Maart 1962. Duidelikheid sou eers verkry moes word of die beplande fondsinsamelingsveldtog 'n nasionale of provinsiale veldtog sou wees, of die Studiefonds sy uniale karakter sou behou en of 'n afsonderlike uniale studiefonds gestig sou word. Die direksie was egter vasbeslote om in die proses nie beheer van die Studiefonds prys te gee nie. ${ }^{46}$

Die besluit oor hulp aan Transvaalse studente is deur 'n tekort aan fondse op die spits gedryf en het die besluit tot die inklusiewe aard van die Studiefonds sedert sy stigting, naamlik dat hy nie provinsiale grense erken nie, aangetas. Daarmee saam, was die onderneming om nie beheer oor die Studiefonds prys te gee nie waarskynlik 'n weerspieëling van die veranderende konteks van Afrikaner-nasionalisme, die gepaardgaande etniese mobilisasie en

\footnotetext{
44 (HSA) HVKP, Notuleboek (8 Feb 1940-9 Des 1966), 30 Nov 1961, HS Direksie, gp.

45 (HSA) HVKP, Notuleboek (8 Feb 1940-9 Des 1966), 22 Feb 1962, HS Direksie, gp.

46 Ibid.; (HSA) HVKP, Notuleboek (8 Feb 1940-9 Des 1966), 22 Feb 1962, HS jaarvergadering, gp.
} 


\section{Die Kaapse Helpmekaar}

soeke na Afrikanereenheid. Met die stigting van die B-fonds in 1942 was die tydsgees onder nasionaalgesinde Afrikaners gekenmerk deur 'n soeke na eenheid en samesnoering van kragte wat klasse en geografiese grense onderspeel het ter wille van 'n soeke na 'n gewaande volkseenheid. Teen die vroeë sestigerjare, met die beveiliging van die politieke mag afgehandel en tekens van 'n groeiende welvarendheid in Afrikanergeledere, het klasse, geografiese grense en eiebelang geneig om meer geredelik te manifesteer.

Die soeke na die steun van die FAK vir die fondsinsamelingsveldtog het vrugte afgewerp toe die Federasie op 'n vergadering van verteenwoordigers van al vier provinsiale Helpmekaarorganisasies in Johannesburg aangedui het dat die FAK sy hele organisasie sou mobiliseer in 'n uniale insameling en die Staatspresident en die Administrateurs sou nader om die oproepkomitee te vorm. 'n Interprovinsiale Koördinerende Komitee sou saamgestel word, waarvan die sekretaris van die Studiefonds, mnr Pretorius, die sameroeper sou wees. Senator Van Zyl het aangedui dat Transvaal reeds 'n fondsorganiseerder aangestel het wat hul insameling in Julie 1962 wou loods. By die Johannesburgse vergadering het Van Zyl ook 'n skema aan die ander provinsies voorgehou wat waarskynlik 'n poging was om die Studiefonds as 'n uniale fonds te vestig. Dit was 'n ideaal wat hy met groot toewyding sedert die stigting van die B-fonds in 1942 nagestreef het. Die provinsies kon, behalwe vir hul eie provinsiale fondse, ook geld in die Studiefonds stort. Sodra 'n provinsie besluit om toe te tree kon hy een direkteur op die Studiefonds-direksie benoem. Sodra hy R20 000 gestort het, kon die provinsie twee direkteure benoem en wanneer 'n provinsie R60 000 gestort het, sou die samestelling van die direksie opnuut heroorweeg word. Die Studiefonds-direksie het egter bedenkinge teen Van Zyl se voorstel geopper (wat'n aanduiding was dat hy dit nie vooraf met die direksie uitgeklaar het nie) en aangedui dat dit indruis teen hul besluit om nie beheer van die Studiefonds prys te gee nie. Die direksie het dus besluit om die voorstel eers te oorweeg as die insameling afgehandel is. ${ }^{47}$

Van Zyl se voorstel is sonder die goedkeuring van die direksie gemaak, maar dit het ten minste ten opsigte van die Natalse Helpmekaar op vrugbare grond geval. Die Vereniging het aangedui dat hulle bereid was om hul bestaande fonds van R15 000, sowel as alle toekomstige insamelings in Natal, aan die Kaapse Helpmekaar oor te dra indien die Kaap verantwoordelikheid vir hul studente sou aanvaar. Die voorstel is in beginsel aanvaar, waarop Natal hom voorlopig bereid verklaar het om R40 000 in die Studiefonds te stort. Die direksie

47 (HSA) HVKP, Notuleboek (8 Feb 1940-9 Des 1966), 24 Mei 1962, HS Direksie, gp. 
het egter besluit om Natal te versoek om 'n lewenskragtige Helpmekaarorganisasie daar aan die gang te hou om die bedrag van tyd tot tyd aan te vul. ${ }^{48}$

$\mathrm{Na}$ verdere samesprekings tussen die vier provinsiale Helpmekaarorganisasies is besluit dat Transvaal solank sonder enige reklame sou voortgaan met fondsinsameling by slegs suiwer Transvaalse instansies. Die nasionale veldtog met die ondersteuning van die onderskeie provinsiale Administrateurs, pers en radio, sou eers op 1 Maart 1963 afskop. Die Studiefonds het 'n kommissie, bestaande uit mnre PJC van Zyl, GJ Horn, JJ Piek en die sekretaris, benoem om planne op te stel en reëlings te tref vir Kaapland se insameling. Dr Albertyn en mnr PJC van Zyl is ook opdrag gegee om Die Burger te nader met die versoek om nie net reklame te verskaf nie, maar gesien in die lig van die noue verbintenis met die Helpmekaar oor jare, die insameling namens die Helpmekaar waar te neem. ${ }^{49}$ Hierdie beroep op Die Burger om eienaarskap van die veldtog te neem is waarskynlik gedoen met die versugting dat dit dieselfde resultate as die 1917-insamelingsveldtog sou oplewer. Die feit dat pogings aangewend is om 'n persoon te kry om 'n groot bydrae te maak op voorwaarde dat 'n sekere aantal skenkers 'n mindere bedrag skenk - op die Japie de Villiers 1917-templaat - asook die versoek aan lede van die direksie om hul invloed te gebruik ten behoewe van die insamelingsveldtog het hierdie verwagting bevestig. ${ }^{50}$ Afgesien van individue sou sakeondernemings ook met die steun van die vier Administrateurs vir skenkings genader word. ${ }^{51}$

Die aanvanklike $a d$ hoc-komitee wat aangestel is om die reëlings vir die Kaaplandse insameling te tref het uitstekende ondersteuning gekry van die Administrateur Nico Malan, Die Burger met reklame - veral ook van die Freddie Kirstenskenking van R20 000 wat die bal aan die rol gesit het - en Rembrandt, wat een van hul amptenare met 'n voertuig vir drie maande aan die Studiefonds beskikbaar gestel het om behulpsaam te wees met die administrasie. ${ }^{52}$ Die ad hoc-komitee is mettertyd tot 'n Breë Komitee, bestaande uit direksielede van die Studiefonds en verteenwoordigers van die breër samelewing onder voorsitterskap van $\mathrm{dr}$ CF Albertyn, uitgebrei. Teen November 1963 was dit duidelik dat die veldtog nie na wense verloop het nie en dat daar selfs kritiek van gebrekkige organisasie was.

48 Ibid; (HSA) HVKP, Notuleboek (8 Feb 1940-9 Des 1966), 30 Aug 1962, HS Direksie, gp.

49 (HSA) HVKP, Notuleboek (8 Feb 1940-9 Des 1966), 30 Aug 1962, gp.

50 (HSA) HVKP, Notuleboek (8 Feb 1940-9 Des 1966), 27 Mrt 1963, gp.

51 (HSA) HVKP, Notuleboek (8 Feb 1940-9 Des 1966), 25 Okt 1962, gp.

52 (HSA) HVKP, Notuleboek (8 Feb 1940-9 Des 1966), 27 Mrt 1963, HS jaarvergadering, Voorsittersverslag, gp; 23 Mrt 1964, HS jaarvergadering, gp. 
Volgens Albertyn het daar oral welwillendheid teenoor die Helpmekaar geheers, maar die insameling het traag verloop en die meeste dorpe, ten spyte van die aanstelling van plaaslike ad hoc-komitees om insamelings te hou, het nog nie 'n kwart gegee van waartoe hulle in staat was nie. In die lig van die vooruitsig dat Die Burger sy ondersteuning teen Desember sou staak en die behoefte aan meer voltydse kollentante, het die direksie dus ingestem dat die Breë Komitee ontbind word. Die voortsetting van die veldtog is in die hande van 'n kleiner Helpmekaar Insamelingskomitee, bestaande uit dr CF Albertyn, GJ Horn, HL Greyling ${ }^{53}$ en SP Pretorius, oorgelaat. Ingesamelde bydraes sou beheer en geadministreer word deur die Insamelingskomitee totdat die veldtog afgeloop het, waarna die Insamelingskomitee die netto ontvangste aan die twee Helpmekaar-fondse op 'n gelykop basis sou oordra. ${ }^{54}$

Met die ondersteuning van Sanlam, wat gratis kantore in die Sanlamsentrum in die Strandgebied in Kaapstad verskaf het, en die aanstelling van JR Albertyn as sekretaris van die Komitee, was dit moontlik vir die Helpmekaar Insamelingskomitee om die administrasie van die insameling van dié Studiefonds te skei. Sanlam het ook vier amptenare, mnre C Slabber, E Burger, Johan Lochner en dr GJ Joubert, beskikbaar gestel om die Kaaplandse dorpe en distrikte te besoek om die organisasie vir die insameling op te knap. ${ }^{55}$ Hoewel hierdie maatreëls bygedra het om die veldtog te red is daar teen Maart 1964 slegs R140 371 van die aanvanklike mikpunt van R600 000 ingesamel. Die vernaamste rede wat vir die teleurstellende resultate aangevoer is, was die uitstel van die veldtog met drie jaar - toe die toestande volgens $\mathrm{DH}$ van Zyl nie meer so gunstig was nie - weens die insamelingsveldtog van die Universiteit van Stellenbosch. Volgens Van Zyl het die toename in verdienstelike organisasies wat intussen fondse van die publiek gevra het individue en organisasies platsak gelaat. Die gebrek aan ywer by baie plaaslike Helpmekaar-komitees is egter ook as rede vir mislukking aangevoer. In die lig van die belastingtoegewings wat die staat vir bydraes tot die Studiefonds toegestaan

53 HL Greyling wat aanvanklik in die staatsdiens en Koringraad gewerk het, het hom in 1956 by die Sagtevrugteraad aangesluit waar hy teen 1962 tot assistant algemene bestuurder (bemarking) gevorder het. Hy is op 1 Augustus 1962 as algemene bestuurder van die Kleurling Ontwikkelings Korporasie aangestel. Hy was ook 'n assessor lid van die Suid-Afrikaanse Akademie vir Wetenskap en Kuns, Voorsitter van die Oranjeklub en vise-voorsitter van die Kaapstadse Afrikaanse Sakekamer. Greyling het as voorsitter van die Insamelingskomitee opgetree en is in Maart 1963 as lid van die HS direksie gekoöpteer na die bedanking van prof DJ Opperman. The Deciduous Fruit Grower, Vol 12, Jul 1962, 176 (Mr HL Greyling); (HSA) HVKP, Notuleboek (8 Feb 1940-9 Des 1966), 23 Maart 1964, HS Direksie, gp.

54 (HSA) HVKP, Notuleboek (8 Feb 1940-9 Des 1966), 28 Nov 1963, HS Direksie, gp.

55 (HSA) HVKP, Notuleboek (8 Feb 1940-9 Des 1966), 27 Mrt 1963, HS jaarvergadering, Voorsittersverslag, gp; (HSA) HVKP, Notuleboek, 1 Apr 1964, Kongres, Hoofbestuur verslag, gp; (HSA) HVKP, Notuleboek (29 Nov 1963-9 Apr 1965), 4 Nov 1964, Helpmekaar Insamelingskomitee, Brief van JR Albertyn-HL Greyling. 
het, is besluit om die veldtog voort te sit met 'n groter fokus op bydraes deur maatskappye. ${ }^{56}$ JR Albertyn, sekretaris van die Helpmekaar Insamelingskomitee, het Van Zyl se analise bevestig in 'n verslag oor sy werwingsbesoek aan Malmesbury in Maart 1964:

"Oral hoor skrywer dieselfde klagte: die distrik is deur o.a. die Universiteit Stellenbosch, die Blinde Instituut en die Lektuurfonds kaalgestroop. 'n Gemeente is so pas gestig en die bouprogram bring 'n swaar las. Niemand wil na die boere gaan nie. Myns insiens is daar in Malmesbury geeneen met die entoesiasme en besieling om aktief ten behoewe van die Helpmekaar op te tree nie." ${ }^{.57}$

Die tydsberekening van die insameling is as die hoofoorsaak vir die teleurstellende resultate aangevoer, maar dit is te betwyfel of dit die volle waarheid beetgehad het. Die aanvanklike insameling sou saamgeval het met die Sharpeville-insident in 1960, wat Suid-Afrika in 'n ekonomiese krisis gedompel het en tot die grootskaalse uitvloei van kapitaal uit die land gelei het wat beide maatskappye en individue nie onaangeraak gelaat het nie. Teen 1963, toe die veldtog uiteindelik plaasgevind het, het ekonomiese stabiliteit reeds weer herstel en was die land in 'n fase van ongekende ekonomiese voorspoed wat in die groeiende voorspoed van maatskappye en individue weerspieël is. In die lig hiervan is die wyse waarop die tydsberekeningsfaktor aangebied word 'n onoortuigende argument wat dieperliggende faktore vir die mislukte veldtog verdoesel. Die argument van toenemende aansprake op individue en maatskappye vir bydraes tot verdienstelike sake was 'n faktor, maar gegewe die ondersteuning en goedkeuring van die FAK as hoof waghond van die Afrikanerkultuur en die feit dat die ander appèlle op dieselfde Afrikanermark gerig was, sou mens laat verwag dat dié ondersteuning ander soortgelyke oproepe sou troef. Die feit dat dit nie die geval was nie, tesame met die teleurstellende reaksie van Helpmekaar-takke en plaaslike komitees, was waarskynlik 'n aanduiding daarvan dat etnies gebaseerde oproepe, ondersteun deur 'n netwerk van organisasies wat as Afrikaner-kulturele intrepreneurs gefunksioneer het, besig was om die houvas te verloor wat hulle vroeër op nasionaalgesinde Afrikaners gehad het (en waarvoor die 1917-insamelingspoging die oorspronklike templaat verskaf het). Hiervan was die aangehaalde Malmesbury-voorbeeld 'n sprekende bewys. Terwyl dié distrik in 1917 verreweg die meeste $£ 100$-bydraes in die land opgelewer het, ${ }^{58}$ kon Albertyn in 1964 niemand met die nodige "entoesiasme en besieling" vind om die saak van die Helpmekaar te bevorder nie. In stede van slegte tydsberekening was die waarheid agter die teleurstellende

56 (HSA) HVKP, Notuleboek (8 Feb 1940-9 Des 1966), 23 Mrt 1964, HS jaarvergadering, gp; (HSA) HVKP, Notuleboek, 1 Apr 1964, Kongres, Hoofbestuur verslag, gp.

57 (HSA) HVKP, Notuleboek (29 Nov 1963-9 Apr 1965), 16 Mrt 1964, Helpmekaar Insamelingskomitee, JR Albertyn: Verslag van besoek aan Malmesbury op Maandag 16 Mrt 1964.

58 A Ehlers, Die Helpmekaarbeweging in Suid-Afrika: die storm- en drangjare, 1915-1920, 143. 


\section{Die Kaapse Helpmekaar}

insamelingsveldtog dus eerder 'n kwessie van tye wat verander het. In die woorde van $\mathrm{CH}$ Brink tydens die 1958-Helpmekaarkongres was dit eerder 'n geval van die Helpmekaar wat "n Beweging vir die Volk, maar nie van die Volk nie"59 geword het.

Afgesien van bogenoemde verklarings het die Helpmekaar se gebrek aan eenheid en eenvormige beheerstelsels veral sy appèl om finansiële ondersteuning op die Afrikanerkorporatiewe sakewêreld benadeel. Op nasionale vlak het die Helpmekaar se provinsiale aard en die oënskynlike onvermoë om samewerking oor kernaspekte, soos die insamelingsveldtog, die verdeling van ingesamelde fondse en die verkryging van 'n eenvormige beleid oor die beginsels wat hul leningstelsels en die voorwaardes daarvan moes onderlê, sommige belangrike Afrikaner-maatskappye ongemaklik gestem om onder dié omstandighede bydraes te maak. Wat die Kaapse Helpmekaar betref, het die verdeling in twee entiteite, Vereniging en Studiefonds, en spesifieke bestuurspraktyke van die Studiefonds, soos die feit dat $\mathrm{DH}$ van $\mathrm{Zyl}$ as amptenaar van die HS ook as voorsitter van die direksie opgetree het ('n duidelike oortreding van die maatskappy se statute,) ${ }^{60}$ tot kritiek gelei wat volgens alle aanduidings 'n impak op die skenkings van maatskappye soos Rembrandt (R2 000), Sanlam (R10 000) en Nasionale Pers (R500) gehad het. ${ }^{61}$

Laasgenoemde maatskappye se finansiële bydraes tot die veldtog is as teleurstellend beskryf en die Fondsinsamelingskomitee het beroepe op hulle gedoen om hul bydraes te heroorweeg. ${ }^{62}$ Die waarde wat die Kaapse Helpmekaar egter aan die betrokke maatskappye se goeie guns geheg het, veral in terme van potensiële toekomstige finansiële ondersteuning, het hul genoop om die kritiek ter harte te neem. Die Helpmekaar Insamelingskomitee het toegegee dat "n Skema bepaal word ten opsigte van 'n sentrale beheer oor die organisasie en dis wenslik dat verteenwoordigers van Sanlam en die Nasionale Pers hierop sal dien indien hul medeseggenskap sou verkies." ${ }^{63}$ Die Komitee het ook besluit dat, na afloop van die beoogde onderhandelinge met alle betrokke partye, wat A J Visser (voorsitter van die Transvaalse

59 (HSA) HVKP, Notuleboek, 11 Jul 1958, Kongres, Kongresrede, 6.

60 (HSA) HVKP, Notuleboek (29 Nov 1963-9 Apr 1965), 27 Nov 1956, Helpmekaar Insamelingskomitee, Statute van Helpmekaar Studiefonds, 6.

61 (HSA) HVKP, Notuleboek (29 Nov 1963-9 Apr 1965), 22 Apr 1964, Helpmekaar Insamelingskomitee, Kontantbydraes van maatskappye, 1-2.

62 (HSA) HVKP, Notuleboek (29 Nov 1963-9 Apr 1965), 18 Feb 1964, Helpmekaar Insamelingskomitee, 1; 5 Feb 1964 Helpmekaar Insamelingskomitee, 1-2; 29 Mei 1964 Helpmekaar Insamelingskomitee, 1.

63 (HSA) HVKP, Notuleboek (29 Nov 1963-9 Apr 1965), 22 Apr 1964, Helpmekaar Insamelingskomitee, 1. 
HS), Pepler Scholtz (Sanlam), Ken Sinclair (Kaapse Helpmekaarvereniging) ingesluit het, "Rembrandt verwittig sal word van die uitslag van die besluit insake 'n beter beheerstelsel." ${ }^{4}$

Op 'n vergadering 'n maand later in Mei 1964 het die Komitee ook besluit dat "by die beëindiging van die veldtog, verteenwoordigers van Sanlam gevra sal word om op die direksie van die Helpmekaar Studiefonds te dien. Op hierdie grondslag kan hul oorreed word om 'n groter bydrae te lewer." ${ }^{65}$ Op 'n direksievergadering van die HS in November 1964 het $\mathrm{DH}$ van Zyl, na 'n bespreking van sy omstrede posisie as amptenaar en voorsitter van die direksie, ook aangebied om as voorsitter van die HS se direksie te bedank en slegs as amptenaar betrokke te bly. Ten spyte van sy bedanking was dit duidelik dat Van Zyl gebelg was deur die kritiek vanuit die geledere van ikoniese Afrikaner-maatskappye. In sy reaksie het hy sy historiese betrokkenheid, stigtersrol en persoonlike opofferinge in die vestiging van die Studiefonds, wat hy as "my brein kind en erfgenaam"66 beskryf het, geskets. Hy het benadruk dat sy dubbele rol die gevolg van 'n uitdruklike wens van die direksie was en dat hy reeds met sy verkiesing as voorsitter teen die gevare daarvan gemaan het. In sy reaksie het hy 'n dwarsklap na die kritici uitgedeel, maar ook terselfdertyd 'n olyftak aangebied:

"Hy voel seer dat hy, wat soveel salaris kry as 'n tikster, deur buite persone beledig word, as ekskuus om niks tot die Helpmekaar by te dra nie. Hy wil die Studiefonds, wat sy skepping is, hou soos hy dit wil hê, en nie soos ander mense wil voorskryf nie. Hy bekommer hom dat die grootste deel van sy boedel, wat na die Studiefonds gaan, onder beheer sal wees van mense wat 'n verkeerde gees openbaar. Hy hoop egter dat, noudat hy sy besluit bekend gemaak het, daar vrugbare en vriendskaplike samewerking sal wees." ${ }^{\text {67 }}$

Van Zyl se reaksie kan afgemaak word as dié van 'n gekwetste individu wat seergemaak gevoel het omdat sy jarelange bydrae tot die opheffing van die volk deur opvoeding nie die nodige erkenning gekry het nie. Op 'n ideologiese vlak was dit waarskynlik 'n manifestasie van die gisting rondom veranderende Afrikaner-lojaliteite in die sestigerjare, waar onbevraagtekende blinde lojaliteit aan Afrikaner-volksbelange, soos deur kulturele en politieke entrepreneurs gedefinieer, toenemend uitgedaag is - ook deur ekonomiese entrepreneurs wie se eie mark en korporatiewe gode toenemend hul eiesoortige lojaliteit begin opeis en afdwing het.

Teen Junie 1964, met die ingesamelde bedrag op ongeveer R160 000, is besluit om die veldtog nog voort te sit totdat die sekretaris, Albertyn, se beskikbaarheid oor enkele maande ten

64 Ibid.

65 (HSA) HVKP, Notuleboek (29 Nov 1963-9 Apr 1965), 29 Mei 1964, Helpmekaar Insamelingskomitee, 1.

66 (HSA) HVKP, Notuleboek (8 Feb 1940-9 Des 1966), 26 Nov 1964, HS Direksie, 3.

67 Ibid.,1-4. 


\section{Die Kaapse Helpmekaar}

einde sou loop. 'n Afsonderlike kantoor het vir die Insamelingskomitee oorbodig geraak en die oorblywende aktiwiteite kon weer uit die Studiefonds se kantore bedryf word. ${ }^{68}$ Mnr Albertyn was ook met die Suidwes-Afrika Helpmekaar in verbinding oor 'n moontlike fondsveldtog in Suidwes. Hulle was te vinde daarvoor dat 'n kollektant soontoe gestuur kon word mits 50 persent van die ingesamelde bydraes aan hulle afgestaan word. Senator Van Zyl is opdrag gegee om met die lede van die Volksraad en senator van Suidwes samesprekings te voer oor die kanse vir sukses van so 'n veldtog. Die Insamelingskomitee is saam met sen Van Zyl volmag gegee om te besluit oor 'n veldtog, al dan nie, in die gebied, met die verstandhouding dat, in geval van 'n veldtog, daar 'n 50 persent-verdeling van die netto ingesamelde bedrag sou wees. ${ }^{69}$

Verskeie ander kwessies, veral wat betref skakeling en koördinering met die Helpmekaarorganisasies van die ander provinsies, was ook nog teen Junie 1964 uitstaande. Daar was geen aanduiding van hoe die ander provinsies met hul insamelingsveldtogte gevorder het nie en veral Transvaal het nie gereageer op Kaapse navrae in dié verband nie. Die verdeling van fondse wat van nasionale maatskappye gewerf is, moes tussen die provinsies verdeel word en wat veral Transvaal betref, moes vasgestel word of hulle enige maatskappyfondse gewerf het wat met ander provinsies gedeel moes word. Verder moes die verskillende provinsies se stelsels van hulp aan studente ook gekoördineer word om byvoorbeeld te verseker dat Transvaalse studente voldoende gehelp word sodat hulle nie weer by die Studiefonds om hulp aanklop nie. HL Greyling het 'n konferensie op amptelike vlak, om die kwessies uit te klaar, as noodsaaklik beskou.

Die direksie het besluit dat die dagbestuur met die byvoeging van K Sinclair, HL Greyling en HF Conradie 'n basis sou opstel vir eenvormige en doetreffende lenings aan studente vir voorlegging aan die ander provinsies se Helpmekaar-fondse. Hoewel 'n ontmoeting van die provinsies se verteenwoordigers vir die Afrikaanse Handelsinstituut se kongres in Durban in September gereël is, ${ }^{70}$ was die poging om die insamelingsveldtog en uitstaande kwessies op dié wyse tot 'n afsluiting te bring nie suksesvol nie, aangesien die Vrystaat dit weens omstandighede nie kon bywoon nie en die Transvaalse afgevaardigdes nie opgedaag het

\footnotetext{
68 (HSA) HVKP, Notuleboek (8 Feb 1940-9 Des 1966), 9 Jun 1964, HS Direksie, gp.

69 (HSA) HVKP, Notuleboek (8 Feb 1940-9 Des 1966), 9 Jun. 1964, HS Direksie, gp.

70 (HSA) HVKP, Notuleboek (8 Feb 1940-9 Des 1966), 9 Jun 1964, HS Direksie, gp; 12 Aug 1964, HS spesiale Direksie gp.
} 
nie. Die samewerking of samesmelting met die Natalse Helpmekaar kon wel met die Natalse sekretaris, mnr Van Rooyen, verder gevoer word. ${ }^{71}$

Teen April 1965 het HL Greyling aan die Studiefonds se direksie gerapporteer dat die Insamelingskomitee 'n afsluitingsvergadering gehou het en gereed was om die boekhouding van die insamelingsveldtog aan die ouditeure te oorhandig voor oordrag na die Studiefonds. Die vernaamste uitstaande finansiële kwessie was steeds die verdeling van nasionale maatskappybydraes tussen die vier provinsies wat hoofsaaklik weens gebrekkige kommunikasie en samewerking vanaf die kant van Transvaal nog nie gefinaliseer kon word nie. ${ }^{72}$ In Augustus 1965 het die direksie besluit dat, aangesien hulle geen reaksie op pogings om met Transvaal in dié verband te skakel ontvang het nie en aangesien hulle nie kon afwyk van die voorwaardes waaronder maatskappye hul skenkings gedoen het nie, die Studiefonds uitvoering sou gee aan die oorspronklike ooreenkoms en die geld gelykop verdeel onder die vier Helpmekaar-fondse en dit aan hulle oorbetaal. ${ }^{73}$

Die Insamelingskomitee het dus R66 360 aan die Studiefonds en Vereniging elk oorbetaal, nadat die R20 000 Kirsten-skenking eers aan die Studiefonds oorbetaal is en ook nadat R2 425 aan elk van die drie ander provinsiale Helpmekaar-fondse oorbetaal is as hulle deel van die maatskappyskenkings wat ontvang is. Die resultaat van die insamelingsveldtog het dus die Studiefonds se eie kapitaal na R271 000 verhoog, wat saam met die R57 000 leningskapitaal sy werkende kapitaal op R328 000 te staan gebring het. Saam met die Vereniging se Hooffonds het die twee Kaaplandse fondse dus oor 'n eie kapitaal van meer as R600 000 beskik. Terwyl die Kaapse Helpmekaar dus finansieel by die veldtog gebaat het en sy verhoudings met die Vrystaatse en Natalse Helpmekaar in die proses ook baat gevind het, kon dieselfde nie van sy verhouding met Transvaal gesê word nie. Afgesien van die mislukte pogings om met die Transvaalse Helpmekaar te skakel oor aspekte soos die verdeling van fondse en 'n eenvormige studieleningstelsel is die Kaapse Helpmekaar en veral die sekretaris, mnr S Pretorius, gebelg gelaat deur die gebrek aan Transvaalse reaksie op Kaapse versoeke vir die uitruil van inligting en hul versuim om die Kaapse oorbetaling van maatskappyfondse met selfs net 'n kwitansie te erken. ${ }^{74}$

\footnotetext{
71 (HSA) HVKP, Notuleboek (8 Feb 1940-9 Des 1966), 24 Sep 1964, HS Direksie, gp.

72 (HSA) HVKP, Notuleboek (8 Feb 1940-9 Des 1966), 14 Apr 1965, HS Direksie, gp.

73 (HSA) HVKP, Notuleboek (8 Feb 1940-9 Des 1966), 19 Aug 1965, HS Direksie, gp; 26 Nov 1964, HS Direksie, gp.

74 (HSA) HVKP, Notuleboek (8 Feb 1940-9 Des 1966), 18 Nov 1965, HS Direksie, gp.
} 


\section{Die Kaapse Helpmekaar}

Afgesien van die bogenoemde resultate of impak van die insamelingsveldtog het die veldtog ook ander onbedoelde of terloopse voorbeelde van impak op die Kaapse Helpmekaar gehad. Die belangrikste hiervan was die wyse waarop dit die onhoudbaarheid van die bestaan van twee afsonderlike fondse en organisasies met basies dieselfde doelstellings binne die Kaapse Helpmekaar blootgelê het en het sodoende momentum verleen aan pogings om 'n amalgamasie van die twee entiteite te bewerkstellig. Een van die uitdagings van die Vereniging en die Studiefonds was dat hulle as twee afsondelike entiteite dieselfde amptenarekorps gedeel het, wat van laasgenoemde vereis het om twee hoede te dra, naamlik dié van Vereniging en van Studiefonds. Hierdie ineengestrengeldheid het dit moeilik gemaak om die onderskeie belange apart te hou en het die potensiaal geskep dat amptenare kon tred verloor met besluite wat geneem is en sodoende kon nalaat om te verseker dat dit deur beide hoofbestuur en direksie goedgekeur is of kennis van geneem is. In 'n poging om dié uitdaging die hoof te bied en om beter koördinasie tussen die Studiefonds en die Vereniging te bewerkstellig het die hoofbestuur van die Vereniging mnr GJ Horn van die Studiefonds gekoöpteer om op die hoofbestuur te dien. Terselfdertyd het die direksie 'n voorstel goedgekeur dat die Vereniging 'n persoon benoem wat op die direksie van die Studiefonds kon dien. ${ }^{75}$ Hierdie baie tydige besluit wat in April 1961 geneem is, was egter te laat om 'n geskil oor die verdeling van die Insamelingsveldtog se opbrengs tussen die Hoof- en Studiefonds te verhoed.

In Januarie 1965 het dit aan die lig gekom dat lede van die direksie van die Studiefonds onbewus was van die besluit dat die opbrengs van die insamelingsveldtog gelykop tussen die Hoof- en die Studiefonds verdeel sou word. PJC van Zyl het dus beswaar gemaak daarteen dat daar nooit formeel aan die direksie gerapporteer is dat die insamelingsveldtog vir albei Helpmekaar-fondse was nie. Hy is hierin deur dr Albertyn ondersteun, wat aangedui het dat hy dit nie teen die verdeling het nie, maar teen die feit dat die direkteure nie oor die ooreenkoms tussen die twee fondse ingelig is nie. DH van $\mathrm{Zyl}$ en S Pretorius het aangedui dat dit ' $n$ ou beleid van die twee fondse was dat grotere insamelings altyd vir albei fondse bedoel is. Hulle het ook as amptenare van albei fondse aangedui dat dit moontlik is dat 'n saak wat by een fonds bespreek is, nagelaat kon wees by die ander. Die vergadering het besluit om die aangeleentheid vir 'n volle direksievergadering te laat oorstaan, terwyl die voorsitter 'n versoek gerig het dat in die toekoms sake wat albei fondse raak by beide besture bespreek moes word. ${ }^{76}$

75 (HSA) HVKP, Notuleboek (8 Feb 1940-9 Des 1966), 3 Apr 1961, HS jaarvergadering, gp.

76 (HSA) HVKP, Notuleboek (8 Feb 1940-9 Des 1966), 28 Jan 1965, HS Direksie, gp. 
By die Februarie direksievergadering het PJC van Zyl weer sy klagte herhaal, naamlik dat die direksie nie deur die amptenare ingelig is dat die opbrengs gelykop tussen die twee fondse verdeel moes word nie en dat die direksie nooit die saak bespreek het of sy goedkeuring aan sodanige verdeling geheg het nie. Sen Van Zyl het aangedui dat daar om taktiese redes besluit is om die veldtog in die naam van die Studiefonds te voer, maar dat daar nog altyd by alle samesprekings en met vorige insamelings van die veronderstelling uitgegaan is dat die inkomste gelykop tussen die twee fondse verdeel word. Sinclair het Van Zyl se interpretasie namens die hoofbestuur van die Vereniging gesteun en almal ook daaraan herinner dat daar in die inligtingstukke vir die insamelingsveldtog, wat deur die Studiefonds se direksie goedgekeur is, melding gemaak is van albei fondse se prestasies.

Die verskillende interpretasies het die hele kwessie van die bestaan van twee afsonderlike fondse, elk met 'n eie beheerliggaam, ter sprake gebring, met PJC van Zyl wat aangedui het dat die twee fondse moes saamsmelt omdat twee beheerliggame nie deug nie en daar geen deeglike beheer oor administrasiekoste kon wees met twee beheerliggame wat deur dieselfde amptenare bedien word nie. Hy het dus aangedui dat hy bereid sou wees om tot 'n verdeling van die fondse in te stem indien die twee fondse saamsmelt - andersins moes die geld slegs na die Studiefonds gaan. In die daaropvolgende debat het dit duidelik geword dat die Studiefonds nie aan die Vereniging kon voorskryf dat hy moes saamsmelt nie - veral nie in die lig van die sensitiewe stadium waarin die Vereniging op dié stadium was in sy pogings om die beheer van die kongres aan die hoofbestuur oor te dra nie. Samesprekings oor samesmelting sou moes wag tot die proses afgeloop was. Die direksie het dus aanvaar dat hy voor 'n voldonge feit staan en dat die direksie ter wille van die fondse se eenderse doelstellings en beoogde latere eenwoording moes berus by 'n gelykop verdeling van die ingesamelde gelde. ${ }^{77}$

Die geskil was 'n verdere resultaat van die botsing tussen die meer sake-ingesteldheid van die Studiefonds versus die Hooffonds se welsyns-ingesteldheid - wat aan die hele aard van die Helpmekaar 'n unieke tweeslagtige bestuursopset besorg het wat groot uitdagings aan die bestuurder daarvan gestel het. Hierdie verdeling het al in 1942 begin toe Van Zyl die B-fonds begin het, geskoei op sakebeginsels, maar terselfdertyd die etniese voordele en basis van die Hooffonds benut het om sy sakemodel te laat slaag. Uiteindelik sou die sakemodel seëvier, wat waarskynlik 'n afskynsel was van die sukses van die ekonomiese opkoms van die Afrikaner en in die Studiefonds se geval die Rupert/Rembrandt-invloed op die HS se direksie.

77 (HSA) HVKP, Notuleboek (8 Feb 1940-9 Des 1966), 25 Feb 1965, HS Direksie, gp. 


\section{Die Kaapse Helpmekaar}

Die geskil oor die ingesamelde fondse het gelei tot besluite om beter koördinasie en kommunikasie oor alle administratiewe sake en finansiële verslagdoening en kontrole tussen die twee fondse te verseker - besluite wat waarskynlik die proses van amalgamasie gefasiliteer het. Besluite oor aangeleenthede wat die fondse oor en weer raak, sou voortaan skriftelik van die een fonds aan die ander oorgedra word. ${ }^{78}$

Op versoek van Greyling is besluit dat die finansiële state wat tot dusver op grond van 'n ontvangste-en-uitgawe-basis gedoen is, in die toekoms op 'n inkomste-en-uitgawe-basis gedoen moes word. Voortaan moes 'n staat van die Studiefonds se beleggings met rente en dividendkoerse, asook besonderhede van die pensioen-voorsiening en die salarisse van die personeel voorgelê word. Die direksie het ook besluit dat, met die oog op beter kontrole, die finansiële state van beide die Hoof- en Studiefonds saam sou dien voor beide beheerliggame en dat in die toekoms ook gekonsolideerde state opgetrek sou word, vergesel van 'n bylaag wat die administratiewe uitgawes uiteensit. Salarisse moes ook een maal per jaar op die agenda verskyn. ${ }^{79}$ Hierdie maatreëls is ook deur die hoofbestuur van die Vereniging aanvaar. ${ }^{80}$ Hierdie versoeke, wat neerkom op meer volledige finansiële verslagdoening, skakeling, beheer en kontrole tussen die twee fondse, was die resultaat van die geskil oor die verdeling van die fondse van die 1963-fondsinsamelingsveldtog. Die geskil het ook oor die Sanlam-invloed wat die kontak met Sanlam tydens die insamelingsveldtog meegebring het, asook die reeds genoemde bevraagtekening van die Helpmekaar se beheerstelsels deur Afrikaner-maatskappye gegaan.

Die onhoudbaarheid van die voortbestaan van twee afsonderlike Helpmekaar-fondse is verder bevestig toe dit by die April 1965-direksievergadering van die Studiefonds aan die lig gekom het dat die hele debat en verskil van mening oor die verdeling van die insamelingsveldtog se fondse onnodig was. Die direksie het inderdaad op 'n vergadering van 22 Maart 1961 die gelyke verdeling van die ingesamelde geld tussen die twee fondse goedgekeur. Die handelinge van die amptenare was dus in ooreenstemming met die direksiebesluite in dié verband. ${ }^{81}$ Die hele insident het egter die potensiaal vir die verwarring wat die dubbele bestuurstelsel in staat was om te skep geillustreer en daardeur die noodsaaklikheid vir samesmelting onderstreep.

\footnotetext{
78 (HSA) HVKP, Notuleboek (8 Feb 1940-9 Des 1966), 25 Feb 1965, HS Direksie, gp.

79 Ibid.

80 (HSA) HVKP, Notuleboek (8 Feb 1940-9 Des 1966), 14 Apr 1965, HS Direksie, gp.

$81 \quad$ Ibid.
} 


\section{WIE MOET GEHELP WORD? KWESSIES VAN KLAS, RAS, ETNISITEIT EN STUDIEFONDS-HULP}

Afgesien van die insamelingsveldtog is die Studiefonds se aandag in die laaste ongeveer vyf jaar van sy bestaan, voor amalgamasie met die Vereniging, deur verskeie ander ontwikkelinge en inisiatiewe, wat ook 'n impak op sy post-amalgamasie-aard en funksionering sou hê, in beslag geneem. Die ontwikkelinge en inisiatiewe is beïnvloed deur die breër Afrikanerpolitieke, sosio-ekonomiese en kulturele konteks waarbinne dit beslag gekry het. Dit was terselfdertyd ook'n spieëlbeeld daarvan en vormgewer daaraan.

Afgesien van die debat oor die rol van geografiese grense vir toegang tot HS-lenings wat tydens die fondsinsamelingsveldtog veral ten opsigte van Transvaalse studente ter sprake gekom het, het die fokus en begrensing van Studiefonds-finansiële ondersteuning ook op 'n aantal ander vlakke ter sprake gekom. In 1960 is vir die eerste keer toegegee oor die beginsel dat slegs senior studente - wat dus eerstejaarstudente uitgesluit het - gehelp kon word toe toestemming verleen is dat amptenare in uitsonderlike gevalle (waar "aansoekers se agtergrond en rypheid dit regverdig") lenings aan eerstejaarstudente kon toestaan. ${ }^{82}$ In 1962 is die potensiële poel van studente verder uitgebrei toe die voorsitter, $\mathrm{DH}$ van Zyl, op grond van die toenemende gehalte en status van tegniese kolleges voorgestel het dat aan studente aan dié instellings dieselfde hulp aangebied word as aan universiteitstudente. ${ }^{83}$

Einde 1963 is die poorte van die Studiefonds verder oopgegooi deur die skrapping van die vroeëre absolute vereiste dat borge van Studiefondsleners vaste eiendom moes besit. Daar is reeds vroeër daarna verwys dat die bepaling toegang tot Studiefondslenings grootliks tot die Afrikaner-middelklas beperk het - 'n wesenlike onderskeid met die Vereniging se Hooffonds wat op verdienstelike behoeftige studente gefokus het. Weens kritiek op die vaste eiendom-vereiste vir borge het die direksie dit laat vaar, maar aangedui "dat wel gelet sal word op karakter en stabiliteit van werk en inkomste by borge." Terselfdertyd is die vroeëre besluit oor hulp aan eerstejaarstudente herbevestig en die amptenare bemagtig om op grond van "verdienste, agtergrond en behoefte van elke geval" lenings aan hulle toe te staan. ${ }^{84}$ Dit is ironies dat die Studiefonds in 1963, in die periode toe Afrikaners meer welvarend begin word het en toenemend die eiendomsvereiste en seniorstudentvereiste kon nakom, dié beperking wat altyd teen arm Afrikaners gediskrimineer het, opgehef het. 


\section{Die Kaapse Helpmekaar}

Terwyl die Studiefonds die begrensing van klas begin ophef het, het die kwessie van ras groter uitdagings gebied. Die rol van ras as 'n voorwaarde in die toegang tot Studiefondsbronne het in die eerste helfte van die sestigerjare pertinent op die voorgrond getree en die Studiefonds genoop om standpunt in te neem en keuses hieroor te maak. Die debat het in die periode nou verweef geraak met die ou strewe van die Helpmekaar om beurse beskikbaar te stel en in dié verband het die posisie en behoeftes van teologiestudente sterk gefigureer. Die kwessie van die wenslikheid om 'n aparte fonds te stig waaruit lenings vir bruin mense toegestaan kon word, is vir die eerste keer in 1960 met die aanvanklike beplanning vir die fondsinsamelingsveldtog bespreek. Daar is geen aanduiding waarom dit ter sprake gekom het nie. Die direksie het aanbeveel dat in die insamelingsveldtog-oproep voornemende donateurs gevra moes word of hulle 'n deel van hulle skenking vir 'n Bruin-studiefonds wou oormerk. ${ }^{85}$

Met die aanvanklike planne vir die insameling op die lange baan geskuif, is daar geen verdere aanduiding of aanbeveling verder oorweeg of geïmplementeer nie. Tydens die algemene jaarvergadering van die Studiefonds in 1961 het mnr Piek, wat as secundus vir Anton Rupert op die direksie gedien het, aangedui dat hy aandag gee aan die stigting van 'n studiefonds vir "Bantoes". ${ }^{86}$ Daar is geen aanduiding of dit 'n Studiefonds-inisiatief was nie en daar was ook geen verdere verwysings daarna nie. Dit is egter nie onwaarskynlik dat, gegewe die rol van Rupert en Rembrandt in die aanvanklike beplanning vir die insamelingsveldtog en gegewe Piek se secundus-rol op die direksie, beide die idees van 'n Bruin- en "Bantoe"studiefonds 'n Rupert/Rembrandt-oorsprong gehad het nie. Dit het juis geklop met Rupert se pogings en siening dat wit kapitaal vir die ontwikkeling van die tuislande benut moes word en sy botsing met Verwoerd in 1959 oor sy voorstel vir die stigting van 'n maatskappy met gelyke wit en bruin aandeelhouding ${ }^{87}$ asook sy idees oor die ontwikkeling van die Suid-Afrikaanse arbeidsmag. ${ }^{88}$

Die Freddie Kirsten-skenking ${ }^{89}$ van R20 000 aan die Studiefonds in 1963, met die doel om aangewend te word vir die bevordering van die verkondiging van die evangelie onder Kaaplandse bruin mense, het ras weer ter sprake gebring. Hoewel Kirsten se skenking nie

85 (HSA) HVKP, Notuleboek (8 Feb 1940-9 Des 1966), 22 Feb 1960, HS Direksie, gp.

86 (HSA) HVKP, Notuleboek (8 Feb 1940-9 Des 1966), 3 Apr 1961, HS jaarvergadering, gp.

87 H Giliomee, Die Laaste Afrikaner-Leiers. 'n Opperste toets van mag, 66, Tafelberg, Kaapstad, 2012.

88 Die Burger, 8 Des 1961, Rupert Skets Plan vir Vennootskap met Afrika-Lande, 12.

89 Freddie Kirsten was 'n bekende boer van die Paarl waar hy op sy plaas Irene geboer het. Hy was ongeveer twintig jaar lid van die Universiteitsraad van die Universiteit van Stellenbosch. Kirsten is in 1971 op 68-jarige ouderdom oorlede. Matieland, Universiteit Stellenbosch, Jaargang 15, No. 2 Aug 1971, p.11. 
verband gehou het met die fondsinsamelingsveldtog nie of in reaksie daarop geskenk is nie en spesifiek aan die Studiefonds geskenk is, is die skenking prominensie gegee om as reklame te dien om momentum aan die insamelingsveldtog te verleen..$^{90}$

Op 'n spesiale direksievergadering in Augustus 1964, wat deur Greyling, PJC van Zyl en dr Albertyn aangevra is, is die idee van 'n DF Malan Studie- en Beursfonds aan die vergadering voorgehou. Albertyn het aangedui dat, omdat Malan as die vader van die Helpmekaar in Kaapland beskou kon word, die direksie vroeër reeds beplan het om 'n DF Malan Studieen Beursfonds op te rig as gepaste monument vir Malan, maar ook as 'n natuurlike en noodsaaklike uitbouing van die Helpmekaar. Malan se weduwee het ook haar goedkeuring aan die tipe "monument" gegee en die destydse staatshoof, goewerneur-generaal CR Swart, het ingewillig om as beskermheer op te tree. Tydens onderhandelinge met die ander provinsies is die plan voorlopig laat vaar omdat Transvaal gevoel het dat hul eers 'n eie fonds vir die provinsie wou stig.

Albertyn het genoem dat Die Burger besig was met 'n insameling vir 'n DF Malan-fonds, waarmee beoog is om 'n borsbeeld vir Malan op te rig, asook 'n amfiteater wat na hom vernoem sou word. Aangesien alle aanduidings was dat daar nie veel entoesiasme vir so 'n "dooie monument" bestaan het nie, het Albertyn voorgestel dat die Helpmekaar 'n voorstel aan die DF Malan-komitee moes maak dat, in plaas van 'n monument, 'n DF Malan Beursfonds gestig moes word. Beide die DF Malan-komitee en die twee Helpmekaar-fondse moes tot die Beursfonds met 'n beoogde kapitaal van R200 000 bydra en die Fonds moes deur die HS geadministreer word. Die kapitaal moes deur die Helpmekaar vir lenings aangewend word, waarop hulle jaarliks vier persent rente sou betaal wat in die DF Malan Beursfonds gestort sou word vir die toekenning van beurse. Albertyn se voorstel is deur die direksie aanvaar, ${ }^{91}$ maar dit het geblyk asof die DF Malan-komitee nie entoesiasties oor die voorstel was nie. ${ }^{92}$

Teen dié agtergrond het die Wes-Kaapse Universiteitskollege se Teologie fakulteit navraag gedoen oor hoe hul studente uit die Kirsten-skenking kon voordeel trek. In 'n ontmoeting tussen dosente van die kweekskool van die Nederduits Gereformeerde Sendingkerk en die Studiefonds ${ }^{93}$ het die Studiefonds aangedui dat hy skrikkerig was om lenings aan bruin

90 (HSA) HVKP, Notuleboek (8 Feb 1940-9 Des 1966), 23 Mrt 1964, HS jaarvergadering, gp; 26 Nov 1964, HS Direksie, gp.

91 (HSA) HVKP, Notuleboek (8 Feb 1940-9 Des 1966), 12 Aug 1964, HS Direksie, gp.

92 (HSA) HVKP, Notuleboek (8 Feb 1940-9 Des 1966), 24 Sep 1964, HS Direksie, gp.

93 (HSA) HVKP, Notuleboek (8 Feb 1940-9 Des 1966), 28 Jan 1965, HS Direksie, gp. 


\section{Die Kaapse Helpmekaar}

studente toe te staan, en dat die bruin mense eerder 'n behoefte het aan beurse. Die direksie se plan om 'n Beursfonds vir teologiestudente op te rig is aan die dosente voorgehou en die direksie het aangedui dat donateurs gevra sou word of hulle bereid sou wees dat die opbrengs van hulle bydraes ook aan nie-blanke studente in die teologie toegeken mag word. Die direksie het aangedui dat hulle gehoop het om op dié manier twee aparte Beursfondse vir blanke sowel as vir bruin teologiestudente te kon oprig. Die dosente het toe versoek dat die direksie dit oorweeg om die rente-opbrengs van die Kirsten-skenking intussen as beurse aan bruin mense toe te ken. In 'n gesprek met Kirsten, waarin die versoek aan hom gestel is, het hy ingestem dat die kapitaal van sy skenking deur die Studiefonds aangewend word vir studiefondse en die rente daarop in die vorm van beurse aan Bruinmense wat in die teologie studeer toegeken word.

Op die direksievergadering van Februarie 1965 het dr Albertyn kennis gegee dat hy op die volgende vergadering of op 'n spesiale vergadering 'n voorstel sou indien wat vir die stigting van drie Beursfondse voorsiening sou maak. Eerstens, 'n Beursfonds vir bruin teologiestudente wat na wyle ds PJG Meiring, die persoon wat mnr Kirsten geïnspireer het om sy skenking te doen en wat baie vir die kerk en die sending gedoen het, vernoem sou word. Tweedens, 'n Beursfonds vir blanke teologiestudente wat na dr DF Malan vernoem sou word en laastens 'n Beursfonds vir algemene studies waarvoor bydraes van sake-ondernemings gevra sou word. Vir die DF Malan Beursfonds sou die hulp van die kuratorium van die Kweekskool van die NG Kerk ingeroep word, wat op hulle beurt weer deur die NG Sinode kon werk. ${ }^{94}$

Albertyn se Beursfondsvoorstelle het 'n algemene debat in die direksie ontketen oor wie gehelp moes word en wie nie. Die debat het getoon dat die 1948-apartheid-dogmas steeds gedomineer of dikteer het, maar daar was ook blyke van nuwe tendense wat sedert die vroeë sestigerjare begin ontstaan het. PJC van Zyl was van mening dat die Studiefonds versigtig moes wees om hulp aan Engelssprekende studente te verleen, aangesien dié bevolkingsdeel die Afrikaner nie goedgesind was nie. Wat lenings aan Engelssprekendes betref, het Sinclair almal daaraan herinner dat die Studiefonds doelbewus beklemtoon het dat die Helpmekaar nie seksioneel was nie en tydens die 1963-fondswerwingsveldtog van Engelse instansies

94 (HSA) HVKP, Notuleboek (8 Feb 1940-9 Des 1966), 25 Feb 1965, HS Direksie, gp. 
bydraes ontvang het ${ }^{95}$ en dat hulle dus op meriete gehelp moes word - 'n standpunt wat deur Albertyn beaam is. Hierdie standpunt was 'n weerspieëling van die politieke tendens in die NP van die tyd, naamlik van 'n soeke na groter toenadering na wit Engelssprekende kiesers in die lig van 'n ontluikende swart Afrika-nasionalisme en Uhuru. Dit het onder andere neerslag gevind in die eerste opname van Engelssprekende ministers in die Kabinet en toenemende verwysings na blanke oorlewing en nie net Afrikaner-oorlewing in Suid-Afrika nie. ${ }^{96}$

Sinclair het egter gemaan tot versigtigheid as dit by bruin mense kom. Terwyl hy geen besware gehad het dat Bruinmense gehelp word uit fondse wat spesifiek vir hulle geskenk is nie, was hy van mening dat die Studiefonds probleme te wagte moes wees as lenings uit eie fondse aan bruin mense toegeken sou word ${ }^{97}$ - 'n sentiment wat deur die dagbestuur ge-eggo is met hul benadering dat "wat die Beursfonds vir Kleurling-sendelinge betref, sal ons geen reklame daaraan gee nie, maar stilweg daarvoor kollekteer by 'n paar individue." ${ }^{98}$ Hierdie benadering was 'n weerspieëling van die ambivalente denke oor ras in die sestigerjare. Die uitlating deur minister Paul Sauer in die krisistyd na Sharpeville en die sluipmoordpoging op Verwoerd in 1960, naamlik dat Suid-Afrika se rassebeleid herbesoek moes word 'n sentiment wat ook deur verskeie ander Afrikaner-leiersfigure gedeel is - was buite die dogmatiese retoriek van die tyd. Verwoerd het dit in die kiem gesmoor en apartheidsdenke het 'n hoogtepunt onder hom bereik. ${ }^{99}$ Die feit dat daar in Helpmekaar-geledere ook in terme van studiehulp aan ander rassegroepe begin dink is - hoewel nog in apartheidsterme en op klein skaal - was 'n aanduiding dat daar'n groter besef was van die geldigheid van Landman se 1942-uitspraak dat:

"Niemand leef vir homself nie. Ook die volke moet mekaar dien. Elke volk moet sy bydrae lewer tot die wêreldgeheel, die mensheid en die algemene beskawing ... As ons streef na grootheid om die grootheid selfsugtig te gebruik en te geniet sal en kan ons die grootheid nooit behou nie. Dit is 'n ewige wet wat geld nie net vir die individu nie, maar ook vir 'n volk." Hierteenoor het 28 Afrikaanse maatskappye R10 231 bygedra. Laasgenoemde bedrag het die bydraes van personeelkorpse van maatskappye, asook nog vier Afrikaanse maatskappye (R15 966) wie se bydraes nog uitstaande was, uitgesluit. (HSA) HVKP, Notuleboek (29 Nov 1963-9 Apr 1965), Helpmekaar Insamelingskomitee, Kontant bydraes van Maatskappye, Groepe en hul Personeel tot 31 Jan 1964, 1-2.

H Giliomee, The Afrikaners. Biography of a people, 525, Tafelberg, Cape Town, 2012. 


\section{Die Kaapse Helpmekaar}

Dat die besef nog in sy kinderskoene was, is ook kwantitatief geillustreer met die besluit dat die Studiefonds R5 000 in die DF Malan Beursfonds en R2 000 in die Kirsten-skenking vir die bruin Beursfonds stort en dat die Hooffonds ook versoek word om R5 000 in die Malan-fonds te stort. ${ }^{100}$ Anders as met die beoogde Bruinfonds sou die R10 000 Helpmekaarstorting vir die Malan-fonds gebruik word as basis om Nasionale Pers (Die Burger) en dan groot individuele skenkers en ook die kerk vir ondersteuning vir die Fonds te nader. Wat Albertyn se derde Beursfonds betref, was die gedagte dat dit net een beurstoekenning per keer moes wees en elke keer vir 'n ander studierigting. Die beurs moes 'n prestige beurs wees, beide vir die ontvanger as vir die Helpmekaar, en na die Helpmekaar heet. Die beurs moes groot genoeg wees om 'n egpaar oorsee te stuur, sowel as om geskikte kandidate van groot salarisposte weg te lok. ${ }^{101}$

In samesprekings met die kuratorium van die Kweekskool in Maart 1965, met die oog daarop om hul ondersteuning vir die idee van 'n DF Malan Beursfonds vir teologiestudente te verkry, het Albertyn die probleme uitgelig van teologiestudente ten opsigte van die skuldlas wat hul studies op hul laai en dat hulle uiteindelik met verskeie lenings om terug te betaal opgesaal sit. Die doel van die Beursfonds was om dié probleem die hoof te bied. Die gedagte was dat die kapitaal van die Fonds by die HS belê word, wat dit vir studielenings sou aanwend. Die Studiefonds sou dan renteopbrengs van vyf persent op die kapitaal na die Beursfonds oordra. Die Beursfonds sou deur 'n raad van trustees en beurskomitee beheer word. Die verteenwoordigers van die Studiefonds het aangedui dat die Helpmekaar reeds tussen 400-500 teologiestudente met hul studies gehelp het en dat daar toe 92 sodanige studente was wat in totaal R52 912.97 geleen het. Hoewel die studente oor die algemeen gereeld terugbetaal het, was dit in klein paaiemente wat die rente aansienlik laat vermeerder het. Daar was 77 gemeentes wat jaarliks 'n deurkollekte vir die Studiefonds gehou het en sommige gemeentes het plaaslike teologiestudente bygestaan. Daar was nog nooit voorheen 'n gekoördineerde plan om predikante by te staan nie.

Die Beursfonds was so 'n poging. Die nodigheid daarvan dat al die verspreide klein gemeentefondse in een fonds onder die Studiefonds se vaandel gekonsolideer word, is dus onderstreep. In die gesprek is ook aangedui dat teologiestudente die probleem vererger deurdat hulle trou terwyl hulle nog studeer en ook motors aanskaf. Voorstelle om studente te belet om te trou of finansieel te penaliseer is bespreek, asook pogings om meer druk op gemeentes uit te oefen om tot die opleiding van teologiestudente by te dra, soos byvoorbeeld om dit deel te maak van die eweredige bydraes waarvolgens gemeentes deur die Sinode aangeslaan word.

100 (HSA) HVKP, Notuleboek (8 Feb 1940-9 Des 1966), 4 Mrt 1965, HS Dagbestuur, gp; 14 Apr 1965, HS Direksie, gp.

101 (HSA) HVKP, Notuleboek (8 Feb 1940-9 Des 1966), 4 Mrt 1965, HS Dagbestuur, gp. 
Die vergadering het besluit dat die volgende Sinode van die dringende behoefte aan ondersteuning vir teologiestudente oortuig moes word. Hulle moes met 'n inisiatief na vore kom en die sanksie van die Sinode verkry om die verskillende Ringe te bearbei om die teologiese Beursfonds te ondersteun. Dit is ook besluit om vir eers nie besluite oor fondse onder die kerk se beheer af te dwing nie. Die Studiefonds het onderneem om na afloop van die vergadering 'n amptelike versoek vir ondersteuning van die Beursfonds aan die kuratorium en die kerk te rig en die kuratorium het onderneem om die saak dan verder te voer. ${ }^{102}$

Hoewel die kuratorium bevestig het dat hulle die saak sou bespreek, het die direksie in April 1965 besluit dat die Beursfondsplanne eers gestol moes word tot na die Studiefonds se amalgamasie met die Vereniging afgehandel was en die Sinode $n$ besluit oor ondersteuning van die Beursfonds geneem het. Die direksie was van mening dat 'n verenigde Helpmekaar met die Sinode se ondersteuning in 'n baie gunstiger posisie sou wees om met die saak na die publiek te gaan. ${ }^{103}$ In November het die Sekretaris gerapporteer dat die Sinode nie die Helpmekaar se aanbod van 'n gesamentlik beheerde Beursfonds vir teologiese studies aanvaar nie, maar besluit het om self 'n Beursfonds op te rig. Die Studiefonds het dus besluit dat die Helpmekaar alleen sou voortgaan met sy skema en dat sen Van Zyl, sonder reklame, die planne sou deurvoer. ${ }^{104}$

In Augustus 1965 is die Studiefonds weer gedwing om 'n standpunt oor ras in te neem toe die maatskappy deur mnr Phil Morkel ${ }^{105}$ genader is met 'n voorstel dat die Helpmekaar die administrasie waarneem van 'n studiefonds vir bruin mense wat hy en ander trustees gestig het. Die administrasie van buite-studiefondse was nie 'n nuutjie vir die Studiefonds nie. Die aanduidings is dat die Studiefonds reeds sedert 1961 betrokke was by die administrasie van lenings uit Rupert-fondse ${ }^{106}$ en in Mei 1962 is die Studiefonds amptelik deur die Rembrandt-groep genader om 'n Rembrandt-personeelstudiefonds te administreer -

102 (HSA) HVKP, Notuleboek (8 Feb 1940-9 Des 1966), 11 Mrt 1965, Vergadering tussen Dagbestuur van Kuratorium van Kweekskool en HS, gp.

103 (HSA) HVKP, Notuleboek (8 Feb 1940-9 Des 1966), 14 Apr 1965, HS Direksie, gp.

104 (HSA) HVKP, Notuleboek (8 Feb 1940-9 Des 1966), 18 Nov 1965, HS Direksie, gp.

105 Die Burger, 13 Sep 1977, Phil Morkel sterf aan hart, 3. Phil Morkel was die stigter van die meubelmaatskappy Phil Morkel. Hy was ook voorsitter van die Telectra Co-operation. Morkel is op 12 September 1977 op die ouderdom van 70 aan 'n hartaanval oorlede.

106 (HSA) HVKP, Notuleboek (8 Feb 1940-9 Des 1966), 25 Mei 1961, HS Direksie, gp; 5 Okt 1961, HS Direksie, gp. 


\section{Die Kaapse Helpmekaar}

waartoe hulle ingestem het ${ }^{107}$ en waarvan 'n bedrag van R10 000 in Mei 1962 ontvang is. ${ }^{108}$ $\mathrm{Na}$ bespreking van die Morkel-versoek het die direksie egter besluit:

"die vergadering sien swarigheid vir die idee, en besluit dat so 'n administrasie buite die raamwerk van die Helpmekaar se werksaamhede val. Dit sal die eie administrasie verswaar en moontlik meer arbeidskragte verg. Bowenal hou dit die gevaar in dat die onvermydelike verlies wat daar sal ontstaan in so 'n fonds, nadelig mag inwerk op die Helpmekaar se reputasie by gereelde en potensiële donateurs van die Helpmekaar. Die versoek word derhalwe met spyt van die hand gewys." ${ }^{109}$

Die besluit was 'n verdere aanduiding van die mate waarin apartheidsdenke Studiefondsbesluite gevorm het en die impak wat die openbare mening op die Studiefonds kon hê indien hulle sou instem om 'n fonds vir bruin mense te administreer. Die aanname dat lenings aan bruin mense noodwendig tot oninbare skulde en verliese sou lei, was ook 'n weerspieëling van algemene persepsies oor bruin mense in Afrikanergeledere in dié verband.

Die teenstrydigheid in die Studiefonds se reaksie teenoor studiehulppogings aan ander groepe buiten blankes is verder geillustreer deur die inisiatief deur dr Albertyn en die sekretaris wat met PW Botha, Minister van Kleurlingsake, geskakel het oor die skepping van 'n Studiefonds vir bruin mense vanaf staatsweë. Die gedagte was dat die staat fondse sou beskikbaar stel wat dan deur die Helpmekaar as agent van die staat geadministreer sou word. Hoewel die Minister aanvanklik die gedagte geesdriftig ontvang het, ${ }^{110}$ het die Departement van Kleurlingsake teen November 1965 laat weet dat die Departement self so 'n studiefonds sou hanteer indien die geld beskikbaar gestel sou word. ${ }^{111}$ Teen die agtergrond van bogenoemde ervarings het die Studiefondsdireksie tydens sy November vergadering "besluit dat die Helpmekaar sy fasiliteite beskikbaar stel uitsluitlik aan blanke studente, behalwe waar bydraes ontvang word spesifiek vir

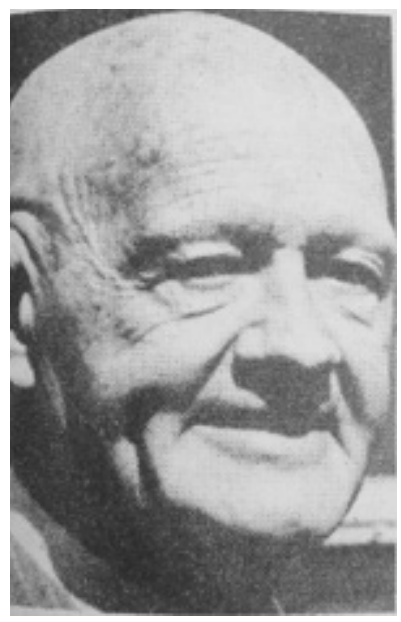

Phil Morkel was die stigter van die meubelmaatskappy Phil Morkel en voorsitter van die Telectra Co-operation

107 (HSA) HVKP, Notuleboek (8 Feb 1940-9 Des 1966), 24 Mei 1962, HS Direksie, gp.

108 (HSA) HVKP, Notuleboek (8 Feb 1940-9 Des 1966), 30 Aug 1962, HS Direksie, gp.

109 (HSA) HVKP, Notuleboek (8 Feb 1940-9 Des 1966), 19 Aug 1965, HS Direksie, gp.

110 Ibid.

111 (HSA) HVKP, Notuleboek (8 Feb 1940-9 Des 1966), 18 Nov 1965, HS Direksie, gp. 
hulp aan Kleurlinge, in welke geval die Helpmekaar sodanige skenking as aparte, losstaande Fonds sal administreer".112

Die Kirsten-skenking en die wyse waarop dit aangewend en hanteer sou word, is teen dieeindevan 1965 in dieligvan bogenoemde besluit en na verdere onderhandelinge met Freddie Kirsten gefinaliseer. Dit sou voortaan die vernaamste inisiatief wees waardeur die Studiefonds by die verskaffing van studiehulp aan ander studente buiten blankes betrokke sou wees. Die skenking van R20 000 sou voortaan as die "Freddie en Bessie Kirstenskenking" bekend staan. Die kapitaal sou deur die Helpmekaar aangewend word vir lenings aan uitgesoekte bruin studente wat deur die Helpmekaar goedgekeur is, of aan enige ander student wat by die Helpmekaar aanklop, of sou op belegging by enige veilige depositonemende instelling belê word.

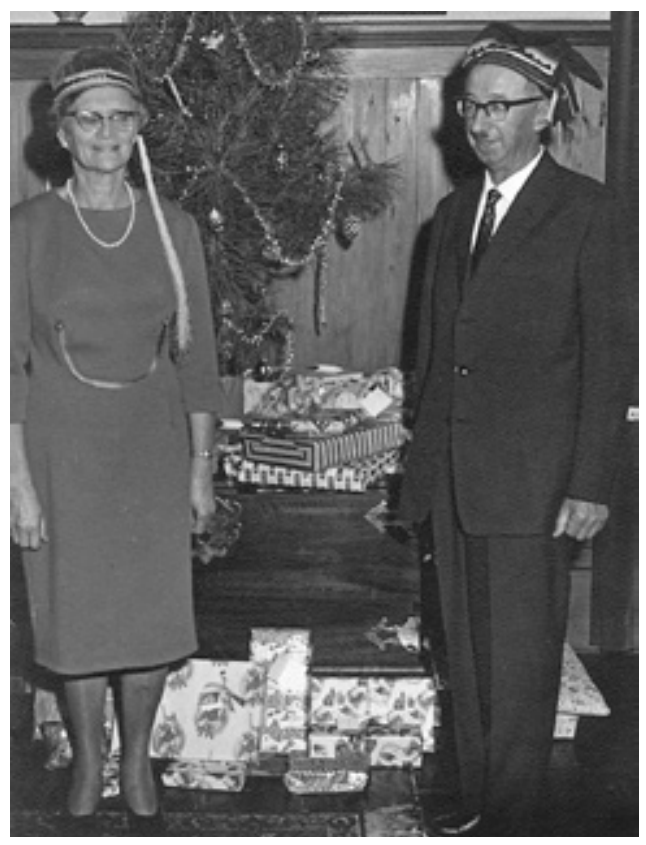

Bessie en Freddie Kirsten tydens ' $n$ Kersfeesviering

'n Bedrag van ses persent op die kapitaal van R20 000 sou jaarliks beskikbaar gestel word vir die toekenning van beurse aan bruin studente wat hulle wou bekwaam vir die evangeliebediening aan die Teologiese Instituut van die NG Kerk. Sodanige rente-opbrengs sou toegeken word as beurse deur 'n raad van trustees wat sou bestaan uit vier lede, waarvan twee deur die Helpmekaar benoem sou word en die ander twee moes professore van die Teologiese Instituut van die NG Sendingkerk wees, soos benoem deur sy raad van kuratore. Hierdie kuratore sou as Beurskomitee funksioneer wat die beurstoekennings sou doen. Ondanks enige ander vertolking, sou dit as geldende doelstelling deurgaans staan dat die geld aangewend moes word om geestelike arbeidskragte onder die NG Sendingkerk beskikbaar te stel vir Kaaplandse bruin mense. Beurse sou aan sowel teologiese as admissiestudente toegeken word. Die Beurskomitee sou bedien word met 'n lys van aanbevelings wat deur die kuratorium opgestel sou word. Daar sou gepoog word om aan die begin van elke jaar die jaarlikse renteopbrengs uit te deel en die balans te hou vir noodgevalle. Die toekennings sou jaarliks aan die saakgelastigde van die 


\section{Die Kaapse Helpmekaar}

NG Kerk in SA oorbetaal word omdat hy die teologiese kweekskool se admininistrasie behartig het. Die Studiefonds het ook beklemtoon dat die Kirsten Beursfonds vir bruin teologiestudente 'n selfstandige fonds was, wat slegs deur die Studiefonds geadministreer is.

Met die beurskomitee se eerste vergadering op 24 Maart 1966 het die Beursfonds oor 'n opgehoopte bedrag van R1 910 beskik met die jaarlikse rentebyvoegings wat R1 200 beloop het. Dit was duidelik dat die aanvraag die aanbod oorskry het, aangesien uit' $n$ totaal van 39 aansoeke om 'n beskikbare bedrag van R5 030 wat deur die Kleurling Instituuut vir Teologiese Opleiding (kuratorium) voorgelê is, is slegs aan tien studente beurse van R100 elk toegeken, met Allan Aubrey Boesak as een van die onsuksesvolle kandidate. Die hoop is uitgespreek dat die R20 000 aan kapitaal deur nog skenkings aangevul sou word sodat meer rente vir beurse beskikbaar sou wees. ${ }^{113}$ Een voorstel van hoe sodanige aanvulling van die Fonds kon geskied, was dié van die sekretaris van die Studiefonds wat aangedui het dat die Helpmekaar se halfeeufees in 1967 as bemarkingsgeleentheid benut kon word deur dit aan die Teologiese Beursfonds en Kirsten Beursfonds te koppel en met hulp van leidende persoonlikhede van buite bydraes te lok. ${ }^{114}$

Die kwessie van hulp oor rassegrense heen is in die eerste helfte van die sestigerjare oorweeg. Die nodigheid en behoefte aan ondersteuning vir veral die bruinbevolking is besef. Tog het die voorskrifte en keurslyf van die breër sosio-politieke konteks - die hoogty van Verwoerdiaanse apartheidsdenke - steeds gedikteer soos weerspieël is in hul besluit om hul hulp ("fasiliteite") tot blanke studente te beperk. Waar die Studiefonds wel betrokke geraak het oor die kleurgrens heen het hulle die afsonderlikheid van die ondersteuning, soos in die geval van die Kirsten Beursfonds, beklemtoon. Hierdie besluite is hoofsaaklik geneem vanweë die moontlike negatiewe reaksie- "kontaminering" - wat dit van hul donateurs kon ontlok, asook die persepsie dat lenings aan bruin mense vanweë hul ekonomiese agterlikheid tot wanbetalings en oninbare skulde sou aanleiding gee. Die Rubicon is dus getoets, maar nie oorgesteek nie.

\footnotetext{
113 (HSA) HVKP Notuleboek (8 Feb 1940-9 Des 1966), 19 Aug 1965, HS Direksie, gp; 18 Nov 1965, HS Direksie, gp; 24 Mrt 1966, HS Kirstenbeurskomitee, gp.

114 (HSA) HVKP, Notuleboek (8 Feb 1940-9 Des 1966), 2 Jun 1966, HS Direksie, gp.
} 


\section{HOOFSTUK AGT}

\section{"TWEE FONDSE IN EEN POT" \\ DIE HELPMEKAAR STUDIEFONDS AMALGAMEER MET DIE HELPMEKAARVERENIGING VAN DIE KAAPPROVINSIE, 1966}

Die twee afsonderlike fondse met dieselfde doelstellings, maar met verskillende beheerstrukture met aparte administrasies onder dieselfde amptenare, het teen 1965 onhoudbaar geword. Die verskillende sakefilosofieë/modelle wat hulle onderlê het, naamlik 'n welsyns-/filantropiese versus 'n sakebenadering, het die twee strukture mettertyd ten opsigte van funksionering, strategie en struktuur in twee eilande omvorm met te min begrip van mekaar se leefwêrelde en te afhanklik van die amptenare as skakel tussen die twee entiteite. Hierdie "vervreemding" sou veral na die omvorming van die B-fonds in die HS in 1956 duideliker uitkristaliseer.

Ten spyte van die versekering dat die Studiefonds nog steeds aan die hoofbestuur en kongres van die Vereniging sou rapporteer, was dit duidelik dat in sy nuwe maatskappyformaat die ou B-fonds baie meer onafhanklik kon optree en wetlik eintlik geen verpligting gehad het om aan die Vereniging te rapporteer nie. Die feit dat hulle van die Vereniging afhanklik was vir die groei in hul kapitaal het hulle egter gedwing om die verhoudinge van vroeër te handhaaf. Dit is egter ongetwyfeld so dat die breintrust van die Helpmekaarbeweging sedert die B-fonds se totstandkoming in die B-fonds geleë was en dat dit sedert die maatskappyvorming selfs meer so geword het. In hul nuwe formaat kon hulle meer kragdadig begin om hul idees op die Vereniging af te forseer. Die toenemende gebrek aan ondersteuning van die takstelsel het die kongres impotent gemaak en die Vereniging is 'n anachronisme gemaak en 'n veel makliker teiken vir beïnvloeding en oorname as in die 1940's toe die B-fonds begin is. Die Studiefonds se finansiële afhanklikheid van die Vereniging as bron van kapitaal en as finansier van hul administratiewe infrastruktuur het die beïnvloeding en oorname egter 'n delikate oefening gemaak wat toenemend en mettertyd ontwikkel moes word. Teen 1965 was die tyd geleë om die liefdadigheidsbenadering met 'n sakebenadering te vervang.

DH van Zyl en Ken Sinclair se jarelange pogings om die kongres te oortuig om te ontbind en beheer van die Vereniging aan die hoofbestuur te oorhandig, is uiteindelik in Maart 1965 met sukses bekroon met die aanvaarding van 'n nuwe grondwet vir die Vereniging wat hiervoor 


\section{Die Kaapse Helpmekaar}

voorsiening gemaak het. Hiermee is voldoen aan Albertyn se voorwaarde vir 'n Studiefondsversoek om een te word met die hoofbestuur en die direksie was dus gretig om die bal aan die rol te sit. ${ }^{1}$ Hoewel hy 'n sterk ondersteuner van eenwording was, was DH van Zyl sensitief oor die tydsberekening van die proses van eenwording. Hy was versigtig om nie onmiddellik nadat die hoofbestuur beheer by die kongres oorgeneem het drastiese stappe te neem nie "omdat dit verkeerd vertolk kan word". Hy was ook van mening dat, anders as die eenstemmigheid wat daar oor eenwording in die Studiefonds se direksie geheers het, daar nie dieselfde algemene eenstemmigheid oor eenwording by alle hoofbestuurslede was nie. ${ }^{2}$

'n Aanduiding van die onkunde wat daar by die direksie van die Studiefonds geheers het oor die Vereniging, is weerspieël in die direksiebesluit van April 1965 dat besonderhede van die samestelling en werksaamhede van die Hooffonds aan direksielede gestuur moes word sodat hulle beter vertroud kon raak met die Hooffonds. Die direksie het ook besluit om die dagbestuur van die Vereniging te versoek om in Mei tydens die sitting van die Provinsiale Raad met die direksie samesprekings te voer met die verwagting dat hulle teen die einde Mei met die volle hoofbestuur sou kon vergader om die kwessie van eenwording te bespreek. ${ }^{3}$

Die direksie het ook tydens hul April-vergadering kennis geneem van die hoofbestuur se besluit dat senator DH Van Zyl einde Junie 1965 uit die administrasie sou tree. Hy sou een maand addisionele verlof saam met sy gewone verlof neem en dan van 1 September as ontwikkelingsdirekteur begin werk teen sy bestaande salaris plus vergoeding vir reiskoste. Alle gelde deur hom ingesamel, sou gelykop verdeel word tussen die twee fondse, behalwe waar die donateur of testateur anders bepaal het. Die hoofbestuur het ook die hoop uitgespreek dat die Studiefonds sou voortgaan om hulle deel van Van Zyl se salaris en kostes te dra. Die direksie het in afwagting van die amalgamasie van die twee fondse akkoord gegaan met die hoofbestuur se besluit op voorwaarde dat, indien eenwording nie plaasvind nie, hulle die saak in heroorweging sou neem sonder dat die status quo betreffende senator Van Zyl daardeur aangetas sou word. ${ }^{4}$

Die eerste samesprekings oor amalgamasie het op 19 Mei 1965 tussen die direksie van die Studiefonds en die dagbestuur van die Vereniging plaasgevind. Die doel was om oor die beginsel van amalgamasie te praat en 'n basis van samewerking te verkry. Uit die standpuntstelling van Albertyn en Sinclair as voorsitters van die twee entiteite was dit duidelik dat beheer vir die direksie ondergeskik gestel is aan eenwording. Die primêre doel was om die ongesonde praktyk

1 (HSA) HVKP, Notuleboek (8 Feb 1940-9 Des 1966), 4 Mrt 1965, HS Dagbestuur, gp.

2 (HSA) HVKP, Notuleboek (8 Feb 1940-9 Des 1966), 14 Apr 1965, HS Direksie, gp.

$3 \quad$ Ibid.

$4 \quad$ Ibid. 
van twee fondse met dieselfde doelstellings, maar aparte administrasies onder dieselfde amptenare en onder aparte beheerliggame uit die weg te ruim. Albertyn het beklemtoon dat dit nie 'n kwessie van oorname was nie, maar eerder een van samesmelting. Hy het die Hooffonds as die moeder en die Studiefonds as die dogter beskryf, maar aangedui dat hulle "moet beplan (word) wat prakties moontlik is, en hoe jy die twee fondse in een pot kan gooi" - tot die grootste voordeel van die Helpmekaar.

Die dagbestuur se sentimente het 'n voorkeur weerspieël om die Vereniging se grondwet te handhaaf, veral in die lig van die feit dat die kongres baie onlangs die nuwe grondwet goedgekeur het en daarmee saam die beheer aan die hoofbestuur oorgedra het. Sinclair was van mening dat die direksie op die hoofbestuur gekoöpteer kon word en dat die Vereniging se grondwet dan gewysig kon word om voorsiening te maak vir die beleid en metodes van die Studiefonds. Die gevoel dat die Studiefonds uit respek eerder in die Vereniging moes opgaan as andersom is ook deur lede van die direksie, soos deur Greyling, gedeel. Ten spyte hiervan het die Studiefonds se maatskappybeheerstruktuur en akte van oprigting besliste voordele ingehou, soos die beperkte aanspreeklikheid van sy lede in geval van likwidasie, die voorsiening vir die oorname en administrasie van ander fondse en ook hulp aan swart mense. Na verdere bespreking en verskeie ander opsies voorgestel is - soos die inlywing van die Studiefonds se grondwet deur die Vereniging en afsonderlike voortbestaan van die twee fondse wat dan saam met die ander fondse wat die Studiefonds administreer as filiale deur die voorgestelde nuwe beheerliggaam bestuur kon word - het die vergadering besluit om die sekretaris opdrag te gee om regsmening in te win. Die inligting moes duidelikheid gee oor wat die veiligste en voordeligste metode sou wees vir die Helpmekaar om as maatskappy te bly werk of om onder die Vereniging se grondwet te bly voortbestaan. ${ }^{5}$

In die periode na die Mei-vergadering het daar twee denkrigtings geheers, naamlik dat net die twee beheerliggame aanvanklik sou saamsmelt met die administrasie van die twee fondse wat voorlopig apart bly bestaan totdat dit uiteindelik ook prakties moontlik was om ten volle saam te smelt - 'n sentiment wat in die Vereniging vaardig was. Die ander denkrigting was dat daar geen sin meer was om apart voort te bestaan nie en dat die oplossing daarin gelê het dat die twee fondse saamsmelt onder een beheerliggaam. Laasgenoemde sentiment was veral in die Studiefonds vaardig en Albertyn het dan ook verklaar dat die Studiefonds heeltemal bereid is om op te gaan in die Vereniging met senator Sinclair as voorsitter. Vanweë onsekerheid oor die regsgeldigheid van dié samesmelting kon daar tydens die eerste gesamentlike vergadering van die direksie en hoofbestuur nog nie oor 'n grondwet vir'n saamgesmelte fonds besluit word nie.

5 (HSA) HVKP, Notuleboek (8 Feb 1940-9 Des 1966), 19 Mei 1965, Vergadering tussen direksie van HS en dagbestuur van Vereniging, gp. 


\section{Die Kaapse Helpmekaar}

'n Kommissie, bestaande uit sen Sinclair, dr Albertyn, ds Delport, mnr Greyling, die sekretaris en soveel ander lede as wat beskikbaar was, is dus benoem om met die regsadviseurs, insluitende adv DP de Villiers, ${ }^{6}$ te onderhandel en om 'n konsepgrondwet op te stel vir die volgende vergadering. Op voorstel van Albertyn is die beginsel van amalgamasie van die twee fondse onder een beheerliggaam, wat alle bates en laste van die Vereniging en die Studiefonds oorneem, aanvaar en het die vergadering ook besluit om die naam Helpmekaar Studiefonds te aanvaar, aangesien dit beskrywend was van die funksie van die fonds. Die onkunde wat daar wedersyds onder die beheerstrukture se lede oor mekaar se werkswyses bestaan het, is weereens bevestig deur 'n versoek van JA van Zyl, een van die hoofbestuurslede van die Vereniging, dat die akte en statute van die Studiefonds aan hoofbestuurslede beskikbaar gestel moes word sodat hulle hulself op hoogte kon stel van die aard van die Studiefonds. Hierdie versoek was waarskynlik ook 'n aanduiding van 'n aanvaarding dat die Studiefonds se grondwet die basis van die beoogde saamgesmelte fonds sou vorm.

Dit was duidelik uit die verdere bespreking oor eenwording dat, benewens die kwessie oor die vind van die beste konstitusionele formaat vir amalgamasie, daar nog verskeie praktiese probleme, soos die aparte soorte assuransiedekking en die verskil in die rentekoerse van die twee fondse, oorbrug sou moes word om samesmelting 'n werklikheid te maak. Oor veral die rentekoerskwessie was daar opponerende standpunte wat die liefdadigheids-/filantropiese benadering van die Vereniging versus die meer sake-ingesteldheid van die Studiefonds weerspieël het. Verskeie sprekers was daarteen gekant dat die rentekoers van drie persent tydens die studiejare verhoog word, terwyl ander weer daarop gewys het dat die surplus inkomste daal namate beleggings teen ses persent onttrek word en teen drie persent lenings uitgeleen word en dat dit die groeikoers van die Fonds sou belemmer. Die vergadering het egter besluit om die kwessie van die rentekoers te laat oorstaan vir die nuwe beheerliggaam. ${ }^{7}$

Na verdere samesprekings oor die konstitutionele wysigings vir amalgamasie tussen die sekretaris, mnr Geof Malherbe, en adv DP de Villiers in Maart $1966^{8}$ was dit duidelik dat die Studiefonds se grondwet die basis sou vorm vir eenwording met aanpassings om die amalgamasie met die Vereniging te akkommodeer. Op 5 Augustus het die direksie en jaarvergadering van die Studiefonds besluit:

6 DP (Lang David) de Villiers het onder andere die Suid-Afrikaanse regspan in die Namibië-saak in Den Haag gelei en was ook later besturende direkteur van Nasionale Pers. http://www.sabar.co.za/law-journals/2014/ april/2014-april-vol027-no1-pp23-24.pdf (Advocate, April 2014, In memoriam: Judge Jan Hendrik Steyn, 24).

7 (HSA) HVKP, Notuleboek (8 Feb 1940-9 Des 1966), 10 Des 1965, Vergadering tussen direksie van HS en hoofbestuur van Vereniging, gp; 18 Nov 1965, HS Direksie, gp.

8 (HSA) HVKP, Notuleboek (8 Feb 1940-9 Des 1966), 3 Mrt 1966, gp. 


\begin{abstract}
"Om die Helpmekaarvereniging van die Kaapprovinsie op te neem in hierdie Maatskappy en dat dit deel vorm daarvan en gevolglik om die fondse, gelde, lenings, beleggings, alle huidige en toekomstige regte en alle bate en laste van die Helpmekaarvereniging van die Kaapprovinsie oor te neem en te administreer onderhewig aan dieselfde voorwaardes as wat daaraan verbonde sou gewees het as dit deur die gesegde Vereniging sou administreer word."
\end{abstract}

Die veranderinge aan die akte van oprigting en die statute van die maatskappy om die amalgamasie met die Vereniging moontlik te maak is eenparig aanvaar. Bogenoemde besluit om die Vereniging in die Studiefonds op te neem is as doelstelling in die akte van oprigting opgeneem, terwyl die statute gewysig is om vir die nuwe beheerstruktuur voorsiening te maak.

Die minimum ledetal van die maatskappy is van 30 tot 7 verminder, soos deur die Maatskappywet vereis is. Voorsiening is gemaak vir die benoeming van 'n uitvoerende komitee (UK) van die direksie en vir 'n dagbestuur van die UK en dat die UK enige magte wat die direksie aan hom toevertrou aan sy dagbestuur mag oordra. Die UK het die Leningskomitee van die Studiefonds, wat altyd as UK opgetree het, vervang. Volgens die nuwe statute sou die direksies uit nie minder nie as sewe en nie meer nie as 20 persone bestaan, met die huidige direkteure wat vir eers as direkteure sou optree. ${ }^{10}$

Die amptelike amalgamasievergadering om die nuwe konstitusionele bedeling goed te keur en te implementeer het op 5 Augustus 1966 plaasgevind en is deur beide die direksie van die Studiefonds en die hoofbestuur van die Vereniging bygewoon. Die Studiefonds is verteenwoordig deur dr CF Albertyn (voorsitter van die vergadering), sen KA Sinclair, oudsen DH van Zyl, mnre PJC van Zyl en HL Greyling, ds JH Roos en met slegs JJ Piek (siekte) en prof TN Hanekom (oorsee) wat afwesig was. Die Vereniging is verteenwoordig deur di JM Delport en J van der Westhuyzen, mnre RA van Rensburg en CP Jamneck en die sekretaris, SP Pretorius, met PS Meyer en GJB Volschenk wat afwesig was.

Die werksaamhede van die vergadering het hoofsaaklik gewentel om die verkiesing van lede tot die nuut geskepte bestuurstrukture en om belangrike beleidsake, waaroor die Vereniging en Studiefonds in die verlede verskil het, uit te klaar. Die Studiefonds-direksie is uitgebrei deur die koöptering van die hoofbestuurslede van die Vereniging, naamlik GJB Volschenk, RA van Rensburg, CP Jamneck, PS Meyer en di JM Delport en J van der Westhuyzen. Die volle direksie het dus bestaan uit: dr CF Albertyn, BJ Conradie, ds JM Delport, HL Greyling, prof TN Hanekom, CP Jamneck, PS Meyer, RA van Rensburg, ds JH Roos, dr AE Rupert (alternatief

9 (HSA) HVKP, Notuleboek (8 Feb 1940-9 Des 1966), 5 Aug 1966, HS Direksie, gp.

10 (HSA) HVKP, Notuleboek (8 Feb 1940-9 Des 1966), 5 Aug 1966, HS spesiale algemene vergadering, gp. 


\section{Die Kaapse Helpmekaar}

JJ Piek), sen KA Sinclair, GJB Volschenk, ds J van der Westhuyzen, oud-sen DH van Zyl, PJC van Zyl en met S Pretorius as sekretaris en openbare amptenaar. Sen Sinclair is eenparig tot voorsitter en dr CF Albertyn tot ondervoorsitter van die direksie verkies. Die direksie sou as beleidmakende liggaam en beheerliggaam van die maatskappy net een maal per jaar met die algemene jaarvergadering in Maart of April vergader. Die algemene sake van die maatskappy sou deur die UK van sewe lede, wat met volmag van die direksie optree, maar aan die direksie verantwoordelik was, hanteer word. Die UK sou 'n dagbestuur van vyf lede verkies wat ook as beleggingskommissie sou optree en wat sy magte aan die UK ontleen het en aan die UK moes verslag doen.

Die volgende lede is tot die UK benoem: dr CF Albertyn, HL Greyling, DH van Zyl, PJC van Zyl, di Roos en JM Delport, met sen Sinclair wat ampshalwe ook lid van die UK was. In Sinclair se afwesigheid sou Albertyn as voorsitter optree. Albertyn (voorsitter), HL Greyling, DH van Zyl, PJC van Zyl, ds JM Delport en Sinclair is as lede van die dagbestuur en beleggingskomitee benoem.

Die vernaamste beleidsake wat aandag geniet het, was dié ten opsigte van lenings en beleggings. Die standpunt van Albertyn is deur die direksie as beleid en voorwaarde vir'n Helpmekaarlening aanvaar, naamlik dat, om doeltreffende studiehulp te verleen en die Helpmekaar se belegging te beveilig, die student in staat moes wees om al sy studiehulp by een bron te kry sodat hy sekerheid kon hê waar hy sy geld vandaan kon kry en dat hy nie aan verskeie instansies geld moes terugbetaal nadat hy afgestudeer het nie. In die praktyk het dit beteken dat studente nie by ander instellings geld mag geleen het sonder die Studiefonds se toestemming nie. Die direksie het ook besluit dat alle leningsaansoeke deur die amptenare oorweeg en toegeken sou word tot 'n maksimum van R3 000 per lening. Aansoeke vir meer as R3 000 sou na die dagbestuur verwys word.

Die debat oor die beleggingsbeleid van die Studiefonds is deur Albertyn se standpunt in dié verband ingelui. Hy was van mening dat, om vir die erosie van kapitaal te kompenseer, een derde van die fondse in vaste eiendom belê moes word. Die orige twee derdes moes geoormerk word vir studielenings in die kategorieë Teologiese Studies, Tegniese Studies en Geesteswetenskappe, Navorsing en Nagraadse Studies. Hy was van mening dat teologiestudente besonderse tegemoetkoming behoort te kry deur óf rentevrye lenings solank hulle studeer óf teen laer rentekoerse. Die Studiefonds moes aan hulle lenings beskikbaar stel van R300 per jaar met die Kerk wat die orige R300 per jaar aan hulle moes skenk. Hy was van mening dat dit die Kerk se plig was om toe te sien dat afgestudeerde predikante nie met sulke groot skuldladings sit nie. 
Greyling het Albertyn se standpunt oor beleggings wat die erosie van kapitaal teenwerk, ondersteun en aangedui dat, aangesien geld depressieer met twee tot drie persent per jaar, 'n studielening wat oor tien jaar terugbetaal word met minstens 20 persent in waarde afneem. Vir hom het die oplossing ook gelê in beleggings in vaste eiendom en aandele. Hy was egter van mening dat die Helpmekaar nie aan die Kerk kon voorskryf nie en dat dié tipe student dan net in die verleentheid gestel sou word.

Ds Van der Westhuyzen was bevrees dat, indien so 'n groot deel van die kapitaal vir eiendomsbeleggings gereserveer word, daar te min vir studielenings kon wees en dat kapitaalerosie teengewerk word terwyl mannekrag-erosie in die hand gewerk kon word. Van der Westhuyzen wou liewer sien dat daar jaarliks bepaal word watter persentasie in eiendom belê moet word. Hy het ook gepleit dat voortgegaan moes word met die planne vir'n Teologiese Beursfonds, aangesien die Kerk nog niks in dié verband gedoen het nie. Die vergadering het uiteindelik besluit dat meer inligting nodig was om 'n ingeligte beleggingsbeleid te formuleer. Die sekretaris is dus versoek om vas te stel hoeveel geld reeds in die verskillende studierigtings belê is en dat beleggings in die genoemde kategorieë eers oorweeg kon word nadat die bestaande beleggings bestudeer is. Die UK is ook versoek om oorweging te skenk aan hoe teologiestudente tegemoetgekom kon word en die beginsel dat gunstiger leningsvoorwaardes aan hulle toegeken word, is ook in beginsel deur die direksie aanvaar. Die direksie het ook 'n komitee, bestaande uit Albertyn, Sinclair, Delport en die sekretaris, opdrag gegee om verdere samesprekings met die kuratorium of ander instansies te voer om te sien hoe die idee van 'n Teologiese Beursfonds bevorder kon word.

Die direksie het ook die leningsvoorwaardes onder bespreking geneem en 'n voorstel aanvaar dat die UK die leningsvoorwaardes moes nagaan en aanpas. Die direksie het besluit dat die voorwaardes moes bepaal dat studielenings vereffen moes word met minimum maandelikse afbetalings van R30. Die rentekoerse het weer eens debat uitgelok met twee standpunte, naamlik'n algemene gevoel dat die drie persent rentekoers tydens die studiejare opgeskuif moes word en ds Van der Westhuyzen en PS Meyer wat daarteen gekant was. Van der Westhuyzen het aangedui dat daar kwaai kritiek teen die Helpmekaar was oor die hoë rentekoerse en dat dit die Helpmekaar skade berokken het. Hy was van mening dat, hoewel die Helpmekaar 'n finansiële instelling was, daar tog iets besonders in sy manier van hulp was en dat die gees van "Helpmekaar" in die rentekoerse weerspieël moes word.

Die ander lede van die direksie het egter gevoel dat sulke kritiek onbillik en ongegrond was. Hulle was van mening dat die Helpmekaar in die eerste instansie 'n volksfonds was, wat sy administrasiekoste moes dek en boonop nog uit eie krag moes groei om voldoende fondse te kon hê vir die toenemende aanvraag na sy hulp. Verder was dit nie "arm studente" wat lenings 


\section{Die Kaapse Helpmekaar}

plus rente moes terugbetaal nie, maar gekwalifiseerde persone wat juis deur hierdie lenings in staat gestel is om potensieel 'n groter verdienste te kon hê. Hulle het ook daarop gewys dat met die beoogde toegewings aan teologiestudente daar tekorte sou kon ontstaan indien verdere toegewings gemaak sou moes word. In vergelyking met die heersende rentekoers ${ }^{11}$ was ses persent relatief laag. Dr Albertyn het die versekering gegee dat, as die fondse eendag so sterk sou staan dat dit toegewings ten opsigte van rentekoerse regverdig, dit sekerlik gedoen sou word. Die vergadering het dus besluit dat alle studente wat nog besig was met hul studies onder die ou voorwaardes van drie persent rente vir die duur van die studietydperk onveranderd sou bly, maar dat alle nuwe lenings voortaan van meet af ses persent rente sou betaal.

Enkele ander minder kontensieuse beleidsaspekte is ook hanteer. Wat assuransiedekking betref, is besluit dat die groepsdekking vir alle toekomstige lenings sou geld, en dat individuele polisse uitgeneem moes word vir lenings wat die maksimum groepsdekking mag oorskry. Verder het die direksie sy mag aan die UK gedelegeer en die UK is volmag gegee om magte aan die dagbestuur te delegeer. Die boekjaar sou op 31 Desember sluit en die jaarvergadering sou voortaan in die Maart-/April-vakansie plaasvind om onderwysers op die direksie tegemoet te kom. Die vorige direksie se handelinge vir die aanstel van 'n fondsorganiseerder, mnr DJ Posthumus, teen 'n salaris van R6 000 per jaar plus vergoedende toelae is goedgekeur. Weens druk wat op hom uitgeoefen is, het Posthumus gevra om eers op 1 Januarie 1968 diens te aanvaar. Die vergadering het ook besluit om die sekretaris voortaan op 'n salarisskaal te plaas en die sekretaris is gevra om 'n staat van administrasiekoste by die volgende UK-vergadering voor te lê. Ook is besluit dat onthaalkoste wat direkteure en amptenare aangegaan het ter bevordering van die Helpmekaar betaal sou word. Reiskoste van amptenare en direkteure is na 10c per myl verhoog (of die prys van 'n vliegkaartjie sou betaal word) en daggelde is na R8 per dag opgeskuif.

Met die vergadering afgehandel, was die grondslag vir die funksionering van die Helpmekaar in sy nuwe saamgesmelte formaat gelê. Vanuit veral die Vereniging se geledere wat in die direksie gedien het, is hulde gebring aan $\mathrm{DH}$ van $\mathrm{Zyl}$ en die wyse waarop hy die besieling van die Helpmekaar die platteland ingedra het. Veral ook vir sy skepping van die B-fonds ten spyte van die aanvanklike teenstand daarteen. RA van Rensburg het Van Zyl verseker dat almal die Helpmekaar-gees wat hy help skep het, sou onthou. Sinclair is ook geloof vir sy sterk leiding en versiendheid in tye toe dit met die Helpmekaar moeilik gegaan het. Die nuwe mylpaal was die

11 Die prima uitleenkoers in 1966 was agt persent. http://liberta.co.za/blog/prime-interest-rate-in-southafrica-current-and-historical/ 
resultaat van sy sterk leiding. Die vergadering is afgesluit met 'n besluit dat dr Albertyn en die sekretaris 'n persverklaring moes opstel oor die nuwe verwikkelinge. ${ }^{12}$

In sy vyftigste bestaansjaar het die Kaapse Helpmekaar dus daarin geslaag om die Vereniging, Studiefonds-kanale en die tradisies waardeur die Helpmekaar sedert 1942 sy doelwit van opheffing deur opvoeding en onderwys probeer bereik het weer in een hoofstroom - een pot te verenig. Daardeur is die filantropiese en sakebenaderings (die tradisionele en die moderne) tot voordeel van die Helpmekaar en die Afrikaner in die HS verenig. As sodanig was die "nuwe" entiteit simbolies van die rasse skrede waarmee die Afrikaner ekonomies gevorder het sedert sy vroeg 20ste eeuse armblankedom en die Rebellie se storm-en drangdae.

12 (HSA) HVKP, Notuleboek (8 Feb 1940-9 Des 1966), 5 Aug 1966, HS Direksie, gp, (Eerste gesamentlike direksievergadering van beide fondse. Die amalgamasievergadering). 


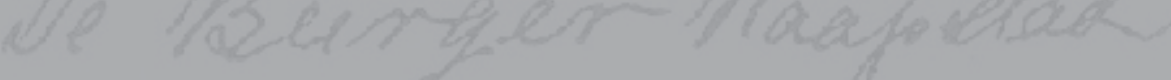

Uperee afeer

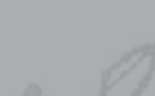

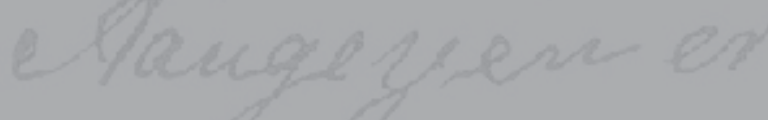

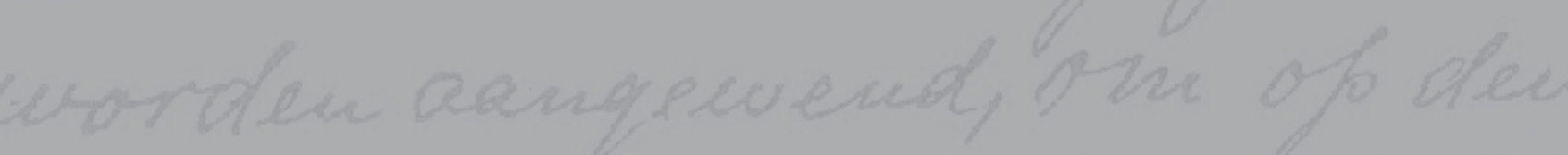

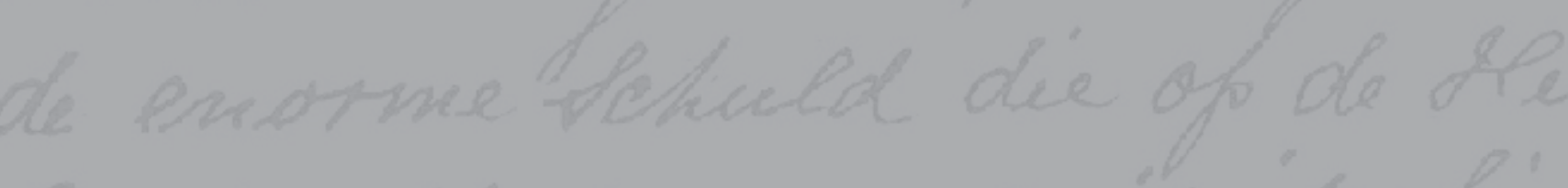

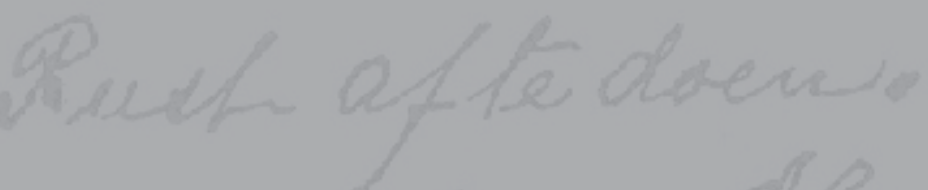

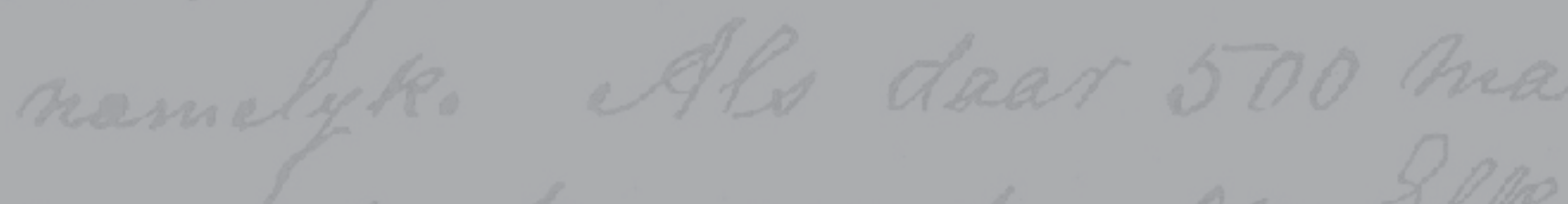

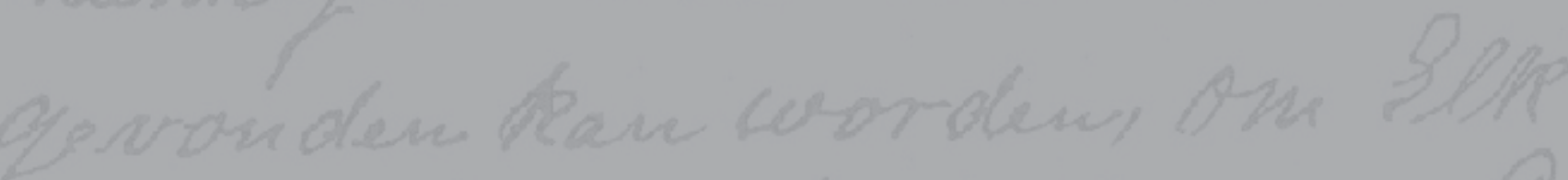

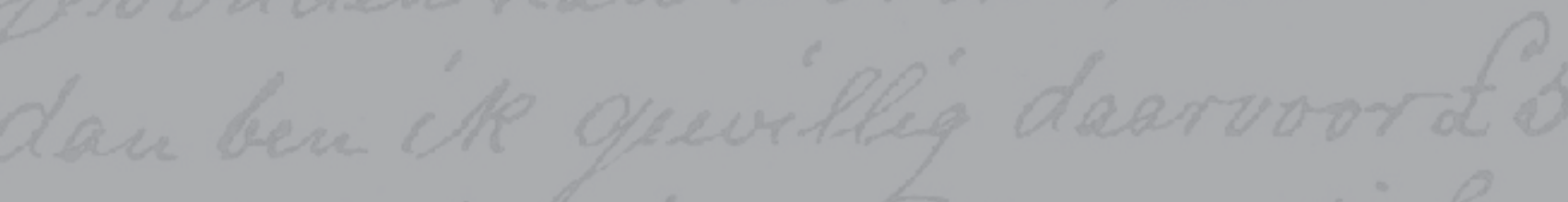

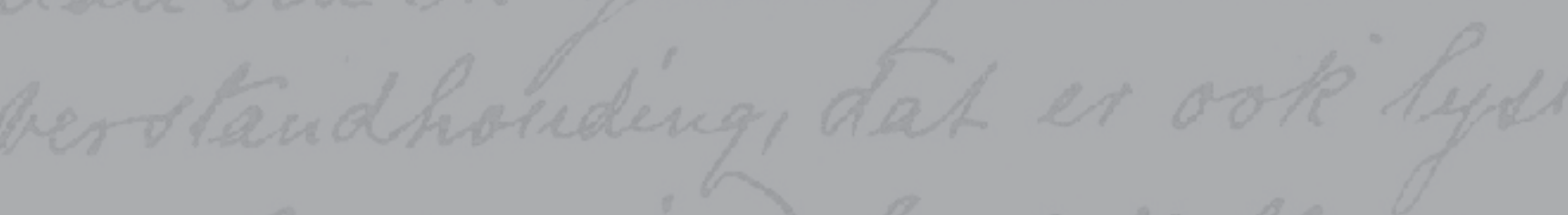

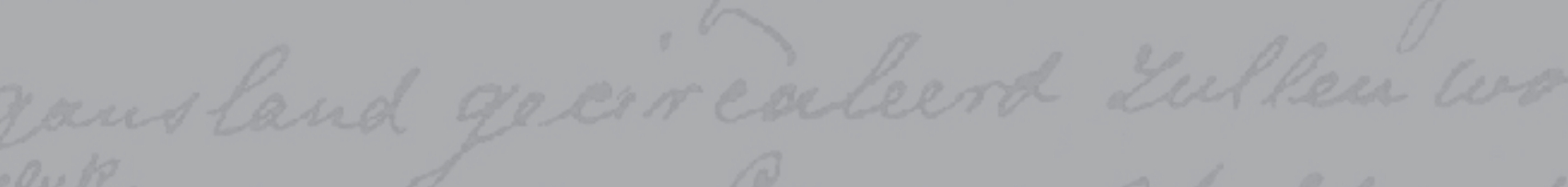

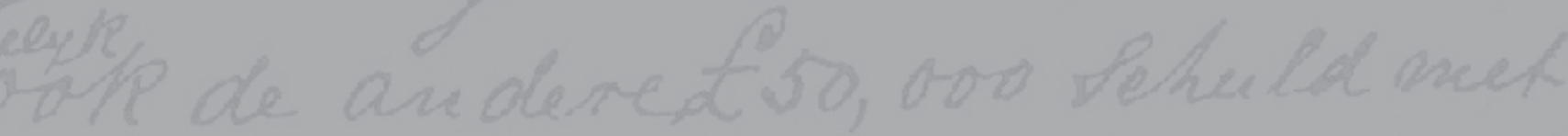
am le verhoede AFDELING D ít

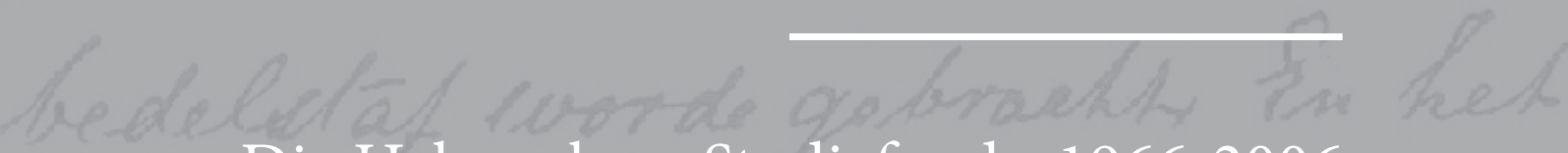
Die Helpmekaar Studiefonds, 1966-2006

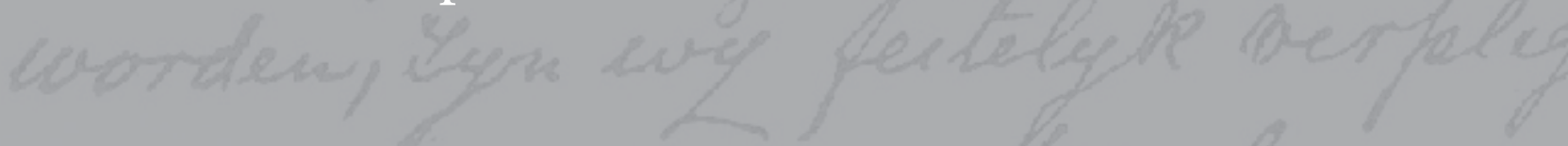




\section{HOOFSTUK NEGE}

\section{IN DIE VAARWATER VAN AFRIKANER- POLITIEKE EN EKONOMIESE HOOGTY, 1966-C.1990: BLOEI, BELOON, BELEËR}

\section{SOSIO-POLITIEKE EN EKONOMIESE MILIEU}

Die post-amalgamasie-era in die geskiedenis van die Helpmekaar het saamgeval met die toppunt van Afrikaner- en wit politieke heerskappy in Suid-Afrika. Dit het egter ook saamgeval met die geleidelike erodering van dié heerskappy onder die gesamentlike aanslag van 'n toenemend vyandelike buitewêreld, groeiende binnelandse swart weerstand teen apartheid en die verbrokkeling van Afrikaner-en wit politieke eenheid onder die druk van toenemende vertwyfeling oor die haalbaarheid en morele regverdigbaarheid van apartheid. Op politieke gebied het die onaantasbaarheid van die NP mettertyd verkrummel onder die interne aanslae van die verlig/verkramp-stryd wat aanvanklik 'n afskilfering na regs in die vorm van die Herstigte NP en Konserwatiewe Party tot gevolg gehad het. Die tagtigerjare onder die impak van die verlig/oorbelig-stryd het die NP sy intellektuele elite ondersteuningsbasis gekos en het bygedra om die Party tot 'n onderhandelde skikking vir die beëindiging van apartheid te oortuig. ${ }^{1}$

Die era is ook gekenmerk deur 'n intensifisering en internasionalisering van die swart bevrydingstryd wat benewens die militarisering van die Suid-Afrikaanse samelewing ook ekonomiese implikasies gehad het. In tandem met die breër internasionale tendens van ekonomiese agteruitgang wat in 1973 deur die eerste energiekrisis ingelui is, het toenemende ekonomiese boikotte en die disinvesterings-kampanje van veral die tagtigerjare tot die ekonomiese stagnasie van die Suid-Afrikaanse ekonomie bygedra. Die ekonomiese vooruitgang van die sestigerjare is dus opgevolg deur lae ekonomiese groei wat teen die tweede helfte van die tagtigerjare 'n hoogtepunt bereik het. ${ }^{2}$ Die Helpmekaar moes dus in die post 1966-periode in sy nuwe HS-gedaante funksioneer in wat vir Afrikaners - sy "kliënte" en sy "kapitaalverskaffers" - en witmense oor die algemeen 'n toenemend politieke en sosioekonomiese beleërde omgewing was.

1 H Giliomee, The Afrikaners. Biography of a people, 548-549, 558, 580, 603. Tafelberg, Cape Town, 2012.

$2 \quad$ Ibid., 597-601. 


\section{INKORPORERING VAN DIE NATALSE HELPMEKAAR}

Die wortels van die amalgamasie van die Natalse Helpmekaar met die Kaapse Helpmekaar kan teruggevoer word tot die 1963-landwye fondsinsamelingspoging deur die Helpmekaar. Die verstandhouding wat in beginsel in 1962 tydens die vergadering tussen die FAK en verteenwoordigers van al vier provinsiale Helpmekaar-organisasies in Johannesburg tussen die Kaapse en Natalse Helpmekaar bereik is, het die proses begin. Die Natalse Helpmekaar het hom bereid verklaar om hul bestaande fonds van R15000, sowel as alle toekomstige insamelings in Natal, aan die Kaapse Helpmekaar oor te dra indien die Kaap verantwoordelikheid vir hul studente aanvaar. ${ }^{3}$ Verdere samewerking en moontlike samesmelting met Natal het tydens die Afrikaanse Handelsinstituut se kongres in Durban in September 1964 met die Natalse sekretaris, mnr Van Rooyen, plaasgevind, maar daar is geen finale ooreenkoms bereik nie. ${ }^{4}$

Die poging tot groter samewerking tussen die twee provinsies het na 'n onderbreking van ongeveer twee jaar weer aan die begin van 1967 momentum gekry toe die Natalse Helpmekaar aangedui het dat hulle die kwessie van samesmelting met die Kaapprovinsie wou bespreek. Hulle het ook 'n afvaardiging gestuur om met die sekretaris in Kaapstad te kom onderhandel. Die Natalse Helpmekaar se versoek was dat hulle met die Studiefonds saamsmelt en die Studiefonds dan die Natalse studente vir hulle rekening neem. Dit ten spyte van die feit dat hulle nie oor die volle R40 000, wat hulle in 1962 onderneem het om in die Studiefonds se kas te stort, beskik het nie. Die versoek was dus dat samesmelting moes plaasvind en dat die Studiefonds Natal se kapitaal van R27 704 met byvoeging van enige ander inkomste moes aanvaar in plaas van die vereiste R40 000 van vroeër. Die dagbestuur het besluit dat, aangesien Natal nie op hul eie bene kon staan nie, die aanbod aanvaar word en dat die sekretaris met die Natalse bestuur moes onderhandel oor die besonderhede van die oorname $e^{5}$ op die reeds ooreengekome basis. Dit het behels dat Natal al hul fondse aan die HS oordra, hulle 'n verteenwoordiger op die direksie kon benoem, die HS jaarliks verslae en state aan hulle voorlê, die HS se leningsvoorwaardes ook vir Natalse studente sou geld en enige ander kwessies wat mag ontstaan het volgens die geldende beleid van die HS opgelos sou word. ${ }^{6}$

3 (HSA) HVKP, Notuleboek (8 Feb 1940-9 Des 1966), 24 Mei 1962, HS Direksie, gp; 30 Aug 1962, HS Direksie, gp.

4 (HSA) HVKP, Notuleboek (8 Feb 1940-9 Des 1966), 24 Sep 1964, HS Direksie, gp; 9 Jun 1964, HS Direksie, gp; 12 Aug 1964, HS spesiale Direksie, gp.

5 (HSA) HS, Notuleboek (19 Jan 1967-16 Feb 1973), 19 Jan 1967, HS Dagbestuur, gp.

6 (HSA) HS, Notuleboek (19 Jan 1967-16 Feb 1973), 26 Apr 1967, HS Dagbestuur, gp. 
Op 'n vergadering in Durban op 12 Junie 1967 tussen die bestuur van die Helpmekaar van Natal en die Studiefonds - verteenwoordig deur sen KA Sinclair (voorsitter) en mnr $S$ Pretorius (sektretaris) - is eenstemmigheid oor die basis van amalgamasie van die twee fondse, gebaseer op bogenoemde, bereik. Daar was die uitsondering dat die Natalse Helpmekaar nie hul studente wou bind om in Kaapland opgelei te word nie omdat dit goedkoper vir hulle was om in Pretoria of Bloemfontein te studeer. Daar is ook ooreengekom dat Natal hul verbandlenings tot geld sou maak en 'n finale ooreenkoms sou opstel en aan die Studiefonds vir goedkeuring sou voorlê. ${ }^{7}$

$\mathrm{Na}$ verdere korrespondensie en onderhandeling is 'n finale ooreenkoms deur die direksie van die Studiefonds in 1968 goedgekeur. Hiervolgens sou die Natalse Helpmekaar al sy bates en laste aan die HS oordra en sou dit vir 'n periode van hoogstens vyf jaar as aparte items op die state van die HS aangedui word. Die voorsitter van die Natalse Helpmekaar, met die sekretaris as sekundus, sou op die direksie van die HS gekoöpteer word; alle aansoeke om lenings van studente wat in Natal woonagtig was, sou deur die Helpmekaar van Natal gekeur word en dan met aanbevelings aan die HS deurgestuur word en die Helpmekaar van Natal sou bly voortbestaan en onder andere die insamelings van fondse en die verkryging van bemakings behartig. Alle sodanige nuwe gelde wat ingesamel word, sou oorbetaal word en by die bestaande Natalse fondse op die HS-balansstaat gevoeg word. Die Natalse studente sou lenings onder dieselfde voorwaardes en vereistes as lenings aan Kaaplandse studente ontvang en alle administratiewe uitgawes van die Natalse Helpmekaar sou deur die HS betaal word. Die ooreenkoms kon met kennisgewing van ses maande opgesê word, maar die kennisgewing moes aan die einde van die boekjaar eindig. Indien albei partye te eniger tyd tydens die volgende vyf jaar, maar nie langer nie, tevrede was dat die stelsel bevredigend werk, sou die amalgamasie deur formele besluite van albei beheerliggame gefinaliseer word. ${ }^{8}$

Deur die loop van 1968 is enkele praktiese probleme met prosedures ondervind en uitgeskakel en die oordragte van fondse en lenings afgehandel. Die samesmelting het dus met die aanvang van die 1969-boekjaar 'n werklikheid geword. WK van Rooyen, voorsitter van die Natalse Helpmekaar, sou voortaan op die Studiefonds se direksie dien met mnr MC van Rooyen, die sekretaris van Natal, as alternatiewe direkteur. ${ }^{9}$ (16 Feb 1973-10 Sept 1993), 16 Feb 1973, HS Direksie, gp.

8 (HSA) HS, Notuleboek (19 Jan 1967-16 Feb 1973), 16 Feb 1968, HS Direksie, gp; 16 Nov 1967, HS UK, gp.

9 (HSA) HS, Notuleboek (19 Jan 1967-16 Feb 1973), 12 Nov 1968, HS Dagbestuur, gp; 14 Feb. 1969 , HS Direksie, (HS Kantoorverslag, 24 Jan 1969), gp; 14 Feb 1969, HS jaarvergadering, gp. 


\section{Die Kaapse Helpmekaar}

Met die bywoning van sy eerste direksievergadering in Februarie 1969 het WK van Rooyen, Natalse Helpmekaar-voorsitter, sy waardering uitgespreek dat Kaapland hulle tegemoetgekom het, en ook insig verskaf in die praktiese redes wat die amalgamasie onderlê het:

"Hulle kon, weens die Afrikaanssprekendes se geringe getalle, nie behoorlik hulp verleen aan hulle studente nie, en hulle wil die jongmense graag help en terselfdertyd sorg dat hulle Afrikaners bly." ${ }^{10}$

(So laat as 1969 was dit dus steeds 'n kerndoel van Helpmekaar-denke, naamlik om Afrikaners Afrikaners te hou - om hulle vir die volk te behou). Van Rooyen het aangedui dat die Natalse bestuur nog oor hul toekomstige funksie moes besin, hy was van mening dat hulle hul op fondsinsameling sou toespits. ${ }^{11}$

Hoewel daar inisiatiewe bespreek is oor hoe om die Helpmekaar se leningsfasiliteite in Natal beter te bemark en wyer bekend te stel deur met die Natalse Onderwysunie en Direkteur van Onderwys te skakel het aansoeke uit dié provinsie onbeduidend gebly. ${ }^{12}$ Vir die periode 1969 tot en met 1972 het slegs tien studente aansoek gedoen en totale lenings ter waarde van R8 430 is ontvang. ${ }^{13}$

In 1972 het WK van Rooyen versoek dat die ooreenkoms met die Studiefonds gewysig moes word om te verseker dat die Natalse rekeninge onbepaald as sodanig in die Studiefonds se balansstaat aangedui sou word. Die artikel dat'n Nataller op die direksie van die Studiefonds moes dien moes duideliker omskryf word. Die Studiefonds het hiertoe ingestem en die veranderde ooreenkoms goedgekeur. ${ }^{14}$ Die hersiene ooreenkoms het dus bepaal dat die Natalse rekeninge as aparte items op die balansstate van die HS aangedui sou word. Daar is ook toekomstige Natalse verteenwoordiging op die direksie verseker deur te bepaal dat die voorsitter (met sekretaris as alternatief) van die Helpmekaar van Natal op die direksie van die HS gekoöpteer word. Indien die Helpmekaar van Natal ooit sou ophou om te bestaan, sou die HS in oorleg met die NG Kerk van Natal, nogtans sorg dat daar altyd op sy direksie 'n geskikte direkteur uit Natal sou dien. ${ }^{15}$

\footnotetext{
10 (HSA) HS, Notuleboek (19 Jan 1967-16 Feb 1973), 14 Feb 1969, HS Direksie, gp.

11 (HSA) HS, Notuleboek (19 Jan 1967-16 Feb 1973), 14 Feb 1969, HS Direksie, gp.

12 (HSA) HS, Notuleboek (19 Jan 1967-16 Feb 1973), 13 Feb 1970, HS Direksie, gp; 12 Feb 1971, HS Direksie, gp.

13 (HSA) HS, Notuleboek (19 Jan 1967-16 Feb 1973), 11 Feb 1972, HS jaarvergadering, Direksieverslag, gp.

14 (HSA) HS, Notuleboek (19 Jan 1967-16 Feb 1973), 11 Feb 1972, HS Direksie, gp; (HSA) HS, Notuleboek (16 Feb 1973-19 Sep 1993), 16 Feb 1973, HS Direksie, gp.

15 (HSA) HS, Notuleboek (16 Feb 1973-19 Sep 1993), 16 Feb 1973, HS Direksie, gp.
} 
Met die afsterwe van WK van Rooyen op 28 November 1976 was die Helpmekaar verplig om laasgenoemde onderneming gestand te doen. Van Rooyen het klaarblyklik sy seun, wat sekretaris van die Natalse Helpmekaar was, as sy opvolger aangewys. Die Studiefonds is nooit amptelik van hierdie veranderinge in kennis gestel nie en het die UK aanvanklik besluit om die saak vir eers daar te laat. ${ }^{16}$ In Februarie 1978 het die Studiefonds besluit om die bepaling van die ooreenkoms met die Natalse Helpmekaar, dat met WK van Rooyen se dood die Natalse NG Kerk 'n opvolger vir hom moes aanwys, te implementeer. ${ }^{17}$ Tydens die 1979-algemene jaarvergadering van die Studiefonds het die voorsitter bevestig dat daar finaal vasgestel is dat die Helpmekaar in Natal nie meer bestaan het nie en dat daar geen liggaam aangewys is wat namens die liggaam kon optree of verteenwoordiging in die Raad van Trustees van die Studiefonds kon aanvaar nie. ${ }^{18}$ Hierdie toedrag van sake het die Studiefonds se eienaarskap/voogdyskap van die eertydse Natalse fondse bevestig. Hoewel daar nie meer 'n toesighoudende Natalse teenwoordigheid op die direksie sou wees nie was die Studiefonds verplig om die bepalings van die ooreenkoms te eerbieding en toekomstige Natalse leningsaansoeke oor dieselfde kam as die van Kaapland te skeer.

\section{KIRSTEN BEURSFONDS: VAN BOESAK TOT VAN BREDA}

Die pad van die Freddie en Bessie Kirsten-skenking was in die post-amalgamasie-periode nou verweef met die ideologiese oriëntering van die Studiefonds en die veranderende politieke konteks van die bruin teologiestudente aan die Teologiese Skool van die NG Sendingkerk aan die Universiteit van Wes-Kaapland. Die dringende behoefte aan beurse onder dié studente is in die sestigerjare met groot simpatie bejeën en pogings is aangewend om dringend die Kirsten-skenking aan te vul om 'n groter bedrag as die R1 200 jaarlikse rente-opbrengs vir beurse tot beskikking te hê. ${ }^{19}$ In 1969 het die Studiefonds besluit om R10 000 uit eie fondse na die Kirsten-skenking oor te dra in 'n poging om die Fonds te versterk. Albertyn het die bydrae gemotiveer op grond van die feit dat die kapitaal van die Kirsten-skenking bygedra het om die Studiefonds in staat te stel om goeie winste met aandelebeleggings te maak. Die bydrae is dus gesien as die Kirsten-fonds se deel van die winste. Die groot behoefte na beurse was'n tweede motivering, aangesien "die meet-en-pas aanwending van die beskikbare

16 (HSA) HS, Notuleboek (16 Feb 1973-19 Sep 1993), 24 Nov 1977, HS UK, 46.

17 (HSA) HS, Notuleboek (16 Feb 1973-19 Sep 1993), 10 Feb 1978, HS jaarvergadering, 48.

18 (HSA) HS, Notuleboek (16 Feb 1973-19 Sep 1993), 16 Mei 1978, HS UK, 50; 9 Feb 1979, HS jaarvergadering, Voorsittersrede, 52.

19 (HSA) HS, Notuleboek (19 Jan 1967-16 Feb 1973), 1 Mrt 1968 HS, Vergadering Beurskomitee, Kirsten Beursfonds, gp. 


\section{Die Kaapse Helpmekaar}

fondse (is) pateties was om te aanskou." ${ }^{20}$ Voortaan sou R1 800 in plaas van R1 200 jaarliks vir beurse beskikbaar wees. ${ }^{21}$

Die Kirsten-skenking is ook saam met die Studiefonds se ander Beursfondse soos die DF Malan Fonds geoormerk vir pogings om spesiaal vir dié fondse geld in te samel. ${ }^{22}$ In Augustus 1973 het die UK verdere maniere bespreek om die opbrengs op die Kirstenskenking te verhoog om meer effektief te voorsien in die groot behoefte na beurse vir bruin teologiestudente. Na bespreking is besluit om nie die bestaande kapitaal van R30 100 (Kirsten se R20 000, die Helpmekaar se R10 000-aanvulling, asook Dawie van Zyl se R100-skenking) verder aan te vul nie, maar om eerder by die direksie aan te beveel dat die rente wat op die geld betaal word van ses na tien persent verhoog word. Dit sou die bedrag beskikbaar vir beurse van R1 204 tot R3 010 per jaar verhoog. Indien die kapitaal later meer word, kon die rentekoers weer afgebring word. Om die verhoogde Beursfonds reeds vir 1974 van krag te maak moes die sekretaris die tien persent-berekening reeds aan die einde van September in werking stel. ${ }^{23}$ Hierdie aanbevelings is in Februarie 1974 deur die direksie goedgekeur. ${ }^{24}$

Die goeie werksverhouding met die Universiteit van Wes Kaapland (UWK) Kweekskool rondom die toekenning van beurse uit die Kirsten-skenking het in die sewentigerjare voortgeduur. Met Richard van der Ross se aanstelling as rektor in 1975 het Van der Ross selfs gedagtes met Fanie Pretorius, bestuurder van die Studiefonds, uitgeruil oor strategiese maniere waarop UWK fondse kon bymekaar maak en moontlike skenkers kon identifiseer om UWK as instelling se sukses te verseker. ${ }^{25}$

Die tagtigerjare het egter'n kentering gebring wat teen 1985 'n opskorting van die toekenning van beurse uit die Kirsten-skenking tot gevolg gehad het en tot 'n nuwe fokus vir toekennings uit die skenking gelei het. Hierdie kentering het gepaardgegaan met gebeure in die breër Suid-Afrikaanse politiek wat in die tagtigerjare gemanifesteer het in 'n radikalisering van die weerstand teen die Suid-Afrikaanse regering en sy beleid van apartheid. Die stigting

20 (HSA) HS, Notuleboek (19 Jan 1967-16 Feb 1973), 18 Jun 1969, HS UK, gp.

21 (HSA) HS, Notuleboek (19 Jan 1967-16 Feb 1973), 13 Feb 1970, HS Direksie, Jaarverslag, 23 Jan 1970, gp.

22 (HSA) HS, Notuleboek (19 Jan 1967-16 Feb 1973), 12 Feb 1971, HS Direksie, Jaarverslag, 22 Jan 1971, gp.

23 (HSA) HS, Notuleboek (16 Feb 1973-10 Sep 1993), 8 Aug 1973, HS UK, 9.

24 (HSA) HS, Notuleboek (16 Feb 1973-10 Sep 1993), 15 Feb 1974, HS jaarvergadering, Jaarverslag, 13; 15 Feb 1974, HS Direksie, 16.

25 (HSA) HS, Notuleboek (16 Feb 1973-10 Sep 1993), 11 Jun 1992, HS, Memorandum met kommentaar oor die besluite en bespreking van UK-vergadering, 120 . 
van die United Democratic Front in $1983,{ }^{26}$ met die UWK as een van sy belangrikste ondersteuningsbasisse, het ook tot 'n radikalisering van die UWK-studentegemeenskap gelei. Tydens die UK-vergadering van die Studiefonds in Desember 1984 het Albertyn meegedeel dat:

"daar by lede van die Raad, al vir die afgelope paar jare onrus en bedenkinge ontstaan het oor die gees wat vaardig is onder studente van die Universiteit van Wes-Kaapland. Daar was die vrees dat, alhoewel die toekennings vir beurstoekennings aan ons voorgelê word deur professore van wie se integriteit en gesindheid ons verseker was, van die Fonds se gelde toegestaan kon word aan studente wat latent militante en anti-blank gesindhede onder lede gehad het. Inligting het ons die laaste tyd bereik wat ons tot groter versigtigheid gedwing het." ${ }^{27}$

Die boikot van klasse deur teologiestudente en hul deelname aan ander radikale protesaktiwiteite het die UK laat besluit om met van die kweekskoolprofessore te beraadslaag om 'n nuwe basis van toekenning van fondse uit die Kirsten-skenking te beding. ${ }^{28}$ Die UK was oortuig dat daar onder dié studente:

“'n gees posgevat het wat ernstige vrae laat ontstaan of daar nog reg geskied aan die gesindheid wat wyle mnr Freddie Kirsten jeens die Bruinmense gekoester het en sy mooi ideale met die skenking."29

Tydens die 1985-jaarvergadering is dus besluit dat beurstoekennings nie meer op die ou basis sou geskied nie, maar dat die Fonds hom sou toelê op nagraadse teologiese studies, veral ook om moontlike toekomstige dosente vir die Teologiese Skool te lewer. ${ }^{30}$ Met die nuwe fokus is gepoog om te verhoed dat wat die Studiefonds as radikale elemente beskou het deur geld uit die Kirsten-skenking gesubsidieer sou word. In 1985 is ook besluit dat die R1 500 wat jaarliks uit die DH van Zyl Beursfonds in die Kirsten Beursfonds gestort is, gestaak word. Dit is onseker of dit deel was van die algemene sanksie op die toekenning van beurse aan UWK se teologiestudente uit die Kirsten-skenking. Die motivering vir die besluit was dat alle opbrengste uit die Van Zyl-bemaking voortaan geoormerk moes word

26 KV Clarkson, The United Democratic Front as exponent of mass-based resistance and protest, 1983-1990, 2, PhD, Rand Afrikaans University, Nov 1997.

27 (HSA) HS, Notuleboek (16 Feb 1973-10 Sep 1993), 7 Des 1984, HS UK, 79.

28 (HSA) HS, Notuleboek (16 Feb 1973-10 Sep 1993), 7 Des 1984, HS UK, 79.

29 (HSA) HS, Notuleboek (16 Feb 1973-10 Sep 1993), 15 Feb 1985, HS jaarvergadering, Bestuurder jaarverslag, 80.

30 (HSA) HS, Notuleboek (16 Feb 1973-10 Sep 1993), 15 Feb 1985, HS jaarvergadering, 82. 
vir die infrastruktuurontwikkeling van Van Zyl's Gift. ${ }^{31}$ Die feit dat daar egter nog steeds voortgegaan sou word met die jaarlikse skenkings uit die DH van Zyl Beursfonds aan die NG Teologiese Skool De Coligny (1984 - R1500) en die NG Kerk Nywerheidskompleks, Mfesane, of Dimbasa (1984 - R500) dui daarop dat dit deel van die "strafmaatreëls" teen die UWK-ontvangers van beurshulp uit die Kirsten-skenking was.

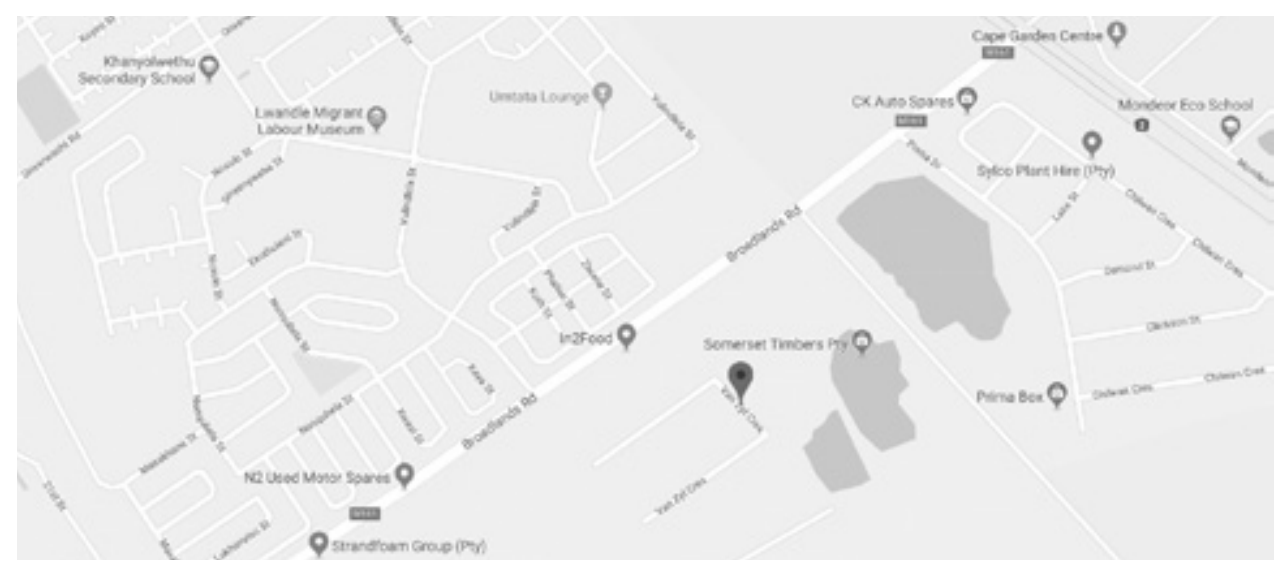

Van Zyl's Gift, Broadlands, Strand. Die straat wat die nywerheidsperseel omsoom is na DH van Zyl vernoem: Van Zyl Crescent.

Die toestand het vir die duur van die tagtigerjare voortgeduur en volgens die Studiefonds se bestuurder se oordeel verder versleg met die aanstelling van Jakes Gerwel as rektor in $1987,{ }^{32}$ aangesien

"die voorlopige beleidsafkondigings van die nuwe rektor is so radikaal links dat hy die bestudering van kommunisme as 'n filosofie wil aanmoedig. Of dit sal beteken dat die lesings oor die evangelie ook die evangelie volgens Marx sal moet insluit, sal maar afgewag moet word" ${ }^{33}$

31 Van Zyl's Gift was 'n blok industriële grond in die Strand en deel van DH van Zyl se erflating aan die Helpmekaar.

32 http://www.litnet.co.za/in-memoriam-jakes-gerwel/ (Jason Lloyd, In Memorium: Jakes Gerwel, 7 Des 2012). Gerwel het verklaar dat UWK die "intellectual home of the left" was.

33 (HSA) HS, Notuleboek (16 Feb 1973-10 Sep 1993), 20 Feb 1987, HS jaarvergadering, Bestuurder verslag, 88. 
Sedert 1985 is slegs aan enkele nagraadse teologiestudente beurse toegeken:

"Hierdie toekenning is gedoen aan enkele bruin predikante wat geweier het om toekennings te ontvang uit die groot beursfonds wat deur dr Allan Boesak beheer is, omdat hulle dan eers deur die omstrede Broederkring gekeur sou moes word."34

Ironies genoeg was Allan Boesak 'n vroeë ontvanger van 'n beurs uit die Kirsten-skenking. ${ }^{35}$ Toekennings uit die Kirsten-skenking het dus vir die res van die tagtigerjare vir alle praktiese doeleindes opgedroog en is eers in 1991 weer'n substansiële beurstoekenning gemaak met 'n beurs van R5 000 wat aan proponent VA van Breda, 'n MA-student van die NG Sendingkerk, vir nagraadse studies aan Princeton toegeken is. ${ }^{36}$

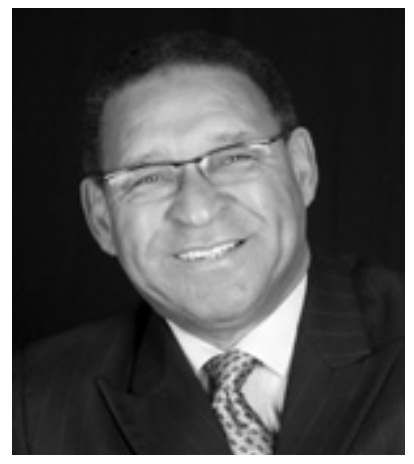

Alan Boesak het in 1967 ' $n$ beurs uit die Freddie en Bessie Kirsten-fonds van die Helpmekaar ontvang
Die hantering van die Kirsten-skenking was 'n duidelike weerspieëling van die Studiefonds se posisie wat in die periode in simpatie met die NP en die regering van die dag was. Ondersteuning is slegs toegeken aan bruin teologiestudente wat as ideologies "veilig" of "aanvaarbaar" beskou is. Dit was ook 'n aanduiding dat teen die einde van die tagtigerjare die flirtasies met 'n minder rigiede rasseperspektief en skemas om ook ander studente buiten wit Afrikaanse studente te ondersteun, wat die Helpmekaar diskoers in die vroeë sestigerjare vlietend gekenmerk het, saam met meer algemene rasseverhoudinge in Suid-Afrika in 'n rigiede skaakmat verval het.

\section{HULP AAN TEOLOGIESTUDENTE}

Sowel voor as tydens die amalgamasie-periode was die besondere posisie van teologiestudente 'n deurlopende debatspunt in die Helpmekaar. Die feit dat hulle lang studiejare hulle met 'n groot skuldlas gelaat het, het die Helpmekaar aangespoor om oplossings vir die probleem te

34 (HSA) HS, Notuleboek (16 Feb 1973-10 Sep 1993), 22 Feb 1991, HS jaarvergadering, Bestuurder Jaarverslag, 6 Feb 1991, 112. Die Broederkring het bestaan uit predikante, dosente en gewone lidmate van die vier Gereformeerde Kerke in Suid-Afrika en het hul aanvanklik vir gereformeerde kerkeenheid beywer. Hulle het onder andere besin oor die profetiese rol van die kerk in apartheid Suid-Afrika. http://kerkargief.co.za/ doks/bely/DF_Broederkring.pdf HS, Notuleboek (19 Jan 1967-16 Feb 1973), 23 Feb 1967 HS, Vergadering Freddie en Bessie Kirsten Beursfonds, gp. 
soek. In 1967 het dit 'n teologiestudent tussen R500-R600 per jaar gekos om te studeer, dws ongeveer R4 $000^{37}$ vir sy totale kursus. In 1967 was R61 429 uitstaande op die rekenings van 99 teologiestudente en/of predikante. Die gemiddelde bedrag wat dienende predikante per jaar aan die Helpmekaar terugbetaal het, was R12 per maand - terwyl die voorgeskrewe paaiement R30 was. $^{38}$ Teen hierdie agtergrond was die Helpmekaar oortuig dat die kerk 'n groter verantwoordelikheid teenoor teologiestudente moes aanvaar en pogings is dus aangewend om die kerk se samewerking te kry. 'n Tweede been van die oplossing is gesoek in gunstiger leningsvoorwaardes vir teologiestudente in kombinasie met 'n Teologiese Beursfonds waaruit teologiestudente en predikante met 'n groot skuldlas tegemoetgekom kon word. Hierdie inisiatiewe is na amalgamasie voortgesit. ${ }^{39}$

In 1967 is die inisiatiewe saamgevat in 'n nuwe skema vir teologiestudente waarvolgens die Helpmekaar onderneem het om hulle te help om hul grade te verwerf deur aan hulle rentevrye lenings vir die duur van die studieperiode toe te staan. Vir die Kweekskool-gedeelte van hul opleiding daarna moes die Kerk en die Kweekskool met die hulp van die Ring waaruit die studente afkomstig was dan verantwoordelikheid vir die studente se finansiering aanvaar deur hul eie beurs- en leningsfondse. As riglyn het die skema beoog om teologiestudente met nie meer as R2 000 se skuld na voltooiing van hul studies te laat nie. Die skema het ook beoog om die situasie waarvolgens die studente aan 'n verskeidenheid instansies geld geskuld het uit te skakel. ${ }^{40} \mathrm{Na}$ voltooiing van hul studies sou teologiestudente vier persent in plaas van ses persent rente op hul lenings betaal. ${ }^{41}$ Hierdie vergunning sou vanaf 1 Oktober 1968 geld. Indien 'n student sy teologiese studies laat vaar, sou die rentekoers van ses persent met terugwerkende krag van toepassing wees. ${ }^{42}$ Die Helpmekaar se gesonde finansiële posisie op dié stadium het die vergunning moontlik gemaak. 'n Bykomende motief met die toegewing was ook dat gehoop is dat dit 'n gunstige uitwerking op potensiële bydraes tot die Teologiese Beursfonds sou hê. ${ }^{43}$

37 In 1967 het 'n nuwe Toyota Corona 1.5 liter motor R1 770 gekos en 'n dagtoer van Cape Coach Tours om blomme in Namakwaland te gaan kyk R5 - middagete ingesluit. Die Burger, 2 Aug 1967, 21, Hier is die motor vir u; Die Burger, 2 Aug 1967, 14, Het u vanjaar die veldblomme gesien?

38 (HSA) HS, Notuleboek (19 Jan 1967-16 Feb 1973), 10 Mei 1967, HS, Vergadering UK, HS en Dagbestuur van Kuratorium, gp.

39 (HSA) HS, Notuleboek (19 Jan 1967-16 Feb 1973), 26 Apr 1967, HS Dagbestuur, gp.

$40 \quad$ Ibid.

41 Ibid.

42 (HSA) HS, Notuleboek (19 Jan 1967-16 Feb 1973), 12 Nov 1968, HS Dagbestuur, gp.

43 (HSA) HS, Notuleboek (19 Jan 1967-16 Feb 1973), 14 Feb 1969, HS Direksie, Kantoorverslag, 24 Jan 1969, gp. 
Die Helpmekaar was ook van mening dat in samewerking met die kuratorium en Universiteit van Stellenbosch pogings aangewend moes word om te probeer verhoed dat die studente wat lenings moes aangaan "by die Kweekskool aankom, kompleet met vrou, kinders, en dikwels nog 'n voertuig ook." ${ }^{44}$ Penalisasie van studente as hulle voor 'n bepaalde tyd trou en 'n bepaling dat hulle nie 'n motor mag aanskaf sonder die toestemming van die instansie wat hulle geldelik help nie is van die voorstelle wat in dié verband aan die hand gedoen is. ${ }^{45}$

Verskeie pogings is deur die Helpmekaar aangewend om die kerk se samewerking vir die skema te verkry. Aangesien kerklike goedkeuring van Sinodebesluite afhanklik was en baie gemeentes 'n apatiese houding teenoor finansiële ondersteuning van teologiestudente geopenbaar het, was die vordering stadig en het samesprekings met die kuratorium van die Kweekskool aangetoon dat nie almal oortuig was dat die skema prakties uitvoerbaar was nie. ${ }^{46}$ Die Helpmekaar se besluit om 'n groot insamelingsveldtog te hou om fondse vir hul beursfondse vir teologiestudente te bekom ${ }^{47}$ is, afgesien van ekonomiese faktore soos droogtetoestande en die ineenstorting van die aandelebeurs in 1969, ${ }^{48}$ ook deur die kerk se gedraal, onvermoë en onwilligheid om deel te word van die Helpmekaar se inisiatief belemmer. ${ }^{49}$

Die Algemene Sinodale Kommissie het uiteindelik in Mei 1968 ten minste sy morele steun aan die Helpmekaar-insameling vir 'n Teologiese Beursfonds toegesê. ${ }^{50}$ Die insamelingsveldtog is weens verskeie ander faktore eers in Februarie 1971 deur die Beurskomitee van stapel gestuur. ${ }^{51}$ Die reaksie van die publiek en besighede was teleurstellend. ${ }^{52}$ Die Teologiese Beursfonds het teen begin 1974 oor 'n kapitaal van ongeveer R10 000 beskik. Die direksie het dus in Februarie 1974 in beginsel besluit dat dienende leraars wat onder 'n groot

(HSA) HS, Notuleboek (19 Jan 1967-16 Feb 1973), 10 Mei 1967, HS, Vergadering UK, HS en Dagbestuur van Kuratorium, gp.

Ibid.

46 (HSA) HS, Notuleboek (19 Jan 1967-16 Feb 1973), 10 Mei 1967, HS, Vergadering UK, HS en Dagbestuur van Kuratorium, gp; 14 Sep 1967, HS UK, gp.

(HSA) HS, Notuleboek (19 Jan 1967-16 Feb 1973), 14 Sep 1967, HS Uitvoerende Komitee, gp; 16 Nov 1967, HS UK, gp; 16 Feb 1968, HS Direksie, gp.

(HSA) HS, Notuleboek (19 Jan 1967-16 Feb 1973), 13 Feb 1970, HS Direksie, Jaarverslag, 23 Jan 1970, gp; 13 Feb 1970, HS Direksie, gp.

(HSA) HS, Notuleboek (19 Jan 1967-16 Feb 1973), 18 Apr 1968, HS UK, gp.

(HSA) HS, Notuleboek (19 Jan 1967-16 Feb 1973), 26 Sep 1968, HS Dagbestuur, gp.

51 (HSA) HS, Notuleboek (19 Jan 1967-16 Feb 1973), 12 Feb 1971, HS Direksie, gp.

52 (HSA) HS, Notuleboek (19 Jan 1967-16 Feb 1973), 21 Okt 1971, HS UK, gp. 
studieskuldlas gebuk gaan uit die Fonds gehelp kon word. Waar moontlik kon skulde wat op verskillende plekke aangegaan is, gekonsolideer word teen vier persent rente met dien verstande dat die totale bedrag van die Helpmekaar-lening nie die perk van R5 000 oorskry nie en mits die nodige borge verskaf word.

In enkele gevalle waar verdere hulp nodig was, is die UK gemagtig om uit die Teologiese Beursfonds op 'n R-vir-R-basis by te dra - bereken op die afbetalings deur die lener aan die Studiefonds gemaak. Oor sulke gevalle moes aan die direksie verslag gedoen word. Ten opsigte van admissiestudente is besluit om in verdienstelike gevalle aan gemeentes voor te stel dat 'n bydrae uit gemeentefondse van R150 per jaar aan admissiestudente gemaak word wat dan deur die universiteit met 'n verdere R150 aangevul sou word. Sodoende sou 'n student dan in sy admissiejare oor 'n beurs van R300 per jaar beskik. In gevalle waar 'n gemeente nie die R150 kon vind nie, maar die kerkraad wel die kandidatuur aanbeveel, kon die UK dit oorweeg om uit Helpmekaar-fondse 'n bedrag van tot R150 per jaar via die gemeente aan so 'n kandidaat beskikbaar te stel. ${ }^{53}$

Die Helpmekaar sou ook mettertyd die Teologiese Beursfonds aanvul deur bydraes uit eie fondse, deur 'n rand te stort vir elke rand wat deur die publiek bygedra word. ${ }^{54}$ Dié fondse het die Helpmekaar in staat gestel om ten minste in ad hoc-gevalle die posisie van sommige van sy predikantleners wat 'n groot skuldlas gehad het tegemoet te kom deur 'n rand by te dra vir elke rand wat deur die leners op hul skuld afbetaal is of hul skuld met 'n eenmalige betaling te verminder. ${ }^{55}$ Die beginsel is ook aanvaar dat die Helpmekaar namens behoeftige admissiestudente R150 per jaar aan die universiteit oorbetaal op 'n R-vir-R-beursstelsel. ${ }^{56}$ Teen die einde van 1973 is teologiestudente en predikante ook tegemoetgekom deur die maksimum leningsbedrag vir dié leners na R5 000 op te skuif. ${ }^{57}$

In Augustus 1973 het die UK verdere maatreëls oorweeg om teologiestudente tegemoet te kom deur te oorweeg om aan hulle rentevrye lenings vir die duur van hul studiejare toe te staan. Bereken teen 1973 se syfers sou so 'n stap die Studiefonds R1 212 per jaar aan renteinkomste kos. Ten spyte hiervan het die UK die voorstel van rentevrye lenings vir die duur

\footnotetext{
53 (HSA) HS, Notuleboek (16 Feb 1973-10 Sep 1993), 15 Feb 1974, HS jaarvergadering, Jaarverslag, 13; 15 Feb 1974, HS Direksie, 16, 17.

54 (HSA) HS, Notuleboek (16 Feb 1973-10 Sep 1993), 22 Jul 1977, HS UK, 44.

55 (HSA) HS, Notuleboek (16 Feb 1973-10 Sep 1993), 22 Jul 1977, HS UK, 44; 20 Sep 1977, HS UK, 45; 19 Jun 1974, HS UK, 20.

56 (HSA) HS, Notuleboek (16 Feb 1973-10 Sep 1993), 10 Feb 1978, HS Jaarvergadering, 49.

57 (HSA) HS, Notuleboek (16 Feb 1973-10 Sep 1993), 8 Nov 1973, HS UK, 12.
} 
van die studiejare by die direksie aanbeveel. ${ }^{58}$ Die direksie het die aanbeveling in Februarie 1974 goedgekeur wat beteken het dat teologiestudente voortaan rentevrye lenings vir die duur van hul studies sou ontvang en daarna vier persent rente sou betaal. Hierdie reëling sou geldig bly tot die Vorster-Muller Fonds aan teologiestudente begin lenings toestaan volgens dieselfde voorwaardes. Daar is dus voorsien dat nadat dié fonds in werking getree het die Studiefonds geen meer lenings uit sy fondse aan teologiestudente sou toestaan nie. ${ }^{59}$

Die Helpmekaarskema het beslis teologiestudente se finansiële dilemma met studieskuld verlig, maar die onbedoelde gevolge van die goedbedoelde pogings het teen 1978 die Helpmekaar gedwing om aspekte van hul skema in heroorweging te neem. Deur die loop van die tweede helfte van die sewentigerjare het dit duidelik geword dat teologiestudente die "goedkoop" geld (rentevrye lenings vir die duur van die studietydperk en vier persent rente daarna) van die Helpmekaar vir eie gewin begin teiken het. Stygende inflasie en gepaardgaande stygende rentekoerse vanweë die invloed van die energiekrisisse van die sewentigerjare het waarskynlik daartoe bygedra om die aanloklikheid van Helpmekaar-geld te verhoog. In 'n kantoorverslag van die bestuurder in 1978 het hy 'n pleidooi gelewer dat die rentevrye lenings aan teologiestudente gestaak moes word, aangesien daar sterk aanduidings was dat die Helpmekaar se toegewings uitgebuit word. Die verslag het aangedui dat met die huidige beleid van rentevrye lenings aan teologiestudente die Helpmekaar net in 1978 alleen R5 344 aan inkomste ingeboet het. Dit is bereken teen vier persent rente. Van die totaal van R948 521 wat aan studente uitgeleen is, was R133 661 die bedrag wat aan teologiestudente uitgeleen is, terwyl die predikante se leningsbedrag maar net R27 111 bedra het. Op R133 661 het die Helpmekaar dus geen inkomste ontvang nie en die bedrag het onrusbarend vinnig gegroei. Die verslag het die tendens as volg beskryf:

“Teologiestudente kom drie/vier op 'n keer in ons kantoor in vir aansoekvorms en vra dan sommer twee/drie vorms vir vriende wat ook teologiestudente is en hulp nodig het, maar nie self kon inkom nie. Heelwat van die in die bondel se vaders het voorheen hulle koste gedra, maar hulle wil hulle vaders se las verlig, is die verduideliking wat ons kry. Vrae duik op. Koop hulle motors, of dalk nuwer modelle? Het die vader besluit dat die geld wat hy voorheen betaal het aan die universiteit, voordelig belê kan word elders en dat hy dan liewer die rentevrye geld van die Helpmekaar sal gebruik. Leen die student dalk

59 (HSA) HS, Notuleboek (16 Feb 1973-10 Sep 1993), 15 Feb 1974, HS jaarvergadering, Jaarverslag, 13; 15 Feb 1974, HS Direksie, 16. Die Vorster-Muller Fonds was 'n uitvloeisel van 'n erflating van Jacoba Vorster wat by voorkeur steun aan teologie studente beoog het. Die Fonds word later in die hoofstuk breedvoerig bespreek. 


\section{Die Kaapse Helpmekaar}

die geld by ons en belê dit dan teen 7 persent elders. Die stelsel leen hom tot misbruik en lei tot ongewenste praktyke." 60

Die memorandum het dus voorgestel dat alle Helpmekaarlenings ses persent rente moet betaal en dat teologiestudente eerder na voltooiing van hul studies tegemoetgekom moet word. Die memorandum het ook daarop gewys dat die Helpmekaar die les alreeds vroeër in sy bestaan geleer het dat die toestaan van rentevrye lenings nie 'n goeie beleid is nie, aangesien goedkoop geld tot misbruik aanleiding gee. Dit het ook die Helpmekaar se fondse uiters stadig laat groei en omdat sulke lenings ook traag terugbetaal is. ${ }^{61} \mathrm{Na}$ aanleiding van die memorandum en 'n verdere ondersoek is besluit dat lenings aan teologiestudente voortaan vier persent rente moet dra vir die duur van die studieperiode en ses persent daarna. As so 'n student egter sy studies staak of nie in die bediening ingaan nie, word die ses persent rentekoers terugwerkend van krag. Enige teologiese student of afgestudeerde predikant wat spesiale tegemoetkoming verdien, kon deur die UK gehelp word uit die Helpmekaar se Beursfondse. ${ }^{62}$ Hierdie episode met rentekoerse het die beheerliggaam laat besluit om toekomstige beheerliggame te waarsku om nooit weer rentevrye lenings of lenings teen lae rentekoerse beskikbaar te stel nie. Daar word net misbruik gemaak van die "goedkoop geld". Dit lei tot traak-my-nieagtigheid by leners en bou nie karakter nie. Rentekoerse moet dus nooit weer laer as ses persent wees nie. ${ }^{63}$

Die opskorting van rentevrye lenings aan teologiestudente in 1978 het nie beteken dat die Helpmekaar sy besondere simpatie met dié studente verloor het nie. Deur die loop van die tagtigerjare het die hoë skuldlas waarmee afgestudeerde teologiestudente opgeskeep gesit het steeds 'n refrein in Helpmekaar-besprekings gebly en is deurlopende pogings aangewend

60 (HSA) HS, Notuleboek (16 Feb 1973-10 Sep 1993), 28 Nov 1978, HS UK, Memorandum rentevrye lenings onbesonne beleid, 14 Nov 1978, 49.

$61 \quad$ Ibid.

62 (HSA) HS, Notuleboek (16 Feb 1973-10 Sep 1993), 28 Nov 1978, HS UK, 52; 7 Des 1978, HS Kommissie, 52; 9 Feb 1979, HS jaarvergadering, Voorsittersrede, 52; 9 Feb 1979, HS jaarvergadering, 52.

63 (HSA) HS, Notuleboek (16 Feb 1973-10 Sep 1993), 2 Mei 1979 HS, Brief aan toekomstige beheerliggame voor in notuleboek geplak, 54 . 
om die kerk mede-verantwoordelikheid te laat aanvaar vir die finansiële ondersteuning van teologiestudente. ${ }^{64}$

In die vroeë tagtigerjare is 'n oproep aan NG gemeentes in Kaapland om deurkollektes by spesiale geleenthede vir die Helpmekaar se Teologiese Beursfonds te hou met gemengde reaksie begroet. Sommige gemeentes het gehoor gegee, maar baie het nie eens die moeite gedoen om op die korrespondensie te antwoord nie. ${ }^{65}$ Ten spyte van die louwarm reaksie het die Helpmekaar voortgegaan met sy benadering om versoeke van predikante met skuldprobleme op 'n ad hoc-grondslag te oorweeg en sulke gevalle uit hul Teologiese Beursfondse finansieel tegemoet te kom. ${ }^{66}$ Geld is ook by geleentheid bewillig aan predikante wat hul nagraadse studies wou voortsit of hulself in die buiteland verder wou bekwaam. ${ }^{67}$ In 1986 is selfs sover gegaan om 'n lening van R1 000 aan J Daniels, 'n bruin onderwyser van die Paarl, toe te staan om sy doktorale proefskrif in Grieks af te handel. Hoewel die lening eers toegestaan is nadat "dr Albertyn en die Bestuurder (het) sy agtergrond nagespoor en gunstige verslae ingewin" 68 het en vasgestel is dat hy na alle waarskynlikheid nadat hy sy graad behaal het 'n aanstelling as lektor aan die UWK sou kry, was dit waarskynlik die eerste lening onder gewone voorwaardes wat aan 'n nie-wit student toegestaan is. ${ }^{69}$

In die krisisjaar van 1987 is ' $n$ voorstel van dr Albertyn, dat proponente wat nog nie beroep is nie van rente kwytgeskeld moet word vir die tydperk wat hulle werkloos is, goedgekeur. ${ }^{70}$ In sy jaarverslag vir 1987 het die bestuurder ook aangedui dat die tyd ryp was vir die verwysing van die aansoeke van teologiestudente na die Vorster-Muller Fonds om hierdie tipe student nie met leë hande weg te stuur nie. Ironies genoeg het sy opmerking saamgeval met 'n

64 (HSA) HS, Notuleboek (16 Feb 1973-10 Sep 1993), 12 Feb 1982, HS jaarvergadering, 67; In Feb 1982 met die prima rentekoers op 18 persent het die Raad in ' $n$ poging om die inflasie-erosie van sy fondse teen te werk besluit om sy rentekoerse aan te pas na ses persent vir die duur van die studietydperk, agt persent vanaf voltooiing van die studies vir 'n periode van vyf jaar, en na 5 jaar tien persent. Vir teologiestudente sou vier persent tydens die studies en ses persent daarna geld, mits so 'n lener in die bediening gaan. Die UK is ook versoek om 'n formule te vind vir rente-aanpassings vir leners met groot studieskuld wat nie hul lenings binne vyf jaar kan delg nie. Ibid., 66, 67 ;17 Nov 1981, HS UK, 64.

65 (HSA) HS, Notuleboek (16 Feb 1973-10 Sep 1993), 11 Feb 1983, HS jaarvergadering, 70.

66 (HSA) HS, Notuleboek (16 Feb 1973-10 Sep 1993), 20 Okt 1983, HS UK, 73; 7 Des 1983, HS UK, 74; 8 Mrt 1984, HS jaarvergadering, 76; 7 Aug 1986, HS UK, 88.

67 (HSA) HS, Notuleboek (16 Feb 1973-10 Sep 1993), 7 Des 1983, HS Uitvoerende Komitee, 74; 14 Aug 1984, HS UK, 78; 10 Feb 1984, HS jaarvergadering, 76.

70 (HSA) HS, Notuleboek (16 Feb 1973-10 Sep 1993), 19 Feb 1988, HS jaarvergadering, Voorsittersrede, 94; (HSA) HS, Notuleboek (16 Feb 1973-10 Sep 1993), 19 Feb 1988, HS jaarvergadering, 94. 


\section{Die Kaapse Helpmekaar}

drastiese afname in aansoeke van teologiestudente vir finansiële ondersteuning. Pretorius het opgemerk:

"Dit is egter opvallend dat ons oor die afgelope twee jaar net een aansoek van 'n voornemende teologiese student ontvang en toegestaan het. Verder is daar net ses lenings (teologie) waarop ons nog verpligtinge het. Die ander doen almal diensplig of is besig om af te betaal op hulle lenings". ${ }^{71}$

Die disproporsionele aandag en inspanning wat aan teologiestudente afgestaan is, was waarskynlik die gevolg van verskeie faktore. Die kerk se noue verbintenis met en ondersteuning van die Helpmekaar sedert sy ontstaan het die Helpmekaar met 'n ere-skuld gelaat wat vereffen moes word. Die hoë status van die "leraar/dominee" in die tradisionele Afrikanersamelewing het moontlik 'n bydrae gelewer. Ten spyte van die alternatiewe stemme in die Afrikanersamelewing van die 1960's, 1970's en 1980's, wat die posisie van tradisionele gesagsfigure toenemend uitgedaag het, was dit ook 'n samelewing onder beleg wat 'n "totale aanslag" moes afweer en wie se seuns in 'n "grensoorlog" die eer van die vaderland moes verdedig. In dié omstandighede was toegang tot die Allerhoogste as bondgenoot in dié stryd in 'n steeds beduidende deel van Afrikanergeledere van kardinale belang. Die poort hiervoor was steeds via die produkte wat kweekskole jaarliks gelewer het. Om na hulle finansiële welstand om te sien en hul van dié las te verlig was 'n manier om hul gefokus te hou op die taak voorhande: die geestelike versterking en opbouing van die "volk" - ter wille van die "volk".

\section{SAMEWERKING MET ANDER PROVINSIES SE HELPMEKAARVERENIGINGS}

Die idee van 'n verenigde nasionale Helpmekaarfonds het by twee vorige geleenthede in die stof gebyt hoofsaaklik vanweë die geneigdheid van die Transvaalse Helpmekaar om op hul eie te funksioneer. Beide in 1918 en weer tydens die uniale insamelingsveldtog van 1963 het die Transvaalse ingesteldheid om beheer oor hul eie fondse te behou - in laasgenoemde geval veral onder leiding van dr Andries Visser en mnr Hoender du Toit ${ }^{72}$ - die totstandkoming van een groot uniale fonds verydel. In die post-amalgamasie-era was die strewe na eenheid nie dood nie en in 1967 is die aangeleentheid weer te berde gebring. Hoofsaaklik vanweë die gevoel by sommige amptenare van die Kaapse Helpmekaar dat die ander provinsiale Helpmekaarverenigings ondoeltreffende studiehulp - te min studente word gehelp en

\footnotetext{
71 (HSA) HS, Notuleboek (16 Feb 1973-10 Sep 1993), 19 Feb 1988, HS jaarvergadering, Bestuurder verslag, 92.

72 (HSA) HS, Notuleboek (16 Feb 1973-10 Sep 1993), 17 Nov 1982, HS, Boodskap van die Kaaplandse Helpmekaar aan die Transvaalse Helpmekaar, gp.
} 
die bedrae wat aan hul geleen word, is te min - aan hul studente bied wat die studente finansieel benadeel.

Hierdie strewe is verwoord in 'n memorandum wat die kantoor opgestel het waarin die ondoeltreffende hulp wat die ander provinsies se Helpmekaar-fondse beskikbaar stel aan hulle studente en die gevolglike benadeling van die studente se geldelike belange onderstreep is. Die memorandum het dus versoek dat onderhandelinge weer eens aangeknoop moes word om die vyf Helpmekaar-fondse te laat saamsmelt in een sentrale fonds wat dan dieselfde doeltreffende en omvattende studiehulp sou aanbied wat Kaapland gebied het. Die betoog in die memorandum was dat met die samesmelting van die twee Kaapse fondse daar nou vir die eerste keer in die geskiedenis voldoende fondse was vir al die behoeftes aan lenings van Kaaplandse studente - ten minste vir die huidige. Die memorandum was van mening dat met dié toedrag van sake die Helpmekaar nog net aan die eerste of primêre vereiste van 'n studiefonds voldoen het. Om 'n studiefonds in die volle sin van die woord te wees moes so 'n fonds in die tweede plek ook in staat wees om beurse te skenk en in die derde plek ook nog gelde vir spesifieke navorsingsprojekte beskikbaar kon stel. Die Fonds kon dus nooit staties wees nie, maar moes altyd groei om tred te hou met die toenemende beroepe wat op hom gedoen sou word.

Volgens die memorandum was die breë landsbelang 'n deurslaggewende faktor in die doelstellings van die HS. Die Studiefonds se doelstelling was om te voorsien in die "skreiende tekort wat die land het in opgeleide manne op alle terreine en ook om ons potensiaal ten volle te benut om ons leiersposisie te handhaaf in Suid-Afrika asook op die Vasteland". ${ }^{73}$

Die memorandum was van mening dat die Studiefonds nog ver tekortgeskiet het in dié verband. Afgesien van die feit dat die Studiefonds nog nie voldoen het aan die tweede en derde doelwitte van 'n studiefonds nie, was die Fonds aandadig daaraan dat die land se volle potensiaal nie benut is nie omdat hulle die "onbeholpenheid, provinsialisme en 'n gebrek aan visie by die ander provinsies se Fondse" verduur het en as volg geargumenteer het: "soos tot nou toe dat die ander provinsies maar moet sien kom klaar omdat hulle ons aanbod vir vereniging van die hand gewys het."74 Volgens die memorandum was die belowende studente uit die ander provinsies net soveel werd as dié uit Kaapland. Daar is daarop gewys dat verskeie sakeleiers in Kaapstad uit ander provinsies afkomstig was, en andersom. in met titel: Memorandum: Gedagtes oor Uitbreiding), gp. 


\section{Die Kaapse Helpmekaar}

Die memorandum was van mening dat die mislukking van die 1963-fondsinsamelings veral in die ander provinsies die klimaat vir samewerking en samesmelting baie gunstiger gestem het as voorheen. Indien dit nie die geval was nie moes die openbare mening en ander instansies ingespan word om druk uit te oefen om vereniging te bewerkstellig. Die memorandum was van mening dat die studiefonds vanweë sy sterk finansiële en morele posisie die leiding moes neem om ook doeltreffende studiehulp aan studente van die ander provinsies te verseker. Die ondoeltreffende hulp van ander provinsies het die hele land benadeel; nie net die provinsies nie.

Die memorandum het ook die voordele van een groot gekonsolideerde studiefonds onderstreep. Afgesien van die voordele vir studente sou die status en beeld van 'n verenigde fonds die kanse vir toegewings van die staat verhoog. Maatskappye sou volgens die memorandum ook meer geneë wees om aan 'n fonds van nasionale omvang jaarlikse skenkings te maak omdat dit die nasionale ekonomie tot voordeel sou strek. Die memorandum het geskat dat so 'n gekonsolideerde studiefonds oor 'n aanvangskapitaal van minstens R1 000000 sou beskik. Volgens die memorandum moes Kaapland die leiding in die inisiatief neem.

Die direksie het egter nie die sentimente van die memorandum gedeel nie. Dr Albertyn was van mening dat die vorige verenigingspogings misluk het en dat die studiefonds liefs op sy eie moes voortgaan. Hy was eerder ten gunste van 'n meer beperkende studiefonds wat vereis dat studente wat deur die Fonds gehelp word aan Kaaplandse inrigtings moes studeer. Op dié basis kon lenings dan ook aan studente van ander provinsies toegestaan word. Sinclair was van mening dat die Transvaalse voorsitter duidelik aangedui het dat hulle liefs op hul eie bene wou staan. Hierdie standpunte, asook die feit dat die Transvaalse Helpmekaar nie eens gereageer het op die vraelys oor besonderhede van die provinsiale fondse nie, het die dagbestuur laat besluit dat verdere onderhandelinge oor eenwording geen nut sou hê nie. ${ }^{75}$

Teen die agtergrond van hierdie besluit het die Studiefonds in November 1967 'n versoek van die Transvaalse HS om Sanlam gesamentlik vir 'n jaarlikse skenking te nader van die hand gewys, aangesien hul van mening was dat dit hul eie kanse om Sanlam vir 'n groot bydrae tot die DF Malan Beursfonds te nader sou benadeel. Die Transvaalse Helpmekaar is dus in kennis gestel om maar op hul eie na goeddunke op te tree. ${ }^{76}$ Daar het dus teen die laat sestigerjare vanweë 'n geskiedenis van onverrigter sake ten opsigte van veral die Transvaalse Helpmekaar 'n "vervreemding" tussen Noord en Suid bestaan. Daar was nie noodwendig 'n direkte

\footnotetext{
75 Ibid.

76 (HSA) HS, Notuleboek (19 Jan 1967-16 Feb 1973), 16 Nov 1967, HS UK, gp.
} 
verband nie, maar dit het saamgeval met 'n periode van 'n breër Noord-Suid-antagonisme en vervreemding wat op politieke gebied in 'n toenemende "verlig/verkramp" 77 -verdeling ontaard het soos die Potchefstroomse akademikus, Willem de Klerk, in Oktober 1967 dit verwoord het. Hierdie verdeling, wat ook toenemend sou neerslag vind in 'n persstryd tussen Nasionale Pers (Die Burger en Die Beeld met onderskeidelik Piet Cillie en Schalk Pienaar as redakteurs) en die Afrikaanse persgroepe (Republikeinse Pers en Die Transvaler met sterk bande met Verwoerd) van die noorde, sou uiteindelik tot 'n skeuring in die NP, die stigting van die Herstigte NP en later die Konserwatiewe Party aanleiding gee. Op ekonomiese gebied het 'n Afrikanerbesigheid soos Sanlam hom ook toenemend in die "verligte" dampkring geposisioneer. ${ }^{78}$

Hierdie "vervreemding" het nie beteken dat die Kaapse Helpmekaar onverskillig gestaan het teenoor wat hulle as ondoeltreffende studiehulp deur die Helpmekaar-fondse van die ander provinsies ervaar het nie. In Februaurie 1968 het die direksie in beginsel besluit dat die HS hulp aan studente uit ander provinsies sou oorweeg en dat die sekretaris sulke aansoeke voor die voorsitter of visevoorsitter sou lê, mits hulle aan Kaaplandse universiteite studeer. ${ }^{79}$ Teen Junie 1969 het die sekretaris, Fanie Pretorius, weer gewag gemaak van die toenemende aantal aansoeke van Transvaalse en Vrystaatse studente wat nie deur hul provinsiale Helpmekaarfondse gehelp kon word nie. Hoewel die Kaapse Helpmekaar bereid was om die studente wat aan Kaaplandse inrigtings studeer te help, was dié tendens vir hul 'n bewys van die ondoeltreffende hulp wat die ander provinsies verleen het. Vereniging met die ander provinsiale verenigings was nie 'n opsie nie, maar die sekretaris is versoek om deur middel van 'n skrywe die HS se stelsel van studielenings aan dié fondse te verduidelik en hul taktvol te versoek of hul nie hul stelsels dienooreenkomstig wou wysig nie, "ook ter wille van die naam 'Helpmekaar' se aansien in die land." ${ }^{\prime 0}$

Teen die vroeë tagtigerjare het die mate van "vervreemding" wat daar tussen die Kaapse en Transvaalse Helpmekaar tydens die sestigerjare ingetree het grootliks verdwyn. Met die Transvaalse Helpmekaar se twintigste verjaarsdag in 1982 het die HS 'n boodskap van gelukwense aan "die fris jong boetie van die Noorde" ${ }^{\text {"1 }}$ gestuur waarin die Kaapse Helpmekaar se belangrike rol in die herstigting van die Transvaalse Helpmekaar in herinnering geroep is.

77 In die breë het dit neergekom op 'n meer oop, liberale benadering tot verandering in die algemeen en spesifiek ten opsigte van apartheid, teenoor 'n geslote verknogtheid aan die tradisionele en aan apartheid. H Giliomee, The Afrikaners. Biography of a People, 544, 548-550. (HSA) HS, Notuleboek (19 Jan 1967-16 Feb 1973), 16 Feb 1968, HS Direksie, gp.

80 (HSA) HS, Notuleboek (19 Jan 1967-16 Feb 1973), 18 Junie 1969, HS UK, gp.

81 (HSA) HS, Notuleboek (16 Feb 1973-10 Sept 1993), 17 Nov 1982, HS, Boodskap van die Kaaplandse Helpmekaar aan die Transvaalse Helpmekaar, gp. 
Die Fonds is gelukgewens met die snelle groei van sy kapitaal en die vertroue is uitgespreek dat die hartlike betrekkinge tussen die twee fondse steeds sou uitbrei. Daar was selfs 'n erkenning dat, met die praktiese ervaring van die afgelope jare en die wysheid van trukennis, afsonderlike provinsiale fondse waarskynlik meer effektief sou wees/beter sou werk as wat een nasionale fonds sou wees. ${ }^{82}$ Die hartlike betrekkinge teen die vroeë tagtigerjare is bevestig deur die teenwoordigheid van HA Sloet. Hy was besturende direkteur van Saambou Nasionaal en voorsitter van die Transvaalse HS. ${ }^{83}$ Hy was as een van die genooide gaste saam met $\mathrm{dr}$ PA Weber, gewese redakteur van Die Burger en voorsitter van Nasionale Pers, asook dr WA Landman, oudvoorsitter van die Helpmekaarvereniging van die Kaapprovinsie in die jare veertig, by die noenmaal na afloop van die 1983 -jaarvergadering van die HS in Kaapstad. ${ }^{84}$

Die verbeterde verhoudinge tussen die Kaapse en Transvaalse Fondse teen die tagtigerjare kan waarskynlik aan 'n verskeidenheid faktore toegeskryf word, naamlik die Sloet-faktor in kombinasie met Albertyn se Saambou Nasionaal-verbintenis en die feit dat die Kaapse Helpmekaar oor jare heelwat kapitaal by die bougenootskap belê het. Die verlig/verkrampstryd met sy aanvang in die tweede helfte van die sestigerjare en die verdelingslyne wat dit in Afrikanergeledere teweeggebring het, was teen 1983 ook duideliker uitgekristalliseer. Landman se teenwoordigheid kan ook as 'n omarming van verligte stemme geïnterpreteer word aangesien hy een van net vier predikante was wat in 1960 ten gunste van die Cottesloe-beraad se besluite gestem het. Terwyl hy aanvanklik in Afrikanergeledere daarvoor verguis is, het hy in 1977 'n eredoktorsgraad van die Universiteit Stellenbosch ontvang.

\section{PERSONEELAANGELEENTHEDE}

Die amalgamasie van die twee Kaapse Helpmekaar-fondse het op administratiewe en bestuursvlak ook die einde van die DH van Zyl-era beteken. Daar is reeds verwys na Van Zyl se uittrede uit die administrasie teen einde Junie 1965 en dat hy een maand addisionele verlof saam met sy gewone verlof sou neem en dan van 1 September as ontwikkelingsdirekteur sou begin werk teen sy huidige salaris plus vergoeding vir reiskoste. Vanaf 1 Mei 1967 is 'n

82 (HSA) HS, Notuleboek (16 Feb 1973-10 Sept 1993), 17 Nov. 1982, HS, Boodskap van die Kaaplandse Helpmekaar aan die Transvaalse Helpmekaar, gp.

83 Universiteit Stellenbosch Dokumentesentrum(USD), Saambou Nasionale Bouvereniging Argief, Notuleboek (7 Feb 1980-4 Apr 1984), Direksievergadering, 1 Mei 1980, 9; 1 Jul 1982, 57. CF Albertyn het sedert die vroeë sestigerjare periodiek op die direksie van Saambou gedien. Hy het ook in die vroeë tagtigerjare saam met Sloet (toe die besturende direkteur) op die direksie gedien. Hulle verhouding was sover vasgestel kon word hartlik. In Julie 1982 het Albertyn in 'n brief die direksie en hoofbestuur byvoorbeeld geluk gewens met die goeie bedryfsresultate soos in die jaarverslag weerspieël is.

84 (HSA) HS, Notuleboek (16 Feb 1973-10 Sept 1993), 11 Feb 1983, HS jaarvergadering, 70. 
pensioen van R75 per maand aan hom betaal. Onder die nuwe bedeling het SP Pretorius dus as sekretaris gefunksioneer en is hy ondersteun deur administratiewe personeel, bestaande uit mej MF Maree, mev C van Blerk (wat vanaf 1 Oktober 1967 aangestel is) en ${ }^{85}$ mej J du Pré (wat in September 1967 as tikster-klerk aangestel is). ${ }^{86}$ Laasgenoemde het nie lank in diens gebly nie, aangesien sy reeds met die 1968-salarisverhogings nie meer genoem word nie. ${ }^{87}$ Deur die loop van die sewentigerjare was daar 'n aansienlike wisseling van personeel ${ }^{88}$ wat teen die einde van die dekade gestabiliseer het met die aanstelling van mev J Steyn in $1977^{89}$ en mev Nita van Zyl in Augustus 1980. ${ }^{90}$

Die administrasie van die Studiefonds in die tagtigerjare is gekenmerk deur die sekretaris/ bestuurder, Pretorius, se uitgerekte uittrede. Pretorius het in Julie 1980 aftree-ouderdom bereik, maar is deur die Raad van Trustees versoek om nog vir vyf jaar op 'n jaar-vir-jaarbasis aan te bly. ${ }^{91}$ Die vyfjaarperiode het op 31 Julie 1985 - na altesaam 35.5 jaar in diens van die Helpmekaar - ten einde geloop ${ }^{92}$ waarop die Raad van Trustees besluit het om SP Pretorius se dienstermyn as bestuurder met een jaar te verleng na verstryking van sy heersende dienstermyn..$^{93}$

85 (HSA) HS, Notuleboek (19 Jan 1967-16 Feb 1973), 16 Nov 1967, HS UK, gp.

86 (HSA) HS, Notuleboek (19 Jan 1967-16 Feb 1973), 14 Sep 1967, HS UK, gp.

87 (HSA) HS, Notuleboek (19 Jan 1967-16 Feb 1973), 26 Sep 1968, HS Dagbestuur, gp.

88 Mev C Van Blerk het die Studiefonds se diens teen einde 1969 verlaat en mev AS Ferguson is vanaf 1 Januarie in haar plek aangestel. (HSA) HS, Notuleboek (19 Jan 1967-16 Feb 1973), 13 Feb 1970, HS Direksie, gp; 23 Jan 1970, HS jaarverslag, gp. Mev AS Ferguson het die diens deur die loop van 1971 verlaat en mev Matthee is in haar plek aangestel. (HSA) HS, Notuleboek (19 Jan 1967-16 Feb 1973), 11 Feb 1972, HS jaarvergadering, Direksieverslag, gp. Mev LE Matthee het uit die maatskappy se diens bedank in Mei 1973 en mej E Greeff is aanvanklik op drie maande proefbasis in haar plek aangestel waarna haar aanstelling in Aug permanent geword het. (HSA) HS, Notuleboek (16 Feb 1973-10 Sep 1993), 24 Mei 1973, HS UK, gp; (HSA) HS, Notuleboek (16 Feb 1973-10 Sep 1993), 8 Aug 1973, HS UK, 9. Met mej Maree se uittrede met pensioen in 1977 na 14 jaar se diens waarvoor sy'n pensioen van R150 per maand vanaf Maart 1977 ontvang het, is mev J Steyn in haar plek aangestel. (HSA) HS, Notuleboek (16 Feb 1973-10 Sep 1993), 11 Feb 1977, HS jaarvergadering, 41. Mej Greeff (na haar troue mev Le Roux) het in 1977 weens die verplasing van haar man bedank en mev Goosen is in haar plek aangestel. (HSA) HS, Notuleboek (16 Feb 1973-10 Sep 1993), 29 Mrt 1976, HS UK, 35; 25 Feb 1977, HS UK, 42. In 1977/78 is mev CC Gresse as sekretaresse aangestel teen R325 per maand. (HSA) HS, Notuleboek (16 Feb 1973-10 Sep 1993), 10 Feb 1978, HS Jaarvergadering, 49. Teen Feb 1979 het die personeel dus bestaan uit mev C Gresse, mev J Steyn en mnr S Pretorius. (HSA) HS, Notuleboek (16 Feb 1973-10 Sep 1993), 9 Feb 1979, HS jaarvergadering, 53.

89 (HSA) HS, Notuleboek (16 Feb 1973-10 Sep 1993), 11 Feb 1977, HS jaarvergadering, 41.

90 (HSA) HS, Notuleboek (16 Feb 1973-10 Sep 1993), 27 Mrt 1987, HS UK, 90.

91 (HSA) HS, Notuleboek (16 Feb 1973-10 Sep 1993), 15 Feb 1980, HS jaarvergadering, 57; 13 Feb 1981 HS jaarvergadering, 62 .

92 (HSA) HS, Notuleboek (16 Feb 1973-10 Sep 1993), 15 Feb 1985, HS jaarvergadering, Bestuurder jaarverslag, 80.

93 (HSA) HS, Notuleboek (16 Feb 1973-10 Sep 1993), 15 Feb1985, HS jaarvergadering, 82. 


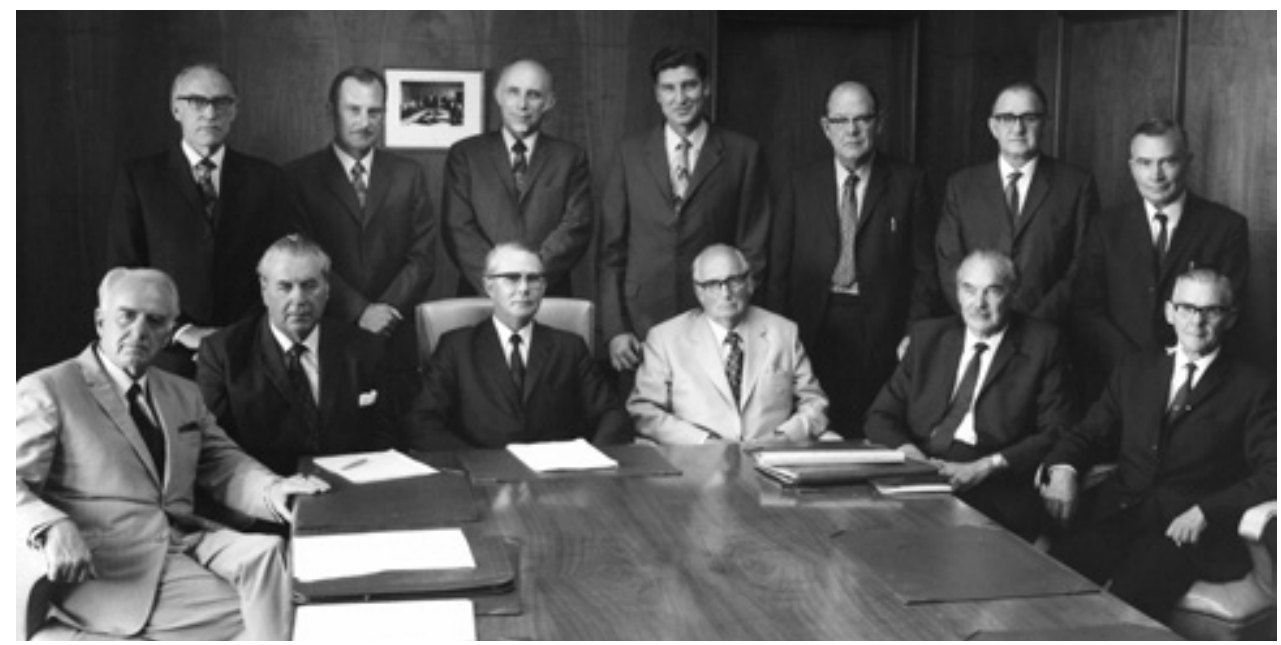

Direksie, Helpmekaar Studiefonds, 1972. Voor van links: dr TN Hanekom, mnr PJC van Zyl, dr CF Albertyn (voorsitter), sen DH van Zyl, mnr WK van Rooyen, mnr GJD Volschenk. Agter van links: mnr SP Pretorius (sekretaris),

ds J van derWesthuyzen, mnr GJ Horn, dr PS Meyer, ds JM Delport, mnr BJ Conradie, mnr CP Jamneck. Afwesig: ds DJ Roos, dr AE Rupert, mnr RA van Rensburg.

In sy verslag aan die 1987-jaarvergadering het Pretorius aangedui dat daar nou ernstig aandag geskenk moes word daaraan om 'n opvolger te kry "vir die man wie se geheue nou gaatjies begin toon". ${ }^{94}$ Die Raad het Pretorius se opmerking vertolk as 'n wens dat daar na 'n opvolger vir hom gesoek moes word en het dus besluit dat die raadslede solank na 'n geskikte opvolger moes begin soek. Die profiel waarna gesoek is, was dié van 'n senior persoon van ouer as vyftig jaar met goeie mensekennis en -verhoudinge. Dit was ook iemand wat respek kon afdwing en hom in die beste geselskap kon handhaaf. Daar is van Pretorius verwag om aan te dui wanneer presies hy die tuig wou neerlê sodat 'n oorvleuelingstydperk van 'n maand gereël kon word waartydens die nuwe aanstelling touwys gemaak kon word. ${ }^{95}$

In 'n verdere gesprek met die UK het Pretorius aangedui dat, indien sy gesondheid hom sou toelaat, hy graag tot sy 75 ste lewensjaar in diens van die Helpmekaar wou bly. Hy was van mening dat sy opvolger drie maande saam met hom moes werk. Volgens Pretorius was mevv Steyn en Van Zyl in staat om sake vlot te laat verloop ingeval sy gesondheid skielik sou ingee. Die UK sou ook daaroor moes besin of vir die pos geadverteer sou word en of

94 (HSA) HS, Notuleboek (16 Feb 1973-10 Sep 1993), 20 Feb 1987, HS jaarvergadering, Bestuurder jaarverslag, 88.

95 (HSA) HS, Notuleboek (16 Feb 1973-10 Sep 1993), 20 Feb 1987, HS jaarvergadering, 90. 
hulle 'n direkte keuse van 'n opvolger sou maak. Die UK sou aanbevelings in dié verband aan die Raad van Trustees doen. ${ }^{96}$ Teen hierdie agtergrond is Pretorius se aanstelling in Februarie 1988 vir nog 'n jaar verleng en is besluit dat, in geval van siekte of sy afwesigheid van die kantoor weens verlof, mev Van Zyl gevra sou word om die verantwoordelikheid van assistent tot die bestuurder op haar te neem vanaf 1 Maart $1988 .{ }^{97}$ Die besluit sou die status quo bly en die oorgang na'n nuwe bestuurder sou uitgestel word tot Pretorius se finale aftrede aan die einde van 1992 na 43 jaar diens aan die Helpmekaar. ${ }^{98}$

\section{STUDIELENINGS: VOORSPOED, INFLASIE, STAGNASIE}

Die amalgamasie van die twee Helpmekaar-fondse in die middel sestigerjare het saamgeval met die ekonomiese oplewing van die periode en die groeiende finansiële voorspoed wat dit gebring het. Die samesmelting en die groei van sy beleggings in veral aandele het die HS in die ekonomiese voorspoed laat deel en hom in 'n gunstige finansiële posisie geplaas. Sy studieleningbesigheid in die tweede helfte van die sestigerjare is dus gekenmerk deur kwessies wat die gevolg was van of verwant was aan die algemene voorspoedgolf. Die Studiefonds se agenda en debatte is dus oorheers deur pogings om toegang tot lenings te vergemaklik en die koste van lenings te verminder.

In November 1967 het die UK die Studiefonds se stelsel van borgskappe vir studielenings heroorweeg in die lig van kritiek wat hulle volgens dr Albertyn oor die heersende stelsel ontvang het. In 'n uiteensetting van die rol wat borge in die geskiedenis van die Helpmekaar gespeel het, is die tweeledige stelsel wat die Helpmekaar sedert die ontstaan van die B-fonds gekenmerk het in oënskou geneem. Dit was vroeër die gebruik by die Helpmekaarvereniging om net die vader of moeder van die lener as borg te neem, terwyl die HS (B-fonds) weer eienaars van vaste eiendom as borge vereis het. Laasgenoemde vereiste was as noodsaaklikgeag omdat die Studiefonds hoofsaaklik met geleende geld gewerk het en sy sekuriteite derhalwe van die beste moes wees. Na die dood van advokaat Wessel Roux is die borgvereistes van die Vereniging hersien omdat daar onder sy administrasie heelwat afskrywings plaasgevind het. Dit het dikwels gebeur weens die feit dat die lener verdwyn het en sy vader óf oorlede is óf verhuis het. Daarteenoor is die strenger borgvereistes van die Studiefonds as rede aangevoer

96 (HSA) HS, Notuleboek (16 Feb 1973-10 Sep 1993), 27 Mrt 1987, HS UK, 90. Die HS het in 1975 sy maatskappystatus prys gegee en weer 'n trust geword. Die direksie het dus weer 'n raad van trustees geword. Dit word in 'n latere afdeling meer breedvoerig bespreek. 


\section{Die Kaapse Helpmekaar}

waarom die Studiefonds nog nooit slegte skuld moes afskryf nie, en die Vereniging ook geen afskrywings gehad het sedert adv Roux se afsterwe nie - met die uitsondering van 'n predikant wie se boedel gesekwestreer is. Daar is beklemtoon dat die Helpmekaar-borgstelsel meer gefokus was op 'n morele borgskap, aangesien die enigste vereiste was dat 'n borg 'n eerbare en stabiele persoon in die samelewing moes wees, en nie noodwendig vermoënd moes wees nie. Die Helpmekaar het nie in die eerste plek na 'n borg gesoek wat kon betaal nie, maar na iemand wat sou help om die lener tot verantwoording te roep, indien nodig. As 'n reël het studente nie moeilik borge gevind nie, veral as verduidelik is dat die lening gedek was deur assuransie in geval van die afsterwe van die lener.

Die praktyk het dan ook bewys dat dit steeds veilig was om borg te teken vir geld wat nie opgebruik is of in verganklike artikels of riskante beleggings gesteek is nie. Studiegeld was 'n belegging in 'n persoon se vermoëns wat hom weer in staat gestel het om 'n beroep te beoefen en sy inkomstepotensiaal te verhoog. Hy het dus die belegging in sy eie persoon gedra.

Daar is wel dikwels van borge gebruik gemaak om byvoorbeeld 'n lener wat van adres verander het op te spoor, of om 'n lener skaam te maak of druk op hom uit te oefen. Sover bekend het die Helpmekaar net in een geval die borge aanspreeklik gehou en was hulle nog besig om te betaal, terwyl die hoofskuldenaar intussen self onder hofbevel begin betaal het. Hoewel die Helpmekaar dus uiters selde 'n borg se geldelike aanspreeklikheid aan hom voorgehou het, moet tog aangeneem word dat in baie gevalle dit juis sy geldelike aanspreeklikheid was wat hom die moeite laat doen het om die Helpmekaar te help. Die kantoor het 'n gesonde en suksesvolle stelsel van kredietkontrole gehad. Dit sou egter moeilik wees om die hoë peil vol te hou sonder dat daar op die hulp van mense staatgemaak kon word wat self aanspreeklik gevoel het, al was dit dan net op morele gronde. Enige verandering in die borgstelsel sou derhalwe hiermee rekening moes hou.

Teen hierdie agtergrond het dr Albertyn voorgestel dat die stelsel aangepas moes word sodat 'n student alleenlik gevra sou word om twee persone te benoem wat hom/haar kon aanbeveel. Die kantoor kon dan skryf aan die persone en vra of hulle die student kon aanbeveel. Indien wel, is hulle versoek om skriftelik te verklaar dat hulle die student aanbeveel het en dat hulle die kantoor sou help om die lening terug te vorder deur druk uit te oefen, indien dit nodig sou word. Hulle sou egter nie geldelik aanspreeklik wees nie. Albertyn se mening was dat die eerste vereiste die morele verantwoordelikheid van die student self was. Hy was ook van mening dat die Helpmekaar nie die reg gehad het om geld wat van die publiek ontvang is onder borgskap uit te leen nie. 
Albertyn se standpunt is egter nie deur almal gedeel nie en mnr PJC Van Zyl was van mening dat iemand wat nie kon betaal nie, nie 'n borg was nie en dat die borgvereistes eerder verhoog moes word. Benewens die feit dat 'n borg 'n eerbare en stabiele persoon moes wees, moes hy ook oor die middele beskik om te kon betaal. Die voorsitter, Ken Sinclair, het ook gewaarsku dat onvoldoende borg-vereistes in die verlede tot afskrywings gelei het en dat die stelsel wat toe in plek was goed gewerk het en dus nie moes verander nie. Hy was van mening dat dit juis die borge se wete was dat hulle finansieel aanspreeklik gehou word wat hulle beweeg het om met die insameling van die skuld te help. Hy is deur ds Delport in dié verband ondersteun. Albertyn het dus in die lig van die weerstand sy voorstel laat vaar. ${ }^{99}$ Die kwessie van borgskappe en die verskillende standpunte daaroor was waarskynlik 'n manifestasie van die stryd in die Helpmekaar-psige oor die vind van 'n balans tussen hulle filantropiese/ welsyns-identiteit en hul toenemende sake-identiteit. Dit was 'n stryd wat ook periodiek in toekomstige debatte na die oppervlak sou borrel.

Leningsaansoeke in die post-amalgamasie-era het nie net die impak van die algemene ekonomiese voorspoed weerspieël nie, maar waarskynlik ook die impak van die triomf van die breër Afrikaner opheffingsprojek met sy wortels in die tweede dekade van die twintigste eeu en sy triomf in die sestigerjare. Volgens die sekretaris was 'n kenmerk van die leningsaansoeke die uitnemendheid van 'n opmerklik groot aantal aansoekers, beide wat betref akademiese prestasies, sowel as karaktereienskappe. Een rede daarvoor was dat daar nie genoeg beurse beskikbaar was vir die groeiende aantal presterende skoliere nie. Die dieperliggende oorsaak hiervan was waarskynlik die impak wat die jarelange pogings van die Helpmekaar en andere soortgelyke organisasies in tandem met die pogings van die staat om verpligte en vry onderwys vir blankes ingestel te kry teen die sestigerjare gehad het. Dié pogings het in die sestigerjare oorvloedige vrugte begin afwerp.

Die finansiële voorspoed en die greep wat die groeiende verbruikersamelewing op ook Helpmekaar-leningsaansoekers gehad het, is geillustreer deur die sekretaris se klagtes oor die tyd wat verspil word met skriftelike argumente met studente oor die "buitensporige groot bedrae wat hulle aanvra. Dit skyn of ons voorspoedgolf ons jong mense mak gemaak het vir skuld." ${ }^{100}$ Dit wil egter voorkom asof die leners in staat was om hul lenings te diens, aangesien die kantoorverslag vir die 1968-finansiële jaar gerapporteer het dat terugbetalings op studielenings steeds baie bevredigend was en melding is gemaak van slegs twee twyfelagtige

\footnotetext{
99 (HSA) HS, Notuleboek (19 Jan 1967-16 Feb 1973), 16 Nov 1967, HS UK, gp.

100 (HSA) HS, Notuleboek (19 Jan 1967-16 Feb 1973), 14 Feb 1969, HS Direksie, Kantoorverslag, 24 Jan 1969, gp.
} 


\section{Die Kaapse Helpmekaar}

rekeninge. ${ }^{101}$ Afgesien van die finansiële voorspoed was die samewerking met instansies soos die administratiewe amptenare van universiteite, kolleges en die beurseafdeling van die Provinsiale Administrasie wat kontrole oor die studente se geldbesteding vergemaklik het en die uitruil van inligting en vasstelling van studente se vordering moontlik gemaak het waarskynlik hiervoor verantwoordelik. ${ }^{102}$

Die sewentigerjare is oorheers deur die drastiese styging in studiekoste en die skuldlas wat dit op afgestudeerde leners gelaai het. 'n Dalende aanvraag na Helpmekaarstudielenings, 'n verskuiwing in studierigtings, vrae oor die moraliteit van die Helpmekaar se beleggingsportefeulje in terme van die balans tussen beleggings in studielenings en beleggings elders, die impak van nasionale militêre diensplig op Helpmekaar-leners en 'n herbevestiging van die Helpmekaar se fokus en aard was ook kwessies van die sewentigs.

Teen die einde van die sestigerjare het die kwessie van drasties stygende studiekoste die debatte van die HS begin oorheers. Hierdie kostestygings het saamgeval met 'n langdurige fase van stygende inflasie in die Suid-Afrikaanse ekonomie. Styging in studiekoste het van die Helpmekaar geverg om die omvang van sy lenings voortdurend aan te pas om sy doelwit van doeltreffende studiehulp te bly handhaaf. Vir studente het dit gelaat met 'n toenemende skuldlas aan die einde van hul studiejare. Die toename in die koste van mediese kursusse het eerste die wenkbroue laat lig. Deur die loop van die tweede helfte van die sestigerjare het die koste van 'n mediese kursus wat tussen R600/R700 per jaar was tot R1 100 per jaar toegeneem. ${ }^{103}$ 'n Ondersoek deur die sekretaris het aan die lig gebring dat die nuwe verhoogde fooie 'n mediese student vanaf sy derde jaar ongeveer R950 per jaar kos. Die direksie het dus in Februarie 1970 besluit dat, hoewel die maksimum leningsbedrag wat toegestaan word R3 000 sou bly, volmag aan die voorsitter en visevoorsitter gegee word om na goeddunke groter bedrae toe te ken na gelang van die meriete van die aansoek. ${ }^{104}$ Met die verhoogde leningsbedrae het die Helpmekaar ook besluit om die bestaande maandelikse terugbetalingsbedrag van R30 te verhoog. Die gevoel was dat die verhoogde salarisse van afgestudeerdes dit regverdig het. Die verhoogde terugbetalingsbedrag sou volgens beroepe gekalibreer word met die vergunning dat toegewings gemaak kon word na gelang van omstandighede. ${ }^{105}$

\footnotetext{
101 Ibid.

102 Ibid.

103 (HSA) HS, Notuleboek (19 Jan 1967-16 Feb 1973), 18 Jun 1969, HS UK, gp.

104 (HSA) HS, Notuleboek (19 Jan 1967-16 Feb 1973), 13 Feb 1970, HS Direksie, gp.

105 (HSA) HS, Notuleboek (19 Jan 1967-16 Feb 1973), 12 Feb 1971, HS Direksie, gp.
} 
Die direksieverslag vir 1971 het gerapporteer dat lenings wat aangevra word weens die styging in klasgelde en losies aansienlik hoër as twee jaar tevore was. ${ }^{106}$ Teen 1974 het die gemiddelde koste per studiejaar R715 beloop. Die direksie het dus besluit om die maksimum bedrag vir langer studierigtings op R5 000 vas te pen met magtiging aan die UK om die bedrag in uitsonderlike gevalle te oorskry met verslag aan die direksie. ${ }^{107}$ 'n Jaar later het die kostes andermaal gestyg om dit vir die gemiddelde student ongeveer R970 per jaar net aan klas- en losiesgelde en boeke (sak- en reisgeld en klerasie uitgesluit) te laat kos. Vir kursusse soos medies, argitektuur en die kunste was dit veel meer. Die direksie was veral bekommerd oor die implikasies wat die stygende kostes vir damestudente ingehou het. Aangesien daar nie vir dames wat nie in die onderwys, mediese of para-mediese rigtings gestudeer het beurse beskikbaar was nie en "gesien die wenslikheid dat soveel as moontlik van 'n volk se moeders een of ander naskoolse opleiding behoort te hê", ${ }^{108}$ was die situasie dat damestudente wat moes geld leen vir hulle studies, afstudeer met skulde van minstens R3 000. Die indruk wat die Studiefonds van sy studente, wat hy vir die duur van hul volle studieperiode ondersteun het, gekry het, was dat die geldelike laste waarmee hulle afgestudeer het te swaar was, en dan veral in die geval van dames. Vanuit hierdie "volksmoeder"-perspektief was die hoë studiekoste dus meer as net 'n finansiële uitdaging - dit het ook implikasies vir die voortbestaan van die "volk" ingehou. Die Helpmekaar-argument was dus dat vanweë hierdie implikasies die staat moes ingryp om die saak te beredder. Die 1974-jaarverslag het dus geargumenteer dat indien die besteding van ander lande aan hul universiteite as maatstaf gebruik word,

"en as mens verder in aanmerking neem dat dit hoofsaaklik die geleerdes uit die 4 miljoen blankes is wat die noodsaaklikste poste moet beman van 'n bevolking van 23 miljoen, dan word dit duidelik dat die subsidies aan die blanke universiteite op 'n relatiewe wyse aangepas moet word met die aan die nie-blanke universiteitskolleges."109

Die verslag het dus geargumenteer vir groter staatsbesteding aan universiteite en groter besteding aan blanke universiteite as aan nie-blanke universiteite, aangesien eersgenoemde die meerderheid van die geskoolde mannekrag verskaf het. Hiermee het die Helpmekaar hom met bestaande staatsbeleid vereenselwig, maar geargumenteer dat die befondsing nog meer skeefgetrek moes word ten gunste van blanke universiteite. Aangesien die verslag veral bekommerd was oor die lot van die gemiddelde student - nie diegene wat onderskeidings op skool en universiteit behaal het nie - het die oplossing nie gelê in groter beurse nie, aangesien

\footnotetext{
106 (HSA) HS, Notuleboek (19 Jan 1967-16 Feb 1973), 11 Feb 1972, HS jaarvergadering, Direksieverslag, gp.

107 (HSA) HS, Notuleboek (16 Feb 1973-10 Sep 1993), 15 Feb 1974, HS Direksie, 17.

108 (HSA) HS, Notuleboek (16 Feb 1973-10 Sep 1993), 14 Feb 1975, HS jaarvergadering, Jaarverslag, 23.

109 (HSA) HS, Notuleboek (16 Feb 1973-10 Sep 1993), 14 Feb 1975, HS jaarvergadering, Jaarverslag 23.
} 


\section{Die Kaapse Helpmekaar}

die meeste beurse, uitgesonder onderwysbeurse, merietebeurse was. Vir die Helpmekaar het die oplossing daarin gelê dat spesifiek klas- en losiesgeld deur die aanwending van belastingbetalers se geld swaarder gesubsidieer moes word. Die verslag het aangevoer dat:

"die belastingbetalers sal net so min murmureer oor groter staatsuitgawes vir hierdie doel as wat hulle murmureer oor die verdedigingsuitgawes. En as ons geloof in ons toekoms het, moet ons ook die mense help wat ons toekoms moet beskerm." ${ }^{110}$

Met die oog op die stygende studiekoste het die UK dus in April 1975 die maksimum jaarlikse lening tot R1 000 en dié per kursus tot R7 000 verhoog met 'n verdere toegewing dat nagraadse studente wat om lenings vir verdere nagraadse studie aansoek doen voortaan slegs een borg benodig het. ${ }^{111}$ In November 1975 het die UK in die lig van 'n verdere styging in losiesgelde die jaarlikse leningsbedrag na R1 200 verhoog, wat met die voorsitter se goedkeuring selfs na R1 400 verhoog kon word. Die maksimum leningsbedrag per student is egter op R7 000 behou. ${ }^{112}$

Teen hierdie agtergrond was die sentrale tema van die 1975-jaarverslag die stygende studiekostes wat deur die viserektor van Universiteit Stellenbosch op ongeveer R2 000 per jaar beraam is. Hierteenoor het die Helpmekaar net hulp van R1 200 - R1 400 per jaar verskaf. Daar is veral gewag gemaak van die skuldlas wat dames tydens hul studiejare opgebou het. Vanweë die Helpmekaar se standpunt dat 'n student selfversorgend moes wees wat betref sakgeld, klere en reisgeld het die Helpmekaar groot simpatie gehad vir dames en plattelandse studente vir wie dit moeiliker was om hierdie tekorte aan te vul: "maar meisies kry nie so maklik vakansiewerk nie, en studente van die platteland het omtrent geen kans nie. As hulle in 'n stad of groter dorp werk kry, verteer losies hulle verdienstes." ${ }^{113}$ Hierby moes hul reiskoste ook nog in berekening gebring word "dikwels van die uithoeke van Kaapland soos die Noordweste." ${ }^{114}$ Die verslag het dus die staatsubsidiëring van losiesgeld as die enigste oplossing vir die probleem gesien. Dames se finansiële probleme is vererger weens hul keuse van kursusse. Die 1975-verslag het byvoorbeeld meegedeel dat:

\footnotetext{
110 Ibid.

111 (HSA) HS, Notuleboek (16 Feb 1973-10 Sep 1993), 10 Apr 1975, HS UK, 28.

112 (HSA) HS, Notuleboek (16 Feb 1973-10 Sep 1993), 26 Nov 1975, HS UK, 30.

113 (HSA) HS, Notuleboek (16 Feb 1973-10 Sep 1993), 13 Feb 1976, HS jaarvergadering, Jaarverslag, 31.

114 Ibid.
} 
“daar het ook so iets soos 'n gier onder dames-studente ontstaan deur dat verreweg die meeste wat by die Helpmekaar aansoek doen, van geen ander kursus as Maatskaplike Werk wil weet nie. En daarvoor is geen beurse beskikbaar nie."115

Teen die einde van die sewentigerjare het die jaarlikse maksimum leningsbedrag per student wat die Studiefonds toegestaan het tot R1 800 gestyg - met uitsonderlike gevalle wat hoër kon wees - met die maksimum lening per student R10 000. ${ }^{116}$

Ten spyte van die groei in die bedrag van uitstaande studielenings van R288 000 in 1968 tot meer as R1 000000 in $1979^{117}$ is die sewentigerjare gekenmerk deur 'n afname in die vraag na Helpmekaar-studielenings. ${ }^{118}$ Die tendens het die Helpmekaar ook gekonfronteer met 'n morele dilemma oor die aanwending en belegging van hul fondse. Vir die periode 1969-1979 het 1969 'n hoogtepunt verteenwoordig met 148 nuwe lenings wat toegestaan is en 1978 'n laagtepunt met slegs 96 nuwe lenings. Die gemiddelde vir die periode was 118,5 nuwe lenings per jaar. Die styging in studiekoste het egter veroorsaak dat, terwyl 1969 se 148 lenings R162 772 verteenwoordig het, 1978 se 96 lenings R332 930 verteenwoordig het. Deur die loop van die sewentigerjare het die Helpmekaar slegs die helfte of minder van die fondse waaroor hy beskik het in studielenings belê. In sy 1976-voorsittersrede het Albertyn aangedui dat van die totale fondse van R1 474145 wat deur die Helpmekaar geadministreer word R675 207 as studentelenings uitstaande was, wat beteken het dat byna R800 000 elders belê was. ${ }^{119}$ Die sewentigerjare is dus gekenmerk deur 'n besinning oor die oorsake vir die tendens, vrae oor of die regte studente bereik word en 'n besinning oor die tradisionele bestaansrede vir die Helpmekaar.

In die soeke na antwoorde vir die afname in die aanvraag na Helpmekaar-studielenings ${ }^{120}$ is verskeie oorsake geïdentifiseer: die verhoging van die beursgelde en die uitbreiding van die kursusse waarvoor beurse beskikbaar gestel word sedert die vroeg sewentigerjare deur

\section{Ibid.}

116 (HSA) HS, Notuleboek (16 Feb 1973-10 Sep 1993), 15 Feb 1980, HS jaarvergadering, 57.

117 Op 30 Sep 1968 was die Helpmekaar se uitstaande studielenings R288 000, op 30 Sep 1977 R836 000 en op 30 Sep 1978 R941 000; (HSA) HS, Notuleboek (16 Feb 1973-10 Sep 1993), 9 Feb 1979, HS jaarvergadering, Voorsittersrede, 52 .

118 (HSA) HS, Notuleboek (16 Feb 1973-10 Sep 1993), 16 Feb 1973, HS jaarvergadering, gp.

119 (HSA) HS, Notuleboek (16 Feb 1973-10 Sep 1993), 13 Feb 1976, HS jaarvergadering, Voorsittersrede, 33.

120 Die afname was ten spyte van die verskyning van inligting oor Helpmekaar-lenings in die jaarboeke van die US en UPE; Hoofde van Opleidingskolleges wat studente na die Helpmekaar verwys en versoeke aan die Sekretaris van die SAOU om inligting oor die Helpmekaar se hulp onder hulle lede te versprei. (HSA) HS, Notuleboek (16 Feb 1973-10 Sep 1993), 24 Mei 1973, HS UK, gp. 
die staat, ${ }^{121}$ asook die baie ander fondse vir beurse en lenings wat beskikbaar geraak het; weens die geweldige verandering in die ekonomiese krag van die Afrikaner - sy toenemende voorspoed dus - was 'n baie kleiner persentasie studente van finansiële ondersteuning afhanklik as 50 jaar tevore; die beskikbaarheid van werksgeleenthede met goeie besoldiging wat veroorsaak het dat matriekleerlinge eerder begin werk het as om 'n paar duisend rand te leen vir verdere studie en die hoë studiegelde het baie belowende studente wat universiteit toe wou gaan van die opsie laat terugdeins.

Die Helpmekaar was bereid om groter lenings te gee, maar teen selfs verminderde rentekoerse was dit nie 'n oplossing vir die probleem nie en kon die Helpmekaar nie universiteite subsidieer nie - alleen groter staatshulp aan universiteite kon dit doen. Hoë studiekoste en die skuldlas wat dit op afgestudeerde studente geplaas het, het ook ander onvoorsiene gevolge gehad. Studente wat op 22 of 24 die universiteit verlaat het, het met 'n skuld van R4 000 tot R6 000 gesit. Hulle het reeds die ouderdom bereik dat hy/sy aan trou dink en begin sy/haar lewe met 'n skuld en rentelas wat dit gebiedend maak dat hy/sy vroeg in sy/ haar lewe 'n salaris moet ontvang wat hy/sy in werklikheid weens 'n gebrek aan ervaring en vakkundige rypheid nog nie verdien het nie. Die situasie het volgens die Helpmekaar 'n geweldige inflasionêre uitwerking op salarisstrukture gehad. Die Helpmekaar se stelsel van borge en die studente en ouers se onwilligheid om borge te soek is ook as rede vir die afname aangevoer. ${ }^{122}$ Hoewel die raad dit nie as 'n oorsaak vir die afname in vraag vir Helpmekaar-lenings geïdentifiseer het nie, het die toenemende militarisering van die SuidAfrikaanse samelewing deur die loop van die sewentigerjare waarskynlik ook 'n bydrae gelewer. Die periode het saamgeval met verlengde verpligte militêre diens wat die siklus, wat veral manlike studente moes deurloop voordat met naskoolse opleiding begin kon word, verleng het. ${ }^{123}$ Die finansiële aansporings wat met verlengde diensplig gepaardgegaan het, het sommige studente wat andersins op die Helpmekaar aangewese sou wees in staat gestel om hulself ten volle of gedeeltelik te finansier.

\footnotetext{
121 (HSA) HS, Notuleboek (19 Jan 1967-16 Feb 1973), 16 Feb 1973, HS jaarvergadering, gp.

122 (HSA) HS, Notuleboek (16 Feb 1973-10 Sep 1993), 14 Feb 1975, HS jaarvergadering, Voorsittersrede, 26.

123 Lt kdr EM Meyers, Drie eeue van militêre diensplig in Suid-Afrika, 10, Scientia Militaria, South African Journal of Military Studies, 16(2), 1986. In 1974 is verpligte diensplig gestandardiseer op 12 maande. Dienspligtiges kon vrywillig ' $n$ verdere ses of twaalf maande diens doen. Hiervoor het hulle kontantbonusse van R1 800 en R3 600 onderskeidelik ontvang. Hulle is ook van verdere militêre verpligtinge na afloop van die verlengde diens onthef. In 1977 is diensplig na 'n verpligte 24 maande verleng.
} 
Die voorsitter, Albertyn, was dus van mening dat die Helpmekaar moes besin oor wat hy aan die situasie kon doen: ${ }^{124}$ "ons sal aan ons die vraag moet begin stel of die Afrikanersaak nie groter aanspraak het op die fondse wat in trust aan ons toevertrou is nie." ${ }^{125}$ Hierdie vraag het hy gestel teen die agtergrond van wat hy as die Helpmekaar se leitmotif beskou het, naamlik:

"As grondslag van ons leningsbeleid moet dit duidelik gestel word dat die Helpmekaar, wat gebore is uit die nood van Afrikaners, in die meer as 60 jaar van sy bestaan hulp verleen het om 'n diens te lewer aan die volk; dat hy in die eerste plek dus 'n liefdadigheidsorganisasie was en is en nie 'n organisasie met winsbejag nie. Daarvoor het duisende individue, kerklike en liefdadigheidsliggame, sowel as sake-ondernemings deur die jare heen fondse aan die Helpmekaarvereniging en die Helpmekaar-studiefonds groot bedrae toevertrou. Waar daar wel met 'n gedeelte van die fondse gewoeker is, was dit met die uitsluitlike doel om die Trustfondse te versterk om dié diens aan die volk te lewer waarvoor die Helpmekaar gestig is." ${ }^{126}$

In hul besinning was hulle veral besorg oor die impak van die hoë studiekoste op veral plattelandse studente en dié studente wat vir hul volle studiekoste van die Helpmekaar afhanklik was. Volgens Albertyn moes die Helpmekaar dus besin of hy iets aan die hoë studiekoste aan universiteite kon doen en of hulle die werklike hulpbehoewende studente bereik en voldoende ondersteun om hul skuldlas te verminder. Hy was dus van mening dat nuwe riglyne bepaal moes word waarvolgens die bestuur lenings kon toeken. ${ }^{127}$

Albertyn het dus vier kategorieë vir skenkings of lenings voorgestel vir oorweging deur die Raad van Trustees: Lenings aan die kinders van beamptes en trustees van die HS tot die maksimum van die jaarlikse of totale bedrae, soos van tyd tot tyd deur die raad bepaal, moes sonder borge en rentevry vir die duur van hul studietyd beskikbaar gestel word. Teologiestudente moes lenings tot die maksimum jaarlikse en totale bedrae, soos van tyd tot tyd deur die raad bepaal, sonder borge en rentevry vir die duur van hul studietyd ontvang en daarna sal die rentekoers vier persent wees. Studente wat verplig was om volgens

124 (HSA) HS, Notuleboek (16 Feb 1973-10 Sep 1993), 14 Feb 1975, HS jaarvergadering, Voorsittersrede, 26.

125 (HSA) HS, Notuleboek (16 Feb 1973-10 Sep 1993), 13 Feb 1976, HS jaarvergadering, Voorsittersrede 33.

126 Ibid.

127 Ibid.; Hierdie besorgdheid oor die "hartseer gevalle" wat nie verder met lenings belas kon word nie, maar eerder met 'n beurs gehelp moes word het reeds in 1971 in 'n voorstel vir 'n algemene Beursfonds, waarin jaarliks R1 000 gestort moes word om sulke gevalle te help, neerslag gevind. Hoewel die direksie die voorstel in beginsel aanvaar het, het hulle besluit om, in plaas van die oorplasing van die geld in 'n afsonderlike beursfondsrekening, die dagbestuur te magtig om jaarliks R1 000 se beurse ten behoewe van sulke gevalle te mag toeken. (HSA) HS, Notuleboek (19 Jan 1967-16 Feb 1973), 11 Feb 1972, HS jaarvergadering, Direksieverslag, gp; 11 Feb 1972, HS Direksie, gp. 


\section{Die Kaapse Helpmekaar}

die Helpmekaar se inligting al hul fondse vir studie by wyse van lenings te bekom moes 'n skenking van R200 per jaar toegestaan word om te voorkom dat hulle met 'n te swaar skuldlas 'n loopbaan begin. (In sulke gevalle moes probeer word om soortgelyke skenkings te verkry van die universiteite waar hulle studeer.) Waar dit aan die trustees bekend was dat die ouers van aansoekers baie vermoënd was, moes lenings alleen oorweeg word as daardie ouers op die een of ander tyd skenkings aan die Helpmekaar gedoen het of hulle sterk vir die Helpmekaar beywer het. ${ }^{128}$

Die trustees het tydens die Februarie 1976-jaarvergadering Albertyn se voorstelle oorweeg en in gewysigde vorm aanvaar. Die maksimum leningsbedrag per jaar sou van Januarie 1976 na R1 400 per jaar en die totale leningsbedrag na R10 000 verhoog word. In spesiale omstandighede kon 'n groter bedrag aan die student beskikbaar gestel word na raadpleging met die voorsitter, maar met behoud van die R10 000 maksimum. In gevalle waar die student werklik behoeftig was, kon daar na raadpleging met die voorsitter van die Raad van Trustees 'n skenking van R200 per jaar aan hom/haar gedoen word om sy/haar lening van R1400 na R1200 per jaar te verminder. Die voorstel oor die lenings aan die kinders van trustees en beamptes van die HS is aanvaar, terwyl die voorstel oor lenings aan teologiestudente ooreengestem het met besluite wat reeds in 1974 aanvaar is. Hoewel Albertyn se voorstel oor lenings aan die kinders van vermoënde ouers nie aanvaar is nie, is besluit om die bestuurder te versoek om "die nodige versigtigheid aan die dag te lê en om gevalle waaroor hy twyfel na die voorsitter te verwys." ${ }^{129}$ Die hernude pogings om werklik die behoeftige studente te identifiseer en te ondersteun - 'n uitvloeisel van Albertyn se siening van die leitmotif van die Helpmekaar - was 'n terugswaai na 'n beklemtoning van die liefdadigheidsaard van die Helpmekaar. Dit was 'n element waarvan daar juis gepoog is weg te beweeg sedert die stigting van die B-fonds in die veertigerjare.

Die neiging om die meer welvarende Helpmekaar-leners te teiken is bevestig deur 'n voorstel deur die bestuurder in November 1976 waarin hy sy twyfel uitgespreek het of die ses persent rentekoers vir alle afgestudeerdes van alle kategorieë van beroepe moes geld. Hy was van mening dat die ses persent kon geld vir leners wat vir salarisse werk, maar dat leners wat nie uit arm huise kom nie en in 'n beroep staan waar die geldverdienste onbeperk is nege persent behoort te betaal vanaf 'n jaar of twee nadat hulle begin werk het. ${ }^{130}$ Die raad het dus in Februarie 1977 besluit dat leningskontrakte voortaan sou bepaal dat lenings binne vyf

130 (HSA) HS, Notuleboek (16 Feb 1973-10 Sep 1993), 24 Nov 1976, HS UK, 38. 
jaar terugbetaal moes word en as dit langer neem, sou die rentekoers nege persent in plaas van ses persent wees. Vir teologiestudente sou die rente ná studie vier persent wees vir die eerste tien jaar, waarna die rentekoers ses persent sou wees. Die bestuurder het die reg gehad om eie diskresie te gebruik in gevalle waar die studente se omstandighede dit vereis het. ${ }^{131}$ Met die verskaffing van gunstige leningsvoorwaardes aan kinders van personeel en trustees was daar ook nou weer die eerste keer sedert die afskaffing van voorkeurtoekenning van lenings aan Helpmekaar-lede bevoordeling deur Helpmekaar-assosiasie. Die toegewing is gemaak teen die agtergrond van Albertyn se stelling:

"dat die persone wat deur baie jare heen hul dienste tot beskikking van die Helpmekaar gestel het, as takbestuurslede, direksielede en nou as Trustees van die HelpmekaarStudiefonds, nooit in enige vorm vergoeding of selfs erkentlikheid vir daardie dienste ontvang het nie." ${ }^{132}$

'n Laaste kenmerk van die sewentigerjare was die impak van verpligte militêre diensplig op die Helpmekaar se leningsaktiwiteite. Daar is reeds verwys na die moontlike bydrae van militêre diensplig tot die afname in die vraag na Helpmekaar-studielenings. In 1976 het die bestuurder vir die eerste keer gerapporteer dat, hoewel die terugbetalings van lenings steeds baie bevredigend was, die verpligte militêre diensplig wat afgestudeerdes moes verrig tog 'n invloed op die terugbetalings gehad het. Hierdie invloed is geillustreer deur 'n afname in die verhouding tussen jaarlikse terugbetalings en die totale bedrag van uitgeleende geld aan studente van 31,5 persent in 1972 tot 21,28 persent in 1975. Militêre diensplig was nie alleen vir die afname verantwoordelik nie, maar dit het 'n besliste bydrae gelewer. ${ }^{133}$

Met die ondersoek in 1977 na die vermindering van die versekeringskostes van lenings deur die instelling van 'n eie groepsassuransieskema vir die Helpmekaar ${ }^{134}$ is spesifiek versoek dat kwotasies vir so 'n skema ook "vir ongevalle op ons grense en in tyd van oorlog" 135 voorsiening moes maak. Hoewel die Helpmekaar daarin kon slaag om 'n gunstiger premie as vroeër te beding het hierdie versoek vanweë die groter risiko wat dit ingehou het waarskynlik die bedinging van 'n nog gunstiger premie verhoed. ${ }^{136}$ In Februarie 1980 het die kwessie van die heffing van rente op lenings vir die duur van die leners se diensplig ook ter sprake

\footnotetext{
131 (HSA) HS, Notuleboek (16 Feb 1973-10 Sep 1993), 11 Feb 1977, HS jaarvergadering, 40-41.

132 (HSA) HS, Notuleboek (16 Feb 1973-10 Sep 1993), 13 Feb 1976, HS jaarvergadering, Voorsittersrede, 33.

133 (HSA) HS, Notuleboek (16 Feb 1973-10 Sep 1993), 24 Nov 1976, HS UK, 38.

134 (HSA) HS, Notuleboek (16 Feb 1973-10 Sep 1993), 22 Jul 1977, HS UK, 44.

135 (HSA) HS, Notuleboek (16 Feb 1973-10 Sep 1993), 24 Nov 1977, HS UK, 46.

136 (HSA) HS, Notuleboek (16 Feb 1973-10 Sep 1993), 6 Apr 1978, HS UK, 49.
} 
gekom na aanleiding van 'n navrae wat ds Van der Westhuyzen in dié verband ontvang het. Die algemene gevoel was dat dienspligtiges vanweë die verbetering in hul besoldiging sedert 1979 en in gevalle soos onderwysers wat hul volle besoldiging tydens diensplig ontvang het dit kon bekostig om hul lenings terug te betaal. Die bestuurder was ook van mening dat die Helpmekaar nie so 'n toegewing kon bekostig nie. Aangesien daar wel gevalle was waar die student onmiddellik nadat hy afgestudeer het diensplig moes doen en dan nog nie 'n pos beklee het waarvoor hy 'n salaris ontvang het nie, is besluit dat die bestuurder in oorleg met die voorsitter in sulke gevalle tegemoetkomend moes wees. ${ }^{137}$

\section{Van oorvloed tot noodtoestand: die 1980's}

Terwyl die sewentigerjare gekenmerk is deur die besondere sterk fondse-posisie van die Helpmekaar en hul vermoë om die aanvraag na lenings te akkommodeer is Helpmekaardebatte in die tagtigerjare oorheers deur die impak wat stygende inflasie op hul fondseposisie, hul vermoë om in die vraag na studentelenings te voorsien en hul leningspraktyke gehad het. Inflasie het reeds in die sewentigerjare 'n beduidende faktor geword en dit het in die tagtigerjare ongekende afmetings aangeneem. Terwyl GPI (gebruikersprysindeks)inflasie vir die periode 1970-1979 gemiddeld 9.853 persent was, was dit vir die periode 19801989 gemiddeld 14.607 persent met 'n hoogtepunt van 18,66 persent in $1986^{138}$ wat ook 'n depresiasie van die Rand tot gevolg gehad het.

Die onstabiele olieprys en die feit dat Suid-Afrika dié noodsaaklike produk weens die sanksies van die OPEC (The Organization of Petroleum Exporting Countries) -lande ten duurste op die swart mark moes koop, was een van die vernaamste faktore vir die volgehoue hoë inflasiekoers. ${ }^{139}$ Die effek van die hoë inflasiekoers het beteken dat R1 000 in 1980 gelykstaande was aan R3 440 in 1989 of met ander woorde 244 persent van sy koopkrag verloor het. Oor die periode 1970-1989 was R1 000 van 1970 gelykstaande aan R9 052 in 1989 - 'n toename van 805 persent. ${ }^{140}$ Die verhoogde studiekostes wat inflasie tot gevolg gehad het en die belegging van Helpmekaar-fondse om hiermee tred te hou het dus groot uitdagings gebied. Saam hiermee is hulle ook gekonfronteer deur die gevolge van die toetrede van nuwe rolspelers tot die studenteleningsmark, naamlik die kommersiële banke.

137 (HSA) HS, Notuleboek (16 Feb 1973-10 Sep 1993), 28 Feb 1980, HS UK, 58.

138 http://www.inflation.eu/inflation-rates/south-africa/historic-inflation/cpi-inflation-south-africa-1979.aspx

139 http://www.photius.com/countries/south_africa/economy/south_africa_economy_inflation.html

140 http://inflationcalc.co.za/?date1=1973-01-01\&date2=1980-01-01\&amount=1000 
Teen hierdie agtergrond het die studiekoste deur die loop van die tagtigerjare dramaties toegeneem. In 1980 was die gemiddelde studiekoste (losies- en klasgeld) aan die Universiteit van Stellenbosch R1 845 per jaar vir nie-mediese studente, terwyl dit vir mediese studente R2 450 was vanaf hul tweede jaar. Hierteenoor het die Helpmekaar maksimum jaarlikse lenings van R1 800 toegestaan. ${ }^{141}$ Op aanbeveling van die bestuurder en die algemene jaarvergadering ${ }^{142}$ is die maksimum jaarlikse bedrag dus na R2 000 en vir mediese studente na R2 500 aangepas met 'n maksimum leningsbedrag van R12 000. Die UK het ook besluit dat voornemende onderwysstudente slegs gehelp sou word as hulle provinsiale beurshouers was, aangesien nie-beurshouers nie van 'n onderwyspos verseker was nie. ${ }^{143}$ Hierdie was die eerste van feitlik jaarlikse verhogings deur die loop van die tagtigerjare wat die Helpmekaar se jaarlikse leningsbedrag teen 1990 op R8 500 per jaar vir tot 'n periode van vyf jaar (R42 500) laat styg het ${ }^{144}$ - 'n toename van 472 persent in die jaarlikse leningsbedrag in vergelyking met 1980 .

Hierdie dramatiese styging het verrykende implikasies vir die bestuur van die Helpmekaar se fondse, sy leningspraktyke en sy vermoë om studente finansieel te ondersteun ingehou. In teenstelling met die afname in die vraag na studielenings in die sewentigerjare het die drastiese styging in studiekoste weens inflasionêre druk die vraag na studielenings drasties laat styg. Hierdie tendens het die Helpmekaar se likiditeit ernstig onder druk geplaas. Hulle het reserwefondse aangewend om in die vraag te voorsien wat hulle met min fondse om op terug te val gelaat het. Dit het die wesenlike gevaar geskep dat hulle nie hul leningsverpligtinge sou kon nakom nie. Hoewel beleggings van R30 000 aflosbaar was, was dit nie voldoende nie en is besluit om R180 000 van Santam te "leen" deur Helpmekaar vaste beleggings by die bank voortydig los te maak.

Verder is die R150 000-verband wat die Helpmekaar oor die Here XVII-gebou in Kaapstad gehou het aan die Vorster-Muller Fonds oorgedra. Hierdie stappe het die gevaar dat die Helpmekaar nie sy reeds aangegane leningsverpligtinge sou kon nakom nie afgeweer. Die UK het egter in Augustus 1982 besluit dat weens die gebrek aan likiditeit geen nuwe lenings vir die voorsienbare toekoms toegeken kon word nie omdat alle beskikbare gelde

141 (HSA) HS, Notuleboek (16 Feb 1973-10 Sep 1993), 13 Feb 1981, HS jaarvergadering, Jaarverslag 21 Jan 1981, 59.

142 (HSA) HS, Notuleboek (16 Feb 1973-10 Sep 1993), 13 Feb 1981, HS jaarvergadering, 61.

143 (HSA) HS, Notuleboek (16 Feb 1973-10 Sep 1993), 2 Mrt 1981, HS UK, 63.

144 (HSA) HS, Notuleboek (16 Feb 1973-10 Sep 1993), 17 Nov 1981, HS UK, 64; 14 Feb 1986, HS jaarvergadering, Jaarverslag, 84; 14 Feb 1986, HS jaarvergadering, 87; 20 Feb 1987, HS jaarvergadering, 90; 8 Nov 1988, HS UK, 97; 23 Feb 1990, HS jaarvergadering, Jaarverslag 13 Feb 1990, 102; 23 Feb 1990, HS jaarvergadering, 105. 
aangewend sou moes word om die Helpmekaar se verpligtinge teenoor reeds toegestane lenings na te kom. ${ }^{145}$ 'n Ander inflasiegevolg wat hiertoe bygedra het, is dat die Studiefonds benewens die lenings wat toegestaan is ook moes voorsiening maak in sy reserwefondse vir moontlike versoeke deur die studente vir bykomende hulp om die finansiële tekorte wat oor die duur van hul studietydperke (in sommige gevalle selfs sewe jaar) weens inflasie ontstaan het, aan te vul. ${ }^{146}$ Die Helpmekaar het dus vir die eerste keer sedert die amalgamasie van die twee fondse in die sestigerjare studente weens 'n gebrek aan fondse weggewys. ${ }^{147}$

Hierdie scenario het 'n feitlik deurlopende kenmerk in die tagtigerjare gebly. Daar is dus baie meer selektief te werk gegaan met die toekenning van nuwe lenings en lenings is slegs toegeken in gevalle waar die ouers ook 'n aansienlike bedrag tot die studiekoste kon bydra of indien die student ook 'n beurs gehad het wat koste kon help dra of waar die ouers al dadelik na die eerste uitbetaling van die lening maandeliks terugbetalings daarop kon doen. Laasgenoemde stelsel is met aanvang van 1987 geïmplementeer in 'n poging om die terugbetaling van leningskapitaal te versnel. In sulke gevalle is dus onmiddellik begin met die delging van die lening, aangesien die wagperiode van ongeveer vyf jaar tot die student afgestudeer het en in die geval van mans wat diensplig voltooi het, uitgeskakel is. ${ }^{148}$ Hoewel gepoog is om die stelsel algemeen te implementeer is ouers wat dit nie kon bybring nie tegemoetgekom. ${ }^{149}$ Ten spyte van hierdie en ander maatreëls soos die verhoging van die voorgeskrewe maandelikse paaiement-terugbetalings van lenings ${ }^{150}$ moes die bestuurder in sy jaarverslag vir die 1987-finansiële jaar meedeel dat:

"vir die tweede keer binne 'n paar jaar moes die kantoor besluit dat ons geen verdere aansoeke kan oorweeg nie, omdat ons reserwes uitgeput sal wees nadat ons al ons verpligtinge teenoor studente vir vanjaar nagekom het."151

145 (HSA) HS, Notuleboek (16 Feb 1973-10 Sep 1993), 18 Aug 1982, HS UK, 70; 11 Feb 1983, HS jaarvergadering, Jaarverslag, 70 .

146 (HSA) HS, Notuleboek (16 Feb 1973-10 Sep 1993), 17 Nov 1982, HS, Boodskap van die Kaaplandse Helpmekaar aan die Transvaalse Helpmekaar, gp.

147 (HSA) HS, Notuleboek (16 Feb 1973-10 Sep 1993), 11 Feb 1983, HS jaarvergadering, Jaarverslag 70.

148 (HSA) HS, Notuleboek (16 Feb 1973-10 Sep 1993), 20 Feb 1987, HS jaarvergadering, Jaarverslag, 88.

149 (HSA) HS, Notuleboek (16 Feb 1973-10 Sep 1993), 19 Feb 1988, HS jaarvergadering, Jaarverslag, 92, 93.

150 (HSA) HS, Notuleboek (16 Feb 1973-10 Sep 1993), 11 Feb 1983, HS jaarvergadering, Jaarverslag, 70. In 1983 is dit van R100 tot R125 per maand verhoog en teen April 1989 was die maandelikse paaiement R225; (HSA) HS, Notuleboek (16 Feb 1973-10 Sep 1993), 2 Mrt 1989, HS jaarvergadering, Jaarverslag 23 Feb 1989, 98; (HSA) HS, Notuleboek (16 Feb 1973-10 Sep 1993), 2 Mrt 1989, HS jaarvergadering, 100.

151 (HSA) HS, Notuleboek (16 Feb 1973-10 Sep 1993), 18 Feb 1988, HS jaarvergadering, Jaarverslag, 92. 
In April 1990 kon geen verdere lenings vir die jaar toegestaan word, tensy die Helpmekaar van sy bates in kontant omsit nie ${ }^{152}$ en het die bestuurder bevestig dat "die publiek is teen hierdie tyd wyd ingelig daaroor dat die Helpmekaar se lenings bevries is."153

Die onsekere fondseposisie van die Helpmekaar in die tagtigerjare, wat hoofsaaklik deur die inflasionêre toestande en die gepaardgaande stygende studiekostes veroorsaak is, het die Studiefonds gekonfronteer met die uitdaging om die groei van sy eie fondse met inflasie te laat tred hou. Dit moes gedoen word deur 'n balans te vind tussen sy beleggingsbeleid wat voldoende groei moes verseker om inflasie te klop en sy studieleningsbeleid wat lenings steeds bekostigbaar en kompeterend aan studente beskikbaar moes stel. Teen hierdie agtergrond het kontantvloeibeplanning en begroting van deurslaggewende belang geword. Debatte oor rentekoerse en rentekoersbeleid op studielenings, beleggingsbeleid, asook maniere om voldoende kontantvloei te verseker het dus die tagtigerjare oorheers.

Die hoë inflasiekoers het veroorsaak dat die nie-markverwante rentekoerse wat die Helpmekaar op hul lenings gevra het die Helpmekaar laat agteruit boer het en die groei van hul fondse geïnhibeer het. Dit was 'n situasie wat vererger het namate meer en meer geld in studentelenings belê is ten koste van ander beleggings soos aandele, eiendom en vaste deposito's wat ten minste inflasieverwant was of opbrengste hoër as inflasie verseker het. Die filantropiese modus waarin die Helpmekaar egter nog steeds sake gedoen het, het die omkeer van dié situasie 'n groter uitdaging gemaak as by 'n maatskappy wat primêr 'n winsmotief nagestreef het. Die omvang van die uitdaging is goed geillustreer deur die bestuurder se reaksie op bogenoemde scenario van verminderde groei:

"Aangesien dit nog altyd die Helpmekaar se eerste prioriteit was om in studente te belê, behoort hierdie feit ons nie te ontstel nie, maar eerder met dankbaarheid te vervul dat daar wel in ons doelwit geslaag word." 154

152 (HSA) HS, Notuleboek (16 Feb 1973-10 Sep 1993), 19 Apr 1990, HS, Kommissievergadering, 106.

153 (HSA) HS, Notuleboek (16 Feb 1973-10 Sep 1993), 7 Jun 1990, Brief van SP Pretorius aan dr CF Albertyn, 106.

154 (HSA) HS, Notuleboek (16 Feb 1973-10 Sep 1993), 11 Feb 1983, HS jaarvergadering, Jaarverslag, 70. 


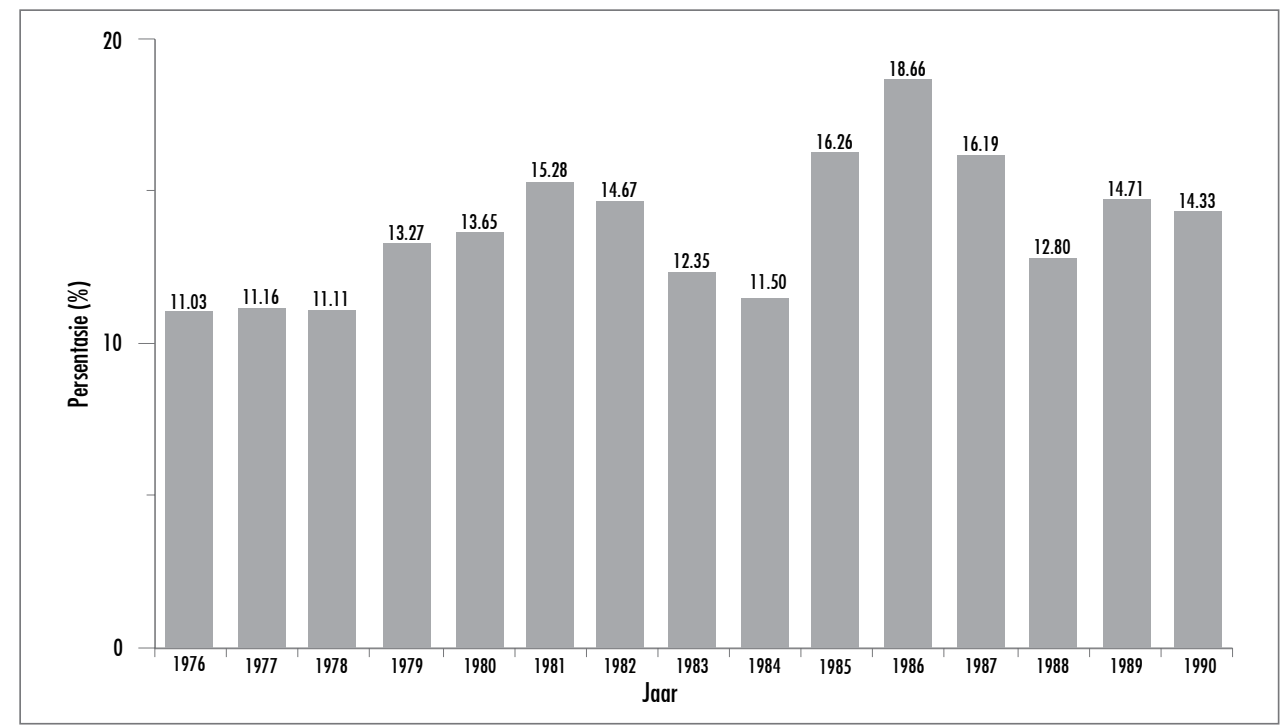

Inflasiekoers in Suid-Afrika tussen 1976 en 1990.

Algemene rentekoerse het vir die tagtigerjare gewissel van 'n laagtepunt van tien persent in Januarie 1981 tot 'n hoogtepunt van 25 persent in Januarie 1985. Dit het vir die grootste deel van die dekade tussen 15 persent en 20 persent gewissel. ${ }^{155}$ Hierteenoor was die rente op Helpmekaarlenings ses persent. Verskeie pogings is dus aangewend om die rentekoerskwessie te hanteer. In Februarie 1982, met die prima rentekoers op 18 persent, het die raad in 'n poging om die inflasie-erosie van sy fondse teen te werk besluit om sy rentekoerse aan te pas na ses persent vir die duur van die studietydperk, agt persent vanaf voltooiing van die studies vir 'n periode van vyf jaar, en ná vyf jaar tien persent. Vir teologiestudente sou vier persent tydens die studies en ses persent daarna geld, mits so 'n lener in die bediening gaan. Die UK is ook versoek om 'n formule te vind vir rente-aanpassings vir leners met groot studieskuld wat nie hul lenings binne vyf jaar kon delg nie. Die filantropiese element van die Helpmekaar het egter nie agterweë gebly nie, aangesien die bestuur versoek is om toegeeflik te wees as die omstandighede van 'n lener dit regverdig. ${ }^{156}$ Die koerse kon nie as markverwant beskryf word nie, maar die belangrikheid van die aanpassing daarin was geleë dat die tradisionele ses persent plafon vir die eerstekeer in die geskiedenis van die Helpmekaar deurbreek is en dit dus die begin van 'n beweging na 'n meer markverwante koers verteenwoordig het. 
Ten spyte van die bestuurder se dankbaarheid dat die Helpmekaar in sy doel slaag deur in studente te kan belê was daar ook stemme op die raad wat die noodsaaklikheid van voldoende kapitaalgroei beklemtoon het. Die bestuurder se versoek dat die raad moes besin daaroor of die huidige aandeleportefeulje, waarop daar R133 000 boekwins te maak was ten spyte van die insinking in die beurs vanweë die skrapping van die finansiële rand, verkoop moes word om in die tekort na leningskapitaal te voorsien, het dus reaksie ontlok. ${ }^{157}$ GJ Horn, met sy sakeagtergrond, ${ }^{158}$ het gewys op die gevaarlike ontwikkeling dat die groei van die Helpmekaar se fondse nie met die inflasiekoers tred hou nie. 'n Pleidooi is gelewer dat 'n balans gehandhaaf moes word tussen die verskillende beleggingsvelde, naamlik studente, aandele, vaste deposito's en vaste eiendom. Sonder voldoende kapitaalgroei sou die Helpmekaar toenemend minder fondse hê om in sy primêre fokus, naamlik studente, te belê. Omdat die Helpmekaar se uitleenkoerse nie markverwant was nie en ook nie met inflasie rekening gehou het nie moes die bestaande aandeleportefeulje behou word en moes die bestaande uitleenkoerse ook weer oorweeg word. Horn is deur ander lede van die raad gesteun en daar is besluit om voorlopig die aandeleportefeulje, wat uit goeie, genoteerde aandele bestaan het, te behou. ${ }^{159}$

$\mathrm{Na}$ aanleiding van die voorstel van Horn dat daar weer oor die Helpmekaar se uitleenkoerse besin moes word, het die UK in Maart 1983 die aangeleentheid indringend bespreek. Teen die agtergrond van die bestuurder se berekening dat die Helpmekaar se fondse in die 1982-finansiële jaar drie persent gegroei het teenoor die inflasiekoers van 13 persent was dit duidelik dat die Helpmekaar teen sy bestaande uitleenkoerse hom sou doodbloei en toenemend minder studente sou kon help ten spyte van die groei in sy fondse. Verskeie standpunte is gestel. Die Helpmekaar se ouditeure het 'n wenk van SPF van Aswegen, ${ }^{160}$ een van die trustees, ondersteun, naamlik dat die koers vasgemaak word aan 'n erkende koers soos die primakoers van die handelsbanke minus vyf persent, of aan die inflasiekoers, terwyl ds Van der Westhuyzen en dr Albertyn van mening was dat die bestaande rentekoerse gehandhaaf moes word in die lig van die feit dat daar toe in elk geval geen nuwe lenings

157 (HSA) HS, Notuleboek (16 Feb 1973-10 Sep 1993), 11 Feb 1983, HS jaarvergadering, Jaarverslag, 70.

158 Horn was getroud met Emma Louw, dogter van Charlie Louw, 'n stigterslid van Naspers en Sanlam. Horn was die eienaar van McManus Blokmakers wat onder andere foto-afdrukke vir Die Burger gemaak het. Hy het ook as lid van die NP die kiesafdeling Kaapstad: Tuine in die Kaaplandse Provinsiale Raad verteenwoordig. Die Burger, 20 Okt 2011, Oudpolitikus, sakeman Gideon Horn (93) sterf; JP Scannell, Uit die volk gebore. Sanlam se eerste vyftig jaar, 5, Nasionale Pers, Kaapstad, 1968.

159 (HSA) HS, Notuleboek (16 Feb 1973-10 Sep 1993), 11 Feb 1983, HS jaarvergadering, 70.

160 Die Burger, 16 September 1995, 2, Bekende rekenmeester sterf. (Van Aswegen was 'n rekenmeester en vennoot in die firma Brink, Roos en Du Toit. Hy was ook 'n raadslid van die Kaapse Genootskap van Geoktrooieerde Rekenmeesters en broer van dr Carel van Aswegen wat 26 jaar voorsitter van Santam was.) 
toegeken is nie. Die bestuurder, daarenteen, het gevra vir 'n koers van ses persent vir die duur van die studietydperk en 12 persent daarna en geargumenteer dat die Helpmekaar nog altyd gekortwiek is deur 'n vasgestelde maksimum koers wat in die leningskontrak ingeskryf was en dus nie verhoog kon word nie. 'n Maksimum koers van 12 persent het voorsiening gemaak vir tye van hoë inflasie, maar die koers kon altyd verlaag word indien inflasie sou daal. Ten spyte van sy vroeëre uitlating dat die tendens van onvoldoende groei nie die Helpmekaar moes "ontstel" nie was hy van mening dat "hulp aan studente, hoe belangrik ookal, mag nie swaarder weeg as die instandhouding en genoegsame groei van die Helpmekaar se fondse nie." ${ }^{161}$ Die belangrikheid van die vergadering lê in die besef dat 'n formule gevind moes word waarvolgens die vasstelling van die Helpmekaar se uitleenkoers wetenskaplik bepaal kon word en wat meer markverwant was. Die vergadering het dus besluit om die ouditeure te versoek om 'n aantal projeksies, gebaseer op verskillende aannames, voor te berei op grond waarvan 'n finale besluit geneem kon word. ${ }^{162}$

Ten spyte van dié insigte en die besluit wil dit voorkom asof daar nie juis haas was met die implementering nie. Die waarskynlikste rede hiervoor was wat deur Van der Westhuyzen en Albertyn tydens die vergadering geopper is, naamlik dat die rentekoers onveranderd gelaat moes word omdat die Helpmekaar in elk geval geen nuwe lenings toegeken het nie. Hierdie vermoede word bevestig deur die bestuurder se opmerking in sy 1983-jaarverslag dat rentekoerse op studielenings vasgestel moes word omdat daar wel enkele nuwe lenings toegestaan kon word. ${ }^{163}$ In die lig hiervan is die bestuurder se voorstel van 'n jaar tevore (dat ses persent op lenings gehef moes word tydens studie en dan 12 persent daarna) by die 1984-jaarvergadering goedgekeur. Dit is gedoen met die motivering dat, terwyl dit 'n plafon bied wat hoog genoeg is, dit ook ruimte gelaat het om op 'n ad hoc-basis studente wie se persoonlike omstandighede dit regverdig teen 'n laer koers, te akkommodeer. ${ }^{164}$

Die verhoogde rentekoers het nie die druk op die Helpmekaar se beskikbare fondse verlig nie en die bestuurder se verslag vir 1986 het aangedui dat die Helpmekaar vroeër of later van sy aandele - wat in September 1986 'n realiseerbare wins van R910 553 getoon het - sou moes verkoop om sy leningsverpligtinge na te kom. ${ }^{165}$ Die hoë rentekoerse en inflasie van die middel tagtigerjare het nie net die Helpmekaar onder finansiële druk geplaas nie, maar

\footnotetext{
161 (HSA) HS, Notuleboek (16 Feb 1973-10 Sep 1993), 2 Mrt 1983, HS UK, 70.

162 Ibid.

163 (HSA) HS, Notuleboek (16 Feb 1973-10 Sep 1993), 10 Feb 1984, HS jaarvergadering, Jaarverslag, 75.

164 (HSA) HS, Notuleboek (16 Feb 1973-10 Sep 1993), 10 Feb 1984, HS jaarvergadering, 76.

165 (HSA) HS, Notuleboek (16 Feb 1973-10 Sep 1993), 20 Feb 1987, HS jaarvergadering, Jaarverslag, 88.
} 
ook sy leners het die spit afgebyt. In wat die bestuurder as 'n "swart jaar" beskryf het, moes die Helpmekaar altesaam R7 542 afskryf omdat die betrokke leners hulle boedels vrywillig laat sekwestreer het, wat dit onmoontlik gemaak het om die skuld te verhaal. ${ }^{166}$

Tydens die algemene jaarvergadering in Februarie 1988 was dit duidelik dat die Helpmekaar se likiede posisie benard was en 'n tekort van R39 929 in 1987 gehad het. ${ }^{167}$ Die toekenning van nuwe lenings is dus op 18 Januarie 1988 opgeskort. ${ }^{168}$ Albertyn het in sy voorsittersrede veral klem geplaas op die steeds stygende studiekoste wat volgens'n projeksie oor 10 jaar teen 'n jaarlikse styging van 12 persent sou beteken dat kursus- en losieskoste vir 'n BA-kursus teen 1998 R42 000 (1988=R13 500) en vir Medies R103 000 (1988=R33 100) sou bedra. Aangesien die verkoop van die Helpmekaar se vaste eiendom en aandele 'n onaanvaarbare opsie was, onder andere omdat dit slegs 'n tydelik uitkoms sou bied, het hy groot klem geplaas op die verantwoordelikheid van ouers om deur middel van versekering vir hul kinders se opvoeding voorsiening te maak. Sy voorstel was dan ook dat ouers van die stygende koste bewus gemaak moes word en hul eie verantwoordelikheid onderstreep moes word. Hy het ook versekering teen verhoogde studiekoste as 'n moontlike teenvoeter vir die Helpmekaar se dilemma voorgestel. ${ }^{169}$ Die algemene jaarvergadering het in hul bespreking van die Helpmekaar se posisie besluit dat die UK so spoedig moontlik 'n aksieplan moes opstel. Daar is egter eenparig besluit dat die Helpmekaar se aandeleportefeulje, wat op 18 Februarie 1988 'n boekwins van R893 231 getoon het ten spyte van die benarde likiede posisie, nie verkoop sou word nie, aangesien dit as teenvoeter vir die impak van inflasie op die Helpmekaar se fondse gedien het. ${ }^{170}$

$\mathrm{Na}$ 'n bespreking van die fondseposisie van die Helpmekaar en die opsies wat deur JCL Oberholster, Anton Rupert se sekundus op die Raad van Trustees, in 'n skrifstuk voorgestel is, het die UK besluit dat die Helpmekaar: slegs aanvullende lenings tot 'n beurs of dit wat die ouers kan bydra sou toeken; "die hulp selektief sou wees wat betref die verstandelike vermoëns van aansoekers"171; dat net behoeftige studente gehelp sou word en dat aandele net verkoop sou word indien dit nodig was om studente aan wie reeds geleen is enduit te help. 'n Ad hoc-komitee, bestaande uit twee trustees (dr Meyer en mnr Lambrechts) en die bestuurder, is ook aangewys om 'n formule te vind vir die seleksie van studente wat

166 Ibid.

167 (HSA) HS, Notuleboek (16 Feb 1973-10 Sep 1993), 19 Feb 1988, HS jaarvergadering, Voorsittersrede, 94.

168 (HSA) HS, Notuleboek (16 Feb 1973-10 Sep 1993), 4 Mrt 1988, HS UK, 94.

169 (HSA) HS, Notuleboek (16 Feb 1973-10 Sep 1993), 19 Feb 1988 HS jaarvergadering, Voorsittersrede, 94.

170 (HSA) HS, Notuleboek (16 Feb 1973-10 Sep 1993), 19 Feb 1988 HS jaarvergadering, 94.

171 (HSA) HS, Notuleboek (16 Feb 1973-10 Sep 1993), 4 Maart 1988, HS UK, 94. 
gehelp moes word. ${ }^{172}$ Die vergadering het ook besluit dat dr Albertyn in sy hoedanigheid as voorsitter van 'n studiefonds ' $n$ verklaring vir publikasie moes opstel waarin hy die hoë studiekoste en tekort aan studiehulp sou uitlig en ouers daarop bedag sou maak om betyds deur middel van versekering of ander spaarmeganismes vir hul kinders se studies voorsiening te maak. ${ }^{173}$ Die ad hoc-komitee het verdere voorstelle gemaak waarin versoek is dat die besluit om slegs aanvullende hulp te verskaf heroorweeg moes word en dat lenings "in ooreenstemming met die land se mannekragbehoeftes" toegeken moes word. ${ }^{174}$ Die ad hoc-komitee se voorstelle is met geringe wysigings deur die UK aanvaar en aan die bestuurder as riglyne oorgedra waarvolgens lenings vir die voorsienbare toekoms toegeken sou word. ${ }^{175}$

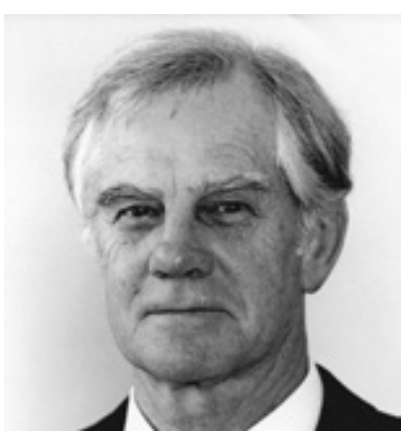

JCL Oberholster was van 1985 tot 1998 by die Helpmekaar Studiefonds betrokke as finansiele bestuurder en bestuurder. Hy het ' $n$ sleutelrol gespeel in die korporatisering van die Studiefonds.

'n Omvattende uitgewerkte plan om leners tegemoet te kom met die terugbetaling van hulle lenings deur polisse uit te neem wat die volle skuld na tien jaar vereffen, is ook na Oberholster en Pretorius verwys vir verdere ondersoek. 'n Skema waarvolgens oudleners ook polisse kon uitneem om hul skuld te delg is ook aanvaar, op voorwaarde dat dit in oorleg met die Helpmekaar moes geskied. ${ }^{176}$

Waar die oplossing vir die hoë studiekostes in die sewentigerjare in hoër staatssubsidies aan universiteite of direkte subsidiëring van studente se losieskostes gesoek is, het die verantwoordelikheid teen die einde van die tagtigerjare na die ouers verskuif en is pogings aangewend om ouers daarvan bewus te maak om deur middel van versekering vir hul kinders se studiekoste voorsiening te maak. Hierdie was egter noodmaatreëls wat nie die strukturele probleme wat die Helpmekaar deur die loop van die tagtigerjare by verskeie geleenthede amper tot stilstand laat knars het weens 'n gebrek aan likiditeit, aangespreek het nie. Soos in die sestigerjare was dit 'n ingreep van Anton Rupert wat die katalisator verskaf

Ibid:; R2 779788 was uitgeleen aan studente, die aandele-portefeulje was R1 129 miljoen werd, R380 000 uit op beleggings en die verwagting was dat ongeveer R500 000 op studielenings terugbetaal sou word gedurende die lopende boekjaar.

173 (HSA) HS, Notuleboek (16 Feb 1973-10 Sep 1993), 4 Mrt 1988, HS UK, 94.

174 (HSA) HS, Notuleboek (16 Feb 1973-10 Sep 1993), 17 Mrt 1988, HS Ad Hoc-komitee, 94, 95.

175 (HSA) HS, Notuleboek (16 Feb 1973-10 Sep 1993), 20 Mei 1988, HS UK, 95.

176 Ibid. 
het vir grondige herbesinning. In 'n skrywe aan die Helpmekaar in November 1988 het Rupert die Helpmekaar gemaan dat, indien hulle nie die rentekoers op studielenings met die reële rentekoers laat tred hou om vir inflasieverlies te kompenseer nie, die Helpmekaar hom sou doodbloei. ${ }^{177}$

Dit was nie 'n nuwe insig nie, maar die feit dat dit van Rupert afkomstig was en die feit dat Rembrandt dit ten opsigte van die fondse wat die Helpmekaar namens dié maatskappy geadministreer het, toegepas het, het 'n andersoortige impak as vorige oproepe in dié verband gehad. Die Helpmekaar se rentekoers is deur die loop van 1988 aangepas van ses persent vir die duur van die studietydperk en 12 persent vandat die lener begin verdien het, na agt persent en 12 persent per jaar. Dit het egter sleg vergelyk met die Rembrandt-groep se besluit om die lenings aan hul personeel se kinders wat deur die Helpmekaar geadministreer is aan Volkskas se rentekoers vir studentelenings te koppel, naamlik 18 persent en 16 persent oor die eerste twee jaar, en daarna 13 persent per jaar. ${ }^{178}$ Die hantering van Rupert se brief het die Helpmekaar gedwing om opnuut sy goedkoop of nie-markverwante rentekoerse, asook die ander strukturele probleme in sy sakemodel, naamlik die balans in en hantering van sy beleggingsportefeulje en 'n meer korporatiewe en professionele benadering in sy stelsel van rekeningkundige beplanning en verslagdoening, te konfronteer.

In die proses het JCL Oberholster, Anton Rupert se alternatiewe trustee op die Raad sedert Februarie $1985,{ }^{179}$ met die rugsteun van die Rembrandt-groep se bewese suksesvolle korporatiewe bestuurstelsels 'n beduidende rol gespeel. Na aanleiding van Rupert se brief is die aktuaris van Homes Trust gevra om te bereken watter rentekoers die Helpmekaar op sy studielenings moes hef om vir inflasie te vergoed en steeds groei te toon. Nadat die aktuariële gegewens met die Helpmekaar se ouditeure bespreek is, is die koerse vasgestel op nege persent vir die duur van die studietydperk en 14 persent daarna. Die ouditeure was van mening dat die toename in die waarde van die Helpmekaar se nywerheidspersele in die Strand (die erflating van DH van Zyl aan die Helpmekaar), asook die 88 persent toename in die waarde van sy aandeleportefeulje dit onnodig gemaak het om hoër rentekoerse as dit te vra. ${ }^{180}$

In tandem met Rupert se brief oor markverwante rentekoerse het Oberholster in November 1988 voorgestel dat die moontlikheid ondersoek word om die tekort aan fondse te verminder.

177 (HSA) HS, Notuleboek (16 Feb 1973-10 Sep 1993), 8 Nov 1988, HS UK, 97.

178 (HSA) HS, Notuleboek (16 Feb 1973-10 Sep 1993), 2 Mrt 1989, HS jaarvergadering, Jaarverslag, 23 Feb $1989,98$.

179 (HSA) HS, Notuleboek (16 Feb 1973-10 Sep 1993), 15 Feb 1985, HS jaarvergadering, 82.

180 (HSA) HS, Notuleboek (16 Feb 1973-10 Sep 1993), 2 Mrt 1989, HS jaarvergadering, 100. 


\section{Die Kaapse Helpmekaar}

Dit is gedoen deur teen die Helpmekaar se eie sekuriteite (sy aandeleportefeulje) geld by finansiële instellings te leen teen spesiale koerse en dit dan teen die Helpmekaar se eie koerse aan studente uit te leen. ${ }^{181}$ Oberholster se voorstel, wat herinner het aan die B-fonds-konsep van die veertigerjare, het dus veronderstel dat markverwante rentekoerse op die betrokke geld gehef sou moes word om die stelsel lonend te maak. Na ondersoek deur die kantoor is die voorstel in Oktober 1989 bespreek. Die bestuurder het in sy betoog aangedui dat, indien die risiko's vir die Helpmekaar verreken word, tesame met die lang siklus wat verloop voordat die Helpmekaar sy geleende geld van studente terug ontvang, dit in die praktyk sou beteken dat rentekoerse van ongeveer 30 persent op lenings gehef sou moes word wat studente ook met 'n baie groot skuldlas sou opsaal. Hy was van oordeel dat studente lenings by die handelsbanke, wat onbeperkte fondse gehad het, kon verkry teen 20 persent. Sou die Helpmekaar die voorstel implementeer, sou hulle spoedig weer wees waar hulle op daardie oomblik was, naamlik so te sê illikied omdat al hul aandele verpand was. 'n Insinking in die beurs sou volgens hom ook kon lei tot 'n opvraging van die geld wat die Helpmekaar geleen het omdat hul aandeleportefeulje onvoldoende sekuriteit gebied het.

"Met 'n eie en geleende fondse-posisie so gebalanseer op 'n mes se sneepunt, sal daar gedurig 'n swaard oor die Raad maar veral oor die Bestuurder se kop swaai."182

Die bestuurder was dus duidelik gekant teen die voorstel. Oberholster het egter aangedui dat waar rentekoerse op beleggings vroeër ses persent per jaar was, was verbandlenings ses en $n$ half persent per jaar en dat die verhouding naastenby dieselfde gebly het. Hy was van mening dat werknemers op daardie tydstip salarisse ontvang het wat sulke hoë rentekoerse kon dra. Die UK het dus ten spyte van die bestuurder se betoog besluit om 'n kommissie, bestaande uit ds Roos, GR Pretorius, Horn, Oberholster en die bestuurder, aan te stel om die aangeleentheid verder te ondersoek. Oberholster het ook onderneem dat Rembrandt se ekonome 'n memorandum sou opstel wat as werkstuk vir bespreking kon dien. ${ }^{183}$ In Februarie 1990 het die kommissie besluit om 'n memorandum wat deur Oberholster opgestel is aan die volle Raad van Trustees vir bespreking voor te lê. ${ }^{184}$

Die bestuurder se jaarverslag vir 1989 was 'n illustrasie van die strukturele probleme waarna hierbo verwys is en die finansiële onsekerheid wat dit by die bestuur geskep het:

181 (HSA) HS, Notuleboek (16 Feb 1973-10 Sep 1993), 8 Nov 1988, HS UK, 97.

182 (HSA) HS, Notuleboek (16 Feb 1973-10 Sep 1993), 5 Okt 1989, HS UK, 100, 101.

183 Ibid.

184 (HSA) HS, Notuleboek (16 Feb 1973-10 Sep 1993), 8 Feb. 1990, HS Kommissievergadering, 101. 


\footnotetext{
“Te oordeel uitsluitlik na die surplus van die jaar wat met R100 000 opgestoot is, sal dit wil voorkom asof ons 'n gunstige jaar gehad het. Maar die newel wat oor ons werk lê, is daardie onsekere en onbepaalbare faktor - gaan ons in staat wees om, bo en behalwe ons aangegane verpligtinge, genoeg fondse hê om die addisionele hulp te verskaf wat benodig word om die verhoogde kostes te dek."185
}

Die res van die bestuurder se verslag het getuig van onsekerheid oor die delging van lenings, die vind van 'n balans tussen die terugbetalings en die uitbetalings van lenings deur die Helpmekaar en hoe die Studiefonds se beleggings ten beste benut kon word in die proses. ${ }^{186}$ Teen hierdie agtergrond het die raad onder invloed van die aanbevelings van die Oberholstermemorandum tydens die jaarvergadering van Februarie 1990 belangrike besluite geneem wat in die eerste paar maande van 1990 die Studiefonds begin herposisioneer het om die uitdagings van die tagtigerjare wat gedreig het om hom teen die einde van die dekade te verswelg aan te pak. Benewens 'n besluit om die voorstelle vervat in die Oberholstermemorandum na 'n kommissie, bestaande uit di JH Roos, J van der Westhuyzen, mnre GJ Horn, GR Pretorius, JCL Oberholster, dr PS Meyer en Fanie Pretorius (bestuurder), vir besluitneming te verwys is belangrike ander besluite oor finansiële en ander bestuurspraktyke en -inligting ook geneem.

Die Raad het besluit dat 'n jaarlikse begroting voortaan uitgewerk moes word sodat daarvolgens besluit kon word hoeveel nuwe lenings toegestaan kon word. Hulle het ook aanbeveel dat die UK op 'n vasgestelde datum (wat vir die volle jaar vooruit bepaal moes word) maandeliks moes vergader om die Studiefonds se fondseposisie te bespreek. ${ }^{187}$ Ten spyte van die kantoorpersoneel se protes ${ }^{188}$ is hulle opdrag gegee om statistieke by te hou van alle telefoniese of skriftelike aansoeke wat afgewys word. Belangrike besluite oor fondse is ook geneem. Die leningsperk per jaar is na R8 500 tot 'n periode van vyf jaar verhoog, maar die maandelikse terugbetalingspaaiement vir afgestudeerdes is op R225 gehou. Daar is besluit dat voortgegaan moes word om ouers te versoek om aan die lening te begin terugbetaal terwyl die student nog studeer het. Rentekoerse op lenings is egter na die kommissie verwys en 'n besluit oor die hantering van nuwe aansoeke is ook uitgestel

185 (HSA) HS, Notuleboek (16 Feb 1973-10 Sep 1993), 23 Feb 1990, HS jaarvergadering, Jaarverslag, 13 Feb 1990, 102.

186 Ibid.

187 (HSA) HS, Notuleboek (16 Feb 1973-10 Sep 1993), 23 Feb 1990, HS jaarvergadering, 105.

188 (HSA) HS, Notuleboek (16 Feb 1973-10 Sep 1993), 23 Feb 1990, HS jaarvergadering, Jaarverslag, 13 Feb 1990, 102. 


\section{Die Kaapse Helpmekaar}

tot na die afhandeling van 'n besinning oor die Helpmekaar se finansiële posisie en die herrangskikking van hul fondse. ${ }^{189}$

Uit'n voorlopige balansstaat wat deur Oberholster in samewerking met die kantoorpersoneel opgestel is en op 'n vergadering van die kommissie in April 1990 gedien het, was dit duidelik dat die Studiefonds geen verdere lenings vir 1990 sou kon toestaan tensy van sy bates in kontant omgesit word nie. Oberholster het dus voorgestel dat die inkomste wat uit die beleggings van Van Zijl's Gift verkry word as studentelenings aangewend moes word en dat as die grond later ontwikkel sou word geld uit ander bronne daarvoor gebruik moes word. Hierdie voorstel, asook sy voorstel dat die Studiefonds sy beleggings aan 'n beleggingsadviseur moes oorhandig om 'n hoër opbrengs te verseker is na die UK verwys. Die kommissie het ook die jaarvergadering se besluit dat rentekoerse op studielenings aan Volkskas se jaarkoers op beleggings gekoppel word, bevestig. ${ }^{190}$

Die kwessies rondom finansiële bestuur, wat hoofsaaklik deur Rupert se rentekoersbrief geïnisieer en daarna deur Oberholster as sy sekundus op die Raad van Trustees verder momentum gegee is, is tydens die UK se vergadering in Mei 1990 suksesvol deurgevoer. Oberholster het by die geleentheid 'n omvattende begroting vir die 1990-finansiële jaar voorgelê. Inkomstes en uitgawes, beleggings en studielenings vir die finansiële jaar tot 31 September 1990, asook kontant beskikbaar vir die jare 1989/90 tot 1992/93 is hierin weerspieël. Die begroting het 'n tekort van R168 000 vir die jaar aangetoon. Die UK het dus besluit om die tekort met 'n lening uit die Van Zijl's Gift-geld aan te vul. Na 'n indringende bespreking van die begroting, waartydens Oberholster "vir sy moeite en leiding" bedank is, is besluit dat die kantoor voortaan elke jaar teen einde Augustus 'n begroting aan die UK moes voorlê sodat oor die fondse beskikbaar vir nuwe lenings besluit kon word. Die finansiële verslagdoening is verder verfyn deur die besluit dat kwartaalstate ook voortaan aan die UK voorgelê moes word. 'n Finale besluit oor 'n formule vir die bepaling van rentekoerse op studielenings is ook geneem. Voortaan sou rentekoerse gelyk wees aan die 12 maande depositokoers van Volkskas soos op 1 Januarie van die betrokke jaar. Na voltooiing van studies sou die lenings rente dra teen prima bankkoers minus een persent vir elke jaar wat suksesvol studeer is, met 'n minimum koers gelyk aan die styging van die verbruikersprysindeks (VPI) soos bepaal deur die reserwebank vir die voorafgaande jaar. Hiermee is vir die eerste keer 'n wetenskaplike basis vir die bepaling van Helpmekaar se rentekoerse - 'n voorstel wat SPF van Aswegen in Maart 1983 vir die eerste keer gesuggereer

189 (HSA) HS, Notuleboek (16 Feb 1973-10 Sep 1993), 23 Feb 1990, HS jaarvergadering, 105.

190 (HSA) HS, Notuleboek (16 Feb 1973-10 Sep 1993), 19 Apr 1990, HS Kommissievergadering, 106. 
het - vasgestel. Die sluitingsdatum vir aansoeke om nuwe lenings is ook op 30 April vasgestel. 'n Laaste belangrike besluit van die UK-vergadering was om te rekenariseer. ${ }^{191}$ Hoewel die bestuurder reeds in November 1988 opdrag gegee is om in samewerking met die ouditeure die moontlikheid van rekenarisering te ondersoek ${ }^{192}$ was die aanvanklike bevinding dat die Studiefonds se stelsel nog goed genoeg werk. ${ }^{193}$ Die UK het op aanbeveling van Oberholster besluit om 'n rekenaar vir die kantoor aan te koop. Oberholster se aanbod dat die personeel deur personeel van Rembrandt op Stellenbosch opgelei kon word, is ook aanvaar. ${ }^{194}$

Die tagtigerjare is ook gekenmerk deur die impak van die toetrede deur die handelsbanke tot die studieleningsmark. Die uitdaging vir die Studiefonds was dat hulle gekonfronteer is deur leningsaansoekers wat vanweë hul blootstellings aan bankstudielenings in finansiële verknorsing beland het en dan by die Helpmekaar om hulp kom aanklop het. Banke se lenings was in die meeste gevalle ontoereikend vanweë die praktyk om eers die verskuldigde rente van die geleende geld af te trek voor uitbetaling en ook vanweë hul weiering om studente verder te help indien hulle 'n jaar sou sak. Met die styging in rentekoerse was daar'n toename in studente wat nie banklenings kon bekostig nie en hulle toevlug dan tot die Helpmekaar geneem het. Die Helpmekaar het dus 'n beginselbesluit geneem om nie studente wat reeds banklenings aangegaan het met lenings te help nie, aangesien dit sulke studente se skuldlas net verder sou verswaar. Dit sou beteken dat terwyl die banke die advertensiewaarde en 'n nuwe kliënt kry dit die Helpmekaar is wat die student moet help om sy studies af te rond.

Die Helpmekaar was ook van mening dat indien dit by die terugbetaal van skuld kom daar aan die finansieel magtiger banke voorkeur gegee sou word en die Helpmekaar agter in die ry sou moes inval wat die risiko vir slegte skulde sou vergroot. Helpmekaar het die aangeleentheid met banke soos Volkskas en Boland Bank opgeneem en die Helpmekaar is deurlopend deur die tagtigerjare gekonfronteer met studente wat in die penarie beland het. Ten spyte van die verbod op hulp aan sulke studente het die Helpmekaar eie aan sy filantropiese ingesteldheid wel in "hartseer gevalle" hulp verleen. ${ }^{195}$

\footnotetext{
191 (HSA) HS, Notuleboek (16 Feb 1973-10 Sep 1993), 10 Mei 1990, HS UK, 106.

192 (HSA) HS, Notuleboek (16 Feb 1973-10 Sep 1993), 8 Nov 1988, HS UK, 97.

193 (HSA) HS, Notuleboek (16 Feb 1973-10 Sep 1993), 2 Mrt 1989, HS jaarvergadering, 98.

194 (HSA) HS, Notuleboek (16 Feb 1973-10 Sep 1993), 10 Mei 1990, HS UK, 106.

195 (HSA) HS, Notuleboek (16 Feb 1973-10 Sep 1993), 13 Feb 1981, HS jaarvergadering, Jaarverslag, 21 Jan 1981 , 59; 13 Feb 1981, HS jaarvergadering, 61; 12 Feb 1982, HS Jaarverslag, 65; 20 Feb 1987, HS jaarvergadering, Jaarverslag, 88; 19 Feb 1988, HS jaarvergadering, Jaarverslag, 92, 93.
} 


\section{HELPMEKAAR-FONDSE: DIE OPBOU EN INSTANDHOUDING VAN KAPITAAL}

Met die beëindiging van die kongresstelsel is die post-amalgamasie-era van HS-aktiwiteite baie meer toegespits op hoofsaaklik twee baie nou verwante aktiwiteite, naamlik die toekenning van studielenings en die bestuur en generering van voldoende fondse om eersgenoemde aktiwiteit op 'n volhoubare grondslag voort te sit. Terwyl eersgenoemde in die voorafgaande afdeling ter sprake was, konsentreer hierdie afdeling hoofsaaklik op laasgenoemde. Die bestuur en generering van Helpmekaar-fondse in dié era is deur 'n aantal uitdagings gekenmerk. Die vernaamste uitdaging was om 'n beleggingsmodel of -portefeulje te vind wat die toenemende bedreiging van inflasie kon hokslaan en die "verliese" wat beleggings in studielenings tot gevolg gehad het goed te maak met beleggings wat inflasie geklop het. Hoe dié balans die beste gehandhaaf kon word sonder om die primêre doelstelling van die Studiefonds, naamlik die verskaffing van studielenings te kort te doen was 'n oorheersende, deurlopende tema. ${ }^{196}$

In die post-amalgamasie-era in die tweede helfte van die sestigerjare het die Studiefonds doelbewus wegbeweeg van die vroeëre meer konserwatiewe beleggingsbeleid met besluite om meer aggressief in aandele en eiendom te belê. ${ }^{197}$ Kenmerkend van die ou Helpmekaarvereniging van die Kaapprovinsie was sy konserwatiewe beleggingsbeleid wat deur sy aanvanklike grondwet beperk is tot beleggings in " $n$ kamer, bank, regeringsfondse, skatkisbiljette of op eerste verband op vaste eiendom". ${ }^{198}$ In die vaarwater van die Eerste Ekonomiese Volkskongres in 1939 het die Vereniging se eerste belegging in aandele bestaan uit 5000 voorkeuraandele van $£ 1$ elk in Federale Volksbeleggings wat in die 1940/41 finansiële state gereflekteer is. Hierdie belegging is in die 1942/1943 finansiële jaar opgevolg deur die aankoop van 2000 volopbetaalde aandele van $£ 1$ elk in Volkskas. Met die Vereniging se laaste kongres in 1965 was dit steeds die enigste aandele in die beleggingsportefeulje met die res van die fondse wat in studielenings, Unieregeringseffekte, vaste deposito's en verbande op eiendom belê is. Hierdie aandelebeleggings het slegs R18 500 (ongeveer sewe persent) van die totale kapitaal van R250 903 verteenwoordig. ${ }^{199}$

Wat beleggings in eiendom betref, is op die 1942-kongres van die Helpmekaarvereniging van die Kaapprovinsie 'n voorstel van $\mathrm{DH}$ van Zyl aanvaar dat die Vereniging 'n deel van sy

\footnotetext{
196 (HSA) HS, Notuleboek (19 Jan 1967-16 Feb 1973), 16 Feb 1968, HS Direksie, gp.

197 (HSA) HS, Notuleboek (19 Jan 1967-16 Feb 1973), 16 Feb 1968, HS Direksie, gps.

198 (HSA) HVKP, Reëls en Regulasies van die HVKP, 1919, 16.

199 (HSA) HVKP, Notuleboek, 30 Mrt 1965, Kongres, Balansstaat op 30 Sep 1964, gp.
} 
fondse tot 'n maksimum van $£ 10000$ in vaste eiendom kon belê indien daar beleggingsfondse beskikbaar was en die regte geleentheid vir 'n eiendomstransaksie hom sou voordoen. ${ }^{200}$ Die besluit het gelei tot die aankoop van die Kaapstadse eiendom Leeuwenrusthof in 1942 vir $£ 8644$ 9s 3d wat die meubels sowel as die hereregte en transportkoste ingesluit het. ${ }^{201}$ In 1946 het hulle ook 'n eiendom met woonhuise in Goodwood bekom deur die verband van $£ 1550$ oor te neem. ${ }^{202}$ Hoewel daar huurinkomste op die eiendomme verdien is, het die Helpmekaar in 1952 besluit om, hoofsaaklik weens die swak toestand van die gebou op Leeuwenrusthof en die aanbeveling van die argitek dat die gebou gesloop moes word, beide Leeuwenrusthof en die Goodwood eiendomme te verkoop. ${ }^{203}$

Die besluit om op'n meer aggressiewe wyse in eiendom en aandele te belê sou in die sestigerjare aanvanklik fenomenale resultate lewer deurdat die Helpmekaar in die vyfjaarperiode vanaf 1964 tot begin 1969 hul kapitaal verdubbel het en net soveel kapitaal gevorm het as in die vorige 45 jaar van die Helpmekaar se bestaan. ${ }^{204}$ Teen die middel sestigerjare, net na amalgamasie, was 60 persent van die totale fondse van die Studiefonds in studielenings en 40 persent in deposito's en aandele, gebaseer op die boekwaarde van laasgenoemde, belê. Die posisie is ook bereik dat die bedrag wat jaarliks ontvang is uit die terugbetalings van studielenings feitlik die uitbetaling van lenings gedek het. ${ }^{205}$

Wat eiendom betref, is die groot uitbreiding in die noordelike voorstede van die Kaapse Skiereiland en die geleenthede wat dit vir winsgewende beleggings in eiendom geskep het, benut. Ten opsigte van aandele is die skouspelagtige groei van die Suid-Afrikaanse ekonomie in die sestigerjare en veral die groei in die ekonomiese bemagtiging van die Afrikaner benut om voordeel te trek uit aandelebeleggings. In beide die gevalle is Afrikaner-netwerke benut om toegang tot winsgewende verkrygings in eiendom en veral aandele te verkry. In die proses is gebruik gemaak van die insigte, kennis en kontakte van Afrikaner-sakeleiers in van die vooraanstaande Afrikaner-maatskappye. Die Studiefonds het dus gedeel in die euforie van die voorspoedgolf van die tweede helfte van die sestigerjare, maar ook in die pyn en

200 (HSA) HVKP, Notuleboek, 8-9 Apr 1942, Kongres, 12.

201 (HSA) HVKP, Notuleboek, 31 Mrt-1 Apr 1943, Kongres, Penningmeester verslag, 5.

202 (HSA) HVKP, Notuleboek, 2-3 Apr 1947, Kongres, Ouditeure verslag, 6.

203 (HSA) HVKP, Notuleboek (1948-1952) 3-4 Apr 1951, Kongres, Aanbevelings van die Hoofbestuur aan die Kongres, 11; 8-9 Apr 1952, Kongres, Hoofbestuur verslag, 1.

204 (HSA) HS, Notuleboek (19 Jan 1967-16 Feb 1973), 14 Feb 1969, HS Direksie, HS Memorandum Groepsassuransie, 3 Feb 1969, gp.

205 (HSA) HS, Notuleboek (8 Feb 1940-19 Des 1966), 2 Sep 1966, HS UK, gp. 


\section{Die Kaapse Helpmekaar}

ontnugtering wat die ineenstorting van die aandelebeurs in 1969 en die vroeë sewentigerjare tot gevolg gehad het. In die proses het die Studiefonds 'n paar harde beleggingslesse geleer.

Nog voor die amptelike deurvoering van die amalgamasie het Albertyn op 'n Beleggingskomiteevergadering in 1966 die noodsaak om die invloed van inflasie op Helpmekaarfondse teen te werk beklemtoon. Volgens die twee opsies beskikbaar, naamlik aandele en vaste eiendom, het laasgenoemde volgens Albertyn inkomste en veiliger kapitaalgroei gelewer, wat die Helpmekaar se behoeftes beter gepas het. Aandele wat beide goeie inkomste en kapitaalgroei verskaf, was volgens hom baie skaars. Hy was dus van mening dat die Helpmekaar 'n deel van sy likiede reserwes moes gebruik om 'n maatskappy saam met ander beleggers soos Saambou te stig wat byvoorbeeld eiendom kon aanskaf waarop woonstelle opgerig kon word. Die komitee het dus besluit om by die direksie aan te beveel dat beleggings in eiendom in beginsel aanvaar moes word. ${ }^{206}$ Albertyn se voorstel is deur die direksie aanvaar, hoewel DH van Zyl op die gevaar gewys het dat die publiek kon argumenteer dat die Helpmekaar-geld wat vir studiehulp ingesamel is in eiedom belê is. Albertyn het egter aangedui dat die eiendomsbeleggings juis die skenkings teen die invloed van inflasie beskerm het. Die direksie het dus besluit om hul Rembrandt en Federale Volksbeleggingsaandele te verkoop en dat die beleggingskomitee dan sou besluit oor die aanwending en belegging van die opbrengs nadat beleggingsadviseurs geraadpleeg is. ${ }^{207}$

Die beleggingsbeleid van die HS het op die amalgamasievergadering van 5 Augustus 1966 met die inwerkingtreding van die nuwe bedeling egter weer aan die orde gekom. Daar was konsensus dat die Helpmekaar se fondse teen waardevermindering deur inflasie beskerm moes word, maar almal was nie eens dat 'n derde van die Studiefonds se kapitaal in eiendom belê moes word nie. HL Greyling was van mening dat die oplossing vir kapitaalerosie in eiendoms- en aandelebeleggings geleë was, terwyl Van der Westhuyzen van mening was dat voorgestelde bekamping van kapitaalerosie tot mannekrag-erosie kon lei indien daar nie genoeg fondse vir studielenings toegedeel word nie. Die vergadering het dus besluit dat eers 'n studie van die huidige beleggings - insluitende studielenings - gemaak moes word voordat finale besluite geneem word. ${ }^{208}$

\footnotetext{
206 (HSA) HS, Notuleboek (8 Feb 1940-19 Des 1966), 21 Apr 1966, HS Beleggingskomitee, gp.

207 (HSA) HS, Notuleboek (8 Feb 1940-19 Des 1966), 2 Jun 1966, HS Direksie, gp.

208 (HSA) HS, Notuleboek (8 Feb 1940-19 Des 1966), 5 Aug 1966, HS Direksie, gp.
} 


\section{Eiendomsbeleggings}

$\mathrm{Na}$ oorweging van die Studiefonds se leningsverpligtinge en likiditeitsposisie is besluit om voort te gaan met Albertyn se idee van die stigting van 'n eiendomsbeleggingsmaatskappy saam met Woltemade Versekeraars Beperk. ${ }^{209}$ Die idee was dat ander instansies soos die NG Kerk later genader kon word om aandeelhouers te word. Die gedagte was dat elke eiendomsprojek wat aangepak word as 'n aparte filiaal van die moedermaatskappy geregistreer sou word waarin ander goedgekeurdes ook aandele kon opneem, maar waarin die moedermaatskappy die beheer sou behou. 'n Akte van oprigting is opgestel en daar is selfs name (Grond en Geboue [Edms] Beperk of Hawee [Edms] Beperk) vir die maatskappy oorweeg. Saambou het hom ook in beginsel verbind om die finansiering vir die eiendomsmaatskappy se projekte te verskaf terwyl Theron Van der Poel en Kie as ouditeure sou optree. ${ }^{210}$ Hierdie poging tot maatskappystigting is egter in die wiele gery deur 'n gesloer in voorgestelde wetgewing ${ }^{211}$ waarvan die stigting afhanklik was. Teen Februarie 1968 was dit duidelik dat die inisiatief nie sou realiseer nie. Die feit dat eiendomspryse in die wagperiode die hoogte in geskiet het, het die Studiefonds genoop om sy opsies te heroorweeg. Daar is dus weer besin oor aspekte soos of hulle op hul eie in eiendom moes belê en of hulle 'n maatskappy moes stig wat die eiendom besit. In dié verband moes hulle die belastingimplikasies vir maatskappye en die onderhoud van eiendom en geboue (indien die Studiefonds eiendomsbeleggings op sy eie sou onderneem) teen mekaar opweeg. Ten spyte van die onsekerheid oor die roete is die beginsel om in vaste eiendom te belê herbevestig en is dit aan die UK opgedra om dit ten beste te implementeer. ${ }^{212}$ Die aankoop van grond in Durbanweg, Bellville, met die oog op die oprigting van 'n woonstelblok en die moontlikheid om dit saam met die

209 Die noue samewerking tussen die Helpmekaar en Saambou (Permanente) Bouvereniging was waarskynlik vanweë die teenwoordigheid van CF Albertyn op die Saambou direksie terwyl HR van der Poel van Theron van der Poel en Kie wat die Helpmekaar Studiefonds se oudituere was ook op die Saambou direksie gedien het. Die verbintenis strek selfs terug tot die vroeë vestigingsjare van Saambou. In die vroeë veertigerjare het dr AJ Stals, voorsitter van die Kaapse Helpmekaar in die twintigerjare, op die Saambou direksie gedien. Woltemade Versekeraars Beperk was Saambou se eie versekeringsmaatskappy wat in 1965 gestig is met MS Louw (Saambou se direksie-voorsitter) as voorsitter en CF Albertyn as vise-voorsitter. Saambou was ook die Helpmekaar goedgesind en het byvoorbeeld in 1963 R3 000 aan die vier Helpmekaar-fondse geskenk waarvan die Kaap R1 000 gekry het. (USD), Saambou Nasionale Bouvereniging Argief, Notuleboek (12 Jun 1942-14 Nov 1946), Direksie 28 Jul 1943, gp; Notuleboek (21 Jun 1963-20 Feb 1970), Direksie 21 Jun 1963,1; 10 Aug 1963, 4; 23 Apr 1965, 1; Voorsittersrede jaarvergadering, 18 Jun 1965, 40.

210 (HSA) HS, Notuleboek (8 Feb 1940-19 Des 1966), 12 Okt 1966, HS UK, gp; 2 Sep 1966, HS UK, gp; 9 Des 1966, HS Direksie, gp.

211 Verwagte aanpassings in Wet no 24 van 1965 wat die aktiwiteite van bougenootskappe bepaal en gereguleer het. L Alcock, Die belangrikheid van permanente bouverenigings as instrument vir die finansiering van privaatbehuising in Suid-Afrika, 109, 113-114, ongepubliseerde MA, Randse Afrikaanse Universiteit, 1986.

212 (HSA) HS, Notuleboek (19 Jan 1967-16 Feb 1973), 16 Feb 1968, HS Direksie, gp. 


\section{Die Kaapse Helpmekaar}

Universiteit van Stellenbosch en die Kaapse NG Kerk te finansier was van die moontlikhede wat ondersoek is. ${ }^{213}$

In November 1968 het die Studiefonds 'n stuk grond van 25 morg, 'n deel van die plaas Bethanie, geleë aan die suidelike kant van Eversdalweg in Durbanville, vir R85 000 gekoop nadat by Saambou kers opgesteek is oor die markwaarde van die eiendom. ${ }^{214}$ Pogings is ook aangewend om 'n addisionele stuk grond wat aangrensend aan die Bethanie eiendom geleë was te bekom om sodoende 'n groter gekonsolideerde eiendom te verkry. Die feit dat die eienaar egter R150 000 vir die eiendom wou hê, het die poging laat misluk. As die nuwe eienaars van Bethanie Beleggings (Edms) Bpk moes die Studiefonds teen R1 per jaar ook lidmaatskap van die KWV verkry sodat die druiwe-oes op hul eiendom verkoop kon word. ${ }^{215}$ Afgesien van toegang tot een van die Afrikaner-"statussimbole" ('n KWV-kwota) van die sestigerjare, was hulle ook as grondeienaars aan die ontvangkant van die regering se apartheidsbeleid en groepsgebiedewetgewing.

Weens die dorpsontwikkeling wat op die grond aangrensend tot die Helpmekaar se eiendom plaasgevind het, het die Departement van Gemeenskapsbou in Oktober 1971 na klagtes van aangrensende grondeienaars oor die teenwoordigheid van Bruin huurders in die vier "volkshuisies" op Bethanie, die Helpmekaar versoek om die strukture te ontruim. Die versoek het uiteindelik tot die uitsetting van die inwoners en die sloping van die strukture aanleiding gegee. ${ }^{216}$ Die positiewe aspek van die ontwikkeling aangrensend tot die Helpmekaar se eiendom was egter dat dit die waarde van die grond laat styg het. ${ }^{217}$ Hoewel die Helpmekaar oorweeg het om Bethanie self of in samewerking met Saambou-Nasionaal as dorpsgebied te ontwikkel het die direksie in Desember 1972 finaal daarteen besluit. ${ }^{218}$ Faktore soos die ooraanbod van erwe - Bellville Munisipaliteit het oor meer as 2000 oop erwe beskik en die stadsingenieur het aanbeveel dat hulle wag tot die mark gunstiger is ${ }^{219}$ - het tot die besluit bygedra. Die grond is aanvanklik aan Afrikaanse instellings aangebied en maatskappye soos Sanlam, Rembrandt,

213 (HSA) HS, Notuleboek (19 Jan 1967-16 Feb 1973), 5 Jul 1968, HS Dagbestuur, gp.

214 (HSA) HS, Notuleboek (19 Jan 1967-16 Feb 1973), 18 Apr 1968, HS UK, gp; 26 Sep 1968, HS Dagbestuur, gp; 12 Nov 1968, HS Dagbestuur, gp.

215 (HSA) HS, Notuleboek (19 Jan 1967-16 Feb 1973), 12 Nov 1968, HS Dagbestuur, gp; 14 Feb 1969 , HS Direksie, Kantoorverslag, 24 Jan 1969, gp.

216 (HSA) HS, Notuleboek (19 Jan 1967-16 Feb 1973), 21 Okt 1971, HS UK, gp; 11 Aug 1972, HS UK, gp.

217 (HSA) HS, Notuleboek (19 Jan 1967-16 Feb 1973), 13 Feb 1970, HS Direksie, gp.

218 (HSA) HS, Notuleboek (19 Jan 1967-16 Feb 1973), 14 Feb 1969, HS Direksie, gp; 12 Nov 1970, HS UK, gp; 11 Feb 1972, HS Direksie, gp; 8 Des 1972, HS UK, gp.

219 (HSA) HS, Notuleboek (19 Jan 1967-16 Feb 1973), 11 Feb 1972, HS Jaarvergadering, Direksieverslag, gp. 
Master Development en Lengro het reageer. Die direksie was van mening dat die grond meer werd was as wat hul aangebied is. Hulle was wel bereid om te verkoop as hulle 'n aanbod bo R150 000 sou ontvang. ${ }^{220}$ In 1972 is die eiendom aan mnr George Israel Groll vir R170 000 verkoop ${ }^{221}$ wat teen die 1968-koopprys van R85 000 op 'n aansienlike wins neergekom het. Die druk om die grond te ontwikkel omdat dit toenemend'n leë stuk grond tussen nuutontwikkelde woonbuurte geword het, die goeie prys wat hulle gekry het, asook die druk wat daar op die Helpmekaar se kontantvloei in die vroeë sewentigerjare was weens die ineenstorting van die aandelemark en die effek wat dit op hul aandeleportefeulje gehad het, ${ }^{222}$ het waarskynlik tot die verkoop van die eiendom en die deregistrasie van Bethanie Beleggings (Edms) Bpk bygedra. ${ }^{223}$

Die Helpmekaar se direksie het in Junie 1969 na die aankoop van die Bethanie eiendom verdere geld vir beleggings in eiendom gestem (R90 000) en ondersoek is ingestel na die koop van erwe in die Table View Landgoed - 'n omgewing waarin daar groot ontwikkeling was. ${ }^{24}$ Die Helpmekaar is ook genader met aanbiedinge van ander aanloklike beleggings in eiendom. Die direksie het egter in Julie 1969 na heroorweging van sy posisie besluit om voorlopig nie aanbiedinge om aan beleggings in eiendom deel te neem te aanvaar nie, tensy die ontwikkeling aan 'n bougenootskap gekoppel was. ${ }^{225}$ Die ineenstorting van die aandelemarkte op die JSE wat in Mei 1969 op 'n hoogtepunt was en teen Julie reeds twee maande in 'n dramatiese afwaartse spiraal verkeer het, het waarskynlik tot die versigtigheid bygedra. ${ }^{226}$ Dit wil voorkom asof die voorwaardelike moratorium op eiendomsbeleggings weens die ineenstorting van die beurs mettertyd die verstekposisie geword het, aangesien geen verdere eiendomsbeleggings gemaak is nie.

\section{Aandele-beleggings}

Daar is reeds verwys na die Helpmekaarvereniging van die Kaapprovinsie se aandeleportefeulje wat uit die veertigerjare gedateer het. Anders as die Vereniging het die B-fonds (later die HS) uit die aard van sy kapitaalbasis aanvanklik nie oor voldoende eie kapitaal beskik om beleggings in aandele te maak nie, behalwe waar hulle deur erflatings in besit van aandele gekom het

220 (HSA) HS, Notuleboek (19 Jan 1967-16 Feb 1973), 8 Des 1972, HS UK, gp.

221 Ibid; (HSA) HS, Notuleboek (16 Feb 1973-10 Sept 1993), 28 Okt 1975, HS UK, 30.

222 (HSA) HS, Notuleboek (19 Jan 1967-16 Feb 1973), 12 Nov 1970, HS UK, gp; 12 Feb 1971, HS Direksie, Jaarverslag, 22 Jan 1971 gp.

223 (HSA) HS, Notuleboek (16 Feb 1973-10 Sept 1993), 19 Jun 1974, HS UK, 20.

224 (HSA) HS, Notuleboek (19 Jan 1967-16 Feb 1973), 18 Jun 1969, HS UK.

225 (HSA) HS, Notuleboek (19 Jan 1967-16 Feb 1973), 17 Jul 1969, HS Beleggingskomitee, gp.

226 http://archive.spectator.co.uk/article/14th-march-1970/25/money-a-tale-of-two-cities 


\section{Die Kaapse Helpmekaar}

of met aandelebeleggings van die Vorster-Muller Fonds gewerk het. ${ }^{227}$ In 1962 is 'n aantal direkteure en die sekretaris, $S$ Pretorius, op 'n spesiale vergadering gemagtig om namens die HS oordragvorms vir die koop en verkoop van aandele te teken. ${ }^{228}$ Teen die vroeë sestigerjare het hulle oor 'n aandeleportefeulje beskik wat Rembrandt Tabakvervaardigingskorporasieaandele ${ }^{229}$ en Federale Volksbeleggingsaandele ingesluit het. ${ }^{230}$ Die aandele is aangewend om kapitaaldepresiasie teen te werk. ${ }^{231}$

In die post-amalgamasie-era is die Helpmekaar se belegging in aandele deur ' $n$ aantal fases gekenmerk: aanvanklik die ongekende groei en spekulatiewe optimisme van die tweede helfte van die sestigerjare in die potensiaal van aandele om kapitaal te vermeerder; die 1969-ineenstorting van die aandelebeurs en die gepaardgaande negatiewe effek op algemene beleggersvertroue; die periode van intense introspeksie, herbesinning en onsekerheid oor hoe die Helpmekaar se aandeleportefeulje bestuur moes word, wat 'n groot deel van die sewentigerjare oorheers het; die toenemende besef in die tagtigerjare van die waarde en afhanklikheid van die Helpmekaar van sy aandeleportefeulje as beskermingsmeganisme teen toenemende kapitaalerosie vanweë weghol-inflasie en 'n meer professionele en volwasse benadering tot die hantering van hul aandeleportefeulje. Die Helpmekaar se aktiewe toetrede tot die vestiging van 'n aandeleportefeulje is verder gesteun deur die benutting van Afrikaner-sakenetwerke wat voordelige aandelebeleggingsgeleenthede geskep het wat hul andersins nie beskore sou wees nie.

Die direksie se besluit dat 25 persent van die Helpmekaar se fondse in aandele belê mag word, ${ }^{232}$ was dus maklik om uit te voer in die holderstebolder groeiperiode van die JSE wat veral vanaf die begin van 1968 momentum gekry het. Die dagbestuur was aanvanklik vir die monitering van die mark verantwoordelik en kon na goeddunk handel. ${ }^{233}$ In November 1968 is senator Ken Sinclair, dr Albertyn, mnr Greyling en die sekretaris aangestel as komitee met volmag om in aandele te belê (tot 'n bedrag van R90 000) om die geleenthede

\footnotetext{
227 (HSA) HVKP, Notuleboek (8 Feb 1940-9 Des 1966), 3 Mrt 1966, HS Direksie, gp.

228 (HSA) HVKP, Notuleboek (8 Feb 1940-9 Des 1966), 14 Nov 1962, HS Direksie, gp.

229 (HSA) HVKP, Notuleboek (8 Feb 1940-9 Des 1966), 27 Mrt 1963, HS Direksie, gp; 23 Mrt 1964, HS Direksie, gp.

230 (HSA) HVKP, Notuleboek (8 Feb 1940-9 Des 1966), 23 Mrt 1964, HS Direksie, gp; 9 Jun 1964, HS Direksie gp.

231 (HSA) HVKP, Notuleboek (8 Feb 1940-9 Des 1966), 3 Mrt 1966, HS Direksie, gp.

232 (HSA) HS, Notuleboek (19 Jan 1967-16 Feb 1973), 18 Jun 1969, HS UK, gp.

233 (HSA) HS, Notuleboek (19 Jan 1967-16 Feb 1973), 16 Feb 1968, HS Direksie, gp.
} 
wat die aandelemark gebied het te benut. ${ }^{234}$ Beleggings is gemaak in Oude Meester, FVB, ${ }^{235}$ Santam, Trust Bank, ${ }^{236}$ in blokke aandele wat Santam vir die Helpmekaar in Monkor, sy dorpsontwikkelingsmaatskappy gereserveer het, ${ }^{237}$ terwyl ook aandele opgeneem is in ongenoteerde maatskappye soos Van Zyl \& Robinson (Edms) Bpk. Die voordele wat Afrikaner sakenetwerke vir die Helpmekaar ingehou het, is prakties geillustreer in die Santam aanbod om 2000 Mondorp-aandele teen R1,20 op te neem. Vier maande later het die aandele teen R5,50 op die JSE verhandel. ${ }^{238}$ Die sekretaris se verslag vir 1968 het die beleid om meer fondse in verhandelbare aandele te belê regverdig deur daarop te wys dat veranderinge in die bankwet dit vir finansiële instellings moeilik gemaak het om soos voorheen die Helpmekaar tegemoet te kom indien hul voortydig van hul vaste beleggings wou opvra om in hul kontantvloeibehoeftes te voorsien.

Aandelebeleggings is as alternatief hiervoor voorgehou vanweë hul likiede vorm en hoewel die inkomste uit die aandelebeleggings minder was as byvoorbeeld vaste deposito's het hul kapitaalwins meer as opgemaak daarvoor. ${ }^{239} \mathrm{Na}$ 'n bespreking van die verslag is die Beleggingskomitee onder voorsitterskap van CF Albertyn gelukgewens met die suksesvolle vermeerdering van die Helpmekaar se kapitaal. Albertyn het voorgestel dat die Helpmekaar na maatskappye moes gaan wat aandele-uitgifte onderskryf en hulle vra om as 'n saak van beleid, spesiale tegemoetkoming te verleen aan die Helpmekaar by die plasing van aandele. ${ }^{240}$ Die direksie het ook die beleid om meer van die Helpmekaar se reserwefondse in verhandelbare aandele te hou met die oog op kapitaalvermeerdering goedgekeur, op voorwaarde dat die Fonds sy hoofdoelstelling, naamlik die verskaffing van studiehulp, ten volle nakom. ${ }^{241}$ Met die oog op die meer aggressiewe uitbouing van die Helpmekaar se aandeleportefeulje is GJ Horn, 'n Kaapstadse sakeman wat voorheen op die Vereniging se hoofbestuur gedien het, op die direksie gekoöpteer, veral met die oog daarop om as bykomende raadgewer die Beleggingskomitee te versterk. ${ }^{242}$

234 (HSA) HS, Notuleboek (19 Jan 1967-16 Feb 1973), 12 Nov 1968, HS Dagbestuur, gp.

235 (HSA) HS, Notuleboek (19 Jan 1967-16 Feb 1973), 18 Apr 1968, HS UK, gp.

236 (HSA) HS, Notuleboek (19 Jan 1967-16 Feb 1973), 15 Jan 1969, HS Dagbestuur, gp.

237 (HSA) HS, Notuleboek (19 Jan 1967-16 Feb 1973), 26 Sep 1968, HS Dagbestuur, gp.

238 (HSA) HS, Notuleboek (19 Jan 1967-16 Feb 1973), 14 Feb 1969, HS Direksie, Kantoorverslag 24 Jan 1969, gp.

239 Ibid.

240 (HSA) HS, Notuleboek (19 Jan 1967-16 Feb 1973), 14 Feb 1969, HS Direksie, gp.

241 Ibid.

242 (HSA) HS, Notuleboek (19 Jan 1967-16 Feb 1973), 21 Feb 1969, HS Dagbestuur, gp. 


\section{Die Kaapse Helpmekaar}

Die bulmark op die JSE wat in die eerste helfte van 1969 sy hoogtepunt bereik het en die winsgewende beleggingsgeleenthede wat dit gebied het, het die Beleggingskomitee genoop om die riglyn dat 25 persent van Helpmekaar-fondse in aandele belê mag word te toets. Albertyn veral het geargumenteer dat die geleenthede wat onder andere hul voorgedoen het vanweë "die belofte wat sekere Afrikaanse maatskappy-base gedoen het dat hulle die Helpmekaar sal ken in die toekenning van privaat plasings of nuwe uitgifte"243 nie onbenut gelaat moes word nie. Albertyn se argumente dat die beskikbare geld op vaste deposito, asook die likiede aard van aandelebeleggings die gevaar uitskakel dat die Helpmekaar nie sy studieleningverpligtinge sal kan nakom nie. Hy het meegedeel dat 'n aandelebeleggingsadviseur, ene mnr Graves wat deur die Beleggingskomitee geraadpleeg is, die Helpmekaar met sy aandeleportefeulje gekomplimenteer het en aangebied het om die komitee van gratis advies te bedien. Na breedvoerige bespreking van die saak is op voorstel van ds Roos besluit om aan die Beleggingskomitee volmag te verleen om met die bestaande belegging in aandele (R193 000) te woeker en hul diskresie te gebruik indien daar verder goeie beleggingsgeleenthede in aandele hulle sou voordoen. Hulle is ook toestemming gegee om van Graves se aanbevelings gebruik te maak op 'n basis van ex gratia-vergoedings. ${ }^{244}$

Te midde van 'n besluit deur die Beleggingskomitee vroeg in Mei om 1000 aandele in Trust Bank, asook 1000 aandele in Glen Anil te koop ${ }^{245}$ het die JSE sy hoogtepunt in Mei 1969 bereik en teen die einde van die maand het die mark gebreek en die ineenstorting ingelui. ${ }^{246}$ Die gebruikmaking van Graves se dienste as beleggingsadviseur het dus hiermee saamgeval. Graves het 'n verslag opgestel met aanbevelings oor hoe die bestaande aandelebeleggingsportefeulje herrangskik moes word. Die Helpmekaar is ook gratis van raad bedien deur sowel die hoofde as beleggingsbestuurders van die groot Afrikaanse finansiële instellings. Die Beleggingskomitee het hulle op dié en Graves se aanbevelings verlaat en besluit dat hy toegelaat moes word om sonder onnodige inmenging volgens sy metode aandele te koop en verkoop. Die bedoeling van die Beleggingskomitee was om later, nadat daar genoegsame papierwins gemaak is, die aanvanklike kapitaal wat in aandele belê is terug te plaas en dan die wins in aandele te belê. ${ }^{247}$

243 (HSA) HS, Notuleboek (19 Jan 1967-16 Feb 1973), 18 Jun 1969, HS UK, gp.

244 Ibid.

245 (HSA) HS, Notuleboek (19 Jan 1967-16 Feb 1973), 8 Mei 1969, HS Beleggingskomitee, gp.

246 N Davenport, Money: a tale of two cities, Spectator, 14 Mrt 1970. http://archive.spectator.co.uk/article/14thmarch-1970/25/money-a-tale-of-two-cities

247 (HSA) HS, Notuleboek (19 Jan 1967-16 Feb 1973), 17 Jul 1969, HS Beleggingskomitee, gp; 13 Feb 1970, HS Direksie, Memorandum: Vertoë oor die Registrateur van Maatskappye se weiering om 'n wysiging in die HS se Akte van Oprigting goed te keur, 18 Feb 1970, gp. 
Die herskikkingsproses van die aandeleportefeulje het egter tekortkominge in die Helpmekaar-grondwet ontbloot wat verreikende beleggingsgevolge vir die Studiefonds kon inhou. Hoewel die Helpmekaar nie probleme ondervind het met die aankoop van FVB, Sanlam, Trust Bank, Volkskas, Rembrandt, SA Brouerye, Glen Anil en talle ander maatskappye nie is hul pogings om aandele in De Beers te koop afgekeur omdat die maatskappy (De Beers) van mening was dat die Helpmekaar volgens sy grondwet nie die mag gehad het om aandele in sy naam te registreer nie. Dis 'n interpretasie wat die Helpmekaar toegeskryf het aan die feit dat De Beers se Afrikaans "vermoedelik ... ontoereikend is." ${ }^{48}$ As korttermyn maatreël het die dagbestuur besluit om die De Beers-aandele voorlopig in die naam van 'n direkteur en die sekretaris te registreer totdat die nodige konstitusionele aanpassings goedgekeur is. Die Helpmekaar se makelaar het die besluit ook toe op verdere aandele-aankope toegepas wat die Studiefonds gelaat het met aandelesertifikate wat in individue se name in plaas van dié van die maatskappy uitgereik is. Die Helpmekaar het dus besluit om artikel 3(h), wat hulle nog altyd geïnterpreteer het as dat dit die direksie magtig om hul fondse op enige wyse te belê aan te pas om hul ook die uitdruklike reg te gee om in die aandele van enige private en openbare maatskappy te belê. ${ }^{249}$

Die wysiging is egter nie deur die Registrateur van Maatskappye goedgekeur nie omdat volgens hom 'n maatskappy sonder winsbejag nie aandele in 'n publieke maatskappy mag opneem nie. ${ }^{250}$ Die interpretasie is gebaseer op 'n ministeriële beslissing dat Artikel 21-maatskappye nie toegelaat mag word om hul beskikbare geld in aandele, dit wil sê beleggings van 'n spekulatiewe aard, te belê nie. Die beperking het egter nie gegeld ten opsigte van beleggings in privaat maatskappye nie. In hul vertoë tot die Registrateur het die Helpmekaar daarop gewys dat sy kantoor nog nooit die maatskappy van dié ministeriële beslissing in kennis gestel het nie terwyl hy bewus was van die Helpmekaar se beleggings in aandele wat reeds oor baie jare gestrek het. Dit het ook beteken dat as'n Artikel 21-maatskappy hulle "mag belê in 'n maatskappy wat blikoopsnyers vervaardig met onvoldoende kapitaal, maar hy mag nie

248 (HSA) HS, Notuleboek (19 Jan 1967-16 Feb 1973), 13 Feb 1970, HS Direksie, Memorandum: Vertoë oor die Registrateur van Maatskappye se weiering om 'n wysiging in die HS se Akte van Oprigting goed te keur, 18 Feb 1970, gp.

249 Artikel 3(h) van die doelstellings van die grondwet van die HM Studiefonds is dus gewysig met die byvoeging van die woorde "asook in aandele in enige privaat of publieke maatskappy" aan die einde van die paragraaf. Die paragraaf sou dus lui: "Om gelde van die Maatskappy wat nie onmiddellik benodig word nie sodanig te belê en daarmee te handel as telkens bepaal mag word en in besonder in staatseffekte, of op deposito, bougenootskapaandele, of in enige Suid-Afrikaanse bank, bougenootskap of deposito-nemende instelling, of erkende en gesonde finansiële inrigting, of op verbande, asook in aandele in enige privaat of publieke maatskappy”. (HSA) HS, Notuleboek (19 Jan 1967-16 Feb 1973), 5 Des 1969, HS spesiale algemene vergadering, gp.

250 (HSA) HS, Notuleboek (19 Jan 1967-16 Feb 1973), 5 Des 1969, HS Direksie, gp. 
belê in aandele van De Beers nie!"251 Die bepaling het beteken dat die HS dus nie die aandele wat met amalgamasie met die Vereniging bekom is kon behou nie, aandele wat hy deur erflatings bekom het of regte-uitgifte wat hulle weens die besit van die aandele mag toekom kon benut nie of die aanbiedings van "bevriende" finansiële instellings wat onderskrywings doen "om blokke aandele in nuwe uitgifte of regte-uitgifte in privaat plasings aan ons te laat toekom om sodoende ons te help om ons kapitaal uit te brei"252 sou kon benut nie.

Die Studiefonds het dus versoek dat die bepalings nie op die Helpmekaar wat "uitgestyg het tot die grootste vrywillige studiefonds in die land en (het) 'n trotse rekord met 'n fantastiese groei, sonder verliese of skokke" ${ }^{253}$ as gevestigde Artikel 21-maatskappy van toepassing gemaak moet word nie. Die direksie het ook besluit dat die voorsitter en sekretaris die registrateur sou gaan spreek en as daar geen bevredigende antwoord verkry word nie daar na die minister geappelleer sou word. ${ }^{254}$ Hoewel daar geen verdere verwysings na die uitkoms van die stappe is nie moet aanvaar word dat die Studiefonds se vertoë suksesvol was, aangesien soos voorheen voortgegaan is met die bestuur van hul aandeleportefeulje, asof die kabaal nooit plaasgevind het nie.

Uit die jaarverslag vir 1969 was dit duidelik dat die ineenstorting van aandelepryse op die JSE vir die Helpmekaar 'n traumatiese en onverklaarbare ervaring was wat ook hul fondseposisie nadelig geraak het. Ten spyte daarvan dat hulle al die regte dinge gedoen het kon dit nie verhoed dat hulle verliese ly nie. Die ineenstorting is uiteindelik aan sielkundige faktore toegeskryf en die Helpmekaar het deur die reeds genoemde herrangskikking van sy aandeleportefeulje en fokus op bekende maatskappye met goeie geskiedenisse en vooruitsigte gehoop om die verliese te verhaal - "maar wanneer die markwaarde van die aandele weer die aankooppryse gaan inhaal, moet die toekoms maar leer." ${ }^{255}$

Die afwaartse spiraal in aandelepryse het in 1970 voortgeduur en die Helpmekaar het hul posisie probeer beredder deur beleggingsgeleenthede waarvan hulle veral deur middel van hul Afrikanernetwerke bewus geword het, te benut. Hulle het ook voortgegaan om die advies van Afrikaner-sakeleiers in te win in die bestuur van hul aandeleportefeulje. In

251 (HSA) HS, Notuleboek (19 Jan 1967-16 Feb 1973), 13 Feb 1970, HS Direksie, Memorandum: Vertoë oor die Registrateur van Maatskappye se weiering om 'n wysiging in die HS se Akte van Oprigting goed te keur, 18 Feb 1970, gp.

252 Ibid.

253 Ibid.

254 (HSA) HS, Notuleboek (19 Jan 1967-16 Feb 1973), 13 Feb 1970, HS Direksie, gp.

255 (HSA) HS, Notuleboek (19 Jan 1967-16 Feb 1973), 13 Feb 1970, HS Direksie, Jaarverslag, 23 Jan 1970, gp. 
Junie 1970 is toestemming verleen om 1000 aandele in Van Zyl en Robinson, waarop dr Albertyn 'n opsie gehad het, teen R60 per aandeel aan te koop. Albertyn was bewus van vertroulike onderhandelinge waarvolgens die amptenare van die maatskappy beoog het om in 'n oornamepoging R75 per aandeel aan alle Van Zyl en Robinson aandeelhouers aan te bied. Die transaksie sou dus die Helpmekaar 'n wins van R15 000 in die sak kon bring. ${ }^{256}$

Die Beleggingskomitee het ook die advies van Dreyer Loubser, bestuurder van Sentrale Aksepbank, weens sy bekwaamheid en wye kennis, asook sy besondere geneentheid jeens die Helpmekaar, ingewin om hulle ten opsigte van die Helpmekaar se aandeleportefeulje te adviseer. Die UK het ook toestemming verleen dat hy die Beleggingskomitee se vergaderings bywoon. Loubser het aanbeveel dat die Helpmekaar sekere aandele, waarvan die groeivooruitsigte sedert 1969 verswak het weens die impak van regeringsmaatreëls om inflasie te bekamp (soos huurkoopbeheer), ten spyte van die verliese wat dit sou meebring te verkoop en dat beleggings eerder in aandele, soos goudaandele, gemaak word om vir die dalings te vergoed. ${ }^{257}$

Die Helpmekaar het dus aandele wat hulle vir R100 222,34 gekoop het vir R23 828,08 verkoop, wat 'n verlies van R76 394,26 meegebring het. Dit sou afgetrek word van die opgeloopte wins op aandeleverkope van R95 673,62. Met die opbrengs van die verkope is 7500 aandele in Klein Auob gekoop. ${ }^{258}$ Die Beleggingskomitee het via Van Rensburg en Vennote, wat'n blok van 7000 Klein Auob-aandele beskikbaar gehad het, van die geleentheid te hore gekom. Die verkoper van die kopermynaandele, waarin FVB, Marine Products en General Mining die grootste blok aandele besit het, het die aandele van R1 aangebied vir R4.20. Daar was egter'n dividend van R1 per aandeel op die aandele betaalbaar wat 'n inkomste van amper 25 persent op die belegging sou beteken. Die myn se lewensduur is op ongeveer 20 jaar gestel, maar verdere prospekteerwerk was aan die gang. ${ }^{259}$ Teen November 1970 het die aandelebelegging van genoteerde en ongenoteerde aandele teen R313 416 in die Helpmekaar se boeke gestaan, terwyl die markwaarde daarvan R172 820 was. Die aandele was dus R140 596 minder werd, maar daar is ook 'n wins van R95 673 op aandele gemaak sedert die Helpmekaar se besluit om meer aggressief in aandele te belê wat die werklike tekort op aandele teen November 1970 se pryse op R44 923 te staan gebring het. ${ }^{260}$

256 (HSA) HS, Notuleboek (19 Jan 1967-16 Feb 1973), 11 Jun 1970, HS Dagbestuur, gp.

257 (HSA) HS, Notuleboek (19 Jan 1967-16 Feb 1973), 12 Nov 1970, HS UK, gp.

258 (HSA) HS, Notuleboek (19 Jan 1967-16 Feb 1973), 12 Feb 1971, HS Direksie, Jaarverslag, 22 Jan 1971, gp.

259 (HSA) HS, Notuleboek (19 Jan 1967-16 Feb 1973), 12 Nov 1970, HS UK, gp.

260 Ibid. 


\section{Die Kaapse Helpmekaar}

Hierdie maatreëls het nie die situasie omgekeer nie, aangesien die jaarverslag vir 1971 gerapporteer het dat vorige winste wat met aandele gemaak is totaal uitgewis was weens die insinking op die beurs en die gevolglike hersamestelling van die aandeleportefeulje "soos aanbeveel deur ons raadgewers in die belangrikste Afrikaanse maatskappye". 261 Hoewel die verliese vir die Helpmekaar aansienlik was, was die jaarverslag steeds oortuig dat die Helpmekaar op die regte pad was met sy beleggingsbeleid:

"Dat so vele ander maatskappye en individue deur dieselfde lot getref is, maak dit nie minder bedroewend vir die Helpmekaar nie. Daar moet egter op gewys word dat dit geen ramp is wat die Helpmekaar getref het nie. Ons geleidelike en gesonde groei deur eie surplusses, asook die aansienlike wins wat nog te maak is uit Bethanie Beleggings, sal die verliese op aandele uitkanselleer en ons veel sterker laat staan as wat die geval sou gewees het as ons die ou konserwatiewe beleggingsbeleid bly volg het."262

Die impak van die beursineenstorting op die Helpmekaar was meer diepgaande as net die finansiële verliese wat dit teweeggebring het. Die twee jaar wat dus gevolg het op die uitwissing van alle vorige winste wat op aandele gemaak is, is gekenmerk deur groot onsekerheid van hoe en deur wie die aandeleportefeulje bestuur moes word. Dit het ook gelei tot verandering in die bestuurstruktuur van die Helpmekaar, waar met die dagbestuur weggedoen is en die beleggingskomitee tot 'n adviserende komitee afgegradeer is. Veranderinge het ook saamgeval met die aftrede van Ken Sinclair en die vul van die vakatures wat weens sy aftrede op die UK, dagbestuur en beleggingskomitee ontstaan het. Hierdie bestuursveranderinge word meer breedvoerig onder 'n volgende afdeling bespreek.

In Augustus 1972 het die sekretaris versoek dat oorweeg moes word om die Helpmekaar se aandeleportefeulje aan die Helpmekaar se makelaars te oorhandig om die verkoop en koop van aandele te hanteer, aangesien hy nie die tyd gehad het om die beurs gedurig dop te hou en aanbevelings te maak nie. Die voorstel het nie by almal byval gevind nie, aangesien sommige lede gevoel het dat die makelaars onnodig kon koop en verkoop ter wille van die kommissie. Die sekretaris is dus versoek om meer inligting oor makelaars in te win en ook 'n lys van aandeelhouding aan die direkteure te stuur. ${ }^{263}$ Die aangeleentheid is by 'n daaropvolgende UK-vergadering breedvoerig bespreek en daar is besluit dat die Helpmekaar nie sy aandele gaan verkoop en aandelebeleggings gaan staak nie, maar dat hulle sou fokus op aandele wat op die lang termyn groei inhou. 'n Aantal deskundiges uit bevriende maatskappye sou ook 
gevra word om die Helpmekaar te adviseer oor sy aandeleportefeulje en dat soveel direkteure as wat byeen gebring kon word daaroor moes besluit en opdragte gee. ${ }^{264}$

Die hele kwessie is indringend bespreek op 'n UK-vergadering in September 1972 waarop die beleggingsbestuurders van Homes Trust, mnr SA Marais, Trust Bank se dr De Swardt, B Baard van die makelaarsfirma PLJ van Rensburg en Vennote, asook P Bothma, finansiële redakteur van Die Burger, teenwoordig was. Op aanbeveling van die adviseurs is besluit dat die Helpmekaar moes konsentreer op aandele wat op die lang termyn groei, maar dit het beteken dat die andele gedurig dopgehou moes word met die oog op moontlike omruiling. 'n Aantal voorstelle oor spesifieke aandele is ook gedoen om die portefeulje beter te balanseer. ${ }^{265}$

In daaropvolgende vergaderings het JJ Piek, Anton Rupert se secundus op die direksie, sterk standpunt ingeneem dat die Helpmekaar se aandeleportefeulje in die hande geplaas moet word van 'n bevoegde instansie wat die tyd en kennis het om dit behoorlik te bestuur. Hy het aangevoer dat nóg die direkteure, nóg die sekretaris voldoende kennis van aandelebeleggings gehad het om dit te bestuur. Hy het ook betoog dat die direksie moes besin oor die wanverhouding tussen die ongenoteerde en genoteerde aandele van die maatskappy, asook die verhouding tussen beleggings in grond, nie-spekulatiewe aandele en vaste beleggings. Hy was gekant teen beleggings in ongenoteerde aandele. ${ }^{266} \mathrm{Hy}$ het ook gepleit vir'n gesonder verspreiding van die Helpmekaar se geld in diverse soorte renderende en groeibeleggings. Op voorstel van Piek het die direksie 'n besluit aanvaar dat die UK ondersoek instel na die voordele om die portefeulje deur 'n bevoegde instansie soos 'n trustmaatskappy te laat administreer, en dat die Helpmekaar sy portefeulje in gesonde verhouding bring tot die ander beleggings, met moontlike verdere belegging in vaste eiendom en ander veilige tipe beleggings. Die sekretaris is dus versoek om Federale Volksbeleggings en Santam te vra om na al die Helpmekaar se beleggings te kyk en die Helpmekaar te adviseer oor die samestellende verhouding daarvan, asook om afsonderlik te sê of hulle die Helpmekaar se portefeulje sal administreer en op watter basis en teen watter vergoeding. ${ }^{267}$

FVB se reaksie was dat hulle nie portefeuljes bestuur nie en nie bereid was om as maatskappy op die Helpmekaar se portefeulje kommentaar te lewer nie. Santam was wel bereid om die portefeulje teen 'n vergoeding van vyf persent kommissie te bestuur. Hulle het die aandele

264 (HSA) HS, Notuleboek (19 Jan 1967-16 Feb 1973), 31 Aug 1972, HS UK, gp.

265 (HSA) HS, Notuleboek (19 Jan 1967-16 Feb 1973), 11 Sep 1972, HS UK, gp.

266 (HSA) HS, Notuleboek (16 Feb 1973-10 Sept 1993), 16 Feb 1973, HS Direksie, gp.

267 (HSA) HS, Notuleboek (16 Feb 1973-10 Sept 1993), 27 Feb 1973, HS Direksie, gp. 


\section{Die Kaapse Helpmekaar}

almal as goeie aandele beskou en was tevrede met die verspreiding van die Helpmekaar se beleggings. $\mathrm{Na}$ 'n verdere breedvoerige bespreking het die UK besluit om vanweë die koste daaraan verbonde en dat "dit aandele-adviseurs was wat ons destyds geadviseer het om die aandele te koop wat toe so geweldig geval het, en dat hulle nou nie noodwendig beter sal vaar nie"268 nie die portefeulje vir administrasie deur 'n buite-instansie te oorhandig nie. Hulle sou dus voortgaan om kwartaalliks hul aandele-adviseurs te raadpleeg soos wat die gebruik sedert begin 1972 was. Hoewel daar aanvanklik gevoel is dat daar nie nog aandele aangekoop moes word nie is op versoek van ds Van der Westhuyzen en mnr Horn besluit om nie die Helpmekaar deur 'n beginselbesluit te laat bind nie, maar dat die UK elke geleentheid om aandele aan te koop deur byvoorbeeld aantreklike regte-uitgifte of bloktoekennings op meriete moes beoordeel. ${ }^{269}$

Teen Mei 1976 het die UK besef dat die stelsel waarvolgens die Helpmekaar self sy aandeleportefeulje bestuur op grond van die advies wat hulle kwartaalliks van die beleggingsbestuurders van Afrikaanse maatskappye inwin, ondoeltrefffend geword het. Die status van 'n aandeel kon in die interim periode tussen vergaderings met die beleggingsbestuurders verander en daar moes op 'n deurlopende basis aan die portefeulje aandag gegee word. Verder het die Rembrandt groep ook hulle beleggingsafdeling se dienste aangebied. Daar is dus besluit om die administrasie daarvan aan die firma PLJ van Rensburg en Huisamen toe te ken. Hulle moes hul aanbevelings aan die bestuurder oordra, wat dit met Rembrandt se beleggingsafdeling sou bespreek, waarna 'n komitee, bestaande uit mnre GR Pretorius, SPF van Aswegen en die bestuurder, desnoods met verdere raadpleging, hulle besluite aan die makelaars sou oordra. ${ }^{270}$ Hiermee het Piek, as Rupert se verteenwoordiger op die direksie, dus sy sin gekry deur die aanvaarding van 'n meer professionele benadering tot die hantering van die Helpmekaar-aandeleportefeulje.

Die tagtigerjare is oorheers deur die toenemende effek van inflasie op die fondse van die Helpmekaar en die vasbeslote wyse waarop die maatskappy aan sy aandelebeleggings vasgeklou het ten spyte van toenemende druk om die tekort aan fondse vir studielenings te herstel met die verkoop van hul aandele. Hierdie beleid het vrugte afgewerp, aangesien die stygende aandelepryse deur die loop van die tagtigerjare ten spyte van die insinking in die mark in 1987 die Helpmekaar teen die einde van die tagtigerjare met aansienlike boekwinste ten opsigte van hul aandeleportefeulje gelaat het.

\footnotetext{
268 (HSA) HS, Notuleboek (16 Feb 1973-10 Sept 1993), 12 Apr 1973, HS UK, gp.

269 Ibid.

270 (HSA) HS, Notuleboek (16 Feb 1973-10 Sept 1993), 11 Mei 1976, HS UK, 36.
} 
Die winste wat die Helpmekaar se aandeleportefeulje teen begin 1983 getoon het - die aandele het 'n boekwins van R133 000 getoon ten spyte van die daling in die mark na die aankondiging dat die finansiële rand afgeskaf gaan word - het die direksie laat besin oor die moontlike verkoop van die aandele om die groei te benut en die geld vir lenings aan te wend. Die jaarvergadering het hieroor besin. Horn het sterk geargumenteer vir die behoud van die aandeleportefeulje op grond van die kapitaalgroei wat dit ingehou het. Dit was 'n noodsaaklike vereiste vir die Helpmekaar se vermoë om steeds in die toenemende aanvraag na studielenings te kon voldoen in die lig van die invloed van inflasie op hul fondse en ook as teenvoeter vir die nie-markverwante koerse wat die Helpmekaar op sy studielenings gehef het. Die invloed van dié faktore het groter geraak hoe meer geld aan studente uitgeleen is. Hy het dus geargumenteer vir 'n balans tussen die verskillende beleggingsvelde: studente, aandele, vaste deposito's en vaste eiendom - sodat die Helpmekaar verseker was van kapitaalgroei aan die een kant om te vergoed vir die erosie aan die ander kant.

Hy het ook aanbeveel dat die Helpmekaar weer na sy uitleenkoerse moes kyk. Horn is deur ander trustees ondersteun en die Raad van Trustees het dus besluit om die aandeleportefeulje voorlopig so te hou, veral omdat al die genoteerde aandele goeie aandele was. ${ }^{271}$ Die besluit het vrugte afgewerp, aangesien die waarde van die aandele teen begin 1984 die aankoopwaarde met R166 686 oorskry het ${ }^{272}$ en teen Januarie 1986 reeds 'n boekwins van R402 100 getoon het. Die groot uitblinker was Tegniese Beleggingskorporasie wat 'n realiseerbare wins van R339 800 op 'n oorspronklike belegging van R21 799 getoon het. ${ }^{273}$ Teen September 1986 het die Helpmekaar se portefeulje 'n realiseerbare wins van R910 553 getoon. ${ }^{274}$

Die wêreldwye ineenstorting van aandelemarkte in Oktober 1987, wat ingelui is deur die daling op Amerikaanse markte op Maandag 19 Oktober waartydens die Standard en Poorsindeks van die 500 topmaatskappye op die New Yorkse aandelebeurs ongeveer 20 persent

271 (HSA) HS, Notuleboek (16 Feb 1973-10 Sept 1993), 11 Feb 1983, HS jaarvergadering, 70; Jaarverslag, 11 Feb. 1983, 70; Paul-Francois Muzindutsi, The Response of the Johannesburg Stock Exchange to Changes in Exchange Rate Regimes, 414-415, Mediterranean Journal of Social Sciences, 4 (6), Jul 2013.

272 (HSA) HS, Notuleboek (16 Feb 1973-10 Sept 1993), 10 Feb 1984, HS Jaarvergadering, 76.

273 (HSA) HS, Notuleboek (16 Feb 1973-10 Sept 1993), 14 Feb 1986, HS jaarvergadering, Jaarverslag, 85.

274 (HSA) HS, Notuleboek (16 Feb 1973-10 Sept 1993), 20 Feb 1987, HS jaarvergadering, Jaarverslag, 88. 
van sy waarde verloor het, ${ }^{275}$ het ook die Helpmekaar se aandeleportefeulje nadelig geraak en die waarde met ongeveer R2 miljoen laat daal. ${ }^{276}$ Soos in 1969 het die Helpmekaar en sy finansiële raadgewers nie die daling voorsien nie en het die bestuurder in sy jaarverslag aangedui dat die drie kenners wat hulle kort voor die ineenstorting in Oktober geraadpleeg het selfs aanbeveel het dat oorweeg moes word om meer van dieselfde aandele te koop vanweë die hoë gehalte van die aandele in hul portefeulje. Ten spyte van die daling was die boekwins van die portefeulje teen Februarie 1988 steeds R893 231. Hierdie daling het ook saamgeval met die groot druk wat die Helpmekaar beleef het ten opsigte van 'n tekort aan fondse om in sy studenteleningsbehoeftes te voorsien. Die 1988-algemene jaarvergadering het egter ten spyte hiervan besluit om nie aan die druk om van hul aandele te verkoop toe te gee nie, maar om die portefeulje te behou as teenvoeter en verskanser teen die invloed van inflasie op die Helpmekaar se fondse. ${ }^{277}$

Die UK het ook besluit om 'n aktuaris te raadpleeg om te bepaal watter persentasie van die Helpmekaar se fondse in aandele belê behoort te word. ${ }^{278}$ Dr Albertyn het ook versoek dat, indien die Helpmekaar wel van sy aandele moes verkoop om lenings te dek, dit op 'n basis van 'n 10 persent-verkoping van alle aandele moes geskied sodat daar 'n eweredige vermindering van die portefeulje sou plaasvind. ${ }^{279}$ Die besluit om sy aandeleportefeulje as verskanser teen inflasie te behou het vrugte afgewerp, aangesien die herstel van die aandelemark in die vaarwater van die 1987-ineenstorting die boekwins van die Helpmekaar se portefeulje van R951 639 teen einde Maart 1988 laat toeneem het tot R1 830794 teen einde Januarie 1989. ${ }^{280}$ Teen die einde van die tagtigerjare het beleggings in aandele hulself dus gevestig as 'n permanente en prominente kategorie van Helpmekaar-fondse wat die beste beskerming teen inflasie-erodering gebied het. Van daar dan ook die vaste voorneme om

https://www.tandfonline.com/doi/abs/10.1080/10291954.1997.11435066 (GDI Barr and L Sharp, The realignment of international stock markets after the $1987 \mathrm{crash}$, with special reference to the Johannesburg Stock Exchange, South African Journal of Accounting Research, II (1), 1997, 1-13); Finance and Economics Discussion Series, Divisions of Research \& Statistics and Monetary Affairs, Federal Reserve Board, Washington, D.C. (A Brief History of the 1987 Stock Market Crash with a discussion of the Federal Reserve Response, Mark Carlson, 2007-13 www.federalreserve.gov/pubs/feds/2007/200713/200713pap.pdf oor raadsbesluite, 16 Aug 1991, 115.

277 (HSA) HS, Notuleboek (16 Feb 1973-10 Sept 1993), 19 Feb 1988, HS jaarvergadering, Jaarverslag, 93; 20 Feb 1987, HS jaarvergadering, Jaarverslag, 88; 18 Feb 1988, HS jaarvergadering, Jaarverslag, 92; 19 Feb 1988, HS jaarvergadering, 94.

(HSA) HS, Notuleboek (16 Feb 1973-10 Sept 1993), 4 Mrt 1988, HS UK, 94. 
ten spyte van die druk van 'n tekort aan leningsfondse nie van enige Helpmekaar-aandele ontslae te raak nie. ${ }^{281}$

Die Helpmekaar se ervaringe in die ongeveer twee dekades na amalgamasie en die besluit om van hul konserwatiewe beleggingsbenadering af te sien was 'n venster op wat ook in die breër Afrikanersamelewing in dié verband hom afgespeel het. Die vroeëre "wantroue" en "antagonisme" jeens die kapitalistiese sakemodel met sy konjunktuurskommelinge en risiko's, maar ook sy gul beloning vir aktiewe en ondernemende deelnemers is grootliks besweer. Soos die breër Afrikanersamelewing se bekering tot die kapitalistiese verbruikerskultuur in dié periode het die Helpmekaar ook tot die insig gekom dat die suksesvolle en volhoubare uitvoering van sy taak van volksopheffing deur onderwys slegs deur sy aktiewe deelname aan en omarming van die kapitalistiese stelsel gewaarborg kon word.

\section{VAN ZYL'S GIFT}

Senator Van Zyl het reeds tydens 'n vergadering van die kuratore van die B-fonds in Junie 1952 sy en sy eggenote se voorneme om die B-fonds die volle erfgenaam van hul nalatenskap te maak, bekend gemaak. ${ }^{282}$ Die voordele van die nalatenskap het eers deur die loop van die sewentigerjare begin realiseer. Aangesien Van Zyl begerig was dat die voordele van sy nalatenskap die Studiefonds reeds tydens sy lewe moes toeval, het hy by verskeie geleenthede in 1962 en weer in 1966 voorstelle gemaak om die Helpmekaar toegang te gee tot die vernaamste bate in sy boedel, naamlik 'n stuk nywerheidsgrond van 10 morg in die Strand. Die Studiefonds kon egter weens 'n kombinasie van die spekulatiewe aard van die voorstelle en 'n gebrek aan fondse nie aan die voorwaardes voldoen nie. ${ }^{283}$

'n Skenkingsooreenkoms is egter in 1972 tussen Van Zyl en die Studiefonds onderteken wat in 'n verdere aanhangsel van Maart 1975 op sekere punte aangepas is en wat behels het dat 'n Senator Dawie Van Zyl Fonds tot stand gebring sou word met die opbrengs van sy bemakings. Die opbrengs van die Fonds sou aangewend word vir die skoling van studente in die Gereformeerde teologie by voorkeur uit die NG Kerk, maar ook studente uit die Gereformeerde Kerk, Nederduitsch Hervormde Kerk en dogterkerke van voormelde kerke. Dis ook aangewend vir studies in genees- en verpleegkunde, onderwys in diens van die sendingveld, maatskaplike werk en aanverwante studies wat mense skool in rigtings waar

281 (HSA) HS, Notuleboek (16 Feb 1973-10 Sept 1993), 23 Feb 1990, HS jaarvergadering, 105.

282 (HSA) HVKP, Notuleboek (8 Feb 1940-9 Des 1966), 11 Jun 1952, B-fonds Kuratore, 133.

283 (HSA) HVKP, Notuleboek (8 Feb 1940-9 Des 1966), 22 Feb 1962, HS Direksie, gp; 24 Mei 1962, HS Direksie, gp; 9 Des 1966, HS Direksie, gp. 


\section{Die Kaapse Helpmekaar}

hulle sou kon help om morele en geestelike verval in die land teë te werk. Die trustees kon egter ook hul diskresie gebruik in geval van aansoeke wat met die gees van laasgenoemde strook. Van Zyl het bepaal dat "die behoeftes van ons eie Afrikaner-volk sal voorkeur geniet wanneer toekennings gemaak word" 284 en dat die trustees se besluite finaal sou wees. Geen provinsiale grense sou ook in die toekenning van hulp erken word nie. Op die eerste R50 000 van die kapitaal van die Fonds moes die Helpmekaar aan Van Zyl rente teen sewe persent per jaar in maandelikse paaiemente betaal en na sy dood aan sy weduwee teen ses persent per jaar. Sy eggenote kon na sy dood jaarliks met die Helpmekaar oor haar behoeftes onderhandel en sy kon vertoë vir meer fondse rig. Die grond moes so spoedig moontlik in nywerheidspersele ontwikkel en verkoop word en die opbrengs in die Senator Dawie Van Zyl Fonds gestort word. Die nywerheidsgebied moes as Dawie Van Zyl's Gift bekend staan. Van Zyl het sy skenking as volg gemotiveer:

"Ek is vanaf 1915/16 verbonde aan die Helpmekaar en ek het deur die jare gesien watter wonderlike resultate behaal is deur die bystand wat die Helpmekaar verskaf het. Ek is veral begaan oor die opheffing van die mindergegoedes onder alle lae van die bevolking, en in hierdie gees moet die hulp uit hierdie Fonds aangebied word."285

In 'n poging om die waarde van Dawie Van Zyl's Gift te ontsluit het die Helpmekaar 'n proses begin om toestemming te verkry om die grond in nywerheidspersele te onderverdeel en in 'n nywerheidsdorp te ontwikkel. Die proses, wat die Afdelingsraad van Stellenbosch, Departement van Beplanning, Frans Conradie (Lid van die UK van die Provinsiale Administrasie) en die Strandse Munisipaliteit ingesluit het, het 'n lang uitgerekte stryd geword. Nadat onderverdeling by verskeie geleenthede óf vertraag óf geweier is, is goedkeuring uiteindelik in Oktober 1977 verleen $^{286}$ en toestemming vir die stigting van 'n nywerheidsdorp in September 1979 verkry. ${ }^{287}$ In die proses het die Afdeling Nasionale Paaie van die Departement van Vervoer 2.56 hektaar van Van Zyl's Gift vir 'n padreserwe onteien

284 (HSA) HS, Notuleboek (16 Feb 1973-10 Sept 1993), Ooreenkoms van skenking, gedateer 24 Apr 1972 en bylae tot die skenkingsakte tussen oudsenator DH van Zyl en die Helpmekaar Studiefonds, gedateer 29 Aug 1973, 10; 26 Mrt 1975, HS UK, Reglement. Bylae tot skenkingsakte tussen oudsenator DH van Zyl en die Helpmekaar Studiefonds, 27.

286 (HSA) HS, Notuleboek (16 Feb 1973-10 Sept 1993), 8 Aug 1973, HS UK, 8; 28 Mrt 1974, HS UK, 18; 26 Mrt 1975, HS UK, 28; 28 Okt 1975, HS UK, 29, 30; 13 Feb 1976, HS jaarvergadering, Jaarverslag, 31; 13 Feb 1976, HS jaarvergadering, 33; 24 Nov 1976, HS UK, 38;10 Feb 1978, HS jaarvergadering, Jaarverslag, 47. 
waarvoor die Helpmekaar R194 250 - gebaseer op 75c per voet ${ }^{2}$ - geëis het. Die Departement van Vervoer het die Helpmekaar uiteindelik R178 000 vir die onteiende grond betaal. ${ }^{288}$

In Februarie 1981 het die raad tydens die algemene jaarvergadering toestemming verleen dat met die verkoop van die eerste nege persele voortgegaan kon word. ${ }^{289}$ Die besluit het saamgeval met DH van Zyl se afsterwe in Februarie $1981^{290}$ en die toeval van sy boedel van ongeveer R300 000, waarop sy weduwee vruggebruik gehad het, aan die Helpmekaar. ${ }^{291}$ Teen die einde van 1981 is die eerste geboue op Van Zyl's Gift opgerig en het die landmeter die waarde van die beskikbare grond, bereken op die prys van die verkoopte persele, op R2,5 miljoen gestel. ${ }^{292}$ Aangesien verdere verkope beteken het dat dienste soos riolering teen 'n geraamde koste van R1 000000 aangelê sou moes word, het die stadsbeplanner van die Strand se munisipaliteit aanbeveel dat die Helpmekaar moes wag tot die Strand se dienste nader aan Van Zyl's Gift kom, aangesien dit die kostes drasties sou verlaag. Die inkomste uit die verkope sou intussen belê en gereserveer word vir die toekomstige aanlê van die nodige dienste. ${ }^{293}$

Teen die einde van 1983 is reeds tien persele van Van Zyl's Gift verkoop met 'n netto opbrengs van R411 000. Die aanvraag vir die persele was besonder goed en die pryse wat herverkoopte persele behaal het, het aangetoon dat die oorspronklike verkooppryse veels te laag was. Die verwagting was dus dat die oorspronklike verwagte inkomste van R2,75 miljoen waarskynlik verdubbel sou kon word. Die Raad het ook besluit dat geen verdere geld in die Senator Dawie Van Zyl Fonds inbetaal sou word nie, maar vir die verdere ontwikkeling van die grond gereserveer sou word. ${ }^{294}$ Teen einde 1984 is reeds 12 persele in Van Zyl's Gift verkoop wat R553 000 opgelewer het. Gebaseer op die markpryse en die 177500 meter $^{2}$ grond wat nog beskikbaar was, het die grond 'n potensiële inkomste van tussen R4-5,3 miljoen verteenwoordig. ${ }^{295}$ Saam met die fondse van die Van Zyl-boedel wat in die DH van

288 (HSA) HS, Notuleboek (16 Feb 1973-10 Sept 1993), 22 Jul 1977, HS UK, 44; 10 Feb 1978, HS jaarvergadering, Jaarverslag, 47; 9 Feb 1979, HS jaarvergadering, Voorsittersrede, 52.

289 (HSA) HS, Notuleboek (16 Feb 1973-10 Sept 1993), 13 Feb 1981, HS jaarvergadering, 61; 26 Nov 1980 , HS UK, 58.

290 (HSA) HS, Notuleboek (16 Feb 1973-10 Sept 1993), 26 Feb 1981, HS UK, 62.

291 (HSA) HS, Notuleboek (16 Feb 1973-10 Sept 1993), 12 Feb 1982, HS jaarvergadering, 66.

292 (HSA) HS, Notuleboek (16 Feb 1973-10 Sept 1993), 12 Feb 1982, HS jaarvergadering, Jaarverslag, 65.

293 (HSA) HS, Notuleboek (16 Feb 1973-10 Sept 1993), 29 Jun 1983, HS UK, 71, 72.

294 (HSA) HS, Notuleboek (16 Feb 1973-10 Sept 1993), 10 Feb 1984, HS jaarvergadering, Jaarverslag, 75; 10 Feb 1984, HS jaarvergadering, 76.

295 (HSA) HS, Notuleboek (16 Feb 1973-10 Sept 1993), 15 Feb 1985, HS jaarvergadering, Jaarverslag, 79. 


\section{Die Kaapse Helpmekaar}

Zyl Trust vervat was en waarvan die Helpmekaar die begunstigde sou wees na die afsterwe van mev Van Zyl ${ }^{296}$ het Van Zyl dus deur sy skenking van Van Zyl's Gift en sy boedelbates 'n aansienlike potensiële bydrae tot die uitbouing van die Helpmekaar-fondse gelewer. Die veranderde konteks van die negentigerjare sou egter uiteindelik die optimistiese verwagtinge oor die opbrengs uit Van Zyl’s Gift aansienlik temper.

\section{Die erwe van ons vad 're}

Afgesien van die bou van Helpmekaar-kapitaal deur eiendoms- en aandelebeleggings was die Helpmekaar in die post-amalgamasie-era erfgenaam en langtermynbegunstigde van Afrikaner inisiatiewe waarvoor die aanvoorwerk hoofsaaklik in die voorafgaande dekades gedoen is. Staatmakers soos die kerk, Helpmekaartakke en erflatings, maar ook oorblyfsels van Afrikaner-nasionalistiese inisiatiewe het as "toevallige" bydraes die Helpmekaar se kapitaalbasis versterk. Die periode is ook gekenmerk deur pogings om deur statutêre belastingtoegewings hierdie stroom van inkomste van die publiek en die sakewêreld te stimuleer.

Die kerk het deurlopend deur die geskiedenis van die Helpmekaar 'n belangrike bron van kapitaal verteenwoordig en dit was veral pogings om deur middel van gereelde deurkollektes deur NG gemeentes Helpmekaar-kapitaal te versterk wat dié periode gekenmerk het. Hoewel die idee van deurkollektes nie nuut was nie en reeds in die vyftigerjare deur beide die Vereniging en Studiefonds as potensiële bron van inkomste geïdentifiseer en benut is, veral met die oog op Helpmekaar-inisiatiewe om 'n Teologiese Beursfonds tot stand te bring, ${ }^{297}$ het 'n inisiatief sedert die laat sewentigerjare na 'n stadige en onseker begin deur die loop van die tagtigerjare baie bevredigende resultate opgelewer.

Briewe wat aan alle Kaaplandse gemeentes van die NG Kerk gestuur is met 'n versoek om spesiale deurkollektes vir die Teologiese Beursfonds te hou het aanvanklik slegs sporadies positiewe reaksie van gemeentes ontlok. $\mathrm{Na}$ 'n voorstel van een van die trustees, GJB Volschenk, dat persoonlik met ringe in dié verband kontak gemaak moet word, ${ }^{298}$ het die reaksie verbeter. Teenoor die agt gemeentes wat in 1982 spesiale deurkollektes vir

296 (HSA) HS, Notuleboek (16 Feb 1973-10 Sept 1993), 23 Feb 1990, HS jaarvergadering, Jaarverslag, 13 Feb 1990, 103.

297 (HSA) HVKP, Notuleboek, 2-3 Apr 1957, Kongres, Voorsittersrede, 1-3; 5-6 Apr 1955, Kongres, 2; (HSA) HVKP, Notuleboek (8 Feb 1940-9 Des 1966), 23 Nov 1956, Kuratore B-fonds, 184-185; 11 Mrt 1965, HS, Vergadering tussen Dagbestuur van kuratorium van Kweekskool en HM Studiefonds, gp. In 1965 het 77 gemeentes van die NG Kerk jaarliks 'n spesiale deurkollekte vir die Helpmekaar gehou.

298 (HSA) HS, Notuleboek (16 Feb 1973-10 Sept 1993), 11 Feb 1983, HS jaarvergadering, 70. 
die Teologiese Beursfonds gehou het, het die getal in die 1983-boekjaar tot 52 gemeentes vermeerder. ${ }^{299}$ In die 1984-boekjaar is op voorstel van Volschenk die name en bedrae van die gemeentes wat die vorige jaar bygedra het by die brief aan die gemeentes ingesluit met 'n verdere versoek dat gemeentes die Oujaarsaandmiddernagdiens vir die Helpmekaarkollekte moes oormerk. ${ }^{300}$ Ten spyte van die aanvanklike skeptisisme onder sommige lede oor die lewensvatbaatheid van die deurkollektes as bron van kapitaal het die bydraes toegeneem van agt gemeentes wat R1 111 in 1982 bygedra het tot 104 gemeentes wat R19 723 in 1991 bygedra het. ${ }^{301}$ Die Kerk het dus op dié wyse sedert die laat sewentigerjare 'n konstante bydrae tot die groei van Helpmekaar-kapitaal gelewer.

Erflatings is reeds vroeg deur die Helpmekaar as potensiële bron van kapitaal geïdentifiseer. Die Helpmekaar is nooit oorval deur erflatings wat hul begunstig het nie. Dié wat hul wel toegeval het en nie van die omvang van die Van Zyl-bemaking was nie, het nogtans 'n bron om Helpmekaar-kapitaal aan te vul gebly waarmee in die post-amalgamasie-era sukses behaal is. Afgesien van Afrikaner sentimente is die feit dat bemakings aan die Helpmekaar vrygestel was van boedelbelasting ook aan potensiële erflaters voorgehou as motivering om die Helpmekaar in hul boedels te begunstig. ${ }^{302}$ Voorbeelde van bemakings wat in die post-amalgamasie-era ontvang is, was dié van mev Van der Westhuyzen van Upington ${ }^{303}$ (ongeveer R50 000) ${ }^{304}$, die Schoon-erflating (ongeveer R24 000) en dié van G van Heerden. ${ }^{305}$

Opgepotte takfondse het ook onverwagte meevallers opgelewer wat Helpmekaar-kapitaal versterk het. Hoewel die takstelsel formeel in 1965 beëindig is, het sommige takke bly voortbestaan en oor fondse beskik wat volgens die Helpmekaar se grondwet die Helpmekaar moes toeval indien die takke sou ontbind. In 1972 is sodanige takke versoek om hul geld by die Helpmekaar te belê sodat dit makliker sou wees om beheer oor die fondse oor te neem indien plaaslike beheer uiteindelik sou verval. ${ }^{306}$ Dit is onduidelik hoeveel takke ter sprake was, wat die bedrae was wat ter sprake was en wat hul reaksie op die versoek was. Die feit dat

299 (HSA) HS, Notuleboek (16 Feb 1973-10 Sept 1993), 10 Feb 1984, HS jaarvergadering, 76.

300 (HSA) HS, Notuleboek (16 Feb 1973-10 Sept 1993), 15 Feb 1985, HS jaarvergadering, 82.

301 (HSA) HS, Notuleboek (16 Feb 1973-10 Sept 1993), 2 Mrt 1989, HS jaarvergadering, Jaarverslag, 23 Feb 1989, 98.

302 (HSA) HS, Notuleboek (19 Jan 1967-16 Feb 1973), 16 Nov 1967, HS UK, gp; 11 Feb 1972, HS Direksie, gp.

303 (HSA) HS, Notuleboek (19 Jan 1967-16 Feb 1973), 5 Jul 1968, HS Dagbestuur, gp.

304 (HSA) HS, Notuleboek (19 Jan 1967-16 Feb 1973), 26 Sep 1968, HS Dagbestuur, gp; 13 Feb 1970, HS jaarvergadering, Jaarverslag, 23 Jan 1970, gp.

305 (HSA) HS, Notuleboek (19 Jan 1967-16 Feb 1973), 14 Feb 1969, HS Direksie, gp.

306 (HSA) HS, Notuleboek (19 Jan 1967-16 Feb 1973), 11 Feb 1972, HS Direksie, gp. 


\section{Die Kaapse Helpmekaar}

die Paarltak so laat as 1985 'n bedrag van R12 743, wat nog in die plaaslike tak se rekening was, aan die Helpmekaar oorbetaal het ${ }^{307}$ en die Villiersdorptak wat met die bedanking van CP Jamneck as trustee in November 1992 die bedrag van R6 000 aan die Studiefonds oorbetaal het as die restant van die fondse van die voormalige tak was egter 'n aanduiding dat plaaslike takke nie almal aan die 1972-versoek gehoor gegee het nie. ${ }^{308}$

Daar is ook aanduidings dat die Helpmekaar in die post-amalgamasie-era die "stortingsterrein" geword het van vroeëre Afrikaner inisiatiewe wat veral sedert die sestigerjare as deel van 'n breër tendens toenemend onaktief geword het. Daar is "voogde" gesoek om die bestuur van nog bestaande fondse waaroor die inisiatiewe beskik het oor te neem. In 1974 het die Robertson RDB-studiefonds R5 314, 95 aan die Studiefonds geskenk ${ }^{309}$ en in Februarie 1985 is die restant van die Wolraad Woltemade Monumente-fonds aan die Helpmekaar oorgedra. Die fonds was 'n oorblyfsel van 'n inisiatief wat in die vaarwater van die 1952-Van Riebeekfees deur Herman Steytler geïnisieer is met die doel om geld in te samel vir 'n Wolraad Woltemade standbeeld. Die beeld wat aanvanklik in die see by Woodstock strand opgerig sou word, het uiteindelik sy plek voor Ou Mutual se hoofkantoor in Pinelands gevind nadat beplande hawe-uitbreidings in die Woodstock kusgebied aan die lig gekom het. Die beheerkomitee van die inisiatief het die aanvanklike restant van die fondse van R12 000 aan die Helpmekaar geskenk. Aangesien die breë publiek en veral skoolkinders van oor die hele Kaapprovinsie tot die Fonds bygedra het, was regsmening op daardie stadium van opinie dat slegs 'n hof toestemming vir so 'n oordrag kon verleen. Aangesien die komitee van dié opsie teruggedeins het, het die fondse wat deur Theron Van der Poel geadministreer is vir jare onaangeraak gelê totdat die firma in 1985 besluit het om die komitee se wense uit te voer en die geld (toe R47 100) aan die Helpmekaar oor te betaal. ${ }^{310}$ In 1986 het die Helpmekaar besluit om die Woltemade skenking onder die kategorie "skenkingsfondse" as aparte item in die balansstaat te behou en die Oranje Klub Fonds op dieselfde wyse te hanteer - en om historiese redes weer die Ons Eie Vlag Fonds wat uit 'n vroeëre era dateer het ook weer op dié wyse in die balansstaat aan te toon. ${ }^{311}$ Sy ikoniese ontstaansgeskiedenis, lofwaardige doelstellings en bewese langlewendheid het waarskynlik bygedra tot bogenoemde keuse van die Helpmekaar as waardige "bewaarder" van Afrikanerkapitaal.

\footnotetext{
307 (HSA) HS, Notuleboek (16 Feb 1973-10 Sept 1993), 14 Feb 1986, HS jaarvergadering, Jaarverslag, 84.

308 (HSA) HS, Notuleboek (16 Feb 1973-10 Sept 1993), 30 Nov 1992, HS Trustees, 124.

309 (HSA) HS, Notuleboek (16 Feb 1973-10 Sept 1993), 15 Feb 1974, HS Direksie, 17.

310 (HSA) HS, Notuleboek (16 Feb 1973-10 Sept 1993), 15 Feb 1985, HS jaarvergadering, 82.

311 (HSA) HS, Notuleboek (16 Feb 1973-10 Sept 1993), 14 Feb 1986, HS jaarvergadering, 86.
} 
Aangesien die Helpmekaarbeweging sedert sy ontstaan in 1915 aangewese was op en die gevolg was van die etniese sentimente, goeie guns, barmhartigheid en vrygewigheid - die filantropie - van die Afrikaner-publiek, is voortdurend na meganismes gesoek om dié publieke geldstroom te tap deur voordele te koppel aan skenkings aan die Helpmekaar. Afgesien van etnisiteit en die bevordering van etniese belange as motiveringsmeganisme is gepoog om statutêre voordele vir skenkers te beding. Met die ingang van die post-amalgamasieera was boedelbemakings aan die Helpmekaar reeds van boedelbelasting vrygestel. Bedrae deur die Helpmekaar geskenk was vrygestel van geskenkbelasting en die Helpmekaar was ook van inkomste- en seëlbelasting vrygestel. ${ }^{312}$ Aangesien die Helpmekaar egter nie as opvoedkundige instelling soos byvoorbeeld universiteite beskou is nie, kon skenkers van fondse aan die Helpmekaar nie hul skenkings vir inkomstebelastingdoeleindes aftrek nie. As deel van die beplande groot nasionale Helpmekaar-insamelingsveldtog van die vroeë sestigerjare het die direksie van die HS in Mei 1961 onder andere besluit om die tesourier te nader met die versoek dat skenkings aan die Helpmekaar belastingvry sou wees soos dié aan universiteite. ${ }^{313}$ Hoewel die presiese uitkoms van die versoek onbekend is, het die staat wel toegewings in dié verband gemaak, aangesien DH van Zyl in sy Maart 1964-jaarverslag dank uitgespreek het teenoor die staat vir die belastingtoegewings ten opsigte van donasies aan die Helpmekaar wat dit voortaan vir maatskappye makliker sou maak om skenkings aan die Helpmekaar te maak.

Die toegewings het ook gelei tot 'n besluit om vir die voortsetting van die insamelingsveldtog voortaan op maatskappye vir skenkings te fokus. ${ }^{314}$ Dit is egter nie duidelik of die toegewings slegs vir die duur van die insamelingsveldtog gegeld het en of dit 'n permanente toegewing was nie. Die feit dat die kwessie weer in 1988 ter sprake gekom het toe besluit is om Sanlam vir 'n skenking aan die Helpmekaar te nader, was 'n aanduiding dat die toegewings slegs van 'n tydelike aard was of op 'n later stadium weer verval of herroep is. In Junie 1988 is dus weer met 'n proses begin om toestemming te verkry dat instansies wat skenkings aan die Helpmekaar doen dit vir belastingdoeleindes mag aftrek. Na aanleiding van 'n skrywe aan die betrokke minister is die Studiefonds meegedeel dat bestaande wetgewing slegs op universiteite betrekking gehad het en nie instansies wat direkte hulp aan studente verleen, ingesluit het nie. Die minister het ook aanbeveel dat hulle die uitnodiging van die Kommissaris van Binnelandse Inkomste, om met hom oor die aangeleentheid in gesprek te tree, moes benut om die saak verder te voer. Hoewel die UK op PS Meyer se voorstel aanvanklik besluit het dat die voorsitter eerder 'n onderhoud met die minister moes aanvra wanneer die parlement weer in sitting was,

312 (HSA) HS, Notuleboek (19 Jan 1967-16 Feb 1973), 16 Nov 1967, HS UK, gp; 11 Feb 1972, HS Direksie, gp.

313 (HSA) HS, Notuleboek (8 Feb 1940-9 Des 1966), 25 Mei 1961, HS Direksie, gp.

314 (HSA) HS, Notuleboek (8 Feb 1940-9 Des 1966), 23 Mrt 1964, HS jaarvergadering, gp. 


\section{Die Kaapse Helpmekaar}

het Oberholster aanbeveel dat hullemnr Piet Marais, LV vir Stellenbosch en voorsitter van die NP se Komitee oor Finansies, in dié verband moes nader. Na 'n gesprek met mnr Horn is besluit om wel met die Kommissaris in gesprek te tree. ${ }^{315}$

Die ondersteuning van die Transvaalse HS is ook in dié verband gesoek en HA Sloet, Transvaalse voorsitter, en Pretorius, die Studiefonds se bestuurder, is gesamentlik deur die Kommissaris te woord gestaan. Die Helpmekaar-afvaardiging was oortuig dat hulle die moontlike struikelblokke, wat vir die belastingvrystelling van bydraes aan die Helpmekaar deur die Kommissaris geopper is, bevredigend aangespreek het. Die Kommissaris het onderneem om die aansoek na die Komitee vir Inkomstebelasting te verwys, wat dan aan die minister moes verslag doen. ${ }^{316}$ Die politieke vloeibaarheid en algemene onsekerheid wat deur FW de Klerk se toespraak van 2 Februarie 1990 geskep is, het egter dié inisiatief ten minste vir die voorsienbare toekoms laat stol.

\section{BESTUURSTRUKTURE}

Met die samesmelting is KA Sinclair tot voorsitter van die HS verkies, wat 'n bevestiging en erkenning was van die belangrike rol wat hy as vernuwer en versoener in die oorgang na die nuwe bedeling gespeel het. In Oktober 1971 het Sinclair egter weens sy verslegtende sig, wat hom feitlik blind gelaat het, as voorsitter bedank. Hy het versoek om steeds een of ander vorm van verteenwoordiging op die direksie te behou vir ingeval hy later weer sy sig mag terugvind. Uit erkentlikheid vir "Oom Ken" se 53 jaar lange verbintenis met die Helpmekaar het die direksie hom tot lewenslange ere-direkteur van die Studiefonds verkies. ${ }^{317}$ CF Albertyn is as Sinclair se opvolger verkies - 'n posisie wat hy vir die volgende drie dekades sou beklee. ${ }^{318}$

Sinclair se bedanking as voorsitter en die vakatures wat dit op die Studiefonds se bestuurstrukture gelaat het, het ook die geleentheid geskep om die strukture te herorganiseer en ook sekere teenstrydighede en tekortkominge wat in die Studiefonds se grondwet gemanifesteer het reg te stel. Hierdie herstrukturering van die bestuurstruktuur was waarskynlik ook 'n reaksie op die Helpmekaar se ervarings ten opsigte van veral sy beleggingsbesluite in die periode sedert amalgamasie.

\footnotetext{
315 (HSA) HS, Notuleboek (16 Feb 1973-10 Sept 1993), 8 Nov 1988, HS UK, 97.

316 (HSA) HS, Notuleboek (16 Feb 1973-10 Sept 1993), 2 Mrt 1989, HS jaarvergadering, Jaarverslag, 23 Feb 1989, 98.

317 (HSA) HS, Notuleboek (19 Jan 1967-16 Feb 1973), 21 Okt 1971, HS UK, gp; 11 Feb 1972, HS Direksie, gp.

318 (HSA) HS, Notuleboek (19 Jan 1967-16 Feb 1973), 11 Feb 1972, HS jaarvergadering, gp.
} 


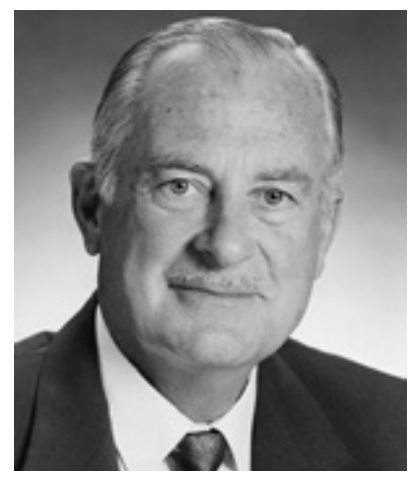

J van der Westhuyzen was sedert 1961 by die Helpmekaar betrokke en was ook vir 20 jaar voorsitter van die direksie.

Die sekretaris het in Februarie 1972 versoek dat toestemming verleen word om sekere bepalings in die grondwet, wat met amalgamasie daarin opgeneem is met die doel om aan die Bankwetvereistes (byvoorbeeld dat 'n maatskappy wat as bank funksioneer uit minstens dertig lede moet bestaan) te voldoen, verander kon word. Die Helpmekaar is uitendelik nie onder die Bankwet geregistreer nie, maar die Bankwet se voorgeskrewe artikels het in sy grondwet bly voortbestaan. Met amalgamasie is die aantal lede waaruit die maatskappy moes bestaan op tussen sewe en 20 vasgestel. Daar het ook ander anomalieë ontstaan wat later tot verwarring kon lei en die sekretaris het dus toestemming gevra om die regskoste aan te gaan om die grondwet te wysig vir voorlegging in konsepvorm aan die volgende algemene jaarvergadering.

Dr Albertyn het ook aangedui dat dit hom verontrus dat die direksie tot so min as sewe lede kan daal. Hy was bang dat mense eendag in beheer kom wat die Helpmekaar met sy groot fondse tot sy beskikking in 'n ander rigting stuur as wat sy huidige doelstellings bepaal het. Dit was vir hom onaanvaarbaar dat so min mense die maatskappy kon beheer en hy het voorgestel dat die direksie se minimum aantal lede op 15 of op die heel minste 12 gestel word. ${ }^{319}$ Die statute is dus uiteindelik gewysig om die minimum aantal lede van die maatskappy op 12 vas te stel en dié van die direksie op tussen 12 en $20{ }^{320}$

Terwyl die statutêre veranderinge van meer akademiese belang was, was die bestuursveranderinge in die vaarwater van Sinclair se vertrek daarop gemik om meer vaartbelynde en effektiewe bestuur te verseker. Aangesien die sekretaris, Fanie Pretorius, vir alle praktiese doeleindes ook as bestuurder van die Studiefonds gefunksioneer het en dit in die praktyk verwarring by die Studiefonds se kliënte veroorsaak het, is 'n voorstel aanvaar dat sy amp voortaan bestuurder, sowel as sekretaris sou wees. ${ }^{321}$ Afgesien van dié verandering is die geleentheid ook benut om die ander bestuurstrukture te herorganiseer. Die dagbestuur is afgeskaf en sy funksies is deur die UK oorgeneem. As UK is benoem: dr CF Albertyn, oudsen DH van Zyl, PJC van Zyl, ds JH Roos, GJ Horn, ds Van der

319 (HSA) HS, Notuleboek (19 Jan 1967-16 Feb 1973), 11 Feb 1972, HS Direksie, gp.

320 (HSA) HS, Notuleboek (16 Feb 1973-10 Sept 1993), 16 Feb 1973, HS jaarvergadering, gp; 15 Feb 1974 , HS jaarvergadering, 16.

321 (HSA) HS, Notuleboek (19 Jan 1967-16 Feb 1973), 29 Mei 1972, HS Direksie, gp; 


\section{Die Kaapse Helpmekaar}

Westhuyzen en PS Meyer. Die beleggingskomitee het bestaan uit dr CF Albertyn, GJ Horn, S Pretorius, ds JH Roos en DH van Zyl. ${ }^{322}$

GJ Horn, wat voor amalgamasie op die hoofbestuur gedien het, maar nie na amalgamasie beskikbaar was nie, is weer genader om op die direksie te dien. Dit was veral met die oog op 'n bykomende raadgewer op die beleggingskomitee. ${ }^{323}$ Die beleggingskomitee is ook van sy volmag ontneem en moes voortaan sy ondersoeke en voorstelle aan die UK vir finale besluit voorlê. Die beleggingskomitee sou dus in 'n raadgewende hoedanigheid funksioneer en indien nodig sou die advies van die maatskappy se ouditeure en prokureurs ook gesoek word. Alle toekomstige beleggings, behalwe korttermynbeleggings by banke en soortgelyke instellings, moes voortaan deur die UK goedgekeur word. Alle tjeks groter as R500 moes voortaan ook deur 'n direkteur mede-onderteken word. Die UK het ook besluit dat waar toekomstige transaksies met privaat individue aangegaan word die werklike sekuriteite gelyktydig met die betaling oorhandig moes word. Die transaksie met Albertyn, in verband met sy outeursreg in die Suid-Afrikaanse Kinderensiklopedie, het volgens die ouditeure op 'n ongemagtigde lening neergekom omdat die sekuriteite vir die lening nie saam met die transaksie oorhandig is nie. ${ }^{324}$ Bogenoemde herstrukturering was hoofsaaklik 'n reaksie op die beleggingsverliese wat die Helpmekaar met die 1969-ineenstorting van die aandelebeurs gely het en die debakel met die Albertyn-transaksie. Die besluit oor die goedkeuring van beleggings deur die UK het egter nie lank gehou nie, aangesien op hul volgende vergadering besluit is om daarvan af te sien. Die sekretaris sou soos voorheen gelde vir belegging versprei onder maatskappye wat ruim bygedra het tot die Helpmekaar se fondse, te wete Santam, Saambou, FVB, Volkskas, Boland Bank en Bank van Johannesburg (Sanlam). Oor alle buitengewone beleggings sou in terme van die vorige ouditverslag deur die UK besluit word. ${ }^{325}$

Benewens die bestuursverandering wat met die Sinclair/Albertyn-oorgang plaasgevind het, was die beoogde veranderinge aan die Maatskappywet in die eerste helfte van die sewentigerjare verantwoordelik vir die ander beduidende verandering in die HS se bestuursmodel. In 1974 het die sekretaris in 'n memorandum aan die UK versoek dat die Helpmekaar as maatskappy moes deregistreer en weer 'n vrywillige organisasie word - met

\section{Ibid.}

323 (HSA) HS, Notuleboek (19 Jan 1967-16 Feb 1973), 21 Feb 1969, HS Dagbestuur, gp; 13 Feb 1970, HS jaarvergadering, gp; 13 Feb 1970, HS Direksie, Jaarverslag, 23 Jan 1970, gp.

324 (HSA) HS, Notuleboek (19 Jan 1967-16 Feb 1973), 11 Aug 1972, HS UK, gp; 24 Apr 1972, HS Beleggingskomitee, gp; 29 Mei 1972, HS Direksie, gp.

325 (HSA) HS, Notuleboek (19 Jan 1967-16 Feb 1973), 8 Des 1972, HS UK, gp. 
ander woorde in 'n trust omskep moes word. Hy het geargumenteer dat die oorspronklike motivering vir maatskappystigting, naamlik die vereiste van die registrateur van banke dat hulle weens hul depositonemende aktiwiteite onder die Bankwet as maatskappy moes registreer, weens hul ooreenkoms met die registrateur verval het. Omdat die ooreenkoms eers beding is nadat hul reeds as maatskappy geregistreer was en die maatskappystatus hulle nie juis beïnvloed het nie, het hulle in dié formaat bly voortbestaan.

Die aanduiding was egter dat die nuwe beoogde wet op maatskappye vanweë sy vereistes oor die indiening van tussentydse finansiële verslae, jaarverslae met die nodige inkomsteseëls, die rapportering van verandering van direkteure en ander vereistes wat beoog is ten behoewe van die aandeelhouers van maatskappye - iets wat die Helpmekaar nie gehad het nie - 'n groot en onhanteerbare administratiewe las op die personeel en veral die sekretaris sou plaas. Nie-nakoming van die verpligtinge kon volgens die sekretaris tot soveel as 60 potensiële strafregtelike oortredings lei. Teen dié agtergrond het hy dus versoek dat die Helpmekaar as maatskappy gederegistreer word. ${ }^{326}$ Tydens die Februarie 1975-jaarvergadering is die versoek deur die direkteure aanvaar en die nodige besluite vir die deregistrasie en die oordrag van alle bates en laste na die trustfonds goedgekeur. Die direkteure sou voortaan as trustees funksioneer en die grondwet van die maatskappy is as die trustakte van die trustfonds aanvaar. ${ }^{327}$

Die statutêre kategorie van die Helpmekaar het hierdeur van maatskappy na trustfonds verander en dit het weinige impak op sy dag-tot-dag-funksionering gehad. As trustees sou die voormalige direkteure hul taak met dieselfde toewyding en ingesteldheid as voorheen benader - 'n toewyding waarvoor Albertyn tydens die 1975-jaarvergadering erkenning gegee het en waarby hy ook die bestuurder en administratiewe personeel ingesluit het. Aangesien die oorgang ook saamgeval het met senator DH van Zyl se testamentêre skenking aan die Studiefonds het Albertyn ook voorgestel dat die trustees uitgebrei word om die groter werkslading wat die skenking vir die bestuurder en UK sou meebring te kon hanteer. Die Raad van Trustees het dus besluit om twee jong plaaslike lede, mnre Ronel G Pretorius en Sarel PF van Aswegen, tot die trustees by te voeg en hulle ook tot die UK te verkies. ${ }^{328}$

326 (HSA) HS, Notuleboek (16 Feb 1973-10 Sept 1993), 19 Jun 1974, HS UK, (Memorandum van S Pretorius: versoek dat HM de-registreer as maatskappy, 27 Mei 1974), 20.

327 (HSA) HS, Notuleboek (16 Feb 1973-10 Sep 1993), 14 Feb 1975, HS jaarvergadering, Jaarverslag, 23; 14 Feb 1975, HS jaarvergadering, 25; 14 Feb 1975, HS Direksie, 24; 19 Jun 1974, HS UK, 20; 14 Feb 1975, HS Trustees, 26; 13 Feb 1976, HS jaarvergadering, Jaarverslag, 31.

328 (HSA) HS, Notuleboek (16 Feb 1973-10 Sept 1993), 14 Feb 1975, HS jaarvergadering, Voorsittersrede, 27; 10 Apr 1975, HS UK, 28; 13 Feb 1976, HS jaarvergadering, 32. 


\section{Die Kaapse Helpmekaar}

Die belangrike rol van die UK het waarskynlik die aanstellings regverdig, aangesien die komitee oor die volmag beskik het om besluite te neem en selfs besluite kon neem wat bots met die besluite van die Raad van Trustees, mits sodanige besluite binne die perke bly soos beskrywe is in die trustakte. Daar is egter van die komitee verwag om ten opsigte van belangrike besluite soveel trustees as moontlik te raadpleeg. ${ }^{329}$

'n Uitstaande kenmerk van Helpmekaar-direksies en -trustees wat in dié era voortgesit en herbevestig is, was die stabiliteit daarvan vanweë die lang verbintenisse van direkteure en trustees met die organisasie. Trustees en direkteure se paaie het meestal nie vrywilliglik van die Helpmekaar geskei nie, maar slegs as hulle vanweë dood, ${ }^{330}$ hoë ouderdom of swak gesondheid $^{331}$ of vanweë loopbaanskuiwe geforseer is om die tuig neer te lê. ${ }^{332}$ In sommige gevalle het die waardering vir hul toewyding en bydraes self hierdie struikelblokke oorkom. In 1989 het die voorsitter, dr CF Albertyn, aangedui dat hy pas 80 geword het en dat hy al vir meer as 30 jaar voorsitter van die Helpmekaar was en gedink het dat dit tyd was om uit te tree. Hy sou egter graag as trustee wou aanbly. Die trustees by monde van ds Van der Westhuyzen het hom egter versoek om sy besluit te heroorweeg omdat sy gesondheid nog goed was en sy verstand helder. Albertyn het dus sy bedanking teruggetrek. ${ }^{333}$

329 (HSA) HS, Notuleboek (16 Feb 1973-10 Sept 1993), 13 Feb 1981, HS jaarvergadering, 61.

330 (HSA) HS, Notuleboek (19 Jan 1967-16 Feb 1973), 12 Feb 1971, HS Direksie, gp.

331 (HSA) HS, Notuleboek (16 Feb 1973-10 Sept 1993), 22 Feb 1991, HS jaarvergadering, 112.

332 (HSA) HS, Notuleboek (16 Feb 1973-10 Sept 1993), 18 Jun 1980, HS Trustees, 58.

333 (HSA) HS, Notuleboek (16 Feb 1973-10 Sept 1993), 2 Mrt 1989, HS jaarvergadering, 100. 


\section{ADMINISTRASIE VAN BUITESTUDIEFONDSE}

Die administrasie van buitestudiefondse het reeds in die periode voor amalgamasie 'n aanvang geneem. Die aanduidings is dat die Helpmekaar reeds sedert 1961 betrokke was by die administrasie van lenings uit Rupert-fondse ${ }^{334}$ en in Mei 1962 is die Studiefonds amptelik deur die Rembrandt-groep genader om 'n Rembrandt-personeel-studiefonds te administreer - waartoe hulle ingestem het ${ }^{335}$ en waarvoor 'n bedrag van R10 000 in Mei 1962 van Rembrandt ontvang is. ${ }^{336}$ Die Studiefonds het ook sedert 1963 die VisseryeOntwikkelingskorporasie se beursskema geadministreer. ${ }^{337}$ Ten spyte van hul reeds genoemde weiering in Augustus 1965 van die Phil Morkel-versoek dat die Helpmekaar die administrasie waarneem van 'n studiefonds vir bruin mense wat hy en ander trustees gestig het en die direksie se besluit dat sodanige administrasie buite die raamwerk van Helpmekaar bedrywighede geval het, het die administrasie van Rembrandt-verwante buitefondse in die post-amalgamasie-era mettertyd vermeerder en het dit 'n permanente deel van die HS se werksaamhede geword.

Die ooreenkoms met die Rembrandt-groep het aanvanklik behels dat die kapitale bedrag wat by die Studiefonds belê is jaarliks met vier persent gekrediteer is terwyl studente ses persent rente op lenings betaal het. Die Helpmekaar se jaarlikse administrasiekoste sou dus die verskil van twee persent bedra. Die Rembrandt-groep het in 1968 hul storting by die Studiefonds van R10 000 na R20 000 verhoog met die versoek dat die kapitale bedrag met vyf persent, in plaas van met vier persent soos voorheen, gekrediteer word. Dit het beteken dat die Helpmekaar 'n kleiner persentasie administrasiekoste ontvang het. Die Rembrandtgroep-filiaal, Oude Meester Kelders, se versoek dat hulle personeelstudiefonds onder dieselfde voorwaardes geadministreer word, is ook toegestaan. ${ }^{338}$ Oude Meester Kelders het R10 000 gestort om hul personeelstudiefonds te loods terwyl

334 (HSA) HVKP, Notuleboek (8 Feb 1940-9 Des 1966), 25 Mei 1961, HS Direksie, gp; 5 Okt 1961, HS Direksie, gp.

335 (HSA) HVKP, Notuleboek (8 Feb 1940-9 Des 1966), 24 Mei 1962, HS Direksie, gp.

336 (HSA) HVKP, Notuleboek (8 Feb 1940-9 Des 1966), 30 Aug 1962, HS Direksie, gp.

337 (HSA) HS, Notuleboek (19 Jan 1967-16 Feb 1973), 14 Feb 1969, HS Direksie, Kantoorverslag, 24 Jan 1969, gp.

338 (HSA) HS, Notuleboek (19 Jan 1967-16 Feb 1973), 14 Feb 1969, HS Kantoorverslag, 24 Jan 1969, gp; (HSA) HS, Notuleboek (16 Feb 1973-10 Sept 1993), 23 Feb 1990, HS jaarvergadering, Bestuurder verslag, 13 Feb 1990, 102-103; (HSA) HS, Notuleboek (19 Jan 1967-16 Feb 1973), 14 Feb 1969, HS Direksie, gp. 


\section{Die Kaapse Helpmekaar}

Rembrandt sy fondse by die Helpmekaar van R20 000 tot R50 000 vergroot het. ${ }^{339}$ Hoewel die Studiefonds bedenkinge gehad het oor die Rembrandtgroep-lenings se vereiste van slegs een borg omdat hulle gevrees het dat dit tot slegte skuld kon lei wat voor die Studiefonds se deur gelê kon word, het Rembrandt die versekering gegee dat hulle enige sodanige verliese sou dra en nie die Helpmekaar se administrasie daarvoor verantwoordelik sou hou nie. ${ }^{340}$

Die Rembrandtgroep-leningsfondse wat deur die Studiefonds geadministreer is, het jaarliks toegeneem en teen einde 1974 reeds R78 665 (Rembrandt R66 465; Oude Meester R12 200) bedra. Met die besluit tydens die 1975-jaarvergadering dat die Helpmekaar van maatskappy na trustfonds moes oorskakel, was die voorsitter van mening dat die Helpmekaar as trust nie sulke buite-leningsfondse behoort te administreer nie. Hy het voorgestel dat die Rembrandtgroep genader moes word met 'n versoek dat die leningsfondse aan die Helpmekaar geskenk word as teenprestasie dat die Helpmekaar dan lenings sal toestaan aan alle normale studente wat deur die twee maatskappye aanbeveel word. Die Helpmekaar sou onderneem om die studente vir die duur van hul studies te help, selfs al sou die ouers van die studente die diens van die maatskappye verlaat. ${ }^{341}$ In 1977 het die voorsitter weer sy voorstel herhaal en het die jaarvergadering besluit om die Rembrandt-groep met so 'n voorstel te nader. ${ }^{342}$ Die direksies van Rembrandt en Oude Meester het egter die versoek van die hand gewys. ${ }^{343}$ By die 1978-jaarvergadering het die voorsitter' $n$ voorstel ingedien waarin aanbeveel is dat die Helpmekaar dit as beleid aanvaar dat die raad ongeag die voorwaardes van die skenkingsakte slegs trusteeskap oor fondse aanvaar wat volkome aan die Helpmekaar geskenk word. Die vergadering het egter nie die voorstel aanvaar nie en as alternatief is die UK opdrag gegee om verder met Rembrandt en Oude Meester te onderhandel om 'n meer aanvaarbare en voordelige formule vir die Helpmekaar te beding. ${ }^{34}$

Die onderhandelinge het tot 'n nuwe, baie voordelige ooreenkoms met die Rembrandt-groep gelei wat voorsiening gemaak het dat die kapitaal van die Rembrandt- en Oude Meesterfondse gekonsolideer is en jaarliks met twee persent rente in plaas van die bestaande vier persent en vyf persent gekrediteer sou word. Aangesien die lenings teen ses persent uitgeleen

\footnotetext{
339 (HSA) HS, Notuleboek (19 Jan 1967-16 Feb 1973), 13 Feb 1970, HS Direksie, Jaarverslag 1969, 23 Jan 1970, gp.

340 (HSA) HS, Notuleboek (19 Jan 1967-16 Feb 1973), 14 Feb 1969, HS Direksie, gp.

341 (HSA) HS, Notuleboek (16 Feb 1973-10 Sep 1993), 14 Feb 1975, HS jaarvergadering, Voorsittersrede, 26.

342 (HSA) HS, Notuleboek (16 Feb 1973-10 Sep 1993), 11 Feb 1977, HS jaarvergadering, 40.

343 (HSA) HS, Notuleboek (16 Feb 1973-10 Sep 1993), 24 Nov 1977, HS UK, 45.

344 (HSA) HS, Notuleboek (16 Feb 1973-10 Sep 1993), 10 Feb 1978, HS jaarvergadering, 49.
} 
is, het dit beteken dat die Helpmekaar se administrasiekoste voortaan op vier persent te staan sou kom. ${ }^{345}$ In 1978 het Oude Meester ook die Helpmekaar versoek om die Oude Meester Kunsstigting, wat hulle gestig het om studente in die uitvoerende kunste en teatertegnieke te ondersteun, te administreer. ${ }^{346}$

In 1980 is die Rembrandt- en Oude Meester-fondse weer geskei weens Rembrandt se veranderde belang in Oude Meester en die nuwe bedeling in die drankbedryf, wat ook Distillers Korporasie toegevoeg het tot die Rembrandtgroep van maatskappye, wie se personeel-studieleningsfondse deur die Helpmekaar geadministreer is. ${ }^{347}$ Die inkomste wat die Helpmekaar uit die nuwe ooreenkoms met die Rembrandtgroep van maatskappye verkry het, het 'n belangrike bydrae gelewer om die Helpmekaar se gewone bedryfswins te versterk en is aangedui as een van die faktore wat die Helpmekaar in staat gestel het om die 1983finansiële jaar met die grootste surplus-inkomste in sy geskiedenis af te sluit. ${ }^{348}$ Teen 1985 het die Rembrandtgroep van maatskappye se beleggings by die Helpmekaar R412 000 bedra en het Westelike Provinsie Kelders, as nog 'n fonds van die groep wat deur die Helpmekaar geadministreer is, bygekom. ${ }^{349}$

In die 1989-finansiële jaar was die inkomste uit die administrasie van die Rembrandt-groep se personeel-studieleningsfondse R43 000. Vir die 1990-finansiële jaar het die Rembrandtgroep egter kennis gegee dat die Helpmekaar se administrasiefooi op R30 000 vasgestel word en vir die 1991- finansiële jaar is dit op drie persent van die uitstaande leningsfondse soos op 30 September vasgestel. Vir die 1990-finansiële jaar het dit 'n daling van R13 000 in inkomste, vergeleke met 1989, beteken. Die daling in inkomste het gepaardgegaan met 'n verdubbeling van die administratiewe werklas sedert die nuwe stelsel in werking getree het.

Die lewering van maandstate aan die Rembrandt-groep het die stand van uitstaande lenings en die kapitale fondse weergegee met die doel dat tekorte dan deur die Rembrandt-groep deur oorbetalings aan die Helpmekaar aangevul moes word. Dit het ook daartoe aanleiding gegee dat die Helpmekaar soms van hul eie beleggings moes opvra om aan Rembrandt-leners te kon uitbetaal indien Rembrandt-oorbetalings nie vinnig genoeg plaasgevind het nie - met

345 (HSA) HS, Notuleboek (16 Feb 1973-10 Sep 1993), 27 Sep 1978, HS UK, 52.

346 (HSA) HS, Notuleboek (16 Feb 1973-10 Sep 1993), 9 Feb 1979, HS jaarvergadering, 53.

347 (HSA) HS, Notuleboek (16 Feb 1973-10 Sep 1993), 25 Apr 1980, HS UK, 58.

348 (HSA) HS, Notuleboek (16 Feb 1973-10 Sep 1993), 10 Feb 1984, HS jaarvergadering, Jaarverslag, 75.

349 (HSA) HS, Notuleboek (16 Feb 1973-10 Sep 1993), 14 Feb 1986, HS jaarvergadering, Jaarverslag, 84. 
die gevolglike renteverliese wat dit vir die Helpmekaar ingehou het. ${ }^{350}$ Die raad het egter die veranderde vergoedingstruktuur, ten spyte van die aanduidings van 'n groter administratiewe las wat die administrasie van die leningsfondse meegebring het, goedgekeur. Rembrandt het by monde van Oberholster onderneem om die renteverliese van die Helpmekaar deur 'n administratiewe regstelling uit te skakel. ${ }^{351}$ Teen die aanvang van die negentigerjare het die administrasie van buitefondse van die Rembrandtgroep van maatskappye, in terme van aantal lenings wat jaarliks toegeken is en bedrae wat toegeken is, die HS verdwerg. In die 1991-boekjaar is R863 149 aan 146 studente toegeken uit buitefondse van die Rembrandtgroep teenoor ongeveer R229 636 aan 53 studente uit Helpmekaar-fondse. ${ }^{352}$

Die administrasie van die Rembrandt-groep van maatskappye was die belangrikste buitefondse wat die Studiefonds geadministreer het, maar die Helpmekaar is ook deur ander instansies genader om hul fondse te administreer, waarvan sommige gematerialiseer het en ander nie. In 1972 is die Studiefonds deur Saambou-Nasionaal genader om 'n studieleningsfonds, geskoei op die Rembrandtgroep-model, vir die kinders van personeel wat die maatskappy beoog het (benewens die beursskema wat reeds bestaan het) te administreer. Die Helpmekaar was bereid om verantwoordelikheid vir die Kaaplandse afdeling van so 'n fonds te aanvaar op voorwaarde dat Saambou-Nasionaal 'n bedrag van R10 000 by die Helpmekaar belê. Hoewel die UK van die Studiefonds die versoek in beginsel goedgekeur het, was daar geen verdere verwysing daarna of rekord daarvan nie en het Saambou waarskynlik 'n ander alternatief gevolg. ${ }^{353}$

Met die ontbinding van die Oranje Klub in 1976 het die Klub die Helpmekaar genader met die versoek om hul fondse van R3 496 as 'n beursfonds te administreer en die opbrengs daarvan aan te wend vir beurse vir studente in studierigtings wat die Afrikaanse kultuur sal bevorder soos drama, musiek en sang. Nadat die Helpmekaar hom bereid verklaar het

350 (HSA) HS, Notuleboek (16 Feb 1973-10 Sep 1993), 23 Feb 1990, HS jaarvergadering, Jaarverslag, 13 Feb 1990, 102-103.

351 (HSA) HS, Notuleboek (16 Feb 1973-10 Sep 1993), 23 Feb 1990, HS jaarvergadering, 105.

352 (HSA) HS, Notuleboek (16 Feb 1973-10 Sep 1993), 21 Feb 1992, HS jaarvergadering, Jaarverslag, 28 Jan 1991 , 118; Aangesien Helpmekaarlenings vir die volle duur van die kursus toegeken word met die aanvang van die kursus het die Studiefonds in werklikheid in die 1991-boekjaar R688 910 aan lenings toegeken. Aangesien Rembrandtgroep-lenings per jaar toegeken word en nie vir die hele kursus nie is die Helpmekaarbedrag met die oog op vergelyking deur drie gedeel met die veronderstelling dat die gemiddelde lengte van kursusse oor drie jaar strek. (HSA) HS, Notuleboek (16 Feb 1973-10 Sep 1993), 22 Feb 1991, HS jaarvergadering, 112.

353 (HSA) HS, Notuleboek (19 Jan 1967-16 Feb 1973), 11 Sep 1972, HS UK, gp. Saambou het oor 'n Beursfonds vir die kinders van Saambou amptenare beskik. Daar kon egter geen aanduiding gevind word of die Fonds uiteindelik in 'n leningskema verander is nie. (USD), Saambou Nasionale Bouvereniging Argief, Notuleboek (21 Jun 1963-20 Feb 1970), Direksievergadering, 21 Jan 1966, 3. 
om die administrasie te hanteer ${ }^{354}$ is besluit om die rente op die belegging by die kapitaal te voeg tot 'n bedrag van R5 000 bereik is waarna verdere rente dan vir beurse aangewend sou word. ${ }^{355}$

Hoewel dit nie hul primêre funksie was nie het die administrasie van buitefondse dus sedert die sestigerjare progressief toegeneem en kon die Helpmekaar die kennis en stelsels wat hy mettertyd en deur praktiese ondervinding opgedoen het, aanwend om 'n addisionele stroom van inkomste vir die Helpmekaar te genereer. Sy status in dié verband in Afrikanergeledere het die Helpmekaar die voorkeurbestemming vir sulke versoeke gemaak. Die intieme assosiasie wat hy oor jare vanweë dié administratiewe funksie met die Rembrandt-groep en Rupert-ryk opgebou het, het hom ook deur toegang tot die sake-bestuurskennis en netwerke van die Ruperts op kritieke stadiums bevoordeel en 'n belangrike invloed op sy ontwikkeling uitgeoefen.

\section{VORSTER-MULLER FONDS}

Die sukses van die Helpmekaar met die groei van hul kapitaal was in 'n groot mate toe te skryf aan verstandige en versigtige bestuur en belegging van fondse met verloop van tyd eerder as vanweë oordadige ondersteuning van die publiek. Waar hulle wel trusteeskap oor fondse verkry het, is dit met groot verantwoordelikheid en omsigtigheid uitgevoer. Die Nicholaas en Jacoba Vorster-Muller Fonds was waarskynlik die uitnemendste voorbeeld in dié verband. Die fonds het sy oorsprong gehad in 'n erflating van ongeveer $£ 16000$ van Jacoba Vorster van Colesberg. ${ }^{356}$ Die testament, wat swak en dubbelsinnig opgestel is, het onder andere bepaal dat die kapitaal belê moes word en dat die opbrengs vir studielenings vir by voorkeur teologie, maar ook vir mediese en onderwysstudente aangewend moes word. Die testament het onder die Helpmekaar se aandag gekom nadat beide die kuratorium van die Kweekskool en daarna die Kommissie van Toesig en Kontrole van die NG Kerk die administrasie daarvan van die hand gewys en van die kerk se regte afstand gedoen het, hoofsaaklik omdat die bepalings van die testament dubbelsinnig was en sommige bepalings moeilik uitvoerbaar was. ${ }^{357}$

\footnotetext{
354 (HSA) HS, Notuleboek (16 Feb 1973-10 Sep 1993), 24 Nov 1976, HS UK, 38.

355 (HSA) HS, Notuleboek (16 Feb 1973-10 Sep 1993), 11 Feb 1977, HS jaarvergadering, 40.

356 (HSA) HVKP, Notuleboek, 4-5 Apr 1956, Kongres, Hoofbestuur verslag, 2; (HSA) HVKP, Notuleboek (8 Feb 1940-9 Des 1966), 12 Des 1955, Hoofbestuur, 481.

357 (HSA) HS, Notuleboek (19 Jan 1967-16 Feb 1973), 14 Feb 1969, HS Direksie, Kantoorverslag, 24 Jan 1969, gp; (HSA) HS, Notuleboek (16 Feb 1973-10 Sep 1993), 16 Feb 1973, HS Direksie, gp; 13 Feb 1976, HS Jaarvergadering, Jaarverslag, 31-32; 13 Aug 1992, HS UK, 122.
} 


\section{Die Kaapse Helpmekaar}

Die HS (B-fonds) het dus in 1955 begin met 'n proses om toestemming te verkry om die administrasie van die trust waarvoor die testament voorsiening gemaak het, oor te neem. ${ }^{358}$ In 1962 het die Kaapse afdeling van die Hooggeregshof die HS as die administrateurs van die Nicholaas en Jacoba Vorster-Muller Fonds aangestel - 'n aanstelling wat die direksie aanvaar het. ${ }^{359}$ Die Nicolaas en Jacoba Vorster-Muller Fonds van R36 000 sou dus as 'n aparte en selfstandige studiefonds geadministreer word. ${ }^{360}$ Aangesien die opbrengs op die kapitaal van die fonds nog nie groot genoeg was nie is besluit om te wag met die toekenning van lenings totdat voldoende fondse beskikbaar was. ${ }^{361}$ Aangesien die dubbelsinnigheid van die testament se bepalings dit moontlik gemaak het om dit te interpreteer dat lenings eers ná die afsterwe van mev Purchase, 'n begunstigde van die bemaking, toegestaan mag word, is in 1970 besluit dat die Studiefonds dit as hul amptelike interpretasie sou aanvaar om daardeur vir hul meer tyd te koop om die fondse vir lenings verder te groei voordat met leningsuitbetalings begin word. Die sekretaris se voorstel in dié verband was gebaseer op die feit dat slegs R25 000 vir lenings in die fonds beskikbaar was en dat die bedrag maar teen R5 000 jaarliks gegroei het wat die toestaan van lenings onverstandig sou maak, aangesien die Fonds baie vinnig uitgeput sou raak. ${ }^{362}$ Met die aanvaarding van die besluit is 'n patroon gevestig wat kenmerkend van die Vorster-Muller Fonds se bestaan sou word, naamlik dat die doelpale vir wanneer die toestaan van lenings uit die fonds 'n aanvang sou neem telkens verskuif is totdat daar uiteindelik teen die einde van die tagtigerjare met leningsuitbetalings begin is.

Met die afsterwe van mev Purchase in 1971 was daar slegs R30 000 in die Vorster-Muller Fonds vir lenings beskikbaar en het die direksie dus besluit om nie met leningsuitbetalings te begin nie, aangesien die fonds te gou uitgeput sou raak en om die besluit jaarliks te heroorweeg. ${ }^{363}$ Met die algemene jaarvergadering in Februarie 1973 - met R41 000 in die fonds beskikbaar vir lenings - is besluit dat geen lenings toegeken sou word alvorens die fonds nie R100 000 Hoofbestuur verslag,

359

(HSA) HVKP, Notuleboek (8 Feb 1940-9 Des1966), 22 Feb 1962, HS Direksie, gp.

(HSA) HVKP, Notuleboek (8 Feb 1940-9 Des1966), 27 Mrt 1963, HS jaarvergadering, Jaarverslag, gp.

(HSA) HVKP, Notuleboek (8 Feb 1940-9 Des1966), 23 Mrt 1964, HS Direksie; (HSA) HS, Notuleboek (19 Jan 1967-16 Feb 1973), 14 Feb 1969, HS Direksie, gp.

(HSA) HS, Notuleboek (19 Jan 1967-16 Feb 1973), 12 Nov 1970, HS UK, gp.

(HSA) HS, Notuleboek (19 Jan 1967-16 Feb 1973), 21 Okt 1971, HS UK, gp; 11 Feb 1972, HS jaarvergadering, Direksieverslag, gp; 11 Feb 1972, HS Direksie, gp. 
sterk was nie. ${ }^{364}$ Met die bereiking van die teiken van R100 000 se opgeloopte rente in 1977 het die algemene jaarvergadering in Februarie 1977 besluit om vanaf einde 1977 lenings uit die fonds aan teologiestudente te begin toestaan. Dit sou beteken dat die Helpmekaar dus nie meer uit sy eie fondse teologiestudente, met hul spesiale rentekoersstruktuur en die verliese wat dit meegebring het, hoef te befonds nie. ${ }^{365}$

Teen Julie 1977 het die UK egter besluit om nie met die uitbetaling van lenings voort te gaan nie. ${ }^{366}$ Waarskynlik omdat hulle besef het dat die eskalasie in studiekoste en die aanvraag na lenings vir teologiestudente die fonds te vinnig sou uitput. Die teiken van R100 000 wat vroeër gestel is, was weens bogenoemde faktore eenvoudig net nie meer genoeg nie. Die teiken vir die aktivering van lenings is dus na R300 000 verhoog. In 1981 is 'n poging aangewend om te bepaal wanneer met die uitbetaling van lenings begin kon word deur na die Studiefonds se verpligtinge teenoor teologiestudente te kyk en ook die aanvraag en terugbetalingspatroon van teologiestudente in ag te neem. Uit die uitstaande saldo's van lenings aan teologiestudente soos op 30 September van elke jaar het dit geblyk dat daar 'n meer as 300 persent toename was van R115 973,73 in 1977 tot R361 927 in 1981. Lenings van R160 000 is tydens die 1981-boekjaar toegestaan, R96 406 is aan teologiestudente uitbetaal, terwyl R22 209 deur hulle terugbetaal is. Aangesien 'n projeksie daarop gedui het dat die opgehoopte bedrag wat vir lenings in die Vorster-Muller Fonds beskikbaar sou wees op 30 September 1985 ongeveer R320 000 sou wees, is geprojekteer dat daar waarskynlik vanaf 1985 lenings uit die Vorster-Muller Fonds toegestaan sou kon word. ${ }^{367}$

Die projeksie vir aktivering in 1985 het egter reeds in 1983 onhaalbaar geblyk te wees, aangesien in dié jaar R156 000 aan teologiestudente uitbetaal is, wat beteken het dat, indien die geld uit die Vorster-Muller Fonds verhaal moes word, die fonds binne twee jaar uitgeput sou wees en dan vir agt jaar sou "stilstaan", behalwe vir die rente op die kapitaal van R108 000 wat vir aanwending beskikbaar sou wees. Die Studiefonds het dus teruggeval na 'n vroeëre benadering, naamlik om jaarliks die situasie in oënskou te neem en daaroor te besluit. ${ }^{368}$ Daar is ook besluit om voort te gaan met 'n besluit wat in 1982 geneem is, naamlik om die hof te versoek om die rentebepalings van die trustakte (wat rentevrye lenings tydens die studiejare en vier persent

\footnotetext{
364 (HSA) HS, Notuleboek (19 Jan 1967-16 Feb 1973), 16 Feb 1973, HS jaarvergadering, gp; (HSA) HS, Notuleboek (16 Feb 1973-10 Sep 1993), 16 Feb 1973, HS Direksie, gp.

365 (HSA) HS, Notuleboek (16 Feb 1973-10 Sep 1993), 13 Feb 1976, HS jaarvergadering, Jaarverslag, 31-32; $11 \mathrm{Feb}$ 1977, HS jaarvergadering, 40.

366 (HSA) HS, Notuleboek (16 Feb 1973-10 Sep 1993), 22 Jul 1977, HS UK, 43.

367 (HSA) HS, Notuleboek (16 Feb 1973-10 Sep 1993), 12 Feb 1982, HS jaarvergadering, Jaarverslag, 65.

368 (HSA) HS, Notuleboek (16 Feb 1973-10 Sep 1993), 10 Feb 1984, HS jaarvergadering, 76.
} 
daarna voorgeskryf het) te skrap en die bepalings van die Vorster-Muller Fonds ten opsigte van lenings in lyn met dié van die Studiefonds te bring, naamlik vier persent terwyl hulle studeer en ses persent sodra hulle begin werk.

Hierdie bepaling het deurlopend bygedra tot die Studiefonds se besluit om telkens die doelpale te verskuif, aangesien dit beteken het dat die rente-inkomste op lenings baie minder sou wees as op gewone Studiefondslenings wat ook rente gedra het tydens die studiejare. Dié faktor het beteken dat die groei van beskikbare leningskapitaal, wat deur rente op lenings gegenereer word, baie minder sou wees en dus die groei van die Vorster-Muller Fonds sou inhibeer. Die feit dat teologiestudente vir wie die lenings geoormerk is lang studieperiodes van sewe jaar of meer gehad het, het die impak van die bepaling vererger. ${ }^{369}$ Die hofaansoek was uiteindelik in 1985/86 suksesvol toe die hof beslis het dat die Vorster-Muller Fonds lenings wat rentekoersbepalings betref voortaan outomaties sou sinkroniseer met dié van die Studiefonds. ${ }^{370}$ Die effek van die verandering was reeds in die bestuurder se jaarverslag vir 1986 duidelik toe hy aangedui het dat die hof se instemming om die rentekoersbepalings te verander in tandem met die verslegtende likiede posisie van die Studiefonds daartoe sou lei dat hulle eerder vroeër as later lenings uit die Vorster-Muller Fonds sou begin toeken. ${ }^{371}$ Hierdie standpunt is deur die jaarvergadering ondersteun toe besluit is dat, indien die Studiefonds se fondse uitgeput sou raak, lenings aan teologiestudente uit die Vorster-Muller Fonds toegeken sou word. ${ }^{372}$

In sy jaarverslag vir 1987 het die bestuurder aangedui dat die tyd toe ryp was om aansoeke van teologiestudente voortaan uit die Vorster-Muller Fonds toe te staan. Die ironie was dat met die verskuiwing van die doelpale oor die jare hierdie voorstel grootliks mosterd na die maal was, aangesien dit saamgeval het met die feitelike opdroog vir die vraag na lenings vir teologiestudente waarna reeds verwys is. Ten spyte van dié tendens het die jaarvergadering besluit dat 'n begin gemaak kon word met die toestaan van lenings aan teologiestudente uit die fonds. ${ }^{373}$ Hierdie besluit is by die 1989 -jaarvergadering herbevestig toe besluit is om die VorsterMuller Fonds in werking te stel. ${ }^{374}$ Met aansoeke van teologiestudente wat feitlik opgedroog het en die fonds wat oor die R800 000 sterk was, kon alle aansoeke dus geakkommodeer

369 (HSA) HS, Notuleboek (16 Feb 1973-10 Sep 1993), 12 Feb 1982, HS jaarvergadering, Jaarverslag, 65; 12 Feb 1982, HS jaarvergadering, 66; 15 Feb 1985, HS jaarvergadering, Jaarverslag, 79.

370 (HSA) HS, Notuleboek (16 Feb 1973-10 Sep 1993), 14 Feb 1986, HS jaarvergadering, 87.

371 (HSA) HS, Notuleboek (16 Feb 1973-10 Sep 1993), 20 Feb 1987, HS jaarvergadering, Jaarverslag, 88.

372 (HSA) HS, Notuleboek (16 Feb 1973-10 Sep 1993), 20 Feb 1987, HS jaarvergadering, 89.

373 (HSA) HS, Notuleboek (16 Feb 1973-10 Sep 1993), 19 Feb 1988, HS jaarvergadering, 94.

374 (HSA) HS, Notuleboek (16 Feb 1973-10 Sep 1993), 2 Mrt 1989, HS jaarvergadering, 100. 
word. ${ }^{375}$ 'n Aanduiding daarvan dat die fonds die behoeftes van teologiestudente en meer kon bevredig, was Oberholster se voorstel in 1992 dat mediese studente ook in die toekoms uit die fonds gehelp moes word, aangesien die Nicolaas en Jacoba Vorster-Muller testament daarvoor voorsiening gemaak het. ${ }^{376}$ Die versigtige en soms baie konserwatiewe bestuur van die fonds het dus uiteindelik na meer as drie dekades vrugte begin dra en die fonds kon vanaf 1989 'n konstante bydrae lewer tot die voorsiening van leningskapitaal vir studielenings wat deur die Studiefonds toegestaan is. Hiervan het die R50 000 wat beskikbaar gestel is vir nuwe studielenings vir 1993 uit die fonds, bykomend tot bestaande studieleningverpligtinge aangegaan tot en met 1992, getuig. ${ }^{377}$

\section{REKLAME (BEMARKING)}

In die periode voor amalgamasie het "propaganda" vir die Helpmekaar ten doel gehad om steun vir die organisasie te werf wat verkieslik ook in 'n finansiële voordeel vir die vereniging sou neerslag vind of om veral die vereniging se opvoedkundige en ander aktiwiteite onder die publiek se aandag te bring met die oog op groter finansiële steun vir die Helpmekaar. Dié propaganda het deurgaans sterk op Afrikaner sentimente gesteun. Hierdie fokus van propaganda het grootliks in die post-amalgamasie-era verdwyn met reklame wat eerder die vorm aangeneem het van die bekendmaking van die Helpmekaar se studieleningsfunksie onder die potensiële studenteteikenmark. Skole is dus geteiken deur die verspreiding van brosjures via onderwysunies en met die hulp van onderwysdepartemente. Die Helpmekaar se leningsfasiliteite is in universiteitsjaarboeke soos dié van die Universiteit van Stellenbosch en Port Elizabeth opgeneem. In 1981 is briewe oor die Helpmekaar se leningsfasiliteite aan skoolhoofde gestuur en Die Unie, mondstuk van die SAOU, is versoek om 'n artikel daaroor te dra. ${ }^{378}$ Die veranderde aard van Helpmekaar-reklame was tekenend van 'n era waarin suksesvolle etniese mobilisering vir die volksaak 'n verskynsel uit 'n vergange era verteenwoordig het en materiële oorwegings die leitmotief geword het wat assosiasie met die Helpmekaar bepaal het.

In sy onlangse publikasie: Kruispaaie. Afrikanerkeuses in die 19de en 20ste eeu, het Leopold Scholtz weer Piet Cillié se Dawie-sprokie in die Die Burger van 29 September 1954 opgeroep.

375 (HSA) HS, Notuleboek (16 Feb 1973-10 Sep 1993), 23 Feb 1990, HS jaarvergadering, Jaarverslag, 13 Feb 1990, 103.

376 (HSA) HS, Notuleboek (16 Feb 1973-10 Sep 1993), 13 Aug 1992, HS UK, 122.

377 (HSA) HS, Notuleboek (16 Feb 1973-10 Sep 1993), 28 Okt 1992, HS UK, 122.

378 (HSA) HS, Notuleboek (19 Jan 1967-16 Feb 1973), 13 Feb 1970, HS Direksie, gp; (HSA) HS, Notuleboek (16 Feb 1973-10 Sep 1993), 15 Feb 1974, HS jaarvergadering, Jaarverslag, 13; 15 Feb 1974, HS Direksie, 16; 13 Feb 1981, HS jaarvergadering, 61. 
Daarin vertel die duiwel hoe hy oor tyd probeer het om die Afrikaners tot'n val te bring, maar hoe hulle dit telkens oorleef het. Uiteindelik wend hy hom tot sy laaste uitweg: "ek wil hul welvarend maak en kyk of hulle dit kan oorleef!"379 Ten spyte van die gewroeg oor 'n tekort aan fondse en die voortdurend beleerde beeld van Afrikaners se voortbestaan wat die post-amalgamasie era gekenmerk het, het die duiwel in die Dawie-sprokie in die Helpmekaar 'n getroue bondgenoot gevind in die "welvarend maak" van Afrikaners. Die naderende milleniumwending sou opnuut die Kaapse Helpmekaar en die produk van sy arbeid oor jare - welvarende Afrikaners - se oorlewingsvermoë toets.

379 L Louw, (red) Dawie, 1946-1964, Kaapstad, Tafelberg, 1965 soos aangehaal in L Scholtz, Kruispaaie. Afrikanerkeuses in die 19de en 20ste eeu, 139-140, Pretoria, Kraal Uitgewers, 2016. 


\section{HOOFSTUK TIEN}

\section{DIE "WISSELING VAN DIE WAG": HERBESINNING, HERORIËNTERING, HERSTRUKTURERING, 1990-2002}

"die ergste swaarkry is ook vir ons in die kantoor al agter die rug, want die publiek is teen hierdie tyd wyd ingelig daaroor dat die Helpmekaar se lenings bevries is."

\section{SOSIO-EKONOMIESE EN POLITIEKE MILIEU}

Die skaakmatsituasie en krisis waarin die Helpmekaar hom weens sy gebrek aan likiditeit met die aanvang van die laaste dekade van die millennium bevind het, het op 'n warm Kaapse middag - "sonnig en baie warm ...Die maksimum temperatuur by die lughawe DF Malan sal $30^{\circ} \mathrm{C}$ wees" ${ }^{\prime 2}$ in 1990 'n nuwe dimensie gekry toe FW de Klerk die politieke skaakmat in Suid-Afrika met sy toespraak van 2 Februarie ontknoop het. As deel van die Afrikaner- en breër Suid-Afrikaanse samelewing was die Helpmekaar nie immuun teen die veranderinge wat sedert die begin van die negentigerjare soos 'n tsunami oor Suid-Afrika gespoel het nie. Soos met die politieke onstabiliteit van die vroeë sestigerjare het die De Klerk-toespraak kragte ontketen wat die Helpmekaar tot 'n periode van versnelde interne herbesinning oor hul fokus, administratiewe en finansiële strukture en funksionering gedwing het. Soos met vroeëre likiditeitskrisisse in die veertiger- en sestigerjare het dit ook gelei tot hernude pogings om die kapitaalbasis van die Helpmekaar te versterk as skans teen die gevolge van die sosioekonomiese grondverskuiwings wat deur die politieke skikking en die nuwe finansiële eise wat dit aan die Helpmekaar gestel het, teweeggebring is.

Die politieke verwikkelinge van die vroeë 1990's het in tandem met 'n verandering in Helpmekaar-bestuur en 'n reeks nuwe trustee-aanstellings die herbesinning en vernuwing 'n nuwe momentum en dringendheid gegee. Die katalisator vir die proses was in die middel van die tagtigerjare te vinde - in die aanstelling van JCL Oberholster as Helpmekaar trustee in 1985. Oberholster se agtergrond as geoktrooieerde rekenmeester en sy jarelange ervaring van

1 (HSA) HS, Notuleboek (16 Feb 1973-10 Sep 1993), 7 Junie 1990, HS Brief van SP Pretoriusdr CF Albertyn, 106.

2 Die Burger, 2 Feb 1990, Die Weergids, 3. 


\section{Die Kaapse Helpmekaar}

die Rupert-sakeryk se finansiële bestuurs- en beleggingspraktyke het hom in staat gestel om insette te lewer wat die Helpmekaar op die pad van vernuwing in terme van administratiewe, finansiële bestuurs- en beleggingspraktyke sou plaas. Hierdie proses is versterk deur Anton Rupert se aanmaning dat die Helpmekaar se leningspraktyke - rentekoerse wat nie met inflasie tred hou nie - onvolhoubaar was en op die lange duur die organisasie onberekenbare skade sou berokken. Met die morele ondersteuning van die Rupert-faktor en die toegang wat Oberholser tot die Rupert-sakeryk se bewese rekord van strategiese, bestuurs- en beleggingspraktyke gehad het, het hy 'n beduidende rol gespeel om die Helpmekaar in die onsekere negentigerjare te stabiliseer en op die pad van korporatisering te plaas.

Hierdie prosesse was egter nie onbetwis nie en is in die vroeë negentigerjare gekenmerk deur spanning tussen beheer (Raad van Trustees) en bestuur (die bestuurder en administratiewe personeel), 'n vernuwende strategie en die status quo. Dit het herinner aan 'n soortgelyke spanning tydens die vestigingsjare van die B-fonds, asook dié van die sestigerjare. In laasgenoemde gevalle het bestuur die magte van moderniteit verteenwoordig en die Kongres was die anakronisme. In die vroeë negentigerjare was die rolle grootliks omgeruil met bestuur die voorstanders van die status quo en minstens 'n beduidende deel van die Raad van Trustees die magte van moderniteit.

Hierdie hoofstuk sal besin oor hoe bogenoemde prosesse binne die Kaapse Helpmekaar ontvou het. As sodanig verskaf dit ook 'n lens op hoe Kaapse Afrikaners in die algemeen en spesifiek die establishment die Nuwe Suid-Afrika ervaar het, daarop gereageer het en ter wille van oorlewing daarby aangepas het.

\section{WINDE VAN VERANDERING: DIE HERSTEL VAN STABILITEIT}

Die konflik tussen bestuur en die Raad van Trustees sou hoofsaaklik manifesteer rondom die Helpmekaar se likiditeitsprobleme en gepaargaande finansiële bestuur. Tweedens sou dit gaan oor die toekomstige fokus van die Helpmekaar in die lig van die politieke veranderinge van die vroeë negentigerjare. Die konteks en manifestasie van die twee konflikareas word dus vervolgens beskou.

Daar is reeds verwys na die noodmaatreëls wat in 1988 aanvaar is om die likiditeitsprobleme van die Helpmekaar te bestuur en die ingrepe wat deur JCL Oberholster geïnisieer is as reaksie op Rupert se November 1988 skrywe. Dit het gehandel oor die potensiële langtermyn impak van die Helpmekaar se nie-markverwante rentkoerse op die organisasie. ${ }^{3}$ 
Die ingryping van bogenoemde maatreëls ten einde die "noodtoestand" die finansiering van studielenings te bestuur of opgehef te kry, het basies neergekom op pogings tot beter en noukeuriger finansiële beplanning, administrasie en die aanwending van beskikbare Helpmekaar reserwefondse. As sodanig het dit 'n refleksie gewerp op die bestaande bestuurspraktyke en -kultuur - praktyke wat gevestig en verpersoonlik is deur die bestuurder, mnr Fanie Pretorius, wat op 75-jarige ouderdom reeds 40 jaar in diens van die Helpmekaar gestaan het. Hierdie intervensies van die kant van die Raad van Trustees het dus getorring aan 'n narratief wat reeds diep in die Helpmekaar se praktyke en kultuur ingebed was en is dus nie onbetwis aanvaar nie. Die spanning tussen bestuur en die Raad van Trustees wat hieruit voortgevloei het, het dus in die vroeë negentigs periodiek gemanifesteer in kritiek vanaf bestuur teen besluite en handelinge van die raad. Wat betref die opdrag om statistieke te hou van aansoekers wat weens gebrek aan fondse nie gehelp kon word nie het Pretorius dit, vanweë die verleentheid wat dit vir amptenare geskep het, as "onmoontlik" beskryf. Waar die bestuur wel uitsonderings gemaak het en lenings toegestaan het, het hy versoek dat die raad die bestuur se goeie oordeel moes aanvaar:

"Ons maak hier ook staat op leiding van Bo wat ons aldag afbid ... Ons wens so dikwels dat 'n trustee of twee by so 'n onderhoud, of by die oorweging van 'n aansoek kan bysit om vir ons te sê of ons reg of verkeerd geoordeel het."

Die aanwending van Van Zyl's Gift-geld - wat vir die ontwikkeling van die grond geoormerk was - om die tekort aan geld vir studentelenings mee te oorbrug het veral Pretorius se argwaan gewek. In 'n lang brief aan Albertyn ter verduideliking van sy teenkanting "wat soveel ergelikheid by $u$ ontketen het dat $u$ my pleidooie en stellinginname met 'n ongeduldige handgebaar afgemaak het," het hy erken dat die ontwikkeling van die grond "'n troetelkind" vir hom geword het "as my een oorblywende ideaal, naamlik om hierdie grond om te skep in fondse van R4-7 miljoen om die Helpmekaar finaal selfstandig en doeltreffend te maak."7 Die aanwending van die geld, waarmee die grond ontwikkel moes word, vir nuwe studielenings het vir hom die einde van die ideaal voorspel:

"Dan moet ons 'n vennoot inbring, of die geld leen met die gevolg dat die uiteindelike moontlike opbrengs van oom Dawie se skenking soveel minder sal wees, en die Helpmekaar met 'n halwe eier sal sit ..."

4 (HSA) HS, Notuleboek (16 Feb 1973-10 Sep 1993), 7 Jun 1990, HS Brief van SP Pretorius-CF Albertyn, 106.

5 (HSA) HS, Notuleboek (16 Feb 1973-10 Sep 1993), 23 Feb 1990, HS jaarvergadering, Jaarverslag, 102.

6 (HSA) HS, Notuleboek (16 Feb 1973-10 Sep 1993), 7 Jun 1990, HS Brief van SP Pretorius-dr CF Albertyn, 106.

$7 \quad I b i d$.

$8 \quad I b i d$. 


\section{Die Kaapse Helpmekaar}

Die trustees se besluit het dus nie net sy ideaal vir 'n finansieel onafhanklike Helpmekaar bedreig nie, maar ook sy persoonlike nalatenskap. In sy jaarverslag vir 1990 het Pretorius weer 'n dwarsklap na die trustees gemik oor hul besluit om die Helpmekaar se reserwes aan te wend om lenings toe te ken:

"en wanneer ons daar aankom waar ons geld op is, sal ons 'n plan maak. Maar watse plan maak 'n mens as jou geld op is? Boonop sit jy dan nog met kontraktuele verpligtinge vir tot ses jaar vorentoe."

In Julie/Augustus 1991 het die bestuur verdere kritiek uitgespreek oor besluite van die UK. Nadat die dagbestuur in Maart aangedui het dat geen bates in kontant omgesit hoef te word om in 1991 se behoeftes te voorsien ${ }^{10}$ nie het Pretorius in Julie voorgestel dat die Helpmekaar van sy Richemont-aandele moes verkoop om verdere lenings aan studente te kon toeken. Pretorius se voorstel is waarskynlik gemotiveer deur die feit dat die Helpmekaar toenemend aansoeke van jong mense moes weier - "daardie soort mense- en studentemateriaal wat geen volk kan bekostig om verlore te laat gaan nie". ${ }^{11}$ Die UK het egter eenparig besluit dat geen aandele verkoop moes word voordat 'n begroting ingedien is nie. ${ }^{12}$ Die besluit het gestrook met die finansiële bestuurspraktyke wat deur Oberholster se voorstelle geïnisieer en deur die trustees aanvaar is. Die afkeur van sy voorstel vir die verkoop van die aandeleportefeulje om fondse vir studentelenings beskikbaar te maak het gelei tot 'n skriftelike kommentaar op die besluite van die raad waarin sy versoek vir die verkoop van aandele gemotiveer is en hy ook ander besware oor raadsbesluite te berde gebring het. Die raad se aandrang op die behoud van die aandele omdat die Beurs nog kon styg is deur Pretorius as "n dobbelspel" en "finansiële vraatsug" bestempel en hy het die raad herinner aan die verliese wat die Helpmekaar in 1969 en 1987 gelei het toe die Beurs op soortgelyke hoogtepunte as op daardie tydstip gestaan het.

Dit was ook duidelik dat die vereiste opstel van jaarlikse begrotings tot groot ongedurigheid by bestuur en amptenare gelei het vanweë die ekstra werklas en die inbreuk wat dit op hul ander verpligtinge gemaak het, die groot aantal onbekende faktore wat hulle finansieel moes probeer verreken en dat dit alles gedoen moes word te midde van "die gejaag om die rekenaar te voer". Hy het ook die feit bevraagteken dat 'n komitee, in plaas van die "behoeftes van die

9 (HSA) HS, Notuleboek (16 Feb 1973-10 Sep 1993), 22 Feb 1991, HS jaarvergadering, Jaarverslag, 6 Feb 1991, 111.

10 (HSA) HS, Notuleboek (16 Feb 1973-10 Sep 1993), 19 Mrt 1991, HS Dagbestuur, 112.

11 (HSA) HS, Notuleboek (16 Feb 1973-10 Sep 1993), 22 Feb 1991, HS jaarvergadering, Jaarverslag, 6 Feb 1991, 111.

12 (HSA) HS, Notuleboek (16 Feb 1973-10 Sep 1993), 31 Jul 1991, HS UK, 114. 


\section{Die "Wisseling van die Wag"}

studente, plus die beskikbare fondse", ${ }^{13}$ die bedrag wat uitgeleen mag word, bepaal het. Volgens Pretorius was die Helpmekaar nie soos 'n maatskappy wat groot gebeurlikheidsreserwes moes hou nie. Omdat hulp aan studente die rede vir die Helpmekaar se bestaan was, was dit volgens die bestuur:

“immoreel om studente weg te wys terwyl ons miljoene in 'n riskante belegging hou.

Dis nog baie erger as om 'n diamant in die brandkas te laat bly lê of 'n Ou Meester aan die muur, terwyl jy kontant nodig het." 14

Hy het aangedui dat terwyl "van ons trustees" sterk daarop aandring dat raadsbesluite nie herroep moet word nie, hulle dit juis doen. As voorbeelde het hy die aanwending van Van Zyl's Gift-geld vir studielenings, asook die aandrang dat die geld van die Vorster-Muller Fonds nie net vir teologiestudente aangewend moes word nie, maar ook na onderwys- en mediese studente uitgebrei moes word - beide voorstelle wat vanaf Oberholster afkomstig was - aangehaal. Teenoor hierdie "uitkoms-planne" het hy voorgestel dat die Helpmekaar se aandeleportefeulje van R4,9 miljoen verkoop en belê word en die rente daarop vir studielenings aangewend word. 'n Stap wat volgens hom 'n bedrag van meer as R1 miljoen beskikbaar sou maak. Daar kon dan weer van vooraf aan 'n nuwe aandeleportefeulje gebou word. Die lys van aandele wat Pretorius voorgestel het wat verkoop moes word, is oorheers deur aandele van die Rembrandt-groep of maatskappye waarin die Rembrandt-groep belange gehad het. Volgend Pretorius sou sy voorstel die pad open "vir effektiewe hulp aan studente. DIT IS IMMERS DIE REDE VIR ONS BESTAAN."15 In sy betoog het Pretorius dus ingespeel op die histories filantropiese aard van die Helpmekaar as teenvoeter vir'n neiging om die Helpmekaar te korporatiseer.

Die kwessie oor die verkoop van aandele is op die spits gedryf deur eksterne wêreldgebeure. Die poging op 17 Augustus 1991 deur onversetlike lede van die Kommunistiese Party van die Sowjetunie om Michail Gorbatsjof se regering in 'n staatsgreep omver te werp ${ }^{16}$ het die vrees by die voorsitter, CF Albertyn, laat ontstaan dat die gebeure 'n negatiewe effek op aandelebeurse kon hê wat die waarde van die Helpmekaar se aandeleportefeulje negatief kon beïnvloed. $\mathrm{Na}$ 'n gesprek met die bestuurder het hy dus al die lede van die raad telefonies gekontak om hulle te raadpleeg met die oog daarop om die besluit dat geen aandele verkoop

13 (HSA) HS, Notuleboek (16 Feb 1973-10 Sep 1993), 20 Aug 1991, HS UK, Kommentaar op Raadsbesluite, 16 Aug 1991, 114.

$14 \quad$ Ibid.

15 Ibid., 114-115.

16 http://www.nytimes.com/2011/08/21/opinion/sunday/the-soviet-coup-that-failed.html?_r=0, Victor Sebestyen, 20 Aug 2011, The KGB`s Bathhouse Plot. 


\section{Die Kaapse Helpmekaar}

mag word voordat 'n begroting ingedien is nie te herroep en om toe te gee aan die versoek van bestuur dat spesifieke aandele wel verkoop moes word. Dr Albertyn, di JH Roos, J van der Westhuyzen en mnr HA Lambrechts het toegestem dat ongeveer 60000 van Richemont, 80000 van Tegkor en 1000 van Joels se aandele voorlopig verkoop mag word. Op die UK-vergadering van 20 Augustus het Albertyn die verloop van gebeure verduidelik en die bestuurder het aangedui dat 45000 van Richmont, 55000 van Tegkor en 1000 van Joel se aandele reeds verkoop is. Hoewel die vergadering die reeds afgehandelde verkope goedgekeur het, is na 'n indringende debat, wat deur verskeie standpunte gekenmerk is, besluit om nie nog Richmont- en Tegkor-aandele te verkoop nie. Daar is ook besluit om 30 persent van elk van die oorblywende groepe aandele te verkoop met die onderneming dat, indien daar twyfel sou ontstaan of met die verkope voortgegaan moes word, JCL Oberholster, GR Pretorius, dr PS Meyer en ds J van der Westhuyzen geraadpleeg moes word. Van die lede van die raad wat die verkoop van aandele na aanleiding van Albertyn se telefoniese navraag goedgekeur het, was slegs Van der Westhuyzen deel van bogenoemde groep raadgewers.

Die voorlopige begroting vir 1992 wat by die vergadering gedien het, is goedgekeur, maar die raad het versoek dat 'n meer volledige begroting ingedien word na afhandeling van die aandeleverkope. ${ }^{17}$ Die verkoop van die aandele het tydelike verligting gebring deur die beskikbaarstelling van meer kontant om studente mee te help. In die lig van die steeds stygende studiekostes was dit nie 'n permanente oplossing nie, aangesien die kontant hoofsaaklik deur "verhoogde studiekoste in plaas van dat ons meer studente kan help ... opgeslurp"18 sou raak.

\section{DIE NUWE SUID-AFRIKA: WAAR SAL ONS HULP VANDAAN KOM?}

Die Helpmekaar se interne likiditeitsprobleme het saamgeval met die politieke en sosioekonomiese kragte wat deur De Klerk se toespraak van 2 Februarie 1990 ontsluit is. Die langertermyn impak daarvan op 'n toekomstige onderwysbedeling en die Helpmekaar wat nog slegs op spekulasie berus het, het Albertyn reeds in sy voorsittersrede van Februarie 1990 genoop om te waarsku dat "op onderwysgebied beweeg die land, en dus ook die Afrikaner student, 'n krisis-tydperk binne". ${ }^{19}$ Hy het kennis gegee van die groot afname wat ten opsigte van staatsubsidies vir onderwys en tersiêre instellings te wagte was en gewaarsku dat ouers

18 (HSA) HS, Notuleboek (16 Feb 1973-10 Sep 1993), 21 Feb 1992, HS jaarvergadering, Jaarverslag, 28 Jan 1991, 118.

19 (HSA) HS, Notuleboek (16 Feb 1973-10 Sep 1993), 23 Feb 1990, HS Voorsittersrede, 105. 
en die sakesektor in die toekoms 'n veel groter bydrae tot die onderwys sou moes lewer as in die verlede. Hy het ouers gewaarsku om nie hul hoop op beurse te plaas nie: "beurse het egter opgedroog tot 'n dun straaltjie, veral wat blanke studente betref." ${ }^{\prime 2}$ Volgens Albertyn het die situasie dit vir te veel jongmense wat daarvoor gekwalifiseer het onmoontlik gemaak om tersiêre onderrig te ontvang - 'n onderbenutting van mensemateriaal wat die land nie kon bekostig nie. ${ }^{21}$

Die impak van die nuwe staatsbedeling het vir die eerste keer pertinent onder die loep gekom tydens 'n vergadering van die UK wat na afloop van 'n middagmaal as gaste van Anton Rupert in Rembrandt se raadsaal op Stellenbosch gehou is. Tydens die vergadering het Van der Westhuyzen op versoek van Albertyn die raadslede kortliks toegelig oor sy sienings van "onderwys in die toekomstige staatsbedeling." Van der Westhuyzen is by die geleentheid versoek om sy gedagtes in 'n memorandum te vervat wat volgens besluit op 'n spesiale vergadering op 3 Desember 1990 bespreek sou word. ${ }^{22}$

Uit Van der Westhuyzen se memorandum, sowel as die bespreking daarvan deur die UK, was dit duidelik dat daar groot onsekerheid bestaan het oor'n strategie vir die pad vorentoe. Daar was konsensus oor die bevoorregte posisie wat blanke Afrikanerstudente, die kliënte van die Helpmekaar onder die ou staatkundige bedeling, beklee het in terme van die gehalte van die onderwys en opleiding wat hulle ontvang het, asook die finansiële ondersteuning om dit te kon bekostig. Daar was ook konsensus dat in die nuwe bedeling hierdie bevoorregting, wat op ras/kleur gebaseer was, nie langer van staatsweë in stand gehou sou word nie. ${ }^{23}$ Benewens hierdie implikasie van die nuwe bedeling het ander faktore ook die Helpmekaar se fondse onder druk geplaas. Tot in die vroeë tagtigerjare kon die Helpmekaar vanweë die bevoorregte posisie van blanke Afrikanerstudente gemaklik in sy kliëntegroep se behoeftes voorsien, aangesien hy slegs aanvullende fondse beskikbaar moes stel waar hulp uit ander bronne nie bestaan het nie. Sedertdien het die vermindering van staatsbesteding aan universiteite en technikons en die gepaardgaande verminderde studiehulp, swak ekonomiese toestande (hoë rentekoerse en inflasie) en die groot styging in studiekoste die behoefte na studiehulp in so

\footnotetext{
$20 \quad$ Ibid.

21 Ibid.

22 HSA) HS, Notuleboek (16 Feb 1973-10 Sep 1993), 6 Nov 1990, HS UK, Vergadering op Stellenbosch gehou na afloop van ete met Anton Rupert, 107.

23 (HSA) HS, Notuleboek (16 Feb 1973-10 Sep 1993), 3 Des 1990, HS Trustees, Memorandum: Hulpverlening in 'n moontlike nuwe onderwysbedeling, ds Kobus van der Westhuyzen. Opgestel nav besluit van UKvergadering van 6 Nov 1990, 108-110.
} 
'n mate laat toeneem dat die Helpmekaar nie in die aanvraag kon voorsien nie. Daar was konsensus dat die nuwe politieke bedeling die impak van die faktore sou verswaar.

Volgens Van der Westhuyzen was bronne van finansiering beperk tot maatskappye en individue. Bydraes van maatskappye vir die bevordering van eksklusiewe Afrikanerbelange sou in die toekoms baie moeilik bekom word. Indien die Helpmekaar dus sou voortgaan om op hulp aan die Afrikanerjeug te fokus, sou hulle grootliks op die ondersteuning van individue aangewese wees. Aangesien die Afrikaner volgens Van der Westhuyzen weens sy nog onlangse "armoed-kultuur" nog nie 'n "oop-hand-kultuur" ontwikkel het nie sou die ontginning van dié bron groot uitdagings bied. 'n Strategie moes dus gevind word "wat sal verhoed dat die Afrikaner sy leidende rol in die toekomstige Suid-Afrika prysgee". ${ }^{4}$ Die beste manier om dit te verseker was om hom "deur kundigheid van die beste gehalte (homself) onmisbaar te maak". ${ }^{25}$ Oor wat die beste modus operandi was om dit te bereik was daar egter geen sekerheid nie. Moes die Helpmekaar voortgaan om sy hulp te beperk tot "ons eie mense" of moes "Afrikanerstudente" verbreed word tot "Afrikaanssprekende studente" 26 en taal in plaas van kleur dus die seleksiemaatstaf vir studiehulp word? Van die vrae waarop antwoorde gesoek is, was: Moes belangegroepe in die Afrikaanssprekende gemeenskap gemobiliseer word met die oog op 'n plan of strategie vir die toekoms? Wie moes dit doen? Wanneer moes dit gedoen word? Wie moes daarby ingesluit word? Van der Westhuyzen het behalwe 'n voorstel om Helpmekaarverenigings op plaaslike vlak te laat herleef met die oog op plaaslike hulpverlening selfs in die retoriek van die twintiger- en dertigerjare 'n "volkskongres oor: Die voorsiening van standaard-onderwys te oorweeg en die eise wat dit mag stel" ${ }^{27}$ gesuggereer. Om antwoorde op al die bogenoemde uitdagings te probeer vind het die UK besluit om 'n komitee, bestaande uit dr Meyer, ds Van der Westhuyzen en mnre Lambrechts en Oberholster, die opdrag te gee "om verkennende samesprekings te hê met sakeleiers, onderwysmanne, ens. om riglyne te bepaal vir toekomstige strategie en die hou van 'n nasionale kongres om die probleme te bespreek en oplossings te vind." 28

24 (HSA) HS, Notuleboek (16 Feb 1973-10 Sep 1993), 3 Des 1990, HS Trustees, Memorandum opgestel deur dr PS Meyer: Die plek en funksie van die Helpmekaar Studiefonds in die Suid-Afrika van die toekoms, $110-111$.

25 (HSA) HS, Notuleboek (16 Feb 1973-10 Sep 1993), 3 Des 1990, HS Trustees, 110. Memorandum: Hulpverlening in 'n moontlike nuwe onderwysbedeling ..., 108-109.

26 HSA) HS, Notuleboek (16 Feb 1973-10 Sep 1993), 3 Des 1990, HS Trustees, Memorandum opgestel deur dr PS Meyer ..., 110-111.

27 (HSA) HS, Notuleboek (16 Feb 1973-10 Sep 1993), 3 Des 1990, HS Trustees, 110. Memorandum: Hulpverlening in 'n moontlike nuwe onderwysbedeling ..., 108-109.

28 (HSA) HS, Notuleboek (16 Feb 1973-10 Sep 1993), 3 Des 1990, HS Trustees, 110. 
Die belangrikste uitvloeisel van die besinning was die pogings wat aangewend is om die Helpmekaar deur reklame en bemarking wyer bekend te stel en sy kapitaalbasis te versterk. Hier is hoofsaaklik teruggeval op die ou gebaande weë en etniese netwerke. Die landswye fondsinsamelingsveldtogte van 1951 en 1961 is in herinnering geroep en mnr Ton Volsoo van Nasionale Pers en Die Burger is in dié verband geraadpleeg. ${ }^{29}$ Die idee het egter 'n stil dood gesterf wat die Helpmekaar genoop het om 'n eie inisiatief te loods om die kapitaal van die Helpmekaar daadwerklik uit te bou. Teen die einde van 1991 is dus begin met 'n proses om JCL Oberholster as finansiële bestuurder van die Helpmekaar aan te stel. Aangesien die anstelling sterk op fondsinsameling en die wyer bekendstelling van die HS gefokus was, sou sy aanstelling hom in staat stel om namens die Helpmekaar met die hoofde van finansiële instellings, prokureurs, makelaars, bankbestuurders, ouditeursfirmas, NG Gemeentes en welgestelde individue te onderhandel met die oog op testametêre of onmiddellike skenkings aan die Helpmekaar. Die aanstelling sou aanvanklik op 1 Februarie 1992 aanvang neem met aftree-ouderdom 70 en het die dagbestuur op 30 Januarie 1992 besluit om in die lig van Pretorius se besluit in Desember 1991 (om aan die einde van 1992 as bestuurder af te tree) Oberholster slegs vir' $n$ jaar aan te stel en dat die hele aangeleentheid rakende die topbestuur van die HS mettertyd bespreek sou word. ${ }^{30}$ Oberholster se aanstelling as finansiële bestuurder sou uiteindelik op 1 Maart 1992 van krag word. ${ }^{31}$

Die inisiatief is beplan om met die Helpmekaar se 75ste bestaansjaar, wat foutiewelik as 1992 geidentifiseer is, saam te val. Dit het dus 'n periode van "terugkyk oor 75 jaar en vorentoe die toekoms in" ${ }^{\prime 2}$ moontlik gemaak. Uit Albertyn se voorsittersrede tydens die algemene jaarvergadering van 1992 was dit duidelik dat die fokus van die Helpmekaar se studiehulp ten minste wat retoriek betref ' $n$ verskuiwing ondergaan het toe hy na bogenoemde verwikkelinge verwys het as "stappe gedoen om gereed te wees vir die diens wat die HS vorentoe aan Afrikaanssprekende studente wat geldelike hulp nodig het, graag wil lewer." ${ }^{33}$ Na 75 jaar het "Afrikanerstudente" vir "Afrikaanssprekende studente" plek gemaak.

29 (HSA) HS, Notuleboek (16 Feb 1973-10 Sep 1993), 22 Feb 1991, HS jaarvergadering, 112; 19 Mrt 1991 , Dagbestuur, 112; 22 Feb 1991, HS jaarvergadering, Jaarverslag, 6 Feb 1991, 111.

30 (HSA) HS, Notuleboek (16 Feb 1973-10 Sep 1993), 30 Jan 1991, HS Dagbestuur, Memorandum: die opvolging van die verslag van die ad hoc-komitee het soos volg verloop, 116-117; 30 Mrt 1992, HS 75ste verjaarsdagkomitee, 118-119; 19 Feb 1993, HS jaarvergadering, Jaarverslag, 5 Feb 1993, 124.

31 (HSA) HS, Notuleboek (16 Feb 1973-10 Sep 1993), 21 Feb 1992, HS jaarvergadering, 118.

32 (HSA) HS, Notuleboek (16 Feb 1973-10 Sep 1993), 21 Feb 1992, HS jaarvergadering, Voorsittersrede, 118.

33 Ibid. 
Net soos die pogings tot finansiële en administratiewe vernuwing onder Oberholster se invloed nie onbetwis aanvaar is nie het die bestuur ook nie bogenoemde verskuiwing in die fokus van Helpmekaar studiehulp onbetwis aanvaar nie. In 'n memorandum waarin "die kantoor" kommentaar gelewer het op wat genoem is die "praktiese implikasies van sekere denkrigtings" na aanleiding van besprekings en besluite wat op die raadsvergadering van 11 Junie 1992 geneem is, was die bestuur duidelik oortuig dat die uitbreiding van studiehulp na Afrikaanssprekende studente die Helpmekaar duur te staan sou kom. Pretorius het aangevoer dat:

"As ons dus twee of drie lenings sou toeken aan Bruin Afrikaanssprekende studente (selfs lede van die Sending Kerk) en dit sou rugbaar word dat hulle gehelp is, ten spyte van die feit dat talle blankes se aansoeke afgewys is weens gebrek aan fondse, kan mens jou voorstel hoe tjekboeke gaan toeklap vir die Helpmekaar. As ons sê 10 bruin studente sou help in 'n bepaalde jaar en dan nie verder kan help nie, is die kanse in die huidige klimaat sterk dat ons beskuldig sal word van diskriminasie omdat ons in dieselfde jaar wel 90 blankes gehelp het." ${ }^{34}$

Hy was duidelik gekant teen die uitbreiding van lenings aan bruin studente van UWK (Jakes Gerwel se mense) en die Kaapse Tegnikon (Franklin Sonn se mense) aangesien hy van mening was dat:

"dit moet eenvoudig aanvaar word dat sommige mense nog nie in 'n 'kultuur' opgegroei het waar geleende geld op verantwoordelike wyse terug betaal word nie. Dit mag hopelik vorentoe verander." ${ }^{35}$

Dieselfde sentimente het ook deurgeskemer in 'n berig wat Pretorius in opdrag van die raad oor die Helpmekaar geskryf het vir publikasie in Die Burger en Kerkbode. Dit was as deel van die 75ste verjaarsdag van die Helpmekaar en die veldtog om die Helpmekaar wyer bekend te stel en nuwe fondse te werf. ${ }^{36}$ Die artikel met die opskrif "Helpmekaar: toekoms hou min rede tot hoop" het die goeie werk van die Helpmekaar belig, maar was besonder pessimisties oor die toekoms en het die regstellende aksie van die periode ook ten opsigte van studiehulp bevraagteken:

"Daar is letterlik oorvloedige beursfondse beskikbaar vir swart studente uit oorsese bronne. Ander jong mense wat gretig is om verder te studeer, moet dié voorreg ontbeer en in 'n oorvol arbeidsmark gaan werk soek. Die Helpmekaar kyk met geregverdigde trots na dit wat agter lê. Die toekoms hou egter min rede tot hoop in."37

34 (HSA) HS, Notuleboek (16 Feb 1973-10 Sep 1993), HS, Kommentaar vanuit die kantoor op praktiese implikasies van sekere denkrigtings soos ons dit vanuit die kantoor se hoek sien (i.s. bespreking en besluite geneem op raadsvergadering 11 Jun 1992), gp.

Ibid.

36 (HSA) HS, Notuleboek (16 Feb 1973-10 Sep 1993), 11 Jun 1992, HS Trustees, 120.

37 Die Burger, 3 Aug 1992, Helpmekaar: toekoms hou min rede tot hoop, 6. 
Pretorius se betwisting van die nuwe fokus van die Helpmekaar ten opsigte van studielenings is ook deur sommige van die trustees op die raad gedeel. CP Jamneck het in November 1992 weens swak gesondheid en hoë ouderdom as lid van die raad bedank. In sy afskeidsboodskap het hy die mening uitgespreek dat die Helpmekaar'n sleutelrol te vervul het om

"die Afrikaner in staat te stel om sy regmatige plek in die Nuwe Suid-Afrika in te neem.

Om hierdie rede is hy gekant teen die voorstel van sekere persone dat Helpmekaarlenings aan nie-Afrikaners beskikbaar gestel word" ${ }^{38}$

Ten spyte van die teenstrydige standpunte en siening was daar 'n vasberadenheid om die Helpmekaar vorentoe die toekoms in te neem deur die uitdagings van die snelveranderende politieke en sosiale milieu en die finansiële eise suksesvol die hoof te bied. Een van die verwikkelinge wat die proses sou bevorder, was die wisseling van lede van beide bestuur en die Raad van Trustees in dié periode. Hierdie proses van die "wisseling van die wag" sou ook die spanning wat die verhouding tussen bestuur en lede van die raad in die eerste twee jaar van die negentigerjare gekenmerk het, ontlont. Daar is reeds verwys na Albertyn se onsuksesvolle poging in Maart 1989 om weens hoë ouderdom as voorsitter af te tree. In Februarie 1991 het ds JM Delport weens hoë ouderdom en die lang ritte wat vergaderings in die Kaap meegebring het, as trustee bedank. ${ }^{39}$ Met die aanstelling van JCL Oberholster as finansiële bestuurder in 1992 het A Crafford hom as Anton Rupert se alternatief op die raad vervang. ${ }^{40}$ Vernuwing en versterking van die Raad van Trustees was in Februarie 1992 een van die prioriteite wat Albertyn in sy voorsittersrede vir onmiddellike aandag uitgesonder het. Hy het voorgestel dat ten minste twee nuwe lede uit byvoorbeeld "die universiteitswêreld en sakewêreld, waarby ek die Nasionale Pers en Die Burger insluit" ${ }^{41}$ aangestel moes word. Hierdie

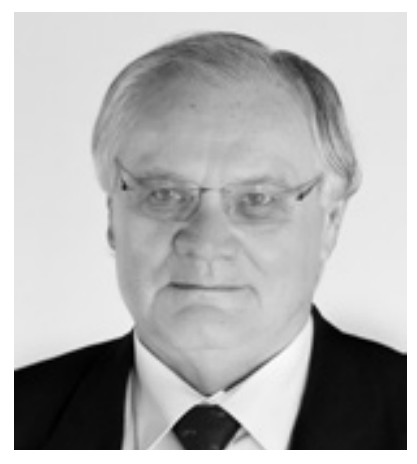

Carel Stander, huidige vise-voorsitter van die Helpmekaar Studiefonds

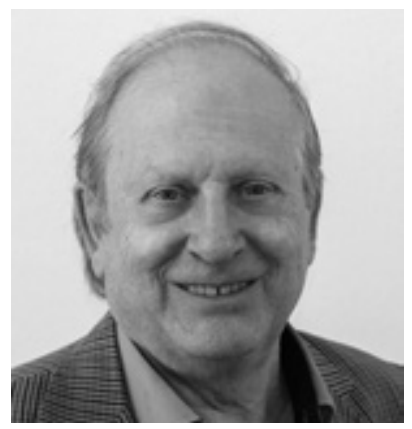

Ebbe Dommisse, huidige voorsitter van die direksie van die Helpmekaar Studiefonds

38 (HSA) HS, Notuleboek (16 Feb 1973-10 Sep 1993), 30 Nov 1992, HS Trustees, 124.

39 (HSA) HS, Notuleboek (16 Feb 1973-10 Sep 1993), 22 Feb 1991, HS Jaarvergadering, 112.

40 (HSA) HS, Notuleboek (16 Feb 1973-10 Sep 1993), 21 Feb 1992, HS Jaarvergadering, 118.

41 (HSA) HS, Notuleboek (16 Feb 1973-10 Sep 1993), 21 Feb 1992, HS jaarvergadering, Voorsittersrede, 21 Feb 1992, 118. 


\section{Die Kaapse Helpmekaar}

voorneme het in April 1993 praktiese gestalte gekry toe vier nuwe trustees, Ebbe Dommisse (redakteur van Die Burger), SPF van Aswegen (rekenmeester en vennoot in die firma Brink, Roos en Du Toit), ${ }^{42}$ dr NJ Kok (verbonde aan die Kaapse Technikon) ${ }^{43}$ en dr CH Stander (van Boland Bank) tot die raad toegetree het. ${ }^{44}$ Die herrangskikking van die Raad van Trustees is in Februarie 1994 voltrek met die uittrede van dr CF Albertyn en ds JH Roos en die verkiesing van ds J van der Westhuyzen as voorsitter in Albertyn se plek. ${ }^{45}$ Met die aankondiging van Pretorius in Desember 1991 dat hy aan die einde van 1992 as bestuurder sou aftree en die aanstelling van JCL Oberholster as sy opvolger vanaf 1 Januarie $1993^{46}$ was die generasiewisseling van beide bestuur en beheer wat die vroeë negentigerjare gekenmerk het grootliks voltrek.

Die “wisseling van die wag” was nie 'n gedwonge proses nie, maar is deur die hoë ouderdom of swak gesondheid van die betrokke trustees teweeggebring. Dit het geleentheid vir vernuwing en nuwe denke geskep en vergemaklik. Voortaan sou slegs Van der Westhuyzen, Meyer en Horn nog daarop kon aanspraak maak dat hulle betrokkenheid by die Helpmekaar uit die Kongres-era gedateer het.

Die uittrede van Pretorius as bestuurder het die Raad van Trustees die geleentheid gebied om te herbesin oor die aard en omvang van die bestuurderspos in die lig van die onmiddellike uitdagings en die behoeftes van die Helpmekaar. 'n Komitee met Van der Westhuyzen as sameroeper is dus opdrag gegee om hieroor te besin en die raad met aanbevelings te bedien. ${ }^{47}$ Twee aspekte is uitgesonder as die fokus van die opdrag van die nuwe bestuurder. Eerstens was dit die uitbouing van die kapitaalbasis en wyer bekendstelling van die Helpmekaar. Die aanvoorwerk is reeds in 1992 deur die finansiële bestuurder, JCL Oberholster, in dié verband gedoen om die Helpmekaar wyer bekend te stel. Hy het dit gedoen deur kontak met 'n verskeidenheid belangegroepe, artikels in dagblaaie en spreekbeurte by geleenthede, soos die kongres van die Kaaplandse Vroue-Landbouvereniging op Kuruman in Augustus met die oog op skenkings en testamentêre bemakings. Die inisiatief moes doelgerig voortgesit word. Tweedens was dit die fokus op die voortsetting van die modernisering van die kantooradministrasie en prosedures met die oog op maksimale rekenarisering

\footnotetext{
42 Die Burger, 16 September 1995, Bekende rekenmeester sterf, 2.

43 http://www.helpmekaarfonds.org/Direksie.html

44 (HSA) HS, Notuleboek (16 Feb 1973-10 Sep 1993), 16 Apr 1993, HS Trustees, 128; (HSA) HS, Notuleboek (13 Okt 1993- 18 Sep 2003), 10 Feb 1994, HS jaarvergadering, Jaarverslag, 21 Jan 1994, gp. jaarvergadering, Jaarverslag, 31 Jan 1995, gp.

46 (HSA) HS, Notuleboek (16 Feb 1973-10 Sep 1993), 20 Jan 1993, HS UK, 124

47 (HSA) HS, Notuleboek (16 Feb 1973-10 Sep 1993), 28 Okt 1992, HS UK, 122-123.
} 


\section{Die "Wisseling van die Wag"}

om doeltreffendheid te verbeter en die personeel se werkslading te verminder. Met die oog hierop is JCL Oberholster met ingang 1 Januarie 1993 vir 'n periode van twee jaar as bestuurder aangestel. ${ }^{48}$

Onder Oberholster se leiding is onmiddellik aandag gegee aan aspekte van die leningsvoorwaardes en rentekoersbeleid om 'n meer eweredige en vinniger deurvloei van kapitaal wat op lenings uitgelê is te verseker. Vanaf 1 Januarie 1994 sou rentekoerse jaarliks vasgestel word vir die kalenderjaar synde 85 persent van Volkskas se prima rentekoers, afgerond tot die volgende half persent gedurende die normale duur van die studiekursus, en daarna word dit terugbetaal teen die prima bankkoers. Vir teologiestudente is die koers 75 persent in plaas van 85 persent vir die normale duur van die kursus en daarna teen prima bankkoers. Indien die studielening terugbetaal word in minder as dubbeld die normale tydperk van studie waarvoor die lening aangegaan is, kry die student 'n toegewing van 0,25 persent per jaar rente tot 'n maksimum van een persent per jaar op die volle lening vir elke volle jaar wat hy/sy gouer afbetaal. Terwyl die student studeer, moet die rente maandeliks vereffen word. Hierdie meer markverwante rentekoerse en die maandelikse delging van rente plus die aanmoediging om lenings oor 'n korter periode terug te betaal het onmiddellike verligting gebring in die kontantvloeiposisie van die Helpmekaar en hom in staat gestel om tot 1996 sy leningsverpligtinge na te kom. ${ }^{49}$ Hoewel hierdie maatreëls onmiddellike druk op die Helpmekaarkapitaal verlig het, was dit egter nie voldoende om in die groeiende vraag na Helpmekaar-lenings te voorsien nie en moes dit gekomplementeer word met poging tot die verdere uitbouing van die Helpmekaar se kapitaalbasis.

\section{DIE ENTREPRENEURSFONDS}

"Dis tyd dat Afrikaners weer die skoenrieme vasvat en 'n koers van hoop inslaan." ${ }^{0}$

Die fokus op die groei van die kapitaalbasis van die Helpmekaar was 'n teenvoeter vir die steeds stygende studiekostes - wat in 1992 alleen met ongeveer 20 persent gestyg het - wat meegebring het dat steeds minder studente gehelp kon word in 'n periode waar die verwagting

(HSA) HS, Notuleboek (16 Feb 1973-10 Sep 1993), 30 Nov 1992, HS Trustees, 124; 20 Jan 1993, HS UK, 124; 19 Feb 1993, HS jaarvergadering, Jaarverslag, 5 Feb 1993.

49 (HSA) HS, Notuleboek (13 Okt 1993- 18 Sep 2003), 13 Okt 1993, HS Trustees, gp; 22 Jun 1994, HS Trustees, gp; 27 Sep 1994, HS Trustees, gp.

50 Die Burger, 11 Mei 1996, Skep so self kanse (Hoofartikel), 10. 
was dat die aanspraak op Helpmekaar-ondersteuning drasties sou toeneem. ${ }^{51}$ Oberholster het dus die mandaat wat hy reeds in 1992 as finansiële bestuurder gekry het in 1993 as bestuurder voortgesit en deur die loop van die jaar 34 persone en groepe besoek met die oog op die bekendstelling van die Helpmekaar en die werwing van fondse. In die proses is hy ook sover moontlik deur die trustees ondersteun. ${ }^{52}$ As deel van die bekendstelling is 'n nuwe embleem ontwerp, ${ }^{53}$ 'n bekendstellingsbrosjure vir die Helpmekaar saamgestel ${ }^{54}$ en artikels in Die Burger geplaas. ${ }^{55}$

Van der Westhuyzen se voorsittersrede tydens die 1995-jaarvergadering het die verslegtende situasie van die Helpmekaar se tradisionele kliëntepoel ten opsigte van studiefinansiering bevestig. Tradisionele bronne van beurse en lenings het opgedroog en volgens Van der Westhuyzen “wil dit nou voorkom of 'regstellende aksies' so algemeen toegepas word dat die sogenaamde 'agtergeblewenes' die beker leeg drink".56 Die Helpmekaar moes dus toenemende getalle belowende studente weens 'n gebrek aan fondse wegwys. In 1994 kon minder as die helfte van die aansoeke weens 'n gebrek aan fondse toegestaan word en het die bestuurder aangedui dat die "noodkreet van 'as die Helpmekaar ons nie kan help nie wie gaan vir ons blanke Afrikaanse studente help' ... gereeld gehoor (word) soos hulle al hoe meer toe deure vind." ${ }^{57}$ Van der Westhuyzen was van mening dat daar ernstig besin moes word "om die groeiende nood van ons mense" aan te spreek en het die vraag gestel of die nood nie op 'n dinamiese wyse aangepak moes word nie.

Die feit dat afgestudeerde studente dit ook toenemend moeilik gevind het om werk te bekom wat hul kwalifikasies regverdig, het die spoed waarteen studente hul lenings kon terugbetaal beïnvloed "met 'n gevolglike sneeubal-effek". ${ }^{8}$ Hy het dus as 'n langtermyn aksieplan

51 (HSA) HS, Notuleboek (16 Feb 1973-10 Sep 1993), 19 Feb 1993, HS jaarvergadering, Jaarverslag, 5 Feb 1993, 124.

52 (HSA) HS, Notuleboek (13 Okt 1993- 18 Sep 2003), 10 Feb 1994, HS jaarvergadering, Jaarverslag, 21 Jan 1994, gp; 10 Feb 1994, HS Trustees, gp.

53 (HSA) HS, Notuleboek (16 Feb 1973-10 Sep 1993), 11 Jun 1992 HS UK, 120; 13 Aug 1992, HS UK, 122.

54 (HSA) HS, Notuleboek (16 Feb 1973-10 Sep 1993), 19 Feb 1993, HS jaarvergadering, Jaarverslag, 5 Feb 1993, 125.

55 (HSA) HS, Notuleboek (16 Feb 1973-10 Sep 1993), 30 Mrt 1992, HS 75ste Verjaarsdagkomitee, 118.

56 (HSA) HS, Notuleboek (13 Okt 1993- 18 Sep 2003), 16 Feb 1995, HS jaarvergadering, Voorsittersrede, 2 Feb 1995, gp.

57 (HSA) HS, Notuleboek (13 Okt 1993- 18 Sep 2003), 16 Feb 1995, HS jaarvergadering, Jaarverslag, 31 Jan 1995, gp.

58 (HSA) HS, Notuleboek (13 Okt 1993- 18 Sep 2003), 16 Feb 1995, HS jaarvergadering, Voorsittersrede, 2 Feb 1995, gp. 
gesuggereer dat die gunstige klimaat wat geskep is deur die besef dat groter hulpverlening as in die verlede aan studente nodig was, benut moes word deur reklame te maak vir die Helpmekaar en sy doelstellings, asook op 'n beplande wyse potensiële donateurs te nader om testamentêre bemakings aan die Helpmekaar te doen. ${ }^{59}$ Die raad het dus na aanleiding van Van der Westhuyzen se suggesties op voorstel van dr Carel Stander 'n komitee die opdrag gegee om 'n plan van aksie vir die bekendstelling van die Helpmekaar en insameling van fondse op te stel. ${ }^{60}$

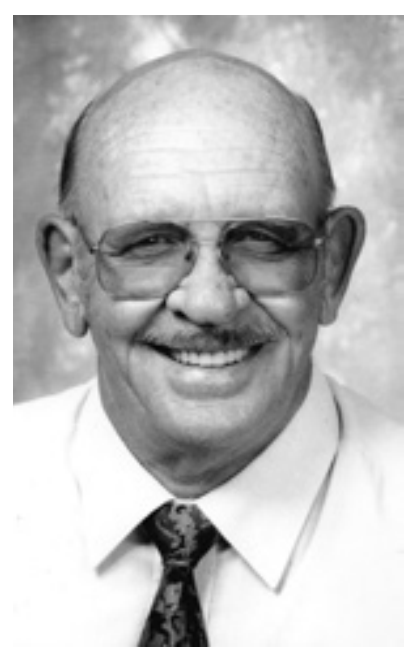

GJ de Swardt, ontwikkelings bestuurder (1996) en bestuurder van die Helpmekaar Studiefonds tot 2007
Die komitee se aanbevelings wat in Desember 1995 deur die raad aanvaar is, het behels dat 'n fondsinsamelingsveldtog in 1996 geloods word onder leiding van mnr GJ de Swardt wat as ontwikkelingsbestuurder vir een jaar aangestel sou word om die projek te lei. De Swardt, wat voorheen by die Universiteit Stellenbosch as fondswerwer werksaam was en op 1 Februarie 1996 diens aanvaar het, sou aanvanklik op 'n beperkte teikengroep wat simpatiek gestaan het teenoor die Helpmekaar konsentreer. 'n Sub-komitee, bestaande uit Van der Westhuyzen, Meyer, Stander en Oberholster, sou vir die toesig oor die insamelingsveldtog verantwoordelik wees. ${ }^{61}$ Die mikpunt van die veldtog was om R6 miljoen oor 'n periode van vyf jaar in te samel. ${ }^{62}$ Die implementering van die voorstelle het die duidelike impak van die staat se regstellende aksie-beleidsrigtings op die denke en fokus van die Helpmekaar weerspieël.

In die lig dat die Helpmekaar se tradisionele kliëntebasis dit toenemend moeilik gevind het om toegang tot "tradisionele werksterreine" te kry en verwag is dat die groter aanvraag na "meer prakties ge-oriënteerde opleiding was," het daartoe aanleiding gegee dat die swaartepunt van studente-befondsing toenemend na technikons en ander aanverwante opleidingsinrigtings sou verskuif. Dit het veroorsaak dat die Helpmekaar die bevordering van entrepreneurskap as die sleutel tot die oorlewing van sy tradisionele kliëntebasis gesien het. Van der Westhuyzen

$59 \quad$ Ibid.

60 (HSA) HS, Notuleboek (13 Okt 1993- 18 Sep 2003), 16 Feb 1995, HS Trustees, gp.

61 (HSA) HS, Notuleboek (13 Okt 1993- 18 Sep 2003), 6 Des 1995, HS Trustees, gp; 15 Feb 1996, HS jaarvergadering, gp; 20 Feb 1997, HS jaarvergadering, Jaarverslag, 3 Feb 1997, gp.

62 (HSA) HS, Notuleboek (13 Okt 1993- 18 Sep 2003), 28 Nov 1996, HS Trustees, gp. 
het verklaar dat studente ter wille van ekonomiese oorlewing "hulle kursusse so moet kies dat hulle intrepreneurs in verskillende rigtings kan wees. Dit open nuwe moontlikhede vir die Afrikanerjeug wat hulle ten goede kan kom". ${ }^{63}$

Aangesien daar reeds 'n toenemende getal afgestudeerdes was wat werkloos was, moes die Helpmekaar hom ook die taak oplê om die jeug se oë vir die nuwe werklikhede te open en hulle te begelei om nie geld te belê in "kursusse en loopbane wat die student voor geslote deure te staan bring" ${ }^{64}$ nie. Die doel van die fondsinsameling sou dus wees om 'n entrepreneursfonds tot stand te bring om Afrikaanssprekendes vir entrepreneurskap te bekwaam. ${ }^{65}$ Die toestande op skoolvlak het al hoe swakker geword en daar is oorweging geskenk daaraan of die Helpmekaar sy ondersteuning tot op skoolvlak moes uitbrei. Ná oorweging het die trustees besluit dat die Helpmekaar nie oor óf die fondse óf die infrastruktuur beskik het om so 'n uitdaging te aanvaar nie. Die trustees was van mening dat die saak op streeks- of plaaslike vlak deur gemeenskappe aangepak moes word. ${ }^{66}$ Met die aanvaarding van 'n entrepreneursfokus het die Helpmekaar egter tog sy hulpprogram verbreed om ook nie-akademiese kursusse en nie-gematrikuleerde studente in te sluit. Dit is bevestig deur die besluit dat wat die Entrepreneursfonds betref, ook studielenings toegestaan sou word aan studente wat nie graad 12 op skool behaal het nie vir studie in tegniese rigtings aan inrigtings wat by die verskillende onderwysdepartemente geregistreer is.$^{67}$ Die voorsitter het die verandering in fokus as volg verduidelik:

"Die Afrikaner-jeug wat veral na die 2de Wêreldoorlog die akademiese weivelde baie aantreklik gevind het - en tereg ook - sal in die nuwe SA sy oorlewing beter verseker as hy ook in die praktiese rigtings homself sal leer help. Sy afhanklikheid van ander wanneer dit kom by meer handvaardige praktyke, het hom onnodig kwesbaar gemaak. Die HS kan ook op hierdie terrein sy bydrae lewer sodat die jeug in al die fasette van die lewe en lewenspraktyke behoorlik toegerus kan wees." 68

63 (HSA) HS, Notuleboek (13 Okt 1993- 18 Sep 2003), 15 Feb 1996, HS jaarvergadering, Voorsittersverslag, 18 Jan 1996, gp.

64 Ibid.

65 (HSA) HS, Notuleboek (13 Okt 1993- 18 Sep 2003), 22 Mei 1997, HS UK, Die Helpmekaar se Entrepreneursfonds: Riglyne vir die toekenning van studielenings aan studente, 22 Mei 1997.

66 (HSA) HS, Notuleboek (13 Okt 1993- 18 Sep 2003), 20 Feb 1996, HS jaarvergadering, Voorsittersverslag, 29 Jan 1997, gp.

67 (HSA) HS, Notuleboek (13 Okt 1993- 18 Sep 2003), 18 Sep 1997, HS Trustees, gp.

68 (HSA) HS, Notuleboek (13 Okt 1993- 18 Sep 2003), 20 Feb. 1998, HS jaarvergadering, Voorsittersverslag $11 \mathrm{Feb}$ 1998, gp. 


\section{Die "Wisseling van die Wag"}

Met hierdie fokus het die Helpmekaar die volle sirkel voltooi. Soos in 1918 met die soeke na 'n oplossing vir die armblankeprobleem, het die Helpmekaar weer in die post 1990-krisis die Afrikaner se heil in ekonomiese opheffing met 'n spesifieke fokus op handelsopleiding en entrepreneurskap gesoek.

Die insamelingsveldtog is dus as 'n entrepreneursfonds bemark met die doel om Afrikaanssprekendes vir entrepreneurskap te bekwaam. ${ }^{69}$ Die veldtog vir die "Helpmekaar Studiefonds vir die opleiding van Entrepreneurs" is formeel geloods tydens 'n middagete vir genooide sakelui wat op 30 Mei 1996 deur Ton Vosloo, voorsitter van Nasionale Pers, aangebied is. 'n Hoofartikel oor die fonds het ook op 11 Mei 1996 in Die Burger verskyn. Die Entrepreneursfonds is geprojekteer as 'n inisiatief waardeur die Afrikaner, soos by talle vorige kere wanneer hulle in die moeilikheid was hulself "aan hul spreekwoordelike skoenrieme moes optrek". Die Afrikaanssprekende jeug moes dus ondersteun word om "eienaar/werknemer te wees in plaas van net werknemer". Deur tot die fonds by te dra kon "die Afrikaanssprekende van vandag help dat die uitwerking van die misplaaste toepassing van 'regstellende aksie' in die toekoms ten volle geneutraliseer word vir sover dit hul taalgenote betref." ${ }^{\prime 0}$ Die veldtog het 'n bemoedigende eerste jaar beleef en teen November 1996 reeds ondernemings van R2 017650 ontvang. Die Rembrandt Groep se skenking van R1 000000 wat in vyf jaarlikse paaiemente betaal sou word, het hiervan die grootse deel uitgemaak. 'n Derde van die beoogde teikenbedrag is dus reeds tydens die eerste jaar in die vorm van beloftes ingesamel. Die raad het dus besluit om De Swardt se aanstelling as ontwikkelingsbestuurder tot 31 Januarie 1998 te verleng. Die subkomitee is ook opdrag gegee om riglyne op te stel vir die toekenning van studielenings uit die Entrepreneursfonds. ${ }^{71}$

Die nuwe fokus op die bevordering van entrepreneurskap en die Entrepreneursfonds het 'n aantal praktiese administratiewe en bestuursuitdagings gebied. In 'n aanvanklike stel konsepriglyne is gepoog om entrepreneurskap te definieer, kursusse en studierigtings wat entrepreneurskap bevorder of hul daartoe leen te identifiseer en selfs toetsing is oorweeg om kandidate met 'n geskikte entrepreneursprofiel vir hulp uit die fonds te identifiseer. ${ }^{72}$ Uiteindelik is besluit dat geen spesifieke voorwaardes vir studielenings uit die

69 (HSA) HS, Notuleboek (13 Okt 1993- 18 Sep 2003), 22 Mei 1997, HS UK, Die Helpmekaar se Entrepreneursfonds: Riglyne vir die toekenning van studielenings aan studente, 22 Mei 1997.

70 (HSA) HS, Notuleboek (13 Okt 1993- 18 Sep 2003), 16 Mei 1996, HS UK, gp; Die Burger, 11 Mei 1996, Skep so self kanse (Hoofartikel), 10.

71 (HSA) HS, Notuleboek (13 Okt 1993- 18 Sep 2003), 28 Nov 1996, HS Trustees, gp.

72 (HSA) HS, Notuleboek (13 Okt 1993- 18 Sep 2003), 22 Mei 1997, HS UK, PS Meyer: die Helpmekaar se entrepreneursfonds ..., gp. 


\section{Die Kaapse Helpmekaar}

Entrepreneursfonds gestel sou word nie en dat die bestaande leningsvoorwaardes sou geld. Die fondse wat ingesamel word vir die Entrepreneursfonds sou ook nie afsondelik belê word nie, maar wel rekeningkundig geïdentifiseer word. ${ }^{73}$ Die belangrikste verandering wat die fokus op entrepreneurskap egter teweeggebring het, was 'n verbreding van die Helpmekaar se tradisionele fokus op tersiêre opleiding van 'n akademiese aard. Daar is besluit dat die Entrepreneursfonds lenings ook sou toestaan aan kandidate wat nie graad 12 op skool verwerf het nie vir opleiding in tegniese rigtings, aan inrigtings wat by die verskillende onderwysdepartemente geregistreer is. ${ }^{74}$ Om die teikengroep te bereik sou die fonds in die Afrikaanse Handelsinstituut se publikasies en die omsendbrief van die Wes-Kaapse tak van die FAK bemark word. ${ }^{75}$

'n Uitdaging van die fondsinsameling was die neiging van sommige instansies om voorwaardelike skenkings te wil maak. Die Klein-Karoo Korporasie was byvoorbeeld bereid om jaarliks R20 000 by te dra. Die voorwaardes was dat studente vir landbougerigte kursusse gehelp moes word, uit die Klein-Karoo streek afkomstig moes wees en die aansoeke aan hulle voorgelê moes word. Die Afrikanerbond van die Noord-Kaap wou studente van die streek gehelp hê en het ook 'n verteenwoordiger op die Raad van Trustees geëis. Die potensiële fragmentasie in die vorm van 'n aantal rigiede eenhede wat sulke skenkings op die fonds kon hê, asook die administratiewe las wat dit sou teweegbring, het die raad laat besluit om nie sulke skenkings te aanvaar nie. Die argument was ook dat die statute nie vir die verteenwoordiging van spesifieke belangegroepe op die raad voorsiening gemaak het nie en dit ook die onafhanklikheid van die raad in gedrang kon bring. Verteenwoordiging op die raad het gewoonlik gevolg op volgehoue belangstelling in die Helpmekaar, en indidvidue kon op die raad dien solank hulle nie spesifieke belangegroepe verteenwoordig het nie en in staat was om die belange van die Helpmekaar te bevorder. ${ }^{76}$

Die ondersteuning wat die Entrepreneursfonds tydens die eerste jaar van die insamelingsveldtog ondervind het, is geïnterpreteer as

“die vroeë tekens van 'n nuwe gees van ondersteuning wat besig is om pos te vat 'n bewuswording dat as die Afrikaner-jeug gehelp moet word, dan moet daar in eie geledere begin word. Die Afrikaner het in sy geskiedenis meermale bewys dat hy onder

\footnotetext{
73 (HSA) HS, Notuleboek (13 Okt 1993- 18 Sep 2003), 18 Sep 1997, HS Trustees, gp.

74 Ibid.

75 (HSA) HS, Notuleboek (13 Okt 1993- 18 Sep 2003), 22 Sept 1997, HS Sub-komitee, gp.

76 (HSA) HS, Notuleboek (13 Okt 1993- 18 Sep 2003), 18 Sep 1997, HS Trustees, PS Meyer; Voorwaardelike skenkings aan die Helpmekaar Studiefonds, 12 Sep 1997, gp.
} 


\section{Die "Wisseling van die Wag"}

moeilike omstandighede die beste presteer. Die geskiedenis van die Helpmekaar is immers 'n bewys hiervan". ${ }^{77}$

Van der Westhuyzen se beoordeling van die sukses van die eerste jaar van die veldtog kan verstaan word, maar 'n tradisioneel getroue ondersteuner van die Helpmekaar, naamlik die NG Kerk, het nie noodwendig die "nuwe gees" bevestig nie. In 1996 het 89 gemeentes gereageer op die jaarlikse oproep om deurkollektes vir die Helpmekaar te hou. Hoewel dit drie meer was as die vorige jaar het slegs 19 persent van die 466 gemeentes aan wie briewe gestuur is positief daarop gereageer en is die bestuurder getref deur die "onbetrokkenheid van gemeentes teenoor 'n instelling soos die Helpmekaar Studiefonds." ${ }^{78}$ Die retoriek waarin die eerste jaar van die insamelingsveldtog se resultate geklee is, het daarop gedui dat daar steeds grootliks in terme van die Afrikaner gedink is. Die verskuiwing van "Afrikaner" na "Afrikaanssprekende" - van ras na taal - het nog meer'n item vir'n toekomstige Helpmekaar wenslys as 'n hartsverandering verteenwoordig.

Vir die voortsetting van die insamelingsveltog in 1997 is De Swardt toestemming gegee om simpatieke organisasies vir finansiële ondersteuning te nader ${ }^{79}$ - 'n proses waarin hy veral deur PS Meyer en Van der Westhuyzen bygestaan is. ${ }^{80}$ Aandag is veral ook gegee aan die werwing van testamentêre bemakings waarvan verskeie bekom is. ${ }^{81}$ Die Helpmekaar se veldtog is ook deur mediaberigte in Die Burger onder die publiek se aandag gebring. Aandag is ook aan maniere geskenk om die ondersteuning van oudstudente van die Helpmekaar se ondersteuning vir die veldtog te verkry. ${ }^{82}$ De Swardt het ook die netwerke van die AHI gebruik om individuele lede van die Sakekamers te motiveer om by die fondswerwingsveldtog betrokke te raak..$^{83}$ Die Helpmekaar het ook sy eie netwerke gebruik om ondernemings te nader om bydraes te maak. Mnr Knoetze, Johann Rupert se sekundus op die raad, het onderneem om met Rupert se samewerking Sanlam weer te nader terwyl hy ook Distillers Korporasie weer sou kontak in die lig van hul vorige weiering om 'n skenking

77 (HSA) HS, Notuleboek (13 Okt 1993- 18 Sep 2003), 20 Feb 1997, HS jaarvergadering, Voorsittersverslag, 29 Jan 1997, gp.

(HSA) HS, Notuleboek (13 Okt 1993- 18 Sep 2003), 20 Feb 1997, HS jaarvergadering, Jaarverslag, gp.

(HSA) HS, Notuleboek (13 Okt 1993- 18 Sep 2003), 20 Feb 1997, HS Trustees, gp.

80 (HSA) HS, Notuleboek (13 Okt 1993- 18 Sep 2003), 22 Mei 1997, HS UK, gp.

81 (HSA) HS, Notuleboek (13 Okt 1993- 18 Sep 2003), 8 Sep 1997, HS Entrepreneursfonds Subkomitee, gp; 18 Sep 1997, HS Trustees, gp.

82 (HSA) HS, Notuleboek (13 Okt 1993- 18 Sep 2003), 20 Nov 1997, HS Trustees, gp; 31 Mrt 1998, HS Dagbestuur, gp.

83 (HSA) HS, Notuleboek (13 Okt 1993- 18 Sep 2003), 31 Mrt 1998, HS Dagbestuur, gp. 


\section{Die Kaapse Helpmekaar}

aan die fonds te maak. ${ }^{84}$ In November 1998 is op voorstel van Van der Westhuyzen besluit om die subkomitee wat vir die eerste twee jaar van die fondswerwingsveldtog die veldtog beplan en gemonitor het te ontbind en dat De Swardt voortaan aan die volle raad verslag sou doen..$^{85}$

Die afskaffing van die subkomitee was die gevolg van veranderinge in die bestuur van die Helpmekaar vanweë Oberholster se aankondiging dat hy teen 28 Februarie 1998 as bestuurder wou uittree en die verstryking van De Swardt se dienstermyn as ontwikkelingsbestuurder op 31 Januarie 1998. 'n Subkomitee, bestaande uit ds J van der Westhuyzen, drr PS Meyer en CH Stander en mnr GR Pretorius, is dus aangestel om te besin oor die samestelling van die bestuurspan van die Studiefonds. ${ }^{86}$ Die uitkoms van die besinning was die aanstelling van De Swardt as bestuurder (vanaf 1 Maart 1998) en mev MC Geldenhuys as finansiële boekhouer en administratiewe beampte (vanaf 7 Januarie 1998). In die proses is die posbeskrywing van die bestuurder hersaamgestel. Die bestuurder sou voortaan as hoof van die kantoor funksioneer en ook fondswerwing hanteer. Die verwagting was dus dat die nuwe bestuurder "meer van sy tyd aan fondswerwing sal bestee o.a. die voortsetting van ons projek oor entrepreneurskap". ${ }^{7}$ 'n Gedeelte van die finansiële bestuur is aan mev Geldenhuys toevertrou. Aangesien mev J Steyn einde Mei 1997 afgetree het, het die Helpmekaar se bestuurspan en kantooradministrasie steeds uit slegs drie personeellede bestaan. ${ }^{88}$

Die herskikking van die bestuurder se posbeskrywing in die praktyk het beteken, dat wat fondswerwing betref, daar in 1998 meestal water getrap is. Dit is bevestig deur die voorsitter se aanduiding dat De Swardt hom in 1999 meer op ontwikkelingswerk sou toespits sodat "ons vyfjaarfondsinsamelingsplan nie nou momentum verloor nie." ${ }^{99}$ De Swardt het bevestig dat wat fondswerwing betref hy meestal in 1998 deur middel van briefwisseling met donateurs, maatskappye en individue kontak gehou het. Hy het beklemtoon dat die swak ekonomiese toestande ook donateurs beïnvloed het en dat sommiges wat skenkings oor 'n termyn beloof

84 (HSA) HS, Notuleboek (13 Okt 1993- 18 Sep 2003), 24 Jun 1998, HS Trustees, gp.

85 (HSA) HS, Notuleboek (13 Okt 1993- 18 Sep 2003), 30 Nov 1998, HS Trustees, gp.

86 (HSA) HS, Notuleboek (13 Okt 1993- 18 Sep 2003), 18 Sep 1997, HS Trustees, gp.

87 (HSA) HS, Notuleboek (13 Okt 1993- 18 Sep 2003), 20 Feb 1998, HS jaarvergadering, Voorsittersverslag, 11 Feb 1998, gp.

(HSA) HS, Notuleboek (13 Okt 1993- 18 Sep 2003), 1 Okt 1997, HS Subkomitee vir beplanning van bestuur en administrasie, gp; 20 Nov 1997, HS Trustees, gp; 20 Feb 1998, HS jaarvergadering, Voorsittersverslag, 11 Feb 1998, gp.

89 (HSA) HS, Notuleboek (13 Okt 1993- 18 Sep 2003), 18 Feb 1999, HS jaarvergadering, Voorsittersverslag 16 Feb 1999, gp. 
het nie hul verpligtinge kon nakom nie. De Swardt was van mening dat die Helpmekaar dikwels laag op donateurs se prioriteitslys was en dat individuele skenkers skaarser sou word. Ondernemings sou dus toenemend as donateurs geteiken moes word. ${ }^{90}$ Hy het dus aangedui dat hy in 1999 opvolgwerk by 'n aantal maatskappye sou doen en het ook 'n lys van nuwe maatskappye wat genader sou word, voorgehou. Benewens maatskappye sou hy ook prokureurs en rekenmeesterspraktyke in die groter Kaapstad nader en voortgaan om sakekamers in die Wes-Kaap te teiken terwyl bemakings voortdurend voor oë gehou word in sy skakeling met individue en ondernemings. ${ }^{91}$

Hierdie fondswerwingsplanne is deur Van der Westhuyzen in sy voorsittersverslag ideologies omraam. Dit was duidelik dat die Helpmekaar die veranderende Suid-Afrika ten opsigte van onderwys negatief ervaar het - veral ten opsigte van die posisie van sy tradisionele kliëntebasis (wit Afrikaners). Dit was ook duidelik dat die Helpmekaar se keuse om ten opsigte van die begrensing van sy terrein van ras na taal te beweeg, nog meestal retories van aard was. Die primêre fokus was steeds op Afrikanerbelange en Afrikaner-lotgevalle gerig en daar is in terme van Afrikaner - nasionalistiese retoriek/kategorieë gedink. Die ou JD Kestell mantra wat uit die Helpmekaar se ontstaansjare gedateer het, naamlik "n Volk red homself", is in 1997 steeds as die enigste redmiddel aangebied. Volgens Van der Westhuyzen wou die Helpmekaar deur sy reaksie op die nuwe omstandighede:

“alles binne ons missie doen om die Afrikaanssprekende 'n beroepstoerusting te gee sodat hy sy onmisbare rol in die nuwe S.A. met waardigheid en bekwaamheid kan vervul ... en dit wil ons graag doen sodat die Afrikaner en Afrikaanssprekendes nie net hul eie sinvolle voortbestaan sal verseker nie, maar ook hul bydrae sal lewer om alle volkere van S.A. se lewenskwaliteit te verbeter ... As dit waar is dat die Afrikaner 'n identiteitkrisis beleef, moet ons probeer verhoed dat hy nie daarin bly vassteek nie. Hy moet homself gou weer vind en sy nuwe rol sinvol definieer. Die Helpmekaar Studiefonds wil vanuit sy eie hoek 'n bydrae lewer om dit moontlik te maak ... Die besef groei al sterker dat as ons onsself nie help nie, ons tot ondergang gedoem is." ${ }^{\prime 92}$

90 (HSA) HS, Notuleboek (13 Okt 1993- 18 Sep 2003), 18 Feb 1999, HS jaarvergadering, Jaarverslag, Feb 1999, gp.

91 Ibid.; Opvolgwerk by: Unifruco; Boland Houtnywerhede; Pep Groep; Distillers; Het Jan Marais-fonds; Bokomo; Sanlam; Naspers; Boland Bank; Absa; Nuwe maatskappye: BOE, MD Vervoer, Retief Vervoer, SAD, Mainline Carriers, Top Wheels, Prima Bande, Saambou Nasionaal, Kaap Goeie Hoop; sakekamers reeds gekontak: Kaapstad, Bellville, Stellenbosch, Helderberg, Malmesbury, Swellendam, Mosselbaai, George, Oudtshoorn, Worcester, Robertson, Paarl.

92 (HSA) HS, Notuleboek (13 Okt 1993- 18 Sep 2003), 18 Feb 1999, HS jaarvergadering,Voorsittersverslag, 16 Feb 1999, gp. 
Die Helpmekaar se idee van die bevordering van entrepreneurskap as deel van die oplossing vir die Afrikaner se herposisionering in Suid-Afrika is ook wyer in die Afrikaner-gemeenskap gedeel. In Februarie 2000 het 'n subkomitee van die Helpmekaar (ds Van der Westhuyzen, drr PS Meyer en CH Stander) die dagbestuur van die Provinsieraad van die Afrikanerbond in Stellenbosch ontmoet vir 'n gesprek oor die Afrikanerbond se beoogde Stigting vir Entrepreneurskap. Die gesprek het gelei tot 'n besluit deur die dagbestuur van die provinsieraad dat hulle by die uitvoerende raad van die Afrikanerbond sal aanbeveel "dat indien fondse by die Stigting vir Entrepreneurskap vir studie en/of beurse beskikbaar word, dit in oorleg met die Helpmekaarfonds, vanweë sy kundigheid op hierdie terrein, toegewys sal word." ${ }^{93}$

Teen Maart 2001 het die Entrepreneursfonds R4 380426 bedra nadat dit veral in 2000 'n aansienlike hupstoot gekry het uit 'n boedelbemaking van R1 494 477, asook die oorname van die Van Riebeeck Studiefonds ter waarde van R95 837. ${ }^{94}$ Ten spyte van die voorsitter se optimistiese 1997-uitspraak van “tekens van'n nuwe gees van ondersteuning” vir die Helpmekaar en die hupstoot wat die insamelingsveldtog die Helpmekaar se kapitaalbasis gegee het, is die aanvanklike vyfjaarteiken van R6 miljoen dus nie bereik nie. Van der Westhuyzen het dit onder andere daaraan toegeskryf dat die "donateursbronne waaruit ons kan put, as gevolg van verwikkelinge in die Suid-Afrikaanse staatkundige-en politieke situasie, veel meer beperkend geword (het)." Ten spyte hiervan was die Helpmekaar gelukkig dat:

"die ondersteuningsbasis uit eie geledere lojaal en sterkgenoeg (is) om 'n noemenswaardige invloei van kapitaal te verseker d.w.s. as daar genoeg moeite gedoen word om die latente kapitaal op te spoor om na die regte kanale te kanaliseer. Ten spyte van al die reklame wat daar reeds gedoen is deur onsself en 'n goedgesinde media, wil dit tog voorkom of daar nog te veel potensiële skenkers oningelig is oor die historiese agtergrond, die aard, en missie van die Helpmekaar." ${ }^{95}$

Van der Westhuyzen het beklemtoon dat die groei in leningsaansoeke om finansiële ondersteuning die Helpmekaar noodsaak om die kapitaalbasis van die Helpmekaar deur fondsinsameling te versnel en het aangedui dat dringend daaroor gesprek gevoer sou moes word. ${ }^{96}$ Hoewel dit nie uitgespel is nie was die realiteit van Van der Westhuyzen se ontleding

93 (HSA) HS, Notuleboek (13 Okt 1993- 18 Sep 2003), 25 Nov 1999, HS Trustees, gp; 17 Feb 2000, HS Trustees, gp; 11 Mei 2000, HS Trustees, gp.

94 (HSA) HS, Notuleboek (13 Okt 1993- 18 Sep 2003), 2 Mrt 2001, HS Jaarvergadering, Jaarverslag, 2 Mrt 2001, gp; 17 Feb 2000, HS Trustees, gp; 11 Mei 2000, HS Trustees, gp.

95 (HSA) HS, Notuleboek (13 Okt 1993- 18 Sep 2003), 2 Mrt 2001, HS Jaarvergadering, Voorsittersverslag, 2 Mrt 2001, gp.

96 Ibid. 
van die donateursbronne: dat maatskappye toenemend onwillig was om instellings met 'n seksionele begrensing - veral ten opsigte van ras, taal en kultuur - te ondersteun vanweë die impak wat dit op hul openbare beeld en hul potensiële kliëntebasis kon hê. Die ondersteuning van vroeëre tradisioneel Afrikaner-ondernemings was dus nie meer'n gegewe nie. Ten spyte van sy verhewe en edele doelstellings was die Helpmekaar vir sommige ondernemings net te nou verweef met vroeëre wit oorheersing en die gepaardgaande diskriminasie om gemaklik mee geassosieer te word. Daarom dan ook Van der Westhuyzen se terugval op "die ondersteuningsbasis uit eie geledere". Hiervan sou testamentêre bemakings 'n belangrike deel uitmaak. Dit was'n bron wat deur die bestuurder in sy jaarverslag as "'n groot potensiële veld waaraan voortdurend aandag gegee moet word", beskryf is. ${ }^{97}$

Hierdie tendens is deur Van der Westhuyzen in sy 2002-voorsittersverslag bevestig toe hy na die drastiese afplatting in fondsinsameling verwys het en aangedui het dat daar nou op individue wat die Helpmekaar goedgesind is en wat deur testamentêre bemakings hul bydrae kan lewer, gefokus word. ${ }^{98}$ Die teenstrydigheid was dus duidelik. Terwyl etniese sentimente in die mobilisering van kapitaal vir die Helpmekaar dus meestal sy trefkrag verloor het in soverre dit maatskappye betref het, het die ontginning van etniese sentimente van die verlede ten opsigte van individue die Helpmekaar se grootste hoop ten opsigte van die versterking van sy fondse verteenwoordig. Sy hoop was dus gevestig op sogenaamde "ou geld".

\section{VAN TRUST TOT ARTIKEL 21-MAATSKAPPY}

Afgesien van die krimpende donateurspoel het veranderinge in die Suid-Afrikaanse belastingwetgewing die Helpmekaar met nuwe uitdagings ten opsigte van sy beskikbare inkomste vir studielenings gekonfronteer. Die nuwe Suid-Afrikaanse regering het kort na 1994 die Katzkommissie aangestel om die belastingstelsel met die oog op hervormings te ondersoek. In sy negende en laaste verslag het die Kommissie aanbevelings ten opsigte van die belasbaarheid van nie-winssoekende organisasies gemaak. In sy 2000-begrotingsrede het die Minister van Finansies dus verreikende veranderinge ten opsigte van die belastingpligtigheid van nie-winssoekende organisasies aangekondig. Die veranderinge is opgeneem in die Wysigingswet op Belastingwette, 2000, wat in Junie 2000 deur die Parlement aanvaar is. In Junie 2002 is verdere amendemente tot die wetgewing aanvaar. Voor die aanvaarding van die nuwe wetgewing is die belastingstatus van nie-winssoekende organisasies, soos die Helpmekaar, deur die inkomstebelastingwet van

97 (HSA) HS, Notuleboek (13 Okt 1993- 18 Sep 2003), 2 Mrt 2001, HS jaarvergadering, Jaarverslag, 2 Mrt 2001, gp.

98 (HSA) HS, Notuleboek (13 Okt 1993- 18 Sep 2003), 22 Feb 2002, HS jaarvergadering, Voorsittersverslag, 22 Feb 2002, gp. 


\section{Die Kaapse Helpmekaar}

1962 bepaal. Volgens Afdeling 10 (1)(f) van die wet was godsdienstige, liefdadigheids- en opvoedkundige openbare instellings kwytgeskeld van belasting. Die nuwe wetgewing het 'n nuwe kategorie, naamlik openbare weldaadsorganisasies wat openbare weldaadsaktiwiteite beoefen, geskep. Dit kon vir belastingvrystelling kwalifiseer indien aan die vereistes vir so 'n organisasie en die gepaardgaande belastingwetgewing voldoen kon word. Die aanpassings aan die Inkomstebelasting-wetgewing ten opsigte van openbare weldaadsorganisasies is met effek van 15 Julie 2001 gepromulgeer. Organisasies wat onder die ou bedeling van belasting kwytgeskeld is, is tot 31 Desember 2004 kans gegun om aansoek te doen vir kwytskelding in terme van die nuwe vereistes. ${ }^{99}$

Teen hierdie agtergrond het die finansiële subkomitee van die Helpmekaar in Januarie 2000 die bestuurder versoek om 'n ontmoeting met die ouditeure, PricewaterhouseCoopers (PwC), te reël oor die moontlike toekomstige belastingpligtigheid van die Helpmekaar in die lig van die beoogde belastingveranderinge. ${ }^{100}$ Gegrond op verdere opvolggesprekke met en verslae van PwC het die finansiële subkomitee in November 2001 aanbeveel dat die Helpmekaar sy status as 'n trust na dié van 'n Artikel 21-maatskappy moes verander en as HS (vereniging ingelyf kragtens Artikel 21) geregistreer word. ${ }^{101}$ Terwyl die Helpmekaar as trust deur trustees volgens 'n trustakte wat by die Meester van die Hooggeregshof geregistreer was, beheer is en aan die Gemenereg en Wet op die Beheer oor Trustgoed, 1988, onderworpe was, sou hulle as Artikel 21-maatskappy van die Maatskappywet van 1973 by die Registrateur van Maatskappye moes registreer. As maatskappy sou hulle volgens 'n akte van oprigting en statute deur 'n direksie beheer word. Anders as in die geval van 'n trust sou die maatskappy oor 'n regspersoonlikheid beskik en as Artikel 21-maatskappy die meeste van die normale aktiwiteite van ander gewone maatskappye kon bedryf. ${ }^{102}$ Teen dié agtergrond is dit as 'n meer geskikte besigheidsvorm vir die Helpmekaar se aktiwiteite geag. In die lig van die veranderde belastingwetgewing sou dit

99 Churces and taxation in Democratic South Africa. http://www.sacc-ct.org.za/taxbook2.html\#TOPOFPAGE; Laws and regulations govering non-profit organisations in South Africa. "International Charity Law: Comparative Seminar”, Beiging, China, October 12-14, 2004. www.icnl.org/news/2004/12-15_South_ Africa.doc.

100 (HSA) HS, Notuleboek (13 Okt 1993-18 Sep 2003), 25 Jan 2000, HS Finansiële subkomitee, gp.

101 (HSA) HS, Notuleboek (13 Okt 1993- 18 Sep 2003), 19 Nov 2001, HS Finansiële Komitee, gp; 30 Nov 2001, HS Finansiële Komitee, gp.

102 Churces and taxation in Democratic South Africa. http://www.sacc-ct.org.za/taxbook2.html\#TOPOFPAGE; Laws and regulations govering non-profit organisations in South Africa. "International Charity Law: Comparative Seminar”, Beiging, China, October 12-14, 2004. www.icnl.org/news/2004/12-15_South_ Africa.doc. SARS Tax Exemption Guide for Public Benefit Organisations in South Africa. 


\section{Die "Wisseling van die Wag"}

die Helpmekaar ook in 'n gunstiger posisie plaas om die potensiële belastingpligtigheid wat hom in die gesig gestaar het die hoof te bied. ${ }^{103}$

Met die 2002-Jaarvergadering was die oorskakeling reeds ver gevorder met die statute wat feitlik gefinaliseer was ${ }^{104}$ en die oordrag van die bates en laste van die trust na die maatskappy in 'n gevorderde stadium. Beide die bestuurder en voorsitter het na die oorgang en die impak van die belastingwetgewing, waarvolgens die Helpmekaar voortaan moontlik belastingpligtig sou wees, verwys. Die voorsitter het sy teleurstelling uitgespreek omdat geld wat voorheen vir studielenings aangewend is nou in die vorm van belasting na die staat sou vloei. Hy was egter nog hoopvol dat "die aksies wat geneem is om hierdie saak ten beste te bestuur, sal hopelik die belastinggaarder tevrede stel". ${ }^{105}$ Teen die agtergrond van die doelstelling en aktiwiteite van die Helpmekaar was daar die verwagting dat dit ook vir belastingvrystelling sou kwalifiseer. Die wetgewing het egter slegs voorsiening gemaak vir vrystelling waar daar studiebeurse toegeken is en nie vir studielenings nie. ${ }^{106}$ Die entiteitsverandering en belastingpligtigheid van die Helpmekaar was vir die bestuurder die begin van 'n periode van ingrypende veranderinge vir die Helpmekaar. Hy was van mening dat die feit dat die Helpmekaar se winste voortaan belasbaar sou wees 'n groot impak sou hê op die omvang van die studielenings wat toegestaan sou kon word:

"tot op datum word lenings hoofsaaklik uit inkomste (rente, dividende en kapitaaldelging deur studente) gefinansier. Indien inkomste dus in die toekoms belasbaar gaan wees, sal die beleid ten opsigte van die aanwend van kapitaal en die toestaan van lenings hersien moet word indien die groei in studentegetalle behou wil word."107

Die finale administratiewe reëlings vir die omskakeling van 'n trust na 'n Artikel 21-maatskappy, soos die finalisering van die statute en akte van oprigting, oordrag van bates en datum waarop dit sou plaasvind, asook die kennisgewing aan die Meester van die Hooggeregshof dat die trust beëindig word, is in samewerking met die ouditeure op die finansiële subkomitee se vergadering op 6 Maart gefinaliseer. ${ }^{108}$

Die HS is op 23 April 2002 deur die Registrateur van Maatskappye as Artikel 21-maatskappy geregistreer waarop die trust se bates na vereffening van alle skulde na die maatskappy

103 (HSA) HS, Notuleboek (13 Okt 1993-18 Sep 2003), 7 Mrt 2003, HS Direksie, Voorsittersverslag, gp; E-posmededeling, dr Charl du Toit, 13 Okt 2015.

104 (HSA) HS, Notuleboek (13 Okt 1993-18 Sep 2003), 22 Feb 2002, HS jaarvergadering, gp.

105 (HSA) HS, Notuleboek (13 Okt 1993-18 Sep 2003), 22 Feb 2002, HS jaarvergadering, Voorsittersverslag, 22 Feb 2002, gp.

106 E-pos-mededeling, dr Charl du Toit, 13 Okt 2015.

107 (HSA) HS, Notuleboek (13 Okt 1993-18 Sep 2003), 22 Feb 2002, HS jaarvergadering, Jaarverslag, gp.

108 (HSA) HS, Notuleboek (13 Okt 1993-18 Sep 2003), 6 Mrt 2002, Finansiële Subkomitee, gp. 


\section{Die Kaapse Helpmekaar}

oorgegaan het en laasgenoemde volgens die goedgekeurde akte van oprigting en statute begin funksioneer het. Die eerste vergadering van die onderskrywers van die akte van oprigting en die statute van die HS (ingelyf kragtens Artikel 21) is op 15 Mei 2002 gehou en deur die trustees J van der Westhuyzen (voorsitter), CH Stander, E Dommisse, NJ Kok, PS Meyer, ML Smith en GR Pretorius bygewoon. Die nuwe akte van oprigting het herbevestig dat die hoofdoelstelling van die maatskappy was "om studielenings en studiebeurse aan verdienstelike leerders en studente toe te staan". ${ }^{109}$ Ebbe Dommisse, Philippus Stefanus Meyer, Johann Peter Rupert, Carel Hendrik Stander, Nicolaas Johannes Kok, Guillaume Ronél Pretorius, Marthinus Luther Smith en Jacobus van der Westhuyzen is as direkteure aangestel met Gideon Jacobus de Swardt as openbare amptenaar en $\mathrm{PwC}$ as ouditeure. ${ }^{110}$ Met die direksie se amptelike bekragtiging van die oordrag van die bates van die trust na die maatskappy was die Helpmekaar in sy nuwe formaat amptelik "oop vir besigheid". 11

Soos vir die res van die Suid-Afrikaanse samelewing was die negentigerjare vir die Helpmekaar'n periode van aanpassing ter wille van oorlewing. Die statistiek vertel die verhaal van die stagnasie en finansiële uitdagings van die vroeë negentigerjare. Ook die wyse waarop die Helpmekaar daarin geslaag het om deur eie inisiatiewe sy kapitaalbasis te versterk en deur vernuwing van sy bestuurs- en administratiewe praktyke, en uiteindelik ook die omskakeling van 'n trust na Artikel 21-maatskappy, die grondslag te lê vir skouspelagtige groei en ontwikkeling in die nuwe millennium. Terwyl die Helpmekaar in 1996 aan slegs 52 nuwe studente lenings kon toestaan, het die getal teen 2002 na 146 gegroei. Terwyl die totale aantal lenings wat bestuur is in 1996 op 366 gestaan het, het dit teen 2001 tot 524 aangegroei. Hierdie groei het plaasgevind teen die agtergrond van grootskaalse eskalering in studiekostes wat die Helpmekaar gedwing het om sy maksimum jaarlikse leningsbedrag van R8 500 in 1990 na R15 000 in 1996 en R25 000 in 2002 te verhoog.

Afgesien van die bestuurs- en administratiewe aanpassings is hierdie groei moontlik gemaak deur 'n volgehoue fondsinsamelingveldtog en ontginning van potensiële donateurs te midde van 'n steeds krimpende donateursmark, asook die oordeelkundige bestuur en belegging van Helpmekaar-fondse. Laasgenoemde is geillustreer deur die groei in die markwaarde van die Helpmekaar se aandeleportefeulje (1996: R4 412 747; 2002: R11 160 642) en vaste deposito beleggings (1996: R3 632 709; 2002: R22 233 350). Hoewel die Helpmekaar se oorlewing van die negentigerjare 'n spanpoging van die trustees en bestuur was, het die bestuurder in 2002

109 (HSA) HS, Notuleboek (13 Okt 1993-18 Sep 2003), 15 Mei 2002, HS Eerste vergadering van onderskrywers van die Akte van Oprigting en Statute van die Maatskappy, gp.

110 Ibid.

111 (HSA) HS, Notuleboek (13 Okt 1993-18 Sep 2003), 15 Mei 2002, HS Direksie, gp. 
veral die rol van die finansiële subkomitee, dr CH Stander, JCL Oberholster en ML Smith, uitgesonder vanweë die "baie ure van hul vrye tyd" wat hulle aan die Helpmekaar bestee. ${ }^{112}$

Die vernaamste uitdagings wat die Helpmekaar in sy nuwe maatskappyformaat in die gesig gestaar het, was die toenemende vraag na finansiële ondersteuning en die snelgroeiende stygings in studie- en verblyfkoste van studente. Dit het weer die vraag laat ontstaan of die Helpmekaar moes voortgaan om minder studente ten volle te finansier of meer studente slegs gedeeltelik te finansier. Die toename in vraag het weer vrae oor die beleggingsbeleid laat ontstaan, aangesien die toenemende vraag na lenings slegs bevredig kon word indien finansiële beleggings in studentelenings omskep word. Die impak van die belastingwetgewing op die invloei van nuwe fondse na die Helpmekaar was 'n verdere uitdaging. Die nuwe belastingwet het dit byvoorbeeld haas onmoontlik gemaak vir die Het Jan Marais Nationale Fonds ${ }^{113}$ om verdere bydraes tot die Helpmekaar te maak. Testamentêre bemakings was ook nie langer aftrekbaar vir boedelbelasting nie, wat bemakings aan die Helpmekaar minder aantreklik gemaak het. Een van die knellendste uitdagings was egter die nuwe belastingpligtigheid van die Helpmekaar wat volgens Van der Westhuyzen:

"groot ongelukkigheid veroorsaak" het en "n onsmaaklike juk op ons skouers geword het ... Dit bly moeilik om te verstaan waarom 'n Art. 21-maatskappy wie se fokus volledig op studentehulpverlening ingestel is belasting moet betaal. Al die tyd en kundigheid wat die direkteure, wat ook die enigste lede van die maatskappy is, beskikbaar stel, geskied sonder vergoeding, uit liefde vir 'n saak wat uiteindelik tot voordeel van die hele land kon strek. 'n Mens het rede om te wonder waarom die staat nie eerder sulke opbouingswerk subsideer nie."114

Die nuwe statutêre omgewing wat in die periode 2000-2002 ontvou het, het 'n fase van oorgang en verandering, wat in die laat 1980's en vroeg 1990's in die Helpmekaar 'n aanvang geneem het, afgesluit. Dit het nie net 'n "wisseling van die wag" ten opsigte van individue verteenwoordig nie, maar het ook ten opsigte van die Helpmekaar se "wagtoring" - sy fisiese kantore - 'n oorgang na 'n nuwe fase verteenwoordig. Die Helpmekaar se kantore wat vanaf sy ontstaan in 1916 in Kaapstad gesetel was, het in 1999/2000 na McIntyrestraat 72 in Parow in die noordelike voorstede verskuif. Die kantore wat vir baie jare uit die Groote Kerk-gebou in Adderleystraat bedryf is, het weens parkeer- en ander probleme toenemend meer ontoeganklik

112 (HSA) HS, Notuleboek (13 Okt 1993-18 Sep 2003), 22 Feb 2002, HS jaarvergadering, Jaarverslag, gp.

113 Die Fonds is in 1915 gestig as 'n uitvloeisel van die testamentêre bemaking van Jannie Marais, Stellenbosse sakeman, politikus en weldoener, na sy afsterwe gedurende die jaar. PH Kapp, Nalatenskappe sonder einde. Die verhaal van Jannie Marais en die Marais-broers, 171, Tip Africa Publishing, 2015.

114 (HSA) HS, Notuleboek (13 Okt 1993-18 Sep 2003), 7 Mrt 2003, HS jaarvergadering, Voorsittersverslag, gp. 


\section{Die Kaapse Helpmekaar}

vir die publiek geword. Na vertoë van die bestuurder in 1999 het die trustees besluit om na 'n meer gebruikersvriendelike en toeganklike omgewing te verskuif. ${ }^{115}$ Die heilsame impak van die verskuiwing op die Helpmekaar se aktiwiteite is in 2001 deur beide die voorsitter en bestuurder bevestig:

"Dit word al hoe meer duidelik dat dit 'n wyse stap was om 'n eie hoofkwartier nader aan ons studente aan te skaf. Nie net is ons eie gebou veel meer besoekersvriendelik nie, maar dit het ook logistieke en sekuriteitsprobleme verminder ${ }^{116}$... weens die ligging van die kantoor word baie meer besoekers ontvang en bedien - faktore - wat meebring dat die werk toeneem."117

Die negentigerjare het die Helpmekaar ook genoop om die nuwe rekenaargedrewe wêreld te omarm. In die oorgang na'n gerekenariseerde administratiewe en leningstoekenningstelsel en die gepaardgaande begrotings- en finansiële bestuurstelsels is die grondslag vir die korporatisering van die Helpmekaar gelê. Die oorskakeling na 'n Artikel 21-maatskappy sou die proses van korporatisering oor die volgende dekade in 'n snelbaan plaas waartydens die vereistes van maatskappy en gepaardgaande wetgewing groot uitdagings sou bied, maar ook geleenthede sou skep wat ou tradisionele Helpmekaar-ideale sou verwesenlik en nuwe moontlikhede sou open.

115 (HSA) HS, Notuleboek (13 Okt 1993-18 Sep 2003), 18 Feb 1999, HS jaarvergadering, Jaarverslag, gp; 18 Feb 1999, HS Trustees, gp; 20 Mei 1999, HS Trustees, gp; 23 Sep 1999, HS Trustees, gp; 25 Nov 1999, HS Trustees, gp.

116 (HSA) HS, Notuleboek (13 Okt 1993-18 Sep 2003), 2 Mrt 2001, HS jaarvergadering, Voorsittersverslag, gp.

117 (HSA) HS, Notuleboek (13 Okt 1993-18 Sep 2003), 2 Mrt 2001, HS jaarverslag, Jaarverslag, gp. 


\title{
HOOFSTUK ELF
}

\section{DIE KORPORATISERING VAN DIE HELPMEKAAR, 2002-2014: OP PAD NA 'N "GOEIE DAG”}

\begin{abstract}
"Dit sal inderdaad 'n goeie dag wees as elke student wat oor die intellektuele vermoë beskik, nie geblokkeer word op grond van finansiële onvermoë nie en dit bly die Helpmekaar Studiefonds se ideaal om hierdie 'goeie dag' te verwesenlik."
\end{abstract}

Die Helpmekaar se oorskakeling na 'n Artikel 21-maatskappy het nuwe uitdagings en moontlikhede ingehou. Hierdie hoofstuk sal dus kortliks fokus op enkele van die belangrikste ontwikkelings in dié verband in die Helpmekaar se op pad wees na sy eeufeesjaar. Die periode is gekenmerk deur 'n hernude besinning oor die fokus van die Helpmekaar en die vaslegging daarvan in 'n duidelik geformuleerde missiestelling. Dit het ook gefokus op 'n doelbewuste poging om die "hulpelement" (beurse en renteverligting) - 'n ontstaanstradisie van die Helpmekaar - baie sterker uit te bou. Verder is gefokus op die hernude pogings om die kapitaalbasis deur fondsinsameling te versterk, die korporatisering van die maatskappy en laastens die verbreking van die laaste skakel met die Helpmekaarvereniging van die Kaapprovinsie met die uittrede van ds J van der Westhuyzen as voorsitter in 2014. Hierdie ontwikkelings het plaasgevind teen die agtergrond van 'n wêreldwye ekonomiese depressie en 'n steeds transformerende binnelandse sosio-ekonomiese en politieke milieu met die gepaardgaande impak op die Helpmekaar se tradisionele kliëntebasis.

In reaksie op die nuwe politieke bedeling na 1994 en die aanvaarding van 'n demokratiese grondwet vir Suid-Afrika het die Helpmekaar in die vroeë negentigerjare etnisiteit (Afrikanerskap) met taal (Afrikaans) as seleksiemaatstaf vir studiehulp vervang. Deur die loop van die negentigerjare was dit egter duidelik dat die verandering hoofsaaklik retories van aard was en weinig praktiese impak gehad het op die demografiese samestelling van die kliëntebasis wat die Helpmekaar bedien het. Met die aanvaarding van 'n maatskappystruktuur en die korporatisering wat daarmee gepaardgegaan het, is die fokus van die Helpmekaar weer te berde gebring. Dr PS Meyer het dus in September 2003, op versoek van die bestuurder, "met Voorsittersverslag, 25 Mrt 2011, 1. 


\section{Die Kaapse Helpmekaar}

die ontstaansgeskiedenis en doelstellings van die Helpmekaar as grondslag, 'n visie en missie geformuleer wat moontlik die rigting of koers vir die toekoms kan aandui." ${ }^{2}$ Hoewel Meyer se formulering mank gegaan het aan verskeie historiese feitefoute, het die belangrikheid van die dokument daarin gelê dat dit 'n poging was om die visie/missie amptelik te formuleer. Met die behoud van die Helpmekaar se historiese wortels is die maatskappyfokus 'n meer inklusiewe aanskyn gegee om dit met die Suid-Afrikaanse Grondwet te versoen. Meyer se dokument was getuie van die uitdaging wat dit gebied het om die Helpmekaar se verlede met die eise van die hede te versoen. Hy het gepoog om deurgaans na Afrikaanse of Afrikaanssprekende studente te verwys, maar hy kon dit nie verhelp om nie in sy visie- en missie-dokument die begrip Afrikaner te gebruik nie. Hy het dus sy dokument afgesluit met:

"Die visie en missie van die Helpmekaar Studiefonds weerspieël die kosbare erflating van sy grondleggers aan die Afrikanerjeug van Suid-Afrka."

Meyer se poging het tot 'n hernude besinning oor die Helpmekaar se fokus gelei, wat uiteindelik in 'n bondig geformuleerde geskiedenis en visie en missie neerslag gevind het - 'n opdrag wat aan Ebbe Dommisse opgedra is. ${ }^{4}$ In Dommisse se verkorte weergawe van Meyer se dokument is deurgaans na hulp aan Afrikaanse studente verwys. $\mathrm{Na}$ aanleiding van Dommisse se dokument is op voorstel van die voorsitter besluit dat verdere besinning oor die Helpmekaar se visie en missie moes plaasvind. In aansluiting hierby, en ook'n aanduiding dat daar nog nie volkome klarigheid oor die aangeleentheid was nie, was Marius Smith se versoek dat duidelikheid oor die begrippe Afrikaner/Afrikaanses verkry moes word. Veral in die mate waarin die Helpmekaar se visie en missie daardeur geraak word. ${ }^{5} \mathrm{Na}$ aanleiding van 'n voorstel van PS Meyer, wat voortgespruit het uit 'n strategiese beplanningsessie wat die direksie in Mei 2004 gehou het ${ }^{6}$ is besluit dat:

"die huidige beleid van voorkeur aan Afrikaanssprekende studente word voortgesit, met dien verstande dat die nie-diskriminerende bepalings van die grondwet nagekom word."”

In die lig van die grondwet het dit by implikasie beteken dat die Helpmekaar Afrikaanssprekende studente, ongeag ras, kleur of godsdienstige oriëntasie, sou help. Die feit dat voorkeur aan Afrikaanssprekende studente gegee sou word, het ook by implikasie

\footnotetext{
2 (HSA) HS, Notuleboek (13 Okt 1993-18 Sep 2003), 18 Sep 2003, HS Direksie, gp.

3 (HSA) HS, Notuleboek (4 Des 2003-18 Jun 2014), 4 Des 2003, HS Direksie, 3.

4 (HSA) HS, Notuleboek (13 Okt 1993-18 Sep 2003), 18 Sep 2003, HS Direksie, gp.

5 (HSA) HS, Notuleboek (4 Des 2003-18 Jun 2014), 4 Des 2003, HS Direksie, 3.

6 (HSA) HS, Notuleboek (4 Des 2003-18 Jun 2014), 20 Mei 2004, HS Direksie, 5.

7 (HSA) HS, Notuleboek (4 Des 2003-18 Jun 2014), 12 Aug 2004, HS Direksie, 3.
} 
beteken dat hulp nie uitsluitlik vir Afrikaanssprekende studente gereserveer is nie en dat ander studente ten minste in teorie ook gehelp sou kon word. Verskeie faktore sou egter vir die voorsienbare toekoms dit onwaarskynlik maak dat die verbreding van die Helpmekaarfokus van Afrikaner- na Afrikaanssprekende studente en die teoretiese moontlikheid van hulp aan studente buiten Afrikaanssprekendes ernstig getoets sou word. Die groeiende stroom internasionale en nasionale beurs- en leningshulpskemas teen gunstige terme wat vir vroeëre agtergeblewe studente na 1990 beskikbaar geraak het, het dit onwaarskynlik gemaak dat dié studente by die Helpmekaar om hulp sou aanklop. Vanweë die ekonomiese posisie van vroeëre agtergeblewe studente was die leningsvoorwaardes van die Helpmekaar vir die oorweldigende meerderheid buite bereik. In die lig van die feit dat die Helpmekaar se dienste selfs binne hul tradisionele Afrikaner-kliëntebasis na 'n bestaan van feitlik 'n eeu steeds nie algemeen bekend was nie was die kanse skraal dat vroeëre agtergeblewe gemeenskappe van hulle finansiële ondersteuning sou kennis dra. Die dokumentering van die visie en missie en die wyse waarop dit geïnterpreteer is, was vir die Helpmekaar 'n Rubicon-oomblik en die voltooiing van 'n proses waarvan die wortels na die onstuimige Sharpeville-jare van die vroeë sestigerjare teruggevoer kon word.

\section{DIE HELPMEKAAR STUDIEFONDS: AFRIKANER OF AFRIKAANSE ORGANISASIE?}

In sy HS-gedaante sedert amalgamasie sou die Kaapse Helpmekaar se vroeër aktiewer sosio-kulturele rol tot 'n toenemend sekondêre posisie gerangeer word vanweë sy groter enkelvoudige fokus op sy rol as studente- "studieleningbank". Hierdie tendens het egter 'n lang aanloop gehad wat teruggevoer kan word na die reeds genoemde debat van 1941-42 oor die fokus van die Helpmekaar na voorstelle dat die Vereniging met die RDB moes saamsmelt en waarna reeds in 'n vorige hoofstuk verwys is. Die 1942-besluit om hul onafhanklikheid te behou en op opvoeding - "studielenings en subsidies vir middelbare onderwys" - te fokus was 'n poging om oorvleueling met ander Afrikaner-organisasies soos die RDB, FAK en ACVV uit te skakel. Die reeds genoemde 1956-besluit om nie meer skenkings aan verdienstelike opvoedkundige, kulturele en sosiaal-maatskaplike organisasies en sake te maak nie, maar om op studiehulp te fokus was 'n keerpunt in die ontwikkeling van die tendens. Dit het nie beteken dat die Kaapse Helpmekaar sy rol as Afrikaner-organisasie en sy vroeëre sentimente ten opsigte van die bevordering van Afrikaner- sosiale en kulturele belange prysgegee het nie. Die tendens was eerder 'n aanduiding van 'n sterker fokus op 'n nismark binne die breër netwerk van Afrikaner-organisasies: Afrikaner-ekonomiese bemagtiging deur die verskaffing van studiefinansiering vir primêr, tersiêre opleiding aan die Afrikaner- jeug. 
Die Kaapse Helpmekaar sou dus deur die loop van die sewentiger- en tagtigerjare ten spyte van sy besluit oor skenkings en donasies steeds periodiek sake van Afrikaner belang ondersteun. Daar is reeds verwys na die vier kategorieë waarin die skenkings verdeel kon word en hoe die Helpmekaar se verweefdheid met Afrikaner belange op kulturele, sosiaal maatskaplike en politieke terreine, en die hoofstroom instellings en beleidsrigtings wat die belange bevorder het, instand gehou en bevestig het.

Deur die periodieke bywoning van FAK-kongresse, ${ }^{8}$ finansiële ondersteuning van die $\mathrm{FAK}^{9}$ en 'n inisiatief soos die beskikbaarstelling van R1 000 per jaar aan die FAK vir die aanwending van 'n prestigeprys vir die beste ontspanningslektuur van die jaar ${ }^{10}$ in die tagtigerjare het die Kaapse Helpmekaar FAK-aktiwiteite en doelwitte bly ondersteun. Die Helpmekaar se betrokkenheid by die FAK is ook onderstreep deur hul teenwoordigheid by die belangrike 1985 FAK-kongres. Tydens die kongres is die aansoek van die Afrikanervolkswag (wat in 1984 gestig is) ${ }^{11}$ om as kultuurorganisasie by die FAK te affilieer deur die hoofbestuur van die FAK afgekeur. ${ }^{12}$ Hierdeur is die politieke skeuring wat in 1982 met die stigting van die Konserwatiewe Party plaasgevind het ook op kulturele vlak in Afrikanergeledere voltrek. Die belangrikheid wat die Helpmekaar aan die kongres geheg het, is onderstreep deur die besluit om nie net een afgevaardigde soos aanvanklik beplan is nie, maar 'n volstrekte span van drie verteenwoordigers, na die kongres te stuur. ${ }^{13}$

Daar is reeds verwys na die herbesinning wat in Helpmekaargeledere plaasgevind het in reaksie op die politieke veranderinge van die negentigerjare en die Nuwe Suid-Afrika wat in dié periode vorm aangeneem het. Hierdie periode van eksperimentering, besinning en heroriëntering oor die pad vorentoe vir Afrikaners het ook op 'n breër front in ander Afrikaner-organisasies plaasgevind. Die wyse waarop die FAK hierop gereageer het, het nuwe uitdagings aan die Kaapse Helpmekaar se verhouding met die FAK gestel. 'n Toenemende gewaarwording oor 'n herrysenis van armoede in Afrikanergeledere teen die agtergrond van regstellende aksie en die afskaling van die bevoorregte sosiaal-maatskaplike ondersteuningsnet vir Afrikaners en witmense, in die algemeen in die negentigerjare, het 'n fokuspunt van Afrikaner-organisasies

8 (HSA) HS, Notuleboek (16 Feb 1973-10 Sep 1993), 4 Jun 1976, HS UK, 37.

9 (HSA) HS, Notuleboek (16 Feb 1973-10 Sep 1993), 12 Feb 1982, HS jaarvergadering, 67.

10 (HSA) HS, Notuleboek (16 Feb 1973-10 Sep 1993), 16 Jul 1982, HS UK, 69; 14 Feb 1986, HS jaarvergadering, 86.

11 Riana Erasmus en JJ Swanepoel, Stigting. Die Afrikanervolkswag, Hoofredes gelewer op 4 en 5 Mei 1984 (INEG, UOVS, 1984).

12 http://www.afrikanergeskiedenis.co.za/organisasies-se-geskiedenis/fak-geskiedenis/ (Kultuur in die brandpunt, 1980-1994.)

13 (HSA) HS, Notuleboek (16 Feb 1973-10 Sep 1993), 24 Apr 1985, HS UK, 82. 
geword. Die toekomsmoontlikhede van die Afrikanerjeug was 'n besondere bekommernis en soos in die geval van die Helpmekaar is die toekomstige saligheid gesoek in 'n fokus op die ontwikkeling van entrepreneurskap onder die jeug. In FAK-geledere is entrepreneurskap ook omarm as die redmiddel vir die toenemende werkloosheid en gepaardgaande armoede onder Afrikaners.

In Julie 1993 het die FAK 'n Volkskongres oor Armoede en Werkloosheid georganiseer waarop die Helpmekaar ook verteenwoordig was $^{14}$ en waartydens die FAK versoek is "om 'n helpmekaaraksie van stapel te stuur, net soos in die dertigerjare." ${ }^{15}$ 'n Komitee vir Maatskaplike Ondersteuning en Ontwikkeling is gestig om projekte te loods om armoede en werkloosheid teen te werk en die komitee het mettertyd onder die naam Nasionale Komitee: FAK-Helpmekaar 2000 begin funksioneer. ${ }^{16}$ Hoewel die Helpmekaar hom met die FAKinisiatief teen armoede en werkloosheid kon identifiseer, ${ }^{17}$ het die trustees die gebruik van die naam "Helpmekaar 2000" as 'n aantasting van hul eie handelsnaam, waaronder hulle in die "volksmond" as "Die Helpmekaar" bekend geraak het, beskou. Die Helpmekaar het dus by die FAK beswaar gemaak en daarop aangedring dat die gebruik van die naam gestaak word. ${ }^{18}$ Tydens 'n ontmoeting met 'n afvaardiging van die FAK, bestaande uit prof Johan Heyns en ds Henno Cronje, was die Helpmekaar se uitgangspunt "dat die Afrikanervolk nie nou kon bekostig om verdeeld te raak nie". ${ }^{19}$ Hulle het gevoel dat hulle as Afrikaners die saak graag onderling en nie in die openbaar sou wou oplos nie. Ten spyte van 'n onderneming deur die FAK om oor die saak te besin kon die partye mekaar nie vind nie. ${ }^{20}$

Ten spyte van die wrywing wat deur die handelsnaamkwessie veroorsaak is, het die Helpmekaar besluit om lid van die FAK te bly. Die trustees het egter besluit om nie meer voortaan die FAK-prestigeprys vir ontspanningslektuur te borg nie, maar eerder die geld

14 (HSA) HS, Notuleboek (13 Okt 1993-19 Sep 2003), 10 Feb 1994, HS jaarvergadering, Jaarverslag, 21 Jan 1944, gp.

15 http://www.afrikanergeskiedenis.co.za/organisasies-se-geskiedenis/fak-geskiedenis/ (Kultuur in die brandpunt, 1980-1994.)

16 http://www.afrikanergeskiedenis.co.za/organisasies-se-geskiedenis/fak-geskiedenis/ (Kultuur in die brandpunt, 1980-1994.)

17 (HSA) HS, Notuleboek (16 Feb 1973-10 Sep 1993), 10 Sep 1993, HS Trustees, 130.

18 (HSA) HS, Notuleboek (16 Feb 1973-10 Sep 1993), 5 Aug 1993, HS Trustees, 130.

19 (HSA) HS, Notuleboek (16 Feb 1973-10 Sep 1993), 10 Sep 1993, HS Trustees, 130.

20 Ibid.; (HSA) HS, Notuleboek (13 Okt 1993-19 Sep 2003), 10 Feb 1994, HS Trustees, gp. 
vir studielenings aan te wend. ${ }^{21}$ Die skaakmatsituasie oor die handelsnaam-aangeleentheid was 'n herinnering aan die historiese onvermoë van Afrikaners en hul organisasies om op nasionale vlak saam te werk. Die onvermoë is onderlê deur die immer teenwoordige, meestal onuitgesproke, provinsiaal geankerde (Noord-Suid) tradisies en benaderingsverskille. Albertyn het die Helpmekaar se standpunt oor die handelsnaam-aangeleentheid as volg in sy voorsittersverslag tydens die 1994-jaarvergadering verwoord:

"Ek glo egter dat ons nie veel van die nuwe koers van die FAK hoef te vrees nie, sekerlik nie in Kaapland nie. 'n Kultuurorganisasie moenie 'n liefdadigheidsliggaam op ekonomiese gebied probeer wees nie. Hulle sal misluk, maar indien hulle optrede die Helpmekaar Studiefonds sou skaad, sal ons dadelik ons belange beskerm."22

Die onvermoë tot nasionale samewerking sou ook in ander soortgelyke inisiatiewe manifesteer. Die Afrikanerbond se skakeling met die Helpmekaar oor hul beoogde Stigting vir Entrepreneurskap was 'n verdere voorbeeld. ${ }^{23}$ Teen Maart 2003 het die voorsitter egter opdrag gegee dat die kwessie van samesprekings met die Afrikanerbond van die Helpmekaar-agenda verwyder word totdat 'n skriftelike versoek van die Afrikanerbond ontvang word. ${ }^{24}$ In 2003 het Rapport die Rapport Onderwysfonds (ROF) gestig met die oog op die beskikbaarstelling van beurslenings aan Afrikaanse onderwysstudente. ${ }^{25}$ Die voorsitter het 'n skrywe aan ROF gerig om hul sukses met die fonds toe te wens. ${ }^{26}$ Dit was ook duidelik dat die gelukwense aan ROF met 'n mate van argwaan gepaardgegaan het as gekyk word na die mislukte poging om met die Afrikanerbond saam te werk, die ROF-inisiatief, wat 'n toetrede tot 'n terrein was wat die Helpmekaar as sy nisfokus beskou het, sowel as die samewerking wat bogenoemde inisiatiewe met Solidariteit gesmee het. Dié sentiment is deur Van der Westhuyzen se verwysing na dié verwikkeling in sy 2004-voorsittersverslag bevestig:

"Nadat die Afrikanerbond vir'n geruime tyd met ons onderhandel het om hulle beoogde bydrae tot onderwys en opvoeding te administreer, het hulle hul versoek teruggetrek, o.a vanweë belastingimplikasies. Ons vertrou dat hulle en hulle vennote, Rapport en

21 (HSA) HS, Notuleboek (13 Okt 1993-19 Sep 2003), 13 Okt 1993, HS Trustees, gp; 10 Feb 1994, HS Trustees, gp.

22 (HSA) HS, Notuleboek (13 Okt 1993-19 Sep 2003), 10 Feb 1994, HS jaarvergadering, Voorsittersrede, gp.

23 (HSA) HS, Notuleboek (13 Okt 1993-19 Sep 2003), 25 Nov 1999, HS Trustees, gp; 17 Feb 2000, HS Trustees, gp.

24 (HSA) HS, Notuleboek (13 Okt 1993-19 Sep 2003), 7 Mrt 2003, HS Direksie, gp.

25 http://www.rof.org.za/

26 (HSA) HS, Notuleboek (4 Des 2003-18 Jun 2014), 4 Des 2003, HS Direksie, 5. 
Solidariteit-vakbond, hulle ideale in dié verband sal verwesenlik. Miskien is dit tog jammer dat hulle in hulle beplanning nie gebruik gemaak het van die kundigheid wat die Helpmekaar Studiefonds oor etlike jare opgebou het en gratis aan hulle kon voorsien het nie. Dit kon hulle moontlike toekomstige probleme gespaar het." ${ }^{27}$

Ten spyte van die handelsnaamdispuut en die onsekerheid wat deur die beplande transformasieproses van die FAK oor sy toekomstige formaat en pad vorentoe geskep is, het die Helpmekaar sy verbintenis met die FAK bly handhaaf. ${ }^{28}$ Hierdie verbintenis is veral onderhou deur die toenemend aktiewe betrokkenheid van dr Carel Stander by die FAK in die negentigerjare en eerste dekade van die 21ste eeu. Stander is in 1995 tot voorsitter van die Federasie van Rapportryerskorpse ${ }^{29}$ en in 1998 tot die hoofbestuur van die FAK verkies. ${ }^{30}$ Sy teenwoordigheid op beide die direksies van die Helpmekaar en die hoofbestuur van die FAK het tot 'n hernude soeke na samewerking met die FAK gelei. ${ }^{31}$ In 2001 is Stander tot ondervoorsitter van die FAK verkies ${ }^{32}$ en hy het die Helpmekaar deurlopend op hoogte gehou van verwikkelinge in die FAK en die verloop van FAK-kongresse. ${ }^{33}$ Die Helpmekaar het ook FAK-inisiatiewe, spesifiek dié wat op die ontwikkeling van die jeug gerig was, finansieel ondersteun. In 2002 het die direksie 'n skenking van R15 000 aan die FAK goedgekeur ${ }^{34}$ wat in 2003 opgevolg is met 'n skenking an R18 000 vir die ontwerp van 'n sentrale webbladsy vir jeugskakeling. ${ }^{35}$ In 2004 het die FAK 'n oorkonde aan die Helpmekaar van Kaapland oorhandig as erkenning vir sy jarelange bydraes. ${ }^{36}$ Die Helpmekaar het deur Stander betrokke gebly by die herposisionering en heroriënteringsproses wat die FAK deur die loop van die eerste dekade van die 21ste eeu deurloop het. In die proses het die FAK afstand gedoen van sy oorkoepelende gesentraliseerde federale struktuur van geaffilieerde lede-organisasies waardeur hy tradisioneel namens Afrikaner-kultuur en gemeenskapsorganisasies gepraat (HSA) HS, Notu
1 Mrt 2004, 4 . Ibid.,

(HSA) HS, Notuleboek (13 Okt 1993-18 Sep 2003), 22 Jun 1994, HS Trustees, gp; 16 Mei 1996, HS UK, gp. (HSA) HS, Notuleboek (13 Okt 1993-18 Sep 2003), 25 Mei 1995, HS Trustees, gp. (HSA) HS, Notuleboek (13 Okt 1993-18 Sep 2003), 8 Okt 1998, HS Trustees, gp.

(HSA) HS, Notuleboek (13 Okt 1993-18 Sep 2003), 1 Des 2000, HS Trustees, gp; 2 Mrt 2001, HS Trustees, gp; 4 Mei 2001, HS Trustees, gp.

(HSA) HS, Notuleboek (13 Okt 1993-18 Sep 2003), 23 Nov 2001, HS Trustees, gp.

(HSA) HS, Notuleboek (13 Okt 1993-18 Sep 2003), 21 Nov 2002, HS Direksie, gp.

(HSA) HS, Notuleboek (4 Des 2003-18 Jun 2014), 4 Des 2003, HS Direksie, 2; (HSA) HS, Notuleboek (13 Okt 1993-18 Sep 2003), 18 Sep 2003, HS Direksie, gp.

(HSA) HS, Notuleboek (4 Des 2003-18 Jun 2014), 2 Des 2004, HS Direksie, 2. 


\section{Die Kaapse Helpmekaar}

het. In 2010 het die FAK in sy soeke na nuwe netwerke en vennootskappe en samewerking by die Solidariteitsbeweging ingeskakel ${ }^{37}$ en het Stander die Helpmekaar meegedeel dat die Oktober 2010 jaarlikse ledevergadering die laaste was van die tradisionele formaat waarin die FAK gefunksioneer het. ${ }^{38}$ In 2013 het die Helpmekaar besluit om amptelik as lid van die FAK te bedank. ${ }^{39}$

Benewens sy kulturele betrokkenheid deur sy skakeling met die FAK sou die Kaapse Helpmekaar in die post 1990-era veral ook betrokke bly by sake wat met die handhawing en behoud van Afrikaans te make gehad het. In dié verband was sy ondersteuning van die pogings vir die behoud van die Universiteit van Stellenbosch as 'n Afrikaans-medium universiteit en die belange van Helpmekaar studente om in hul moedertaal onderrig te ontvang die belangrikste fokus. Die Helpmekaar het dus veral sedert 2009 meer aktief by die US taaldebat betrokke geraak en ondersteuning verleen aan die belangegroepe wat hulle vir die behoud van Afrikaans as onderrigtaal beywer het. Die dryfkrag vir hierdie pogings sou veral van dr Ebbe Dommisse en dr Carel Stander uitgaan. ${ }^{40}$

Die HS: Afrikaner of Afrikaanse organisasie? Miskien lê die antwoord opgesluit in die Helpmekaar se vermoë om in die toekoms maniere te vind om die elemente vervat in ds Kobus van der Westhuyzen se filosofiese uitspraak - "As jy nie wil wees wat jy is nie, sal jy nooit word wat jy graag wil wees nie" - in die praktyk met mekaar te versoen.

\section{DIE VERWESENLIKING VAN 'N “OU BEGEERTE”: DIE HELPMEKAAR TRUST}

Die Helpmekaar se aanvanklike betrokkenheid by opvoeding was die gevolg van hul strewe om die vroeë 20ste eeuse armblankevraagstuk waaronder Afrikaners gebuk gegaan het, op te los. Hulpverlening het aanvanklik die vorm van beurse aan studente aangeneem. 'n Gebrek aan fondse het die toekenning van beurse as 'n langtermyn strategie onvolhoubaar gemaak. Dit het bygedra tot die oorskakeling na die toestaan van lenings wat deur die hersirkulasie van kapitaal 'n baie meer volhoubare vorm van hulpverlening was.

37 http://www.afrikanergeskiedenis.co.za/organisasies-se-geskiedenis/fak-geskiedenis/ (Kulturele Herdefiniëring (1994-2011) en Kulturele Opstaan (2012- )

38 (HSA) HS, Notuleboek (4 Des 2003-18 Jun 2014), 17 Nov 2010, HS Direksie, 4.

39 (HSA) HS, Notuleboek (4 Des 2003-18 Jun 2014), 13 Sep 2013, HS Direksie, 3.

40 (HSA) HS, Notuleboek (4 Des 2003-18 Jun 2014), 19 Jun 2009, HS Direksie, 5; 16 Sep 2009, HS Direksie, 5; 18 Nov 2009, HS Direksie, 2; 4 Jun 2010, HS Direksie, 2; 2 Sep 2011, HS Direksie, 1-2; 6 Jun 2012, HS Direksie, 3. 
Die toestaan van studentelenings het aan die Helpmekaar-hulpverlening die aard van 'n saketransaksie besorg - ten spyte van die gunstige voorwaardes waaronder geld aan studente geleen is. Die strewe om studente se finansiële las te verlig deur die toestaan van die laagste moontlike rentekoerse en die toekenning van beurse was egter soos 'n goue draad deur die Helpmekaar se geskiedenis verweef. Teologiestudente is vir lang periodes deur gunstiger rentekoerse tegemoetgekom. Die strewe om studente deur die toekenning van beurse tegemoet te kom was immer teenwoordig - "'n ou begeerte"41 - maar weens 'n gebrek aan fondse het dit 'n item op die Helpmekaar-wenslys gebly. Met die draai van die millennium en die hermanifestering van blanke armoede, in tandem met die groot toename in studiekostes, het die ou strewe van 'n groter "hulpelement" aan studente om die skuldlas waarmee hulle afgestudeer het te verlig, toenemende prominensie binne Helpmekaar-geledere gekry. Die oorskakeling van 'n trust na 'n maatskappy sou bydra tot die skep van 'n institusionele struktuur wat die verwesenliking van die strewe bevorder het.

Hoewel daar sedert die tweede helfte van die sestigerjare verskeie skenkings, soos die Freddie en Bessie Kirsten-skenking, ontvang is wat vir teologiestudente geoormerk is en waaruit beurse sporadies aan teologiestudente toegeken is, ${ }^{42}$ is geen beurse as 'n reël uit hoofstroom Helpmekaar-kapitaal toegeken nie. In Augustus 1992 het die Helpmekaar 'n voorstel van Oberholster aanvaar dat 'n beurs jaarliks aan 'n belowende Helpmekaarstudent toegeken moes word. 'n Beurskomitee, bestaande uit HA Lambrechts, dr PS Meyer en Obersholster, is benoem om die praktiese implementering van die besluit te ondersoek. ${ }^{43}$ Op aanbeveling van die komitee is besluit dat die jaarlikse beurs as die Helpmekaarbeurs sou bekendstaan. Dit sou toegeken word aan 'n verdienstelike student wat met 'n lening van die HS gestudeer het en sy/haar kursus suksesvol voltooi het. Kriteria wat oorweeg sou word, was onder andere studieprestasie, karakterhoedanighede, standvastigheid, betroubaarheid, morele integriteit, asook leierskap en deelname aan studente-aktiwiteite. Dit herinner aan die vestigingsjare wat "respektabiliteit" onder Helpmekaar studente gesoek en bevorder het. Die beurs sou R6 500 bedra en 'n eerste toekenning sou vir 1994 gemaak word met die amptelike oorhandiging wat op 'n spesiale noenmaal sou plaasvind. ${ }^{44}$ Die eerste sodanige beurs is aan dr GE Bruwer, wat sy mediese studies in 1993 voltooi het, toegeken. ${ }^{45}$

\footnotetext{
41 (HSA) HVKP, Notuleboek, 1 Apr 1964, Kongres, gp.

42 (HSA) HS, Notuleboek (13 Okt 1993-18 Sep 2003), 16 Feb 1995, HS Trustees, Beursfondse, 21 Jan 1995, gp.

43 (HSA) HS, Notuleboek (16 Feb 1973-10 Sept 1993), 13 Aug 1992, HS UK, 122.

44 (HSA) HS, Notuleboek (16 Feb 1973-10 Sept 1993), 11 Mei 1993, HS Subkomitee insake studiebeurse, 130; (HSA) HS, Notuleboek (13 Okt 1993-18 Sep 2003), 13 Okt 1993, HS Trustees, gp.

45 (HSA) HS, Notuleboek (13 Okt 1993-18 Sep 2003), 27 Sep 1994, HS Trustees, gp.
} 
Die instelling van die beurs is opgevolg deur 'n besluit om uit die bestaande beskikbare beursfondse vir teologiestudente van die fondse te konsolideer en ook 'n beurs of beurse op 'n jaarlikse basis aan teologiestudente toe te ken. ${ }^{46}$ Die eerste beurs van dié aard (R7 000) is in 1996 aan proponent CJ du Raan, wat sy B.Th-graad einde 1995 cum laude voltooi het, toegeken. ${ }^{47}$ Hiermee is 'n nuwe gebruik, naamlik die toekenning van merietebeurse aan Helpmekaar-leningshouers, gevestig. Met die proses is begin om 'n jarelange strewe om die "hulpelement" van die Helpmekaar te versterk deur studente finansieel deur beurse te ondersteun en daardeur hul skuldlas te verminder - hoewel nog op 'n klein skaal te verwesenlik.

Die verdere uitbreiding van die "hulpelement" van die Helpmekaar was 'n direkte uitvloeisel van hul nuwe belastingpligtige status. Die nuwe belastingstatus van die Helpmekaar het 'n negatiewe impak op hul beskikbare fondse om lenings toe te staan gehad. in Verdere negatiewe gevolg van hul belastingstatus, naamlik die impak op hul vermoë om skenkings te werf, het 'n onbedoelde positiewe uitkoms gehad. In sy bestuursverslag vir 2003 het die bestuurder aangedui dat die Het Jan Marais Nationale Fonds vanweë die Helpmekaar se nuwe belastingstatus van 'n derde skenking aan die Helpmekaar afgesien het. Na aanleiding van die verwikkeling het Ebbe Dommisse aangebied om met die voorsitter van die trusteeraad van die fonds, prof Andreas van Wyk, te onderhandel oor 'n moontlike verdere skenking aan die Helpmekaar. ${ }^{48}$ In sy gesprek met Dommisse het Van Wyk aanbeveel dat die Helpmekaar die stigting van 'n trust wat slegs beurse toeken, moes oorweeg. $\mathrm{Na}$ aanleiding hiervan het die direksie dus besluit om mnr Ronel Pretorius en die bestuurder die opdrag te gee om die stigting van 'n trustfonds in oorleg met prof Haupt (belastingkenner en professor in Belasting verbonde aan die Universiteit van Kaapstad $)^{49}$ en die Helpmekaar se nuutaangestelde ouditeure, Rademeyer Wesson, ${ }^{50}$ te ondersoek met 'n aanbeveling aan die direksie..$^{51}$

46 Ibid., ; 16 Feb 1995, HS Trustees, Beursfondse, 31 Jan 1995, gp; 16 Feb 1995, HS Trustees, gp; 25 Mei 1995 , HS Trustees, gp.

47 (HSA) HS, Notuleboek (13 Okt 1993-18 Sep 2003), 15 Feb 1996, HS Trustees, gp.

48 (HSA) HS, Notuleboek (4 Des 2003- 18 Jun 2014), 4 Mrt 2004, HS jaarvergadering, Jaarverslag, 11 Feb 2004, 4.

49 http://www.saipa.co.za/page/308024/prof-philip-haupt

50 (HSA) HS, Notuleboek (4 Des 2003-18 Jun 2014), 4 Des 2003, HS Direksie, 3-4; 4 Mrt 2004, HS jaarvergadering, 2. Rademeyer Wesson het PwC vervang as ouditeure met ingang van die 2004-finansiële jaar.

51 (HSA) HS, Notuleboek (4 Des 2003- 18 Jun 2014), 20 Mei 2004, HS Direksie, 2. 
Pretorius se konsepverslag het gelei tot 'n verdere opdrag aan die finansiële komitee om ondersoek te doen en 'n volledige aanbeveling aan die direksie te maak. ${ }^{52}$ Die bespreking van voorstelle, wat die uitkoms van 'n strategiese beplanningsessie was wat die direksie op 20 Mei 2004 gehou het, het die idee van die stigting van 'n trust ondersteun en verdere impetus daaraan gegee. As deel van 'n voorstel van PS Meyer is besluit dat die skep van 'n trustfonds vir beurse aan "verdienstelike, hulpbehoewende Afrikaanssprekende studente"53 so spoedig moontlik geskep moes word. Na aanleiding van 'n strategiese beplanningsverslag van Carel Stander oor gesubsidieerde beurse en lenings aan studente is besluit dat die stigting van 'n trust 'n voorvereiste vir die verdere uitbreiding van dié tipe van "hulpelement" was. As 'n tussentydse maatreël totdat 'n trust gestig word, is besluit om die definisie van verdienstelikheid uit te brei om ook behoeftigheid in te sluit sodat beurse voorlopig binne die bestaande stelsel van meriete/prestasiebeurse aan sulke studente toegeken kon word. ${ }^{54}$ Met hierdie definisie van verdienstelikheid het die Helpmekaar 'n volle sirkel in sy saamstap met die Afrikaner oor feitlik 'n 100 jaar voltooi. Aangesien die definisie geresoneer het met dié van die twintigerjare van die vorige eeu, naamlik hulp aan "behoeftige en skrandere" studente. Dit het ook erkenning gegee aan die realiteit dat armoede - hoewel nie van dieselfde intensiteit en omvang as vroeër nie - weer vir sommige Afrikaners 'n realiteit geword het.

Op aanbeveling van die finansiële komitee het die direksie die stigting van 'n trust goedgekeur en na die aanvaarding van 'n trustakte is die Helpmekaar se ouditeure opdrag gegee om met die stigting en registrasie van die trust voort te gaan. Mnr GR Pretorius sou as stigter en ds J van der Westhuyzen, dr CH Stander en mnr ML Smith sou as trustees van die trust optree. Sodra die stigtingsakte van die trust deur die Hooggeregshof goedgekeur is, sou die HS 'n stigtingsbedrag aan die trust skenk sodat met sy aktiwiteite 'n begin gemaak kon word..$^{55}$ Hoewel die bestuurder by die algemene jaarvergadering van Maart 2005 aangekondig het dat die trust so pas by die Hooggeregshof geregistreer is, ${ }^{56}$ is besluit dat die werwing en aanvaarding van skenkings 'n aanvang sou neem sodra die trust vrystelling ingevolge artikel 10(1), 18(a) van die Belastingwet verkry het. Afgesien van die feit dat die trust nie belasting op inkomste betaal het nie sou dié status skenkings aan die trust vir belastingdoeleindes aftrekbaar maak, terwyl testamentêre bemakings binne voorgeskrewe

\footnotetext{
52 (HSA) HS, Notuleboek (4 Des 2003- 18 Jun 2014), 12 Aug 2004, HS Direksie, 1.

53 Ibid., 3

54 Ibid., 4-5.

55 (HSA) HS, Notuleboek (4 Des 2003- 18 Jun 2014), 2 Des 2004, HS Direksie, Finkomverslag, 1.

56 (HSA) HS, Notuleboek (4 Des 2003- 18 Jun 2014), 3 Mrt 2005, HS jaarvergadering, 6.
} 
perke van boedelbelasting vrygestel sou wees. ${ }^{57}$ Die Helpmekaar sou dus voortaan tien persent van sy jaarlikse belasbare inkomste aan die trust kon skenk wat aftrekbaar ten opsigte van inkomstebelasting sou wees. Deur hierdie skenkings aan die trust kon die Helpmekaar dus die impak van sy belastingpligtigheid effens versag. ${ }^{58}$

Die HS Trust is amptelik tydens die eerste vergadering van sy Raad van Trustees op 11 April 2006 gekonstitueer. Hoewel die trust op inisiatief van die HS gestig is, het hy oor sy eie akte van oprigting en grondwet beskik en onafhanklik van die maatskappy gefunksioneer. Terwyl die maatskappy lenings toegeken het, sou die trust beurse toeken. Die trust sou jaarliks bepaal watter bedrag vir beurse beskikbaar is en die maatskappy versoek om jaarliks 'n voorlegging te doen van potensiële kandidate vir beurse. Die trust se primêre doel was om behoeftigheidsbeurse toe te ken, maar hulle sou ook die toekenning van prestasiebeurse kon oorweeg. Trust-inkomste kon gegenereer word uit skenkings en bemakings en die HS sou ook jaarliks om 'n skenking genader word. Die trust se plan was om in samewerking met die maatskappy 'n bemarkingsplan te ontwikkel om 'n donateursmark te ontwikkel. Die trust sou ook oor sy eie finansiële jaarstate beskik. ${ }^{59}$ 'n Aantal kategorieë van beurse wat deur die trust toegeken kon word, is goedgekeur. Daar is aanvanklik op die toekenning van rentebeurse gekonsentreer. Hierdie beurse is aan Helpmekaar-leningshouers toegeken wat vir lenings gekwalifiseer het, maar nie oor die finansiële bronne beskik het om die rente op die lenings tydens die studietyd te delg nie. ${ }^{60}$ Die trust het in 2007 'n aanvang gemaak met die toekenning van beurse deur 82 rentebeurse ter waarde van R353 030,08 toe te ken. ${ }^{61}$ Hiermee is 'n lang gekoesterde ideaal verwesenlik soos bevestig deur die voorsitter van die HS in sy 2009-jaarverslag:

"Die droom wat ons vir jare het om aan behoeftige studente groter steun te verleen, is stadig besig om 'n werklikheid te word, al is dit in hierdie stadium nog heel beskeie. Ek

57 (HSA) HS, Notuleboek (4 Des 2003- 18 Jun 2014), 7 Sep 2005, HS Direksie, 2; 3 Mrt 2006, HS jaarvergadering, (Bylaag 2 Jaarverslag, 6 Feb 2006, 2), 3.

58 (HSA) HS, Notuleboek (4 Des 2003 - 18 Jun 2014), 3 Mrt 2006, HS jaarvergadering, 2; Teen die belastingkoers waarteen die maatskappy belas word (28 persent), "spaar" die maatskappy dus R28 000 op elke R100 000 wat aan die trust geskenk word tot 'n maksimum van tien persent van die maatskappy se belasbare inkomste. Op 'n skenking van R800 000 is die "besparing" dus R224 000. (HSA) HST, Notuleboek (11 Apr 200612 Sep 2014), 1 Sep 2010, Helpmekaar Studiefonds Trust (HST), 2.

59 (HSA) HST, Notuleboek (11 Apr 2006-12 Sep 2014), 13 Jun 2006, HST Trustees, (Bylaag: Helpmekaar Studiefonds Trust-beleid, 1).

60 (HSA) HS, Notuleboek (4 Des 2003- 18 Jun 2014), 9 Mrt 2007, HS Direksie, gp. (Bylaag A: Finkomverslag, 6 Mrt 2007, 2; Bylaag A4: Implementeringskedule Helpmekaar beurse en lenings); 7 Jun 2007, HS Direksie, gp.

61 (HSA) HS, Notuleboek (9 Mrt 2007-25 Mrt 2014), 14 Mrt 2008, HS jaarvergadering, gp, (Bylaag A: Bestuurder verslag, 7 Mrt 2008, gp). 
verwys hier na rentebeurse ter waarde van R770 613 wat in 2008 deur die Helpmekaar Trust aan 108 behoeftige studente toegeken is."

In Maart 2010 het die finansiële komitee voorgestel dat die trust en HS as deel van hul burgerlike verantwoordelikheid dit moet oorweeg om lenings en/of beurse aan "arm, skrander, verdienstelike, agtergestelde Afrikaanssprekende studente toe te staan". ${ }^{2} \mathrm{Na}$ 'n verdere ondersoek deur 'n taakgroep in 2010 oor die uitbreiding van die toekenning van beurse deur die trust aan agtergestelde studente is besluit om vanaf 2011 volle beurse aan studente van drie instellings, naamlik die Universiteit van Stellenbosch, Universiteit van Wes-Kaap en die Kaapse Skiereiland Universiteit van Tegnologie (Wellington-kampus voormalige Wellingtonse Onderwyskollege) toe te ken. ${ }^{63}$

Hoewel die taakgroep in hul verslag aanbeveel het dat daar vanweë die groot behoefte veral op behoeftige bruin Afrikaanssprekende studente gefokus moes word, het hul ook aanbeveel dat ras nie die enigste vereiste vir toekenning moet wees nie. In die direksie se aanvaarding van die riglyne van die taakgroep is nie van bruin studente melding gemaak nie, maar verwys na werklik behoeftige en verdienstelike Afrikaanssprekende studente met 'n verwysing dat ras nie die enigste oorweging sou wees nie. Die vereistes is egter steeds aangebied onder die opskrif "Beurse aan Agtergestelde" studente. ${ }^{64}$ In die trust se aanvaarding van die riglyne wat vir die toekenning van die beurse gebruik sou word, is egter geen melding van ras gemaak nie, maar slegs verwys na werklik behoeftige Afrikaanssprekende studente wat ook die vermoë het om 'n naskoolse kwalifikasie te verwerf.

Die toekennings sou uit 'n beurs- en leningskomponent bestaan met die trust wat vir die beurs en die maatskappy wat vir die lening verantwoordelik sou wees. ${ }^{65}$ Volbeurse sou toegestaan word aan studente wat reeds hul eerste studiejaar suksesvol voltooi het. ${ }^{66}$ Die feit dat UWK en KSUT twee van die drie geïdentifiseerde instellings was, het vanweë die demografie van hul studentesamestelling feitlik verseker dat die meerderheid van die beurse aan bruin studente toegeken sou word. In dié sin was dit die eerste doelbewuste inisiatief van die Helpmekaar om die verskuiwing van hul seleksievoorwaardes in die negentigerjare

62 (HSA) HST, Notuleboek (11 Apr 2006-12 Sep 2014), 19 Mrt 2010, HST Trustees, 2.

63 (HSA) HS, Notuleboek (9 Mrt 2007-25 Mrt 2014), 25 Mrt 2011, HS jaarvergadering, 2, (Bylaag B, Bestuurder verslag, 25 Mrt 2011,3).

64 (HSA) HST, Notuleboek (11 Apr 2006-12 Sep 2014), 17 Nov 2010, HST Trustees, 2, (Taakgroepverslag: Direksiebesluit soos vervat in notule van 1 Sep 2010).

65 (HSA) HST, Notuleboek (11 Apr 2006-12 Sep 2014), 17 Nov 2010, HST Trustees, 2, (Bylaag C, HS Taakgroep: Verslag aan HS Trust en Direksie, 1-3).

66 E-pos kommunikasie, 24 Nov 2015, Helpmekaar - Ehlers. 


\section{Die Kaapse Helpmekaar}

van ras na taal 'n konkrete praktiese werklikheid te makk. 'n Wenslys-item het dus waar geword. In 2011 is nege beurse (aan drie behoeftige studente van elke instelling) met 'n totale waarde van R412 990 vir studie vanaf 2012 toegeken. ${ }^{67}$ Die getal beurshouers sou vir eers nie uitgebrei word nie en nuwe beurshouers sou slegs toegevoeg word soos die bestaande nege beurshouers afstudeer. ${ }^{68}$ In 2014 is 'n beurs ook vir die eerste keer aan 'n student toegeken wat nie aan een van die drie universiteite in die Wes-Kaap studeer nie, en wel aan 'n student wat aan Northlink Kollege studeer het. ${ }^{69}$

Teen 2015 is reeds 18 studente (17 bruin en een wit student; 15 dames en drie mans) met volbeurse ondersteun. ${ }^{70}$ Die Helpmekaar Trust se beurstoekennings aan behoeftige studente het dus van R353 030 in 2007, aan aanvanklik slegs rentebeurse, tot R1 339761 in 2013, aan rentebeurse en volbeurse aan behoeftige studente, toegeneem. ${ }^{71}$ Teen Julie 2013 het die trust deur hoofsaaklik die ontvangs van skenkings en erflatings oor bates van R7 924301 beskik. ${ }^{72}$ Die suksesvolle wyse waarop daar geslaag is om deur middel van die trust fondse vir die Helpmekaar te genereer is geillustreer deur die besluit van die direksie van die maatskappy in 2014 om die jaarlikse skenking van die HS aan die trust te staak tot tyd en wyl daar weer 'n behoefte na fondse by die trust ontstaan. ${ }^{73}$

Benewens bogenoemde rente- en volbeurse was die aanvanklike idee dat die merietebeurse wat ontstaan het uit die 1992-Oberholster voorstel en mettertyd as prestasie- of prestigebeurse bekend geraak het, ook deur die trust uit trustfondse toegeken sou word. Dit was in 2007 met die trust se eerste toekenning van beurse die geval (die nege prestigebeurse ter waarde van R104 000 is deur die trust toegeken en befonds). Dit het geblyk dat aangesien die beurse deur die ontvanger na goeddunke aangewend kon word, dit nie gekwalifiseer het as beurse wat die trust kon toeken nie. As opvoedkundige trust kon die trust slegs beurse vir studie, navorsing en onderrig toeken. Daar is dus besluit om voort te gaan met die toekenning van die prestigebeurse, maar dat dit'n funksie van die HS sou bly en deur die maatskappy befonds

67 (HSA) HS, Notuleboek (9 Mrt 2007-25 Mrt 2014), 23 Mrt 2012, HS jaarvergadering, 2, (Bylaag B: Bestuurder verslag, 23 Mrt 2012, 3).

68 (HSA) HST, Notuleboek (11 Apr 2006-12 Sep 2014), 2 Sep 2011, HST Trustees, 1.

69 (HSA) HS, Notuleboek (9 Mrt 2007-25 Mrt 2014), 25 Mrt 2014, HS jaarvergadering, 2.

70 E-pos kommunikasie, 24 Nov 2015, Helpmekaar - Ehlers.

71 (HSA) HS, Notuleboek (9 Mrt 2007-25 Mrt 2014), 25 Mrt 2014, HS jaarvergadering, (Bylaag C: Finkom verslag, 19 Mrt 2014, gp).

72 (HSA) HST, Notuleboek (11 Apr 2006-12 Sep 2014), 13 Sep 2013, HST Trustees, 2, (Bylaag B: Bates van Trust soos op 31 Jul 2013).

73 (HSA) HS, Notuleboek (4 Des 2003-18 Jun 2014), 18 Jun 2014, HS Direksie, 3. 
sou word. ${ }^{74}$ Hoewel die prestigebeurse sedert die aanvanklike instelling daarvan in 1992 geleidelik uitgebrei is, soos met die toevoeging van 'n beurs aan 'n Afrikaanssprekende onderwysstudent wat in 2002 op voorstel van PS Meyer toegevoeg is, ${ }^{75}$ het die herbesinnig oor beurstoekennings wat met die stigting van die trust gepaardgegaan het ook nuwe dinamika aan dié beurse verleen. Die beurse wat dit ten doel gehad het "om pligsgetrouheid en harde werk aan te moedig en sodoende die kanse op akademiese sukses en uiteindelike terugbetaling van ons lenings te verhoog"76 (die minimum vereistes om te kwalifiseer was 'n cum laude-slaagpunt ${ }^{77}$ het in finansiële terme oor tyd aansienlik toegeneem. Terwyl daar vir die 2005-toekennings R50 000 bewillig is, ${ }^{78}$ is daar in 2009 reeds R204 000 aan 16 leningshouers in verskillende kategorieë wat gekwalifiseer het, toegeken. ${ }^{79}$ As gevolg van die dalende getalle van studente wat die toekenningsfunksie vir die prestigebeurse bygewoon het, is in 2012 besluit om oor die formaat en begroting van die prestigebeurse te herbesin. ${ }^{80}$ Vanaf 2013 is die waarde van die toekennings verhoog en tot slegs vyf beperk: vier toekennings van tot R40 000 elk pro rata verdeel tussen die bestaande kategorieë van vorige toekennings en een toekenning van R60 000 plus 'n spesiaal ontwerpte Helpmekaar-medalje aan die toppresteerder. 'n Sesde toekenning sou ook op meriete aan 'n teologiestudent toegeken word. In 2013 sou 'n bedrag van R260 000 dus in die vorm van prestigebeurse toegeken word. Die toekenningsfunksie sou voortaan ook as " $n$ prestige geleentheid tydens 'n aandfunksie waarheen 'n uitgelese groep/werklik belanghebbendes genooi word", 81 hanteer word. Op die vooraand van sy eeufees was die "hulpelement" in die vorm van die toekenning van beurse dus stewig gevestig en 'n "ou begeerte" is verwesenlik. (11 Apr 2006-12 Sep 2014), 12 Sep 2007, HST Trustee, 2.

75 (HSA) HS, Notuleboek (13 Okt 1993-18 Sep 2003), 21 Nov 2002, HS Direksie, gp.

76 (HSA) HS, Notuleboek (4 Des 2003-18 Jun 2014), 22 Aug 2006, HS Direksie, 2.

77 (HSA) HS, Notuleboek (4 Des 2003-18 Jun 2014), 9 Mrt 2007, HS Direksie, gp, (Bylaag A: Finkom-verslag, 6 Mrt 2007, 2; Bylaag A4: Implementeringskedule Helpmekaar Beurse en Lenings); (HSA) HS, Notuleboek (9 Mrt 2007-25 Mrt 2014), 19 Mrt 2010, HS jaarvergadering, 2.

78 (HSA) HS, Notuleboek (4 Des 2003-18 Jun 2014), 2 Des 2004, HS Direksie, 5.

79 (HSA) HS, Notuleboek (9 Mrt 2007-25 Mrt 2014), 19 Mrt 2010, HS jaarvergadering, 1, (Bylae B: Bestuurder verslag, 19 Mrt 2010).

80 (HSA) HS, Notuleboek (4 Des 2003-18 Jun 2014), 6 Jun 2012, HS Direksie, 1; 7 Sep 2012, HS Direksie, 1.

81 (HSA) HS, Notuleboek (4 Des 2003-18 Jun 2014), 21 Nov 2012, HS Direksie, 1-2; (HSA) HS, Notuleboek (9 Mrt 2007-25 Mrt 2014), 27 Mrt 2013, HS jaarvergadering, (Bylaag D: Beursekomitee, 27 Mrt 2013, gp). 


\section{Pogings tot kapitaaluitbreiding}

Die uitbreiding van die Helpmekaar se kapitaalbasis deur fondswerwing was 'n altydteenwoordige tema in sy geskiedenis, asook die strewe na die uitbreiding van die Helpmekaar se "hulpelement" wat grootliks daarvan afhanklik was. Daar is na die Entrepreneursfonds-inisiatief van 1996, waartydens gepoog is om R6 miljoen oor 'n vyfjaarperiode in te samel, aanvanklik nie 'n spesiale fondsinsamelingsinisiatief geloods nie aangesien die Helpmekaar oor voldoende fondse beskik het. ${ }^{82}$ Hoewel daar met die stigting van die trust in 2006 oor aspekte soos bemarking, reklame en die ontwikkeling van 'n donateursmark besin is en oorweging geskenk is aan die vestiging van 'n alumnidatabasis met die oog op fondswerwing, is hoofsaaklik gekonsentreer op die uitbouing van die Helpmekaar se verhouding met sy bestaande donateurs en die ontginning van potensiële testamentêre bemakings. ${ }^{83}$ Die beklemtoning van laasgenoemde bronne was die gevolg van die tendens by groter maatskappye om al minder skenkings aan die Helpmekaar te doen. Van der Westhuyzen het die feit dat die Helpmekaar slegs 'n gedeelte van die land se jeug bedien, naamlik dié van die ou Kaapprovinsie en Natal, as moontlike rede hiervoor aangevoer. ${ }^{84}$ Hierdie evaluering was waarskynlik deels korrek, maar dit het niks met geografie te doen gehad nie, maar wel alles te doen gehad met die Helpmekaar se Afrikaanse fokus. Maatskappydireksies, selfs dié van die tradisionele Afrikaanse maatskappye, het weens swart ekonomiese bemagtiging en regstellende aksie nie meer uit net wit Afrikaanse mans bestaan nie. Hul ekonomiese heil was ook afhanklik van 'n veel wyer mark as net die Afrikaanse. Dit was dus toenemend moeilik vir maatskappye om skenkings aan 'n maatskappy soos die Helpmekaar met sy skerp Afrikaanse fokus te regverdig.

Die tendens is in 2008 deur die voorsitter bevestig en in 2010 as 'n realiteit aanvaar toe hy in sy jaarverslae aangedui het dat:

"As dit nie was vir die klein, maar gewaardeerde groepie donateurs wat ons bronne aanvul nie, sou die Fonds nie naastenby die hulpverlening kon gee wat tans die geval is nie. Namate mense meer bewus gemaak word van die nood in eie geledere, kan ons

82 (HSA) HS, Notuleboek (4 Des 2003-18 Jun 2014), 2 Sep 2011, HS Direksie, 3, (Bylaag B: Strategiese Beplanningsessie, 23 Aug 2011, 1).

83 (HSA) HS, Notuleboek (4 Des 2003-18 Jun 2014), 24 Nov 2005, HS Direksie, 2, Bylaag 1; 13 Jun 2006, HS Direksie, 2; 22 Aug 2006, HS Direksie, 3, (Bylaag 1, Finkom-verslag, 10 Aug 2006, 2); (HSA) HS, Notuleboek (9 Mrt 2007-25 Mrt 2014), 3 Mrt 2006, HS jaarvergadering, 3, (Bylaag 3, Finkom-verslag, 3 Mrt 2006, gp).

84 (HSA) HS, Notuleboek (9 Mrt 2007-25 Mrt 2014), 4 Mrt 2004, HS jaarvergadering, 4, (Voorsittersverslag, 1 Mrt 2004). 
deur middel van skenkings en erflatings ons posisie verbeter. ${ }^{85}$... Die invloei van nuwe kapitaal is nie soos ons dit graag sou wou sien nie. Tog moet dankbaar vermeld word dat testamentêre bemakings deur welwillende Helpmekaar-vriende nog steeds 'n periodieke invloei van kapitaal verseker ... Ons moet egter aanvaar dat die Afrikaanse stempel van ons organisasie onvermydelik sekere instansies ongeneë sal stem om deel van die donateurskorps te word." ${ }^{86}$

In 2010 is besluit dat in die lig van die 2008-resessie en sy nagevolge dit nie 'n gunstige tyd vir 'n amptelike fondsinsameling was nie en dat vir die afsienbare toekoms slegs op die uitbouing van die Helpmekaar se verhouding met sy bestaande donateurs en die ontginning van testamentêre bemakings gekonsentreer sou word. ${ }^{87} \mathrm{Na}$ aanleiding van 'n strategiese beplanningsessie in September 2011 is egter besluit om 'n spesiale fondsinsameling van stapel te stuur. ${ }^{88}$ Hierdie besluit was onder andere die uitkoms van 'n besluit wat na aanleiding van 'n strategiese beplanningsessie in 2004 geneem is, naamlik dat daarna gestreef moes word om minstens 75 persent van die Helpmekaar se beskikbare fondse in studielenings te belê. ${ }^{89}$ Teen 2006 het die 859 lenings aan studente 51 persent van die Helpmekaar se bates beloop en teen 2010 het dit tot 71 persent (1 284 lenings) toegeneem.

Die Helpmekaar moes dus besin daaroor of hy tevrede was met die 75 persent-beginsel binne bereik. Moes dit as 'n plafon beskou word en slegs die geld van leningsterugbetalings in nuwe lenings belê word? Daar was ook die opsie om die persentasie fondse wat in lenings belê word te verhoog of toekomstige groei deur die uitbreiding van sy fondse te akkommodeer vir organiese groei. Hierdie besinning het plaasgevind teen die agtergrond van die feit dat 97 persent van die staat se Fundsa Lusaka Beursfonds van ongeveer R500 miljoen aan swart studente toegeken is wat die verwagting geskep het dat die behoefte aan studiehulp vir Afrikaanssprekende studente sou toeneem. ${ }^{90}$ Die direksie het besluit om die organiese groeiroete te volg, asook om die 75 persent mikpunt ten opsigte van die belegging van fondse in

(HSA) HS, Notuleboek (9 Mrt 2007-25 Mrt 2014), 14 Mrt 2008, HS jaarvergadering, gp. (Bylaag A: Verslag van die Voorsitter, gp).

86 (HSA) HS, Notuleboek (9 Mrt 2007-25 Mrt 2014), 19 Mrt 2010, HS jaarvergadering, 1, (Bylaag A: Voorsittersverslag).

87 Ibid.; (HSA) HS, Notuleboek (4 Des 2003-18 Jun 2014), 19 Mrt 2010, HS Direksie, 4.

88 (HSA) HS, Notuleboek (4 Des 2003-18 Jun 2014), 2 Sep 2011, HS Direksie, 3.

89 (HSA) HS, Notuleboek (4 Des 2003-18 Jun 2014), 12 Aug 2004, HS Direksie, 3-5.

90 (HSA) HS, Notuleboek (4 Des 2003-18 Jun 2014), 2 Sep 2011, HS Direksie, 3, (Bylaag B: Strategiese Beplanningsessie, 2 Sep 2011, 23 Aug 2011, 1-2). 


\section{Die Kaapse Helpmekaar}

studielenings te behou. Dit het gelei tot 'n opdrag aan die finansiële komitee om dringend 'n plan van aksie vir 'n spesiale fondswerwingsveldtog op te stel..$^{91}$

Die resultaat van die inisiatief was die aanvaarding van 'n fondswerwingsveldtog in twee fases met die mikpunt om teen 2016 met die Helpmekaar se eeufeesherdenking R5 miljoen in te samel. ${ }^{92}$ Vir fase een is dr Carel Stander, 'n direksielid, as fondswerwer vir ses maande vanaf 1 Januarie 2012 aangestel met die doel om instansies en individue vir skenkings te nader. Sy kontrak vir fase een sou uiteindelik tot 31 Desember 2013 verleng word. Die tweede fase sou hoofsaaklik die samestelling van 'n databasis van Helpmekaar alumni met die oog op skenkings en die identifisering van individue met die oog op testamentêre bemakings behels. ${ }^{93}$ Die uitdagende taak wat Stander homselfopgelêhet, is goed verwoord deur Van der Westhuyzen in sy 2012-voorsittersrede waarin hy onder andere na die fondsinsamelingsinisiatief verwys het:

"Dit is ongelukkig waar dat die histories Afrikaanse sakeondernemings sterk afgeneem het en daarmee saam sekere sentimentele waardes. Bydraes uit hierdie kringe het byna tot 'n zero-punt gedaal. Ons is al meer op testamentêre bemakings aangewys." 94

Teen November 2013 is voorleggings aan 49 potensiële skenkers gemaak waarvan slegs sewe suksesvol was en in totaal R3 053000 opgelewer het - 'n bedrag wat teen Maart 2014 tot R4 056000 aangegroei het. Hoewel dit'n "trefpersentasie" van slegs 14 persent verteenwoordig het, is dit "gesien teen die stramheid van die skenkersmark, as suksesvol beskou." ${ }^{95}$ As in ag geneem word dat Naspers en Remgro vir R3 200000 van die R4 miljoen wat ingesamel is verantwoordelik was, het die veldtog Van der Westhuyzen se waarneming dat "sentimentele waardes" (lees: Afrikaner sentimente) by vroeëre Afrikaner-sakeondernemings tot feitlik zero-punt gedaal het, onomwonde bevestig. Die direksie het in Maart 2014 besluit om die fondsinsamelingsveldtog te beëindig. ${ }^{96}$ Pogings om ' $n$ databasis van alumni met die oog op fondswerwing saam te stel is egter voortgesit. Die fokus op testamentêre bemakings was 'n bevestiging dat die Helpmekaar in sy pad na die eeufees vir toekomstige kapitaaluitbreiding

91 (HSA) HS, Notuleboek (4 Des 2003-18 Jun 2014), 2 Sep 2011, HS Direksie, 3.

92 (HSA) HS, Notuleboek (4 Des 2003-18 Jun 2014), 27 Mrt 2013, HS Direksie, 2.

93 (HSA) HS, Notuleboek (4 Des 2003-18 Jun 2014), 18 Nov 2011, HS Direksie, 2, (Bylaag C1: Finkom-verslag: Fondswerwing, 1-2); 18 Nov 2011, HS Direksie, 2; 19 Jun 2013, HS Direksie, 2; 20 Nov 2013, HS Direksie, 2.

94 (HSA) HS, Notuleboek (9 Mrt 2007-25 Mrt 2014), 23 Mrt 2012, HS jaarvergadering, 1, (Bylaag A: Voorsittersverslag, 1).

95 (HSA) HS, Notuleboek (4 Des 2003-18 Jun 2014), 20 Nov 2013, HS Direksie, 1-2; 25 Mrt 2014, HS Direksie, 2, (CH Stander, Twintigste verslag aan die Direksie, 13 Mrt 2014).

96 (HSA) HS, Notuleboek (4 Des 2003-18 Jun 2014), 25 Mrt 2014, HS Direksie, 1. 
hoofsaaklik aangewese sou wees op die prospektering en ontginning van oorblywende Afrikaner-sentiment-draende "riwwe". In die post-1994 Suid-Afrika het die "riwwe" (individue) toenemend na die veiligheid en geborgenheid van die binnekamers van die private en individuele domein migreer.

Te midde van die stram donateursmark en die besluit van Maart 2014 om die fondsinsamelingsveldtog te beëindig het die Helpmekaar 'n welkome kapitaalinspuiting ontvang met die beslissing van die Suid-Afrikaanse Inkomstediens (SAID) dat die Helpmekaar voortaan nie meer belastingpligtig sou wees nie. ${ }^{97}$ Die Helpmekaar het met maatskappystigting in 2002 regs- en ouditadvies ingewin ${ }^{98}$ om hul belastingpligtige status ter syde gestel te kry op grond van die destydse adviesbesluit om "voorlopig daarin (te) berus dat die HS belastingpligtig is." ${ }^{99}$ Van der Westhuyzen het egter die finansiële komitee versoek om met ander nie-winssoekende organisasies wat in dieselfde posisie verkeer het te skakel met die oog daarop om die SAID gesamentlik te nader. Die direksie het sy versoek ondersteun met die opdrag dat die navrae gerig word, maar dat daar nie tot enige optrede oorgegaan word nie. ${ }^{100}$

Die belastingpligtige status van die Helpmekaar het ten spyte van die stigting van die trust, wat onder andere 'n poging was om die impak daarvan te versag, 'n doring in die Helpmekaar se vlees gebly. ${ }^{101}$ In 2011 is die Helpmekaar se ouditeure versoek om 'n voorlegging oor die Helpmekaar se belastingpligtigheid aan die direksie te doen. Ten spyte van die ouditeure se bevestiging dat die Helpmekaar volgens die huidige wetgewing steeds belastingpligtig was, is die ouditeure versoek om die SAID te nader om te bepaal of die Helpmekaar vir belastingvrystelling in aanmerking sou kon kom. ${ }^{102}$ Hiermee is ' $n$ proses begin waarin Pieter van der Poel, alternatief vir Johann Rupert op die Helpmekaar-direksie, ${ }^{103}$ en dr Charl du Toit van PwC'n belangrike rol gespeel het. Na vertoë aan die SAID op grond van 'n 2008-wysiging in die regulasies vir vrystelling van belasting aan openbare weldaadsorganisasies waarvolgens

97 (HSA) HS, Notuleboek (4 Des 2003-18 Jun 2014), 25 Mrt 2014, HS Direksie, 2.

98 (HSA) HS, Notuleboek (13 Okt 1993-18 Sep 2003), 21 Nov 2002, HS Finkom, gp; 21 Nov 2002, HS Direksie, gp; 3 Feb 2003, HS Finkom, gp.

99 (HSA) HS, Notuleboek (13 Okt 1993-18 Sep 2003), 7 Mrt 2003, HS Direksie, gp.

100 (HSA) HS, Notuleboek (13 Okt 1993-18 Sep 2003), 7 Mrt 2003, HS Direksie, gp; 8 Mei 2003, HS Direksie, gp.

101 (HSA) HS, Notuleboek (9 Mrt 2007-25 Mrt 2014), 14 Mrt 2008, HS jaarvergadering, gp, (Bylaag A: Voorsittersverslag, gp).

102 (HSA) HS, Notuleboek (4 Des 2003-18 Jun 2014), 18 Nov 2011, HS Direksie, 1; 23 Mrt 2012, HS Direksie, 1.

103 (HSA) HS, Notuleboek (9 Mrt 2007-25 Mrt 2014), 25 Mrt 2011, HS jaarvergadering, 1, (Bylaag A, Voorsittersverslag). 


\section{Die Kaapse Helpmekaar}

die toestaan van studielenings ook vir vrystelling ingesluit is, is belastingvrystelling aan die Helpmekaar verleen. Hierdie vrystelling het ook 'n terugbetaling van R5 621 762,31 van die SAID aan die Helpmekaar ingesluit op belasting wat reeds betaal is. ${ }^{104}$

\section{VERSNELDE KORPORATISERING}

Soos met die meeste historiese prosesse kan die korporatisering van die Helpmekaar nie aan 'n presiese dag of datum gekoppel word nie en was dit eerder 'n proses wat mettertyd met rukke en stote ontwikkel het. As met korporatisering verwys word na 'n groter sakeingesteldheid sal die stigting van die B-fonds in 1942 waarskynlik as die begin van die proses beskou kon word. Die registrasie van die B-fonds as maatskappy sonder winsbejag in die vorm van die HS in 1956 sou moontlik as 'n verdere ontwikkeling in dié verband gesien kon word, asook die amalgamasie van die Vereniging met die HS in 1966 as 'n konsolidering van die proses. Die besluit om in 1975 die HS weer in 'n trust te omskep en as maatskappy te deregistreer, hoofsaaklik omdat die bestuur van mening was dat hulle nie aan al die vereistes van die nuwe maatskappywetgewing ten opsigte van finansiële en ander verslagdoening sou kon voldoen nie, het die Helpmekaar "bevry" van die regulatoriese omgewing van die sakewêreld. In terme van korporatisering was dit dus waarskynlik 'n terugwaartse stap. Soos reeds aangedui, was Hannes Oberholster se aanstelling as aanvanklik Rupert se sekundus in 1985, daarna sy aanstelling as finansiële bestuurder in 1992 en uiteindelik bestuurder in 1993 die katalisator wat die Helpmekaar weer geleidelik met die praktyke van die sakewêreld sou versoen in terme van finansiële en administratiewe verslagdoening en -prosedures. Die grondslag vir die korporatisering van die Helpmekaar in die 21ste eeu het deur die loop van die negentigerjare onder Oberholster beslag gevind. Dit was aanvanklik'n "vrywillige"” proses en nie die gevolg van statutêre regulering nie. Die besluit in 2002 om sy status as trust vir dié van 'n Artikel 21-maatskappy te verruil het die Helpmekaar se korporatisering in 'n snelbaan geplaas. Meer sakegedrewe bestuur is toegepas wat ook deur statutêre regulering aangedryf is.

Bestuurstrukture, finansiële en administratiewe stelsels en -prosedures is met korporatiewe en statutêre voorskrifte en gebruike versoen. Die bestaande komiteestelsel is verder ontwikkel deur die formulering van die mandate, pligte en magte van die finansiële en beurskomitees. Die bestuurder het volgens maatskappywetgewing te werk gegaan ${ }^{105}$ en 'n maatskappyjaarprogram

104 (HSA) HS, Notuleboek (4 Des 2003-18 Jun 2014), 25 Mrt 2014, HS Direksie, 1; 18 Jun 2014, HS Direksie, 2 ; E-pos kommunikasie van dr C du Toit aan dr C Stander en A Ehlers, 13 Okt 2015.

105 (HSA) HS, Notuleboek (13 Okt 1993-18 Sep 2003), 8 Mei 2003, HS Direksie, gp; (HSA) HS, Notuleboek (4 Des 2003-18 Jun 2014), 4 Des 2003, HS Direksie, 3. 
met vergadering- en verslagdoeningsdatums is aanvaar. ${ }^{106}$ Die "uitstekende werk"107 en toenemend leidende rol wat die finansiële komitee onder voorsitterskap van dr Carel Stander in die proses vervul het, is gesimboliseer deur die aanlê van 'n afsonderlike notuleboek vir die finansiële komiteevergaderings sedert April 2003. ${ }^{108}$ Die komitee se verslag is as 'n vaste item op die agenda van direksievergaderings sedert Desember 2004 ingesluit. ${ }^{109}$ Wetgewing soos die Wet op Bevordering van Toegang tot Inligting, 2000 (Wet no. 2 van 2000) $)^{110}$, die Nasionale Kredietwet no. 34 van $2005^{111}$ en die Maatskappywet no. 71 van $2008^{112}$ het toenemend die Helpmekaar se daaglikse aktiwiteite gerig. Die toenemende betrokkenheid van direksielede ${ }^{113}$ vanuit die korporatiewe omgewing, veral via die finansiële komitee, kredietkeuring en beheer, ${ }^{114}$ kontantvloeibegrotings, verklaring van belange deur direkteure, ${ }^{115}$ korporatiewe leiding, beheer en waardes, ${ }^{116}$ strategiese beplanningsessies, ${ }^{117}$ bemarkingstrategieë en bemarkingsaksies ${ }^{118}$ en opvolgingsbeplanning ${ }^{119}$ was deel van die daaglikse Helpmekaar omgangstaal.

Die Studiefonds het dus'n korporatiewe bestuursmodel aanvaar, maar met die eiesoortigheid dat dit 'n Artikel 21-maatskappy sonder winsbejag was. Die taak was dus nie primêr om winste te genereer ter wille van aandeelhouers nie, maar om deur goeie finansiële bestuur

106 (HSA) HS, Notuleboek (13 Okt 1993-18 Sep 2003), 21 Nov 2002, HS Direksie, gp; 8 Mei 2003, HS Direksie, gp.

107 (HSA) HS, Notuleboek (4 Des 2003-18 Jun 2014), 28 Nov 2007, HS Direksie, gp.

108 (HSA) HS, Notuleboek (13 Okt 1993-18 Sep 2003), 11 Apr 2003, HS Finkom; 7 Mrt 2003, HS Direksie, Bestuurder verslag, 3 .

109 (HSA) HS, Notuleboek (4 Des 2003-18 Jun 2014), 2 Des 2004, HS Direksie, 2.

110 (HSA) HS, Notuleboek (13 Okt 1993-18 Sep 2003), 8 Mei 2003, HS Direksie, gp.

111 (HSA) HS, Notuleboek (4 Des 2003-18 Jun 2014), 9 Mrt 2007, HS Direksie, (Bylaag A: Finkom-verslag, 6 Mrt 2007, 2).

112 (HSA) HS, Notuleboek (4 Des 2003-18 Jun 2014), 16 Sep 2009, HS Direksie, 2; 18 Nov 2009, HS Direksie, 1.

113 (HSA) HS, Notuleboek (4 Des 2003-18 Jun 2014), 3 Mrt 2005, HS jaarvergadering, 3, Bestuurder verslag, 7 Feb 2005.

114 (HSA) HS, Notuleboek (4 Des 2003-18 Jun 2014), 12 Aug 2004, HS Direksie, 4.

115 (HSA) HS, Notuleboek (13 Okt 1993-18 Sep 2003), 7 Mrt 2003, HS Direksie, gp.

116 (HSA) HS, Notuleboek (4 Des 2003-18 Jun 2014), 18 Jul 2006, HS Direksie, 2; 9 Mrt 2007, (Bylaag A: Finkom-verslag, 6 Mrt 2007, 2).

117 (HSA) HS, Notuleboek (4 Des 2003-18 Jun 2014), 4 Mrt 2004, HS jaarvergadering, 3, Finkom-verslag, 4 Feb 2004; 20 Mei 2004, HS Direksie, 4-5; 18 Jul 2006, HS Direksie, 2; 13 Sep 2013, HS Direksie, 2.

118 (HSA) HS, Notuleboek (4 Des 2003-18 Jun 2014), 3 Mrt 2006, HS jaarvergadering, 3 (Bylaag, Finkomverslag, 3 Mrt 2006, gp).

119 (HSA) HS, Notuleboek (9 Mrt 2007-25 Mrt 2014), 25 Mrt 2014, HS jaarvergadering, 3. 


\section{Die Kaapse Helpmekaar}

tog te verseker dat die maksimum geld beskikbaar is vir die bevordering van hul primêre en enigste fokus, naamlik die verskaffing van studiefinansiering deur lenings en beurse. Die proses het ook nie die filantropiese aard van die Helpmekaar verswelg nie, aangesien korporatisering voortdurend aan die historiese narratief en identiteit van die Helpmekaar getoets en selfs daaraan ondergeskik gestel is. In reaksie op 'n voorstel van die finansiële komitee in 2003 of die Helpmekaar nie van sy konserwatiewe benadering tot beleggings moes wegbeweeg nie ${ }^{120}$ het die voorsitter, ds Van der Westhuyzen, bevestig dat dit die taak van die Helpmekaar was om die geld so te bestuur dat risiko's geminimaliseer word en dat die konserwatiewe opsies te alle tye in beleggingsbesluite oorweeg moes word. ${ }^{121}$

$\mathrm{Na}$ aanleiding van 'n 2004-strategiese beplanningsoefening is besluit dat rentekoerse die minimum moes wees wat met gesonde besigheidsbeginsels versoenbaar was. ${ }^{122}$ Die Helpmekaar is dus nie deur 'n korporatiewe strewe na maksimum wins gedryf nie. In 2004 het die voorsitter die bestuurder versoek om nie streng by 'n kontantvloeibegroting te hou en in die proses aansoeke met meriete te weier nie. Sy versoek was na aanleiding van die 266 aansoeke vir lenings vir 2005 wat ontvang is en waarvan 175 goedgekeur en 91 afgekeur is. Die voorsitter se mening was dat "die filosofie van die Helpmekaar is om te help en die filosofie moet so ver moontlik uitgeleef word". ${ }^{123}$ Met die aanvang van die strategiese beplanningsessie in Julie 2006 te Laborie in die Paarl, wat in die gees van die korporatisering van die Helpmekaar gestaan het, het Van der Westhuyzen die direksie herinner aan die laaste opdrag van die kongres, naamlik:

"dat die strewe en doelstellings wat in die Helpmekaar se geskiedenis vervat is, in ere gehou moet word. Slegs so sal die organisasie getrou bly aan die grond waaruit dit gegroei het." 124

Ten spyte daarvan dat korporatisering nie'n ongebreidelde proses was wat die organisasieprofiel en narratief verander het nie ${ }^{125}$ het dit tog 'n wesenlike invloed op die daaglikse beheer en bestuur van die maatskappy uitgeoefen.

120 (HSA) HS, Notuleboek (13 Okt 1993-18 Sep 2003), 4 Feb 2003, HS Finkom, gp.

121 (HSA) HS, Notuleboek (13 Okt 1993-18 Sep 2003), 7 Mrt 2003, HS Direksie, gp.

122 (HSA) HS, Notuleboek (4 Des 2003-18 Jun 2014), 12 Aug 2004, HS Direksie, 5.

123 (HSA) HS, Notuleboek (4 Des 2003-18 Jun 2014), 2 Des 2004, HS Direksie, 3.

124 (HSA) HS, Notuleboek (4 Des 2003-18 Jun 2014), 18 Jul 2006, HS Direksie, 1.

125 (HSA) HS, Notuleboek (4 Des 2003-18 Jun 2014), 2 Sep 2011, HS Direksie, 3. (Bylaag B: Strategiese Beplanningsessie, 23 Aug 2011,2). 
Die aanvaarding van die Nasionale Kredietwet 34/2005 het die Helpmekaar genoop om as kredietverskaffer by die Nasionale Kredietreguleerder te registreer. ${ }^{126}$ Helpmekaardokumentasie moes dus volgens die vereistes van die wet opgestel word. ${ }^{127}$ Soos die implementering van die Kredietwet gevorder het en die administratiewe vereistes deur regulasies uitgebrei is, het dit geblyk dat die impak van die wet in terme van werkslading op die Helpmekaar se administratiewe personeel baie groter was as wat aanvanklik voorsien is. Die groot groei in die aantal Helpmekaar leningshouers het die impak van die wet vererger, soveel so dat dit 'n uitbreiding van die Helpmekaar se administratiewe personeel genoodsaak het. ${ }^{128}$ 'n Administratiewe/Finansiële beampte is dus in November 2008 tot die personeel toegevoeg. ${ }^{129}$

Die aanvaarding van die Maatskappywet no. 71 van 2008 wat in Junie 2010 in werking getree het, het die verantwoordelikheid van die direkteure ten opsigte van interne beheer van die maatskappy onderstreep en die maatskappy genoop om opnuut oor die samestelling van die direksie te besin. Hulle moes veral oor die posisie van Johann Rupert besluit het - hy kon selde direksievergaderings bywoon en is deur 'n sekundus op die direksie verteenwoordig. ${ }^{130}$ Mnr Pieter van der Poel van die Rupert Familiestigting het na raadpleging aanbeveel dat Johann Rupert as direksielid bedank en 'n alternatiewe persoon moes aanwys om die Rupert-familie op die direksie te verteenwoordig. Die direksie het gevoel dat "die naam van mnr Rupert tog waarde toevoeg op die amptelike korrespondensie van die Helpmekaar en dat hy liefs as direkteur behou moet word." ${ }^{131}$ Op Rupert se voorstel is hy as direkteur behou en mnr Pieter van der Poel as sy alternatief, is ook op die direksie aangestel. ${ }^{132}$ Die direksie het ook besluit dat direksievergaderingnotules voortaan aan Rupert gestuur sou word. ${ }^{133}$ Benewens die besinning oor die verantwoordelikhede van die direkteure het die nuwe maatskappywet ook gelei tot 'n besluit om die akte van oprigting van die Helpmekaar met 'n nuwe memorandum van inkorporasie te vervang om dit met die voorskrifte van die nuwe

126 (HSA) HS, Notuleboek (4 Des 2003-18 Jun 2014), 9 Mrt 2007, HS Direksie, gp; 17 Sep 2008, HS Direksie, 3.

127 (HSA) HS, Notuleboek (4 Des 2003-18 Jun 2014), 7 Jun 2007, HS Direksie, gp.

128 (HSA) HS, Notuleboek (9 Mrt 2007-25 Mrt 2014), 14 Mrt 2008, HS jaarvergadering, gp (Bylaag A; Verslag van die Bestuurder, 7 Mrt 2008, gp); (HSA) HS, Notuleboek (4 Des 2003-18 Jun 2014), 16 Sep 2009, HS Direksie, 3.

129 (HSA) HS, Notuleboek (9 Mrt 2007-25 Mrt 2014), 27 Mrt 2009, HS jaarvergadering, gp (Bylaag B: Bestuurder verslag, 20 Mrt 2009).

130 (HSA) HS, Notuleboek (4 Des 2003-18 Jun 2014), 16 Sep 2009, HS Direksie, 2; 18 Nov 2009, 1.

131 (HSA) HS, Notuleboek (4 Des 2003-18 Jun 2014), 1 Sep 2010, HS Direksie, 1.

132 (HSA) HS, Notuleboek (4 Des 2003-18 Jun 2014), 17 Nov 2010, HS Direksie, 1.

133 (HSA) HS, Notuleboek (4 Des 2003-18 Jun 2014), 4 Jun 2010, HS Direksie, 1. 


\section{Die Kaapse Helpmekaar}

wetgewing te versoen. ${ }^{134}$ Die nuwe memorandum van inkorporasie het vir 'n maksimum van 15 lede in die maatskappy voorsiening gemaak, daar was slegs agt lede. Daar is besluit om persone te nader "wat die gesindheid openbaar wat die etos van die Helpmekaar weerspieël"135 om lede te word en wat ook in die toekoms die direksie sou kon anvul en sodoende kontinuïteit en 'n voldoende opvolgstrategie kon verseker. ${ }^{136}$

Die korporatisering van die Helpmekaar het ook op die domein van sy kantooradministrasie en die gepaardgaande stelsels 'n beduidende impak gehad. Die oorkoepelende doel van die vernuwing in dié verband was om deur rekenarisering en die gebruik van elektroniese stelsels die werklas van amptenare te verlig. Dit het ook terselfdertyd meer effektiewe beheer en kontrole oor aspekte soos kredietbeheer, voldoening aan die Kredietwet in dié verband, kontantvloeiprojeksies en finansiële transaksies, kommunikasie met leningshouers en algemene kantooradministrasie moontlik gemaak. ${ }^{137}$ Die proses het 'n baie groter belegging in rekenaarstelsels en -programme as voorheen vereis en ook die voortdurende byhou en opdatering daarvan genoodsaak soos die administratiewe behoeftes vanweë die groter volume studielenings ${ }^{138}$ en statutêre vereistes dit genoodsaak het. ${ }^{139}$ Daar is reeds verwys na die aanvanklike weerstand wat die aanvang van die prosesse in die negentigerjare van amptenare ontlok het omdat die aanleer en implementering van die nuwe stelsels in tandem met die normale voortgaan van die daaglikse administrasie aanvanklik die druk op amptenare vergroot het. Soos met implementering gevorder is, is die voordele en moontlikhede van rekenarisering en die nuwe informasietegnologie egter besef en omarm. Die gehalte en volume werk wat deur 'n klein toegewyde personeelkorps baasgeraak is, is jaarliks deur die direksie bewonder:

\footnotetext{
134 (HSA) HS, Notuleboek (4 Des 2003-18 Jun 2014), 18 Nov 2011, HS Direksie, 1; 23 Mrt 2012, 1.

135 (HSA) HS, Notuleboek (9 Mrt 2007-25 Mrt 2014), 25 Mrt 2014, HS jaarvergadering, 2-3.

136 (HSA) HS, Notuleboek (4 Des 2003-18 Jun 2014), 13 Sep 2013, HS Direksie, 1; (HSA) HS, Notuleboek (9 Mrt 2007-25 Mrt 2014), 25 Mrt 2014, HS jaarvergadering, 3.

137 (HSA) HS, Notuleboek (9 Mrt 2007-25 Mrt 2014), 14 Mrt 2008, HS jaarvergadering, gp (Bylaag A: Bestuurder verslag, 7 Mrt 2008, gp).

138 (HSA) HS, Notuleboek (13 Okt 1993-18 Sep 2003), 7 Mrt 2003, HS Direksie, gp, Bestuurder verslag, 2003, 3. Teenoor die 52 nuwe lenings wat in 1996 toegeken is en die totaal van 366 studentelenings wat hulle moes administreer, is daar teen 2003 reeds 182 nuwe lenings toegeken en 'n totaal van 689 studielenings wat geadministreer moes word.
}

139 (HSA) HS, Notuleboek (9 Mrt 2007-25 Mrt 2014), 14 Mrt 2008, HS jaarvergadering, gp, (Bylaag A: Bestuurder verslag, 7 Mrt 2008, gp). 


\begin{abstract}
"Hulle is inderdaad mense wat nie soos 'huurlinge' werk nie, maar soos trotse voorlopers in 'n saak wat ons beskou as 'n familiesaak ${ }^{140}$... Deur hulle werksetiek, insette en onbaatsugtige diens lewer hulle as individue en uiteindelik as span 'n unieke bydrae tot die hoë standaard van diens wat so eie aan die Helpmekaar is." ${ }^{\text {141 }}$
\end{abstract}

In 2002 is die elektroniese oorplasing van gelde vir die eerste keer ingevoer. Benewens die tydsbesparing wat dit meegebring het, het dit ook 'n aansienlike vermindering in bankkoste tot gevolg gehad. ${ }^{142}$ In 2004 is begin met die opgradering van die rekenaarstelsel en die implementering van 'n nuwe rekenaarprogram. Hiermee is 'n proses begin wat die rekenarisering van die Helpmekaar se administrasie, wat onder Oberholster begin is, tot 'n nuwe vlak sou verhef. Dit sou ook tot 'n proses van voortdurende vernuwing in dié verband lei. Die finansiële komitee, veral Marius Smith en dr Carel Stander sou n belangrike rol hier gespeel het. ${ }^{143}$ Sommige van die stelsels het aansienlike tyd en insette van

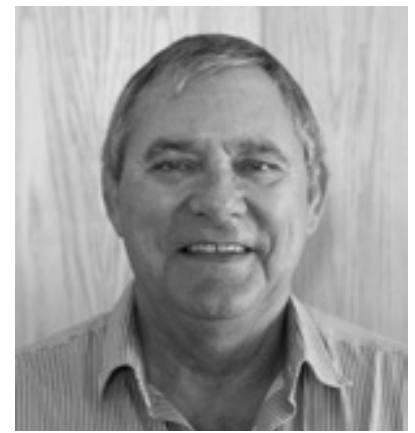

Barry van der Merwe, huidige bestuurder van die Helpmekaar Studiefonds direksielede, amptenare en diensverskaffers vereis om optimale funksionering te bereik. 'n Kenmerk van korporatisering was die groter fokus op en die verfyning van monetering van agterstallige skuld. ${ }^{144}$ Wat kredietbeheer betref, kon die bestuurder eers in September 2009 verklaar dat "ons nou vir die eerste keer 'n betroubare verslag beskikbaar het." ${ }^{145}$

In 'n poging om 'n eenvormige betaalstelsel te vestig, is vanaf Januarie 2010 van alle nuwe leningshouers verwag om hul maandelikse rentepaaiemente per debietorder te betaal. ${ }^{146}$

140 (HSA) HS, Notuleboek (9 Mrt 2007-25 Mrt 2014), 23 Mrt 2012, HS jaarvergadering, 1, (Bylaag A: Voorsittersverslag, 23 Mrt 2012, 2).

141 (HSA) HS, Notuleboek (9 Mrt 2007-25 Mrt 2014), 23 Mrt 2012, HS jaarvergadering, 2 (Bylaag B: Bestuurder verslag, 23 Mrt 2012, 3).

142 (HSA) HS, Notuleboek (13 Okt 1993-18 Sep 2003), 7 Mrt 2003, HS Direksie, gp (Bestuurder verslag, 2003, 3).

143 (HSA) HS, Notuleboek (4 Des 2003-18 Jun 2014), 4 Mrt 2004, HS jaarvergadering, 3, Finkom-verslag, 4 Feb 2004; (HSA) HS, Notuleboek (4 Des 2003-18 Jun 2014), 20 Mei 2004, HS Direksie, 4; (HSA) HS, Notuleboek (4 Des 2003-18 Jun 2014), 3 Mrt 2005, HS jaarvergadering, 3-4, Finkom, 24 Jan 2005; (HSA) HS, Notuleboek (4 Des 2003-18 Jun 2014),13 Jun 2006, HS Direksie, 2, (Bylaag 1: Finkom-verslag, 11 Apr 2006, 2); (HSA) HS, Notuleboek (4 Des 2003-18 Jun 2014), 11 Jun 2008, HS Direksie,1-2; (HSA) HS, Notuleboek (9 Mrt 2007-25 Mrt 2014), 27 Mrt 2009, HS jaarvergadering, gp, (Bylaag B: Bestuurder verslag, 20 Mrt 2009); 25 Mrt 2014, HS jaarvergadering, (Bylaag B: Bestuurder verslag, 25 Mrt 2014, 2).

144 (HSA) HS, Notuleboek (4 Des 2003-18 Jun 2014), 17 Nov 2010, HS Direksie, 2.

145 (HSA) HS, Notuleboek (4 Des 2003-18 Jun 2014), 16 Sep 2009, HS Direksie, 1.

146 (HSA) HS, Notuleboek (4 Des 2003-18 Jun 2014), 19 Jun 2009, HS Direksie, 3. 
In 2006 is 'n rekenaar ook vir die eerste keer vir die bestuurder se kantoor aangekoop, dit het ' $n$ groot leemte in administrasie gevul. ${ }^{147}$ In 2007 het die Helpmekaar die geglobaliseerde wêreld betree met die aktivering van 'n eie webbladsy wat ook 'n aanduiding was van die mate waarin die elektroniese era deur die maatskappy omarm is. ${ }^{148}$ In 2010 is die rekenaarprogram aangepas om elektroniese dokumentasie per elektroniese pos met die nodige aanhangsels te kan versend ${ }^{149}$ en in 2011 is na 'n papierlose liasseerstelsel oorgeskakel wat die liassering van harde kopieë en die hantering van lêers uitgeskakel het. ${ }^{150}$ In 2014 is 'n nuwe rekenaarmodel vir kontantvloeiprojeksies deur Marius Smith ontwikkel en in bedryf gestel. ${ }^{151}$ Deur rekenarisering en die voortdurende vernuwing van die rekenaarprogram is 'n uiters doeltreffende administrasie ontwikkel wat ligjare verwyder was van die vroeëre grootliks "handaksie"152-gedrewe era. Benewens rekenarisering is Helpmekaar administrasie ook deur ander korporatiewe elemente soos die opstel van 'n bestuurshandleiding, ${ }^{153}$ indiensnemingsvoorwaardes, ${ }^{154}$ reëls vir langdienstoekennings, afskeidsgeskenke, ${ }^{155}$ personeelvoorsiening- en vergoedingsbeleide gekenmerk. ${ }^{156}$ In hul strewe om 'n doeltreffende diens te lewer het opgradering, vernuwing en ontwikkeling dus 'n integrale deel van die Helpmekaar-administrasie se DNS geword.

Korporatisering het ook nie die bestuur en belegging van die Helpmekaar se finansies verbygegaan nie. Die beleggingsbeleid is reeds vroeër verbreed om mettertyd ook eiendomsen aandelebeleggings in te sluit. Veral laasgenoemde het 'n geskakeerde geskiedenis gehad wat gekenmerk is deur tydperke van die uitkontraktering van die Helpmekaar se

147 (HSA) HS, Notuleboek (4 Des 2003-18 Jun 2014), 18 Jul 2006, HS Direksie, 1.

148 (HSA) HS, Notuleboek (4 Des 2003-18 Jun 2014), 28 Nov 2007, HS Direksie, gp.

149 (HSA) HS, Notuleboek (9 Mrt 2007-25 Mrt 2014), 25 Mrt 2011, HS jaarvergadering, 2, (Bylaag B: Bestuurder verslag, 25 Mrt 2011,2).

150 (HSA) HS, Notuleboek (4 Des 2003-18 Jun 2014), 10 Jun 2011, HS Direksie, 3; (HSA) HS, Notuleboek (9 Mrt 2007-25 Mrt 2014), 23 Mrt 2012, HS jaarvergadering, 2, (Bylaag B: Bestuurder verslag, 23 Mrt 2012, 2).

151 (HSA) HS, Notuleboek (4 Des 2003-18 Jun 2014), 25 Mrt 2014, HS Direksie, 2.

152 (HSA) HS, Notuleboek (9 Mrt 2007-25 Mrt 2014), 25 Mrt 2011, HS jaarvergadering, 2, (Bylaag B: Bestuurder verslag, 25 Mrt 2011,2).

153 (HSA) HS, Notuleboek (4 Des 2003-18 Jun 2014), 3 Mrt 2005, HS jaarvergadering, 2, (Bestuurder verslag, 7 Feb 2005).

154 (HSA) HS, Notuleboek (4 Des 2003-18 Jun 2014), 9 Mrt 2007, HS Direksie, gp, (Bylaag A: Finkomverslag, 9 Mrt 2007, 2; Bylae A3: Helpmekaar Studiefonds - Personeelbeleid: Algemene Diensvoorwaardes, 5 Mrt 2007).

(HSA) HS, Notuleboek (4 Des 2003-18 Jun 2014), 7 Jun 2007, HS Direksie, gp.

(HSA) HS, Notuleboek (4 Des 2003-18 Jun 2014), 25 Mrt 2011, HS Direksie, 3-4. 
aandeleportefeulje gevolg deur periodes van ontnugtering. Dit was gewoonlik die gevolg van sikliese markineenstortings waarin uitkontraktering opgeskort of aan 'n groot mate van kontrole onderwerp is. Die besef van die belangrike rol van aandelebeleggings as 'n skans in die stryd teen die verwoesting van inflasie het sedert die negentigerjare hernude traksie in die Helpmekaar se denke oor die bestuur van sy fondse gevind.

Oberholster se voorstel in 1990 dat die Helpmekaar sy beleggings aan 'n beleggingsadviseur moes toevertrou om 'n beter opbrengs te verseker ${ }^{157}$ is in 1993 opgevolg deur die aanvaarding van 'n voorstel van dr Carel Stander dat Boland Bank se voorstelle, oor hoe die Helpmekaar se aandeleportefeulje herskik kan word, aanvaar word. ${ }^{158}$ Verdere ondersoek in 1998 deur 'n subkomitee, bestaande uit Stander, Oberholster, De Swardt en die voorsitter, na die wenslikheid om die Helpmekaar se aandeleportefeulje deur makelaars te laat bestuur het gelei tot 'n aanbeveling dat BOE Sekuriteite as makelaars aangestel moes word met die opdrag dat riskante en spekulatiewe transaksies beperk moes word en dat eerder op langtermyn groei gefokus word. ${ }^{159}$ Die subkomitee sou BOE se hantering van die aandeleportefeulje monitor en jaarliks aan die Raad van Trustees verslag doen. ${ }^{160}$ Met die oorgang van 'n trust na 'n Artikel 21-maatskappy in 2002 is die bestuur van die Helpmekaar se aandeleportefeulje dus deur BOE Sekuriteite hanteer. ${ }^{161}$ Hierdie benadering tot en hantering van die Helpmekaar se aandeleportefeulje het vrugte afgewerp, aangesien die markwaarde daarvan byvoorbeeld van ongeveer R4.4 miljoen in 1996 tot R11 miljoen in Januarie 2002 toegeneem het. ${ }^{162}$

Korporatisering en die nuwe belastingpligtige status van die Helpmekaar het ook 'n herevaluering van sy beleggingstrategie genoodsaak. Dit het gelei tot 'n hernude erkenning van die gespesialiseerde aard van die bestuur van 'n beleggingsportefeulje; spesifiek 'n aandeleportefeulje. In die lig van die riglyne vervat in die King-verslag ${ }^{163}$ oor korporatiewe beheer is dus opnuut oor die Helpmekaar se finansiële bestuursbeleid besin wat uiteindelik in 'n stel riglyne neerslag gevind het. Wat vaste deposito's en beleggings in geldmarkfondse betref, sou nie meer as 25 persent van beskikbare beleggingsfondse by een instelling belê

\footnotetext{
157 (HSA) HS, Notuleboek (16 Feb 1973-10 Sep 1993), 19 Apr 1990, HS Kommissie, 106.

158 (HSA) HS, Notuleboek (16 Feb 1973-10 Sep 1993), 6 Mei 1993, HS Subkomitee van Trustees, 129.

159 (HSA) HS, Notuleboek (13 Okt 1993-18 Sep 2003), 19 Aug 1998, HS Subkomitee, gp.

160 (HSA) HS, Notuleboek (13 Okt 1993-18 Sep 2003), 8 Okt 1998, HS Trustees, gp.

161 (HSA) HS, Notuleboek (13 Okt 1993-18 Sep 2003), 20 Mei 1999, HS Trustees, gp.

162 (HSA) HS, Notuleboek (13 Okt 1993-18 Sep 2003), 22 Feb 2002, HS jaarvergadering, Bestuurder verslag, 22 Feb 2002, gp.

163 http://www.mervynking.co.za/downloads/CD_King2.pdf
} 
word nie en sou beleggings deur die bestuurder in samehang met die finansiële komitee en met verslagdoening aan die direksie geskied. Wat genoteerde aandele betref, sou voortgegaan word met die bestaande beleid dat 'n kundige makelaarsfirma die portefeulje sou hanteer en beleggings in oorleg met die finansiële komitee en met verslagdoening aan die direksie sou doen. ${ }^{164}$ Met maatskappyvorming is BOE Sekuriteite se aanstelling as aandelemakelaar van die Helpmekaar herbevestig met die opdrag om gereelde verslae vir voorlegging aan die direksie op te stel. ${ }^{165}$ In 2003 is 'n gedeelte van die aandeleportefeulje aan die makelaarsfirma Barnard, Jacobs \& Mellett toevertrou. ${ }^{166}$ Hoewel die makelaars se bestuur van die Helpmekaar-aandeleportefeulje op 'n gereelde basis geëvalueer en heroorweeg is, ${ }^{167}$ het bevredigende resultate tot 'n langtermyn verbintenis met die betrokke makelaars aanleiding gegee. Die jarelange verhouding wat die Helpmekaar met mnr Mof Terreblanche van BOE Sekuriteite opgebou het, het in 2011 na sy indienstrede by Stonehage, asook die verkoop van Barnard Jacobs en Mellet aan Rencap in 2010, gelei tot die konsolidering en verskuiwing van die Helpmekaar se aandeleportefeulje na die Stonehage makelaarsfirma. ${ }^{168}$

Die korporatisering van die Helpmekaar is gekenmerk deur 'n eksponensiële groei in hul bates. Tewyl die Helpmekaar in 2003, die eerste volle boekjaar van sy status as belastingpligtige maatskappy, oor kontant en beleggingsbates van R59,8 miljoen beskik het, het hulle in 2007 die eerste keer die R100 miljoen kerf oorskry met bates van R101,7 miljoen. Teen 2013 het die maatskappy reeds oor bates van R152 miljoen beskik. ${ }^{169}$ Hierdie toename in totale bates het ook gereflekteer in hul belegging in studielenings. Terwyl hul belegging in studielenings in 2003 R23,1 miljoen beloop het, ${ }^{170}$ is die R100 miljoen-kerf vir die eerste keer in 2012

164 (HSA) HS, Notuleboek (13 Okt 1993-18 Sep 2003), 26 Apr 2002, HS Trustees, gp, Finansiële Subkomitee memorandum, 17 Apr 2002, gp.

165 (HSA) HS, Notuleboek (13 Okt 1993-18 Sep 2003), 5 Jun 2002, HS Finkom, gp.

166 (HSA) HS, Notuleboek (4 Des 2003-18 Jun 2014), 4 Des 2003, HS Direksie, 3-4.

167 (HSA) HS, Notuleboek (9 Mrt 2007-25 Mrt 2014), 14 Mrt 2008, HS jaarvergadering, gp, (Bylaag A: Finkom verslag, 7 Mrt 2008, gp).

168 (HSA) HS, Notuleboek (4 Des 2003-18 Jun 2014), 10 Jun 2011, HS Direksie, 4; (HSA) HS, Notuleboek (9 Mrt 2007-25 Mrt 2014), 25 Mrt 2014, HS jaarvergadering, 3; (HSA) HS, Notuleboek (4 Des 2003 18 Jun 2014), 25 Mrt 2014, HS Direksie, 3; Mail and Guardian, 3 May 2010, Rencap buys Barnard Jacobs Mellett for R207m.

169 (HSA) HS, Notuleboek (9 Mrt 2007-25 Mrt 2014), 14 Mrt 2008, HS jaarvergadering, gp; 14 Mrt 2008, HS jaarvergadering, gp, (Bylaag A: Finkom verslag, 7 Mrt 2008, gp); (HSA) HS, Notuleboek (4 Des 2003 18 Jun 2014), 25 Mrt 2014, HS Direksie, Finkom-verslag, 19 Mrt 2014, gp.

170 (HSA) HS, Notuleboek (9 Mrt 2007-25 Mrt 2014), 14 Mrt 2008, HS jaarvergadering, gp, (Bylaag A: Finkom verslag, 7 Mrt 2008, gp). 
oorskry en teen 2013 het die totale belegging in studielenings R105,8 miljoen beloop. ${ }^{171}$ Die groei in die toekenning van nuwe lenings het na die laagtepunt in 1990 van slegs 37 nuwe lenings ${ }^{172}$ veral in die tweede helfte van die negentigerjare momentum gekry. In 2000, weer vir die eerste keer, is 'n lang gekoesterde Helpmekaar-mikpunt van 100 nuwe lenings per jaar gebreek, met 117 nuwe lenings wat in daardie jaar toegeken is. ${ }^{173}$ Teen 2007 is die 200kerf bereik met die toekenning van 210 nuwe lenings ${ }^{174}$ wat die totale aantal Helpmekaarlenings onder administrasie op 963 (teenoor die 524 van 2001) te staan gebring het. ${ }^{175}$ In 2011 is 'n piek bereik met die toekenning van 298 lenings ter waarde van R12 732500 wat die totale aantal Helpmekaar-lenings onder administrasie op 1439 te staan gebring het. (Dit was benewens die 334 lenings wat hulle ook namens buitefondse geadministreer het.) $)^{176}$

Dié hoogtepunt was, benewens die groeiende vraag na lenings vir n eerste tersiêre kwalifikasie, die gevolg van 'n toenemende vraag na addisionele lenings vir nagraadse studies na afloop van die voltooiing van 'n eerste graad. $\mathrm{Na}$ 'n versoek van die bestuurder in 2004 vir 'n wysiging in die bestaande beleid, waarvolgens lenings vir nagraadse studies slegs toegeken is indien dit 'n integrale deel van die graad vorm, soos in die geval van BRek, 'n onderwysdiploma na 'n graad en vir LLB na voorgraadse studie, het die direksie dit goedgekeur dat addisionele lenings in uitsonderlike gevalle aan bestaande Helpmekaarstudente vir Honneurs of 'n MA-graad toegeken kon word. ${ }^{177}$ In 2008 is 19 sodanige addisionele lenings toegeken waarna dit tot 'n hoogtepunt van 76 in 2011 gestyg het. ${ }^{178}$ 'n Verwagte toekomstige tekort aan fondse het in 2011 tot 'n besluit gelei dat (behalwe vir “sekere 'beroepsgerigte' kursusse waarvoor 'n nagraadse kwalifikasie onontbeerlik is vir die

171 (HSA) HS, Notuleboek (9 Mrt 2007-25 Mrt 2014), 25 Mrt 2014, HS jaarvergadering, Finkom verslag, 19 Mrt 2014, gp; 25 Mrt 2014, HS jaarvergadering, (Bylaag A: Voorsittersverslag, 25 Mrt 2014, gp).

172 (HSA) HS, Notuleboek (16 Feb 1973-10 Sep 1993), 22 Feb 1991, HS jaarvergadering, 112.

173 (HSA) HS, Notuleboek (13 Okt 1993-18 Sep 2003), 2 Mrt 2001, HS jaarvergadering, Bestuurder verslag, 2 Mrt 2001, gp.

174 (HSA) HS, Notuleboek (9 Mrt 2007-25 Mrt 2014), 14 Mrt 2008, HS jaarvergadering, gp, (Bylaag A: Bestuurder verslag, 7 Mrt 2008, gp).

175 (HSA) HS, Notuleboek (9 Mrt 2007-25 Mrt 2014), 27 Mrt 2009, HS jaarvergadering, gp, (Bylaag C: Finkom verslag, 16 Mrt 2009).

176 (HSA) HS, Notuleboek (9 Mrt 2007-25 Mrt 2014), 25 Mrt 2011, HS jaarvergadering, 2, (Bylaag B: Bestuurder verslag, 25 Mrt 2011, 1).

177 (HSA) HS, Notuleboek (4 Des 2003-18 Jun 2014), 2 Des 2004, HS Direksie, 6; 3 Mrt 2005, HS jaarvergadering, 5, Beursekomitee verslag, 28 Jun 2005.

178 (HSA) HS, Notuleboek 9 Mrt 2007-25 Mrt 2014, 23 Mrt 2012, HS jaarvergadering, 2, (Bylaag B: Bestuurder verslag, 23 Mrt 2012, 1). 


\section{Die Kaapse Helpmekaar}

beoefening van 'n spesifieke beroep" ${ }^{179}$ ) lenings in beginsel nie vir nagraadse studie toegeken word nie. ${ }^{180}$ Dit het addisionele lenings tot ongeveer 50 per jaar laat daal, maar dit het 'n permanente deel van die jaarlikse leningstoekennings gebly. ${ }^{181}$

Hierdie groei in die aanvraag na lenings wat die totale aantal Helpmelaar-lenings onder administrasie van 366 in $1996^{182}$ na 'n hoogtepunt van 1439 in 2011 laat toeneem het, het plaasgevind, ten spyte van en waarskynlik ook, weens die groot toename in tersiêre studiekoste. Die kostetoename het die maksimum jaarlikse Helpmekaar-leningstoekenning laat styg van R17 000 in $1996^{183}$ tot R60 000 in 2014 vir die deursnee universiteitskursus. ${ }^{184}$ Behalwe vir die groeiende aanvraag na studiehulp was die Helpmekaar se gestelde doelwit, naamlik om minstens 75 persent van sy bates in studielenings te belê, waarskynlik die ander groot dryfveer van die groot groei in sy leningsboek. Terwyl slegs 39 persent van sy bates in 2003 in lenings belê was, is die gestelde doelwit van 75 persent teen 2011 bereik toe 76 persent van sy bates in lenings belê is. ${ }^{185}$ Die doelwit wat bereik is het die Helpmekaar genoop tot 'n besinning oor die toekenning van lenings. Indien daar met die huidige 'stelsel' voorgegaan sou word, het kontantvloeiprojeksies op $n$ toekomstige tekort aan fondse gedui. ${ }^{186}$ $\mathrm{Na}$ aanleiding van 'n strategiese beplanningsessie in Augustus 2011 is besluit om die status quo, naamlik om 75 persent van Helpmekaar-fondse as beleggings in studielenings en 25 persent in aandele en kontant te hou, te handhaaf. ${ }^{187}$ Die implikasie van die besluit was dat die toekenning van nuwe lenings voortaan tot 'n spesifieke aanbevole jaarlikse bedrag beperk sou moes word om steeds in staat te wees om die reeds toegestane leningsverpligtinge te honoreer en die 25 persent beleggingsbuffer te behou. Die verwagting was dat bogenoemde benadering 'n grondige impak op die toekomstige toekenning van lenings sou uitoefen. ${ }^{188}$

179 (HSA) HS, Notuleboek (4 Des 2003-18 Jun 2014), 2 Sep 2011, HS Direksie, 2.

180 Ibid.

181 (HSA) HS, Notuleboek (9 Mrt 2007-25 Mrt 2014), 25 Mrt 2014, HS jaarvergadering, (Bylaag B: Bestuurder verslag, 25 Mrt 2014, 1-2).

182 (HSA) HS, Notuleboek (13 Okt 1993-18 Sep 2003), 20 Feb 1997, HS jaarvergadering, Voorsittersverslag, 29 Jan 1997.

(HSA) HS, Notuleboek (13 Okt 1993-18 Sep 2003), 5 Sep 1996, HS Trustees, gp.

(HSA) HS, Notuleboek (9 Mrt 2007-25 Mrt 2014), 25 Mrt 2014, HS jaarvergadering, (Bylaag B: Bestuurder verslag, 25 Mrt 2014, 2).

(HSA) HS, Notuleboek (9 Mrt 2007-25 Mrt 2014), 23 Mrt 2012, HS jaarvergadering, 2; 25 Mrt 2014 HS jaarvergadering, (Bylaag C: Finkom-verslag, 19 Mrt 2014, gp).

(HSA) HS, Notuleboek (4 Des 2003-18 Jun 2014), 2 Sep 201, HS Direksie, 2, (Bylaag A: Finkom-verslag).

(HSA) HS, Notuleboek (4 Des 2003-18 Jun 2014), 2 Sep 2011, HS Direksie, 3.

(HSA) HS, Notuleboek (4 Des 2003-18 Jun 2014), 25 Mrt 2011, HS Direksie, 3. 
'n Periode van dalende algemene rentekoerse het Helpmekaar-kontantvloei onder groot druk geplaas en jaarliks moes aandele verkoop word om in die aanvraag na lenings te voorsien. Terwyl die mikpunt van 75 persent nog nagejaag is, was daar beweegruimte om dit te doen - 'n posisie wat na 2011 verander het. Vanaf 2012 het die direksie dus 'n perk op die bedrag beskikbaar vir die toekenning van nuwe lenings gestel (ongeveer R9 miljoen vir 2012). ${ }^{189}$ Reeds voor die 75 persent bereik is, was daar aanduidings dat die toekenning van lenings vir eerste tersiêre kwalifikasies (in teenstelling met addisionele lenings vir nagraadse studie) afgeplat het. ${ }^{190}$ Die beperking op die jaarlikse beskikbare bedrag vir lenings het die tendens versterk wat die toekenning van nuwe lenings vir eerste tersiêre kwalifikasies van die hoogtepunt van 240 in 2009 tot 156 in 2014 laat afneem het. Die druk op beskikbare leningsfondse het die Helpmekaar genoop om skerper te fokus op die primêre doel van die Helpmekaar, naamlik om studente te help om n éérste tersiêre kwalifikasie te behaal (ten koste van addisionele lenings vir nagraadse studie). ${ }^{191}$

In sy 2012-Bestuursverslag het die bestuurder ook gewaarsku dat jaarlikse leningsbedrae per kursus nie onbeperk verhoog kan word nie aangesien die meeste afgestudeerdes wat die arbeidsmark betree (indien hy/sy 'n werk kry), (vind) dit uiters moeilik (vind) om die paaiemente op 'n lening van R150 000/R200 000 by te bring. ${ }^{192}$

Die waarskuwing en waarneming van die bestuurder was waarskynlik gebaseer op kommer oor die uitstaande skuld van afgestudeerdes sedert veral $2009^{193}$ en aanduidings dat daar 'n toename was in die kategorie van afgestudeerdes met agterstallige skuld van 90 dae en ouer. ${ }^{194}$ Teen September 2011 het dié kategorie ten spyte van 'n klein afname steeds die aansienlike bedrag van ongeveer R573 000 beloop. Die feit dat oorweging geskenk is aan die moontlikheid om van skuldinvorderaars, in plaas van die tradisionele skuldinvordering deur prokureurs, gebruik te maak en ook om met die ouditeure oor die afskryf van slegte skuld te raadpleeg, was verdere bevestiging van die probleem. ${ }^{195}$ Die Helpmekaar moes dus

189 (HSA) HS, Notuleboek (9 Mrt 2007-25 Mrt 2014), 23 Mrt 2012, HS jaarvergadering, 2, (Bylaag B: Bestuurder verslag, 23 Mrt 2012, 1).

190 (HSA) HS, Notuleboek (4 Des 2003-18 Jun 2014), 25 Mrt 2014, HS Direksie, 2.

191 (HSA) HS, Notuleboek (9 Mrt 2007-25 Mrt 2014), 23 Mrt 2012, HS jaarvergadering, 2.

192 (HSA) HS, Notuleboek (9 Mrt 2007-25 Mrt 2014), 23 Mrt 2012, HS jaarvergadering, 2, (Bylaag B: Bestuurder verslag, 23 Mrt 2012, 1-2).

193 (HSA) HS, Notuleboek (4 Des 2003-18 Jun 2014), 19 Jun 2009, HS Direksie, 2; 16 Sep 2009, HS Direksie.

194 (HSA) HS, Notuleboek (4 Des 2003-18 Jun 2014), 10 Jun 2011, HS Direksie, 2.

195 Ibid.; 2 Sep 2011, HS Direksie, 2, (Bylaag A: Finkom-verslag); 18 Nov 2011, HS Direksie, 1, (Bylaag C: Finkom-verslag, 18 Nov 2011). 


\section{Die Kaapse Helpmekaar}

'n gebrek aan leningsfondse balanseer met pogings om die finansiële druk op studente te verlig. Om die druk op die Helpmekaar se kontantvloei te verlig is rentekoerse dus vir nuwe lenings vanaf 2013 verhoog en die maksimum terugbetalingstermyn tot sewe jaar ingekort met die opsie van 'n verlaagde aanvangspaaiement vir langer kursusse (vyf-tot-ses jaar) om studente met 'n groter skuldlas tegemoet te kom. ${ }^{196}$

Teen dié agtergrond het die direksie na aanleiding van 'n strategiese beplanning in 2013 besluit om met die oog op besinning oor die toekomsige rol van die Helpmekaar 'n marknavorsingsprojek te loods om meer inligting oor hul kliënte-teikengroep te bekom. Met die projek wou hulle inligting inwin ten opsigte van aspekte soos die behoefte na studiehulp, vermoë om studielenings terug te betaal en die mate waarin potensiële kliënte bewus was van die hulp wat die Helpmekaar kon verskaf. ${ }^{197}$

Te midde van die proses van besinning oor die toekoms het die voorsitter, ds J van der Westhuyzen, in Junie 2014 aangekondig dat hy as voorsitter uittree en dat 'n nuwe voorsitter by die September-vergadering aangewys moes word. ${ }^{198}$ Sy uittrede was presies 50 jaar nadat hy op 1 April 1964 sy eerste Helpmekaarkongres in Port Elizabeth bygewoon het en as verteenwoordiger van Cradock en Sirkel $4^{199}$ tot lid van die hoofbestuur verkies is. ${ }^{200}$ Dit was ook 20 jaar nadat hy in 1994 tot voorsitter van die Helpmekaar verkies is. Van der Westhuyzen se voorsitterskap het dus grootliks saamgeval met die korporatisering van die Helpmekaar waartydens finaal afskeid geneem is van die oorblyfsels van die praktyke wat uit die Helpmekaar se kongres-era gedateer het. As voorsitter het hy 'n dualistiese rol, naamlik dié van behoudende gewete sowel as van progessiewe denker, vertolk. Hierdie dualisme is reeds tydens sy eerste Helpmekaarkongres in 1964 geillustreer toe hy enersyds voorgestel het dat lenings rentevry aan studente tydens hul studiejare en teen drie persent na voltooiing van studie toegeken moes word. Dit was 'n stap wat tot voordeel van die studente sou wees, maar wat die Helpmekaar se groei ernstig sou belemmer.

196 (HSA) HS, Notuleboek (9 Mrt 2007-25 Mrt 2014), 27 Mrt 2013, HS jaarvergadering, 2.

197 (HSA) HS, Notuleboek (4 Des 2003-18 Jun 2014), 20 Nov 2013, HS Direksie, 3; (HSA) HS, Notuleboek (9 Mrt 2007-25 Mrt 2014), 25 Mrt 2014, HS jaarvergadering, (Bylaag A: Voorsittersverslag, 25 Mrt 2014, gp); (HSA) HS, Notuleboek (4 Des 2003-18 Jun 2014), 25 Mrt 2014, HS Direksie, 3.

(HSA) HS, Notuleboek (4 Des 2003-18 Jun 2014), 18 Jun 2014, HS Direksie, 3.

199 Sirkel 4 het ingesluit: Cradock, Steynsburg, Burgersdorp, Aliwal-Noord, Molteno, Dordrecht, Middelburg, Lady Grey, Hofmeyr en Indwe.

200 (HSA) HVKP, Notuleboek, 1 Apr 1964, Kongres, gp. 


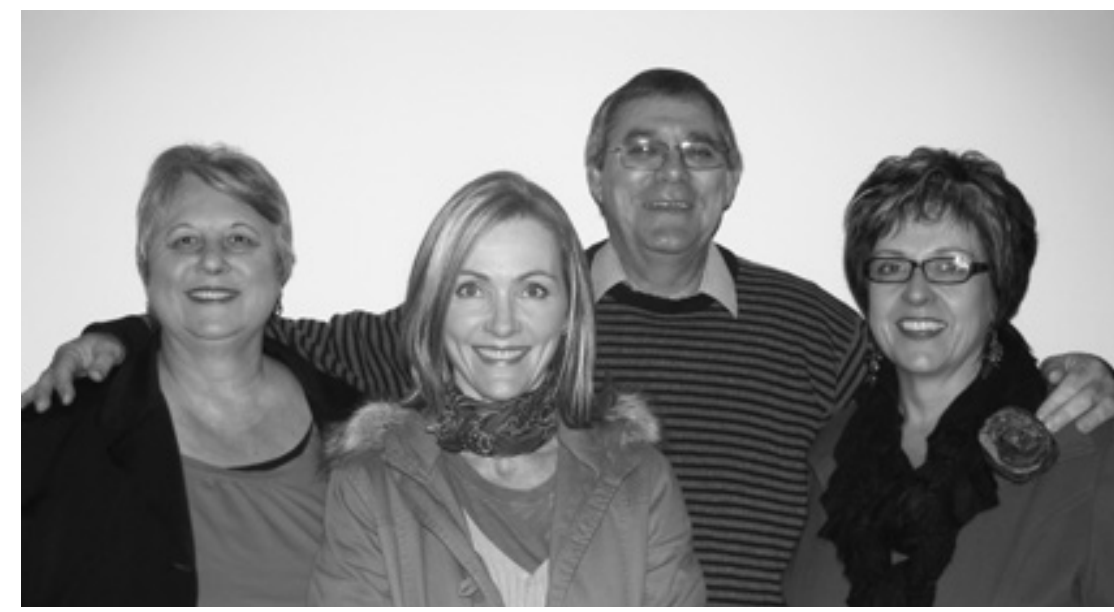

Helpmekaar Studiefonds kantoorpersoneel, 2016. Van links: mev Nita van Zyl, mev Retha Geldenhuys, mnr Barry van der Merwe (bestuurder), mev Wilma Steenkamp. Nita van Zyl, wat sedert 1980 in die Helpmekaar se diens is, was die konstante faktor terwyl vier bestuurders gekom en gegaan het.

Hy het ook die progressiewe voorstel, naamlik dat die oorspronkike aanvangskapitaal van die Helpmekaar ook vir studielenings aangewend moes word en nie as "reserwe" gehou moes word terwyl lenings aan studente geweier word nie, gesteun. ${ }^{201}$ Die gemene deler in beide die voorstelle was dat dit die studente tot voordeel sou strek. Dit is dan ook in dié verband dat Van der Westhuyzen te midde van korporatisering die gewete van die Helpmekaar sou bly. Hy sou telkens die behoudende sowel as die progressiewe aan die histories gewortelde filantropiese bestaansdoel van die Helpmekaar: opheffing deur onderwys - tot die beste voordeel van Afrikaanssprekende studente, toets. Dit was 'n vaandel wat deur die Helpmekaar-direksie onder leiding van die nuutverkose voorsitter, dr Ebbe Dommisse, en ondervoorsitter, dr Carel Stander, die volgende eeu ingedra sou word. ${ }^{202}$ 


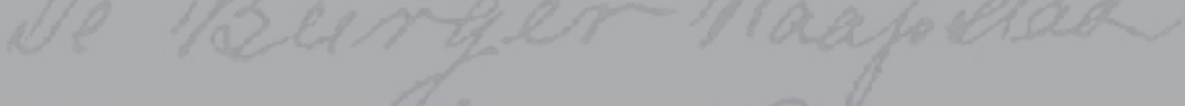

Uleper afeer

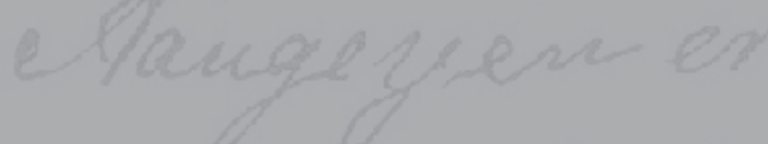

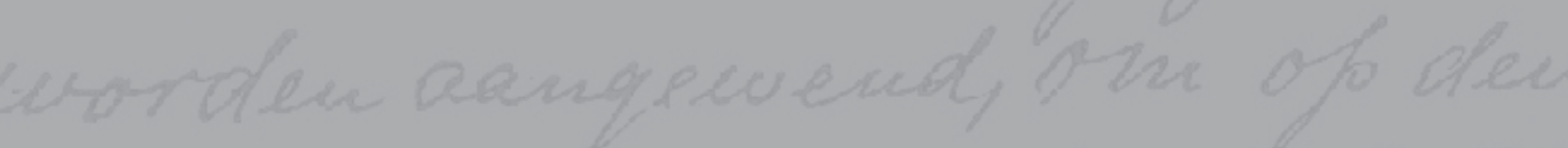

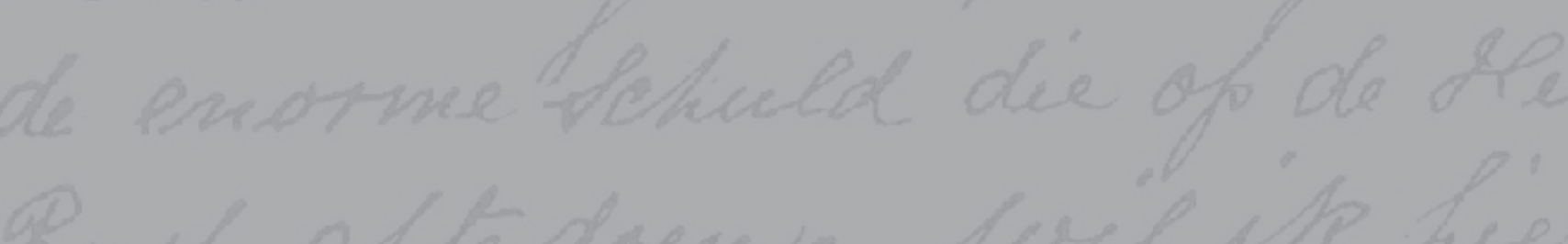

aple abeve were whe hee

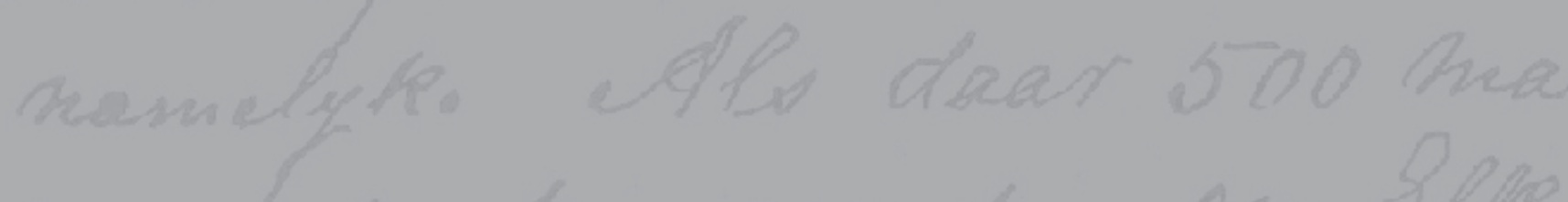

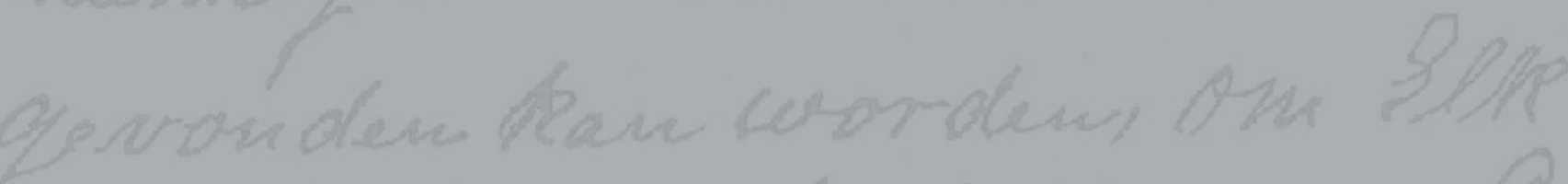

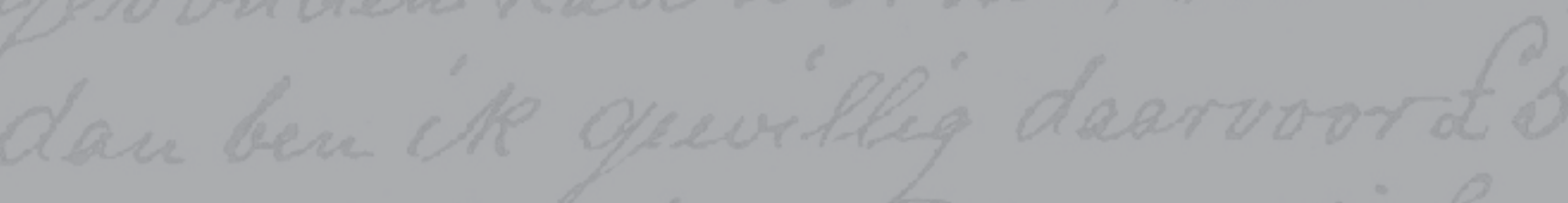

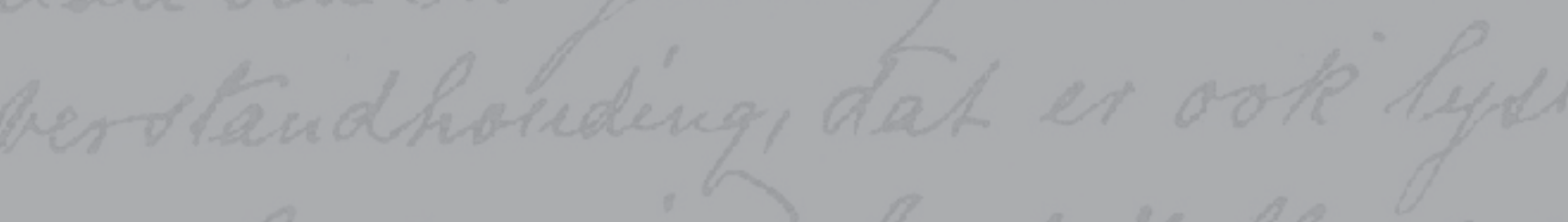

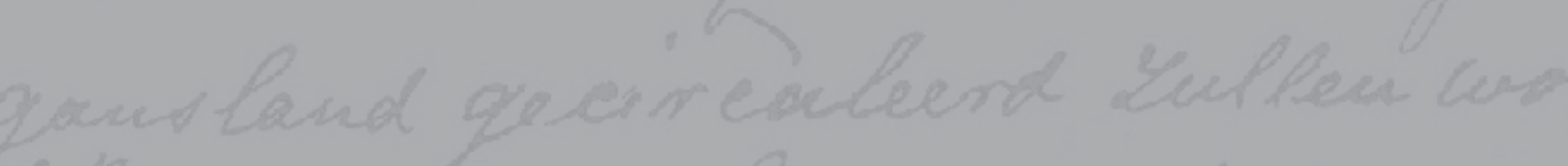

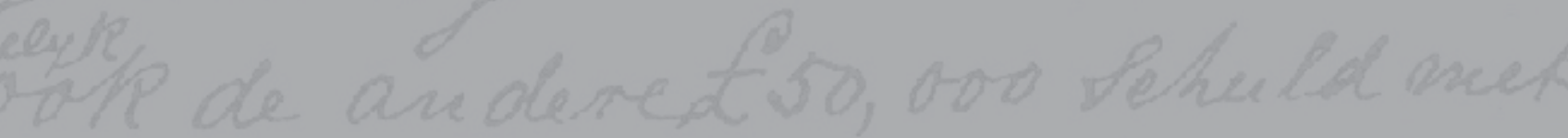
DADELINGE den dat arowit

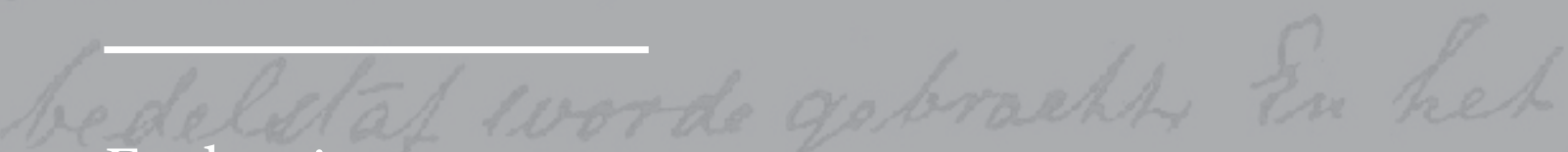
Evaluering

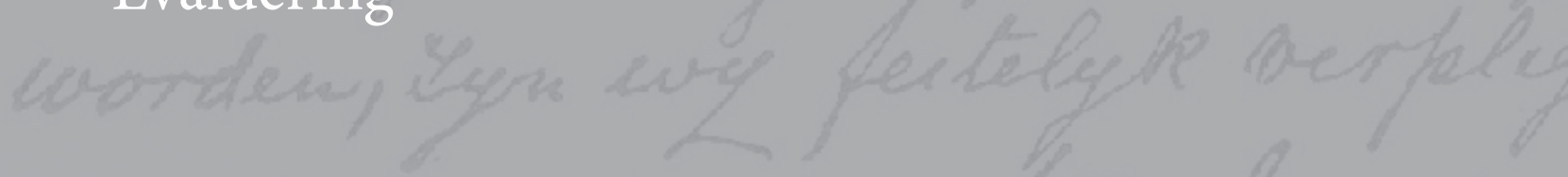




\section{HOOFSTUK TWAALF}

\section{BEMIDDELAAR IN AFRIKANER OPHEFFING, SELFRESPEK EN RESPEKTABILITEIT: 'N BALANSSTAAT}

In enige poging om die invloed of impak van die Kaapse Helpmekaar te bepaal, moet daar begin word by die grondslag en patroon of templaat wat deur die breër Helpmekaarbeweging tydens sy storm-en-drangjare (1915-1920) neergelê is. In hierdie vestigingsjare is 'n Helpmekaar narratief en DNS vasgelê waaraan die Kaapse Helpmekaar ten spyte van veranderende kontekste oor tyd moeilik sou ontkom. Daar was 'n noue verweefdheid met die lotgevalle en doelstellings van mede-Afrikaners, in die besonder nasionaalgesinde Afrikaners, en 'n verantwoordelikheidsgevoel het teenoor hierdie mede-Afrikaner-volksgenote gemanifesteer in 'n gedrewe idealisme. Daar was ook 'n geloof in selfopheffing deur volgehoue inspanning, spesifiek deur middel van onderwys en opvoeding. As deel van die breër Helpmekaarbeweging het dit in die ontstaans- en stigtingsjare 'n prominensie in die openbare oog beklee waardeur die beweging op verskeie terreine van die Afrikanersamelewing 'n invloed in ooreenstemming met bogenoemde DNS uitgeoefen het.

Na die aanvanklike hoogty het die Kaapse Helpmekaar in sy Helpmekaarvereniging van die Kaapprovinsie-gedaante deel van die bolwerk van Afrikanerorganisasies geword. Dit het rondom Afrikaner-etnisiteit gemobiliseer en as uitingsvorm van Afrikaner-nasionalisme gemanifesteer. In dié hoedanigheid het die Helpmekaar ook 'n impak uitgeoefen wat hoofsaaklik gesentreer het rondom die implementering van die ideale en doelstellings wat in die jare van hoogty gestel is. Hierdie tweede fase is die kongresfase van die Helpmekaar genoem en het breedweg in die middel sestigerjare met die ontbinding van die kongres as beheerliggaam van die Vereniging ten einde geloop.

'n Derde fase waarin die Helpmekaar se impak beoordeel kan word, is wat as sy "sakefase" beskryf kan word. Dit was 'n fase wat al in 1942 met die stigting van die B-fonds begin het, maar eers met amalgamasie in 1966 onder die vaandel van die HS werklik 'n dominante identiteit geword het. Hoewel dit in dié fase as 'n studenteleningsbank gefunksioneer het met 'n suiwerder kwantifiseerbare impak is dit steeds hoofsaaklik deur sy oorspronklike DNS gerig - 'n DNS wat deur die veranderende kontekste vanaf die sestigerjare tot by die 
eeuwending, ten spyte van eksterne druk vir verandering en interne besinning, hoofsaaklik ten diepste en in wese dieselfde sou bly. Die impak en bydrae van die Kaapse Helpmekaar oor die drie fases kom vervolgens onder die loep.

\section{STORM-EN-DRANGJARE, 1915-1920}

\section{Politiek}

"Het werd gevoeld dat men eerst een echt Nationalist was als men ook daarbij een Saamwerk man was, en spreker's gulden raad aan een ieder was 'wordt lid van de Saamwerk, want voor de toekomst was dit de weg om de erkentelikheid en vertrouwen van het volk te verwerven."

"Brief van Ds Viljoen, Bredasdorp ter tafel gelegd. Hij vraagt waarom ontvangsten ook niet in 'Ons Land' erkend worden en waarom er geen Z.A.P.-man op het Bestuur dient. Sekr gelast te antwoorden dat de Helpmekaar niets met de party-politiek te maken had. Er werd besloten ontvangsten ook in 'Ons Land' te erkennen."

Die Helpmekaarbeweging het 'n ekonomiese ontstaansrede gehad, naamlik om die rebelle van die Noord-Vrystaat en Wes-Transvaal van finansiële ondergang te red. Die vraag ontstaan hoe dit moontlik was vir 'n beweging met 'n ekonomiese ontstaansrede om in so 'n mate in die partypolitiek betrokke te raak dat dit 'n beduidende politieke invloed kon uitoefen. 'n Antwoord op die vraag lê hoofsaaklik opgesluit in drie faktore.

Eerstens het die aard van die Helpmekaar se hulp 'n bydrae gelewer. Aangesien die Rebellie 'n hoogs emosionele politieke kwessie was wat die verdeeldheid in Afrikanergeledere blootgelê en ook verskerp het, het die Helpmekaarbeweging by sy ontstaan reeds die potensiaal besit om, indien sy pogings nie met groot omsigtigheid gehanteer sou word nie die Helpmekaar by die politiek sou betrokke raak.

'n Tweede faktor wat bygedra het om die Helpmekaarbeweging by die politiek te betrek, was die reaksie van die NP en sy ondersteuners ten opsigte van die Helpmekaar. Die NP was een van die eerste organisasies wat die noodsaaklikheid besef het om die rebelle finansieel by te staan. Persone wat leiding geneem het in die totstandkoming en uitbreiding van die Helpmekaar was feitlik uitsluitlik Nasionaliste. Die sentrale besture van die onderskeie provinsiale Helpmekaarverenigings het feitlik sonder uitsondering bestaan uit ondersteuners

1 De Burger, 4 Sep 1915, Vrouwen Saamwerk Bazaar te Senekal; Het Volksblad, 7 Sep 1915, Helpmekaar Vereniging Senekal.

2 (HSA) HVKP, Notuleboek (3 Jul 1916-20 Mei 1919), Sentrale Bestuur, 9 Des 1916, 30. 
van die NP. Nasionaliste het hulle in groot getalle as lede by die Helpmekaar aangesluit - in so 'n mate dat Helpmekaar-bedrywighede feitlik totaal deur hulle oorheers is. Die Helpmekaar is deur die Nasionaliste aangegryp as 'n geleentheid om hul gevoel vir hul volksgenote en hul nasionalisme te illustreer en uit te leef. Soos die Helpmekaarbeweging gegroei het, het dit noodsaaklik geword vir alle Nasionaliste om die beweging te steun, omdat dit vir hulle 'n bewys geword het van ware Afrikanerskap ${ }^{3}$ en by implikasie ook van ware Nasionalis-wees. Sommige Nasionaliste het die rebelleskuld gesien as die prys wat betaal moes word vir die nasionale ontwaking wat deur die Rebellie onder die Afrikaners gestimuleer is. Om te kon deel in die nasionale ontwaking moes elke Nasionalis dus 'n deel van die rebelleskuld op homself neem. ${ }^{4}$ Deur die Helpmekaar te ondersteun kon Nasionaliste hul solidariteit met die rebelle en hul afkeer van die regering en sy beleid, aantoon. As gevolg van hierdie benadering van baie nasionaalgesinde Afrikaners ten opsigte van die Helpmekaar, het daar by hulle 'n onvermoë en "onwilligheid" bestaan om onderskeid te tref tussen hul partypolitieke affiliasie en -bedrywighede en hul Helpmekaarlidmaatskap en -deelname.

Nasionaliste het dus met groot ywer as ondersteuners van die Helpmekaar aan die beweging se bedrywighede deelgeneem. Die Helpmekaar se basaars, konserte, vendusies en vergaderings het deurgaans 'n nasionale kleur vertoon, wat in intensiteit van plek tot plek gewissel het. ${ }^{5}$ Basaars het groot belangstelling gaande gemaak en is gewoonlik deur persone van omliggende distrikte bygewoon. ${ }^{6}$ Belangstelling is verder gaande gemaak deurdat die organiseerders "nasionale voormanne", sonder uitsondering leiers of ondersteuners van die NP, genooi het om sulke geleenthede by te woon en te open. Leiers soos generaal Hertzog, dr DF Malan en NP-parlementslede is met groot entoesiasme en optogte ontvang. ${ }^{7}$ Daar is talle voorbeelde waar sulke besoeke van NP-leiers saamgeval het met politieke aktiwiteite van die party. Soms is 'n basaar of konsert geopen deur 'n polities gekleurde toespraak of is so 'n toespraak gehou kort voor of net na 'n Helpmekaarfunksie. Tydens die toesprake is die regering gewoonlik

(VKA) Helpmekaar van die Oranje-Vrystaat: Helpmekaar Korrespondensie 1916-1919, NC Havenga - Manne en Broeders, Mede Afrikaners, 20 Apr 1915; Het Volksblad, 2 Mrt 1917, Meer Hulp vir die Helpmekaar Vereis.

4 De Burger, 24 Sep 1915, Steun uw Broeders in het Noorden; De Burger, 18 Nov 1915, Korrespondenties De Nood in de OVS is hoog!

5 De Burger, 5 Okt 1915, Ladismith; De Burger, 3 Aug 1915, Dewetsdorp; Het Volksblad, 23 Jul 1915 , Bethulie Helpmekaar; De Burger, 3 Feb 1916, Helpmekaar te Malmesbury.

6 De Burger, 23 Mrt 1916, Helpmekaar; De Burger, 19 Mrt 1917, Stellenbosch.

7 De Burger, 6 Des 1915, Stellenbosch; Het Volksblad, 25 Jun 1915, Dist Ladybrand; Het Volksblad, 18 Jun 1915, Ladybrand in feesdos; De Burger, 26 Feb 1917, Helpmekaar te Wellington. 


\section{Die Kaapse Helpmekaar}

gekritiseer en NP-alternatiewe daarteenoor gestel. ${ }^{8}$ 'n Goeie voorbeeld in dié verband was tydens die Helpmekaarbasaar op Theunissen in Julie 1915. C Fichardt, 'n Volksraadslid van die NP, het by dié geleentheid saam met CTM Wilcocks, die NP-kandidaat vir die betrokke kiesafdeling, opgetree. Hy het die stelling gemaak dat dit tyd was dat die Afrikanervolk moes mobiliseer en toe voortgegaan:

"Hoe moeten we optrekken? Zorg dat allen bij de stembus komen. Maakt de Nationale Partij groot en sterk. Een ieder drage zijne bij en werpt die Botha Regering er uit ... Ons doel is om onze vrienden te helpen. Helpmekaar om onze Nationale Partij groot te maken. Helpmekaar om onze schulden te betalen. Helpmekaar om ou Kokkie in te brengen, die Nationale beginsels heft. Hij heeft alles voor zijn volk opgeofferd."

Hierdie Helpmekaarfunksies het ook aan nasionaalgesindes die geleentheid gebied om meer persoonlike kontak te maak met hul leiers op 'n vlak wat normaalweg nie moontlik was nie. ${ }^{10}$

Die basaars en konserte se inhoud het in baie gevalle ook nie twyfel gelaat oor waar die simpatie van die mense gelê het nie. Lapelknopies en foto's met die gesigte van rebelle en Nasionalisteleiers daarop is vertoon of te koop aangebied, ${ }^{11}$ terwyl poppe wat rebelle voorgestel het reuse-pryse behaal het teenoor 'khakhi'-poppe wat vir net 'n paar sjielings verkoop is. ${ }^{12}$ Op konserte is gedigte oor Jopie Fourie, ${ }^{13}$ en sangstukke soos 'Helpmekaar,', 'Mama ik wil 'n Afrikaner, 'n regte Herzogiet hê!', ${ }^{5}$ 'Slagtersnek' en 'Piet Retief'16 gehoor.

8 De Burger, 4 Sep 1915, Wolmaransstad; De Burger, 4 Okt 1915, de Potchefstroom Zetel; De Burger, 24 Okt 1916, Groot Helpmekaarfeest.

9 Het Volksblad, 3 Aug 1915, Theunissen OVS.

10 De Burger, 20 Mrt 1916, Genl Hertzog te Montagu; Het Volksblad, 23 Jul 1915, Bethulie Helpmekaar.

11 Het Volksblad, 20 Jul 1915, Bloemfontein; De Burger, 5 Okt 1915, Ladismith.

12 Het Volksblad, 23 Jul 2015, Helpmekaar en NP te Marquard, OVS; Het Volksblad, 7 Sep 191, Helpmekaar Vereniging Senekal; De Burger, 14 Sep 1915, Bethlehem.

13 Het Volksblad, 31 Aug 1915, Helpmekaar Verenigingen; Het Volksblad, 18 Feb 1916, Helpmekaar Vereniging.

14 Het Volksblad, 27 Nov 1917, Warden.

15 Het Volksbald, 23 Jul 1915, Bethulie Helpmekaar.

16 De Burger, 16 Aug 1916, Helpmekaar Konsert. 
"Leef voort, o, Afrikaner skaar,

Sing vrolik, al te gaar!

Ons nasionaliteit

Stem elk tot dankbaarheid:

'n Jubeltoon klink wijd en sijd: -

Dus, voorwaarts, voorwaarts, immer voort!

Elk volksdeel word bewaard;

Ons Help-mekaar met daad en woord:

Leef voort, o, huis en haard!

Maar naas die jubeltoon, ' $n$ traan,

'n Stem: "Help ons vergaan!"

' $n$ Woltemade swom;

En menig held riep: "Kom!"

Sal ons dan staan, of selfs verstom?

Van edel afkoms durf ons praat,

Dit is ons ruggeraat!

En ruggeraat is krag:

Met eendrag, dan, en mag,

Dwing ons van ieder af: ontsag!

Sulk vorst'lik nasaat mag nie dood

Daarom help ons in nood.

"God wil het!" roep ons luid,

Saam met die oûes uit:

Niks sal puur Helpmekaar ooit stuit!"

(Die Burger, 18 Okt 1917, “Ons Volksgebed" en "Helpmekaar")

ML de Villiers, die persoon wat Die Stem getoonset het,

het ook 'n Helpmekaarlied vir 10 November 1917 geskryf

Amptelik het die NP ook nooit geskroom om die Helpmekaar te ondersteun nie. In die parlement het dié party die saak van die Helpmekaar verdedig ${ }^{17}$ en met die groot Helpmekaarinsamelings van 1917 is die amptelike partymasjinerie ook ingespan om geld

17 De Volkstem, 21 Mrt 1916, De Volksraad; Cape Times, 17 Mar 1916, Nationalists and Government. 
vir die Helpmekaar in te samel. ${ }^{18}$ As 'n Afrikanervolksaak het die NP hom ten volle met die doelstellings van die Helpmekaar vereenselwig.

Die Helpmekaar het dus, sonder dat dit doelbewus so beplan is, die geleentheid geskep vir die politieke stimulasie van nasionaalgesinde Afrikaners. Die honderde byeenkomste landswyd het geleenthede geskep vir Nasionaliste om saam te kom en saam te werk vir'n gemeenskaplike doel, waardeur die eenheid en eensgesindheid onder hulle versterk is. ${ }^{19}$ In dié verband het 'n korrespondent van Middelburg in die Kaapprovinsie as volg geskryf:

"Ik ken geen machtiger middel tot samensnoering van het afrikaanse volk dan deze basaars. Wat ten kwade werd bedoeld, wordt ten goede gekeerd. Door de nood gedreven komen wij dichter tot elkaar. Tussen hen die helpen, komt een nauwe band. En tussen hen, die helpen en die geholpen worden, komt een band, die niet licht verbroken zal worden. Dit is in mijn ogen de grote betekenis van onze Helpmekaar bazaars." ${ }^{20}$

Die byeenkomste het verder vir nasionaalgesinde leiers die geleentheid gebied om groot groepe volgelinge op een slag te bereik. Die kontak wat plaasgevind het, was in die eerste plek bedoel om die saak van die Helpmekaar te bevorder. Die onderlinge politieke gesprekke wat by sulke geleenthede sekerlik moes plaasvind het, kon slegs die NP se saak bevorder. Die inspirasie wat van sulke byeenkomste na die teenwoordiges uitgegaan het, was dan ook besonder sterk. ${ }^{21} \mathrm{Hul}$ werk vir die Helpmekaar het Nasionaliste saamgesnoer en 'n eenheid gebring wat voorheen nog grootliks afwesig was. Die sukses waartoe hulle in staat was indien hulle sou saamstaan, soos deur hul deelname aan die Helpmekaar aan hulle geillustreer is, het hul selfvertroue gegee en hul selfbeeld verbeter. Die geloof het ontstaan dat hulle hul sukses op Helpmekaargebied ook sou kon oordra en op politieke gebied herhaal.

Die wyse waarop die nasionaalgesinde Afrikaners die Helpmekaarbeweging beleef het, het die beeld van 'n sterk assosiasie tussen die NP en die Helpmekaar geprojekteer. Dit het veral by die NP se opposisie gelei tot die gevolgtrekking dat dié party die Helpmekaar tot sy eie voordeel misbruik het.

'n Laaste faktor wat bygedra het tot die verpolitisering van die Helpmekaarbeweging was die houding van die regering en die SAP teenoor die beweging. Dit was vir die regering en

18 Het Volksblad, 5 Okt 1917, Derde Kongres van de Vrijstaatse Nasionale Partij.

19 Het Volksblad, 10 Aug 1915, Helpmekaar Verenigingen; De Burger, 5 Okt 1915, Ladismith; De Burger, 12 Nov 1915, Caledon.

20 De Burger, 29 Jan 1916, Middelburg, KP.

21 De Burger, 3 Mrt 1916, Hopefield Helpmekaar; Het Volksblad, 23 Jul 1915, Bethulie Helpmekaar; De Burger, 6 Mrt 1916, Rouxville. 
die SAP uit die aard van die saak besonder moeilik om enige optrede ten gunste van die Helpmekaar te ondersteun. Ten spyte hiervan was die regering die basiese beginsels van die Helpmekaarbeweging goedgesind. Die praktiese ervaring wat die regering en SAP egter van die Helpmekaar opgedoen het, het aan hom genoeg gronde verskaf om 'n argument op te bou dat die Helpmekaar 'n politieke beweging was wat deur die NP tot sy eie voordeel gekaap is. Die SAP se ervaring van die Helpmekaar het hoofsaaklik gespruit uit die wyse waarop die nasionaliste die Helpmekaar beleef het. Die nasionaalgesinde toesprake, aktiwiteite en gees van die Helpmekaarbyeenkomste, was vir die SAP voldoende bewys dat die NP die Helpmekaar as 'n politieke hulpmiddel ingespan het. ${ }^{22}$

Die SAP kon homself nooit daartoe bring om die Helpmekaar amptelik te steun nie. Op partykongresse is die Helpmekaar as 'n politieke organisasie uitgesonder en die amptelike standpunt van die party was aanvanklik dat die rebelle gehelp kon word, maar dat die partylede nie as lede by die beweging moes aansluit nie. ${ }^{23}$ Met die Helpmekaardagoproep van 1917 is besluit dat die party nie aktief sou deelneem aan die Helpmekaar nie, maar dat dit aan die diskresie van individuele lede oorgelaat sou word om na gelang van hul eie gewete te handel. ${ }^{24}$

Die amptelike standpunt van die SAP ten opsigte van die Helpmekaar het nie die goedkeuring van al sy ondersteuners weggedra nie. SAP-ondersteuners se reaksie ten opsigte van die Helpmekaar was hoofsaaklik drieledig van aard, wat die party ten opsigte van dié saak in drie groepe verdeel het.

Daar was die groep wat as sterk ondersteuners van die regering en die SAP die amptelike standpunt van laasgenoemde party ondersteun het. Hulle wou niks met die Helpmekaar te doen hê nie, was nie bereid om geldelike bydraes te mak nie en het die beweging as politiek afgemaak. ${ }^{25}$ Die gevoel van dié groep is goed verwoord deur 'n SAP-ondersteuner van Caledon:

"Het is duidelik dat zolang de Helpmekaar een politieke beweging blijft, ten grondslag hebbende het veredelen van opstand en rebellie, gepaard met minachting en swartsmering

22 De Volkstem, 28 Apr 1916, Genl Botha en minister De Wet over de Politieke Situasie; De Volkstem, 2 Okt 1917, ZAP Kongres.

23 De Volkstem, 28 Apr 1916, Genl Botha en minister De Wet over de Politieke Situasie.

24 De Volkstem, 2 Okt 1917, ZAP Kongres; Ons Land, 4 Okt 1917, Vierde ZAP Kongres.

25 Ons Land, 27 Sep 1917, De Helpmekaar; Ons Land, 13 Okt 1917, Korrespondenties. De Helpmekaar Dag. 


\section{Die Kaapse Helpmekaar}

van mede-afrikaners, net zolang zal het onmogelik zijn voor enig zelfrespekterend ZA partij-man met die beweging mede te werken, ..." ${ }^{26}$

'n Middelgroep was wel bereid om, ten spyte van die feit dat hulle nie die rebelle se optrede goedgekeur het nie, geldelike bydraes tot die Helpmekaar te maak. ${ }^{27}$ Onder dié groep was daar selfs 'n SAP Volksraadslid, JH Schoeman, asook 'n toekomstige SAP Volksraadslid, dr JA Raubenheimer, ${ }^{28}$ wat elk 'n bydrae tot die $£ 100$-fonds gemaak het. ${ }^{29}$

'n Derde groep was die SAP-ondersteuners wat aktief aan Helpmekaarbedrywighede deelgeneem het en in baie gevalle ook lidmaatskap van die beweging verkry het. ${ }^{30}$ Vanuit die laaste twee groepe, maar veral vanuit die derde aktiewe groep, het die persone gekom wat geklassifiseer kon word deur die term "Nasionale Sappe". Die groep het hulle vereenselwig met die Helpmekaar omdat hulle dit as 'n Afrikanervolksaak beskou het waardeur medeAfrikaners gehelp kon word, en dit vir hulle groter gewig gedra het as hul lojaliteit aan partybesluite. By Helpmekaarbyeenkomste is die "Nasionale Sappe" blootgestel aan die nasionale gees, toesprake en sienswyses. Die moontlike invloed wat dié blootstelling op hul politieke oriëntasie kon hê, was waarskynlik die partyleiding van die SAP se grootste bekommernis ten opsigte van die Helpmekaar en ook die grondliggende rede vir hul houding teenoor die beweging.

Dit is baie moeilik om die omvang van die laaste twee groepe in die SAP te bepaal. Op 'n SAP-kongres in 1917 het een van die afgevaardigdes beweer dat die meeste SAP-lede die Helpmekaar gesteun het. ${ }^{31}$ Hierteenoor is generaal Louis Botha deur De Burger daarvan beskuldig dat hy deur sy beleid teenoor die Helpmekaar duisende Afrikaners van die SAP daarvan weerhou het om deel te neem aan die beweging. ${ }^{32}$ 'n Bestudering van die bywoning van Helpmekaarbyeenkomste dui daarop dat, hoewel SAP-ondersteuners in baie gevalle in 'n mindere of meerdere mate bygedra het of teenwoordig was by die byeenkomste, hulle altyd verreweg in die minderheid was in vergelyking met die Nasionaliste. Wat beslis waar was, was dat steun vanuit SAP-geledere vir die Helpmekaar beduidend genoeg was om in

\footnotetext{
26 Ons Land, 11 Sep 1917, Helpmekaar-vergadering te Caledon.

27 De Volkstem, 26 Feb 1915, Vredefort; De Burger, 7 Mrt 1916, Colesberg.

28 Parlementêre Register 1910-1961, 110, 113.

29 JD Kestell, Helpmekaar Gedenkboek, 241, 247.

30 De Burger, 16 Mrt 1916, Helpmekaar; De Burger, 3 Jan 1917, Adv Conradie te Prins Alfred Hamlet; (KAB) Aanwins 1469 HVKP-versameling, no 2, Ontvange Briewe 1917, Gert Jordaan-mev H Roux, 3 Sep 1917.

31 De Volkstem, 2 Okt 1917, ZAP Kongres.

32 De Burger, 31 Okt 2016, Hoofartikel.
} 
die lig van dié party se standpunt dat die Helpmekaar 'n hulpmiddel van die NP was, 'n bron van kommer vir die partyleiding was. Die kommer blyk ook uit hul reaksie teenoor die Helpmekaar.

Die Helpmekaarbeweging het, ten spyte van sy ekonomiese ontstaansrede, hom hoofsaaklik as gevolg van genoemde drie faktore midde in die partypolitieke arena van sy tyd bevind. Wat was die amptelike standpunt van die Helpmekaarbeweging ten opsigte van politieke betrokkenheid? Met die ontstaan van die beweging was die vraag of die Helpmekaar politiekgeoriënteerd sou wees al dan nie nog nie so'n aktuele kwessie nie. Die twee Vrystaatse organisasies, naamlik die Sentrale Rebellefonds en die ANHV, het dus geen spesifieke verwysings na politiek in hul reëls gehad nie. Dit is egter duidelik gestel dat lidmaatskap en deelname vir alle persone oop was. Die basis vir die politiek se betrokkenheid by die Helpmekaar is veral gelê in die periode voor die 1915-verkiesing toe NP-ondersteuners en -kandidate Helpmekaarbyeenkomste gebruik het om hul verkiesingsveldtogte te bevorder. Met die stigting van die Helpmekaarverenigings in die Kaapprovinsie, Transvaal en Natal in 1916 en 1917 was die vraag oor die politieke betrokkenheid van die Helpmekaar die algemene gesprekspunt. Die verenigings het dus spesiale melding gemaak van die feit dat die Helpmekaar nie-polities van aard was, geen politieke party ondersteun het nie en bo partypolitiek verhewe was. ${ }^{33}$

Die Helpmekaarleiers het dit van die begin af duidelik gestel dat die beweging oop was vir alle Afrikaners sonder enige politieke voorkeure van hul kant af. Veral in die loop van 1915 het hul dié beginsel nie soveel beklemtoon nie en is dit selfs by geleentheid deur hulle verontagsaam. In Augustus 1915 het dr CP van der Merwe, die sekretaris van die Sentrale Rebellefonds, hom soos volg uitgelaat by 'n Helpmekaarbasaar wat hy op Senekal geopen het:

"Ofschoon de Saamwerk Verenigingen niet juis bedoeld waren politieke propaganda te maken, toch zouden zij de richting aangeven aan onze voormannen op politieke gebied ... Spreker maakte geen bezwaar dat de Saamwerk Verenigingen gebruikt warden door personen om politieke doeleinden te bereiken, hetwelk werkelik het geval was geweest, maar dan moesten die mannen niet later alleen tijd hebben voor de politiek en de Saamwerk vergeten. Het Centraal-bestuur had besloten te trachten alle Nationalisten te krijgen om leden te worden van onze Saamwerk Verenigingen. Het werd gevoeld dat men eerst een echt Nationalist was als men ook daarbij een Saamwerk man was, en spreker's

33 De Volkstem, 10 Mrt 1916, Helpmekaar-vergadering; De Burger, 9 Jun 1916, Koncept-Konstitutie; (KAB) HVKP-versameling no 1, Die Helpmekaar Vereniging in Transvaal-Statute, 6. 


\section{Die Kaapse Helpmekaar}

gulden raad aan een ieder was 'wordt lid van de Saamwerk', want voor de toekomst was dit de weg om de erkentelikheid en vertrouwen van het volk te verwerven." ${ }^{4}$

Met die besef in die tweede helfte van 1915 dat die Vrystaatse nasionaliste nie alleen die Helpmekaarskuld sou kon vereffen nie, tesame met die bedreiging van die indirekte eise van die begin van 1916 af het openbarings soos dié van dr CP van der Merwe grootliks uit die woordeskat van Helpmekaarleiers verdwyn. Daar is besef dat die Helpmekaar slegs die mas sou kon opkom as hulle die steun van so 'n groot groep Afrikaners as moontlik kon verkry.

Teen dié agtergrond is die nie-politieke aard van die Helpmekaar tot vervelens toe deur die sentrale besture en Helpmekaarleiers beklemtoon. Hullet het 'n daadwerklike poging aangewend om die Helpmekaar so ver as wat menslik moontlik was uit die politiek te hou. Oproepe om hulp is tot alle Afrikaners gedoen en besondere klem is gelê op die feit dat dit 'n "volksaak" was waarby alle Afrikaners belang gehad het. Waar die Helpmekaar aan politieke gebeure en uitsprake gekoppel is, het die leiers dit sover moontlik teëgespreek. Advokaat HS van Zijl het selfs beweringe wat in die parlement gemaak is, dat die Helpmekaar polities was, met die betrokke minister in 'n briefwisseling opgeneem. ${ }^{35}$ WA Hofmeyr, sekretaris van die NP in die Kaapprovinsie, het sy lidmaatskap van die sentrale bestuur van die Helpmekaarvereniging van die Kaapprovinsie beëindig toe sy aandeel in die stigting van Helpmekaartakke, wat saamgeval het met sy propagandareise vir die NP in die Kaapprovinsie, die Helpmekaar se posisie as nie-politieke organisasie in gedrang gebring het. ${ }^{36}$ In Transvaal het BR Hattingh daadwerklike pogings aangewend om die Helpmekaar buite die politiek te hou. ${ }^{37}$ Die sekretarisse van beide die SAP- en NP-takke is betrek by die uitbreiding van die Helpmekaar ${ }^{38}$ en waar takke oorspronklik, voor die bestaan van 'n oorkoepelende Helpmekaarorganisasie in Transvaal, deur die NP gestig is, is die takke eers ontbind en dan weer gestig om sodoende enige politieke verbintenisse aan 'n bepaalde politieke party uit te skakel. ${ }^{39}$

34 De Burger, 4 Sep 1915, Vrouwen Saamwerk Bazaar te Senekal; Het Volksblad, 7 Sep 1915, Helpmekaar Vereniging Senekal.

35 Ons Land, 16 Jun 1917, De Helpmekaar van de Kaap-Provincie; Het Volksblad, 22 Jun 1917, Minister Malan en de Kaapse Helpmekaar.

36 (KAB) Aanwins 1469 HVKP-versameling no 2, Ontvange Briewe 1916 WA Hofmeyr-mev P Roux, 8 Nov 1916.

37 De Volkstem, 10 Mrt 1916, Transvaalse Helpmekaar.

38 De Volkstem, 4 Apr 1916, Tvl Helpmekaar.

39 De Volkstem, 5 Mei 1916, Genl Botha en die Helpmekaar. 
Die grootste probleem van die sentrale besture was egter dié van effektiewe beheer oor die takke en hul aktiwiteite. Die wyse van aanbieding van Helpmekaarbyeenkomste, die gees wat daar geopenbaar sou word en die uitsprake wat deur persone wat die geleenthede geopen het, gemaak sou word, was grootliks buite hul beheer. Hoewel hulle nie beheer daaroor kon uitoefen nie, moes dié besture en die Helpmekaarbeweging die verantwoordelikheid en gevolge dra van wat by sulke geleenthede gebeur het. Hierdeur is die pogings van die sentrale besture en Helpmekaarleiers om die nie-politieke aard van die Helpmekaar te vestig, grootliks ongedaan gemaak. Die polemiek wat daar deurgaans rondom die Helpmekaar se verbintenis al dan nie met die partypolitiek geheers het, is 'n bewys van bogenoemde.

Die Helpmekaar se betrokkenheid by die politiek het ook gelei tot die manifestasie van die noue verwantskap tussen politiek en kultuur. Dit het 'n kenmerk van die twintigste-eeuse Afrikanerpolitiek in Suid-Afrika geword. Die NP is gestig ter beskerming, ontwikkeling en verwesenliking van die aspirasies van nasionaalgesinde Afrikaners. Van die aspirasies het spesifieke Afrikanerkultuurbelange (taal, geskiedenis, godsdiens) 'n primêre komponent verteenwoordig. Om bogenoemde doelwit te bereik was die NP op die uitkyk vir openbare gebeure van hoë sigbaarheidswaarde waar hy Afrikaners kon mobiliseer en kanaliseer ter bevordering en bereiking van hierdie spesifieke kultuurbelange. Die Helpmekaar het vanweë sy polities-gekoppelde ontstaansgeskiedenis 'n ideale geleentheid in dié verband gebied.

Die pogings van Afrikaners om die finansiële behoeftes van die Helpmekaar te probeer bevredig het aan hulle die geleentheid gebied deur basaars, vendusies, konserte en 'n nuut gestimuleerde verenigingslewe om hul taal te gebruik, hul geskiedenis te herbeleef en, uit dankbaarheid teenoor hul Skepper, hul naasteliefde uit te leef. Hierdeur het die Helpmekaar ook 'n kulturele karakter ontwikkel. Die Helpmekaar het dus, sonder dat dit sy bedoeling was, gedien as 'n sterk stimulant vir Afrikaner-etniese mobilisasie en nasionalisme en die daarmee gepaardgaande bevordering en vestiging van 'n "Afrikanerkultuur". Die NP se totale identifikasie met die doelstellings en praktiese manifestasie van die Helpmekaarbeweging het dié party se status as die politieke tuiste van nasionaalgesinde, en kultuur- en identiteitsbewuste Afrikaners gevestig.

Teenoor die NP se suksesvolle diagnose van en identifisering met Afrikaners se kultuurbehoeftes en -strewes kon die SAP se eenstroombeleid ('n samesmelting van Boer en Brit tot één Suid-Afrikaanse nasie) nie Afrikaners se kultuurstrewes akkommodeer nie. Daarby het die SAP se status by nasionaalgesinde Afrikaners 'n verdere knou gekry vanweë sy onderdrukking van die Rebellie en deelname aan die Eerste Wêreldoorlog. Vanweë die voordele wat die Helpmekaarbeweging vir die NP ingehou het, sou die SAP graag die 
Helpmekaar, as'n polities-kulturele faktor wat die party benadeel het, doeltreffend wou beveg. Doelbewuste pogings van die Helpmekaar-leierskorps om die beweging buite die politiek te hou het dit vir die SAP egter onmoontlik gemaak om bogenoemde doel te bereik. Die SAP se onvermoë om Afrikaners vir 'n alternatiewe polities-kulturele model te mobiliseer, tesame met hul onsuksesvolle pogings om die Helpmekaar polities te neutraliseer, het dus die wegdreinering van die party se Afrikanersteun (ten gunste van die NP) verhaas.

Gegewens ontbreek om klinkklaar te bewys dat dié "Nasionale Sappe" of "wordende nasionaliste" op groot skaal by die NP aangesluit het. Enkele individuele gevalle is wel bekend. Een hiervan was Johannes Bührman. Hy het as vooraanstaande SAP-lid van Ermelo by die Helpmekaarbeweging aangesluit en voorsitter van Ermelo se tak geword. In die tweede helfte van 1916 het hy egter besluit om die SAP te verlaat en homself as NPkandidaat verkiesbaar te stel. ${ }^{40}$ Die steeds groeiende steun vir die NP ten koste van die SAP in die periode na 1915 , soos blyk uit verkiesingsuitslae, ${ }^{41}$ ondersteun die tendens wat deur bogenoemde individuele geval aangedui word.

'n Verdere politieke invloed van die Helpmekaarbeweging was die mate waarin dit die gedagte van 'n hereniging van Afrikaners op politieke gebied gestimuleer het. Die hoop het in sommige kringe opgevlam dat samewerking in die Helpmekaar kon aanleiding gee tot 'n politieke vereniging tussen die SAP en die NP. Hierdie gedagte is veral deur'n persoon soos B. Hattingh ondersteun. ${ }^{42}$ Ten spyte van die politieke polemiek rondom die Helpmekaar was daar wel gevalle waar die takke van die SAP en NP op plaaslike vlak kragte saamgesnoer het ter wille van die Helpmekaar. ${ }^{43}$ Met die reaksie teen die indirekte eise in die eerste helfte van 1916 was daar in talle gevalle samewerking tussen die partye op takvlak om die eise te beëindig en het die gedagte van hereniging 'n hoogtepunt beleef. Die gebeure in Middelburg (Transvaal) was 'n goeie voorbeeld hiervan. BP Coetzee het oor die samewerking soos volg kommentaar gelewer:

40 (TAB) Aanwins 1500 JR Bührman-versameling vol 2, 1902-1950, Dokumente rakende Politieke aangeleenthede AP Otto-JR Bührman, 23 Sep 1916.

41 JH le Roux, Die Algemene Verkiesing van 1920 (O Geyser en AH Marais (reds), Die Nasionale Party deel I, 402); C Marais, Die Verkiesingstryd van 1921 (O Geyser en AH Marais (reds), Die Nasionale Party deel I, 420); C Marais, Die NP en die 1924-Verkiesing - Die Pakt aan die Bewind (O Geyser en AH Marais (reds), Die Nasionale Party deel I, 574-575).

42 De Burger, 4 Mrt 2016, Standerton; De Volkstem, 10 Mrt 2016, Transvaalse Helpmekaar.

43 De Volkstem, 24 Mrt 2016, Vrijstaatse Mensen en Dingen; Ons Land, 27 Sep 2017, Helpmekaar Piketberg; (KAB) Aanwins 1469 HVKP-versameling, no 1, Korrespondensie 1917, JA Visser-mev Paul Roux, 23 Okt 1917. 
"Nog wens ik hier by te voegen, dat de geest van samewerking van beide partijen uitstekend was, en ik ben overtuigd ervan als wij op deze wijze aangaan, wij nog in de toekomst andere grote dingen zaam zullen kunnen verrichten, en niet meer twee partijen zullen wezen, maar éen krachtige partij en éen volk dat slechts éen doel zal hebben." ${ }^{44}$

Die Afrikaner se kenmerkende onvermoë om sy mooi woorde oor eenheid in betekenisvolle en blywende gebeure gestalte te gee, het in dié periode duidelik geblyk. Die verwagtinge wat van die Helpmekaar gekoester is ten opsigte van hereniging het nie gerealiseer nie, aangesien die verwagtinge nie deur die onderskeie partyleidings met dieselfde entoesiasme gekoester en ondersteun is nie. Drome van hereniging het dus hoofsaaklik beperk gebly tot plaaslike vlak. Ten spyte van die afwesigheid van sigbare sukses op die gebied van hereniging het die Helpmekaar wel 'n bydrae gelewer deurdat dit groepe Afrikaners met verskillende politieke sienings bymekaar uitgebring het, laat saamwerk het, weer hul gemeenskaplikheid in hul gedeelde Afrikanerskap laat besef het, en sodoende die hoop vir 'n moontlike hereniging in die toekoms lewend gehou het.

In die laaste instansie het die Helpmekaargebeure ook die noue bondgenootskap tussen koerante en politieke partye beklemtoon. Regerings- en SAP-gesinde koerante soos Ons Land en De Volkstem het deurgaans regeringstandpunte oor die Helpmekaar gestel. Soos die Helpmekaar toenemend 'n politieke bedreiging vir die regering en SAP ingehou het, het aantygings van die koerante dat die Helpmekaar 'n politieke liggaam was, toegeneem. Met die groei van openbare steun vir die Helpmekaar in veral die tweede helfte van 1917 was die koerante genoodsaak om toenemend die beweging te ondersteun. Daar is egter nooit nagelaat om enige aspek of optrede van die Helpmekaar wat tot die NP se voordeel kon strek te kritiseer en verdag te maak nie. Sodoende het die koerante as die verlengde arm van die regering en SAP opgetree om enige voordeel wat die NP uit die Helpmekaar kon behaal te neutraliseer. Nasionaalgesinde koerante soos Die Burger en Het Volksblad het as bondgenote van die NP die party en sy volgelinge se gevoelens en strewes in verband met die Helpmekaar verwoord. Behalwe dat die Helpmekaar as Afrikanersaak bevorder is, het die koerante ook die regeringsreaksie teenoor die Helpmekaar gekritiseer en vir die NP politieke munt daaruit probeer slaan deur laasgenoemde se ondersteuning van die Helpmekaar te onderstreep.

Wat die politieke impak van die Helpmekaarbeweging en sy simboliese vaandeldraer - die $£ 100$-fonds - op die lotgevalle van Afrikaner mobilisering en nasionalisme betref, het 'n ontleding gedui op 'n beduidende positiewe korrelasie tussen steun vir die Helpmekaarbeweging en steun vir die NP, en omgekeerd. Die patroon van die NP se

44 De Volkstem, 7 Apr 1916, Onze Gevangenen. 
groeiende steun, soos geillustreer in die 1915-verkiesing, het geografies gekorreleer met die stortvloed steun vir die rebelle en die $£ 100$-fonds gedurende die tweede helfte van 1917. Die feit dat dieselfde korrelasie getoon kon word in die 1948-verkiesing is 'n sterk aanduiding dat die steun vir die Helpmekaarbeweging en die $£ 100$-fonds meer as net 'n emosionele hoogtepunt in die geskiedenis van Afrikaner mobilisering en nasionalisme verteenwoordig. Die historiese betekenis van hierdie eerste populêre uitstorting van Afrikanernasionalisme in die 20ste eeu (die tweede synde die eeufeesvieringe van die Groot Trek in 1938) lê in sy aktivering, identifisering en mobilisering van die belangrikste toekomstige rolspelers en boublokke vir Afrikaner-nasionalisme.

Die $£ 100$-fonds en Helpmekaarbeweging het 'n openbare verhoog met 'n hoë sigbaarheidswaarde gebied waarop hierdie rolspelers hulself kon voorstel en vestig as voorvegters vir die saak van Afrikanernasionalisme en etniese mobilisasie en waar hulle die beleid van die regerende SAP kon verwerp. 'n Ontleding van die $£ 100$-fonds toon 'n aantal van hierdie rolspelers: 'n samelewing oorheers deur 'n patriargale familiestruktuur met die oorgrote meerderheid - 571 ( $£ 57$ 100) - van die $£ 100$-bydraes geskenk deur mans, of mans en hul seuns (De here ... en zoons); die NP, as politieke werktuig met 264 ( $£ 26400$ ) bydraes; die Kerk as geestelike huis met 135 ( $£ 13500$ ) bydraes; die jeug (wat onder die stelsel van CNO die voetsoldate was wat die NP in 1948 tot oorwinning sou lei) met 102 ( $£ 10200)$ bydraes $^{45}$ en Afrikanervroue wie se 52 ( $£ 5$ 200) individuele bydraes net 'n afskynsel verteenwoordig het van hul werklike invloed. 'n Invloed wat die nasionaalgesinde Afrikanersamelewing deur 'n magdom van vroue-, godsdiens-, sosiale- en politieke verenigings - 96 bydraes ( $£ 9600)$ - tot 'n eenheid saamgeweef het. Die Helpmekaarbeweging en $£ 100$-fonds het die patroon vir die toekomstige groei en uiteindelike sukses van Afrikanernasionalisme en etniese mobilisasie in 1948 gevestig. Gedryf deur De Burger en georkestreer deur sy predikant-redakteur, dr DF Malan, het die $£ 100$-fonds en Helpmekaarbeweging 'n "profesie" 46 geword van die aard en lotgevalle van Afrikanernasionalisme in die eerste helfte van die 20 ste eeu. ${ }^{47}$

Geld is op 'n verskeidenheid maniere ingesamel: donasies van sakgeld, die opsegging van die gebruik van botter en konfyt in skoolkoshuise, organisering van basaars en kollektelyste, opsegging van sosiale rugbyfunksies en die skenking van geld aan die Helpmekaar, ens. JD Kestell, Helpmekaar Gedenkboek, 33.

In sy beoordeling van die bydrae van die Afrikanerjeug tot die $£ 100$-fonds in die Helpmekaar Gedenkboek van 1918 het JD (Vader) Kestell 'n baie optimistiese siening gehuldig. Hul bydrae en betrokkenheid het hom met hoop vir die toekoms vervul en hy het hul deelname as 'n teken van die lewenskragtigheid van die (Afrikaner-) volk geïnterpreteer: "Aan die einde het dit geblijk dat Jong Suid-Afrika, wat self eientlik niks besit, vir 44 honderdpond-gifte gesorg het. Wat is dit 'n profesie!"

A Ehlers, Rescuing the Rebels from Ruin: Afrikaner Nationalism and the Political Economy of the Helpmekaar (Mutual Aid) Movement and its $£ 100$ Fund, 1915-1917, Economic History of Developing Regions, 26:1, 2011, 75-100. 


\section{Kerk en Godsdiens}

Op geestelike terrein het die Helpmekaargebeure ook sy invloed laat geld. As "kulturele entrepreneur" het die Helpmekaar bygedra om veral twee "kenmerke" van die Afrikaner se geestelike lewe, naamlik 'n noue verwantskap tussen volk en kerk en 'n geneigdheid om sy lotgevalle in godsdienstige terme te verwoord, te verstaan, verklaar, vorm te gee en in die proses dieper in die "volkskarakter" in te bed.

Die kerk het hom vanaf 1915 op 'n deurlopende basis op sentrale vlak (sinodes en moderature) sowel as op plaaslike vlak (kerkrade en predikante) beywer om status en aansien te gee aan die Helpmekaar, as 'n saak wat die welsyn van die volk bevorder het. Die kerk het deur sy sentrale gesagsliggame en -persone steun gegee aan aspekte soos die stryd teen indirekte eise, die erkenning van Helpmekaar Dag en gepaardgaande insamelings, asook die aansporing van sy lidmate tot ondersteuning van die Helpmekaar in die algemeen. Die algemeen gunstige reaksie (byvoorbeeld ten opsigte van die indirekte eise en bydraes tot die $£ 100$-fonds) wat die kerk se bemoeienis met die Helpmekaar van sy lidmate ontlok het, het enersyds die gesag wat die kerk se stem by Afrikaners gedra het, bevestig. Anersyds kan dit ook gesien word as 'n reaksie gebore uit die waardering wat die lidmate (Afrikaners) gehad het vir die simpatieke ondersteuning en identifisering van die kerk met die volksbelange. Hierdie wisselwerking het die noue verwantskap tussen volk en kerk gestimuleer en in die proses verder gevestig.

Op plaaslike vlak was die steun van die kerk, by monde van die plaaslike predikant en kerkraad, 'n belangrike faktor wat die sukses van die Helpmekaar beïnvloed het, hoewel dit vir die bedrywighede van dié vereniging nie onontbeerlik was nie. Dit was vir Afrikaners belangrik dat hul plaaslike leraar die Helpmekaar moes ondersteun en goedgesind wees. Hierdie behoefte aan die steun van die kerk kan enersyds toegeskryf word aan die Afrikaner se godsdienstige ingesteldheid en andersyds aan 'n behoefte na 'n versekering dat sy politieke, sosiaal-maatskaplike en kulturele strewes geregverdig was en God se "goedkeuring en seën" weggedra het. Waar die plaaslike predikant die Helpmekaar goedgesind was en aan die aktiwiteite deelgeneem het, het dit die Helpmekaar se saak bevorder en harmonie tussen kerk en volk gebring.

Hierdie behoefte is verwoord deur "Pijpsteel" van Philippolis wat soos volg oor die predikante se betrokkenheid by 'n Helpmekaarbasaar wat op die dorp gehou is, geskryf het:

"Maar kyk, de Afrikaners van Smithfield hebben een groot voorrecht. Als daar onder het nog enkele zijn die nog Jingoes zijn, dan is dit niet de predikant $\mathrm{z}$ 'n schuld. Dit is lekker om naar zo 'n Afrikaner predikant te luisteren. Hij zei o. m., dat God het Afrikaner volk samengevoegd heeft en dat de mens tevergeefs zal trachten het te scheiden. Om maar 


\section{Die Kaapse Helpmekaar}

kort te zijn zal ek maar met één woord zeggen, hij is een 'nationale man', die staat voor zijn volk." ${ }^{48}$

Van Wolmaransstad het 'n korrespondent oor die predikant se teenwoordigheid by 'n Helpmekaarkonsert geskryf: “... ons seer geachte Dominee was ook teenwoordig - hij is mos nie alleen Godsman, maar ook Volksman!"49

In gevalle waar die predikant die beweging vyandiggesind was of neutraal gestaan het, was dit 'n remmende faktor, maar nie 'n onoorkomelike probleem vir die Helpmekaar se aktiwiteite nie. ${ }^{50}$ Op Villiersdorp het die predikant sy steun van die Helpmekaarbasaar weerhou en geweier dat die kerksaal vir die basaar gebruik word. Ten spyte van die feit dat die Helpmekaar as gevolg van die predikant se houding steun op die dorp ingeboet het, het die korrespondent die gemeente se reaksie op die predikant se houding beskryf as: "Baie van die gemeente voel erg hartseer hieroer." ${ }^{51}$ Die basaar is nogtans gehou en wel in die saal van die sendinggemeente. ${ }^{52}$

Daar was gevalle van teenkanting (hoofsaaklik as gevolg van politieke oorwegings) van plaaslike predikante teen die Helpmekaar. Dit kan sonder twyfel gestel word dat die oorgrote meerderheid predikante en kerkrade, hoewel sensitief vir enige moontlike verdeeldheid wat hul besluite kon veroorsaak, die saak goedgesind was. ${ }^{53}$ Deurdat kerk en volk se belange en strewes ten opsigte van die Helpmekaar oorwegend met mekaar ooreengestem het, is die band tussen volk en kerk verstewig en bevestig.

Die godsdienstige terme waarin Afrikaners die ontstaan en ontwikkeling van die Helpmekaar verwoord het, het hul godsdienstige ingesteldheid onderstreep. Daar is talle voorbeelde soos byvoorbeeld die siening van JE de Villiers jr, naamlik dat die Helpmekaar die wyse was waarop God die volk getoets het, president Steyn se wyd ondersteunde siening dat die Helpmekaar uit God gebore is, die godsdienstige skakering waarin dr Malan die Helpmekaargebeure

\footnotetext{
48 Het Volksblad, 20 Jul 1915, Helpmekaar te Philippolis.

49 De Burger, 27 Jul 1915, Ten bate van die Helpmekaar-fondse.

50 De Burger, 10 Apr 1916, Helpmekaar te Vanrhijnsdorp.

51 De Burger, 8 Mrt 1916, Villiersdorp.

52 Ibid.

53 (Neder-Duits Gereformeerde Kerk Argief) G.1 1/43 Kaapstad Notule 1913-1922, Kerkraadsvergaderings, 15 Okt 1917; G.5 1/5 Swartland Notule 1913-1926, Kerkraadsvergadering, 15 Okt 1917; G.7 1/5 Swellendam Notule 1911-1926, Kerkraadsvergadering, 8 Okt 1917; G.27 1/5 Victoria-Wes Notule 1914-1933, Kerkraadsvergadering, 8 Okt 1917.
} 
van 1917 geskilder het, asook Afrikaners se algemene dankbaarheid teenoor God vir die suksesvolle afloop van die Helpmekaar is voldoende bewys van bogenoemde.

Die wyse waarop die Afrikaners tot die slotsom gekom het dat die Helpmekaar en die daarmee gepaardgaande nuwe gees onder Afrikaners Godgegewe was, is raak verwoord deur mev $\mathrm{HJ}$ van der Walt van Middelburg in die Kaapprovinsie toe sy die saak as volg beredeneer het:

"Als ik zo stil sit te denken aan de toestand, de treurige toestand van ons land, dan komt het bij mij op: van waar die geest onder de mensen? Van waar die nationale ijver? Zou het wezen een hersenschim die aanstekelik is, en bij iedereen grond vat, of zou het wezen een hijgen naar iets anders, iets dat de eentonigheid van ons alledaagse leven verwisselt? Maar neen, deze antwoorden op mijn vraag geven mij zelf geen bevrediging. Het is iets niet van de mens. Het is een inspiratie van een Hoger hand. Een inspiratie van de Vader, die ons volk van oudsher geleid en bestierd heeft; en wij moeten Hem de eer en de dank brengen voor die inspiratie, voor die geest van volksbestaan, die wij ondanks onsself, niet kunnen weerstaan ... het is een voorrecht ons van gode toegekend, een voorrecht waarvoor wij Hem immer dankbaar zullen zijn. Niet in onze eigen kracht gaan wij, niet in onze eigen menseliefde, of onze eigen goedheid, maar wij zeggen Gode dank, dat Hij ons de wil daartoe gegeven heeft, om Helpmekaar-moeders en -dochters te worden." ${ }^{54}$

\section{Ekonomie}

Daar kan slegs gespekuleer word oor die invloed wat die eise van die lojaliste op die ekonomiese posisie van die rebelle sou gehad het indien die Helpmekaar nie tot stand gekom het nie. RT van der Merwe het in 'n verslag aan die Bethlehem-Saamwerk die potensiële uitwerking van die eise, asook die voorkomende rol wat die Helpmekaar in dié verband gespeel het, soos volg verduidelik:

"Die (Helpmekaar) het persone vir uitroei-ing bewaar, sodat daar tot vandag in ons distrik nog nie 'n duim Grond, Bees, Perd of Skaap of wat ook al, naar die mark gedrijf is. Wat anders sou gebeur het as dit nie was vir die beweging nie? Grond en goed sou in die mark geforseer gewees het en gevolgelik sou daar so 'n daling in waarde ontstaan het dat daar 'n paniek in die geldmarkte sou gekom hê, dat minstens 75 persent van onse Boere en andere vandag in die bankroet howe sou gewees hê, en sou dit dan net die opstandelinge geraak het. Het hij alleen 'n verband op sy plaas of alleen skuld? So of ons al 'n opstandeling of Goevernements ondersteuner of wat ook al is, die posisie raak ons almal." ${ }^{\text {55 }}$

54 De Burger, 22 Des 1915, Staat Allen Bij Elkaar!

55 Het Volksblad, 20 Mrt 1917, Bethlehem Saamwerk. 


\section{Die Kaapse Helpmekaar}

Van der Merwe se waarneming en evaluering het die algemene gevoel van die tyd weerspieël. Deurdat die Helpmekaar bogenoemde proses verhoed het, het hy 'n moontlike ineenstorting van die Noord-Vrystaatse en Wes-Transvaalse ekonomieë, wat ook die ekonomiese posisie van die Unie as 'n geheel sou beïnvloed, voorkom. Die gedeelte van die Helpmekaarkapitaal wat vir bogenoemde doel aangewend was, het geen verbetering of groei in die ekonomiese posisie van die Afrikaners veroorsaak nie, maar slegs verseker dat die status quo gehandhaaf word. In dié sin kan hiervan as "negatiewe" kapitaalaanwending gepraat word. Die feit dat die Helpmekaar egter ook oor 'n surpluskapitaal beskik het, het hom in staat gestel om ook deur middel van "positiewe" kapitaalaanwending 'n bydrae te lewer. Die surplus sou in die toekoms aangewend word om die ekonomiese vooruitsigte van Afrikaners te bevorder en dit is op dié terrein wat die Helpmekaar in die jare na die vereffening van die rebelleskuld, 'n invloed sou uitoefen.

Daar bestaan geen twyfel dat die Helpmekaar groot getalle rebelle van finansiële ondergang gered het nie. Daardeur is nie net die rebelle nie, maar ook die Unie 'n finansiële katastrofe gespaar. Die enorme taak wat die Helpmekaarbeweging uitgevoer het, word ten beste geillustreer deur die feit dat oorspronklike eise van $£ 4198057 \mathrm{~s} 9 \mathrm{~d}$ in die Noord-Vrystaat deur Helpmekaar-intervensie verminder en uiteindelik met $£ 255419$ 16s 5 d betaal is; ${ }^{56}$ dat 'n verdere $£ 30000$ se eise in Transvaal en nog enkele duisende in die Suid-Vrystaat en Kaapprovinsie betaal is en dat daar nog $£ 92501$ as 'n surplus vir toekomstige aanwending oorgebly het. ${ }^{57}$

Afgesien van die ekonomiese invloed wat die Helpmekaar deur middel van sy harde kontant uitgeoefen het, het die finansiële suksesverhaal van die beweging ook 'n besondere invloed op die ingesteldheid van Afrikaners ten opsigte van die ekonomiese en sakewêreld uitgeoefen. Tot voor die Helpmekaar was die steeds groeiende armblankeprobleem vir Afrikaners'n bewys van hul onvermoë om aan te pas en vordering te maak in die meer stedelik georiënteerde ekonomiese- en sakewêreld. Die ekonomiese minderwaardigheidskompleks waaraan Afrikaners in dié verband gelei het, is deur die Helpmekaar se sukses aangespreek. Die finansiële sukses van die Helpmekaar het Afrikaners laat besef dat, hoewel hulle as individue nie besonder kapitaalkragtig was nie, hul wel deur samewerking en die Vereniging van hul kapitaal in staat was tot 'n kapitaalkragtigheid waarmee hulle die armblankeprobleem,

56 (HSA) HVKP, Notuleboek, 21-22 Mei 1919, Kongres, 5, 7.

57 (KAB) Aanwins 1469 HVKP-versameling no 1 Sentrale Rebelle Fonds, 9 Jul 1919; (HSA) HVKP, Notuleboek, 21-22 Mei 1919, Kongres, 5. 
asook hul ander ekonomiese probleme, met vertroue kon aandurf. ${ }^{58}$ Die ekonomiese en finansiële selfvertroue en prikkeling wat die Helpmekaar verskaf het, het die proses waardeur die Afrikaner uit sy ekonomiese dop begin kruip het, gestimuleer. Die groot aantal ekonomiese skemas en planne waarmee vorendag gekom is nadat dit bekend geword het dat daar 'n surpluskapitaal sou wees, getuig hiervan.

De Burger het in 'n bespreking van die faktore wat vir die ekonomiese oplewing onder Afrikaners verantwoordelik was, die Helpmekaar se invloed in dié verband soos volg beskryf:

"Hierbij kan nog gevoegd worden de invloed van de grote, historiese Helpmekaarbeweging, die bij de Afrikaner zijn zelfrespekt verhoogd, bij hem een vroeger ongekend zelfvertrouwen heft gewekt, en hem getoond heft waartoe het Afrikaner volk instaat is indien het zijn richting kiest en zijn krachten verenigt. Het gevolg van dit alles is een sterke en toenemend begeerte voor de oprichting van handelshuizen en ander finantiële ondernemingen, voor organisatie onder alle klassen van boeren en voor de stichting van een boeren koöperatiewe bank om met zulke organisaties samen te werken en hun sukses te verzekeren." ${ }^{59}$

In hierdie verband is dit nodig om ook die rol van die kapitaalkragtige Afrikaners in die Wes-Kaap uit te sonder. Daar is reeds verwys na die bydrae van bogenoemde Afrikaners tot die sukses van die $£ 100$-fonds. Deur hul flinke reaksie op die oproep het hulle die oorgrote meerderheid van die eerste honderd bydraes gelewer. Die Afrikaners van die Wes-Kaap, en meer spesifiek die boere-element, het die geleentheid benut om hul kapitaal aan te wend vir 'n Afrikanersaak waardeur hulle Afrikaner mobilisasie en nasionalisme op nasionale vlak kon bevorder. Deur hul flinke reaksie het hulle nie net die sukses van die insameling verseker nie, maar ook die pas van die insameling aangegee. Dit het onder andere die Vrystaatse Afrikaners aangespoor om bydraes te maak waaroor hulself nie meer gedink het hulle beskik nie, in so 'n mate dat hulle uiteindelik meer as die Kaapprovinsie tot die $£ 100$-fonds bygedra het. Hierdie optrede van die kapitaalkragtige, nasionaalgesinde Afrikaners in die Wes-Kaap het deel gevorm van 'n tendens wat veral na 1914 ontwikkel het. Dit was naamlik dat bogenoemde Afrikaners die leiding geneem het om Afrikanerkapitaal te mobiliseer ter bevordeing van die nasionale belange van Afrikaners en Afrikanernasionalisme. Die totstandkoming van Nasionale Pers en die koerant De Burger in 1915 was 'n eerste sukses in dié verband. Dit is

58 De Burger, 23 Nov 2017, Open Brief; De Burger, 23 Nov 2017, Generaal Hertzog oor die Helpmekaar; Het Volksblad, 23 Nov 2017, Het Voortbestaan van de "Helpmekaar". 
gevolg deur die $£ 100$-fonds van die Helpmekaar, Santam en Sanlam. ${ }^{60}$ Van die Afrikanerfinansiële instellings wat in die vaarwater van die Helpmekaar ontstaan het en inspirasie uit die beweging geput het, is Santam en Sanlam seker die bekendste. ${ }^{61}$

Dit is insiggewend dat verskeie lede van Sanlam se eerste direksie noue verbintenisse met die Helpmekaar gehad het. WA Hofmeyr, eerste voorsitter van die direksie, asook TJ Louw, 'n direksielid, ${ }^{62}$ het albei op die sentrale bestuur van die Helpmekaarvereniging van die Kaapprovinsie gedien. ${ }^{63}$ Fred Dormehl het as eerste besturende direkteur, ${ }^{64}$ onder andere in die beleggingskommissie belas met die belegging van die Kaapse Helpmekaar se surplus, gedien. ${ }^{65}$ Die Helpmekaar-vereniging van die Kaapprovinsie het Santam in sy eerste bestaansjaar ook van broodnodige ondersteuning voorsien. Die vereniging het naamlik 'n bedrag van $£ 26850$ in verbande deur die tussenkoms van Santam belê. ${ }^{66}$ In die proses van die ekonomiese bemagtiging van Afrikaners, verteenwoordig die Helpmekaarbeweging dus 'n vroeg twintigste-eeuse stimulis. Die Helpmekaar se belangrikste ekonomiese bydrae sou egter sy betrokkenheid by die finansiering van onderwys en opvoeding wees - 'n bydrae wat later onder die loep kom.

\section{Kultureel}

Die Helpmekaarbeweging het ook as agent van kultuurskepping en vaslegging gedien. Deur die talle Helpmekaarkonserte het Afrikaners 'n geleentheid gekry om in Afrikaans te skep, te sing, voor te dra en toneel te speel. Afrikaners is ook by die geleenthede bewus gemaak van hul gemeenskaplike verlede deurdat baie van die temas teruggegryp het na gebeure rondom die Voortrekkers en die Anglo-Boereoorlog. ${ }^{67}$ Die inspirasie wat van die Helpmekaar uitgegaan

60 H Giliomee en H Adam, Afrikanermag Opkoms en Toekoms. UUB, Stellenbosch, 1981, 109-110; EP du Plessis, 'n Volk staan op. Human \& Rousseau, Kaapstad, 1964, 35-36, 52-54.

61 NJ le Roux, WA Hofmeyr - sy werk en waarde, 124-125; (Sanlam-argief) Kabinet N2070(d) Lêer 980 Sanlam Deel I, Manuskrip van WJ Bezuidenhout oor die Geskiedenis van Sanlam, 2.

62 NJ le Roux, WA Hofmeyr - sy werk en waarde, 128-129.

63 (HSA) HVKP, Notuleboek, 28-29 Jun 1916, Kongres, 9.

$64 \quad$ NJ le Roux, WA Hofmeyr - sy werk en waarde, 128.

65 (HSA) HVKP, Notuleboek (3 Jul 1916-20 Mei 1919), 8 Jun 1918, Sentrale Bestuur, 117.

66 (HSA) HVKP, Notuleboek, 21-22 Mei 1919, Kongres, 3.

67 Het Volksblad, 29 Jun 1915, Bethulie, OVS; De Burger, 25 Nov 1915, Helpmekaar Konsert; De Burger, 16 Aug 1916, Helpmekaar Konsert. 
het, het ook neerslag gevind in talle gedigte in Afrikaans waarin die Helpmekaar besing is. ${ }^{68}$ Die Helpmekaar se verbintenis tot Afrikaans het ook geblyk uit die feit dat die beweging in al die provinsies Afrikaans as hul amptelike taal aanvaar het. ${ }^{69}$ Op bogenoemde wyse het die Helpmekaar dus ook 'n bydrae gelewer tot die bevordering van Afrikaans en die stimulering van Afrikaners se historiese bewussyn.

Die Helpmekaarbeweging het dus 'n etniese mobiliseringsoomblik - 'n laboratorium geskep waarin politiek, ekonomie, godsdiens, taal en kultuur as bestanddele tot 'n resep saamgevoeg is om 'n kragtige hoë-oktaanmengsel te vorm wat Afrikaner mobilisasie en nasionalisme, hoewel in verskillende kontekste oor tyd, vir 'n groot deel van die twintigste eeu sou stook en aandryf. Hierdeur is die templaat en DNS gevorm wat uitendelik sou lei "tot die verbroedering tussen die NP, die Afrikaanse kerke en Afrikanerkultuur" en 'n "verhouding tussen party, kerk, koerant, skool en kultuur" wat oor tyd "benoud en ideologies verweef" $" 70$ sou word.

\section{DIE KONGRES-ERA, C1916-1966}

Vir die duur van die kongres-era sou die Kaapse Helpmekaar om sy konstitusionele doelwitte te bereik hom deurgaans belyn met en beweeg binne die breër raamwerk van die doelwitte en belange van nasionaalgesinde Afrikaners soos dit in die NP beliggaam is. Die beskrywingspunte, besprekings, resolusies, besluite en die rigtinggewende voorsittersredes het die ekonomiese, sosiale, kulturele en politieke belange van nasionaalgesinde Afrikaners en hoe dit oor tyd verander het, weerspieël.

Die naelstring wat die Helpmekaarbeweging in sy storm-en-drangjare met die NP verbind het, sou in die geval van die Kaapse Helpmekaar 'n permanente verhouding word waarin die Helpmekaar hom deurgaans met die beleidsrigtings en standpunte van die

68 De Burger, 3 Okt 1917, Die Slag van Helpmekaar; De Burger, 15 Nov 1917, Helpmekaar; De Burger, 11 Des 2015, Helpmekaar.

69 (VKA) Helpmekaar van die Oranje-Vrystaat, Notuleboek (1927-1937), Grondwet van die Nasionale Vrouwe Helpmekaar Vereniging, 13; (VKA) Helpmekaar van die Oranje-Vrystaat, Notuleboek (16 Mrt. 191518 Aug 1926), Reëls en Regulasies van die Helpmekaar van die Oranje-Vrijstaat, 8; De Volkstem, 14 Jan 1916, Helpmekaarbeweging in Transvaal; (HSA) Helpmekaar-vereniging van die Kaapprovinsie, Reëls en Regulasies van die HVKP, 9; (KAB) Aanwins 1469 HVKP-versameling no1, Die Helpmekaar Vereniging in Transvaal-Statute, 6 .

70 http://www.afrikanergeskiedenis.co.za/organisasies-se-geskiedenis/fak-geskiedenis/ (Kultuur in die brandpunt, 1980-1994.) 
party sou vereenselwig. Die bronne het gemengde seine ${ }^{71}$ oor die Kaapse Helpmekaar se betrokkenheid in party-politiek na die aanvanklike storm-en-drangjare gegee. Daar was 'n tendens sedert die twintigerjare om die grens periodiek oor te steek en het die kongres deur sy resolusies, beskrywingspunte en standpunte in voorsittersredes met standpunte van die NP geïdentifiseer en dit ook aktief bevorder. In teenstelling met die reedsgenoemde WA Hofmeyr-geval in 1916, het die sentrale bestuur in 1924 'n aanbod van dr AJ Stals van die hand gewys om as voorsitter te bedank vanweë sy aktiewe toetrede tot die politiek. ${ }^{72}$ Die oorgrote meerderheid van die resolusies, met 'n hoogtepunt teen die einde van die dertigerjare, het met rasseskeiding ${ }^{73}$ te doen gehad en gevra vir aparte skole ${ }^{74}$ treinvervoer ${ }^{75}$ woonbuurte, ${ }^{76}$ 'n verbod op gemengde huwelike, ${ }^{77}$ voorkeur aan blanke arbeid en 'n verbod op die indiensneming van blanke meisies deur Asiate. ${ }^{78}$ Die Wellington-tak het selfs in 1940 die sentrale bestuur versoek om by Unisa op aparte gradeplegtighede aan te dring - 'n beginsel wat volgens hulle nie op Wellington toegepas is nie:

"Nie eers word die name van kleurlinge apart by dieselfde funksie in dieselfde saal, gelees nie. Dit geskied dwarsdeur mekaar met blankes. Dieselfde pet wat gedruk word op die hoof van die blanke dogters word so natuurlik ook vir die kleurlinge gebruik." ${ }^{79}$

Die nasionalistiese sentimente van die kongres het ook op ekonomiese vlak gemanifesteer met die aanvaarding van 'n voorstel in 1941 om die bankrekening van die vereniging van die Nederlandse Bank na Volkskas oor te plaas, indien hulle dieselfde fasiliteite kon verskaf. ${ }^{80}$

71 Soms is voorstelle op kongresse as polities van aard bestempel en teruggetrek of buite orde gereël, terwyl ander voorstelle met 'n duidelike politieke strekking aanvaar is. (HSA) HVKP Notuleboek, 23-24 Apr 1935, Kongres, 10; (HSA) HVKP Notuleboek (13 Jun 1928-12 Des 1935), 24 Feb 1932, Sentrale Bestuur, 91; (HSA) HVKP Notuleboek, 7-8 Apr 1926, Kongres, 10.

72 (HSA) HVKP Notuleboek (21 Mei 1924-3 Apr 1928), 30 Jun 1924, Sentrale Bestuur, 16.

73 Beskikbare gegewens oor aktiwiteite op takvlak dui daarop dat rasseskeiding ook op dié vlak 'n kwessie was, veral by die Oos-Kaapse takke soos Port Elizabeth en Uitenhage met 'n groot persentasie verarmde Afrikaners. In Mrt 1926 was die tema van 'n "goedgeslaagde konferensie" wat deur die PE- en Uitenhagetakke gehou is en deur 80 persone bygewoon is: "Wat kan die Helpmekaar doen om die euwel van saamwoon van blankes en gekleurdes." (HSA) HVKP, Notuleboek (21 Mei 1924-3 Apr 1928), 19 Mrt 1926, Sentrale Bestuur, 132.

74 (HSA) HVKP, Notuleboek, 30 Mrt 1932, Kongres, 5.

75 (HSA) HVKP, Notuleboek, 16-17 Apr 1930, Kongres, 7.

76 (HSA) HVKP, Notuleboek, 20-21 Apr 1938, Kongres, 13.

77 (HSA) HVKP, Notuleboek, 12-13 Apr 1939, Kongres, 11; 30-31 Mrt 1937, Kongres, 12, 13.

78 (HSA) HVKP Notuleboek, 15-16 Apr 1936, Kongres, 11.

79 (HSA) HVKP Notuleboek (1940-1941), 27-28 Mrt 1940, Kongres, 15, (NPE Venter, Sekretaris-DH van Zyl, Sekretaris Sentrale Bestuur, 3 Feb 1940).

80 (HSA) HVKP, Notuleboek, 16-17 Apr 1941, Kongres, 13. 
Hierdie sentimente het vir die duur van die kongres-era voortgeduur, soos die 1961-besluit deur die hoofbestuur om " $n$ boodskap van bemoediging aan dr HF Verwoerd te stuur by SA se uittrede uit die Statebond en ons republiekwording" ${ }^{11}$ van getuig. Dit het nie beteken dat hulp en studielenings net vir Nasionaliste beskore was nie. Die Helpmekaarleierskap het inteendeel soos tydens die ontstaansjare by herhaling oor tyd die nie-politieke aard van die Helpmekaar beklemtoon en bevestig. Te midde van die hoogty van politieke uitsprake in die laat dertigerjare het die 1939-kongres 'n voorstel aanvaar dat die kongres andermaal bevestig "dat die Vereniging niks te doen het met politiek nie, maar dat dit bestaan om elke Afrikaner te dien." ${ }^{82}$ Dit het egter nie verhoed dat die Helpmekaarleierskap deur nasionaliste oorheers is ${ }^{83}$ nasionalistiese beleidsrigtings ondersteun is en hulle deurlopend die nasionalistiese projek ondersteun het nie.

Soos in die geval van sy verhouding met die NP sou die intieme verhouding tussen die NG Kerk en Kaapse Helpmekaar na sy vestigingsjare voortduur. Daar is reeds verwys na die kerk se rol as vennoot in wat deur die NP en 'n netwerk van Afrikaner-burgerlike organisasies, soos die Helpmekaar as die oorlewingstryd van die Afrikaner, gesien is. As sodanig het die kerk 'n belangrike rol gespeel in die regverdiging van die NP se beleidsrigtings en optrede deur God se goedkeuring daaraan te heg. ${ }^{84}$ Die spesiale pogings wat deur die Helpmekaar aangewend is om teologiestudente te akkommodeer en tegemoet te kom was waarskynlik vanweë die besondere rol wat die kerk en predikante as die vertolkers van God se Woord in Afrikanergeledere gespeel het. Die Helpmekaar se definisie van teologiestudente was vir die grootste deel van sy bestaan beperk tot predikante van die NG Kerk (en die tradisionele Afrikaner-susterskerke). Dat hulle eers in 1992 besluit het dat hulle in die toekoms ook studente sou help wat aan die Apostoliese Geloofsending Teologiese Kolleges hulle as pastore wou bekwaam, ${ }^{85}$ het die verhouding bevestig.

Ten spyte van die sekularisering wat mettertyd in Afrikanergeledere ingetree het, het Afrikaners se toenemend beleërde posisie in Suid-Afrika hulle genoop om hul verhouding

81 (HSA) HVKP, Notuleboek (8 Feb 1940-9 Des 1966), 2 Apr 1961, Hoofbestuur, gp.

82 (HSA) HVKP, Notuleboek, 12-13 Apr 1939, Kongres, 11.

83 Suid-Afrikaanse Biografiese Woordeboek IV (CJS Strydom, Roux, JWJW, 550). 'n Uitsondering op die patroon was advokaat Wessel Roux wat in 1934 met die samesmelting tussen die NP en die SAP anders as die meerderheid Kaaplandse Nasionaliste, generaal Hertzog na die Verenigde Party gevolg het nadat hy van 1920 tot 1938 die NP as Volksraadslid vir Ceres verteenwoordig het. Dit is onduidelik of Roux se weerstand teen DH van Zyl se idee van'n B-fonds ook uit die skeiding van politieke weë gespruit het. Dit het egter nie verhoed dat Roux tot met sy dood in 1958 die penningmeester van die Helpmekaar gebly het nie. Parlementêre Register 1910-1961, 112, Elsiesrivier, 1970.

84 Rapport Weekliks, 12 Jun 2016, Ben du Toit, Moet liefs nie 1976-jeug en troepies vergelyk nie, 4-5.

85 (HSA) HS, Notuleboek (16 Feb 1973-10 Sept 1993), 13 Aug 1992, UK, 122. 


\section{Die Kaapse Helpmekaar}

met die kerk in stand te hou. Volgens getuienisse van predikante wat tydens hul nasionale diensplig as kapelane in die Grensoorlog diens gedoen het, het sommige dit as "hul vrugbaarste tyd" van hul bediening beskryf, aangesien hulle "'n ongekende getal bekerings beleef het", "want my broer, as daai MiG's oorkom, bid die gehardste troep tot God." Die kerk sou ook deurlopend 'n bron van kapitaal vir die Helpmekaar bly - ten spyte van die ontnugtering wat mettertyd by die Helpmekaar-leierskorps ingetree het oor die toenemende onverskilligheid van die kerk teenoor die Helpmekaar. Op leiersvlak sou die Helpmekaar ook vir 'n groot deel van sy bestaan onder leiding van predikante staan wat sou bydra om die verhouding tussen die Kaapse Helpmekaar en die kerk in stand te hou. ${ }^{87}$

Vir die duur van sy kongresbestaan sou die Kaapse Helpmekaar ooreenkomstig sy grondwet hom met die bevordering van 'n Afrikaanse kultuur vereenselwig. Die volgende mosies wat in 1932 en 1934 deur die Helpmekaarkongres aanvaar is, het hierdie fokus waarskynlik die beste verwoord:

"Die Kongres besluit dat waar takke samekomste hou in verband met Helpmekaar, dat daar by dié geleenthede nadruk gelê word op Algemene Afrikaanse kulturele ontwikkeling, bv. deur voorlesings, toesprake en debatte ${ }^{88}$... Die Helpmekaarvereniging van die Kaapprovinsie is altoos bereid om na goeddunke en sover dit van tyd tot tyd in sy vermoë is, geldelike en morele ondersteuning te verleen aan liggame wat hul beywer vir die bewaring, redding en instandhouding van allerlei voorwerpe, selfs geboue van geskiedkundige en kulturele waarde uit ons Suid-Afrikaanse geskiedenis." ${ }^{\prime 9}$

Die Helpmekaar se kulturele bevordering het dus 'n wye verskeidenhied van betrokkenheid gedek. Hiervan was die bevordering van Afrikaans 'n belangrike element. ${ }^{90}$ Reeds in 1918 het die sentrale bestuur gerapporteer "Soals deur die laaste Kongres beslote, is Afrikaans die taal van die Helpmekaar geword, en word nou bijna algemeen gebruik in die verrigtinge van die Vereniging en sijn takke." ${ }^{91}$ Deur die finansiële ondersteuning van Afrikaanse opstelwedstryde, ${ }^{92}$

86 Rapport Weekliks, 12 Jun 2016, Ben du Toit, Moet liefs nie 1976-jeug en troepies vergelyk nie, 4-5.

87 Wat die HVKP betref was ds FX Roome (1928-1940), ds WA Landman (1941-1949) en Ds DPM Beukes (1949-1961) voorsitters. Na 1966 is die Helpmekaar Studiefonds vanaf 1994-2014 deur ds J van der Westhuyzen gelei. Benewens die voorsitters was daar oor die jare weinige jare wat daar nie ook predikante as gewone bestuurslede gedien het nie.

88 (HSA) HVKP, Notuleboek, 30 Mrt 1932, Kongres, 5.

89 (HSA) HVKP, Notuleboek, 3-4 Apr 1934, Kongres, 7.

90 (HSA) HVKP, Notuleboek, 30 Mrt 1932, Kongres, 5.

91 (HSA) HVKP, Notuleboek, 22-23 Mei 1918, Kongres, 5, Sentrale Bestuur verslag.

92 (HSA) HVKP, Notuleboek, 21-22, Mei 1919, Kongres, 8. 
eisteddfods, ${ }^{93}$ leeskamers, ${ }^{94}$ Bybelvertaling ${ }^{95}$ en die aandrang op tweetaligheid in die staatsdiens, ${ }^{96}$ die Suid-Afrikaanse Uitsaaikorporasie ${ }^{97}$ en die sakewêreld ${ }^{98}$ was die Helpmekaar deel van die proses om Afrikaans as taal te vestig en in die woorde van Isabel Hofmeyr by te dra tot "building a nation from words".99 Hul pogings tot die skepping van 'n Afrikaanse leefwêreld het ook die bevordering van 'n Afrikaner-historiese bewussyn ingesluit deur die ondersteuning van pogings tot die skryf en bewaring van 'n Afrikaner-geskiedenis soos blyk uit die volgende mosie wat eenparig deur die 1930-kongres aanvaar is:

"Die Kongres van die Helpmekaarvereniging op Uitenhage besef dat die deel van die verlede van Suid-Afrika wat tuisgebring word onder die hoof 'Konsentrasiekampe', die Afrikaner 'n besonder eie en baie heilige geskiedenis is, en dat dit die dure plig van die Afrikaner is om alle offisiële dokumente en stukke wat daarop betrekking het in bewaring te hou, maar dat ook die gedagtenis, volksoffers hoog en suiwer gehou word, en dra daarop aan die Sentrale Bestuur op om ondersoek in te stel en met die volgende Kongres 'n konsepvoorstel in te dien." 100

Afgesien van die finansiële ondersteuning vir pogings om die geskiedenis op te teken van die Rebellie, ${ }^{101}$ "Boere-oorlog", ${ }^{102}$ 'n Suid-Afrikaanse Geskiedenis, ${ }^{103}$ en die daarstelling van 'n databasis van konsentrasiekampsterftes ${ }^{104}$ is die skepping van 'n Afrikaner-historiese bewussyn

93 (HSA) HVKP, Notuleboek (21 Mei 1924-3 Apr 1928), 15 Jun 1927, Sentrale Bestuur, 189.

94 (HSA) HVKP, Notuleboek (13 Jun 1928-12 Des 1935), 10 Okt 1928, Sentrale Bestuur, 11.

95 (HSA) HVKP, Notuleboek, 25-26 Apr 1923, Kongres, 14; (HSA) HVKP, 7-8 Apr 1926, Kongres, Sentrale Bestuur verslag, 5 .

96 (HSA) HVKP, Notuleboek (13 Jun 1928-12 Des 1935), 15 Aug 1935, Sentrale Bestuur, 159; (HSA) HVKP, Notuleboek, 4-5 Apr 1950, Kongres, 31.

97 (HSA) HVKP, Notuleboek (15 Apr 1936-6 Des 1939), 25 Jun 1936, Sentrale Bestuur, 175; (HSA) HVKP, Notuleboek, 15-16 Apr 1936, Kongres, 11.

98 (HSA) HVKP, Notuleboek, 4-5 Apr 1928, Kongres, 13, 15; 30 Mrt 1932, Kongres, 5.

99 The penetrating analysis by Isabel Hofmeyr is the best source. Hofmeyr, 'Building a Nation from Words: Afrikaans language, literature and 'ethnic identity', 1902-1924', in S Marks and S Trapido (eds), The Politics of Race, Class and Nationalism in Twentieth Century South Africa. Harlow: Longman, 1987.

100 (HSA) HVKP, Notuleboek, 16-17 Apr 1930, Kongres, 4, 7.

101 (HSA) HVKP, Notuleboek (19 Mrt 1921-15 Apr 1924), 1 Okt 1920, Sentrale Bestuur, 49; 30 Jul 1921, Sentrale Bestuur, 28.

102 (HSA) HVKP, Notuleboek, 22-23 Mei 1918, Kongres, 4.

103 (HSA) HVKP, Notuleboek (28 Jun 1919-19 Feb 1921), 7 Aug 1920, Sentrale Bestuur, 110; (HSA) HVKP, Notuleboek, 25-26 Mei 1921, Kongres, Sentrale Bestuur verslag, 5.

104 (HSA) HVKP, Notuleboek (15 Apr 1936-6 Des 1939), 6 Des 1939, Sentrale Bestuur, 240; (HSA) HVKP, Notuleboek, (8 Feb 1940-9 Des 1966), 27 Mrt 1940, Sentrale Bestuur, 246. 


\section{Die Kaapse Helpmekaar}

en simboliek ondersteun. Pryse aan skoliere vir opstelle oor die Suid-Afrikaanse Geskiedenis, ${ }^{105}$ bydraes tot die oprigting van Afrikaner-monumente ${ }^{106}$ en agitasies om dae van simboliese historiese betekenis as nasionale vakansiedae erken te kry is voorbeelde in dié verband. ${ }^{107}$

Vir die Afrikaner se kroniese beleg was die Helpmekaar se konstante antwoord en oplossing: volksopbou deur onderwys en opvoeding. Soos reeds aangetoon, het die Helpmekaar in die kongresfase op drie vlakke 'n bydrae tot onderwys en opvoeding gelewer. Eerstens was dit as kampvegter vir die onderwysbehoeftes van Afrikaners op primêre en sekondêre onderwysvlak in terme van die verskaffing van verpligte en vry onderwys. Dit was 'n doelwit wat teen die sestigerjare grootliks bereik is. Tweedens was daar die verskaffing van beroepsvoorligting en 'n ondersteuningstelsel vir skoliere en studente in 'n periode toe die dienste minder vrylik beskikbaar was. Laastens was dit deur die verskaffing van finansiële ondersteuning aan studente deur middel van aanvanklik beurse en daarna studielenings. In die periode 1916-1966 het die Helpmekaarvereniging van die Kaapprovinsie 2393 studente met 'n totale bedrag van $£ 23642813$ s 6 d finansieel ondersteun. Van die totale aantal studente wat lenings ontvang het, was 1540 (64 persent) mans, 745 (31 persent) vroue en 108 (vyf persent) kon nie uit die beskikbare bronne geïdentifiseer word nie.

Benewens die onderwys en opvoedingshulp deur middel van beurse en lenings is die kongresera ook gekenmerk deur finansiële bydraes tot kulturele-, opvoedkundige- en welsynsinstellings en sake wat Afrikanerbelange bevorder en goedgesind was. Ten spyte van 'n bombardement van versoeke om hulp wat gewissel het van "'n karretjie om naar Kroonstad te gaan om te sien om aldaar 'n lewe te maak"108 tot geld "om skape te koop"109, 'n "Kafe" ${ }^{110}$ op te rig, "'n motor fiets te koop","11 "om 'n broeikas en opregte hoenders te koop"112 of "bokke ... en osse ... te koop"113 is

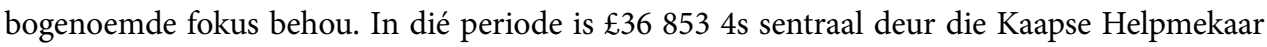

(HSA) HVKP, Notuleboek (28 Jun 1919-19 Feb 1921), 20 Des 1919, Sentrale Bestuur, 64-65.

106 (HSA) HVKP, Notuleboek (19 Mrt 1921-15 Apr 1924), 16 Feb 1923, Sentrale Bestuur, 153; (HSA) HVKP, Notuleboek (13 Jun 1928-12 Des 1935), 15 Aug 1935, Sentrale Bestuur, 158; Sentrale Bestuur, 29 Mrt 1932, 93; Sentrale Bestuur, 6 Des 1930, 72.

(HSA) HVKP, Notuleboek (19 Mrt 1921-15 Apr 1924), 1 Okt 1921, Sentrale Bestuur, 46; (HSA) HVKP, Notuleboek, 27-28 Mrt 1940, Kongres, 12.

108 (HSA) HVKP, Notuleboek (28 Jun 1919-19 Feb 1921), 28 Jun 1919, Sentrale Bestuur, 6.

109 (HSA) HVKP, Notuleboek (28 Jun 1919-19 Feb 1921), 20 Des 1919, Dagbestuur, 63.

110 (HSA) HVKP, Notuleboek (21 May 1924-3 Apr 1928), 1 Sep 1924, Sentrale Bestuur, 33.

111 (HSA) HVKP, Notuleboek (21 May 1924-3 Apr 1928), 23 Okt 1924, Sentrale Bestuur, 43.

112 (HSA) HVKP, Notuleboek (21 May 1924-3 Apr 1928), 2 Nov 1927, Sentrale Bestuur, 206.

113 (HSA) HVKP, Notuleboek (21 May 1924-3 Apr 1928), 3 Apr 1928, Sentrale Bestuur, 235.
} 
aan meer as 70 sake uitbetaal. Hierdie hulp was onder andere Die Wieg ('n tehuis vir ongehude moeders in Claremont), die Bond vir Maatskaplike Werk, konsentrasiekampkerkhowe, Suid-Afrikaanse Geskiedenispryse, Voortrekkerbeweging tot handelsklasse in die Paarl, die Skool vir Blindes in Worcester en die Universiteit van Stellenbosch. ${ }^{14}$ Hierdie bydraes het nie die reeks subsidies aan plaaslike takke vir die bevordeing van primêre onderwys en aanverwante sake soos skoolbiblioteke en leeskamers, waarna reeds verwys is, ingesluit nie. In 1951 het die kongres besluit om voortaan slegs skriftelike aansoeke om ondersteuning te oorweeg. ${ }^{115}$ Die besluit is in 1956 opgevolg met 'n besluit om voortaan al sy fondse vir studiehulp aan te wend ${ }^{116}$ en dat

"vir die getroue nakoming van die Helpmekaar se eie doelstellings en pligte, dit onmoontlik geword het om gereëlde skenkings te doen aan universiteite en ander liggame, hoe lofwaardig hulle doelstellings en verdienstelik hul werk ookal mag wees."117

Die besparing van $£ 500$ per jaar wat deur die besluit bewerkstellig is, sou voortaan vir studiehulp beskikbaar gestel word. ${ }^{118}$ Voortaan sou slegs in hoogs uitsonderlike gevalle bydraes gemaak word soos die R100 in 1961 aan Die Burger-Noodlenigingsfonds ${ }^{119}$ en die R1 000 aan die Universiteit van Port Elizabeth met sy stigting in 1964. In laasgenoemde geval was die kongres van mening dat:

"die stigting van die Universiteit van Port Elizabeth die geleentheid bied waar die Helpmekaar sy fondse met vrug kan gebruik op die terrein van sy eie doelstellings en wil die Helpmekaar graag meedoen aan die geskiedkundige gebeurtenis en sy beste wense oordra met die stigting van die Universiteit."120

114 (HSA) HVKP, Notuleboek, 4-5 Apr 1945, Kongres, 12; (HSA) HVKP, Notuleboek, 3-4 Apr 1929, Kongres, 5-7.

115 (HSA) HVKP, Notuleboek, 3-4 Apr 1951, Kongres, 11.

116 (HSA) HVKP, Notuleboek (8 Feb 1940-9 Des 1966), 12-13 Des 1957, Hoofbestuur, 499.

117 (HSA) HVKP, Notuleboek, 4-5 Apr 1956, Kongres, 8.

118 Ibid.

119 (HSA) HVKP, Notuleboek, 3 Apr 1961, Kongres, gp. Die bydrae tot die Fonds wat die vloedgeteisterde gebiede in die Noordweste moes ondersteun, is gemaak op grond van die "gulde bydraes wat die Helpmekaar al uit Noordwes-Kaapland ontvang het". Die Helpmekaar was dus van mening dat dit gepas was om "in hulle uur van nood weer aan hulle (te) dink." Die Burger, 7 Mrt 2000, 13, Vervloë vloed-tragedies.

120 (HSA) HVKP, Notuleboek, 1 Apr 1964, Kongres, gp. Die Helpmekaar se ondersteuning van die Universiteit met sy kontroversiële ontstaansgeskiedenis en die hand wat die NP en Broederbond daarin gehad het, was ook ' $n$ bevestiging van die Helpmekaar se tradisionele assosiasie met nasionaalgesinde Afrikanerdom en die ideale waarvoor dit gestaan het. In die geval van UPE: 'n tuiste vir Afrikanerstudente van die Oos-Kaap. R Fourie, Die hond wat nie geblaf het nie. 'n Analise van die Afrikaanse studente se stilswye aan die einde van die Universiteit van Port Elizabeth, 5-12. Ongepubliseerde Honneurstesis, Universiteit Stellenbosch, 2015. 


\section{Die Kaapse Helpmekaar}

Terwyl die bydrae wat die Helpmekaar deur sy kongres en sentrale bestuur (later hoofbestuur) tot onderwys en opvoeding gemaak het met groot akkuraatheid gekwantifiseer kan word, is die teenoorgestelde waar van die bydraes van die takke. Op takvlak is daar ook soos op sentrale vlak 'n hoofsaaklik tweeledige investering gemaak. Eerstens was dit finansiële bydraes tot plaaslike onderwys en opvoeding en tweedens was dit sosio-kulturele bydraes tot plaaslike kultuurbevordering onder Afrikaners. Dit het die ondersteuning van welsynsorganisasies ingesluit wat die Afrikaner goedgesind was. Takbydraes was egter geografies oneweredig en kronologies sporadies. Om hul bydrae te kwantifiseer is dus veel moeiliker as in die geval van Helpmekaar-ondersteuning wat sentraal befonds is. Die onvolledigheid van takverslae en die laksheid om verslae in te dien, asook die feit dat die bydraes van takke oor tyd op verskillende wyses en in verskillende kategorieë gerapporteer is dra hiertoe by. Die feit dat geen oorspronklike takverslae behoue gebly het nie speel ook'n rol.

Dit beteken egter nie dat takke nie 'n betekenisvolle bydrae op plaaslike vlak tot onderwys, opvoeding (op primêre en sekondêre skoolvlak) en algemene kultuurbevordering gelewer het nie. Ten spyte van bogenoemde probleme om hul bydrae te kwantifiseer is dit tog moontlik om uit die gegewens wat wel beskikbaar is in jaarlikse kongresverslae 'n idee te kry van die bydraes wat hul gelewer het. Vir die periode 1937-1958 moes takke rapporteer hoeveel geld hulle jaarliks plaaslik aan opvoeding spandeer het. Uit die beskikbare inligting het Helpmekaartakke in die periode $£ 28167$ 13s 5d plaaslik in dié kategorie spandeer. Soos reeds angedui, is hierdie geld aangewend om in behoeftes soos skoolgeld, boeke, koshuisfooie en skoolklere vir plaaslike behoeftige leerlinge te voorsien. Die omvang van plaaslike behoeftes was moeilik om te bepaal en het oor tyd en ook geografies gewissel. Beskikbare getuienis dui daarop dat die plaaslike takke aan wesenlike onderwysbehoefte voorsien het. Vir die periode 1941-1958 moes takke rapporteer oor die hoeveelheid aansoeke wat ontvang is wat hulp soek, asook die getal persone wat jaarliks deur hulle gehelp is. Uit die 48 takke wat gedurende hierdie periode hieroor gerapporteer het, is in totaal 6919 aansoeke om hulp ontvang en 6135 persone gehelp. As dit as maatstaf gebruik word, het takke daarin geslaag om te voorsien in gemiddeld 89 persent van die plaaslike versoeke wat hulle ontvang het.

Die beskikbare gegewens vir bogenoemde periode (1941-1958) dui ook op 'n verstedeliking van plattelandse armoede. Die Port Elizabeth/Uitenhage-kompleks (wat uit vyf takke, naamlik Port Elizabeth (PE), PE-Noord, PE-Wes, Uitenhage en Uitenhage-Kirkwood bestaan het) was verantwoordelik vir 26 persent (1 808 van 6919 versoeke) van die versoeke om hulp wat ontvang is. In hierdie geval was die behoefte na Helpmekaar- ondersteuning waarskynlik die dryfveer agter die groot ondersteuning wat die takke in die Port Elizabeth/Uitenhage-kompleks ontvang het. Die gemiddelde gesamentlike jaarlikse ledetal van die PE/Uitenhage-kompleks was 592 
(teenoor slegs enkele ander Helpmekaartakke wat vir enige volhoubare periode 100 lede of meer kon handhaaf) met 'n gemiddelde jaarlikse opbrengs van 28 sjielings per lid. Die entoesiasme waarmee hier vir die Helpmekaar op plaaslike vlak gewerk is en die merkwaardige opbrengs per lid per jaar ten spyte van die armoede, ${ }^{121}$ word duidelik as dit met die posisie van die Malmesburytak vergelyk word. Die Malmesbury-tak was tradisioneel een van die aktiefste Helpmekaartakke en het 'n vooruitstrewende gemeenskap bedien. (Tydens die 1917-fondsinsameling het die Malmesbury-distrik die meeste $£ 100$-bydraes in die land opgelewer.) As individuele tak het hulle verreweg die meeste versoeke om hulp in die 1941-1958 periode ontvang (1058 van 6919 of 15 persent). Dit was waarskynlik enersyds die gevolg van die sterk en entoesiastiese besture wat die tak oor jare bedien het, die middele waartoe hulle toegang gehad het, asook die relatiewe aard of definisie van armoede of behoeftigheid. Behoeftigheid in Malmesbury was nie noodwendig dieselfde as behoeftigheid in Port Elizabeth/Uitenhage nie. Die Malmesbury-tak het in die tydperk onder bespreking 'n gemiddelde jaarlikse ledetal van 195 gehandhaaf wat in Helpmekaar-terme uitsonderlik was. Ten spyte van hul groot ledetal en die relatiewe gegoede omgewing waarbinne hulle gefunksioneer het, het Malmesbury 'n gemiddelde jaarlikse opbrengs per lid van 15 sjielings opgelewer. Dit was 'n syfer wat deur die 28 sjielings per lid van die PE/Uitenhage-kompleks in die skadu gestel word. (Dit is weer deur byvoorbeeld die Paarl-tak met sy gemiddelde jaarlikse ledetal van 53 se 56 sjielings per lid per jaar oorskadu.)

Alle takke het nie dieselfde patroon gevolg nie en die breë algemene tendens van die aansoeke om hulp was hoog in die veertigerjare. 'n Hoogtepunt is teen die laat veertiger- en vroeë vyftigerjare bereik waarna dit drasties afgeneem het. 'n Paar voorbeelde in dié verband: Malmesbury het in 1951 'n hoogtepunt van 128 versoeke gehad en slegs 40 teen 1958; Murraysburg het 19 in 1949 en slegs een teen 1958 gehad en PE het in 'n 1951 'n hoogtepunt van 80 gehad en slegs 12 teen 1958. Hierdie tendens by Helpmekaar-takke stem in die breë ooreen met die toenemende voorspoed van Afrikaners wat in 1956 deur prof CGW Schumann in 'n Die Burger-artikel (Afrikaners raal ál welvarender ${ }^{122}$ ) beskryf is en ook die tema gevorm het van Grundlingh

121 Port Elizabeth het van die grootste toestromings van arm plattelandse Afrikaners in die eerste dekades van die 20ste eeu ervaar. Dr Muir, die SGO van Kaapland het reeds in 1913 geskryf dat PE "were receiving a larger proportion of the bywoner class than any other town in South Africa. It was very well to talk about paying for education but when the Government paid men 3/6 a day on the railways, those men could not pay for education." (Eastern Province Herald, 19 Jul 1913). Dr NJ van der Merwe het as jong proponent in PE in 1914 as volg die armoede bevestig in 'n brief aan sy toekomstige eggenote: "O, die verskriklike armoede en treurigheid wat ek vandag gesien het en waarvan ek gehoor het, is genoeg om 'n taamlike biblioteek van treurspele en treurromans te vul. Soveel trane, soveel nood en ellende! ... Ek het geen idee gehad dat Port Elizabeth soveel arm mense het en dat soveel van hulle Hollandssprekendes is nie ... Ek wens ek kon jou by 'n paar huise gebring het net om te sien wat 'n moeder kan ly ... "(GD Scholtz, $d r$ Nicolaas Johannes van der Merwe, 1888-1940, 40-41.) Beide gedeeltes soos aangehaal in HO Terblanche, Die Afrikaner in Port Elizabeth, 1902-1937: 'n Kultuurhistoriese Ondersoek, 29-31, PhD, Universiteit van Port Elizabeth, 1993. 
se 2008-artikel. Die voorspoed was die gevolg van 'n kombinasie van volgehoue amptelike regeringsinisiatiewe en nie-regeringsinisiatiewe uit die burgerlike samelewing oor 'n wye front oor dekades. Helpmekaartakke het in die gemeenskappe waarin hulle werksaam was deur hul fokus op onderwys en opvoeding as kuur vir armoede ook hiertoe 'n bydrae gelewer. In die woorde van die Helpmekaar-tak van PE:

"As a society we believe that the salvation of a nation lies in the education of its youth ...

The only solution is to animate and educate the children of these less fortunate people, and all these problems of poverty and poor whites will disappear". ${ }^{123}$

Benewens die finansiële investering in onderwys en opvoeding het plaaslike takke ook op kulturele gebied 'n beduidende bydrae gelewer. Hoewel die bydraes in intensiteit en ook oor tyd van tak tot tak verskil het, het feitlik alle takke dié doelstelling van Helpmekaar probeer nastreef. Dit is onmoontlik om die impak daarvan te kwantifiseer. Daar word dus volstaan met Terblanche se evaluering in sy studie oor die Afrikaner in Port Elizabeth van die Helpmekaar se bydrae in dié verband:

"Die Helpmekaar het ook veel gedoen om die Afrikaanse kultuur in Port Elizabeth te bevorder. Die plaaslike tak het gewoonlik so vyf of ses vergaderings per jaar gehou, waarheen die publiek ook hartlik uitgenooi is. 'n Groot verskeidenheid nommers is aangebied. Daar was musiek- en liedjiesaande, voordragte, sang, lesings, debatte en dies meer. Die Helpmekaar het ook Afrikaanse toneelstukke opgevoer ... 'n Belangrike kulturele bydrae van die Helpmekaar was die jaarlikse viering in November van Afrikaneraand, wat die samehorigheidsgevoel onder die plaaslike Afrikaners versterk het. By so 'n byeenkoms het die geleentheidspreker gewoonlik die woord oor die bestaanstryd van die Afrikaner gevoer. Die toehoorders is gemaan om hul identiteit as Afrikaners te behou, hul eie te handhaaf en hulself in die gemeenskap te laat geld ... Die plaaslike tak het beslis sý deel bygedra om die Afrikaner in die stad van sy kultuureie bewus te maak." ${ }^{24}$

Helpmekaartakke het dus ook as plaaslike kulturele entrepreneurs gefunksioneer wat die draaiboek van 'n "Afrikanerkultuur" - die "kultuureie" - help skryf en inoefen het.

123 Eastern Province Herald, 23 Sep 1925 soos aangehaal in HO Terblanche, Die Afrikaner in Port Elizabeth, 1902-1937: 'n Kultuurhistoriese Ondersoek, 382, PhD, Universiteit van Port Elizabeth, 1993.

124 HO Terblanche, Die Afrikaner in Port Elizabeth, 1902-1937: 'n Kultuurhistoriese Ondersoek, 191, 383-384, $\mathrm{PhD}$, Universiteit van Port Elizabeth, 1993. 


\section{HELPMEKAAR STUDIEFONDS, 1966-C.2014}

"Die seuns en dogters van ons volk moet hulle bekwaam vir die toekoms sodat hulle nie altyd houthakkers en waterdraers mag wees nie." 125

Ad hoc-toekennings en skenkings in reaksie op spesifieke versoeke of noodlenigingsomstandighede is in die post-amalgamasie-era voortgesit. Deur die sake wat ondersteun is, het die Helpmekaar sy verknogtheid en intieme verweefdheid met Afrikaner belange, hoofstroom instellings, beleidsrigtings wat die belange bevorder en in stand gehou het, bevestig. Die bydraes het in hoofsaaklik vier breë kategorieë geval. Eerstens ondersteuning van die NG Kerk sendingaksies of verwante aktiwiteite. Dit het skenkings ingesluit aan instansies soos die NG Kerk se teologiese skool vir die opleiding van predikante van die NG Kerk in Afrika by Decoligny $^{126}$ (R1 500 jaarliks vir die toekenning van beurse). ${ }^{127}$ Daar was ook Mfesani, die nywerheidstigting van die NG Kerk in Ciskei vir swart mense wat uit die Skiereiland na Ciskei teruggestuur is, ${ }^{128}$ asook vir die werk wat hulle in Khayelitsha gedoen het ${ }^{129}$ en dan skenkings (R3 000) aan die Hugenote Kollege Beursfonds vir die opleiding van Christelike maatskaplike werkers of werksters. ${ }^{130}$

Op kultuurvlak is veral ondersteuning verleen aan inisiatiewe wat Afrikaans bevorder het. Dit sluit in Die Taalinstituut wat deur die Universiteit van Stellenbosch gestig is (R7 500), ${ }^{131}$ die beskikbaarstelling van R1 000 per jaar aan die FAK vir die aanwending van 'n prestigeprys vir die beste ontspanningslektuur van die jaar, ${ }^{132}$ 'n skenking van R10 000 aan die Hugenote Gedenkskool Restourasie Fonds vir die herstel van die skool waar bekendes soos AG Visser,

125 Uitspraak van mnr De Kock, voorsitter en ere-president van die PE Helpmekaartak. Die Patriot, 12 Jul 1929 soos aangehaal in HO Terblanche, Die Afrikaner in Port Elizabeth, 1902-1937: 'n Kultuurhistoriese Ondersoek, 383, PhD, Universiteit van Port Elizabeth, 1993.

126 (HSA) HS, Notuleboek (16 Feb 1973-10 Sept 1993), 13 Feb 1976, Jaarvergadering, 33; 7 Des 1976, Uitvoerende Komitee (UK), 39.

127 (HSA) HS, Notuleboek (16 Feb 1973-10 Sept 1993), 10 Feb 1978, Jaarvergadering, 48.

128 (HSA) HS, Notuleboek (16 Feb 1973-10 Sept 1993), 24 Aug 1983, UK, 72.

129 (HSA) HS, Notuleboek (16 Feb 1973-10 Sept 1993), 17 Nov 1987, UK, 92.

130 (HSA) HS, Notuleboek (16 Feb 1973-10 Sept 1993), 15 Jan 1981, UK, 58; 13 Feb 1981, Jaarvergadering, 61.

131 (HSA) HS, Notuleboek (16 Feb 1973-10 Sept 1993), 13 Feb 1976, Jaarvergadering, 33; 10 Feb 1978, Jaarvergadering, 49.

132 (HSA) HS, Notuleboek (16 Feb 1973-10 Sept 1993), 16 Jul 1982, UK, 69; 14 Feb 1986, Jaarvergadering, 86. 


\section{Die Kaapse Helpmekaar}

Totius, DF Malherbe en dr Izak Perold leerlinge was, ${ }^{133}$ die Stigting vir Afrikaans, ${ }^{134}$ die Simon van der Stel Stigting, ${ }^{135}$ die Tygerberg Kinderkoor, ${ }^{136}$ die Voortrekkerbeweging ${ }^{137}$ en die FAK. ${ }^{138}$

Op politieke vlak het die Helpmekaar se assosiasie met die NP voortgeduur en is praktiese bewyse hiervan die bydraes tot die NP van Kaapland se fondsinsamelingspogings vir hul Trustfonds om die toenemende administratiewe uitgawes van die party te dek. ${ }^{139}$ Die fonds is in 1978 deur PW Botha, die nuwe eerste minister, van stapel gestuur. Die motivering vir die skenking van R2 $500^{140}$ deur die Helpmekaar het ingespeel op al die politieke retoriek van die tydperk:

"Die Voorsitter wys op die bydrae wat die NP deur sy takke gedoen het tydens die insameling vir die rebelle-fonds, en vra of ons nie die Party moet steun noudat hy self met 'n groot insamelingsveldtog besig is nie. Ander sprekers wys op die totale aanslag op die regering, en sê dat dit in werklikheid'n aanslag op die Afrikanervolk self is en dat die Party gesterk moet word om die aanslag af te weer. Die Helpmekaar is die eiendom van die volk en die Helpmekaar het derhalwe hier 'n plig om na te kom. Die trustakte maak ook voorsiening vir sulke skenkings. Die vergadering besluit om 'n bedrag van R2 500 te skenk."141

Die Helpmekaar se ondersteuning vir die NP se fondsinsamelingspoging het egter nie met die eerste skenking geëindig nie. Met die organiseerders van die veldtog wat begin twyfel het of die gestelde mikpunt van R1 miljoen teen einde September 1979 bereik sou word, het Die Burger deur sy beriggewing oor die fonds en die rapportering van die bydraes in sy kolomme 'n spesiale poging aangewend om entoesiasme vir die insameling op te wek. Benewens die oproep is ook besluit om voortaan die bydraes op 'n daaglikse basis in Die Burger te rapporteer. ${ }^{142} \mathrm{Na}$ dié hernude oproep om steun in Die Burger op 18 September het die Helpmekaar deur middel van 'n telefoonvergadering op 20 September besluit om 'n

133 (HSA) HS, Notuleboek (16 Feb 1973-10 Sept 1993), 19 Jun 1974, UK, 21; 15 Feb 1985, Jaarvergadering, 82.

134 (HSA) HS, Notuleboek (16 Feb 1973-10 Sept 1993), 18 Mei 1992, Telefoonvergadering, 119.

135 (HSA) HS, Notuleboek (16 Feb 1973-10 Sept 1993), 31 Okt 1979, Telefoonvergadering, 55.

136 (HSA) HS, Notuleboek (16 Feb 1973-10 Sept 1993), 15 Feb 1980, Jaarvergadering, 57.

137 (HSA) HS, Notuleboek (16 Feb 1973-10 Sept 1993), 25 Mei 1981, UK telefoonvergadering, 64.

138 (HSA) HS, Notuleboek (16 Feb 1973-10 Sept 1993), 12 Feb 1982, Jaarvergadering, 67.

139 Die Burger, 13 Feb 1979, Die NP se fonds groei stewig, 1.

140 Die Burger, 23 Mrt 1979, NP-Trustfonds, 1.

141 (HSA) HS, Notuleboek (16 Feb 1973-10 Sept 1993), 9 Feb 1979, Jaarvergadering, 53.

142 Die Burger, 18 Sept 1979, Nou 'n hupstoot vir R1 miljoen (hoofartikel), 10; Laaste Groot Poging vir NPFonds, 1. 
verdere R15 000 tot die fonds by te dra. ${ }^{143}$ Die bydrae is op 24 September as 'n anonieme bydrae in Die Burger erken. ${ }^{144}$ Daar kan slegs gespekuleer word oor die anonimiteit van die bydrae. Terwyl die eerste bydrae van R2 500 nie substansieel genoeg was om openbare reaksie uit te lok nie sou 'n tweede bydrae van R15 000 moontlik negatiewe gevolge kon inhou.

Dit is gedoen in 'n periode van skerp stygende studiekostes en 'n afname in die vraag na studielenings. So 'n groot bydrae kon die Helpmekaar ook in die maalkolk van die politieke verdeeldheid van die post-Inligtingskandaal periode laat beland het. Die ondersteuning van die NP Trustfonds was 'n duidelike keuse deur die Helpmekaar vir PW Botha se hervormings gesinde inisiatiewe en was teen die verkrampte benaderinge. ${ }^{145}$ Dit het egter nie PW Botha verhoed om in sy toespraak tydens die NP van Kaapland se kongres in Parow op 25 September 1979 die sukses van die NP Trustfonds-insameling te vergelyk met die "groot dade van die verlede soos die stigting van die Helpmekaar-fonds"146 nie.

'n Laaste kategorie van bydraes was die ondersteuning van Die Burger-geleide insamelingsveldtogte van uiteenlopende aard - 'n tradisie deur Die Burger wat juis met die Helpmekaarinsamelingsveldtog in 1917 gebore is. Dit was soos dié vir sending, ${ }^{147}$ die Rampfonds vir noodleniging in die Bolandse Dorpe wat deur die 1969-aardbewing getref is, ${ }^{148}$ Die Burger Kersfonds $^{149}$ en die Bybelgenootskap. ${ }^{150}$

In die opmaak van 'n balansstaat van Helpmekaar bydraes en impak, verdwerg die investering van die Helpmekaar in studielenings aan studente vir tersiêre opleiding oor 'n periode van bykans 'n eeu die impak van alle ander bateklasse in die arsenaal van bydraes deur die Kaapse Helpmekaar. Dit verteenwoordig ook die Kaapse Helpmekaar se kernbesigheid en dié aktiwiteit wat mettertyd sy volle strategiese, administratiewe en fondswerwingsenergie in beslag geneem het. Dit verteenwoordig die een konstante aktiwiteit in die geskiedenis van die Kaapse Helpmekaar. Dié Helpmekaar-aktiwiteit wat die akkuraatste numeries gekwantifiseer

143 (HSA) HS, Notuleboek (16 Feb 1973-10 Sept 1993), 20 Sept 1979, Telefoonvergadering, 54.

144 Die Burger, 24 Sept 1979, NP-Fonds vat-vat aan R1 miljoen, 1, 4.

145 Die Burger, 25 Sept 1979, NP se fonds verby R1 miljoen, 1; Die Burger, 25 Sept 1979, Dit is 'n triomf (Hoofartikel), 12.

146 Die Burger, 25 Sept 1979, NP se fonds verby R1 miljoen, 1.

147 (HSA) HS, Notuleboek (19 Jan 1967-16 Feb 1973), 16 Feb 1968, Direksie, gp.

148 (HSA) HS, Notuleboek (19 Jan 1967-16 Feb 1973), 17 Jul 1969, Dagbestuur, gp.

149 (HSA) HS, Notuleboek (16 Feb 1973-10 Sept 1993), 4 Nov 1974, Direksie telefoonvergadering, 22; 28 Nov 1978, UK, 52; 28 Nov 1979, Telefoonvergadering, 56.

150 (HSA) HS, Notuleboek (16 Feb 1973-10 Sept 1993), 25 Mrt 1982, UK telefoonvergadering, 68. 
kan word, maar terselfdertyd die aktiwiteit waarvan die impak onmeetbaar of onbepaalbaar is - maar tog die belangrikste bydrae wat die Helpmekaar gelewer het, bly.

Daar is reeds vroeg tydens die aanvangsjare van die Helpmekaar besluit om te kyk hoe die armblankekwessie opgelos kan word deur opheffing deur onderwys en opvoeding en mettertyd te fokus op naskoolse tersiêre opleiding. Dit het getuig van 'n oortuiging dat die armblankekwessie struktureel aangespreek moes word en dat slegs langtermyn oplossings blywende resultate sou lewer. Ten spyte van periodieke druk, ook vanuit eie geledere, om oor dié benadering te herbesin, is met groot idealisme hiermee volhard.

Met die voordeel van terugskoue, kan vandag onomwonde verklaar word dat dit die regte keuse was en van 'n besondere insig getuig het. In 2016 beskik ons immers oor die insigte van die Organization of Economic Co-operation and Development (OECD) ${ }^{151}$ se 2012-verslag oor die impak van 'n belegging in tersiêre opleiding op individue, asook state. Die Helpmekaarbesluitnemers het nie in die onstaantydperk van die Helpmekaar oor die resultaat van hierdie gesofistikeerde navorsing beskik nie. Volgens die 2012-verslag van die OECD word die langtermyn ekonomiese voordeel vir 'n individu wat oor 'n tersiêre graad beskik teenoor individue wat slegs oor sekondêre skoolopleiding beskik op USD 175000 vir mans en USD 110000 vir vrouens bereken. Die langtermyn ekonomiese voordeel vir individue met 'n tersiêre opleiding is gemiddeld ongeveer twee maal groter as vir individue daarsonder. Volgens die verslag bevoordeel 'n tersiêre opleiding nie net die individu nie, maar ook die breër gemeenskap. Die netto opbrengs op die geld van belastingbetalers wat vir die tersiêre opleiding van 'n individu spandeer word, word deur die OECD op USD 91000 vir 'n man en USD 55000 in die geval van 'n vrou bereken. Die OECD-verslag kom dus tot die gevolgtrekking dat:

"The long-term economic benefits of investing in higher education have been good for both individuals and countries - and will probably remain so in the future, as long as societies need more high-level skills."152

151 Die OECD het amptelik in 1961 tot stand gekom en bestaan vandag uit 34 lidlande vanoor die hele wêreld. Die doel van die organisasie is om ekonomiese ontwikkeling aan te moedig en lidlande ondersteun mekaar wedersyds deur ondersoeke en navorsing om uitdaging in dié verband te bowe te kom. http://www.oecd. org/about/history/; http://www.oecd.org/

152 Education Indicators in Focus, 2012/06 (Jun). https://www.oecd.org/edu/skills-beyond-school/ Education\%20Indicators\%20in\%20Focus\%206\%20June\%202012.pdf 
FIGUUR 1: AANTAL LENINGS PER JAAR TOEGEKEN, 1919-2014 (TOTAAL: 8 381)

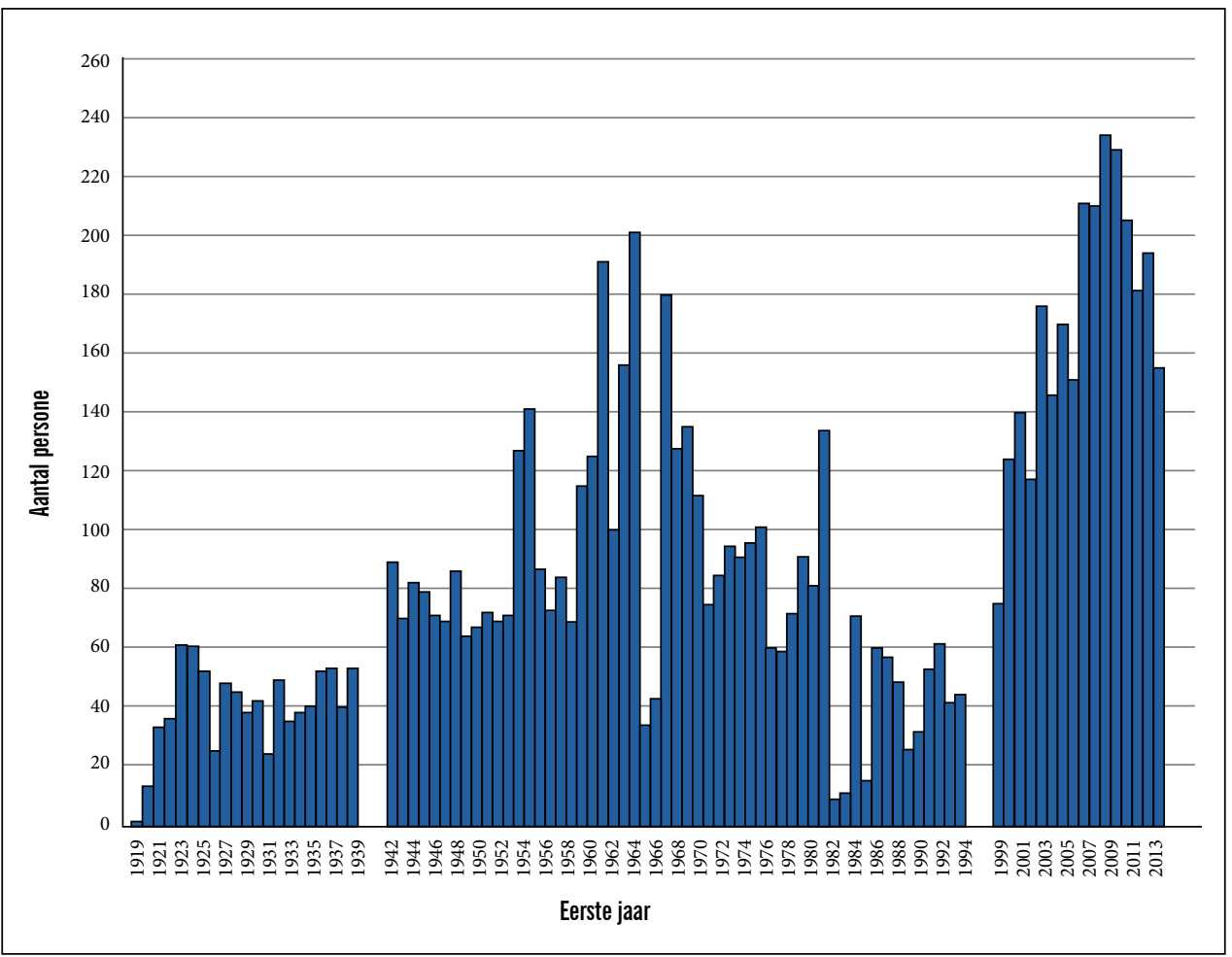

Vir die periode 1916-2014 het die Kaapse Helpmekaar 8381 studente met studielenings ondersteun. Indien die impak hiervan in terme van die OECD se 2012-verslag in 2012 waardes uitgedruk word, het die Kaapse Helpmekaar in totaal USD $1254190000^{153}$ in die vorm van ekonomiese voordeel tot die studente toegevoeg terwyl die staat 'n opbrengs van USD $644987000^{154}$ op sy investering ontvang het. Die patroon waarvolgens hierdie waarde oor die bestaansperiode van die Kaapse Helpmekaar toegevoeg is, kan waarskynlik die beste geilllustreer word deur die histogram van lenings wat jaarliks toegeken is (sien figuur 1). Die histogram is ook 'n weerspieëling van die aanvraag na lenings oor tyd en die Helpmekaar se vermoë om daarin te kon voorsien. Dit is dus ook 'n refleksie van hulle finansiële welstand en groei oor tyd soos in die voorafgaande hoofstukke bespreek is.

153 Die bedrag was R18 109374829 uitgedruk in Suid-Afrikaanse rand (R) teen die wisselkoers van 23 Jun 2016 (R14.44 vir \$1).

154 Die bedrag was R9 313031791 uitgedruk in Suid-Afrikaanse rand (R) teen die wisselkoers van 23 Jun 2016 (R14.44 vir \$1). 


\section{FIGUUR 2: GEOGRAFIESE VERDELING VAN LENINGS VOLGENS PROVINSIES (EN ENKELE LANDE)}

Ten spyte van die deurlopende debat in Helpmekaar-geledere oor die provinsiale grense van Helpmekaar-ondersteuning en die vrees dat teveel hulp aan studente buite die Kaaplandse grense, veral aan Transvaalse studente, verleen word, word aangetoon in die volgende analise van die provinsiale verspreiding van Helpmekaar- studielenings 92 persent (4 956) van alle lenings is aan Kaaplandse studente toegeken met slegs vier persent (236) van alle lenings aan Transvaalse studente (sien figuur 2).

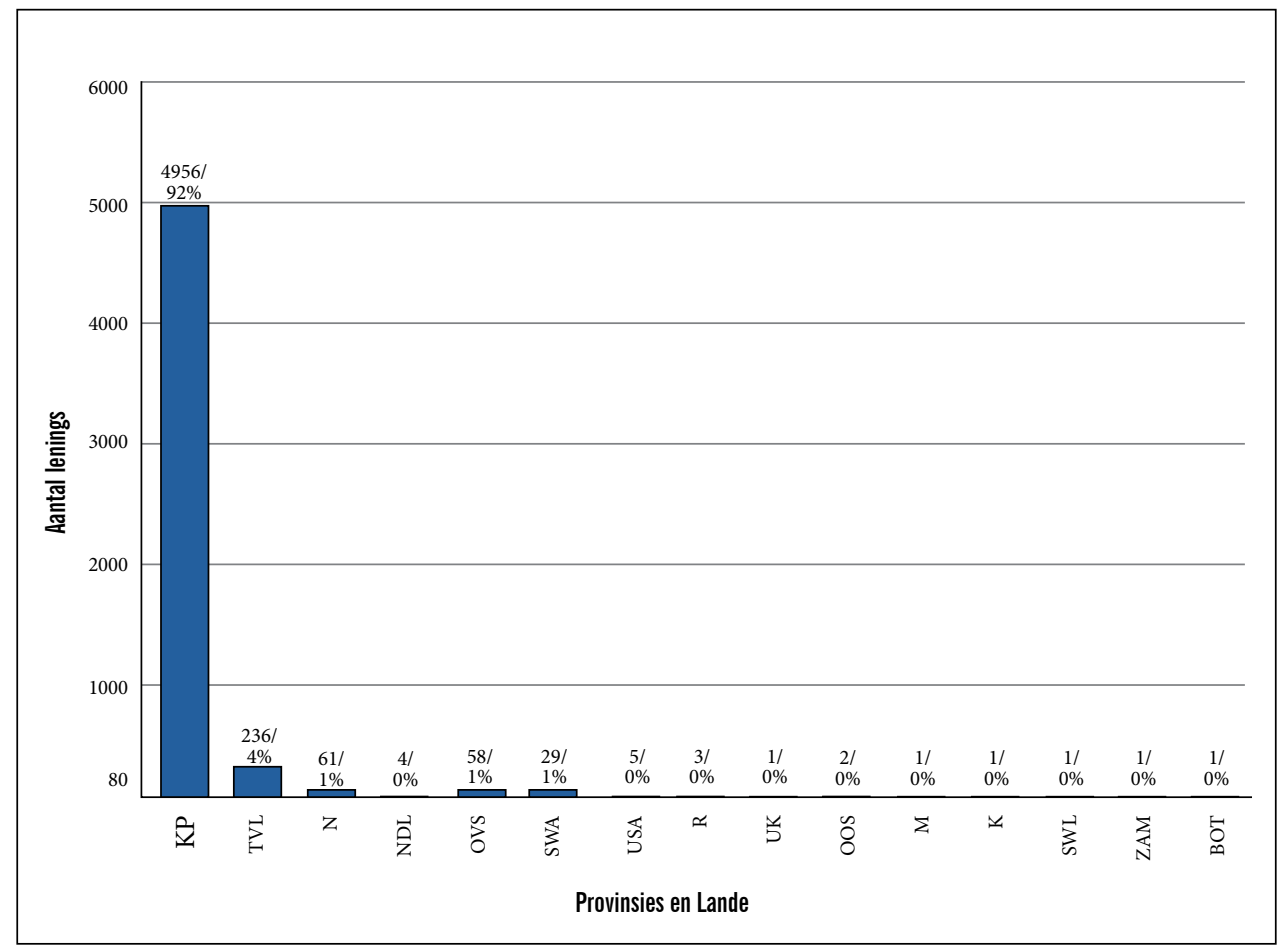

\section{Sleutel:}

Kaapprovinsie (KP); Transvaal (Tvl); Natal (N); Nederland (Ndl); Oranje-Vrystaat (OVS); Suidwes-Afrika/Namibië (SWA); Amerika (USA); Rhodesië/ Zimbabwe (R); Verenigde Koninkryk (UK); Oostenryk (Oos); Malawi (M); Kenia (K); Swaziland (Swl); Zambië (Zam); Botswana (Bot). 


\section{FIGUUR 3: GEOGRAFIESE TOEKENNING VAN LENINGS VOLGENS SIRKELS VAN HELPMEKAARVERENIGING VAN DIE KAAPPROVINSIE}

Wat die verspreiding van lenings binne die Kaapprovinsie betref, is daar tydens die kongresera gepoog om ten opsigte van die vereniging se toekenning van lenings, 'n regverdige verspreiding tussen die verskillende takke te verkry. Takke is in agt groepe of sirkels verdeel. $\mathrm{Na}$ amalgamasie het geografie binne die Kaapprovinsie nie meer' $n$ rol gespeel in die toekenning van lenings nie. Indien die geografiese verdeling van alle lenings wat deur die Kaapse Helpmekaar toegeken is, geanaliseer word volgens die sirkelverdelings van die Vereniging, vertoon dit die patroon van bevolkingskonsentrasies wat deur Afrikaner-verstedeliking teweeggebring is. Die oorgrote meerderheid van die lenings is dus aan studente afkomstig uit die dorpe in die Kaapse Skiereiland en Port Elizabeth/Uitenhage se stedelike komplekse toegeken (sien figuur 3).

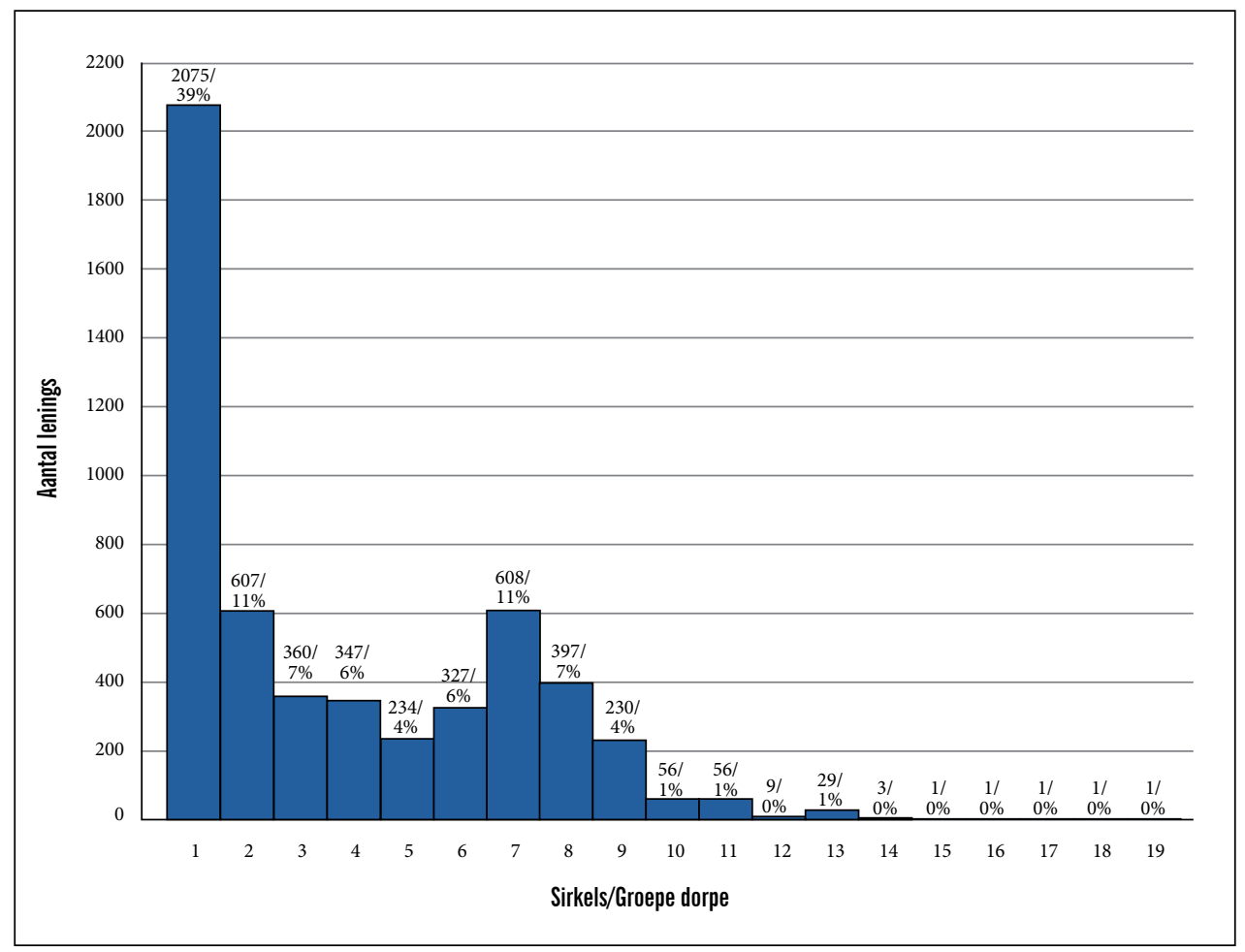




\section{Sleutel:}

Sirkel 1: $\quad$ Kaapstad, Malmesbury, Stellenbosch, Strand, Somerset-Wes, Wynberg, Goodwood, Tygerberg, Tiervlei, Parow, Bellville, Durbanville.

Sirkel 2: $\quad$ Paarl, Wellington, Villiersdorp, Ceres, Riversdal.

Sirkel 3: $\quad$ Victoria-Wes, Beaufort-Wes, Loxton, Carnarvon, Britstown, Kakamas, Murraysburg.

Sirkel 4: $\quad$ Kimberley, Du Toitspan, Petrusville, Colesberg, De Aar, Vryburg, Douglas

Sirkel 5: $\quad$ Cradock, Hofmeyr, Middelburg, Steynsburg, Noupoort.

Sirkel 6: Burgersdorp, Venterstad, Aliwal-Noord, Molteno, Cathcart, Dordrecht, Lady Grey, Indwe.

Sirkel 7: $\quad$ Port Elizabeth, Uitenhage, Riebeeck-Oos, Kirkwood, Oos-Londen, Sunland, Bedford, Steytlerville, Port Elizabeth-Noord, Port Elizabeth-Wes, Alexandria.

Sirkel 8: $\quad$ Graaff-Reinet, Aberdeen, Uniondale, George, Mosselbaai.

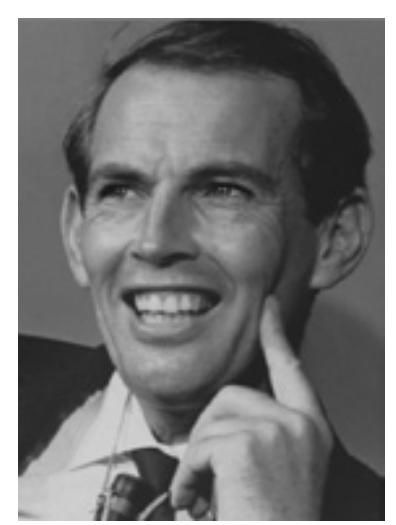

Dr Christiaan Barnard wat die eerste hartoorplanting in die wêreld gedoen het. Barnard was ' $n$ ontvanger van ' $n$ Helpmekaar lening.

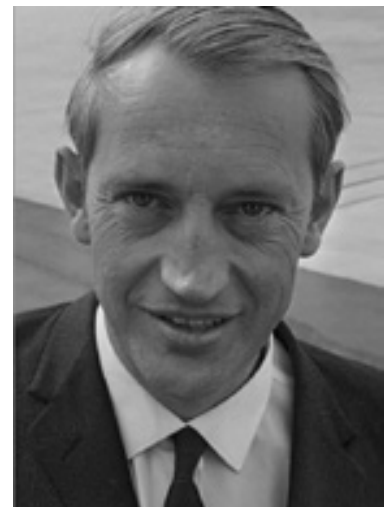

Dr Marius Barnard broer van Christiaan Barnard en deel van die hartspan wat die eerste hartoorplanting gedoen het. Barnard was ' $n$ ontvanger van 'n Helpmekaar lening.

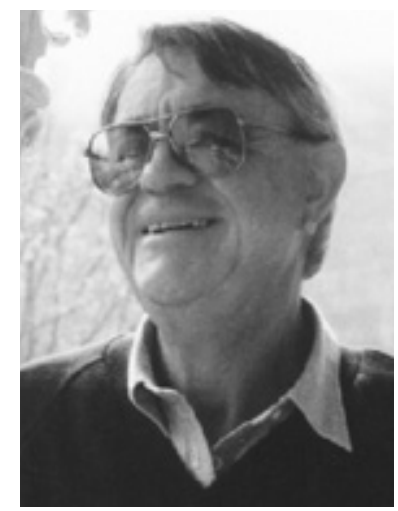

Dr MC Botha die derde lid van die hartspan van Christiaan Barnard wat met ' $n$ Helpmekaarlening studeer het. 


\section{FIGUUR 4: AKADEMIESE VERSUS TEGNIESE OPLEIDING}

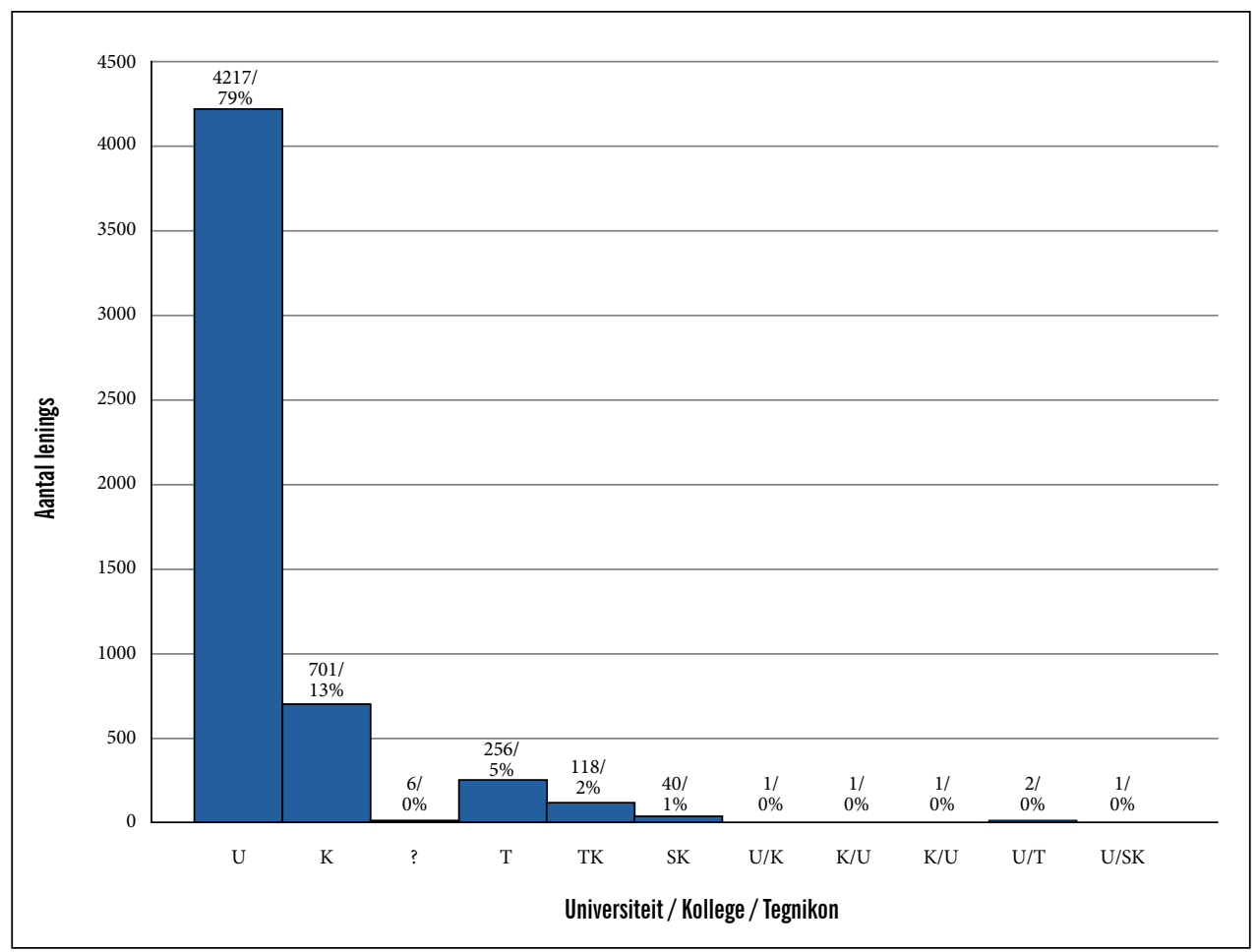

\section{Sleutel:}

- Universiteit (U)

- $\quad$ Kollege (hoofsaaklik onderwyskollege) (K)

- $\quad$ Tegnikon (T)

- $\quad$ Tegniese Kollege (TK)

- $\quad$ Skool (SK)

Die Helpmekaar se fokus op opheffing deur onderwys en opvoeding en die spesifieke fokus van sy studielenings op tersiêre onderrig word deur figuur 4 geïllustreer. Die oorheersende fokus op universitêre opleiding binne die tersiêre sektor is duidelik met 79 persent van alle studielenings wat hiervoor toegeken is. Indien in ag geneem word dat die kollege-kategorie (13 persent) hoofsaaklik die onderwyskolleges behels het, word die keuse vir akademiese teenoor meer tegniese rigtings nog meer oorheersend. Die Helpmekaar bestuurder het eers in sy jaarverslag van 1988 melding gemaak van " $n$ beduidende en verblydende swaai weg van universiteite 
na die technikons van studente wat in die verlede gedwing het na die universiteite ten spyte van middelmatige matrieksimbole". ${ }^{155}$ Die tegnikon- en tegniese kolleges-kategorieë het eers werklik sigbaar geregistreer in die toekenning van Helpmekaar lenings aan sulke studente na die Helpmekaar se doelbewuste pogings in die negentigerjare om entrepreneurskap te bevorder en sy besluit om sy hulpprogram te verbreed om ook nie-akademiese kursusse en nie-gematrikuleerde studente in te sluit. Hierdie "daling" in universiteitsopleiding was egter van korte duur, aangesien die lenings vir universiteitsopleiding teen 2006/7 weer 80 persent of meer van toegekende lenings uitgemaak het (sien figuur 5).

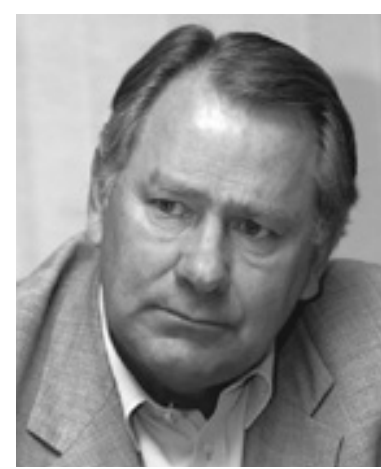

Frederik van Zyl Slabbert. Akademikus en politikus en ontvanger van 'n Helpmekaar lening.

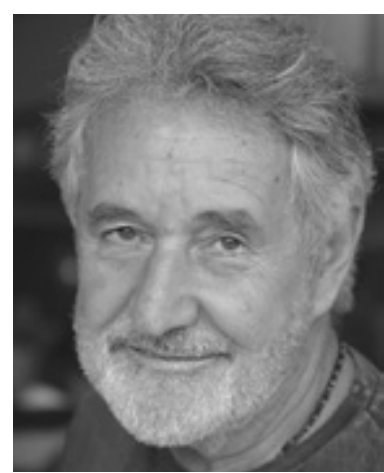

Breyten Breytenbach, digter, skrywer en aktivis en ontvanger van

'n Helpmekaar lening.

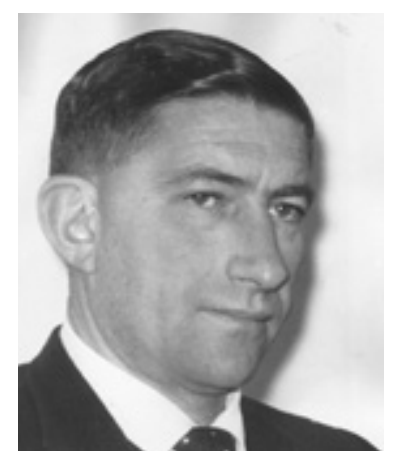

Piet Koornhof.

Politikus en ontvanger van 'n Helpmekaar lening.

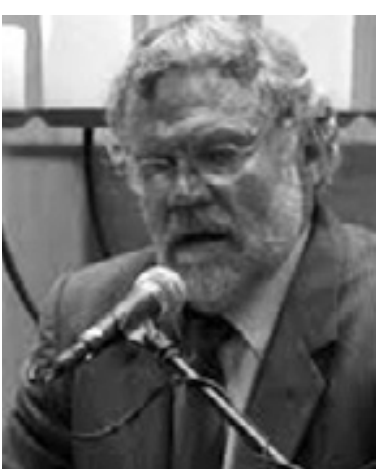

Johannes Ian Kerr Gagiano, politieke wetenskaplike en ontvanger van 'n Helpmekaar lening. 
FIGUUR 5: LENINGS VIR UNIVERSITEITSOPLEIDING AS PERSENTASIE VAN ALLE LENINGS, 1919-2014

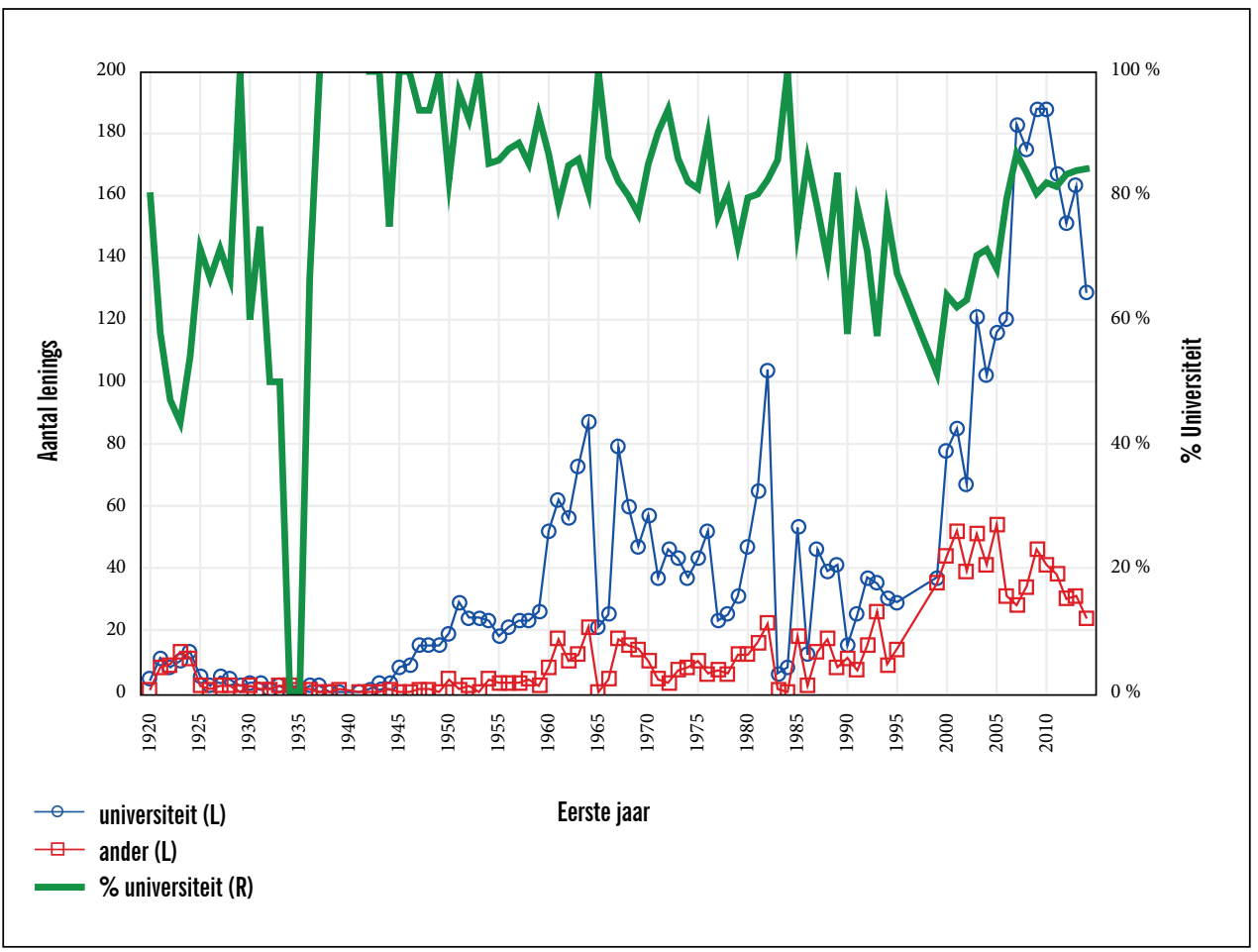

Ten spyte van die tradisioneel paternalistiese aard van die Afrikanersamelewing het die Helpmekaar nooit doelbewuste besluite geneem om op grond van geslag te gediskrimineer in die toekenning van lenings nie. Opvattings oor die rol en posisie van vroue in die Afrikanersamelewing kon wel onbewustelik die keuse van kandidate vir lenings beïnvloed het - veral tydens die kongres-era toe plaaslike takke kandidate aanbeveel het. Onder die eerste 13 beurse wat in 1919 toegeken is, was reeds twee vroue, naamlik mej G Dekker vir die studie van "opvoedkunde" in Pretoria en mej M Kruger "om kleermakery op Stellenbosch te leer". ${ }^{156}$ 'n Ander aanduiding van die Helpmekaar se benadering tot geslag was die besluit in 1919 om 10 pryse vir die beste opstelle oor die geskiedenis van Suid-Afrika vir skoliere beskikbaar te stel: 5 vir “jongens” en 5 vir "meisies” met gelyke prysgeld vir beide geslagte. ${ }^{157}$

156 (HSA) HVKP, Notuleboek, 26-27 Mei 1920, Kongres, 3-4.

157 (HSA) HVKP, Notuleboek, 21-22 Mei 1919, Kongres, 8. 
Van die totale aantal lenings wat oor bykans 'n eeu deur die Helpmekaar toegestaan is, is 39 persent aan vroue en 61 persent aan mans toegestaan. (Sien figuur 6.) Hierdie verdeling is dus eerder ' $n$ weerspieëling van die aanvraag oor tyd en die opvattings oor geslagsrolle in die Afrikanersamelewing as die gevolg van 'n spesifieke voorkeur deur die Helpmekaar vir manlike kandidate.

\section{FIGUUR 6: STUDIELENINGS VOLGENS GESLAG}

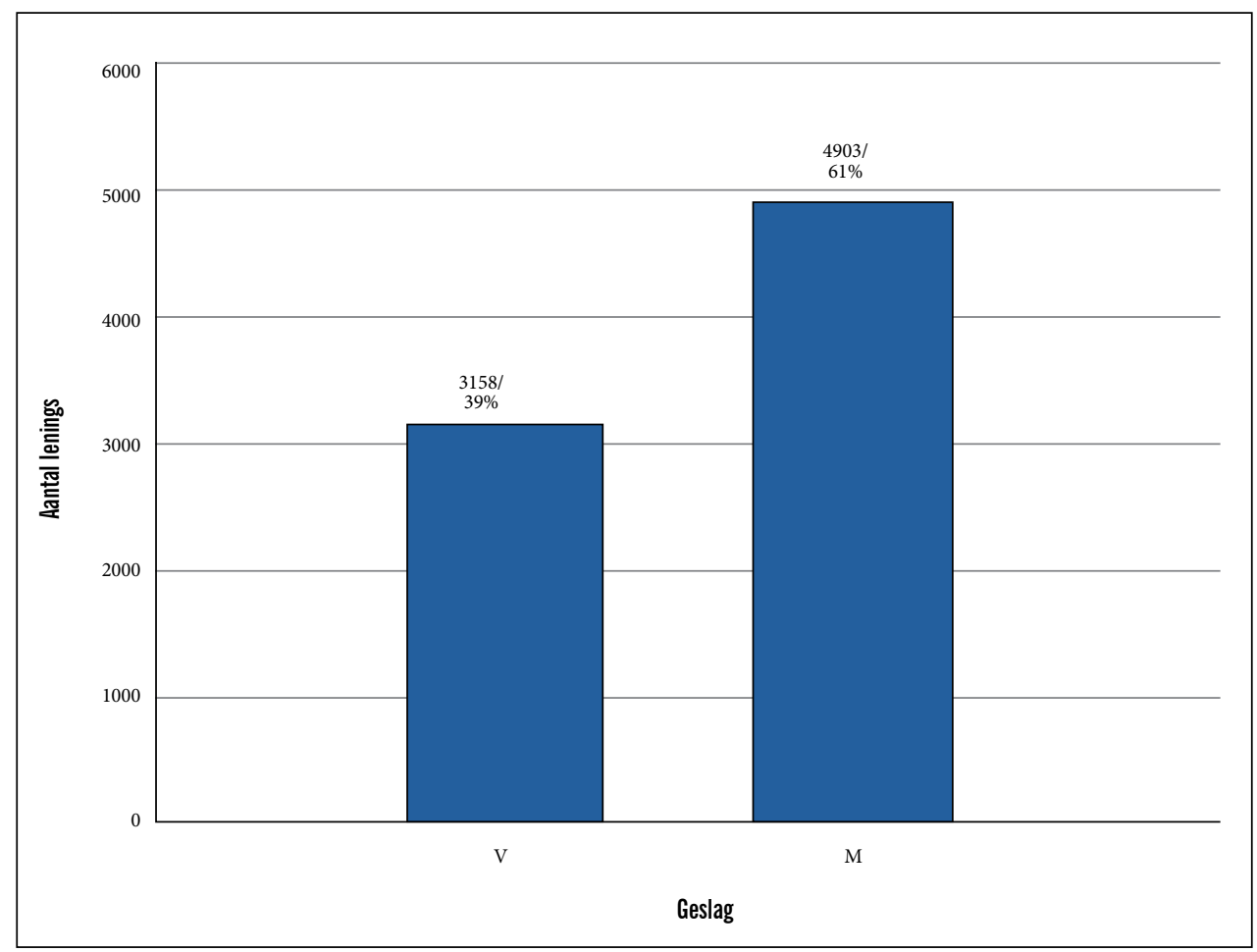




\section{FIGUUR 7: GESLAGSVERDELING VAN LENINGS OOR TYD}

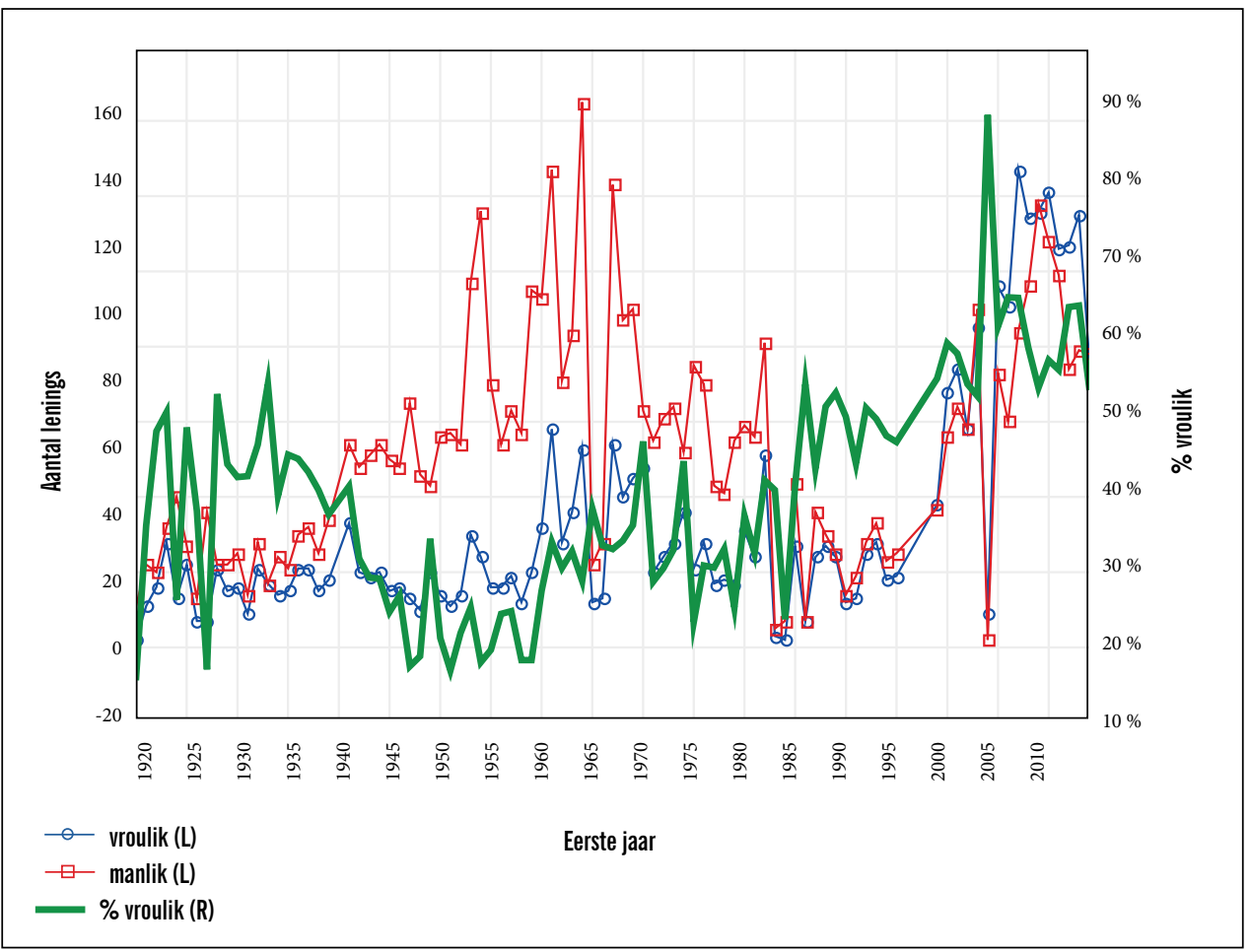

Die verdeling volgens geslag oor tyd vertoon variasies wat nie altyd te verklaar is nie (sien figuur 7). Die twintiger- en dertigerjare is gekenmerk deur 'n aansienlik hoër as die gemiddelde persentasie lenings wat aan vroue toegestaan is - tot soveel as 50 persent van toegekende lenings in sommige jare. Die veertiger- en vyftigerjare verteenwoordig 'n aansienlike daling in die persentasie lenings aan vroue toegestaan met die periode tussen 1945 en 1960 waar die persentasie tot so laag as 20 persent gedaal het. Hierdie tendense word ook bevestig deur die geslagsverdeling in totale jaarlikse pondwaardes van lenings toegeken uitgedruk soos geïllustreer in figuur 8. 'n Moontlike verklaring vir dié persentasie daling was waarskynlik die invloed van die B-fonds-lenings wat sedert 1942 toegeken is en waarvan 'n baie groter persentasie aan mans as vroue (slegs nege persent) toegeken is. Die fonds het veral op die professionele beroepe, soos medies, gefokus en dit was beroepe waarin vroue onderverteenwoordig was (sien figuur 9). 
FIGUUR 8: GESLAGSVERDELING VAN HELPMEKAARLENINGS IN POND (£), $1919-1960$

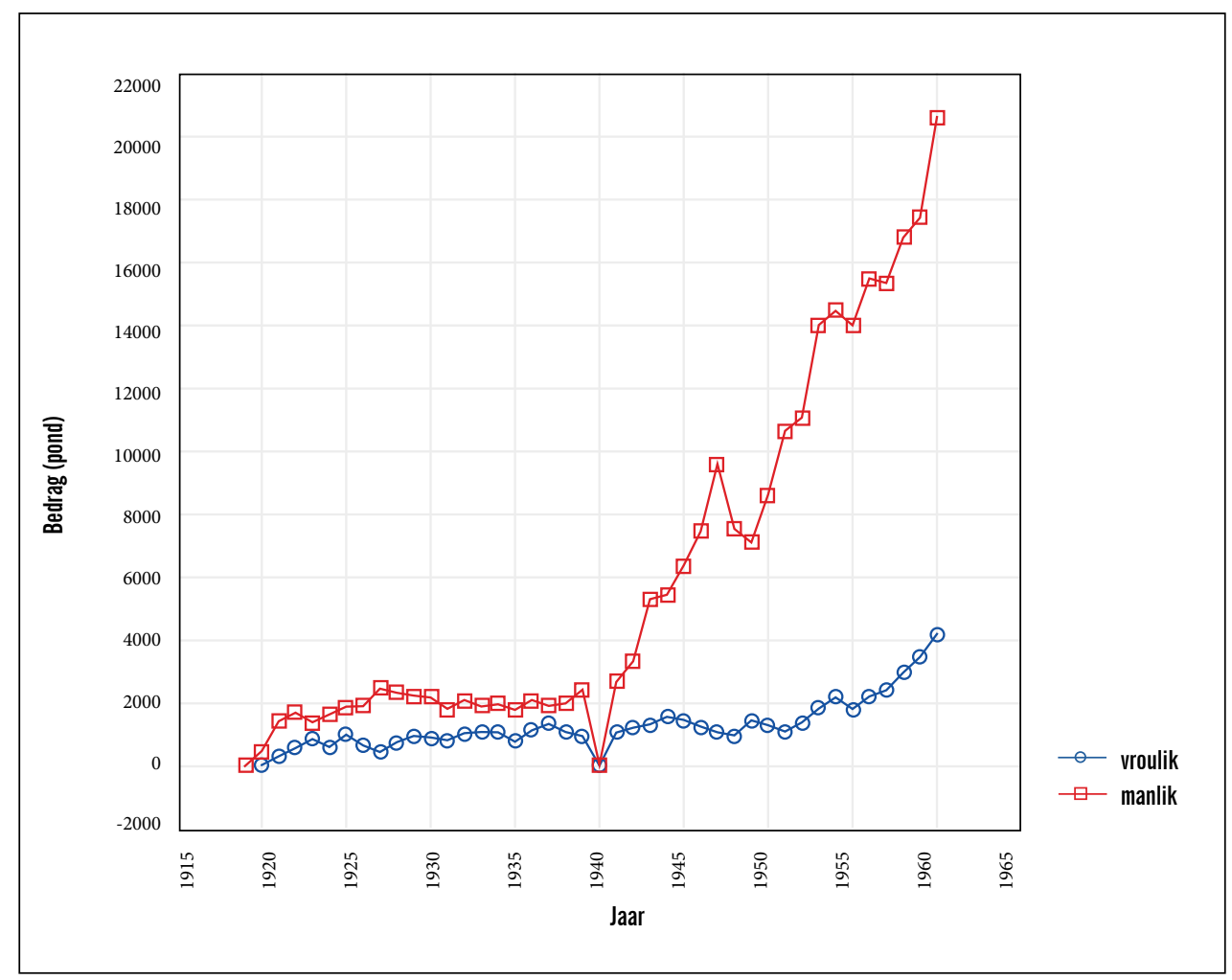




\section{FIGUUR 9: GESLAGSVERDELING VAN B-FONDS-LENINGS}

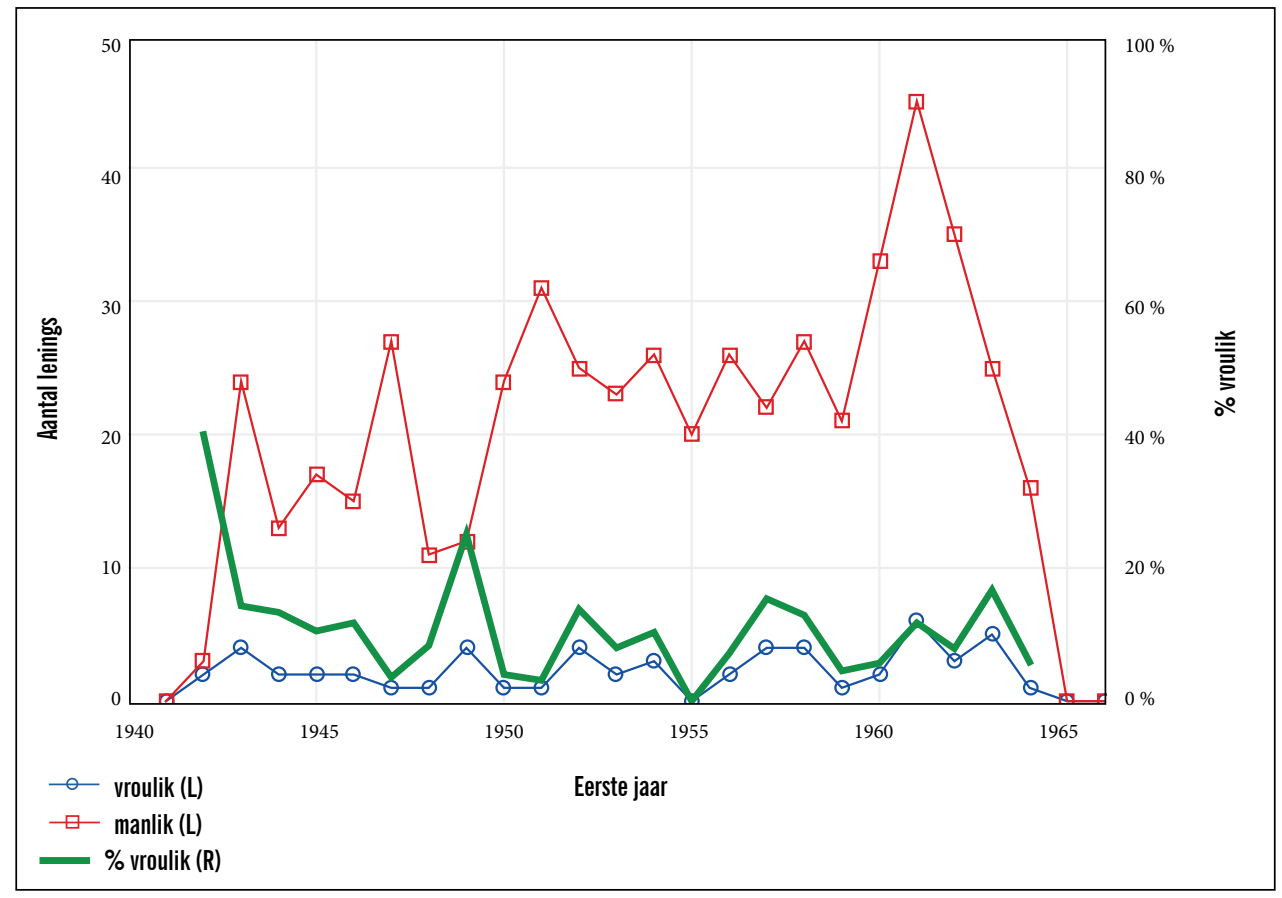

Lenings aan vroue in die sestigerjare en sewentigerjare het ' $n$ algemeen opwaartse neiging getoon. Dit het egter eers in die tweede helfte van die tagtigerjare weer die persentasievlakke van die twintigeren dertigerjare bereik. Sedert ongeveer 2000 is feitlik deurlopend meer lenings aan vroue as aan mans toegeken (sien ook randwaarde-toekennings vir 1960-2014 in figure 8 en 10). 'n Moontlike verklaring vir die algemeen opwaartse tendens van die persentasie lenings aan vroue mag gesetel wees in die veranderende opvatting oor die rol van vroue as broodwinners en die feit dat meer vroue dus universitêre opleiding ondergaan het. Die feit dat veral sedert 2000 selfs meer lenings aan vroue as aan mans toegeken is, mag wees omdat mans meer professionele beroepe betree het waarin beurse geredelik beskikbaar was - en hulle dus minder geneig was om by die Helpmekaar om lenings te kom aanklop. Hierdie toename in vrouestudente strook ook met die nasionale tendens. In die periode 19931999 was daar 'n nasionale toename van 44 persent in die aantal vrouestudente in die tersiêre sektor (van 202000 studente in 1993 tot 291000 in 1999). In kontras hiermee het manstudente met slegs een persent in dié periode toegeneem. 'n Piek van 307000 is in 1995 bereik waarna dit begin daal het. Teen 1999 het vrouestudente dus 52 persent van studente in die tersiêre sektor uitgemaak teenoor 43 persent in $1993 .{ }^{158}$

158 Draft National Plan for Higher Education in South Africa, Ministery of Education, February 2001, 33-34 (http://www.unisa.ac.za/contents/projects/docs/National\%20Plan\%20Higher\%20Education.pdf ) 
FIGUUR 10: GESLAGSVERDELING VAN HELPMEKAARLENINGS IN RAND (R), 1960-2014

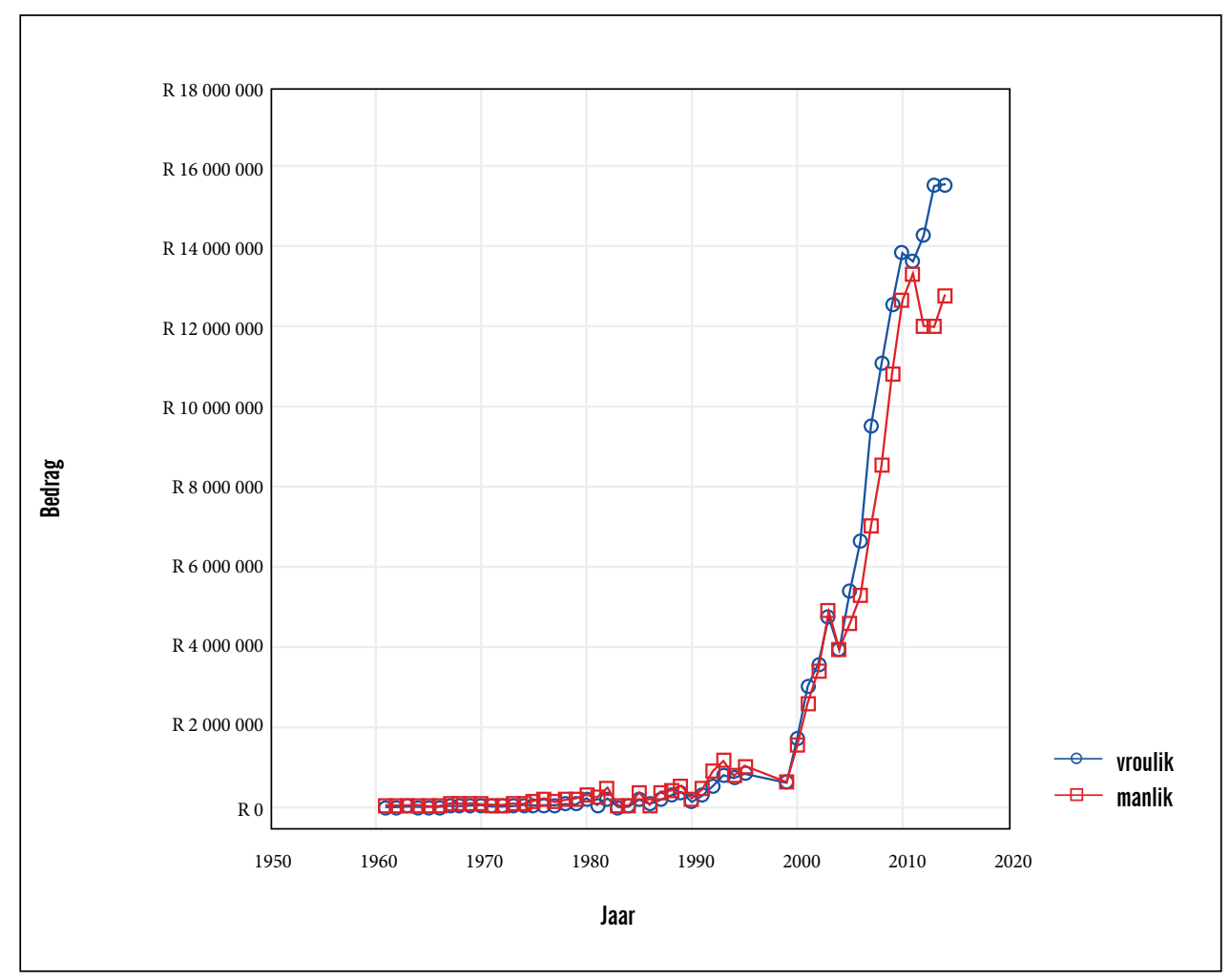




\section{FIGUUR 11: LENINGS GEKATEGORISEER VOLGENS STUDIERIGTING}

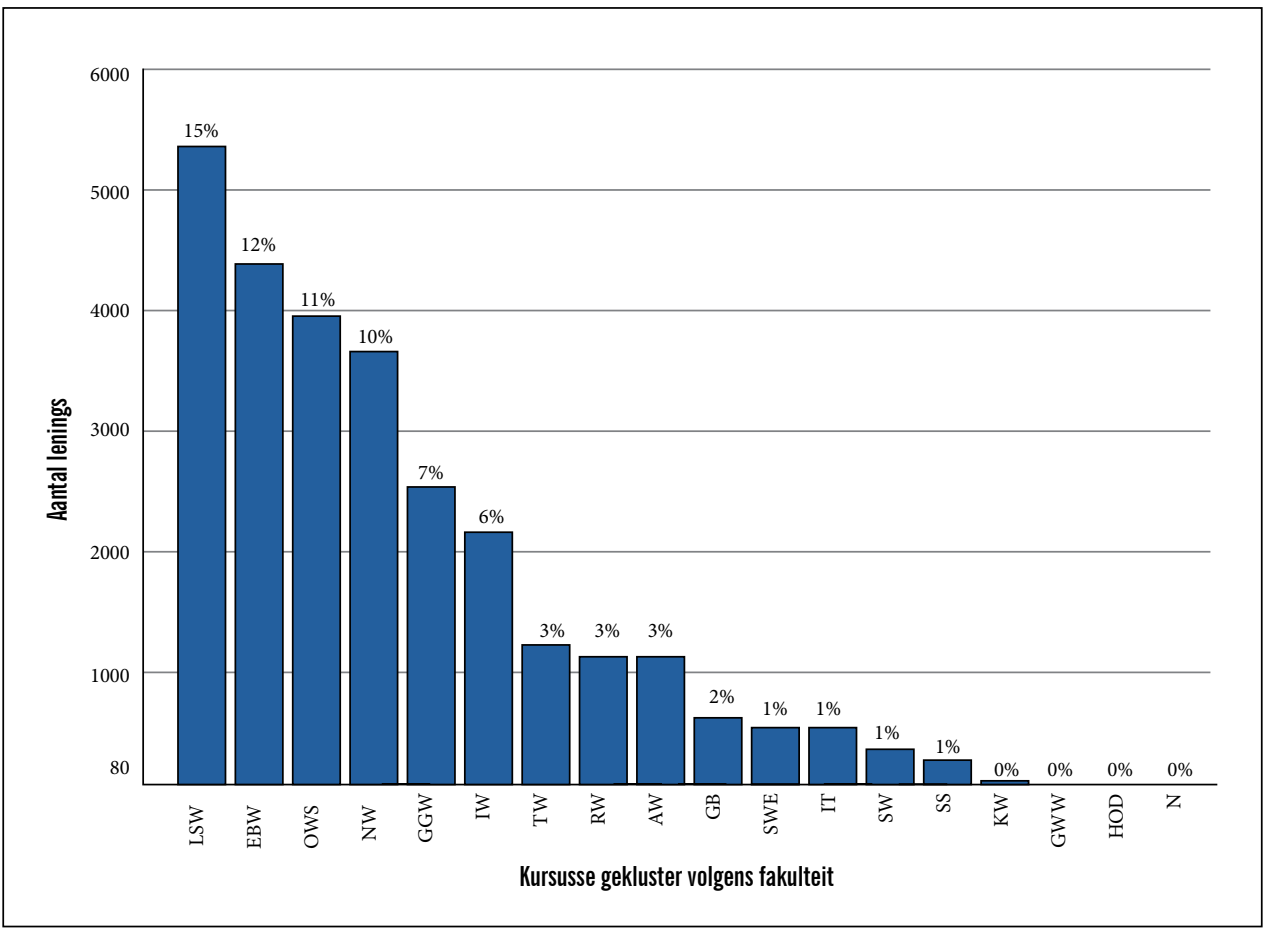

Sleutel: Lettere en Sosiale Wetenskappe (LSW); Ekonomiese en Bestuurswetenskappe (EBW); Opvoedkunde(OWS); Natuurwetenskappe(NW); Geneeskundeen Gesondheidswetenskappe (GGW); Ingenieurswese (IW); Teologie (TW); Regsgeleerdheid (RW); Agriwetenskappe (AW); Gasvryheidsbedryfs (GB); Sportwetenskap (SWE); Informasietegnologie (IT); Skoonheidswetenskappe (SW); Skoolgaande (SS); Krygskunde (KW).

In 'n poging om die Helpmekaar se bydraes per studierigting te bepaal is die lenings volgens die fakulteitsindeling van die Universiteit van Stellenbosch se jaarboek vir 2015 gekategoriseer (Sien figuur 11). Kategorieë wat nie deur die indeling geakkommodeer is nie is addisioneel bygevoeg. Van die studielenings waarvan die studierigting geïdentifiseer kon word, was die voorkeur rangorde van leningshouers oor die ongeveer honderd jaar van die Kaapse Helpmekaar se bestaan: Lettere en Sosiale Wetenskappe (15 persent), Ekonomiese en Bestuurswetenskappe (12 persent), Opvoedkunde (11 persent), Natuurwetenskappe (tien persent), Geneeskunde en Gesondheidswetenskappe (sewe persent) en Ingenieurswese (ses persent). 


\section{FIGUUR 12: STUDENTE IN EKONOMIESE EN BESTUURSWETENSKAPPE (EBW), 1919-2014}

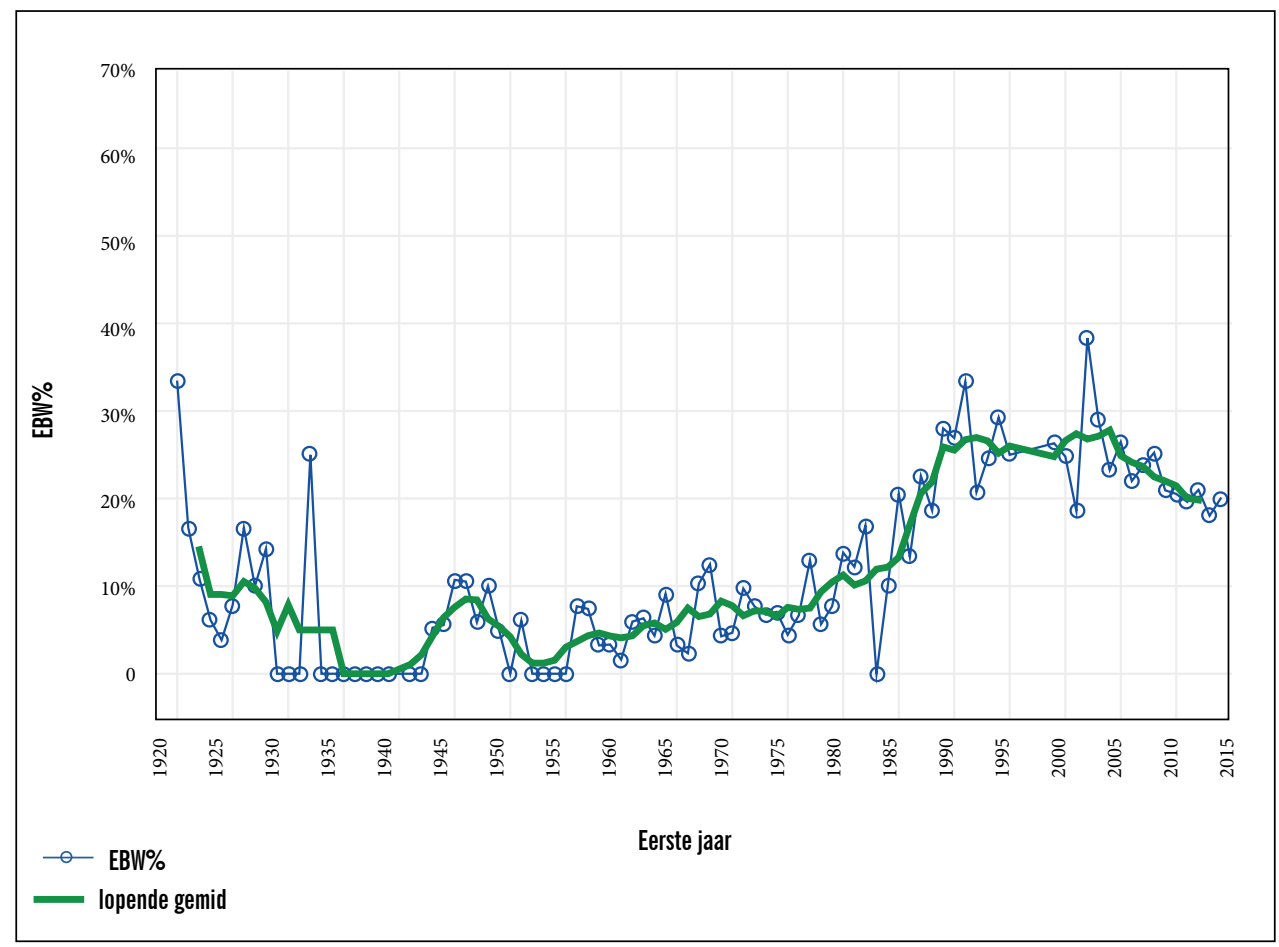

Dit is nie moontlik om uit die data van die Kaapse Helpmekaar tendense vir wit Afrikaanse studente as geheel af te lei nie, maar die grafieke vir EBW (figuur 12) en LSW (figuur 13) Helpmekaarlenings bied tog interessante insigte. Na die doelbewuste pogings in sy aanvangsjare om handelsopleiding onder Afrikaners te bevorder (wat in die grafiek bevestig word), was daar 'n duidelike afname in die dertigerjare. In die veertigerjare was daar 'n oplewing in die belangstelling om handelsopleiding te volg, wat moontlik die gevolg was van die impak van die Eerste Ekonomiese Volkskongres van 1939 en die doelbewuste pogings om Afrikaners aan te moedig om die kapitalistiese wêreld te verower.

Die algemeen stygende belangstelling sedert die laagtepunt in die eerste helfte van die vyftigerjare het uiteindelik'n hoogtepunt in die negentigerjare bereik. Hierdie tendens stem in die breë ooreen met die toenemende welvaart van Afrikaners en hul omhelsing van 'n materialistiese verbruikerskultuur wat veral sedert die sestigerjare sigbaar gemanifesteer het. Die Helpmekaar se eie fokus op entrepreneurskap in die negentigerjare het hierdie neiging 
na ekonomiese en bestuurstudierigtings verder ondersteun. Die "winste" van Ekonomiese en Bestuurswetenskappe was in 'n groot mate ten koste van Lettere en Sosiale Wetenskappe. $\mathrm{Na}$ die groot groei in Lettere en Sosiale Wetenkappe in die periode 1960 tot 1980 was daar 'n daling in getalle wat gesinkroniseer het met die periode van groei in EBW. Die sterk groei in LSW in die genoemde periode was waarskynlik ook die resultaat van die neiging van eerste generasie universiteitstudente om LSW as intreepunt vir tersiêre opleiding te gebruik. Die Helpmekaar het ook in die vroeë vyftigerjare doelbewuste pogings aangewend om studente aan te moedig om die onderwysprofessie te betree deur meer fondse daarvoor beskikbaar te stel. Dalende werksgeleenthede in die onderwyssektor vir wit Afrikaanse studente wat veral sedert die negentigerjare deur regstellende aksie versterk is, het waarskynlik ook bygedra tot die daling in LSW studente en dit is ook weerspieël in die daling in die aantal onderwysstudente - wat in die vroeë negentigerjare 'n laagtepunt bereik het (figuur 14).

\section{FIGUUR 13: STUDENTE IN LETTERE EN SOSIALE WETENSKAPPE (LSW), 1919-2014}

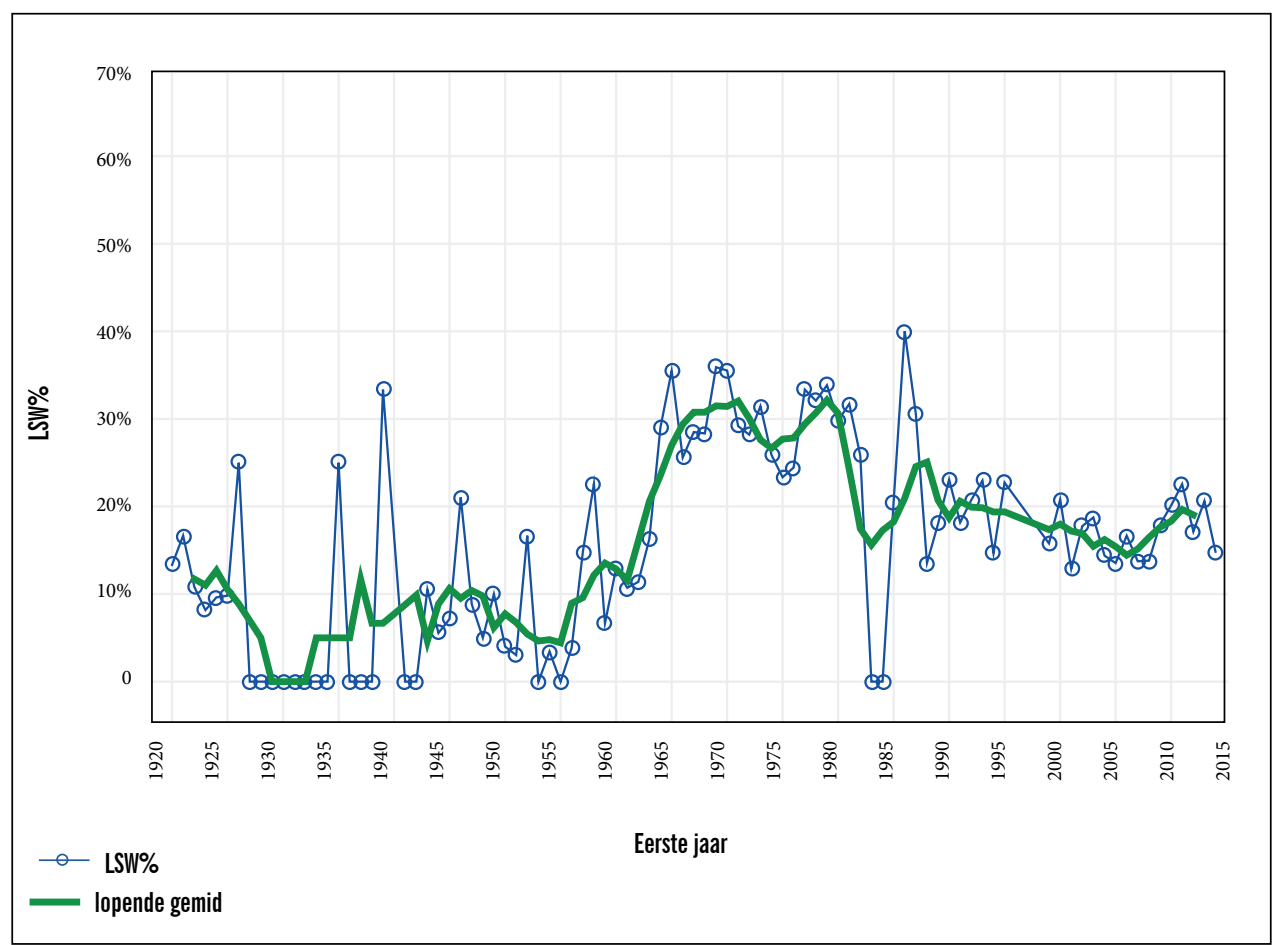




\section{FIGUUR 14: STUDIELENINGS VIR ONDERWYS EN OPVOEDKUNDE STUDIERIGTINGS (OWS), 1919-2014}

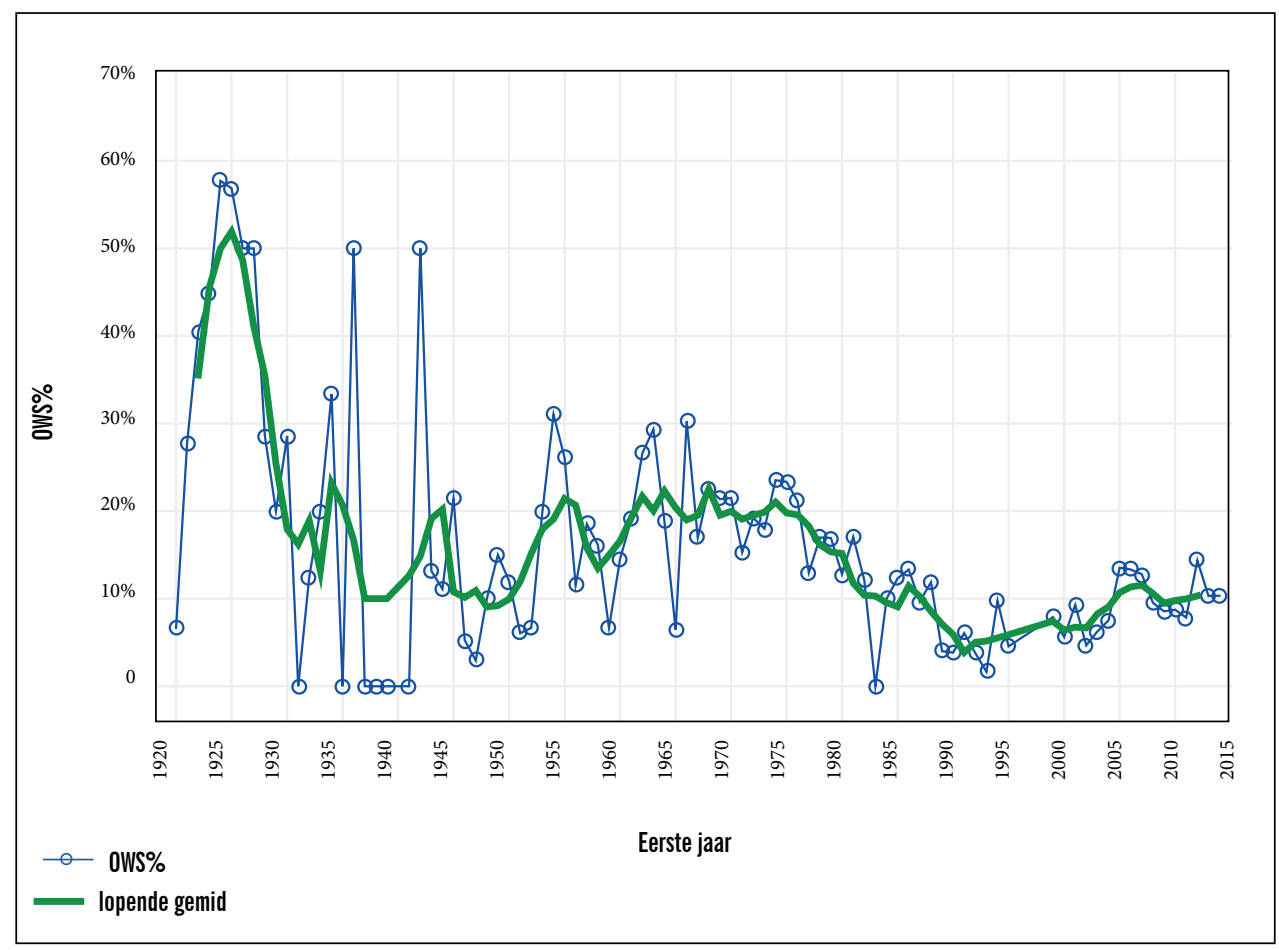

Die impak van regstellende aksie en die groei van die kennisekonomie is ook in Helpmekaarhulpverlening weerspieël. Professionele beroepe wat hulle tot entrepreneurskap geleen het, soos ingenieurswese (figuur 15), het sedert die negentigerjare 'n toename getoon. Nuwe beroepsrigtings met entrepreneurspotensiaal soos sportwetenskappe, die gasvryheids- en skoonheidsbedryf en informasietegnologie (figuur 16) het veral sedert die tagtigerjare op die Helpmekaar-radarskerm begin verskyn. Die verbreding van Helpmekaarhulp na nie-akademiese kursusse en nie-gematrikuleerde kandidate as deel van hul klem op entrepreneurskap in die negentigerjare het hierdie verskuiwing ondersteun. 
FIGUUR 15: HELPMEKAARLENINGS VIR INGENIEURSWESE (IW), 1919-2014

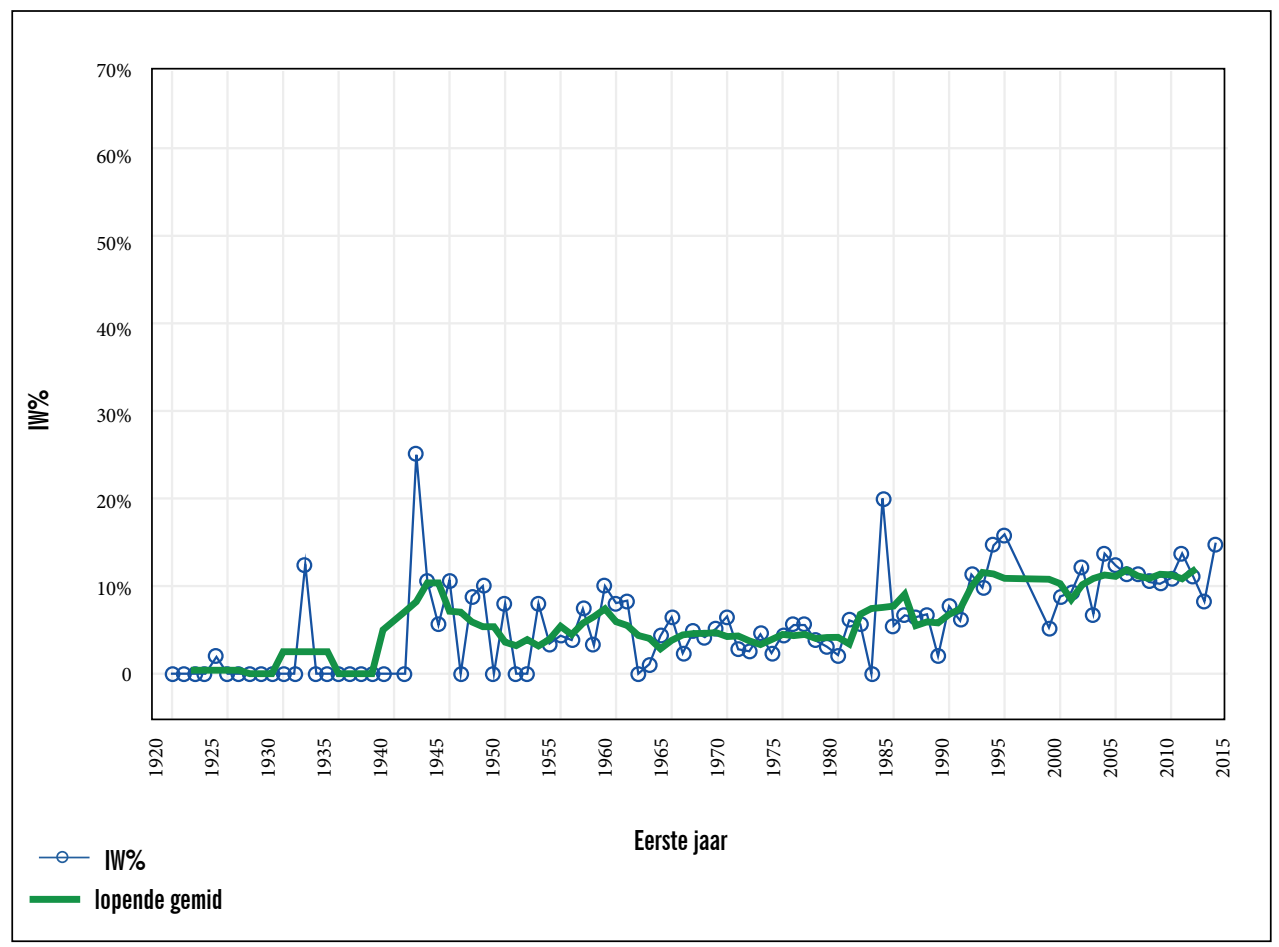


FIGUUR 16: HELPMEKAARLENINGS VIR INFORMASIETEGNOLOGIE (IT), 1919-2014

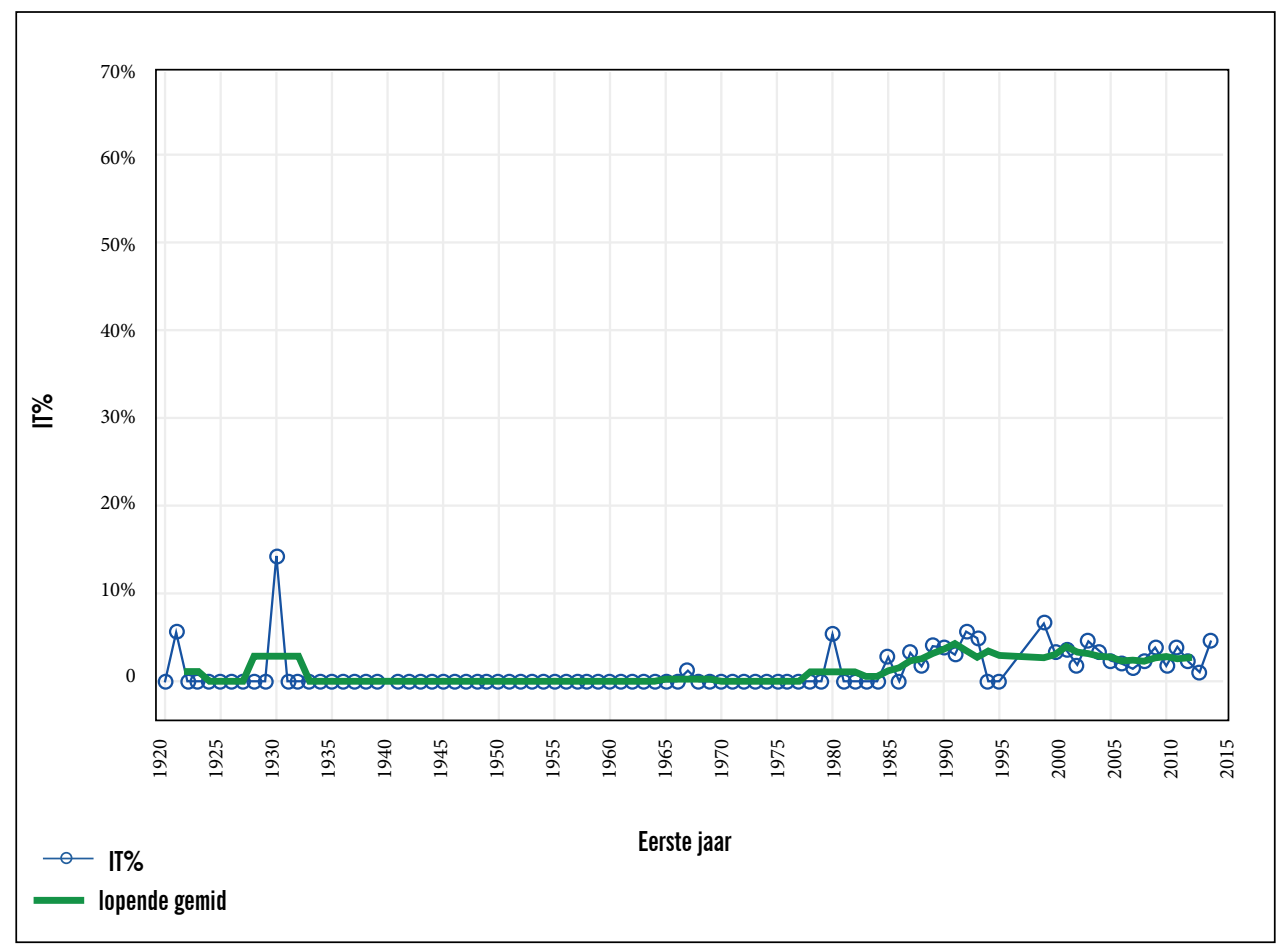

Om enigsins sin te maak uit die inligting is dit noodsaaklik om dit tog te probeer spieël teen die tendense wat veral in die laaste kwart van die 20ste eeu in die Suid-Afrikaanse ekonomie gemanifesteer het. In terme van die Bruto Binnelandse Produk het die primêre sektor van die ekonomie met vier persent afgeneem, terwyl die dienstesektor met ses persent gegroei het in die periode 1970-1995. Werksgeleenthede in die landbousektor het in die periode met 50 persent en dié in die mynbousektor met 31 persent gedaal. In alle sektore het professionele en tegniese indiensneming met 312 persent en indiensneming in bestuursberoepe met 272 persent gegroei. Hoëvlak beroepe het in dié periode dus toegeneem - selfs gedurende tydperke van ekonomiese agteruitgang toe totale indiensneming afgeneeem het. In dié periode het die arbeidsmark se vraag na persone met sekondêre opleiding met 53 persent en dié met matriek met 400 persent vermeerder. Die vraag na werkers met 'n tersiêre opleiding het met 2028 persent toegeneem. Die periode is dus gekenmerk deur 'n verskuiwing na professionele en bestuursberoepe en is gekenmerk deur spesifieke tekorte in wetenskap en 
ekonomiesverwante velde in veral informasietegnologie, ingenieurswese, tegnologiese en tegniese beroepe, ekonomiese en finansiële beroepe en rekeningkundigverwante beroepe. ${ }^{159}$

Hierdie verskuiwing en die nuwe beroepsmoontlikhede of mark wat dit geskep het, is ook gereflekteer in die studentegetalle binne fakulteits- of studierigting- verband. Teen die einde van die eeu het syfers vir die tersiêre sektor vir die periode 1993-1999 'n duidelike verskuiwing van die Humaniora na Sake- en Handelswetenskappe weerspieël. Oor dié periode het studentegetalle in die Humaniora van 57 persent van alle inskrywings na 49 persent gedaal en Handelswetenskappe van 19 persent na 26 persent toegeneem. Studente in die Natuurwetenskappe, Ingenieurswese en Tegnologie het met een persent toegeneem. ${ }^{160}$ Hierdie tendense het ook in die breë in studente met Helpmekaarstudielenings gemanifesteer soos in bogenoemde grafieke geïllustreer is.

Die Helpmekaar se fokus op Afrikaners en die feit dat hulle eers in die negentigerjare hul fokus na Afrikaanssprekende studente (wat teoretiese beteken het dat ook swart studente vir lenings kon kwalifiseer) verbreed het, het veroorsaak dat, ten opsigte van die nasionale demografie van die tersiêre sektor en veranderinge wat in dié verband ingetree het, dit nie deur die Helpmekaarstudente se demografiese profiel weerspieël is nie. Nasionale syfers vir die periode 1993-1999 weerspieël 'n toename van 61 persent in swart studente van 53 persent (249 000) tot 71 persent (414 000) in die tersiêre sektor op nasionale vlak. Die groei in etniese swart studente was selfs meer, naamlik 80 persent en het teen 199959 persent van die totale getal studente uitgemaak. ${ }^{161}$

Ten spyte van die verbrede fokus van die Helpmekaar het die demografiese profiel van Helpmekaar-studente geen meetbare verandering in dié periode getoon nie. Teenoor die toename in swart studente was daar'n afname van 26 persent (van 222000 tot 164000 ) in wit studente in die periode 1993-1999 op nasionale vlak. Hierdie afname, wat die Departement van Onderwys onder andere toegeskryf het aan 'n verskuiwing van wit studente na private hoëronderwysinstellings en studente wat geïmmigreer het na afhandeling van hul skoolloopbane, ${ }^{162}$ is nie in die aanvraag na Helpmekaar-studielenings na 1990 weerspieël

159 Draft National Plan for Higher Education in South Africa, Ministery of Education, February 2001, 15. (http://www.unisa.ac.za/contents/projects/docs/National\%20Plan\%20Higher\%20Education.pdf)

160 Draft National Plan for Higher Education in South Africa, Ministery of Education, February 2001, 16. (http://www.unisa.ac.za/contents/projects/docs/National\%20Plan\%20Higher\%20Education.pdf)

161 Draft National Plan for Higher Education in South Africa, Ministery of Education, February 2001, 31. (http://www.unisa.ac.za/contents/projects/docs/National\%20Plan\%20Higher\%20Education.pdf)

162 Draft National Plan for Higher Education in South Africa, Ministery of Education, February 2001, 33. (http://www.unisa.ac.za/contents/projects/docs/National\%20Plan\%20Higher\%20Education.pdf) 


\section{Die Kaapse Helpmekaar}

nie. Na die 1990-laagtepunt in die aantal Helpmekaarlenings wat toegeken is en wat die gevolg was van 'n tekort aan fondse en nie 'n tekort aan aanvraag nie, het die aantal lenings wat jaarliks toegestaan is, eksponensieel gegroei. Hierdie groei te midde van 'n tendens van dalende getalle wit studente in die nasionale tersiêre sektor was waarskynlik die gevolg van die afname in staatsondersteunde en ander vorms van studiefinansiering soos beurse vir wit studente as gevolg van regstellende aksie. Vir sommige Afrikaanse wit studente het die Helpmekaar die verstek-opsie en in van die gevalle die enigste opsie geword.

\section{FIGUUR 17: NSFAS-BYDRAES VIR 1994-2001163}

Die groot behoefte na studiefinansiering en die belangrike rol wat die Kaapse Helpmekaar in die finansiering van sy tradisionele kliëntebasis se behoeftes in die post-1990-era gespeel het, word in perspektief gestel as na finansiering van die tersiêre sektor op nasionale vlak gekyk word. Die staat se pogings om na 1994 die hindernisse vir toegang tot die tersiêre sektor vir voorheen benadeelde studente te verminder het gelei tot die stigting van die National Student Financial Aid Scheme (NSFAS). NSFAS is deur die Education Fund of South Africa geadministreer. Die liggaam het in 2000 'n statutêre liggaam geword. Sedert 1994 het die staat reeds meer as R2 biljoen aan NSFAS-geld toegeken.

Indien skenkergeld en die kapitaal van lenings wat terugbetaal is in ag geneem word, was die bedrag vir studiefinansiering deur hierdie inisiatief net minder as R2,9 biljoen vir die periode 1994-2001 (Sien figure 17 en 18). Die omvang van die behoefte na studiefinansiering word duidelik, as in ag geneem word, dat in dié periode slegs 20 persent van studente deur NSFAS ondersteun is. Hoewel die staat jaarliks sy NSFAS-befondsing vergroot het, het dit tot slegs 'n klein toename in die aantal studente wat jaarliks gehelp is, gelei. In die periode 1996 tot 2000 is die befondsing met 50 persent vermeerder terwyl die toename in die aantal studente wat gehelp kon word slegs 12 persent was. Inflasionêre druk op klasgelde en verblyfkostes is deur die Departement van Onderwys as die vernaamste oorsake hiervan aangevoer. ${ }^{164}$ Teen 2016 het die NSFAS reeds R21 miljard in totaal sedert sy ontstaan aan studente geleen. Een van die NSFAS se grootste uitdagings bly die verhaling van die geld wat aan studente geleen word. Die lae verhalingskoers van NSFAS - slegs R200 miljoen van die

163 Draft National Plan for Higher Education in South Africa, Ministery of Education, February $2001,37$. (http://www.unisa.ac.za/contents/projects/docs/National\%20Plan\%20Higher\%20Education.pdf)

164 Draft National Plan for Higher Education in South Africa, Ministery of Education, February 2001, 37-38. (http://www.unisa.ac.za/contents/projects/docs/National\%20Plan\%20Higher\%20Education.pdf) 
R21 miljard wat sedert sy ontstaan uitgeleen is - bly'n belangrike beperkende faktor in sy kapasiteit om studente in die tersiêre sektor finansieel te ondersteun. ${ }^{165}$

\begin{tabular}{|l|l|l|l|}
\hline JAAR VAN NSFAS BYDRAES & REGERING & SKENKERS & VERHAAL \\
\hline 1994 & R $10,3 \mathrm{~m}$ & R $60,1 \mathrm{~m}$ & Nie van Toepassing \\
\hline 1995 & R $57,1 \mathrm{~m}$ & R $97,2 \mathrm{~m}$ & Nie van Toepassing \\
\hline 1996 & R283,8 m & R 49,6 m & Nie van Toepassing \\
\hline 1997 & R197,7 m & R153,3 m & Nie van Toepassing \\
\hline 1998 & R296,5 m & R 98,0 m & Nie van Toepassing \\
\hline 1999 & R384,9 m & R 56,3 m & Nie van Toepassing \\
\hline 2000 & R437,4 m & R 33,5 m & R 27,5 m \\
\hline 2001 & R440,0 m & Nie Beskikbaar & R160,0 m \\
\hline TOTAAL & R2 $107,7 \mathrm{~m}$ & R548,0 m & R187,5 \\
\hline
\end{tabular}

FIGUUR 18: NSFAS-TOEKENNINGS, 1996-2000166

\begin{tabular}{|l|l|}
\hline Jaar van Toekenning & TOTAAL \\
\hline 1996 & 72788 \\
\hline 1997 & 70574 \\
\hline 1998 & 75764 \\
\hline 1999 & 75344 \\
\hline 2000 & 81609 \\
\hline
\end{tabular}

165 Rapport, 29 Oktober 2017, 2, 'Gratis klasse nie moontlik'. Hefer-kommissie maak talle aanbevelings (Sedert 1992 is meer as R59 miljard aan 3,4 miljoen studente bestee in die vorm van beurse en lenings. Die verdeling tussen beurse en lenings is onseker. Sedert 1992 kon NSFAS slegs R5,9 miljard se skuld verhaal. Rapport, 13 Mei 2018, Net 10\% betaal hul studieskuld terug, 9).

166 Draft National Plan for Higher Education in South Africa, Ministery of Education, February 2001, 38. (http://www.unisa.ac.za/contents/projects/docs/National\%20Plan\%20Higher\%20Education.pdf) 
FIGUUR 19: HELPMEKAARLENINGS IN POND (£) PER JAAR, 1919-1960

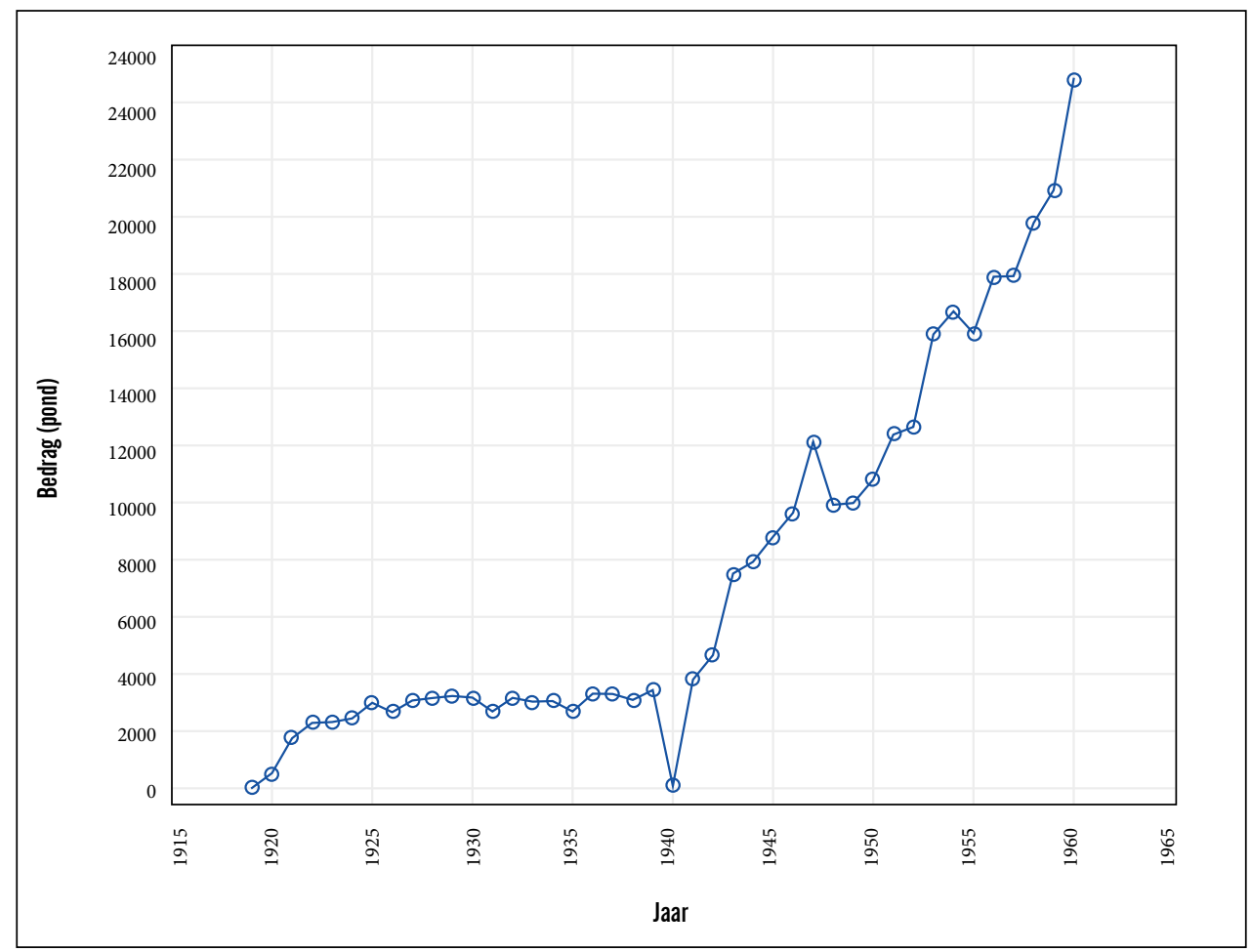


FIGUUR 20: HELPMEKAARLENINGS IN RAND (R) PER JAAR, 1961-2014

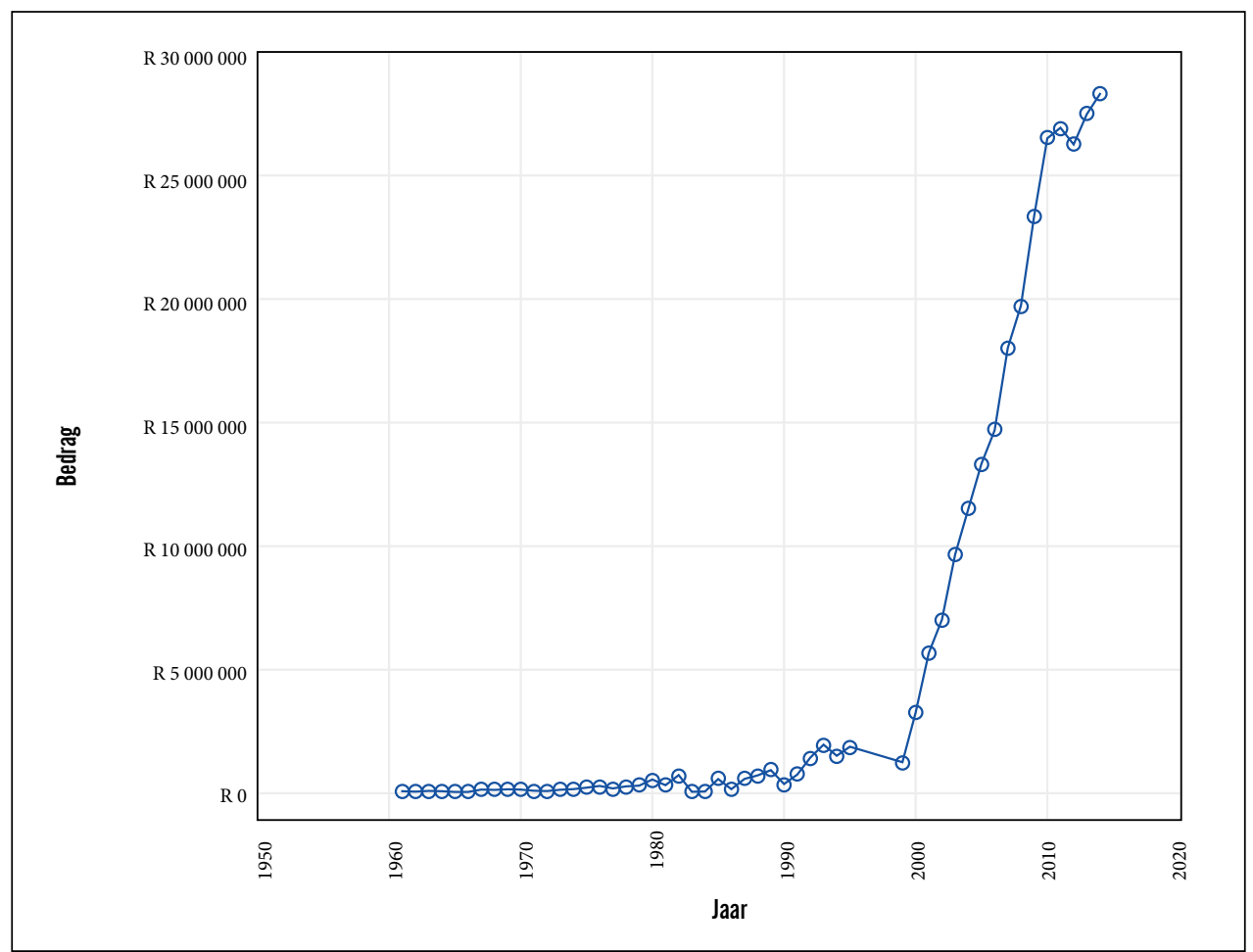




\section{FIGUUR 21: HELPMEKAARLENINGS IN RAND (R) PER JAAR, 1960-2000}

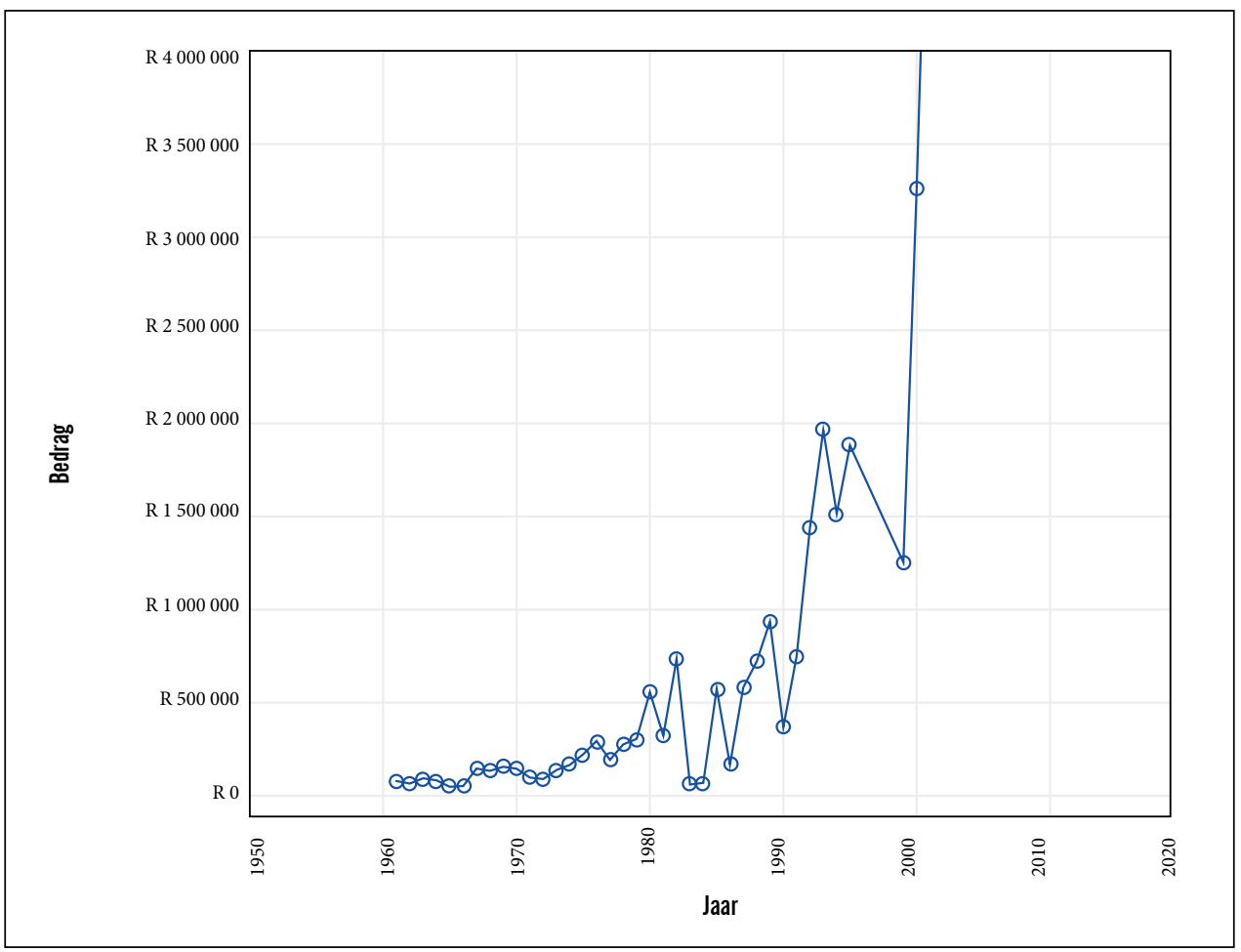

Bogenoemde syfers verskaf die nodige perspektief op die relatiewe bydrae van die Helpmekaar as studiefinansier binne die Suid-Afrikaanse konteks. In die periode 1996-2000 het die NSFAS 376079 studente (met R2 018,5 miljoen) ondersteun. In vergelyking met die ongeveer 500 studente wat die Kaapse Helpmekaar met ongeveer R11 miljoen in die dienooreenkomstige periode gefinansier het of selfs in vergelyking met die 8381 studente (met $£ 314698$ van 1919-1960 en R350 902429 van 1961-2014 (sien figure 19, 20, 21)) van die Helpmekaar oor bykans 'n eeu, vertoon die Helpmekaar soos 'n druppel in die nasionale emmer.

Gegewe egter die spesifieke Afrikaner fokus van die Helpmekaar oor sy bestaan en in die konteks van die Afrikaner-armoede van die eerste helfte van die 20ste eeu het die Kaapse Helpmekaar 'n belangrike skakel (nasionaal, maar veral binne die geografiese Kaaplandse konteks waarbinne dit hoofsaaklik gefunksioneer het) gevorm in die bydrae wat die Afrikaner-burgerlike samelewing gelewer het om armoede in hul geledere tot 'n val te bring. In die vroeg 20ste eeu was die Kaapse Helpmekaar as bemiddelaar in opheffing, selfrespek 
en respektabiliteit 'n vroeë wegbereider en bydraer in die uiteindelike skepping van 'n substansiële Afrikaner-middelklas wat veral teen die sestigerjare tot hul reg gekom het. As historiese sinnebeeld en simbool van suksesvolle Afrikanerreaksie op krisisomstandighede sou die Kaapse Helpmekaar na 1990 opnuut 'n toevlugsoord word vir Kaapse Afrikaners. Hierdie keer was dit egter nie om hul uit hul houthakker- en waterdraer-status op te hef nie, maar eerder om 'n terugkeer daarna te voorkom. Indien daar te leer is uit die verlede lê die Kaapse Helpmekaar se belangrikste les waarskynlik in hul stukturele benadering tot opheffing en armoedeverligting, hul geloof in volhehoue arbeid, selfredsaamheid, die hersirkulering van geleende kapitaal deur die handhawing van ' $n$ baie hoë verhalingskoers ten opsigte van geleende kapitaal, en die wonder van saamgestelde rente. 


\section{BRONNE}

\section{LITERATUUR}

Alcock, L. Die belangrikheid van permanente bouverenigings as instrument vir die finansiering van privaatbehuising in Suid-Afrika. Ongepubliseerde MA, Randse Afrikaanse Universiteit, 1986.

Bruwer, AJ. Kapitalisme Party-Politiek en Armoede, Nasionale Pers Beperk, Bloemfontein, 1934.

Clarkson, KV. The United Democratic Front as exponent of mass-based resistance and protest, 1983-1990. PhD, Rand Afrikaans University, Nov 1997.

De Witt, JT. Dr WJ Viljoen as onderwyshoof van Kaapland, 1918-1929. PhD, US, 1973.

Du Plessis, EP. 'n Volk staan op. Die Ekonomiese Volkskongres en Daarna. Human \& Rousseau, Kaapstad, 1964.

Du Toit, PS. Onderwys in Kaapland, 1652-1975, 'n Oorsig. JL Van Schaik Bpk, Pretoria, 1976.

Ehlers, A. Die Helpmekaarbeweging in Suid-Afrika: die Storm- en-Drangjare, 1915-1920. MA, Universiteit Stellenbosch, 1986.

Fourie, R. Die hond wat nie geblaf het nie. 'n Analise van die Afrikaanse studente se stilswye aan die einde van die Universiteit van Port Elizabeth. Ongepubliseerde Honneurstesis, Universiteit Stellenbosch, 2015.

Geyser, O \& AH. Marais (reds). Die Nasionale Party, Deel I. Akademica, Kaapstad, 1983.

Giliomee, H \& H Adam. Afrikanermag. Opkoms en Toekoms. UUB, Stellenbosch, 1981.

Giliomee, H. Die laaste Afrikaner-leiers. 'n Opperste toets van mag. Tafelberg, Kaapstad, 2012.

Giliomee, H. The Afrikaners. Biography of a People. Tafelberg, Cape Town, 2012.

Grundlingh, A \& S Swart, Radelose rebellie? Dinamika van die 1914-1915 Afrikanerrebellie. Protea Boekhuis, Pretoria, 2009.

Kapp, P. Die verhaal van Jannie Marais en die Marais-broers. Nalatenskappe sonder einde. Tip Africa Publishing, Soutrivier, 2015. 
Kestell, JD. Helpmekaar Gedenkboek. De Nationale Pers, Kaapstad, 1918.

Koorts, L. DF Malan and the Rise of Afrikaner Nationalism. Tafelberg, Cape Town, 2014.

Le Roux, NJ. WA Hofmeyr - sy werk en waarde. Nasionale Boekhandel, Kaapstad, 1953.

Malan, M. Heart Transplant: The Story of Barnard and the "Ultimate” In Cardiac Surgery. Voortrekkerpers, Johannesburg, 1968.

Malan, MPA \& MC van Rensburg. Verkiesingsuitslae 1910-1943 met volledige naamlys van Volksraadslede vanaf 1910. NPB, Bloemfontein, gd.

Marks, S \& S Trapido (eds). The Politics of Race, Class and Nationalism in Twentieth Century South Africa. Harlow: Longman, London, 1987.

Meyer, PJ. Nog nie ver genoeg nie. Perskor, Johannesburg, 1984.

Morrell, R (ed). White but poor: essays on the history of poor whites in Southern Africa 1880-1940. Unisa, Pretoria, 1992.

O'Meara, D. Volkskapitalisme: class, capital and ideology in the development of Afrikaner nationalism, 1934-1948. Cambridge University Press, Cambridge, 1983.

Rosenthal, E. Manne en Maatskappye. Die Geskiedenis van die Eerste Afrikaanse Sakemanne. Human \& Rousseau, Kaapstad, 1963.

Ross, R. Status and Respectability in the Cape Colony 1750-1870, A Tragedy in Manners. Cambridge University Press, 2009.

Rossouw, JJ. Inflation in South Africa: 1921-2006. History, Measurement and Credibility. PhD, UKZN, 2007.

Scannell, JP. Uit die volk gebore. Sanlam se eerste vyftig jaar. Nasionale Boekhandel Beperk, Kaapstad, 1968.

Scholtz, L. Kruispaaie. Afrikanerkeuses in die 19de en 20ste eeu. Kraal Uitgewers, Pretoria, 2016.

Slabbert, F van Zyl. The Other Side of History: An Anecdotal Reflection on Political Transition in South Africa. Jonathan Ball, Johannesburg, 2006.

Southall, R The New Black Middle Class in South Africa, 1914-1915. Jacana, 2016.

Spies, SB. The Rebellion in South Africa. MA thesis, University of the Witwatersrand, 1962. 
Standard Encyclopaedia of Southern Africa, vol 2, BAC-CAL. Nasou Limited, London, 1970.

Suid-Afrikaanse Biografiese Woordeboek II. RGN, Goodwood, 1986.

Suid-Afrikaanse Biografiese Woordeboek III. Tafelberg Uitgewers, Kaapstad, 1977.

Suid-Afrikaanse Biografiese Woordeboek IV. Butterworth \& Kie, Durban, 1981.

Suid-Afrikaanse Biografiese Woordeboek V. RGN, Pretoria, 1987.

Terblanche, HO. Die Afrikaner in Port Elizabeth, 1902-1937: 'n Kultuurhistoriese ondersoek. Ongepubliseerde PhD, Universiteit Port Elizabeth, 1993.

Van der Merwe, NJ. Marthinus Theunis Steyn, 'n lewensbeskrywing, Deel II. De Nationale Pers Beperkt, Kaapstad, 1921.

Venter, CR. Ontwikkelingsrigtings in die Onderwys van Kaapland hoofsaaklik met betrekking tot sekondêre onderwys, 1930-1958. PhD, US, 1973.

\section{KOERANTE}

Cape Times, Jul 1914-Jan 1918.

De Burger, Nov 1914-Des 1920.

De Kerkbode, 1917.

Het Volksblad, Maart 1915-Mei 1918, Jan 1919-Okt 1919.

Het Westen, Nov 1914-Maart 1915.

Ons Land, Julie 1914-Des 1918.

The Star, Nov 1914-Dec 1914.

\section{ARTIKELS IN PERIODIEKE PUBLIKASIES}

Die Burger, 20 Aug 1937, Mnr DH van Zyl se seun oorlede.

Die Burger, 12 Nov 1941, Helpmekaar se plan om meer te doen. Nuwe fonds beoog vir hulp aan studente.

Die Burger, 21 Mrt 1956, Afrikaners raak ál welvarender. 
Die Burger, 4 Aug 1958, Dr JS du Toit bekende oogarts van Kaapstad aan hartaanval dood.

Die Burger, 7 Aug 1958, Treffende begrafnis vir Dr JS du Toit.

Die Burger, 23 Feb 1961, Eeufeesfonds Gestig: Nuwe Uitdagings aan SA Universiteite.

Die Burger, 29 Mrt 1961, Vloedskade uit die lug gesien; Vloedwaters bedreig Kakamas, Kenhardt en Prieska.

Die Burger, 30 Mrt 1961, Riviere bars oor hul walle in Oos-Kaapland.

Die Burger, 4 Apr 1961, Vloedfonds staan al op R900.

Die Burger, 8 Des 1961, Rupert Skets Plan vir Vennootskap met Afrika-Lande.

Die Burger, 2 Aug 1967, Hier is die motor vir u.

Die Burger, 2 Aug 1967, Het u vanjaar die veldblomme gesien?

Die Burger, 13 Sep 1977, Phil Morkel sterf aan hart.

Die Burger, 11 Apr 1978, Oud-sen Sinclair oorlede.

Die Burger, 13 Feb 1979, Die NP se fonds groei stewig.

Die Burger, 23 Mrt 1979, NP-Trustfonds.

Die Burger, 18 Sept 1979, Nou 'n hupstoot vir R1 miljoen (hoofartikel); Laaste Groot Poging vir NP-Fonds.

Die Burger, 24 Sept 1979, NP-Fonds vat-vat aan R1 miljoen.

Die Burger, 25 Sept 1979, Dit is 'n triomf (Hoofartikel).

Die Burger, 25 Sept 1979, NP se fonds verby R1 miljoen.

Die Burger, 5 Mei 1986, Klub Here XVII. 'n Tyd om te herdenk.

Die Burger, 28 Aug 1986, Hoofartikel.

Die Burger, 4 Des 1986, Brief van Vivia Ferreira.

Die Burger, 2 Feb 1990, Die Weergids.

Die Burger, 3 Aug 1992, Helpmekaar: toekoms hou min rede tot hoop. 


\section{Die Kaapse Helpmekaar}

Die Burger, 16 Sept 1995, Bekende rekenmeester sterf.

Die Burger, 11 Mei 1996, Skep so self kanse (Hoofartikel).

Die Burger, 3 Feb 1999, Oudhoofbestuurder (89) van Naspers oorlede.

Die Burger, 7 Mrt 2000, Vervloë vloed-tragedies.

Die Burger, 20 Okt 2011, Oudpolitikus, sakeman Gideon Horn (93) sterf.

Die Burger, 22 Jun 2015, Die Hardste Baklei met Homself: Uys vir Lewenswerk Vereer.

Die Burger, 31 Mei 2016, “The Echo of a Noise”. Fokus op familiegeskiedenis. Uys se 7 000ste optrede begin vandag.

Die Suid-Afrikaan, Winter 1985, Van Zyl Slabbert in Gesprek met Breyten Breytenbach.

Die Suid-Afrikaan, Sept 1987, Giliomee Hermann, Die ANC, die Afrikaners en die storie van die bobbejaan.

Mail and Guardian, 3 May 2010, Rencap buys Barnard Jacobs Mellett for R207m.

Matieland, Universiteit Stellenbosch, Jaargang 15, No. 2 Aug 1971.

Rapport Weekliks, 12 Jun 2016, Ben du Toit, Moet liefs nie 1976-jeug en troepies vergelyk nie.

Rapport, 13 Mei 2018, Net 10\% betaal hul studieskuld terug.

The Deciduous Fruit Grower, vol 12, July 1962, Part 7, Mr HL Greyling.

Universiteit Stellenbosch Jaarboek, 1965, 2015.

\section{AKADEMIESE ARTIKELS}

Brink, E. 'Only Decent Girls are Employed': The Respectability, Decency and Virtue of the Garment Workers on the Witwatersrand during the Thirties. Paper presented at Wits History Workshop, The Making of Class, Johannesburg, 9-14 Feb 1987.

Cope, N. The Zulu Petit Bourgeoisie and Zulu Nationalism in the 1920's: Origins of Inkatha. Journal of Southern African Studies, vol. 16, no 3 (Sep 1990). https://doi. org/10.1080/03057079008708245 
Ehlers, A. Rescuing the Rebels from Ruin: Afrikaner Nationalism and the Political Economy of the Helpmekaar (Mutual Aid) Movement and its $£ 100$ Fund, 1915-1917. Economic History of Developing Regions, 26:1

Ehlers, A, The Helpmekaar: rescuing the 'volk' through reading writing and arithmetic, c1916-c1965. Historia, 60:2.

Erasmus, R. \& JJ. Swanepoel. Stigting. Die Afrikanervolkswag, Hoofredes gelewer op 4 en $5 \mathrm{Mei}$ 1984. INEG, UOVS, 1984.

Giliomee, H. Western Cape Farmers and the beginnings of Afrikaner nationalism, 1870-1950. Journal of Southern African Studies. Vol 14(1), Oct 1987. https://doi. org/10.1080/03057078708708159

Grundlingh, AM. Are We Afrikaners Getting Too Rich? Cornucopia and Change in Afrikanerdom in the 1960's. Journal of Historical Sociology, Vol 21(2/3), Jun/Sep 2008.

Klee, J. Die verwesenliking van 'n Afrikaner-droom: Die stigting van die Randse Afrikaanse Universiteit, 1955-1968. New Contree, No 60, Nov 2010.

Marks, S. Patriotism, Patriarchy and Purity: Natal and the Politics of Zulu Ethnic Consciousness. University of the Witwatersrand. African Studies Institute. African Studies Seminar Paper no 193, Monday 4 August 1986.

Meyers, EM. Lt kdr, Drie eeue van militêre diensplig in Suid-Afrika. Scientia Militaria, South African Journal of Military Studies, Vol 16(2): 10, 1986.

Muzindutsi, P-F. The Response of the Johannesburg Stock Exchange to Changes in Exchange Rate Regimes. Mediterranean Journal of Social Sciences, Vol 4 (6): 414-415, Jul 2013. https://doi.org/10.5901/mjss.2013.v4n6p413

Swart, S. Desperate men: the 1914 rebellion and the politics of poverty. South African Historical Journal, 42, May 2000. https://doi.org/10.1080/02582470008671372

Thomas, LM. The Modern Girl and Racial Respectability in 1930's South Africa. Journal of African History, 47, 2006. https://doi.org/10.1017/S0021853706002131

Vincent, L. Bread and Honour: White Working Class Women and Afrikaner Nationalism in the 1930's. Journal of Southern African Studies, 26, 1, 2000. https://doi. org/10.1080/030570700108388 


\section{Die Kaapse Helpmekaar}

\section{REGERINGSPUBLIKASIES}

Parlementêre Register 1910-1961, Uitgegee deur die Volksraad, Elsiesrivier, 1970.

UG 28-15, Department of Justice. Annual Report for the Calendar Year 1914.

UG 40-16, Report of the Rebellion Losses Commission.

UG 46-16, Report of the Judicial Commission of Inquiry into the Causes of and Circumstances relating to the recent Rebellion in South Africa.

UG 8-1947, First annual report of the Registrar of Banks for the period ended $30^{\text {th }}$ June 1946.

UG 59-1949, Derde Jaarverslag van die Registrateur van Banke vir die tydperk geëindig 31 Desember 1948.

UG 34-1956, Registrateur van Banke, Tiende Jaarverslag, 31 Des 1955, Bylae A.

Union of South Africa Statutes, 1916, Act no 24 of 1916

\section{ARGIVALE BRONNE}

\section{Helpmekaar Studiefonds Argief, Parow (HSA)}

Die Helpmekaar van Natal, Notuleboek (6 Jun 1917-24 Aug 1940).

Helpmekaar Studiefonds, Argiefstukke, Koncept-Konstitutie (pamflet).

Helpmekaarvereniging van die Kaapprovinsie (hierna HVKP), Notuleboeke, 1916-1965, Kongresse.

Helpmekaarvereniging van die Kaapse Skiereiland, Notuleboek (9 Feb 1916-12 Feb 1931).

HVKP, Notuleboeke, 3 Jul 1916-6 Des 1939, Sentrale Bestuur.

HVKP, Notuleboek (8 Feb 1940-9 Des 1966).

Helpmekaar Studiefonds, Notuleboeke, (19 Jan 1967- 18 Jun 2014).

Helpmekaar Studiefonds, Notuleboek (11 Apr 2003-27 Aug 2014), Finansiële Komitee.

Helpmekaar Studiefonds, Notuleboek (9 Mrt 2007-25 Mrt 2014), Algemene Jaarvergaderings.

Helpmekaar Studiefonds Trust, Notuleboek (11 Apr 2006-12 Sept 2014). 
HVKP, Notuleboek (29 Nov 1963-9 Apr 1965), Helpmekaar Insamelingskomitee.

HVKP, Notuleboek (9 Feb 1916-12 Feb 1931), Sentrale Bestuur.

Nationale Vrouwe Helpmekaar Genootschap, Notuleboek (16 Feb 1915-20 Des 1915).

Reëls en Regulasies van die HVKP, De Nationale Pers, Beperkt, 1919.

\section{Kaapse Argiefbewaarplek, Kaapstad (KAB)}

Aanwins 1469 HVKP versameling no. 1, Die Helpmekaar Vereniging in Transvaal-Statute.

Aanwins 1469 HVKP-versameling no. 2, Ontvange Briewe 1916.

Aanwins 1469 HVKP-versameling no. 2, Ontvange Briewe 1917.

Aanwins 1469 HVKP-versameling no.1, Helpmekaar.

Aanwins 1469 HVKP-versameling no.1, Sentrale Rebelle Fonds.

Aanwins 1469 HVKP-versameling no. 1, Korrespondensie 1914-1915.

Aanwins 1469 HVKP-versameling, no. 1, Korrespondensie 1917.

Aanwins 1469, HVKP-versameling, Korrespondensie 1914.

Aanwins 1469, HVKP-versameling, Korrespondensie 1915.

Aanwins 1793, D H van Zyl-versameling.

AG 14128, Photograph with the organizers of the National Party, Cape, 1936.

AG 14130, Photograph with National Party delegates, c1926.

AG 14211, Senator David Hermanus van Zyl, his wife Bess and their only son Frikkie. Frikkie was killed in 1937 during a motor-car accident.

\section{Instituut vir Eietydse Geskiedenis, Bloemfontein (INEG)}

PV 138 M Hutton-versameling, lêer no. 6 Inligtingstukke.

PV 21 Nasionale Party van die Oranje-Vrystaat-versameling: lêer no. 39. Deel I 8 Jan 1918-25 Apr 1919. Onderwerp: Finansies Sentrale Rebelliefonds Korrespondensie, Helpmekaar. 


\section{Die Kaapse Helpmekaar}

PV 38 Dr JHO du Plessis versameling, lêer no 43. I no. 36 Inligtingstuk (Brosjure in verband met die ontstaan van die Helpmekaar).

\section{Vrystaatse Kerkargief, Bloemfontein (VKA)}

Helpmekaar van die Oranje-Vrystaat, Helpmekaar Korrespondensie 1916-1919.

Helpmekaar van die Oranje-Vrystaat, Notuleboek (16 Mrt 1915-18 Aug. 1926).

Helpmekaar van die Oranje-Vrystaat, Notuleboek (1927-1937).

Helpmekaar van die Oranje-Vrystaat: Helpmekaar Korrespondensie en Finansiële Stukke 1916-1919, Afrikaner Nasionale Helpmekaar Vereniging.

Vrystaatse Nederduitse Gereformeerde Kerk-versameling, Acta Sinodi, 1916.

\section{Universiteit Stellenbosch Dokumentesentrum, Stellenbosch (USD)}

Saambou Nasionale Bouvereniging Argief, Notuleboeke, 12 Jun 1942-14 Nov 1946; 21 Jun 1963-20 Feb 1970; 7 Feb 1980-4 Apr 1984.

\section{Universiteit Stellenbosch Beyers Naude Sentrum vir Openbare Teologie, Stellenbosch}

Beyers Naude Versameling, Afrikanerdag toespraak deur Beyers Naude, 19 November 1942.

\section{Transvaalse Argiefbewaarplek, Pretoria (TAB)}

Aanwins 1500 JR Bührman-versameling vol 2, 1902-1950, Dokumente rakende Politieke aangeleenthede.

\section{Neder-Duits Gereformeerde Kerk Argief, Stellenbosch}

G.1 1/43 Kaapstad Notule, 1913-1922, Kerkraadsvergaderings.

G.5 1/5 Swartland Notule, 1913-1926, Kerkraadsvergaderings.

G.7 1/5 Swellendam Notule, 1911-1926, Kerkraadsvergaderings.

G.27 1/5 Victoria-Wes Notule, 1914-1933, Kerkraadsvergaderings. 


\section{Sanlam-argief, Belville}

Kabinet N2070 (d) lêer 980 Sanlam Deel I, Manuskrip van WJ Bezuidenhout oor die Geskiedenis van Sanlam.

\section{Elektroniese internetbronne}

https://store.lexisnexis.co.za/categories/products/butterworths-wetgewingsdiens-wet-oplanddroshowe-32-van1944-skuZASKU060BWDLANDSYS/details

(2011) "Die Wynstok 1980," Die Wynstok: Vol. 1: Iss. 6, Article 1. Available at: http:// dk.cput.ac.za/wynstok/vol1/iss6/1 (Die Wynstok, Nuusblad van die Onderwyserskollege Wellington, 1980, Jaargang 18 no 28, p5 (Uit die Kantoor)).

http://ujdigispace.uj.ac.za/handle/10210/3393?show=full (University of Johannesburg Library and Information centre).

http://www.sabar.co.za/law-journals/2014/april/2014-april-vol027-no1-pp23-24.pdf (Advocate, April 2014, In memoriam: Judge Jan Hendrik Steyn).

http://liberta.co.za/blog/prime-interest-rate-in-south-africa-current-and-historical/ http://www.litnet.co.za/in-memoriam-jakes-gerwel/ (Jason Lloyd, In Memorium: Jakes Gerwel, 7 Des 2012).

http://kerkargief.co.za/doks/bely/DF_Broederkring.pdf

http://www.inflation.eu/inflation-rates/south-africa/historic-inflation/cpi-inflation-southafrica-1979.aspx

http://www.photius.com/countries/south_africa/economy/south_africa_economy_inflation.html http://inflationcalc.co.za/?date1=1973-01-01\&date2=1980-01-01\&amount=1000 http://liberta.co.za/blog/prime-interest-rate-in-south-africa-current-and-historical/ Davenport, N, Money: a tale of two cities, Spectator, 14 Mrt 1970.

http://archive.spectator.co.uk/article/14th-march-1970/25/money-a-tale-of-two-cities http://.sajar.co.zadocumentsVol11\%20Realignment\%20of\%20int\%20stock\%20markets.pdf 


\section{Die Kaapse Helpmekaar}

(GDI Barr and L Sharp, The realignment of international stock markets after the 1987 crash, with special reference to the Johannesburg Stock Exchange, South African Journal of Accounting Research vol II no1, 1997).

Finance and Economics Discussion Series, Divisions of Research \& Statistics and Monetary Affairs, Federal Reserve Board, Washington, D.C. (A Brief History of the 1987 Stock Market Crash with a discussion of the Federal Reserve Response, Mark Carlson, 2007-13) www.federalreserve.gov/pubs/feds/2007/200713/200713pap.pdf

http://www.nytimes.com/2011/08/21/opinion/sunday/the-soviet-coup-that-failed.html? r=0 (Victor Sebestyen, 20 Aug 2011, The KGB`s Bathhouse Plot.)

http://www.helpmekaarfonds.org/Direksie.html

Churches and taxation in Democratic South Africa. http://www.sacc-ct.org.za/taxbook2. html\#TOPOFPAGE

Laws and regulations govering non-profit organisations in South Africa. "International Charity Law: Comparative Seminar”, Beiging, China, October 12-14, 2004. www.icnl.org/ news/2004/12-15_South_Africa.doc

SARS Tax Exemption Guide for Public Benefit Organisations in South Africa.

Hanley, L Respectable: The Experience of Class, Alan Lane, 2016. https://www.goodreads. com/book/show/29744398 respectable

http://www.afrikanergeskiedenis.co.za/organisasies-se-geskiedenis/fak-geskiedenis/ (Kultuur in die brandpunt, 1980-1994.)

Hoggarts, R, The Uses of Literacy. Aspects of Working Class Life, Penguin, 2009. https://www. penguin. co.uk/books/175505/the-uses-of-literacy

http://www.rof.org.za/

http://www.afrikanergeskiedenis.co.za/organisasies-se-geskiedenis/fak-geskiedenis/

(Kulturele Herdefiniëring (1994-2011) en Kulturele Opstaan (2012-)

http://www.saipa.co.za/page/308024/prof-philip-haupt

E-pos kommunikasie, 24 Nov 2015, Helpmekaar - Ehlers.

E-pos kommunikasie van dr C du Toit aan dr C Stander en A Ehlers, 13 Okt 2015.

http://www.mervynking.co.za/downloads/CD_King2.pdf

http://www.oecd.org/about/history/; http://www.oecd.org/ 
Education Indicators in Focus, 2012/06 (Jun). https://www.oecd.org/edu/skills-beyondschool/Education\%20Indicators\%20in\%20Focus\%206\%20June\%202012.pdf

Draft National Plan for Higher Education in South Africa, Ministry of Education, February 2001 (http://www.unisa.ac.za/contents/projects/docs/National\%20Plan\%20Higher\%20 Education.pdf) 


\section{INDEKS}

Albertyn, CF (dr) 107-108, 159-160, 190, 246, $249,253-254,260,265-268,270,274-$ 281, 287, 289, 297, 300, 302, 304-307, $311,313-315,319,321-324$,332-333, 336-338, 341, 346, 354-358, 369, 371, $373-375,377,379-380,402,502$

Albertyn, JR 254-255, 257-258

Baard, B 343

Barnard, Chris (Christiaan) (dr) 1, 468

Barnard, JH 183

Barnard, Marius (dr) $\quad 1,468$

Barry, RL $\quad 63,175,177$

Bauling, RE 235

Benning, AJ 46-49, 64

Beukes, DPM (ds) 126, 130, 132-134, 137$143,145,198,231-233,236,454$

Beyers, generaal 10

Binedell, Dalene (mej) 226

Boesak, Allan Aubrey (dr) 272, 287, 291

Bonthuys, JB 221, 231

Botha, JS 28-29

Botha, Louis (generaal) 9, 434, 438

Botha, MC (mev) 107

Botha, MC (prof) 107, 158, 166, 191

Botha, MC (dr) 1, 468

Botha, Philip R 61

Botha, PW 270, 462-463

Bothma, P 343

Breytenbach, Breyten $\quad 1,470$
Brink, CH 246, 256

Brink, Melt 47

Bruwer, AJ 63

Bruwer, GE (dr) 405

Bruwer, LC 231

Bührman, Johannes 442

Burger, E 254

Burger, NFP (ds) 159

Burmeister $\quad 126,154,161$

Buys, SPB 184

Carstens, Arno 1

Celliers, FJ 177

Cillié, GG (dr) 64

Cillié, Piet $\quad 301,367$

Cillie, PJ $\quad 69,88,95$

Cloete, $\mathrm{R} \quad 47$

Coetzee, BP 442

Coetzee, HE (mej) 123, 171

Conradie, BJ 243-244, 277, 304

Conradie, DG $\quad 13,22$

Conradie (ds) 195

Conradie, Frans 348

Conradie, HF 258

Conradie, JH (adv) 239

Crafford, A 379

Cronje 171

Cronje, Henno (ds) 401 
Daniels, J 297

De Beer, ZJ 47

De Bruyn, JG (ds) 46, 48

De Bruyn, JG (mev) 41, 42, 44, 46-49, 113, 192-193

Dekker, G (mej) 471

Dekker, TJP 65

De Klerk, FW $\quad 354,369,374$

De Klerk, P 41

De Klerk, Willem 301

De Kock, Maria (mej) 41

De Kock, MH 1,61-62, 177

De la Rey, Koos 10

Delport, JM (ds) 276-279, 304, 307, 379

Delport, Willem 148

De Swardt, (dr) 343

De Swardt, GJ (Gideon Jacobus) 383, 385, $387-389,394,423$

De Villiers, Annie (mej) 226

De Villiers, CC $\quad 47-49,56$

De Villiers, CC (mev) 47-49

De Villiers, DP (adv) 276

De Villiers, JE (Japie) 31-33, 195, 216, 248, 253,446

De Villiers, JE (jr) 33, 446

De Villiers, W (mej) 11, 31-32, 40-41, 46-47, 49,53

De Vos, J (adv) 215, 243-244

De Vos (mev) 41, 215

De Waal, Frederic (sir) 167

De Wet, generaal $\quad 10,12,43$
Dommisse, Ebbe (dr) 379-80, 394, 398, 404, 406, 429

Dormehl, Fred $\quad 48,64,173,450$

Dreyer, JC 170

Du Plessis, DJ 13,159

Du Plessis, JS (mej) 226

Du Pré, J (mej) 303

Du Raan, CJ 406

Du Toit, APN 52-53

Du Toit, Charl (dr) 393, 415-416

Du Toit, Hoender 298

Du Toit, JS (dr) 214-215, 217, 219, 226, 241, 243-244, 246

Du Toit, PP 69

Erasmus, Francois C $\quad 1,83,212$

Eybers, BB 176

Fagan, HA (adv) 47, 219, 231, 239

Fichardt, C 22, 434

Fischer, PU 16, 41

Fourie, CPJ 28

Fourie, Jopie 10,434

Fraser, Gordon 16

Gagiano, Jannie $\quad 1,470$

Geldenhuys, MC (mev) 388

Gerdener, H 110

Gerwel, Jakes 290, 378

Geyer, A (mev) 106-107

Gie, SFN (dr) 69

Gorbatsjof, Michail 373

Graves 338

Greeff, CG 177 
Greeff, E (mej) 303

Greeff, Johan (mev) 53, 87, 89-92

Greyling, HL 239, 254, 258-259, 262, 265, 275-279, 332, 336

Groll, George Israel 335

Hanekom, TN (dr) (prof) 114, 181, 243-244, $249,277,304$

Hattingh, BR 440,442

Haupt, (prof) 406

Hertzog, JBM (generaal) 9, 51, 164, 433, 449, 453

Heyns, Johan (prof) 401

Hofmeyr, Isabel 455

Hofmeyr, WA $47-49,51,53,57,64,94,170$, $241,440,450,452$

Hofmeyr, WA (mev) 41, 43, 47

Horn, GJ 243-244, 249, 253-254, 260, 304, $321,326-327,337,344-345,354-356,380$

Hugo, JPP 96

Jamneck, CP 147, 149, 161, 199, 277, 304, 352,379

Jansen, ZB 58

Johnson, WW 42

Jones, Stanley 101

Jooste, Charl J 178

Jordaan, G (Gert) 45, 53, 56-57, 88, 438

Jordaan, G (mev) 45

Jordaan, JJ 170

Jordaan, JL 177

Jordaan, PHG (ds) 113-114

Joubert, F 69

Joubert, GJ (dr) 254
Karremacher (mev) 47

Kestell, JD $\quad$ 14-17, 22, 32, 34, 44, 389, 438, 444

Kestell (mev) 44

Kirsten, Freddie $\quad$ 264, 266, 271, 289

Knoetze 387

Kok, NJ (Nikolaas Johannes) (dr) 380, 394

Koornhof, Piet $\quad 1,211,470$

Kritzinger, DJ 114, 229

Kruger, M (mej) 471

Kruger, Paul 83

Lambrechts, HA $374,376,405$

Landman, WA (ds) (dr) 112-118, 123, 130, $217,219,267,302,454$

Le Roux, $\mathrm{H} \quad 43$

Le Roux, J (mev) 160

Lochner, Johan 254

Lombard, HK 232

Loubser, Dreyer 341

Louw, B 90

Louw, mej 41

Louw, MS (dr) 231, 333

Louw, TJ (Tobie) 53, 57, 450

Lubbe (ds) 194-195

Luckhoff (ds) 173

Malan, DF (dr) 1, 19, 21, 31-34, 37, 46-48, 5152, 57, 64, 83, 98, 164, 169-170, 212, 231, 241, 265-266, 268, 288, 300, 369, 433, 444,446

Malan, DF (mev) 231

Malan, DJ 226

Malan, Nico 253 
Malan, W de Vos (dr) 166

Malherbe, DF 462

Malherbe, Gawie 232-233

Malherbe, Geof 276

Marais, Christiaan (mev) 49

Marais, Piet 354

Marais, SA 343

Marchand (ds) 42

Maree, MF (mej) 303

McHardy, JL 95, 226

Meiring, PJG (ds) 266

Meyer, Frederik 1,63

Meyer, PS (dr) 208, 277, 279, 304, 327, 353, $356,374,376,380,385-388,390,394$, 397-398, 405, 407, 411

Moolman, JH 231

Morkel, Phil 269-270

Muller (mev) 41

Nel, W 43

Olivier, IW 67

Otto, HJ 226

Perold, Izak (dr) 462

Piek, JJ 253, 264, 277-278, 343-344

Pienaar, Boy (mev) 161

Pienaar, Schalk 301

Posthumus, DJ 124,280

Pretorius, GR (Guillaume Ronél) 326-327, $344,357,374,388,394,406-407$

Pretorius, JC 16

Pretorius, SP (Fanie) 126, 227, 240, 242-244, 252, 254, 259-260, 277-278, 285, 288,290,
$301303-305,319,327,336,355-356,371-$

373

Purchase (mev) 364

Puren, Gert 179

Rabie, DJ 222

Rabie (ds) 40

Rabie, JC (dr) 232

Raubenheimer, JA (dr) 438

Rompel, Frederick 94

Roome, FX (ds) 98-99, 100-104, 106, $107-$ $108,110-114,128-129,191-192,219,454$

Roos, $\mathrm{HH} 226$

Roos, DJ, 304, 326

Roos, JH (ds) 277, 327, 338, 355-356, 374, 380

Roos, Paul 175, 177

Roussouw, GJ 231

Roux, HD 136-137, 145, 237, 244

Roux, Paul (mev) (Hester) 32, 49, 53-54, 76, $95,105,107-108,111,164,167,174,211$

Roux, Wessel (adv) 57, 58, 86, 105, 108, 111, $113,120-121,126,164,189,200,206$, $215-216,218-219,221,227,235,245$, 305-306, 453

Rupert, Anton E (dr) 82, 233, 243-244, 246, 248-249, 264, 277, 304, 323-325, 328, $343-344,370,375,379$

Rupert, Johann Peter $\quad 387,394,415,416,419$

Sauer, Paul $\quad 83,241,267$

Schaap, AM 125

Schoeman, JH 438

Scholtz $13,22,47$

Scholtz, Pepler 173, 257 
Schumann, CGW (prof) 1, 62-63, 65, 107108,459

Schutte, E 219

Serfontein, $\mathrm{H} \quad 13,47$

Siebrits, FK $\quad 113,122,126,192-193,219$

Sinclair, KA (Ken) 126, 132-136, 140, 144149, 257-258, 261, 266-267, 273, 275$280,285,300,307,336,342,354-356$

Slabber, C 254

Slabbert, Frederick Van Zyl $\quad 1,470$

Sloet, HA $\quad 302,354$

Smith, ML (Marthinus Luther) (Marius) 394$395,398,407,421-422$

Sonn, Franklin 378

Stals, AJ (dr) 59, 82-83, 84-86, 90, 94, 112, $127-128,155,333,452$

Stander, CH (Carel Hendrik) (dr) 166, 379380, 383, 388, 390, 394-395, 403-404, $407,414,417,421,423,429$

Steenkamp, WP (dr) 69

Steyn, Colin 16

Steyn, Douw 177

Steyn, J (mev) 303, 304, 388

Steyn, MT (Marthinus) 83, 214-215, 231, 446

Steytler, Herman 352

Swart, CR 83, 265

Terreblanche, Mof 424

Theron, PF 226

Thom, HB (dr) (prof) 231

Tomlinson, Gordon $\quad 13,22,24$

Trouw, TCC (mev) 113, 161

Uys, Pieter Dirk 1, 209
Van Arkel (ds) 113, 123-124

Van Aswegen, SPF (Sarel) 321, 328, 344, 357, 380

Van Barneveld, JH 21, 24-25

Van Blerk, C (mev) 303

Van Breda, VA 291

Van Dam, H Kennedy 40

Van der Merwe, AJ (dr) 231, 238

Van der Merwe, CA (ds) 47

Van der Merwe, CP (dr) 13, 47, 50, 439-440

Van der Merwe, MH (mev) 111

Van der Merwe, Nikolaas Johannes 459

Van der Merwe, Paul 154

Van der Merwe, Rosa 176

Van der Merwe, RT $\quad 13-14,21,23,28-30,447-$ 448

Van der Poel, HR $\quad 214,217-219,333$

Van der Poel, Pieter $\quad 415,419$

Van der Poel, Roux $\quad$ 213-214, 218, 221, 226

Van der Ross, Richard 288

Van der Spuy, Hubert 149

Van der Walt, HJ (mev) 447

Van der Westhuysen (mev) 351

Van der Westhuyzen, Jacobus (Kobus) (ds) 199, 277-279, 316, 321-322, 327, 332 , 344, 351, 355, 358, 374-376, 380, $382-383,387-391,394-395,397,402$, $404,407,412,414-415,419,420$, 428429, 454

Van Dyk, CJ 126, 214

Van Heerden, G 53, 351

Van Heerden, GW (mev) 154 
Van Heerden, JL $\quad$ 16, 39

Van Hoogstraten, HA 165

Van Nierop, PJ (dr) 114, 241

Van Reenen, A 46-47

Van Rensburg, A (mej) 45

Van Rensburg (eerwaarde) 40

Van Rensburg, PLJ 343-344

Van Rensburg, RA 126, 148, 277, 280, 304

Van Rensburg, W (mev) 45

Van Riebeeck, Jan $\quad$ 105, 133, 170

Van Rooyen 43, 94, 284

Van Rooyen, MC 285

Van Rooyen, R 43

Van Rooyen, WK $\quad 259,285-287,304$

Van Velden 47

Van Wyk, Andreas (prof) 406

Van Zijl, HS 2, 5, 31-32, 35, 47-49, 52-53, 57, $60,65,67,73-74,77,79,440$

Van Zyl, DH (Dawie), (senator) 112-114, 116, 119, 120-121, 124, 126, 133-134, 136, 144, 147-148, 164, 194-195, 197, 202, 211-219, 221-229, 231, 233-237, 240249, 252, 254, 256-258, 260-261, 263, 269, 273-274, 277-278, 280, 288-290, $302,304,325,330,332,347-349,353$, 355-357, 453

Van Zyl, JA 147, 204, 206, 276

Van Zyl, JE 165

Van Zyl (mev) 305, 350

Van Zyl, Nita (mev) 303, 429

Van Zyl, PJC 233, 243-244, 249, 253, 260-261, 265-266, 277-278, 304, 307, 355

Venter, DG (ds) $\quad 113,219$
Verwoerd, HF (dr) 145, 264, 267, 301, 453

Viljoen (ds) 432

Viljoen, WJ (dr) 151-153, 164, 188

Visser, AG 461

Visser, AJ (Andries), (dr) 256, 298

Visser, Annie 47

Visser, WJM 13, 29

Volschenk, GJB 126, 134, 149, 277-278, 304, 350-351

Vorster, Jacoba $\quad 247,295,363$

Vosloo, JE 57

Vosloo, Ton 385

Wahl, mej 96

Wapenaar, JS 61

Webber, Fluffy 10

Weber, PA (dr) 302

Werdmuller (dr) 41, 90

Wessels, J Brand 13, 47

Wiener, Ludwig 64,173

Wilcocks, CTM 434 